
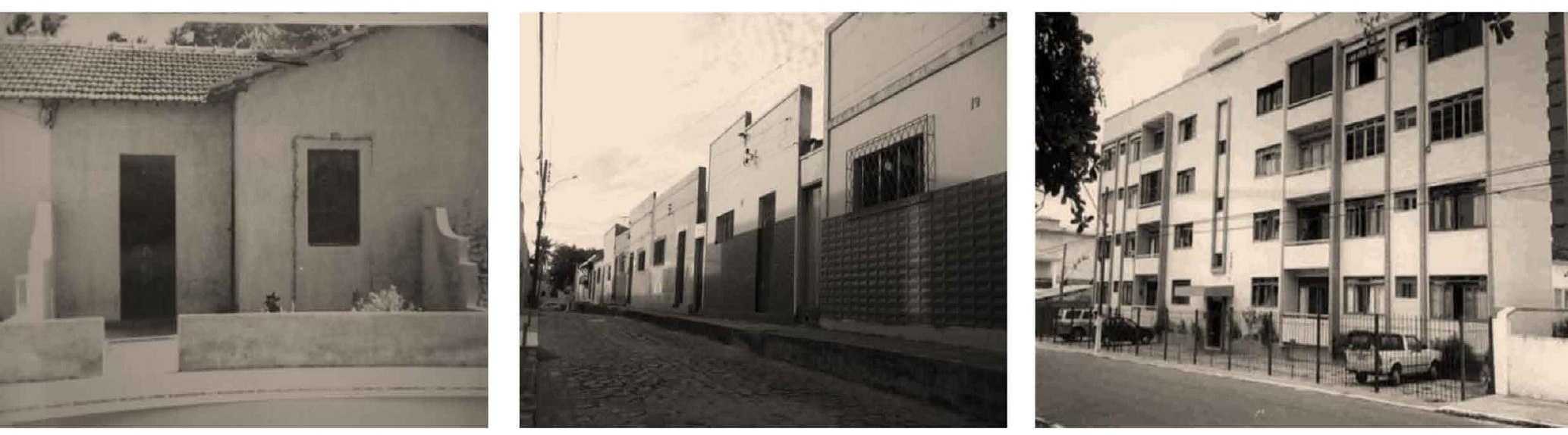

Caliane Christie Oliveira de Almeida

\title{
HABITAÇÃo SOCIAL NO NORDESTE A ATUAÇÃo dAS CAPS E DOS IAPS \\ (1930-1964)
}

SÃO CARLOS-SP

SETEMBRO DE 2012

Versão Corrigida 


\section{FOLHA DE JULGAMENTO}

Candidata: Arquiteto e Urbanista CALIANE CHRISTIE OLIVEIRA DE ALMEIDA SILVA

Título da tese: "Habitação social no nordeste: a atuação das CAPs e dos IAPs (1930-1964)"

Data da defesa: 03/08/2012

\section{Comissão Julgadora:}

Prof ${ }^{a}$. Associada Telma de Barros Correia (Orientadora)

(Instituto de Arquitetura e Urbanismo/USP)

Prof ${ }^{\text {. }}$ Associada Maria Ruth Amaral de Sampaio

(Faculdade de Arquitetura e Urbanismo/USP)

Prof ${ }^{\mathrm{a}} \mathrm{Dr}^{\mathrm{a}}$ Virginia Pitta Pontual

(Universidade Federal de Pernambuco/UFPE)

Prof ${ }^{\mathrm{a}} \mathrm{Dr}^{\mathrm{a}}$ Ana Maria Fernandes

(Universidade Federal da Bahia UFBA)

Prof $^{2}$ Dr. Francisco Sales Trajano Filho

(Instituto de Arquitetura e Urbanismo/USP)
Resultado:
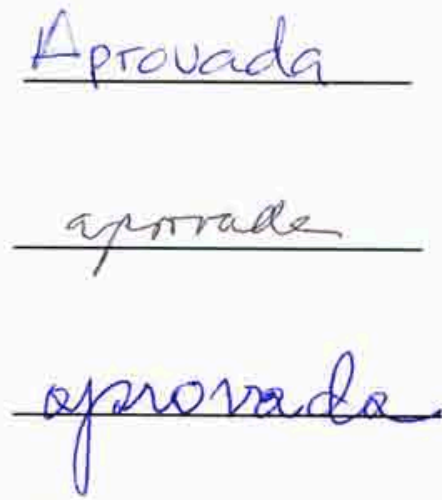

Aprovada

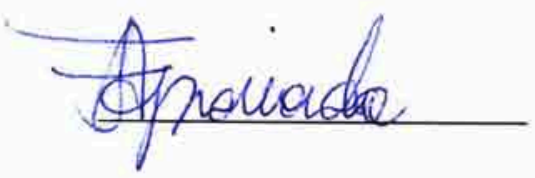

Coordenador e Presidente da Comissão de Pós-Graduação: do Programa de PósGraduação em Arquitetura e Urbanismo: Prof. Titular Renato Luiz Sobral Anelli 


\author{
UNIVERSIDADE DE SÃO PAULO \\ INSTITUTO DE ARQUITETURA E URBANISMO \\ Pós-GraduaÇ̃̃o em ARQuITETURA E URBANISMO \\ SUB-ÁREA DE TEORIA E HISTÓRIA DA ARQUITETURA E DO URBANISMO
}

TESE DE DOUTORADO

\title{
HABITAÇÃO SOCIAL NO NORDESTE: A ATUAÇÃO DAS CAPS E DOS IAPS (1930-1964)
}

DOUTORANDA: CALIANE Christie OliveIRA DE AlmeidA

OrIentadora: Profa. DRA. Telma de BarRos CorReia

Tese apresentada à Comissão de Pós-Graduação em Arquitetura e Urbanismo, do Instituto de Arquitetura e Urbanismo de São Carlos, Universidade de São Paulo (IAU-USP), como requisito à aquisição do título de doutor em Arquitetura e Urbanismo. 
Ficha catalográfica preparada pela Seção de Tratamento da Informação do Serviço de Biblioteca - EESC/USP

A447h

Almeida, Caliane Christie Oliveira de Habitação social no nordeste : a atuação das CAPs e dos IAPs (1930-1964). / Caliane Christie Oliveira de Almeida ; orientadora Telma de Barros Correia, 2012.

Tese (Doutorado - Programa de Pós-Graduação em Arquitetura e Urbanismo e Área de Concentração em Teoria e História da Arquitetura e do Urbanismo)-Instituto de Arquitetura e Urbanismo de São Carlos da Universidade de São Paulo, 2012.

1. Política pública habitacional. 2. Caixas e Institutos de Aposentadoria e Pensões (CAPs/IAPS). 3. Nordeste. 4. Habitação social. I. Título. 
Hos meus pais.. 
Quatro anos! Período de muita pesquisa histórica e documental, de viagens para realização de levantamentos primários em diversas capitais do Nordeste, de muitos encontros, reencontros e, por vezes, desencontros. Muitas alegrias, mas também, alguns momentos de ansiedade, nervosismo e aflição diante da responsabilidade de defender uma tese que se contrapõe a algumas verdades fossilizadas e, muitas vezes, perpetuadas por algumas figuras já consagradas no meio historiográfico brasileiro. Uma tentativa de trazer para o centro-sul do país uma produção habitacional ainda pouco conhecida, de profissionais "litorâneos nordestinos", como diria Euclides da Cunha ${ }^{1}$. Espero que um novo caminho acerca da trajetória e da atuação das CAPs e dos IAPs agora se faça. Parafraseando Gilberto Freyre, espero ver a "velha ciranda agora renovada"; Oh de Casa!

A principal certeza que tenho ao concluir mais uma etapa acadêmica - trilhada e almejada desde 0 início da graduação - depois desses quarenta e oito meses passados, vinte e três viagens realizadas, quase duas mil legislações lidas, mais de dois mil processos imobiliários levantados, mais de seis mil imagens registradas in loco e outras tantas mil de documentos oficiais, muitos meses longe da família e dos amigos e, essencialmente, muitos dias de dedicação, é que em muito amadureci profissionalmente, espiritualmente e emocionalmente, e que muito tenho a agradecer.

Em primeiro lugar agradeço a Deus, força maior, sem a permissão do qual, nada seria possível de se realizar. Sem a benção Dele, nada eu teria feito. Em segundo lugar, à Fundação de Amparo à Pesquisa do Estado de São Paulo (FAPESP), cujo apoio financeiro tornou esta extensa pesquisa viável. À Profá. Dra. Telma de Barros Correia pela orientação e dedicação concedida, além dos muitos momentos de incentivo e apoio emocional, que foram fundamentais nesta jornada. Por diversos episódios, ela foi mais que orientadora e conselheira, foi como uma amiga e, por vezes, como uma mãe. Para ela devo o meu muito obrigada! Agradeço também aos membros da banca examinadora pelas contribuições desprendidas para uma melhor apresentação e redação do conteúdo da pesquisa.

Aos meus pais, Maria Édna de Oliveira e Carlos Antônio de Almeida, e irmãos, Carlos A. de Almeida Segundo e Cáion Cristian de Oliveira, meus alicerces, pelo carinho, compreensão e apoio, sem os quais eu não teria concluído mais essa etapa da minha formação. Aos parentes e amigos que me acolheram em suas casas por muitos dias. Sem essa ajuda esta pesquisa também seria inviável. Mais precisamente à Rosalia e Flávio Cavadas (Salvador), Ana Virgínia e família (Recife), Regina Serrano e família (João Pessoa), Eláina e família (Fortaleza), à minha grande amiga Alexandrina Rocha e sua família (Teresina) e ao meu irmão de vida Leandro Nakashima e sua família (São Luís).

Agradeço também aos gerentes, aos responsáveis pelos setores de engenharia e de patrimônio e aos funcionários das sete gerências administrativas do INSS no Nordeste, por viabilizarem 0 acesso à documentação fundamental para o desenvolvimento desta tese e por todo auxílio técnico e atenção dada no período de permanência em cada uma das localidades. Agradecimentos especiais devo à Meire e à Maria do Socorro Castro (INSS-BA), a Clovis Campelo (INSS-PE), a Imis e Francisco (INSS-RN), à Jerusa Alcântara e Teodózio Oliveira (INSS-CE), a Ulpiano José Tavares (INSS-PI) e a José de Ribamar Nunes (INSS-MA), nesse sentido. Por esse mesmo viés, agradeço a todos os técnicos e funcionários dos diversos arquivos públicos e privados do país. Diversas formas de auxílio também foram concedidas pelos colegas de pesquisa do Grupo de Pesquisa História da Cidade e do Urbanismo, do Departamento de Arquitetura e Urbanismo da Universidade do Rio Grande do Norte (HCUrb-UFRN), ao qual mantenho vínculos desde a graduação, principalmente, à Luíza Medeiros, a Yuri Simonini, a George Dantas e à Profa. Drạ. Angela Lúcia de Araújo Ferreira, coordenadora do Grupo, mentora e amiga.

${ }^{1}$ Expressão bastante utilizada pelo autor em sua obra Os Sertões. 
Agradeço ainda, aos meus avós - Maria de Lourdes, José Alves (que se foi neste corrente ano) e Maria Almeida da Silva - aos meus padrinhos - Maria Ledeclede e Ivan Carneiro - por todas as palavras de incentivo, orações e diversas formas de ajuda. Às minhas tias Edlene, Edneide, Leneide e Lourdes, e aos meus tios Jailson e Edson, pelos estímulos e carinho. Aos meus velhos amigos natalenses (Michele Mendes, Raquel Madera, Sâmela Alves, Artur Nascimento, Juliana Mester, Renata Barros, Carla e Carine Santos, James Josino, Luis Felipe, Daniel Câmara, Alberto Vilanova, Orlando Rodrigues, Rafael Pace, Leonardo e Gabriel Mocan, Leonardo Rêgo e "Déco"), aos grandes amigos conquistados ao longo desses anos em que estive em São Carlos (Débora Foreste, Luciana Margoni, Patrícia Leal, Alexandrina Paiva, Danielle Veloso, Carla Guilard, Ana Cláudia Sibin, Lucyani Taroda, Ana Cristina Fazza, Daniel Reis e Amadeu Coelho), aos amigos de morada (Roberta Torres, Adriana Costa, Ricardo Boffa, Wagner Correr, Pedro Henrique e Adriana Leal), pelas mais variadas formas de amparo e pelos muitos momentos de descontração, fundamentais para a renovação das minhas forças ao longo desta jornada. Há ainda muitos nomes, figuras passageiras, distantes e novos personagens, que de uma forma ou de outra me auxiliaram nestes quatro longos e frutíferos anos. "Agradecida", como diria o sertanejo. 
ALMEIDA, Caliane Christie Oliveira de. Habitação Social no Nordeste: a atuação das CAPs e dos IAPs (1930-1964). 2012. 395p. Tese (Doutorado) - Instituto de Arquitetura e Urbanismo de São Carlos (IAUSC), Universidade de São Paulo (USP), São Carlos, 2012.

Criados principalmente ao longo das três primeiras décadas do século $X X$, os institutos de previdência existentes possuíam como objetivo primordial conceder auxílios financeiros em caso de doença ou morte do chefe de família, voltados principalmente ao funcionalismo público do país. Paulatinamente, suas funções foram se ampliando para o campo do trabalho, passando a se conformarem como órgãos de assistência e de seguro para as demais categorias trabalhistas, culminando na criação e diversificação das Caixas e Institutos de Aposentadoria e Pensões subordinados ao MTIC. Foi nesse contexto que a construção e 0 financiamento de unidades habitacionais passaram a serem tidos como de responsabilidade estatal no Brasil. A identificação e análises da política pública habitacional empreendida pelos referidos órgãos no Nordeste do país, entre 1930 e 1964, bem como da produção de moradias resultante, sua arquitetura, urbanismo e profissionais envolvidos, se conformaram como os principais objetivos desta tese. Um estudo empírico analítico, baseado em distintas fontes, sobretudo primárias, que dialogam em diferentes níveis para a desconstrução de verdades historiográficas fossilizadas sobre 0 tema e para o conhecimento de uma atuação ainda ofuscada por análises centradas na produção do centro-sul do país. Livrando-se do atual otimismo historiográfico acerca da atuação dos IAPS, que pouco estudou sobre as CAPs, evidenciou-se no Nordeste uma política restritiva focada, sobretudo, no atendimento dos anseios imobiliários dos trabalhadores urbanos mais abastados, incluindo os empregadores, que chegou a representar $45,74 \%$ dos pleitos concedidos. A quantificação dessa produção habitacional se coloca em torno das 20.000 unidades, que corresponde a $62,46 \%$ do volume de pleitos apontados pela historiografia para as regiões Norte, Sul e Nordeste do país, confirmando a hipótese da necessidade de estudos mais aprofundados acerca da atuação dos supracitados institutos de previdência em todo o território nacional. Mais precisamente foram identificados 147 grupos residenciais, entre unidades unifamiliares e edifícios coletivos, na maior parte das vezes, destituídos de equipamentos de uso coletivo. Amplo também foi o quadro do corpo técnico, conformado principalmente por engenheiros e arquitetos, atuantes direta ou indiretamente por meio das CAPs/IAPs no campo da moradia naquela região: um montante de aproximadamente 200 profissionais. No que concerne à arquitetura e urbanismo, constatou-se um diversidade de modelos vinculados a diferentes referências arquitetônicas. Surpreendentemente, evidenciou-se que para além do financiamento dos primeiros conjuntos residenciais modernos, as CAPs e os IAPs foram os responsáveis pela execução de diversas obras urbanas, pela criação e/ou ampliação de diferentes indústrias de base, se configurando como importante ator no processo de industrialização no país, financiando inclusive a construção de alguns dos principais ícones da arquitetura moderna brasileira, a citar, os prédios do Ministério da Educação e da Previdência, além da construção de Brasília. No Nordeste, mais precisamente, foram os propulsores da verticalização da maior parte de suas capitais.

Palavras Chave: Políticas Públicas Habitacionais. Caixas e Institutos de Aposentadoria e Pensões (CAPs/IAPs). Nordeste. Habitação Social. 
ALMEIDA, Caliane Christie Oliveira de. Social Housing in the Northeast: the role of CAPs and IAPs (1930-1964). 2012. 395p. Thesis (PhD) - Institute of Architecture and Urbanism of São Carlos (IAUSC), University of São Paulo (USP), São Carlos, 2012.

The existing security institutes were created mainly along the first three decades of the twentieth century, and they had as main objective to ensure financial assistance in case of illness or death of the breadwinner, mainly focused on the civil service of the country. Gradually, their roles were expanding to the field of work, going to conform to service agencies and insurance for other labor categories, culminating in the creation and diversification of boxes and the Retirement and Pension Institutes subordinated to MTIC. It was in this context that the construction and financing of housing units started to be regarded as a state responsibility in Brazil. The identification and analysis of public policy undertaken by the aforementioned housing agencies in the Northeast, between 1930 and 1964, and the resulting production of housing, architecture, urbanism and professionals involved, conformed as the main objectives of this thesis. An empirical analytical, based on different sources, especially primary, that dialogue at different levels for the deconstruction of historiographic fossilized truths on the subject and the knowledge of an action still overshadowed by analyzes focused on the production of the center-south. Getting rid of the current historiographical optimism about the role of IAPS, which are little studied on the CAPs, there was a restrictive policy in the Northeast focused mainly on meeting the housing aspirations of the wealthier urban workers, including employers, who came to representing $45.74 \%$ of the granted claims. The quantification of this housing production stands around 20,000 units, representing $62.46 \%$ of the volume of claims raised by the history for the North, South and Northeast, confirming the hypothesis of the need for further studies on the activities the above security institutes throughout the country. One hundred fifty more residential groups were precisely identified, including single-family units and collective buildings, in most cases devoid of equipment for collective use. Broad was also the part of staff, formed mainly by engineers and architects, acting directly or indirectly through the CAPs/IAPs in the field of housing in the region: an amount of approximately 200 professionals. In terms of architecture and urbanism, it was found a variety of models linked to different architectural references. Surprisingly, it was observed that in addition to the funding of the first modern residential complexes, the CAPs and the IAPs were responsible for the implementation of various urban development, the creation and/or expansion of different industries, shaping up as an important actor in the process industrialization in the country, including financing the construction of some of the major icons of modern Brazilian architecture, quote, the buildings of the Ministry of Education and Welfare, besides the construction of Brasilia. In the Northeast, more precisely, were the drivers of vertical integration of most of their capital.

Keywords: Public Housing Policy. CAPs/IAPs. Northeast. Social Housing. 


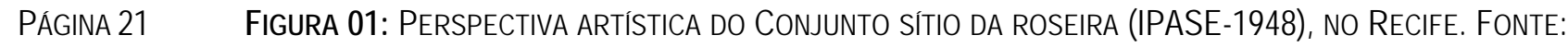
INSS-PE.

PÁgina 41 hgura 02: Perspectiva artística do Conjunto Brigadeiro Francisco Bentes Monteiro (IPASE/SUDENE-1964), NO RECIFE. FONTE: INSS-PE.

PÁGINA 102 HGURA 03: VISTA AÉREA DO CONJUNTO PASSO D'AREIA, EDIFICADO PELO IAPI-RS, E SUAS DISTINTAS TIPOLOGIAS. FONTE: BONDUKI, 2002.

PÁGINA 102 FGURA 04: VISTA AÉREA DO CONJUNTO JARDIM PIRATININGA, EDIFICADO PELO IAPI EM OSASCO-SP. FONTE: BRUNA, 2010.

PÁgina 103 hgura 05: Conjunto de Paquetá, na ilha de Paquetá/Baía de Guanabara. Exemplo de RACIONALIZAÇÃO DO ESPAÇO CONSTRUÍDO. FONTE: BONDUKI, 2002.

PÁGINA 104

FGURA 06: EDIF́́CIO JAPURÁ (IAPI-SP). FONTE: BRUNA, 2010.

PÁGINA 104

FGURAS 07: EDIF́́CIO ANCHIETA (IAPC-SP). FONTE: BRUNA, 2010.

PÁGINA 104

FGURAS 08: EDIFÍCIO NOVE DE JULHO (IAPB-SP). FONTE: BRUNA, 2010.

PÁGINA 104 HGuRAS 09: Planta-TIPO DO EDIF́́CIO GENERAL OSÓRIO (IAPI-CAMPINAS), COM SUAS DISTINTAS FUNÇÕES. FONTE: BRUNA, 2010.

PÁGINA 105 FGURA 10: IMPLANTAÇÃo DO CONJ. VILA GUIOMAR (IAPI-SANTO ANDRÉ), COM APROXIMAÇÕES AO MODELO DE CIDADE-JARDIM. FONTE: BRUNA, 2010.

PÁGINA 105 HGURA 11: VISTA AÉREA DO CONJUNTO SANTA CRUZ do IAPB-SP. ATENTAR PARA A ABUNDÂNCIA DE VEGETAÇÃO. FONTE: BRUNA, 2010.

PÁGINA 105 HGURA 12: MAQUETE DA CIDADE-JARDIM DO IAPC-SP. FONTE: BRUNA, 2010.

PÁGINA 106 HGURA 13: CONJUNTO RESIDENCIAL VÁRZEA DO CARMO (IAPI-SP), EDIFICADO EM 1942. FONTE: BRUNA, 2010.

PÁGINA 106 FGuRA 14: CONJUNTO INDUSTRIÁRIO (IAPI-BH), DE WHITE LÍRIO, COM INFLUÊNCIA DA HÖFE VIENENSE. FONTE: BONDUKI, 2002

PÁGINA 106 FGURA 15: CONJUNTO SANTO ANTÔNIO (IAPB-SP), EDIFICADO NO INÍCIO DA DÉCADA DE 1950. FONTE: BRUNA, 2010.

PÁGINA 107 HGURA 16: ELEMENTOS VAZADOS, PILOTIS E PASSARELAS INTERNAS DO EDIFíCIO DOS BANCÁRIOS (IAPB), CONSTRUÍDO EM MARÍLIA (SP), NA DÉCADA DE 50. FONTE: BONDUKI, 2002.

PÁGINA 107 HGURA 17: CONJ. HONÓRIO GURGEL DO IAPI-RJ, EDIFICADO NA DÉC.1950. DESTAQUE PARA A MARQUISE E A SOLUÇÃO DE CAIXA DE ESCADA ABERTA. FONTE: BONDUKI, 2002.

PÁGINA 107 FGURA 18: VISTA AÉREA DO CONJUNTO TERRA NoVA (IAPI-RJ), EDIFICADO NA DÉCADA DE 1950. FONTE: BONDUKI, 2002.

PÁGINA 108 HGuRA 19: CONJUNTO PIRATININGA CONSTRUÍDO PELO IAPI EM OSASCO, NA DÉCADA DE 1940. FONTE: BRUNA, 2010.

PÁGINA 108 FGURA 20: CONJUNTO DO IAPB EM SANTOS, EDIFICADO ENTRE AS DÉCADAS DE 1940 E 1950. FONTE: BONDUKI, 2002.

PÁGINA 109 FGURA 21: CONJUNTO DA MOOCA (IAPI-SP). FONTE: BRUNA, 2010.

PÁGINA 109 FGURA 22: CONJUNTO DA MOOCA (IAPETC-SP). FONTE: BRUNA, 2010

PÁGINA 110 HGURA 23: VISTA AÉREA DOS BLOCOS DO CONJUNTO VILA GUIOMAR, EM SANTO ANDRÉ-SP (IAPI). FONTE: BRUNA, 2010.

PÁGINA 110 HGURA 24: CONJUNTO RESIDENCIAL DO IAPI EM SANTOS. ATENTAR PARA O USO DE TRELIÇAS DE MADEIRA NO PROJETO ORIGINAL. FONTE: BRUNA, 2010.

PÁGINA 110 FGURA 25: Planta-tiPO dOS BLOCOS DO CONJUNTO dA MOOCA EM SÃo PAULO (IAPI). FONTE: BRUNA, 2010.

PÁGINA 117 HGURA 26: HOSPITAL JoÃo GOULART (IAPC-1956), EDIFICAdO PRÓXIMO À VILA PRESIDENTE JoÃo GOULART, EM PEIXINHOS-OLINDA/PE. FONTE: INSS-PE.

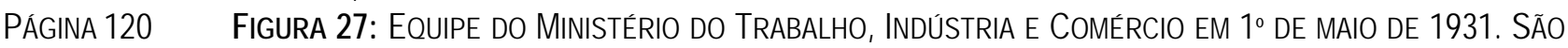
PERCEBIDOS DA ESQUERDA PARA A DIREITA E SENTADOS: HEITOR MUNIZ (TERCEIRO), JOAQUIM PIMENTA (QuARTO), ANTÔNIO EVARISTO DE MORAES (QUinto) E LINDOLFO COLLOR (AO CENTRO, DE ÓCULOS). FONTE: ARQUIVO LINDOLFO COLLOR, CPDOC/FGV, 2010.

PÁGINA 125 HGURA 28: PRÉdIO do MinISTÉRIO dO TRABALHO, INDÚSTRIA E COMÉRCIO NO RIO dE JANEIRO, 1938. FONTE: ARQUIVO GUSTAVO CAPANEMA, CPDOC/FGV, 2010.

PÁGINA 127 HGuRA 29: CARTA ENDEREÇADA AO MINISTRO DO TRABALHO EVARISTO DE MORAIS, EM 1944, ENVIADA PELO ENGENHEIRO DO IAPETC, HELVÉCIO XAVIER. INDICA A EXISTÊNCIA DE ATIVIDADES RECREATIVAS NO 
PÁgINA 141

PÁGINA 142

PÁGINA 144

PÁGINA 146

PÁGINA 149

PÁGINA 156

PÁGINA 157

PÁGINA 158

PÁGINA 159

PÁGINA 159

PÁGINA 167

PÁGINA 168

PÁGINA 169

PÁGINA 173

PÁGINA 175

PÁGINA 176

PÁGINA 179

PÁGINA 182

PÁGINA 183

PÁGINA 185

PÁGINA 190

PÁGINA 191

PÁGINA 196

PÁGINA 197

PÁGINA 197

PÁgINA 199

PÁGINA 203

PÁGINA 205

CEIO de ALGUNS INSTITUTOS DE PREVIDÊNCIA, COMO PRECONIZADO POR RUBENS PORTO NA DÉCADA ANTERIOR. FONTE: ACERVO DA BIBLIOTECA VIRTUAL EVARISTO DE MORAIS, 2010.

FigurA 30: PARALELOGRAMO DE OWEN. FONTE: BENÉVOLO, 1987.

FIGURA 31: MODELO DE CIDADE IDEAL DE JAMES S. BUCKINGHAM. FONTE: BUCKINGHAM, 1849.

FIGURA 32: REPRESENTAÇÃO GRÁFICA DO MODELO DE CIDADE-JARDIM HOWARDIANO.

FONTE: AYMONINO, 1973.

FiguRA 33: MAQUETE dO CONJUNTO GAMBOA, NO RIO DE JANEIRO. FontE: SAMPAIO (2002).

FIGURA 34: RESIDÊNCIA EDIFICADA POR MEIO DE FINANCIAMENTO CONCEDIDO PELO IPASE EM JOÃO PESSOA, NO ANO DE 1959. FONTE: INSS-PB

FIGURA 35: ESCOLA EDIFICADA PELO IAPETC EM SALVADOR, NA DÉCADA DE 1940.

FONTE: ARQUIVO PESSOAL, 2011.

FIGURA 36: GRÁFICO DE DISTRIBUIÇÃO DA ATUAÇÃO DAS CAPS E DOS IAPS EM SALVADOR NO PERÍODO DE 1938 A 1964. FONTE: ELABORAÇÃO PRÓPRIA COM BASE NOS DADOS COLETADOS NO INSS-BA.

FIGURA 37: EDIFÍCIO HELENA (IAPC-1955). FONTE: INSS-BA, 2011.

FIGURA 38: QUADRO DE DISTRIBUIÇÃO DA ATUAÇÃO DOS ESCRITÓRIOS ESTADUAIS DOS INSTITUTOS DE PREVIDÊNCIA ATUANTES EM SALVADOR. FONTE: ELABORAÇÃO PRÓPRIA COM BASE NOS DADOS COLETADOS NO INSS-BA.

FIGURA 39: QUADRO DE CLASSIFICAÇÃO DAS AÇÕES IMOBILIÁRIAS DAS CAPS E DOS IAPS EM SALVADOR. FONTE: ELABORAÇÃO PRÓPRIA COM BASE NOS DADOS COLETADOS NO INSS-BA.

FIGURA 40: QUADRO GERAL DAS LIBERAÇÕES PARA CONSTRUÇÃO E/OU FINANCIAMENTO DE MORADIAS DAS CAPS E DOS IAPS NO RECIFE. FONTE: ELABORAÇÃO PRÓPRIA COM BASE NOS DADOS COLETADOS NO INSS-PE.

FIGURA 41: QUADRO GERAL DA ATUAÇÃO (UNIDADES CONSTRUÍDAS E/OU FINANCIADAS) DAS CAPS E DOS IAPS NO RECIFE. FONTE: ELABORAÇÃO PRÓPRIA COM BASE NOS DADOS COLETADOS NO INSS-PE.

FIGURA 42: QUADRO DE CLASSIFICAÇÃO DAS AÇÕES IMOBILIÁRIAS DAS CAPS E DOS IAPS NO RECIFE. FONTE: ELABORAÇÃO PRÓPRIA COM BASE NOS DADOS COLETADOS NO INSS-PE.

FGGURA 43: GRÁFICO GERAL DA ATUAÇÃO DAS CAPS E DOS IAPS EM JOÃO PESSOA. FONTE: ELABORAÇÃO PRÓPRIA COM BASE NOS DADOS COLETADOS NO INSS-PB.

FIGURA 44: QUADRO DE DISTRIBUIÇÃO DA ATUAÇÃO DOS ESCRITÓRIOS ESTADUAIS DAS CAPS E DOS IAPS EM JOÃO PESSOA. FONTE: ELABORAÇÃO PRÓPRIA COM BASE NOS DADOS COLETADOS NO INSS-PB.

FIGURA 45: QUADRO DE CLASSIFICAÇÃO DAS AÇÕES IMOBILIÁRIAS DOS INSTITUTOS DE PREVIDÊNCIA EM JOÃO PESSOA. FONTE: ELABORAÇÃO PRÓPRIA COM BASE NOS DADOS COLETADOS NO INSS-PB.

FGGURA 46: BASE AÉREA NORTE-AMERICANA NAS PROXIMIDADES DE NATAL, NA DÉCADA DE 1940. FONTE: JAECI (2006).

FIGURA 47: QUADRO DE CLASSIFICAÇÃO DAS AÇÕES IMOBILIÁRIAS DOS IAPS E DAS CAPS EM NATAL. FONTE: ELABORAÇÃO PRÓPRIA COM BASE NOS DADOS COLETADOS NO INSS-RN.

FIGURA 48: QUADRO DE DISTRIBUIÇÃO DA ATUAÇÃO DAS CAPS E DOS IAPS EM NATAL NO PERÍODO DE 1944-1964. FONTE: ELABORAÇÃO PRÓPRIA COM BASE NOS DADOS COLETADOS NO INSS-RN.

FIGURA 49: QUADRO DA ATUAÇÃO DAS CAPS E DOS IAPS EM NATAL AO LONGO DAS DÉCADAS DE 1940 A 1960. FONTE: ELABORAÇÃO PRÓPRIA COM BASE NOS DADOS COLETADOS NO INSS-RN.

FIGURAS 50 E 51: GRÁFICO E QUADRO DE CLASSIFICAÇÃO DOS TIPOS DE FINANCIAMENTOS CONCEDIDOS PELAS CAPS E IAPS EM FORTALEZA. FONTE: ELABORAÇÃO PRÓPRIA COM BASE NOS DADOS COLETADOS NO INSS-CE.

FIGURA 52: QUADRO DE DISTRIBUIÇÃO DA ATUAÇÃO DAS CAPS E DOS IAPS EM FORTALEZA NO PERÍODO DE 1938-1966. FONTE: ELABORAÇÃO PRÓPRIA COM BASE NOS DADOS COLETADOS NO INSS-CE.

FIGURA 53: QUADRO DE DISTRIBUIÇÃO DA ATUAÇÃO DAS CAPS E DOS IAPS EM TERESINA. FONTE: ELABORAÇÃO PRÓPRIA COM BASE NOS DADOS COLETADOS NO INSS-PI.

FIGURA 54: GRÁFICO DA ATUAÇÃO DOS DIFERENTES ESCRITÓRIOS ESTADUAIS DAS CAPS E DOS IAPS EM TERESINA. FONTE: ELABORAÇÃO PRÓPRIA COM BASE NOS DADOS COLETADOS NO INSS-PI.

FIGURA 55: QUADRO DE CLASSIFICAÇÃO DAS AÇÕES IMOBILIÁRIAS DAS CAPS E DOS IAPS EM TERESINA. FONTE: ELABORAÇÃO PRÓPRIA COM BASE NOS DADOS COLETADOS NO INSS-PI.

FIGURA 56: QUADRO DE ESPECIFICAÇÃO DO NÚMERO DE UNIDADES EDIFICADAS EM GRUPOS DE MORADIAS E DIRETAMENTE PELOS INSTITUTOS DE PREVIDÊNCIA EM SÃO LUÍS. FONTE: ELABORAÇÃO PRÓPRIA COM BASE NOS DADOS DO INSS-MA.

FGURA 57: ESPACIALIZAÇÃO DA PRODUÇÃO HABITACIONAL DAS CAPS E DOS IAPS EM SALVADOR. FONTE: ELABORAÇÃO PRÓPRIA, COM BASE CARTOGRÁFICA DA PREFEITURA E DADOS COLETADOS NO INSS-BA.

FIGURA 58: ESPACIALIZAÇÃO DA PRODUÇÃO HABITACIONAL DAS CAPS E DOS IAPS NO RECIFE. FONTE: ELABORAÇÃO PRÓPRIA, COM BASE CARTOGRÁFICA DA PREFEITURA E DADOS COLETADOS NO INSS-PE. 
PÁGINA 207 FGURA 59: ESPACIALIZAÇÃO DA PRODUÇÃO HABITACIONAL DAS CAPS E DOS IAPS EM JOÃO PESSOA. FONTE: ELABORAÇÃO PRÓPRIA, COM BASE CARTOGRÁFICA DA PREFEITURA E DADOS COLETADOS NO INSS-PB.

PÁGINA 211 FGURA 60: ESPACIALIZAÇÃO DA PRODUÇÃO HABITACIONAL DAS CAPS E dOS IAPS EM NATAL. Fonte: ELABORAÇÃO PRÓPRIA, COM BASE CARTOGRÁFICA DA PREFEITURA E DADOS COLETADOS NO INSS-RN.

PÁGINA 212 FGURA 61: ESPACIALIZAÇÃO DA PRODUÇÃO HABITACIONAL DAS CAPS E DOS IAPS EM FORTALEZA. FONTE:

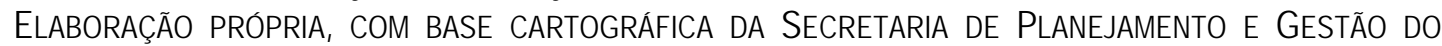
ESTADO DO CE, E DADOS COLETADOS NO INSS-CE.

PÁGINA 213 HGURA 62: ESPACIALIZAÇÃO DA PRODUÇÃO HABITACIONAL DOS INSTITUTOS DE PREVIDÊNCIA EM TERESINA. FONTE: ELABORAÇÃO PRÓPRIA, COM BASE CARTOGRÁFICA DA PREFEITURA E DADOS COLETADOS NO INSS-PI.

PÁGINA 214 FGURA 63: ESPACIALIZAÇÃO DA PRODUÇÃO HABITACIONAL DOS ÓRGÃOS EM SÃO LUÍS. FontE: ELABORAÇÃO PRÓPRIA, COM BASE CARTOGRÁFICA DO GOOGLE MAPS E DADOS COLETADOS NO INSS-MA.

PÁGINA 232 FGURA 64: QUADRO DE CLASSIFICAÇÃO DOS VALORES DOS PLEITOS CONCEDIDOS AOS ASSOCIADOS PELAS CAPS E IAPS EM SALVADOR. FONTE: ELABORAÇÃO PRÓPRIA COM BASE NOS DADOS COLETADOS NO INSS-BA.

PÁGINA 232 HGURA 65: QUADRO DE CLASSIFICAÇÃO DOS SALÁRIOS DOS ASSOCIADOS DOS ÓRGÃOS EM SALVADOR. FONTE: ELABORAÇÃO PRÓPRIA COM BASE NOS DADOS COLETADOS NO INSS-BA.

PÁGINA 233 FGURA 66: QUADRO DE CLASSIFICAÇÃO DOS SALÁRIOS DOS ASSOCIADOS DOS ÓRGÃOS NO RECIFE. FONTE: ELABORAÇÃO PRÓPRIA COM BASE NOS DADOS COLETADOS NO INSS-PE.

PÁGINA 234 FGURA 67: QUADRO DE CLASSIFICAÇÃO DOS VALORES DOS PLEITOS CONCEDIDOS AOS ASSOCIADOS PELOS ÓRGÃOS NO RECIFE. FONTE: ELABORAÇÃO PRÓPRIA COM BASE NOS DADOS COLETADOS NO INSS-PE.

PÁGINA 235 HGURA 68: QUADRO DE CLASSIFICAÇÃO DOS VALORES DOS PLEITOS CONCEDIDOS AOS ASSOCIADOS PELOS ÓRGÃOS EM JOÃO PESSOA. FONTE: ELABORAÇÃO PRÓPRIA COM BASE NOS DADOS COLETADOS NO INSS-PB.

PÁGINA 236 FGURA 69: QUADRO DE CLASSIFICAÇÃO DOS SALÁRIOS DOS ASSOCIADOS DOS ÓRGÃOS EM JOÃO PESSOA. FONTE: ELABORAÇÃO PRÓPRIA COM BASE NOS DADOS COLETADOS NO INSS-PB.

PÁGINA 240 HGURA 70: QUADRO DE ESPECIFICAÇÃO DOS VALORES SALARIAIS RECEBIDOS PELOS TRABALHADORES CONTEMPLADOS COM FINANCIAMENTOS IMOBILIÁRIOS CONCEDIDOS PELAS CAPS E IAPS EM NATAL. FONTE: ELABORAÇÃO PRÓPRIA COM BASE NOS DADOS DO INSS-RN.

PÁGINA 240 HGURA 71: QUADRO DE CLASSIFICAÇÃO DOS VALORES DOS PLEITOS CONCEDIDOS AOS ASSOCIADOS PELOS ÓRGÃOS EM NATAL. FONTE: ELABORAÇÃO PRÓPRIA COM BASE NOS DADOS COLETADOS NO INSS-RN.

PÁGINA 241 HGURA 72: QUADRO DE CLASSIFICAÇÃO DOS VALORES DOS PLEITOS CONCEDIDOS AOS ASSOCIADOS PELOS ÓRGÃOS EM FORTALEZA. FONTE: ELABORAÇÃO PRÓPRIA COM BASE NOS DADOS COLETADOS NO INSS-CE.

PÁGINA 242 HGURA 73: QUADRO DE CLASSIFICAÇÃO DOS VALORES DOS SALÁRIOS RECEBIDOS PELOS TRABALHADORES EM FORTALEZA. FONTE: ELABORAÇÃO PRÓPRIA COM BASE NOS DADOS COLETADOS NO INSS-CE.

PÁGINA 243 FGURAS 74 E 75: QUADROS DE CLASSIFICAÇÃO DOS VALORES DOS SALÁRIOS RECEBIDOS PELOS TRABALHADORES E DOS PLEITOS CONCEDIDOS AOS ASSOCIADOS PELOS ÓRGÃOS EM TERESINA. FONTE: ELABORAÇÃO PRÓPRIA COM BASE NOS DADOS COLETADOS NO INSS-PI.

PÁGINA 245 HGURA 76: CONJUNTO RESIDENCIAL DOS INDUSTRIÁRIOS (IAPI-BA) NA ÉPOCA DA CONSTRUÇÃO (DÉCADA DE 1940). FONTE: ARQUIVO PESSOAL.

PÁGINA 254 FGURA 77: PLANTA BAIXA DE MORADIA DA VILA ALDEOTA DO IAPI-CE, COM CÔMODOS INTERLIGADOS. FONTE: INSS-CE.

PÁGINA 254 FGURA 78: PLANTA BAIXA DE UNIDADE DA VILA DA CAPESP-CE. FONTE: INSS-CE.

PÁGINA 255 FGURAS 79 E80: FACHADA E PLANTA BAIXA DE RESIDÊNCIA DA VILA DOS BANCÁRIOS EM TERESINA. FONTE: INSS-PI.

PÁGINA 256 HGURA81: FACHADA DE UMA DAS TIPOLOGIAS HABITACIONAIS DA VILA IPIRANGA (IAPI-1938), NA CAPITAL CEARENSE. FONTE: INSS-CE.

PÁGINA 256 FGURA 82: OUTRA TIPOLOGIA DE MORADIA DA VILA IPIRANGA EM FORTALEZA. FonTE: INSS-CE.

PÁgina 256 hGura 83: ResidênCIA da VILA HenRIQue de La RoQue (IAPC-1954), em JoÃo PessoA. Fonte: ARQUIVO PESSOAL.

PÁGINA 257 FGURA 84: RESIDÊNCIA DO CONJUNTO JK (IPASE-1960), EM JOÃO PESSOA. FONTE: ARQUIVO PESSOAL.

PÁGINA 257 FGURA 85: FACHADA DE UNIDADE HABITACIONAL DO CONJUNTO JACINTO MEDEIROS, EM JOÃO PESSOA. FONTE: INSS-CE.

PÁGINA 258 FGURA 86: RESIDÊNCIA DO CONJUNTO FILIPINHO (IAPC-1950), EM SÃo LUís. FONTE: ARQUIVO PESSOAL.

PÁGINA 258 HGURA 87: PLANTA BAIXA DE UNIDADE DO CONJUNTO RESIDENCIAL FILIPINHO (IAPC-1950). FonTE: VASCONCELOS, 2007. 
Figura 88: UNIDADE HABITACIONAL DA SEGUNDA ETAPA DO CONJUNTO RESIDENCIAL HENRIQUE DE LA ROQUE, EM JOÃO PESSOA. FONTE: ARQUIVO PESSOAL.

PÁgina 261 Figura 89: ResidênCIa do Conjunto Paulo Gentile (IPASE-1945), Em Natal. Fonte: Arquivo PESSOAL.

PÁGINA 262 FGURA 90: MORADIA DA VILA JOAQUIM NABUCO (IAPETC-1942), NO RECIFE. FONTE: ARQUIVO PESSOAL.

PÁGINA 264 FIGURAS 91 A 93: FACHADA FRONTAL, LATERAL E PLANTA BAIXA DE UNIDADE HABITACIONAL DA VILA DOS BANCÁRIOS, NO BAIRRO DE BROTAS EM SALVADOR. FONTE: INSS-BA.

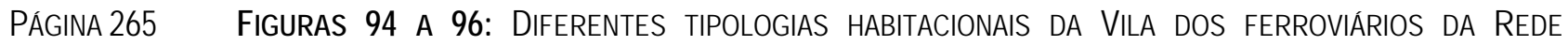
CEARENSE, NO BAIRRO DE ALDEOTA. FONTE: INSS-CE.

PÁGINA 266 Figura 97: FACHADA DAS RESIDÊNCIAS DO CONJUNTO MONTE CASTELO (IPASE-1964), EM TERESINA. FONTE: INSS-PI.

PÁGINA 266

PÁGINA 267

FiguRAS 98 E 99: IMPLANTAÇÃO DO CONJUNTO MONTE CASTELO. FONTE: INSS-PI.

PÁGINA 267

Figuras 100 E 101: IMPLANTAÇÃo dOS CONJUNTOS AEROPORTO I, EM TERESINA, E PARNAÍBA, NO MUNICÍPIO DE MESMO NOME, EDIFICADOS PELO IPASE NA DÉCADA DE 1960. FONTE: INSS-PI.

PÁGINA 268

PÁGINA 268 FIGURA 102: RESIDÊNCIAS GEMINADAS DUAS

PÁGINA 268

FGURA 103: FACHADA DAS MORADIAS DO I CONJ. SANTA JÚLIA, EM JOÃO PESSOA. FONTE: INSS-PB

PÁGINA 268 PESSOAL.

PÁGINA 269

FiGURA 105: RESIDÊNCIA DA VILA SÃO MIGUEL (IAPB-1940), NO RECIFE. FONTE: ARQUIVO PESSOAL.

PÁGINA 269

FIGURA 106: FACHADA PRINCIPAL DOS BLOCOS GEMINADOS DA VILA PRESIDENTE DUTRA, DA DÉCADA DE 1940, NO RECIFE. FONTE: INSS-PE.

PÁGINA 269

FIGURA 107: FACHADA DAS RESIDÊNCIAS EDIFICADAS PELO IAPC (1958), NO BAIRRO DE SAN MARTIM, NO RECIFE. FONTE: INSS-PE.

PÁGINA 269 Figura 109: Planta BaIXA DE UNIDADE DO CONJUNTO TAMBAUZINHO (IAPB-1958), EM JoÃo PESSOA. FONTE: INSS-PB.

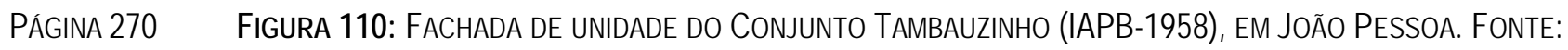
INSS-PB.

PÁGINA 270 FGURA 111: PLANTA BAIXA DE UNIDADE HABITACIONAL DO GRUPO SANTA JÚLIA (IPASE-1955), EM JoÃo PESSOA. FONTE: INSS-PB.

PÁGINA 271 FIGURA 112: RESIDÊNCIA DA VILA ASSIS RIBEIRO (IAPFESP-1943), NO RECIFE. FONTE: ARQUIVO PESSOAL

PÁGINA 271

PÁGINA 271

FIGURA 113: FACHADA DE MORADIA DA VILA RESIDENTE ALVIN (IAPFESP-1940), NO RECIFE.

FONTE: INSS-PE

Página 272 Figura 115: Planta do Conjunto da Mangueira (IAPB-1961), no bairRo de mesmo nome, no RECIFE. FONTE: INSS-PE.

PÁGINA 272

PÁGINA 273

PÁGINA 273

FIGURA 116: PRANCHAS DAS RESIDÊNCIAS DA VILA SÃO PEDRO (IAPI-1945), EM NATAL. FONTE: INSS-RN. FIGURA 117: FACHADA DAS RESIDÊNCIAS DA VILA PLATINICK (IAPB-1947), EM NATAL. FONTE: INSS-RN.

PÁGINA 273

Figura 118: Planta baiXa PADRÃO DA VILA PLATINICK EM NATAL, COM DESTAQUE PARA OS RECUOS LATERAIS. FONTE: INSS-RN.

PÁGINA 273

FIGURA 119: RESIDÊNCIA DA VILA GASPAR (CAPESP-BA). FONTE: INSS-BA.

PÁGINA 274

FIGURA 120: PLANTA BAIXA DAS RESIDÊNCIAS DA VILA GASPAR EM SALVADOR. FONTE: INSS-BA.

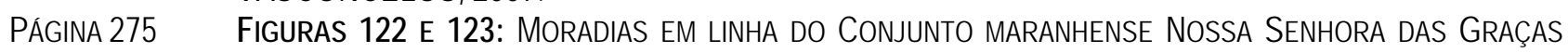
(IAPC-1957). FONTE: ARQUIVO PESSOAL.

Página 275 Figuras 124 e 125: Plantas das Vilas do iaPe, em Fortaleza, e do iapetc, no Recife, RESPECTIVAMENTE. FONTE: INSS-CE E PE.

PÁGINA 277 FiguRAS 126E127: PROJETO dO CONJUNTO JoÃo XXI (IAPB-1949), NO RECIFE (AO LADO) E RESIDÊNCIAS GEMINADAS DUAS A DUAS DO CONJUNTO POTILÂNDIA (IPASE-DÉC.1960), EM NATAL. FONTE: INSS-PE E ARQUIVO PESSOAL.

PÁGINA 278 FIGURAS 128E 129: FACHADA E PLANTA BAIXA DAS MORADIAS DA VILA FERROVIÁRIA EM CABEDELO-PB. FONTE: INSS-PB.

PÁGINA 279 Figuras 130 a 136: TIPOLOGIAS de FACHADAS B, C E A, RESPECTIVAMENTE, E TIPOLOGIAS DE PLANTAS D, A E C DO CONJUNTO JOSÉ BONIFÁCIO (IPASE-1953), EM SÃo LUÍS. FONTE: INSS-MA E ARQUIVO PESSOAL. 
PÁGINA 280 HGuRA 137: IMPLANTAÇÃo do CONJUNTO JosÉ BoNIFÁCIO (IPASE-1953), EM SÃo Luís. FONTE: INSS-MA.

PÁGINA 280 FGURA 138: FACHADA DAS RESIDÊNCIAS DA PRIMEIRA ETAPA DO CONJUNTO HENRIQUE EBoli (CAPESPRN). FONTE: INSS-RN

PÁGINA 280 FGURA 139: RESIDÊNCIAS DA SEGUNDA ETAPA DO CONJUNTO HENRIQUE EBOLI, EM NATAL. FONTE: INSS-RN.

PÁgINA 281 FGuras 140 a 142: TIPOLOGIAS HABITACIONAIS VERIFICADAS NO CONJUNTO SítIO do RosÁRIO (IPASE1948), NO RECIFE. FONTE: INSS-PE.

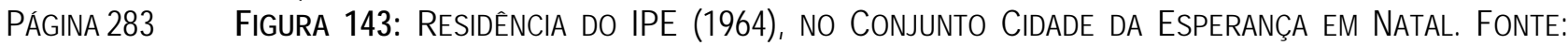
ARQUIVO PESSOAL.

PÁGINA 288 FGuRA 144: EdIFÍCIO JOIA (IAPB-1950), EM BOA VIAGEM, NO RECIFE. FONTE: INSS-PE.

PÁGINA 289 hguras 145 e 146: EdifícIo PRESIDENTE JoÃo PESSOA (IAPB-1957), EM JoÃo PeSSOA. Fonte: ARQUIVO PESSOAL E CHAVES, 2006; RESPECTIVAMENTE.

PÁgina 290 hgura 147: Detalhes da fachada principal do EdifícIo Presidente JoÃo Pessoa (IAPB-1957). FONTE: ACERVO PESSOAL.

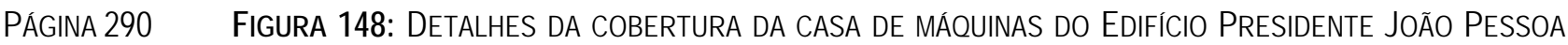
(IAPB-1957) FONTE: ACERVO PESSOAL (AO LADO).

PÁGINA 290 FGura 149: COBERTURA EM CASCA DE CONCRETO CURVA DA RODOVIÁRIA DE LONDRINA, DE VILANOVA ARTIGAS (ACIMA). FONTE: SCULLY JR, 2002.

PÁGINA 291 FGURA 150: PlantA BAIXA TIPO dOS PAVIMENTOS RESIDENCIAIS DO Ed. PRESIDENTE JOÃo PESSOA. FONTE: CHAVES, 2006.

PÁGINA 291 FGURA 151: EDIFÍCIO INCONFIDÊNCIA (IAPI-1945), NO RECIFE. FONTE: ARQUIVO PESSOAL.

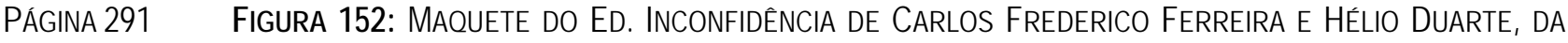
DÉCADA DE 1940. FONTE: BRUNA, 2010.

PÁGINA 292 FGURAS 153 E154: DETALHES DAS FACHADAS DO EDIFÍCIO INCONFIDÊNCIA (IAPI-1945), NO RECIFE. FONTE: ARQUIVO PESSOAL.

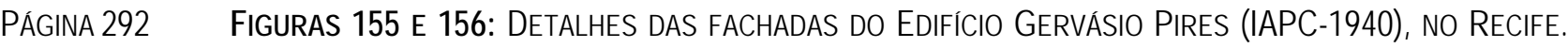
FONTE: ARQUIVO PESSOAL.

PÁGINA 294 HGURA 157: CONJUNTO BRIGADEIRO FRANCISCO BENTES MONTEIRO (IPASE/SUDENE-1964).

FONTE: ARQUIVO PESSOAL.

PÁGINA 295 HGURAS 158 a 160: RESIDÊNCIA, PLANTA-TIPO E IMPLANTAÇÃO DO CONJUNTO CASA AMARELA (IAPC1945), NO RECIFE. FONTE: ARQUIVO PESSOAL E INSS-PE.

PÁGINA 296 hGuras 161 a 163: PLANTAS DO PAVIMENTO TÉRREO E SUPERIOR E FACHADA DAS RESIDÊNCIAS DO CONJUNTO IMPERATRIZ (CAPESP-BA/SE), EM SALVADOR, EDIFICADO NA DÉCADA DE 1950.

FONTE: INSS-BA.

PÁGINA 296 FGURA 164: CONJ. JK (IAPB-1949), NO RECIFE. FONTE: ARQUIVO PESSOAL.

PÁGINA 297 FGURA 165: VISTA DE UM DOS BLOCOS DO II CONJUNTO AREIAS DO IAPI (1960), NO RECIFE. Fonte: ARQUIVO PESSOAL.

PÁGINA 298 HGURAS 166 a 170: FACHADAS DOS BLOCOS, PLANTA-TIPO, DETALHES DA PORTA DE ENTRADA E DAS ESCADAS DOS EDIFÍCIOS DO CONJUNTO DOS BANCÁRIOS, EM SÃO LUÍS. FONTE: ARQUIVO PESSOAL.

PÁGINA 299

PÁGINA 299

FGURA 171: CONJUNTO DOS BANCÁRIOS EM SÃO LUÍS-MA. FONTE: ARQUIVO PESSOAL.

PÁGINA 299

FGURA 172: PLANTA DO CONJUNTO MUTTI CARVALHO (IAPB-BA). FONTE: INSS-BA.

PÁGINA 299

FGURA 173: CONJUNTO RESIDENCIAL ANTÔNIO BALBINO (IAPC-BA). FONTE: ARQUIVO PESSOAL.

PÁGINA 299

FGURA 174: IMPLANTAÇÃO DO CONJUNTO DOS INDUSTRIÁRIOS, EM SALVADOR. FONTE: INSS-BA.

PÁGINA 299

FGURA 175: CONJUNTO MONTE SERRAT (IAPC-BA). FONTE: ARQUIVO PESSOAL.

PÁGINA 300

PÁGINA 301

FGURAS 176: IMPLANTAÇÃO DO CONJUNTO RESIDENCIAL JK (IAPC-BA). FONTE: INSS-BA.

FGURA 177: IMPLANTAÇÃO DO CONJUNTO CHICO CITY (IPASE/SUDENE-1964), NO RECIFE. FONTE: INSS-PE

PÁGINA 301

PÁGINA 302

PÁGINA 303

FGURAS 178 E 179: BLOCOS LAMINARES E CONSTRUÇÃO DO CONJUNTO DOS INDUSTRIÁRIOS (IAPI-1952), NO ATUAL BAIRRO DO IAPI EM SALVADOR. FONTE: ARQUIVO PESSOAL.

FGURA 180: IMPLANTAÇÃO DO CONJ. NOVA TIROL (IAPC-1957), EM NATAL. FONTE: INSS-RN.

FGURAS 181 E 182: BLOCO IV E PLANTA-TIPO DOS APARTAMENTOS DO CONJUNTO RESIDENCIAL NOVA TIROL (IAPC-1957), PROJETADO PELO ARQUITETO MOACYR MAIA NO BAIRRO NATALENSE DO TIROL. FONTE: ARQUIVO PESSOAL E INSS-RN.

PÁGINA 303 FGURA 185: CONJUNTO CASTRO AlVES (IAPETC-1953), EM SALVADOR. EXEMPLAR PRÓXIMO ÀS HÖFES. FONTE: ARQUIVO PESSOAL 
PÁGINA 303

PÁGINA 304

PÁgINA 304

PÁGINA 305

PÁGINA 306

PÁGINA 307

PÁGINA 308

PÁgINA 308

PÁGINA 309

PÁGINA 310

PÁGINA 311

PÁGINA 312

PÁGINA 314

PÁGINA 315

PÁgINA 316

PÁgINA 316

PÁGINA 316

PÁGINA 317

PÁGINA 317

PÁGINA 317

PÁGINA 317

PÁGINA 318

PÁGINA 319

PÁgINA 319

PÁGINA 320

PÁGINA 320

PÁGINA 320

PÁGINA 320

PÁGINA 321

PÁGINA 321

PÁGINA 321

PÁgINA 321

PÁGINA 321

Figura 186: ConJunto SÃo CRISTOVÃo, EM BELO HORIZONTE (IAPI-1948). FONTE: BONDUKI, 2002.

FIGURAS 187 E 188: PLANTA-TIPO DOS APARTAMENTOS E MORADIAS GEMINADAS DUAS A DUAS DO CONJUNTO CASTRO AlVES (IAPETC-1953), EM SAlVAdOR. Fonte: INSS-BA E ARQUIVO PESSOAL; RESPECTIVAMENTE.

FIGURA 189: IMPLANTAÇÃO DOS DOIS BLOCOS DO CONJ. ITAPAGIPE (IAPB-1953), EM SALVADOR.

FONTE: INSS-BA.

FIGURAS 190 A 192: BLOCOS DE APARTAMENTOS E MORADIAS ISOLADAS QUE COMPÕEM O CONJUNTO AlmiRANTE VALDEMAR MOtA OU ITAPAGIPE (IAPB-1953), EM SALVAdOR. FontE: ACERVO PESSOAL.

FiguRAS 193 E 194: BLOCOS DE APARTAMENTOS E ESCOLA PRIMÁRIA DO CONJUNTO GENERAL EULER BENTES MONTEIRO (IPASE-1964), NO RECIFE. FONTE: ARQUIVO PESSOAL.

FiGURAS 195 A 198: IMPLANTAÇÃO, BLOCOS DE APARTAMENTOS, DETALHES COMBOGÓS E UNIDADES GEMINADAS DUAS A DUAS DO I CONJUNTO AREIAS (IAPI-1943), NO RECIFE. FONTE: INSS-PE E ARQUIVO PESSOAL.

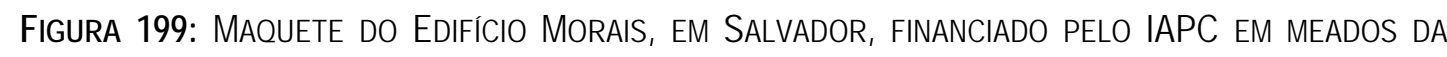
DÉCADA DE 1950. FONTE: INSS-BA.

Figura 200: Edifício Nosso Senhor do Bonfim (IAPC-1957), em Salvador. Fonte: ArQuivo PESSOAL.

FIGURA 201: EDIFÍCIO IGARASSU (IPASE-1957), NO RECIFE. FONTE: INSS-PE.

FIGURA 202 E203: EDIF́́CIO CAPIBARIBE (IAPC-1945) NA ÉPOCA DA CONSTRUÇÃO. FONTE: INSS-PE.

FIGURA 204: PERSPECTIVA ARTíSTICA DO EDIFÍCIO GILKA (IAPC-1953), EM BOA VIAGEM, NO RECIFE. FONTE: INSS-PE.

FigurAS 205 A 207: TIPOLOGIAS HABITACIONAIS DO I E II CONJUNTO DO IPASE (1963/1966) E NO CONJUNTO PRESIDENTE JOÃO GOULART (IPASE-1963). FONTE: ARQUIVO PESSOAL.

Figura 208: MORADIAS UNIFAMILIARES EM LINHA DA VILA JANETE (IAPI-1947), EM NATAL. FonTE: ALMEIDA, 2007.

FiguRAS 209 E 210: BLOCOS E IMPLANTAÇÃO DOS BLOCOS QUE COMPÕEM O CONJUNTO MONDUBIN (IAPC1955), EM FORTALEZA. FONTE: INSS-CE.

FIGURAS211E212: MORADIA FINANCIADA PELO IAPI (1950), EM SALVADOR. FONTE: INSS-BA.

FIGURAS 213 E 214: MORADIAS FINANCIADAS PELO ESCRITÓRIO DO IAPC EM NATAL, NA DÉCADA DE 1940, LOCALIZADAS NO BAIRRO DE PETRÓPOLIS E CIDADE ALTA. FONTE: INSS-RN.

FGURA 215: MORADIA FINANCIADA PELO IAPC EM SALVADOR, NO ANO DE 1947. FONTE: INSS-BA.

FigurAS 216 E 217: PLANTA BAIXA E FACHADA DE CASA FINANCIADA PELO IPASE-BA (DÉCADA DE 1960). FONTE: INSS-BA.

FIGURA 218: PLANTA BAIXA DE UNIDADE FINANCIADA PELO IAPC-BA (1950). FONTE: INSS-BA.

FIGURA 219: RESIDÊNCIA FINANCIADA PELO IPASE (1960), EM TERESINA. FONTE: INSS-PI

FIGURA 220: MORADIA FINANCIADA PELO IPASE (1964), EM TERESINA. FONTE: INSS-PI.

FIGURAS 221 A 227: RESIDÊNCIAS FINANCIADAS PELO IPASE-PI (60), IAPB-RN (50), IPASE-PB (59), IPASE-RN (50), IAPI-PB (49), IAPB-RN (50) E IPASE-PI (44). FONTE: INSS-PI, RN E PB.

FIGURAS 228 A 230: MORADIAS EDIFICADAS PELOS SEGURADOS DO IPASE-RN (1950), IAPB-RN (1940) E IAPB-CE (1961), RESPECTIVAMENTE. FONTE: INSS-PB.

(1). FONTE: INSS-PE E RN.

FIGURA 234: HABITAÇÃO GEMINADA COM COBERTURA ASA DE BORBOLETA (IAPB-PE). FONTE: INSS-PE.

FGURA 235: VOLUMETRIA SIMPLES DE MORADIA FINANCIADA PELO IAPC EM NATAL. FONTE: INSS-RN.

FIGURA 236: PLANTA BAIXA DE HABITAÇÃO EDIFICADA POR SEGURADO DO IPASE EM JOÃO PESSOA. FONTE: INSS-PB.

FIGURA 237: PLANTA DE RESIDÊNCIA FINANCIADA NO RECIFE. FONTE: INSS-PE.

FIGURA 238: PLANTA DE MORADIA NO RECIFE. DESTAQUE PARA O TERRAÇO DE REFEIÇÕES.

FONTE: INSS-PE.

Figura 239: Planta baixA de habitaÇÃo FinANCIADA PELO IAPB EM NATAL, NA DÉCADA DE 1950. DESTAQUE PARA A ÁREA DE SERVIÇO SEPARADA DO CORPO DA CASA. FONTE: INSS-RN.

FIGURA 240: PLANTA DE MORADIA EDIFICADA NO RECIFE. DETALHE PARA O JARDIM DE INVERNO PREVISTO. NO LAUDO DE AVALIAÇÃO O PROJETO FOI DENOMINADO MUITO SATISFATÓRIO. FONTE: INSS-PE

Figura 241: Planta de CASA FinANCIADA PELO IAPB EM NATAL. ATENTAR PARA A GRANDE ÁREA DE PERGOLADO PREVISTA. FONTE: INSS-RN.

Figura 242: Planta de CASA NO ReCIFE. ATENTAR PARA O JARDIM DE INVERSO NO CENTRO DA RESIDÊNCIA. FONTE: INSS-PE. 
FGura 243: PLANTA de RESIDÊNCIA FINANCIADA PELO IAPB EM NATAL, NA DÉCADA DE 1950. Fonte: INSS-RN.

PÁGINA 322 FGURA 244: PLANTA BAIXA DE RESIDÊNCIA CONSTRUÍDA COM FINANCIAMENTO CONCEDIDO PELO IAPB EM JOÃO PESSOA, EM 1949. FONTE: INSS-PB.

PÁGINA 322 HGura 245: FACHADA de MORADIA, COM tRAÇOS DECó, FINANCIADA PELA CAP do NoRdeste BRASILEIRO, NO RECIFE. FONTE: INSS-PE.

PÁGINA 323 HGURA 246: FACHADA PRINCIPAL DE MORADIA FINANCIADA PELO IPASE EM JOÃO PESSOA. FONTE: INSS-PB.

PÁGINA 323 FGURA 247: RESIDÊNCIA EDIFICADA POR SEGURADO DO IAPB EM NATAL, NA DÉCADA DE 1950. FonTE: INSS-RN.

PÁGINA 323

FGURA 248: FACHADA DE RESIDÊNCIA EM FORTALEZA (IAPC-1947). FONTE: INSS-CE.

PÁGINA 323

HGURA 249: RESIDÊNCIA FINANCIADA PELO IAPI EM FORTALEZA. FONTE: INSS-CE.

PÁGINA 323

HGURA 250: MORADIA FINANCIADA PELO IAPC EM FORTALEZA. FONTE: INSS-CE.

PÁGINA 323

HGURA 251: HABITAÇÃO EDIFICADA EM FORTALEZA (IAPI-CE). FONTE: INSS-RN.

PÁGINA 324

FGURA 252: MORADIA EDIFICADA COM FINANCIAMENTO CONCEDIDO PELO IAPC EM RECIFE. FONTE: INSS-PE E RN.

PÁGINA 324 HGURA 253: MORADIA EDIFICADA COM FINANCIAMENTO CONCEDIDO PELO IAPC EM NATAL. FONTE: INSS-PE E RN.

PÁGINA 327 HGURA 254: EdiFícIO SEDE dO IPASE EM SALVAdOR. FonTE: ANDRADE JR, 2007.

PÁGINA 328 HGURA 255: TEATRO CASTRO ALVES EM SALVADOR. FONTE: WWW.TCA.BA.GOV.BR.

PÁGINA 330 FGURA 256: IGREJA NosSA SenHORA DA FÁtIMA, NO RECIFE. FonTE: SMITH, 2008.

PÁGINA 330 FGURA 257: RESIDÊNCIAS DE MUNIER NO RECIFE. FONTE: SMITH, 2008.

PÁGINA 332

PÁGINA 333

FGURA 258: SEDE DO IPSEP NO RECIFE. FONTE: ARQUIVO PESSOAL.

PÁGINA 336

HGURA 259: ED. RIO SUL, NO RIO DE JANEIRO. FONTE: SENDKY, 2000.

FGURA 260: VISTA AÉREA DO JÁ DEMOLIDO ESTÁDIO JOÃO MACHADO E DO GINÁSIO HUMBERTO NESI, À DIREITA O CENTRO ADMINISTRATIVO, EM NATAL. FontE: TRIBUNA DO NORTE, 2010.

PÁGINA 341 FGURA 261: VISTA AÉREA DO CONJUNTO CIDADE DA ESPERANÇA (IPE/SUDENE-1964), EM NATAL. FONTE: ARQUIVO PESSOAL.

PÁGINA 351 HGuRA 262: GRÁFICO GERAL dO PERÍOdO DE ATUAÇÃO DAS CAPS E DOS IAPS NO CAMPO DA MORADIA, NAS SETE CAPITAIS NORDESTINAS ESTUDADAS. FONTE: ELABORAÇÃO PRÓPRIA COM BASE NOS DADOS LEVANTADOS NAS AGÊNCIAS DO INSS NA BA, PE, PB, RN, CE, PI E MA.

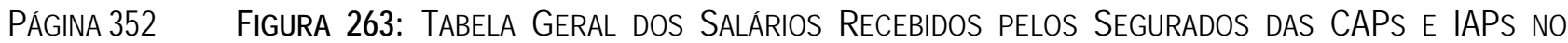
NORDESTE (1943-1951). FOI APRESENTADO SOMENTE O NÚMERO DE PROCESSOS QUE ESPECIFICARAM OS SALÁRIOS DOS SEGURADOS. FONTE: ELABORAÇÃO PRÓPRIA COM BASE NOS DADOS LEVANTADOS NAS AGÊNCIAS DO INSS NA BA, PE, PB, RN, CE, PIE MA.

HGuRA 264: TABELA GERAL DOS FINANCIAMENTOS CONCEDIDOS AOS SEguRAdOS DAS CAPS E IAPS NO NORDESTE (1943-1951). FOI APRESENTADO SOMENTE O NÚMERO DE PROCESSOS EM QUE O VALOR DO FINANCIAMENTO FOI ESPECIFICADO. FONTE: ELABORAÇÃO PRÓPRIA COM BASE NOS DADOS LEVANTADOS NAS AGÊNCIAS DO INSS NA BA, PE, PB, RN, CE, PIE MA.

PÁGINA 353 FGURA 265: GRUPOS DE MORADIAS EDIFICADOS E/OU FINANCIADOS PELAS CAPS E IAPS NO NORDESTE (1930-1964). FONTE: ELABORAÇÃO PRÓPRIA COM BASE NOS DADOS LEVANTADOS NAS AGÊNCIAS DO INSS NA BA, PE, PB, RN, CE, PIE MA.

PÁGINA 371 HGURA 266: EdIF́́CIO CAPIBARIBE NA ÉPOCA DE SUA CONSTRUÇÃO, NA SEGUNDA METADE DA DÉCADA DE 1940. FONTE: PROCESSO PILOTO DO EMPREENDIMENTO, 1945.

PÁGINA 385 HGURA 267: MORADIA EDIFICADA POR MEIO DE FINANCIAMENTO ATUARIAL EM FORTALEZA, NA DÉCADA DE 1940. FONTE: INSS-CE. 
AABB

ABNT

BHLB

$\mathrm{BNH}$

CAERN

CAPESP

CAPFESP

CAPIN

CAPOE

CAPS

CARPS

CECAP

CED

CEF

CFIEX

CHEEBB

CIAM

COHEX

CNOC

CNT

COHAB

CONESG

$\mathrm{CP}$

CPIN

CREA

CSN

CSN

DNT

DNPS

DOU

DSE

EESC

FAU

FCORS

FCP

FDES

FGTS

FIESP

FUNDHAP

GTB

HCURB

IAPAS

IAPB

IAPC

IAPE

IAPETC

IAPFESP

|API

IAPM

IAPS

IAUSC
ASSOCIAÇÃO ATÉTICA DOS BANCÁRIOS BRASILEROS

ASSOCIAÇÃOBRASILERA DE NORMAS TÉCNICAS

BANCOHPOTECÁRIOLAR BRASILERO

BANCO NACIONAL DE HABITAÇÃO

COMPANHA DEÁGUA E ESGOTOSDORIOGRANDE DONORTE

CAIXA DE APOSENTADORIA E PENSÃo dOS EMPREGADOS EM SERMÇOS PúBUCOS

INSTITUTO DE APOSENTADORIA E PENSÕES DOS FERROMÁRIOS E EMPREGADOS NOS

SERMÇOS PÚBUCOS

CAIXA DE APOSENTADORIA E PENSÕES DA IMPRENSA NACIONAL

CAIXA DE APOSENTADORIA E PENSÕES DOS OPERÁRIOS DE ESTIVAS

CAIXAS DE APOSENTADORIASE PENSÕES

COMSSÃODE APUCAÇÃO DE RESERVASDA PREVDÊNCIA SOCIAL

CAIXA ESTADUAL DE CASAS PARA OPOVO

COMSSÃOESTADUAL DE DESENVOLVMENTO

CAIXA ECONÔMCA FEDERAL

CAIXA DE FINANCIAMENTOIMOBILÁRIO DOEXÉRCITO

CONJUNTO HABITACIONAL DOS EMPREGADOS EM ESTABEFCIMENTOS BANCÁRIOS DA

BAHA

CONGRESSO NACIONAL DE ARQUITETURA MODERNA

CONJUNTOHABITACIONAL DOS SUBTENENTES DA BAHA

COMSSÃONACIONAL DE OBJECTORES DE PORTUGAL

CONSEHONACIONAL DO TRABALHO

COMPANHA DE HABITAÇÃO

COMPANHA NORDESTINA DE SONDAGENS E PERFURAÇÕES

CARTERA PREDIAL

CAIXA DE PENSÕES DA IMPRENSA NACIONAL

CONSEHOREGIONAL DE ENGENHARIAE ARQUTIETURA

COMPANHA SIDERÚRGICA NACIONAL

COMSSÃOdE SANEAMENTODENATAL

DEPARTAMENTONACIONAL DOTRABALHO

DEPARTAMENTO NACIONAL DE PREMDÊNCIA SOCIAL

DiÁRIO OFCIAL DA UNIÃO

DEPARTAMENTODE SANEAMENTO DOESTADO DO RIO GRANDE DO NORIE

ESCOLA DE ENGENHARIA DE SÃOCARLOS

FACULDADE DE ARQUITETURA E URBANISMO

FEDERAÇÃo dOS CírCulOS OPERÁRIOS DORIO GRANDE DO SUL

FUNDAÇÃOdA CASA POPULAR

FUNDODE DESENVLVMENTO ECONÔMCOE SOCIAL

FUNDODE GARANTIA POR TEMPODE SERVÇO

FUNDAÇÃODA INDÚSTRIA DOESTADODE SÃOPAULO

FUNDAÇÃOdA HABITAÇÃO POPULARDORO GRANDE DO NORTE

GRUPODE TRABALHODE BRASÍLA

GRUPO DE PESQUISA HISTÓRIA DA CIDADE EURBANISMO

INSTITUTO DE ADMINISTRAÇÃOFINANCERA DA PREMDÊNCIA SOCIAL

INSTITUTO DE APOSENTADORIA E PENSÃO DOS BANCÁRIOS

INSTITUTO DE APOSENTADORIA E PENSÃO DOS COMERCIÁRIOS

INSTITUTODE APOSENTADORIA EPENSÃODOS ESTIVADORES

INSTITUTO DE APOSENTADORIA E PENSÃO DOS EMPREGADOS NOS TRANSPORTES E CARGAS

INSTITUTO DE APOSENTADORIA E PENSÕES dOS FERROMÁRIOS E EMPREGADOS NOS SERVÇOS PÚBUCOS

INSTITUTODE APOSENTADORIA E PENSÃODOS INDUSTRIÁRIOS

INSTITUTO DE APOSENTADORIA E PENSÃO DOS MARITIMOS

INSTITUTOS DE APOSENTADORIASE PENSÕES

INSTITUTO DE ARQUTTETURA E URBANSMO DE SÃOCARLOS 


\begin{tabular}{|c|c|}
\hline IBGE & INSTTTUOBRASILERODE GEOGRAPA E ESTATÍSTICA \\
\hline IDORT & INSTTTUTODERACIONAUZAÇÃODOTRABALHO \\
\hline INP & INSTTUTOONACIONAL DE PREMDÊNCIA \\
\hline INPS & INSTTTUTO NACIONAL DE PREMDÊNCIA SOCIAL \\
\hline INSS & INSTTTUTO NACIONAL DE SEGURO SOCIAL \\
\hline IPASE & INSTTTUTO DE PREMDÉNCIA E ASSISTÊNCIA SOCIAL DOESTADO \\
\hline IPE & INSTTTUTO DE PREMDÉNCIA DOESTADO DORIO GRANDE DONORIE \\
\hline IPSEP & INSTTTUTO DE PREMDÊNCIA DOS SERMDORES DO ESTADO DE PERNAMBUCO \\
\hline ISSB & INSTTTUTO DE SERMÇO SOCIAL DOBRASIL \\
\hline ITE & INSTITUTO DE TECNOLOGIA \\
\hline JK & JUSCEUNO KUBITSCHEK \\
\hline LEC & LGAEIETORAL CATÓUCA \\
\hline LOPS & LE DEORDENAMENTO DA PREMDÊNCIA SOCIAL \\
\hline MAIC & MNSTÉRIO DA AGRICULTURA, INDÚSTRIA E COMÉRCIO \\
\hline MTIC & MNISTÉRIO DOTRABALHO, INDÚSTRIA E COMÉRCIO \\
\hline N.E. & NÃOESPECIACADO \\
\hline OIT & ORGANIZAÇÃOINITERNACIONAL DOTRABALHO \\
\hline PAR & PROGRAMA DE ARRENDAMENTORESIDENCIAL \\
\hline PC & PARTIDOCOMUNISTA \\
\hline RSN & REPARTIÇÃODE SANEAMENTODE NATAL \\
\hline$S / D$ & SEMDATA \\
\hline S/E & SEMESPECIFCAÇÃO \\
\hline SITI & SOCIEDADE IMOBIUÁRIA DE TERRENOS E INCORPORAÇÃO LMTADA \\
\hline SOTIL & SOCIEDADE DE TERRENOS IBURA LDA \\
\hline S/P & SEMPÁGINA \\
\hline SBPE & SISTEMA BRASILERO DE PENSÃO \\
\hline SESI & SERMÇOSOCIAL DA INDÚSTRIA \\
\hline SFH & SISTEMA FINANCERODE HABITAÇÃO \\
\hline SUDENE & SUPERINIENDÊNCIA DE DESENOLVMENTO DO NORDESTE \\
\hline TELERN & COMPANHA TEEFFÔNICA DORIO GRANDE DO NORTE \\
\hline UFRN & UNIVERSIDADE FEDERAL DORIO GRANDE DO NORTE \\
\hline USAID & AUANÇA PARA OPROGRESSO \\
\hline USP & UNIVERSIDADE DE SÃOPAULO \\
\hline
\end{tabular}


CAPítulo 01 CAPS E IAPS: Um PANORAMA dAS AçõES no CAMPO HABTTACIONAL

1.1. A previdência e a moradia no Brasil: considerações gerais acerca da atuação do poder público ao longo do século XX

1.2. Reavaliando Alguns Consensos Historiográficos

1.3. "Pelo Menor Preço a Melhor Casa": a Atuação das

CAPs e dos IAPs no Campo Habitacional no País e a Produção Resultante

1.4. A Nova Cultura da Habitação: as Diretrizes Arquitetônicas e Urbanísticas Adotadas Pelos Órgãos no País

CAPÍTULO 02 RE-ERÊNCIAS E MODEOS: A ESTRUTURAÇÃO DAS CAPS EDOS IAPS

2.1. O Engenheiro-Arquiteto Rubens Porto e as Reformas Legislativas

2.2. Rubens Porto: as Diretrizes Construtivas e sua Arquitetura Ideal

CAPítulo 03. As CAPS E os IAPS no NORDESTE

3.1. Atuação e Produção de Moradias nas Capitais

4.3. Os Profissionais Envolvidos nos Processos de Avaliação, Projeto, Construção 


\section{$0.0 \cdot$ INTRODUÇÃO}

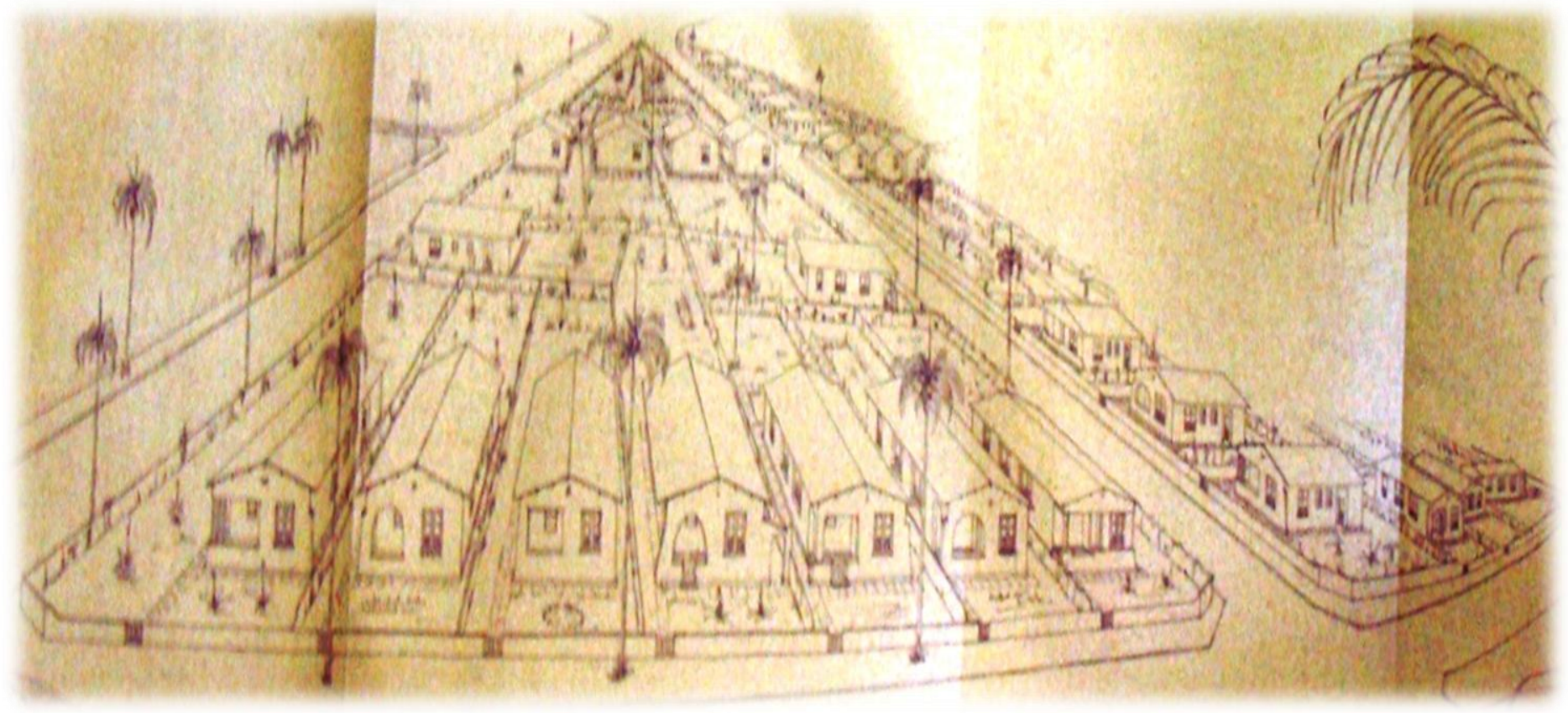




\section{INTRODUÇÃO}

No Brasil, a preocupação do Estado para com a proteção social dos cidadãos começou a ser vislumbrada com mais ênfase no século XIX, com a criação de órgãos sobre a influência da Igreja Católica, a exemplo de algumas caixas de socorros e montepios públicos, como o Montepio Geral de Economia dos Servidores do Estado (Mongeral) - criado em 1835 e destinado à cobertura previdenciária do funcionalismo público nacional - e da Caixa de Socorros para os Trabalhadores das Estradas de Ferro de Propriedade do Estado, fundada em 18881, ampliada no ano seguinte, para os trabalhadores dos Correios, Oficinas da Imprensa Régia e Montepio dos Empregados do Ministério da Fazenda.

Os institutos de previdência brasileiros continuaram a serem criados ao longo das quatro primeiras décadas do século XX, e possuíam como objetivo primordial a concessão de auxílios financeiros em caso de doença ou morte do chefe de família, voltados principalmente ao funcionalismo público. Paulatinamente, suas funções foram se ampliando, passando a se conformarem como órgãos de assistência e de seguro para os demais trabalhadores assalariados brasileiros. Esses órgãos ganharam corpo, sobretudo, a partir da década de 1920, com a socialização da previdência no país e a incorporação de parte dessas entidades, essencialmente as mútuas públicas, às recém-criadas CAPs subordinadas ao Ministério da Agricultura, Indústria e Comércio (MAIC) e, posteriormente, aos IAPs do Ministério do Trabalho, Indústria e Comércio (MTIC).

As Caixas e os Institutos de Aposentadoria e Pensões (CAPs/IAPs) correspondem a importantes órgãos vinculados não só à história da previdência e do trabalho no país, mas também à história da moradia urbana brasileira. Colaboraram, mais precisamente, tanto para o alargamento da ação estatal no que diz respeito à legislação trabalhista e à previdência social, quanto no que condiz à construção e ao financiamento de unidades habitacionais no Brasil. Foi ao longo do período de estruturação e atuação dos órgãos nesses setores - décadas de 1920 e 1930 -, que diversos reclames dos trabalhadores brasileiros, no tocante ao melhoramento das condições de vida e de trabalho e atrelados aos altos aluguéis e ao déficit de habitações vigentes, foram atendidos pelo poder público, que realizou uma considerável reforma em sua estrutura, tanto legislativa como institucional. Dessa forma, em nosso país a gênese e a trajetória da atuação estatal no campo da moradia, sobretudo social, estão intimamente vinculadas às questões previdenciárias e trabalhistas.

Nesse sentido, a presente tese aborda as temáticas das políticas públicas habitacionais, da história da habitação e da previdência estatal, abarcando ainda aspectos relacionados à atuação de engenheiros e arquitetos ao longo de quatro décadas de século XX, tendo a região Nordeste como estudo de caso. Mais especificadamente, refere-se ao estudo das proposições e das ações do poder público no âmbito habitacional, por meio principalmente das Caixas e Institutos de Aposentadorias e Pensões (CAPs/IAPs) nas

\footnotetext{
${ }^{1}$ Por meio da Lei n.3.397 de 24 de novembro de 1888, considerada uma importante lei de conteúdo previdenciário brasileira.
} 
cidades de São Luís, Teresina, Fortaleza, Natal, João Pessoa, Recife e Salvador, no que concerne à produção de moradias², entre os anos de 1930 e 1964.

Tal abordagem conforma-se como um desdobramento da dissertação de mestrado intitulada "Habitação Social: origens e produção (Natal, 1889-1964)", defendida em setembro de 2007, dando prosseguimento aos estudos desenvolvidos pela autora desde a iniciação científica (2001). Vincula-se também às pesquisas sobre a produção privada e pública de moradias para trabalhadores e aos debates em torno da habitação popular ocorridos no Brasil no século XX, empreendidos e orientados pela Profá. Drạ. Telma de Barros Correia.

No âmbito das atividades de pesquisa e levantamentos realizados nos arquivos públicos e privados de Natal, enquanto bolsista de iniciação científica vinculada ao Grupo de Pesquisa História da Cidade e Urbanismo (HCURB-UFRN), evidenciou-se a ausência de historiografia local que abordasse o processo de produção de moradias na cidade. Questionou-se naquele momento, quais seriam as ações pensadas e concretizadas pelo poder público na capital norte-riograndense no campo da habitação ao longo do século XX? Tal questão resultou na elaboração do trabalho de conclusão de curso, no ano de 2005. Concluída essa etapa, percebeu-se que ainda existia uma lacuna no tocante à produção de moradias pelo Estado, fosse por meio de incentivos ou por construção direta, no período compreendido entre os anos de 1889 e 1964 , especialmente àquela fruto das atuações dos IAPs, da FCP e demais órgãos estaduais e municipais. Indagava-se, essencialmente, quais seriam as origens e as particularidades da atuação estatal em Natal no campo da moradia social? Essas especulações resultaram na formulação da já referida dissertação de mestrado.

No mestrado, observou-se no tocante à atuação, sobremaneira dos IAPs em Natal, diversas peculiaridades quanto à estruturação desses órgãos, à organização das ações imobiliárias, ao caráter de suas atuações, bem como no que concerne às tipologias edificadas e aos materiais utilizados. Especificidades essas que se conformam como contraditórias e/ou muito distantes das colocações apresentadas pela historiografia especializada acerca da atuação, sobretudo, dos IAPs nas cidades de São Paulo, Rio de Janeiro e Belo Horizonte. Passou-se então a indagar, principalmente, quais seriam as semelhanças e as diferenças entre as atuações das Caixas e dos Institutos no Nordeste e nas demais cidades do centro-sul do país? Como se estruturou essa atuação em aspectos arquitetônicos e urbanísticos? O que há de local nas moradias financiadas e/ou construídas por esses órgãos no Nordeste? Quais as constantes e as especificidades arquitetônicas das casas proletárias no Nordeste? Dessa maneira, a identificação das especificidades na cidade de Natal despertou 0 interesse em averiguar as ações empreendidas pelos Institutos e Caixas de Aposentadoria e Pensões nas demais capitais nordestinas,

\footnotetext{
2 Vale aqui apontar que se previa inicialmente realizar o estudo de todas as nove capitais nordestinas, mas questões relacionadas às dificuldades de levantamentos e ao tempo para a conclusão da pesquisa contribuíram para que se deixasse de fora das análises aqui empreendidas, as cidades de Maceió e Aracajú, que serão abordadas num momento posterior a esta pesquisa.
} 
identificando e analisando suas especificidades e os dilemas das políticas sociais de habitação no Nordeste, contextualizado-as no cenário das mudanças sociais contemporâneas, num esforço de compreensão da história da moradia no Brasil e das políticas públicas habitacionais brasileiras.

Sabe-se que a produção relacionada à história da habitação no país, essencialmente aquela vinculada ao poder público e aos órgãos subordinados a ele e destinada à população carente, chamada nesta tese de habitação social, ainda não esclareceu uma gama de questões, sobretudo, aquela que traça o perfil da atuação e a produção de unidades habitacionais por órgãos, profissionais e outros atores, antes da criação do Banco Nacional de Habitação $(\mathrm{BNH})$, em 1964. Essa produção atualmente se encontra bastante pulverizada em diversos artigos específicos sobre um determinado órgão, período ou obra edificada, nos diversos eventos científicos regionais e nacionais no país ${ }^{3}$. Ainda são poucos os títulos publicados em formato de livro ou estudos mais aprofundados, decorrentes de pesquisas de mestrado ou doutoramento.

Destaca-se nesse sentido, a dissertação de mestrado apresentada à Faculdade de Filosofia, Letras e Ciências Sociais da USP, em 1983, intitulada "Estado e habitação no Brasil: o caso do Instituto da Previdência" de autoria de Marta Ferreira Farah, que corresponde à primeira pesquisa conhecida acerca da atuação das CAPs e dos IAPs tanto no setor previdenciário como no campo da habitação. Cabe aqui destacar que essa pesquisa se conformou e ainda se conforma até os dias de hoje, como a mais importante referência teórica e bibliográfica para os diversos estudos subsequentes nesse sentido. Em linhas gerais, Farah (1983) estudou a política desses órgãos, concentrando-se especificamente nos IAPs, e formulou um panorama geral de sua atuação e produção no país, periodizando-a. Apesar de sua importância inquestionável como precursora desta temática no Brasil, a autora toma como base para suas análises essencialmente algumas Portarias dos Escritórios Estaduais dos órgãos, principalmente do centro-sul do país - uma documentação complementar e, de certa forma, superficial dos aspectos da previdência social. Aliado a isso, a supracitada autora concentrou sua pesquisa na identificação e na análise dos fatores que levaram à intervenção do poder público no campo habitacional no contexto das transformações sociais brasileiras decorrentes, em sua concepção, da Revolução de 1930, ficando a produção habitacional propriamente dita, em segundo plano 4 .

Outro trabalho relevante refere-se à dissertação de mestrado apresentada à Faculdade de Arquitetura e Urbanismo da Universidade de São Paulo (FAU-USP), no ano de 1988, elaborada por Conceição de Maria Ferraz de Varon, sob o título "E a história se repete... as vilas operárias e os conjuntos residenciais dos IAPs no Rio de Janeiro". Nesse estudo, a autora concluiu que a intervenção do poder público no campo habitacional de 1850 a 1964 na cidade, foi um meio de viabilizar o desenvolvimento do setor da construção e, num plano maior, da economia do país. Atrelou seus objetivos à identificação de processos de produção e de apropriação do espaço urbano da região metropolitana do Rio de Janeiro, através da construção de vilas

\footnotetext{
${ }^{3}$ São exemplos de artigos: Santos et all (2002), Szücs et all (2003),Veiga et all. (2004), Koury et all (2005); Lapolli (2005), Santos et all (2005), Martins et all (2006), Antonucci (2007), Pereira et all (2009), dentre muitos outros.

${ }^{4}$ Cabe destacar que a identificação e análise dos grupos de moradias edificados pelos órgãos não foram empreendidas pela autora.
} 
operárias e dos conjuntos residenciais, exclusivamente, dos IAPS. Apesar de não possuir como enfoque a análise arquitetônica desses grupos de moradias, a dissertação se destaca por corresponder ao primeiro estudo que se propôs a identificar a produção dos Institutos de Aposentadoria e Pensões em âmbito estadual.

Outra pesquisa significativa nesse sentido foi empreendida por Marcus André Melo (1992) em seu doutoramento, denominada "O Estado, o boom do século e a crise da habitação: Rio de Janeiro e Recife (1937-1946)". Sua importância consiste em ampliar o vislumbre da ação do poder público no campo da moradia em uma capital nordestina, no intuito de instaurar uma política pública de habitação. Apesar de enfocar com mais afinco as questões que permeiam à política habitacional, deixando os aspectos associados à produção de moradias propriamente dita em um segundo plano, o supracitado trabalho foi de grande valia por comparar as atuações da administração pública entre uma importante cidade do Nordeste e o Rio de Janeiro, apontando as aproximações e distanciamentos das ações no campo da moradia, bem como por trazer o Recife para o rol do universo de estudo dos grupos de pesquisa do centro-sul do país.

Nabil Bonduki, por sua vez, em livro publicado no ano de 1998, intitulado "Origens da habitação social no Brasil: arquitetura, Lei do Inquilinato e difusão da casa própria", fruto de sua pesquisa de doutorado, delimitou o caminho da intervenção estatal no campo habitacional a partir da década de 1930, tanto no plano legislativo, quanto por meio da atuação de órgãos subordinados, como os Institutos de Aposentadoria e Pensões (IAPs) e a Fundação da Casa Popular (FCP), especialmente nas cidades do Rio de Janeiro e São Paulo. Uma análise que apesar de ser mais abrangente do ponto de vista arquitetônico e urbanístico que a empreendida por Farah (1983) e essencial para a difusão da necessidade de aprofundamento dos estudos e pesquisas voltadas à habitação de interesse social no Brasil pré-BNH, apresenta inúmeras lacunas, principalmente quanto às ações no restante do território nacional, sintetizando a atuação dos IAPs no Brasil como reflexo das ações desses órgãos no centro-sul do país. Associado a isso, o referido autor recai num comum engano historiográfico ao associar a produção dos Institutos quase que exclusivamente à arquitetura e urbanismo modernos, além de perpetuar alguns equívocos apresentados em trabalhos anteriores e repetir as lacunas e imprecisões encontradas, sobretudo, em Farah $(1983)^{5}$.

\footnotetext{
5 Um dos primeiros equívocos que merecem ser sanados diz respeito à numeração da legislação que autorizou as Caixas de Aposentadoria e Pensões do Ministério da Agricultura, Indústria e Comércio a edificarem unidades habitacionais para os seus segurados. Em Farah (1983, p.41) e, posteriormente, em Bonduki (1998, p.103), está especificado o Art 2. do Decreto n.19.469 de 17/12/1930, como o responsável por essa liberação. Realmente foi o segundo artigo que autorizou a construção de moradias pelas referidas CAPs, mas foi do Decreto n.19.496, de 17/12/1930, publicado no Diário Oficial de 19/12/1930 o responsável por tanto. Essa pequena confusão numérica é repercutida em diversas publicações recentes, a citar o livro de Adriano Botelho, "O urbanismo em fragmentos: a produção do espaço e da moradia pelas práticas do setor imobiliário", publicado em 2007 pela Fapesp, em parceria com a Annablume. A legislação apresentada por os autores acima elencados, na verdade, data de 08 de dezembro de 1930, e foi um decreto que restituiu à jurisdição do Ministério da Viação e Obras Públicas os assuntos relativos à Marinha Mercante e empresas de navegação de cabotagem, que trata do Decreto n.19.433 de 26/11/1930. No dia 17 de dezembro de 1930, data colocada, foram outorgados 22 itens legislativos (19 de abrangência nacional e 3 estaduais), dentre eles o Decreto n.19.495, que dispôs sobre a primeira organização do MTIC. Inclusive o regulamento para a construção de casas, baixado pelo Decreto n.21.326 de 27/04/1932, descrimina as alterações no Decreto n.19.496: "(...) atendendo ao que o decreto n.19.496, de 17 de dezembro de 1930, pelo qual foram alteradas disposições da lei n.5.109, de 20 de dezembro de 1926, estabeleceu a aplicação dos fundos das Caixas de Aposentadoria e Pensões na aquisição de títulos de renda federal e na construção de casas para os associados das respectivas Caixas, com suficiente garantia hipotecária, e a que, na conformidade do art. 21 do decreto n.20.465, de 1 de outubro
} 
O livro organizado por Maria Ruth Amaral Sampaio (2002), "A promoção privada de habitação econômica e a arquitetura moderna (1930-1964)", também se destaca nesse sentido. Essa publicação foi um dos frutos do projeto temático desenvolvido entre os anos de 1996 e 2000, junto à FAU-USP e, naquela época, ao Departamento de Arquitetura e Urbanismo da EESC-USP ${ }^{6}$, com financiamento da Fapesp. Detevese a investigar a produção de diferentes tipologias de moradia no país. Um importante estudo que trouxe à tona o debate em torno da habitação econômica ao longo das décadas em questão, como também empreendeu um contraponto entre as ações públicas e privadas nesse setor, atentando para a incorporação de alguns ditames arquitetônicos que vinham sendo empreendidos pelo Estado por parte da iniciativa privada, especialmente em se tratando dos novos padrões de valorização imobiliária associada à imagem do apartamento e do condomínio ${ }^{7}$.

Consideravelmente mais recente e aludindo uma questão extremamente pertinente quanto à contemporaneidade da produção habitacional moderna, Paulo Bruna em sua tese de livre docência publicada sob o título "Os primeiros arquitetos modernos: habitação social no Brasil, 1930-1950", em 2010, trás a tona 0 teor de vanguarda da produção dos IAPs, revelando que foi a partir de 1930 que começou a ser trilhado 0 "caminho dos tijolos de ouro" da arquitetura e urbanismo ditos modernos no Brasil. Uma questão já tratada por Nabil Bonduki, mas que com Bruna (2010) ganhou aprofundamento e riqueza de análises e dados. Buscando no repertório internacional, sobretudo nas experiências das sociais-democracias europeias e na noção de "moderno" entre 1920-1930 naquele cenário, o berço e o modelo de intervenção dos IAPs no campo da habitação social, o estudo preencheu uma importante lacuna da historiografia nesse sentido. No entanto, as análises acerca da habitação social foram concentradas apenas no estado de São Paulo, por meio de alguns conjuntos habitacionais construídos pelos IAPs e vinculados aos preceitos da arquitetura e urbanismo modernos.

Outros artigos publicados principalmente nos anais dos Seminários Docomomo Nacional e Regionais, mormente analisam a política habitacional de modo geral ou uma produção habitacional específica (um conjunto ou edifício), como já citado anteriormente, ou fazem rápidos comentários sobre o tema e as questões relacionadas a ele, enumerando-as sem maiores aprofundamentos, colocando a análise da produção arquitetônica desses órgãos em segundo ou terceiro plano.

Os referidos títulos representam importantes obras elaboradas num esforço de ampliar e aprofundar o restrito quadro da história da arquitetura habitacional pré-BNH no Brasil. Atualmente, o repertório de

de 1931, o emprego dos recursos na construção de prédio deve ser feito de acordo com o regulamento que foi expedido para esse fim (...)" (DECRETO N.21.326, 27/04/1932).

${ }^{6}$ Atualmente Instituto de Arquitetura e Urbanismo de São Carlos (IAUSC-USP).

${ }^{7}$ Alguns poucos exemplares edificados pelo poder público no Recife foram citados no artigo "Economia de Morar no Recife (19301964), de autoria de José Tavares de Lira que, da mesma forma que Marcus André de Mello (1992), trouxe à tona uma produção fora do circuito Rio de Janeiro-São Paulo-Belo Horizonte. A sua pesquisa de doutoramento, intitulada "Mocambo e cidade: regionalismo na arquitetura e ordenação do espaço habitado", concluída em 1997, também se conforma como uma importante contribuição no campo da moradia no país. 
arquitetura residencial dos IAPs é sem sombra de dúvida mais conhecido que no momento da divulgação do primeiro título, em 1983, e nos anos diretamente subsequentes. Apesar do aumento e diversificação dos estudos acerca da produção arquitetônica nesse período, que inclui as trajetórias dos IAPs e outros diversos órgãos públicos e privados que coexistiram nas décadas de 1930 a 1960, ainda são vislumbrados hiatos importantes nessas formulações. Os dados apresentados por Farah (1983) em se tratando da produção habitacional e da organização dos órgãos e de suas ações imobiliárias, por exemplo, ainda são reproduzidos e perpetuados em outros estudos posteriores.

Vale apontar também, que a produção das CAPs do MAIC 8 no campo habitacional, contemporânea e concomitante à atuação dos IAPs do MTIC no país, foi escanteada por esses estudos, bem como as ações de um número considerável de Institutos de Previdência estaduais - como o IPSEP (Instituto de Previdência dos Servidores do Estado de Pernambuco) e do IPE-RN (Instituto de Previdência do Estado do Rio Grande do Norte), dentre outros - criados em fins da década de 1950 e nos primeiros anos da década seguinte, além das diversas parcerias instituídas entre os supracitados órgãos e o poder público em âmbito estadual e municipal. Vale ainda destacar, que os poucos estudos desenvolvidos nesse sentido, geralmente não consideram a produção habitacional das Caixas de Aposentadoria e Pensões como representativa, deixando de lado a sua identificação e/ou análise em decorrência dessa afirmação. Há apenas uma publicação que aponta essa produção, o estudo monográfico de autoria do engenheiro-arquiteto Rubens Porto (1938), intitulado "O problema das casas operárias e os Institutos e Caixas de Pensões", que restringe a atuação das CAPs apenas às capitais Rio de Janeiro, Belo Horizonte e Porto Alegre. Trata-se, dessa forma, de assunto que merece se melhor aprofundado.

A produção posterior à de Farah (1983) revela não somente a importância da fundamentação de pesquisas em dados primários, mas também expõe os complexos processos de "construção de verdades historiográficas" e de "generalização de especificidades" relacionadas, essencialmente, àquelas evidenciadas no centro-sul do país e tomadas como modelo nacional. Essa questão é há tempos criticada no meio historiográfico. Bernard Lepetit (2001), por exemplo, coloca o perigo em tomar características e especificidades locais como verdades universais, como o faz diversos autores comprometidos a estudar as questões da política pública habitacional no nosso país. Para o autor, mais precisamente, são extremamente pertinentes os estudos que se propõem a ampliar a inteligibilidade do real, aqueles que tendem a fugir das verdades estabelecidas sobre questões históricas, sendo esse um dos intentos primordiais da tese ora apresentada.

Por outro lado, é curiosa a ausência do tema em algumas obras de autores de prestígio. Paulo Bruna (2010) mostra que um crítico de renome da arquitetura brasileira como Mário Pedrosa nunca abordou a produção dos Institutos de Aposentadoria e Pensões, e que esse fato se dava não pelo desconhecimento de

\footnotetext{
${ }^{8}$ Que posteriormente passaram a ser da alçada do Ministério do Trabalho, Indústria e Comércio (MTIC).
} 
sua existência, mas sim, por respeito a posturas ideológicas. Um dos primeiros estudos, nesse sentido, foi elaborado por Phillip Goodwin, "Brazil Builds", no contexto da exposição realizada pelo Museu de Arte Moderna de Nova York, em 1943. Esse volume que, de acordo com a historiografia, foi um dos principais responsáveis pela divulgação da "nova arquitetura" de nosso país até a década de 1940, cita apenas 0 Conjunto Realengo de Carlos Frederico Ferreira (IAPI) e a sede do IAPI dos irmãos MM Roberto, ambos no Rio de Janeiro, mas não indica a atuação desse órgão no campo habitacional no país; o que colaborou para ofuscar 0 teor de vanguarda dessa produção, praticamente uma epifania declarada com o título de Paulo Bruna, publicado em 2010.

Outros diversos artigos sobre a arquitetura brasileira foram publicados em jornais e periódicos em todo o mundo após a divulgação do trabalho de Goodwin. Um importante estudo nesse contexto foi empreendido pelo arquiteto russo naturalizado, Henrique E. Mindlin, intitulado "Arquitetura Moderna no Brasil" e publicado em meados da década de 1950 em inglês, francês e alemão. Nesse livro, Mindlin faz referências a diversas obras projetadas por arquitetos brasileiros de renome e a alguns projetos de habitação coletiva empreendidos pelo poder público, principalmente no Rio de Janeiro, como o Conjunto Pedregulho cujo projeto foi concebido pelo arquiteto Affonso Eduardo Reidy (Departamento de Habitação do Rio de Janeiro) e 0 Conjunto Deodoro da FCP (1954), de autoria de Flávio Marinho Rego, além de algumas realizações do Banco Hipotecário Lar Brasileiro. A única referência às obras dos IAPs pontuada pelo arquiteto em seu livro foi direcionada ao Conjunto Habitacional em Santo André (1949), de Carlos Frederico Ferreira. No entanto, não especifica qual o órgão responsável pela obra, nem oferece maiores detalhes quanto às suas ações.

Na conclusão do livro "Arquitetura Contemporânea no Brasil", publicado em 1981, Yves Bruand cita diversas categorias de edificações construídas no Brasil a partir da década de 1930, analisando-as quantitativa e qualitativamente, dentre edifícios públicos, teatros, museus, cinemas, hotéis, hospitais, escolas, universidades, clubes, ginásios, edifícios de escritórios, fábricas, igrejas, pavilhões de exposições, rodoviárias, aeroportos e habitações. Em se tratando da moradia, o autor afirmou que "(...) os dois tipos de programas que poderiam atender à demanda, casas e prédios, tiveram 0 mesmo desenvolvimento e ofereceram aos profissionais da construção no Brasil o mais vasto campo de ação de que dispuseram (...)" (BRUAND, 1981, p.375). No entanto, restringiu a abordagem da habitação social a poucos exemplares edificados pelo Departamento de Habitação do Rio de Janeiro, destacando obras largamente apresentadas e divulgadas por periódicos e publicações internacionais, como os Conjuntos Pedregulho e Gávea de Reidy, da década de 1950. Em sua concepção "(...) houve uma desproporcionalidade entre a habitação de caráter social, cujos canteiros ficaram muito secundários e não deram origem senão a algumas poucas tentativas válidas (...)" (BRUAND, 1981, p.375). Para o autor, apenas os mercados de casas e de apartamentos de luxo incorporaram a grande parcela de construções de qualidade, os quais constituíram "(...) a parte dominante da obra da maioria dos arquitetos e, em muitos casos, a parte onde eles conseguiram expressar-se melhor (...)" (BRUAND, 1981, p.375). Ora, para questionar essa última afirmativa, basta citar uma representativa figura da 
arquitetura habitacional no país, Carlos Frederico Ferreira, cujas principais realizações se deram no campo da moradia social ${ }^{9}$.

Diante do exposto, a presente pesquisa se justifica primeiramente, pela possibilidade de contribuir para sanar algumas lacunas e equívocos historiográficos que ainda permeiam as pesquisas e publicações, bem como pela escassez de historiografia acerca da atuação do poder público no campo da habitação social no período pré-BNH, especificamente àquela resultante da ação das CAPs, deixada à margem dos estudos identificados ${ }^{10}$. A elaboração desta tese é justificada ainda pelo limitado quadro divulgado das obras construídas e/ou financiadas pelas Caixas e Institutos no campo da moradia no Brasil, em especial no Nordeste. Como se pode observar, os trabalhos significativos sobre o tema concentram seus universos de estudo nos estados do centro-sul do país. Por outro viés, nos poucos títulos que quantificam a produção das CAPs e dos IAPs, como o fez Farah (1983), os dados referentes à região Nordeste são apresentados, quando o são, em conjunto com os da região Sul e/ou Norte. Mostra-se de suma importância uma estimativa mais aproximada desse volume de obras, bem como demarcar a atuação desses institutos de previdência em outras localidades do país, para se compreender efetivamente sua importância e contribuição para a formulação de uma política pública no Brasil e, ainda, para entender a dimensão e o significado da intensificação da intervenção do Estado no campo da habitação social como controlador, financiador e/ou promotor da moradia.

Essa necessidade latente da identificação e análise do conjunto arquitetônico e urbanístico resultante da ação das Caixas e Institutos em outras localidades do país, por sua vez, não deve se restringir somente àquele representado pelos grandes grupos habitacionais coletivos, principalmente verticais, e/ou associado às premissas da arquitetura e do urbanismo modernos, como empreendido na maioria das publicações existentes. Mostra-se importante também, o apontamento da diversidade de referências e/ou aproximações arquitetônicas e urbanísticas adotadas ou incorporadas pelos profissionais do corpo técnico dos supracitados órgãos e de outros institutos de previdência, assim como do Conselho Nacional do Trabalho (CNT) que, por vezes, desenvolveu projetos de conjuntos no período. Somente dessa forma, a produção dos referidos órgãos no que tange à habitação será efetivamente conhecida.

\footnotetext{
${ }^{9}$ No já citado livro de Paulo Bruna (2010), o autor ainda cita o lapso referencial relacionado à produção habitacional dos IAPs nas publicações "História Geral do Brasil" (1983), coordenado por Walter Zanini, no qual, consta um texto de Carlos A. C. Lemos acerca da arquitetura contemporânea em nosso país, e "Arquitetura moderna brasileira: depoimento de uma geração", organizada por Alberto Xavier, de 1987.

${ }^{10}$ A questão da escassez de dados sobre as ações do poder público no campo habitacional antes da criação do BNH foi inclusive colocada por formulações oficiais, muitas das quais datam dos últimos dez anos, como foi o caso dos volumes "Estatísticas do Século XX", elaborados e publicados pelo IBGE em 2006: "(...) no que se refere às políticas públicas habitacionais, observa-se a limitada divulgação de dados sobre um dos temas de maior visibilidade política no Brasil do século XX. Sua importância na agenda do Estado brasileiro não encontra expressão nos AEBs, que pouco informam sobre indicadores de políticas habitacionais, em nítido contraste com a divulgação de dados estatísticos referidos a outras políticas sociais como saúde, previdência e trabalho. Apenas aparecem registradas informações sobre programas implementados pelo Banco Nacional da Habitação - BNH - durante o período de 1965 a 1978 (...)" (INSTITUTO..., 2006, s/p).
} 
Outra justificativa para a realização da presente pesquisa refere-se ao ainda restrito quadro de profissionais envolvidos na atuação das Caixas e Institutos de Aposentadoria e Pensões apresentado pela historiografia especializada. Atualmente, são apontados apenas poucos engenheiros e arquitetos responsáveis pela elaboração de projetos arquitetônicos, e por vezes urbanísticos, dos grandes empreendimentos, sobremaneira. Deixa-se de lado uma gama de profissionais que estavam envolvidos nos processos de concepção projetual das unidades modelo, das unidades isoladas ou mesmo dos pequenos grupos residenciais, da própria edificação e fiscalização dessas obras, bem como aqueles vinculados às avaliações empreendidas pelos órgãos nas concorrências públicas e/ou internas, para a construção dos conjuntos, e necessária para a liberação das concessões de financiamentos aos associados. Cabe lembrar que muitos desses profissionais, após 1964, com a criação do Banco Nacional de Habitação, encerraram suas carreiras ou deixaram de atuar no campo da habitação social, e não são devidamente estudados na história da arquitetura brasileira. Especificamente, a questão da diversidade de profissionais atuantes no cenário da construção civil em nosso país, entre os anos de 1930 e 1950, ainda não conhecidos ou estudados foi colocada em diversas publicações do gênero a partir, sobretudo, da década de 1960, com destaque para a Revista do IAB-Guanabara.

Por outro lado, nas últimas décadas passou-se a exigir um contínuo processo de recaracterização historiográfica acerca da existência do objeto arquitetura moderna brasileira, que levou à realização de uma revisão da historiografia no Brasil. Essa necessidade de revisão historiográfica não se restringe apenas à temática da arquitetura e urbanismo modernos em nosso país, mas também a uma diversidade de temas, como 0 da política pública habitacional brasileira. A observação de lacunas nos estudos e pesquisas existentes sobre o assunto, como apontado ao longo deste texto, assim como a perpetuação dos equívocos quanto à quantificação e a qualificação dessa produção, são indícios consideráveis e também justificam a pesquisa ora apresentada.

Apoiando-se e incorporando novos elementos documentais e, concomitantemente, questionando narrativas consolidadas numa tentativa de construir "novos olhares, novos cenários e novos atores"11 (MARTINS, 2007, p.192), procurou-se realizar a releitura de um período significativo da história da arquitetura brasileira, no que consiste à atuação dos distintos institutos de previdência, com mais ênfase nas Caixas e nos Institutos de Aposentadoria e Pensões (CAPs/IAPs) no campo habitacional em sete estados nordestinos. Dessa forma, esta pesquisa objetivou estudar a atuação desses órgãos no Nordeste do país, entre os anos de 1930 e 1964, identificando, registrando, mapeado, analisando as unidades habitacionais fruto dessa ação e apontando os profissionais envolvidos nesse processo. Mais especificadamente, pretendeu-se identificar e analisar as ações imobiliárias dos institutos de previdência em cada capital nordestina e eventualmente em suas regiões metropolitanas, bem como as diferenças e as semelhanças das suas atuações nas cidades em

\footnotetext{
${ }^{11}$ De acordo com o referido autor, o intuito, mais precisamente, é o de lançar olhares mais detalhados sobre momentos ou atores já destacados nas narrativas convencionais, trazendo à luz novos personagens ou propondo novas matrizes interpretativas.
} 
questão; identificar e registrar a produção de moradias, assim como, analisar as especificidades dessa produção no Nordeste; mapear a produção de unidades de habitação e estudar a sua distribuição no espaço de cada capital; quantificar essa produção e compará-la ao quadro nacional e analisar as configurações arquitetônicas e urbanísticas dos conjuntos de moradias erguidos pelos escritórios estaduais nordestinos; além de apontar os profissionais (engenheiros e arquitetos) envolvidos nas etapas de avaliação, projeto e construção de moradias no âmbito dos Institutos e das Caixas no Nordeste.

No bojo dessas questões, supunha-se, em se tratando dos financiamentos concedidos pelos supracitados órgãos, que ocorreu no Nordeste um processo semelhante ao vislumbrado na capital norteriograndense, na qual, o caráter social da atuação foi deixado em segundo plano em privilégio das ações atuariais, desmontando a teoria de que esses órgãos constituíam-se como essencialmente voltados a objetivos sociais, promovendo significativas contribuições para a amenização do déficit habitacional das camadas mais carentes da população a partir, sobretudo, da década de 1940. Nesse contexto, acredita-se que o volume de financiamentos concedidos para os trabalhadores mais abastados e com valores que extrapolam os limites sociais foi consideravelmente maior que aquele endereçado aos mais carentes (menores salários). Tal caráter é coerente com o imputado ao Estado e às políticas públicas habitacionais formuladas a partir da década de 1930, que excluíam uma considerável parcela populacional conformada por aqueles que não possuíam carteira profissional assinada, pobres, desempregados, alguns autônomos, trabalhadores do setor primário, sobretudo, da agricultura, empregados pelo setor informal e aqueles residentes na zona rural.

No tocante à produção de unidades habitacionais, conjecturava-se que o modelo de moradia isolada no centro do lote e com jardim frontal e quintal espaçoso, foi a solução mais empregada pelas CAPs e pelos IAPs no Nordeste. Isso provavelmente ocorreu, dentre outras questões, devido ao fato de que o processo densificação das áreas centrais das capitais nordestinas foi mais tardio que o vislumbrado nas cidades do centro-sul do país, o que possibilitou que espaços livres localizados próximos aos centros daquelas localidades não se tornassem alvo de intensa especulação imobiliária nas décadas de 1930 e 1940 (período de formação do patrimônio dos órgãos), permitindo que os mesmos fossem adquiridos por preços razoáveis, e utilizados para a construção de moradias para os associados dos institutos de previdência. Acredita-se que essa especificidade contribuiu para uma atuação muito maior nas áreas centrais daquelas capitais por parte desses órgãos, que a evidenciada em grandes cidades como São Paulo e Rio de Janeiro, por exemplo. Nessas, apenas os Institutos com reservas mais vultosas, como o IAP dos Bancários (IAPB), ergueram unidades habitacionais para os seus associados nas áreas centrais, ficando a massiva parcela de moradias edificadas e/ou adquiridas pelos referidos órgãos, localizadas nas periferias.

Por esse mesmo viés, pressupunha-se que o modelo de moradia coletiva vertical, situada em conjuntos com equipamentos e espaços coletivos, não foi priorizado pelos Institutos e Caixas no que se refere às moradias destinadas às camadas mais carentes das carteiras profissionais, bem como as unidades 
habitacionais situadas em vilas e conjuntos construídos diretamente pelos departamentos ou seções de engenharia e pelos profissionais envolvidos com a elaboração projetual dos conjuntos. Ambos os modelos foram alocados aos trabalhadores empregados nos cargos mais altos. Aos trabalhadores menos abastados foram "reservados" os financiamentos para a compra de moradias a terceiros, compra de residência alugada e já habitada pelo segurado, compra de terrenos para a autoconstrução da casa própria ou construção em terreno do próprio trabalhador, e ainda para a realização de melhoramentos em moradias próprias que, por vezes, não apresentavam condições adequadas de habitabilidade e de higiene, e estavam situadas inclusive em áreas impróprias e de risco.

Em se tratando da apropriação dos preceitos da arquitetura e do urbanismo modernos nas realizações das CAPs e dos IAPs no campo habitacional, acredita-se que no Nordeste essa não se deu de forma tão significativa como verificado pelo IAP dos Industriários de São Paulo, do Rio de Janeiro e de Belo Horizonte. Provavelmente a construção de exemplares da arquitetura e implantação modernas ocorreu mais nas Carteiras Prediais cujas reservas orçamentárias apresentaram maiores volumes, como no IAP dos Bancários e nos Institutos dos Servidores Públicos. Mesmo assim, considera-se que essa produção ficou muito mais a cargo dos próprios beneficiados, por meio da autoconstrução ou da construção independente (profissionais contratados pelos associados), que diretamente pelos institutos de previdência e seus corpos técnicos. Isto é, acredita-se que as diretrizes da arquitetura e do urbanismo moderno estavam muito mais presentes nas unidades habitacionais resultantes dos financiamentos para a construção, que naquelas fruto dos financiamentos liberados para a compra de residências construídas ou adquiridas pelos órgãos e, dessa forma, muito mais presentes nos discursos dos profissionais dos Institutos e Caixas que em suas realizações. Devido às questões econômicas, de indisponibilidade de material e de falta de capacitação da mão de obra no Nordeste, pressupunha-se que o emprego de materiais e como o vidro, o ferro e o concreto armado, da mesma forma que a arquitetura moderna, ficou relegado aos projetos destinados aos mais altos escalões profissionais.

Acredita-se que as consequências da ação coorporativa dos institutos de previdência em questão e das suas realizações no campo habitacional, que abriram caminho para a construção dos grandes empreendimentos habitacionais situados em áreas distantes dos centros das cidades nordestinas, podem ser atreladas à proliferação dos loteamentos, a partir da década de 1940, e à consolidação da periferia nas décadas de 1950 e 1960, com a generalização das casas construídas por mutirões ou autoempreendidas, locadas em conjuntos e/ou loteamentos com infraestrutura precária, responsável em grande parte pela expansão horizontal das cidades.

No tocante às contribuições da formulação da referida tese, cabe lembrar que diversos programas e políticas habitacionais posteriormente formuladas, incluindo a FCP e o $\mathrm{BNH}$, tomaram como baliza e/ou parâmetro de comparação as atuações dos IAPs e das CAPs, além dos diversos órgãos que atuavam nesse setor até então, podendo ser citados a CECAP (Caixa Estadual de Casas para o Povo) de São Paulo, a 
FUNDAHP (Fundação da Habitação Popular do Rio Grande do Norte). Sendo assim, para se entender 0 processo iniciado em 1964 com a criação do BNH, marcado de acordo com a historiografia essencialmente pela mudança da abrangência e estruturação das políticas públicas habitacionais brasileiras, configura-se necessário resgatar a gênese da intervenção estatal nesse setor, bem como, o entendimento de como se moldou e se desenvolveu essa atuação a partir de reestruturação do sistema previdenciário do país ao longo da década de 1920 e da institucionalização das suas ações, incluindo a moradia, por diversos órgãos e suas Carteiras Prediais, a partir da década seguinte.

Vislumbram-se também em praticamente todo o período de atuação, sobremaneira, dos IAPs, críticas em se tratando da gestão dos recursos da previdência e das políticas instituídas, mais precisamente, ao sistema de apropriação de recursos sociais por parte desses órgãos para o financiamento e a edificação de moradias para os contribuintes de classe média e alta. O presente estudo contribuirá também para um maior conhecimento do caráter da atuação dos Institutos e das Caixas no campo habitacional, no Nordeste do país, bem como o papel efetivo e a importância de suas ações nesse sentido.

As análises empreendidas referentes ao período compreendido entre os anos de 1930 e 1964, ainda contribuem para o entendimento dos processos de estruturação do movimento operário na década de 1920, de autoconstrução de moradias, de favelização das cidades, de proliferação dos loteamentos e assentamentos irregulares, de difusão dos apartamentos e dos conjuntos habitacionais para a classe média, a partir da década de 1940, e até mesmo de verticalização e do surgimento dos condomínios fechados. O estudo da atuação dos institutos de previdência no Nordeste, suas diretrizes e produção, fornece inclusive elementos para as pesquisas referentes às representações, modificações da planta e tratamento formal das moradias no país. Outro aspecto importante que merece ser destacado refere-se ao fato de que, ao se propor resgatar a trajetória da produção e do financiamento de unidades habitacionais pelas CAPs e IAPs em sete capitais nordestinas, esta pesquisa resgata também as figuras dos profissionais envolvidos nesse processo, desde empreiteiros, construtores, engenheiros e, principalmente, arquitetos atuantes entre as décadas de 1930 e 1960, ainda não identificados e/ou estudados devidamente pela historiografia específica.

É importante destacar também, que os institutos de previdência em questão são responsáveis pela edificação de uma gama de conjuntos e grupos residenciais testemunhos de um importante período da arquitetura e urbanismo moderno no país. A existência de muitas dessas construções está comprometida pela falta de conservação e/ou frente ao intenso processo especulativo que cerca a produção imobiliária brasileira. Muitos se encontram em processo de descaracterização e, até mesmo demolição, outros tantos nem existem mais. Para essa produção estão se voltando, recentemente e cada vez mais, os olhares para a preservação. Alguns grandes conjuntos residenciais edificados essencialmente pelos IAPs no país já se encontram tombados, como é o caso do Conjunto dos Industriários em Belo Horizonte e em Salvador, construídos ao longo da década de 1940 e 1950 pelo IAPI, e o Edifício Presidente João Pessoa (IAPB-1957), localizado na capital de mesmo nome, além dos já conhecidos casos cariocas e paulistas. Mas, ainda há 
muito o que se conhecer, o que se estudar e, porque não, o que se preservar. Sugestões de tombamentos não faltam, o Conjunto Casa Amarela do IAPC no Recife, o Conjunto dos Bancários em São Luís e 0 Conjunto Nova Tirol em Natal, representam a mudança no modo de morar e na paisagem das cidades e estão passando por grandes processos de remodelação e reforma, tendendo à completa descaracterização. Esta tese também pretende contribuir para o conhecimento dessa produção no Nordeste e espera fornecer subsídios para a abertura de novos processos de tombamentos.

Quanto aos procedimentos metodológicos, o presente estudo deu-se, essencialmente, a partir da análise de três variáveis: a estruturação das ações imobiliárias e as diretrizes que balizavam a atuação dos escritórios centrais dos Institutos e Caixas de Aposentadoria e Pensões (âmbito federal); as regulamentações dos escritórios nordestinos (âmbito regional); e as realizações pensadas e efetivadas por esses órgãos no campo da habitação em cada uma das sete capitais nordestinas. A delimitação do objeto de estudo deu-se pelo reduzido quadro de estudos sobre a temática habitacional nessa região do país e pelo fato que as produções relacionadas à atuação dos supracitados órgãos reverberam informações e dados de produções antigas, sobretudo da década de 1980, e de certa forma incompletas, por não possuírem o enfoque habitacional específico ou pela insuficiência de dados propriamente dita. Sendo assim, a pesquisa em questão fundamentou-se essencialmente em dados primários coletados nos arquivos públicos e privados do país (Anexos A, B e C).

O recorte temporal da pesquisa abrange o período definido pela historiografia específica como o de atuação das Caixas e Institutos de Aposentadoria e Pensões no campo habitacional, e foi estabelecido entre os anos de 1930, período em que as CAPs subordinadas ao MAIC foram autorizadas pelo Conselho Nacional do Trabalho (CNT) a executarem atividades imobiliárias para os seus segurados, e se estende até 0 ano de 1964, via de regra, quando em decorrência do Golpe Militar e da instauração de um novo Plano de Habitação no país, as ações no campo habitacional dos institutos de previdência existentes sofreram modificações e remanejos, apesar de não cessarem suas atividades, vale frisar. Engloba os intentos e as ações concretizadas durante as administrações dos presidentes Getúlio Vargas, Dutra, Juscelino Kubitschek, Jânio Quadros e João Goulart, no âmbito das CAPs e IAPs, que marcaram o alargamento da intervenção estatal na questão habitacional no país.

Para a compreensão das ações imobiliárias destes órgãos, foi preciso entender primeiramente 0 processo que a historiografia afirma, equivocadamente, ter sido iniciado no ano de 1923, com a outorga da Lei Elói Chaves, que representa um marco no tocante à legislação social para assegurar 0 atendimento das necessidades e das condições de trabalho dos operários urbanos do país, assim como, para propiciar as condições necessárias para a sua industrialização. Processo que ganhou vulto, sobretudo, a partir da década de 1930 com a criação do Ministério do Trabalho, Indústria e Comércio (MTIC). Para tanto, realizou-se revisão bibliográfica sobre o tema e pesquisa documental nos acervos jurídicos do país, com o propósito de 
entender como se estruturou a base da política habitacional implementada pelas CAPs e IAPs, posteriormente.

No tocante às atuações das Caixas e dos Institutos tanto a nível nacional como no Nordeste, foi realizado um levantamento documental nos arquivos dos escritórios nordestinos do INSS, do Ministério do Trabalho (DF) e do Instituto Nacional de Seguridade Social (RJ/DF), principalmente, enfocando a busca dos processos de financiamentos realizados, os relatórios das ações dos IAPs e das CAPs, os Boletins do MTIC e a legislação referente. Ao longo dos levantamentos foi encontrada uma gama de documentos, merecendo destaque os processos imobiliários concedidos pelos órgãos aos seus segurados, os Acordões estabelecidos entre o Conselho Nacional do Trabalho (CNT), os empregados e empregadores de 1923 até 1939, os pareceres do Ministério do Trabalho, Indústria e Comércio (MTIC) e as atas das reuniões do CNT, além das legislações (decretos, decretos-lei, leis, leis ordinárias, pareceres e resoluções) encontradas nos arquivos do Senado, Câmara dos Deputados, Supremo Tribunal do Trabalho, Advocacia Geral da União, dentre outros. Concomitantemente, realizou-se o levantamento dos artigos nos periódicos locais e nacionais, com destaque para as revistas Acrópole e O Observador Econômico e Financeiro, e para o jornal O Operário, encontrados, sobretudo, na Biblioteca Nacional do Rio de Janeiro. Utilizou-se ainda dados encontrados nos levantamentos censitários realizados pelo IBGE, que muito contribuíram para as análises comparativas e estatísticas realizadas nesta tese.

Para análise arquitetônica e urbanística dos conjuntos de moradias construídos e/ou adquiridos pelas Caixas e Institutos no Nordeste foi de suma importância a realização de revisão bibliográfica em obras de história e teoria da arquitetura, e de pesquisa iconográfica nos arquivos do INSS das capitais nordestina e, principalmente, o registro in loco dessa produção. Para complementar os dados acerca da atuação dos supracitados órgãos também foram realizadas entrevistas com os profissionais dos institutos de previdência, essencialmente engenheiros e arquitetos, como também com funcionários ativos nos Escritórios Estaduais do INSS visitados, contemporâneos à atuação das CAPs e dos IAPS, além de moradores dos conjuntos e vilas edificadas e/ou financiadas pelos referidos órgãos.

O tratamento dos dados primários coletados nos arquivos públicos e privados visitados foi realizado com base nos objetivos da pesquisa e nos eixos de investigação delineados. Os dados secundários deram respaldo às análises comparativas em âmbito regional e do Nordeste com o cenário nacional, sendo imprescindíveis para contextualizar o objeto de estudo e introduzir as análises específicas. As entrevistas, por sua vez, serviram para a complementação das informações sobre a atuação dos institutos de previdência nas localidades em questão e a respeito dos projetos arquitetônicos e urbanísticos dos grupos de residências.

Para a classificação do caráter da atuação dos referidos órgãos no campo habitacional levou-se em consideração os valores praticados nos financiamentos concedidos aos associados dos Institutos, comparando-os com os limites (piso e teto) especificados nas determinações federais/estaduais, bem como, os salários dos trabalhadores atendidos, tomando como base os valores dos salários mínimos praticados em 
cada capital em questão (1943-1951) ${ }^{12}$. Para a análise da abrangência, quantificação e qualificação desta atuação, considerou-se a produção quanto à habitabilidade e ao déficit de moradias, comparando o trato da questão nas dimensões municipais, estaduais, regionais e, por fim, equiparando-a ao cenário nacional. Utilizou-se para tanto, os dados apresentados nas bibliografias sobre o tema e os dados levantados nos arquivos. As informações, especialmente as de cunho primário, foram coletadas por meio de fichas padronizadas para cada uma das categorias de dados (Anexos D e E). Os documentos angariados nos levantamentos nos arquivos e nas pesquisas em campo, assim como, as imagens cartográficas e da produção habitacional, registradas in loco, foram arquivados em banco de dados criado pela autora no programa ACCESS, de modo que pudessem ser tratados e cruzados satisfatoriamente (Anexo F).

É importante salientar que ao se optar pela redação de um trabalho baseando-o essencialmente em dados primários, o pesquisador está sujeito a uma série de contratempos, sem citar a morosidade para a identificação, coleta e registros dos dados. Em relação à morosidade dos levantamentos é importante ser citada a dificuldade da coleta de dados devido às péssimas condições de conservação e de arquivamento dos documentos e à da própria estrutura dos arquivos visitados. O registro das informações significativas encontradas nos processos imobiliários foi feito por meio de fichas padronizadas, como acima mencionado, e o seu preenchimento à mão. Um processo lento devido à extensão dos documentos ${ }^{13}$, mesmo se tirando 0 máximo proveito das tecnologias disponíveis - câmera digital, scanner de mão, fotocópia, etc. - para 0 registro do material encontrado durante as visitas em campo. As condições de manutenção, essencialmente de limpeza dos arquivos, são precárias. Ratos, baratas e outros insetos, sobretudo traças, foram constantemente encontrados nas gavetas dos arquivos e nos processos empilhados nas estantes e/ou armários. Grande parte desse importante material relacionado à história da previdência, do trabalho e da habitação no país já se encontrava impossível de ser manuseado. As próprias condições dos documentos dificultaram ainda mais o levantamento. Folhas quebradiças e amareladas, textos apagados, folhas rasgadas e/ou comida por traças também foram comumente encontradas. A falta de padronização de arquivamento desses documentos nos arquivos do INSS no Nordeste, diante da imensa diversidade e volume, representa outro fator que dificultou a realização da presente pesquisa.

Nesta tese, a habitação social é entendida como àquela concebida pelo Estado e destinada às camadas mais carentes da população por meio de ações diretas ou indiretas, sendo considerados os casos de incentivos (isenções fiscais, programas, parcerias, etc.), auxílios parciais (concessão de materiais, mão de obra, dentre outros), doações, financiamentos, reformas e construção. Devido à variedade de denominações de Caixas e Institutos de Aposentadoria, Pensões, Assistência e/ou Previdência no país, de subordinações -

\footnotetext{
12 Período em que o salário mínimo foi mantido congelado no país.

13 Os processos, de maneira geral, constavam de um conjunto de diversos documentos, desde xérox autenticadas de carteiras de identidade e carteira profissional, assim como, certidões negativas, de casamento, diversos contratos e súmulas de contratos, escrituras, além das requisições encaminhadas para os escritórios regionais dos Institutos, do laudo de avaliação do imóvel e do formulário de requisição do financiamento com todos os dados do interessado e do Instituto para o qual ele contribuía.
} 
ora ao Ministério da Agricultura ou do Trabalho, Indústria e Comércio, ora ao Ministério da Guerra ou ao Ministério da Fazenda -, bem como dos anos de fundação desses órgãos ao longo das décadas de 1920 e 1930, principalmente, muitas vezes fez-se menção apenas a institutos de previdência, como já citado ao longo deste texto introdutório à pesquisa. Em se tratando das residências edificadas e/ou financiadas pelos referidos órgãos, considerou-se vilas, os grupos de casas, isoladas ou geminadas, distribuídas ao longo de uma ou mais vias, corredor ou pátio, destituídas de equipamentos coletivos. Os conjuntos residenciais, por sua vez, são aqui entendidos como os grupos de moradias unifamiliares e/ou coletivas de maiores dimensões, para os quais foram pelo menos previstos equipamentos coletivos e/ou espaços de lazer.

No tocante à estrutura, a presente tese encontra-se dividida em quatro capítulos. A necessidade de sanar os equívocos e hiatos historiográficos, perpetuados até os dias de hoje em grande parte das publicações relacionadas à história da previdência e da habitação, a qual faz parte a atuação dos institutos de previdência abordados nesta tese, levou à elaboração dos primeiros tópicos da tese intitulados: "A previdência e a moradia no Brasil: considerações gerais acerca da atuação do poder público ao longo do século XX" e "Reavaliando alguns consensos historiográficos". Para tanto, fez-se uma releitura do material legislativo oficial vinculado às CAPs e aos IAPs e às questões trabalhistas e assistencialistas do país, desde a Proclamação da República até fins da década de 1960, bem como o cruzamento dessas informações com dados publicados em periódicos oficiais nacionais, especialmente o Diário Oficial da União (DOU). Numa tentativa de escapar do peso das tradições acumuladas, a bibliografia existente sobre o tema se configurou como complementar, quando necessário, e para exemplificações comparativas, de modo que fosse possível investigar diversos aspectos relacionados às ações estatais no campo da moradia e da previdência intimamente atrelados no caso brasileiro desde, sobremaneira, a década de 1930. Questões relacionadas à macro estrutura das Caixas e Institutos e ao progresso das suas ações imobiliárias em âmbito nacional, assim como a identificação e análises acerca da produção resultante, especificamente em se tratando da quantificação, características dos pleitos concedidos e da arquitetura e urbanismo dos grupos de residências e das unidades isoladas produzidas, também foram abordados num primeiro momento, no capítulo inicial denominado CAPs e IAPS: um panorama das ações no campo habitacional, mais precisamente nos tópicos "Pelo menor preço a melhor casa: a trajetória da atuação das CAPs e dos IAPs no campo habitacional no país e a produção resultante" e, em seguida, na seção "A nova cultura da habitação: as diretrizes arquitetônicas e urbanísticas adotadas pelos órgãos no país". Esse primeiro capítulo da tese também foi elaborado com o intuito de analisar a instauração da previdência oficial no Brasil, que culminou numa ação contundente do poder público no campo da habitação, bem como contextualizar e compreender os motivos pelos quais o alargamento da atuação estatal no campo habitacional foi empreendido no seio de órgãos cuja principal finalidade era organizar e aprimorar a previdência no país.

Na sequência, com o intento de salientar a importância e as contribuições de determinados agentes no processo acima elencado, especificadamente do engenheiro-arquiteto Rubens Porto, cuja atuação é ainda 
hoje pouco aprofundada pela produção bibliográfica, foi elaborado o capítulo Referências e modelos: a estruturação das CAPs e IAPs. A identificação e o estudo das ações desse profissional, inclusive para a criação dos IAPs do MTIC e de suas proposições no setor habitacional, além das diferentes publicações relacionadas à moradia urbana e ao trabalhador brasileiro, que se mostraram atreladas aos preceitos do higienismo, do sanitarismo e apregoados pela Igreja Católica, com forte influência das ações empreendidas pelos poderes públicos na Europa, principalmente em Frankfurt via Ernest May, foram abordadas nos tópicos "O engenheiro-arquiteto Rubens Porto e as reformas legislativas", "Rubens Porto: as diretrizes construtivas e sua arquitetura ideal" e "Os modelos adotados como referências e balizas por Rubens Porto", que compõem 0 segundo capítulo desta tese. As colaborações dos primeiros ministros do Trabalho, Indústria e Comércio para a concretização dos intentos e propostas formuladas por Rubens Porto também foram colocadas nesse momento.

Em seguida foram apresentados os estudos e as análises mais especificas acerca da atuação dos institutos de previdência nordestinos, abordados a partir do terceiro capítulo, identificado pelo título As CAPS e os IAPs no Nordeste. Essa seção da tese foi segmentada em tópicos referentes à produção - número de unidades edificadas e/ou financiadas e modalidades imobiliárias, essencialmente ("Atuação e produção de moradias nas capitais"), à localização dessa atuação nas sete capitais em questão ("A espacialização da produção habitacional") e aos pleitos liberados - características e valores dos financiamentos, população atendida, etc. ("Os financiamentos concedidos: caracterização e análises do perfil social dos órgãos"). 0 objetivo primordial foi o de identificar as semelhanças e as diferenças das atuações dos Institutos e Caixas de Aposentadoria e Pensões nas capitais abordadas, assim como da região geográfica em comparação ao cenário conhecido do centro-sul do país.

A arquitetura e o urbanismo dos grupos residenciais ou moradias isoladas edificadas ou cuja construção foi financiada pelas CAPs e pelos IAPs, além dos casos de parcerias estabelecidas com outros órgãos, mormente estatais, foram tratadas no capítulo quatro do trabalho: A arquitetura e o urbanismo. As informações e dados levantados, assim como as considerações elaboradas, encontram-se divididas em duas principais categorias relacionadas à atuação - direta ou indireta - e aos aspectos tipológicos - conjunto ou isoladas, unifamiliares ou coletivas - que conformam os tópicos: "Grupos habitacionais edificados pelas CAPs e IAPs" e "Unidades habitacionais financiadas pelos órgãos". Os dados foram organizados de modo que fosse possível captar facilmente as aproximações e distanciamentos da produção resultante da atuação no campo habitacional em cada uma das categorias acima apontadas, bem como em cada uma das sete capitais nordestinas aqui abordadas. Em seguida, no tópico "Os profissionais envolvidos nos processos de avaliação, projeto, construção e fiscalização habitacional" foram apresentados os quadros dos corpos técnicos, entre construtores, engenheiros e arquitetos principalmente, vinculados às ações imobiliárias empreendidas pelos supracitados Institutos e Caixas no Nordeste. Quando possível, diante dos dados encontrados nas pesquisas históricas e em campo, procedeu-se à apresentação de informações acerca, essencialmente, da formação e 
da atuação profissional de engenheiros e arquitetos de destaque nas cidades em questão, assim como a descrição de obras empreendidas por essas figuras ao longo de suas carreiras, para além do executado no âmbito dos referidos institutos de previdência no Nordeste.

As considerações finais do trabalho trazem além das observações tidas como pertinentes à atuação dos supracitados órgãos na referida região geográfica do país, as análises comparativas das ações pensadas e empreendidas efetivamente pelas CAPs e IAPs no campo habitacional, contrapondo-se o discurso apresentado a nível federal, especialmente nas publicações oficiais e na legislação, e num segundo momento na historiografia existente sobre o assunto, e o que foi realmente concebido pelos órgãos nas sete capitais nordestinas estudadas. Informações destoantes ou distantes do colocado pela historiografia acerca da perpetuação das ações imobiliárias a partir de 1964, especialmente no tocante ao Banco Nacional de Habitação, como também em se tratando da estruturação e atuação desse Banco no país, além da reverberação de problemas constatados no âmbito dos órgãos pré-existentes, identificadas ao longo desta pesquisa, também foram expostas nesta seção. A importância do apontamento desses aspectos recai na necessidade de se retificar a sinuosa trajetória da intervenção estatal no campo habitacional no país, no sentido de se instituir uma política pública habitacional brasileira, que a atual historiografia imputa como sendo quase que exclusivamente de responsabilidade do BNH e somente empreendida a partir de meados da década de 1960. Questões vinculadas à estruturação do órgão, perfil de atuação, quantidade e qualidade construtiva e, até mesmo, relacionadas à tipologia, além dos problemas e virtudes associadas ao Banco, foram germinadas no âmbito das organizações trabalhistas que deram origem às Caixas de Aposentadoria $e$ Pensões subordinadas ao MAIC e, consequentemente, aos IAPs do MTIC ${ }^{14}$.

\footnotetext{
${ }^{14}$ É importante ressaltar ainda, que nesta tese optou-se por manter as citações com a redação original, mesmo quando identificados erros ortográficos, de tipografia (como era comum nas primeiras décadas do século XX) ou de digitação (no caso das publicações mais recentes). 0 texto da presente pesquisa também se encontra adaptado à reforma ortográfica da língua portuguesa empreendida em 2009 e que, a partir de janeiro do corrente ano, passou a ser obrigatória, bem como às normas para a elaboração e apresentação determinadas pela ABNT, sobretudo, à NBR 6023, e às especificações apresentadas pelo Sistema Integrado de Bibliotecas da USP.
} 


\section{CAPÍTULO 01. \\ CAPS E IAPS: UM PANORAMA DAS AÇÕES NO CAMPO HABITACIONAL}

\subsection{A Previdência e a Moradia no Brasil: Considerações gerais acerca da atuação do poder público ao longo do século XX}

No Brasil, antes da intervenção estatal no campo previdenciário e habitacional, até pelo menos a virada do século XIX para o século XX, essas questões ficavam a cargo essencialmente de entidades privadas. Mais precisamente, esse quadro era composto no que tange às questões previdenciárias, de modo geral, pelas entidades sociais e de classe - corporações de ofício ${ }^{15}$ e irmandades ${ }^{16}$, inicialmente - e pelas sociedades de socorros mútuos, beneficentes e montepios, sobremaneira, a partir de meados do século XIX. Esses últimos organismos gestores da previdência privada advieram das corporações (proibidas pela Constituição de 1824) e de algumas irmandades de cunho espiritual e/ou religioso, diante do aumento da necessidade de proteção social, associada ao medo do desemprego e desamparo da família e à necessidade de criação de vínculos sociais (principalmente pelas minorias e migrantes) ou trabalhistas, além da concentração populacional possibilitada pela urbanização (IBGE, 1990, p.34).

As mútuas e montepios, especificadamente, limitavam sua cobertura a certos grupos sociais e, mesmo quando subvencionadas pelo Estado, não operavam o seguro - proibido por lei ${ }^{17}$-, 0 que limitou suas atuações ${ }^{18}$. Diversas eram as formas e tipos de classificação das mútuas e montepios: por tipo de comodato; tipo de abertura (grupo étnico, categoria profissional, classe, etc.); pelo tipo de controle (privado,

\footnotetext{
15 Organizações formadas por pequenos produtores e artesãos livres que contribuíam com quantias periódicas para o custeio dos funerais dos seus associados. Esses mecanismos de proteção social foram instituídos pelos próprios cidadãos ainda no período colonial. Eram formadas, mormente por mestres, oficiais e aprendizes, que buscavam o preço justo para a "mercadoria", de acordo com o material utilizado e o trabalho empreendido para a sua produção, bem como o ensino de um ofício (PEREIRA JR., 2007). Até as primeiras décadas do século XIX, a maior parte das profissões no Brasil dependia de uma corporação (PISTORI, 2005). Esse quadro se manteve praticamente inalterado até 0 ano de 1824, quando a Constituição Imperial (Art.179, §XXV) proibiu essa modalidade de associação trabalhista no país. Foi a partir dessas organizações que se abriu caminho para o surgimento de outras associações e entidades de cunho trabalhista no país e essas, por sua vez, deram respaldo organizacional para a criação das CAPs e, consequentemente, dos IAPs.

${ }^{16}$ Organizações de cunho religioso e de inspiração na caridade representadas no Brasil, sobremaneira, pelas Casas de Misericórdia dos séculos XVII e XVIII, cuja finalidade principal era prestar serviços médicos e hospitalares aos pobres e indigentes. Os principais objetivos dessa modalidade de associação eram, além de conceder o enterro dos falecidos, a prestação de socorros aos "irmãos" indigentes em suas enfermidades, socorrer aos seus "irmãos" com todo o auxílio possível, tanto espiritual como temporal, incluindo o pagamento de diárias em caso de prisão (SILVA JR., 2007, p.89). As Irmandades apresentavam tanto um caráter fortemente espiritual, associado à Igreja Católica, como uma essência previdenciária, ao se propor a conceder auxílios em dinheiro aos necessitados. No campo habitacional, essas entidades realizaram trabalhos de assistência aos migrantes e indigentes, essencialmente.

${ }^{17}$ A prática de seguros de vida era proibida no país desde a publicação do Código Comercial de 1850.

18 Tanto os montepios quanto as mútuas eram sociedades sem fins lucrativos, que não possuíam capitais, nas quais os segurados se conformavam como seguradores, sendo representados por um presidente escolhido por decisão estatal, como o foi durante muito tempo no Brasil. A vinculação às mútuas e aos montepios se dava de modo facultativo, objetivando a assistência e ajuda comuns. As contribuições arrecadadas, deduzidas as despesas necessárias, eram agrupadas e distribuídas pelos segurados em forma de benefícios, pequenos pecúlios (parcelas em dinheiro) pagáveis após a morte ou por acidente ou doença que impossibilitasse um de seus membros de trabalhar. Algumas entidades ofereciam, ainda, a possibilidade de "adiantamentos" para pagamento de dívidas ou para construção, reforma ou aquisição de edificações, inclusive, supõe-se, de moradias. A diferença essencial das entidades no âmbito legal se dava apenas em relação ao caráter temporal de seus serviços, apesar de, na prática, essa especificidade se confundir (DECRETO n.2.711, 19/12/1860).
} 
patronal, estatal); de abrangência, etc. Mas, com o passar dos anos, surgiram mútuas e montepios puramente profissionais, que foram ganhando espaço em detrimento dos demais, de acordo com o processo de formação da identidade profissional no país ${ }^{19}$. De acordo com a legislação vigente na época, tanto os montepios quanto as mútuas teriam que solicitar aval estatal para sua criação, não podendo atuar sem o crivo legal. Diversas das propostas e/ou solicitações de fundação de entidades foram negadas, nesse sentido 20 . Por outro lado, muitas dessas mútuas e montepios permaneceram na ilegalidade, uma vez que o controle por parte do poder público sobre elas era ineficaz naquele momento e, posteriormente, menos intenso comparando-se à fiscalização exercida sobre os sindicatos e a previdência estatal21.

Assim 0 foi até 0 ano de 1923, quando foi criado o Conselho Nacional do Trabalho ${ }^{22}$ e todas as instituições de previdência social do país, incluindo os montepios e as mútuas, passaram a ser fiscalizadas e "controladas" por esse órgão23. Nesse sentido são percebidas diversas semelhanças, em se tratando da estruturação e dos objetivos, entre as entidades sociais e de classe privadas pré-existentes e as CAPs do Ministério da Agricultura, revelando uma importante baliza adotada pelo poder público para a instauração da previdência estatal brasileira. As mútuas e montepios principalmente, também se conformaram como

\footnotetext{
${ }^{19}$ As invocações aos padroeiros e santos, tão típicas das irmandades anteriores, foram se esvaindo, dando espaço à identificação com os associados, à atividade profissional, interesses em comum, localização da sede da mútua em relação ao local de trabalho e/ou moradia e, posteriormente, às reivindicações trabalhistas.

${ }^{20}$ Alegava-se, geralmente, a constituição de grupos de pressão social, que comprometeriam a ordem e a tranquilidade social. Da mesma forma que ocorreu com os sindicatos no contexto de reação governamental à Intentona Comunista, representada no plano legislativo por leis como a de n.136, de 14/12/1935, que proibiu empresas, institutos, caixas, casas subvencionadas ou qualquer entidade e serviço prestado, criado ou mantido pela União, estados ou municípios do país, de manter membros vinculados à violação da ordem pública e social.

${ }^{21}$ A defasagem de fiscalização também pode ser justificada pela dificuldade em enquadrar essas entidades em uma esfera específica (pública, privada, comercial, patronal, etc.).

22 O Conselho Nacional do Trabalho (CNT) foi criado por meio do Decreto no.16.027, outorgado em 30 de abril de 1923, no âmbito do Departamento Nacional do Trabalho (DNT), subordinado ao Ministério Agricultura, Indústria e Comércio. O DNT foi o primeiro órgão federal responsável pela fiscalização e gestão do CNT e até o ano de 1918 era denominado Diretoria do Serviço de Povoamento. Surgiu em meio às inúmeras reivindicações operárias que ocorreram no cenário brasileiro no período, não sendo possível, no entanto, considerar sua criação como resposta governamental para tanto. Tratava inicialmente dos assuntos relacionados à colonização do país, à migração e às questões trabalhistas e suas regulamentações. Mais especificadamente, competia ao Departamento o estudo e o preparo da regulamentação da legislação operária geral, a organização de trabalhos comparados de diversas legislações, a organização de instruções e regulamentos referentes à inspeção do trabalho e a coordenação de dados estatísticos precisos para organização definitiva da estatística do trabalho no país (DECRETO N.3.550, 16/10/1918). Pelo Decreto de criação, o CNT foi definido como órgão consultivo dos poderes públicos em geral, nos assuntos relacionados à organização do trabalho e à previdência social, além de outros aspectos que pudessem interessar a essas questões. Mais especificadamente, era de responsabilidade do Conselho as questões relacionadas: "(...) ao dia normal de trabalho nas (...) industrias, systemas de remuneração do trabalho, contractos collectivos do trabalho, systemas de conciliação e arbitragem, especialmente para prevenir ou resolver as pendências, trabalho de menores, trabalho de mulheres, aprendizagem e ensino technico, accidentes do trabalho, seguros sociaes, caixas de aposentadoria e pensões de ferro-viários, instituições de credito popular e caixas de credito agrícola (...)" (DECRETO N.16.027, 30/04/1923). Foi por meio das supracitadas ações que o Estado intensificou sua atuação no campo trabalhista e previdenciário no país, a partir da década de 1920. Em sua primeira formação, 0 Conselho Nacional do Trabalho era composto por 12 membros escolhidos pelo presidente da República, sendo o Ministro da Agricultura, Indústria e Comércio o seu presidente honorário e o Secretário Geral, o responsável pela sua administração.

${ }^{23} \mathrm{O}$ número preciso de entidades que atuaram no país entre meados do século XIX e primeiros anos do século XX não é possível ser estimado, uma vez que eram as províncias as responsáveis por cadastrar e comunicar ao governo nacional esses dados, não havendo um padrão de registro no Brasil naquele período. Segundo Silva Júnior (2007), o único levantamento deste gênero realizado no país até a década de 1930, ocorreu no ano de 1917. No entanto, esse levantamento não discriminou a natureza das organizações, englobando sociedades de socorros mútuos, montepios, sociedades beneficentes, dentre outras, em uma mesma classificação. Naquele ano constava um total de 3.505 entidades distribuídas por todo o território nacional, sendo os estados de São Paulo e Minas Gerais os que mais possuíam organizações (INSTITUTO..., 1936, p.307).
} 
significativas entidades privadas no atendimento das necessidades da população do país, no que condiz a assistência previdenciária, alimentícia, médica e funerária, além de propiciarem as condições econômicas, sociais e políticas necessárias para o alargamento desta intervenção no Brasil.

Em se tratando da moradia, foram os empregadores donos de fábricas, os principais responsáveis pelo provimento de habitação para os trabalhadores do país até a terceira década do século XX. As maiores contribuições dos empregadores, nesse sentido, se deu por meio da edificação das vilas e núcleos operários $^{24}$. A partir da década de 1920, a construção de vilas operárias nas cidades e, principalmente, de núcleos fabris em áreas suburbanas e rurais por empresas ganhou vulto no país ${ }^{25}$. Devido ao distanciamento da cidade, a instalação das indústrias/fábricas requeria investimentos abrangentes com a infraestrutura necessária e edificação de uma diversidade de equipamentos e serviços, dentre eles a moradia. As empresas situadas nas zonas rurais e/ou em áreas suburbanas se comprometiam a realizar todas as obras necessárias para o seu funcionamento, dentre as diversas instalações, interessando-nos citar a edificação de unidades habitacionais, fossem elas isoladas, coletivas ou especializadas, como para solteiros. As fábricas se responsabilizavam, muitas vezes, também pela gestão e todo 0 aparato necessário para o bem-estar de seus operários, disponibilizando serviços e dotando esses grupos residenciais de equipamentos coletivos diversos (CORREIA, 1998).

Os "rentistas", detentores de grande parte dos imóveis urbanos no país desde o século XIX, também tiveram papel importante no provimento de residências no Brasil26. Nessa época, o quadro brasileiro era marcado por processos de industrialização e pela urbanização, acompanhados pela exacerbação de problemas como o rápido crescimento populacional27, as precárias condições dos serviços básicos, essencialmente a distribuição de água e coleta de esgotos, os altos índices de mortalidade e de desemprego, além do déficit de habitações. Sem locais disponíveis e/ou condições para angariar uma residência, grandes parcelas populacionais se renderam às condições precárias de moradias, bem como às exigências dos rentistas. Nesses casos, as moradias absorviam significativas parcelas do ordenado mensal do trabalhador para o pagamento do seu aluguel, além de se conformarem geralmente como insalubres. A grosso modo, as

\footnotetext{
${ }^{24}$ As vilas e núcleos fabris no país se conformavam, principalmente, como empreendimentos privados que concederam diversos benefícios aos seus operários, como moradia a baixo custo, serviços e/ou tratamentos médicos para eles e suas famílias, além de lazer, escolas para seus filhos e espaços de convívio social.

${ }^{25}$ De modo geral, 0 aumento da construção de núcleos operários acompanhou o desenvolvimento da grande indústria no país, a partir do século XX, sendo caracterizado pela edificação de milhares de moradias por empresas, em especial, as usinas de açúcar, fábricas, companhias de mineração e de produção de energia (CORREIA, 1998).

${ }^{26}$ Os rentistas eram, mormente, construtores e/ou proprietário de edificações urbanas, que alugavam e/ou sublocavam suas camas, cômodos, dependências ou unidades completas, de acordo com seus critérios e a preços definidos por eles. Para Bonduki (2002), os rentistas eram aqueles que tinham recursos ou poupanças e investiam-nas de modo a proporcionar rendimentos, dentre eles, a edificação de moradias para aluguel. Eram pessoas que viviam de renda e não do "trabalho" - viúvas, órfãos, idosos, etc. - e outros proprietários de bens como profissionais liberais abastados.

${ }^{27}$ Decorrentes, sobretudo, dos constantes fluxos migratórios para os principais centros urbanos.
} 
tipologias habitacionais mais empreendidas pelos rentistas foram os cortiços ${ }^{28}$, e também foram as que mais preocupações suscitavam entre as elites letradas e entre os higienistas da época ${ }^{29}$.

Os rentistas regeram o mercado de locação e parte do mercado de imóveis no Brasil, essencialmente aquele destinado às camadas mais carentes, até o alargamento da intervenção estatal no campo habitacional, ainda embrionariamente a partir da década de 1920, quando essa responsabilidade foi paulatinamente sendo assumida pelo poder público. As ações dos construtores de unidades habitacionais urbanas e o repasse delas à população pobre, mesmo que em condições subumanas e a um alto custo, contribuiu para amenizar o quadro de déficit de moradias no país. Em contrapartida, as ações dos rentistas comprometeram consideravelmente, dentre outros aspectos, o saneamento urbano, a qualidade de vida e a saúde da população como um todo, fazendo emergir diversos reclames por parte dos letrados, da classe média e da própria população assistida na época, endereçados à administração pública.

De modo geral, as primeiras reivindicações operárias evidenciadas no país diziam respeito ao direito de greve ${ }^{30}$, à redução da jornada de trabalho e à regulamentação do trabalho de jovens, mulheres e imigrantes, que resultaram nas primeiras greves gerais do século XX. As melhorias das condições de trabalho e de segurança nas fábricas foram incorporadas aos anseios operários, ainda na década de 1910, seguidas por protestos para aumento salarial, proteção estatal (auxílios funerais, assistência médica, aposentadoria e pensões, principalmente), redução dos preços dos gêneros de primeira necessidade e dos aluguéis ${ }^{31}$, que eclodiram a onda de greves gerais que ocorreu no Brasil a partir de 191732. Esses anseios ganharam voz e organização no âmbito das entidades e associações de classe e nos partidos ${ }^{33}$.

\footnotetext{
${ }^{28}$ Eram considerados cortiços, dentre outras variações, as moradias coletivas seriadas dispostas em torno de um pátio ou corredor, aquelas subdivididas ou adaptadas para coabitação.

29 Às moradias dos pobres urbanos foram imputados diversos estigmas que se conformaram ao longo do século XIX e nos primeiros anos do século XX entre as elites. De modo geral, foram associadas à difícil situação econômica dos trabalhadores que nelas habitavam (comprometimento da organização do trabalho), consideradas como abrigo para a população responsável pela desordem social (vícios e devassidão), como cenário de luta dos negros contra a escravidão (antes da abolição, e de refúgio, após), além de serem vistas como ambientes inadequados higienicamente e causadores de doenças (CHALHOUB, 1996; CORREIA, 2004). As representações das tipologias habitacionais das camadas mais carentes da população estavam arraigadas por uma visão elitista acerca das precárias condições higiênico-sanitárias e "morais". Para o aprofundamento desse assunto, consultar: Eva Blay (1985), Sidney Chalhoub (1996), Celine Sachs (1999), Telma Correia (2004) e Andrea Piccini (2004).

${ }_{30}$ As paralisações de trabalhadores no país eram proibidas desde, praticamente, a vinda da corte portuguesa ao Brasil e permaneceram ilegais até a outorga da Lei $n^{0} 7.783$, de 1889.

${ }^{31}$ Mais precisamente em se tratando da moradia, a questão começou a permear as exigências dos trabalhadores para com o poder público, não diretamente sob a forma de concessão, mas de modo indireto, por meio da redução dos custos desprendidos para 0 pagamento dos aluguéis. Cabe aqui ressaltar, que as Ligas dos Inquilinos de São Paulo e do Rio de Janeiro já vinham fazendo exigências e reivindicações para a redução dos aluguéis. Mais precisamente em São Paulo, as manifestações expressas pelas Ligas também refletiam "(...) os descontentamentos e o repúdio dos operários em relação à organização das vilas operárias (...)" (CARPINTÉRO, 1997, p.69).

${ }^{32}$ Sucintamente, as paralisações foram organizadas, essencialmente, pelos próprios trabalhadores (Ligas, Federações e a Confederação, das quais faziam parte os sindicatos, caixas, mútuas, montepios e outros), mas também contou com 0 apoio e a ação dos muitos militantes políticos. A historiografia especializada retrata a participação e 0 engajamento de verdadeiras multidões de trabalhadores, que saíram às ruas para protestar e reivindicar seus direitos como operários e como cidadãos. Em 1919, 0 movimento ganhou força e voltou a exigir do Estado melhorias trabalhistas e nas condições de vida. Esse momento foi considerado pela historiografia como o mais intenso de ações operárias no país, sendo marcado pela ocorrência de uma nova grande onda de manifestações e paralisações gerais, contando com uma maior participação social. Foi nesse momento de agitação social e trabalhista das primeiras décadas do século XX, que entrou em cena o movimento comunista no país (DEL ROIO, 2007).

${ }^{33}$ No Brasil, esses grupos se aproximavam enquanto objetivos e realizações e, por vezes, se uniam em prol do movimento trabalhista.
} 
Durante muito tempo, as principais respostas estatais tanto às organizações e grupos operários, quanto às reivindicações elaboradas por eles, veio sob a forma de repressão, que limitou a liberdade de expressão e de organização trabalhista no país. Foi nesse contexto, que o clima de pressão operária sobre 0 Estado para 0 atendimento de suas reivindicações, essencialmente trabalhistas, foi crescendo. Na mesma proporção foi se agravando o processo de lutas, violência, prisões, deportações e repressão por parte do poder público e dos empregadores, que acompanhou a história do movimento operário brasileiro. Cada vez mais, as reivindicações dos populares de uma maneira geral e aquelas formuladas/geridas por entidades sociais e trabalhistas direcionadas ao poder público, enveredaram para as questões relacionadas à melhoria das condições de vida e à moradia - redução do valor do aluguel, solicitações para intervenções estatais por meio de legislação mais adequada, pelo financiamento e pela própria construção, dentre outras. Concomitantemente, profissionais, sobretudo, médicos, engenheiros e arquitetos intensificaram as discussões sobre essas questões nos diversos eventos e periódicos organizados a partir da década de 1920, principalmente.

Até então, no campo da moradia, as ações do Estado se davam por meio essencialmente de legislação com caráter repressor e eram representadas, principalmente, por regimentos para a construção de moradias $^{34}$. Em se tratando das construções de moradias, as ações estatais eram pontuais e pulverizadas pelo país e se concentravam na edificação de poucos núcleos fabris por estatais, além de parcerias para a construção de vilas operárias estabelecidas com entidades privadas e da criação de órgãos nesse sentido, como as CAPs e os IAPs do MTIC, que serão abordados adiante. No plano legislativo merece ser citado 0 Decreto n.11.544, de abril de 1915, que autorizou o Ministério da Fazenda a custear a construção de vilas operárias em todo o país, bem como o Decreto n.4.209, de dezembro de 1920, por meio do qual, teve início no cenário nacional a política oficial de aluguel de moradias para a população carente ${ }^{35}$.

Em se tratando das parcerias, o poder público passou a conceder, em alguns casos, isenção fiscal (de foros, laudêmios e outras taxas), aforamento de terrenos, efetivando desapropriações por utilidade pública, construção de abrigos temporários e/ou dispensários, e até realizando empréstimos àqueles (empresas, associações ou pessoa física) que tivessem interesse em edificar grupos de moradias higiênicas (vilas operárias em especial) e repassá-las ou alugá-las a preços módicos à população carente, e/ou reformar

\footnotetext{
${ }^{34}$ Comumente chamados de Códigos de Posturas, legislavam acerca da proibição da coabitação entre homens e animais; da necessidade do calçamento e iluminação de pátios, áreas externas e/ou no interior das moradias; da instalação de latrinas; do fornecimento por parte do poder público de compartimentos para se depositar as águas servidas e as matérias fecais, assim como, da remoção desses vasilhames em determinadas horas do dia. Posteriormente passaram a ser solicitadas a ligação das residências ao sistema de esgotamento sanitário, a pavimentação de área externa, a ampliação da altura do pé direito e das dimensões dos vãos das janelas e portas - de modo a oferecer melhor ventilação e iluminação aos cômodos -, alterações dos tipos de revestimentos e imposição de limites de lotação máxima de cada residência. No tocante aos cortiços, ocorreu inicialmente a proibição da construção sem a aprovação da Câmara Municipal e/ou das Juntas de Higiene, e o total impedimento a partir de fins do século XIX e nos primeiros anos do século seguinte, nas principais cidades do país (PICCINI, 2004; ALMEIDA, 2007).

${ }^{35}$ Mais precisamente, por meio desse Decreto o Poder Executivo foi autorizado a edificar unidades habitacionais para serem alugadas, essencialmente aos proletários.
} 
os cortiços e mocambos ${ }^{36}$. No entanto, essas ações não alcançaram a repercussão almejada e o crescimento do mercado imobiliário nas cidades brasileiras e as crescentes elevações nos valores de locação, resultantes da escassez de moradias, foram intensificadas nas décadas seguintes. O Estado passou então a lançar mão de outras alternativas, como a regulamentação da relação entre os inquilinos e os proprietários dos imóveis urbanos, por meio de leis restritivas e de fixação dos valores dos aluguéis praticados no país ${ }^{37}$. Segundo Melo (1992), foi a legislação argentina que se conformou como a referência direta para esse conjunto de leis, que ficou conhecido como Leis do Inquilinato. Contudo, com base em diversas citações e apontamentos verificados em trabalhos e publicações da época, acredita-se que essas ações se aproximam mais das soluções empreendidas no campo da moradia social pelas sociais-democracias europeias do primeiro PósGuerra, como Viena e Berlim ${ }^{38}$.

Os primeiros projetos de lei outorgados nesse sentido datam ainda da década de 192039 e foram sendo aprimorados e adquirindo um caráter mais contundente ao longo da primeira metade do século XX, ganhando força e destaque na década de 194040. A decisão de congelar os aluguéis no país, na década de 1940 em especial, foi largamente divulgada pelos periódicos em circulação na época, que apontaram como

\footnotetext{
36 Os mocambos, também conhecidos como palhoças, são moradias simples edificadas essencialmente em taipa e palha, que se destacaram no cenário nordestino, principalmente em Pernambuco. Um dos exemplos que podem ser citados no Nordeste refere-se à construção da Vila do Arraial no Recife, em 1924, pela Fundação da Casa Operária, criada pela Lei estadual n.1.651, com a finalidade de construir moradias para serem alugadas à população verdadeiramente carente, mediante pagamentos ínfimos. Também no Recife, com intento próximo, foi fundada a Liga Social Contra o Mocambo (Resolução estadual n.02, de julho de 1939, que passou a ser chamada de Serviço Social Contra o Mocambo, graças ao Decreto-Lei n.1.118, de fevereiro de 1945), uma instituição civil, criada no contexto do programa estadual realizado pela Companhia de Erradicação do Mocambo (LIRA, 2002), coordenada por Agamenon Magalhães, que chegou a ser Ministro do MTIC. Por meio desse programa, entre os anos de $1939 \mathrm{e}$ 1942, foi demolido um total de 9.174 mocambos em todo o estado, sendo 3.121 unidades habitacionais edificadas no Recife e mais 6.222 unidades distribuídas nos demais municípios pernambucanos (GAP, 1985). Em meados da década de 1940 foi a vez do governo do estado da Bahia empreender ações contra as tipologias habitacionais urbanas das camadas mais carentes. Nesse sentido foi outorgada a Lei n.347, de 06 de outubro de 1944, por meio da qual se pretendia abolir, essencialmente de Salvador, as habitações conhecidas pelas denominações de mocambo, cortiços e casebres (GAP, 1985).

${ }^{37}$ Até esse momento, as relações proprietário/locatário eram delineadas pelo Código Civil, o qual determinava que o valor do aluguel deveria ser estabelecido pelo locador quaisquer que fossem seus critérios, tendo o locatário que aceitar essas condições. 0 mesmo se procedia em relação aos prazos para o término do contrato e as decisões de despejo (FARIA, 1963). Por meio das Leis do Inquilinato, de modo geral, foi proibida a elevação dos valores dos aluguéis, definido o prazo mínimo para a locação, bem como as normas para se proceder ao despejo (quando autorizado), além dos direitos e deveres dos locatários e locadores.

${ }_{38}$ As referências que aqueles países exerceram para os profissionais e, consequentemente, nas realizações no Brasil, principalmente no que se refere à outorga das Leis do Inquilinato, bem como à estruturação e à atuação das CAPs e dos IAPs no campo habitacional, podem ser justificadas pelas possibilidades de solução dos altos custos dos aluguéis vigentes, de alojamento, organização e disposição de serviços que, de modo geral, intentavam associar o planejamento a um programa formulado a partir de experimentos, que obtiveram grandes e satisfatórios resultados no campo habitacional naqueles países. Outro aspecto que vale ser apontado é que até aquele momento, década de 1920 essencialmente, nenhuma administração de país capitalista pensou e interveio na questão da moradia em tamanha magnitude (AYMONINO, 1973). As proposições das sociais-democracias, principalmente a que esteve à frente do poder em Berlim, nesse sentido, foram muito provavelmente incorporadas nas falas e almejos varguistas por terem se configurado "um sucesso".

${ }_{39}$ Representado principalmente pelo Decreto n. 4.403, de 1921, publicado no contexto da crise no campo da construção civil decorrente da Primeira Guerra Mundial, que comprometeu consideravelmente a produção de moradias nas grandes capitais do país, das manifestações operárias que eclodiram a partir de meados da década de 1910, do movimento dos inquilinos em prol do melhoramento das condições das moradias alugadas e da redução dos valores dos aluguéis em diversos países, nas décadas de 1910 e 1920 (ROLNIK, 1997).

40 Mais precisamente após a outorga do Decreto-Lei n.4598, de 1942. As Leis do Inquilinato perduraram até a década de 1960, se mostrando mais brandas a partir de 1961 (Projeto n.3.834, em 14 de setembro de 1961), quando os reajustes anuais não poderiam ultrapassar $12 \%$ do valor cobrado pelo aluguel.
} 
justificativa a defesa da economia popular, abalada pela elevação do custo de vida, decorrente, dentre outros aspectos, da II Guerra ${ }^{41}$.

Alguns autores como Oliveira (1971) e Bonduki (2002) vão além das justificativas oficiais expressas nos documentos históricos e especificam que a outorga das Leis do Inquilinato foi proposital para redirecionar os investimentos do mercado imobiliário para outras atividades. Mais precisamente, para esses autores, "(...) a Lei do Inquilinato estava relacionada a uma intenção governamental de reduzir a atração que 0 setor imobiliário exercia sobre os investimentos e capitalistas em geral, com o objetivo de concentrar recursos na montagem do parque industrial brasileiro (...)" e que "(...) ao reduzir a rentabilidade da locação, limitar drasticamente a liquidez do imóvel locado e introduzir incerteza e insegurança no mercado, a Lei do Inquilinato cumpriu plenamente esse papel" (BONDUKI, 2002, p.227 e 241). Em suas concepções, os empresários foram os maiores interessados no congelamento dos aluguéis, que contou com 0 apoio do Serviço Social da Indústria (Sesi) e da Fiesp, dentre outros. Bonduki (2002) sustenta sua hipótese em dados das compras de ações da Companhia de Cimento Portland Paraná na década de 1940. Segundo ele, "(...) dos 120 primeiros subscritores de São Paulo (...) em 1943, nada menos que 25 declaravam, como 'profissão', serem proprietários (...)" (BONDUKI, 2002, p.244). Um dado bastante relativo, uma vez que ser proprietário não necessariamente significava ter unidades habitacionais para aluguel.

Tais ideias se configuram como hipóteses. Supõe-se que a compra de ações não permeava a mentalidade e os intentos dos pequenos rentistas, como muitos dos proprietários de unidades habitacionais no país da época. Acredita-se que o que ocorreu naquele momento, dentre outras consequências, foi a desvalorização do aluguel e o prejuízo dessa atividade para essas pessoas, ou até mesmo seu abandono e venda de imóveis. Talvez os grandes proprietários de unidades, aqueles com grandes riquezas a serem investidas, por meio de incentivos fiscais ou outras formas de atrativo, tenham redirecionado parte de suas finanças para as indústrias, mas isso também permanece no plano da especulação. Acertadamente, Weffort (1966, p.144) colocou que é "(...) difícil saber, diante de uma decisão particular do Estado, se ele corresponde, primeiramente, a uma política deliberada ou se é meramente uma decisão útil para ampliar as bases do poder". Estudos específicos e muito mais aprofundados precisam ser elaborados nesse sentido para se poder afirmar com convicção os reais objetivos dessa ação. Por ora, resta-nos propor hipóteses cautelosas sobre 0 assunto.

Bonduki (2002, p.209) colocou também que "(...) a regulamentação do mercado de aluguéis a partir de 1942, ano em que os aluguéis foram congelados, constitui uma das principais causas da transformação das formas de provisão habitacional do Brasil (...)". Contudo, as referidas Leis não alteraram a forma de fornecimento de moradias no país, nem quando foram outorgadas pela primeira vez, em 1921, nem quando

\footnotetext{
41 Outros objetivos que estão associados à outorga das Leis do Inquilinato no Brasil, apontados no relatório do projeto de lei encaminhado ao Congresso, são: instrumento de defesa do inquilino (já instalado); brecar o atrativo que o mercado de locação exercia sobre os investimentos imobiliários; reduzir a parcela populacional que vivia basicamente da renda de locação e transformála em ativa e produtiva, a fim de aquecer a economia; empreender a casa própria; reduzir o custo da reprodução da força de trabalho e ampliar a acumulação das empresas; além de fornecer mão de obra barata às indústrias.
} 
suas restrições se mostraram mais incisivas, duas décadas depois. Continuou-se a operar a construção e 0 aluguel de unidades pelos rentistas, a se estabelecer parcerias do poder público com a iniciativa privada, por meio essencialmente da concessão de benefícios fiscais para a edificação de residências, e o poder público continuou a edificar e alugar ou financiar moradias aos trabalhadores. $O$ que foi efetivamente alterado, a partir da década de 1940, foi a abrangência das ações estatais no campo da moradia social, através da aprovação de dispositivos para alargamento de investimentos públicos, bem como a intensificação no cumprimento dessas normativas por meio de fiscalização. Esse autor afirmou ainda que as Leis do Inquilinato provocaram "(...) o surgimento de formas alternativas de produção de moradias, baseadas no autoempreendimento em favelas, loteamentos periféricos e outros assentamentos informais" (BONDUKI, 2002, p.209). Foi realmente vislumbrado o deslocamento significativo da população para as periferias, morros, alagados, loteamentos populares, etc., colaborando para o crescimento em extensão dos principais centros urbanos do país, bem como para o aumento e diversificação das favelas em cidades como o Rio de Janeiro, São Paulo, Salvador, Recife e Natal, mas não o surgimento dessas formas de morar que já eram percebidas desde fins do século XIX no Brasil.

No geral, a resposta do governo à carência de habitações nas principais cidades brasileiras, sob a forma de congelamento dos aluguéis, ao mesmo tempo em que se propunha a assegurar residência digna a baixo custo aos trabalhadores e às classes menos favorecidas, acabou por agravar ainda mais a "crise de moradia", marcada principalmente pelo déficit habitacional, desacelerando o mercado de locação/construção e favorecendo os despejos (AZEVEDO, 1996), que continuaram a ocorrer. Por outro lado, supõe-se que ao visarem o controle do mercado rentista, as Leis do Inquilinato retiraram de cena uma série de investidores no setor e incentivaram aqueles que permaneceram nele, a construírem ou adquirirem outras edificações, para nelas, aplicarem as brechas legislativas que a nova aquisição ou construção garantia para os reajustes de aluguel ${ }^{42}$. Sendo assim, essas Leis não brecaram o mercado de locação, apenas podem ter direcionado parte dos investimentos nele aplicados para outros setores, não necessariamente o industrial, ou à poupança, e fizeram muito possivelmente, com que a outra parte se reestruturasse. De qualquer forma, atendeu parte das reivindicações populares e resultou numa maior adesão ao modelo de moradia própria unifamiliar por parte dos trabalhadores e da classe média em geral.

As supracitadas ações não se mostraram suficientes para apaziguar os ânimos populares nem para sanar o déficit de moradias averiguado nos principais centros urbanos do país. Para reverter esse quadro, 0 poder público teve que se armar de outras soluções, como a institucionalização das ações imobiliárias praticadas por ele. Indubitavelmente, foram as ações empreendidas no campo habitacional por órgãos

\footnotetext{
42 Isso ocorreu, dentre outros aspectos, devido ao fato das Leis do Inquilinato serem aplicáveis, principalmente, às unidades já construídas e não às novas moradias; o que acabou por incentivar também o mercado de construção.
} 
federais criados a partir da década de 1920 - como as CAPs e os IAPs, a FCP43 e o BHN, principalmente -, que contribuíram para amenizar o quadro de déficit de moradias evidenciado naquele momento no país.

As CAPs foram criadas com essa denominação a partir de 1923, no âmbito do Ministério da Agricultura, Indústria e Comércio ${ }^{44}$, com o intuito de efetuar a organização e exercer o controle das ações dos sistemas previdenciários privados pré-existentes ${ }^{45}$. A legislação que fundou esses órgãos, sob essa denominação, é largamente conhecida como Lei Eloy Chaves ${ }^{46}$. Esse diploma legal representou a incorporação de diversos dos reclames dos trabalhadores brasileiros na legislação relativa à previdência social e, consequentemente, a consideração delas como direito social. Atendeu, essencialmente, às reivindicações da categoria trabalhista mais organizada do movimento operário no país naquela época, que apresentava um relativo poder de pressão sobre o Estado e que possuía a Caixa de Socorros mais antiga (desde 1888): os ferroviários ${ }^{47}$.

Para Farah (1983) e Bonduki (2002), a partir da década de 1910, o poder público passou a acreditar que as instituições previdenciárias privadas estavam contribuindo para as aglomerações de trabalhadores e, consequentemente, para a estruturação dessa classe e para a lapidação de suas reivindicações para com os patrões e o Estado, que resultaram nas, já citadas, das greves operárias e gerais, que ocorreram entre os anos de 1917 e 1919. Para esses autores, portanto, era imprescindível para a administração pública 0 controle das ações das mútuas, montepios e das sociedades beneficentes, por meio da criação das CAPs.

Indubitavelmente, os anos que precederam à outorga da referida Lei, sobretudo em fins da década de 1910, foram marcados por diversas reivindicações e greves de trabalhadores urbanos. Essas manifestações, como já se viu, eram direcionadas às questões salariais e às condições de trabalho, sobremaneira, o que levou a solicitações para assistências por meio de aposentadoria e pensões aos incapacitados de exercer suas atividades. Como resposta às manifestações populares daquele período, o Estado interveio por meio de medidas repressivas, determinando a ilegalidade das organizações de trabalhadores, principalmente dos sindicatos, bem como manteve as determinações restritivas quanto à liberdade de expressão. Colaborou para tanto, o significativo crescimento do movimento comunista no país. Dessa forma, considera-se que a criação das CAPs do MAIC não foi uma resposta somente às reivindicações dos trabalhadores, como colocado pelos autores acima citados, mas sim a uma série de fatores associados, que levaram o Estado a rever o seu posicionamento frente às questões sociais em nosso país. As solicitações da Liga das Nações endereçadas

\footnotetext{
${ }^{43}$ A FCP foi instituída pelo Decreto n.9.218 de 1946. Para maiores informações acerca do referido órgão, consultar: Andrade e Azevedo (1982), GAP (1985) e Melo (1990).

${ }^{44}$ Maiores detalhes acerca dessa especificação serão apresentados no tópico seguinte da tese.

45 Vale relembrar que as instituições previdenciárias estabelecidas pelo Estado até os primeiros anos da década de 1920 assistiam apenas ao funcionalismo público e ao corpo militar e o seu custeio era de responsabilidade do poder público.

${ }^{46}$ Decreto-Lei n.4.682, de 24 de janeiro de 1923.

47 O mesmo ocorreu no âmbito dos IAPs, no que se refere à criação do IAP dos Bancários. A fundação do IAPB foi precedida por uma greve nacional ocasionada por uma campanha denominada "pró-IAPB", em 18 de abril de 1934, promovida pelos sindicatos dos Bancários do Rio de Janeiro e apoiada por vários outros sindicatos do país. A greve durou três dias e é considerada pela historiografia como a primeira greve nacional da categoria. Seu objetivo se concentrava essencialmente na conquista da aposentadoria aos trinta anos de serviço e cinquenta anos de idade, a estabilidade financeira no emprego a partir de um ano de serviço e a criação de uma Caixa de Aposentadoria e Pensões unificada para a categoria (HISTÓRIA..., 07/1934, s/p).
} 
aos líderes dos países para solucionar as questões referentes à normatização do trabalho e da previdência, aliada a aceleração do processo de industrialização e de urbanização das cidades brasileiras são alguns aspectos, para além das reivindicações trabalhistas, que levaram à fundação das CAPs no âmbito das empresas ferroviárias em todo o país.

Por meio do Decreto n.4.682 de 1923, os empregados de qualquer empresa ferroviária do país passaram a serem atendidos por uma Caixa de Aposentadoria e Pensões, a qual ficaria responsável pela concessão de aposentadoria (ordinária ou por invalidez), pensão para os herdeiros do beneficiado, socorros médicos a ele ou ao membro de sua família registrado previamente, além da aquisição de remédios com descontos especiais determinados pelo Conselho de Administração das CAPs e um pecúlio pago em dinheiro aos membros da família em caso de morte do empregado 48 .

As Caixas atuavam no âmbito estadual e municipal e a vinculação dos trabalhadores a elas se dava por meio das empresas. A administração das CAPs era realizada por um colegiado conformado por representantes dos empregadores e dos empregados, que tinham o mesmo poder de decisão - o Conselho Administrativo $^{49}$-, cuja responsabilidade era de fiscalizar as ações e arrecadações das empresas e nomear 0 pessoal necessário para a realização de suas atividades. O Estado apenas fiscalizava todo o processo por meio do Conselho Nacional do Trabalho50.

A forma de vinculação de um empregado de empresa ferroviária à sua CAP se dava por meio de registro e uma contribuição mensal, deduzida em folha de pagamento pelo empregador. A contribuição poderia ser realizada mesmo após dispensa do empregado "(...) por serem prescindíveis os seus serviços, ou por motivo de economia (...)", se ele possuísse mais de cinco anos de serviço (DECRETO, n.4.682, 24/01/1923). O esquema de arrecadação, por sua vez, se estruturava essencialmente nas contribuições dos empregadores e dos empregados, sendo administrado pelas próprias empresas e somente fiscalizado pelo Estado. Mais precisamente, formavam os fundos das Caixas:

a) uma contribuição mensal dos empregados, correspondente a $3 \%$ dos respectivos vencimentos;

b) uma contribuição anual da empreza, correspondente a $1 \%$ de sua renda bruta;

c) a somma que produzir um augmento de $1 \frac{1 / 2}{2} \%$ sobre as tarifas da estrada de ferro;

d) as importancias das joias pagas pelos empregados na data de creação da caixa e pelos admittidos posteriormente, equivalentes a um mez de vencimentos e pagas em 24 prestações mensaes;

\footnotetext{
48 Eram considerados empregados não somente aqueles que prestassem os seus serviços mediante ordenado mensal, mas também os trabalhadores diaristas, de qualquer natureza, que executassem serviços de caráter permanente - aqueles que possuíssem mais de seis meses de serviços contínuos em uma mesma empresa (DECRETO, n.4.682, 24/01/1923).

49 Mais especificadamente, conformavam o Conselho: o superintendente ou inspetor geral da empresa (que viria a ser o presidente do Conselho), dois empregados seguintes ao cargo de superintendente ou inspetor na hierarquia da empresa e mais dois representantes dos trabalhadores. Todos os supracitados membros desempenhavam suas funções gratuitamente e eram eleitos a cada três anos. A partir de 1931, devido à outorga do Decreto n.20.465, de primeiro de outubro, 0 número de membros que compunha o Conselho das CAPs passou a ser proporcional ao número de associados, bem como às funções pela Caixa desempenhadas.

50 Criado por meio do Decreto $n^{\circ}$. 16.027, outorgado em 30 de abril de 1923.
} 
e) as importancias pagas pelos empregados, correspondentes á differença no primeiro mez de vencimentos, quando promovidos ou augmentados de vencimentos, pagas tambem em 24 prestações mensaes;

f) 0 importe das sommas pagas a mais e não reclamadas pelo poder público dentro do prazo de um anno ${ }^{51}$;

g) as multas que attinjam o público e o pessoal;

h) as verbas sob rubrica de venda de papel velho e varreduras;

i) os donativos e legados feitos á, Caixa;

j) os juros dos fundos acumulados (DECRETO, n.4.682, 24/01/1923).

Ainda em 192352, as tarifas das estradas de ferro foram elevadas na proporção citada $(1,5 \%)$ para auxiliar os fundos das CAPs dessas empresas. Os valores arrecadados pelas empresas deveriam ser depositados em uma conta em banco a ser escolhido pela administração da Caixa. Esses fundos eram aplicados, de acordo com as resoluções do Conselho de Administração, na aquisição de títulos de renda nacional ou estadual, ou que tivesse garantia da Nação e dos estados ${ }^{53}$.

A determinação de criação das Caixas de Aposentadoria e Pensões no âmbito dos ferroviários foi estendida para os trabalhadores das empresas portuárias (exploração) e para os trabalhadores da navegação marítima e fluvial no ano de $1926^{54}$. De modo geral, o modelo de organização e regulamentação das ações das CAPs dos ferroviários foi ampliado às demais ao logo da década de 1920.

Em 192855, o regime da Lei Elói Chaves foi ampliado aos trabalhadores dos serviços telegráficos e radiotelegráficos. As normas para funcionamento desta CAP eram as mesmas estabelecidas pelo decreto ${ }^{56}$ que instituiu o Regulamento da CAP dos Ferroviários aos Marítimos ${ }^{57}$. A criação das CAPs foi ampliada a outras carteiras trabalhistas ${ }^{58}$, através do Decreto n.19.497, de 17 de dezembro de 1930.

Passado um ano da data de criação da CAP dos ferroviários já existiam no país 26 Caixas de Aposentadoria e Pensões, cujas receitas somadas totalizavam Cr\$21.497.317,20 (cruzeiros), aumentando para Cr\$60.808.507,90 (cruzeiros), em 1928. O número de segurados pelas CAPs, por sua vez, em 1923, era ínfimo, subindo para 22.991 trabalhadores após a criação das CAPs dos portuários e para 140.435, em 1929, após a ampliação das CAPs para os serviços telegráficos e radiotelegráficos. As aposentadorias e

\footnotetext{
${ }^{51}$ A quantia referente a toda e qualquer pensão ou aposentadoria não solicitada ou reclamada por herdeiros em um ano depois de concluído o desligamento do associado da empresa, e aquelas perdidas sob pena ou autorização do CNT eram encaminhadas às contas bancárias das CAPs.

52 Com a outorga do Decreto n.4.682, em janeiro.

53 Não era permitido que os valores arrecadados pelas empresas provenientes dos vencimentos salariais fossem menores que aqueles de sua renda bruta anual. Caso isso ocorresse, as empresas não poderiam haver nada dos fundos de sua CAP. As empresas ferroviárias que não depositassem no devido tempo e pelas formas estabelecidas por lei, as quantias a que eram obrigadas, incorreriam em multas de 1:000\$ por dia de atraso, até que fossem efetuados os depósitos. Cabe lembrar que 0 Conselho era conformado em sua grande parte por representantes das empresas, o que deve ter contribuído para a inadimplência na arrecadação.

54 Por meio do Decreto n.5.109, de 20 de dezembro.

55 Graças à Lei $n^{\circ} 5.485$, de 30 de junho.

56 De n.5.109, de 20/12/1926.

57 Apesar de passarem a serem assistidos pelos benefícios da aposentadoria e pensões, os trabalhadores em empresas de telégrafos e rádio-telégrafos não recebiam auxílios referentes aos serviços e/ou socorros médicos e obtenção de medicamentos (DECRETO N.5.485, 30/06/1928).

58 Aos serviços de força, luz, bondes e telefones a cargo dos estados, municípios e particulares, e aos serviços de telegrafia e radiotelegrafia, mantidos por particulares o regime do Decreto n.5.109, de 20 de dezembro de 1926 (DECRETO N.19.497, 17/12/1930).
} 
pensões concedidas pelos órgãos no ano de 1929 totalizavam 10.797 beneficiados, sendo 6.930 aposentadorias e 3.867 pensões (PROJETO DO DECRETO N.20.465, 01/10/1931). Em 1930, já existiam em todo o país 47 Caixas de Aposentadoria e Pensões, num total de aproximadamente 150.000 segurados (GAP, 1985).

A partir de outubro de $1931^{59}$, passou a ser exigida e obrigatória a criação de uma Caixa de Aposentadoria e Pensão no âmbito de toda e qualquer empresa nacional. Até então, a existência de uma CAP dependia do interesse dos trabalhadores e/ou da empresa particular ou pública:

(...) Os serviços públicos de transporte, de luz, força, telégrafo, portos, água, esgotos ou outros que venham a ser considerados como tais, quando explorados diretamente pela União, pêlos Estados, Municípios ou pôr emprêsas, agrupamentos de empresas ou particulares, terão, obrigatoriedade, para os empregados de diferentes classes ou categorias, Caixas de Aposentadoria e Pensões, com personalidade jurídica, regidas pelas disposições desta lei e diretamente subordinadas ao Conselho Nacional do Trabalho (...) (DECRETO N.20.465, 01/10/1931).

Dentre as modificações empreendidas por essa legislação, estava a obrigatoriedade de realização de exame médico antes de qualquer contratação de pessoal, para que fosse averiguada e comprovada a capacidade física para o exercício de qualquer função e a obrigatoriedade da contribuição permanente dos associados ativos para com a CAP60. A partir desse momento, a vinculação/contribuição dos trabalhadores das empresas a uma CAP passou a ser obrigatória61.

Ainda em 1932, foram estendidas as determinações vigentes para as empresas de mineração em geral e para a empresa Cia Vale do Rio Doce S.A., cujas atividades envolviam mineração, transporte e outros serviços $^{62}$. Pela legislação outorgada nesse ano, também passaram a ser considerados como de utilidade pública os serviços relacionados à Impressa Nacional (CAPIN). A partir de 1933, algumas CAPs foram incorporadas aos IAPs e passaram a seguir os seus regulamentos, tanto no que concerne à previdência como à habitação.

Os Institutos de Aposentadoria e Pensões subordinados ao MTIC foram criados, sob essa denominação63, no contexto do projeto getulista, para aperfeiçoar o sistema previdenciário do país, atender

\footnotetext{
59 Por meio do Decreto n.20.465, outorgado em 01 de outubro daquele ano.

60 Essa taxa passou a ser calculada com base no salário dos trabalhadores e a ser variável para cada Caixa. Também a partir da outorga desse Decreto, 0 cálculo da aposentadoria passou a ser variável dentre as Caixas e somente aprovadas pelo CNT. 0 presidente do Conselho de Administração da CAP passou a ser eleito por votação dentre os membros que o compunham e não mais designado pelo poder público ou pelo CNT. O mandato de três anos dos membros do Conselho passou a ser cabível de renovação por mais três (DECRETO N.20.465, 01/10/1931).

61 Pelo mesmo diploma legal foi determinado a contribuição das empresas de $11,5 \%$ da renda bruta anual. A contribuição do Estado passou a ser direta, configurando o formato de arrecadação tripartite para as empresas de transporte. A sua denominação passou a ser "quota da previdência", que já existia para os serviços públicos. A elaboração dos regulamentos para criação e funcionamento de uma CAP, exigidos pelo CNT no ato de sua criação, que até o momento era de responsabilidade de seu Conselho Administrativo, tornou-se de responsabilidade do poder público, passando a ser redigido pelo próprio Conselho Nacional do Trabalho, que poderia expandi-lo ou reduzi-lo quando julgasse necessário. O CNT que funcionava até então como órgão de análise, de aprovação das regulamentações e de fiscalização das arrecadações realizadas pelas Caixas, passou a representar também um órgão deliberativo, subordinado ao recém-criado MTIC.

62 Por meio do Decreto n.22.096, de 16 de novembro de 1932.

63 Especificações sobre esse aspecto serão apresentadas no tópico seguinte.
} 
de forma mais eficaz às necessidades básicas dos trabalhadores e reafirmar o papel do Estado após a Revolução de 1930, a partir do ano de 1933. O primeiro deles foi o IAP dos Marítimos (IAPM) ${ }^{64}$, em 1933, seguido pelo dos Comerciários (IAPC) ${ }^{65}$ e dos Bancários (IAPB) ${ }^{66}$, em 1934, e pelo dos Industriários (IAPI) ${ }^{67}$, em 1936. O Instituto dos Servidores Públicos passou a ser denominado de Instituto de Previdência e Assistência dos Servidores do Estado (IPASE) ${ }^{68}$, em 1938.

Merece ser destacado, que ao mesmo tempo em que estavam sendo criados os Institutos, diversas Caixas foram fundadas, como foi o caso da CAP dos Trabalhadores em Trapiches e Armazéns de Café69 e dos Estivadores (CAPE) ${ }^{70}$, nos ano de 1932 e 1934. Apesar de suas denominações permanecerem Caixas de Aposentadoria e Pensões, os órgãos fundados após 1933, possuíam abrangência nacional e atendiam às categorias trabalhistas de modo geral, diferente das CAPs da década de 1920, que apesar de existirem em todo o país, os vínculos se davam somente e diretamente por empresas específicas, como as estradas de ferro. De acordo com Farah (1983), a alteração na abrangência dos IAPs foi uma medida essencial para a extensão dos direitos sociais a todos os assalariados urbanos do país, uma vez que se passou também a exigir a contribuição aos Institutos. No entanto, diferente do colocado por aquela autora, e como percebido anteriormente, a contribuição obrigatória às CAPs já era percebida desde 1931, garantida pelo Decreto n.20.465, de 01 de outubro daquele ano.

Os IAPs do MTIC possuíam objetivos mais amplos e diversificados que as CAPs do MAIC. Eram eles: garantir pagamentos mensais aos seus associados em caso de doenças, incapacidade ou morte do chefe de família; assistência médica ${ }^{71}$; investimentos em setores diversos, inclusive em obras públicas; além de assistência aos programas sociais governamentais, inserindo-se nessa categoria, apesar de ínfima inicialmente, a produção de moradias.

Primeiramente, as reservas disponíveis dos Institutos poderiam ser aplicadas em operações de crédito realizadas com seus contribuintes, em imóveis para abrigo da sede, títulos com garantia real e títulos garantidos pelo Governo Federal. Posteriormente, foi autorizada a aquisição ou construção de moradias para

\footnotetext{
64 Por meio do Decreto n.22.872, de 29 de junho.

65 Instituído pelo Decreto n.21.273, de 22 de maio de 1934.

${ }^{66}$ A partir do Decreto n.24.615, de 09 de julho de 1934.

67 Através da Lei n.367, de 09 de setembro de 1936.

68 Por meio do Decreto-Lei n.288, de 23 de fevereiro de 1938. Eram contemplados pelo IPASE os trabalhadores que exerciam função civil ou militar, federal, estadual ou municipal, inclusive os empregados do próprio Instituto e os membros do Poder Legislativo e Executivo. Os montepios e caixas de socorros pré-existentes foram contemplados pelo Decreto-Lei de criação do IPASE, passando a ser possível a opção entre o regime anterior e o instituído por esta lei, para o efeito de benefício de família. As despesas para a organização do IPASE foram custeadas com os recursos do Instituto Nacional de Previdência (Decreto-Lei n. 288, 23/02/1938). No caso especial deste Instituto, havia a possibilidade de contratação de seguros facultativos, como de renda e de morte. As administrações estaduais e/ou municipais ainda poderiam, ao seu gosto, criar outras modalidades de seguros facultativos ou assistências e previdência.

69 Fundada pelo Decreto n.24.274, de 22 de maio de 1934.

70 Criada pelo Decreto n.24.275, de 22 de maio de 1934. A CAPE foi transformada em IAP dos Estivadores (IAPE) e a CAP dos Trabalhadores em Trapiches e Armazéns de Café, em IAP dos Empregados em Transportes e Cargas (IAPTEC), ambas no ano de 1945.

71 Não previam a concessão de medicamentos, nem a aquisição dos mesmos com descontos especiais, como observado em algumas Caixas.
} 
os associados, como se verá mais detalhadamente a seguir. Com isso, o país passou da previdência social isolada para o sistema de seguridade social, abarcando não somente a previdência propriamente dita, mas também a assistência social e a saúde ${ }^{72}$.

Segundo Farah (1983), houve uma limitação inicial dos investimentos dos IAPs no campo da moradia, associada ao caráter contencionista instituído pelo Estado à Previdência Social no período de 1930 a 1945, que teve como principal finalidade garantir o maior volume possível de recursos arrecadados pelas instituições de previdência para setores estratégicos ao desenvolvimento econômico do país. De acordo com a autora, isso somente se mostrou possível devido à centralização política estabelecida a partir de 1930 e ao controle imposto pelo Estado às manifestações dos trabalhadores durante o Estado Novo. No entanto, acredita-se que aquele aspecto assim se conformou também pelo fato do período, compreendido entre os anos de 1930 e 1945, equivaler ao de aquisição de terrenos para a formação do patrimônio imobiliário dos órgãos, onde foram edificados os grupos de moradias, além de representar o tempo de construção de muitos deles, uma vez que, diversos começaram a ser comercializados a partir de meados da década de 1940, como será colocado mais detalhadamente no capítulo acerca da atuação dos institutos de previdência no Nordeste.

De acordo com os decretos e decretos-lei de criação dos IAPs do MTIC, a forma de arrecadação das contribuições para os Institutos e a administração desses órgãos também sofreram alterações em relação às das CAPs precedentes. Até então, no âmbito das Caixas, o modelo de arrecadação era conformado pelas contribuições dos empregados e empregadores essencialmente ${ }^{73}$. As quantias acumuladas eram geridas pelas próprias Caixas, enquanto o Estado, somente participava da fiscalização dessas ações. A administração das CAPs do MAIC era realizada por um colegiado, formado por representantes das empresas e dos trabalhadores. Com a criação dos IAPs do MTIC, a partir de 1933, o modelo de arrecadação passou a ser oficialmente tripartite com a inclusão do Estado, definitivamente, como contribuinte ${ }^{74}$ e a Previdência Social começou a ser gerida diretamente pelo poder público, que também passou a nomear os presidentes de cada Instituto - como se procedia com as mútuas e montepios anteriormente -, além de controlar, administrar e fiscalizar suas ações por meio do recém-criado Ministério do Trabalho, Indústria e Comércio (MTIC).

A partir de meados da década de 1930, o que se vislumbrou foi a incorporação de novas categorias profissionais assistidas pela previdência estatal, bem como a ampliação do número de trabalhadores urbanos associados. O Anuário Estatístico do Brasil, elaborado pelo IBGE, no ano de 1950, quantificou essa afirmativa. No ano de 1932 estavam registrados 200.000 (duzentos mil) trabalhadores vinculados às CAPs. Em 1940, esse número passou para 2.000 .000 (dois milhões) de associados aos IAPs e às CAPs, passando

\footnotetext{
72 Oficialmente, esse aspecto só passou a ser garantido pela Constituição de 1988.

73 Refere-se aos órgãos antes da outorga do Decreto n.20.645, de 1931, com exceção das CAPs dos serviços públicos que recebiam a taxa previdenciária, como colocado no tópico anterior.

74 Para a definição das contribuições mensais dos trabalhadores aos Institutos de Aposentadoria e Pensões, bem como os benefícios de cada categoria, foram organizadas comissões para a realização de pesquisas censitárias em todo 0 país. Cabe ressaltar, que a contribuição tripartite só passou a constar em carta magna, na Constituição de 1934.
} 
para 3.000.000 (três milhões) de empregados urbanos cadastrados no ano de 1949. As questões vinculadas à atuação dos referidos órgãos no campo habitacional no país serão apresentadas a seguir.

Antes de iniciarmos as análises das ações das CAPs e dos IAPs do MTIC no campo habitacional, bem como a trajetória, o volume e a caracterização delas no decorrer das quatro décadas de atuação aqui enfocadas, mostra-se imprescindível reavaliar algumas considerações que foram repetidas na historiografia especializada e são perpetuadas em diversos trabalhos e estudos sobre a temática da habitação e a ela relacionados ${ }^{75}$.

Além dos equívocos apresentados e discutidos no tópico anterior, relacionados, sobretudo, à Lei do Inquilinato e às justificativas para a criação de uma Caixa de Aposentadoria e Pensões em cada empresa do país, mostra-se ainda necessária a discussão de diversos outros aspectos, que vão desde a especificação de marcos históricos, como o de criação das CAPs e o de "início" da atuação estatal no campo previdenciário, passando pela cronologia das ações no campo habitacional e, até mesmo, no que diz respeito ao suposto encerramento das ações dos IAPs, no ano de 1964.

\subsection{Reavaliando Alguns Consensos Historiográficos}

Inicialmente, vale destacar que as Caixas de Aposentadoria e Pensões (CAPs) as quais, a historiografia especializada afirma terem sido criadas em 1923, por meio do Decreto-Lei n.4.682, de 24 de janeiro (FARAH, 1983; VARON, 1989; BONDUKI, 2002), já existiam bem antes disso. Autores que estudam a história do trabalho no país, como Angela de Castro Gomes (2007), também recaem nesse equívoco: "(...) as Caixas de Aposentadorias e Pensões (CAPs) foram criadas em 1923, mesmo ano de instalação do Conselho Nacional do Trabalho, inicialmente, apenas para os ferroviários. (...)" (GOMES, 2007, p.136).

A primeira Caixa, aos moldes das demais CAPs, foi criada em 188976, no âmbito do Ministério da Fazenda e refere-se à Caixa de Pensões da Imprensa Nacional (CPIN) ${ }^{77}$. Essa Caixa atendia aos funcionários da Casa da Moeda, do Tesouro da União, do Diário Oficial, dos Correios, do Ministério da Fazenda e das demais repartições subordinadas. Apesar de não incluir a aposentadoria em sua nomenclatura, realizava o pagamento de pecúlios ao associado por velhice, como especificado na legislação relacionada: "(...) Art.51. As pensões serão concedidas sob as bases e condições seguintes: $§ 1^{\circ} 0$

\footnotetext{
${ }^{75}$ É importante destacar que o propósito da formulação deste tópico da tese, bem como da apresentação de alguns lapsos e/ou análises críticas nesse sentido, não foi o de negar as contribuições dos autores mencionados. Contribuições essas, devidamente destacadas na introdução (vide páginas 25 a 29). Mas sim, o de complementar e/ou sanar algumas informações e considerações acerca da atuação do poder público no campo da moradia social em nosso país.

${ }^{76}$ Por meio do Decreto n.10.269, de 20 de junho daquele ano.

${ }^{77}$ A Imprensa Nacional foi criada por meio da Lei n.369, de 18 de setembro de 1845, sendo subordinada ao Ministério da Fazenda. Era composta pelos funcionários, inicialmente da capital federal, vinculados à publicação e impressão de leis e decretos, bem como dos demais trabalhos gráficos e complementares das repartições e estabelecimentos públicos (DECRETO N.4.680, 14/11/1902).
} 
empregado ou operario que contar 25 annos ou mais de serviço effectivo e se achar impossibilitado de nelle continuar, por moléstia ou velhice, tem direito a uma pensão (...)" (DECRETO n.4.680, 14/11/1902) ${ }^{78}$.

As CAPs, criadas a partir de 1923 no país, diferentemente da Caixa de Pensões da Imprensa Nacional vinculadas ao Ministério da Fazenda, foram subordinadas ao Ministério da Agricultura, Indústria e Comércio (MAIC). Contudo, ambas seguiram o modelo de estruturação e regulamentos implementados, inicialmente, pela CPIN. A semelhança dessa, as CAPs criadas na década de 1920, concediam auxílio funeral, pensões aos associados e herdeiros, nas mesmas condições da anterior. Operavam essencialmente com as contribuições dos trabalhadores e das "empresas", incluindo também as multas, importâncias não solicitadas por eles ou seus herdeiros, juros de título de dívida pública e outras contribuições diversas, inclusive doações. Suas ações, do mesmo modo, eram regidas e fiscalizadas por uma Junta Administrativa.

Da mesma forma que as publicações sobre a temática da habitação e da previdência imputam a criação das CAPs à Lei Eloy Chaves, consideram-na como o principal marco historiográfico nesse sentido: "(...) a regulamentação da previdência social teve início em 1923 com a aprovação da Lei Elói Chaves, que deu origem às Caixas de Aposentadoria e Pensões (CAPs)" (BONDUKI, 2002, p.101); "(...) 0 deputado paulista Eloi Chaves aprova seu projeto de criação da Caixa de Aposentadoria e Pensões para os ferroviários, a primeira das CAPs. É considerada a lei de previdência inaugural do país (...)" (GOMES, 2007, p.24). No entanto, o supracitado Decreto-Lei somente estendeu o benefício da aposentadoria e pensões às empresas ferroviárias brasileiras. Cabe lembrar que apenas a CAP dos Ferroviários foi criada naquela ocasião e não todas as CAPs, como comumente apontado por diversos autores. As demais Caixas foram fundadas ao longo das décadas de 1920 e 1930. Somente em 193179, mais precisamente, o benefício das CAPs foi ampliado a todas as empresas e serviços de caráter público ou privado no país.

Até os primeiros anos da década de 1930, apenas algumas empresas relacionadas à prestação de serviço e à infraestrutura, bem como os serviços militares e os servidores públicos, tinham regimento e autorização para criar uma CAP. Os trabalhadores das demais empresas de caráter privado não recebiam assistência médica, aposentadoria ou pensões subsidiadas pelo poder público até aquele momento. Dessa forma, elenca-se o Decreto n.20.465 de 1931, não o Decreto-Lei n.4.682 de 1923, como o marco principal da ação estatal no campo previdenciário do país entre os anos de 1920 e 1930. Vale salientar, que esse deslize não é cometido apenas por autores das áreas de história, arquitetura e ciências sociais, como também ocorre em diversos trabalhos de cunho jurídico. Dessa forma, mais incisivamente, a Lei Eloy Chaves não criou as CAPs como apresentado até então por alguns autores, mas sim e apenas, a Caixa de Aposentadoria e Pensões dos Ferroviários.

Seguindo a mesma linha de raciocínio, a Lei Eloy Chaves não equivale à primeira legislação previdenciária brasileira, como colocado pela historiografia da habitação. Desde a Constituição Imperial de

\footnotetext{
${ }^{78}$ Esse benefício passou a ser obrigatório com a outorga da Constituição de 1891.

${ }^{79}$ Com a outorga do Decreto n.20.465, em 01 de outubro, que reforçou e reformulou o Decreto n.5.109, de 20 de dezembro de 1926.
} 
1824, o poder público se comprometeu com o sustendo e atendimento assistencial, ainda incipiente, à população sem condições de trabalho, por velhice, doença ou invalidez. Da mesma forma, os servidores públicos da União contavam desde 1888, com a Caixa de Socorros para os Trabalhadores das Estradas de Ferro de Propriedade do Estado ${ }^{80}$, ampliada, em 1889, para os trabalhadores dos Correios, Oficinas da Imprensa Régia, sob a denominação de CPIN. Desde 1890, funcionários públicos já possuíam também 0 Montepio Obrigatório dos Empregados do Ministério da Fazenda, reestruturado em 1926, a partir de quando passou a ser chamado de Montepio dos Funcionários Públicos da União. Organizações de caráter estatal, assistencial e previdenciário. Sendo assim, a gênese da intervenção do poder público no âmbito previdenciário no Brasil, não se deu a partir de 1923, com a outorga da Lei Eloy Chaves, mas sim, bem antes disso. Não podendo ser imputada a supracitada Lei um marco tão importante como colocado por aqueles autores ${ }^{81}$.

Também é largamente perpetuada pela historiografia especializada, a noção de que até a "criação das CAPs", em 1923, observava-se a ineficiência das instituições privadas quanto à garantia da concessão de benefícios e assistência à população atendida. Afirma-se, mais especificadamente que, por vezes, as receitas arrecadas por aquelas instituições eram insuficientes para garantir, essencialmente, a aposentadoria para os trabalhadores, como apontado por Farah (1983), Varon (1988) e Bonduki (2002). No entanto, vale aqui ressaltar que, excetuando a Caixa de Pensões da Imprensa Nacional, apesar da criação das CAPs do MAIC e suas regulamentações oficiais dadas pelo CNT, diversas brechas legislativas foram encontradas e revelam que não era plenamente assegurado ao trabalhador/contribuinte o recebimento dos benefícios, aposentadoria e pensões. Para atestar essa afirmativa basta-nos referenciar uma das regulamentações outorgadas nesse sentido:

(...) A aposentadoria a que este artigo se refere (...) deixará de ser concedida (...) quando ficar devidamente comprovada, a juízo do Conselho Nacional do Trabalho e com recurso para o ministro do Trabalho, Indústria e Comércio, a impossibilidade do pagamento integral, decorrente de razões de ordem atuarial, econômica e política (...) (DECRETO N.21.465, 24/02/1932).

Mais precisamente, o Art.72, do Decreto n.20.465, deixa clara a possibilidade de fechamento de uma empresa e o consequente desligamento de sua CAP e, dessa maneira, do atendimento de seus funcionários quanto às pensões e aposentadorias:

(...) extinguindo-se alguma das empresas a que se aplicar a presente lei, o Conselho Nacional do Trabalho promoverá a liquidação da respectiva Caixa (...). Solvidas as dívidas,

\footnotetext{
80 Criada por meio da Lei n.3.397, em 24 de novembro de 1888.

81 Em contrapartida, cabe destacar que algumas inovações foram possibilitadas por meio do Decreto-Lei n.4.682 de 1923. Uma delas refere-se à criação do Conselho Nacional do Trabalho (CNT), também subordinado ao Ministério da Agricultura, Indústria e Comércio. Até então, a arrecadação dos fundos, bem como a fiscalização das ações da CPIN eram geridas e fiscalizadas por uma Junta Administrativa vistoriada, por sua vez, diretamente pelo Ministro da Fazenda. O que passou a ocorrer com a criação da CAP dos Ferroviários, além da criação de uma Caixa no âmbito do Ministério da Agricultura, foi a institucionalização daquelas funções pelo CNT. .
} 
as contribuições dos associados Ihes serão restituídas, respeitadas, porém, tanto quanto possível, as aposentadorias e pensões em vigor (...) (DECRETO N.20.465, 01/10/1931).

O Art.79 da mesma legislação especificou ainda que os benefícios de aposentadoria, pensões e outros poderiam ser menores que aqueles estabelecidos por lei, caso os fundos das Caixas não pudessem suportar os encargos respectivos. Essa redução ou até cessação das funções de uma CAP poderia ser perpetuada enquanto permanecesse a insuficiência de recursos, mediante a aprovação do CNT, ou definitiva, ficando seus associados desamparados nesse sentido. Apenas a partir da consideração desses direitos como sagrados e de responsabilidade do poder público, por meio da Constituição de 1934, que os trabalhadores do país foram realmente assegurados, mediante o pagamento de contribuições.

Por outra ótica, historiadores, a exemplo de Silva Júnior (2007), colocaram que para que o sistema previdenciário privado, representado especialmente pelas mútuas e montepios, não se conformasse como um concorrente na efetivação do sistema estatal, o Estado, ao longo dos anos, interveio ao ponto de inviabilizar essas entidades, contribuindo para a sua extinção com 0 início da previdência estatal em maior escala na década de 1920. Acredita-se que esta tentativa pode até ter existido, mas não obteve êxito, uma vez que dados estatísticos do IBGE apontam para a existência de uma gama de mútuas ainda na década de 1930 e que, aproximadamente, $20 \%$ da população atendida pela previdência no país, incluindo a estatal, estava associada às mútuas, nesse período.

Mais especificadamente, os dados levantados no IBGE colocam que quase 40\% das entidades mutuais no Brasil foram criadas a partir de 1942, reforçando ainda mais a afirmativa anterior. Esse elevado número pode ser justificado, provavelmente, porque parte da população do país, como alguns trabalhadores rurais, os trabalhadores informais urbanos, dentre outros, não eram atendidos pela previdência estatal naquele momento, e passaram a se organizar independentemente. Cabe aqui destacar, porém, que o número de filiados às mútuas e aos montepios não corresponde efetivamente ao número de segurados, uma vez que essas associações concediam benefícios também às famílias dos associados. É claro que o número de mutuais foi reduzido após a criação da previdência estatal, não somente por este motivo, mas devido também à inadimplência de alguns dos associados e ao não atendimento de outros, além de problemas de organização e distribuição dos valores arrecadados e empecilhos legislativos criados pelo poder público nesse sentido. A redução do tempo de existência e do número de mútuas a partir da década de 1920, também se deve à falta de incentivo estatal.

Outra avaliação negada pelos dados acima e facilmente encontrada na historiografia é a de que as mútuas e montepios se conformam como a "pré-história" do movimento operário e da organização dos trabalhadores e que originaram os sindicatos. As sociedades de socorros mútuos, na realidade, coexistiram com os sindicatos até, pelo menos, meados da década de 1940, como foi o caso de sociedades em São Paulo, Minas Gerais, Rio Grande do Sul, Salvador e Recife, não se excluindo o fato de algumas sociedades de socorros mútuos terem se transformado em sindicais (SILVA JR., 2007). Cláudia Viscardi e Ronaldo Jesus 
(2007, p.24), em estudo sobre a esquerda no Brasil, também compartilham desta ideia, afirmando que "(...) a experiência mutualista foi simultânea à organização dos sindicatos (inclusive os de esquerda) e contribuiu para a formação e o fortalecimento de uma cultura cívica entre os trabalhadores, indispensável ao processo de construção da cidadania no Brasil". Por outro lado, os referidos autores acreditam que as mútuas e montepios foram extintos após a instituição da previdência estatal, o que não ocorreu.

Neste momento, é importante ressaltar que a contribuição estatal às CAPs não se dava de modo homogêneo a todas as Caixas, nem de forma direta, como colocado por Farah (1983) e reafirmado em diversos trabalhos posteriores: "(...) Nas CAPs, o Estado participava apenas (...) como um dos contribuintes em um sistema tripartite que envolvia, além do próprio Estado, os empregados e os empregadores (...)" (FARAH, 1983, p.22); "(...) o esquema de funcionamento das CAPs, que serviria de modelo para a criação dos Institutos de Aposentadorias e Pensões, estava estruturado na contribuição tripartite (empregado, empregador e Estado)" (BONDUKI, 2002, p.102).

Essa contribuição estatal não era dada a todas as CAPs. Só ocorria no âmbito das empresas de transporte, inclusive após a criação de outras CAPs ao longo das décadas de 1920 e 1930. Nos casos que ocorria, a verba não era reservada no orçamento da União e repassada automaticamente àqueles órgãos. Ocorria um aumento das tarifas públicas e o redirecionamento dele para as reservas - abrangendo as contribuições pagas pelo público em transporte de passageiros, de mercadorias, encomendas, bagagens, armazenagem, carga, descarga, dentre outras - para os fundos, o que foi convencionado ser chamado de "taxa de previdência" (DECRETO N.5.485, 30/06/1928). O Decreto n.20.465, de 01 de outubro de 1931, especificou claramente essa forma de contribuição estatal:

(...) As emprêsas de transporte enviarão, de três em três meses, ao Conselho Nacional do Trabalho, uma demonstração da receita arrecadada, proveniente das passagens nos trens de subúrbios de pequeno percurso, nos bondes e nos ônibus, para que sobre a importância produzida seja calculada a taxa de $2 \%$ e possa, assim, o Ministério da Fazenda, à vista da requisição do Ministério do Trabalho, Indústria e Comércio, providenciar no sentido de serem emitidas apólices da dívida pública federal a juros de $5 \%$, as quais serão entregues às suas Caixas de Aposentadoria e Pensões, como contribuição do Estado (DECRETO N.20.465, 01/10/1931).

Por esse mesmo Decreto de 1931, a taxa de previdência passou a ser chamada de cota de previdência e foi estendida a outros serviços de infraestrutura. É interessante notar que a taxa ou cota de previdência, equivalia ao valor pago pelo Estado às CAPs e se conformava como sua contribuição, oriunda das taxas de utilização e uso de alguns serviços públicos oferecidos pelas empresas. Sendo assim, a contribuição do Estado às CAPs era, em parte, financiada pelas próprias Caixas e pela população em geral.

Da mesma forma, pode-se afirmar que o ônus da edificação e/ou aquisição de moradias realizada pelas CAPs do MTIC, a partir da década de 1930, não recaiu sobre o poder público como colocado por Bonduki (1996, p.981): “(...) o Estado, ao produzir ele próprio a moradia (...)"; mas sim, sobre as empresas e os trabalhadores contribuintes do país. Isso pode ser observado mesmo depois da criação dos IAPs do MTIC, 
no âmbito dos quais foi instituída efetivamente a contribuição tripartite, uma vez que por diversos momentos, o poder público e até algumas empresas se mostraram inadimplentes, ficando a cargo dos trabalhadores associados às CAPs e aos IAPS, o verdadeiro ônus para aquisição, construção ou aluguel de uma moradia no país ${ }^{82}$.

A administração pública financiou com as verbas de seus cofres efetivamente, a construção de moradias apenas para o funcionalismo público e para os militares, que contavam, como especificado no Decreto n.21.330, de 27 de abril de 1932, “(...) com as contribuições mensais permanentes e obrigatórias dos seus associados (...), a contribuição anual da Imprensa Nacional e a contribuição do Estado (...)". Somente a partir de 1934, foi instituída efetivamente a contribuição tripartite em todas as CAPs e IAPs.

Da mesma forma que a CAP dos ferroviários não correspondeu à primeira do país, uma vez que já existia a Caixa de Pensões da Imprensa Nacional subordinada ao Ministério da Fazenda, o IAP dos Marítimos (IAPM) ${ }^{83}$, não o foi. O mesmo equívoco é perpetuado por autores já citados: "(...) as CAPs, ao lado dos Institutos de Aposentadorias e Pensões (os IAPS), se multiplicaram após a criação do Ministério do Trabalho. O primeiro IAP, o dos marítimos, data de 1933 (...)" (GOMES, 2007, p.136).

Ao contrário do que é colocado pela historiografia, desde 1926, já existia o Instituto de Previdência dos Funcionários Públicos da União ${ }^{84}$, subordinado ao Ministério da Fazenda. Suas funções e responsabilidades são praticamente um espelho daquelas observadas nos IAPs do MTIC; confirmando sua referência quanto à estruturação e ações a partir de 193385. Dessa forma, mostra-se mais adequado referenciar a atuação desses órgãos, inclusive à das CAPs do MTIC e da CAPIN, por meio da denominação Institutos de Previdência.

O desmerecimento dado pela historiografia à atuação do Conselho Nacional do Trabalho (CNT), como órgão de gestão, fiscalização e, inclusive, deliberativo das ações das CAPs, inicialmente, e dos IAPs a partir de 1933, conforma-se como outro equívoco que necessita ser reparado. Em se tratando a atuação do Conselho no campo previdenciário e habitacional, Farah (1983) afirma que o órgão permaneceu quase que inoperante até a sua vinculação ao MTIC na década de 1930. Bonduki (2002, p.102), por sua vez, colocou que "(...) enquanto as CAPs eram administradas apenas por um colegiado de trabalhadores e empregadores, nos Institutos a participação do Estado passou a ser determinante".

No entanto, tanto as CAPs como os IAPs eram administrados por um colegiado, junta ou conselho conformado por representantes dos trabalhadores e dos empregadores e subordinados e supervisionados ao CNT. O que foi alterado com a criação do MTIC foi a intensidade da intervenção do poder público nessa área, que passou a ser maior. Por outro lado, foi no âmbito do Conselho Nacional do Trabalho que grande parte da

\footnotetext{
82 Esse aspecto será mais desenvolvido no Capítulo 03 da tese, mais precisamente no tópico "Os financiamentos concedidos: caracterização e análises do perfil social dos órgãos".

83 Instituído pelo Decreto n.22.872, de 29 de junho de 1933.

${ }^{84}$ Criado por meio do Decreto n.5.128, de 31 de dezembro de 1926 e regulamentado pelo Decreto n.17.778, de 20 de abril de 1927 .

85 Em 1934, por meio de uma reforma empreendida no setor previdenciário do país, o Instituto de Previdência dos Funcionários Públicos da União passou a ser chamado de Instituto Nacional de Previdência (INP), por meio do Decreto n.24.563, de 03 de julho, sendo incorporado ao IPASE no momento de sua criação, em 1938.
} 
legislação referente às ações imobiliárias das Caixas e às reformas empreendidas no setor previdenciário foi formulada pelo seu corpo técnico, inclusive a proposição de se criar um Instituto para a categoria profissional dos marítimos, como ser verá mais detalhadamente no segundo capítulo desta tese.

Dentre as ações empreendidas pelo CNT no período considerado por alguns autores como "inoperante" pode-se citar: 1) Todos os cálculos de aposentadoria e pensões, bem como de contribuição das CAPs foram definidas e fiscalizadas pelo Conselho; 2) Em 192686, o Conselho organizou e geriu a confecção e a distribuição da caderneta de nomeação, cujo modelo muito provavelmente balizou a formulação da carteira de trabalho, criada legalmente em 193287; 3) Todos os projetos de sedes institucionais, de ambulatórios e outras edificações foram elaborados no âmbito do CNT, por seu corpo técnico e/ou aprovado por ele; 4) Qualquer ação utilizando-se as reservas das CAPs só poderia ser executada mediante 0 consentimento do Conselho; e 5) A nível estadual, competia ao inspetor regional do CNT, a organização das Caixas de Aposentadoria e Pensões de todos os serviços públicos de sua região, assim como averiguar as queixas e reclamações relativas às CAPs e encaminhá-las ao Ministro ou ao escritório central do CNT, sendo responsáveis também pelos bens da União locados em seu território.

A partir da legislação outorgada em 193188, que subordinou o CNT ao MTIC, somente o Conselho Nacional do Trabalho estava autorizado a demitir os empregados das empresas associados às CAPs. Após esse ano, a elaboração dos regulamentos para criação e funcionamento de uma CAP, que até o momento era de responsabilidade de seu Conselho Administrativo, tornou-se de responsabilidade do poder público, passando a ser redigido pelo próprio Conselho Nacional do Trabalho, que poderia expandi-lo ou reduzi-lo quando julgasse necessário.

Bruna (2010) seguindo as colocações de Farah (1983), afirmou que passou a ser responsabilidade do IDORT a "(...) organização e administração das carteiras hipotecárias dos institutos (...), sobretudo após a Segunda Guerra Mundial (...)" (BRUNA, 2010, p.248). Provavelmente os autores se referiam à Comissão Permanente da Habitação Econômica, instituída a partir de 1942, uma das consequências da Jornada de

\footnotetext{
86 Por meio do Decreto n.5.109, de 20 de dezembro.

${ }^{87}$ Criada por meio do Decreto n.21.175, de 21 de março. A partir de 1926, a caderneta de nomeação constava além da identidade do trabalhador, a natureza das funções exercidas, a data de nomeação, promoções, vencimentos recebidos, tempo de serviço, dentre outras informações relacionadas ao trabalho e ao associado. A partir de 1931, por meio do Decreto n.20.645, de 01 de outubro, esse documento devidamente escriturado e autenticado, sem rasuras ou emendas, passou a servir como base para a inscrição do empregado como associado da Caixa e para a contagem do tempo para sua aposentadoria. Esse modelo em muito se aproxima da carteira profissional criada em 21 de março de 1932; representando uma grande inovação gerada pelas CAPs no campo do trabalho formal. A carteira profissional destinava-se aos maiores de 16 anos, sem distinção de sexo, que exercessem emprego ou prestassem serviços remunerados no comércio ou na indústria. Esse documento, a partir da outorga da referida legislação, passou a ter a mesma importância, para fins de direito, que a cédula de identidade; da mesma forma que o era no âmbito das CAPs. Nessa, eram especificados: número, série e data da solicitação da carteira, foto, características físicas, impressões digitais, nome, filiação, data e lugar de nascimento, estado civil, profissão, residência, assinatura e grau de instrução, nome, localização e detalhamento dos serviços prestados, salários e data de admissão e saída, além de especificado o nome do sindicato ao qual o trabalhador estava vinculado. Todos esses dados também estavam presentes na caderneta das CAPs, se conformando como a diferença principal entre ambas, a cobrança de $5 \$ 000$ (cinco mil réis) para a confecção daquela, sendo 0 próprio trabalhador o financiador da carteira profissional no Brasil, até pelo menos meados da década de 1930, o que não ocorria no âmbito das CAPs, nas quais a elaboração da carteira era gratuita.

88 Decreto n.20.465, de 01 de outubro de 1931.
} 
Habitação Econômica de 1941, que permaneceu inoperante até setembro de 1945, quando suas reuniões voltaram a acontecer. Esses encontros contaram com a participação de diversas entidades de classe e empresas relacionadas à construção civil, arquitetura e bem estar social, como a Liga das Senhoras Católicas, a Ação Social e o SENAI, além de alguns dos presidentes de Institutos e representantes estaduais do IPASE, IAPC, IAPB e IAPI, no âmbito dos quais se cogitou uma intervenção direta do IDORT no que concerne à administração e gestão dos IAPs, mas que não chegou a acontecer (COMISSÃO..., out.1945, p.230). As diretrizes e proposições, essencialmente construtivas, formuladas nessas reuniões, por outro lado, podem ter influenciado à atuação dos Institutos no campo habitacional, em seus projetos para a edificação de conjuntos de moradias, mas não intervieram na gestão ou fiscalização desses órgãos, que continuou a ser operada pelo Conselho Nacional do Trabalho.

A necessidade de criação de um Conselho de Habitação de caráter permanente no país, também foi uma proposição formulada no I Congresso de Habitação de 1931. Esse órgão seria vinculado ao Instituto de Engenharia e ao Departamento de Tecnologia. A possível referência direta dessa proposta foi a Comisión Nacionale de Casas Baratas, órgão federal do governo argentino criado em $1915^{89}$, que desde então era responsável pela edificação de unidades habitacionais econômicas que foram alugadas aos pedreiros, jornaleiros e outros operários carentes, essencialmente em Buenos Aires. Essa instituição foi apresentada aos congressistas durante a palestra inaugural da primeira sessão temática, apresentada pelo arquiteto Raul Pasman (ANAIS..., 1931). Rubens Porto também sugeriu a criação de um Serviço de Arquitetura e Engenharia subordinado ao CNT, por volta de 1935, que ficaria responsável essencialmente pela elaboração dos projetos dos conjuntos e unidades habitacionais das CAPs e IAPs e cuja estrutura e objetivos se assemelham bastante aos propósitos do IDORT, como se verá mais detalhadamente no capítulo seguinte. Mas, essa proposição também não foi acatada.

Em 1939, o CNT passou por uma significativa reforma legislativa quanto a sua organização e suas funções. O Conselho foi dividido em duas Câmaras, a Câmara da Justiça do Trabalho e a Câmara de Previdência Social, e seus serviços passaram a serem executados pelos Departamentos de Justiça do Trabalho e da Previdência Social, que ficou responsável por inspecionar e fiscalizar as CAPs e os IAPs. Mais à frente, em 194690, o Conselho Nacional do Trabalho passou a ser denominado de Tribunal Superior do Trabalho e, novamente, nenhuma referência foi feita ao IDORT. Os Decretos n.34.828, de 17 de dezembro de 1953 e 0 n.35.448, de 01 de maio de 1954, que publicaram os regulamentos gerais dos IAPs no campo habitacional e previdenciário, respectivamente, deixaram bem clara a subordinação desses órgãos ao Departamento Nacional de Previdência Social e seus Conselhos Fiscais, sem intervenção direta do IDORT.

É muito comum também, encontrar na historiografia especializada trechos como: "(...) o período de Vargas marca o surgimento da habitação social no Brasil. Abandonando o liberalismo, o Estado brasileiro

\footnotetext{
89 Por meio da Lei n.9.677, de 05 de outubro de 1915, cujo regulamento foi publicado em 1917, naquele país.

90 Graças à outorga do Decreto-Lei no 9.797, de 09 de setembro.
} 
passa a intervir em todos os aspectos da vida econômica do país e a questão da habitação não foi deixada de fora" (BONDUKI, 1996, p.981). Acertadamente Sampaio (1996, p.1142) mostrou que "(...) a preocupação em construir habitação barata, econômica, com espaços mínimos, atendendo a todas as normas de higiene já estava presente em projetos e discussões nas primeiras décadas do século [XX] no país".

Mais precisamente, a atuação do poder público no que concerne à produção de habitação para as camadas mais carentes já era percebida desde o século XIX de forma pontual e pulverizada nos estados do país. O que ocorreu com a criação das CAPs do Ministério da Agricultura, Indústria e Comércio, mais exatamente a partir da década de 1930, foi a institucionalização e o alargamento dessa ação estatal no Brasil. Sendo assim, não é correto afirmar que o Estado não operava no campo da moradia antes da criação das CAPs e dos IAPs.

Da mesma forma, o início da atuação das CAPs do MAIC no campo habitacional por meio do financiamento e/ou edificação de moradias no país também não é demarcado corretamente por alguns autores. Nabil Bonduki (2002) remete-a ao ano de 1930:

A possibilidade de utilizar esses recursos em programas de habitação social veio com a Revolução de 1930, graças ao artigo 2o do decreto 19.496, de 17/12/30: 'Excluídas as importâncias indispensáveis às despesas normais com os pagamentos de benefícios legais e dos serviços administrativos, tais fundos serão aplicados na aquisição de títulos de renda federal e na construção de casas para os associados das respectivas caixas, com a suficiente garantia hipotecária' (BONDUKI, 2002, p.103).

Ainda na década de 1910, o Decreto n.12.681, de 17 de outubro de 1917, que divulgou a reforma do regulamento da Caixa de Pensões da Imprensa Nacional ${ }^{91}$, autorizou além das já apontadas ações no campo da assistência e da previdência, a realização de empréstimos aos seus contribuintes para a aquisição de prédios para sua moradia: "(...) effectuará emprestimos aos seus contribuintes, para acquisição de predios, na importancia maxima de 6:000\$ (seis contos de réis), a juros de $8 \%$ ao anno, não podendo a amortização exceder de um terço dos vencimentos" (DECRETO N.12.681, 17/10/1917) ${ }^{92}$. O mesmo Decreto concedeu, ainda, autorização àquele órgão para a edificação de unidades habitacionais, em grupos ou isoladas, por meio da realização de concorrências públicas e do estabelecimento de contratos de compra e venda com os construtores. Nesse sentido, era elaborada uma relação nominal dos contribuintes interessados em adquirir uma residência, organizada pela ordem de inscrição, para posterior distribuição das unidades. Adquirido 0 imóvel pela Caixa, eles eram ocupados pelos seus pretendentes, que só teriam direito sobre eles após a conclusão do pagamento do empréstimo ao referido órgão.

\footnotetext{
${ }^{91}$ A partir de 27 de abril de 1932, graças ao Decreto n.21.330, a Caixa de Pensões da Imprensa Nacional (CPIN) passou a se chamar efetivamente Caixa de Aposentadoria e Pensões da Imprensa Nacional (CAPIN), subordinada ao CNT. Cabe ressaltar que os objetivos permaneceram os mesmos, reforçando a afirmativa que foi a Caixa da Imprensa Nacional a primeira a ser criada no país. O Decreto-Lei n.6.209, de 19 de janeiro de 1944, por sua vez, incorporou a CAPIN (Caixa de Aposentadoria e Pensões da Impressa Nacional) ao IPASE, criado em 1938.

92 Muito próximo ao possibilitado às demais CAPs a partir de 1931, por meio do Decreto n.20.465, como se verá mais detalhadamente a seguir.
} 
Os empréstimos para a aquisição de casa e a concessão de auxílios para o aluguel de prédios ${ }^{93}$ para a moradia dos associados já percebidos no âmbito da Caixa de Pensões dos Operários da Imprensa Nacional desde outubro de 1917, só foi estendida às demais CAPs e aos IAPs existentes no ano de $1934^{94}$ e de 193995, respectivamente. A legislação baixada em 1917, também apontava para a existência de um fundo de garantia, não relacionado ao tempo de serviço, mas sim, ao tempo de empréstimo, que se conformava mais como um adiantamento de férias e/ou de ordenados, que um empréstimo propriamente dito. De qualquer forma, percebe-se certa semelhança desta proposição ao Fundo de Garantia por Tempo de Serviço (FGTS), instituído no âmbito do Plano Nacional de Habitação e, mais precisamente, do Banco Nacional de Habitação (BNH), em meados da década de 1960. Esses aspectos comprovam o caráter de referência importante da Caixa de Pensões da Imprensa Nacional para o alargamento da atuação estatal no campo habitacional no país.

Posteriormente, em 192096, o Poder Executivo foi autorizado a construir moradias operárias no país. A partir de então, diversos foram os grupos e vilas de casas edificadas, reformadas e/ou concluídas no país, podendo ser citada a Vila Orsina da Fonseca, no Rio de Janeiro. Seguindo as diretrizes especificadas pela legislação do período, o poder público adquiriu ou edificou unidades habitacionais e, por meio de avaliação e concorrência pública, as repassava (venda ou arrendamento), às empresas "(...) fundadas especialmente para o objectivo (...), e que se proponham ao fim social collimado pelo Governo com aquellas construcções (...)" (DECRETO N.4.209, 11/12/1920). Na mesma ocasião foi ainda autorizada a doação de terrenos da União e/ou a desapropriação dos demais para a construção de imóveis ou o parcelamento em lotes de 300 a $750 \mathrm{~m}^{2}$, bem como seu encaminhamento aos funcionários, operários e diaristas federais e municipais que se propusessem a edificar moradias. Para a execução dessas determinações, o poder público contou com 10.000:000\$000 (dez mil contos de réis), retirados dos saldos das Caixas Econômicas. Foi a partir desse momento, intensificada a ação das entidades e órgãos do funcionalismo público federal e municipal no campo da moradia, a citar o Montepio Obrigatório dos Empregados do Ministério da Fazenda e a Caixa da Imprensa.

No ano seguinte, o Decreto n.14.813, de 20 de maio de 1921 regulamentou, com uma década de atraso, o Decreto n.2.407 de 18 de janeiro de 1911, que concedia favores às associações que se propusessem a edificar moradias operárias no país. Os acordos deveriam ser estabelecidos entre a empresa ou entidade e o governo municipal de onde estavam locadas, e solicitada ao Poder Legislativo a publicação do decreto concedendo os favores, que se referiam essencialmente à isenção de impostos e taxas federais e municipais, bem como de importação de materiais para a edificação da vila. Mais especificadamente, essa legislação apontou que as associações de caráter mútuo, como as cooperativas, as sociedades beneficentes e anônimas, os montepios e as, já existentes, Caixas e Institutos de Previdência Estatal, como a de Imprensa

\footnotetext{
93 A referida Caixa concedia fiança para aluguel das casas, sob consignação em folha de férias e cobrava $1 \%$ de juros mensalmente para tanto (DECRETO N.12.681, 17/10/1917).

94 Por meio do Decreto n.24.488 de 28 de junho.

95 Pelo Decreto n.1.308, de 31 de maio.

96 Decreto n.4.209, de 11 de dezembro de 1920.
} 
e dos Servidores Federais, estavam autorizadas a adquirir terrenos e/ou edificar moradias destinadas aos operários do país, por meio do desconto em folha de até 30\% dos vencimentos dos trabalhadores. Os modelos e determinações especificados nesse Decreto de 1921 foram praticados na Caixa da Imprensa Nacional e, posteriormente, no Instituto de Previdência dos Funcionários Públicos da União, como também foram incorporadas às ações das CAPs do Ministério da Agricultura a partir de $1923{ }^{97}$.

Desde 192798, o Instituto de Previdência dos Funcionários Públicos da União ${ }^{99}$ também atuava no campo da habitação por meio da concessão de empréstimos para a aquisição ou construção de imóveis por iniciativa própria. Esse Instituto, em especial, estava autorizado a investir até 80\% de suas reservas totais em empréstimos para os seus associados, operando uma taxa de juros de até $12 \%$ ao ano, mediante desconto em folha ou qualquer outra garantia ${ }^{100}$. Para contrair um empréstimo para a edificação ou aquisição de residência, o associado deveria realizar uma inscrição junto à administração do Instituto, apresentando o valor do imóvel, a renda mensal, o local da edificação, o nome do vendedor, o vencimento disponível do associado para a ação, o tempo de pagamento e uma entrada em dinheiro para iniciar a operação. 0 atendimento das solicitações, da mesma forma que na Caixa da Imprensa Nacional, era dado por ordem de inscrição e depois de realizada a avaliação por um perito do Instituto, considerados o valor do imóvel, a quantia a ser desprendida pelo associado para a aquisição ou construção da residência e o menor prazo para pagamento proposto ${ }^{101}$; exigências praticamente idênticas àquelas empreendidas pelos IAPs do MTIC, anos depois.

A partir do ano seguinte, o referido Instituto, da mesma forma que a CPIN, passou a conceder sinais para o pagamento de aluguéis de moradias de seus associados, comprometendo até dois terços do seu ordenado102. Em fevereiro de 1931, a primeira vila edificada diretamente por esse Instituto foi concluída e dizia respeito à Vila Proletária Marechal Hermes, no Rio de Janeiro ${ }^{103}$ e, em 1932, foi incorporado 0 seguro

\footnotetext{
${ }^{97}$ Os quadros gerais do custo da construção, de aluguel e de venda da residência proposto pelo Decreto são praticamente idênticos aos quadros de especificações e avaliações empreendidos pelas CAPs a partir da década de 1930, por exemplo.

${ }^{98}$ Graças à outorga do Decreto n.17.778, de 20 de abril.

99 Como já citado, o Instituto de Previdência dos Funcionários Públicos da União foi criado pelo Decreto n.5.128, de 31 de dezembro de 1926. A partir de 1931, saiu da alçada do Ministério da Fazenda, passando a compor o Ministério do Trabalho, Indústria e Comércio, devido à publicação do Decreto n.19.646, de 30 de janeiro de 1931.

$10030 \%$ a mais do que o liberado para os IAPs a partir de 1937, como se verá mais detalhadamente adiante.

1010 empréstimo contava do valor do imóvel descontada a quantia disponibilizada pelo associado para a sua aquisição - que não poderia ser superior à metade de seu salário -, os juros do empréstimo e as despesas com impostos e escrituras, ficando a cargo do trabalhador o pagamento dos impostos municipais e federais, o seguro contra fogo feito junto a uma companhia designada pelo Instituto, bem como as obras para conservação da moradia e para possíveis adaptações exigidas pelas autoridades municipais e federais, durante o prazo de arrendamento ou pagamento (no máximo de 20 anos). A aquisição do imóvel a terceiros era feita em nome do Instituto e entregue ao contribuinte por um contrato de arrendamento. Era facultada ainda a locação do imóvel para facilitar o pagamento do empréstimo feito junto ao órgão. Concluído o pagamento, o imóvel era transferido ao trabalhador, com a obrigação de constituir bem de família e servir para o seu domicílio.

102 Um benefício possibilitado pela aprovação do Decreto n.5.407, de 30 de dezembro de 1927. Da mesma maneira que observado no âmbito da Caixa da Imprensa Nacional, as ações empreendidas pelo Instituto dos Funcionários Públicos da União eram fiscalizadas pelo Ministério da Fazenda.

${ }^{103}$ Por falta de dados históricos, não foi possível afirmar a localização exata e as características desse empreendimento.
} 
de vida temporário para garantir a aquisição de um imóvel104. Em 1933, o Instituto deu início à edificação de mais quatro vilas na cidade do Rio de Janeiro ${ }^{105}$.

Portanto, é correto afirmar que no início da década de 1930 as CAPs vinculadas ao Ministério da Agricultura, Indústria e Comércio e, posteriormente, ao MTIC foram autorizadas a adquirir e construir moradias no país. Pois, já se sabe que no âmbito do Ministério da Fazenda essa ação se fazia perceber desde 0 ano de $1917^{106}$ e, no que condiz ao Ministério das Obras Públicas, desde 0 início do século XX107. Dessa forma, os Institutos de Aposentadoria e Pensões e a Fundação da Casa Popular, não foram os primeiros órgãos federais a atuarem no setor da habitação social. Da mesma maneira, mostra-se um equívoco afirmar que somente a partir de 1937, com a outorga do Decreto n.1.749 e a consequente criação das Carteiras Prediais no âmbito dos referidos órgãos, se deu o início da construção de moradias sociais pelos IAPS: "(...) até 1937, os dispositivos legais autorizando e regulamentando a atuação dos Institutos de Aposentadoria e Pensões no setor habitacional não chegaram a ser implementados" (FARAH, 1983, p.45), a partir de quando "(...) surgiram as condições para a atuação dos IAPs no campo habitacional, podendo ser considerado o marco inicial da atuação dos Institutos nessa área (...)" (VARON, 1988, p.232).

Outro equívoco historiográfico acerca da atuação dos órgãos de previdência no campo da moradia brasileiro, diz respeito às causas da redução da produção e do financiamento de unidades habitacionais a partir, sobretudo, de meados da década de 1950. Muitos autores apontam a pouca rentabilidade do aluguel e das vendas de moradias aos trabalhadores mais carentes associados às Carteiras Prediais, como a maior causa: "(...) no interior do órgão havia se desenvolvido um corpo técnico preparado para equacionar de uma forma consistente uma política habitacional. Entretanto, não era este o objetivo primeiro dos IAPS (...) que, ao avaliarem a ausência de retorno dos investimentos realizados, reduziram drasticamente as inversões (...)" (BONDUKI, 1996, p.991). Porém, um dos principais motivos para a redução dos investimentos não só no campo da moradia social, como também no da previdência e da assistência médica, foi a descapitalização dos fundos das Caixas e Institutos, que em meados da década de 1950, especialmente, operaram praticamente sob retorno nulo.

\footnotetext{
104 A partir de 1933, o Instituto foi autorizado a operar o empréstimo garantido por hipoteca comprometendo até $90 \%$ de suas reservas. Essas operações ficaram isentas de quaisquer impostos ou taxas federais, estaduais e municipais (Decreto n.23.245, 18/10/1933).

105 De acordo com o Decreto n.23.247, de 18 de outubro. Essas vilas estavam locadas em: 1) um terreno medindo $385 \mathrm{~m}$ de testada para a Rua da Alegria (lado par) e 90m de largura, confrontando pelo lado direito com a Rua Lopes da Silva, 2) terreno de forma trapezoidal com testada de $410 \mathrm{~m}$ para a Avenida Suburbana e Avenida Rio Petrópolis, 250m de fundos, $165 \mathrm{~m}$ no lado esquerdo e 200m no direito, situado após o n.54 da Avenida Suburbana, 3) terreno de forma triangular com 130m de testada para a Avenida Rio Petrópolis, $120 \mathrm{~m}$ para a Avenida Suburbana e $55 \mathrm{~m}$ de fundos, 4) terreno de forma trapezoidal com $115 \mathrm{~m}$ de testada para a Avenida Rio Petrópolis, $37 \mathrm{~m}$ e $50 \mathrm{~m}$ nas laterais e $160 \mathrm{~m}$ de fundos. $O$ Instituto se tornou fiador e pagador do associado adquirente, que teria o prazo máximo de 15 anos para sanar a dívida.

106 Além da Caixa da Imprensa Nacional e do Instituto de Previdência dos Funcionários Públicos da União, os trabalhadores de empresas ou órgãos estatais contavam ainda com a Caixa Econômica e o Banco dos Funcionários Públicos para contrair empréstimos para aquisição e/ou edificação de uma moradia, ou fianças para o aluguel (LEI N.105, 22/10/1935).

107 São diversos os registros de unidades financiadas e/ou edificadas para a moradia de operários empenhados na construção/ampliação de estradas de ferro, de empregados nas estradas de ferro e de engenheiros.
} 
Esses órgãos possuíam verba suficiente para contribuir consideravelmente para atenuar o quadro de déficit habitacional do país naquele momento. Descontados os gastos com benefícios, assistências, pensões, aposentadoria, construções de moradias e empréstimos no início da década de 1945, por exemplo, não se chegava à metade das reservas dos IAPs. Infelizmente, a prática de concessão de empréstimos ao poder público para financiar obras de modernização da infraestrutura em diversas cidades do país e das indústrias de base nacionais, empreendidas desde a década de 1930, além da construção de Brasília, posteriormente, aliada à sua inadimplência para com a contribuição tripartite, comprometeu essa capacidade; como se verá mais detalhadamente nos tópicos seguintes.

Outros lapsos repercutidos nos estudos e publicações sobre o tema, dizem respeito à unificação das Caixas e Institutos, bem como à extinção desses órgãos e, consequentemente, ao fim das suas atuações no campo habitacional. O primeiro esclarecimento que deve ser feito diz respeito aos intentos em unificar as CAPs e os IAPs observados a partir da década de 1940. Nesse sentido, Melo (1990 e 1991) e Bonduki (2002) compartilham do mesmo pensamento, afirmando que em meados da década de 1940, intentava-se a “(...) reestruturação dos IAPS, os quais seriam unificados no Instituto de Serviços Sociais do Brasil (ISSB), instituído por decreto em 1945. Se implementado, o ISSB reuniria os fundos dos IAPs, alavancando 0 financiamento de uma política universal de habitação social" (BONDUKI, 2002, p.100). No entanto, cabe aqui ressaltar, que o intento do não instituído ISSB era 0 de "(...) executar, orientar e coordenar as atividades pertinentes (...)" aos serviços de previdência e assistência social, de modo que fosse "(...) reduzido ao mínimo o tempo e as formalidades necessárias à concessão dos benefícios". Para tanto, iria subordinar 0 Departamento de Previdência Social (antigo Conselho Nacional do Trabalho) à sua delegação, como também "(...) exercer supervisão administrativa dos atuais Institutos e Caixas de Aposentadoria e Pensões, expedindo, para êsse efeito, as instruções que se fizerem necessárias (...)" (DECRETO-LEI N.7.526, 07/05/1945). 0 ISSB representaria, portanto, um órgão intermediário entre o Ministério do Trabalho, Indústria e Comércio e as CAPs e os IAPs, não intervindo de forma direta nas questões da moradia.

Em se tratando da extinção dos Institutos e Caixas com a criação do BNH, em 1964, Bonduki (2002) colocou que:

(...) uma nova ditadura - agora antipopulista - implantaria, contraditoriamente, um projeto de unificação semelhante ao de Vargas, por um lado, extinguindo os IAPs e centralizando a previdência no INPS e, por outro lado, transferindo as atribuições das carteiras prediais da FCP para o Banco Nacional de Habitação (BONDUKI, 2002, p.119).

Nessa passagem há, pelo menos, dois equívocos. O primeiro deles é o mais simples de ser solucionado e refere-se à Fundação da Casa Popular. A Lei n.4.380, de 21 de agosto de 1964, que, dentre outras providências, instituiu a correção monetária nos contratos imobiliários de interesse social, como também o sistema financeiro para aquisição da casa própria e o Banco Nacional da Habitação (BNH), especificou claramente que "(...) a Fundação da Casa Popular, criada pelo Decreto n.9.218, de $1^{0}$ de maio de 
1946, passa a constituir com o seu patrimônio, (...), o 'Serviço Federal da Habitação e Urbanismo' (...)" (LEI N.4.380, 21/08/1964). Suas funções e todo o pessoal também foram incorporados àquele órgão, constituinte da nova política habitacional. Seus objetivos passaram a ser:

a) promover pesquisas e estudos relativos ao déficit habitacional, aspectos do planejamento físico, técnico e sócio-econômico da habitação; b) promover, coordenar e prestar assistência técnica a programas regionais e municipais de habitação de interêsse social, os quais deverão necessàriamente ser acompanhados de programas educativos e de desenvolvimento e organização de comunidade; c) fomentar o desenvolvimento da indústria da construção, através de pesquisas e assistência técnica, estimulando a iniciativa regional e local; d) incentivar o aproveitamento da mão-de-obra e dos materiais característicos de cada região; e) estimular a organização de fundações, cooperativas, mútuas e outras formas associativas em programas habitacionais, proporcionando-lhes assistência técnica; f) incentivar a investigação tecnológica, a formação de técnicos, em qualquer nível, relacionadas com habitação e urbanismo; g) prestar assistência técnica aos Estados e Municípios na elaboração dos planos diretores, bem como no planejamento da desapropriação por interêsse social, de áreas urbanas adequadas a construção de conjuntos habitacionais; h) promover, em colaboração com o Instituto Brasileiro de Geografia e Estatística, a realização de estatísticas sôbre a habitação no país; i) prestar assistência técnica aos Estados, aos Municípios e às emprêsas dos país para constituição, organização e implantação de entidades de caráter público, de economia mista ou privadas, que terão por objetivo promover a execução de planos habitacionais ou financiálos, inclusive assistí-los para se candidatarem aos empréstimos do Banco Nacional de Habitação ou das sociedades de crédito imobiliário; j) prestar assistência técnica na elaboração de planos de emergência, intervindo na normalização de situações provocadas por calamidades públicas; I) estabelecer normas técnicas para a elaboração de Planos Diretores, de acôrdo com as peculiaridades das diversas regiões do país; $m$ ) assistir aos municípios na elaboração ou adaptação de seus Planos Diretores às normas técnicas a que se referem o item anterior (LEI N.4.380, 21/08/1964, Art.54).

Dessa maneira, foi o Serviço Nacional de Habitação e Urbanismo que incorporou a FCP mantendo, quase que em sua totalidade, suas características organizacionais e suas funções no campo habitacional, e não transferindo sua Carteira Predial para o BNH. Esse Serviço atuou em conjunto com o BNH, as Caixas Econômicas Federais, o IPASE, as Caixas Militares, além de outros órgãos federais de desenvolvimento regional e das sociedades de economia mista. Vale lembrar, nesse contexto, que o Banco Nacional de Habitação não era um órgão construtor, mas sim gestor dos fundos para a edificação de moradias no país até, pelo menos, os primeiros anos da década de 1970.

Os IAPs por sua vez, não foram extintos com a criação do BNH, como colocado também por Farah (1983) e Varon (1989): "(...) a atuação dos Institutos de Aposentadoria e Pensões no campo habitacional, desde a sua criação na década de 30, até o encerramento de suas atividades no setor, em 1964, com a criação do Banco Nacional da Habitação" (FARAH, 1983, p.113); "(...) a falência da atuação do Estado, via IAPs, nessa área, que a nova ordem política, implantada em 1964, terminou de um só golpe" (VARON, 1989, p.273). Esse indício é apontado pelo próprio texto legislativo de criação do novo plano de habitação: “(...) Art.2․ O Govêrno intervirá no setor habitacional por intermédio: I - do Banco Nacional da Habitação; II - do Serviço Federal de Habitação e Urbanismo; III - das Caixas Econômicas Federais, IPASE, das Caixas Militares, dos órgãos federais de desenvolvimento regional e das sociedades de economia mista" (LEI 
N.4.380, 21/08/1964). Além de não serem extintos, alguns dos órgãos foram inclusive incorporados ao novo plano habitacional brasileiro, como o IPASE e as Caixas Militares. Os demais IAPs passaram a recolher e repassar $1 \%$ do arrecadado mensalmente para a constituição do capital do $\mathrm{BNH}^{108}$.

O próprio Ministro do Trabalho, naquela ocasião afirmou que “(...) depois do Golpe de 1964, instaurada a devassa, nada se apurou na administração do Ministério do Trabalho ou contra mim pessoalmente. E o presidente do IAPI era o paulista Armando Marcondes Machado Júnior que chegou a ser elogiado" (ENTREVISTA..., 2007, p.166). Em toda a legislação levantada no período, não há sequer uma referência à extinção desses órgãos. Tratava-se apenas da subordinação de grande parte de suas ações imobiliárias ao recém-criado Banco da Habitação e, mais a frente, da extinção somente de suas Carteiras Prediais, o que só veio a ocorrer no final da década de 1960, apesar do Decreto de 1964:

(...) Art. 64. A partir da data da vigência desta Lei as Carteiras Imobiliárias dos Institutos de Aposentadoria e Pensões não poderão iniciar novas operações imobiliárias (...). $\S 1^{0}$ - Os Institutos (...) efetuarão, no prazo máximo de doze meses, a venda de seus conjuntos e unidades residenciais em concordância com o sistema financeiro da habitação de que trata esta Lei, de acôrdo com as instruções expedidas, no prazo de 90 (noventa) dias, conjuntamente, pelo Banco Nacional de Habitação e Departamento Nacional de Previdência Social (...). $\S 70$ - Realizadas as operações previstas no parágrafo primeiro, extingüir-se-ão as Carteiras Imobiliárias dos IAPs. $\S 8^{\circ}$ - Os atuais inquilinos ou ocupantes de imóveis residenciais dos IAPs e, sucessivamente, os seus contribuintes, êstes inscritos e classificados de acôrdo com a legislação vigente, terão preferência no atendimento pelos órgãos estatais integrantes do sistema financeiro da habitação (...) (LEI N.4.380, 21/08/1964).

Mais a frente, o mesmo diploma legal especificou que "(...) dentro do prazo de noventa (90) dias, 0 Poder Executivo baixará os atos necessários à adaptação do funcionamento das Caixas Econômicas Federais, Caixas Militares e IPASE aos dispositivos desta Lei" (LEI N.4.380, 21/08/1964, Art.68). No entanto, nem os imóveis dos IAPs foram vendidos em um ano, nem as instruções previstas na Lei nesse sentido foram outorgadas nos três meses seguintes à sua publicação. Diversos decretos foram baixados nos três anos subsequentes, especificando e regulamentando a venda e/ou o repasse das unidades habitacionais dos Institutos. Até 0 ano de 1967, essas atividades ainda não haviam sido concluídas e se vislumbra legislações sobre 0 assunto, enfocando naquele momento o já criado Instituto Nacional de Previdência Social. O Decreto n.262 de 28 de fevereiro é um exemplo nesse sentido, indicando que mesmo após a unificação da previdência, os órgãos ainda eram proprietários de imóveis.

O primeiro regulamento previsto publicado equivale ao Decreto n.55.738, de 04 de fevereiro de 1965, o qual deixou bem claro que nem todos os imóveis foram "vendidos" ao BNH. Somente aquelas unidades situadas em Brasília, que passaram a serem geridas pelo Grupo de Trabalho de Brasília (GTB) ${ }^{109}$; as residências de propriedade do Instituto (adquiridas ou edificadas) que estavam sob aluguel aos associados; e

\footnotetext{
108 As empresas sujeitas a descontos para os demais Institutos também tiveram que contribuir com essa taxa.

${ }^{109}$ A partir de 1965 sua função era gerir e utilizar o fundo resultante das vendas dos imóveis de propriedade dos IAPs localizados em Brasília para a edificação ou conclusão de outros conjuntos habitacionais naquela localidade. O GTB foi criado por meio do Decreto n.43.285, de 25 de fevereiro de 1959, e pelo Decreto n.55.955, de 20 de abril de 1965 passou a ter aquela função.
} 
os terrenos adquiridos para a edificação de residências ou grupo delas, também para serem alugadas, isto é, essencialmente aquelas de cunho popular, "(...) as unidades residenciais cujo valor, na data de avaliação, não exceda a 120 (cento e vinte) vezes o maior salário-mínimo vigente no país" (DECRETO N.55.738, 04/02/1965). Permanecendo as práticas de venda de casas ou apartamentos adquiridos pelos IAPs de terceiros e destinados às camadas mais altas das categorias trabalhistas e a realização de financiamentos para aquisição, construção, conservação, reforma ou ampliação de moradias (sob contrato de compra e venda ou garantia hipotecária), autorizadas até a conclusão das vendas das unidades populares. Dentre os imóveis não alienados estavam àqueles essenciais:

(...) para garantir as necessidades de instalações para a prestação de seus serviços, inclusive no que se refere à expansão, bem como permitir o adequado aproveitamento de suas áreas de terrenos, os Institutos, a seu critério excluirão da venda (...) as unidades residenciais: a) situadas nos imóveis nos quais funcionam os aludidos serviços, ou nas respectivas vizinhanças; b) adquiridas com o propósito da futura instalação dos mesmos serviços; c) localizadas em áreas de terrenos ou glebas ainda não utilizadas de acordo com as possibilidades sócio econômicas oferecidas pelas respectivas características (DECRETO N. 55.738, 04/02/1965).

Dessa forma, a data exata da extinção das Carteiras Prediais dos IAPs não pode ser assegurada. Mas, sabe-se que pelos menos até o final da década de 1960 eles, excetuando o IPASE 110 e as Caixas Militares, continuaram a operar no campo habitacional de forma restrita, uma vez que foi somente a partir de 1969 que a legislação federal passou a se referir aos órgãos como ex ou extintos IAPs ${ }^{111}$.

Outra justificativa, para tanto, remete ao fato de que os conjuntos cujas obras iniciadas em 1964 e aqueles cujos projetos já estavam aprovados no momento da criação do BNH, continuaram da alçada dos IAPs. Muitos desses grupos habitacionais foram concluídos até a década seguinte, sendo que a partir de 1966, sob a orientação e fiscalização do INPS112. Além disso, muitas brechas foram encontradas pelos Institutos nas legislações outorgadas após 1964, para que continuassem a operar no campo habitacional, bem como foram evidenciados casos de fraudes e desfalques nos repasses de verbas para o $\mathrm{BNH}$, como colocado pela impressa da época113.

\footnotetext{
110 Mais precisamente, em 1965, o IPASE se adaptou ao Sistema Financeiro da Habitação (SFH) e dois anos mais tarde foi criado 0 Fundo Especial para o Desenvolvimento do Programa Habitacional do IPASE (FUNDASE) (FINEP, 1985).

111 Cabe lembrar que as escolas, hospitais, creches, ambulatórios, sanatórios, colônia de férias, refeitórios, restaurantes, associações de trabalhadores, dentre outros imóveis edificados ou adquiridos com as verbas dos IAPs, permaneceram com os órgãos e foram incorporados ao patrimônio do IAPAS e INSS, posteriormente. Dentre os órgãos extintos a legislação aponta: o IAP dos Bancários (IAPB), Comerciários (IAPC), Marítimos (IAPM), Industriários (IAPI), dos Empregados em Transporte e Cargas (IAPETC) e dos Ferroviários e Empregados em Serviços Públicos (IAPFESP) (DECRETO N.65.678, 29/10/1969).

${ }^{112}$ A unificação administrativa dos demais Institutos ocorreu com a criação do Instituto Nacional de Previdência Social (INPS), por meio do Decreto-Lei n.72, em 21 de novembro de 1966. Dentre os órgãos unificados no INPS, pode-se citar: os IAPs, o Serviço de Assistência Média Domiciliar e de Urgência, a Superintendência dos Serviços de Reabilitação da Previdência Social e o Instituto Brasileiro de Sal (DECRETO N.65.679, 29/10/1969).

${ }^{113}$ Esses aspectos serão mais aprofundados nos capítulos subsequentes desta tese.
} 
A adaptação do IPASE e das Caixas Militares ao novo plano, por sua vez, só passou efetivamente a ocorrer em 1965114. Ao contrário dos demais IAPS, o IPASE continuou a operar no campo habitacional, inclusive através da construção de imóveis:

(...) as operações imobiliárias custeadas pelos recursos orçamentários do IPASE serão realizados exclusivamente em benefício dos servidores públicos contribuintes obrigatórios do seu seguro social, em prazo de amortização compatível com o estado e características do imóvel, e a idade do segurado contratante, a juros de $8 \%$ (oito por cento) ao ano. Art. 30 Os empréstimos imobiliários do IPASE serão realizados mediante garantia hipotecária do imóvel cuja aquisição ou construção seja objeto do contrato. (...). Art. $5^{\circ}$ Em qualquer dos planos de operações imobiliárias do IPASE, para fins residenciais, as prestações mensais de amortização e juros não excederão a 40\% (quarenta por cento) da remuneração do segurado contratante (...). Art. $6^{\circ} \mathrm{Na}$ execução da política habitacional no campo da atuação específica, o IPASE, estabelecerá, (...) 0 regime de seleção dos candidatos à obtenção de casa própria (...). Art. $7^{\circ} \mathrm{Na}$ venda das habitações de sua propriedade já construídas, nesta data, o IPASE, tendo em conta as características dos imóveis e sua localização, poderá reduzir a taxa de juros (...). Art. $8^{\circ}$ (...) poderá o IPASE tomar a iniciativa da construção de conjuntos residenciais em terrenos adequados, já de sua propriedade, e em outros que venha adquirir, com o objetivo de contribuir para a redução do déficit de residências destinadas aos seus segurados obrigatórios, respeitados os preceitos da Lei n.4.380, de 21.8.64 e as normas estabelecidas pelo Banco Nacional da Habitação (...) (DECRETO N.56.995, 01/10/1065).

Em 1969115, a Caixa de Construções de Casas do Ministério do Exército foi integrada ao Sistema Financeiro da Habitação, passando a ser denominada de Caixa de Financiamento Imobiliário do Exército (CFIEx), sendo orientada, normalizada e controlada pelo BNH. Da mesma forma que o IPASE, a CFIEx também atuou no campo imobiliário após 1964, possuindo como objetivos principais: “(...) a) captar, incentivar e disseminar a poupança entre os militares e servidores civis, do Ministério do Exército; b) financiar a construção ou aquisição de casa própria aos seus associados (...)" (DECRETO N.63.977, 10/01/1969).

Cabe ressalvar também, que em toda a legislação levantada não houve nenhuma referência à extinção das Caixas de Aposentadorias e Pensões. Sabe-se que no início da década de 1950, uma reforma reestruturou algumas CAPs e remanejou diversos dos associados, agrupando-as ou extinguindo-as, como se verá mais detalhadamente no tópico seguinte.

Discutidas algumas informações e análises imprecisas encontradas na historiografia especializada, resta-nos proceder à análise da estruturação e da atuação das CAPs e dos IAPs no campo da habitação social no Brasil116.

\footnotetext{
114 Com a publicação do Decreto n.56.995, de 01 de outubro daquele ano.

115 Por meio do Decreto n.63.977, outorgado em 10 de janeiro de 1969.

${ }^{116}$ Alguns esclarecimentos que se julgam necessários ainda serão apresentados ao longo dos capítulos seguintes.
} 


\title{
1.3. "Pelo menor preço, a melhor casa" 117: \\ A atuação das CAPs e dos IAPs no campo habitacional no país e a produção resultante
}

\begin{abstract}
“(...) pelos diversos Institutos e Caixas, milhares de pequenas casas têm sido construídas, procurando o Ministério do Trabalho resolver o problema da habitação adequada para os operários das grandes cidades do país, a fim de que dentro de alguns anos tenham desaparecido os núcleos de populações pobres, tais como as 'favelas' do Rio e os 'mocambos' de Pernambuco (...)". Agamenon Magalhães, Ministro do Trabalho, Indústria e Comércio, 1941.
\end{abstract}

Como dito anteriormente, a ampliação da atuação do poder público no campo da moradia social por meio das CAPs vinculadas ao MAIC ocorreu efetivamente, a partir do ano de 1930118. O Decreto publicado, nesse sentido, concedeu à possibilidade, ainda incipiente, de edificar moradias para os trabalhadores urbanos com carteira assinada. A partir de então foi permitida a todas as CAPs, a construção de casas para os trabalhadores associados com a suficiente garantia hipotecária, após a prévia autorização do Ministro e observadas algumas condições.

Para a realização dessa operação, uma CAP só poderia investir os valores dos seus fundos de reservas, deduzidos os custos das despesas normais com os serviços administrativos e com os pagamentos dos benefícios aos seus associados, para aquisição de títulos de renda federal e na construção de moradias para os seus associados. Essa operação só era possível, no entanto, às Caixas que possuíssem altas reservas orçamentárias, cujos valores ultrapassassem 500:000\$000 (réis). A importância a ser desprendida para essa ação também não poderia ser superior a 75\% dos saldos acumulados, convertidos ou não em títulos públicos, pelas CAPs. Poucas eram as Caixas que possuíam essa quantia em reserva, como as Caixas do Pessoal de Guerra e da Marinha. A solicitação para a realização desta operação imobiliária deveria ser elaborada formalmente pelo Conselho Administrativo da CAP e encaminhada ao CNT, apresentado 0 interesse em sua realização, os valores das suas verbas acumuladas e especificados os associados que pretendiam possuir um imóvel. O número de habitações a ser edificado não poderia ser inferior a dez unidades.

A legislação publicada nesse sentido especificou ainda que os regulamentos para a construção de moradias por meio das CAPs seriam formulados e aprovados no âmbito do MTIC. Essas normas seriam elaboradas para cada caso em particular, apontando os valores a serem gastos, os tipos de residências possíveis de serem construídas, as zonas e as condições para a edificação, a forma e os prazos para 0 pagamento, as taxas de juros - que não poderiam ser inferiores a 8\% ao ano -, além de todas as demais cláusulas relacionadas à administração e à fiscalização das obras. Os referidos "manuais", bastante específicos e de caráter individual para cada grupo de casas que se pretendesse edificar, tornaram 0

\footnotetext{
${ }^{117}$ Bordão que passou a ser utilizados por políticos e/ou profissionais relacionados direta e indiretamente ao projeto e à construção de moradias no país, após o discurso dado pelo então presidente da República Getúlio Vargas, em 1945, quando proferido pela primeira vez.

118 Mais precisamente, a legislação publicada nesse ano modificou os artigos 10 e 13 do Decreto n.5.109, referentes à aplicação dos fundos das Caixas.
} 
processo moroso, contribuindo em muito para o reduzido número de unidades habitacionais edificadas por esses órgãos no período119.

Até então, a edificação de moradias por parte das Caixas era regida pelo Decreto n.14.813, de 20 de maio de 1921. Por ele ficou decidido que era de responsabilidade dos governos municipais a escolha das áreas ou zonas onde seriam implantados os grupos de moradias, assim como, todas as obras relacionadas ao arruamento e aos serviços de higiene, como distribuição de água e coleta de esgotos ${ }^{120}$. O número de moradias não poderia ultrapassar dez e a lotação não poderia exceder doze ocupantes adultos por unidade ${ }^{121}$. A empresa, Caixa ou entidade teria o prazo máximo de dois anos para a conclusão da obra, 0 custo dessas residências não poderia chegar a 5:000\$ (cinco contos de réis) e o aluguel nunca poderia ser superior ao custo do imóvel acrescido de 15\% sobre ele, divididos nos doze meses do ano. Os imóveis comprados não poderiam ser alugados, repassados a terceiros, ser objeto de hipotecas ou de qualquer ônus que pudesse acarretar a perda da propriedade e nenhum comprador/locatário poderia adquirir mais de um imóvel122.

Antes mesmo da ampliação dos benefícios das CAPs a todas as empresas do país, já se buscava 0 barateamento das construções. Em 1930, por exemplo, se especificou que "(...) o ministro do Trabalho, Indústria e Comércio, providenciará, junto aos demais ministérios e autoridades Públicas no Distrito Federal e nos demais Estados, a concessão de favores de que trata o decreto n.14.813, de 20 de maio de 1921, naquilo que for aplicável, atendendo à necessidade do barateamento das casas (...)" (DECRETO N.19.496, 17/12/1930)123. Essa legislação corresponde à principal baliza para 0 projeto e edificação das casas e conjuntos residenciais das CAPs e posteriormente dos IAPs, até, pelo menos, a aprovação dos regulamentos de suas ações imobiliárias.

\footnotetext{
${ }^{119}$ Cabe aqui ressaltar que alguns desses regulamentos não foram publicados na íntegra, sendo incorporados nos decretos de criação dos Institutos do MTIC elou das suas Carteiras Prediais.

120 Mais precisamente, exigia-se que os terrenos dos conjuntos deveriam ser salubres e dotados de vias com 15m de largura; que nos terrenos baldios localizados nas grandes cidades formassem vilas, precedidas por arruamentos para permitir a instalação posterior dos serviços de água, luz e esgotos; e que cada prédio tivesse uma entrada independente para seus ocupantes.

${ }_{121}$ Para solicitar por meio do CNT a edificação de moradias isoladas ou grupos delas, a CAP deveria apresentar as plantas dos tipos das casas que pretendia construir, acompanhadas das respectivas especificações técnicas, os orçamentos dos detalhes e do conjunto numa tabela de custos da construção, os valores pretendidos para 0 aluguel, a planta geral do terreno onde seriam locadas as unidades e os arruamentos e quatro cópias das especificações dos materiais e objetos que se intentava importar. Esses documentos ficavam arquivados na Diretoria da Receita do Tesouro Federal, na Alfândega, na prefeitura municipal e na associação requerente. As obras eram fiscalizadas por um engenheiro civil determinado pelo poder público, que tinha autoridade inclusive para mandar demolir o grupo de moradias caso houvesse alguma disparidade entre 0 acordado e 0 executado em planta (DECRETO N.14.813, 20/05/1921).

${ }^{122}$ As demais especificações, incluindo as leis no que se refere à higiene das habitações eram determinadas pelos regulamentos do Departamento Nacional de Saúde Pública.

${ }^{123}$ Os fatores a que se refere o Decreto n.14.813, diziam respeito à isenção de impostos de importação e taxa de expediente sobre os materiais para a edificação das moradias, exceto madeiras, bem como, quaisquer outros impostos, foros e laudêmios relacionados aos terrenos e aos prédios, sua aquisição e transmissão; a isenção do selo federal em qualquer contrato referente à construção que forem autorizadas; concessão de terrenos de propriedade federal que não forem necessários a outros serviços da União; doação de terrenos desapropriados pelo governo (para tanto, os construtores deveriam solicitar essa ação a partir da apresentação da planta da construção); descontos e até isenção das taxas de transporte rodoviários para os proprietários dos grupos de moradias, bem como para seus futuros moradores; direito a contrariar empréstimos hipotecários, retirados nas Caixas Econômicas ou por intermédio do Banco do Brasil para a realização das construções, assim como, o direito a caução de título de dívida pública, para o mesmo fim.
} 
A reforma legislativa empreendida no início da década de 1930124 possibilitou a aplicação das receitas das Caixas existentes, na construção de casas para os seus associados, que passou a ocupar, cada vez mais, o lugar da aquisição de títulos de dívida pública. Isso ocorreria, porém, condicionado a um regulamento que seria expedido pelo Ministro do Trabalho. Esse regulamento só foi publicado em abril do ano seguinte ${ }^{125}$. Por ele ficou decidido que caberia ao Conselho Nacional do Trabalho (CNT), a liberação de quaisquer ações imobiliárias das CAPs. A cota mínima de reserva, exigida para a realização dessas operações (500:000\$000) foi mantida. O referido documento apenas determinou que a construção das sedes e/ou escritórios deveria se dar por meio de concorrência pública, e especificou que quando liberados os financiamentos e a construção de moradias: o prazo para amortização da dívida seria de cinco, dez ou quinze anos; os juros das ações seria de $8 \%$ ao ano, de modo que a prestação mensal não comprometesse mais que 30\% do salário do associado; deveria ser realizado o pagamento de uma cota mensal de conservação da casa correspondente a 3\% do seu valor; além do pagamento dos impostos e taxas prediais e administrativas, seguro contra fogo e outros a serem fixados por cada Caixa. Também foram estabelecidas as modalidades de ações imobiliárias permitidas: as construções seriadas, quando realizadas em conjunto (em área pertencente à Caixa e em número nunca inferior a dez) e as construções não seriadas, quando edificadas isoladas em terrenos dos associados com o financiamento concedido pela CAP.

De qualquer modo, a atuação das Caixas de Aposentadoria e Pensões no campo habitacional por meio da construção de moradias aos associados foi ínfima até o ano de 1937, quando foram criadas as Carteiras Prediais ${ }^{126}$. Cabe aqui ressaltar também, que a possibilidade de aplicação dos fundos de reservas das Caixas de Aposentadoria e Pensões do MTIC para a aquisição e/ou edificação de unidades habitacionais para seus associados, iniciada em 1930, não consistiu numa iniciativa dos trabalhadores, por meio de solicitações ou reivindicações, mas surgiu no âmbito do próprio Ministério do Trabalho e do seu corpo técnico. Nesse período (1930-1937), de acordo com Rubens Porto (1938), as CAPs foram responsáveis pela edificação de aproximadamente 670 (seiscentos e setenta) unidades habitacionais locadas, essencialmente, em três cidades: Rio de Janeiro/RJ (570 unidades), Belo Horizonte/MG e Porto Alegre/RS (100 unidades no total).

No âmbito dos IAPs, a atuação no setor da habitação social, no que concerne à provisão de moradias aos seus beneficiados pela construção de unidades habitacionais, começou a ser observada já em 1933, ano de criação do primeiro Instituto de Aposentadoria e Pensões do MTIC, o dos Marítimos ${ }^{127}$. Por meio do Decreto-Lei de criação do IAPM também foi determinado que as importâncias arrecadadas pelo Instituto, e posteriormente pelos demais IAPS, deduzidos os gastos previstos, deveriam ser depositadas mensalmente

\footnotetext{
124 Por meio do Decreto n.20.465, de 01 de outubro de 1930, mais especificadamente por seu Art.19.

125 Pelo Decreto n.21.326, de 27 de abril de 1932, publicado no Diário Oficial do dia 30 de abril, do mesmo ano.

${ }^{126}$ Essas informações são baseadas naquelas contidas nas publicações sobre a temática. A falta de estudos e, consequentemente, de dados sobre 0 assunto, nos impede de formular afirmativas nesse sentido. Até mesmo nos levantamentos realizados nas capitais nordestinas não foram encontrados dados suficientes para traçar conclusões mais precisas sobre a atuação das CAPs no campo habitacional.

127 Instituído pelo Decreto-Lei n.22.872, de 29 de junho de 1933.
} 
em conta especial do Banco do Brasil, e que esses recursos deveriam ser aplicados de modo que se obtivesse o maior rendimento possível. A aquisição de títulos de renda federal e a edificação de residências para os seus associados, mediante hipoteca e descontos mensais, bem como, a aquisição ou construção de edifícios para servir de sede definitiva para o Instituto, eram as modalidades possíveis de investimento dos fundos desse órgão. A partir de então, não era mais necessária a prévia autorização do Conselho Nacional do Trabalho para tanto.

No ano de $1934^{128}$, a possibilidade de investimento no mercado de imóveis, sobretudo no campo habitacional, foi ampliada aos demais IAPs existentes, mais precisamente, ao IAP dos Comerciários e ao IAP dos Bancários. As Caixas e Institutos foram então autorizados a investirem até $40 \%$ de suas reservas na construção de moradias. Nesse contexto, apenas os associados não proprietários de imóveis de qualquer natureza poderiam ser beneficiados ${ }^{129}$.

Observa-se, dessa maneira, que a ampliação da percentagem das reservas das CAPs e dos IAPs a ser investida no campo habitacional não foi somente consolidada com a criação das Carteiras Imobiliárias, em 1937, como indicou Bonduki (2002, p.103): “(...) a liberação dos recursos para investimentos permaneceram limitados até 1937 (...)". Ela foi disponibilizada três anos antes (40\%), pelo Decreto n.24.488, de 1934.

Foi também por esse Decreto, dada a possibilidade de encampar ${ }^{130}$ a dívida para a aquisição de moradia, elevada a parcela de comprometimento do salário do beneficiado com as parcelas de amortização da dívida de 30\% para 50\%, estabelecida a importância máxima liberada para os financiamentos (30:000\$000 contos de réis) e introduzido o seguro de garantia de dívida - a ser somado às taxas de manutenção e/ou administração do imóvel e ao seguro contra fogo já em curso - cujas especificações não eram claras. 0 número mínimo liberado para a construção de casas seriadas também foi reduzido. O limite até então era dez residências conjugadas e passou a ser de quatro moradias, conjugadas ou não.

Quando a construção de moradias para a venda ou aluguel para os associados dos Institutos e Caixas começou a se configurar como uma ação possível, nem todas as categorias trabalhistas se mostraram favoráveis. Isso, provavelmente, ocorreu pelo fato de que nos primeiros anos da década de 1930 e nas duas décadas anteriores, as reivindicações dos assalariados do país diziam respeito, sobremaneira, aos aumentos dos vencimentos mensais, melhora das condições e redução das jornadas de trabalho, bem como 0 recebimento de aposentadoria e pensões. Nas greves gerais ocorridas nos anos de 1917 e de 1919, por exemplo, a questão habitacional apareceu diluída dentre tantas outras. As Ligas dos Inquilinos e outros sindicatos e/ou organizações trabalhistas do Rio de Janeiro e São Paulo exigiam ações estatais, essencialmente, para a redução dos aluguéis e não para a edificação de moradias ${ }^{131}$. Essa afirmativa é

\footnotetext{
128 Por meio do regulamento publicado em 28 de junho naquele ano, no Decreto n.24.488, divulgado no Diário Oficial, em 02 de junho de 1934 e no Boletim do Ministério do Trabalho, Indústria e Comércio, n.07, de março de 1935.

129 Também foi estabelecido o prazo para a amortização da dívida entre 10 e 15 anos e manteve-se a taxa de juros anual em 8\%.

130 Contrariar empréstimo para cobrir dívida anterior.

131 Outras preocupações estavam relacionadas à descapitalização dos fundos previdenciários dos órgãos.
} 
facilmente percebida no trecho de um memorando formulado pelo IAP dos Ferroviários, em meados da década de 1930:

(...) os ferroviários aplaudem a determinação do governo de permitir a construção de casas econômicas para os trabalhadores; no entanto, observam que a principal finalidade das Caixas é garantir aposentadoria e pensões a seus associados, para o que é necessário "fazer renda", enriquecendo a associação em proveito de seus fins beneficentes (ARAÚJO, 1979, p.97).

O regulamento de criação de órgãos que pela primeira vez passou a considerar a realização de empréstimos para a aquisição e/ou construção de moradias, além dos empréstimos para a quitação de dívida de aluguel de residências e a compra de unidades já edificadas (residências de terceiros) para o repasse aos associados, foi o do Instituto de Aposentadoria e Pensões dos Bancários, por meio das disposições que regeram as suas ações, publicadas um ano após a sua criação ${ }^{132}$. Essas modalidades de investimento foram ampliadas aos demais Institutos no ano de 1939133.

Ainda em 1934, foi decidido que o CNT além das atribuições que lhes eram cabíveis, passaria a delimitar sua atuação por zonas ou regiões, instalando escritórios estaduais nessas localidades, e a superintender a fiscalização desses órgãos, das instituições de seguro social e demais entidades congêneres criadas oficialmente, além de estudar e julgar os planos e projetos de construção de casas para os associados das CAPs e IAPs, bem como de prédios para suas respectivas sedes ${ }^{134}$. Mais especificadamente, no âmbito de sua Secretaria, no tocante ao serviço de engenharia, foi resolvido que era de sua responsabilidade:

(...) organizar as bases para o concurso de projectos de construção de casas para associados das Caixas de Aposentadorias e Pensões e outras instituições de congêneres e de predios para installação definitiva de suas sédes. (...) Apreciar os projectos apresentados e opinar sôbre elles, indicando o preferivel. (...) Propôr modificacções, que se tornem necessarias, ao projecto escolhido e organizar as bases para as respectivas especificações. (...) Informar as propostas de construcção de predios, e fiscalizar as respectivas obras. (...) Organizar, quando fôr indispensavel, projectos e especificações, orçamentos e outros trabalhos dessa natureza. (...) Executar serviços de ordem technica, quando digam respeito ás Caixas de Aposentadoria e Pensões e a outras instituições de previdencia (...) (DECRETO N.24.784, 14/07/1934).

No mesmo ano, também foram modificadas as nomenclaturas dos cargos que compunham o órgão, a citar: os inspetores das Caixas de Aposentadoria e Pensões, que no momento de outorga do Decreto eram no total de nove fiscais em todo o país, passaram a ser denominados de inspetores de previdência; 0 engenheiro-fiscal de construção passou a ser chamado de engenheiro-chefe; o engenheiro-fiscal ajudante de construção passou a ser designado como engenheiro-ajudante; e o desenhista-arquiteto passou a ser 0

\footnotetext{
132 No Decreto n.54, de 12 de setembro de 1934.

${ }_{133}$ Por meio do Decreto-Lei n.1.308, de 31 de maio.

134 Pelo Decreto n.24.784, de 14 de julho de 1934.
} 
arquiteto da Sessão de Engenharia do CNT, provavelmente, um reflexo do processo de reconhecimento da profissão (DECRETO N.24.784, 14/07/1934).

Ao engenheiro-chefe, particularmente, cabia as funções relacionadas à edificação de imóveis, dirigir, examinar, fiscalizar e promover todos os trabalhos que eram executados sob sua responsabilidade, bem como encaminhar ao diretor geral os respectivos pareceres, além de legalizar e autenticar, depois de devidamente conferidos, as cópias e documentos expedidos e relacionados à construção. Ao engenheiroajudante e ao arquiteto cabia executar os trabalhos e plantas de que forem incumbidos pelo engenheirochefe. Os inspetores de previdência, antigos inspetores das Caixas e Institutos de Aposentadoria e Pensões, eram locados em diferentes regiões do país, conforme as exigências do serviço, e a eles cabiam:

(...) I- Verificar a applicação das leis, regulamentos e instruções referentes ás instituições fiscalizadas, e, proceder ás necessarias inspecções e tomadas de contas, na fórma das instruções existente. II - Conceder prazo, nunca superior a 15 dias, para preenchimento das formalidades que não estejam sendo observadas pelas Caixas e Institutos fiscalizadores exepto nos casos de responsabilidade pecuniária ou que tragam prejuizos á instituição em que providenciarão immediatamente communicando-se com o diretor geral da Secretaria. III - Examinar os processos de (...) construcção de casas (...) (DECRETO N.24.784, 14/07/1934).

Cabe aqui destacar, que nem todos os projetos aprovados e/ou construídos pelas Caixas de Aposentadoria e Pensões foram escolhidos por meio de concursos públicos ou concursos fechados como especificava a supracitada legislação. E muito menos, que todos os projetos formulados eram de autoria do engenheiro-chefe, ajudante ou do arquiteto da Sessão de Engenharia, da Secretaria do Conselho Nacional do Trabalho. Diversos dos grupos habitacionais edificados pelas CAPs e IAPs foram elaborados pelos corpos técnicos que compunham as Carteiras Prediais e/ou as Sessões de Engenharia dos referidos órgãos, seus escritórios centrais ou estaduais.

Em 1937, graças à outorga do Decreto n.1.749 de 28 de junho, foram criadas as Carteiras Prediais de cada Instituto. Essa resolução foi responsável, mais uma vez, pelo alargamento e intensificação das ações desses órgãos no campo da moradia social no país. Por ela, os institutos de previdência ficaram autorizados a utilizar até a metade de suas reservas na construção, aquisição e/ou financiamento de habitações econômicas para os seus associados, $10 \%$ a mais que permitido até então. De modo geral, por meio desse Decreto foi também estabelecida a redução da taxa de juros anual sobre essas ações de 8\% para 6\%, elevado o prazo máximo para a amortização da dívida junto ao órgão de 20 para 25 anos no caso do beneficiado ter família numerosa e permitida a compra de imóveis pelos IAPs e CAPs, com a condição que os mesmos possuíssem até cinco anos de edificado. Foi também autorizado o pleito de um novo imóvel pelos associados que já possuíssem residência - o que até o momento era estritamente proibido -, dando margem para que muitos associados abastados adquirissem imóveis. Foi ainda elevado o limite máximo do financiamento de 30:000\$000 (trinta conto de réis) para 80:000\$000 (oitenta contos de réis). Tais 
determinações em muito contribuíram para a aceleração do processo de construção de casas para os trabalhadores brasileiros assalariados, a partir de então.

Os regulamentos das Carteiras Prediais dos Institutos e Caixas de Aposentadoria e Pensões foram publicados ao longo do segundo semestre do ano de 1937 e durante os anos de 1938 e 1939. As primeiras Carteiras regulamentadas foram a do IAP dos Comerciários e a da CAP dos Estivadores e dos Trabalhadores em Trapiches e Armazéns de Café em meados de 1937135, seguidas pela do IAP dos Bancários em fins de 1937136, do IAP dos Marítimos no ano seguinte ${ }^{137}$ e pela do IAP dos Industriários e do IPASE, posteriormente.

Outro ponto importante estabelecido pelo Decreto de criação das Carteiras Prediais dos Institutos de Aposentadoria e Pensões foi a definição das categorias de operações imobiliárias passíveis de serem realizadas. Eram elas:

a) compra de prédios e respectivos terrenos; b) compra de terreno e construção do prédio, ou construção de prédio em terreno já de propriedade do associado; c) compra de terreno e construção de casas ou prédios de apartamentos, por iniciativa direta dos Institutos e Caixas, para a venda dos seus associados; d) concessão de empréstimo, garantido com hipoteca até $2 / 3$ (dois terços) do valor do prédio (...) de propriedade do associado (PORTO, 1938, p.124).

Em se tratando das possíveis ações no campo habitacional, diversos autores afirmam existir um padrão de classificação, organizado em Planos bem definidos, que não foi confirmado na presente tese. De acordo com autores como Farah (1983), Varon (1989) e Bonduki (2002), sobremaneira, e perpetuado em diversos outros estudos posteriores, as operações imobiliárias dos Institutos e Caixas de Aposentadoria e Pensões eram organizadas em três Planos: o Plano $A$, que equivalia à locação ou à venda de unidades habitacionais, adquiridas ou construídas pelos Institutos, aos seus associados; o Plano $B$, que se referia ao financiamento para construção de moradia em terreno do próprio associado; e o Plano C que abrangia todos os empréstimos hipotecários concedidos a qualquer pessoa física ou jurídica e todas as outras operações imobiliárias pertinentes aos IAPS, com o objetivo de elevar o volume de recursos capitados. Os autores afirmam também, que esse modelo de organização foi inicialmente aplicado pelo IAP dos Industriários (IAPI) e foi sendo paulatinamente adotado pelos demais Institutos, se tornando a base para a atuação da grande maioria deles no campo habitacional.

No entanto, o que se procedia era uma grande diversidade de ações, que não foram ordenadas de forma homogênea em um número restrito de Planos. Esses autores, possivelmente, assim procederam para simplificar 0 agrupamento das ações imobiliárias praticadas pelos IAPs e pelas CAPs, facilitando a análise e formulação de suas conclusões. Porém, no processo de levantamento e sistematização de dados, realizado nesta pesquisa, chegou-se a enumerar sete Planos, conformados por uma gama de Classes que chegavam a

\footnotetext{
135 Publicadas no Boletim do Ministério do Trabalho, Indústria e Comércio, n.36, de agosto daquele ano.

136 Divulgada pelo Boletim do MTIC, n.40, de dezembro de 1937.

137 Publicada no Boletim do MTIC, n.43, de março de 1938.
} 
passar de dez em algumas Carteiras Prediais. O próprio regulamento da Carteira Predial ao IAPC, o primeiro a ser formulado e que serviu de base para a elaboração dos demais, ao contrário do colocado pela historiografia ${ }^{138}$, especificava quatro possíveis planos de ação no campo habitacional, como observado na citação anterior.

A classificação das solicitações em planos e classes, bem como a denominação e abrangência delas, variava bastante de um Instituto para outro, e de uma localidade para outra, havendo inclusive alguns órgãos (escritórios estaduais) que não apresentavam nenhuma classificação por Planos e/ou por Classes. Essa afirmativa pode ser atestada pelo próprio Decreto de criação das Carteiras Prediais dos Institutos:

(...) 0 desenvolvimento dessa atuação (...) teve seus parâmetros estabelecidos pelas instruções relativas ao funcionamento das Carteiras Prediais, que se caracterizam pela ausência de uniformidade, devendo pautar-se cada Instituto por normas particulares, distintas das definidas para cada uma das Instituições (BRASIL, Decreto n.1.749, 28/06/1937, s/p).

Mesmo se não houvesse as instruções estabelecidas pelo supracitado Decreto, a classificação das ações imobiliárias por meio dos Planos A, B e C, estipuladas por aqueles autores, cujos Planos A e B atendiam somente aos associados, não seria válida. A própria Portaria que regulamentou a atuação da Carteira Predial do IAPI ${ }^{139}$, por exemplo, considerava a possibilidade de atendimento dos não associados nas operações definidas pelos autores citados anteriormente, como o "Plano A" (venda ou aluguel de imóveis de propriedade do Instituto), caso o número de interessados associados fosse inferior ao número de habitações disponíveis.

Somente com a outorga do Decreto n.34.828, de 17 de dezembro de 1953, se pode traçar uma aproximação a um esquema de Planos, mas, de qualquer forma, não se assemelha ao modelo consagrado pela historiografia existente. Esse documento legal especificou o regulamento geral das ações imobiliárias dos IAPs, numa tentativa de organizar e, de certa maneira, uniformizar suas ações no campo habitacional140. No entanto, essa carta legislativa explicita claramente que "(...) as operações imobiliárias das Instituições de Previdência Social obedecerão a programas próprios, com o fim de atender, nas diversas zonas geográficas, sob os aspectos econômico, financeiro e social, ao interêsse das instituições, dos segurados e da população em geral (...)" e "(...) na elaboração dos programas próprios, as Instituições poderão, quando houver justo motivo, cingir suas atividades a determinados planos e, dentro dêstes, as modalidades que julgarem mais convenientes" (DECRETO N.34.828, 17/12/1953, Art.1/2). Cabe lembrar ainda, que essa classificação de baliza não foi incorporada por Institutos como o IPASE ou pelas diversas CAPs nacionais existentes.

As operações imobiliárias especificadas pelo referido Decreto variavam do Plano A ao E. Suas finalidades eram assim especificadas: Plano A - preponderantemente social e de renda; Plano B - social e de

\footnotetext{
138 Alguns autores colocam que o primeiro regulamento de carteira predial foi o do IAPI. Dados encontrados nas publicações de FARAH (1983), BONDUKI (2002), dentre outros.

139 Portaria n.SCM-192, em seu Art.1ㅇ, de 28 de novembro de 1939.

140 Procedimento semelhante ocorreu no plano da previdência e outros serviços prestados aos associados dos IAPs no país.
} 
renda; Plano C - administrativa, patrimonial, social e de renda; Plano D - essencialmente econômica/financeira para as Instituições; Plano E - social e interesse coletivo.

As operações compreendidas pelo Plano A estavam relacionadas à locação de moradias aos associados dos IAPs, essencialmente àquelas de propriedade dos Institutos. O plano B incorporava os financiamentos realizados aos segurados, com a finalidade de proporcionar a aquisição, construção, conservação, reforma e ampliação de imóveis para moradia e, ainda, para a encampação de dívida hipotecária contraída para os mesmos fins. Por meio dessa modalidade de atuação, os IAPs também poderiam vender aos associados os imóveis de sua propriedade, inclusive terrenos, mediante a assinatura simultânea do contrato de financiamento para a edificação do imóvel para sua residência. O Plano C compreendia todas as inversões realizadas em imóveis para uso ou venda dos IAPs, tendo em vista a estabilidade de seu patrimônio. Por esse Plano também eram "(...) edificados ou adquiridos os imóveis a serem locados pelo Plano A e, bem assim, os que se destinarem a venda aos assegurados, na forma do (...) Art.10" (DECRETO N.34.828, 17/12/1953), relacionado às operações do Plano B. Isto é, o Plano C era 0 plano primeiro, a base sobre a qual se realizava qualquer operação imobiliária dos IAPs no campo social e de renda. O Plano D incorporava os empréstimos hipotecários realizados a qualquer pessoa física ou jurídica pelos Institutos, com o propósito de obter constante e a mais elevada remuneração de sua reserva, e o Plano E abrangia os empréstimos destinados a custear a construção ou aquisição de escolas, hospitais, creches, ambulatórios, sanatórios, colônia de férias, refeitórios, restaurantes, sedes e associações de moradores ou sindicais.

Apesar do supracitado Decreto organizar de modo homogêneo as ações imobiliárias passíveis de serem realizadas pela maior parte dos IAPS, o que se observou foi uma continuidade das modalidades préexistentes e/ou a utilização das novas possibilidades para a realização de ações atuariais. A dualidade das ações dos Institutos é facilmente percebida na redação da legislação acima referenciada. Por exemplo, quando os imóveis não fossem alugados aos trabalhadores menos abastados (operação com caráter social), poder-se-ia proceder pelo Plano B, com uma taxa de juros 4\% maior sobre o imóvel, passando a ser de 10\% ao ano. Ou ainda, quando os imóveis edificados ou adquiridos pelos órgãos (Plano A) não fossem alugados aos contribuintes poderiam ainda ser disponibilizados à população em geral pelo Plano $\mathrm{C}$.

Sendo assim, ressalta-se com mais afinco que cada Instituto era regulamentado por dispositivos legais específicos, o que resultou numa diversidade de atuação, produção, qualidade e serviços. Essas diferenças em muito dificultaram as análises referentes ao caráter social dos financiamentos concedidos aos associados nas capitais nordestinas, como se verá nos capítulos seguintes, assim como, acerca das características dos pleitos e da organização das modalidades dos financiamentos nos diferentes institutos abordados nesta tese.

De qualquer modo, as ações imobiliárias que se caracterizavam pela venda ou aluguel de unidades habitacionais adquiridas ou edificadas pelos Institutos e Caixas, em conjuntos habitacionais ou isoladamente, 
se conformavam juntamente com o financiamento para a construção de moradia no terreno do associado ou para a compra de terreno e construção de residência e suas variações, como as modalidades que se enquadravam na política pública pretendida. Os financiamentos e/ou empréstimos para as demais ações direcionadas aos trabalhadores das classes mais abastadas e a terceiros, o que incluía empresas e o próprio Estado em suas três instâncias, são nesta tese classificadas como atuariais. Isso procede devido às elevadas taxas de juros praticadas nessas ações que, algumas vezes, chegavam a 15\% ao ano. Atuando dessa maneira, os Institutos se caracterizavam como investidores interessados em "sobrelucros".

A possibilidade de realização dessas ações voltadas a terceiros e aos associados mais abastados foi incorporada inicialmente, como já colocado, na Carteira Predial do IAPI, no momento de sua criação, sendo seguida pelo IAPTEC, ainda em 1939141, e pelo IPASE, em 1941 ${ }^{142}$. Somente em 1953, essa modalidade foi estendida aos demais Institutos ${ }^{143}$.

Em se tratando das exigências para a concessão e liberação dos financiamentos para a compra ou construção de moradias aos associados, os Institutos e Caixas de Aposentadoria e Pensões exigiam uma grande quantidade e diversidade de documentos que, de maneira geral, coincidiam entre os diferentes órgãos. Nos primeiros anos de atuação, para solicitar um financiamento, 0 associado deveria ser funcionário com carteira profissional (ativo ou inativo), ser contribuinte obrigatório do Instituto há mais de cinco anos, ter encargos de família e possuir margem consignável permissiva à averbação de prestação imobiliária. 0 solicitante obrigatoriamente não poderia ser proprietário, condômino ou promitente comprador de qualquer outro imóvel144.

A solicitação deveria ser enviada ao escritório estadual do Instituto por meio de carta registrada em nome do solicitante, especificando o pleito e enquadrando-o em um dos planos e/ou classes nos quais se trabalhava. Aprovada a requisição do financiamento pelo Instituto, seria então realizada uma avaliação do imóvel pelo engenheiro responsável do IAP ou profissional indicado por ele. Após aprovada e liberada, a proposta deveria ser entregue pelo próprio associado ao setor responsável no escritório do Instituto, apresentando no ato de entrega da proposta, a caderneta de contribuições do IAP e o título de identidade (carteira profissional, carteira de identidade, etc.), além dos documentos referentes à descrição do pleito. Uma vez autorizada a proposta de financiamento de imóvel e/ou terreno pelo órgão, o assegurado estava comprometido a realizar a operação, sob pena de multa ou processo dependendo do valor pleiteado.

A partir de fins da década de 1930 e no decorrer da década de 1940, principalmente, foram concluídos os primeiros grandes conjuntos habitacionais edificados pelos Institutos no país. Para dar visibilidade à intervenção estatal nesse campo e respostas concretas às reivindicações por moradias dos trabalhadores, as inaugurações dos conjuntos passaram a se conformar como verdadeiros eventos, com

\footnotetext{
141 Por meio da Portaria n.SCM-202, de 12 de dezembro, publicada no Diário Oficial de 14 de dezembro de 1939.

142 Instruções n.03, do Instituto.

${ }_{143}$ Por meio do já citado Decreto n.34.828, de 17 de dezembro, referente às operações imobiliárias das instituições previdenciárias.

${ }^{144}$ Apesar do Decreto n.1.749 de 28 de junho de 1937 ter permitido que associados proprietários de imóveis pleiteassem outra moradia juntos às Carteiras Prediais, parte dos Institutos e Caixas continuou a considerar esse procedimento como proibido.
} 
cerimônias, festividades e contando com a participação de figuras ilustres da política brasileira, em diversas ocasiões, inclusive do presidente da República. Para Lira (1996), esses grandes projetos tiveram um considerável impacto político e valor simbólico, cujo intento principal foi o de reafirmar o poder de decisão e a força da modernização do Estado no país.

Essa realidade pode ser atestada pelos próprios Boletins e Relatórios formulados pelo corpo técnico dos Institutos e apresentados ao MTIC:

(...) com menos de um ano de funcionamento a Carteira Imobiliária teve coroados os seus esforços em 21 de março do corrente ano, com o lançamento da pedra fundamental da primeira vila operária do Brasil - Vila Operária Waldemar Falcão! Nesta vila foram construídas 52 casas que, após receberem completo mobiliário, foram inauguradas, em 19 de novembro de 1938, pelo Presidente Getúlio Vargas (IAPC..., 1939, s/p).

No trecho do Relatório de Exercício do ano de 1938, do IAP dos Comerciários, acima citado, percebese o sensacionalismo da notícia de inauguração da Vila do IAPC - que recebeu o nome do então Ministro do Trabalho - sendo considerada como a primeira, o que não procedia ${ }^{145}$. Essa Vila, localizada na Ilha do Governador (RJ), foi projetada e edificada pelo engenheiro Helvécio Xavier Lopes, sendo antecedida por uma série de pequenos grupos de moradias e vilas edificadas em diversas partes do país, como a Vila Hermes da Fonseca e a São Cristovão edificadas pelo Instituto de Previdência dos Funcionários Públicos da União, em 1931 e 1933 respectivamente, além de outras tantas que serão apresentadas nos capítulos que se seguem.

O número de unidades habitacionais edificadas pelos IAPs e CAPs no país, encontrado nas publicações sobre o tema, não é resultado de levantamentos oficiais. Foram estipulados e/ou apontados apenas por meio das informações encontradas em algumas Portarias e publicações específicas, como os Boletins do Ministério do Trabalho, Indústria e Comércio e as revistas dos Comerciários e dos Industriários. Vale lembrar, que nem o MTIC, nem o Conselho Nacional do Trabalho (CNT), órgão subordinado a ele, apresentaram e/ou publicaram o balanço completo dessa produção no país. Por vezes, eram divulgados balanços parciais acerca de alguns órgãos por estado, como foi encontrado do IAPI, IAPB e IAPC em cidades como São Paulo e Rio de Janeiro. Grande parte deste material foi destruída e/ou comprometida por incêndios que assolaram o Arquivo da Previdência, no Rio de Janeiro, ainda nos anos de 1900, e o prédio do INSS em Brasília, em 2005146, onde estavam arquivados muitos dos dados oficiais acerca da história da previdência em nosso país. O número exato de moradias disponibilizadas por esses órgãos só poderá ser atestado, dessa maneira, após a realização de levantamentos minuciosos em cada um dos estados da federação. Mesmo assim, o volume de unidades habitacionais financiadas (aquisição de terreno para construção,

\footnotetext{
145 Percebe-se ainda, referências à incorporação do mobiliário nas moradias operárias, proposta pelo corpo técnico do MTIC, em concordância com as proposições dos CIAMs, em âmbito mundial, e do I Congresso de Habitação, de 1931, como será tratado no tópico seguinte.

146 Esse incêndio ocorreu em 27 de dezembro de 2005 e destruiu seis dos dez pavimentos que conformavam o edifício do INSS em Brasília. A nova sede só foi inaugurada em março de 2010 e para a sua construção foram desprendidos $\mathrm{R} \$ 56.000 .000$ de reais, como destacou o Ministério da Previdência, na ocasião.
} 
edificação em terreno próprio ou compra de terceiros), praticamente será impossível de ser apontada, frente às condições precárias dos acervos e arquivos brasileiros.

Acredita-se que os dados que até hoje servem de baliza para a elaboração de estudos sobre a temática em questão foram, primeiramente, apontados por Farah (1983) e foram largamente difundidos em trabalhos posteriores como GAP (1985) e Bonduki (2002). Assim, por hora, é com base nas informações desses autores que se pautam as afirmativas acerca da produção das CAPs e dos IAPs em escala nacional nesta tese. Sendo assim, entre os anos de 1938 (quando a historiografia indica que foi edificado o primeiro conjunto habitacional) 147 e 0 ano de 1945, os IAPs adquiriram seis grupos de moradias já concluídos e construíram 33 (trinta e três) em todo o território nacional, além de três edifícios de apartamentos, totalizando 6.626 (seis mil, seiscentos e vinte e seis) unidades habitacionais.

Nesse contexto, o IAP dos Industriários e o IAP dos Comerciários foram os que mais edificaram grupos residenciais em número, 11 (onze) cada um. Os conjuntos habitacionais do IAPI eram significantemente maiores que os do IAPC. Enquanto os 11 (onze) grupos construídos para os industriários totalizavam 4.749 (quatro mil, setecentos e quarenta e nove) moradias, os do IAPC correspondia apenas a 711 (setecentos e onze) unidades; se aproximando do número de residências edificadas pelo IAP dos Estivadores, 467 (quatrocentos e sessenta e sete). Em contrapartida, o IAPC foi um dos Institutos que adquiriu o maior número de conjuntos para os seus associados durante esse período, um total de 64 conjuntos (FARAH, 1983).

Em se tratando das residências adquiridas ou edificadas pelos associados por meio de empréstimos sociais concedidos pelos IAPs, entre 1938 e 1945, destaca-se a atuação do IAP dos Bancários, que financiou 1.008 (mil e oito) unidades habitacionais. Enquanto o IAPI concebeu 716 (setecentos e dezesseis) financiamentos, e o IAPE e o IAPTEC, em conjunto, promoveram 146 (cento e quarenta e seis). Nesse período, a grande maioria das unidades habitacionais foi edificada na capital federal, o Rio de Janeiro.

Cabe lembrar que o número incipiente de moradias construídas ou adquiridas tanto pela iniciativa dos IAPs quanto pela dos próprios associados, nos primeiros anos de sua atuação, deve-se aos largos investimentos em obras públicas e à necessidade de montagem e/ou aumento das reservas de fundos para investimento na compra de terrenos para a edificação dos conjuntos habitacionais, sedes administrativas, hospitais, restaurantes, etc. para onde foram direcionadas grandes parcelas das reservas dos órgãos. Associado a isso estava à necessidade de resposta às reivindicações trabalhistas no período por assistência e previdência, que colaboraram para que a moradia permanecesse em segundo plano.

Em fins da década de 1930, a questão da descapitalização dos fundos de reservas das Caixas e Instituto foi exacerbada. Esse quadro foi resultante também da crise que culminou no país naquele momento, caracterizada pela alta inflação, e pela inadimplência do Estado e das empresas no tocante ao sistema de contribuição tripartite. Na década seguinte, no contexto mundial, houve uma revisão da finalidade e papel do

147 O que já sabemos que não é o correto. 
Estado, que resultou numa ampliação dos objetivos da Previdência Social, ganhando força à seguridade social (extensão dos direitos sociais), na qual a administração pública se mostrava responsável pela manutenção do estado de Bem-Estar Social. O Welfare State pressupunha a extensão dos gastos públicos nas áreas sociais e uma mudança na forma de encarar os problemas relacionados, que incluía a habitação. Esses preceitos chegaram ao país, sobretudo, por meio de publicações, convenções e congressos, os quais, os técnicos do Ministério do Trabalho e das Caixas e Institutos de Aposentadorias e Pensões participaram e/ou tiveram acesso aos documentos produzidos. Muitas dessas publicações foram elaboradas no âmbito do Bureau Internacional do Trabalho, a antiga Organização Internacional do Trabalho (OIT), essencialmente a conhecida "Tese da Seguridade Social". Nos Relatórios de Exercícios e Boletins do MTIC de diversos Institutos eram recorrentes as referências ao Bureau nesse sentido:

(...) Na América Latina e Setentrional, o problema dos riscos cobertos e benefícios concedidos é de difícil solução. Todavia, o sistema de proteção social integral, posto em vigor no último ano pelo IAPTEC, é a primeira aplicação prática dos princípios do programa de seguridade social; conforme a opinião expressa no relatório que acompanha o projeto de lei orgânica da Previdência Social - 0 plano geral da aplicação das reservas preconizado nesse projeto segue fielmente o mais moderno dos Regulamentos dos Institutos - 0 do [IAPTEC] (...) - 0 qual, por sua vez, seguiu também a orientação técnica recomendada pela Bureau Internacional do Trabalho (...) (OLIVEIRA, 1940, p.305-306).

Diante do supracitado contexto, a solução encontrada pelo corpo técnico do MTIC em conjunto com os presidentes das CAPs e dos IAPs foi inicialmente 0 alargamento da política de aluguel das unidades habitacionais adquiridas ou edificadas pelos órgãos e, em seguida, a liberação da realização de empréstimo a qualquer pessoa física ${ }^{148}$ - uma vez que os juros para essas atividades eram consideravelmente maiores.

De acordo com as Portarias dos Institutos e Caixas, o aluguel era o modo pelo qual a parcela de trabalhadores mais carentes iria conseguir acesso à moradia. Mas, também se mostrava uma operação rentável, uma garantia de controle do imóvel e de certa forma do trabalhador, além de contribuir para a constituição de um patrimônio para as Carteiras Prediais. A política de aluguel foi adotada timidamente pelas Caixas do MTIC, em 1930, e pelos Institutos desde a sua criação. Desde então, até a volta da vigência das Leis do Inquilinato, em 1942, a ausência do congelamento de aluguéis colaborou para viabilizar 0 desenvolvimento dessa linha de atuação nos órgãos. A partir da década de 1940, por outro lado, observou-se um decréscimo dessa prática, sendo exacerbada a partir de 1945 com o processo de redemocratização do país e a adoção de outras perspectivas no campo habitacional por parte do novo presidente da República, como a criação da Fundação da Casa Popular (FCP). Concomitantemente, havia por parte de diversos membros do corpo técnico dos IAPs e das CAPs, a defesa da venda das unidades habitacionais adquiridas ou edificadas pelas suas Carteiras Prediais, no contexto de consideração da propriedade como um importante fator de estabilidade social; merecendo destaque nesse sentido, a figura do engenheiro-arquiteto Rubens Porto.

148 Por meio da, já apontada, Portaria n.SCM-202 de 12 de dezembro de 1939. 
Com a intensificação da crise de moradias ao longo dos anos de ocorrência da II Guerra Mundial, Vargas ampliou mais uma vez o limite para aplicação das Carteiras Prediais dos IAPs, liberando a percentagem de investimento de reservas no campo habitacional, como colocado pelo presidente no discurso do Dia do Trabalho, em maio de 1944:

(...) Terminada a fase de experiência e solidificação dos Institutos e Caixas, cujas reservas vinham sendo aplicadas sob o critério de imediata segurança e rendimento certo, é tempo de iniciarmos uma política de mais largo alcance relativamente ao emprego dos fundos acumulados (...). Quanto à aplicação de capital também serão adotados rumos diferentes (...). O cálculo da mobilização financeira das reservas atuais permite-nos anunciar 0 propósito de nelas inverter inicialmente quinhentos milhões de cruzeiros (VARGAS, 1945, p.288/289).

Paralelamente, foi criada a Comissão de Aplicação das Reservas da Previdência Social (CARPS), também subordinada ao MTIC, para efetuar o controle e a fiscalização de suas ações. Vislumbrou-se a partir de 1945, um considerável alargamento da atuação dos Institutos e das Caixas no campo habitacional tanto por meio da edificação de conjuntos, como no que condiz ao financiamento para aquisição de terrenos e construção de moradias, que perdurou até o início da década de 1950149. Contribuiu para tanto, o fato dos governos municipais terem começado a colaborar com os Institutos e Caixas de modo mais íntimo, no que concerne à incorporação dos projetos de conjuntos habitacionais nos planos de urbanização das cidades, como destacou o próprio presidente:

(...) Com a colaboração das administrações, que entrosarão os respectivos projetos nos seus planos de urbanização, construiremos cidades-modelo nas proximidades dos grandes centros industriais, com instalações de tratamento de saúde, de educação profissionais e físicas (...) (VARGAS, 1945, p.289).

Para Farah (1983), as pressões dos associados nesse setor, propiciadas pela redemocratização do país, e os interesses da indústria da construção civil em muito colaboraram para essa expansão. Segundo a autora, o aumento das reivindicações operárias ocorrido após 1945, não advinha somente da deterioração das condições das moradias urbanas brasileiras, mas também, do fim do regime autoritário do Estado Novo. No que diz respeito à indústria da construção civil, acrescenta-se que com o fim da Guerra e o progresso econômico conseguinte, o mercado imobiliário voltou a estar em foco diante do aumento do êxodo rural para as cidades e da inflação. Por outro lado, vale ressaltar que também contribuiu para tanto, as investidas da OIT (Organização Internacional do Trabalho) para a ampliação dos objetivos da previdência social em todo 0 mundo. Esse, provavelmente, foi o principal fator que incitou uma maior intervenção do poder público no setor e, consequentemente, o aumento da produção de moradias e concessão de financiamentos por parte dos IAPs, principalmente. Foi também a partir de meados da década de 1940, que se vislumbrou a substituição gradativa no âmbito dos IAPs, da política de aluguel pela política da casa própria.

149 Quando as realizações no campo habitacional começaram a decrescer. 
De 1945 a 1950, os IAPs edificaram aproximadamente 50\% das unidades habitacionais produzidas entre os anos de 1930 e 1964, sendo o IAPI o maior produtor de moradias nesse momento (BONDUKI, 2002). Mais precisamente, 0 autor afirma:

Muito provavelmente, o que o IAPI construiu ou financiou na década de 1940 foi o maior volume de obras de construção civil que um único órgão ou empresa tinha edificado, até então, em todo o país. Suas realizações, até 1950, somavam 17.725 unidades habitacionais de interesse social em conjuntos de propriedade do Instituto, que incluíam ainda escolas e vários outros equipamentos comunitários (...), localizados em 663 edifícios de apartamentos (incorporações), além do financiamento para a construção de 1.161 unidades habitacionais em conjuntos residenciais de empregadores, vinte instituições hospitalares, quinze sedes de sindicatos, 26 edifícios de lojas e escritórios e 10 instituições educativas (BONDUKI, 1996, p.989).

Entre os anos de 1945 e 1950, foram edificados 72 (setenta e dois) conjuntos habitacionais, um total de 19.670 (dezenove mil, seiscentos e setenta) unidades. O Instituto que mais edificou moradias nesse período, mais uma vez, foi o IAPI (23 conjuntos e 12.976 unidades de moradia) (FARAH, 1983). Cabe ressaltar, que o destaque do referido Instituto no campo habitacional, se deve também ao número de trabalhadores que compunham essa categoria, que chegou a representar aproximadamente a metade dos associados aos IAPs em todo o país. Para se ter uma noção, no ano de 1950, de acordo com o Relatório Estatístico do IBGE, publicado no mesmo ano, dos quase 3.000 .000 (três milhões) de associados aos Institutos, quase 1.400.000 (um milhão e quatrocentos mil) eram industriários.

O IAPB foi o segundo Instituto que mais edificou moradias no período, um total de 2.325 (dois mil, trezentos e vinte e cinco) unidades que conformavam 15 conjuntos, seguido pelo Instituto de Previdência e Aposentadoria dos Servidores Estaduais (IPASE), totalizando 1.348 (mil, trezentos e quarenta e oito) unidades distribuídas em 19 conjuntos habitacionais. Os grupos residenciais edificados nesse momento aumentaram em número de unidades e em extensão, incorporando cada vez mais equipamentos e serviços (FARAH, 1983). Foi também observado nesse período, que a atuação dos Institutos se deu de forma muito mais abrangente no território nacional.

No tocante aos financiamentos concedidos durante a segunda metade da década de 1940, foram realizados pelo IAPI 7.987 (sete mil, novecentos e oitenta e sete) financiamentos; 7.271 (sete mil, duzentos e setenta e um) a mais que no período anterior. O IAPTEC elevou o número de financiamentos concedidos de 146 (cento e quarenta e seis) unidades habitacionais até 1945, para 991(novecentos e noventa e um), entre 1945 e 1950. No que concerne ao volume de recursos destinados a essa modalidade de ação no campo habitacional, o IAPB, nesse mesmo período, investiu seis vezes mais, e o IPASE, duas vezes mais que no momento anterior (FARAH, 1983).

O aumento considerável das ações no campo habitacional evidenciado a partir de meados da década de 1940 ocasionou a consolidação no âmbito de alguns Institutos (escritório centrais e estaduais) de sessões específicas de engenharia e arquitetura, especializadas em projeto e execução. O objetivo primordial dessas 
Secretarias, como passaram a ser chamadas, era a redução do custo de construção das moradias. Esses órgãos, muitas vezes, com o discurso de viabilizar economicamente a produção de unidades habitacionais para que as faixas de menor poder aquisitivo pudessem ter acesso a uma residência, adotaram padrões de construção e normas urbanísticas inferiores ao determinado inclusive pela legislação em vigor; antecipando 0 que viria a ocorrer massivamente na vigência do BNH e das Companhias de Habitação (COHABs) a partir de 1964.

A criação e/ou consolidação das sessões de engenharia no âmbito das Caixas e Institutos contribuiu, por outro lado, para a realização de pesquisas no que diz respeito à utilização de novos materiais e aplicação de novas técnicas construtivas no campo habitacional; o que vinha ocorrendo no âmbito de poucos institutos, como o IAPI desde a sua fundação. Nesse sentido, foram identificadas algumas experiências isoladas com madeiras, no âmbito do Instituto de Aposentadoria e Pensões dos Estivadores, dos Empregados em Transporte e Cargas e dos Industriários, que também promoveram construções com taipa, como se verá mais adiante.

Ainda na década de 1940, procedeu-se à formulação de um projeto para a unificação das ações previdenciárias e habitacionais dos Institutos de Aposentadoria e Pensões do país, com o intuito, dentre outros, de aumentar o poder de atuação no campo habitacional (volume de produção, qualidade e dimensão dos conjuntos), estendendo a sua atuação para toda a população, em todo território nacional, de modo a concretizar uma política habitacional no Brasil. Nesse sentido foi pretendida a criação do Instituto de Serviço Social do Brasil (ISSB) ${ }^{150}$. No entanto, a almejada unificação dos recursos dos IAPs não se concretizou. Dentre os principais motivos estava à resistência de algumas categorias trabalhistas com maior volume de arrecadação, como o IAP dos Bancários e o IPASE, que alegavam que a diferença existente entre oS recursos acumulados pelas diferentes carteiras prediais das classes trabalhadoras, comprometeria 0 atendimento dos contribuintes e que não seria possível balancear as diferenças e necessidades habitacionais.

Apesar do alargamento dos investimentos no campo habitacional por parte das CAPs e dos IAPS, vislumbrada nesse momento, a possibilidade de atuação nesse setor e, consequentemente, de amenizar 0 quadro de déficit habitacional no país, era muito maior que o realizado. Em 1950, o valor dos fundos desses órgãos somados ${ }^{151}$ equivalia à grande quantia de $\mathrm{Cr} \$ 2.360 .263 .092,30$ (dois bilhões trezentos e sessenta milhões duzentos e sessenta e três mil noventa e dois cruzeiros e trinta centavos) ${ }^{152}$, enquanto suas receitas para com benefícios médicos, aposentadoria, pensões, construções de sedes e de moradias, empréstimos, taxas administrativas e de manutenção naquele ano, não chegaram à metade desse valor, não ultrapassando

\footnotetext{
150 Por meio do Decreto ㄲo 7.536, de 1945.

151 No início de 1950, o número de Caixas de Aposentadoria e Pensões oficiais era de trinta instituições, e no mesmo momento havia seis Institutos. O número de associados desses órgãos em conjunto era precisamente 2.997.947 (dois milhões, novecentos e noventa e sete, novecentos e quarenta e sete) trabalhadores. Neste ano, de acordo com os dados do IBGE (1950), foram atendidos pelas CAPs 110.724 aposentados e 124.401 pensionistas.

152 Valor equivalente à 6.211.219 salários mínimos da época (Cr $\$ 380,00$ cruzeiros).
} 
Cr\$ 994.711.150,80 (novecentos e noventa e quatro milhões, setecentos e onze mil, cento e cinquenta cruzeiros e oitenta centavos) de acordo com os relatórios financeiros. Em contrapartida, o que se divulgava por meio de Boletins, Portarias e até pela imprensa popular da época, era uma crise previdenciária crescente cujos rombos nos cofres dos órgãos, cada vez mais, comprometia a ação das CAPs e IAPs em diferentes níveis e campos.

Diante do exposto e averiguado, acredita-se que considerável parte dessa verba restante (Cr\$ 1.365.551.941,50) foi incorporada pelo Governo Federal em seus projetos de modernização como, por exemplo, para diversas obras de infraestrutura em todo o país, a implantação e desenvolvimento de diversas indústrias nacionais de base e para a construção da nova capital federal, sobremaneira. Receberam auxílio financeiro para a construção e/ou modernização: a Escola de Aprendizes de Marinheiros em Salvador, 0 prédio do MTIC, o prédio do Ministério da Educação, as obras no Porto do Rio de Janeiro da década de 1930, as obras de abastecimento d'água em Porto Alegre, a Carteira Agrícola do Banco do Brasil, a indústria Klabin de celulose e papel no Paraná, o Hospital Ipiranga em São Paulo, a Companhia Nacional de Álcalis, a Companhia Hidroelétrica de São Francisco, a Fábrica Nacional de Motores, a Companhia Siderúrgica Nacional, variadas obras de linhas férreas e de iluminação pública, dentre diversas outras que podem ser citadas nesse sentido.

Mais precisamente, as construções das residenciais em Brasília foram financiadas em sua quase totalidade pelos IAPs, bem como a supervisão e, em alguns casos, a administração dessas obras. De acordo com Farah (1983), até 1964, foram construídas na nova capital pelos IAPs e pela Fundação da Casa Popular (FCP) 7.315 (sete mil, trezentos e quinze) unidades habitacionais; aproximadamente $28 \%$ do edificado diretamente pelos IAPS em todo o território nacional até 0 ano de 1950. Grande parte dessas residências estava locada em edifícios de luxo, cuja demanda e procura foram maiores que por moradias de classe média, que passaram um bom tempo desocupadas. Cabe ressaltar que essas moradias não foram edificadas para os associados dos Institutos financiadores, mas financiadas por eles e destinadas, mormente aos funcionários da União ${ }^{153}$. Esses investimentos não visavam, tampouco, o equilíbrio financeiro dos fundos da Previdência por sua vertente atuarial.

As unidades construídas em Brasília foram ainda alugadas à União a preços mais baixos que os praticados no mercado. O poder público após alugar os apartamentos dos Institutos sublocava-os aos funcionários da União transferidos para a nova capital federal. Nessa transferência, reduzia ainda mais o valor do aluguel, subsidiando parte significativa dos gastos desses funcionários com moradia (FARAH, 1983). Essa prática, na proporção apresentada, não se enquadrava em nenhuma modalidade de ação imobiliária empreendida pelos Institutos. Para viabilizar a sua realização, o Estado procedeu a uma reformulação da legislação. A adaptação da legislação previdenciária no que concerne à edificação de moradias pelos

153 O financiamento foi realizado, sobretudo, pelo Instituto dos Industriários. 
Institutos, por parte do governo federal, e os investimentos de grandes quantias em outros setores, além da habitação, foi largamente criticada pela imprensa geral:

(...) existia um decreto-lei do governo (o de número 34828 de 17.12.1953), estipulando (...) que os imóveis construídos pelos Institutos de Previdência só poderiam ser alugados aos seus associados (...). Que fizeram então os representantes do governo? (...) alteraram 0 decreto com um outro (que recebeu o número 47370 de 4 de dezembro de 1959), de uma maneira a permitir que o poder público pudesse figurar como locatário (...) (HABITAÇÃO..., 1985, p.2).

(...) 0 documento assinado pelos representantes de 28 sindicatos que se reuniram em Caraguatatuba (...) é também a denúncia fortemente documentada, do desvio de somas astronômicas que da sacrificada algibeira dos operários de São Paulo se canalizam, por intermédio do IAPI, para as obras de interesse público e para o sonho megalômano do Sr. Juscelino Kubitschek em Brasília (...). O IAPI ainda está desviando 300 milhões para as nababescas suntuosidades de Brasília (...). (OS TRABALHADORES..., 17/12/1958, p.5).

Cabe ressaltar que os investimentos "retirados" das reservas dos Institutos pelo Estado não foram reavidos. Essa crise resultante da descapitalização das reservas previdenciárias comprometeu consideravelmente a atuação desses órgãos no campo da moradia, sobretudo, social. O quadro inflacionário do país mais uma vez em muito contribuiu para tanto. As crescentes taxas de inflação também contribuíram para que os investimentos nos moldes existentes se tornassem inviáveis no campo da moradia, uma vez que as prestações fixas referentes aos contratos de compra e venda de imóveis pagas pelos associados, tornaram-se módicas, não garantindo aos IAPs o retorno dos recursos investidos.

De acordo com Farah (1983), para homogeneizar a produção e manter o processo de legitimação do Estado, a solução encontrada foi a redução do número de unidades habitacionais dos conjuntos residenciais edificados pelas Caixas e Institutos. Acrescenta-se ainda, a redução da qualidade projetual e construtiva dos grupos de moradias, que também passaram a não contar com uma diversidade de equipamentos coletivos e de lazer percebida até então, bem como a sua pulverização em diversos estados da federação.

Paralela às mudanças no plano habitacional verificadas na década de 1950, observou-se ainda 0 reconhecimento, por parte do corpo técnico e administrativo dos referidos órgãos, da necessidade do estabelecimento para o conjunto das aplicações de cada instituição, de uma taxa média de remuneração do capital, suficiente para garantir a sua estabilidade financeira mediante incidência de diferentes taxas de juros nos diversos planos e, dentro de cada plano, nas várias classes ou modalidades de operação154. Isto é, foi reconhecida verbalmente a necessidade de se assegurar permanentemente a manutenção do valor do patrimônio e de segurança nas operações realizadas, que deveriam proporcionar meios adicionais para a realização das finalidades gerais de cada IAP ${ }^{155}$.

Segundo os dados disponíveis, no período compreendido entre a década de 1950, quando começou a decair o volume de ações no campo habitacional, até 1964, os Institutos de Aposentadoria e Pensões

154 Decerto n.34.828, de 17 de dezembro de 1953.

155 Que só foi colocada efetivamente em prática com a aprovação da correção monetária dos contratos imobiliários de interesse social na década seguinte. 
adquiriram elou edificaram 121 (cento e vinte e um) conjuntos habitacionais, dos quais, 28 (vinte e oito) eram edifícios de apartamentos, num total de 11.429 (onze mil, quatrocentos e vinte e nove) unidades. Em se tratando dos financiamentos, foram realizados 12.308 (doze mil, trezentos e oito), com uma média anual de 3.934 (três mil novecentos e trinta e quatro). O IAPI, por exemplo, reduziu os financiamentos em 17\%, concedendo no referido período 6.602 (seis mil, seiscentos e dois) empréstimos para os seus associados, numa média anual cada vez menor (FARAH, 1983).

De acordo com a historiografia existente, essas quedas começaram a se intensificar, sobretudo, a partir de 1955. A única atuação que se mostrou exceção à regra foi a do IPASE, que tanto no que concerne à aquisição e à construção de moradias para os seus associados, quanto no que tange ao financiamento para compra e construção de unidades habitacionais, manteve um padrão de concessão muito próximo ao do período anterior, representado pelo intervalo entre os anos de 1945 e 1950. Esse aspecto pode ter influenciado na decisão de manter oficialmente o IPASE mesmo após a criação do BNH.

Também a partir de meados da década de 1950 passou-se a verificar com maior frequência, os casos de apadrinhamento, clientelismo, etc.. Essa situação chegou ao ponto de existir uma reserva de unidades habitacionais nos conjuntos adquiridos e/ou construídos pelos Institutos, para a "distribuição" política e para os comitês eleitorais, independente das listas de associados inscritos para a aquisição ou aluguel de residência ${ }^{156}$. Diversos artigos foram publicados nesse sentido, essencialmente nos jornais de cunho operário:

Para terminar com o abuso nas locações de imóveis (...) fiz publicar no "Diário Oficial" a relação dos inscritos para cada conjunto residencial a fim de os interessados conhecerem 0 quanto chegava a vez para o seu aproveitamento, obstando assim que a fraude ou as recomendações prestigiosas pudessem ferir 0 seu direito (RESULTADOS..., 04/02/1956, $\mathrm{s} / \mathrm{p})$.

A ausência da regulamentação aconselhada pelas leis não paralisa a movimentação evolutiva dos fatos, que se transformou numa corrida para pistolões, áspera para muitos e fácil para poucos (...). Inverteu-se e deformou-se a estrutura processual e administrativa. A Carteira Imobiliária (...), teve a partir de 1956, maior atividade que em tempos normais, com 0 acesso permitido àqueles que traziam numa simples petição o 'autorizo' do Presidente da República na maioria das vezes e, em outras, o do próprio presidente do IPASE (FAVORÁVEL..., 04/07/1962, p.19-21).

De modo geral, segundo os boletins e relatórios das ações dos Institutos, entre os anos de 1937 (quando foram criadas as suas Carteiras Prediais) e de 1964, os Institutos edificaram aproximadamente 130.000 moradias em todo país, excluindo os financiamentos realizados para a classe média e alta e para os não associados - para os quais não há estudo até os dias de hoje. Esse número correspondia a mais de 4\% do total de moradias urbanas ocupadas no país, em fins da década de 1950, de acordo com os dados censitários do IBGE.

\footnotetext{
${ }^{156}$ Esses casos foram percebidos mesmo após a incorporação do IPASE no novo plano de habitação da década de 1960, como ser verá mais detalhadamente no tópico seguinte.
} 
Mais especificadamente, foram 47.789 (quarenta e sete mil, setecentos e oitenta e nove) unidades habitacionais adquiridas ou construídas pelos Institutos e disponibilizadas aos associados dos IAPs, no período de sua atuação, e 76.206 (setenta e seis mil, duzentos e seis) financiamentos para aquisição de terreno e/ou para a construção de moradia ou para a compra de residência a terceiros. Não se tem computado o número de financiamentos/empréstimos realizados às empresas, aos não sócios e ao Estado, como também a produção dos IAPs até o ano de 1937, quando a historiografia costuma afirmar, erroneamente, ter começado a ação dos referidos órgãos no campo habitacional. Também não são apresentados, como já observado e colocado ao longo do texto, a produção habitacional das CAPs.

Em se tratando da espacialização da produção dos Institutos, de acordo com a historiografia existente, os estados da região Sudeste foram privilegiados em relação aos demais estados brasileiros. A referida região recebeu aproximadamente $70 \%$ da produção habitacional desses órgãos estatais. Estados como Rio de Janeiro, São Paulo e Minas Gerais e a cidade de Brasília, receberam vultosos investimentos dos Institutos e foram beneficiados com mais de 90.000 (noventa mil) unidades habitacionais. Isso pode ser justificado pelo fato que aqueles centros urbanos possuíam as maiores concentrações populacionais do país e, conseguinte de associados, uma maior organização do setor e maiores déficits habitacionais. Os demais estados do país, com exceção da região Norte - não excluída do processo, como apontado por alguns autores, vale salientar - foram beneficiados com aproximadamente 36.000 (trinta e seis mil) moradias (PORTO, 1938; FARAH, 1983).

A partir de meados da década de 1960, muitas das áreas adquiridas pelos Institutos e Caixas para a formação de sua reserva de terras que permaneceram vazias, e aquelas onde estavam situados os empreendimentos de sua propriedade, foram incorporadas ao patrimônio do Banco Nacional de Habitação (BNH) e de outros órgãos de economia mista e, posteriormente, pelo Instituto de Administração Financeira da Previdência Social (IAPAS) e pelo Instituto Nacional de Previdência Social (INSS), para a edificação de outros conjuntos e/ou venda das unidades já construídas. Vale lembrar que, já na década de 1940, os IAPs e CAPs, juntamente com a FCP eram os maiores detentores de terras urbanas do país, como colocou Farah (1983).

\subsection{A nova cultura da habitação:}

\section{As diretrizes arquitetônicas e urbanísticas adotadas pelas CAPs e IAPs no campo habitacional157}

"Ora, a época é de cabello curto e liso, das vestimentas simplíssimas, dos sapatos de bico largo" (OBRAS..., 28/05/1931).

\footnotetext{
157 Cabe destacar que nesta seção da tese restringiu-se à exposição e à análise dos exemplares habitacionais divulgados e estudados pelas principais publicações existentes sobre o tema, como aqueles encontrados em FARAH (1983), VARON (1989), BONDUKI (2002) e BRUNA (2010). As conclusões, observações e/ou especificidades neste tópico formuladas serviram de baliza para as análises específicas dos conjuntos de moradias nordestinos, apresentadas no capítulo 4, bem como para as confrontações e apreciações comparativas finais. Por esse motivo, em especial, foram aqui apresentados quase que exclusivamente, empreendimentos projetados e/ou edificados por engenheiros e arquitetos atuantes no centro-sul do país.
} 
Como observado até, pelo menos, a década de 1920, o poder público atuou no campo da moradia por meio essencialmente da legislação. No plano de ação indireto, o Estado em sua instância federal através de isenções fiscais e doações de terrenos, incentivava a edificação de residências e grupo delas por industriais e outros atores do mercado privado e/ou, nas instâncias estaduais e municipais, atuava em parcerias público-privadas. Nesse quadro, a moradia operária, como era designada, foi produzida em grande parte de acordo com a lógica rentista e conformava, sobremaneira, vilas com residências geminadas ou grupos de casas isoladas, sem o apoio de equipamentos coletivos e muitas vezes sem ligação a redes de serviços básicos de água, esgoto, transporte e até, iluminação.

$\mathrm{Na}$ década de 1930, o projeto desenvolvimentista instituído por Getúlio Vargas ao assumir a presidência do Brasil, dentre outros objetivos, pretendia construir um país mais moderno, em aspectos econômicos, sociais, construtivos e institucional. Nesse contexto, o Estado almejava formar um novo perfil de trabalhador urbano, diferente daquele que vinha se constituindo no contexto do movimento operário brasileiro. Para tanto, utilizando-se das palavras de Otilia Arantes (1995, s/p), “(...) era preciso romper com qualquer resquício passadista (...), demolir sem remorso, (...) medida higiênica disciplinar, visando o aparecimento de 'um homem novo'". Também foi preciso dar respostas concretas às reivindicações trabalhistas, por meio da outorga de legislação e da criação de órgãos específicos, e conter o desenvolvimento, ampliação e disseminação de ideias e ações dos militantes e partidos vinculados aos movimentos sociais e políticos que estavam em curso naquele momento, sobremaneira, o comunismo. Além das ações repressivas e da declaração de ilegalidade dada a diversos partidos e entidades sociais e de classe, outra importante ação oficial, nesse sentido, foi impulsionar o processo chamado pela historiografia especializada de sindicalismo oficial ${ }^{158}$.

Foi julgado importante ainda "reeducar o trabalhador" para adaptá-lo ao novo modo de vida que se pretendia instituir, por meio da realização de eventos e da publicação de artigos em revistas especializadas e periódicos diários da época (Imprensa Nacional, Cultura Política, dentre outras), além de reformas nos ensinos de base e profissionais ${ }^{159}$. No entanto, não se mostrava suficiente a formação ideológica de um novo trabalhador. Era importante também conceder uma moradia para ele e sua família e, igualmente preponderante, reformular o modelo de habitação urbana vigente, tornando-a mais higiênica e mais condizente ao novo estilo de vida: uma nova moradia para um novo homem.

De modo geral, o novo modelo de moradia pretendido deveria ser acessível aos trabalhadores sem residência própria. Era preciso, portanto, rever todo o processo de concepção e de construção, preconizando a utilização de novos materiais e técnicas construtivas e novas distribuições espaciais. Acredita-se que 0

158 Por meio do qual, os sindicatos do país deveriam ser registrados, recebendo assim, o aval para funcionamento e o título de oficial. A partir de então, seus membros poderiam concorrer politicamente.

159 Destaca-se, nesse sentido, a reforma empreendida no âmbito da Escola Nacional de Belas Artes, do Rio de Janeiro, no ano de 1930, que contou brevemente com a participação do arquiteto Lúcio Costa, tendo a figura de José Mariano Filho como o coibente. A rápida permanência de Lúcio Costa na Escola (1930/1931), segundo Bruand (1981), contribuiu significativamente para uma mudança no ensino de arquitetura no país e, consequentemente, para a consolidação das bases da arquitetura moderna brasileira. 
intento era ao mesmo tempo o de modificar a forma pela qual a moradia urbana do país era viabilizada, instituindo o mercado de imóveis em detrimento do de aluguel e, dessa forma, aquecer a economia. Era necessário, portanto, a formulação de uma linha de financiamento em grande escala e adoção de uma "nova forma de construir".

No que condiz à nova proposta de moradia preconizada pelo poder público por meio dos órgãos subordinados a ele a partir da década de 1930, merecem destaque as colocações e proposições formuladas, apresentadas e/ou divulgadas pelo IV Congresso Pan-Americano de Arquitetos, que teve o Rio de Janeiro como cenário em 1930, no âmbito do Instituto de Engenharia, que em 1931 promoveu o I Congresso de Habitação, e do Instituto de Organização Racional do Trabalho (IDORT), que em 1941 realizou a Jornada de Habitação Econômica. Também cabe ressaltar que para a difusão das novas proposições e estruturação do debate acerca da moradia social em nosso país foi preponderante a publicação de artigos na imprensa diária e em revistas especializadas, como Arquitetura e Engenharia, Revista do IDORT, Arquitetura e Urbanismo, Revista de Engenharia, Acrópole, A Casa, etc.

A opção pela casa própria ganhou força nesse momento. Nas publicações oficiais e nos periódicos da época, observou-se que a administração pública, em seu discurso, utilizou o sonho da aquisição de uma moradia como meio para a valorização do trabalho e do progresso material do trabalhador, assim como uma possibilidade para sua ascensão social. Adquirindo o significado de propriedade, a casa própria converteu-se em expressão de valor e do direito básico consagrado pela sociedade burguesa, como símbolo de poder e de status (CORREIA, 2004). Esse posicionamento também ia ao encontro das proposições da Igreja Católica e se vinculava ainda ao projeto estatal de moralização do trabalhador, uma vez que se fundamentava na fixação dele em ambiente compatível com o gosto pelo lar, associado à incorporação de hábitos de ordem, de previdência e economia. Essa forma de moradia também foi defendida por profissionais, engenheiros e arquitetos sobremaneira, que participaram da Jornada de Habitação Econômica de 1941.

O alargamento da ação direta do Estado no campo da habitação, por meio da atuação das CAPs, a partir de 1930, e dos IAPs, a partir de 1933, se deu nesse contexto desenvolvimentista e de idealização de um "novo trabalhador" e de um "novo país", mais moderno e desvinculado das heranças coloniais. Foi também por esse viés, justificada a própria criação dos Institutos de Aposentadoria e Pensões (IAPs) ${ }^{160}$.

Concomitantemente, estava em curso na Europa e na América do Norte, um processo de revisão e de reformulação dos procedimentos e técnicas arquitetônicas e urbanísticas para a concepção de cidade e de edificações adequadas à nova conjuntura socioeconômica das potências mundiais, consolidado nas primeiras décadas do século XX. As proposições, nesse sentido, foram elaboradas e difundidas a partir da década de

160 Além dos motivos e objetivos já apontados. 
1920, principalmente por meio das publicações resultantes dos Congressos Internacionais de Arquitetura Moderna (CIAMs) ${ }^{161}$.

O Movimento Moderno também trouxe consigo a necessidade de repensar a planta da moradia. Profissionais propunham, nesse sentido, reduzir as circulações internas, principalmente corredores, e um novo agrupamento das funções da casa a fim de minimizar o tempo gasto para a realização das atividades domésticas, garantindo à mulher mais tempo para a realização de atividades de trabalho externo e de lazer, assim como, reduzir o custo com a construção das habitações. Novos modelos de moradias e de conjuntos residenciais foram propostos nesse momento. Diversos projetos foram pensados enfatizando-se a organização do bloco, as vias de acesso e circulação de pedestres e automóveis, a área ocupada pela edificação, o volume resultante da construção, a abertura de janelas e o número de camas. Foi difundida a concepção de edifício coletivo com grandes alturas e serviços centralizados. Julgava-se essencial, nesse contexto, o desenvolvimento de novos materiais e a padronização desses para produção industrial. Essas edificações deveriam apresentar, no geral, estruturas independentes dando liberdade para concepção de plantas e fachadas.

Modelos arquitetônicos e urbanísticos baseados nos conceitos de unidade de vizinhança e de unidade de habitação surgiram, assim como difundiram-se procedimentos como o zoneamento de funções, as preocupações com a iluminação e a ventilação dos cômodos das unidades habitacionais, o planejamento regional e a valorização dos espaços verdes. De acordo com as premissas da arquitetura e urbanismo modernos:

\begin{abstract}
(...) Tudo se calcula: resistência e estabilidade; consumo de ar e de luz; transmissão de calor, de frio e de som; influencia das cores e das proporções harmoniosas... No campo puramente constructivo, a tendencia é a da officina, isto é procura-se 'seriar', 'usinificar', fortificar'... Procura-se usar elementos 'stardards' trazidos promptos das usinas, e armados com auxilio da força mecanica dos guindastes e elevadores. É a reducção da mão-de-obra, e do tempo necessário para a terminação dos serviços. Em substituição ao tijolo e á pedra procuram-se materiaes novos, homogeneos, leves, resistentes ás mudanças atmosphericas, incombustíveis, máos conductores de calor e de frio. A casa, tende para a 'mobilisação' completa. Querem os pioneiros da arte nova que nella (...) surja nova arrumação dos moveis, das paredes, dos soalhos. Adeus solares immutaveis de avós desconhecidos. Tudo dynamismo...(...) (ALBUQUERQUE, 1931, p.308).
\end{abstract}

Mais especificadamente, percebe-se o emprego de platibandas ou de teto-jardim, o jogo de cheios e vazios proporcionados pelas aberturas das janelas, portas e varandas que dão movimento ao plano limpo das fachadas das edificações, a justaposição dos volumes geométricos simples, o emprego de ângulos e linhas retas na composição da edificação, a laje impermeabilizada, a transparência das fachadas garantida pelas

\footnotetext{
161 Especialmente as teses e palestras apresentadas nas quatro primeiras edições do evento pelos arquitetos: Alexandre Kein (exposição do plano tipo para bairros operários na Alemanha), Walter Gropius (Fundamentos sociológicos da habitação mínima para uma população trabalhadora urbana), Le Corbusier (Análise dos elementos fundamentais no problema da habitação mínima e O parcelamento dos solos nas cidades), Victor Bourgeois (A organização da habitação mínima), Hans Schmidt (Código de Obras e habitação mínima) e Ernst May (livro "Die Wohnung fur das Existenzminimum", que compilou os 105 projetos de moradias mínimas elaborados durante o CIAM de 1930) (AYMONINO, 1973; BRUNA, 2010).
} 
grandes superfícies envidraçadas, as fachadas desprovidas de ornamentos, os elementos padronizados, a correspondência da fachada com o interior das edificações, a utilização de elementos em balanço, o emprego de mobiliário que em muito se aproximava das experiências da Bauhaus, e soluções originais que levaram em conta as imposições materiais do meio ambiente:

(...) uma verdadeira revolução. Está assegurado definitivamente o emprego de novas estruturas, a parede não é mais sustentáculo do edifício, é apenas elemento de vedação (...). A fachada liberou-se da estrutura, a janela pode ser horizontal (...), a mansarda dá lugar ao teto-jardim. Além disso, surge uma nova possibilidade: 0 uso da altura (...), os elevadores resolvem o problema do tráfego vertical. (...) é radical a transformação dos edifícios com o emprego de novas estruturas (...) (MELLO, 1950).

A parede, como conhecida entre os profissionais da construção, perdeu sua função primeira no âmbito da arquitetura dita moderna e novos materiais elaborados em laboratórios de construção surgiram, em especial, a aço, o vidro e o alumínio:

É dos nossos dias, o primeiro abalo nesta velha concepção da esthetica architectonica. Na arte 'pré-concreto' a parede foi elemento de supporte e ao mesmo tempo isolador thermico. Da taipa, de adobe, de tijolo ou de pedra, devia, antes de tudo resistir ás cargas estaticas. Hoje, 0 aço ou o concreto, constitue o esqueleto resistente, capaz de receber sósinho todas as cargas estaticas. A parede ficou apenas reservada a missão isolador. Esta separação de funcções, trouxe, á architectura da casa moderna, novas orientações tanto no caracter technico como no esthetico (ALBUQUERQUE, 1931, p.307).

Em síntese, tratou-se conforme Bruna (2010, p.102), “(...) o projeto derivado de uma compreensão científica da habitação; o projeto como indutor de uma nova cultura da habitação e de um novo comportamento social; a produção industrial dos componentes da habitação; e finalmente o reconhecimento do papel essencial do planejamento do Estado (...)". Esses aspectos representavam a essência do que se convencionou chamar de Movimento Moderno.

A arquitetura e urbanismo modernos encontraram campo para a sua difusão no Brasil, passando a serem considerados por alguns profissionais como os mais condizentes com o projeto de desenvolvimento proposto por Getúlio Vargas na década de 1930. Algumas figuras vinculadas ao corpo técnico estatal, no que condiz à moradia social, especialmente no âmbito do CNT, e até mesmo, o próprio presidente da República, na época de instauração dos IAPs subordinados ao MTIC, destacaram a importância da adoção de uma arquitetura inovadora e mais eficaz, como vinha sendo implantado em países europeus e na América do Norte.

Incorporando os avanços da ciência e da técnica em diversos campos e instâncias, o Estado viabilizou uma modernidade no país, essencialmente no campo habitacional, estreitamente associada ao progresso e, consequentemente, à valorização da novidade. Esses diversificados preceitos modernos chegaram ao Brasil essencialmente por meio de profissionais que frequentaram eventos e reuniões sobre a temática pelo mundo, pelos que estudaram e/ou cursaram arquitetura, artes e/ou engenharia em instituições 
estrangeiras, por aqueles que assinavam revistas elaboradas fora do país ${ }^{162}$, pelo contato com a literatura especializada163, por viajantes e/ou interessados na arquitetura daquele momento ${ }^{164}$, por palestras, entrevistas e aulas especiais dadas por profissionais estrangeiros aqui no Brasil 165. De modo geral, muitos dos engenheiros e arquitetos brasileiros, além de parte considerável do corpo técnico das Caixas e Institutos de Aposentadoria e Pensões seguiram essa linha de atuação, sobretudo, a partir década de 1930.

Para Bonduki (1996), os partidos arquitetônicos adotados por parte das Caixas e Institutos no campo habitacional, bem como as preocupações presentes e que regeram essas realizações, a partir de meados da década de 1930 mais intensamente, não foram resultados apenas das decisões pessoais dos técnicos dos referidos órgãos ou do Ministério do Trabalho, Indústria e Comércio, mas nasceram de reflexões no próprio núcleo de poder do Estado Novo. No entanto, acredita-se que foram sim os profissionais vinculados aos IAPS e às CAPs, as Portarias e Resoluções formuladas por seus Conselhos Administrativos e/ou pelo Conselho Nacional do Trabalho (CNT), que determinavam a incorporação, sempre que possível e adequado, dos preceitos e dos ideais de referências modernas, bem como de modelos e práticas construtivas, em suas formulações e realizações no campo da moradia, como especificado inclusive no corpo textual de alguns projetos de lei e diplomas legais outorgados nesse sentido, como se verá mais detalhadamente no capítulo seguinte. Bruna (2010) afirma, nesse sentido, que a clareza com que as diretrizes do movimento moderno foram consideradas por arquitetos e administradores em nosso país foram indicações do conhecimento e compreensão do debate internacional e interno acerca do papel do Estado e da moradia.

A adoção do "modelo moderno" por parte dos referidos órgãos sofreu a influência direta do engenheiro-arquiteto responsável pelo Setor de Engenharia do CNT, subordinado ao MTIC, Rubens Porto; um dos responsáveis pela formulação das diretrizes que balizaram a edificação e/ou financiamento de conjuntos e unidades residenciais pelas CAPs e IAPs e, mais diretamente, pela elaboração e/ou reforma dos principais decretos que regeram a atuação desses órgãos ${ }^{166}$. Porto defendia a racionalização de todo 0 processo construtivo e do programa da própria moradia, a fim de baratear a produção e o repasse delas aos operários brasileiros, como também a estandardização dos materiais e das peças a serem utilizadas; sendo

\footnotetext{
162 Dentre elas as revistas Architectural Review, Casabella-Continuità e L'Architecture d'Aujourd'hui, as publicações do De Stijl e da Bauhaus, a revista Das Neue Frankfurt (1926-1931), denominada de Die Neue Stadt, a partir de então (1931-1933), de autoria de Ernst May e Joseph Ganter respectivamente, dentre muitas outras.

163 Podem-se citar, nesse sentido, uma série de livros publicados entre os anos de 1925 e 1930, como os de Wlater Gropius (Internacionale Architektur, de 1925, e Bauhausbauten Dessau, de 1930), de Bruno Taut (Bauen: der neue Whonbau, de 1927, e Modern Achitecture, de 1929), de Le Corbusier (Por uma Arquitetura, de 1923, tido como o manifesto da arquitetura moderna) e de Adolf Behne (Der Moderne Zweckbau: die baukunst, de 1926) que, como apontado por Bruna (2010), teve grande repercussão, além das publicações posteriores e aquelas resultantes dos CIAMs e dos debates nacionais.

164 Diversos arquitetos e engenheiros vieram ao país entre as décadas de 1920 e 1930, para visitar e, principalmente, exercer a profissão como foi o caso especial de Warchavchik e Rino Levi. Muitos eventos e projetos também se destacaram nas décadas de 1910 e 1930 e alcançaram uma repercussão mundial como o projeto da Casa Dominó de Le Corbusier, de 1915, a exposição internacional da "nova habitação", em Dessau, que contou com projetos de arquitetos como Walter Gropius, Bruno Taut, Le Corbusier, Vitor Bourgeois e Mies Van der Rohe, em 1927, e a exposição de Artes Decorativas de Estocolmo, de 1930, cujas ideias circularam por meio de artigos e, principalmente, manifestos por décadas (BRUNA, 2010).

165 Uma das principais referências nesse sentido foi dada por Le Corbusier ao proferir as suas duas primeiras conferências no Brasil, nos anos de 1929 e 1936.

${ }^{166}$ A trajetória detalhada da atuação do referido engenheiro-arquiteto será tratada com mais afinco no capítulo que se segue.
} 
essas as principais premissas pretendidas para a construção de habitações no âmbito das Caixas e Institutos de Aposentadoria e Pensões. Suas propostas e diretrizes construtivas para as novas moradias conformaram um verdadeiro "manual para conjuntos habitacionais", e foi endereçado ao Ministro do Trabalho, Indústria e Comércio juntamente com uma proposta gráfica, nos primeiro anos da década de $1930^{167}$ (O PROBLEMA..., 1937).

Esse manual, muito provavelmente, serviu como referência para a atuação de muitos dos IAPs e CAPs no país. Diversos profissionais envolvidos no processo projetual e na construção dos conjuntos habitacionais no âmbito dos Institutos e Caixas, seguiram o modelo moderno e se aproximaram das sugestões construtivas apontadas por Rubens Porto, algumas delas incorporadas nas regulamentações das Carteiras Prediais, como se verá no capítulo seguinte.

Dentre esses profissionais engajados na produção habitacional social realizada pelos IAPs e pelas CAPs, destaca-se 0 arquiteto Carlos Frederico Ferreira, autor dos modernos Conjuntos do Realengo, construído entre os anos de 1939 e 1943, no Rio de Janeiro-RJ, e Vila Guiomar, edificado entre 1942 e 1951, em Santo André-SP. O arquiteto foi chefe do setor de projeto e engenharia do IAP dos Industriários-RJ, desde a sua criação até meados da década de 1960, e concordava com muitas das proposições de Porto; adotandoas e agregando-as na produção do referido Instituto. Segundo Bonduki (2002), o IAPI foi o Instituto que mais incorporou as balizas modernas em suas realizações habitacionais.

Cabe aqui apontar outro equívoco que constantemente é percebido na historiografia acerca da atuação desse profissional no âmbito do IAPI. Comumente são encontradas publicações que imputam Carlos Frederico Ferreira como "o engenheiro e arquiteto do IAPI". Primeiramente, deve-se lembrar que os Institutos de Aposentadoria e Pensões, em cada uma das categorias trabalhistas atendidas, eram conformados institucionalmente por um escritório central, situado na capital federativa, e por diversos escritórios estaduais locados na maior parte das capitais brasileiras. Ambos contavam com uma estrutura organizacional muito próxima, no que tange às questões habitacionais, possuindo um setor de engenharia e arquitetura, seções relacionadas à burocracia e um grupo administrativo, composto por delegado e fiscais, a nível estadual, além do presidente, no caso do escritório central. Sendo assim, o corpo técnico de um Instituto, seus engenheiros e arquitetos, não estavam concentrados apenas no escritório central. Em cada um dos escritórios estaduais, posteriormente chamados de agências, havia um grupo de profissionais na área da construção civil.

A esses profissionais era facultado o vínculo direto ao órgão, como contratado permanente ${ }^{168}$, ou indireto, uma espécie de free-lance ${ }^{169}$. Carlos Frederico Ferreira se conformava como um profissional

\footnotetext{
167 Os desenhos referentes ao "Manual de Moradia" de Rubens Porto não foram encontrados até hoje.

168 Exercendo suas atividades projetuais, de acompanhamento de obras, etc., nas diversas localidades de atuação de um determinado instituto quando necessário ou a convite.

169 Nesses casos, o engenheiro ou arquiteto poderia atuar junto ao corpo técnico de qualquer um dos IAPs ou CAPs em todo o país. Havia ainda a possibilidade dos profissionais participarem de concursos abertos pelo CNT ou internos, realizados no âmbito do próprio órgão contratante.
} 
contratado diretamente pelo escritório central do IAPI atuando, sobremaneira, no Rio de Janeiro ${ }^{170 .}$ Contudo, não se conformava como o principal arquiteto daquela instituição a nível nacional. Dessa forma, Carlos Frederico Ferreira estava longe, mesmo enquanto chefe do setor de engenharia do escritório central, de ser o responsável único pela elaboração e concepção projetual dos conjuntos residenciais edificados e financiados pelo IAPI em todo o Brasil. Outros profissionais como os arquitetos Affonso Eduardo Reidy, Alim Pedro, que inclusive foi presidente do IAPI (1946-1951), Attílio Corrêa Lima, Eduardo Kneese de Mello, Hélio Lage Uchôa Cavalcante, Joaquim de Almeida Santos, José Theodulo da Silva, etc., atuaram como arquitetos do IAPI, inclusive no Rio de Janeiro, mesmo enquanto Carlos Frederico Ferreira estava à frente da Seção de Engenharia do órgão.

Pode-se citar ainda, o fato que acima dos chefes do setor de engenharia dos escritórios estaduais estavam os delegados estaduais e o presidente da instituição, sendo esses, na verdade, os principais responsáveis pela adoção das diretrizes inovadoras da arquitetura e do urbanismo dos conjuntos de moradias edificados pelas Caixas e Institutos ${ }^{171}$. Sendo assim, acredita-se que Carlos Frederico Ferreira foi muito mais um executor de propostas, ao longo da década de 1940, que um proponente de novas diretrizes construtivas em se tratando dos regulamentos e das determinações no âmbito do IAPI, que já estavam sendo colocadas, desde meados da década anterior por profissionais vinculados inclusive ao CNT, como ser verá no capítulo seguinte.

É claro que o seu projeto arquitetônico e urbanístico para o Conjunto Realengo (IAPI-RJ) equivale a uma proposta ímpar no que diz respeito, dentre outros, à arquitetura adotada, à racionalização do canteiro de obras, ao emprego de materiais e ao número de unidades habitacionais construídas, mas seu exemplo não se tornou modelo para a concepção de conjuntos implantados posteriormente pelo IAPI no país ou até mesmo no Rio de Janeiro, como se verá mais detalhadamente nos capítulos seguintes. Dessa forma, os projetos inovadores de Carlos Frederico Ferreira se conformaram muito mais como exceção que regra no âmbito, não só do IAPI, mas de todos os outros órgãos se compararmos as suas produções como um todo.

Diversos outros profissionais incorporaram os ditames da arquitetura e urbanismo modernos em suas trajetórias pessoais e no âmbito do corpo técnico das CAPs, IAPs e suas Carteiras Prediais, bem como no Conselho Nacional do Trabalho e sua sessão de engenharia. Dentre eles estão os arquitetos: Affonso Eduardo Reidy (IPASE e, no já citado, IAPI), Álvaro Vital Brasil (IPASE), Marcial Fleury de Oliveira (IAPB), Marcos Kruter (IAPI), MMM Roberto (IAPI e IAPC), Nicolau H. Barbieri (IAPB), Paulo Antunes Ribeiro (IAPI), Plínio Arruda Botelho (IAPB), Roberto J. G. Tibau (IAPB); e os engenheiros Alberto de Mello Flores (IAPI), Helvécio Xavier Lopes (IPASE) e White Lírio da Silva (IAPI) (PORTO, 1938; BONDUKI, 2002; ALMEIDA, 2007; BRUNA, 2010). Inúmeros outros profissionais envolvidos nesse processo, desde empreiteiros,

\footnotetext{
170 Alguns projetos desse engenheiro e arquiteto podem ser encontrados também nas cidades de Santo André-SP e no Recife, como arquiteto convidado ou por concurso, como foi o caso do Edifício Inconfidência.

171 Os projetos arquitetônicos e urbanísticos precisavam da aprovação e assinatura do presidente, no Rio de Janeiro, ou do delegado, no caso dos demais estados brasileiras, para serem executados.
} 
construtores, engenheiros e, principalmente, arquitetos atuantes entre as décadas de 1930 e 1960, podem ser citados.

Cabe lembrar que muitos desses profissionais, devido à crise econômica pela qual os IAPs e as CAPs vinham passando desde a década de 1940, agravada ainda mais com a criação do Banco Nacional de Habitação, encerraram suas carreiras ou deixaram de atuar no campo social da moradia em 1964, sem sequer serem citados em publicações sobre o tema. Tal lapso historiográfico foi colocado em diversas publicações do gênero, com destaque para a Revista do IAB-Guanabara a partir, sobretudo, da década de 1960.

Em se tratando dos aspectos urbanísticos, o corpo técnico das CAPs, dos IAPs e do CNT aconselhava a instalação de equipamentos coletivos nos conjuntos, bem como todos os serviços básicos, como distribuição de água, coleta de esgotos e luz, alguns previam inclusive abastecimento de gás e telefone. No entorno do grupo de moradias, induzia-se à pavimentação das vias, arborização, além da iluminação e transporte público. Carpintéro (1997) colocou que as concepções de urbanismo moderno, essencialmente, formar, moralizar e higienizar os indivíduos, além de assegurar a ordem por meio da moradia, foi uma das principais tarefas dos arquitetos empenhados em conceber moradias aos trabalhadores do país, neste momento.

Mais precisamente, os conjuntos habitacionais edificados pelas CAPs e IAPs propiciavam ao Estado um maior controle da reprodução da força de trabalho no país, no contexto de idealização do novo trabalhador. A inclusão de diversas atividades, sobremaneira, de lazer, nesses empreendimentos representava, segundo Farah (1983, p.56), “(...) o controle paternalista implícito nessa concepção (...) desenvolvido na Primeira República (...), por alguns empresários, através da construção de vilas operárias". Correspondem também à sintonia das propostas dos corpos técnicos daqueles órgãos e da sessão de engenharia do CNT, aos ideais da arquitetura e do urbanismo modernos que permeavam o pensamento e a prática de engenheiros e arquitetos nessa época, na Europa e na América do Norte, principalmente.

Essas diretrizes podem ser observadas em alguns dos grandes conjuntos residenciais edificados diretamente pelos Institutos e Caixas de Aposentadoria e Pensões, mormente no centro-sul do país, concluídos ao longo da década de 1940, como também, nos projetos elencados por meio de concursos abertos convocados pelo Conselho Nacional do Trabalho (CNT), desde a sua criação em 1923.

Parte das realizações desses órgãos se destacou no plano nacional e internacional pela qualidade projetual e construtiva, sendo diversos deles premiados e/ou aclamados pela crítica e reconhecidos internacionalmente, como o conjunto residencial da Penha, projetado pelos irmãos Roberto (Marcelo e Milton), que recebeu o prêmio de honra na Exposição do V Congresso Pan-Americano de Arquitetos, realizado em Montevidéu, no ano de 1940 (EDIÇÃO..., 1945); os projetos de Eduardo Kneese de Mello, do Edifício Japurá (IAPI-1949) e da Cidade-Jardim do IAPC (1946-não edificado), ambos localizados em São Paulo, que foram publicados na revista francesa L'Architecture d'Aujourd'hui, em 1952; o projeto da escola 
primária do Conjunto Vila Guiomar (IAPI-Santo André; não edificada) de Carlos Frederico Ferreira, premiada na 1a Bienal de Arte em São Paulo, em 1950; e o Conjunto Realengo, também de autoria de Carlos Frederico Ferreira (IAPI) e a sede do IAPI no Rio de Janeiro dos irmãos MM Roberto, amplamente divulgados por meio do livro Brazil Builds - Architecture New and Old (1652-1942), de autoria do arquiteto Philip Goodwin, de 1943, além de diversas outras publicações elaboradas a partir de então.

Bonduki (2002) sustenta a hipótese de que a qualidade arquitetônica e urbanística dos conjuntos dos IAPs e das CAPs, assim como a existência de equipamentos coletivos nesses empreendimentos, foi resultado da adoção da política de aluguel como meio para provimento das moradias edificadas por esses órgãos. De acordo com o referido autor, mais especificadamente:

(...) a adoção da locação como a forma de acesso largamente predominante às moradias produzidas nos conjuntos habitacionais dos Institutos (...), representou uma vitória dos que se opunham à casa própria e exerceu influência no partido arquitetônico dos projetos dos conjuntos, sobretudo na valorização do espaço público e na qualidade dos materiais e da construção. A opção por blocos de edifícios coletivos, com equipamentos sociais e comunitários, é uma clara consequência desta visão, em oposição à concepção da casa própria, isolada, com quintal, horta e criação, preferida pelos conservadores (BONDUKI, 1996, p.984).

No entanto, acredita-se que a principal base da diretriz projetual adotada foi a incorporação dos modelos e experimentos precedentes nesse campo, essencialmente europeus, como citado em diversos documentos e publicações do gênero, por parte do corpo técnico das Secretarias e Sessões de Engenharia das CAPs, dos IAPs e do CNT. Questões relacionadas à preservação dos bens desses órgãos, também os levaram a escolher materiais construtivos de boa qualidade, durabilidade e resistência, como especificado pelo próprio IAPI: “(...) as instalações devem ser (...) duráveis e as estruturas permanentes, evitando-se soluções provisórias que possam comprometer a preservação da garantia durante o período de recuperação do capital empregado (...)" (IAPI, 1950, p.292).

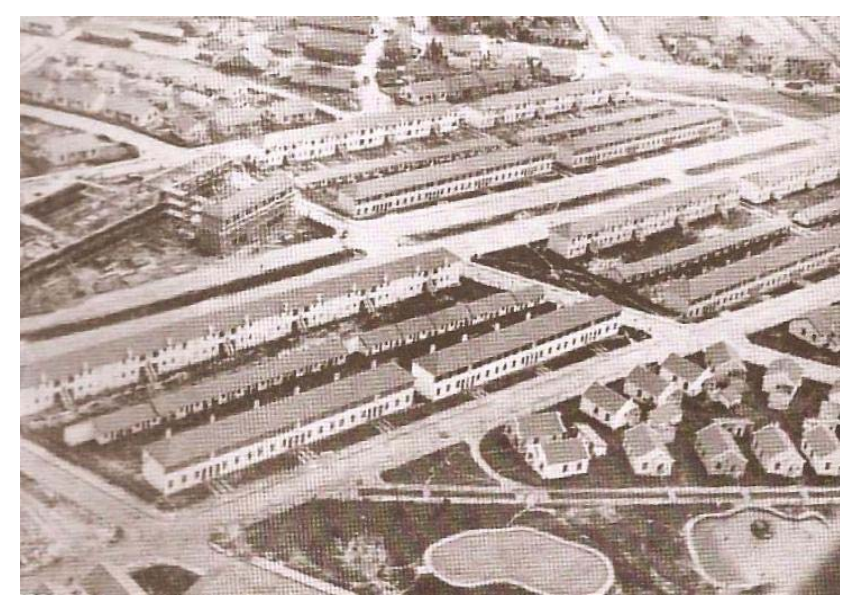

Figura 03: Vista aérea do Conjunto Passo d'Areia, edificado pelo IAPI-RS, e suas distintas tipologias.

Fonte: BONDUKI, 2002

Associado a esse aspecto estava 0 interesse dos IAPs e das CAPs em edificar seus grupos habitacionais no menor tempo possível, num “(...) ritmo acelerado de obras, pois a abreviação da fase construtiva conduz a resultados práticos de extrema relevância (...)" (IAPI, 1950, p.295). Esses resultados referiam-se à antecipação da locação ou venda do imóvel edificado e, consequentemente, da renda investida para a construção do conjunto, à redução do tempo de imobilização do capital que aliviava os juros de 
inversão na medida em que se reduzia o prazo de investimento, e ao barateamento das despesas com administração, direção e fiscalização das obras (IAPI, 1950).

Em se tratando das tipologias habitacionais praticadas pelos referidos órgãos, operaram-se essencialmente os blocos de apartamentos; os conjuntos mistos (moradias isoladas, geminadas e blocos de apartamentos), como o Conjunto Passo d'Areia (IAPI) (Figura 03), em Porto Alegre, projetado pelo arquiteto Marcos Kruter e construído entre as décadas de 1940 e 1950; as residências coletivas para solteiros, promovidas principalmente no âmbito do IAP dos Bancários e pelo IAP dos Comerciários; e as vilas suburbanas, como o Conjunto Piratininga construído pelo IAPI em Osasco, na década de 1940 (Figura 04).

Bonduki (1996) entende que Getúlio Vargas indicou "(...) soluções baseadas em grandes núcleos habitacionais multifamiliares em substituição às unidades isoladas unifamiliares" (BONDUKI, 1996, p.980). Entretanto, o presidente, como observado em seu discurso proferido no ano de 1938, no aniversário da Constituição do Estado Novo, apenas instruiu “(...) ao Ministério do Trabalho para que, sem prejuízo das construções isoladas onde se tornarem aconselháveis, estude e projete grandes núcleos de habitações modestas e confortáveis (...)"

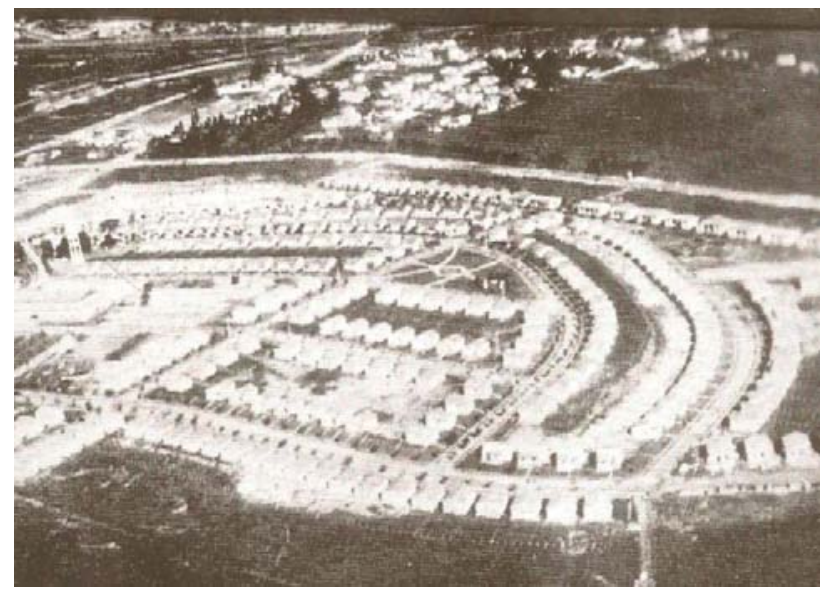

Figura 04: Vista aérea do Conjunto Jardim Piratininga, edificado pelo IAPI em Osasco-SP. Fonte: BRUNA, 2010

(VARGAS, 1945, p.99), aconselhando inclusive a desapropriação de áreas de utilidade pública, como colocado por profissionais na ocasião do I Congresso de Habitação, em 1931, e realizado largamente nas sociais-democracias europeias e na URSS, no primeiro Pós-Guerra.

De qualquer forma, pretendia-se "pelo menor preço, a melhor casa" (VARGAS, 1945, p.100) independente de isolada ou locada em grandes núcleos habitacionais modernos -, contando que fosse repassada aos trabalhadores do país a baixos custos. Como exposto em publicação do IAPI:

Os projetos devem ser padronizados, tanto quanto o permitirem as condições do meio, objetivando sempre economia em todos os pontos não essenciais ao dimensionamento da habitação, de modo a tornar o valor construtivo compatível com os salários médios locais. As instalações devem ser simples, padronizadas e duráveis e as estruturas permanentes, evitando-se soluções provisórias (...) (IAPI, 1950, p.292).

No tocante aos conjuntos mistos e de moradias coletivas, precisamente, evidenciaram-se muitos empreendimentos que simplificaram processos construtivos por meio da incorporação de novas tecnologias e da eliminação de ornamentos, da uniformização de unidades e blocos e da racionalização do traçado urbanístico, como foi o caso do Conjunto Residencial de Paquetá, na ilha de Paquetá da Baía de Guanabara, edificado pelo IAPI na década de 1940 (Figura 05) e diversos outros construídos por esse Instituto. 
Observam-se projetos que utilizaram tipologias inovadoras à época, como blocos de habitação coletiva de grande densidade. Alguns dos blocos de moradia coletiva passaram a serem concebidos com serviços, equipamentos coletivos (lavanderias e refeitórios principalmente) e inclusive comércio, em concordância com 0 conceito de unidade de habitação corbusiano, como o Conjunto Japurá - Conjunto Residencial Armando de Arruda Pereira (IAPI-SP), de autoria do engenheiro-arquiteto Eduardo Kneese de Melo172 (Figura 06). Outros exemplos importantes que seguem essa linha são o Edifício Anchieta, dos irmãos MM Roberto (IAPC-SP/1943) (Figura 07), o Conjunto Nove de Julho do arquiteto Plínio Arruda Botelho (IAPB-SP/1946)173 (Figura 08), ambos com formato em "L" e o Edifício General Osório (IAPI) em Campinas, edificado entre os anos de 1950 e 1951 (Figura 09). Esse conjunto, em especial, representa uma interessante solução ao incorporar em um mesmo pavimento duas funções, como especificou Bruna (2010) 174:

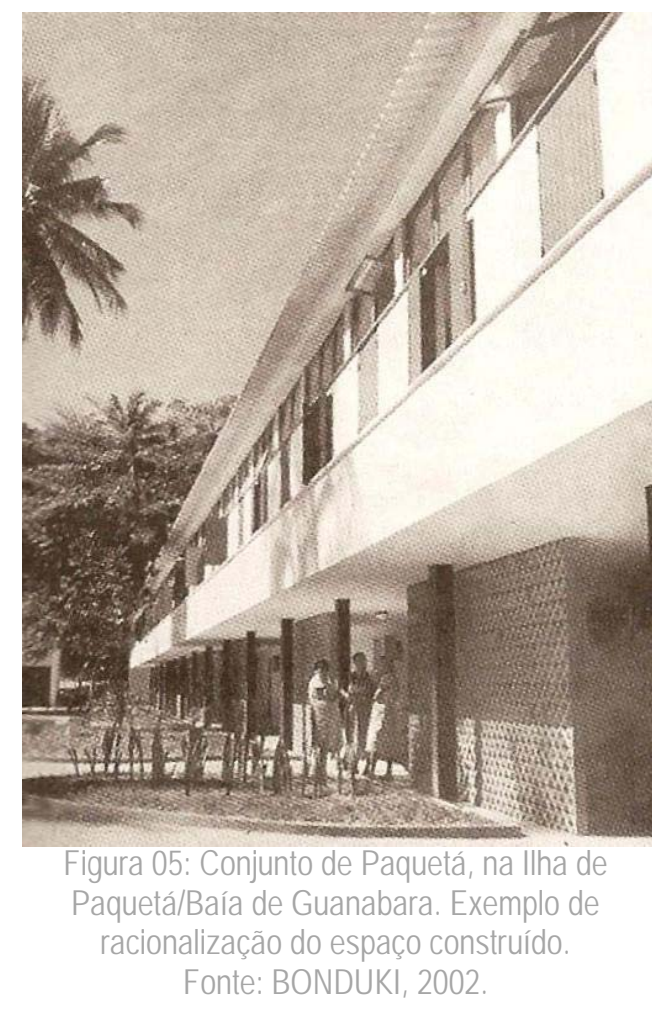

(...) No pavimento tipo alojam-se duas funções - de um lado estão as unidades residenciais, e de outro as salas comerciais. As duas alas não possuem comunicação entre si. No primeiro pavimento localiza-se o que originalmente seria uma agência do lapi, e 0 segundo pavimento abriga salões e lojas. $O$ apartamento do zelador fica no décimo andar. No total são quatorze pavimentos que abrigam cerca de setenta habitações (BRUNA, 2010, p.211).

Percebeu-se grupos de moradias em que se empregou uma volumetria mais movimentada, referenciando o partido adotado por Affonso Eduardo Reidy no Conjunto Pedregulho no Rio de Janeiro (Departamento de Habitação), como no já citado Conjunto da Rua Japurá (Figura 06). Determinados empreendimentos se assemelharam ainda a outras construções da época, como foi o caso do Conjunto do

\footnotetext{
172 Segundo Bruna (2010), esse conjunto faz referência além da Unidade de Habitação de Marselha, ao parque Guinle e ao Conjunto Pedregulho. São observadas passagens, passarelas e uma marquise com traçado orgânico. $O$ conjunto da Rua Japurá foi edificado em 1947 e é composto por dois edifícios: um com dezesseis pavimentos e 288 apartamentos duplex e outro com três pavimentos, sendo o primeiro e o segundo andar ocupados por comércio e serviços e 0 terceiro por 22 kitchenettes.

173 Conformado por 452 apartamentos.

${ }^{174} \mathrm{~A}$ autoria deste conjunto não foi apontada pelo autor. Outro aspecto que merece ser mencionado a respeito desta edificação refere-se à dimensão das unidades habitacionais em planta, que chegam próximo aos $100 \mathrm{~m}^{2}$, indicando que não foram direcionados aos trabalhadores mais carentes associados ao IAPI.
} 
IAPI em Santos. No qual, o arquiteto Alim Pedro "apropriou-se" do modelo orgânico da caixa d'água do Ministério da Educação, no Rio de Janeiro ${ }^{175}$.
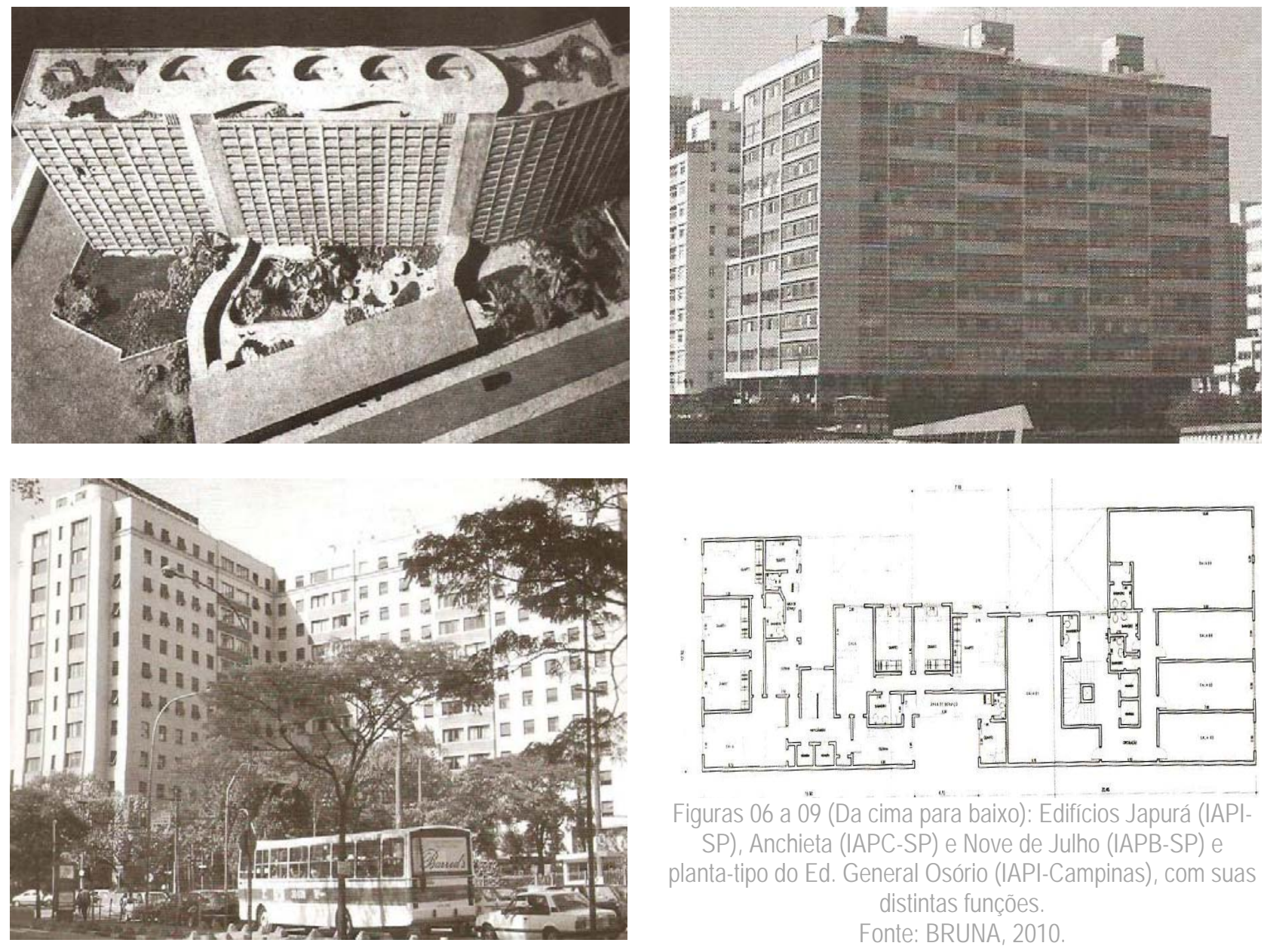

Em se tratando dos grandes conjuntos

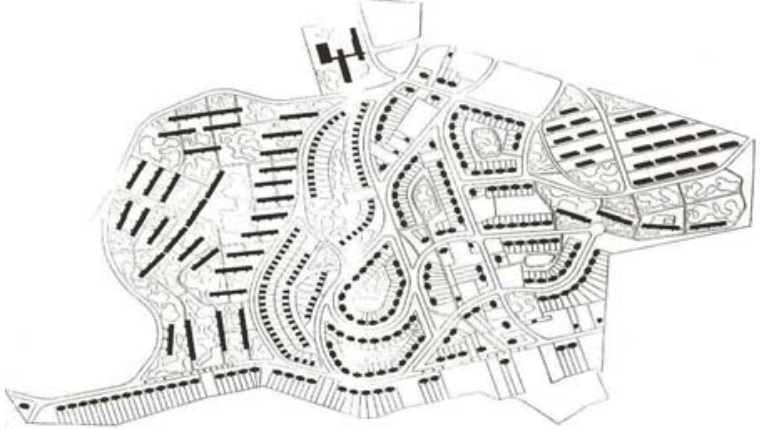

residenciais, horizontais ou não, são vislumbradas propostas urbanísticas associadas ao modelo de Cidade-Jardim, como a Vila Guiomar (IAPI), em Santo André (SP), projetada pelo arquiteto Carlos Frederico Ferreira, na década de $1940^{176}$, no qual, as unidades são dispostas de forma sinuosa aproveitando-se da trajetória solar e das curvas de nível do terreno, onde também são encontrados diversos espaços verdes e

$175 \mathrm{O}$ arquiteto em questão também foi presidente do IAPI e pensou o conjunto com 35 blocos de apartamentos e diversos equipamentos sociais e de serviço, mas somente cinco dos blocos foram construídos em 1953, num total de 200 unidades de moradia (BRUNA, 2010). Na planta de situação do empreendimento, apresentada por Paulo Bruna em seu já citado livro, observase ainda a existência de ruas cul-de-sac, de acordo com a prática de Clarence Perry.

176 O projeto foi concebido no ano de 1940 e foi edificado entre os anos de 1942 e 1950. O referido grupo de edifícios coletivos e unidades geminadas e isoladas é composto por um total de 1.724 unidades (61 blocos de apartamentos, 265 casas geminadas duas a duas e 313 residências isoladas), distribuídas em um milhão de metros quadrados (BRUNA, 2010). Neste conjunto, 0 arquiteto utilizou-se do jogo de volumes na fachada, salientando a caixa de escada do corpo principal do edifício, um diferencial volumétrico dessa concepção. 
jardins de contemplação e lazer, além de vias de acesso exclusivo para pedestres (Figura 10). Referências diretas à unidade de vizinhança de Clarence Perry, essencialmente no que concerne às vias para os pedestres e serviços concentrados no interior do conjunto, podem ser citadas, como observado no Conjunto Santa Cruz, do IAPB, em São Paulo177 (Figura 11). Esse modelo incita o convívio entre os moradores, sendo margeado por vias de automóveis e/ou de tipologia cul-de-sac, como evidenciado no Conjunto Cidade Jardim do IAPC-SP (Figura 12). Alguns conjuntos, de acordo com esse conceito, passaram a ser pensados e projetados levando-se em consideração o número de habitantes a que se iria destinar.

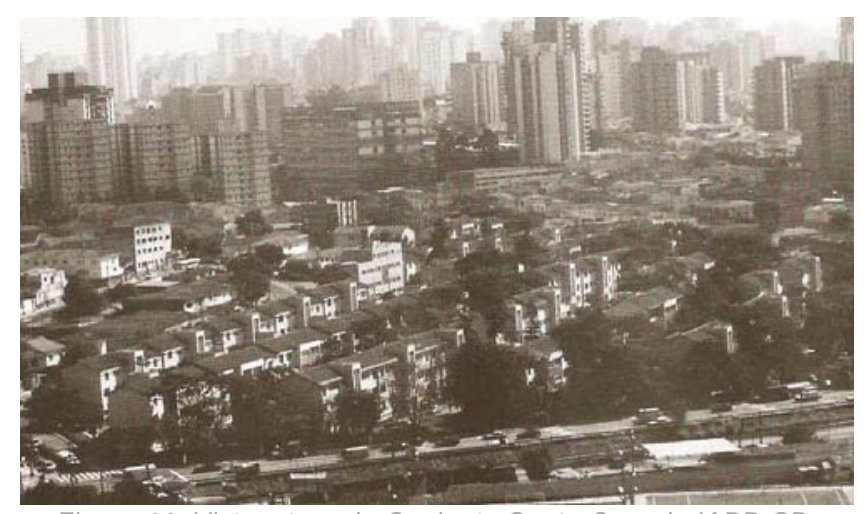

Figura 11: Vista aérea do Conjunto Santa Cruz do IAPB-SP. Atentar para a abundância de vegetação.

Fonte: BRUNA, 2010.

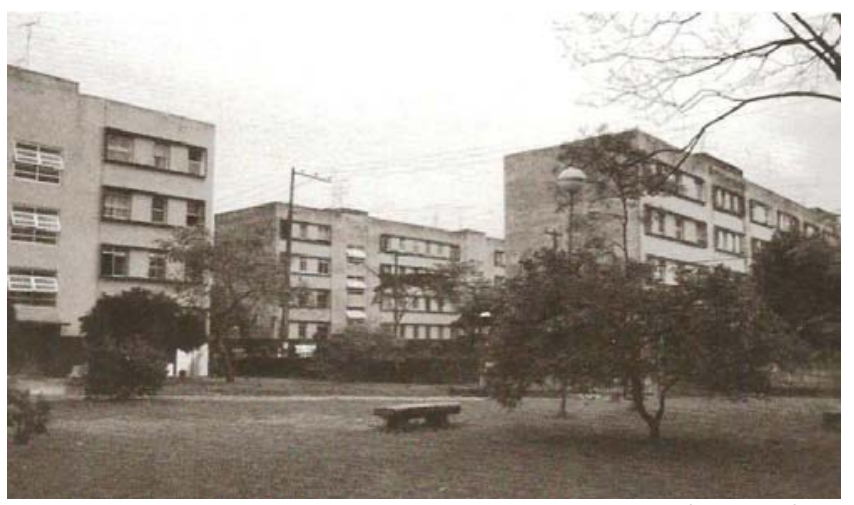

Figura 13: Conjunto Residencial Várzea do Carmo (IAPI-SP), edificado em 1942. Fonte: BRUNA, 2010.

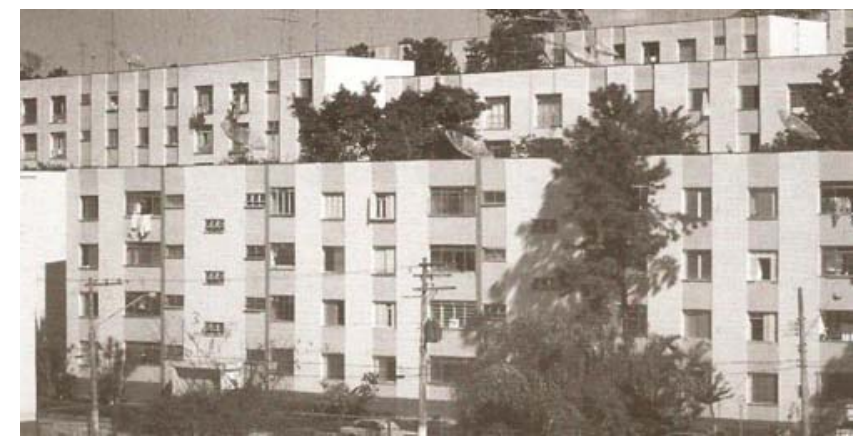

Figura 15: Conjunto Santo Antônio (IAPB-SP, déc.1950) Fonte: BRUNA. 2010

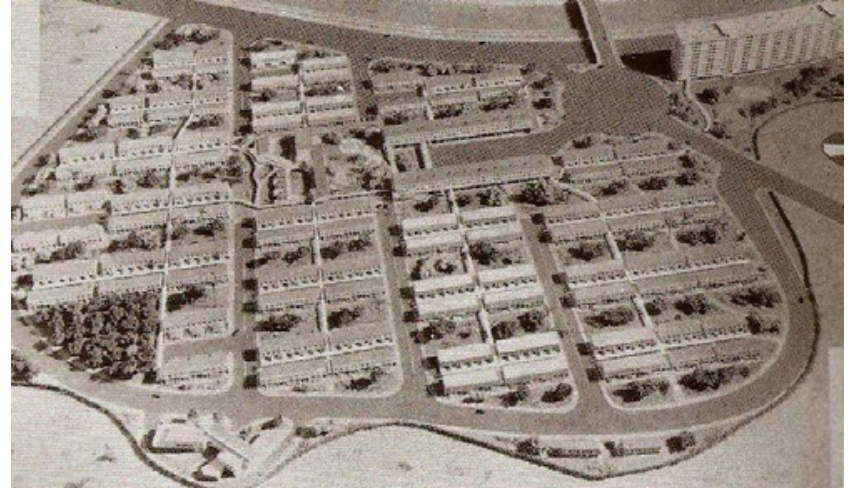

Figura 12: Maquete da Cidade-Jardim do IAPC-SP (não edificado) Fonte: BRUNA, 2010

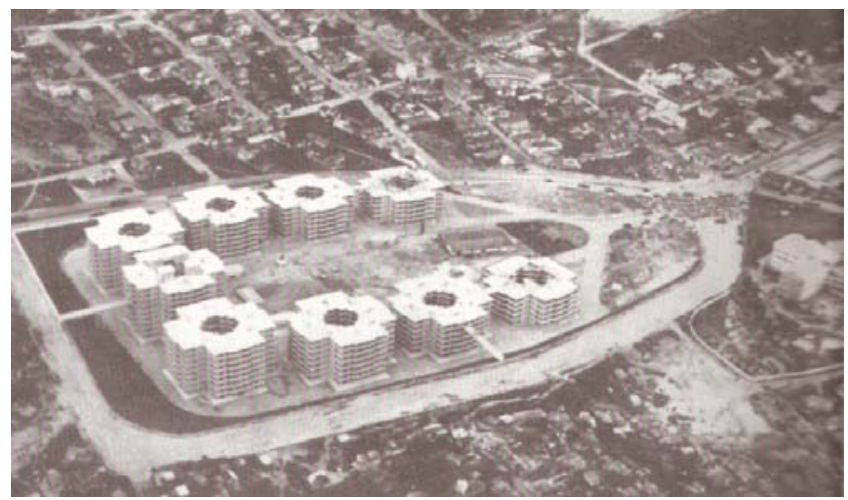

Figura 14: Conjunto Industriário (IAPI-BH), de White Lírio, com influência da Höfe vienense. Fonte: BONDUKI, 2002

Evidenciam-se ainda, alguns projetos que em muito se aproximam das experiências realizadas nos países europeus, em especial as sociais-democracias do Entre-Guerras, tais como as tipologias habitacionais coletivas do Conjunto

177 Conjunto projetado pelos arquitetos Marcial Fleury de Oliveira e Roberto J. G. Tibau, entre os anos de 1946 e 1950. Conformase por 282 unidades, distribuídas em 47 blocos de apartamentos, isolados, em fila e agrupados em 2, 3, 4, 5 e 6 edifícios, e dispostos em um terreno com abundância de verde e equipamentos de lazer em seu interior. As vias de veículos foram reduzidas ao máximo e dispostas em torno do Conjunto (BRUNA, 2010). As tipologias são muito próximas às largamente empreendidas pelas Cohab's, a partir de meados da década de 1960, com blocos implantados ao nível do terreno, cobertura em duas águas em telha colonial e combogós nas caixas de escada. 
Residencial Várzea do Carmo (IAPI-SP) ${ }^{178}$ (Figura 13), que se aproximam da concepção do siedlungen alemão179 (com a utilização de planos brancos simples, teto-jardim, esquadrias em ferro e vidro e gradis em metal), e o Bairro Industriário do IAPI, em Belo Horizonte, de autoria de White Lírio (Figura 14), provavelmente o único exemplar com influência da höfe vienense no país, de acordo com Bonduki (2002). Essa última aproximação é feita devido à existência de um pátio interno nos blocos e pela arquitetura imponente, que remete a uma fortificação. Alguns desses empreendimentos apresentaram consideráveis dimensões e grandes densidades à semelhança daquelas realizações europeias, como o Conjunto Santo Antônio, em São Paulo (IAPB-1951), tido como um dos maiores em número de unidades residenciais do país na época180 (Figura 15).

Nos conjuntos e/ou unidades verticais, se mostrou comum a utilização de pilotis $^{181}$, teto-jardim, plantas e fachadas livres, elementos vazados, ângulos retos e jogo de volumes simples, além das ruas internas, como observado no Edifício dos Bancários (IAPB), construído em Marília (SP), na década de 1950

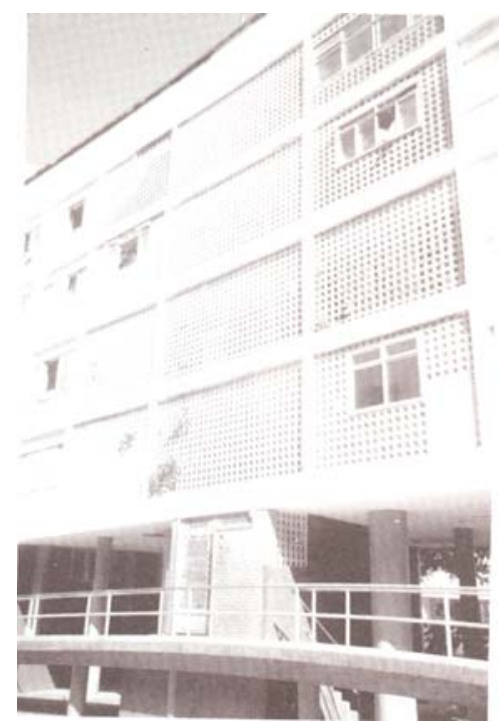

Figura 16: Elementos vazados, pilotis e passarelas internas do Edifício dos Bancários (IAPB-Marília, déc.50). Fonte: BONDUKI, 2002.

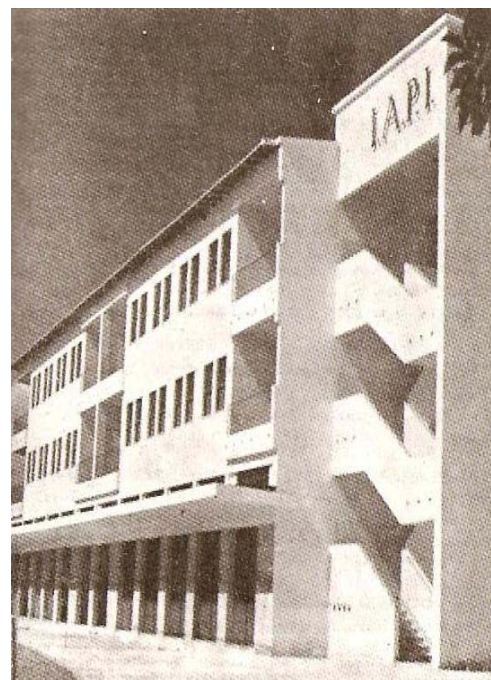

Figura 17: Conj. Honório Gurgel do IAPI-RJ, edificado na déc.1950. Destaque para a marquise e a solução de caixa de escada aberta. Fonte: BONDUKI, 2002.

(Figura 16) e do Conjunto Honório

Gurgel (IAPI-RJ) (Figura 17), além da tipologia de planta duplex, dentre vários outros.

Segundo o memorial descritivo do Edifício Japurá, do arquiteto Kneese de Mello, o emprego da tipologia duplex trazia diversas vantagens de ordem social e econômica, tais como a redução de $0.50 \mathrm{~m}$ de altura em cada dois pavimentos, possibilitando o aumento dos andares no edifício; a abolição do corredor de ligação entre os dormitórios, garantindo uma redução de área construída e consequentemente dos custos

\footnotetext{
178 Projeto dos arquitetos Attílio Corrêa Lima, Hélio Lage Uchôa Cavalcante, José Theodulo da Silva e do engenheiro Alberto de Mello Flores. O Conjunto é conformado por 602 moradias e foi edificado no ano de 1942 (BRUNA, 2010).

179 De maneira geral, como colocado por Bruna (2010), essas tipologias habitacionais eram conformadas por centenas e até milhares de moradias mínimas dispostas em torno de serviços sociais coletivos, concebidas em conjunto a partir da realização de estudos dos detalhes internos das habitações, pelo uso das técnicas de produção industrial, pelo cuidado com a insolação e a ventilação nas unidades, assim como da implantação paisagística, que resultaram numa inovação em termos organizacionais e de planejamento, que acabaram por se tornar marcos da nova concepção urbana e de arquitetura. Essa tipologia habitacional foi projetada inclusive por Walter Gropius na década de 1930, inserida inclusive nas diretrizes da Dessau.

180 Projetado pelo arquiteto Nicolau H. Barbieri, consta de 1.302 unidades habitacionais distribuídas em 53 edifícios laminares de quatro pavimentos (BRUNA, 2010).

181 Podendo ser parciais ou totais. Os pilotis totais são nesta tese considerados aqueles que abarcam toda área conformada pela edificação e são mais comumente encontrados em nosso país. Os pilotis parciais são aqueles que tomam apenas parte daquele espaço sob o prédio, como empregado pelo arquiteto Paulo Antunes Ribeiro, no Conjunto da Mooca (IAPI-SP). Nesse exemplar, optou-se por implantar apartamentos com menor área também no térreo, fincando os pilotis com dupla função de circulação e acesso às unidades.
} 
para a edificação da unidade; a utilização de um único poço de iluminação e ventilação para quatro banheiros de apartamentos; a separação entre os cômodos sociais e os privados; a diminuição do número de paradas do elevador pela metade; e uma economia total de aproximadamente $12.000 \mathrm{~m}^{3}$ de construção, com a redução dos pés-direitos das salas para 2,5m. Cabe lembrar, que a tipologia em questão também foi utilizada em unidades isoladas por parte das CAPs e dos IAPs. Para Bruna (2010), alguns dos arquitetos que se utilizaram desse artifício construtivo, a citar também Reidy, balizaram suas realizações nas maiosonettes inglesas, largamente empreendidas nas obras de reconstrução daquele país ${ }^{182}$.

De acordo com as diretrizes construtivas encontradas nas portarias e regulamentações dos órgãos, dever-se-ia evitar os trabalhos de movimentação de terra, que em muito encareciam o custo da construção, por meio da adequação da implantação às curvas de níveis, bem como estimulavam a concentração dos cômodos de serviços a fim de se tirar proveito das paredes hidráulicas e, consequentemente, alcançar uma maior economia. Seguindo essas diretrizes, em muitos dos conjuntos horizontais de propriedade das Caixas e Institutos optou-se pela tipologia geminada, mormente, em múltiplos de dois, como observado no Conjunto Residencial Jardim Piratininga, em Osasco (IAPI) ${ }^{183}$ (Figura 18). Mais especificadamente, as moradias dos IAPs apresentavam: pequenas varandas e/ou terraços onde aparecem os pilotis ou pilares esguios em "V", aos moldes de Niemeyer - como no Conjunto do IAPB em Santos (Figura 19) -, fachadas livres, elementos

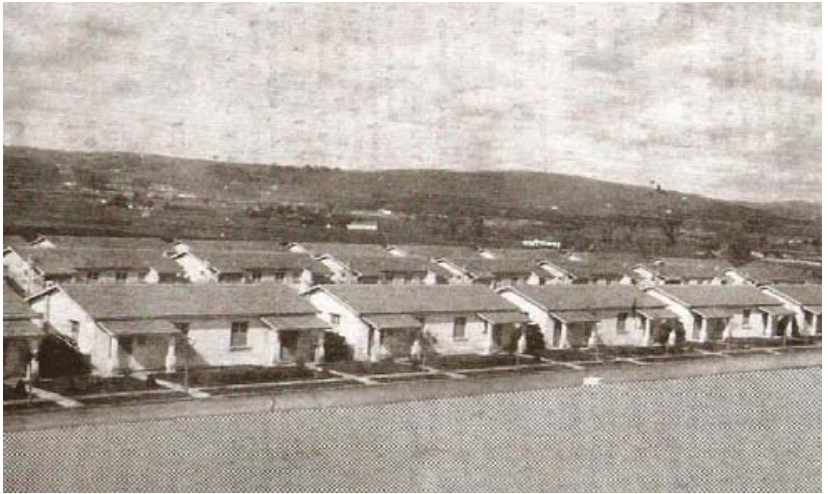

Figura 18: Conjunto Piratininga construído pelo IAPI em Osasco, na década de 1940.

Fonte: BRUNA. 2010.

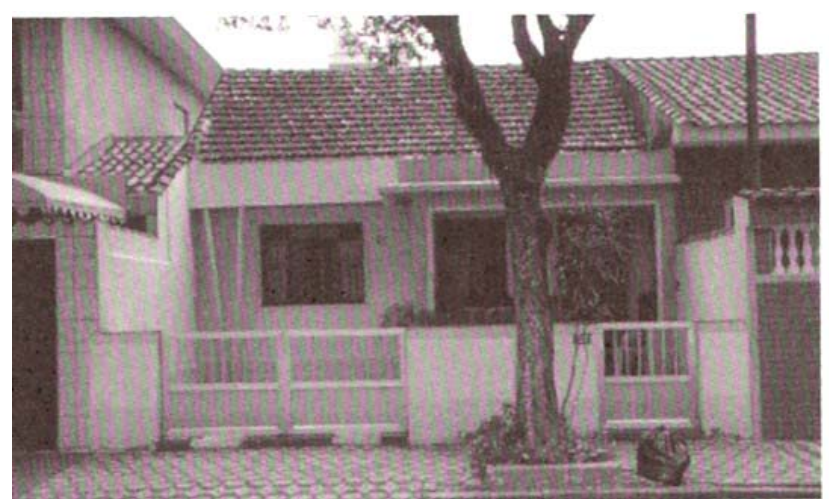

Figura 19: Conjunto do IAPB em Santos, edificado entre as décadas de 1940 e 1950.

Fonte: BONDUKI. 2002.

De modo geral, em planta, as unidades habitacionais, edificadas e/ou financiadas, se conformavam por um terraço, garagem ou varanda, uma ou duas salas (estar e/ou jantar), banheiro social, um a três quartos, cozinha e, por vezes, copa, área e dependência de serviço e depósito. Mais precisamente, a cozinha, os banheiros e a área de serviço foram agrupados por questões higiênicas e econômicas. Procedeuse também à redução das dimensões e do número de cômodos na habitação e à eliminação das grandes áreas de circulação interna. Em apartamentos optou-se ainda pela concentração de serviços e da própria

\footnotetext{
182 A questão da separação física entre a área social e íntima, associada à privacidade, foi bastante discutida nesse período. Em alguns casos, quando não foi possível o emprego da tipologia duplex, utilizou-se por vezes, a chamada porta íntima, como observado em planta no Conjunto Santa Cruz (IAPI-SP).

183 Esse conjunto foi projetado em 1942 e delegado, de acordo com Bruna (2010), ao arquiteto Carlos Frederico Ferreira. Constituise por 406 unidades, dentre residências geminadas duas a duas e isoladas, implantadas levando-se em consideração a topografia do terreno e as condições climáticas locais.
} 
edificação ao longo de eixos principais, e pela circulação externa por meio de passarelas, escadarias e/ou galerias abertas com o intuito de reduzir a quantidade de material utilizado para a sua concepção. Por questões de economia também foi percebida, para as moradias coletivas de diversos pavimentos, a utilização de diversas tipologias de plantas em uma mesma torre, para aproveitamento mais adequado de todos os espaços ${ }^{184}$, bem como a fusão dos acessos de serviço e social, como observado no Edifício Japurá. Em outros exemplares desta tipologia, percebe-se a abolição do elevador e a conseguinte adoção do gabarito de quatro pavimentos.

Mais especificamente, influenciada pelas ideias afloradas dos movimentos feministas do século XIX, das proposições advindas da economia doméstica e da engenharia do lar, das ideias difundidas nos CIAMs e pelo crescimento da indústria de equipamentos e utensílios domésticos na terceira década do século $\mathrm{XX}$, a cozinha da moradia brasileira também sofreu processo de reorganização e mecanização a partir da década de 1930. Incorporada ao corpo principal da residência, o espaço do fogão foi reelaborado, ganhando armários embutidos, espaços com funções específicas, eletrodomésticos e uma nova configuração mais integrada às áreas sociais, em especial às salas de estar e de jantar, o que se convencionou chamar de cozinha americana ou copa-cozinha, com bancadas, passa pratos e aberturas de meia parede para aqueles espaços.

Para Bruna (2010), o planejamento interno das unidades habitacionais nesse momento, especialmente da cozinha, empreendidas pela primeira vez na Siedlungen de Praunheim, em Frankfurt, de autoria do arquiteto Ernst May, afastou-se da prática que previa um grande ambiente, que funcionava como espaço de refeições, sala de estar e possuía ainda dois ou três cômodos sem uso definido, chamado de "wohnkuche", empreendendo a racionalização do espaço mínimo da casa185. Em alguns casos pontuais, observou-se ainda a existência de cômodos e/ou espaços inusitados, como 0 abrigo antiaéreo previsto pelo arquiteto Paulo Antunes Ribeiro ${ }^{186}$, em todo o terceiro pavimento de um dos blocos do Núcleo da Mooca do IAPI, descrito por Sampaio (1996).

Adaptações das premissas modernas às especificidades locais, essencialmente ao clima e aos materiais, também foram vislumbradas. Algumas edificações substituíram o teto-jardim por cobertura em telha colonial, francesa ou de amianto, como verificado no Conjunto Residencial da Mooca do IAPI-SP ${ }^{187}$ e do

\footnotetext{
184 Alguns edifícios chegavam a apresentar quatro ou cinco tipologias distintas numa mesma estrutura, como ocorreu no Edifício Anchieta, projetado pelos irmãos MM Roberto, para o IAPC em São Paulo, no ano de 1943. Essa edificação, destinada à classe média alta, mescla apartamentos simples, com duplex e lojas e sobrelojas no nível do terreno, além de um playground na cobertura. Os 72 apartamentos possuíam $106 \mathrm{~m}^{2}, 114,5 \mathrm{~m}^{2}, 117 \mathrm{~m}^{2}$ e $122,4 \mathrm{~m}^{2}$ de área construída. O Conjunto do IAPB na Nove de Julho é outro exemplo, possuindo cinco tipologias de planta, com $66,15 \mathrm{~m}^{2}$ a $114,5 \mathrm{~m}^{2}$ de área construída (BRUNA, 2010).

${ }^{185}$ De acordo com o referido autor, esse projeto foi desenvolvido pela arquiteta austríaca Grete Schutte-Lihotsky, da equipe de May em Frankfurt, e elaborada por meio de estudos isométricos. Referia-se a um espaço de $6,5 \mathrm{~m}^{2}$ altamente industrializado, semelhante à cozinha de um navio, a fim de se permitir a racionalidade e a eficiência de acordo com os estudos desenvolvidos por Frederick Taylor, pelas norte-americanas Christine Frederick e May Pattison, e pela alemã Ema Meyer, essencialmente na década de 1920. Nos primeiros anos da década de 1930, mais precisamente no ano de 1933, o governo Francês encomendou a Ernst May cerca de 100 mil cozinhas de Frankfurt para os novos bairros que estavam sendo edificados naquele país.

186 Não edificado.

187 Projetado pelo arquiteto Paulo Antunes Ribeiro, entre os anos de 1946 e 1950, é composto por 476 unidades de habitação distribuídas em blocos coletivos sobre pilotis (BRUNA, 2010).
} 
IAPETC-SP188 (Figuras 20 e 21), bem como no Conjunto Vila Guiomar, em Santo André (IAPI-SP) (Figura 22). Pode-se apontar a ampla utilização do sistema de brise-soleil concebido por Le Corbusier, e todas as suas variações adaptadas por diversos arquitetos, podendo ser móveis ou fixos, orientáveis, basculantes, horizontais ou verticais, utilizados para dar movimento às fachadas a partir dos jogos de sombra e luz, dentre outros, observados em residências das CAPS e dos IAPS, em especial aos projetos dos cariocas Irmãos Roberto ${ }^{189}$, como o Edifício Anchieta de propriedade do IAPI (1941), e Paulo Antunes Ribeiro, nos projetos da sede do IAPC, no Rio de Janeiro.

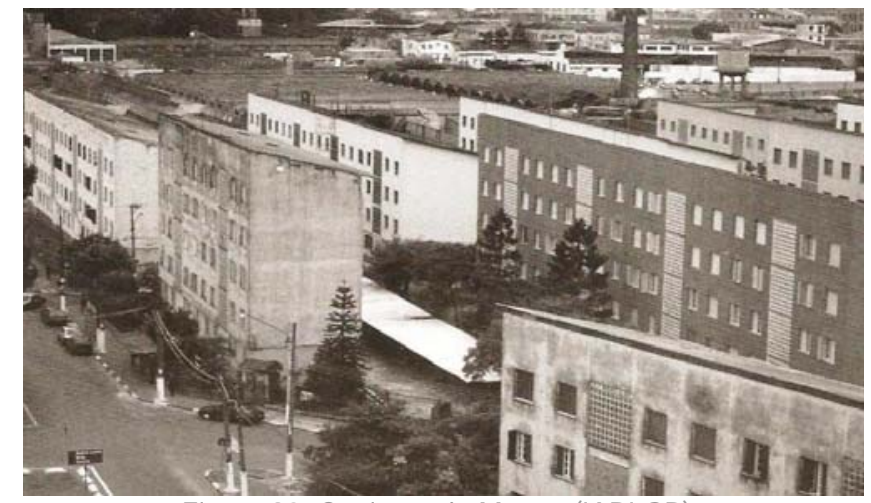

Figura 20: Conjunto da Mooca (IAPI-SP). Fonte: BRUNA, 2010.

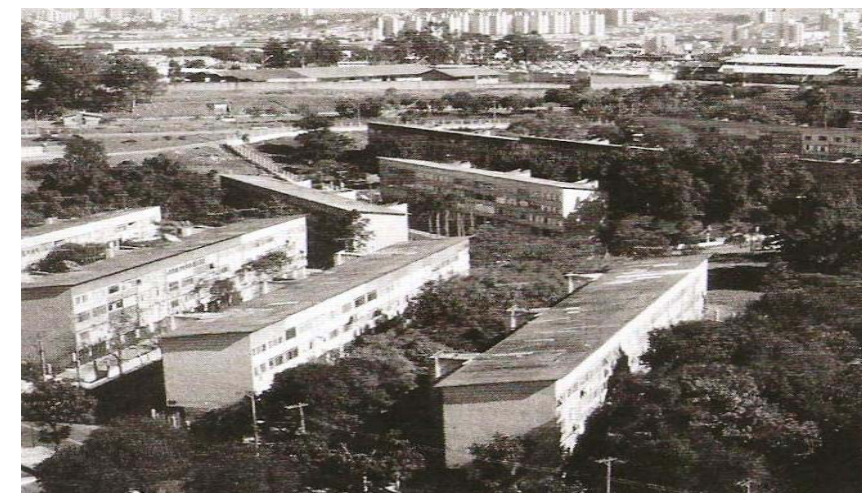

Figura 22: Vista aérea dos blocos do Conjunto Vila Guiomar, em Santo André-SP (IAPI). Fonte: BRUNA, 2010.

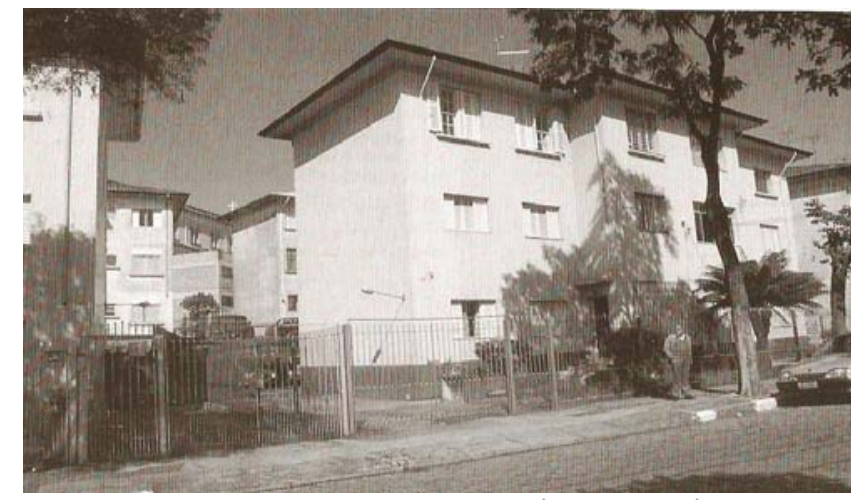

Figura 21: Conjunto da Mooca (IAPETC-SP). Fonte: BRUNA, 2010

O uso do combogós também foi outro reflexo dessa tendência de construção ampliada com o passar dos anos pelo corpo técnico dos IAPs e CAPs. Construídos em alvenaria, cerâmica ou vidro, os combogós se tornaram cada vez mais frequentes nas construções dos referidos órgãos, sendo empregados como elementos para otimizar a ventilação e/ou insolação e, por vezes, até como elementos de vedação e incorporados no partido arquitetônico de fachadas, sobretudo, de edifícios. Treliças em aço e madeira, principalmente, também foram empreendidas para essas mesmas funções, como adotado pelo engenheiro Alim Pedro, no Conjunto Residencial de Santos (IAPI), na década de 1950190 (Figura 23).

Nos conjuntos horizontais e nas unidades isoladas, essencialmente, as premissas ditas modernas observadas incitavam a distribuição das unidades no terreno de modo a melhor aproveitar a ventilação e

188 Próximo ao Conjunto do IAPI. Consta de 242 unidades habitacionais, distribuídas entre blocos isolados e geminados dois a dois, de três pavimentos, e residências geminadas em quatro e seis unidades (BRUNA, 2010).

189 Marcello, Milton e Maurício Roberto. Os irmãos são assumidamente influenciados pelas proposições de Le Corbusier e pela produção teórica e obras de Warchavchik, essencialmente, no que se refere à estrutura independente, à fachada livre, ao plano livre e ao teto-jardim (SAMPAIO, 1996).

190 Nesse conjunto, em especial, percebe-se a utilização de treliça em madeira em grande extensão da fachada posterior dos edifícios, desde o nível do térreo, incorporando toda a caixa de escada que, posteriormente, foi substituída por alvenaria e vidro por questões de segurança (BRUNA, 2010). 
iluminação natural, como no I Conjunto Terra Nova (IAPI-RJ) (Figura 24). Algumas plantas foram reorganizadas levando-se em consideração questões de insolação e/ou ventilação, como ocorreu no projeto de Paulo Antunes Ribeiro para, o já citado, conjunto da Mooca do IAPI. Nele, a sala de estar e jantar, mormente localizadas imediatamente após a entrada social, foram "deslocadas" para o final do corredor, após os acessos aos quartos e às áreas de serviço devido à disposição da edificação no terreno em relação à trajetória solar (Figura 25).

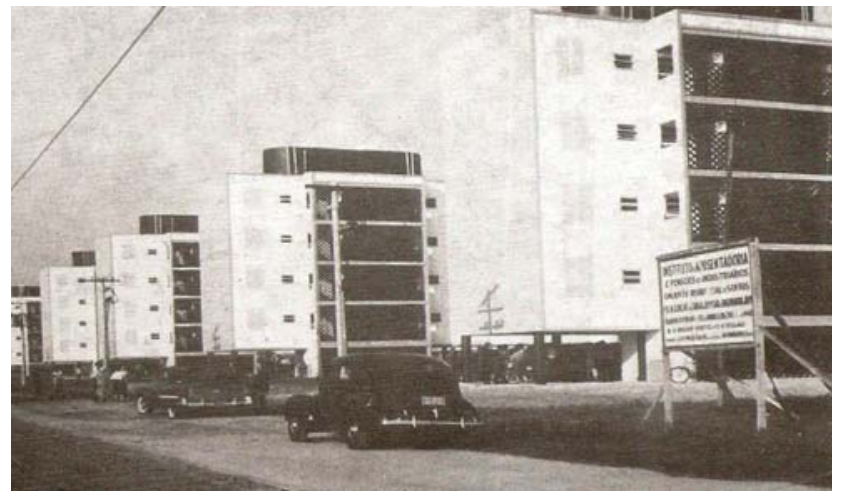

Figura 23: Conjunto Residencial do IAPI em Santos. Atentar para o uso de treliças de madeira no projeto original. Fonte: BRUNA, 2010.

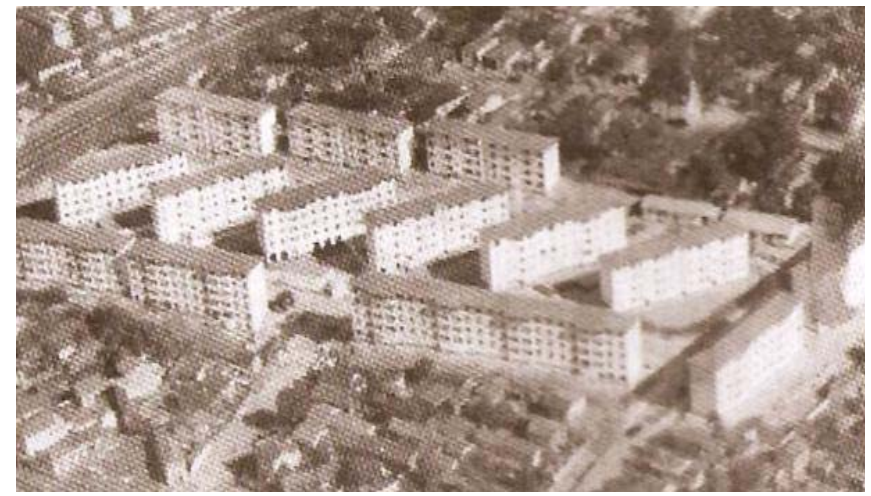

Figura 24: Vista aérea do Conjunto Terra Nova (IAPI-RJ), edificado na década de 1950.

Fonte: BONDUKI, 2002.

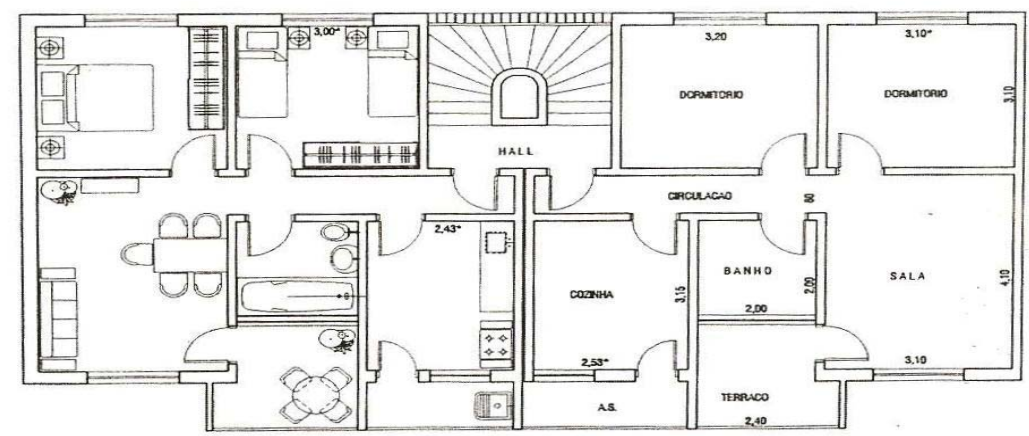

Figura 25: Planta-tipo dos blocos do Conjunto da Mooca em São Paulo (IAPI). Fonte: BRUNA, 2010.

O intento de racionalizar a moradia e seus elementos construtivos foi ampliado inclusive para 0 mobiliário da casa operária. Foram percebidos conjuntos nos quais os projetistas planejavam móveis adaptados à planta mínima, como mesas e camas desmontáveis que permitiam uma maior flexibilidade de uso dos cômodos da edificação, essencialmente apartamentos; armários embutidos e/ou projetados para objetos específicos, para se evitar a obstrução de entradas, acessos e janelas, bem como 0 aproveitamento adequado dos espaços; armários e divisórias separando os ambientes para economia de espaço e material; detalhes e elementos decorativos modernos condizentes, segundo seus projetistas, como o novo modo de vida da população brasileira, em especial, mesas e cadeiras; o uso de cores fortes; além do tratamento especial dado às áreas externas, adotando-se muitas vezes o paisagismo simplista dos cactos.

Em se tratando das inovações dos elementos e espaços, observa-se a valorização da área de serviço, que não apresenta mais semelhança com o alpendre da casa colonial. Apareceu, nesse contexto, 0 aparelho de lavanderia em cimento, localizado geralmente no recuo lateral próximo ao acesso à cozinha, um 
aspecto recorrente nas casas edificadas pelas CAPs e pelos IAPS, especialmente no nordeste do país. A chamada, nesta tese, de porta íntima, cuja função principal é separar a sala da circulação íntima, foi outra inovação percebida nos estudos das plantas de muitos dos maiores conjuntos edificados pelas Caixas e Institutos no centro-sul e nordeste brasileiro.

Cabe aqui lembrar, que apesar de proporem a reforma da moradia urbana brasileira, muitos dos profissionais arquitetos e engenheiros atuantes no âmbito dos referidos órgãos, incorporaram apenas parcialmente as premissas da arquitetura moderna. Nesse sentido, eram comumente encontradas sugestões da utilização de concreto armado por meio do emprego de tijolos revestidos com cimento branco, referências ao teto-jardim através da utilização da platibanda e elementos de fachadas que não correspondiam às soluções internas de planta. Dentre as justificativas para a restrição da adoção da arquitetura moderna no campo habitacional no Brasil, nas primeiras décadas do século XX, estavam os altos custos para manuseio e aquisição de alguns materiais e a escassez de mão de obra especializada. Posteriormente, o tijolo cedeu lugar ao concreto armado e a varanda às marquises. Percebe-se também o emprego da impermeabilização e da laje plana. $O$ atrativo formal e funcional das edificações tidas efetivamente como modernas contribuiu para a adoção dessas referências largamente em todo o território nacional.

Sendo assim, não foram apenas exemplares com referências à arquitetura e à urbanística modernas que foram projetados, financiados e/ou edificados pelas Caixas e Institutos de Aposentadoria e Pensões no país, como frisa a maior parte das publicações sobre a temática. Até o momento são poucos os conjuntos residenciais conhecidos e estudados pela historiografia, se comparados ao volume total das ações dos órgãos em todo território nacional ${ }^{191}$. Na verdade, ousa-se conjecturar que esses grupos habitacionais foram a exceção à regra e que a maioria das atuações daqueles órgãos continuou a empregar a lógica e o modelo rentista de casas geminadas em vilas higiênicas e fachadas de porta e janela em seus empreendimentos. Isso ocorreu, vale salientar, apesar das investidas oficiais e do corpo técnico do Conselho Nacional do Trabalho.

Esse foi o caso de alguns órgãos já apontados pela mesma historiografia que imputa uma arquitetura principalmente de vanguarda às realizações das Caixas e dos Institutos no campo habitacional. Podem ser citadas, nesse sentido, a CAP da Central do Brasil e da Light, no Rio de Janeiro, além de diversas outras realizações dos IAPs distribuídas pelo país, que continuaram a produzir moradias de viés eclético, bem como retomaram interesses e motivos de arquiteturas anteriores, como do período colonial, remetentes ao Art Decó e próximas ao Missões. As referências passam ainda pelo Neocolonial, pelos bangalôs norte-americanos, até chegar à sobriedade das linhas modernas, como ser verá mais detalhadamente nos capítulos seguintes desta tese.

A variedade de menções se deu pelo fato que, da mesma forma que a legislação, a adoção de referências arquitetônicas, a tipologia adotada, os aspectos construtivos da habitação, bem como o modelo

$191 \mathrm{E}$, repete-se, estão principalmente localizados no centro-sul do país. 
de implantação dos conjuntos nas cidades, variavam de Instituto para Instituto e, no âmbito deles, de cada engenheiro e/ou arquiteto responsável pela elaboração e execução projetual - quando não resultante de concurso aberto ou público a nível nacional ou fosse projetado a partir da iniciativa do escritório central. As formulações também variavam em função de outros aspectos, a citar: a disponibilidade de material e de mão de obra; as condições climáticas e de relevo locais; os valores desprendidos para a concepção do grupo de moradias; o terreno designado para tanto; além do público alvo e da conjuntura econômica no momento de consolidação do projeto, como veremos mais adiante.

Dentre os empecilhos encontrados pelas CAPs e pelos IAPs no que concerne à produção de moradias, nesse sentido, além da escassez de materiais específicos como o concreto armado, o ferro e 0 vidro e a falta de mão de obra adequada em algumas localidades do país, como já citado, estava muitas vezes a falta de adequação dos códigos de posturas e de obras municipais às novas tipologias e gabaritos propostos pelas Caixas e Institutos. Questões colocadas, como de urgente solução, pelos profissionais participantes do I Congresso de Habitação (1931) e que até a década de 1950 ainda eram vislumbradas. De acordo com publicação do IAPI (1950), os principais pontos de "colisão" diziam respeito às especificações dos loteamentos, às dimensões das glebas, quadras, ruas e lotes; ao gabarito das edificações que, muitas vezes, não poderia ultrapassar dez pavimentos e/ou não poderia exceder duas vezes a largura da via na qual seriam implantadas; ao pé direito mínimo, que ainda deveria possuir entre 3,0 e 3,5m de altura, especialmente nos dormitórios; e em relação às vias de circulação192.

Algumas críticas já podem ser traçadas quanto à configuração urbanística desses conjuntos. Uma deles refere-se a não adaptação dos grupos residenciais ao automóvel, apesar da instalação da indústria automobilística no país, na década de 1950, os conjuntos projetados e edificados pelas CAPs e IAPs naquela época ainda não previam estacionamentos. Uma das justificativas utilizadas pelo próprio corpo técnico era a da função social desses empreendimentos e a faixa de renda atendida por eles. No entanto, mesmo nos conjuntos de moradias isoladas ou apartamentos destinados à classe média e alta são escassos os exemplos onde constam vagas para automóvel. O resultando observado foi a adaptação das vias de acesso e de circulação interna desses conjuntos para estacionamento, bem como o fechamento e reaproveitamento de áreas comuns e de lazer, para esse fim.

Como destacou Bruna (2010), são diversos os exemplos de conjuntos de propriedade das CAPs e dos IAPs em que os habitantes se apropriaram dos espaços públicos e coletivos, em especial a área comum dos jardins e aquela conformada por pilotis, convertendo-os para espaços privados por meio de cercas, gradis

\footnotetext{
192 De um modo geral, esses empecilhos foram enfrentados por todos os que pretendiam e edificaram grandes conjuntos de moradias nas décadas de 1920 e 1930, como apontado por Bruna (2010), inclusive por Ernst May, em Frankfurt. Nesse caso em específico, segundo o autor, foi a dificuldade em encontrar pedreiros que se configurou como o maior obstáculo para a construção dos grandes Siedlungens na Alemanha. A solução encontrada por aquele arquiteto foi a incorporação da mão de obra não especializada abundante na pré-fabricação dos painéis de concreto leves para as primeiras casas do conjunto de Praunheim.
} 
e até alvenaria, como ocorreu na Vila Guiomar (IAPI-Santo André) ${ }^{193}$. Em alguns casos, como o colocado pelo autor, essa iniciativa partia da própria administração do conjunto, como foi no Conjunto da Mooca em São Paulo (IAPI), no qual, a Associação cercou a área comum do empreendimento e passou a gerenciá-la com horários de abertura e fechamento.

Cabe ressaltar que com o passar o tempo outros fatores colaboraram para essas iniciativas da população e/ou das administrações dos grupos habitacionais das CAPs e IAPs, com destaque para a segurança pública. Esse aspecto colaborou consideravelmente para 0 aparecimento e intensificação da utilização de cercas e gradis nesses conjuntos, principalmente os conformados por diversos edifícios, que após cercados passaram a equivaler cada um a um condomínio, como também para a descaracterização de diversos partidos originais, como observado no já citado Conjunto do IAPI em Santos e em diversos outros empreendimentos habitacionais das CAPs e IAPs em todo o país.

Outra crítica pode ser direcionada aos equipamentos de infraestrutura e serviços que intentavam tornar o empreendimento autossuficiente, mas que por vezes não foram concluídos ou até mesmo iniciadas as obras. Esse foi o caso apontado por Bruna (2010), do Conjunto de Santos (IAPI-1953), cujo projeto previa além da implantação de 35 blocos de apartamentos, diversos equipamentos como escola, ginásio, praça de esportes e centro comercial, que por questão de economia não foram edificados. Acredita-se que essa tendência se intensificou nos anos 50 e equivale a um dos reflexos da descapitalização dos fundos das CAPs e IAPs. Mais especificadamente, a partir desse momento, os grupos de moradias, conjuntos coletivos e até mesmo os prédios isolados projetados por esses órgãos passaram a contar com um número menor de unidades e, principalmente, de equipamentos urbanos, que com o desenrolar dos anos passaram, muitas vezes, a não constar nos projetos.

Por diversos momentos, o corpo técnico dos Institutos e Caixas utilizou-se do eufemismo para retratar esse quadro, alegando que os conjuntos destinados à população mais carente, devido aos seus baixos vencimentos, não comportavam equipamentos, como observado em publicações da época:

(...) Nas regiões onde os salários são bastante baixos, surge a solução parcial e então os conjuntos residenciais são apenas núcleos de casa, com requisitos higiênicos, sem comparação com os mocambos, favelas ou cortiços, sacrificando-se, porém, as soluções urbanísticas aconselháveis, com o intuito de reduzir ao mínimo o valor da habitação (OS CONJUNTOS..., 1942, p.34).

Essa infundada ${ }^{194}$ justificativa foi a utilizada para a edificação dos três conjuntos do IAPI projetados pelo arquiteto Joaquim de Almeida Santos, em Jundiaí, Campinas e Taubaté, nos anos de 1950195. Para

\footnotetext{
193 Nesse conjunto residencial, em especial, a área térrea formada pelos pilotis foi dividida com alvenaria e os cômodos formados, alugados aos membros das famílias residentes nos apartamentos e casas do conjunto. Esses espaços foram utilizados de diversas formas: para moradia, estacionamento, depósitos ou, até mesmo, pequenos comércios (BRUNA, 2010).

194 Refiro-me a infundada, pelo simples fato, que no início da atuação dos IAPs e CAPs no campo habitacional na década de 1930, os mesmos conjuntos direcionados à população menos abastada associada às Carteiras Prediais desses órgãos, eram dotados de toda a infraestrutura e uma diversidade de equipamentos coletivos, como apontado ao longo da tese. A questão da descapitalização da previdência pode, mais uma vez, ser mencionada como justificativa mais plausível.
} 
Bruna (2010), esses grupos de moradias "(...) possuem o mesmo tipo de implantação e programa bastante modesto, composto de sobrados geminados que seguem sempre a mesma tipologia", afirmando ainda, que “(...) os equipamentos que habitualmente eram previstos nos conjuntos na cidade de São Paulo não foram incluídos nos projetos de cidades menores (...)" (BRUNA, 2010, p.213 e 216).

A questão da falta e/ou precariedade da infraestrutura e serviços básicos, apontada em alguns estudos e observada ao longo da pesquisa, também se deve em parte ao Estado. Geralmente os Institutos e Caixas se responsabilizavam pela implantação dos serviços e pelas obras que dotavam seus empreendimentos com a infraestrutura básica, a semelhança das vilas e núcleos fabris do início do século XX. Porém, quando esse encargo recaia por sobre o poder público, por acordo ou outras questões, comumente, se configurava como um problema. Por vezes, as obras não eram realizadas ou permaneciam incompletas. Esse foi o caso do Conjunto do IAPI em Osasco, no qual, por problemas na rede de abastecimento d'água, que era precária, as 4.000 unidades habitacionais, zona comercial, escolas, instituto de ensino profissional, hospital, creche, centro de puericultura, clubes recreativos e terminal rodoviário previstos no projeto original, não foram edificadas. As obras foram paralisadas em sua primeira fase, sendo disponibilizadas somente uma escola, um posto de saúde e 406 moradias aos associados do Instituto dos Industriários (REVISTA DOS INDUSTRIÁRIOS, 1950). Vale lembrar, que os IAPs e CAPs também atuaram em conjunto com a FCP e outros órgãos estaduais e municipais, nesse sentido.

Os fatores acima listados contribuíram para as alterações de muitas das construções das Caixas e Institutos de Aposentadoria e Pensões no país. Essa conjuntura ocasionou a descaracterização de moradias, equipamentos e espaços públicos pelas administrações dos conjuntos e até pelos próprios moradores. Essas modificações ocorreram no sentido e/ou tentativa de suprir as carências de funções, serviços e equipamentos não previstos ou realizados pelos referidos órgãos. As posteriores reformas foram também resultado da falta de adequação dessas construções às especificidades, especialmente do clima, em algumas localidades. Mais uma vez, faz-se referência ao projeto de Alim Pedro, para o IAPI em Santos. Bruna (2010) analisou esse processo de adaptação/descaraterização, destacando que devido à elevada unidade do local, os moradores revestiram os blocos com material cerâmico muito distinto do original.

O aprofundamento dessas especificações e diretrizes construtivas, bem como as possíveis influências e modelos tomados como referência e/ou baliza para as realizações das CAPs e dos IAPs no campo da moradia no país, em especial as contribuições do engenheiro-arquiteto Rubens Porto nesse sentido, serão tratadas nos capítulo seguinte.

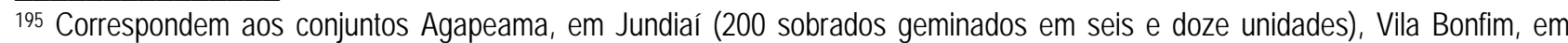
Campinas (412 sobrados geminados em grupos de dezesseis pelo menos) e o Taubaté, em Taubaté (316 moradias geminadas em grupos diversos) (BRUNA, 2010).
} 


\section{0 . CAPÍtulo 2}

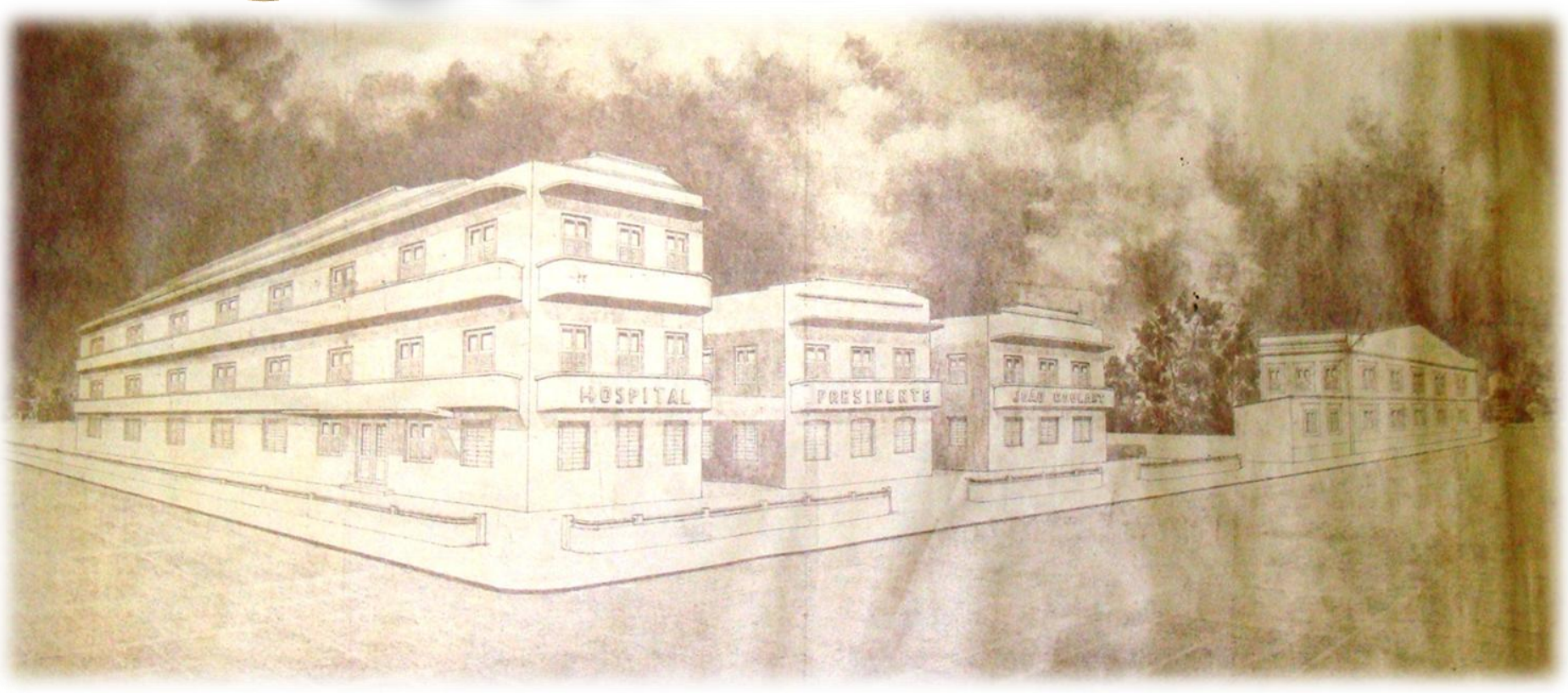




\section{CAPÍTULO 02}

\section{REFERÊNCIAS E MODELOS: A ESTRUTURAÇÃO DAS CAPS E dOS IAPS}

Este capítulo da tese tem por objetivo estudar a atuação e a colaboração técnica e intelectual de profissionais engajados na estruturação do sistema previdenciário estatal no país, bem como de uma política pública habitacional, no âmbito do Ministério do Trabalho, Indústria e Comércio (MTIC) ${ }^{196}$, em especial do engenheiro-arquiteto Rubens Porto, que se destacou nesse processo devido às suas proposições, publicações e/ou na tomada de decisões. No contexto de reformas dos regulamentos para ação das CAPs e dos IAPs no campo habitacional, também pretende-se identificar, ao longo da década de 1930, as semelhanças e aproximações das proposições desse profissional aos modelos e às experiências no campo da moradia precedentes e/ou contemporâneas às suas ações, que possivelmente foram tomadas como balizas para a estruturação e atuação dos supracitados órgãos no país.

Mais especificadamente, Rubens Porto se conformou como um mediador entre as reflexões, estudos e proposições em curso, principalmente acerca da moradia, elaboradas por engenheiros, arquitetos e médicos, bem como das proposições e reivindicações formuladas pela igreja católica e até mesmo por parcelas da população nesse sentido, sobretudo na década de 1930, e a estruturação das ações no campo estatal. Esse aspecto, por si só, justifica a abordagem mais aprofundada sobre sua atuação.

Além do supracitado engenheiro-arquiteto, existiram outras figuras que contribuíram para a consolidação de uma política social no país, inclusive no âmbito da moradia, a citar os ministros do Trabalho Indústria e Comércio Lindolfo Collor, Agamenon Magalhães e Waldemar Falcão, principalmente, e 0 conselheiro jurídico Evaristo de Morais. Personagens da história do trabalho, da previdência e da habitação que, como tantos outros, ainda não foram devidamente estudados pela historiografia brasileira e, que aqui, serão apenas referenciados, bem como citadas algumas de suas mais significativas realizações naqueles setores sociais.

Cabe frisar que 0 intuito principal ao elencar essas figuras não foi o de esgotar 0 assunto ou 0 de aprofundar e analisar suas bibliografias profissionais, mas sim, o de apontar a existência de outras importantes contribuições ao aparelhamento e atuação das CAPs e dos IAPs no país, ocupantes de cargos diretamente relacionados à tomada de importantes decisões ao longo da década de 1930 como, por exemplo, 0 alargamento da atuação das CAPS, a criação dos Institutos subordinados ao MTIC e a ampliação de suas reservas financeiras para a construção de moradias para trabalhadores brasileiros. Essas contribuições foram vislumbradas no âmbito daquele Ministério e estavam intimamente associadas à atuação do engenheiroarquiteto Rubens Porto e às suas formulações enquanto membro do CNT.

\footnotetext{
196 Vale lembrar que, até a década de 1930, as questões em torno do trabalho, da previdência e, consequentemente, da habitação, ainda muito restritas ao funcionalismo público, ficavam a cargo do Ministério da Agricultura, Indústria e Comércio e do Ministério da Fazenda, principalmente.
} 
A primeira delas foi observada já na primeira gestão do Ministério do Trabalho, Indústria e Comércio, admitida por Lindolfo Collor, em 1931197. Durante sua administração foi montada e mantida uma equipe para discussões e para a elaboração de um conjunto de projetos de leis relacionadas à organização sindical, à normatização trabalhista e à previdência social, na palheta da qual, foram outorgadas diversas determinações vinculadas à moradia social concebida e/ou financiada pelas CAPs do MTIC e, posteriormente, pelos recémcriados IAPs do MTIC, principalmente. Nesse sentido, de acordo com Mendonça (2007, p.212), Lindolfo Collor “(...) procurou reunir no seu ministério um grupo de pessoas experientes no trato da 'questão social', alguns dos quais com tradição de militância em torno do tema e uma história de aproximação com os movimentos operários (...)". Dentre esses nomes, pode-se citar Joaquim Pimenta, o empresário paulista Jorge Street ${ }^{198}$, Agripino Nazareth e o seu assessor jurídico, Evaristo de Morais (VÉLEZ, 1988) (Figura 27). Acredita-se ainda, que Rubens Porto participou desses debates e formulações devido às referências apontadas pelo próprio engenheiro-arquiteto em suas contribuições, que serão estudadas adiante.

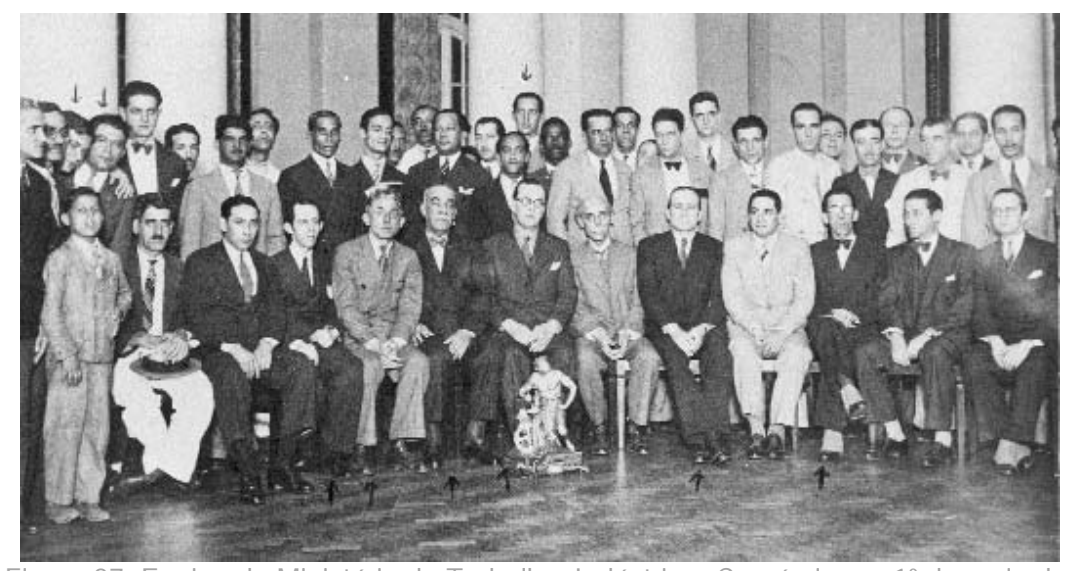

Figura 27: Equipe do Ministério do Trabalho, Indústria e Comércio em $1^{0}$ de maio de 1931. São percebidos da esquerda para a direita e sentados: Heitor Muniz (terceiro), Joaquim Pimenta (quarto), Antônio Evaristo de Moraes (quinto) e Lindolfo Collor (ao centro, de óculos).

Fonte: Arquivo Lindolfo Collor, CPDOC/FGV, 2010.
Lindolfo Collor e sua equipe foram responsáveis por implantar e regulamentar os sindicatos oficiais no país, bem como, por idealizar uma organização social de âmbito nacional sobre bases corporativas que otimizasse a atuação e 0 reconhecimento dos sindicatos patronais e, consequentemente, das categorias trabalhistas, muito próxima ao que foi implementado em seguida nos IAPs do MTIC.

Mais precisamente, em sua gestão, Collor foi um dos idealizadores da extensão das CAPs do MTIC, até então restritas aos marítimos, portuários, ferroviários, telégrafos e radiotelégrafos, a todas as categorias trabalhistas, assim como, da possibilidade de criação dos Institutos (VÉLEZ, 1988), com sugestões diretas de Rubens Porto. Foi o primeiro ministro do TIC e sua equipe que também definiram, como ressaltado por Moog (1978), a alteração das bases de utilização das reservas daquelas Caixas de Aposentadoria e Pensões, bem como, a modificação da abrangência do Instituto de Previdência dos Funcionários Públicos da União para

\footnotetext{
197 Permaneceu nesse cargo até 0 ano seguinte.

198 Foi diretor do Departamento Nacional de Indústria e Comércio e do Departamento Estadual do Trabalho de São Paulo, na década de 1930 (MORAIS, 10/11/1990).
} 
atender aos trabalhadores dos serviços de luz e telefone a cargo dos estados, municípios e empresas privadas, antecipando um dos objetivos do IPASE ${ }^{199}$.

Evaristo de Morais, um dos componentes da equipe do então Ministro do Trabalho, Indústria e Comércio, por sua vez, antes de ingressar no corpo técnico do Ministério atuou ativamente no movimento operário brasileiro como delegado de diversas agremiações no Rio de Janeiro, em especial junto aos sindicatos nos primeiros anos do século XX, além de ter sido membro do Partido Operário e de ter participado de diversos eventos, como o Congresso Operário de 1906. Foi ainda o responsável, a partir de 1903, pela redação da coluna operária em um dos maiores periódicos do país, o Correio de Manhã, bem como do jornal tido como socialista na década de 1920, o Echo Popular (MENDONÇA, 2007).

Por meio dessas vertentes de atuação, Evaristo de Morais pretendia, de acordo com Mendonça (2007, p.205), "(...) legitimar as ações dos grevistas, criticava a ação da polícia e defendia um programa de transformação das relações de trabalho, pregando a necessidade de uma intervenção efetiva do Estado no sentido de proteger os trabalhadores (...)", incluindo a concessão de moradias. Atuando por meio da legislação, segundo Evaristo de Morais, o poder público atenderia os reclames dos proletariados e manteria 0 equilíbrio social. Esses e outros ideais foram incorporados em sua participação do âmbito do MTIC junto ao Ministro Lindolfo Collor, como já citado. Cabe ressaltar, que desde a década de 1910, Evaristo também defendia a criação das CAPs aos moldes que ficaram largamente conhecidos na década seguinte. Suas sugestões foram publicadas em diversos artigos nos periódicos acima referenciados.

Outras importantes contribuições profissionais para o campo previdenciário e 0 da moradia brasileira foram dadas por Agamenon Magalhães, o Ministro do Trabalho cuja gestão foi iniciada no ano de 1934200. No âmbito do trabalho deu continuidade à criação dos Institutos de Aposentadoria e Pensões subordinados àquele Ministério, para outras categorias profissionais, bem como suas normatizações; ação iniciada na gestão de Lindolfo Collor. Muito próximo ao presidente Getúlio Vargas, como o foi Rubens Porto, Agamenon pode ter influenciado as decisões nesse sentido. Em 1937, Waldemar Falcão passou a ocupar a pasta do Ministério. Era amigo direto de Rubens Porto e em muito acatou suas sugestões no campo habitacional, como largamente referenciado pelo engenheiro-arquiteto em seus escritos 201.

\footnotetext{
199 Lindolfo Collor ainda instituiu o salário mínimo e criou as Comissões de Conciliação no âmbito do Conselho Nacional do Trabalho em sua gestão. De acordo com Vélez (1988), os ideais políticos que levaram Lindolfo Collor a tomar e aprovar todas as realizações supracitadas foram: a ideia de que o bem público estava acima dos interesses individuais, a consolidação da democracia, a implantação da justiça social e o equacionamento técnico dos problemas, com a instituição de uma nova e modernizadora política econômica.

200 Com sua saída do MTIC, em 1937, Agamenon Magalhães foi para a interventoria federal no estado de Pernambuco onde, muito provavelmente, estruturou e aperfeiçoou o sistema previdenciário e habitacional das CAPs e dos IAPs, essencialmente no Recife; um dos aspectos responsáveis pelo considerável volume de ações imobiliárias naquela cidade, como ser verá nos capítulos seguintes.

${ }^{201}$ Como se verá mais detalhadamente adiante.
} 


\subsection{0 engenheiro-arquiteto Rubens Porto e as reformas legislativas}

Acredita-se que Porto atuou e/ou esteve à frente de diversas decisões relacionadas à regulamentação das Carteiras Prediais dos IAPS e CAPS, essencialmente no tocante à aquisição e à edificação de habitações para os seus associados, como também, às próprias diretrizes construtivas adotadas no campo da moradia por esses órgãos.

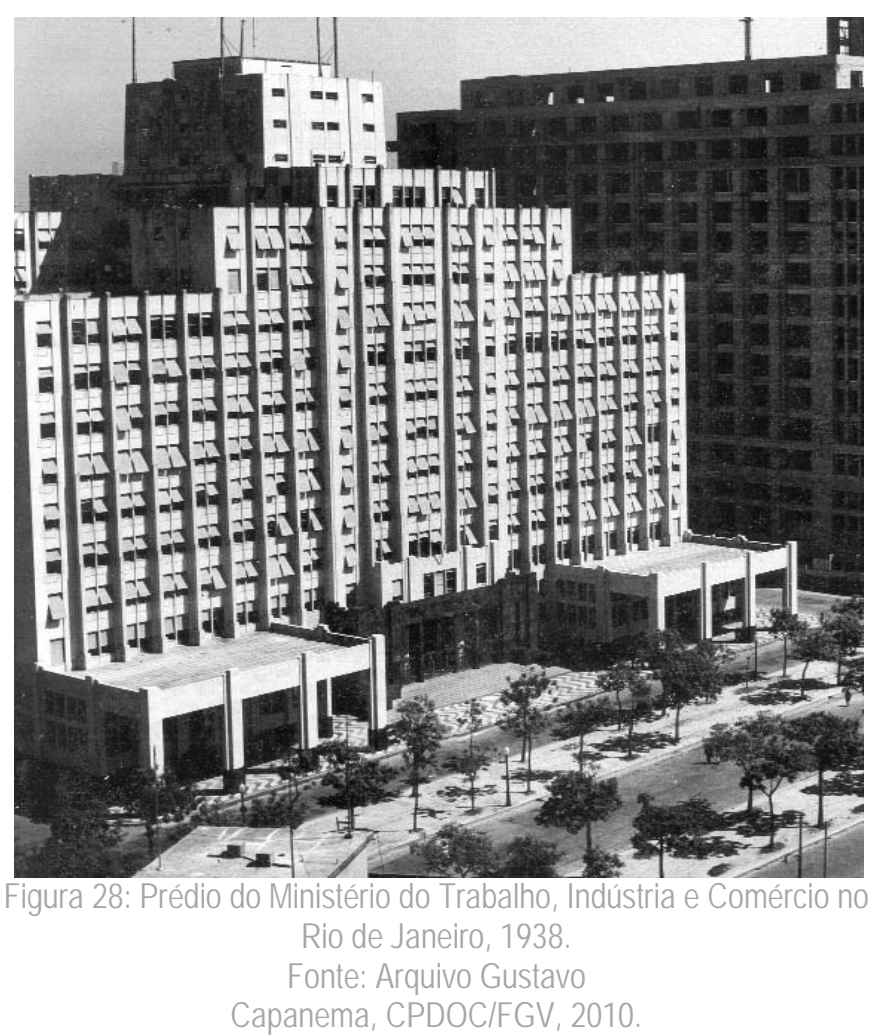

Durante quase toda a década de 1930, Rubens Porto foi chefe da Secretaria de Engenharia do Conselho Nacional do Trabalho $(\mathrm{CNT})^{202}$, órgão técnico subordinado e encarregado de prestar serviços ao Ministério do Trabalho, Indústria e Comércio (MTIC), no tocante à fiscalização e à normatização das instituições de previdência social do país (Figura 28). Além de engenheiro chefe do CNT, Rubens Porto também foi conselheiro técnico do Ministro do Trabalho, Agamêmnon Magalhães, assistente-técnico do Gabinete do Ministro subsequente, Waldemar Falcão, entre os anos de 1930 e 1938, e conselheiro direto do Presidente Getúlio Vargas.

Foi também Presidente do Secretariado Econômico-Social da Ação Católica (AC), que atuou em conjunto com o Estado no que tange às políticas sociais do país, sobretudo a partir de década de 1930, presidente de honra da Federação dos Círculos Operários do Rio Grande do Sul (FCORS) ${ }^{203}$ e conselheiro técnico da Comissão Nacional de Objectores de Consciências (CNOC-Portugal), órgãos vinculados à Igreja Católica (PORTO, 1937/1938)204.

Diversas também foram as publicações de Porto nesse sentido. Podendo ser citados desde artigos em periódicos de circulação diária ou quinzenal em todo o país, como os jornais $A$ Nação/RJ, Correio da Manhã/RJ, O Jornal/RJ, O Clamor/RJ, Diário da Noite/RJ, O Comércio/RJ, O Diário/BH e O Trabalho/RS, entrevistas, pareceres de anteprojetos, relatórios técnicos, relatórios de análises, projetos de leis, conferências, até a elaboração de uma tese apresentada na Primeira Semana da Ação Social do Rio de

\footnotetext{
202 Posteriormente transformado em Serviço de Engenharia do Conselho Nacional do Trabalho. Cabe ressaltar que não se tem registros do engajamento de Rubens Porto para com a questão habitacional do país, no âmbito do CNT, antes de 1930.

203 Antes denominada de Confederação Nacional de Operários Católicos. Foi fundada em 1931 e, a partir de 1950, passou a se chamar Federação dos Círculos Operários e a responder por dois movimentos, o movimento operário e o movimento dos trabalhadores cristãos.

204 Participou ainda da equipe responsável pela avaliação de bens e direitos destinados pela União para compor o capital da recémcriada Petrobrás, em 1954 (DECRETO N.35.308, 02/04/1954; DOU, 03/05/1954).
} 
Janeiro, um evento organizado pela Igreja Católica, que ocorreu em meados da década de 1930. Parte das proposições, colocações e resultados apresentados nessa tese foi publicada na forma de livro, no ano de 1938, intitulado "O problema das casas operárias e os Institutos e Caixas de Pensões".

Dentre algumas das participações desse profissional, por meio de sugestões diretas às comissões e/ou da elaboração de pareceres ou relatórios, destaca-se: o parecer sugerindo a reforma do Decreto n.24.488, de 28 de junho de 1934, que regulamentou até 0 ano de 1937, as construções e financiamentos promovidos pelas Caixas e Institutos de Aposentadorias e Pensões; 0 anteprojeto de reforma do Decreto n.24.488, que resultou no Decreto n.1.749, em junho de 1937, e promoveu a ampliação da cota das reservas permitida para a construção e/ou aquisição de moradias por parte dos IAPs e das CAPs; e o relatório encaminhado ao Ministro do Trabalho em 1938, sugerindo modificações no Decreto n.1.749.

Como arquiteto interino do Serviço de Engenharia do Conselho Nacional do Trabalho, Rubens Porto participou efetivamente do processo de reforma dos regulamentos das CAPs e dos IAPS no campo habitacional em 1934, que, dentre outras determinações, possibilitou que esses órgãos utilizassem até 40\% de suas reservas para investimentos na área da moradia. Acredita-se inclusive que Porto foi o principal responsável pela ampliação dos investimentos no campo habitacional permitido pelo Decreto n.1.749, que elevou essa percentagem para 50\%. Essa participação se deu por meio de comentários apresentados no projeto de reforma por ele elaborado 205 e por referências à sua contribuição.

Antes mesmo da formulação deste projeto, Porto afirmou que o caminho a ser percorrido pelas CAPs e IAPs para a solução do problema habitacional dos trabalhadores no país, consistia no alargamento da porcentagem dos fundos e reservas a serem investidos no financiamento e para a construção de moradias sociais. Como se sabe, até então, o emprego das reservas na concessão de empréstimos era restrito, não atendendo às demandas, e a construção de moradias estava relegada a um segundo plano. Para Porto, este consistia no principal problema referente à atuação das Caixas de Aposentadorias e Pensões. Em sua opinião, por algum tempo os títulos de dívidas públicas federais apresentaram vantagens à aplicação das reservas disponíveis desses órgãos, mas, a concorrência das próprias instituições resultou na alta dos títulos na praça e os tornaram não mais rentáveis como investimentos.

Essa conjuntura contribuiu para que uma nova forma de investimento fosse vislumbrada. Uma das sugestões em voga naquele momento foi a aplicação de parte das reservas em "bônus da Carteira Agrícola do Banco do Brasil" (PORTO, 1938, p.28), que para Porto, também não possuía grandes alcances sociais e retorno econômico para o país. A solução defendida por ele, enquanto chefe do Serviço de Engenharia do CNT, no início da década de 1930 e também apresentada no parecer ao anteprojeto do Decreto n.1.749 de sua autoria, foi a liberação da aquisição e da construção de imóveis por parte dos Institutos: "(...) nos parece a maior conveniência o emprego, ou melhor, a inversão das reservas em apreço em imóveis" (PORTO, 1938,

205 Projeto de lei n.13.161-34, publicado no Boletim do MTIC, n.30, em fevereiro de 1937. 
p.28). No artigo intitulado "Financiamento para construção", publicado no dia 29 de maio de 1937, no jornal 0 Trabalho, de Porto Alegre, Porto afirmou:

Formando um grande reservatório representado pela reunião dos patrimônios individuais dos institutos e caixas de aposentadoria e pensões, na parte destinada à aplicação em imóveis, teríamos mais de cem mil contos, que seriam canalizados às diversas sociedades de construção que num regime de fiscalização pelo Estado procurariam solucionar a crise do teto para o homem do trabalho (FINANCIAMENTO..., 1937).

O volume das reservas das Caixas e Institutos era imenso. Para exemplificar, de acordo com os dados apresentados no anteprojeto de 1937, o total patrimonial dos órgãos de previdência social, que em 1930 era de 171.216:136\$000 (contos de réis) ultrapassou, em 1936, o valor de 702.966:709\$000 (contos de réis). Só o Instituto de Aposentadorias e Pensões dos Industriários (IAPI), criado em 01 de janeiro de 1936, tinha a sua arrecadação avaliada em cerca de 120:000\$000 anuais.

Porto afirmava com base nesses dados que, até 0 ano de 1937, apenas 118 imóveis haviam sido adquiridos e construídos pelas Caixas e Institutos existentes no Distrito Federal (Rio de Janeiro), São Paulo, Minas Gerais e Rio Grande do Sul, o que correspondia a uma importância total de 3.123:609\$000 (contos de réis). Segundo o engenheiro-arquiteto, o mesmo quadro restrito de produção habitacional poderia ser observado nos demais estados do país. Em sua concepção, o principal responsável por esse número incipiente de aquisições e construções de moradias nos âmbito das CAPs e dos IAPs, era a legislação que guiava suas ações. Segundo ele, "(...) as inúmeras exigências, para cada operação, dificultavam realmente as iniciativas individuais, além de encarecê-las" (PORTO, 1938, p.29).

No parecer justificativo ${ }^{206}$ que Rubens Porto apresentou ao Conselho Nacional do Trabalho, em março de 1937, sugerindo a reforma do Decreto n.24.488, outra sugestão apresentada referia-se à proteção da família. Para o engenheiro-arquiteto, a legislação das CAPs e IAPs deveria ser alterada de modo a proteger e beneficiar as famílias numerosas no processo de escolha dos associados que iriam receber a assistência moradia e outros serviços. Sugeria, nesse sentido, que o aumento das cotas para o financiamento de construções fosse proporcional ao número de filhos dos trabalhadores.

Mais especificadamente, recomendava que para o associado que tivesse família numerosa, com três ou mais filhos, o prazo de amortização da dívida do empréstimo deveria ser dilatado para vinte anos - dez anos a mais que o em voga e cinco anos a mais que o sugerido pela comissão do CNT. Dever-se-ia também dar preferência para aquisição das casas ou apartamentos construídos pelos IAPs e CAPs, bem como 0 aluguel desses, aos associados casados na proporção direta da quantidade de filhos que possuíssem. 0 valor liberado para o financiamento também deveria ser dilatado em 10\%, nos casos em que as famílias possuíssem entre três e cinco filhos, e em $20 \%$ nos casos em que o número de filhos fosse maior.

\footnotetext{
206 Esse parecer de sugestão foi elaborado anteriormente ao parecer do anteprojeto do Decreto n.24.488, de 08/06/34, que resultou no Decreto n.1.749, de 28/06/37 e foi publicado no Diário Oficial, em 02 de julho de 1937, e no Boletim do MTIC, n.36, de agosto de 1937.
} 
Para Porto, a concretização dessas medidas nada mais era que o cumprimento do que estava previsto na Constituição Federal de 1934. A Carta Magna, em seu artigo n.138, afirmava que era incumbência da União, dos estados e municípios do país, amparar a infância, dar assistência às famílias de prole numerosa, adotar medidas legislativas e administrativas a fim de restringir a mortalidade e a morbidade infantis e de higiene social para impedir a propagação de doenças transmissíveis, bem como, conceder serviços médicos e condições básicas de alimentação, trabalho e moradia à população. Porto estava de acordo com as colocações de Rui Barbosa, quando afirmava que somente o espírito cristão poderia salvar 0 mundo da crise grave que o assolava. Julgava que por meio de uma legislação social, inspirada no cristianismo poder-se-ia também solucionar o problema da habitação do homem de trabalho no país (CRISTIANISMO..., 1937).

As sugestões e proposições formuladas por Porto, nesse sentido, foram acatadas pela Comissão responsável pela elaboração do já citado Decreto n.1.749, de 1937, que em sua essência, permitiu a construção de grandes edificações, por iniciativa das próprias instituições, para sediar suas agências, bem como, para a residência dos trabalhadores associados às Carteiras Prediais de cada órgão, criadas também nessa ocasião. O próprio Porto confirma essa afirmação em suas publicações, deixando clara a influência que exerceu nesse campo. Em seu livro, ratifica que o Ministro do Trabalho, Indústria e Comércio, na época, Agamemnom Magalhães, "(...) mandou incluir algumas das nossas sugestões no novo regulamento que baixou com o Decreto n.1.749" (PORTO, 1938, p.89). De acordo com o engenheiro-arquiteto, o acato de suas sugestões no supracitado Decreto, em muito colaborou para amenizar o problema da moradia operária no país naquele momento.

Dez meses depois, em abril de 1938, o Ministro subsequente Waldemar Falcão, incorporou ao regulamento da Carteira Predial do Instituto de Aposentadorias e Pensões dos Marítimos (IAPM) ${ }^{207}$, as seguintes sugestões de Porto:

I) os associados casados terão preferência na classificação e, entre eles, os que tivessem filhos, na proporção direta do número destes; II) no caso do associado ter mais de três filhos, o prazo máximo de financiamento, que é de 20 anos, poderá ser dilatado para 25 anos; III) tendo o associado família numerosa, o limite do financiamento, que é estabelecido em 80:000 $\$ 000$, terá o aumento de $20 \%$ [ $10 \%$ a mais do que Porto sugeria] ou sejam 96:000\$000 no caso de haver de 3 a 5 filhos, sendo o número destes superior a cinco, 0 aumento será até 30\% [10\% a mais do que Porto sugeria] ou sejam 104:000\$000; IV) ao Instituto é facultado alugar a terceiros os prédios ou apartamentos adquiridos, construídos ou devolvidos, dando preferência, na locação, aos que possuam filhos, sendo contemplado primeiramente os que contêm prole mais numerosa; $V$ ) dar-se-á preferência, para a venda de prédios ou apartamentos construídos diretamente pelo Instituto, aos associados casados e aos que tiverem filhos, na proporção direta do número destes (BOLETIM..., n.44, 1938).

Aliado às supracitadas sugestões era preciso que o brasileiro descrente por natureza, na concepção de Porto, acreditasse nos benefícios que uma moradia própria, conseguida por intermédio dos Institutos ou

207 O seu regulamento foi publicado no Boletim do Ministério do Trabalho, Indústria e Comércio, n.44, de abril de 1938. 
Caixas, e nos descontos salariais promovidos por essas instituições para a quitação da dívida de compra ou de construção do seu imóve|208. Para tanto, era preponderante a realização de atividades educadoras junto aos trabalhadores a serem atendidos pelas CAPs e IAPs. De acordo com Porto, garantindo alojamento higiênico aos seus associados e promovendo a educação dos operários quanto à utilização dessas moradias, além das funções que já competiam aos referidos órgãos, seriam reduzidos os índices de doenças (auxílio saúde) e dessa maneira a mortalidade, o número de pensões concedidas, além dos índices de criminalidade, beneficiando os Institutos e o próprio poder público, que pouparia vultosas quantias com saúde e segurança pública (BOLETIM..., n.36, 1937):

(...) as construções financiadas pelos institutos e caixas de aposentadorias e pensões, é obra primordialmente de previdência das próprias instituições que as realizam, pois, assim promovendo, elas melhoram consideravelmente o estado físico dos seus associados, diminuindo, destarte, os encargos que se vão acumulando. Não bastam dos Serviços Médicos, que remedeiam os males físicos, é preciso o trabalho preventivo, e este será obtido com a melhoria do local de habitação do homem do trabalho (BOLETIM..., n.36, 1937, p.267).

Provavelmente, as colocações de Rubens Porto referentes à concessão de moradias aos associados dos IAPs e das CAPs sofreram influência do trabalho do economista belga Valère Fallon, que visitou o Brasil em 1935, quando fundou a Associação do Lar Proletário, no Rio de Janeiro, a quem Rubens Porto cita diversas vezes, tanto em seu livro, como nos pareceres de anteprojetos elaborados por ele, nos anos de 1936, 1937 e 1938. Fallon, em sua obra "Princípios da Economia Social", cuja terceira edição foi publicada em 1924, afirmou: "Se pusessem os pais em estado de habitar, de vestir e de alimentar seus filhos, se faria não somente uma obra de alcance social e humanitário, como também se pouparia dinheiro" (FALLON, 1924, p.269).

Rubens Porto ainda cita no parecer de 1937, diversas experiências no campo da previdência e de moradia, tais como: as Bausparkasse (empresa de construção) e Wohnungsfursorgegesellschaft (organização governamental responsável pela realização de assentamentos e construção de moradias), na Alemanha; as Building societies anglo-saxônicas; as instituições de créditos do Norte da Europa; 0 Banco Norueguês de crédito à pequena propriedade; a Caixa Sueca de crédito para habitação; o Banco Hipotecário de moradia na Finlândia; o regulamento dos Comités de Patronage na França, que promoviam financiamentos para construção; a Sociedade Nacional de Habitações Econômicas na Bélgica; e a Casa Depositti e Prestiti na Itália (O PROBLEMA..., 1937).

Também semelhante ao propósito da Associação do Lar Proletário, Rubens Porto defendia que os IAPs e as CAPs, além de promoverem a concessão de moradias, deveriam garantir e supervisionar o uso adequado de seus cômodos, unidades e equipamentos de uso coletivo. Nesse sentido, Porto acreditava ser de suma importância a criação de um órgão de assistência social no âmbito dos Institutos e das Caixas, 0

208 Provavelmente, uma resposta ao descrédito das ações imobiliárias dos órgãos entre a população e, inclusive, no âmbito dos próprios IAPS e CAPs. Alguns dos quais, se mostraram contra a criação das Carteiras Prediais, como abordado no capítulo anterior. 
Serviço Social Familiar209. Em sua concepção, a garantia da moradia se mostrava tão importante quanto à conservação delas, não apenas no sentido técnico do termo, mas também no humanitário.

O principal objetivo desse serviço seria o de melhorar as condições sociais e elevar o nível de vida dos trabalhadores atendidos pelos IAPs e CAPs. Essa assistência concebida pelos institutos de previdência social seria responsável: pela realização de visitas regulares às famílias beneficiadas com permanência por horas fixas nos casos mais graves e/ou urgentes; por orientações e encaminhamentos aos diferentes serviços médicos (ambulatórios, hospitais, etc.); pelo controle da regularidade e da frequência escolar das crianças; pela educação pré-natal das mães; pela realização de conferências, palestras, atividades recreativas, cursos profissionalizantes e cursos de educação doméstica para mães e moças (Figura 29); pelo ensino de higiene elementar de limpeza, de cozinha, de costura; dentre outros. O Serviço Social Familiar, também seria responsável pela escolha (triagem) das famílias que receberiam as novas residências, a partir da realização de entrevistas e da aplicação de questionários. Dessa forma, seria preponderante a participação de um psicólogo e/ou psiquiatra no corpo técnico desse órgão, que também deveria contar com padre, médico, enfermeira, educador, dentre outros profissionais.

O Serviço Social Familiar nunca foi instituído em sua essência. Por meio do Decreto n.1.749, algumas atividades imobiliárias das Carteiras Prediais de alguns Institutos e Caixas foram regulamentadas; ficando a maior parte desses órgãos, livre para a formulação de seus regulamentos e portarias, a partir de então. De maneira geral, os IAPs e CAPs promoviam visitas de acompanhamento educacional e, principalmente, de supervisão da manutenção e da preservação dos seus imóveis, além da cobrança de taxas administrativas e/ou de uso das residências. Mas, esses serviços ficaram restritos somente às unidades habitacionais alugadas e ocorriam apenas nos primeiros anos da concessão. Não havia, nesse sentido, uma regra clara e específica, e essa ação variava de instituição para instituição. Quanto à triagem das famílias para a ocupação das residências, ficou

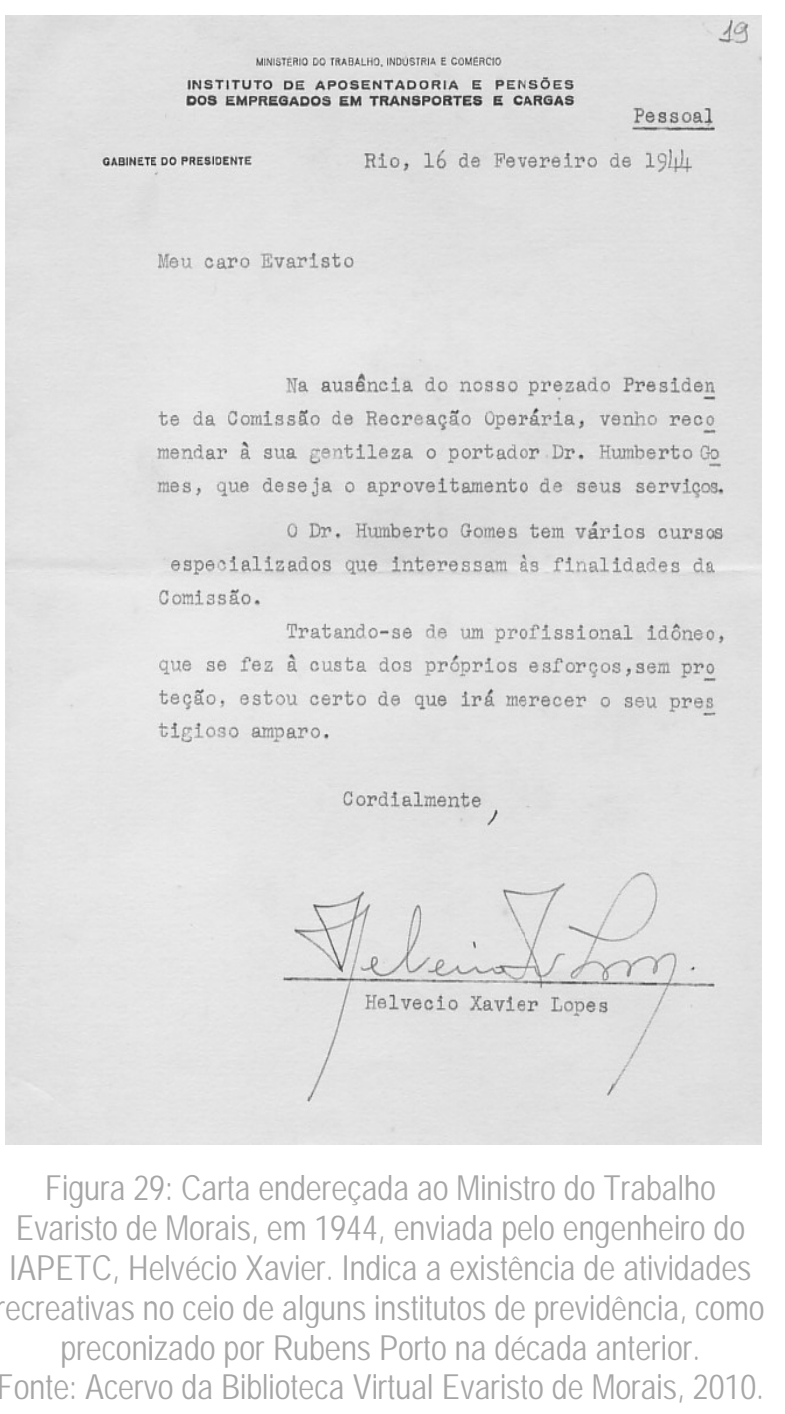

${ }^{209}$ Esse papel de referência pode ter ocorrido inclusive no âmbito da Jornada de Habitação Econômica, promovida pelo IDORT, em 1941. Na qual, também se percebe a sugestão de programas públicos para a educação do trabalhador, bem como a criação de um órgão nesse sentido. 
decidido por meio do supracitado Decreto que seria considerada a ordem de inscrição e observados os critérios de tempo de contribuição junto à Caixa ou Instituto, tempo de serviço, idade e somente depois, seriam considerados os associados casados e com filhos.

Diversas portarias foram publicadas posteriormente, de modo que para cada Instituto e Caixa existente havia uma regulamentação específica. No caso do Instituto de Aposentadoria e Pensão dos Comerciários (IAPC) em São Paulo e no Rio de Janeiro, por exemplo, apenas a metade das unidades habitacionais disponibilizadas por esse Instituto para os seus associados destinava-se à demanda social, ficando a outra metade escolhida por sorteio; mecanismo utilizado por diversos órgãos em todo o Brasil. Isso conferia aos Institutos e Caixas, para Porto, um caráter de loteria, que se mostrava injusto com aqueles que realmente necessitavam dos serviços, como também, revelava a incapacidade de alguns órgãos de solucionar os problemas racionalmente.

Apenas o Instituto de Aposentadoria e Pensão dos Marítimos (IAPM) ${ }^{210}$, como já colocado, acatou a sugestão de Porto, que também participou, a convite de seu presidente, da comissão responsável pela formulação de seu regulamento. Nesse sentido, no IAPM, uma comissão instituída pelo presidente do Instituto ou pelo delegado responsável pela agência local, realizava um trabalho de acompanhamento com os candidatos e, a partir de critérios estabelecidos por ela, indicava a ordem da escolha das famílias beneficiadas, que também recebia assistência e acompanhamento depois de adquirida a moradia.

Após a liberação de até metade das reservas dos Institutos e Caixas para a construção e/ou aquisição de moradias para seus associados, em 1937, Porto destacou que o Estado, em suas três instâncias (nacional, estadual e municipal), deveria "(...) facilitar o surto de construções por medidas equânimes (...). Tamanhas são as vantagens decorrentes de semelhante iniciativa, que custa-nos a crer nos abscessos de toda a espécie com que se procura embaraçar a solução do problema" (PORTO, 1938, p.97/98).

De acordo com o engenheiro-arquiteto, os maiores desses "abscessos" eram as elevadas taxas dos impostos e a diversidade deles. No relatório enviado ao Ministro do Trabalho, em 14 de agosto de 1937, Porto identificou algumas das dificuldades ainda enfrentadas para a aplicação dos fundos patrimoniais na construção de moradias, regulamentada pelo referido Decreto de 1937. Além das taxas de seguro de vida e de fogo, era cobrada uma série de impostos municipais que, sem dúvidas, se conformavam como fator que dificultava a aquisição da moradia própria. Sugeria, nesse sentido, a exemplo das Caixas de Construções de Casas para o Pessoal do Ministério da Guerra211 e do Pessoal da Marinha212, que a isenção dos impostos, emolumentos e contribuições municipais, concedida aos imóveis localizados no Distrito Federal de propriedades desses órgãos, fossem aplicados aos demais Institutos atuantes no país, principalmente, para os beneficiados que adquirissem prédios de baixo custo.

\footnotetext{
210 O regulamento da Carteira Predial desse Instituto foi elaborado juntamente com as instruções do Decreto n.1.749 e também contou com a participação de Rubens Porto.

211 Regulamentada por meio do Decreto n.5.528, de 05 de abril de 1935.

212 Regida pelo Decreto n.882, de 05 de junho de 1936.
} 
Em maio de 1938, essas sugestões foram atendidas pelo Ministro Waldemar Falcão, por meio do Decreto n.398, publicado no Diário Oficial, que isentou as ações imobiliárias executadas pelos Institutos e Caixas de Aposentadorias e Pensões para os seus associados, de impostos de transmissão e prediais que incidissem sobre as edificações adquiridas ou construídas no país. O ideal para Porto era que aliada à isenção de impostos fosse proporcionada a doação de terrenos por parte do Estado. O que também foi vislumbrado a partir, sobretudo da década de 1940, em estados como Pernambuco, em que o Interventor doou grande área para a construção de moradias à CAPs dos Trapiches (PORTO, 1938), e no Rio Grande do Norte, na década de 1950, onde o governo do estado concedeu diversos terrenos aos IAPs e CAPs atuantes no estado ${ }^{213}$, com 0 intuito de amenizar a escassez de moradias. Em fins de 1952, o governo norteriograndense cedeu terras ao IAP dos Comerciários para a construção de 50 residências e à CAP dos Servidores Aéreos e Telecomunicações para edificar um conjunto habitacional, ambos situados no Tirol, bairro residencial periférico da cidade de Natal naquele momento (ALMEIDA, 2007).

Voltando às disposições do Decreto n.1.749, Porto, no relatório de análise dessa legislação214, encaminhado em fins de 1937 ao Ministro do Trabalho, naquela ocasião o advogado Waldemar Falcão215, criticava o fato dos associados atendidos pelos Institutos e Caixas de Aposentadorias e Pensões terem, em sua maioria, condições para angariar uma moradia própria. Esse aspecto foi ainda mais agravado pelo fato de, por meio daquele Decreto, ter sido liberada a aquisição de imóveis por associados que já possuíam casa própria, como também, elevados os valores dos financiamentos. Essa questão também foi discutida na I Jornada de Habitação Econômica, promovida pelo IDORT, em 1941. De acordo com o engenheiro-arquiteto, a limitação dos vencimentos salariais dos associados a serem atendidos pelas Carteiras Prediais, bem como a fixação dos valores máximos a serem liberados para empréstimos e financiamentos pelas agências, eram necessidades urgentes.

Em artigo publicado no periódico carioca Correio da Manhã, em 07 de agosto de 1937, Porto fez um apelo à população nesse sentido, e afirmou que era preciso "(...) fugir da mania das construções destinadas aos mais afortunados, invertendo para poucos, grandes somas, quando melhor seria aplicá-las em construções em série do tipo individual ou coletivo para atender a estes que a sorte menos tem favorecido, e cujo salário não permite sadia moradia de aluguel" (CASAS..., 1937, p.03) ${ }^{216}$.

\footnotetext{
${ }^{213}$ Em concordância com o a Lei no 92, de 24 de novembro de 1951.

${ }^{214}$ Relatório formulado com base nos dados do Serviço de Engenharia do Conselho Nacional do Trabalho (PORTO, 1938).

${ }^{215}$ Cabe lembrar que o Ministro Waldemar Falcão, nomeado em 1937, também era membro da Liga Eleitoral Católica (LEC), assim como Rubens Porto.

${ }^{216}$ Outra importante contribuição para a implementação da política dos aluguéis e, em segundo plano, para a criação das carteiras prediais dos IAPs do MTIC foi dada pelo engenheiro-arquiteto Paschoal Totti Filho, em meados da década de 1920. O referido profissional elaborou um projeto de criação de uma Caixa de Recursos para Inquilinos, publicado no formato de livro na década de 1930, aos moldes da Liga dos Proprietários, por ele também fundada, atuante no município mineiro de Uberaba, em 1927. A Liga dos Proprietários era considerada uma sociedade destinada a defender coletiva ou individualmente os direitos e deveres de seus associados, por meio de conselhos. A Caixa de Recursos para Inquilinos, por sua vez, teria como objetivo arregimentar uma associação administrada pelos próprios inquilinos, que trouxesse "(...) todas as vantagens de uma instituição modelar nesse gerero" (TOTTI FILHO, 1931, p.291). Essa Caixa deveria ser moldada num sistema mesclado de cooperativismo, previdência e capitalização, sob a forma de uma sociedade predial. O capital das contribuições de seus associados seria empregado na
} 
Em entrevista concedida ao jornal Correio da Manhã, em abril de 1937, sobre a reforma do regulamento para o emprego dos fundos das CAPs e IAPs, Porto citou a importância dos empréstimos concedidos não terem um padrão rígido, indiferente às regiões do país. Afirma, nesse sentido, que "(...) o mal de muitas das nossas leis é justamente o de abrangerem preceitos universais para aplicações peculiares às regiões, e mais ainda, sofrendo a influência direta do local em que são elaboradas - a Capital Federal (...)" (O PROBLEMA..., 1937, p.12).

Os preços dos terrenos e dos materiais variavam bastante de localidade para localidade e os valores liberados deveriam levar em consideração essas variações (preço por metro quadrado e do terreno) ${ }^{217}$. Era também por esse motivo, que Porto criticava a elevação do limite de financiamento de 30:000\$000 (trinta contos de réis) para 80:000\$000 (oitenta contos de réis). Segundo ele, com igual importância de financiamento concedida no Rio de Janeiro, poder-se-ia construir casas com o dobro da área em Porto Alegre, e continuava:

Para ilustrar, posso declarar que há beneficiados na Carteira Predial do Instituto de Previdência que, gozando de crédito de que dispõem, adquirem não um, mas dois lotes para a construção de suas casas, enquanto outros aguardam a possibilidade de se servirem do que lhes faculta a lei, para construírem os seus modestos lares. Urge, pois, que aquilo que a lei faculta para o bem-estar dos que trabalham não se destine ao lucro dos aproveitadores de primeira hora (...) (O PROBLEMA..., 1937, p.23).

As sugestões de Rubens Porto, nesse sentido, foram aceitas e incorporadas nos regulamentos da Caixa de Aposentadorias e Pensões dos Operários de Estivas (CAPOE) e das Carteiras Prediais do Instituto de Aposentadorias e Pensões dos Marítimos (IAPM), nos anos de 1937 e $1938^{218}$ (O PROBLEMA..., 1937).

Em se tratando das críticas ao Decreto de criação das Carteiras Prediais dos IAPs, observadas no relatório elaborado em fins de 1937, Porto sugeria a "substituição do seguro de vida ilógico e privado do regulamento em vigor" (AS CAIXAS..., 1937), que obrigava uma duplicidade de previdência (O PROBLEMA..., 1937). Esse seguro equivalia a uma taxa de valor decrescente, correspondente a $10 \%$ do valor do imóvel, que teria que ser pago pelo associado em parcelas mensais embutidas naquelas para a amortização da dívida de financiamento ou compra de imóvel ao órgão e que cessaria juntamente ao pagamento total da dívida. Em entrevista concedida ao jornal carioca Diário da Noite, em 24 de dezembro de 1937, Porto afirmou que esse

construção de moradias. Os associados deveriam, em sua proposta, serem essencialmente operários e, de preferência inquilinos. A Caixa beneficiaria o inquilino, estimulando a aquisição de terrenos, construção de moradias e tornando-o proprietário ao fim de certo tempo. Além desses, outros benefícios foram previsto pelo engenheiro para os futuros associados às Caixas para Inquilinos, tais como proteção do inquilino contra infortúnios, garantindo aluguéis de casas em caso de doença, assistência médica, realização de empréstimos em dinheiro com sorteios mensais, amparo à família em caso de morte. "(...) Isso, minuciosamente estudado e muito cuidadosamente previsto em estatuto" (TOTTI FILHO, 1931, p.291). Essa proposta foi apresentada em forma de tese no I Congresso de Habitação, ocorrido em São Paulo no ano de 1931, no qual formulou-se o seguinte parecer: "(...) 0 trabalho apresentado consta apenas de suggestões de ordem geral sobre os quaes o proprio autor não tira conclusões. A Commissão julga portanto que o referido trabalho não deve ser discutido em plenario. Entretanto lembro ao Congresso solicitar a remessa do livro "Caixa de Recursos para Inquilinos' da lavra do autor, para posterior estudo" (ANAIS..., 1931, p.292). Apesar de não ter sido discutido no evento, a referida publicação foi encaminhada ao poder público.

${ }^{217}$ Vale ressaltar que até o próprio salário mínimo variava dependendo da profissão e de região para região.

${ }_{218}$ Publicados respectivamente, em 07 de julho de 1937 e em 23 de fevereiro de 1938, no Diário Oficial. 
seguro, na modalidade em que estava sendo aplicado, era um impeditivo para se solicitar financiamento ou a compra de imóvel com base nos salários que os trabalhadores do país recebiam (SERÁ..., 1937).

Como substitutivo, Porto propunha a criação de um seguro de renda temporário. De acordo com essa nova modalidade de seguro, em caso de doença ou morte do beneficiado (o chefe da família), ocorreria a transferência obrigatória da apólice para a Caixa ou Instituto, que se responsabilizaria pelo pagamento do restante da dívida, sem se proceder à perda da moradia ou à transferência da dívida para os outros membros da família. No mesmo ano foi criada a Carteira Predial da Caixa de Aposentadorias e Pensões dos Operários Estivadores (CAPOE) e regulamentada suas ações ${ }^{219}$, bem como, essa modalidade de seguro. Em 1938, 0 Ministro do Trabalho Waldemar Falcão autorizou os Institutos de Previdência a efetuarem o seguro de renda temporária com período de carência de seis meses após contratado 220.

No projeto de lei elaborado em 1936, e apresentado ao MTIC em 1938, acerca da atuação da Secretaria de Engenharia do Conselho Nacional do Trabalho, Porto colocava que a reforma legislativa no âmbito das ações imobiliárias dos Institutos e das Caixas de Aposentadorias e Pensões deveria seguir orientações seguras, que devido à proporção de suas atuações, extrapolavam os limites administrativos e a capacidade técnica do CNT e, consequentemente, do seu Serviço de Engenharia, do qual Porto era o chefe. Propôs, nesse sentido, a criação de um Serviço de Arquitetura e Engenharia subordinado diretamente ao Ministério do Trabalho, Indústria e Comércio, cuja função principal seria a de orientar, coordenar e dirigir a construção em ampla escala de moradias econômicas para os associados dos IAPs e CAPs. Para Porto, "(...) sem um órgão central como este, capaz de organizar um plano geral, de estudar o problema em série, de procurar as soluções mais baratas e mais adotáveis aos casos particulares, harmonizando o individual e 0 coletivo, qualquer tentativa no assunto nasceria marcada de um vício (...) que poderia levar ao fracasso" (PORTO, 1938, p.105).

O Serviço de Arquitetura e Engenharia trabalharia em conjunto com o Instituto Nacional de Tecnologia e seria responsável pelo estudo experimental e prático da racionalização dos processos construtivos e dos materiais mais adequados à aplicação de tais processos. Mais especificadamente seriam funções a ele atribuídas:

a) projetar, orçar e fiscalizar a construção e reparação de quaisquer edifícios do Ministério do Trabalho, Indústria e Comércio; b) estudar e aprovar os projetos de casas a serem construídas pelos institutos e caixas de aposentadoria e pensões fiscalizadas pelo Ministério do Trabalho, Indústria e Comércio; c) organizar, para as construções referidas no item anterior, um plano geral e racional, destinado a torná-las mais econômicas e a coordená-las mais harmoniosamente; d) fiscalizar (...) a construção e reparação das casas dos referidos institutos e caixas; e) estudar e experimentar (...) processos de racionalização de construção civil, de modo a permitir um maior rendimento construtivo para os recursos (...); f) colaborar (...) com a direção dos institutos e caixas, na parte técnica de arquitetura e engenharia, correspondente à manutenção e administração das vilas e cidades-jardins

\footnotetext{
219 Por meio da Portaria de 07 de julho de 1937, publicada no Diário Oficial no dia 09 de abril de 1938 e no Boletim do MTIC, n.45, de maio de 1938.

220 Pela Portaria de 19 de março, publicada no Diário Oficial, em 28 de março do mesmo ano.
} 
construídas (...), quer no que se refere aos problemas de saneamento urbano (abastecimento d'água, esgoto, lixo, etc.), quer no que se relaciona com a questão de transporte, para maior facilidade de acesso às referidas vilas e cidades-jardins; $\mathrm{g}$ ) promover a publicação de folhetos (...) a esclarecer os associados (...), de modo a poderem (...) escolher os tipos de habitações mais econômicos e que mais Ihes convenham, a melhor usá-los e a lhes aproveitar todas as vantagens técnicas; h) publicar (...) os resultados obtidos nos estudos relativos à racionalização dos processos construtivos, bem como os referentes às construções feitas; i) preparar, na parte relativa à arquitetura e engenharia, os regulamentos necessários à manutenção das vilas e cidades-jardins construídas, sempre que para isso fosse solicitado pela direção dos institutos e caixas e na medida das suas possibilidades; j) organizar os regulamentos das Carteiras Prediais dos institutos e caixas, submetendo-os à aprovação do Ministro do Trabalho (PORTO, 1938, p.106/107).

Essa iniciativa, no entanto, não foi concretizada. De qualquer modo, são percebidas muitas aproximações e semelhanças dessas proposições formuladas por Porto àquelas imputadas à Jornada Econômica de Habitação promovida pelo IDORT e aos preceitos para construção de moradias elaborados, sobretudo nos Congressos Internacionais de Arquitetura Moderna (CIAMs) ocorridos em Frankfurt (1929) e Bruxelas (1939). Os supracitados objetivos também são muito próximos aos da Fundação da Casa Popular221 (FCP), fundada maio de em 1946, bem como do Banco Nacional de Habitações (BNH), criado em 1964.

A partir do exposto, evidenciou-se a inegável importância do engenheiro-arquiteto Rubens Porto, no tocante à reforma da moradia operária no Brasil e na instituição de uma política habitacional no país, por meio da organização das Carteiras Prediais das Caixas e Institutos de Aposentadorias e Pensões e na formulação das diretrizes construtivas de suas moradias - aspecto pouco abordado pela historiografia especializada, que será estudado a seguir.

\subsection{Rubens Porto: as diretrizes construtivas e sua arquitetura ideal}

Porto possuía um modelo de conjunto habitacional ideal, conformado por um agrupamento de propostas arquitetônicas e urbanísticas no campo da moradia social, que pôde ser identificado a partir do estudo e da análise de sua produção técnica e intelectual elaborada ao longo de sua carreira, sobretudo, na década de 1930; representada essencialmente por sua, já citada, tese "O problema das casas operárias e os Institutos e Caixas de Pensões", publicada em 1938.

Nesse conjunto de proposições, Rubens Porto especificou desde as dimensões, materiais, tipologias habitacionais, etc., consideradas mais adequadas para a concepção de moradias, a um ensaio de plano urbanístico que deveria acompanhar essas sugestões. 0 engenheiro-arquiteto apresentou diretrizes básicas para o planejamento urbano, indicando as dimensões, quantidades e as localizações mais coerentes e adequadas dos equipamentos e serviços públicos, das áreas de lazer, das vias de circulação de veículos e de pedestres e do próprio conjunto de moradias, até a importância e especificações de serviços de assistência

\footnotetext{
${ }^{221}$ A FCP objetivava: construir moradias para a população carente, elaborar medidas que complementassem as administrações locais, visando o fortalecimento do mercado da construção civil e a qualificação da mão de obra, realizar estudos das práticas comunitárias de construção (técnicas e materiais utilizados nas diferentes regiões do país), a fim de baratear 0 preço das construções, e financiar empresas e industriais no campo da habitação popular (ANDRADE E AZEVEDO, 1982).
} 
aos moradores para os "novos núcleos habitacionais operários", dos programas de educação familiar (que deveriam ser oferecidos e acompanhar as realizações das CAPs e IAPS), e do controle populacional desses empreendimentos.

Defendia o planejamento e a construção de conjuntos habitacionais em grandes áreas afastadas dos centros principais das cidades e deixava claro que os empreendimentos deveriam ser realizados em uma única etapa e não em "doses homeopáticas". Mostrava-se contra a edificação de habitações econômicas entre construções pré-existentes. Quanto à localização desses grupos de moradias, Porto propunha sumariamente a implantação em grandes planos de organização regional, segundo eixos cuidadosamente estudados, como autoestradas, próximo às riquezas naturais existentes, rios, florestas, vales, etc.

Para ele, também era inconcebível construir unidades sem se prever ao mesmo tempo os espaços livres, as creches, as escolas, as áreas de lazer, o comércio, etc.; o que não era possível nos pequenos terrenos livres na cidade. Na mesma linha, Porto acreditava que a construção de casas espaçadas e isoladas, situadas no centro, atrairia os especuladores, fazendo com que as moradias concebidas e/ou adquiridas pelos órgãos de Previdência Social fossem submetidas ao mesmo processo de especulação de todo o resto da cidade.

Afirmava que a maior dificuldade a ser vencida para a concepção de moradias mínimas e higiênicas era o preço do terreno. Também por esse aspecto, Porto defendia a compra e a construção de moradias mais afastadas dos centros urbanos por parte dos IAPS e CAPS, onde os valores dos terrenos eram menores, reduzindo o preço da habitação, uma vez que o valor do terreno era absorvido pelo preço de venda ou aluguel da moradia. Num segundo plano, a edificação de unidades afastadas do centro promovia ainda 0 descongestionamento da cidade (PORTO, 1938, p.58).

A adoção das soluções habitacionais no centro, só seria justificada e aceitável no caso dos apartamentos para locação, destinados aos solteiros ou casais sem filhos, uma vez que os espaços seriam demasiadamente reduzidos devido ao alto custo do terreno nessas localidades; como empreendeu o IAP dos Bancários e o IAP dos Comerciários em diversas localidades. Em sua concepção era perfeitamente possível a reunião de um grande número de pessoas em uma pequena área, com ótimas condições higiênicas, caso os passos propostos pelo seu "manual" fossem seguidos.

A ocupação dessa tipologia por casais com filhos não era indicada por Porto. A seu ver, era essencial para a formação e educação das crianças e para a sanidade das mães, espaços generosos, onde poderiam ser desenvolvidas atividades diversas de lazer. Nesse sentido, o modelo mais adequado consistia em um conjunto habitacional, conformado por um grupo de 2.000 moradias padronizadas e produzidas em série. Essa vila, como chamada por vezes, deveria ser autossuficiente com escola, igreja, playgrounds e comércio, onde somente seria permitido o tráfego de pedestres em seu interior, evitando acidentes e conferindo à vila um "caráter bastante pituresco". 
Mais especificadamente, previa um edifício administrativo, com serviços públicos, instalações para a administração do conjunto, a residência do administrador, oficinas, garagens, serviço médico (pronto socorro), telégrafos e correio, além do posto policial. Haveria também um clube com piscina, biblioteca, ginásio e quadras esportivas; uma escola, instalada em uma área de $245 \times 345 \mathrm{~m}^{2}$, dotada de dois grandes playgrounds, para meninos e meninas separadamente; além de reservas florestais e viveiros de plantas.

Porto atentava ainda para algumas medidas de ordem técnica na concepção dos grandes conjuntos. A densidade deveria ser de 200 a 250 pessoas por hectare. O espaço reservado para as vias deveria corresponder entre $12 \%$ e $20 \%$ do terreno e os espaços entre as edificações deveriam ser aproveitados como jardins, quadras de esporte, etc. Os espaços livres entre os edifícios deveriam corresponder a um ângulo vertical que variava entre $15^{\circ}$ e $2^{\circ}$. Paulo Bruna (1998, p.97) afirma acerca desse aspecto, que Rubens Porto recorreu à "(...) formula preconizada por Gropius para a disposição dos blocos sobre o terreno". Também são percebidas preocupações quanto à orientação das edificações em relação ao sol, proposições fundamentadas em estudos acerca do tempo de insolação de cada fachada, e à orientação dos ventos. Nesse sentido, Porto sugeria que os quartos fossem projetados de modo a se evitar a insolação vespertina, a mais prejudicial, e as janelas das salas deveriam ser orientadas no sentido do vento principal, mormente para o Sudeste.

O modelo de moradia considerado por Porto (1938) como o mais adequado às famílias dos trabalhadores era o das casas geminadas dispostas em fila, com um ou dois pavimentos, encimadas por uma laje contínua em concreto, onde poderiam ser desenvolvidas atividades diversas e também se conformariam como passagens, ou jardins para o recreio das crianças. No modelo de conjunto habitacional de Porto eram vislumbradas tanto células coletivas quanto unidades unifamiliares contínuas. Para os solteiros e casais sem filhos, como já citado, preconizava-se as moradias coletivas situadas nos centros das cidades. As unidades habitacionais seriam de vários tipos, variando em área de 50 e $60 \mathrm{~m}^{2}$.

Tanto os apartamentos quanto as residências isoladas ou contíguas deveriam, preferencialmente, ser duplex, uma vez que ofereciam uma economia de 15\% de espaço e 20\% nas despesas com corredores, iluminação, além da separação física entre as áreas social e íntima. Essa tipologia aliava, segundo Porto (1938), a intimidade da habitação isolada às comodidades e à economia proporcionada pela moradia coletiva $^{222}$.

No caso da concepção de blocos de apartamentos, atentava para os aspectos referentes à sua implantação no terreno, à disposição dos cômodos em planta, em especial os banheiros, e à disposição do mobiliário nos cômodos. Destacava que a principal vantagem dessa tipologia habitacional era de cunho econômico e referia-se ao fato de que apenas $20 \%$ dos custos para a construção eram direcionados para a fundação e para a estrutura da edificação, podendo os 80\% restantes - empregados nas instalações, vedações e revestimentos - serem pré-fabricados e estandardizados; aspectos essenciais para a produção

222 Muito próximo ao preconizado pelo arquiteto Kneese de Mello em suas realizações. 
em série de moradias. Para os prédios não providos de elevador, Porto sugeria que o gabarito máximo deveria ser de quatro pavimentos, por razões de ordem econômica, higiênica e humana. Operando-se dessa forma, os idosos e as mulheres, principalmente as grávidas e com crianças de colo, seriam poupados do grande esforço físico desprendido para subir os andares. Propostas também discutidas no âmbito dos CIAMs.

Porto defendia o emprego dos pilotis nos blocos de apartamentos. Segundo ele, esse elemento oferecia diversas vantagens em termos da salubridade, da visibilidade do horizonte e do contato com a natureza; da circulação, uma vez que as ruas seriam substituídas por passagens cobertas permitindo 0 tráfego de pessoas independente das intempéries; por possibilitar a utilização das áreas térreas das edificações para a instalação de serviços públicos; e de privacidade, por evitar apartamentos térreos, que muitas vezes são desvalorizados por estarem constantemente expostos à rua. Do ponto de vista econômico, os pilotis eram indicados: por reduzir a necessidade e os custos com a terraplanagem, uma vez que permitiam a adequação da edificação ao terreno; por não exigir a impermeabilização do terreno; por evitar problemas de infiltrações nos passeios; por evitar a utilização de materiais caros para o revestimento do embasamento da edificação; e por facilitar as instalações de água, esgotos e iluminação.

Contudo, a principal vantagem da implantação dos pilotis nos blocos de apartamentos estaria, para Porto, relacionada ao desenvolvimento da vida social. Mais eficiente que os serviços e atividades oferecidas pelo órgão de assistência social proposto por Porto, no que concerne à educação do novo morador, seria tirar proveito dessas áreas térreas criadas pelos pilotis, que recuperam 95\% da área construída. Para Rubens Porto:

(...) viver em sociedade é uma das melhores maneiras de educá-lo [0 trabalhador], tanto mais quanto, dada a sua natural tendência no sentido de fazer melhor figura que o vizinho, se esforçará por não deixar transparecer, nas reuniões que ali se derem, seus eventuais maus instintos, procurando controlar-se para aparecer e para brilhar, o que não faria quando isolado ou mesmo em família (PORTO, 1938, p.45/46).

Observa-se, dessa forma, que Rubens Porto compartilhava da ideia da educação do novo trabalhador, do novo homem, imbuída no projeto desenvolvimentista instituído pelo presidente Getúlio Vargas a partir da década de 1930, e se mostrava preocupado com o aproveitamento mais adequado das horas vagas:

(...) com um pouco de jeito e persistência, pode-se forçar o operário a freqüentar com assiduidade essas reuniões, bastando, para tal, atraí-los por meio de distrações, como sejam: leitura de jornais (gratuitos), um bom rádio, ping-pong, bilhar, xadrez, damas e mesmo 'cartas', que geralmente tanto aprecia (PORTO, 1938, p.46).

Numa visão associada às ideias católicas, sanitaristas e higienistas, Porto acreditava que com 0 tempo ocioso, o operário era naturalmente atraído pelas rodas de botequim, onde imperavam os vícios e os maus costumes. Em sua concepção, os pilotis resolveriam essa questão. Mais especificadamente, acreditava que as horas de folga não poderiam ser encaradas como horas vagas, deveriam ser bem aproveitadas e 
dedicadas ao progresso humano. Sendo assim, os Institutos e Caixas deveriam investir em bibliotecas e teatros, bem como em atividades instrutivas como a realização de cursos para o "aperfeiçoamento moral e cristão" (PORTO, 1938, p.81). Em se tratando desse aspecto em especial, Porto não propõe soluções concretas, apenas indica e/ou sugere caminhos.

Voltando ao modelo de moradia, Porto sugeria a produção em série e a inclusão das instalações modernas, como a água corrente, as canalizações, iluminação, etc., nas novas habitações. No já citado parecer do Decreto de criação das Carteiras Prediais dos Institutos do MTIC, Porto afirmou que era necessário, por parte do Serviço de Engenharia do Conselho Nacional do Trabalho (CNT), do qual fazia parte, a elaboração de projetos de casas tipo, a fim de se obter uma solução racional, que atendesse aos critérios de higiene, conforto e à qualidade dos materiais, além das necessidades da simplicidade de concepção, da solução racional da planta, da estandardização dos elementos de construção e do emprego racional dos materiais.

O engenheiro-arquiteto criticava a transferência dos modelos das construções europeias, com uso abusivo de vidros, por exemplo, para um país tropical como o Brasil. Cita como referencial nesse sentido, 0 "Estudo sobre o conforto térmico e o conforto visual no Brasil", de autoria de Paulo Sá, do Instituto Nacional de Tecnologia (O PROBLEMA..., 1937); revelando uma tentativa de sintetizar as linhas do racionalismo internacional com a tradição local, sugerindo a utilização de materiais próprios das regiões.

Segundo Porto (1938), os materiais para a construção das unidades habitacionais por parte dos IAPS e das CAPs deveriam ser de primeira ordem e de fácil conservação. Mais especificadamente, o chefe da Secretaria de Engenharia do Conselho Nacional do Trabalho acreditava que seria justificada pela economia, a construção de casas utilizando-se materiais próprios dos locais onde seriam implantadas. Porto cita, essencialmente, o emprego da madeira nos estados da região Sul do país (O PROBLEMA..., 1937).

No tocante à planta das unidades habitacionais, Porto apresentou como melhor solução a tipologia conformada por duas salas, vestíbulo, cozinha, banheiro e dois ou três quartos, concebida por meio de uma arquitetura funcional223. Em se tratando dos ornamentos, Porto defendia a extinção da decoração e da exuberância das fachadas construídas pelas CAPs e IAPs para os seus associados, e que fosse abolida toda "(...) a fantasia, toda a decoração supérflua, tudo que encareça a mão-de-obra e exija material custoso, como, por exemplo, telhados complicados, varandas em balanço, etc. (...)" (PORTO, 1938, p.254). As varandas em balanço se mostravam uma inovação na moradia empreendida pela Bauhaus (Escola de Design, Artes Plásticas e Arquitetura de Vanguarda), que funcionou entre os anos de 1919 e 1933, na Alemanha. As proposições que defendem a simplicidade das fachadas e um estudo mais aprofundado da planta, em muito se assemelham ao colocado nos primeiros CIAMs e, no caso brasileiro, ao preconizado no I Congresso de Habitação, de 1931, e pela Jornada de Habitação Econômica, de 1941.

223 Muito adotada pelas residências edificadas pelos órgãos no Nordeste, como se verá mais adiante. 
Na concepção de Porto (1938), os IAPs e as CAPs deveriam disponibilizar não somente as moradias, mas também, todo o mobiliário necessário a uma vida regrada e ao conforto mínimo do trabalhador e sua família. O mobiliário deveria ser adquirido em atacado por questões econômicas. Para ele, a entrega da casa devidamente equipada ofereceria, além de vantagens de ordem econômica, vantagens higiênicas. Nesse sentido, evitar-se-iam problemas comumente encontrados nas moradias operárias, como a incompatibilidade do tamanho e da quantidade da mobília dos trabalhadores às dimensões dos cômodos e à disposição das aberturas, portas e janelas; o que resultava, na maior parte dos casos, na obstrução das mesmas por armários e estantes que impediam a passagem e a distribuição adequada da luz natural e da ventilação; revelando também as preocupações de cunho higienista e de conforto térmico e lumínico do engenheiroarquiteto.

Porto foi ainda mais a fundo, ao propor que também fossem incluídos nas residências concebidas pelos Institutos e Caixas, utensílios domésticos, tais como “(...) baterias de alumínio, aparelhos de boa louça, talheres de bom metal, toalhas e lençóis de bom pano (...)", que deveriam ser adquiridos também em atacado, mediante o pagamento a vista, o que reduziria consideravelmente os custos (PORTO, 1938, p.36). O objetivo de Rubens Porto nessa proposta era garantir ao pobre viver em um ambiente são e confortável. Em sua concepção, tudo o que fosse necessário à vida doméstica deveria ser incorporado ao plano e não entregue ao livre arbítrio do ocupante 224 .

Apesar de reduzir o custo de aquisição dos equipamentos e utensílios domésticos supracitados com a compra em grandes quantidades e o pagamento a vista, a boa qualidade pretendida e a diversidade dos mesmos, resultaria no desprendimento de vultosas quantias. Isso causaria um descompasso, no sentido que os estudos e tentativas de redução do custo de produção e de repasse das moradias, com a utilização de novos materiais, técnicas e a redução de ornamentos, seria comprometido e, por vezes, anulado pelos valores da aquisição desses equipamentos domésticos. Esse quesito confere a essa proposta de Rubens Porto, em especial, uma dimensão distante da realidade social pretendida.

Não obstante o caráter quimérico dessa sugestão, que promoveria um distanciamento da essência social das ações das Carteiras Prediais dos Institutos e Caixas de Aposentadoria e Pensões, alguns presidentes a levaram em consideração. Pode-se citar como exemplo, a iniciativa do engenheiro chefe do IAP dos Comerciários, Helvécio Xavier Lopes, que incluiu em cada residência devidamente mobiliada da Vila Valdemar Falcão, na Ilha do Governador (RJ), um rádio portátil.

A disposição do mobiliário, bem como dos utensílios nas moradias dos trabalhadores construídas e/ou adquiridas pelas Carteiras Prediais, deveriam ser resultado de estudos. Mais especificadamente, os armários, os cabides, as prateleiras destinadas aos objetos usuais, cada compartimento, deveria ser previsto no plano, de acordo com Porto. Dessa maneira, os espaços livres seriam aumentados, pondo fim aos

224 Sugeria ainda a utilização de duchas e chuveiros ao invés de banheiras e o aquecimento central quando necessário. 
obstáculos que comprometiam os movimentos e a vida dos trabalhadores em suas antigas casas não higiênicas e não econômicas (PORTO, 1938, p.43).

Dentre os regulamentos e portarias que incorporaram as sugestões e propostas defendidas por Rubens Porto para a construção das moradias operárias, se destaca o regulamento da Carteira Predial do Instituto de Aposentadoria e Pensão dos Marítimos (IAPM). Nesse regulamento é clara a semelhança entre as proposições de Porto e as diretrizes para a construção de moradias. No Art.48 do regulamento, que especifica as normas para as construções por iniciativa do órgão, lê-se: os prédios ou apartamentos serão do tipo econômico, respeitada a simplicidade de concepção, a solução racional da planta, a padronização dos elementos de construção e o emprego racional dos materiais, e obedecerão aos requisitos que os tornem higiênicos, confortáveis, de preço razoável, de conservação fácil e econômica, levando-se em consideração os hábitos e os gostos das regiões onde forem construídos.

\subsection{Os modelos adotados como referências e balizas por Rubens Porto}

Os cargos representativos ocupados por Porto possibilitaram o contato direto do engenheiro-arquiteto com a rotina e a vida de muitos dos operários do país, permitiram o acesso a diversos dados e pesquisas desenvolvidas no Brasil e nos países da Europa nesse sentido, bem como, o conhecimento dos procedimentos implantados por diversas instituições de crédito e de previdência em diversas localidades. Isso se deu em virtude das muitas viagens realizadas para a participação de palestras, conferências, apresentação de teses e, inclusive, para representar o Ministro do Trabalho em variados eventos. Essas experiências fundamentaram seus escritos e proposições, essencialmente acerca da reforma da legislação do sistema previdenciário brasileiro e da aquisição e construção de moradias para os trabalhadores por parte dos órgãos de previdência social do país, representados inicialmente pelas Caixas e Institutos de Aposentadorias e Pensões.

Assim como diversos historiadores do século XIX e das primeiras décadas do século XX, bem como a própria elite brasileira desse período, Rubens Porto acreditava que uma significativa parcela da população desprovida de recursos, como também o acúmulo de moradias precárias, representava para qualquer cidade um grave perigo. Configuravam-se como ameaças não somente à saúde pública, mas também à ordem social. As representações da população pobre e do lugar que estes habitavam estavam, nesse período, intimamente relacionadas e recaiam na noção de que o meio formava os indivíduos ${ }^{225}$. Dessa forma, a

\footnotetext{
225 Essa teoria permeou o pensamento e as práticas dos letrados do século XIX e dos primeiros anos do século XX, sobremaneira os médicos. Nesse momento, era essencialmente a teoria miasmática que dominava o pensamento técnico. Nela, 0 ar e a água eram tidos como meios transmissores de doenças. Acreditava-se, nesse sentido, que a matéria animal ou vegetal em putrefação, assim como, as águas servidas e estagnadas, as matérias fecais e o lixo acumulado eram causadores de doenças, devido às emanações fétidas e pútridas originadas por eles, chamadas de miasmas. Nos ambientes fechados, onde se verificava 0 acúmulo de materiais, pessoas e objetos, apontava-se a estagnação dos fluídos e, consequentemente, a sua contaminação por miasmas. A iluminação e a ventilação deficientes nesses locais eram tidas como agravantes para a contaminação miasmática. Outras teorias médicas e biológicas foram formuladas ao longo do século XIX como, por exemplo, a teoria microbiana de Pasteur, que conferiram novos direcionamentos teóricos às propostas e às intervenções no meio construído, em especial, às habitações (CHALHOUB,
} 
solução dos problemas da cidade e de suas edificações era a chave para o melhoramento do "homem urbano".

Nesse contexto, a moradia dos trabalhadores passou a ser alterada de acordo com os preceitos da higiene e da economia. Porto compartilhava dessa ideia, defendendo o modelo da casa própria, econômica e higiênica, como a solução mais adequada ao problema de habitação urbana pobre do país. Propunha, nesse sentido, a construção de moradias diretamente pelo poder público e pelos órgãos a ele vinculados, principalmente, pelas Caixas e Institutos de Aposentadorias e Pensões possuidores de vultosas reservas, que poderiam ser investidas nesse campo. Para Porto, a oferta de moradia por parte do Estado deveria ser concretizada, da mesma forma que ocorria com o abastecimento de água, a coleta de esgotos, os sistemas de transporte, a iluminação pública, etc.

De acordo com o engenheiro-arquiteto, o modelo da moradia operária brasileira deveria ser mais estudado. Mostrava-se necessária a redução dos custos para a compra das residências populares, por meio da alteração dos processos de produção e provisão, a fim de tornar possível a sua aquisição por parte dos trabalhadores. Somente desse modo, colocar-se-ia fim aos abusos da especulação imobiliária e das vantagens alcançadas pelos rentistas, em sua concepção. Mais especificadamente, Rubens Porto considerava de suma importância a realização de estudos e pesquisas acerca das dimensões adequadas da moradia, da disposição dos ambientes em planta, dos materiais a serem utilizados, das melhores técnicas a serem empregadas, etc. Dever-se-ia empreender também uma reforma legislativa de modo a facilitar 0 acesso à moradia pelos mais pobres, além de um programa de educação do morador. Posicionamentos muito próximos àqueles adotados pelo poder público no campo habitacional, a partir de 1930.

Tais preocupações se aproximam também daquelas observadas no IV Congresso Pan-Americano de Arquitetos, que ocorreu no Rio de Janeiro em 1930, no I Congresso de Habitação, promovido em São Paulo pelo Instituto de Engenharia, no ano de 1931, mais precisamente das colocações e proposições dos engenheiros Marcelo Taylor Carneiro de Mendonça e Bruno Simões Magro participantes do evento, e na Jornada de Habitação Econômica, promovida pelo IDORT (Instituto de Organização Racional do Trabalho) nas cidades do Rio de Janeiro e São Paulo, em 1941, cujas propostas foram amplamente divulgadas por meio da Revista de Organização Científica, além de folhetos, conferências e programas de rádio. Em escala internacional, já se pode fazer aproximações ao empreendido por Ernest May, em Frankfurt226.

Percebe-se nos escritos de Porto um grande vínculo de suas ideias àquelas defendidas e implementadas pela Igreja Católica no país. Um exemplo mostra-se o supracitado trabalho apresentado na Primeira Semana de Ação Social de 1936. Nessa obra, são citados estudos e pensadores católicos envolvidos com a questão habitacional e/ou relacionada às classes operárias, tais como: Catherina Bauer; Celine Lhote e Elizabeth Dupeyrat, autoras do livro "Revelações sobre a saúde das jovens operárias"; a

1996; CORREIA, 2004). Tantos os clínicos positivistas quanto os sanitaristas adeptos da bacteriologia concordavam que o meio conformava o indivíduo.

${ }^{226}$ As dez sugestões que compõem o "manual" de Rubens Porto são muito próximos ao colocado por aquele arquiteto em Frankfurt. 
Associação Francesa da Juventude Operária Católica Feminina; o Cardeal Inglês Maning; o economista católico Belga, Valère Fallon, autor do livro "Princípios da Economia Social" e responsável pela criação da Associação do Lar Proletário no Brasil, em 1935; o escritor católico Paulo Sá, que também desenvolveu estudos sobre conforto térmico e ambiental na década de 1930; o estudo sobre corporação do jesuíta Eduardo M. Lustosa, de 1936; e o arquiteto francês Pierre Bourdeix (1906-1987), responsável por estudos referentes à relação entre a mortalidade e a oferta de moradias à classe trabalhadora. Os cargos ocupados por Porto também revelam sua estreita ligação com a Igreja Católica.

Cabe ressaltar, nesse sentido, que a Igreja Católica estava associada ao Governo frente à solução dos problemas sociais do país, por meio da Ação Católica, mais intensamente a partir de meados da década de 1930, com a instalação no Brasil de um movimento já em curso na Europa - 0 Grupo de Ação Social responsável pela realização das Semanas de Ação Social. A primeira delas, como já citado, ocorreu no ano de 1936, no Rio de Janeiro, que também sediou a segunda Semana, em 1937. A terceira ocorreu, em 1939, no Recife, na Federação das Classes Trabalhadoras de Pernambuco e por ocasião da qual foi instituída a Liga Social Contra o Mocambo (LIRA, 2002). Essas Semanas contavam com a presença dos Interventores estaduais e do Ministro do Trabalho, Indústria e Comércio, além de católicos, estudiosos e interessados no tema. O objetivo da realização dessas Semanas, bem como do próprio grupo de Ação Social, era a divulgação da doutrina social católica, a avaliação das condições de vida e de trabalho das camadas populares a fim de proporcionar soluções, bem como colaborar com o Estado na vigilância das leis trabalhistas, das condições de vida e da garantia de moradia aos trabalhadores brasileiros (GOMINHO, 2007).

Os resultados da pesquisa desenvolvida por Rubens Porto foram também decorrentes de sua vasta experiência no campo habitacional devido à sua formação de engenheiro-arquiteto, bem como de diversos estudos realizados na área da habitação social, principalmente acerca das sociais-democracias dos anos de 1920, e dos cargos ocupados por ele ao longo de sua carreira. Cabe aqui assinalar também que os dados apresentados em sua tese foram resultado de sete anos de pesquisa, apurados em 31 de julho de 1937, enquanto chefe da Secretaria de Engenharia do Conselho Nacional do Trabalho. Essa publicação, juntamente com os pareceres de anteprojetos dados por Porto ("O problema da habitação operária" e "O problema da habitação operária e a reforma do regulamento"), resultou em reformas legislativas nos anos de $1934^{227} \mathrm{e}$ 1937228, e correspondem às mais significativas contribuições de Rubens Porto nesse sentido, como também, às principais referências para a realização das análises de suas propostas e ações no campo da moradia operária, que podem ter exercido influência direta em algumas das resoluções governamentais.

\footnotetext{
${ }_{227}$ Representada pelo Decreto n. 24.488, de 28 de junho, que criou as Carteiras Prediais das Caixas de Aposentadorias e Pensões (CAPs) e foi publicado no Boletim do Ministério do Trabalho, Indústria e Comércio, n.30, de 1934.

228 Corresponde ao Decreto n.1.749, de 28 de junho de 1937, que permitiu a aquisição e a construção de moradias por parte dos IAPs e CAPs e foi publicado no Boletim do MTIC, n.35, de 1937.
} 
Em sua produção, o engenheiro-arquiteto revelou as principais referências que guiaram suas proposições, o que muito facilitou a identificação das semelhanças e das proximidades a outras formulações no campo habitacional, bem como às diretrizes construtivas das Carteiras Prediais dos Institutos e Caixas. A diversidade de citações observada nas notas e sugestões de Rubens Porto, também revela sua erudição e 0 vasto conhecimento sobre 0 tema da moradia. Eram comumente citados pelo engenheiro-arquiteto diversos estudos e autores contemporâneos à sua época, os quais Porto considerava de suma importância para se alcançar a solução mais adequada dos problemas da moradia operária brasileira. Seu discurso também era marcado pelo conservadorismo católico típico de sua formação religiosa, como já apontado.

Concomitantemente à realização de estudos e pesquisas, Rubens Porto, julgava importante o resgate histórico e 0 entendimento dos problemas da habitação econômica ao longo dos anos em diversas localidades, como na França, Inglaterra, Dinamarca e Alemanha229. Observou-se, nesse sentido, que 0 referido engenheiro-arquiteto era adepto, dentre outros, das ideias e das experiências de comuna ideal, dos núcleos autônomos e da descentralização proporcionada pelas Cidades-Jardins. Tais soluções vislumbradas no século XIX e/ou nas primeiras décadas do século XX alcançaram grandes repercussões no mundo, chegando ao Brasil por meio, sobretudo, das revistas especializadas e convenções sobre o tema. Nesse contexto, Porto cita como modelos para referência projetual, a teoria dos Paralelogramos de Robert Owen, 0 ideal de Cidade-Jardim de Ebenezer Howard, o modelo de cidade-ideal de James S. Buckingham e os estudos do arquiteto alemão Julius Posener, acerca dos núcleos auto-suficientes.

Mais especificadamente, a Teoria do Paralelogramo de Robert Owen (1771-1858) mostra-se uma das diversas utopias formuladas no decorrer do século XIX, sobretudo por pensadores europeus. De modo geral, propunha um modelo de "cidade ideal", cujo objetivo primordial era a solução dos problemas de superlotação e insalubridade

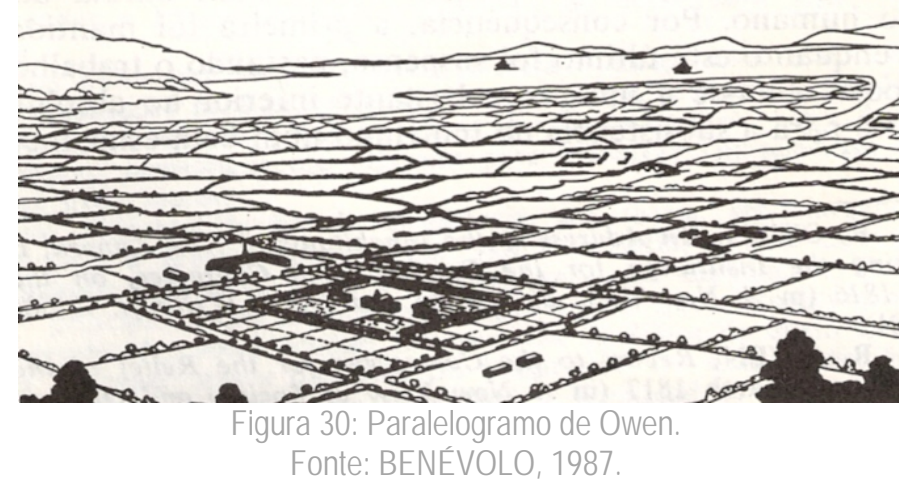
dos aglomerados industriais, no contexto da Revolução Industrial, especialmente das habitações operárias, consideradas como focos de doenças e de imoralidade pelas elites, naquele momento (BENEVOLO, 1987). Owen acreditava que para sanar o supracitado quadro de crise era preciso conceber habitação associada a trabalhos mecânicos aos pobres e desempregados. Propôs então uma série de aldeias com capacidade para 1.200 pessoas em média, nas quais, se locaria atividades de ensino, trabalho e lazer, com o intuito de manter a população afastada das "tentações inúteis" (Figura 30). Esse modelo corresponderia, resumidamente, a edifícios de configuração quadrangular com arestas envoltas por um grande terreno destinado às atividades

${ }^{229}$ Esse posicionamento se mostrava muito próximo aos objetivos de criação do CNT, essencialmente quanto à criação do museu, biblioteca e a realização de estudos acerca das questões sociais, bem como incentivava o intercâmbio de ideias e experiências com outros países, inclusive por meio de viagens de pesquisa e eventos científicos. 
de lazer e contemplação e ao centro, os equipamentos públicos, como escolas, salas de leitura, sala de reuniões, biblioteca e cozinha (CHOAY, 1992).

Em relação às células habitacionais, Owen pregava que deveriam ter espaço em abundância e divisão interna muito simples. As janelas dos quartos deveriam abrir para as hortas-jardins e as das salas para o pátio interno. As residências não possuiriam cozinhas, haveria apenas um refeitório coletivo. As dimensões das unidades habitacionais do paralelogramo seriam especificadas de acordo com o estado civil dos indivíduos e o tamanho da família; semelhante ao que propunha Porto em seu modelo de conjunto residencial. Além de determinar as funções, dimensões e localização de cada atividade, Owen especificou desde as obrigações reservadas a cada parcela da população - homens, mulheres, jovens e crianças - e devidas condutas, ao planejamento orçamentário necessário a implantação do seu modelo de cidade.

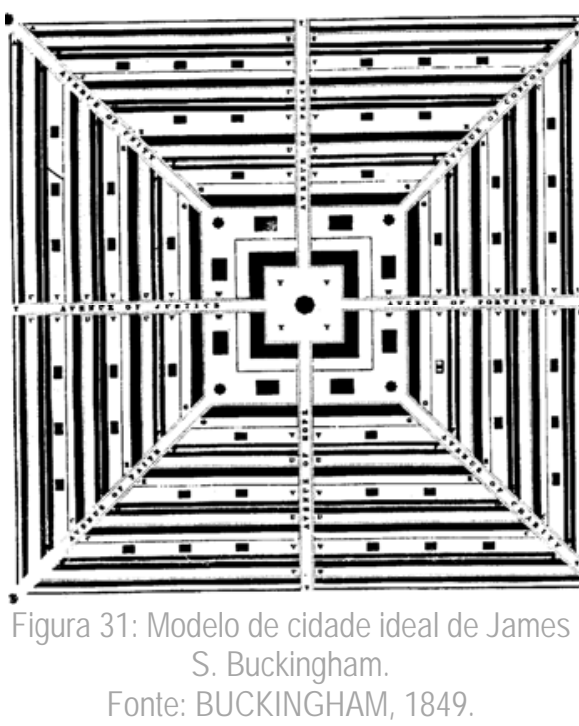

James S. Buckingham (1786-1855), também citado por Porto, foi o autor do livro "National Evils and Practical Remedies. With the Plan of a Model Town", publicado em Londres, no ano de 1849230 (BUCKINGHAM, 1849). Buckingham era um defensor da comunidade autônoma, como Owen, e acreditava que o problema da habitação econômica ou barata, como colocada naquele momento, era uma questão urbana e assim deveria ser encarada com urgência (PORTO, 1938). Em seu livro, propôs uma série de reformas econômicas e políticas, bem como, descreveu um plano de cidade modelo, no contexto da reconstrução de Londres. Para Buckingham (1849), a cidade deveria possuir ruas retas (32 ruas) e diagonais (8 avenidas) que deveriam irradiar de um centro, com o objetivo de facilitar a circulação - redução das distâncias - e a ventilação (Figura 31); preocupações elencadas por Porto em seu "modelo ideal".

Sua cidade também possuiria grandes áreas verdes para facilitar a troca do ar e reduzir os gases poluentes. No centro haveria uma ampla área verde e uma praça, onde seriam realizadas as atividades sociais e as manifestações populares e em torno da qual, estariam dispostos os edifícios públicos de caráter monumental e as residências dos governantes. Dever-se-ia optar pela simplicidade e a economia nas construções, embora não rejeitasse o ornamento. Os espaços deveriam ser condicionados de modo a oferecerem um maior grau de ordem, o maior aproveitamento do ar e da luz, o melhor sistema de drenagem, a melhor adequação das classes no espaço e o planejamento mais adequado ao número de unidades habitacionais.

As habitações seriam dispostas em fileiras (geminadas), intercaladas por passagens cobertas, que permitiriam que um transeunte tivesse acesso a qualquer parte da cidade, em meio a diversos jardins,

230 Buckingham, após se aposentar de suas atividades no Parlamento Inglês, onde trabalhou entre os anos de 1832 a 1837 , começou uma turnê pelo mundo, que resultou na elaboração de diversos volumes sobre os Estados Unidos, Canadá, Bélgica, Holanda, França e Itália (BUCKINGHAM, 1849). Mas, sua principal publicação foi o livro citado. 
gramados e flores, importantes para a realização de atividades de lazer. As habitações seriam hierarquizadas. As dos trabalhadores seriam dispostas nas proximidades das oficinas, economizando tempo nos percursos, e receberiam mobiliário mínimo, que naquele momento correspondia aos armários; muito próximo ao colocado por Porto. A cidade deveria ser implantada na proximidade de um rio ou do mar. Todas as coberturas das edificações deveriam ser planas e construídas em ferro, se conformando também com passagens. $O$ autor faz, nesse sentido, analogias às construções de navios (BUCKINGHAM, 1849).

O conceito de "cidade-jardim", por sua vez, surgiu na Inglaterra no último quartel do século XIX, conformando-se uma alternativa para o crescimento explosivo da capital do país, que culminou no livro "Garden Cities of Tomorrow", publicado por Ebenezer Howard, em 1898. Sua proposição também objetivava solucionar os problemas de insalubridade e pobreza encontrados em Londres, por meio de novas cidades marcadas pela íntima relação com o campo. Em linhas gerais, correspondia a uma estratégia de planejamento regional para conter o fluxo migratório em direção às grandes cidades, propondo núcleos autoorganizados conformados a partir do estabelecimento de indústrias e comércios, com cinturões agrícolas, interligados por um sistema de transporte público eficiente.

Em seu livro, Howard especificou todos os passos para se estabelecer uma cidade-jardim, desde os critérios de escolha do terreno até questões relativas à forma de aquisição e tipo de contribuição dos futuros moradores; assim como procedeu Porto em seu "manual". Em síntese, cada núcleo seria composto por: uma área central onde estariam dispostos os edifícios públicos e institucionais em torno de uma grande área verde; quarteirões residenciais; uma larga "avenida-parque" com grandes canteiros arborizados, na qual, estaria disposto o comércio da região; seis grandes bulevares responsáveis pela dinamização e otimização da circulação; uma área destinada às pequenas indústrias; espaços destinados a hortas e jardins; área de habitação rural; e grandes áreas para plantio circundando toda a ocupação, margeada por linhas de trem, responsáveis pela contenção do crescimento da cidade-jardim e pela ligação com o centro urbano mais próximo 231 (HOWARD, 1996).

O ideal de cidade-jardim foi amplamente difundido, principalmente após a Primeira Guerra Mundial, quando o movimento tornou-se modelo de planejamento de novas cidades para a reconstrução da Inglaterra. No Brasil, esse ideário encontrou solo fértil para a sua difusão por atender e coadunar com as questões que estavam colocadas no ambiente técnico e cultural da época, bem como pelo seu "esquema de desenho urbano" que muito interessou ao corpo técnico e intelectual brasileiro por atender, para além das propostas de reforma urbana, às necessidades e conveniências da cultura urbanística moderna em formação no país

\footnotetext{
231 Seriam aglomerações com dimensões e densidades fixas, totalizando 2.400 hectares. Ao ser atingido o número máximo de 58.000 habitantes na primeira cidade-jardim ou cidade-central, a população "excedente" seria responsável pelo estabelecimento de um segundo núcleo (ou primeira cidade-satélite), com capacidade para 32.000 habitantes, e assim por diante (HOWARD, 1996).
} 
(LAMAS, 1992) (Figura 32). Nesse sentido, a cidade-jardim foi utilizada como uma ideia de fácil apropriação e com possibilidades claras de execução, no sentido de promover a construção de cidades salubres ${ }^{232}$.

É evidente a semelhança da cidade pensada por Bunckingham, daquela preconizada por Ebenezer Howard no seu ideal de CidadeJardim, desde a quantidade muito próxima de vias diagonais partindo de um centro ocupado por praça e edifícios públicos, até as preocupações referentes à circulação do ar e à diversificação dos espaços verdes. A hierarquização de moradias e a preocupação com o sítio também conformam pontos semelhantes entre ambas as propostas, apesar de Howard não especificar diretrizes construtivas em seu modelo. Os dois autores são citados por Rubens Porto,

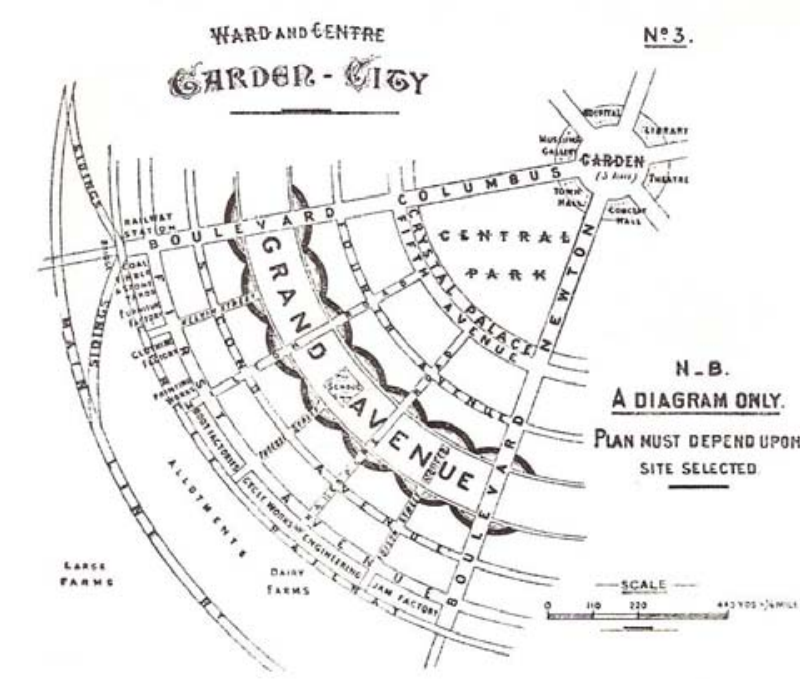

Figura 32: Representação gráfica do modelo de cidade-jardim howardiano Fonte: AYMONINO, 1973. principalmente, no livro publicado em 1938.

De maneira geral, Porto estava em concordância com James S. Buckingham e considerava que a questão da habitação econômica era antes de tudo uma questão de urbanismo. Nessa linha, Porto defendia como solução mais adequada ao problema habitacional operário do país, um modelo que em muito se aproxima da cidade ideal do arquiteto, bem como da proposta de Owen e de Cidade-Jardim de Ebenezer Howard. Defendia, nesse sentido, uma cidade apropriada a uma vida sadia e a uma indústria suficientemente grande para tornar possível uma vida social completa, cercada por zona rural e terreno pertencente à comunidade.

Em se tratando do custo dos terrenos e da defesa por uma localização dos grupos de moradias dos IAPs mais afastada do centro das cidades, Porto se aproxima mais uma vez das proposições Howard, que difundiu o princípio econômico de aproveitar a diferença do custo do solo para investir na própria habitação. Porto o considerava como um dos seguidores de Buckingham e um dos pioneiros sobre 0 assunto, 0 qual merecia receber mais atenção por parte dos arquitetos dispostos a solucionar o problema habitacional brasileiro (PORTO, 1938, p.58).

Ao descrever o seu modelo de ocupação habitacional com um número "ideal" de moradores, dentre outras características, como a autossuficiência de serviços, percebe-se a aproximação da proposta de

\footnotetext{
232 Não se pode deixar de citar também, a vinda do arquiteto Barry Parker ao Brasil, em 1917, onde permaneceu e atuou até 1919. Parker foi um dos principais vetores, se não o mais significativo, de difusão do ideal de Cidade-Jardim no Brasil (ANDRADE, 1998). No escopo de referência de cidade-jardim ligada à tradição sanitarista, destacam-se as atuações de diversos engenheiros e arquitetos para além de Barry Parker, como Armando de Godoy, Abelardo Caiubí, Lincoln Continentino, Jorge de Macedo Viana, Francisco Batista de Oliveira, Attílio Corrêa Lima e Saturnino de Brito.
} 
Rubens Porto também à proposta de Owen e, num segundo plano, ao conceito de Unidade de Vizinhança233 formulado por Clarence Perry no contexto do Plano de Nova York, em 1929. Apesar de não fazer referência direta a essa concepção, Porto especifica todo o procedimento para o cálculo do número de habitantes de cada "célula urbana", a partir da população a ser atendida e do número de escolas existentes. As escolas eram consideradas os principais elementos estruturadores do seu conjunto habitacional ideal, como no referido conceito, e seriam dispostas de modo que nenhuma criança percorresse, por meio das vias interiores do conjunto, mais de $600 \mathrm{~m}$ entre a sua casa e a escola; também em semelhança aos superblocos de Perry. Dessa forma, para Porto:

(...) cada sala de escola basta para 80 crianças (em duas turmas de 40). Uma escola 'planton 12' dos tipos P.D.F. com 12 salas bastará, pois, para 12×80=960 crianças. Por outro lado, em 2.000 casas cabem cerca de $2.000 \times 6=12.000$ pessoas, das quais umas 2.000 serão crianças em idade escolar primária (...). Se haverá nas nossas 2.000 casas cerca de 2.000 escolares e se cada escola (...) serve perto de 1.000 alunos, são necessárias 2 escolas; resolvemos o nosso problema então com 2 'células urbanas' cada uma com cerca de 1.000 casas (...). (PORTO, 1938, p.52).

A questão do zoneamento, da hierarquização das vias, da separação dos fluxos de pedestres e veículos, do planejamento dos espaços e equipamentos de acordo com a população a ser atendida, bem como a proposição de passeios sinuosos são pontos semelhantes entre as duas propostas. As dimensões do lote residencial proposto por Rubens Porto $(11 \times 30 \mathrm{~m})$ praticamente se equipara às do subúrbio de Radburn, em Nova Jersey, projetado por Clarence Stein e Henry Wright, bem como às propostas por Perry (12x30m).

Julius Posener (1904-1996), por sua vez, foi um historiador arquitetônico alemão, com o qual Rubens Porto concordava acerca da solução do problema habitacional. Para Posener a solução estava na "formação de unidades quase autônomas, apresentando, em sua forma exterior, as leis da nossa economia, mas construídas sob uma base de cooperação" (PORTO, 1938, p.23). Exatamente o que Porto pretendia que os Institutos e Caixas de Aposentadorias e Pensões se propusessem a fazer.

O modelo de moradias geminadas em fila, com aproveitamento da laje como passagem de Porto é muito próximo também do observado na Vila Fuggerei, financiada, projetada e concebida por Jacob Fugger (1459-1525) ${ }^{234}$, um importante comerciante e banqueiro católico alemão, cuja primeira edição de sua biografia "Jacob Fugger the Rich: Merchant and Banker of Augsburg, 1459-1525", foi publicada no ano de 1931. Sua principal realização no campo habitacional foi a edificação de uma vila, entre os anos de 1516 e

\footnotetext{
${ }^{233}$ De acordo com Peter Hall (1998), a unidade de vizinhança objetivava retomar por meio do planejamento e desenho das cidades, as relações sociais, essencialmente de confiança, entre vizinhos, verificadas em bairros antigos. Clarence Perry previu uma diversidade de equipamentos, desde escolas primárias, quadras de jogos, lojas, igreja, salas de reuniões e de teatro, clube, piscinas, até museus, nos casos de unidades com mais de 10.000 habitantes. Para Lamas (1992), sua concepção privilegiava, dessa forma, o zoneamento de funções, a distribuição dos equipamentos dentro do bairro - geralmente localizados dentro da área central - e a circulação de pedestres devido ao traçado viário adotado, que conciliava o tráfego de automóveis à proteção dos moradores de seus perigos e inconvenientes; proporcionando 0 isolamento das habitações e 0 aproveitamento dos espaços livres centrais.

${ }^{234}$ Fugger tinha grande prestígio na cidade alemã de Augsburg e construiu diversas igrejas e edificações na cidade. Também promoveu doações em dinheiro aos pobres de todo o mundo, investindo inclusive no Brasil.
} 
1525, em Augsburg, denominada de Fuggerei. A referida vila era conformada por 106 unidades habitacionais geminadas, com dois pavimentos, dotadas de grandes jardins, cozinha coletiva, igreja e hospital; uma solução filantrópica. Para residirem nessas habitações, os moradores tinham necessariamente que ser pobres e católicos (AUGSBURG, 2004). Para Porto (1938), Fugger foi um dos principais precursores da previdência social, cujos ensinamentos e formulações deveriam servir como exemplos a serem seguidos pelas CAPs e IAPs. A tipologia habitacional pretendida por Porto também é facilmente equiparada ao modelo encontrado na cidade de Buckingham. Ambas as experiências são apontadas por Rubens Porto como exemplos construtivos que deveriam ser adotados pelas Carteiras Prediais das Caixas e Institutos e seus engenheiros e arquitetos.

No Brasil, outra referência possível pode ter sido o projeto do conjunto para operários na Gamboa (RJ), edificado em 1932, pelo arquiteto russo Gregori Warchavchik e por Lúcio Costa, mormente, quanto à preocupação com 0 aproveitamento das condições climáticas e da iluminação natural, à adoção das unidades geminadas e à solução da laje contínua em concreto armado (Figura 33).

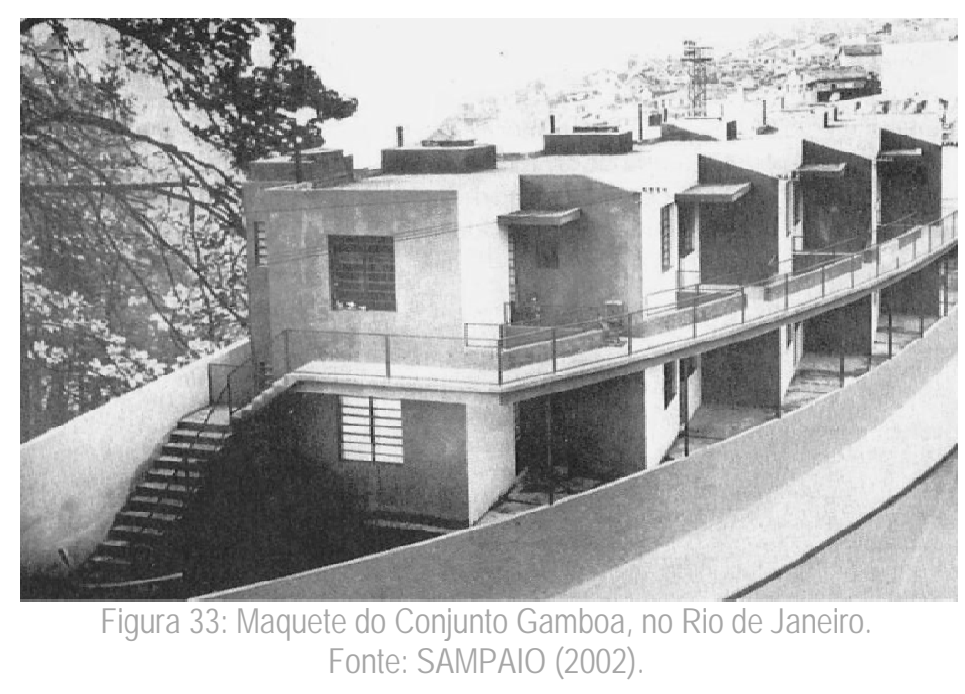

No tocante às moradias coletivas, a historiografia afirma que a preferência por apartamentos duplex sobre pilotis para os solteiros, representa a materialização da influência de Le Corbusier nas proposições de Rubens Porto. Nesse sentido, Paulo Bruna (1998; 2010) afirma que o modelo adotado pelo engenheiroarquiteto do CNT se mostrava muito próximo ao preconizado por Le Corbusier no "Immeuble Villa", de 1922. No entanto, a Unidade de Habitação 235 apesar de ter adquirido visibilidade na proposta de Le Corbusier na década de 1920, só foi largamente difundida a partir, sobretudo, da década de 1940, no contexto do processo de reconstrução da França após a Segunda Guerra Mundial e, dessa forma, em um período posterior ao da publicação do livro de Porto, em 1938; não sendo inclusive citado por ele. Cabe lembrar que Le Corbusier não foi o primeiro a sugerir a tipologia duplex de moradias e apartamentos. Porto, em seu livro, por exemplo, fazia referência ao sistema "duplex" introduzido por M. Pratt, em Nova York, no ano de 1905, sendo muito usado nos Estados Unidos a partir de então segundo o autor. Essa solução também foi observada em algumas casas comunais soviéticas na década de 1920.

A proposta de utilização de materiais locais por Porto, por outro lado, mostra-se uma provável influência da valorização vernacular das obras corbusianas de fins da década de 1920, como a Vila Mandrot, que fizeram uso de técnicas como a taipa. Outra experiência contemporânea às proposições residenciais de

235 Grandes edifícios laminares de alto gabarito, composto por unidades habitacionais, pontos comerciais, equipamentos de serviço e lazer, além de pilotis e teto-jardim, cujo objetivo é tornar o empreendimento autossuficiente (LE CORBUSIER, 1956). 
Porto refere-se ao projeto para a vila operária em Monlevade (MG), da década de $1930^{236}$, de Lúcio Costa (BRUAND, 1981; FORTY e ANDREOLI, 2004).

Diversos estudos concluídos e em andamento nas primeiras décadas do século XX, foram ainda citados e provavelmente serviram como baliza e/ou referência direta para a concepção do modelo habitacional de Porto, como os estudos da Associação Francesa da Juventude Operária Católica, desenvolvidos alguns anos antes da elaboração do livro de Porto e citados nele, bem como os estudos influenciados pelas ideias afloradas dos movimentos feministas do século XIX, das proposições advindas da economia doméstica e da engenharia do lar, das ideias difundidas nas primeiras quatro edições do Congresso Internacional de Arquitetura Moderna (CIAMs) e pelo crescimento da indústria de equipamentos e utensílios domésticos.

Associações podem ser feitas às unidades unifamiliares da Cidade Industrial de Tony Garnier, de 1901; aos princípios do fordismo e do taylorismo, quanto à dinamização e à racionalização da produção; aos escritos de Le Corbusier, em "espírito novo", sobre as necessidades de se ensinar a morar; às formulações referentes à adequação dos pressupostos modernos às condições específicas de cada localidade de Lúcio Costa; as colocações de Warchavchick, em "Acerca da Arquitetura Moderna" (1925); às publicações do Instituto de Engenharia, do I Congresso de Habitação (1931), do IDORT e de sua I Jornada de Habitação Econômica (1941); além das discussões do I Congresso Nacional de Arquitetura (1945).

Entendida a estruturação, o alargamento e a trajetória da intervenção direta do poder público no campo habitacional, trilhado paulatinamente desde o século XIX, bem como apontada a produção de unidades habitacionais por meio dos órgãos representativos de sua atuação nesse sentido, sobretudo, as Caixas e Institutos de Aposentadoria e Pensões no centro-sul do país, além de enfatizado o papel e a significância de alguns personagens neste processo, resta-nos agora entender como se deu o rebatimento desse quadro nas sete capitais nordestinas abordadas nesta tese.

\footnotetext{
236 Projeto apresentado no Concurso promovido pela Companhia Siderúrgica Belgo-Mineira para a construção de um núcleo fabril na cidade de Monlevade, em Minas Gerais, com residências, igreja, armazém e cinema para os empregados da Companhia. As moradias propostas por Costa apresentavam pilotis devido ao terreno acidentado e com materiais da região. 0 projeto, no entanto, não foi executado (BRUAND,1981).
} 


\section{CAPÍTULO 03: As CAPS E OS IAPS NO NORDESTE}

Antes de discorrer sobre os intentos e as ações concretizadas pelo poder público no campo da moradia social no Nordeste, por meio essencialmente das CAPs e IAPs do MTIC, como também acerca da criação, estruturação e atuação desses institutos de previdência, no que concerne ao financiamento e à edificação de unidades habitacionais para os seus associados, é de suma importância apontar e analisar o contexto social, econômico e político no qual ocorreram aquelas ações no Nordeste.

Ao iniciarem sua atuação na região, as referidas Caixas e Institutos de Aposentadoria e Pensões se depararam com um território em significativo processo de urbanização e dotado de uma arquitetura popular, com fortes traços locais. Em Fortaleza, Natal e João Pessoa, a abundância de terra e a relativa escassez de matérias-primas, como a madeira de lei, devido ao tipo da vegetação local237, colaboraram consideravelmente para a sobressaliência da utilização de materiais como o barro e técnicas construtivas associadas a ele em detrimento às outras técnicas, que aos poucos foi sendo substituída pelo tijolo em barro cozido ${ }^{238}$. Em São Luís e Teresina foi percebido o uso mais abundante de madeiras típicas da região, especialmente a carnaúba. Em Salvador, por sua vez, observou-se um uso mais constante de bambu na construção civil239. No Recife, principalmente, a abundância de áreas alagadiças induziu à população a edificar muito mais sobre palafitas, bem como a prática de aterros. Essas construções são caracterizadas por estarem estruturadas em grandes e profundos alicerces fundamentalmente de pedras amarradas, sobre os quais, eram construídos 0 calçamento resistente e suas largas paredes.

A disposição e a divisão territorial da referida região como a conhecemos nos dias de hoje foi paulatinamente sendo configurada ao longo dos séculos XIX e XX, principalmente. A primeira divisão do país em regiões geográficas data do início do século XX, mais precisamente de 1913, na qual os atuais estados nordestinos estavam divididos em duas regiões: norte oriental, conformado pelo Maranhão, Piauí, Ceará, Rio Grande do Norte, Paraíba, Pernambuco e Alagoas, e a região oriental, da qual Sergipe e a Bahia faziam parte. Até a década de 1950, outras divisões se sucederam levando em consideração, além dos aspectos físicos, os indicadores socioeconômicos e culturais de todo o território. Nesse período, foram subdivididas as antigas regiões norte oriental e oriental em outras três: Norte, Nordeste e Leste. Os estados do MA e PI passaram a compor a nova região Norte, enquanto do RN, PB, PE e AL conformavam o Nordeste, ficando a BA e SE locados na região Leste. Somente em 1950, o MA e o PI passaram a fazer parte do Nordeste, mas a BA e SE continuaram fazendo parte da Leste. A atual configuração do país só foi instituída nos anos 1970,

${ }^{237}$ Caracterizada por uma cobertura vegetal de baixo porte, conformada principalmente por pequenas árvores, arbustos e cactos.

${ }^{238}$ Mais precisamente, na Natal do século XVIII, principalmente, as residências eram edificadas em taipa e assim o foram durante um significativo espaço de tempo diante das dificuldades na fabricação de tijolos e telhas, pela falta de argila apropriada no perímetro da cidade, bem como pela ausência de oleiros, que somente anos depois vieram diretamente de Portugal e das capitanias limítrofes (SOUZA, 25/07/1943).

239 Esses exemplos não restringem as técnicas construtivas evidenciadas na região ao longo dos anos, mas servem como referência à diversidade, abundância e/ou escassez de materiais utilizados para a edificação de moradias, sobremaneira, sociais. 
reafirmada na Constituição de 1988, pelo qual, o Nordeste passou definitivamente a ser composto por nove estados, dos quais sete são abordados nesta tese, totalizando $1.561 .177,80 \mathrm{~km}^{2}$ e equivalendo a $18,30 \%$ do território nacional.

Sua população atual, de acordo com os dados censitários do IBGE, é de 115.257.763 habitantes. No início do século XX, mais precisamente no ano de 1900, era de 6.749.507 habitantes, o que equivalia a $38,97 \%$ da população nacional240. No início da década de 1920 , quando foram criadas as Caixas de Aposentadoria e Pensões, sua população cresceu em 4.496.414hab., passando a apresentar 11.245.921 residentes. Os estados que mais cresceram nesse contexto foram a Bahia, seguida de Pernambuco e da Paraíba. Em se tratando das capitais, as que apresentavam o maior número de moradores no ano de 1920 eram Salvador (283.422 hab., 8,49\% da população do estado), Recife (238.843 hab., 11,08\% da população do estado) e Fortaleza (78.536 hab., 5,95\% da população do estado), mas a maior taxa de crescimento médio anual do Nordeste era relegada à cidade de Maceió (0,0368) (IBGE, 1950; 2010).

Em se tratando das edificações, também de acordo com o levantamento censitário do IBGE, existiam em 1920, um total de 136.488 domicílios nas capitais nordestinas. Considerando-se a quantidade de habitações em cada uma das capitais, bem como as densidades relativas e o número de moradores urbanos, foi encontrado uma aproximação de 850.000 hab. atendidos por moradia e cerca de 57.000 hab. residentes em domicílios informais, irregulares ou sem moradia, o que correspondia a um pouco mais de $6 \%$ da população das capitais nordestinas naquele ano.

Com bases nos dados do recenseamento e do censo, entre os anos de 1930 e 1940, período marcado também pela intensificação da atuação das Caixas e Institutos de Aposentadoria e Pensões do MTIC no campo habitacional no país, por meio da construção e financiamento de moradias para os trabalhadores brasileiros, a população nordestina cresceu de 13.473 .906 hab. $(35,81 \%$ da população brasileira) para 14.434 .080 (mantendo-se a percentagem nos 35\% da população residente em todo o país). Em 1940, o estado que mais apresentou crescimento populacional foi o Ceará241, seguido pela Bahia e Pernambuco242. Um dado curioso é que, no estado de Sergipe, o crescimento habitacional foi ínfimo, de apenas 65.262 moradores em quase duas décadas, e em Alagoas houve um decréscimo da população, que passou de 978.748 para 951.300 habitantes. Esses quadros, bem como os crescimentos reduzidos de toda a região Nordeste, podem ser justificados pelas taxas migratórias do período. Praticamente todos os estados sofreram uma perda de moradores deslocados para o norte e para o sudeste do país, principalmente ${ }^{243}$.

\footnotetext{
240 Para esse cálculo foi considerada a conformação atual da região Nordeste.

${ }^{241}$ Apresentando 771.804 hab. a mais que o censo de 1920.

242 Apresentando, respectivamente, 583.647 hab. e 533.405 hab. a mais que aquele censo.

243 Para trabalhar nas obras urbanas e no cultivo e colheita de café e da borracha. Diversos foram esses episódios e suas consequências para a região, que não cabem ser aprofundadas nesta tese. Os únicos estados que apresentaram ganho populacional foram o Maranhão (49.914 hab. de acordo com o censo de 1940), provavelmente devido ao crescimento econômico impulsionado pelo cultivo da borracha, da carnaúba e do coco de babaçu na região, e o Rio Grande do Norte, que apresentou a menor taxa de evasão, provavelmente devido ao surto econômico, ou como era largamente divulgado pelos periódicos locais, à "febre de construções" por que a cidade passou na primeira metade da década de 1940, no contexto da II Guerra..
} 
Em se tratando da questão urbana, as capitais cresceram em extensão e número de prédios. $A$ população residente nos centros nordestinos passou a ser de 1.285 .733 habitantes e o número de domicílios particulares ocupados nessas capitais subiu de 136.488 para 242.790 residências, isto é, uma média aproximada de 5.300 moradias edificadas por ano. Considerando-se a população média por prédio em cada uma das capitais em questão, tem-se um total de 1.114.000 habitantes ocupantes de residências regulares, 0 que resulta em aproximadamente 171.000 habitantes residentes em áreas impróprias e/ou irregulares ou sem moradia244, um crescimento que atesta que mesmo concedendo um número significantemente maior de unidades habitacionais, provavelmente colaborando para o aumento do número de domicílios urbanos nas capitais nordestinas, os IAPs em conjunto com as CAPs e outros órgãos e programas no campo da moradia, não conseguiram atender ao déficit de moradias naquela região, que entre os anos de 1920 e 1940, mais que duplicou.

Esse contexto nordestino pode ter contribuído consideravelmente para o aumento das realizações no campo habitacional em suas capitais por parte dos supracitados órgãos, que intensificaram a sua produção a partir, sobretudo de meados da década. Apesar do alargamento das ações no campo habitacional e aumentos dos investimentos públicos no setor, o déficit habitacional continuou a se elevar. Diversas foram as justificativas para tanto, que permeiam pelos fenômenos naturais inerentes à região, principalmente a seca, além de enchentes 245 e o próprio processo de migração, cujos fluxos populacionais em direção aos centros urbanos foram intensificados.

\subsection{Atuação e Produção de Moradias nas Capitais}

Sabe-se, como colocado nos capítulos anteriores, que o número preciso de ações imobiliárias realizadas pelas Caixas e Institutos de Aposentadoria e Pensões no país é praticamente impossível de ser precisado. Diversos são os fatores que contribuem para tanto. O primeiro deles refere-se à ausência de registros gerais oficiais dos imóveis edificados, adquiridos ou financiados por esses órgãos ${ }^{246}$. Existem apenas boletins parciais ou relatórios pulverizados dessa quantificação, geralmente restritos a um escritório específico, locado principalmente no centro-sul do país, como já colocado no primeiro capítulo desta tese.

Um segundo aspecto que pode ser citado recai sobre o estado problemático que se encontram muitos dos arquivos onde estão guardados, e por vezes amontoados, os processos imobiliários relacionados a essas ações. Em muitos deles, como em São Luís, foi quase impossível recuperar muitas das informações acerca da produção dos órgãos na cidade, devido ao estado precário daquele material. Muitos dos documentos estão ilegíveis pelo amarelamento das páginas ou fragilidade do papel, ocasionados pelo arquivamento

$24413,33 \%$ do total da população residente nas capitais nordestinas.

245 No ano de 1924, a capital norte-riograndense foi acometida por chuvas torrenciais que agravaram ainda mais as precárias condições dos serviços e infraestrutura da cidade, atingindo principalmente os canais de drenagem, pontes e estradas, além de deixar um grande número de famílias desabrigadas (ALMEIDA, 2007). Diversos também foram os episódios identificados no Recife e em São Luís, principalmente.

246 Elaborados pelas gerências executivas, setores de engenharia ou até mesmo pela junta administrativa desses órgãos, ou ainda, pelo corpo técnico do Conselho Nacional do Trabalho, ao qual, tanto os IAPs quantos às CAPs eram subordinados. 
inadequado (umidade associada ao tempo de exposição), ou até mesmo por parte deles terem sido comprometidos por rasgos ou por infestações de traças e ratos, como colocado mais detalhadamente na introdução desta tese. Há ainda o agravante de muitos desses documentos terem sido incinerados devido à política do próprio INSS, onde grande parte está arquivada, na qual, os processos liquidados com mais de dez anos devem ser queimados. Quando não incinerados, os processos imobiliários foram comumente encaminhados para os arquivos mortos da instituição, onde são fadados, muitas vezes, ao abandono e depreciação. Cabe nesse momento ressaltar a ação de alguns profissionais que se responsabilizaram pela conservação desse acervo tão importante realizando, pessoalmente, o controle e a manutenção desse material247.

A maior parte da historiografia especializada afirma que em conjunto, os Institutos e Caixas atuantes no país, foram responsáveis pela edificação de aproximadamente 124.000 moradias em todo o território nacional, excluindo os financiamentos concedidos àqueles trabalhadores de classe média e alta, e aos não associados, incluindo as diversas obras públicas e outros investimentos estatais. Nesse contexto, Marta Ferreira Farah, em sua já citada dissertação de mestrado "Estado, previdência social e habitação", apresentada à Faculdade de Filosofia, Letras e Ciências Humanas da USP no ano de 1983, considerada aqui a mais completa publicação sobre o tema, afirma que os supracitados órgãos foram responsáveis pela construção de 35.214 unidades habitacionais no Sul, Norte e Nordeste, em conjunto. De acordo com o levantamento realizado pelo GAP (1985, p.56), por sua vez, de 1937 até dezembro de 1950 foram edificadas pelos IAPs na região Nordeste do país somente 2.606 unidades habitacionais distribuídas apenas pelas cidades do Recife, Salvador e Fortaleza; o que mostra-se um grande equívoco.

Diante da escassez de dados e imprecisão de informações observadas nas publicações sobre a temática, pretendia-se inicialmente nesta pesquisa, analisar tanto a produção direta de unidades habitacionais por meio principalmente da construção de moradias aos associados das Caixas e Institutos de Aposentadoria e Pensões no Nordeste do país, quanto à produção indireta, representada essencialmente pela concessão de financiamentos para a compra de terrenos e edificação de residências por iniciativa dos segurados. Esse objetivo foi elaborado com base nos dados dessa produção apresentados pela historiografia até então248. No entanto, ao dar prosseguimento ao trabalho de levantamento documental nas capitais nordestinas, observouse que somente em se tratando das unidades construídas diretamente pelos referidos órgãos e locadas em grupos ou conjuntos residenciais na região, o número passava da metade daquela estimativa.

Foi diante desse quadro que se procedeu a um redirecionamento do foco de levantamento e análise inicialmente proposto para dar ênfase, essencialmente, às unidades edificadas ou adquiridas diretamente pelos órgãos, especialmente àquelas situadas em grupos de moradias. Vale salientar, que quando possível

\footnotetext{
${ }^{247}$ Projetos interessantes, nesse sentido, podem ser aqui destacados, como o digitalizar todos os processos imobiliários das CAPs e dos IAPs na cidade de Fortaleza, a qual vale frisar, possui o mais organizado e conservado acervo do Nordeste. No entanto, a maior parte dos arquivos está em completo estado de abandono, como na já citada capital maranhense.

${ }^{248}$ Que indicava um montante em torno de 30.000 unidades distribuídas entre as regiões Sul, Norte e Nordeste do país, como anteriormente especificado.
} 
serão apresentadas ao longo deste capítulo e dos seguintes, informações, críticas e considerações acerca das demais ações imobiliárias. Mas, as principais análises se concentraram naquelas tipologias. Também devido ao grande volume de realizações com o qual se deparou, não foi possível o levantamento de todos os processos imobiliários de financiamento para compra de moradias de propriedade das CAPs e IAPs. Em alguns casos, quando encontrados registros, listagens ou qualquer outro documento relacionado à produção de determinado órgão, numa das sete capitais nordestinas, se procedeu ao levantamento de pelo menos $10 \%$ daquele volume. Nos casos distintos, foram levantados os processos imobiliários até serem angariadas todas as informações pertinentes a esta pesquisa.

\section{Salvador-BA:}

No levantamento de dados históricos e nos arquivos visitados em Salvador, sobretudo, no INSS-BA, foram identificados imóveis edificados e/ou adquiridos pelas Caixas e Institutos de Aposentadoria e Pensões, para além da referida capital. Municípios como Santo Amaro, São Félix, Valença, Ilhéus, Maragogipe, Paulo Afonso, Feira de Santana, Muritiba, Alagoinhas, Juazeiro, Jequié, Nazaré, Caravelas, Itabuna, Vitória da Conquista, Amargosa, Barra, Barreiras, Caetité, Jacobina, Esplanada, Itamaraju e Morro do Chapéu também foram contempladas com grupos residenciais e/ou financiamentos concedidos pelos institutos previdenciários do estado.

O número de liberações de pleitos na capital baiana, de acordo com aqueles documentos, foi de aproximadamente 1.700 unidades habitacionais ${ }^{249}$. Dessas, 300 foram efetivamente levantadas, correspondendo a $18 \%$ do total de pleitos concedidos na cidade 250 . Foram identificados 24 grupos residenciais, entre vilas, conjuntos e loteamentos na referida capital baiana ${ }^{251}$, assim como 10 empreendimentos com outras funções, principalmente comercial e institucional, edificados diretamente ou financiados pelos órgãos em Salvador, entre os anos de 1938 e 1964.

Dentre os empreendimentos não habitacionais edificados, direta ou indiretamente, pelos IAPs e CAPs na capital, pode-se citar a Maternidade de Salvador, construída em parceria estabelecida entre o IAPB e 0 governo do estado. Nesse caso, os terrenos - doados ao referido Instituto para o loteamento e/ou edificação de moradias, que acabaram por conformar o Loteamento Almirante Waldemar Falcão em 1953 - foram acordados em troca da construção daquela instituição de assistência médica. Caso semelhante foi percebido no âmbito do IAPETC, na ocasião da edificação da Vila Operária do Instituto, em 1940, situada em terreno

\footnotetext{
249 Das quais, 1.666 estão situadas em grupos residenciais (vilas, conjuntos ou loteamentos) e 34 referem-se aos financiamentos de unidades isoladas, identificadas na pesquisa documental. Devido a um impasse tributário que existiu entre o Governo Municipal de Salvador e a CAPFESP/IAPFESP, como se verá adiante, foi realizado um levantamento de todos os imóveis de propriedade do órgão que estavam sobre promessa de venda, ou seja, que o pagamento do pleito ainda estava ativo. Segundo esse levantamento, havia 135 unidades habitacionais naquelas condições na cidade, além das unidades locadas no interior do estado, no ano de 1958, distribuídas nas Ruas Eloy Chaves, 24 de Janeiro, Galiléia e na Avenida Fernandes, principalmente. Esses imóveis também foram contabilizados para a apresentação do número total de pleitos concedidos, acima especificado.

250 Além das pastas dos empreendimentos, nas quais, constavam inúmeras informações sobre as realizações dos órgãos em Salvador.

251 Um deles foi efetivamente edificado após 1964, o Conjunto do IPSEP-BA (Dr. Adriano Gordilho), situado no bairro de Itapagipe, conformado por 10 blocos de apartamentos sobre pilotis.
} 
doado pelo governo do estado, no bairro Mares ${ }^{252}$. Em acordo firmado entre 0 órgão e a administração pública, deveria ser edificado, além das unidades habitacionais, uma "(...) escola moderna, atendendo aos princípios de higiene e de técnica (...) determinadas pela Secretaria da Educação e Saúde do Estado (...)" (DECRETO N.11.447, 23/10/1939), que iria substituir o prédio da então Escola Cincinato Franca253 (Figura 35).

Há referências ainda à edificação do edifício comercial São José, pelo IAPETC (1946) e à aquisição, em maio de 1954, do Sanatório Manoel Vitoriano S/A, próximo à Praça Almeida, por parte do IAPI, para comportar serviços ambulatoriais e hospitalares para os seus segurados. Em 1968, o Parque Jockey Clube de Salvador foi adquirido pelo IPASE ${ }^{254}$. Também foi edificado em terreno de propriedade desse Instituto, em 1969, o Conjunto Habitacional dos Subtenentes e Sargentos da Bahia (COHEX I) 255 , e em 1976, o

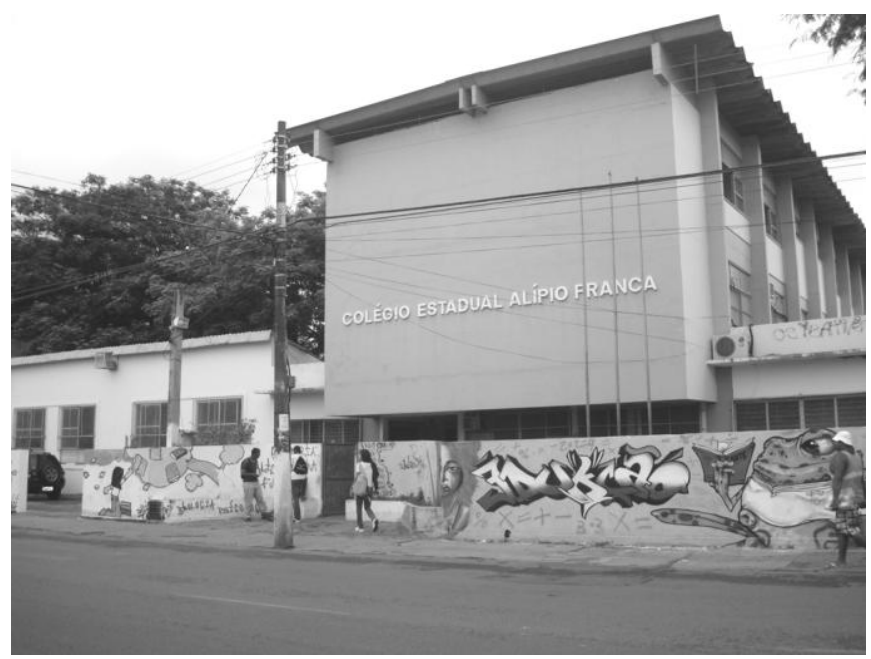

Figura 35: Escola edificada pelo IAPETC em Salvador, na década de 1940.

Fonte: Arquivo pessoal, 2011.

Conjunto da Cooperativa Habitacional dos Empregados em Estabelecimentos Bancários da Bahia $(\text { CHEEBB })^{256}$. Outras edificações foram locadas, posteriormente, em terrenos que originalmente eram de propriedade das CAPs e dos IAPs em Salvador e em outras cidades próximas, como o Instituto de Saúde do Estado da Bahia (1980), o Prolongamento da Avenida Professor Magalhães Neto e sua articulação com a Avenida Luiz Viana Filho, a Estação Rodoviária do Município de Barreiras, o COTEGIPE em Caetitéia e a Praça da Bandeira em Canavieiras.

Em se tratando da produção das CAPs e dos IAPs entre as décadas de 1930 e 1960, o primeiro empreendimento habitacional concebido pelos órgãos em Salvador, de acordo com a pesquisa documental, não diz respeito a uma vila ou conjunto residencial, e sim a um loteamento realizado pela CAP dos Portuários. Segundo a escritura, a área foi adquirida por compra feita à Companhia Imobiliária da Bahia e concedidos pela Cessionária das Docas do Porto da Bahia ${ }^{257}$, para a referida Caixa, ainda na década de 1920. 0 terreno compreendia uma grande área do centro comercial de Salvador $\left(59.148,40 \mathrm{~m}^{2}\right)$, próximo à Praça da Inglaterra,

\footnotetext{
252 Próximo ao Conjunto Castro Alves, também de propriedade do IAPETC.

${ }^{253}$ A escola passou a se chamar Alípio Franca.

254 Uma área de 274.212,75m², conforme escritura lavrada em 24 de dezembro de 1968.

255 Compreende uma área de $45.200 \mathrm{~m}^{2}$.

256 Uma área de $180.021,00 \mathrm{~m}^{2}$.

257 De acordo com as determinações do Decreto n.14.417, de 16 de outubro de 1920, e do acordo firmado entre o Governo e a Cessionária em 24 de maio de 1921. A planta do empreendimento foi aprovada pelo Decerto n.14.787, de 30 de abril de 1924.
} 
abrangendo a Rua da Alfândega ${ }^{258}$, e foi destinado para a edificação de moradias para os trabalhadores portuários de Salvador ${ }^{259}$, bem como para a edificação da sede da CAP, situada na Avenida França, em 1938260 .

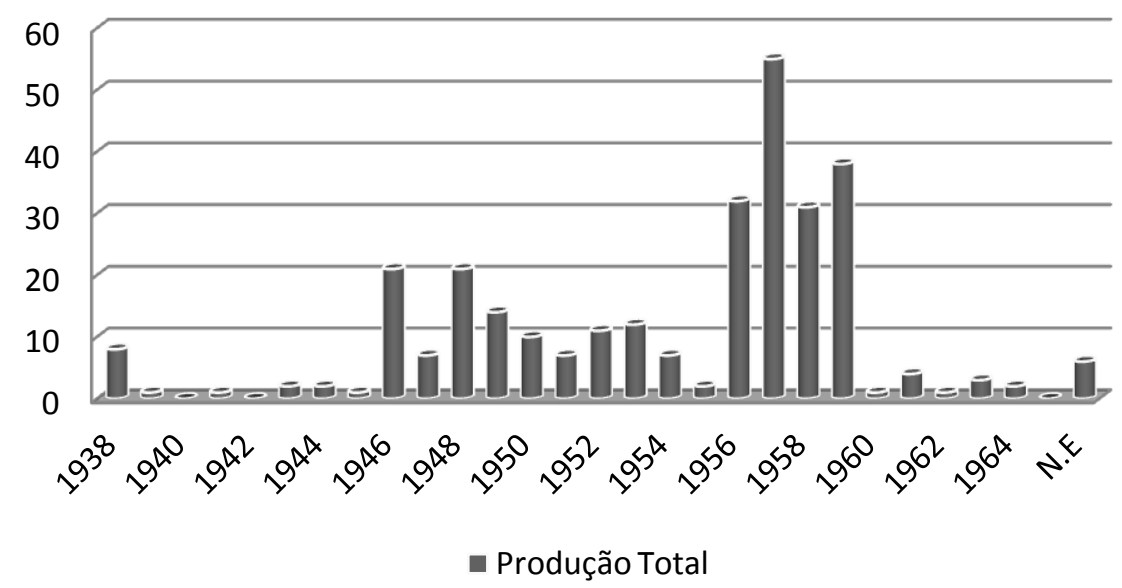

\section{Figura 36: Gráfico de distribuição da atuação das CAPs e dos IAPs em Salvador no período de 1938 a 1964. Fonte: Elaboração própria com base nos dados coletados no INSS-BA.}

No tocante ao período da realização dessas iniciativas ousa-se afirmar que, em Salvador, as CAPs e os IAPs apresentaram uma atuação mais homogênea que na maior parte das capitais nordestinas. O período de maior liberação de pleitos na cidade foi evidenciado entre os anos 1946 e 1959, apresentando picos de produção nos últimos quatro anos da década de 1950 (Figura 36). Também coincide com o período de agravamento da crise habitacional na cidade. Intensificado ainda mais com o término da vigência das Leis do Inquilinato e, consequentemente, do congelamento dos aluguéis urbanos, como se verá mais detalhadamente adiante $^{261}$. Para se ter noção desse quadro na capital baiana, basta apresentar os dados relacionados à concorrência para a locação de unidades do Conjunto Mutti de Carvalho (IAPB-1957)262. Na qual, para cada residência disponibilizada para aluguel havia 32 segurados do Instituto concorrendo. Vale ressaltar que esse quadro assim se configurou mesmo diante dos rígidos critérios de financiamento estabelecidos pelo IAPB-BA, em relação às possibilidades consignáveis e ao curto prazo para pagamento do pleito263.

0 órgão mais atuante em Salvador, tanto no que condiz às realizações diretas (construções de unidades habitacionais), como indiretas (representadas essencialmente pelos financiamentos para a

258 Excetuando as vias e praças públicas pré-existentes, bem como terrenos reservados à Associação Comercial da Bahia, à Companhia de Navegação Baiana, ao Serviço de Esgotos e os lotes já vendidos.

259 O número exato, bem como a planta do loteamento, não foi encontrado na pesquisa documental realizada na cidade.

260 Em 1940, todos os imóveis de propriedade da CAP dos Portuários, especialmente aqueles localizados em Conceição da Praia, passaram a integrar o patrimônio imobiliário do IAPM, de acordo com o Decreto-Lei n.2.120, de 20 de abril daquele ano.

261 Esse período extrapolou aquele colocado pela historiografia específica como o de maior produção dos órgãos no centro-sul do país, que começa a decair, progressivamente, a partir de 1950.

262 O IAPB em Salvador elegeu o aluguel em detrimento à venda das unidades de sua propriedade a partir, sobretudo, de meados da década de 1950, de acordo com o Ato n.649, de 09 de agosto de 1956. Essa modalidade de ação imobiliária foi inclusive reivindicada pelos próprios segurados do órgão, como vislumbrado no Conjunto Almirante Waldemar Mota (IAPB-1957).

263 Provavelmente por questões de retorno monetário priorizadas pelo supracitado Instituto. 
aquisição de terreno e/ou construção e reforma de moradia) foram o IAPB (101 pleitos) e o IAPC (64 pleitos), que em conjuntos foram responsáveis por $55 \%$ das ações empreendidas na cidade em todo o período estudado (Figura 38, página 159).

Em se tratando das categorias imobiliárias praticadas pelos referidos órgãos na cidade, observou-se que a ação mais empreendida foi a edificação de unidades habitacionais locadas em grupos de moradias, que representa $58,66 \%$ dos pleitos levantados (Figuras 38 e 39, página 159). Vale salientar que alguns desses conjuntos não foram edificados diretamente pelas delegacias regionais locadas em Salvador, e sim, por empresas construtoras contratadas, como se verá adiante, especialmente no que diz respeito à edificação dos exemplares de moradias coletivas verticais na cidade.

As unidades que constituem os grupos de moradias de propriedade dos Institutos e Caixas de Aposentadoria e Pensões foram, sobremaneira, alugadas aos trabalhadores soteropolitanos, vinculados às Carteiras Imobiliárias daqueles órgãos. Dos 24 conjuntos habitacionais identificados nesta pesquisa em Salvador, mais da metade permaneceu alugada aos segurados até meados da década de 1960, quando parte deles foi incorporada ao patrimônio do BNH ou do IPASE. Sendo assim, ao contrário do que se acreditava ter ocorrido na maior parte do Nordeste do país, a atuação dos supracitados órgãos no campo habitacional na capital baiana se deu, sobretudo, por meio de uma política de aluguel e não de venda de casa.

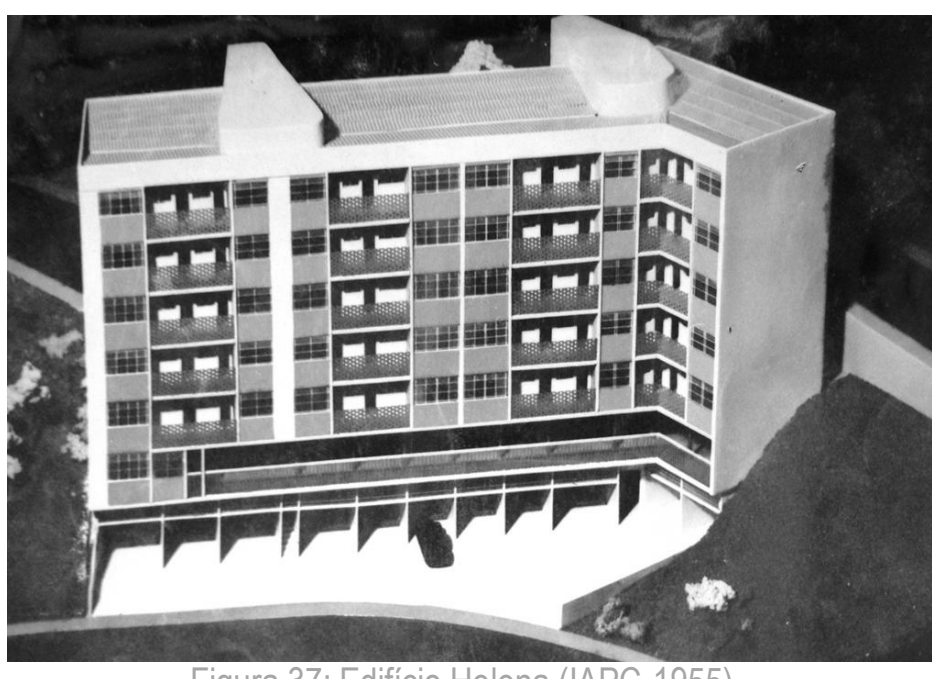

Figura 37: Edifício Helena (IAPC-1955). Fonte: INSS-BA, 2011

Foram identificados também, casos de aquisição de imóveis, principalmente edifícios de apartamentos, já edificados por terceiros, como o Edifício Morais, localizado no bairro de Brotas. 0 qual foi construído por João da Costa Falcão em meados da década de $1950^{264}$, adquirido por compra feita pelo IAPC, em 1957, e repassado para os associados por meio de venda (hipoteca). Referem-se também às 39 moradias que compunham a Vila dos Ferroviários

(CAPFESP/IAPFESP-1951), em Paripe, subúrbio de Salvador265, edificadas pela Sociedade Construtora Residencial Lida, adquiridas pelos referidos órgãos e repassadas aos seus segurados, durante a década de 1950. Outro caso interessante é o relacionado ao Edifício Helena (IAPC-1955), cuja construção foi solicitada por um grupo de segurados pleiteantes de financiamentos, de acordo com o Plano B daquele escritório estadual, e edificado a partir de então pelo Instituto (Figura 37).

\footnotetext{
264 Mais precisamente, a construção do edifício de apartamentos foi iniciada em 20 de agosto de 1956. Esse exemplar é conformado por seis pavimentos e duas unidades habitacionais por andar, totalizando 12 apartamentos.

265 Como especificado nos laudos de avaliação dos imóveis situados nessa Vila.
} 


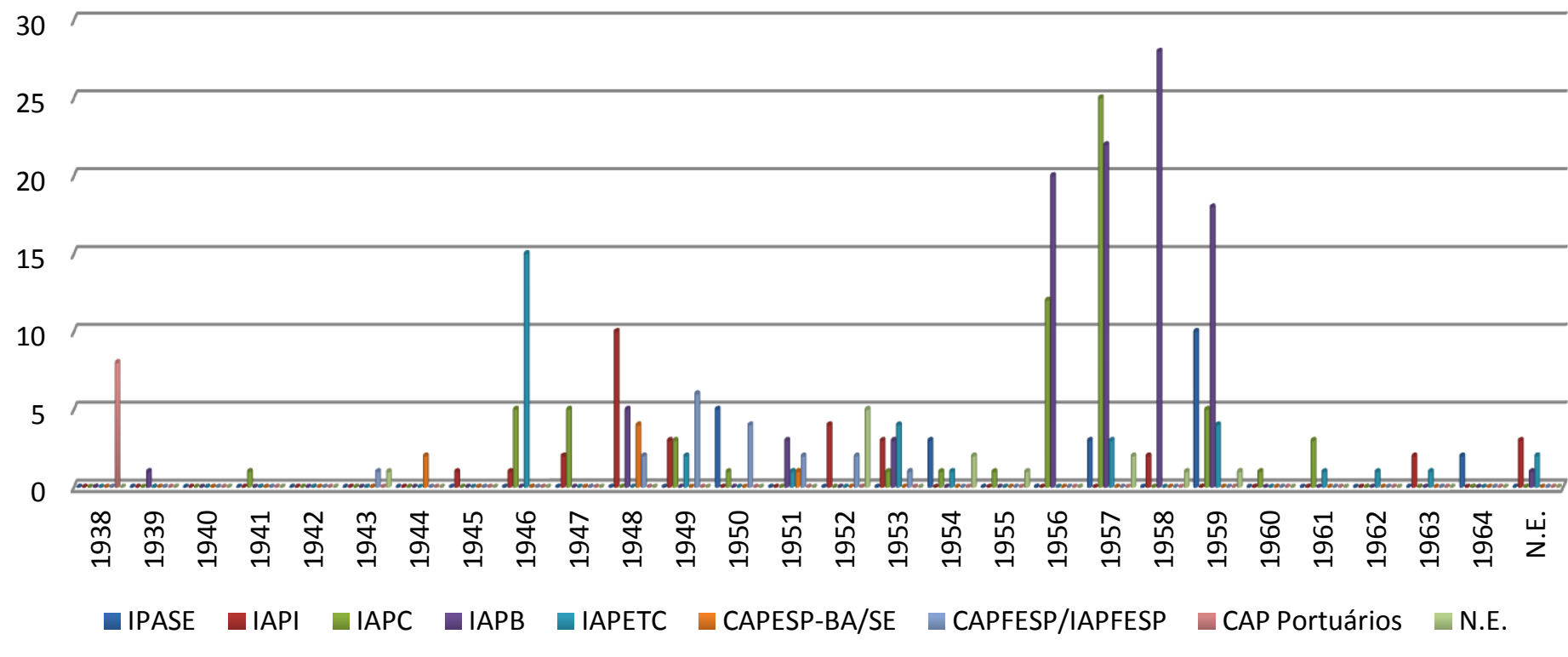

Figura 38: Quadro de distribuição da atuação dos escritórios estaduais dos institutos de previdência atuantes em Salvador. Fonte: Elaboração própria com base nos dados coletados no INSS-BA

\begin{tabular}{|c|c|c|c|c|c|c|c|c|c|c|c|c|c|c|c|c|c|c|c|c|}
\hline \multicolumn{21}{|c|}{ ATUAÇÃO DAS CAPS E DOS IAPS EM SALVADOR } \\
\hline \multirow{2}{*}{ Ações Imobiliárias } & \multicolumn{2}{|c|}{ IAPI } & \multicolumn{2}{|c|}{ IPASE } & \multicolumn{2}{|c|}{ IAPC } & \multicolumn{2}{|c|}{ IAPB } & \multicolumn{2}{|c|}{ IAPTEC } & \multicolumn{2}{|c|}{ CAPESP } & \multicolumn{2}{|c|}{ IAPM } & \multicolumn{2}{|c|}{ IAPFESP } & \multicolumn{2}{|c|}{ N.E. } & \multirow{2}{*}{ T. } & \multirow{2}{*}{$\%$} \\
\hline & No. & $\%$ & №. & $\%$ & №. & $\%$ & No. & $\%$ & No. & $\%$ & No. & $\%$ & No. & $\%$ & No. & $\%$ & No & $\%$ & & \\
\hline Compra do IAP/CAP & 26 & 83,8 & - & - & 43 & 67,18 & 51 & 50,5 & 35 & 100 & 04 & 57,14 & 07 & 87,5 & 07 & 38,88 & 03 & 23,07 & 176 & 58,66 \\
\hline Compra de terceiros & 04 & 12,9 & 20 & 86,95 & 14 & 21,87 & 30 & 29,7 & $-\overline{-}$ & 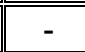 & 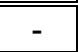 & 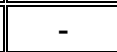 & - & - & 02 & $\overline{111,11}$ & 02 & 15,38 & 72 & 24 \\
\hline Compra de terreno/const. & 01 & 3,23 & 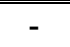 & - & 06 & 9,37 & 12 & 11,88 & - & - & 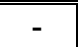 & - & $\overline{-1}$ & $\overline{-1}$ & 03 & 16,66 & 08 & 61,53 & 30 & 10 \\
\hline Const. terreno do segurado & - & - & 03 & 13,04 & 01 & 1,56 & - & - & - & 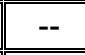 & 03 & 42,85 & - & - & - & - & - & - & 07 & 2,33 \\
\hline Reforma & - & - & - & - & - & - & 04 & 3,96 & - & - & - & - & - & - & 01 & 5,55 & - & - & 05 & 1,66 \\
\hline Aumento de Financ. & - & - & - & - & - & - & - & - & - & - & - & - & - & - & 01 & 5,55 & - & - & 01 & 0,33 \\
\hline Outras & 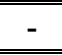 & - & - & - & - & 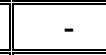 & - & - & - & - & - & - & - & 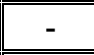 & 03 & 16,66 & 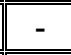 & - & 03 & 1 \\
\hline N.E. & - & - & - & - & - & - & - & - & - & - & - & - & 01 & 12,5 & 01 & 5,55 & - & - & 06 & 2 \\
\hline Total Abs. & \multicolumn{2}{|c|}{31} & \multicolumn{2}{|r|}{23} & \multicolumn{2}{|c|}{64} & \multicolumn{2}{|c|}{101} & \multicolumn{2}{|c|}{35} & \multicolumn{2}{|c|}{07} & \multicolumn{2}{|c|}{08} & \multicolumn{2}{|c|}{18} & \multicolumn{2}{|c|}{13} & \multicolumn{2}{|c|}{300} \\
\hline Atuação IAP & \multicolumn{2}{|c|}{$10,33 \%$} & \multicolumn{2}{|c|}{$7,66 \%$} & \multicolumn{2}{|c|}{$21,33 \%$} & \multicolumn{2}{|c|}{$33,66 \%$} & \multicolumn{2}{|c|}{$11,66 \%$} & \multicolumn{2}{|c|}{$2,33 \%$} & \multicolumn{2}{|c|}{$2,66 \%$} & \multicolumn{2}{|c|}{$6 \%$} & \multicolumn{2}{|c|}{$4,33 \%$} & & $0 \%$ \\
\hline
\end{tabular}


Nesse contexto, algumas parcerias estabelecidas entre os órgãos e terceiros, mormente empresas construtoras, no caso de Salvador, também podem ser aqui apontadas. Em 1955, o IAPC assinou contrato de financiamento para a compra de terreno e construção de um edifício de apartamentos para seus segurados, com a Imobiliária Nosso Senhor do Bonfim (pacto adjeto de hipoteca), "(...) respeitável êmpresa construtora sediada nesta capital, com um importante acêrvo de realizações urbanas e elevado crédito social e comercial (...)" (CARTA..., 28/05/1955, p.02). Nesse caso, em específico, o Instituto se comportou apenas como credor do valor pleiteado266, sendo a imobiliária responsável pela edificação do imóvel, que recebeu a mesma denominação da empresa, bem como pelo repasse dos seus apartamentos aos 32 associados contemplados pelo empreendimento ${ }^{267}$. Curiosamente, esse empreendimento já pretendia desde a solicitação para a realização, enviada ao Ministério do Trabalho pelo delegado do IAPC em Salvador no ano de 1955, atender aos trabalhadores da classe média:

(...) a aquisição de unidades residenciais apropriadas à classe média, como a dos comerciários, constitui um problema na Bahia ainda sem solução, conforme observa pessoalmente e pelos constantes e reiterados pedidos verbais de informações para financiamentos (...) nesta delegacia. Êste processo, que se originou de iniciativa de alguns comerciários, junto ao Exmo. Sr. Ministro do Trabalho, há mais de um ano, ora reiterado, é mais uma prova de que o problema continua atual. À vista do exposto, e desde as condições financeiras e conveniência administrativa o permitam, sou favorável a que se conceda autorização a esta delegacia para 0 processamento dos financiamentos requeridos (...) (CARTA..., 28/05/1955, p.01).

Talvez as recorrentes solicitações para financiamento e/ou aquisição de imóveis empreendidas pelos trabalhadores de classe média, não somente em Salvador, como também no restante do Nordeste e do país, tenham se conformado como uma das justificativas para legitimar a ação dos órgãos no campo habitacional para àquela camada populacional. No entanto, vale lembrar que a proposta original das CAPs e dos IAPs não abarcava esse objetivo, se propondo a conceder moradias aos que não tinham condições de angariá-las somente pelos seus esforços, sendo necessária a intervenção do poder público para tanto. Mais precisamente, esses órgãos pretendiam atender principalmente aos mais carentes, àqueles trabalhadores que não recebiam mais que três salários mínimos.

Apelos exaltados elaborados por trabalhadores com melhores condições financeiras, enviados aos escritórios estaduais, aos governos locais, ao CNT e, inclusive, diretamente endereçados ao Ministro do Trabalho, Indústria e Comércio, em diversos exercícios, podem ter contribuído da mesma forma. Em Salvador, essas solicitações, por assim dizer, foram encontradas tanto nas publicações da imprensa local, como em cartas redigidas por representantes de associações de trabalhadores e outras entidades, ou por

\footnotetext{
${ }^{266}$ A operação se enquadrava no Plano B, classe VII-B, do escritório estadual. O valor pleiteado e concedido, no ano de 1957, foi de $\operatorname{Cr} \$ 15.510 .000,00$ (cruzeiros), de acordo com o contrato de financiamento e com os laudos de avaliação realizados pelo IAPC, por meio do engenheiro avaliador Rivadavia Alves Barbosa, que também empreendeu a fiscalização da obra para o órgão, naquele ano.

267 Locado numa área de $1.636,50 \mathrm{~m}^{2}$, no bairro de Santo Antônio. Inicialmente pretendia-se edificar apartamentos para 65 segurados, mas questões relacionadas ao custo da construção e ao valor do financiamento liberado pelo Instituto levaram à redução daquele número.
} 
trabalhadores esporádicos. Outros chegaram a se reunir para solicitar ações mais específicas no tocante aos Institutos e Caixas, como foi o caso dos segurados atendidos pelo, já mencionado, Edifício Nosso Senhor do Bonfim (IAPC-1955):

(...) V. Exa não ignora os vexames por que passa a classe trabalhadora do Brasil, de nível médio, já no que diz respeito à dificuldade da simples manutenção da existência humana, já diante do problema da moradia, de solução tanto mais angustiante, como mais urgente. E V. Exa não ignora êsses vexames que alarmam a Administração Pública porque, homem de Govêrno hoje, em tão boa hora, à frente do Ministério do Trabalho, êsses são os problemas que, tão insistentemente, têm exigido de $V$. Exa dedicação invulgar e acendrado zêlo patriótico na solução dos casos que amiudamente the são levados a estudos e decisão. Somos 65 trabalhadores do Instituto dos Comerciários, 65 famílias trabalhadores da economia baiana e do engrandecimento do Brasil que, através dos respectivos chefes, pedem e requerem-Ihes não seja afastada a oportunidade de adquirirem a casa própria, o lar que abrigará seus filhos, ora sem confôrto e injustamente sacrificados na saúde, na educação e no próprio modus-vivendi, porque quase a metade, para uns, e a metade, para outros é desviada para o aluguel da casa em que residem, sem o mínimo confôrto e sem higiene (...) (CARTA..., 07/04/1954, p.01).

É claro que se deve levar em consideração o agravamento da crise habitacional, nas décadas de 1940 e de 1950, marcada essencialmente pelo déficit habitacional e pelas precárias condições das moradias urbanas no país, que levou o poder público a ampliar as verbas destinadas à edificação de moradias, por parte principalmente dos Institutos e Caixas de Aposentadoria e Pensões em 1945, além de outros atos legislativos, como a outorga de novas Leis do Inquilinato e o consequente congelamento dos aluguéis dos imóveis urbanos brasileiros até meados da década de 1950. Vale destacar ainda, que findado o período da estabilização dos valores cobrados pelos proprietários para locar seus imóveis em Salvador, mais precisamente a partir da outorga da Lei n.3.085 de 29 de dezembro de 1956, os aluguéis sofreram um reajuste astronômico na capital, colaborando ainda mais para a intensificação daquele quadro de crise. Também deve-se atentar para o fato da classe média, nesse período, ter sido atingida pelo déficit habitacional e ter endereçado ao poder público, direta ou indiretamente como salientou o delegado do IAPC em Salvador, uma série de reivindicações e solicitações nesse sentido. Porém, o volume de ações efetivadas para essa camada social e para as mais abastadas foi significantemente mais representativo que das ações sociais naquele campo, como se verá ao longo deste capítulo.

O supracitado trecho de carta redigida pelo delegado do IAPC, no ano de 1955, revela ainda que alguns dos escritórios estaduais, locados nas capitais nordestinas, ainda dependiam da autorização do MTIC, mais precisamente do Departamento Nacional de Previdência Social, antigo Conselho Nacional do Trabalho, para a execução de algumas obras no campo habitacional268. Essas autorizações diziam respeito essencialmente aos acordos e contratos firmados entre os referidos órgãos e terceiros, sobretudo empresas

268 É importante lembrar que, em 1939, o CNT passou por uma significativa reforma legislativa quanto à sua organização e funções. O Conselho passou a ser dividido em duas Câmaras (a Câmara da Justiça do Trabalho e a Câmara de Previdência Social), e seus serviços passaram a serem executados pelos Departamentos de Justiça do Trabalho e da Previdência Social, que passou a inspecionar e fiscalizar as CAPs e os IAPs, dentre outras funções. Juntamente ao Conselho passou a funcionar a Procuradoria do Trabalho e a Procuradoria da Previdência Social. 
construtoras, para a edificação de unidades coletivas verticais, cujo custo construtivo ultrapassasse meio milhão de cruzeiros ${ }^{269}$, assim como às solicitações endereçadas diretamente ao presidente da instituição ou diretamente ao Presidente da República em exercício. Outro aspecto que contribui para essa afirmativa refere-se ao fato que a maior parte dos empreendimentos efetivados pelos IAPs e pelas CAPs na região, foi adquirida ou construída sem a expressa autorização do DNPS e do MTIC.

Outro exemplo de parceria encontrado foi a estabelecida entre o IAPB, o Sindicato dos Empregados em Estabelecimentos Bancários da Bahia, a Empresa Carvalho \& Hosken (fundação e estrutura) e a Empresa Brasileira de Engenharia e Construtora Lippi (demais serviços), para a edificação de 44 unidades habitacionais que compõem o Conjunto Almirante Waldemar Mota, no bairro do Bonfim, na década de 1950. O IAPB era o proprietário da área de $4.012,80 \mathrm{~m}^{2}$ onde foram edificados os blocos de apartamentos, 0 concessionário do financiamento para a sua construção, o fiscalizador das obras, bem como o responsável pelo aluguel das unidades aos seus segurados por meio de concorrência ${ }^{270}$. As empresas construtoras também foram escolhidas por concorrência aberta271, enquanto o Sindicato, por meio da realização de debates com os trabalhadores, decidiu as diretrizes do financiamento, quanto ao aluguel ou alienação dos imóveis 272 .

Em Salvador, em particular, foram percebidos diversos registros de morosidade na entrega das unidades pleiteadas, assim como problemas quanto ao recebimento de unidades escolhidas ou adquiridas por concorrência. Em alguns casos, essa entrega demorou tanto que certos dos núcleos familiares dos trabalhadores sofreram modificações, sobretudo, quanto ao número de filhos e às condições financeiras. Casos como esses foram observados também no, já mencionado, Conjunto Almirante Waldemar Motta do IAPB.

Mais um aspecto curioso da atuação dos IAPs em Salvador, diz respeito aos cálculos estruturais de alguns conjuntos verticais, bem como a algumas fiscalizações de obras e avaliações de imóveis de propriedade dos órgãos. Mais precisamente, nos levantamentos documentais empreendidos na agência do INSS-PE foram encontradas pranchas arquitetônicas e documentos relacionados aos cálculos do Edifício do

\footnotetext{
269 De acordo com o Decreto n.15.175-A aprovado em 03 de julho de 1948. Casos semelhantes só foram evidenciados no Recife e em Fortaleza, como se verá adiante.

270 O profissional responsável pela avaliação da proposta piloto, bem como das solicitações dos segurados, para esse conjunto foi 0 engenheiro fiscal local do IAPB, Manoel Augusto Leon. Esse foi um caso parecido com o do Conjunto Nosso Senhor do Bonfim (IAPC-1955), no qual, os segurados pleiteantes enviaram carta ao presidente do IAPB solicitando a aprovação, assim como o aceleramento dos trâmites inerentes à proposta.

271 Mais precisamente, a escolha das empresas para o estabelecimento dessa parceria, em especial, foi dada por meio de concorrência pública, realizada na primeira metade da década de 1950. O projeto foi de autoria dos arquitetos Diógenes Rebouças e José Bina Fonyat Filho, professores do Curso de Arquitetura da Escola de Belas Artes de Salvador.

272 Esses debates, ou mesas redondas como eram chamadas, eram realizadas, mormente, pelos representantes do Sindicato e 0 Chefe da Divisão do Patrimônio Imobiliário do Departamento de Inversões do IAPB em Salvador, que naquela época era 0 engenheiro Accio Luciano Borges, e aberta aos trabalhadores da classe. Somente depois de decididas essas diretrizes de repasse das unidades, em junho de 1958, que os editais para a inscrição dos segurados na concorrência foram publicados nos periódicos da época. Participaram da concorrência para o aluguel das 44 unidades que compunham o supracitado conjunto, 107 trabalhadores. $O$ número de trabalhadores vinculados ao IAPB, naquele momento, era de 1.500 associados.
} 
Salvador, de propriedade do IAPC, edificado a partir do ano de 1954273, provavelmente devido a uma parceria estabelecida entre os escritórios estaduais do Instituto. Outro exemplo está relacionado à fiscalização das obras de construção do Conjunto Almirante Waldemar Motta (IAPB-1957), empreendida pelo engenheiro Benedito Toledo Patrício, do corpo técnico do IAPB do Rio de Janeiro. Ainda podem ser citados os episódios das avaliações para a venda das unidades habitacionais que conformam o Conjunto Residencial do Salvador (IAPI-1952), realizadas a partir de $1964^{274}$, pelo arquiteto Adauto S. S. Ferreira e pelo engenheiro civil Paulo A. F. de Castro, no Recife.

Em meados da década de 1950 foram registradas denúncias apontando para a ação ilegal da Prefeitura Municipal de Salvador, que estava se recusando a conceder isenção dos impostos que incidiam sobre os imóveis de propriedade da Caixa de Aposentadoria e Pensões dos Ferroviários e Empregados nos Serviços Públicos (CAPFESP), como previsto em lei. Essa instituição de previdência social, como já se sabe, era uma autarquia federal cujos bens, rendas e serviços, por força de diplomas legais, equiparavam-se aos da União, para fins de imunidade tributária prevista pela Constituição. Esse episódio revela o quão eram independentes os Institutos e Caixas, sobretudo no campo habitacional, de fiscalização e intervenção governamental, essencialmente nas instâncias estaduais e municipais.

A isenção de taxas e impostos prediais, concedida aos institutos de previdência que atendiam ao funcionalismo público - que além da CAPFESP eram representadas pelo IPASE, pelos IPEs e outras Caixas Militares - era pretendida para outras categorias trabalhistas por membros que compunham o corpo técnico do MTIC, especialmente do Conselho Nacional do Trabalho e, posteriormente o DNPS, desde o início da década de 1930, quando começaram a serem criados os IAPs subordinados ao referido Ministério, e já praticado para a CAPIN e por Institutos de Previdência do Ministério da Fazenda e da Guerra, desde o início da década de 1920. Esse intento foi percebido, sobretudo, no discurso e nas publicações formuladas pelo engenheiro-arquiteto Rubens Porto, chefe da Seção de Engenharia do CNT desde quando foi criado o MTIC, em 1931, mas só foi alcançado nos primeiros anos da década de 1940, quando foi ampliado para todas as CAPs e IAPs atuantes no campo da moradia no país 275 .

Da mesma forma que certas obras de embelezamento e remodelação urbana do início do século XX, alguns empreendimentos habitacionais dos institutos de previdência atuantes em Salvador, como em outras capitais nordestinas, resultou na demolição e/ou desapropriação de famílias carentes, na maior parte das vezes, que viviam nas áreas de modo irregular. Esse foi o caso do Conjunto Residencial do Salvador ou dos Industriários (IAPI-1952), que para a sua edificação foram desapropriadas cerca de dez famílias que habitavam o terreno em pequenos casebres de taipa e cobertos por palha, além de barracões improvisados.

\footnotetext{
273 Esses cálculos foram desenvolvidos pelos engenheiros civis Delano Lins e Geraldo Vieira.

274 Os apartamentos daquele conjunto permaneceram alugados aos segurados até esse ano.

275 Por meio do Decreto-lei n.6.601, de 22 de novembro de 1943, que especificava que os bens imóveis que as autarquias de previdência social prometessem vender aos segurados, mediante escritura de promessa de venda, conservavam a sua imunidade, até que fosse desvinculada, definitivamente, do patrimônio das referidas entidades.
} 


\section{Recife-PE:}

Com base nos levantamentos documentais realizados nos arquivos do Recife foi possível identificar 49 empreendimentos efetivados direta ou indiretamente pelos IAPs e CAPs na cidade. Todas essas edificações comportam exclusivamente moradias ou compartilham a estrutura com outras funções, como institucional e comercial, como foi mais largamente empreendido na capital pernambucana. Essas realizações somam um montante de 11.895 moradias, a maior parte das quais, construída até o ano de 1964276 .

Esse expressivo volume de realizações identificados na cidade destoa da ínfima produção habitacional elencada aos Institutos e às Caixas pela historiografia sobre o assunto. Só a produção de unidades habitacionais diretamente pelos órgãos no Recife, sem considerar a produção indireta, aquela incitada pelos segurados, chega-se a 33,78\% do que Farah (1983) afirma ter sido concedido em todo o Norte, Nordeste e Sul do país, e supera em mais de $400 \%$ o volume de produção especificado no estudo realizado pela GAP (1985), que dá ênfase somente a edificação do conjunto Areias e alguns poucos financiamentos isolados, que totalizam 1.790 moradias.

Segundo o Clovis Campelo, técnico do seguro social do INSS-PE no ano de 2011, em entrevista concedida à autora, o Recife foi a segunda capital brasileira mais contemplada com realizações no campo habitacional, tanto no que concerne às ações diretas quanto às indiretas, só perdendo em número de unidades edificadas para a cidade do Rio de Janeiro. Atualmente, o arquivo do patrimônio daquela agência consta de aproximadamente 4.000 processos imobiliários, e o dobro deste volume está arquivado no CDOC do Instituto, o chamado arquivo morto.

Além das realizações no campo da moradia, no Recife, diferente do vislumbrado na maior parte das capitais nordestinas, foi identificado um número considerável de empreendimentos não habitacionais financiados ou edificados diretamente pelos órgãos ou em parceria com agentes construtores privados e 0 governo. São alguns exemplos: o Hotel Guararapes situado no bairro de Santo Amaro; o Hospital João Goulart em Olinda; o edifício JK, que já foi sede do INSS-PE; o prédio Independência (IPASE-dec.1950); 0 Edifício da Procuradoria Geral de PE (antiga sede do IPSEP); e o prédio sede do FUNRURAL em Santo Amaro. Os hospitais Getúlio Vargas, Agamenon Magalhães e Barão de Lucena (adquirido pelo IPASE, da Associação dos Produtores de Cana) também foram edificados ou angariados nas décadas de 1940 e 1950 pelos Institutos, dentre diversos outras edificações que serão apresentados ao longo desta tese. No contexto de incentivos à produção de automóveis e caminhões com capitais privados estabelecidos pelo Grupo Executivo da Indústria Automobilística (GEIA), criado na década de $1940^{277}$, foram ainda concedidos diversos financiamentos para a aquisição de veículos de médio e grande porte no Recife.

276 Esse número foi identificado com base nos documentos e projetos originais dos conjuntos e edifícios. Algumas das etapas de construção dos empreendimentos foram concluídas ao longo da segunda metade da década de 1960 e posteriormente. Também não foi possível identificar e/ou precisar o número de unidades habitacionais que compunham seis dos 49 conjuntos, vilas, grupos ou edifícios edificados no Recife.

277 Por meio do qual, diversas empresas estrangeiras foram atraídas para o país, como a Ford, Willys Overland, a Volkswagem e a General Motors, que passaram a delinear o ABC paulista (FAUSTO, 2007). 
Assim como em Salvador, parcerias estabelecidas entre as CAPs e os IAPs podem ser apontadas. Algumas foram firmadas entre o IPASE e o IPSEP e a SUDENE ${ }^{278}$, para a edificação de conjuntos residenciais, situados no bairro lbura ${ }^{279}$. Mormente, as construções eram financiadas pelo IPASE ou pelo IPSEP, e suas unidades eram destinadas aos empregados e prestadores de serviço vinculados à SUDENE. Esse foi o caso do Conjunto Residencial General Euler Bentes Monteiro ou, como é comumente chamada, Vila da SUDENE, localizada no bairro de Ibura280. Na qual, as unidades foram adquiridas pelos segurados, principalmente pelos empregados do Departamento de Energia e da Companhia Nordestina de Sondagens e Perfurações (CONESG), por meio de concorrência281 realizada sob a fiscalização e responsabilidade da SUDENE ${ }^{282}$. Uma curiosidade quanto a esse Conjunto, em especial, refere-se ao fato que os associados escolhidos, a partir da assinatura do termo de ocupação e da entrega das chaves, residiram gratuitamente nas unidades até a determinação do preço de venda:

(...) Que, a partir da data de assinatura do presente Têrmo de Ocupação, será o aludido imóvel ocupado gratuitamente, até a ocasião em que fôr fixado o seu preço de venda, o qual será determinado pelo IPASE, tão logo sejam elaborados os respectivos cálculos de custos e, em conseqüência com o estipulado nas Leis 4.380 de 21.08.64; 5.049 de 29.06.66; no Decreto-Lei no 19 de 30.08.66; no Decreto 56.995 de 01.10.65; e nas instruções do Senhor Presidente do IPASE (...) (PORTARIA N.100, 1966).

Parcerias também foram percebidas entre os Institutos e Caixas e Sindicatos de trabalhadores no Recife. Vale destacar, que poucos foram os casos expressos de acordos firmados entre essas entidades de classe, identificados ao longo da pesquisa documental realizada nas sete capitais nordestinas trabalhadas nesta tese. Esse foi o caso observado no Conjunto Jardim São Paulo, localizado no bairro de Areias, edificado pelo IAPC, no ano de 1952. Nele, os imóveis foram escolhidos por sorteio realizado pelo Sindicato

278 Segundo Fausto (2007), a SUDENE foi criada para atuar paralelamente ao DNOCS (Departamento Nacional de Obras Contra as Secas), para promover o planejamento e a industrialização do Nordeste, sendo diretamente subordinado à presidência da Repúbica.

${ }^{279}$ Após 1964, também são percebidos contratos entre esses órgãos e o BNH, no contexto do Plano da Casa Própria empreendido pelo referido Banco.

280 A decisão de acordo entre o IPASE e a SUDENE começou a ser discutida ainda nos primeiros anos da década de 1960, mas somente em 1966 que o acordo entre os órgãos foi assinado.

281 Para solicitar um financiamento nesse conjunto, o segurado deveria apresentar: 1- declaração fornecida pelo DRP/DPE da SUDENE, comprovando ser trabalhador vinculado ao órgão, bem como o valor dos vencimentos recebidos por tal; 2- Proposta de compra elaborada pelo segurado; 3- Último contra cheque; 4- Declaração de ser viúvo, solteiro, desquitado ou certidão de casamento; 5- Termo de tutela ou de responsabilidade firmado por uma autoridade judicial; 6 - Certidões de nascimentos dos filhos e/ou demais dependentes; 7- Apresentação de documento comprobatório de notificação judicial para fins de despejo (se fosse 0 caso); 8- Recibo de pagamento do último aluguel da casa em que reside (se fosse o caso); 9- Certidão negativa de imóveis firmada por cartórios da cidade; 10- Certidão negativa de débitos nos cartórios da Fazenda; 11- Certidão negativa do cartório de títulos e protestos da cidade; 12- Cópia do título de eleitor; 13- Termo de ocupação (quando da entrega das chaves do imóvel) e 14- Ficha financeira.

${ }^{282}$ A SUDENE também estava autorizada a determinar a imediata desapropriação do imóvel se 0 ocupante realizasse obras de alteração e/ou modificação de qualquer natureza, sem o prévio consentimento do IPASE ou se o ocupante não concordasse com os termos da venda do imóvel ou retardasse a assinatura dos documentos no prazo de mais de 30 dias. À SUDENE também cabia à responsabilidade integral da conservação, estado de habitabilidade e as despesas para com a administração dos imóveis que constituem o conjunto habitacional até que essas especificações fossem estabelecidas na escritura de Convenção e Condomínio do Conjunto, executando as suas custas, as obras para isso exigidas pelas autoridades competentes, podendo o IPASE vistoriá-las, sempre que julgasse conveniente. Também era responsabilidade da SUDENE, orientar a elaboração das normas relativas à administração do Conjunto e até que elas entrassem em vigor, realizar a administração sem qualquer ônus ao IPASE, podendo cobrar cotas para o custeio desse serviço dos segurados beneficiados. 
dos Empregados do Comércio do Recife, cujo resultado foi somente informado ao Presidente do IAPC, para ser encaminhado aos segurados vinculados às duas instituições. A edificação das unidades ficou a cargo do referido Sindicato e o financiamento e a fiscalização das obras foi elencada ao Instituto.

Vale destacar, que no contexto de estruturação e reforma dos institutos de previdência, em fins da década de 1920 e nos primeiros anos da década de 1930, utilizou-se o artifício da sindicalização das entidades de classe, especialmente, para a incorporação delas no contexto previdenciário brasileiro, de modo significativo e participativo ${ }^{283}$. Os sindicatos oficiais, como passaram a serem chamados após o processo de legalização284, foram subordinados ao recém-criado Ministério do Trabalho, Indústria e Comércio (MTIC) e, no plano do discurso, incorporados no processo de estruturação e criação dos Institutos de Aposentadoria e Pensões do MTIC. Contudo, esse intento (ou justificativa para legitimação do controle estatal sobre essas organizações dos trabalhadores, dependendo da ótica da interpretação), não foi efetivamente empreendido. Ainda na década de 1930, pretendia-se deixar a assistência médica e odontológica a cargo dos sindicatos. Mas, da mesma forma, a incapacidade orçamentária de manter essas formas de assistência fez com que os sindicatos passassem a pressionar os IAPs e CAPs a oferecê-las. Somente com a outorga das Leis do Trabalho285 foi determinada a utilização da contribuição sindical pelas entidades de empregados (institutos de previdência) para o financiamento da assistência médica, dentária, hospitalar e farmacêutica, concessão de auxílio-funeral, dentre outros benefícios. Porém, são poucos os registros históricos de parcerias firmadas entre as supracitadas instituições no campo habitacional, como a já apontada em Salvador e a elencada acima no Recife.

Voltando às ações dos IAPs e CAPs na capital pernambucana, pode-se dizer que além dos órgãos tipicamente atuantes no campo habitacional em praticamente todo o nordeste do país, representados essencialmente pelo IPASE, IAPI, IAPC, IAPB, IAPETC e CAPFESP/IAPFESP, teve um papel de representatividade no Recife o IPSEP (Instituto de Previdência dos Servidores do Estado de Pernambuco) que, como colocado anteriormente, estabeleceu parcerias e edificou um número significativo de moradias na cidade, sobretudo, a partir da segunda metade da década de $1960^{286}$.

Em se tratando das autorizações para a edificação de unidades habitacionais, percebeu-se um padrão contínuo de concessões ao longo dos anos no Recife, apresentando ápice de autorizações nos anos de 1947, quando foram autorizadas a edificação de 1.648 residências distribuídas em quatro conjuntos, de 1952, na ocasião da qual foram liberadas para a construção 1.450 moradias situadas em um único conjunto

\footnotetext{
${ }^{283}$ Representado pelo Decreto n.19.770, de 19 de março de 1931. Nesse período, as organizações dos trabalhadores só poderiam, por exemplo, eleger representantes nas CAPs e posteriormente nos IAPs, a menos que se sindicalizassem, não possuindo desta maneira, voz ativa nos debates sobre a estruturação da previdência estatal no Brasil, bem como sua legislação e gestão caso contrário (SILVA JR., 2007).

${ }^{284}$ Consistia basicamente na reavaliação dos regulamentos de criação e funcionamento dos sindicatos existentes para a aprovação e/ou reforma, quando fosse julgado necessário, por parte do Ministério do Trabalho, Indústria e Comércio (MTIC).

285 Sobremaneira do Decreto-Lei n.5.452, de 01 de maio de 1943.

286 Em João Pessoa, Natal e Fortaleza, também foi percebida a atuação de um Instituto de Previdência do Estado, como será detalhadamente colocado adiante.
} 
residencial, e nos anos 1960, 1963 e 1964, ao longo dos quais foram autorizadas as construções de oito conjuntos, um total de 4.810 unidades habitacionais ${ }^{287}$ (Figura 40). Nesse sentido, o Instituto que mais liberou financiamentos para a edificação de grupos residenciais no Recife foi o IAPC, responsável pela construção de nove conjuntos de moradias, compostos por um total de 4.440 residências. Sendo seguindo pelo IPSEP, que se comprometeu à edificação de quatro grupos residenciais ( 2.800 casas), e pelo IPASE, que edificou, no total, 2.004 moradias distribuídas em quatro conjuntos.

A partir da análise dos dados históricos e relacionados ao volume de liberações de unidades habitacionais já se pode perceber que o funcionalismo público, em suas três instâncias, foi a parcela populacional mais atendida pela política pública habitacional implementada pelos institutos de previdência no Recife. Quadro muito semelhante ao observado em outras capitais nordestinas e que segue a tendência observada

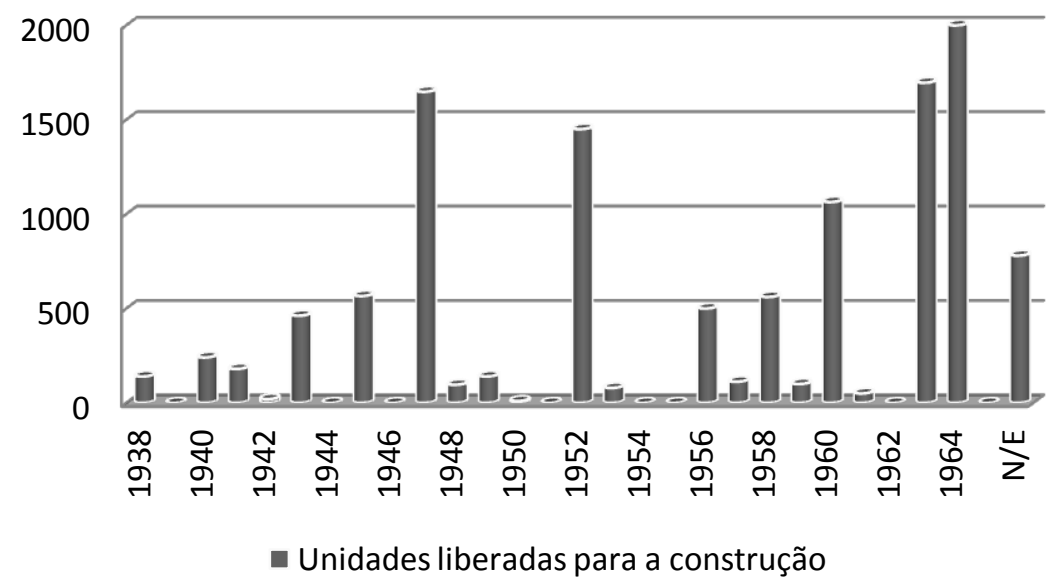

Figura 40: Quadro geral das liberações para construção e/ou financiamento de moradias das CAPs e dos IAPs no Recife.

Fonte: Elaboração própria com base nos dados coletados no INSS-PE. antes mesmo da criação das

CAPs e IAPs subordinadas ao MTIC, pela Caixa de Pensões da Imprensa Nacional (CPIN) ${ }^{288}$, que atendia aos trabalhadores da Casa da Moeda, do Diário Oficial, dos Correios, dentre outros órgãos, e pelo Instituto de Previdência dos Funcionários Públicos da União, que desde a década de 1920 atendia, privilegiadamente, aos funcionários do Estado, concedendo moradias e outros benefícios exclusivos àquela população, muitas vezes sem custo algum para aqueles trabalhadores.

Ainda em se tratando das liberações para a edificação de conjuntos, destaca-se a atuação do IAPB e do IAPETC, que edificaram cinco grupos habitacionais cada um. No entanto, esses exemplares se conformaram, mormente, por um pequeno número de moradias, que somadas não chegam a representar $5 \%$ da produção total. O IAPM, por sua vez, foi o órgão que menos realizou concessões aos seus segurados e edificou moradias no Recife. Sendo responsável apenas pela construção de um pequeno conjunto residencial composto por doze unidades unifamiliares isoladas, situado na Av. Beberibe, no ano de 1949.

\footnotetext{
287 Nesse período, se destaca a atuação do IPASE e do IPSEP no setor, no Recife.

288 Subordinada ao Ministério da Fazenda, como já colocado no primeiro capítulo desta tese.
} 
Um panorama muito próximo ao supracitado, tanto em relação ao período de atuação quanto ao volume de produção, foi encontrado ao se analisar as fichas dos levantamentos processuais na capital pernambucana ${ }^{289}$. No tocante ao período de produção, observou-se que os momentos de maior produção habitacional e realização de financiamentos no Recife foram praticamente os sequentes aos maiores períodos de liberação para a edificação de conjuntos, representados, sobretudo, pelos anos de 1947 a 1949 e de 1956 (Figura 41). Mais especificadamente, a produção dos órgãos decresceu nos três primeiros anos da década de 1960, alcançando novamente o cume em 1963, devido essencialmente às ações do IPASE e do IPSEP. Cabe lembrar, que tanto o IPASE quanto o IPSEP continuaram a construir e a financiar moradias no Recife após 1964 e ao longo da década seguinte. Foram identificados, inclusive, grupos residenciais cuja construção e

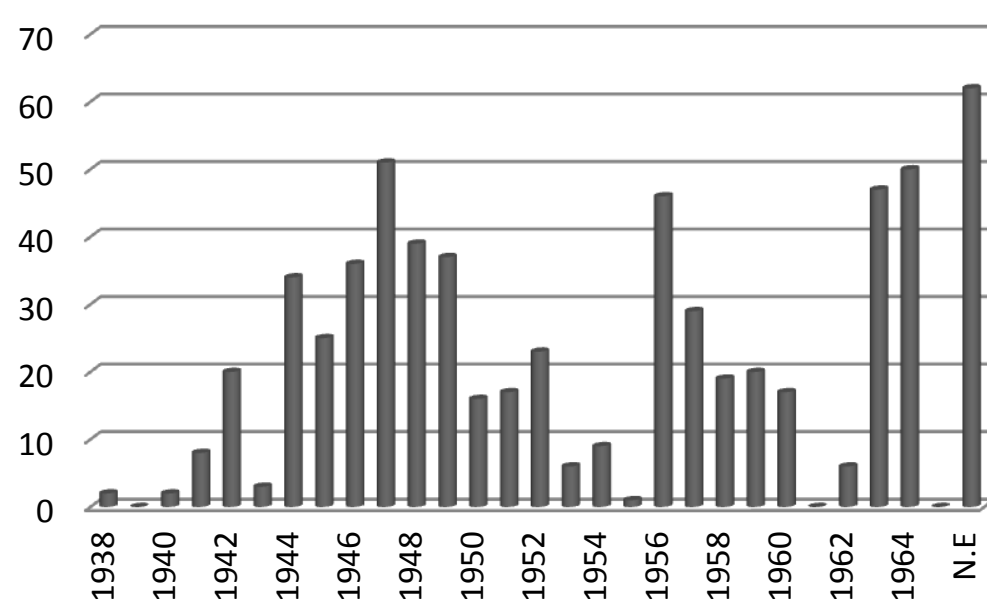

- Produção Geral

Figura 41: Quadro geral da atuação (unidades construídas e/ou financiadas) das CAPs e dos IAPs no Recife.

Fonte: Elaboração própria com base nos dados coletados no INSSPE. comercialização perduraram pelas décadas de 1970 e 1980, no caso específico do IPSEP ${ }^{290}$.

O início da atuação dos órgãos quanto à liberação da construção se deu no ano de 1938, quando foram autorizadas as construções de três conjuntos (140 moradias) pela CAP do Nordeste Brasileiro291, pela CAPESP/CAPFESP-PE/AL e pelo IAPETC, destinadas, especialmente, aos ferroviários, portuários e operários da indústria têxtil. 0 mesmo recorte inicial pode ser atestado nos levantamentos documentais. Foi também no ano de 1938, que foi identificado o primeiro financiamento para aluguel de unidade de propriedade da CAP do Nordeste Brasileiro, na cidade.

No Recife, é evidente o aumento do número de unidades dos conjuntos residenciais, bem como a extensão deles, com o passar dos anos, especialmente a partir de fins da década de 1950 e nos primeiros anos de 1960. Esse aspecto foi percebido principalmente no âmbito dos Institutos que se destinavam a atender aos funcionários públicos recifenses; uma tendência que viria a ser concretizada na nova política habitacional, instituída a partir de 1964.

\footnotetext{
289 Vale apontar que no levantamento documental foram angariados 625 processos imobiliários empreendidos pelas CAPs e IAPs atuantes na cidade, que se encontram arquivados no Setor de Patrimônio do INSS-PE.

290 Uma vez que o IPASE foi incorporado ao IAPAS no ano de 1979.

291 A CAP do Nordeste Brasileiro, assim como a CAP da Great Western, foi incorporada à CAPFESP, na década de 1940, e essa, por sua vez, foi posteriormente englobada pelo IAPFESP, ainda em fins dessa década. 0 mesmo ocorreu no âmbito da CAP dos Serviços Aéreos e Telecomunicações, cuja reserva orçamentária e patrimonial foi incorporada ao IPASE, em meados dos anos de 1950.
} 
Em se tratando dos processos levantados, o Instituto mais atuante no Recife também foi o IAPC, responsável pela edificação e financiamento de $27,68 \%$ dos pleitos levantados (Figura 42). A ele foi seguido 0 IPASE, encarregado pela concessão de $23,04 \%$ dos processos liberados na capital pernambucana. Quanto às categorias imobiliárias, observou-se que foi a venda e/ou aluguel de unidades de propriedade dos órgãos, a que mais representatividade teve no período, correspondendo a $93,60 \%$ dos pleitos levantados. Essas ações foram empreendidas de modo significativo por todos os Institutos e Caixas atuantes na referida capital, os quais reservaram pelo menos $80 \%$ de suas verbas para investimentos diretos no setor da moradia. As demais categorias imobiliárias tiveram pouco destaque no quadro habitacional recifense ${ }^{292}$.

\begin{tabular}{|c|c|c|c|c|c|c|c|c|c|c|c|c|c|c|c|c|}
\hline \multicolumn{17}{|c|}{ ATUAÇÃO DAS CAPS E DOS IAPS NO RECIFE } \\
\hline \multirow{2}{*}{$\begin{array}{c}\text { Ações } \\
\text { Imobiliárias } \\
\end{array}$} & \multicolumn{2}{|c|}{ IAPI } & \multicolumn{2}{|c|}{ IPASE } & \multicolumn{2}{|c|}{ IAPC } & \multicolumn{2}{|c|}{ IAPB } & \multicolumn{2}{|c|}{ IAPTEC } & \multicolumn{2}{|c|}{ IAPFESP } & \multicolumn{2}{|c|}{ N.E. } & \multirow{2}{*}{ Total } & \multirow{2}{*}{$\%$} \\
\hline & No. & \%\% & No. & 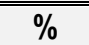 & No. & 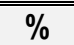 & No. & \% & No. & $\%$ & No. & "\% & No & \%\% & & \\
\hline $\begin{array}{c}\text { Compra de } \\
\text { unidade do } \\
\text { Instituto/Caixa }\end{array}$ & 53 & 100 & 136 & 94,44 & 159 & 91,9 & 50 & 86,2 & 85 & 94,44 & 87 & 94,55 & 15 & 100 & 585 & 93,6 \\
\hline $\begin{array}{c}\text { Compra de } \\
\text { imóvel já } \\
\text { edificado de } \\
\text { terceiros }\end{array}$ & - & - & - & - & 01 & 0,58 & - & - & - & - & - & - & - & - & 01 & 0,16 \\
\hline $\begin{array}{c}\text { Compra de } \\
\text { terreno e const. } \\
\text { de residência }\end{array}$ & - & - & - & - & 12 & 6,94 & 04 & 6,9 & - & - & - & - & - & - & 16 & 2,56 \\
\hline $\begin{array}{l}\text { Construção em } \\
\text { terreno do } \\
\text { segurado }\end{array}$ & - & - & - & - & - & - & 04 & 6,9 & - & - & 05 & 5,44 & - & - & 09 & 1,44 \\
\hline Reforma & - & - & - & - & - & - & - & - & - & - & - & - & - & - & - & - \\
\hline $\begin{array}{l}\text { Aumento de } \\
\text { Financiamento }\end{array}$ & - & - & - & - & - & - & - & - & 05 & 5,56 & - & - & - & - & 05 & 0,8 \\
\hline Outras & - & - & 08 & 5,56 & 01 & 0,58 & - & - & - & - & - & - & - & - & 09 & 1,44 \\
\hline N.E. & - & - & - & - & - & - & - & - & - & - & - & - & - & - & - & - \\
\hline Total Absoluto & \multicolumn{2}{|c|}{53} & \multicolumn{2}{|c|}{144} & \multicolumn{2}{|c|}{173} & \multicolumn{2}{|c|}{58} & \multicolumn{2}{|c|}{90} & \multicolumn{2}{|c|}{92} & \multicolumn{2}{|c|}{15} & \multicolumn{2}{|c|}{625} \\
\hline Atuação IAP & \multicolumn{2}{|c|}{$8,48 \%$} & \multicolumn{2}{|c|}{$23,04 \%$} & \multicolumn{2}{|c|}{$27,68 \%$} & \multicolumn{2}{|c|}{$9,28 \%$} & \multicolumn{2}{|c|}{$14,4 \%$} & \multicolumn{2}{|c|}{$14,72 \%$} & \multicolumn{2}{|c|}{$2,4 \%$} & \multicolumn{2}{|c|}{$100 \%$} \\
\hline
\end{tabular}

Figura 42: Quadro de classificação das ações imobiliárias das CAPs e dos IAPs no Recife.

Fonte: Elaboração própria com base nos dados coletados no INSS-PE.

Em muitos processos imobiliários no Recife, procedeu-se o aluguel por um prazo pré-determinado e depois era facultada a aquisição do imóvel aos seus ocupantes. Quando não firmados os contratos de compra e venda, a residência voltava à pauta da concorrência e era repassada para outro trabalhador associado. Em outros casos, como nas unidades do Conjunto Lafayete Coutinho (IAPC-1946), as unidades foram inicialmente alugadas até a quitação do financiamento, no caso de compra, ou alugada por dois anos renováveis ${ }^{293}$. Para permanecer na residência, passado esse prazo, o segurado deveria, necessariamente,

292 Foram elas: o financiamento para aquisição de terreno e edificação de residência (2,56\%), a construção de moradias em terreno do segurado $(1,44 \%)$ e a hipoteca da casa $(1,44 \%)$.

293 Inicialmente a unidade era alugada pelo prazo máximo de dois anos a começar da data de assinatura do contrato (a maior parte foi firmada no ano de 1946). Passado esse tempo, independente de qualquer aviso ou interpelação judicial, o aluguel mensal que era de $\mathrm{Cr} \$ 150,00$ (cruzeiros em 1946) era ajustado. A escolha dos segurados para alugar as unidades do conjunto foi feita por meio de concorrência levando-se em consideração a idade do pleiteante, o número de dependentes e a situação da moradia em que residiam. Para os trabalhadores que estivessem em situação de eminente despejo, por exemplo, contava-se 100 pontos adicionais na concorrência. 
manifestar por escrito o interesse em permanecer no imóvel294, declarando também aceitar 0 reajuste procedido tendo por base a revisão bienal dos valores locativos do Conjunto, estabelecida em $1954{ }^{295}$. No período dos dois anos de aluguel, o segurado só poderia utilizar o imóvel para sua moradia, teria que manter todos os aparelhos sanitários, todos os acessórios, instalações em geral, ladrilhos e caixa de gordura, em perfeito estado de funcionamento e fazer às suas custas, todos os consertos, reparos e/ou substituições de aparelhos ou peças que se inutilizarem, por outros da mesma qualidade, sem defeitos de fabricação296. Para a entrega do imóvel ao IAPC, a casa deveria estar no mesmo estado em que foi recebida pelo associado, ressalvadas as depreciações naturais de usos regular. Cotidianamente, o segurado tinha ainda que seguir 0 regulamento baixado como normas do Conjunto, que deveria ser de pleno conhecimento do locatário, fixado na portaria da Delegacia.

No entanto, a maior parte dos imóveis de propriedade das Caixas e Institutos locados no Recife permaneceu alugada aos associados, até fins da década de 1960, mais precisamente até o ano de 1968, quando teve início o processo de vendas das unidades pelo INPS. Esse processo ficou conhecido como alienação de imóveis, pretendida desde a outorga da Lei n.4.380, de 21 de agosto de 1964, na ocasião da qual foi instituído o Plano Nacional de Habitação, mas que até fins da década de 1960 ainda não havia sido concluída. Somente com a aprovação da Resolução do INPS n.101-2, de 1967 e do posterior Decreto-Lei n.713, em 29 de julho de 1969, que o processo teve início. Aquela resolução foi o ponto de partida para a venda maciça dos imóveis residenciais de propriedade dos Institutos e das Caixas e até então, como especificado pela própria resolução, "(...) poucas foram as unidades residenciais alienadas, quase que, exclusivamente pelo (...) IAPI, pois todos os outros (...) Institutos estavam aguardando a regulamentação da aplicação da correção monetária (...)" (RESOLUÇÃO..., 30/11/1967, p.13). Essa regulamentação foi aprovada ainda em 1967, mas não incitou à venda das residências das CAPs e dos IAPs no país. Somente em 1968 foi “(...) efetivamente desencadeado o processo de venda da grande maioria dos imóveis residências de propriedade dos Institutos, através das Equipes de Vendas formadas nas diversas Superintendências Regionais" (AGUIAR, 1971, p.14). Após determinadas às diretrizes das vendas e dos seguros das operações, bem como a fixação dos critérios para alienação, os conjuntos tiveram que se enquadrar no modelo do contrato particular de Convenção de Condomínio, assinado após as vendas das moradias que os compunham (RESOLUÇÃO...11/01/1968, p.03).

Nesse período no Recife, documentos do INPS apontaram que o número de unidades de propriedade dos referidos institutos de previdência, que ainda estavam sob o domínio dos seus segurados, no ano de 1968, era de 1.347 moradias pertencentes principalmente ao IAPB, IAPETC, IAPC e IAPI, além de diversos

\footnotetext{
294 Um mês antes do final do prazo estabelecido pelo Instituto.

295 Para a solicitação ser aprovada o fiscal deveria observar se o locatário continuava como segurado do Instituto e se continuava sem possuir imóveis registrados em cartório. Ao administrador do conjunto cabia verificar se todas as cláusulas contratuais e do regulamento estavam sendo cumpridas e se não havia impedimentos do tipo moral ou social para a renovação do aluguel. $A$ carteira do patrimônio, por sua vez, teria que informar a quitação de todos os aluguéis anteriores à data de solicitação.

296 Estavam obrigados ainda a não utilizarem pregos comuns nas paredes das edificações.
} 
edifícios comerciais e institucionais, como escolas e sedes administrativas. As determinações pertinentes àquele diploma legal expedido em 1969 foram exigidas pelo Presidente da República e passaram por severa fiscalização, principalmente no que dizia respeito à venda das unidades locadas em conjuntos residenciais. Mas, de qualquer forma, esse processo perdurou pela segunda metade da década de 1960 e pelas décadas seguintes. Até hoje, nem todos os processos imobiliários realizados pelas CAPs e IAPs foram liquidados, um dos motivos pelos quais, as seções de patrimônio imobiliário ainda perduram no âmbito das agências do INSS, em todo o país.

Vale salientar, que esse processo de inicialmente alugar os imóveis e posteriormente proceder à venda deles foi mais evidente no Recife que em outras localidades do Nordeste, como se verá ao longo deste capítulo. Outro diferencial observado no âmbito dos Institutos e Caixas na capital pernambucana refere-se à comum existência de regulamentos em se tratando dos conjuntos e vilas edificados pelos órgãos na cidade. Em quase todos os empreendimentos dos órgãos havia um manual ou conjunto de normas de convivência, como era comumente chamado, referenciados essencialmente a partir da década de 1950, na cidade. Esse aspecto era previsto e exigido por Lei federal, bem como as visitas de vistoria nos imóveis da União. Contudo, ambas as exigências, como já colocado no segundo capítulo da tese, não foram praticadas na maior parte dos grupos residenciais no país. Uma das possíveis justificativas para esse diferencial observado na capital pernambucana, diz respeito, mais uma vez, à representatividade e estrutura organizacional que respaldava a atuação dos órgãos, bem como à maior fiscalização de suas ações, sobretudo no campo habitacional, realizadas especialmente pelo CNT.

De modo geral, por meio desses documentos (regulamentos, manuais, etc.), foi determinado que as administrações dos conjuntos recifenses eram as responsáveis por atender às reclamações feitas pelos locatários, bem como observar o cumprimento das observações e limitações impostas pelo regulamento aprovado pelo Instituto ou Caixa. Os locatários eram obrigados a manter em perfeito estado os imóveis em que residiam, suas instalações, cercas ou muros existentes e que viessem a existir, como também, evitar invasões, depreciações ou qualquer dano aos imóveis confrontantes. Eram obrigados ainda, a permitir a entrada do pessoal do órgão, responsável pela vistoria das residências; o "pessoal da conservação". Os que residiam nos apartamentos eram obrigados a depositar todo o lixo embrulhado em papel, no depósito geral do edifício ou do conjunto, e aqueles que moravam nas unidades isoladas, a depositar em recipiente próprio. Também relacionado às questões higiênicas e sanitárias, remanescentes ainda das décadas anteriores, os moradores locatários elou proprietários de unidades de conjunto residencial eram obrigados a informar imediatamente à administração do Conjunto, a existência de pessoas assoladas por moléstia infecciosa ou contagiosa 297 .

297 Eram proibidos ainda de: colocar faixas, placas ou qualquer outro elemento que pudesse ser visto fora do imóvel; instalar toldos ou persianas sem o prévio consentimento do órgão; incomodar de qualquer modo os moradores; produzir ruído após as $22 \mathrm{~h}$; praticar esportes nas ruas do Conjunto; armazenar explosivos, inflamáveis ou qualquer química perigosa ou com odor; criar animais, salvo nas casas com quintal; e colocar objetos no parapeito dos andares superiores, de modo a constituir perigo. 
Não se pode deixar de perceber uma aproximação dessas especificações e determinações aos Códigos de Postura, outorgados essencialmente a partir da Proclamação da República e que, pelo menos, até a década de 1920 foram levados em consideração quanto ao ordenamento e à salubridade das cidades brasileiras e suas moradias. Num tempo mais próximo, percebem-se também semelhanças aos termos de convivência estabelecidos pelos proprietários de fábricas e indústrias em suas vilas operárias. Dentre os dispositivos de controle e vigilância que constavam nos regulamentos expedidos pelos empregadores estavam noções de higiene e salubridade, os padrões de moral e civilidade, o controle dos horários e das frequências dos trabalhadores e o controle de movimentos nas fábricas (CORREIA, 1998).

Assim como a questão dos regulamentos dos conjuntos de moradias de propriedade dos Institutos e Caixas no Recife e da política de aluguel praticada por eles na localidade, o perfil das ações desses órgãos (caráter social, planos, diretrizes construtivas, arquitetônicas e urbanísticas, etc.), em muito se aproximam do observado nas cidades do centro-sul do país. Dessa forma, pode-se aventar que a política pública habitacional desenvolvida pelos referidos órgãos na capital pernambucana se aproxima das empreendidas e largamente estudadas nas cidades de São Paulo, Rio de Janeiro e Belo Horizonte, principalmente, e, consequentemente, se distancia das realidades do restante da região, nas quais, a política da casa própria foi mais marcante, sendo representada pela venda preponderante das unidades para os segurados, antes mesmo de 1964.

\section{João Pessoa-PB:}

Em João Pessoa foram identificados 1.798 (mil setecentos e noventa e oito) processos de financiamento para compra e/ou edificação de residência, dos quais, 304 (trezentos e quatro) concessões de unidades habitacionais foram levantadas. Esse valor corresponde a $16,90 \%$ do volume total das ações imobiliárias identificadas na cidade. Do montante identificado, 1.708 (mil setecentos e oito) processos correspondem a financiamentos diretos $(94,99 \%)^{298}$ e 90 fichas foram levantadas especificando-se financiamento indireto299 $(5,01 \%)$.

É importante relembrar que o número de pleitos concedidos não equivale ao total de habitantes atendidos pelos supracitados órgãos nas cidades. Sendo assim, utilizando-se do índice de população média por unidade residencial na Paraíba, apresentado no anuário estatístico do Brasil, que em de $1940^{300}$ era de 4,56 membros, têm-se uma estimativa de 8.200 (oito mil e duzentas) pessoas contempladas pela política habitacional das Caixas e Institutos naquela cidade. Aquele número de pleitos corresponde a $11,36 \%$ do total das 15.817 edificações existentes em João Pessoa naquele ano. O volume de habitantes atendidos, por sua

\footnotetext{
298 Desse total foram levantados 214 processos de financiamentos para compra de unidades ou terrenos de propriedade do Instituto.

299 Vale ressaltar, que esse montante identificado corresponde somente aos pleitos levantados na pesquisa documental e que 0 total dessas realizações na cidade se mostra ainda maior.

300 Data de apresentação do primeiro censo acerca desse aspecto.
} 
vez, equivale a $11,37 \%$ da população residente na capital paraibana que era, no mesmo ano de 1940, de 72.063 pessoas.

Merece ser apontado de antemão, que o número de realizações apresentado anteriormente destoa do colocado por algumas publicações do gênero acerca da cidade. Da mesma forma, o volume de habitantes atendidos aponta para a necessidade de reavaliação dos estudos existentes que consideram as atuações das CAPs e dos IAPs como ínfimas ou apenas pontuais naquela capital. Mais precisamente, são comumente encontrados dados acerca da produção dos IAPs, da FCP, do Montepio dos Funcionários do Estado e de outros agentes públicos nessa cidade que, em conjunto, resultaram na edificação de 899 unidades habitacionais (BONATES, 2007; LAVIERI \& LAVIERI, 1999, dentre outros); um número muito aquém do identificado. Vale ressaltar ainda que o volume absoluto daquela produção não pode ser precisado porque muitos dos processos imobiliários estão espalhados por diversas agências, estão comprometidos pela ação do tempo ou não existem mais.

Em se tratando das ações dos institutos de previdência paraibanos, constantes nos processos imobiliários levantados na pesquisa documental, percebeu-se certa regularidade de ações imobiliárias entre os anos de 1942 a 1964, com exceção dos anos de 1943 e 1944301, bem como do ano de 1961, no qual, não foi identificada uma solicitação sequer aprovada. O maior pico de liberação de pleitos foi identificado no ano de 1955 , que abrange $9,54 \%$ do total de financiamentos aprovados. 0 segundo e o terceiro picos de liberações de processos podem ser percebidos nos anos de 1952 e de 1960, respectivamente, cada um contemplando $6,57 \%$ do total das ações realizadas. O IPASE foi o Instituto que mais empreendeu ações ao

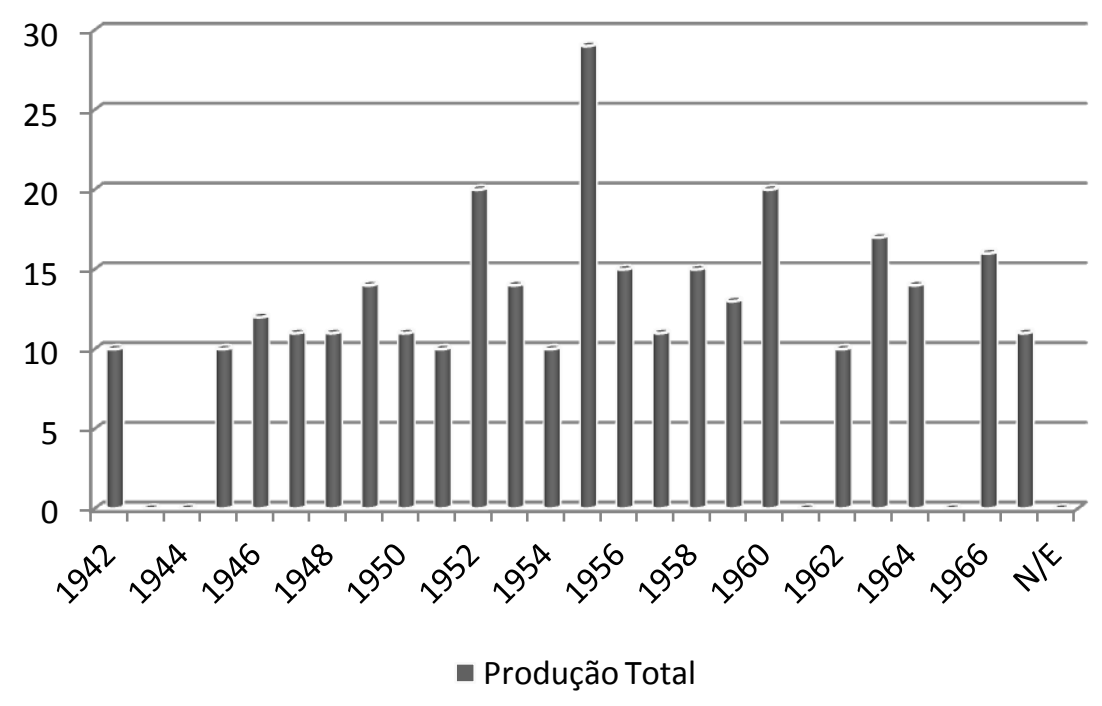

Figura 43: Gráfico geral da atuação das CAPs e dos IAPs em João Pessoa. Fonte: Elaboração própria com base nos dados coletados no INSS-PB. longo do recorte temporal estudado, se responsabilizando por $49,34 \%$ dos pleitos concedidos em João Pessoa, sendo seguido pelo IAPI $(17,76 \%)$. Porém, a atuação do Instituto dos Industriários, nessa cidade, se deu de modo mais constante na década de 1940 , passando a ser pontual a partir de então302. O IPASE, por sua vez, empreendeu ações de modo mais contínuo a partir de 1950 (Figura 43).

\footnotetext{
301 Também refere-se ao período de estruturação dos órgãos na cidade.

302 Autorizando pleitos essencialmente nos anos de 1952 e 1962.
} 
Quanto à liberação e/ou aprovação da edificação dos Conjuntos, o maior pico foi evidenciado no de 1963, quando foi liberada a edificação de 668 unidades habitacionais pelos Institutos e Caixas, distribuídas em três conjuntos residenciais. Outro ápice de produção foi evidenciado no ano de 1955, no qual foi autorizada a construção de 466 casas, também distribuídas em três conjuntos de menor porte. 0 terceiro ano de maior liberação da construção de conjuntos ou grupos de moradias foi o de 1954, ano em que foram iniciadas as obras de dois conjuntos compostos por 204 imóveis, sendo seguido pelo ano de $1963^{303}$ e pelo ano de $1958^{304}$. Percebem-se, dessa forma, três picos no que concerne à aprovação e ao início da edificação dos conjuntos e grupos de moradias diretamente pelos órgãos na capital paraibana. 0 primeiro compreende ao período conformado pelos anos de 1954 e 1955, o segundo no ano de 1958 e outro entre os anos de 1963 e 1964. O primeiro e o terceiro apresentam um total de cinco conjuntos cada, sendo edificados exclusivamente pelo IPASE, no terceiro momento. Esses últimos grupos de moradias, por sua vez, apresentaram um número consideravelmente maior de unidades habitacionais: um total de 819 moradias (47,95\% das liberações para construção em todo o período de atuação dos órgãos).

Percebeu-se que o início da atuação tanto das Caixas de Aposentadoria e Pensões, quanto dos Institutos de Aposentadorias e Pensões em João Pessoa se deu mais tardiamente que em outros estados nordestinos, nos quais, foram identificadas concessões de financiamentos a partir de fins da década de 1930. Um dos motivos que se conjectura para esse quadro refere-se ao papel representativo, econômico e populacionalmente, que a cidade de Campina Grande desempenhou no cenário do estado, podendo ter "desviado" as ações imobiliárias dos órgãos para àquela localidade. No entanto, estudos mais aprofundados acerca desse aspecto merecem ser realizados para a contestação ou afirmação do colocado acima.

Até os primeiros anos da década de 1950, apenas um conjunto havia sido liberado para a edificação, os demais só tiveram seus projetos aprovados e autorizados a partir, sobretudo, do ano de 1953. Mais precisamente, no caso paraibano, a primeira e a única aprovação para edificação de conjunto residencial ou grupo de moradia, até os primeiros anos da década de 1950, ocorreu no ano de 1942 e correspondia à Vila CAPFESP/IAPFESP ${ }^{305}$. No mesmo ano foi liberado o financiamento para aquisição de moradia locada nesse grupo. As modalidades imobiliárias associadas à edificação direta dos Institutos e das Caixas, como já colocado, só ganharam mais espaço de atuação no cenário paraibano a partir de meados da década de 1950. Três conjuntos residenciais foram edificados na capital paraibana entre 1953 e 1955. Foram eles: o chamado I Bloco de residências Santa Júlia (IPASE-1954) e a primeira etapa do Conjunto Henrique de La Roque (IAPC-1954), ambos situados no bairro Expedicionários ${ }^{306}$; e o Conjunto do IAPI (1953), locado no bairro Torre $^{307}$. Até então, a atuação das Caixas e Institutos de Aposentadoria e Pensões na localidade se restringia,

\footnotetext{
${ }^{303}$ Com 151 residências, também distribuídas em dois conjuntos residenciais.

304 Com três conjuntos, conformados por 111 residências.

305 Situada no atual bairro dos Estados, composta por dez unidades habitacionais geminadas em fila.

306 A segunda etapa deste conjunto só foi concluída no ano de 1966. O conjunto, em seu total, é conformado por 168 unidades habitacionais. No entanto, o número de residências edificada em cada uma das etapas não pode ser precisado por falta de dados.

307 Cujo número de casas que o compõe não pode ser afirmado por falta de dados.
} 
essencialmente, à liberação de financiamentos para aquisição de terreno e edificação de residências ou para edificação de moradia em terreno do segurado, realizadas por iniciativas deles. Nesse sentido, os primeiros financiamentos liberados foram vislumbrados no ano de 1945 e diziam respeito a empréstimos para a aquisição de terrenos e edificação casas no atual centro histórico da cidade e no bairro Tambauzinho.

Ainda em se tratando do período de atuação dos IAPs e CAPs na cidade, vislumbrou-se que além de terem iniciado suas atividades posteriormente em relação à maior parte dos estados nordestinos estudados, a atuação desses órgãos em João Pessoa, para além do IPASE, foi reduzida consideravelmente com mais antecedência, essencialmente, em fins dos anos de 1950. Das 1.708 unidades edificadas na cidade em todo o período de atuação, 839 foram liberadas para serem edificadas antes do ano de 1960, isto é, 49,12\% daquela produção ${ }^{308}$. Desse montante, 740 pleitos $(88,20 \%)$ foram concedidos por outros institutos que não 0 IPASE. A partir de 1960, por sua vez, 869 residências e apartamentos (50,87\% da produção total) foram edificados pelo IPASE na capital paraibana e apenas 81 delas (9.32\%) foram disponibilizadas por todos os outros órgãos atuantes. Mais precisamente, essas unidades correspondem somente ao Conjunto dos Marítimos (IAPM), locado no município de Cabedelo, edificado a partir do ano de 1963, e composto por 81 unidades habitacionais (Figura 44).

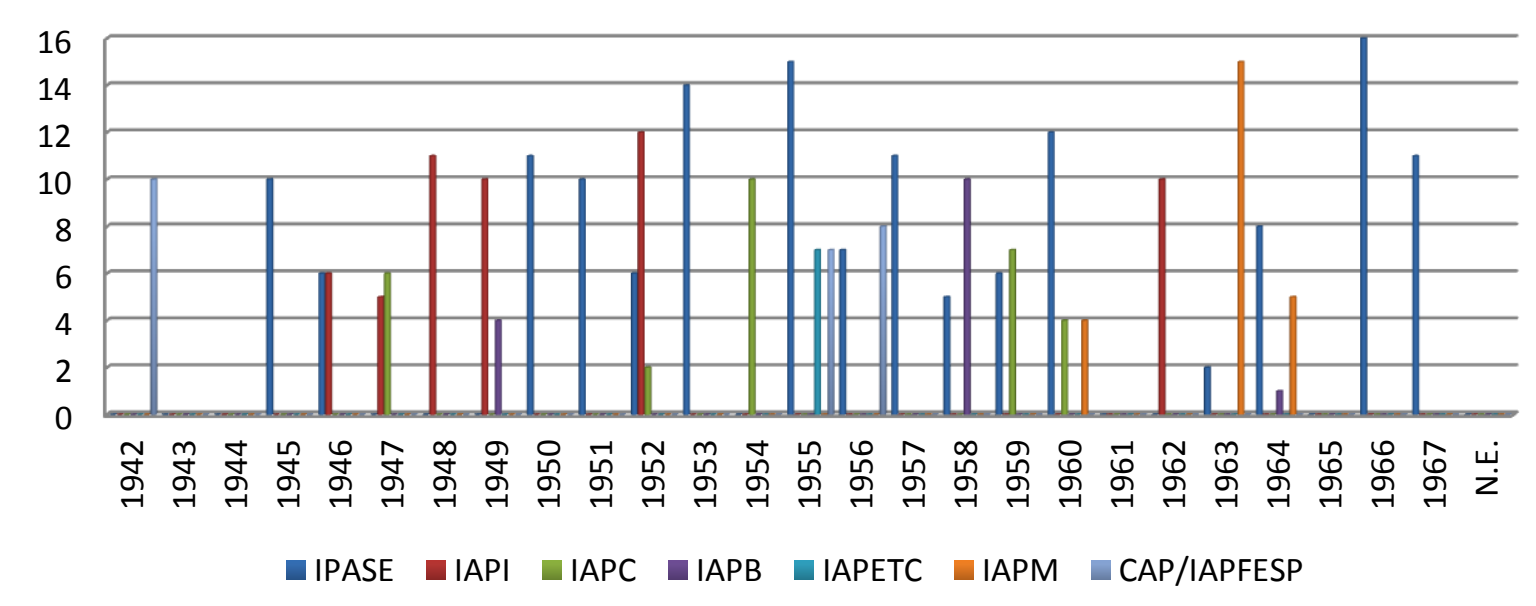

Figura 44: Quadro de distribuição da atuação dos escritórios estaduais das CAPs e dos IAPs em João Pessoa. Fonte: Elaboração própria com base nos dados coletados no INSS-PB.

Os únicos Institutos que procederam à concessão de empréstimos aos trabalhadores de modo indireto em João Pessoa, de acordo com a pesquisa realizada, foram o IPASE, o IAPI, o IAPC e o IAPB. Dentre eles, o IPASE foi o que mais financiou unidades habitacionais isoladas na cidade, o equivalente a $21,05 \%$ do total trabalhado, sendo seguindo pelo IAPI $(13,48 \%)$ - contradizendo o quadro das concessões diretas em que esse Instituto se mostrou praticamente inoperante. No tocante aos procedimentos, categorias

308 Cabe lembrar que a data de liberação da edificação e de efetiva construção de todas as unidades difere. 
(planos e classes), cabe ressaltar que poucos foram os Institutos e Caixas que especificaram a classe das suas operações imobiliárias indiretas em João Pessoa ${ }^{309}$.

Uma curiosidade percebida quanto à atuação dos Institutos e Caixas na capital paraibana, é que entre os anos de 1947 e 1952 não foi identificada nenhuma liberação, concorrência administrativa interna ou externa para a edificação de conjunto residencial ou grupo de moradia na cidade. O mesmo ocorreu entre os anos de 1943 e 1951, quanto à aprovação dos financiamentos para aquisição de moradias edificadas pelos órgãos. Nesse período, os processos identificados se enquadram nas categorias indiretas, realizadas por iniciativa dos associados, e equivalem, mormente, às unidades isoladas. Esse aspecto indica, dentre outras coisas, que em João Pessoa em especial, a trajetória de escolha à ocupação de uma unidade construída pelas CAPs ou IAPs era muito morosa, podendo perdurar por quase uma década, como foi o caso do Conjunto Henrique de La Roque (IAPC), cujo início das construções data de 1954 e ainda na década de 1960 são percebidas solicitações para a aquisição de uma unidade residencial.

\begin{tabular}{|c|c|c|c|c|c|c|c|c|c|c|c|c|c|c|c|c|}
\hline \multicolumn{17}{|c|}{ ATUAÇÃO DAS CAPS E DOS IAPS EM JOÃO PESSOA } \\
\hline \multirow{2}{*}{ Ações Imobiliárias } & \multicolumn{2}{|c|}{ IAPI } & \multicolumn{2}{|c|}{ IPASE } & \multicolumn{2}{|c|}{ IAPC } & \multicolumn{2}{|c|}{ IAPB } & \multicolumn{2}{|c|}{ IAPETC } & \multicolumn{2}{|c|}{ IAPM } & \multicolumn{2}{|c|}{ CAPFESP } & \multicolumn{2}{|c|}{ Total } \\
\hline & No. & $\%$ & No. & $\%$ & №. & $\%$ & №. & $\%$ & №. & $\%$ & No. & $\%$ & №. & $\%$ & No & $\%$ \\
\hline $\begin{array}{l}\text { Compra de unidade } \\
\text { do Instituto/Caixa }\end{array}$ & 01 & 1,85 & 30 & 20 & 10 & 34,48 & 08 & 53,33 & 05 & 71,42 & 21 & 87,5 & 20 & 80 & 95 & 31,25 \\
\hline $\begin{array}{l}\text { Compra de imóvel já } \\
\text { edificado de terceiros }\end{array}$ & 17 & 31,48 & 20 & 13,33 & 08 & 27,58 & - & - & - & - & - & - & - & - & 45 & 14,8 \\
\hline $\begin{array}{l}\text { Compra de terreno e } \\
\text { const. de residência }\end{array}$ & 20 & 37,03 & 19 & 12,66 & - & - & - & - & - & - & - & - & - & - & 39 & 12,83 \\
\hline $\begin{array}{c}\text { Construção em } \\
\text { terreno do segurado }\end{array}$ & 04 & 7,4 & 25 & 16,66 & 05 & 17,24 & 04 & 26,66 & - & - & - & - & - & - & 38 & 12,5 \\
\hline Reforma & - & - & 23 & 15,33 & - & - & - & - & - & - & - & 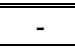 & - & - & 23 & 7,57 \\
\hline $\begin{array}{c}\text { Aumento de } \\
\text { Financiamento }\end{array}$ & 05 & 9,26 & 04 & 2,66 & 06 & 20,69 & 03 & 20 & 02 & 28,57 & 03 & 12,5 & 05 & 20 & 28 & 9,21 \\
\hline Outras & 07 & 12,96 & 11 & 7,33 & - & - & - & - & - & - & - & - & - & - & 18 & 5,92 \\
\hline N.E. & - & - & 18 & 12 & 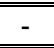 & - & 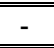 & - & 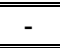 & - & - & - & 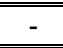 & - & 18 & 5,92 \\
\hline Total Absoluto & \multicolumn{2}{|c|}{54} & \multicolumn{2}{|c|}{150} & \multicolumn{2}{|c|}{29} & \multicolumn{2}{|c|}{15} & \multicolumn{2}{|c|}{07} & \multicolumn{2}{|c|}{24} & \multicolumn{2}{|c|}{25} & \multicolumn{2}{|c|}{304} \\
\hline Atuação & \multicolumn{2}{|c|}{$17,76 \%$} & \multicolumn{2}{|c|}{$49,34 \%$} & \multicolumn{2}{|c|}{$9,54 \%$} & \multicolumn{2}{|c|}{$4,93 \%$} & \multicolumn{2}{|c|}{$2,3 \%$} & \multicolumn{2}{|c|}{$7,9 \%$} & \multicolumn{2}{|c|}{$8,22 \%$} & \multicolumn{2}{|c|}{$100 \%$} \\
\hline
\end{tabular}

Figura 45: Quadro de classificação das ações imobiliárias dos institutos de previdência em João Pessoa.

Fonte: Elaboração própria com base nos dados coletados no INSS-PB.

A maior parte dos processos levantados em João Pessoa diz respeito à compra de unidades de propriedade do Instituto, que corresponde a $31,25 \%$ dos pleitos levantados ${ }^{310}$ (Figura 45). De modo geral, houve um equilíbrio entre os pleitos liberados quanto da compra de unidades já edificadas por terceiros, a compra de terreno e construção de moradias e a edificação de residência em terreno do segurado, que abarcaram respectivamente $14,80 \%, 12,83 \%$ e 12,50\% da produção. As demais realizações diziam respeito à

309 Somente o IAPB especificou o plano B, classe II, de acordo com a Portaria Ministerial SCM-306, no ano de 1949, como sendo o financiamento para a construção de moradia em terreno de propriedade do associado e o IAPI, definiu o plano B-III, como sendo 0 financiamento para aquisição de moradia de terceiros, no ano de 1947.

310 No total de 304 processos imobiliários. 
reforma e/ou ampliação de residência $(7,57 \%)$ e à encampação de dívida hipotecária $(9,21 \%)^{311}$. No panorama geral, o IPASE foi o instituto que praticou uma maior diversidade de ações imobiliárias na cidade, sobretudo, a venda de unidades de sua propriedade $(20,00 \%)$ e o financiamento para a aquisição de moradia no terreno de propriedade do associado $(16,66 \%)$. Outros Institutos concentraram suas realizações essencialmente na venda de seus imóveis, como foi o caso do IAPM $(87,50 \%)$ e da CAPFESP/IAPFESP $(80,00 \%)$. O IAPI, por outro lado, foi o órgão que mais empreendeu financiamentos para a compra de lote e edificação de moradia (37,03\%), entre os demais Institutos e Caixas.

O volume de pleitos diretos identificado está distribuído em 19 conjuntos ou grupos de moradias ${ }^{312}$. São eles: a Vila da CAPFESP (1942); o Conjunto do IAPI (1953); o Conjunto Henrique de La Roche (IAPC1954/1959)313; os dois blocos de residências Santa Júlia (IPASE-1954/1955); a Vila dos Ferroviários (CAPFESP/IAPFESP-1955); o Conjunto Ministro José Américo de Almeida (IAPETC-1955); o Edifício Presidente João Pessoa (IAPB-1957); o Conjunto Presidente João Pessoa (IAPB-1958); o Conjunto Presidente João Goulart (IPASE-1958); o Conjunto Tambauzinho (IAPB-1958)314; o Conjunto Juscelino Kubitscheck (IPASE-1960)315; o Conjunto dos Marítimos (IAPM-1963); a primeira etapa do Conjunto do IPASE em parceria com o 10 Grupamento de Engenharia (1963); o Conjunto Boa Vista (IPASE-1964); o Conjunto 13 de Maio (IPASE-1964); o Conjunto Jacinto de Medeiros (IPASE-1964); o Conjunto Mandacaru (IPASE-s/d)316; e a segunda etapa do Conjunto do IPASE em parceria com 0 1 Grupamento de Engenharia, cuja liberação e previsão de construção foi apresentada em 1963, mas o início das obras se deu em 1966.

Diante do levantamento realizado, observou-se que os Institutos atuantes em João Pessoa foram 0 IAPC, IAPB, IAPM, IAPI, IAPFESP, IAPTEC e o IPASE, e em se tratando das Caixas apenas um órgão atuou na cidade, o CAPFESP, responsável pelo financiamento de dez unidades habitacionais no bairro dos Estados, no início da década de 1940 e parte das residências da Vila Ferroviária, em Cabedelo, na década seguinte. Não foram percebidas realizações concretizadas por parte do IPEP (antigo Montepio do Estado da Paraíba) no levantamento e no período estudado, ao contrário do colocado por algumas publicações, como Bonates (2007). O Instituto que mais edificou conjuntos habitacionais na cidade foi o IPASE, responsável pela edificação de dez grupos de moradias (52,63\%). A esse seguiu a atuação do IAPB, responsável pela

$311 \mathrm{Em} 5,92 \%$ dos financiamentos levantados especificaram-se outras atividades, como o refinanciamento de unidades habitacionais, como se verá a seguir, e em $5,92 \%$ dos pleitos trabalhados não foi possível identificar a sua categoria, ou por não estar especificado no processo imobiliário ou por ele estar incompleto. É importante destacar também que em João Pessoa, alguns dos conjuntos de propriedade dos Institutos e Caixas foram se conformando à medida que os terrenos foram sendo adquiridos pelos órgãos e, em seguida, sorteados (ou por concorrência) entre os trabalhadores inscritos, justificando em parte, o elevado número de processos de compra de terrenos para a edificação de residências na capital em questão.

312 Foram considerados como pertencentes ao montante edificado pelas CAPs e IAPs em João Pessoa, os conjuntos locados em Cabedelo, pelo fato que os próprios órgãos assim procediam e os processos referentes aos pleitos estão locados, até hoje, na agência do INSS daquela cidade.

${ }_{313}$ Conjunto realizado em duas etapas, ambas localizadas no atual bairro Expedicionários.

314 Não foram encontrados processos imobiliários em relação a esse conjunto, em especial. A sua inclusão nessas considerações se deu devido a diversas referências a sua edificação em fins da década de 1950, por meio de periódicos da época, principalmente o Jornal A União.

315 Em diversos processos imobiliários também se especifica "Boi Só" como o nome do conjunto.

316 Localizado no bairro de mesmo nome. A data precisa da liberação e início da construção desse conjunto não pode ser precisada por falta de dados. 
construção de três grupos de casas (15,78\%) e o IAPFESP em conjunto com a CAPFESP ${ }^{317}$, que resultaram na conformação de dois conjuntos (10,52\%). O IAPM, o IAPC, o IAPI e o IAPETC edificaram o mesmo número de grupos residenciais, um cada $(5,26 \%)$.

Em relação ao número de unidades edificadas diretamente pelos órgãos e locadas em grupos de moradias, constatou-se que também foi o IPASE o Instituto que mais construiu, um total de 887 unidades $(51,93 \% \text { do volume total de realizações })^{318}$, enquanto o IAPFESP/CAPFESP edificaram apenas 260 moradias $(15,22 \%)$. A esses foram seguidos o IAPETC (200 unidades habitacionais, 11,70\%), o IAPC (168 moradias, 9,83\%), o IAPB (112 habitações, 6,55\%) e o IAPM (81 casas, 4,74\% do total produzido pelos Institutos e Caixas). Não foi possível apontar a produção de unidades habitacionais edificadas pelo IAPI na cidade, uma vez que não foram encontrados registros que apontassem o número de residências que compunham 0 Conjunto do IAPI (1953), situado no bairro Torre.

Diferente do que foi percebido em outras capitais nordestinas, em João Pessoa praticamente não existiu a liberação de verba ou empréstimo, como já era comumente especificado nos processos imobiliários da época, para custear a realização de obras públicas na cidade, ou mesmo, a construção de edifícios com outras funções além da moradia, executada pelos órgãos ou por empresas terceirizadas. 0 caso mais próximo percebido, nesse sentido, ocorreu no âmbito do IAPB e refere-se ao Edifício Presidente João Pessoa ou Edifício 18 andares, como ficou popularmente conhecido, que além de unidades habitacionais previstas no projeto inicial comporta, em uma mesma estrutura, funções institucional e de comércio.

Ao contrário de cidades como Natal e Fortaleza, como se verá a seguir, não foram observados em João Pessoa casos em que o Instituto ou a Caixa adquiriu unidades ou vilas habitacionais já edificadas por terceiros ou por empresas privadas, nem casos de concessão de financiamentos para empresas construtoras ou particulares edificarem conjuntos de moradias, especialmente verticais, como foi percebido no Recife e em Salvador. A única parceria identificada, no que tange à edificação de residências, foi estabelecida pelo IPASE e pelo IAPFESP com 0 1ำ Grupamento de Engenharia do Exército, que ficou responsável pela construção de alguns conjuntos no bairro dos Estados e Pedro Gondim, e no município de Cabedelo, representada pela chamada Vila dos Ferroviários nessa localidade. Alguns projetos foram compartilhados entre os corpos técnicos de escritórios estaduais, como o IAPB-PB e o IAPB-PE, em se tratando da construção do, já citado, Edifício Presidente João Pessoa, na segunda metade da década de 1950.

Como em outros exemplos identificados no Nordeste, na Paraíba há um caso de construção em parceria entre um Instituto, o IAPM, e a Fundação da Casa Popular (FCP). Trata-se do Conjunto Residencial dos Marítimos, locado no município de Cabedelo, onde 50\% dos custos para a implantação e a edificação

317 Considerou-se essa produção em conjunto uma vez que muitas das unidades construídas em Cabedelo, mais precisamente na Vila dos Ferroviários, foram financiadas por ambos os órgãos, como já citado.

318 Vale salientar que a produção absoluta de unidades é ainda maior, uma vez que não pode ser precisado o número de moradias que compõem os Conjuntos Jacinto de Medeiros, no bairro 13 de Maio, e Mandacaru, locado no bairro de mesmo nome. 
ficou sob a responsabilidade da Fundação e equivaleu ao montante de $\operatorname{Cr} \$ 2.627 .689,30$ (cruzeiros), no início da década de 1960. Coube ao IAPM à soma restante e à realização das obras do Conjunto.

Quanto ao caráter do financiamento, compra ou aluguel, pode-se dizer que em todos os processos levantados foram relacionados à venda de unidade habitacional por hipoteca ou por promessa de compra $\mathrm{e}$ venda, através dos IAPs e da CAPFESP, não sendo vislumbrada solicitações ou aprovação de pleito para a locação temporária das unidades de propriedade dos órgãos ou a possível aquisição do imóvel após um determinado período (variando de 10 a 25 anos), como verificado no Recife, especialmente.

Assim como em outras localidades no Nordeste, na capital paraibana foram observados episódios de financiamentos aprovados em áreas irregulares, apontando a ineficiência da fiscalização e das avaliações empreendidas pelos órgãos para a liberação da verba. Esse foi o caso da segurada, escrituária do IPASE, cujo financiamento foi liberado no ano de 1952 pelo órgão. O terreno onde se encontra edificada a sua residência, à Rua Frei Afonso, n.236, no bairro Jaguaribe, foi desmembrado de duas áreas maiores que pertenciam ao senhor Alpiniano Viegas da Silva, que os remembrou, fazendo desaparecer os limites oficiais. Posteriormente, sem a autorização da Prefeitura, o proprietário ainda abriu uma via, a Rua Frei Afonso, e loteou o terreno que a margeava.

\section{Natal-RN:}

Em Natal, a atuação dos IAPs do MTIC no campo habitacional, começou no ano de 1939, quando os referidos órgãos foram autorizados por decreto municipal a iniciarem suas ações, bem como reduzidas as taxas e laudêmios que incidiam sobre suas transações imobiliárias (DECRETO N.29, 29/04/1939). No entanto, o primeiro registro de financiamento encontrado nos levantamentos documentais realizados, principalmente no INSS-RN, apontam para o ano de 1942, como sendo o início da atuação dos Institutos na cidade 319 .

O início das atividades dos Institutos na localidade coincide com 0 ano da instalação da base norte-americana em Natal (Figura 46), período dos chamados "surto econômico" e "febre de construções" pelos periódicos locais, bem como, de agravamento do déficit habitacional ${ }^{320}$, das condições de habitabilidade e de diversos problemas urbanos, inclusive de abastecimento d'água,

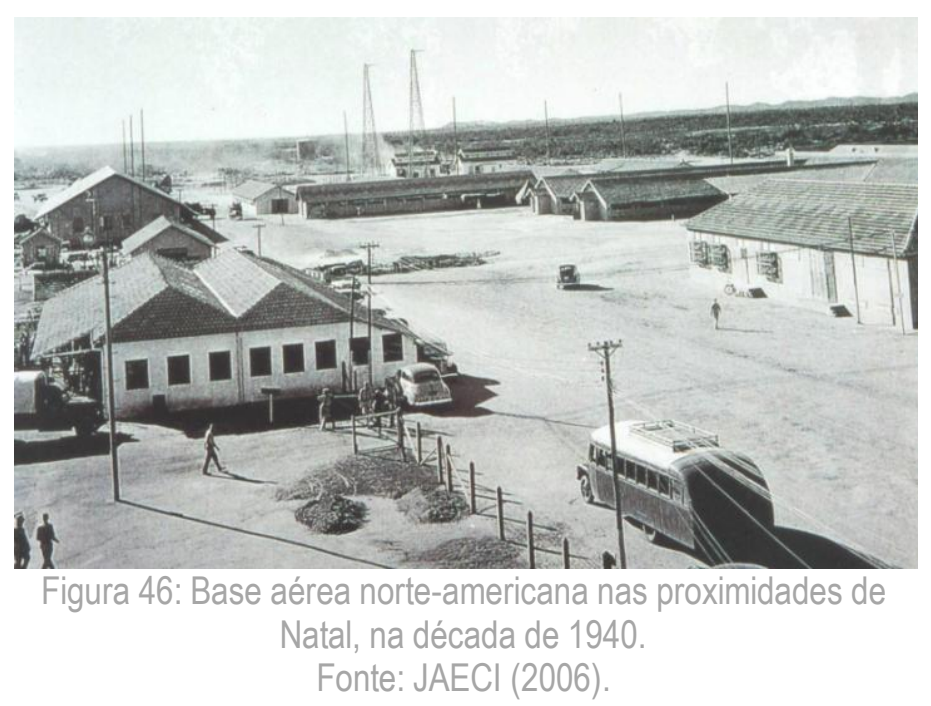

319 Vale lembrar que o levantamento dos processos imobiliários empreendidos pelas CAPs e IAPs nas capitais nordestinas do país, não esgotam as possibilidades de atuação dos órgãos naquelas localidades, se comportando muito mais como um referencial de suas ações, que um atestado de realizações.

320 Não sanado pelas construções que estavam em andamento naquele momento (ALMEIDA, 2007). 
decorrentes, sobretudo, da intensificação dos fluxos migratórios (internos e externos). Acredita-se que esse quadro de agravamento de crise habitacional tem relação direta com o início da atuação dos institutos de previdência no campo da moradia na cidade.

Em se tratando das Caixas de Aposentadoria e Pensões, a CAPESP-RN (dos Serviços Públicos), e posteriormente a CAPFESP, já atuavam no setor habitacional da cidade antes de 1942, por meio essencialmente da edificação de unidades habitacionais e do repasse delas por aluguel. Vale ressaltar nesse contexto que, como permitido por lei, os servidores municipais natalenses não se vincularam ao IPASE, pelo menos nos primeiros anos de sua atuação, sequenciais a 1938, e sim à supracitada CAPESP, que empreendeu ações no campo habitacional até o ano de 1953, quando foi incorporada ao IPASE; contexto semelhante ao observado no Recife, em Fortaleza e em São Luís, como se verá adiante. De acordo com Lima (2011), os associados ao IPASE em Natal eram representados principalmente por empregados de suporte das bases militares do exército, aérea e naval, dos Correios e Telégrafos, dos ministérios públicos e pelos funcionários que compunham o próprio Instituto. No entanto, é importante ressaltar que para atender aos militares no país, pelo menos no campo habitacional, existiam Caixas específicas, as chamadas Caixas do Pessoal da Guerra.

Com base nos levantamentos realizados em Natal - processos imobiliários, documentos históricos e periódicos locais do período, principalmente - foram aproximadamente 2.000 pleitos concedidos na cidade, em todo o período de atuação dos órgãos. Levanto-se em consideração a média da família natelense, que permaneceu praticamente inalterada ao longo da década de $1940^{321}$, tem-se um montante de 8.560 pessoas atendidas, entre segurados e os seus membros familiares, que corresponde a aproximadamente $16,50 \%$ da população residente na cidade, em fins de 1940.

Do total de realizações empreendidas e dos processos imobiliários arquivados em Natal foram efetivamente levantados 560 pleitos, principalmente, nas dependências do INSS-RN. Em relação aos grupos de moradias, vilas ou conjuntos residenciais, foram identificados 24 empreendimentos na cidade, quatro dos quais, foram edificados já na segunda metade da década de 1960. Em ordem cronológica, foram eles: Vila 19 de Abril (IAPE-1941), Vila Régis (IAPI-1947), Vila Gomes (IAPI-1947), Vila Janete (IAPI-1947), Vila São Pedro (IAPI-1947), Vila e Loteamento Henrique Eboli (CAPESP-1948), Vila Platinick (IAPB-1947), Conjunto Paulo Gentile (IPASE-1947), Vila São João (IAPI-1948), Vila Seabra (IAPI-1949), Vila Lustosa (IPASE-1950), grupo de casas da Rua Manoel Miranda (IPASE-1953), Vila Ferroviária das Rocas (IAPFESP-1954), grupo de casas no bairro das Rocas (CAPESP-1954), II Conjunto do IPASE (1956), Conjunto Nova Tirol (IAPC-1958), I e II grupo de casas no Alecrim (CAPESP-1954/1961), grupo de casas na Rua Mossoró (IAPB-1963), Grupo de casas na Av. Jaguarari (IAPB-1963), III, IV e V Conjunto do IPASE (a partir de 1964)322 e o grupo de

\footnotetext{
321 Que segundo o IBGE era de 4,28 pessoas por prédio domiciliar urbano.

322 Localizados, mais especificadamente, nos bairro de Lagoa Nova e Nova Descoberta que, em conjunto, conformam o atualmente conhecido Conjunto Potilândia.
} 
residências do Instituto de Previdência do Estado (IPE-1964) locado no Conjunto Cidade da Esperança, cujas unidades somam, aproximadamente 470 residências ${ }^{323}$.

Documentos e periódicos da época apontam ainda para a existência de um grupo de casas edificado pelo governo do estado para o funcionalismo público, no ano de 1932, por meio de uma Caixa, que se conjectura ser a CAPESP324. Contudo, o número exato, a localização e maiores informações sobre esse grupo residencial não puderam ser precisadas por falta de dados. Dessa forma, pesquisas mais aprofundadas sobre essas realizações ainda se fazem necessárias. Excetuando essa possibilidade, a primeira Vila edificada diretamente por um Instituto em Natal, de acordo com os processos imobiliários, foi a Vila 19 de Abril (IAPE1942). Vale ser destacado que em toda a pesquisa realizada, somente nessa capital nordestina e em Fortaleza registraram-se ações empreendidas pelo IAP dos Estivadores, que foi incorporado ao IAPTEC, por lei, em julho de 1948.

Além dos grupos residenciais edificados e adquiridos pelos IAPs e CAPs em Natal, destaca-se a atuação das Caixas de Construções de Casas para os Militares (Exército, Marinha e Aeronáutica), subordinados ao Ministério da Guerra, que em 1941 edificou 189 residências para os marinheiros, no bairro do Alecrim, após a instalação da Base Naval no bairro, que também contou com os clubes militares Atlântico e Camana. A atuação dessas Caixas Militares no campo habitacional, não somente em Natal325 como em diversas capitais brasileiras, ainda é pouco conhecida, uma vez que não há estudos mais detalhados sobre a temática antes de meados da década de 1960, quando esses órgãos foram incorporados ao Novo Plano Habitacional do país ${ }^{326}$. Essa modalidade de Caixa existe desde meados da década de 1930 e serviu como referência para algumas das reformas regulamentares por que passaram às demais CAPs e IAPs do MTIC ao longo dos anos, como destacou Rubens Porto (1938).

Num panorama geral, a maior parte das unidades habitacionais financiadas pelos IAPs e pelas CAPs em Natal foi adquirida diretamente de terceiros ou por meio da administração pública e, posteriormente, transferida às Carteiras Prediais dos órgãos. Processo diferente do que a historiografia especializada

\footnotetext{
${ }^{323} \mathrm{Em}$ cinco dos grupos de moradia não foi possível precisar o número de edificações efetivamente construídas e/ou financiadas, como foi o caso das Vilas Platinick (IAPB-1947), São João (IAPI-1948), Seabra (IAPI-1949) e dos grupos de casas localizado na Rua Manoel Miranda (IPASE-1953) e que compõem o II Conjunto do IPASE (1956). Também não foram computadas naquele montante, as unidades habitacionais edificadas pelo IPASE distribuídas nos três conjuntos residenciais, que conformam 0 atual Conjunto Potilândia. De acordo com Lima (2011), foram 810 unidades residenciais edificadas pelo IPASE em parceria com 0 Serviço Social do Comércio (SESC), ao longo das décadas de 1960 e 1970. Se fossem computadas essas unidades, os IAPs e as CAPs em conjunto, teriam edificado 1.280 residências, só levando em consideração as moradias que constituem as vilas e conjuntos residenciais adquiridos ou construídos pelos órgãos na cidade.

324 Tida como a primeira vila operária edificada por parte da municipalidade, no ano de 1932. Esse grupo de pequenas habitações foi construído no bairro do Alecrim e caracterizava-se por apresentar casas "(...) dotadas (...) do conforto indispensavel ás habitações modernas e com predominio de observancia dos preceitos de higiene arquitectural. (...) graciosas e elegantes, (...) serão, (...) abrigo e lar de modestos operarios (...) (A REPÚBLICA, 03/12/32, p.01). Foi a partir desse momento em Natal, que 0 Estado passou a conceber diretamente moradias, modificando definitivamente o seu papel de atuação no setor habitacional (ALMEIDA, 2007).

325 Existem em Natal, pelo menos, seis vilas militares. Essas unidades também não foram contabilizadas no total de produção apresentado anteriormente.

${ }^{326}$ A partir de quando receberam vultosos investimentos para a edificação e o repasse de moradias, sem custos adicionais para militares de alto e baixo escalão no país.
} 
descreve para as grandes e médias cidades brasileiras, principalmente da região Sudeste, no período de atuação desses institutos de previdência no país. A porcentagem de unidades habitacionais construídas pelos Institutos e pelas Caixas na cidade é de $17,5 \%$ do volume total de moradias de propriedade dos órgãos financiado em Natal $(40,71 \%)$. Mais detalhadamente, $39,38 \%$ do total de unidades financiadas corresponde às moradias adquiridas por compra direta dos associados a terceiros ou construídas por eles em terrenos próprios, e 5\% refere-se às solicitações de reforma, ampliação, financiamento para liberação da dívida hipotecária contraída pelo associado ou aquisição/construção de pontos comerciais (Figura 47).

Esse diferencial da atuação dos IAPs em Natal, sobretudo do IAPI, diz respeito à aquisição de grupos residenciais, já edificados por terceiros na cidade. Foram no total, oito grupos de residências que se adequaram a essa modalidade imobiliária ${ }^{327}$. Desses, quatro encontram-se situados no bairro do Alecrim e foram edificadas por terceiros no ano de 1947. Esse aspecto é reflexo, muito provavelmente, da intensificação dos incitamentos para o estabelecimento de parcerias público-privadas para a edificação de vilas operárias ${ }^{328}$, ou higiênicas como ainda eram nominadas pelos periódicos locais na década de 1940, bem como dos incentivos fiscais e doações de terrenos empreendidos tanto pelo governo estadual quanto pelo municipal para a construção de moradias na cidade, que perduraram nos anos quarenta e se estenderam até a década seguinte ${ }^{329}$.

\begin{tabular}{|c|c|c|c|c|c|c|c|c|c|c|c|c|c|c|c|c|}
\hline \multicolumn{17}{|c|}{ ATUAÇÃO DAS CAPS E IAPS (NATAL) } \\
\hline \multirow{2}{*}{$\begin{array}{c}\text { Ações } \\
\text { Imobiliárias }\end{array}$} & \multicolumn{2}{|c|}{ IAPI } & \multicolumn{2}{|c|}{ IPASE } & \multicolumn{2}{|c|}{ IAPC } & \multicolumn{2}{|c|}{ IAPB } & \multicolumn{2}{|c|}{ IAPTC/IAPE } & \multicolumn{2}{|c|}{ CAPESP } & \multicolumn{2}{|c|}{ N.E. } & \multicolumn{2}{|c|}{ Total } \\
\hline & No. & $\%$ & No. & $\%$ & No. & $\%$ & No. & $\%$ & No. & $\%$ & №. & $\%$ & No & $\%$ & No & $\%$ \\
\hline $\begin{array}{c}\text { Compra de } \\
\text { unidade do } \\
\text { Instituto/Caixa }\end{array}$ & 58 & 34,52 & 42 & 36,20 & 32 & 36,78 & - & - & 43 & 86 & 46 & 80,70 & 07 & 43,75 & 228 & 40,71 \\
\hline $\begin{array}{c}\text { Compra de } \\
\text { terreno e/ou } \\
\text { construção de } \\
\text { residência }\end{array}$ & 95 & 56,54 & 49 & 42,24 & 30 & 34,48 & 40 & 66,6 & 01 & 02 & 02 & 3,52 & 03 & 18,75 & 220 & 39,38 \\
\hline Reforma & 03 & 1,78 & 09 & 7,75 & 04 & 4,59 & - & - & 01 & 02 & - & - & 02 & 12,50 & 19 & 3,4 \\
\hline $\begin{array}{l}\text { Aumento de } \\
\text { Financiamento }\end{array}$ & - & - & 02 & 1,75 & 04 & 4,59 & - & - & - & - & - & - & - & - & 06 & 1,07 \\
\hline Outras & - & - & - & - & 02 & 2,32 & - & - & - & - & - & - & 01 & 6,25 & 03 & 0,53 \\
\hline N.E. & 12 & 7,16 & 14 & 12,06 & 15 & 17,24 & 26 & 39,4 & 05 & 10 & 09 & 15,78 & 03 & 18,75 & 84 & 15 \\
\hline Total Absoluto & & 168 & & 16 & & 37 & & 6 & & & & 57 & & 16 & & 60 \\
\hline Atuação IAP & & $0 \%$ & & $71 \%$ & & $53 \%$ & & $78 \%$ & & & & $17 \%$ & & $35 \%$ & & $0 \%$ \\
\hline
\end{tabular}

Figura 47: Quadro de classificação das ações imobiliárias das CAPs e dos IAPs em Natal.

Fonte: Elaboração própria com base nos dados coletados no INSS-RN.

327 Vila Régis (IAPI-1947), Vila Gomes (IAPI-1947), Vila Janete (IAPI-1947), Vila Platinick (IAPB-1947), Vila São João (IAPI-1948), Vila Seabra (1949), Vila Lustosa (IPASE-1950) e as casas da Rua Manoel Miranda (IPASE, 1953).

328 Processo iniciado em meados da década de 1930, na ocasião do qual, diversas empresas construtoras instalaram escritórios na cidade, como já colocado no início deste capítulo.

$329 \mathrm{Na}$ década de 1950, mais precisamente no ano de 1951, o governo do estado ampliou novamente o projeto de incentivo à construção de casas próprias, verbalizado principalmente pelo aumento das concessões de terrenos aos IAPs e às CAPs, em concordância com a Lei №. 92, de 24 de novembro daquele ano, numa tentativa de se instituir um programa habitacional consistente no estado (TERRENO..., 24/11/1951, p.03). 
Esse quadro pode ser justificado por três vertentes. A primeira diz respeito à escassez de verbas nos cofres das Carteiras Prediais dos órgãos em âmbito estadual, o que comprometia a aquisição de terrenos, materiais de construção, pagamento de mão de obra, dentre outras despesas que acarretariam à construção de um conjunto residencial. A segunda justificativa recai sobre a economia e a redução do tempo para reaver o capital investido, alcançados comumente por meio da produção em série e, consequentemente, na rapidez da execução da obra. No entanto, ao proceder dessa maneira em Natal, os Institutos perdiam em termos de durabilidade do imóvel, visto que estes apresentavam entre cinco a vinte anos de construção, o que resultava em grandes investimentos em reparos e reformas dessas moradias. A terceira explicação remete à latente necessidade de construção de unidades habitacionais para as camadas mais carentes na cidade devido aos momentos de agravamento da crise de moradias ocasionada por diversos fatores, dentre eles, a exacerbação do fluxo de migrantes em direção à capital decorrentes das secas constantes na região (ALMEIDA, 2007).

O Instituto que mais atuou na capital norte-riograndense no recorte temporal estudado (considerandose todas as ações imobiliárias) foi o IAP dos Industriários, responsável por 30\% dos pleitos concedidos em Natal. O IAPI foi um dos Institutos que mais mobilizou verba para a efetivação de financiamentos para aquisição e/ou construção de moradias (56,54\%). No entanto, não se dedicou a edificação de residências de modo direto, como a maior parte dos institutos de previdência atuantes em Natal. $O$ único exemplar edificado por esse Instituto corresponde à Vila São Pedro, construída no ano de 1946, que da mesma forma que as demais Vilas de sua propriedade, encontra-se situada no bairro do Alecrim, considerado na época, como de natureza mista (comercial e residencial), destinado às classes de renda baixa e média baixa, principalmente (LAUDOS..., 1944-1949) (Figura 48).

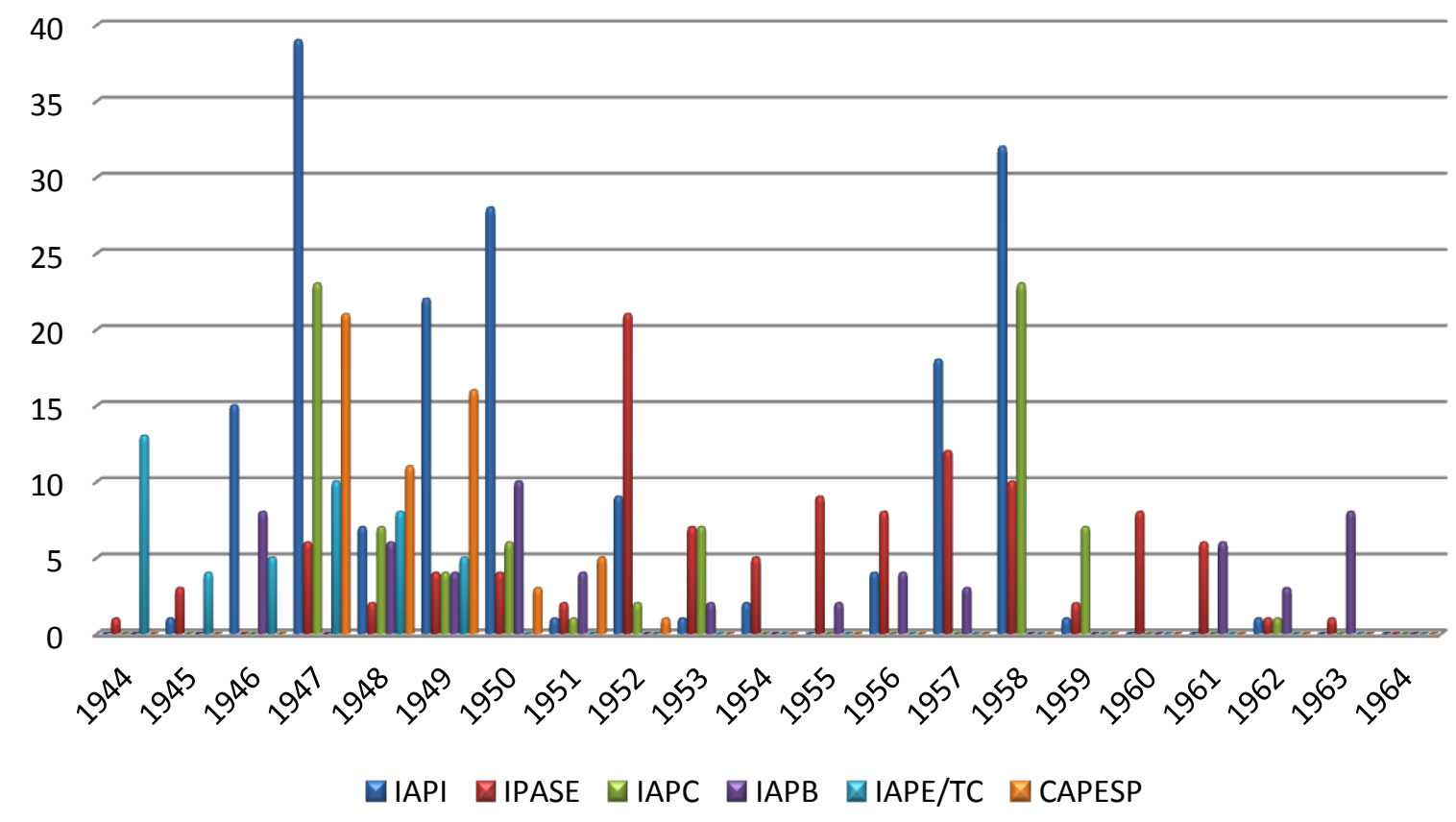

Figura 48: Quadro de distribuição da atuação das CAPs e dos IAPs em Natal no período de 1944-1964. Fonte: Elaboração própria com base nos dados coletados no INSS-RN. 
O IAP dos Industriários também foi o Instituto que mais adquiriu grupos de moradias já edificados por terceiros para os seus associados em Natal, um total de cinco empreendimentos, $20,83 \%$ do total que se acredita ter sido de propriedade dos órgãos na cidade. Porém, as residências desses grupos somados totalizam somente 40 unidades $^{330}, 7,14 \%$ do levantado na pesquisa (560 processos imobiliários) e 8,51\% do número de residências locadas em vilas ou conjuntos de moradias na capital norte-riograndense (470 unidades). Sendo assim, observa-se que apesar de ter um maior número de grupos residenciais, o IAPI, em relação às concessões diretas gerais não teve uma atuação de representatividade. Ao passo que o IPASE construiu quatro conjuntos $(16,66 \%)^{331}$ e no único que foi possível apontar as unidades edificadas, o número se aproxima do total de realizações do IAPI na cidade (Conjunto Paulo Gentile, conformado por 30 unidades habitacionais).

Esse Instituto criado para atender aos servidores públicos estaduais foi o segundo mais atuante em Natal, responsável por $20,71 \%$ dos financiamentos concedidos entre meados da década de 1940 e meados da década de 1960. Por outro lado, se for levado em consideração o fato que a CAPESP332 foi incorporada pelo IPASE em fins da década de 1940, como colocado anteriormente, e somar-se a atuação de ambos os órgãos ao longo dos anos na capital norte-riograndense, verifica-se um montante de onze grupos de moradias, oito dos quais foram edificados antes de 1964 (33,33\%) e um total de 225 financiamentos imobiliários (47,87\% das unidades edificadas e/ou construídas pelos órgãos em Natal), superando inclusive a atuação do IAPI na cidade.

O IPASE também foi o responsável pela edificação do primeiro Conjunto Residencial de Natal, o já citado Conjunto Paulo Gentile (1947). Assim como as primeiras vilas adquiridas pelo IAPI, o referido Conjunto também foi construído em meados da década de 1940, só que num bairro mais abastado que o Alecrim e essencialmente residencial, o bairro do Tirol33, provavelmente por ser destinado a uma categoria mais privilegiada economicamente que os industriários, o funcionalismo público do estado. Porém, essa modalidade de ação no campo habitacional só se tornou mais comum a partir de meados da década seguinte. Dessa forma, observa-se que em Natal, os Institutos e Caixas iniciaram sua atuação por meio da edificação ou aquisição de vilas operárias, no início da década de 1940, ao passo que os conjuntos residenciais, munidos de equipamentos, espaços públicos e de lazer, só se tornaram mais recorrentes, como observado em João Pessoa, em meados dos anos de 1950. Esses conjuntos se mostraram maiores em número de unidades habitacionais, bem como mais diversificados quanto aos serviços e aos equipamentos existentes, pelo menos em projeto, como foi o caso do II Conjunto do IPASE, edificado em 1956, e do Conjunto Nova Tirol (IAPC), construído no final da década, em 1958.

\footnotetext{
330 Como já colocado anteriormente, o número de unidades habitacionais que conformam a Vila São João e a Vila Seabra do IAPI não pode ser apontado nesta pesquisa.

331 Não considerando-se os conjuntos edificados após 1964.

332 A Caixa de Aposentadoria e Pensões dos Servidores Públicos Estaduais (CAPESP) financiou 10,17\% dos processos em Natal.

333 De natureza residencial, considerado pelos periódicos da época como novo, moderno e destinado às classes média alta e alta, sobretudo.
} 
O terceiro instituto de previdência mais atuante foi o IAP dos Comerciários, responsável por 15,53\% dos pleitos concedidos. O IAPC foi o único Instituto que edificou moradias coletivas na capital norteriograndense, encontradas no Conjunto Residencial Nova Tirol, que também corresponde ao maior conjunto habitacional erguido na cidade pelos IAPs e CAPs no período estudado, só perdendo para a Cidade da Esperança construída pela FUNDHAP em parcerias com outros órgãos, na década de 1960. O IAP dos Bancários, por sua vez, aprovou $11,78 \%$ dos financiamentos em Natal. Esse órgão foi o Instituto que menos construiu e/ou adquiriu moradias isoladas, em conjuntos ou vilas de caráter operário. Edificou apenas três grupos conformados por um total de 28 residências, situadas nos bairros de Cidade Alta e Petrópolis, na década de $1950^{334}$. A grande maioria dos financiamentos realizados por esse Instituto em Natal correspondia à compra de terrenos a terceiros para a edificação de moradias, geralmente sob a responsabilidade de construtores contratados pelos segurados.

Em se tratando da atuação dos IAPs entre as décadas de 1940 e 1960, o maior volume de financiamentos, em concordância com o cenário nacional, foi concedido entre os anos de 1946 e 1950, decaindo na primeira metade da década e crescendo mais uma vez nos anos de 1957 e $1958^{335}$ (Figura 49). Mais especificadamente, o IAPI concedeu financiamentos em todo o período que se estende entre os anos de 1946 e 1958, quando foi praticamente interrompida a sua atuação na cidade.

Esse é um aspecto instigante, ao passo que a SUDENE foi instituída em 1959, impulsionando a criação, crescimento e fortalecimento de fábricas e indústria, até então em número incipiente no Rio Grande do Norte. Esse processo foi acompanhado pelo aumento da demanda por mão de obra e, consequentemente, pelo aumento dos

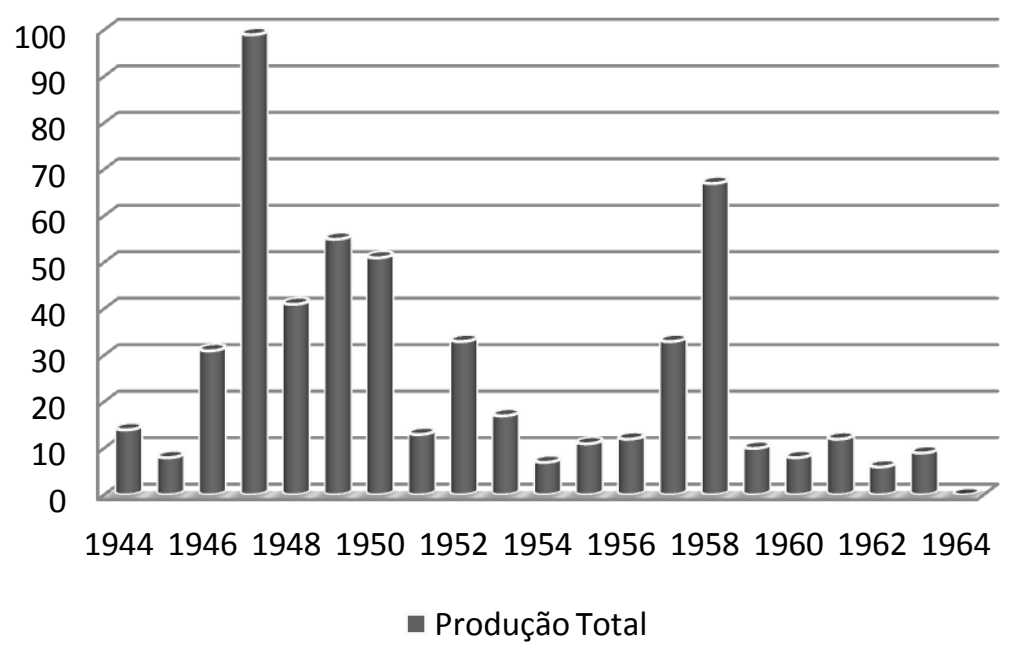
segurados a esta carteira profissional, que deveria ter sido acompanhado pelo aumento das ações do IAPI no

Figura 49: Quadro da atuação das CAPs e dos IAPs em Natal ao longo
das décadas de 1940 a 1960. Fonte: Elaboração própria com base nos dados coletados no INSSRN.

\footnotetext{
334 Há registros de outro conjunto edificado pelo IAPB na cidade de Mossoró, no início da década de 1960, com aproximadamente trinta casas.

335 Contrariando a historiografia existente, os anos de 1947 e 1958 equivalem aos maiores picos de agravamento da crise de moradias em Natal, resultantes respectivamente, da crise econômica e social por que passou a cidade com o fim da II Guerra Mundial e perda de considerável parcela de capital circulante, e do grande período de estiagem que culminou no aumento do número de favelas na cidade. Para aprofundamento dessa questão ver Almeida (2007).
} 
campo habitacional, mas não o foi. A interpretação inversa também mostra-se curiosa. Como e por que numa capital tida como atrasada industrialmente até fins da década de 1950, foi tão expressiva a atuação do órgão que justamente atendia àquela demanda?

Uma das possíveis justificativas recai por sobre o fato de Natal ter, desde cedo ${ }^{336}$, direcionado sua economia para o turismo, ou como colocado nos periódicos locais da época, para a "indústria do turismo", sendo parte do pessoal envolvido nessas atividades, assistido pelo IAPI. Outra justificativa ainda mais plausível remete, mais uma vez, à II Guerra Mundial e ao impressionante crescimento econômico e populacional da cidade, nesse momento. A instalação da base militar norte-americana na capital foi acompanhada pela instalação, por parte do governo norte-americano, de fábricas para atender às necessidades de seus militares, principalmente àqueles de alta patente. Natal contou inclusive com a primeira fábrica da Coca-Cola instalada fora dos perímetros daquele país, além de muitas outras relacionadas às atividades do conflito. A maior parte delas foi desativada ou decretou falência na década seguinte; seguindo 0 decréscimo da atuação do IAPI na cidade ${ }^{337}$.

Mais detalhadamente, o período de maior produção do referido Instituto compreende os anos de 1946, 1947, 1949 e 1950 - que somados correspondem a mais de $70 \%$ do volume total de financiamentos concedidos pelo IAPI em Natal. Essa elevação do número de financiamentos concedidos nos primeiros anos da segunda metade da década de 1940 foi provavelmente uma resposta à conjuntura de crise, sendo também justificada pelo aumento de crédito dos fundos dos Institutos, concedida pelo Governo Federal, para a construção de moradias populares. Posteriormente, percebeu-se uma elevação significativa da produção entre os anos de 1957 e 1958, provavelmente devido ao considerável aumento da população da capital nesse período.

Da mesma forma que vislumbrado nas cidades de João Pessoa, o IAPB em Natal teve uma atuação mais prolongada que os demais Institutos, continuando a operar nos anos de 1961 a 1963, nesse caso específico, juntamente ao IPASE. No entanto, diferente do procedido na capital acima elencada, as realizações do órgão no campo habitacional em Natal, não foram materializadas em unidades habitacionais situadas em edifícios coletivos verticais e sim, em financiamentos para a aquisição/construção de residências isoladas ou em grupos de moradias unifamiliares de sua propriedade. Dessa forma, em Natal, o escritório do IAPB não construiu edifícios verticais no centro da cidade, como observado no centro-sul do país, mas sim

\footnotetext{
${ }^{336}$ Desde o início do século XX e ao longo dos seus anos, observaram-se intentos administrativos e das elites locais em transformar Natal numa cidade de representatividade nacional e internacional, essencialmente devido às suas belezas naturais e moderna estrutura urbana. Em fins da década de 1920, a cidade se tornou alvo de um dos mais ousados planos de modernização e crescimento, o Plano de Sistematização (1929), que ganhou destaque na exposição do IV Congresso Pan-Americano de Arquitetos (1930), no Rio de Janeiro, sendo apresentado pela própria colaboradora a engenheira Carmen Portinho. No mesmo período, também ganhou destaque mundial por se tornar um novo importante entreposto aéreo, sendo contemplada com um dos primeiros aeroportos de hidroaviões do país. Na década seguinte, essa tendência se consolidou e a cidade concentrou novamente os olhares de parte do mundo, por se tornar palco para uma importante base militar norte-americana. Dentre muitos outros episódios que podem ser apontados. Para maiores detalhes, ver Almeida (2007).

${ }_{337}$ É importante lembrar que havia a possibilidade do segurado continuar contribuindo com a CAP ou IAP mesmo se desligando do emprego, como foi apontado no primeiro capítulo desta tese.
} 
construiu e financiou, sobretudo, unidades isoladas (ações indiretas) e alguns poucos conjuntos de moradias unifamiliares pulverizados pelos bairros da cidade. Por outro lado, se aproximando do perfil construtivo tipológico dos conjuntos residenciais de Salvador e do Recife, o IAPC foi o Instituto que mais se responsabilizou pela edificação de exemplares coletivos verticais na capital norte-riograndense, que nessa cidade, se resumiu aos quatro blocos que fazem parte do, já citado, Conjunto Nova Tirol.

Apesar de terem sido edificados ao longo das décadas de 1940 e 1950, as unidades habitacionais que conformam os supracitados conjuntos e vilas de propriedade dos Institutos e Caixas de Aposentadoria e Pensões na cidade de Natal foram comercializadas, essencialmente, por promessa de compra e venda ou por hipoteca, mesmo depois de criado o Banco Nacional de Habitação. Somente as unidades que constituem a Vila Ferroviária, situada no bairro das Rocas (IAPFESP-1954) e alguns grupos residenciais de propriedade da CAPESP foram alugadas aos segurados, que em conjunto não chegam a representar $10 \%$ do montante de moradias localizadas nos grupos residenciais.

Em se tratando de parcerias, além daquelas vislumbradas entre as instâncias estadual e municipal do governo e as CAPs e IAPs recorrentes em praticamente todo o Nordeste do país, pode-se apontar uma atuação conjunta do IPE (Instituto de Previdência do Estado) e a FCP (Fundação da Casa Popular), na década de 1960, para a edificação de parte do Conjunto de Cidade da Esperança. Foram pelo menos noventa residências, reservadas ao funcionalismo estadual e edificadas por meio dessa parceria, na primeira etapa de construção do Conjunto. No entanto, os dados levantados não foram suficientes para afirmar 0 modo pelo qual aquele instituto atuou nessa ocasião.

Ainda no que concerne à atuação das CAPs e dos IAPs em Natal, é importante destacar, que em alguns estudos recentes, como Lima (2011), são geralmente confundidas as características dos pleitos, uma vez que, na maior parte das vezes, a assinatura do contrato de promessa de compra e venda, quando retificado, isto é, quando já acordado e/ou adquirido o terreno pelo órgão de terceiros, era especificado que a área a ser construída era de propriedade do Instituto ou Caixa, mas, na verdade, o pleito se referia à aquisição do terreno e construção de moradia por parte do segurado. Mais detalhadamente, ao se enquadrar nessa categoria de aquisição imobiliária, o segurado deveria enviar juntamente à requisição do financiamento ao Instituto ou à Caixa, a especificação do local a ser edificada a residência e um termo de comprometimento de venda do imóvel pretendido assinado pelo proprietário, fosse ele terreno ou habitação. Aceito o pleito pelo órgão, e passadas as etapas já colocadas no capítulo 1, era firmado um primeiro contrato entre os promitentes vendedor e comprador e o IAP ou a CAP, na ocasião do qual, era liberado parte do montante solicitado pelo segurado ${ }^{338}$. Ao ser iniciada a edificação da moradia ou findada a mesma era assinado outro contrato. Esse somente entre o órgão e 0 associado, 0 promitente comprador. Esse aspecto, indubitavelmente, em muito dificulta a análise sobre a atuação desses órgãos no campo habitacional. Para precisar essa informação é muito importante ler a escritura final detalhada, na qual são especificados os

338 No caso de terrenos para a construção. 
trâmites desde a aquisição inicial da área desmembrada ou lote. Sendo assim, para essas análises devem ser desconsideradas, na maioria dos casos, as minutas de escritura inclusas nos processos imobiliários.

Outro aspecto que merece ser esclarecido é que a reforma ou ampliação de moradia, quase sempre, se dava em unidade habitacional de propriedade do Instituto ou Caixa, por aquisição ou construção, ou em residências financiadas por eles. Poucos foram os casos de modificações financiadas pelos referidos órgãos em residências que não fossem adequadas a essas categorias.

\section{Fortaleza-CE:}

De acordo com os dados levantados nos arquivos de Fortaleza, os IAPs e as CAPs em conjunto edificaram e/ou financiaram aproximadamente 3.000 unidades habitacionais na cidade ${ }^{339}$, o que corresponde a aproximadamente 14.940 pessoas atendidas pela política habitacional do país instituída e alargada a partir da década de 1930340. O número de pleitos liberados correspondia a 10,48\% dos prédios urbanos da cidade, em 1940, e a $12 \%$ da população urbana da cidade, no período. Desse montante foram levantados na pesquisa documental 300 processos imobiliários (10\%), que contemplam ações em 16 grupos residenciais construídos e/ou adquiridos pelos Institutos e Caixas, além de diversas unidades isoladas, consideradas nesta tese como ações indiretas.

Assim como nas outras capitais nordestinas estudadas até o momento, foram encontradas em Fortaleza exemplares de processos de financiamento para a construção de edifícios não habitacionais. Dentre esses exemplares identificados na pesquisa está a Maternidade Popular de Fortaleza (Escola), cuja edificação foi financiada pelo IAPI em 1959341. Vale ressaltar que em cada escritório estadual ou delegacia regional, como eram oficialmente chamados, as reservas orçamentárias para a realização das ações imobiliárias praticadas pelos órgãos, via de regra, eram separadas. No entanto, para a realização de obras, como a citada acima, muitas vezes se retirava verbas de mais de uma categoria, o que acabava por comprometer as realizações em outros âmbitos habitacionais, principalmente quanto à edificação de moradias de modo direto, em conjuntos residenciais, pelos IAPs e CAPs. No caso específico da construção da referida Maternidade pelo IAPI em Fortaleza, o delegado regional frisou que o escritório no estado só teria condições de disponibilizar $30 \%$ do valor pleiteado visto que iria comprometer as reservas construtivas do Instituto. Mas, o presidente da Instituição, bem como o Presidente da República, autorizou o pleito ${ }^{342}$. Reflexo

\footnotetext{
339 O número absoluto é ainda maior, considerando o fato que em três dos dezesseis empreendimentos identificados no Ceará não foi possivel apontar o total de unidades habitacionais.

340 Número estipulado considerando-se a média da família e a média de ocupantes dos domicílios particulares urbanos na cidade, no ano de $1940(4,98)$, de acordo com o IBGE.

341 O custo do financiamento autorizado pelo Presidente da República e acordado com o órgão para a edificação de tal obra foi de Cr\$ 20.000.000,00 (cruzeiros), se inserindo nos Planos D e E daquela delegacia estadual. Foi estabelecido ainda na ocasião da assinatura do contrato do IAPI com a Sociedade Pró-Construção da obra, que seria dado prioridade ao atendimento dos familiares dos segurados daquele Instituto, concedendo-lhes uma redução de $20 \%$ sobre os preços de tabela e procedendo a manutenção de leitos destinados às esposas de seus funcionários e associados.

342 A solicitação de empréstimo foi realizada diretamente ao Presidente da República e não ao Instituto, o que confirma que também era possível essa modalidade de solicitação de financiamento para determinadas realizações.
} 
ou não dessa ação, a produção habitacional do Instituto dos Industriários caiu consideravelmente em fins da década de $1950^{343}$, como se verá mais detalhadamente adiante.

O quadro dos órgãos atuantes em Fortaleza é maior e mais diversificado que os observados nas capitais nordestinas próximas, sobretudo, Teresina e São Luís. Naquela localidade foram identificados para além dos IAPs e das CAPs recorrentes, a atuação de uma diversidade de Caixas de Aposentadoria e Pensões, como no Recife, representadas principalmente pela CAP dos Serviços Aéreos e Telecomunicações, incorporada ao IAPECT ainda na década de 1930, pela CAP dos Serviços Urbanos, que diferente da identificada nas pesquisas em Salvador ${ }^{344}$ e no Recife ${ }^{345}$, só atendia ao estado do CE (CAPESP-CE), e pela CAP dos Ferroviários da Rede de Viação Cearense. Essas duas últimas instituições também foram incorporadas a outro IAP, o IAPFESP, nas décadas de 1950 e 1940, respectivamente.

Sem sombra de dúvidas, o IAPI foi o órgão mais atuante no campo habitacional em Fortaleza, da mesma forma que o verificado em Natal, sendo responsável por $46 \%$ dos pleitos concedidos entre os anos de atuação dos institutos de previdência na capital. A esse seguiu o IAPC (15\%), o IAPB (9,33\%), o IAPETC (8\%) e a CAP dos Serviços Públicos do CE (7,66\%), os demais institutos de previdência tiveram uma atuação mais pontual na cidade ${ }^{346}$. As ações desses órgãos começaram a ser vislumbradas no ano de 1938, semelhante ao ocorrido nas cidades do Recife e Salvador, por meio de três órgãos, essencialmente, o IAPB, o IAPE e a já citada CAP dos Serviços Públicos do CE (Figuras 50 e 51, página 190).

Um diferencial percebido em Fortaleza quanto ao volume de produção refere-se ao ínfimo número de concessões praticadas pelo IPASE. Em grande parte das capitais estudadas, esse foi o instituto mais operante no campo habitacional, ocupando as posições mais representativas nesse sentido. Essa realidade acompanha o perfil da população economicamente ativa naquela localidade no período, que se concentrava, mormente, nas atividades relacionadas à indústria e ao comércio, justificando assim, a atuação mais significativa dos Institutos dos Industriários e dos Comerciários. Por outro lado, essa informação nos leva a crer, que em Fortaleza, a CAP dos Serviços Públicos do CE e, posteriormente o IAPFESP, se mostraram alternativas estaduais à atuação daquele órgão, como autorizado por lei e semelhante ao ocorrido em Natal. O IPASE, seguindo a tendência nacional se mostrou operante a partir, sobretudo, da segunda metade da década 1960.

Também como vislumbrado em Natal, a atuação dos IAPs se deu inicialmente por meio da aquisição de vilas operárias já edificadas por terceiros e o posterior repasse das unidades por venda aos segurados de Fortaleza, no ano de 1938. Fortaleza foi uma das poucas capitais nordestinas onde se encontrou operações (processos imobiliários) que tratavam da aquisição de vilas operárias já edificadas por parte dos Institutos e

\footnotetext{
${ }^{343}$ Essa informação não pode ser precisada por não se ter tido acesso aos documentos e balanços financeiros do Instituto.

344 CAP dos Serviços Urbanos da BA e SE.

345 CAP dos Serviços Urbanos de PE e AL.

346 Foram eles: o IAPM, o IPASE, o IAPE e o CAPEFESP/IAPFESP.
} 



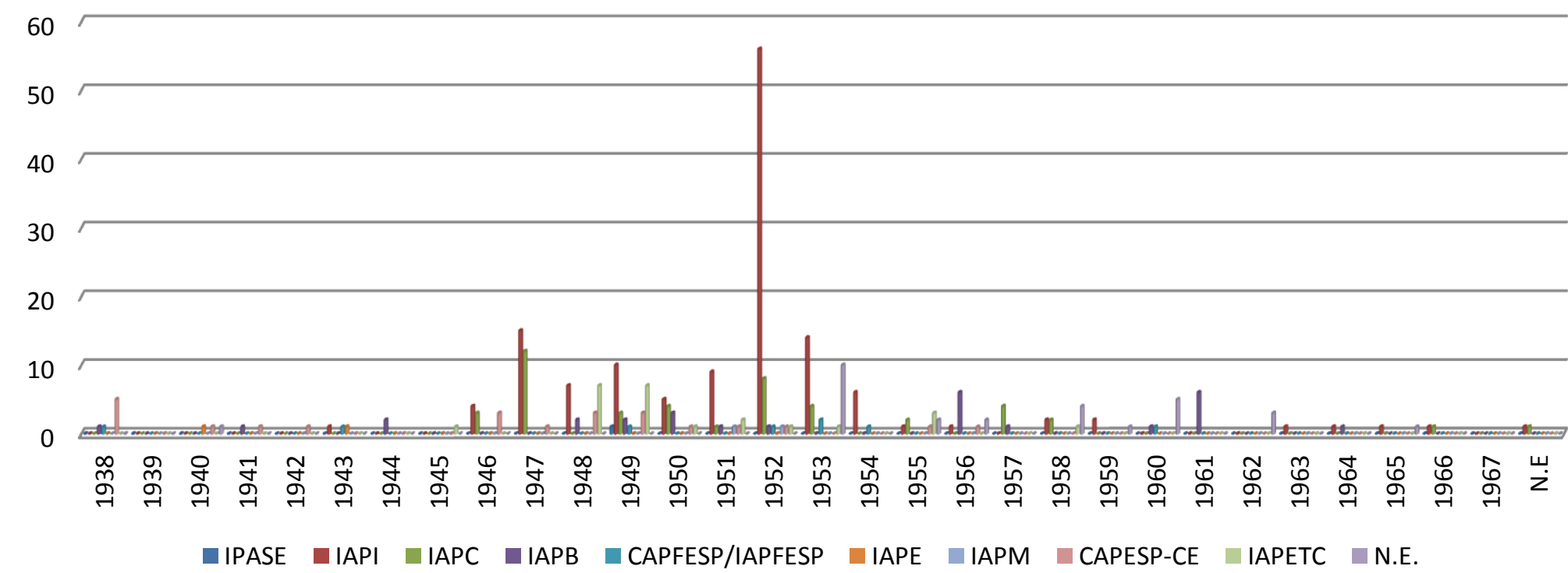

\begin{tabular}{|c|c|c|c|c|c|c|c|c|c|c|c|c|c|c|c|c|c|c|c|c|c|c|}
\hline \multicolumn{23}{|c|}{ ATUAÇÃo DAS CAPS E DOS IAPS EM FoRTALEZA } \\
\hline \multirow{2}{*}{$\begin{array}{c}\text { Ações } \\
\text { Imobiliárias }\end{array}$} & \multicolumn{2}{|c|}{ IAPI } & \multicolumn{2}{|c|}{ IPASE } & \multicolumn{2}{|c|}{ IAPC } & \multicolumn{2}{|c|}{ IAPB } & \multicolumn{2}{|c|}{ IAPFESP } & \multicolumn{2}{|c|}{ CAPESP } & \multicolumn{2}{|c|}{ IAPE } & \multicolumn{2}{|c|}{ IAPM } & \multicolumn{2}{|c|}{ IAPETC } & \multicolumn{2}{|c|}{ N.E. } & \multirow{2}{*}{ Total } & \multirow{2}{*}{$\%$} \\
\hline & 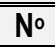 & $\%$ & $\mathrm{~N}^{\circ}$ & $\%$ & $\mathrm{~N}^{\circ}$ & $\%$ & $\mathrm{~N}^{\circ}$ & $\%$ & $\mathrm{~N}^{\circ}$ & $\%$ & $\mathrm{~N}^{\circ}$ & $\%$ & $\mathrm{~N}^{\circ}$ & $\%$ & $\mathrm{~N}^{\circ}$ & $\%$ & № & $\%$ & $\mathrm{~N}^{\circ}$ & $\%$ & & \\
\hline $\begin{array}{l}\text { Compra do } \\
\text { IAP/CAP }\end{array}$ & 19 & 13,76 & - & - & 01 & 2,22 & 07 & 25 & 03 & 37,5 & 10 & 43,47 & 01 & 50 & 02 & 100 & 06 & 25 & 05 & 17,24 & 54 & 18 \\
\hline $\begin{array}{c}\begin{array}{c}\text { Compra de } \\
\text { terceiros }\end{array} \\
\end{array}$ & 65 & 47,1 & - & - & 15 & 33,33 & 12 & 42,85 & 02 & 25 & 07 & 30,43 & 01 & 50 & - & - & 04 & 16,66 & - & - & 105 & 35 \\
\hline $\begin{array}{c}\text { Compra } \\
\text { terreno/const. }\end{array}$ & 30 & 21,74 & 01 & 100 & 02 & 4,44 & 02 & 7,14 & 02 & 25 & 05 & 21,74 & - & - & - & - & 02 & 8,33 & 04 & 13,8 & 49 & 16,33 \\
\hline $\begin{array}{c}\text { Constr. } \\
\text { terreno } \\
\text { segurado } \\
\end{array}$ & 05 & 3,62 & - & - & 21 & 46,67 & 04 & 14,29 & 01 & 12,5 & - & - & - & - & - & - & 03 & 12,5 & 05 & 17,24 & 39 & 13 \\
\hline Reforma & 11 & 7,97 & - & - & 01 & 2,22 & 01 & 3,57 & - & - & - & - & - & - & - & - & - & - & 03 & 10,34 & 16 & 5,33 \\
\hline $\begin{array}{l}\text { Aumento de } \\
\text { Financ. }\end{array}$ & 05 & 3,62 & - & - & 03 & 6,66 & 01 & 3,57 & - & - & 01 & 4,34 & - & - & - & - & 07 & 29,16 & 02 & 6,9 & 19 & 6,33 \\
\hline Outras & 03 & 2,17 & - & 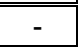 & 02 & 4,44 & - & - & - & - & - & & - & - & - & - & 01 & 4,16 & & & 06 & 2 \\
\hline N.E. & & $\overline{\bar{l}}$ & $\overline{-1}$ & $\overline{-1}$ & 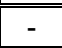 & & 01 & 3,57 & - & $\bar{~}$ & $\overline{-1}$ & & $\overline{-1}$ & $\overline{-1}$ & 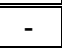 & & 01 & $4 \quad 4,16$ & 10 & 34,48 & 12 & $\overline{44}$ \\
\hline $\begin{array}{c}\text { Total } \\
\text { Absoluto }\end{array}$ & \multicolumn{2}{|c|}{138} & \multicolumn{2}{|c|}{01} & \multicolumn{2}{|c|}{45} & \multicolumn{2}{|c|}{28} & \multicolumn{2}{|c|}{08} & \multicolumn{2}{|c|}{23} & \multicolumn{2}{|c|}{02} & \multicolumn{2}{|c|}{02} & \multicolumn{2}{|c|}{24} & \multicolumn{2}{|c|}{29} & \multicolumn{2}{|c|}{300} \\
\hline Atuação IAP & \multicolumn{2}{|c|}{$46 \%$} & \multicolumn{2}{|c|}{$0,33 \%$} & \multicolumn{2}{|c|}{$15 \%$} & \multicolumn{2}{|c|}{$9,33 \%$} & \multicolumn{2}{|c|}{$2,66 \%$} & \multicolumn{2}{|c|}{$7,66 \%$} & 0,6 & $6 \%$ & 0,6 & $6 \% \%$ & & $3 \%$ & & $66 \%$ & 10 & $\%$ \\
\hline
\end{tabular}

Figuras 50 e 51: Gráfico e quadro de classificação dos tipos de financiamentos concedidos pelas CAPs e IAPs em Fortaleza. Fonte: Elaboração própria com base nos dados coletados no INSS-CE. 

Caixas, como foi o caso da Vila São Luís, implantada em terreno da Fábrica de Fiação e Rêde S. Luíz e edificada pelo seu proprietário Luiz Vieira, no ano de 1935, adquirida pelo IAPI, em $1943^{347}$.

A edificação do primeiro grupo residencial também se deu em 1938, pela CAPESP-CE. Como percebido em João Pessoa, em alguns dos conjuntos edificados em Fortaleza, procedeu-se a escolha dos associados antes da edificação das moradias, que foram edificadas aos poucos, em grupos de cinco a dez, até conformarem um conjunto, como no Conjunto Vila Aldeota (1938), originalmente de propriedade da CAP dos Funcionários da Viação Férrea Cearense, cujos pleitos se enquadravam na ação imobiliária empréstimo para a compra de terreno e construção de prédio, e sua construção foi administrativa, isto é, realizada por engenheiro componente do corpo técnico da Carteira Predial, nesse episódio, o próprio engenheiro chefe da C.P.

O maior número de concessões de financiamentos para a realização das ações imobiliárias pretendidas pelos órgãos em Fortaleza ocorreu, sobretudo, entre os anos de 1946 e 1955, período que coincide com o especificado pela historiografia acerca da atuação das CAPs e dos IAPs no campo da moradia no centro-sul do país. As concessões empreendidas nesses anos correspondem a 79\% do concedido em todo o período de atuação dos órgãos na capital cearense (237 processos imobiliários). 0 maior pico, nesse sentido, foi identificado no ano de 1952, especialmente pelas liberações empreendidas pelo IAPI (Figura 52).

Esse aspecto aproxima a
atuação desses institutos de
previdência, das observadas nas
capitais Recife e Salvador, as mais
representativas, econômico e
politicamente, no período nessa região
do país. Período de reformulações
regulamentares das ações no campo
habitacional empreendidas pelo poder
público nos órgãos, principalmente no
que concerne à burocracia para a
solicitação de um pleito e à isenção de

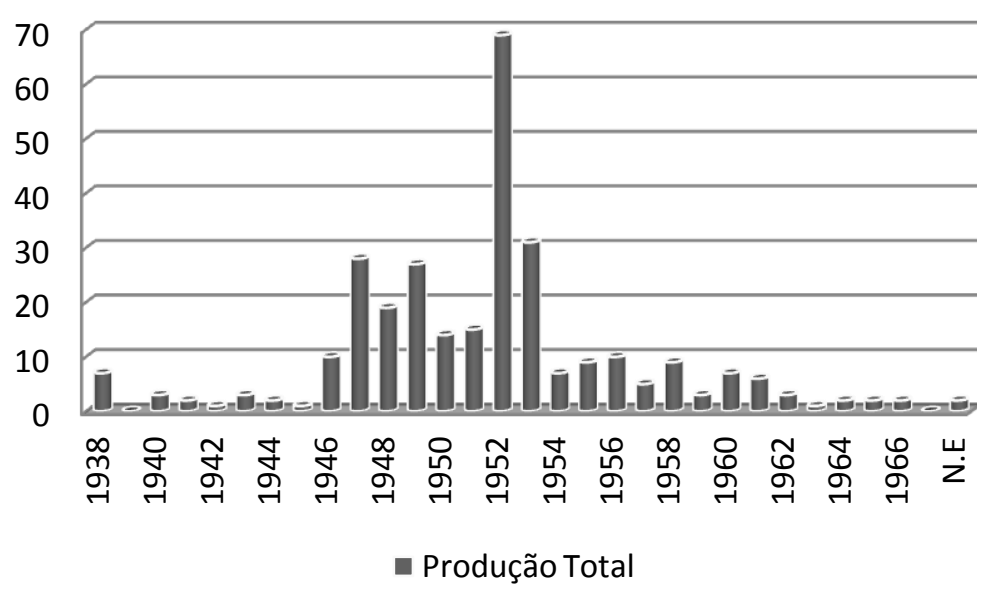

Figura 52: Quadro de distribuição da atuação das CAPs e dos IAPs em Fortaleza no período de 1938-1966.

Fonte: Elaboração própria com base nos dados coletados no INSS-CE. taxas e impostos que incidiam sobre os imóveis de propriedade ou envolvidos em ações com os Institutos e Caixas, como já colocado anteriormente, que resultaram no aumento nos investimentos nesse setor, como também, na doação de terrenos por parte do poder público, no pós-Segunda Guerra.

Uma curiosidade percebida na capital cearense acaba por dar mais afinco à afirmativa que os supracitados órgãos de previdência social não foram extintos em 1964, conforme defendido no primeiro

347 Vila conformada por 70 unidades residenciais situadas nas Ruas do Imperador e Tristão Gonçalves. 
capítulo desta tese. Em Fortaleza, especialmente, os IAPs, para além do IPASE, continuaram a conceder financiamentos tanto para a edificação de moradias, quanto para a locação de unidades de propriedade dos órgãos, como foi o caso do IAPI após aquele ano. Nesse sentido, foram identificados pleitos liberados pelo órgão até 1968, relacionados principalmente ao aluguel de moradias edificadas pelo IAPI.

Quanto às categorias imobiliárias praticadas, a concessão de pleitos para aquisição de residência edificada por terceiros (iniciativa dos segurados) se destaca em relação às demais, compreendendo $35 \%$ das ações no período, sendo o IAPI o órgão que mais contribuiu para tanto (Ver figura 51). A aprovação de pleitos para a aquisição de terreno e construção de moradia também foi outra ação que se destacou no âmbito dos Institutos e Caixas em Fortaleza se comparada às demais capitais nordestinas. Essas ações também foram realizadas principalmente pelo IAPI. O IAPC, por sua vez, empreendeu, sobretudo, o financiamento para a edificação de casa em lote de propriedade do próprio segurado. Nesse Instituto especificadamente, de acordo com os dados levantados, a venda de unidades só se deu no ano de 1966 e essencialmente na cidade do Crato. $O$ número de reformas e pleitos autorizados para amortização ou encampação de dívida hipotecária vislumbrado em Fortaleza também é consideravelmente superior aos demais estados nordestinos, liberados principalmente pelo IAPTEC.

Uma das justificativas para esse quadro diferenciado da atuação dos órgãos em Fortaleza recai sobre o fato que a maior parte dos IAPs e das CAPs na cidade, empreendia um esquema de avaliação por pontuação, que se distinguia das demais capitais do Nordeste, quando praticado. Nele, as próprias categorias imobiliárias recebiam pontuações, de modo que a construção em terreno do segurado recebia a maior delas (10 pontos a mais que as demais).

Ações irregulares e aproveitamentos das brechas legislativas por parte dos segurados das Carteiras Imobiliárias dos órgãos, com o intuito de angariar um ou mais imóveis, também podem ser apontadas em Fortaleza, assim como identificado no âmbito de Salvador e João Pessoa, principalmente ${ }^{348}$. Naquela capital, percebeu-se que foram atendidos, além de associados abastados, como se verá adiante, trabalhadores que não residiam na cidade e, inclusive, no estado do Ceará. Esse aspecto permitia que alguns segurados adquirissem imóveis, financiamentos ou hipotecas, por mais de um escritório estadual, alegando por vezes mudança ou trabalho itinerante. Diversos trabalhadores natalenses e piauienses adquiriram moradias em um estado e financiamentos para construção e/ou reforma em outro, mesmo quando não era permitida à aquisição de mais de uma unidade por promitentes. Na maior parte das vezes, esses imóveis eram repassados por venda a terceiros não vinculados às CAPs e aos IAPs logo após concluídos os pleitos. Como as certidões negativas de propriedade imobiliária eram expedidas pelos cartórios locais e como a fiscalização dessas ações, na maioria do tempo, era ineficiente e/ou insuficiente, esse se tornou um viés recorrente no

348 É importante destacar que, apesar desta possibilidade ter sido autorizada em 1937, parte dos escritórios estaduais nordestinos se posicionaram contra a aquisição de mais de um imóvel por parte de seus segurados. 
período, sendo intensificado, assim como outras ações de clientelismo e apadrinhamento, com o passar dos anos.

Casos de fraude na sublocação de imóveis dos Institutos e Caixas também podem ser apontados na capital cearense. Como já é de conhecimento, a sublocação de cômodos, bem como das moradias adquiridas por meio de financiamentos concedidos pelos institutos de previdência, não eram permitidas ${ }^{349}$, salvo os casos muito bem justificados e autorizados pela instituição concedente, o que era muito incomum ${ }^{350}$. Ocorria, por vezes, a aquisição de uma residência por meio da política habitacional empreendida pelos órgãos, na maior parte dos casos por trabalhadores abastados, que as repassavam para terceiros sob pagamento de aluguel. Diversas unidades do Conjunto Coqueirinho ou Vila dos Industriários como é popularmente conhecida (IAPI-1964), foram realugadas por seus promitentes proprietários (uma vez que o título de propriedade, bem como a escritura definitiva, só era passada para o nome do segurado após a quitação da dívida com o Instituto) que, mormente, residiam em bairros mais abastados.

Houve casos ainda, em que o pleito se enquadrava como social e posteriormente, modificações de dimensões e até na qualidade dos materiais empregados e, consequentemente, o aumento do custo da construção, faziam com que alguns segurados empreendessem o aumento da concessão, por meio da solicitação da encampação da dívida hipotecária ou um novo pleito de reforma. Essa prática se conformava como ilegal, desde os primeiros anos da década de 1940. No entanto, muitos processos dessa natureza foram aprovados pelos Departamentos Financeiros de diversas delegacias regionais, não somente na capital cearense, como também em variadas cidades do país.

Exemplos de ineficiência da atuação dos órgãos no campo habitacional, assim como da morosidade do atendimento da necessidade de moradia dos trabalhadores realmente necessitados, também são facilmente encontrados em Fortaleza. Alguns segurados passaram mais de três anos, depois de inscritos nas Carteiras Imobiliárias, esperando para serem contemplados com um imóvel. Em outros casos, como observado no âmbito do Conjunto Vila Valdemar Falcão (IAPFESP-1943), as avaliações dos imóveis - cujas solicitações para aquisição por parte dos segurados foram enviadas e os processos aprovados em 1946 - só foram atendidas na década de 1950. Diversos foram os relatos de segurados, nesse sentido, especialmente por meio de cartas endereçadas ao escritório central de um Instituto ou Caixa ou diretamente para seu delegado na cidade.

Problemas relacionados à concorrência para aquisição por compra ou aluguel de habitação locada em grupos residenciais, de propriedade dos Institutos, também foram recorrentes em Fortaleza. No âmbito do IAPB, por exemplo, foram variadas as reclamações de segurados que se sentiram prejudicados pelo sistema

\footnotetext{
349 De acordo com os dados encontrados nos contratos de locação em Fortaleza, mais precisamente, não era permitido "(...) transferir ou ceder o presente contrato, nem sublocar, emprestar ou ceder, no todo ou em parte. O imóvel a quem quer que seja (...) destina-se à moradia exclusiva do locatário e respectiva família (...)" (CONTRATO..., 28/08/1953, p.01).

${ }^{350}$ A maioria das solicitações para a sublocação ou o repasse de habitações para terceiros, mesmo que temporária, enviada por segurados dos Institutos e Caixas de Aposentadoria e Pensões, era negada por parte dos órgãos.
} 
de contagem de pontos ${ }^{351}$ (que levava em consideração o número de filhos, de inscrições em concorrências anteriores, a categoria do pleito e o tempo de serviço principalmente) e que solicitaram a sua revisão. $\mathrm{Na}$ maioria dos casos, "ocorria" erro na contagem dos pontos. Alguns relatos encontrados em periódicos e em documentos da época incitam para favorecimentos nesse sentido:

(...) o segurado recorreu em tempo hábil contra a totalidade dos pontos que thes foram atribuídos (...), pressupondo haver um engano relativo ao item (...) número de inscrições anteriores de financiamento (...) o que the possibilitaria a adição de 20 pontos (...).

(...) esta segurada recorreu em tempo hábil contra a posição que the coube na Classificação Imobiliária havida em Fortaleza - Ceará, alegando como principal motivo para fundamentar o seu recurso o fato de não terem sido computados os pontos relativos aos seus cindo (5) filhos menores (...) (INSTITUTO..., 1964, p.01).

Outro problema relacionado à venda de unidades dos institutos de previdência aos seus associados refere-se ao impedimento do repasse dos imóveis adquiridos pelos segurados, mesmo depois de concluído 0 pagamento da dívida junto aos órgãos, sobretudo, daqueles locados em grupos residenciais. Essa restrição foi perpetuada no âmbito da maioria dos Institutos e Caixas até o início do, já citado, processo de alienação dos imóveis do INPS, em fins dos anos de 1960.

Assim como em Salvador, foram identificados em Fortaleza alguns regulamentos administrativos de conjuntos. Para a Vila Antônio Ferreira Filho (IAPECT-1940), por exemplo, foi contratado inclusive um administrador ${ }^{352}$, por parte do Instituto, ainda na década de 1950, para se fazer executar as normas de convívio e uso dos seus imóveis. De modo geral, essas determinações eram muito próximas em ambas as capitais nordestinas, como as encontradas no âmbito do Conjunto Coqueirinho (IAPI-1952). A maior parte das obras e escolhas de profissionais era realizada por meio de concorrência aberta ou interna, em Fortaleza.

Em algumas situações, o empréstimo pleiteado chegava a considerar a aquisição de móveis e utensílios domésticos. Esse foi o caso do pleito solicitado para a compra de terreno e edificação de moradia empreendido por um escrituário da Contadoria do Ceará, no ano de 1940, à CAP dos Funcionários da Viação Férrea Cearense. No qual, o segurado solicitou a quantia adicional para a compra de guarda-roupa, cama de casal e "cabideiro", dentre outros móveis, mais modernos e condizentes com a nova unidade habitacional a ser construída. Apesar da aquisição desses elementos não ficar a cargo da instituição de previdência, coaduna com o intento do Chefe do Setor de Engenharia do CNT, o engenheiro-arquiteto Rubens Porto, de dotar as novas moradias edificadas ou financiadas para os trabalhadores urbanos do país, com novo mobiliário mais adequado à configuração da casa pretendida.

\footnotetext{
351 Nesse Instituto era considerado o tempo de contribuição de acordo com a seguinte contagem: até 2 anos $=0$ pontos; de 2 a 5 anos $=5$ pontos; de 5 a 10 anos $=10$ pontos; de 10 a $15=15$ pontos; de 15 a $20=20$ pontos e acima de 20 anos $=25$ pontos. Nos casos de remoção do segurado para outra cidade devido ao trabalho, essa pontuação variava de 5 a 10 pontos, sendo esse conquistado quando o segurado tinha sido relocado em até seis meses.

352 Recebendo remuneração de $\mathrm{Cr} \$ 600,00$ (cruzeiros) e adquirindo o diretito de residir gratuitamente em uma das unidades da Vila.
} 


\section{Teresina-PI:}

O número de processos levantados nos arquivos da cidade de Teresina foi 260 (duzentos e sessenta), mas a maior parte deles referem-se a pleitos liberados depois do ano de 1964. Esse quadro se deu pelo fato que, inicialmente, pretendia-se nesta tese, empreender a análise da atuação dos órgãos, sobretudo o IPASE, para além de 1964, bem como, estender o recorte espacial da pesquisa para as principais cidades dos estados nordestinos - não somente algumas capitais, como acabou ocorrendo. Porém, o elevado volume de processos imobiliários com que se deparou nos levantamentos documentais realizados, como já colocado no início do trabalho, e o reduzido espaço de tempo para a sua conclusão, impossibilitou a concretização desse intento original. Sendo assim, dos 260 pleitos imobiliários liberados e levantados nos arquivos da cidade, 170 (cento e setenta) se encaixam no recorte temporal firmado para a pesquisa (65,38\%), que inicia nos primeiros anos da década de 1930 até meados da década de 1960.

Outra justificativa para o levantamento das ações que extrapolaram 1964 recai no fato que em Teresina, especificamente, a maior parte dos conjuntos residenciais empreendidos pelos poucos Institutos atuantes, só se deu a partir daquele momento. Dos oito grupos habitacionais identificados na pesquisa e locados em todo o estado do Piauí353, cinco encontram-se situados em sua capital e apenas três foram edificados e liberados antes daquele ano. A maioria das obras de construção desses empreendimentos adentrou a segunda metade da referida década, e a comercialização de suas unidades perdurou por toda ela, chegando inclusive à década de 1970, como foi o caso do I Conjunto Aeroporto (IPASE-1964). A aprovação e a liberação da realização desse Conjunto foram especificadas por decreto ainda em 1964. Contudo, as obras só foram concluídas por volta de 1966, e o repasse de suas unidades unifamiliares isoladas por venda, só ocorreu, concomitantemente ao processo de alienação dos imóveis do INPS em 1968, sobretudo354. Isso provavelmente ocorreu pela própria conjuntura política e econômica do país da época, bem como diante das diversas reformulações regulamentares e administrativas por que passou o órgão a partir de meados daquela década. É importante destacar ainda que, a partir da década seguinte, o IPASE, órgão que procedeu à edificação da maioria dos conjuntos residenciais no Piauí, também foi incorporado parcialmente nesse processo de venda de imóveis que ainda se encontravam sob o domínio dos segurados dos órgãos, devido à outra reforma estrutural que incorporou as suas funções no campo habitacional ao IAPAS.

Como mencionado anteriormente, a atuação dos Institutos de Previdência em Teresina, se mostrou mais restrita, se comparada ao restante do quadro nordestino. Tanto no que condiz ao número de conjuntos

\footnotetext{
353 São eles: I e II Conjunto Aeroporto (IPASE-1964/1969), Conjunto Coronel Vitorino Corrêa (IPASE-1953), Conjunto Monte Castelo (IPASE-1966), Conjunto Nossa Senhora das Lourdes, em Campo Maior (IPASE-déc.1960), Conjunto Boa Esperança, em Parnaíba (IPASE-1958), Conjunto São Raimundo (IAPC-1957) e a Vila Operária dos Bancários (IAPB-1960).

${ }_{354}$ A edificação das unidades habitacionais que conformaram o referido Conjunto, a semelhança do procedido pelo escritório estadual do IPASE em João Pessoa, se deu pelo 20 Grupamento de Engenharia, posteriormente denominado Batalhão de Engenharia da Construção, só que no caso teresinense, a maior parte das moradias do conjunto foram reservadas aos trabalhadores do Batalhão. Uma segunda etapa do Conjunto foi empreendida pelo IPASE em parceria com a SUDENE, em fins da década de 1960.
} 
edificados e pleitos indiretos liberados pelos IAPS, quanto ao número de órgãos na cidade ${ }^{355}$. Apenas 0 IPASE e o IAPC apresentaram um montante de concessões representativo em Teresina, enquanto o IAPI e 0 IAPB se mostraram praticamente inoperantes, financiando algumas poucas unidades unifamiliares, que estão concentradas na pequena Vila Operária do IAPB, na Alameda Paraíba, e o restante está pulverizado pela capital.

Em se tratando dos aspectos temporais, não se percebe uma continuidade da atuação dos supracitados Institutos na capital piauiense, no campo habitacional (Figura 53). O IAPC apresentou picos de financiamentos concedidos nos anos de 1947 (36,84\% do total de processos levantados no período) e 1952 $(23,68 \%)$, a partir de quando, praticamente deixou de empreender ações imobiliárias. Suas realizações se concentraram especialmente na segunda metade da década de 1940, que abarca $63,15 \%$ dos pleitos liberados pelo IAPC em todo o recorte temporal estudado.

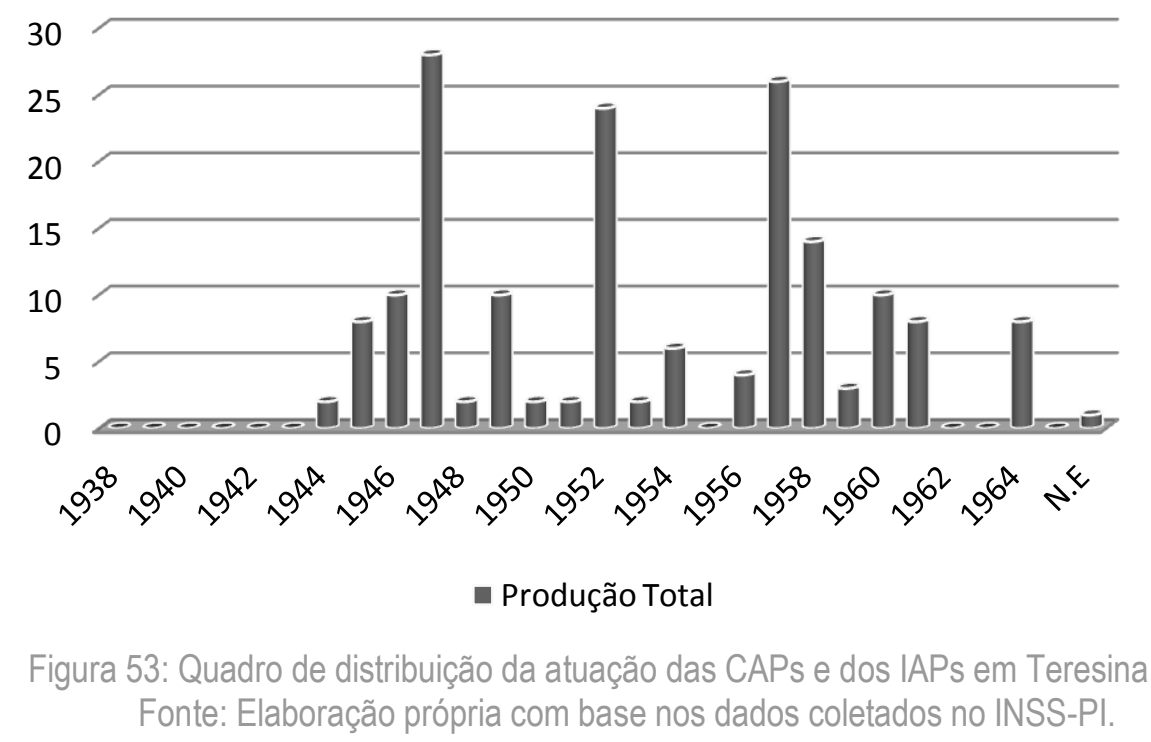

O IPASE, por sua vez, teve um momento de produção considerável nos anos de 1957 (35,13\%) e 1958 (10,81\%), decaindo a liberação de financiamentos até o ano de 1964, quando voltou a operar consideravelmente. Essa produção significativa perdurou até o final da década de 1960, período em que 0 órgão atuava em parceria com o BNH. A partir desse momento, quatro grandes conjuntos residenciais foram edificados pelo Instituto na cidade, cujas unidades somadas chegam próximo ao financiado pelos demais órgãos até 1964. No âmbito do IAPI, só foram identificadas concessões em três anos - 1949, 1952 e 1956 -, que marcaram a sua atuação pontual em Teresina, entre 1944, quando foi identificado o primeiro pleito na cidade, até 1956, quando o órgão praticamente deixou de atuar nessa capital nordestina. O IAPB, por sua vez, só operou na cidade a partir de 1961, época do repasse das unidades de sua vila operária aos bancários teresinenses 356 (Figura 54).

355 Refere-se somente aos IAPs pelo fato que não foi identificada nenhuma ação imobiliária empreendida por uma Caixa de Aposentadoria e Pensões em todo o estado do Piauí.

356 Uma atuação mais tardia, em concordância com o observado em grande parte das cidades analisadas até o momento. 


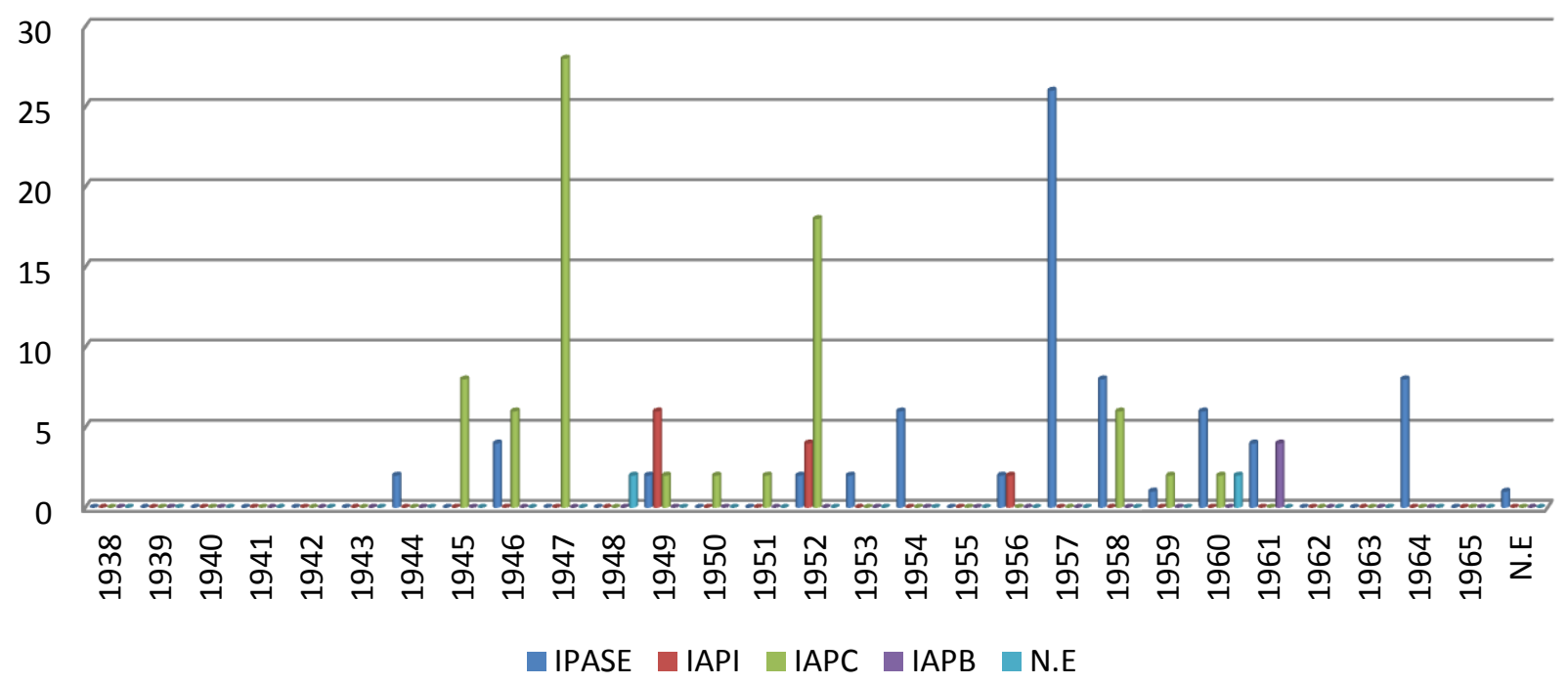

Figura 54: Gráfico da atuação dos diferentes escritórios estaduais das CAPs e dos IAPs em Teresina. Fonte: Elaboração própria com base nos dados coletados no INSS-PI.

No que concerne às categorias imobiliárias praticadas na cidade, ao contrário do encontrado na maior parte das capitais nordestinas estudadas nesta tese, os IAPs não edificaram diretamente um número considerável de moradias. Procedeu, essencialmente, o financiamento para a aquisição de unidades habitacionais já edificadas por terceiros ${ }^{357}(37,05 \%)$, bem como, para a construção de residência em terreno de propriedade dos segurados (30,58\%) (Figura 55). O Instituto que mais edificou unidades diretamente, entre os anos de 1944 e 1964, foi o IPASE (10\% $)^{358}$. Da mesma forma, foi o IAP que mais concedeu pleitos para a aquisição de moradias prontas (18,82\%), de acordo com os dados levantados.

\begin{tabular}{|c|c|c|c|c|c|c|c|c|c|c|c|c|}
\hline \multicolumn{13}{|c|}{ ATUAÇÃO DAS CAPS E DOS IAPS EM TERESINA } \\
\hline \multirow{2}{*}{ Ações Imobiliárias } & \multicolumn{2}{|c|}{ IAPI } & \multicolumn{2}{|c|}{ IPASE } & \multicolumn{2}{|c|}{ IAPC } & \multicolumn{2}{|c|}{ IAPB } & \multicolumn{2}{|c|}{ N.E. } & \multirow{2}{*}{ Total } & \multirow{2}{*}{$\%$} \\
\hline & No. & $\%$ & No. & $\%$ & No. & $\%$ & No. & $\%$ & № & $\%$ & & \\
\hline Compra de unidade do Instituto/Caixa & 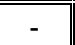 & $\overline{-1}$ & 17 & 22,97 & 10 & 13,15 & 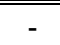 & - & 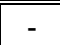 & $\overline{-1}$ & 27 & 15,88 \\
\hline $\begin{array}{c}\text { Compra de imóvel já edificado de } \\
\text { terceiros }\end{array}$ & 02 & 16,66 & 32 & 43,24 & 23 & 30,26 & 04 & 100 & 02 & 50 & 63 & 37,05 \\
\hline Compra de terreno e const. de residência & 02 & 16,66 & 04 & 5,4 & 05 & 6,58 & - & - & - & - & 11 & 6,47 \\
\hline Construção em terreno do segurado & 03 & 25 & 18 & 24,32 & 29 & 38,15 & 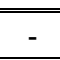 & 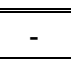 & 02 & 50 & 52 & 30,59 \\
\hline Reforma & 05 & 41,66 & 03 & 4,05 & 03 & 3,94 & - & - & - & - & 11 & 6,47 \\
\hline Aumento de Financiamento & - & - & - & 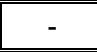 & 06 & 7,9 & 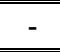 & - & 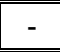 & - & 06 & 3,53 \\
\hline Outras & 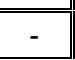 & 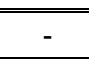 & $\overline{-1}$ & 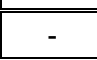 & 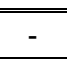 & - & $\overline{-1}$ & $\overline{-1}$ & $\overline{-1}$ & $\overline{-1}$ & $\overline{-1}$ & - \\
\hline N.E. & - & - & 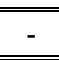 & - & & - & & - & 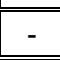 & - & - & - \\
\hline Total Absoluto & \multicolumn{2}{|c|}{12} & \multicolumn{2}{|c|}{74} & \multicolumn{2}{|c|}{76} & \multicolumn{2}{|c|}{04} & \multicolumn{2}{|c|}{04} & \multicolumn{2}{|c|}{170} \\
\hline Atuação IAP & \multicolumn{2}{|c|}{$7,05 \%$} & \multicolumn{2}{|c|}{$43,53 \%$} & \multicolumn{2}{|c|}{$44,7 \%$} & \multicolumn{2}{|c|}{$2,35 \%$} & \multicolumn{2}{|c|}{$2,35 \%$} & \multicolumn{2}{|c|}{$100 \%$} \\
\hline
\end{tabular}

Figura 55: Quadro de classificação das ações imobiliárias das CAPs e dos IAPs em Teresina.

Fonte: Elaboração própria com base nos dados coletados no INSS-PI.

Semelhante ao evidenciado nas capitais Recife e Salvador, em Teresina, as unidades residenciais dos Institutos permaneceram alugadas aos associados da cidade. Observou-se que mesmo após 1964, 0

357 Por iniciativa dos segurados.

358 As unidades habitacionais edificadas pelos órgãos, em Teresina, apresentavam a mesma tipologia construtiva e partido arquitetônico, mesmo depois da década de 1960, como se verá mais detalhadamente no capítulo seguinte. 
IPASE continuou a empreender o aluguel e posterior venda de imóveis de sua propriedade locados em conjuntos. Essa modalidade de ação tão comum a partir da década de 1950, especialmente, era permitida desde a publicação da Instrução do MTIC n.22, de 1952. Na qual, mais precisamente em seu Art.30, especificava-se que as quantias pagas a título de aluguel passaram a ser consideradas como amortização e juros do valor do imóvel em questão, devendo ser descontados os gastos para tanto daquele montante, por um prazo pré-determinado 359 .

\section{São Luís-MA:}

Em todo o estado do Maranhão foram encontrados conjuntos e grupos de moradias edificados nas cidades de São Luís, Caxias, Codó, Carolina, Pedreiras, Bacobal, Porto Franco e Timón. Em se tratando das unidades isoladas, observou-se ainda a concessão de financiamentos em Coroatá. Juntos, somam-se treze empreendimentos (conjuntos residenciais ou grupos de moradias) edificados no referido estado ${ }^{360}$. No entanto, percebeu-se no levantamento documental que, apesar de edificarem um número razoável de grupos de moradias no estado do Maranhão, como um todo, na capital verificou-se uma das menores atuações em termos de quantidade de conjuntos no Nordeste.

Foram apenas cinco grupos construídos pelos órgãos na capital maranhense: o Conjunto dos Bancários (IAPB-1946) ${ }^{361}$, o Conjunto Filipinho (IAPC-1950), os grupos de casas do IPASE (1958); 0 Conjunto Nossa Senhora das Graças (IAPC-1964) e o Conjunto José Bonifácio (IPASE-1964) ${ }^{362}$. Somente 0 IAPC, o IAPB e o IPASE edificaram conjuntos habitacionais na localidade (Figura 56). Em termos de ações indiretas, o mesmo quadro reduzido pode ser identificado. Assim como em Teresina, também não foram encontradas ações imobiliárias empreendidas por CAPs na localidade.

Em contrapartida ao ínfimo número de grupos residenciais construídos diretamente pelos Institutos, de acordo com os relatos do gestor do setor de Patrimônio Imobiliário do INSS-MA, José de Ribamar Nunes ${ }^{363}$, as unidades habitacionais dos conjuntos edificados são em número significativo. Somente os Conjuntos Filipinho e o Conjunto do IPASE juntos, somam aproximadamente 1.000 residências. Sendo assim, apesar de não edificarem uma diversidade de grupos de moradias como verificado em Salvador, Recife, João Pessoa, Natal e Fortaleza, em São Luís, alguns dos poucos grupos habitacionais eram de porte consideravelmente maior. As unidades concedidas e produzidas nessa capital chegam próximo à totalidade dos pleitos liberados em João Pessoa, que conforma os dezoito empreendimentos lá edificados, por exemplo.

\footnotetext{
${ }^{359}$ Esse prazo, inicialmente, era de seis meses e, ao longo dos anos, após outras Instruções posteriores, foi elevado para até dois anos renováveis. Ousa-se considerar essa iniciativa como o embrião do arrendamento residencial praticado, sobretudo, com a criação do PAR, em 1999, a qual a historiografia imputa como inédita.

360 Não foi encontrado na cidade nenhum exemplar de vila.

361 Data da autorização da edificação do conjunto na cidade, por meio de decreto federal. A construção do conjunto, propriamente dita, só foi iniciada praticamente oito anos depois, em 1954, como se verá mais detalhadamente no capítulo que se segue.

362 Nos levantamentos realizados em São Luís, foram ainda encontradas referências a um conjunto residencial construído no bairro de São Raimundo pelo IAPC, em Teresina.

363 Por meio de conversas informais.
} 


\begin{tabular}{|c||c|c|c|c||c||c||}
\hline \multicolumn{7}{|c|}{ Produção Direta (grupos de moradias) em São Luís } \\
\hline \hline Conjunto & Instituto & Data & Tipologia & $\begin{array}{c}\text { No de } \\
\text { Unidades }\end{array}$ & Bairro & Produção (\%) \\
\hline \hline Filipinho & IAPC & 1950 & Unifamiliar isolada & 320 & Filipinho & $32,85 \%$ \\
\hline \hline Bancários & IAPB & 1954 & Coletiva vertical & 48 & Centro & $4,92 \%$ \\
\hline \hline IPASE & IPASE & 1958 & Unifamiliar isolada & 30 & $\begin{array}{c}\text { Morro do } \\
\text { Alecrim }\end{array}$ & $3,08 \%$ \\
\hline \hline $\begin{array}{c}\text { Nossa } \\
\text { Senhora das } \\
\text { Graças }\end{array}$ & IAPC & 1964 & Unifamiliar isolada & 40 & João Paulo & $4,11 \%$ \\
\hline $\begin{array}{c}\text { José } \\
\text { Bonifácio }\end{array}$ & IPASE & 1964 & $\begin{array}{c}\text { Diferenciadas (5 } \\
\text { tipos) }\end{array}$ & 536 & Vinhais & $55,04 \%$ \\
\hline $\begin{array}{c}\text { Total } \\
\text { Absoluto }\end{array}$ & $\mathbf{5}$ grupos residenciais & $\mathbf{9 7 4}$ unidades habitacionais & $\mathbf{5}$ bairros & $100 \%$ \\
\hline
\end{tabular}

Figura 56: Quadro de especificação do número de unidades edificadas em grupos de moradias e diretamente pelos institutos de previdência em São Luís.

Fonte: Elaboração própria com base nos dados do INSS-MA.

Mais detalhadamente, foram 974 unidades habitacionais construídas e 128 pleitos de financiamentos indiretos concedidos (identificados na pesquisa documental). Um total de 1.102 operações imobiliárias empreendidas na capital maranhense. Para se ter noção da abrangência da atuação dos IAPs em São Luís mostrou-se necessário fazer uma análise comparativa à população residente na capital. Como a produção desses órgãos se deu, sobremaneira, na década de 1950, utilizou-se como referencial o número de unidades concedidas nessa década. Cruzando esse número com o índice da população média por prédio naquela época, disponibilizado pelo IBGE ${ }^{364}$, tem-se um total de aproximadamente 6.000 pessoas atendidas pela política habitacional dos IAPs na cidade, entre os trabalhadores associados e suas famílias, o equivalente à quase $6 \%$ da população residente na referida capital no período.

A maior parte das unidades, assim como observado em Salvador, Teresina e no Recife, permaneceu alugada aos associados até a segunda metade da década de 1960, mais precisamente até o ano de 1968, a partir de quanto, de acordo com o processo de desmobilização instituído pelo Presidente da República, todas as unidades habitacionais que ainda estavam de posse dos segurados, através do pagamento de aluguel ou parcelamento financeiro, passaram efetivamente a ser de propriedade daqueles trabalhadores, por meio da quitação da dívida ou pela venda direta através da assinatura de contratos de promessa de venda. Como na maior parte das cidades do país, apesar de propor o repasse completo daquelas residências aos associados, a desmobilização não foi concluída em sua essência, existindo até os dias de hoje muitos processos ainda abertos ou, utilizando-se o termo habitualmente empreendido, não liquidados.

De modo geral, os conjuntos locados na capital eram dotados, além de um número maior de residências, de equipamentos coletivos, enquanto, os situados nos demais municípios do estado, possuíam de oito a trinta moradias somente, sem equipamentos ou espaços coletivos previstos. Esses grupos de moradias encontram-se atualmente muito descaracterizados, essencialmente aqueles locados nos bairros mais centrais da cidade, como as unidades que conformam os grupos de casas do IPASE, no centro, que

364 Que equivalia a 5,44 habitantes por residência urbana. 
devido à função predominante na área, o comércio, foram em sua maioria reformadas para se adaptar a esse uso ou, como foi mais frequentemente empreendido, demolidas para dar lugar a grandes estabelecimentos comerciais, muitos dos quais, situados à margem da Avenida General Sampaio; o que em muito dificultou 0 registro e análise das unidades.

Diante dos dados documentais e oficiais levantados na cidade, percebeu-se em São Luís, como averiguado em outras capitais do Nordeste, a citar João Pessoa, que a atuação dos IAPs ${ }^{365}$ de modo direto ocorreu a partir, sobretudo, da segunda metade da década de 1950, em se tratando mais precisamente do IAPC, se intensificando na primeira metade da década de 1960 por meio essencialmente do IPASE e, para além dele, curiosamente, pelo IAPB graças à construção do Conjunto dos Bancários e alguns pleitos indiretos. Nesse sentido, o IPASE foi o Instituto responsável pela edificação do maior número de conjuntos (dois) e também de unidades habitacionais (556), o que equivale a $58,11 \%$ do total edificado pelos órgãos em São Luís.

Uma possível explicação para a intensificação da produção a partir da década de 1950 em São Luís, especificamente, foi que nesse período, o Maranhão ao contrário do que estava ocorrendo na maior parte dos estados nordestinos, recebeu uma grande leva de migrantes. De acordo com a publicação do IBGE, "Brasil em Números", de 1950, o estado recebeu um adicional populacional de 61.000 habitantes, devido às migrações interiores, diante do quadro de crescimento econômico pelo qual vinha passando, devido ao cultivo do algodão e da indústria extrativa da carnaúba e do coco de babaçu.

Uma justificativa para a sobressaliência da atuação do IPASE, nesse contexto, recai por sobre o fato que até a década e 1950, esse Instituto atendia além do funcionalismo estadual do Maranhão, à parte dos servidores do Piauí. Eram constantemente liberados financiamentos para segurados piauienses, residentes em municípios próximos à São Luís, para edificarem ou adquirirem moradias locadas em conjuntos do IPASE nessa capital ou em outras cidades do estado, como no município de Timón ${ }^{366}$.

A atuação mais destacada do IPASE em cidades como São Luís, Natal e João Pessoa pode ser justificada pelo fato de significativa parcela populacional daquelas capitais - essencialmente a classe média, que passou também a ser assolada pelo déficit de moradias a partir, sobretudo, da década de 1940 - era composta essencialmente por servidores públicos estaduais e municipais, atendidos geralmente por aquele Instituto. Salvo os casos da atuação dos institutos de previdência estaduais ou Caixas locais, que se conformavam como as únicas variações dos órgãos que não tinham abrangência nacional, contrariando 0 colocado por alguns autores sobre o assunto, como Farah (1983). São exemplos, o IPEP (Instituto de Previdência do Estado da Paraíba), o IPEM dos servidores do Maranhão, o IPSEP de Pernambuco e as CAPESP do Rio Grande do Norte e do Ceará. Ainda em se tratando da abrangência das Caixas e IAPs, ao

\footnotetext{
365 Refere-se exclusivamente aos IAPs pelo fato, já apontado, de não ter sido encontrado nenhum processo de financiamento realizado por Caixa de Aposentadoria e Pensões na cidade em questão.

366 São Luís não contava até a década de 1960 com um escritório do IPASE próprio. A delegacia regional do órgão, locada em Teresina, atendia às solicitações de trabalhadores do Piauí e do Maranhão. Outro aspecto que merece ser lembrado é a divisão do território brasileiro até a década de 1950, no qual, ambos os estados pertenciam á região Norte do país.
} 
longo da pesquisa foram encontrados exemplos de Caixas que atuavam também em âmbito regional como a Caixa de Aposentadoria do Nordeste Brasileiro, que empreendeu ações essencialmente nas cidades do Recife e de Natal, reforçando a afirmativa anterior.

O comércio era outro setor da economia que se destacava no contexto de capitais como São Luís e João Pessoa, e também compunha os setores médios da sociedade, justificando também o destaque das atuações do IAPC nesse contexto. Somente com a criação da SUDENE, em fins da década de 1950, as indústrias ganharam um maior destaque no cenário econômico nordestino - salvo alguns casos relacionados principalmente à indústria têxtil que, desde fins do século XIX, ganhou destaque em algumas localidades como no Recife e em São Luís ${ }^{367}$ - e as ações no campo habitacional do IAPI ganharam vulto no Nordeste.

Na sequência quantitativa de moradias em São Luís, ao IPASE foi seguido o IAPC, que edificou e financiou dois conjuntos compostos, no total, por 320 moradias (36,95\%), e o IAPB, que dotou a cidade com o único conjunto coletivo vertical da época, com 8 blocos e 48 apartamentos (4,92\%). É importante, mais uma vez, destacar que ao contrário do vislumbrado nas demais capitais nordestinas, pouco se edificou ou financiou isoladamente em São Luís, excetuando os financiamentos concedidos para a aquisição das trinta residências de propriedade do IPASE, locadas na Avenida General Sampaio e na Rua Coronel João Costa, já em 1964.

Em se tratando das modalidades de acesso a uma residência, um aspecto interessante acerca dos Institutos em São Luís pode ser apontado. Refere-se ao fato que entre as possibilidades de venda e/ou financiamento de uma unidade habitacional de propriedade os órgãos, somente o IAPC praticava a aquisição por meio da promessa de compra e venda. Os demais IAPs atuantes na cidade utilizavam-se essencialmente da hipoteca. Em relação aos aspectos organizacionais das operações imobiliárias, vale destacar que no âmbito do IPASE, quase nunca eram especificados os planos e classes ou descritas as modalidades em que se enquadravam os processos em São Luís; o que em muito dificultou as análises acerca desta capital nordestina.

Nos processos imobiliários levantados no INSS-PE foram encontradas pranchas projetuais do conjunto residencial do IPASE, no bairro de Vinhais, principalmente plantas e cálculos estruturais que indicam que a elaboração e a concepção arquitetônica do Conjunto José Bonifácio foram desenvolvidos naquele escritório estadual e não no de São Luís. Dessa forma, conjectura-se que, semelhante ao ocorrido em João Pessoa, o escritório do IPASE da capital maranhense não possuía suporte técnico para tal tarefa, por representar o primeiro conjunto dessa magnitude edificado na cidade. Outro aspecto curioso acerca do supracitado conjunto residencial recai no fato que concluídas as unidades, por volta de 1964, elas permaneceram inabitadas uma vez que não foram determinadas as questões relacionadas aos financiamentos. Provavelmente por se tratar de um empreendimento de grande porte, extrapolava a demanda por moradia por parte dos associados do IPASE na cidade. Sem uma definição sobre para quem financiar as

367 Devido principalmente às plantações de algodão das décadas de 1940 e 1950. 
moradias, o referido grupo de residências passou mais de dois anos praticamente abandonado. Somente em 1966, o referido Instituto decidiu abrir as vendas com o IAPB e o IAPC, bem como aos seus segurados ${ }^{368}$.

Como ocorreu no âmbito dos demais Institutos e Caixas de Aposentadoria e Pensões, os terrenos remanescentes dos conjuntos construídos, bem como aqueles que permaneceram inutilizados e/ou abandonados por parte desses órgãos foram reincorporados ao patrimônio imobiliário do BNH e/ou do IPASE, como foi o caso do Conjunto Filipinho do IAPC, situado na Avenida João Pessoa, cuja área remanescente cedida ao Banco totalizou 206.086,16 $\mathrm{m}^{2}$, onde posteriormente, mais precisamente na segunda metade da década de 1960, foi edificado um conjunto pela COHAB-MA.

\subsection{A Espacialização da Produção Habitacional}

Analisar a espacialização da atuação dos Institutos e Caixas de Aposentadoria e Pensões no Nordeste se mostra uma importante vertente de estudo acerca do crescimento e do ordenamento das capitais da região posteriormente, bem como representa um importante indicativo do processo de periferização daqueles núcleos urbanos intensificados, sobretudo, a partir da década de 1950 na maior parte das cidades do país. Para tanto, seria necessária a precisão da localização dos grupos residenciais identificados nesta pesquisa, bem como das unidades adquiridas ou edificadas por iniciativa dos segurados das Carteiras Prediais dos institutos de previdência nordestinos, por meio dos financiamentos concedidos, em todo 0 recorte temporal estudado. Entretanto, devido à variação das condições de pesquisa e diversificação da qualidade e do detalhamento dos documentos encontrados, como também do próprio montante levantado, esse intento inicial foi comprometido ${ }^{369}$. Somente foi possível a interpretação da espacialização quanto aos loteamentos, vilas e conjuntos residenciais construídos ou adquiridos por parte daqueles órgãos nas sete capitais nordestinas estudadas e, quando possível, serão apresentadas considerações sobre os empreendimentos indiretos.

\section{Salvador-BA:}

Como já especificado no tópico sobre a atuação dos órgãos nas capitais nordestinas, foram identificados pleitos em diversas cidades da Bahia. Mais precisamente, em se tratando especificamente dos grupos de moradias edificados pelos órgãos em questão, podem ser apontadas vilas e/ou conjuntos residenciais, principalmente, em Salvador, Feira de Santana e Vitória da Conquista. Porém, a totalidade dos processos levantados e considerados para as análises quanto à localização dos empreendimentos, aqui exposta, só se refere à Salvador.

\footnotetext{
368 Todas as áreas destinadas aos equipamentos coletivos previstos, como igreja, supermercado, quadras de esportes, etc., não saíram do papel. Houve ainda uma concorrência posterior para a construção desses elementos, mas mesmo assim, não foram executados em sua íntegra. Somente uma igreja e uma escola foram edificadas, como será mais a frente detalhado.

$369 \mathrm{Em}$ algumas cidades, o número de financiamentos indiretos foi ínfimo para sustentar as análises e as conclusões sobre a atuação dos órgãos nessa vertente imobiliária na cidade. Em outros episódios, como no âmbito de alguns Institutos e Caixas de Fortaleza, mais precisamente do IAPE e do IAPM, só foram encontrados dois processos imobiliários, o que impossibilitou as apreciações relacionadas, dentre outros exemplos.
} 
De maneira geral, as ações das CAPs e dos IAPs na capital baiana se deram de modo bastante centralizado, em bairros já consolidados da cidade. Alguns poucos exemplos fogem a essa regra, como foi 0 caso do Conjunto dos Industriários, bem como de uma das vilas operárias da CAPESP. Mais detalhadamente, essas foram as atuações mais limítrofes observadas na capital baiana. A edificação da Vila dos Ferroviários da CAPFESP/IAPFESP (1951) foi um dos principais responsáveis pela intensificação da ocupação do bairro Paripe, já denominado de subúrbio nos primeiros anos da década de 1950 (Figura 57).

Processo semelhante procedeu-se no âmbito do Conjunto Residencial do Salvador ou Conjunto dos Industriários (IAPI-1952), que foi implantado próximo a bairros populosos na época (Liberdade, Retiro e Pau Miudo) e induziu a ocupação daquela região, chamada atualmente de bairro IAPI. O Conjunto foi projetado para atender a um número significativo de trabalhadores na época. Foram edificados, nesse sentido, cinco grandes blocos laminares de apartamentos que passaram a atender 264 trabalhadores segurados do Instituto e suas respectivas famílias. Sua implantação naquela localidade induziu e contribuiu para a instalação de diversos pontos comerciais na área, aspecto facilitado pela boa infraestrutura (energia elétrica, saneamento, água encanada, iluminação pública, arborização, largas vias de acesso e extensão das linhas de transporte urbano), que acompanhou a sua implantação e, aos

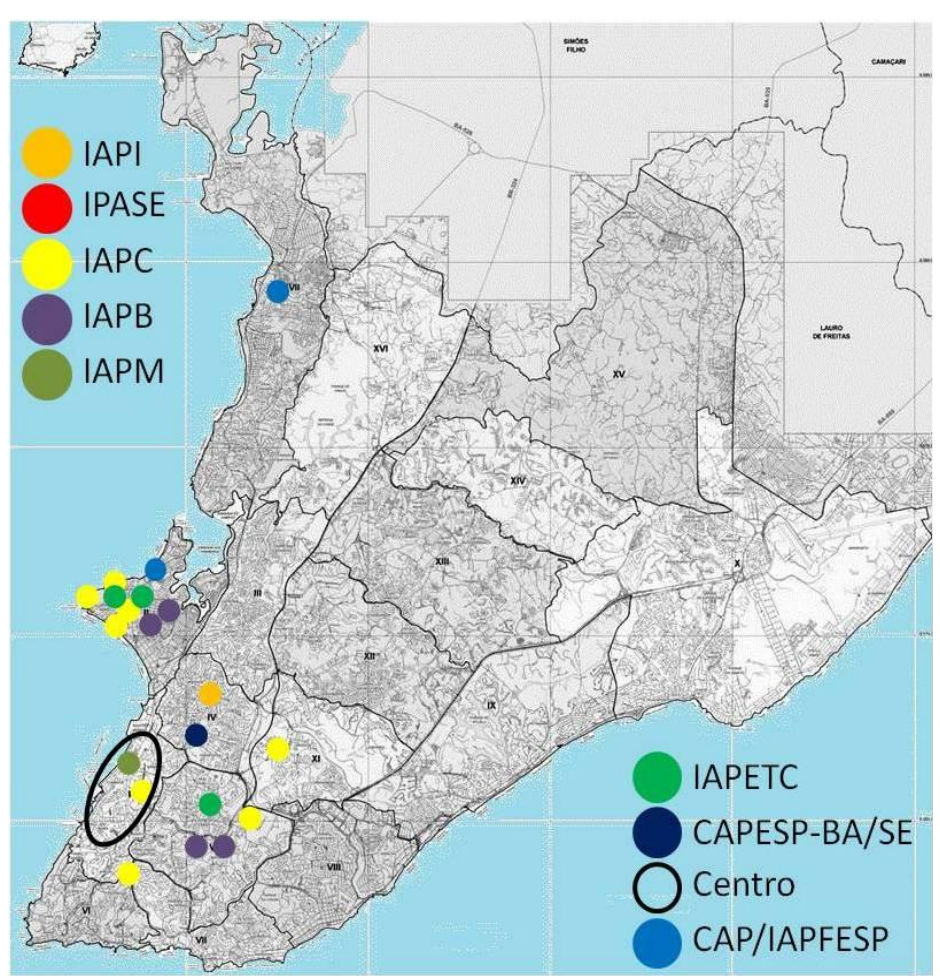

Figura 57: Espacialização da produção habitacional das CAPs e dos IAPs em Salvador.

Fonte: Elaboração própria, com base cartográfica da Prefeitura e dados coletados no INSS-BA. poucos, o bairro foi se ampliando. $O$ referido Conjunto também se conforma como um importante exemplar de moradia social, em Salvador.

As realizações diretas foram locadas em sete bairros da cidade ${ }^{370}$, essencialmente, em Itapagipe, Santo Antônio e Brotas, que somados abrigam quinze dos vinte e quatro empreendimentos habitacionais identificados na pesquisa, 62,5\% daquela produção. Os conjuntos e vilas de propriedade do IAPC, o Instituto que mais edificou grupos residenciais na cidade, foram locados no bairro Itapagipe (4 grupos residenciais) e Brotas (2 conjuntos). Outros órgãos que construíram moradias nesses bairros foram o IAPB ${ }^{371}$ e 0 IPSEP,

\footnotetext{
370 Santo Antônio, Itapagipe, Baixa do Bonfim, Brotas, Graças, Paripe e ao longo da Avenida Tiradentes, chamada na época de Caminho da Areia.

371 Dois conjuntos situados no bairro de Brotas (22,22\% do total de grupos residenciais edificados na cidade) e um conjunto em Itapagipe, que correspondem a $75 \%$ de suas realizações diretas na cidade.
} 
esse, sobretudo, em Itapagipe, já na segunda metade da década de 1960, em parceria com o BNH. Outros conjuntos edificados pelos órgãos em Salvador estão locados na Avenida Tiradentes, como o Conjunto Castro Alves do IAPETC (1939), cujo número de unidades habitacionais é 362.

O único Instituto que especificou as diretrizes para a localização dos seus conjuntos, de acordo com os dados levantados na pesquisa em Salvador, foi o IAPB. No âmbito desse órgão, considerava-se a proximidade do empreendimento em relação ao centro bancário da cidade, se a área era servida de transporte coletivo próximo (ônibus e/ou bonde) e se era zona residencial cercada por "boas construções". Provavelmente devido a esses aspectos, a maior parte das realizações dos órgãos, não só em Salvador, como também nas demais capitais nordestinas trabalhadas, se dava em áreas valorizadas e em bairros tidos como de alto padrão. No caso específico de Salvador, os grupos residenciais daquele Instituto foram locados, essencialmente, no bairro de Brotas, considerado nas publicações da imprensa diária da época, como o bairro mais saudável de Salvador em fins da década de 1930, e, posteriormente, já na década de 1950, no Bonfim, área nobre na época.

Outro aspecto interessante acerca desse Instituto na capital baiana recai sobre a expressa filiação de suas realizações, não somente no campo habitacional, aos planos urbanísticos e de embelezamento da cidade, empreendidos pelo prefeito, nos primeiros meses de 1939. Poucos foram os casos de adaptação das construções aos planos públicos. A maior parte dos exemplos encontrados na pesquisa no Nordeste foi de solicitações para a edificação de grupos residenciais à margem de determinações dessa natureza, como também foi percebido no Rio de Janeiro, no conhecido exemplo do Conjunto da Gávea e outros empreendimentos efetivados naquela cidade.

A inauguração de alguns conjuntos e vilas concebidas pelos Institutos e Caixas na cidade, também se tornou, a exemplo de muitas realizações cariocas, um grande evento local. Esse foi o caso da comemoração da conclusão da primeira residência edificada pelo IAPB em Salvador, situada na Vila Operária Bancária, como era designada na época, em março de 1940. O convite para a participação desse evento, por assim dizer, foi publicado nos principais jornais baianos da época e foi estendido ao público em geral, bem como ao Presidente da República (Getúlio Vargas), ao Ministro do TIC (Waldemar Falcão), ao Interventor do Estado (Landulho Alves), ao Delegado do Trabalho no Estado (Moacyr Cruz de Mesquita), ao Prefeito de Salvador (Neves da Rocha), além de representantes do Sindicato dos Bancários de Salvador, aos bancários e banqueiros do estado, aos presidentes de todas as Caixas e Institutos de Aposentadoria e Pensões na cidade e aos engenheiros das Carteiras Imobiliárias atuantes em Salvador.

\section{Recife-PE:}

Foram identificados na pesquisa documental realizada no INSS-PE, 51 grupos de residências edificados, direta ou indiretamente, pelos Institutos e Caixas de Aposentadoria e Pensões em Pernambuco. Esses empreendimentos estão distribuídos em quatro municípios do estado de Pernambuco, mais 
precisamente, no Recife (89,58\%), Olinda (6,25\%), Garanhuns (2,09\%) e Caruaru (2,09\%). Aqueles locados na capital, por sua vez, estão distribuídos em 17 bairros da cidade do Recife ${ }^{372}$, principalmente nos bairros de Santo Amaro (8 grupos residenciais; 18,60\%), Ibura/IPSEP373 (7 conjuntos; 16,28\%), Areias (cinco conjuntos; $11,62 \%$ ) e Afogados (5 grupos de moradias; 11,62\%). Diferente do caso de Salvador, estes eram bairros populares (Figura 58) $)^{374}$.

Já vale apontar, que um processo semelhante ao que passou o Conjunto dos Industriários, em Salvador, ocorreu com os Conjuntos Casa Amarela (IAPC), Vila do IPSEP e Areias (IAPI), no Recife, e Peixinhos (IAPC) em Olinda. Esses grupos habitacionais foram locados em áreas pouco adensadas entre as décadas de 1940 e 1950, principalmente, e acabaram por originar bairros com sua mesma denominação.

No Recife, os conjuntos residenciais, conformados por um grande número de moradias e dotados de equipamentos coletivos e/ou de lazer, encontram-se situados, sobretudo, nos bairros de Ibura do Norte e Areias. As vilas operárias, por sua vez, estão concentradas, essencialmente, no bairro de Santo Amaro. Também foram identificados exemplares locados

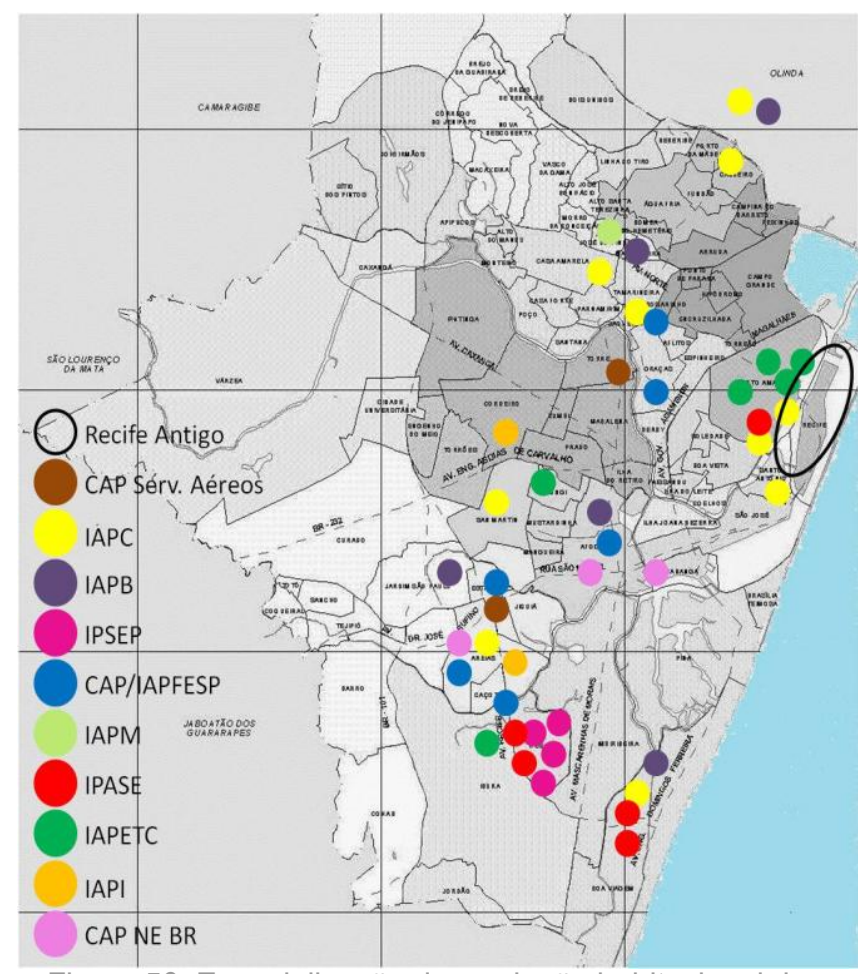

Figura 58: Espacialização da produção habitacional das CAPs e dos IAPs no Recife.

Fonte: Elaboração própria, com base cartográfica da Prefeitura e dados coletados no INSS-PE.

no bairro Afogados. Essas vilas foram edificadas principalmente por Caixas de Aposentadoria e Pensões, mais precisamente, pela CAP dos Serviços Públicos de Pernambuco e Alagoas, pela CAP do Nordeste Brasileiro, pela CAPFESP e pela CAP dos Empregados nos Serviços Aéreos e Telecomunicações, que ao passar do tempo foram sendo incorporadas ao IAPFESP e ao IPASE, principalmente.

O bairro de Santo Amaro, área central e mais próxima aos braços de rios que cortam a cidade, também recebeu o maior número de edifícios verticais edificados ou financiados pelos IAPs, sobremaneira. Essas tipologias habitacionais coletivas estão da mesma forma, situadas no bairro de Boa Viagem; esses destinados à população mais abastada, segurada pelas Carteiras Imobiliárias dos órgãos.

\footnotetext{
372 Santo Amaro, Areias, Ibura do Norte, Boa Viagem, Afogados, San Martim, Graças, Torre, Estância, Farapa, Cajueiro, Rosarinho, Mangueira, Casa Amarela, Jardim São Paulo, Cordeiro e Cabanga.

373 Chamado de lbura do Norte ao longo das décadas de 1940 a 1960, de acordo com os dados levantados.

${ }^{374}$ Não foi especificada a localização do Ed. Imbiribeira (1942) no mapa, por não ter sido identificado o instituto de previdência responsável pela sua concepção.
} 


\section{João Pessoa-PB:}

As CAPs e os IAPs edificaram aproximadamente 2.200 moradias em todo o estado da Paraíba. Desse volume apresentado em documentos oficiais e portarias dos órgãos no período, 1.467 unidades estão locadas em João Pessoa (66,68\%) e 331 moradias encontram-se situadas no município de Cabedelo $(15,04 \%)$, consideradas como parte da produção dos órgãos na capital, assim como procederam as próprias Carteiras Prediais. As demais unidades dizem respeito às residências isoladas locadas em cidades como Campina Grande, Bayeux e Santa Rita (22,36\%), encontradas nos levantamentos de dados nos arquivos do INSS-PB. Há ainda referências nos periódicos locais à existência de dois conjuntos residenciais e um edifício de apartamentos edificados pelo IPASE e pelo IAPB, em Campina Grande, mas devido ao restrito tempo para a realização da pesquisa em campo, não foi possível o aprofundamento da questão.

Uma curiosidade percebida em se tratando da espacialização das ações das CAPs e dos IAPs na Paraíba já pode ser apontada e refere-se ao fato que alguns dos agrupamentos de moradias tidos como de médio porte ${ }^{375}$, identificados nos levantamentos documentais realizados em João Pessoa, não estão locados na capital e sim em um município próximo, Cabedelo, o que propõe uma atuação mais limítrofe nesse caso, comparando-o aos demais estados nordestinos já elencados até o momento. 0 significativo volume de unidades edificadas pelos órgãos naquele município pode ser justificado pelo fato de lá estar localizado 0 maior porto marítimo comercial do estado na época, sendo latente a necessidade de moradia para que a mão de obra desempenhasse os serviços a ele associados.

Com base em documentos encontrados nos periódicos locais, bem como nos dados levantados nos processos imobiliários, acredita-se que outras cidades, como Patos e Campina Grande, devido ao importante papel econômico desempenhado nas décadas de 1940 a 1960, receberam um significativo volume de financiamentos liberados pelas CAPs e IAPs no estado. Infelizmente, o número exato das ações empreendidas pelos órgãos em questão não pode ser precisado devido, mais uma vez, ao fato que a maioria dos processos de concessão de financiamentos com unidades alocadas naqueles municípios foi transferida pelo escritório estadual central do INSS-PB, situado em João Pessoa, para

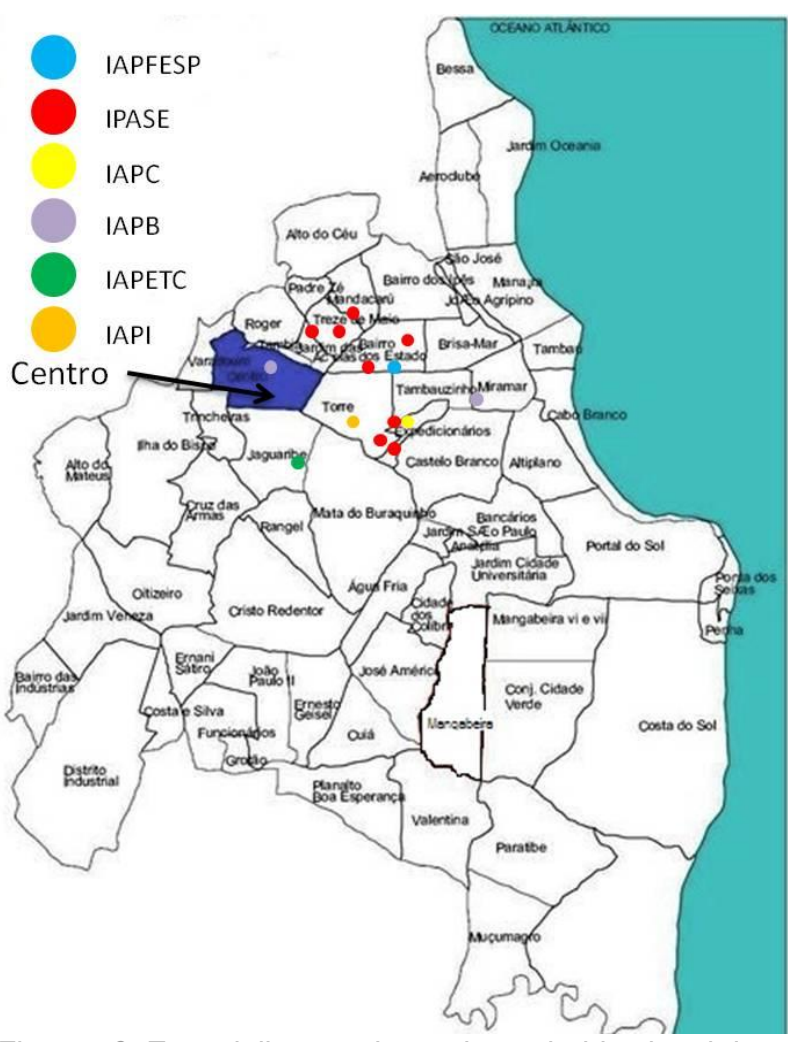

Figura 59: Espacialização da produção habitacional das CAPs e dos IAPs em João Pessoa.

Fonte: Elaboração própria, com base cartográfica da Prefeitura e dados coletados no INSS-PB.

375 Conformados por aproximadamente 100 (cem) unidades habitacionais. 
outras agências no interior do estado, e diante do curto tempo disponível para a realização da pesquisa em campo.

Em se tratando da localização dos empreendimentos no espaço urbano de João Pessoa, especificamente, percebe-se inicialmente uma concentração das realizações diretas nos bairros que conformam a atual zona norte da cidade, que abrange o seu núcleo inicial e a principal zona comercial (Figura 59). Atualmente os bairros que compõem essa região são tidos como comerciais/residenciais, abrangendo ainda o centro histórico da capital. Nas décadas de 1940 e 1950, bairros como dos Estados, Torre e 13 de Maio, ainda eram considerados de recente ocupação, crescente valorização e como área de expansão. Observou-se ainda a implantação de um dos conjuntos em bairro tido como de classe alta naquele momento, o Expedicionários, situado na zona lesta da cidade; área até hoje bastante valorizada.

Os bairros mais contemplados no que tange à construção de conjuntos habitacionais foram Torre e dos Estados, que abarcam em conjunto 532 moradias, correspondente a 31,14\% do edificado em grupos residenciais pelos órgãos em João Pessoa. A esses são seguidos os bairros Expedicionários que abrigou 215 residências (12,58\%) e Jaguaribe, no qual, estão endereçadas 200 unidades habitacionais em grupos de moradias, o equivalente a $11,70 \%$ da produção direta total. Só I e o II Conjunto do IPASE e o Conjunto JK, totalizam 470 unidades habitacionais e também deram impulso à ocupação dos atuais bairros dos Estados e Pedro Gondim. Esse aspecto coloca os supracitados conjuntos na categoria de médio porte, indo de encontro ao que alguns autores locais colocam sobre as CAPs e os IAPs atuantes em João Pessoa:

(...) entre 1935 e 1963, a atuação conjunta dos IAPs (...) resultou na produção de (...) empreendimentos considerados de pequeno porte, pois se caracterizavam pela construção de poucas unidades habitacionais. Em outras palavras, a produção de habitações nesse recorte temporal apresenta ações ainda muito tímidas, em relação ao que se conheceu depois, com as ações do BNH (BONATES, 2007, p.147).

Dessa forma, diante do exposto, observa-se que os empreendimentos dos Institutos e Caixas de Aposentadoria e Pensões na cidade de João Pessoa, foram situados essencialmente em bairros limítrofes daquela época, em áreas de expansão e inclusive suburbanas, não necessariamente nas franjas da cidade, nas áreas contíguas ao centro, como especificado em algumas publicações sobre a cidade ${ }^{376}$ :

(...) a produção de pequenos conjuntos, aliada à inserção destes em bairros contíguos ao centro, não provocou, no período em questão, grandes transformações estruturais nem tampouco na paisagem de João Pessoa - como viria a ocorrer no período subsequente (do BNH) -, diferentemente do que ocorria em muitas outras cidades, onde a produção dos IAPs e da FCP foi mais intensa (...) (BONATES, 2007, p.147).

Muito se fala também, que apesar de não terem edificado predominantemente nos bairros mais centrais de João Pessoa, os IAPs não foram responsáveis por uma periferização da cidade, o que só veio a ocorrer num período posterior, durante a vigência do $\mathrm{BNH}$. No entanto, acredita-se que o embrião dessa

376 Laviere \& Laviere (1987), Bonates (2007), dentre outros. 
consequência já pode ser imputado à atuação dos órgãos não somente na capital paraibana, mas também em outras cidades nordestinas. Uma das justificativas para tanto, remete ao fato que a grande maioria dos terrenos onde foram edificados os grandes conjuntos residenciais do referido Banco, largamente exaltados pela historiografia, foram locados em áreas que compunham o patrimônio imobiliário das CAPs e dos IAPs. Inclusive em grandes glebas adjacentes e/ou remanescentes de tantos conjuntos, algumas com mais de $10.000 \mathrm{~m}^{2}$, como foi o caso do terreno remanente do Conjunto do IPASE, no bairro dos Estados, adquirido pelo Instituto ao longo da década de 1950 e que a partir de meados da década de 1960, passou também a se configurar como cenário para a edificação de moradias pelas COHAB's, além de outros exemplos em Salvador, Recife, Fortaleza e São Luís.

Além dos aspectos acima elencados, a supracitada citação ainda se mostra equivocada ao afirmar com tamanha convicção que a atuação das CAPs e dos IAPs não teve como consequência uma alteração na paisagem da cidade. Pelo contrário, além do já citado Edifício Presidente João Pessoa (IAPB), que se configurou como o primeiro exemplar de moradia coletiva vertical da cidade, instituindo uma nova forma de morar e o uso misto de funções numa mesma estrutura, diversas outras residências (isoladas ou geminadas) construídas ou financiadas pelos Institutos e Caixas imprimiram uma nova imagem construtiva à cidade, com referências a uma arquitetura mais sóbria, de linhas e ângulos retos e de simplicidade volumétrica, associada à arquitetura moderna.

Essas unidades deram visibilidade à "nova arquitetura" que aos poucos foi permeando o imaginário da população pessoense, o que vinha ocorrendo paulatinamente desde os anos 1940. Esse processo ocorreu inicialmente por meio da incorporação de alguns elementos e aspectos construtivos, principalmente nas fachadas das edificações, mesclando-os a outras referências já largamente empreendidas na construção civil local, essencialmente o Art Decó, e até mesmo em modelos tipológicos recorrentes, como os bangalôs, ou a arquitetura mais popular de porta e janela, que aos poucos foi perdendo seus adornos e estuques, como percebido em diversas construções contemporâneas à atuação daqueles órgãos na capital paraibana. Esses e outros aspectos serão mais detalhadamente estudados no capítulo seguinte desta tese.

Retomando a localização dos empreendimentos imobiliários edificados e adquiridos pelos institutos de previdência paraibano, o montante de 1.377 moradias locadas em conjunto residenciais está distribuído por 10 bairros da cidade de João Pessoa ${ }^{377}$, um quadro muito próximo ao identificado quanto às ações imobiliárias indiretas, pulverizadas em 11 bairros da cidade $^{378}$, dos quais, cinco são comuns a ambas as ações: Tambauzinho, Jaguaribe, Torre, dos Estados e Mandacaru, que receberam tanto unidades isoladas, quanto grupos de moradias. No tocante exclusivamente à produção indireta, o bairro que foi mais 
contemplado com imóveis isolados na cidade foi o Jaguaribe, recebendo $18,88 \%$ dos imóveis identificados no levantamento. Os demais bairros receberam de $6,66 \%$ a $8,88 \%$ do total de pleitos trabalhados ${ }^{379}$.

De modo geral, tanto os conjuntos quanto as unidades isoladas foram locadas em diversos bairros. 0 padrão construtivo dessas moradias em muito se aproximava. Salvo os casos de residências unifamiliares edificadas no centro da cidade - principalmente nas proximidades do Parque Solón de Lucena e em bairros mais próximos à praia, como Tambiá e Tambauzinho, tidos com de classe alta naquela época - que, seguindo essa lógica, correspondiam a grandes áreas construídas e um partido arquitetônico mais apurado, como se verá mais detalhadamente no capítulo seguinte.

\section{Natal-RN:}

Com base na análise dos dados coletados, pode-se afirmar que $89,83 \%$ dos imóveis financiados pelos escritórios estaduais dos Institutos mais atuantes no Rio Grande do Norte estavam localizados na capital, e apenas 2,5\% em outros municípios do estado, principalmente, em Macau, Santa Cruz, Caicó e Mossoró380. Mais precisamente, em se tratando da distribuição dos imóveis financiados, fossem eles comprados e/ou construídos pelos IAPs ou pelas CAPs em Natal, percebeu-se que a mesma não se deu de forma homogênea no espaço construído da cidade. A maior parte dos pleitos concedidos encontra-se situada na zona leste, correspondendo a $98,17 \%$ do volume total de financiamentos, concentrados mais especificadamente nos bairros do Alecrim (39,10\%), Tirol $(21,96 \%)$, Petrópolis $(13,93 \%)$ e Cidade Alta $(11,43 \%)$, respectivamente. Os demais imóveis estão distribuídos entre as zonas sul $(0,44 \%)$ e leste $(1,38 \%)$. Uma das justificativas para a não realização de ações imobiliárias na zona norte de Natal, refere-se à incipiente ocupação dessa área na cidade, ainda relegada, nas décadas de 1940 e 1950, a poucas residências de veraneio e sítios.

Sendo assim, as operações habitacionais empreendidas em Natal se deram, sobretudo, em bairros centrais já consolidados (Alecrim e Cidade Alta) e em áreas que se pretendiam adensar, desde o início do século XX, como foi o caso dos bairros de Tirol e Petrópolis. Mais detalhadamente, esses bairros eram tidos como área de expansão da cidade desde 1904, no contexto do Plano de Cidade Nova, mas, continuaram pouco ocupados mesmo depois da instituição do Plano. Foram também objeto de interesse em outras iniciativas da administração pública local, como no Plano de Sistematização (1929) e no Plano Geral de Obras (1939) e, até a quarta década do século XX, não haviam sido consideravelmente ocupados. Um intento estatal recorrente que só veio a se consolidar em meados da década de 1950, ocasião na qual foi edificado 0 Conjunto Residencial Nova Tirol (IAPC-1958). Acredita-se, inclusive, que a denominação do Conjunto mostrase uma referência ou trocadilho ao Plano de Cidade Nova, do agrimensor italiano Antônio Prolidrelli.

\footnotetext{
379 Um total de noventa fichas levantadas se enquadrava na categoria (unidades isoladas).

380 A base de comparação foi o montante dos processos imobiliários levantados no INSS-RN. Em 7,67\% dos processos analisados não foi possível a identificação da localização do pleito.
} 
Apenas 2,02\% dos pleitos especificavam bairros novos e/ou periféricos, representados na época por Ponta Negra, Nova Descoberta e Lagoa Seca. Sucintamente, observou-se que esses imóveis equivaliam aos pleitos concedidos, essencialmente, para a construção de moradias em terrenos dos próprios associados e para a realização de reformas nas residências. Muito dessa atuação mais central deveu-se às doações empreendidas pelo poder público às CAPs e aos IAPs em Natal, como também, à existência de grandes parcelas de terras vazias na área central no período, especialmente localizadas nos já citados bairros de Tirol e Petrópolis. Esse aspecto possibilitou que os órgãos adquirissem terrenos com consideráveis dimensões por preços condizentes com a construção de moradias sociais.

Como já colocado, o bairro do Alecrim ${ }^{381}$ foi o mais contemplado com realizações imobiliárias pelos órgãos na cidade, abrigando em seus limites tanto vilas operárias quanto unidades isoladas. Cabe ressaltar,

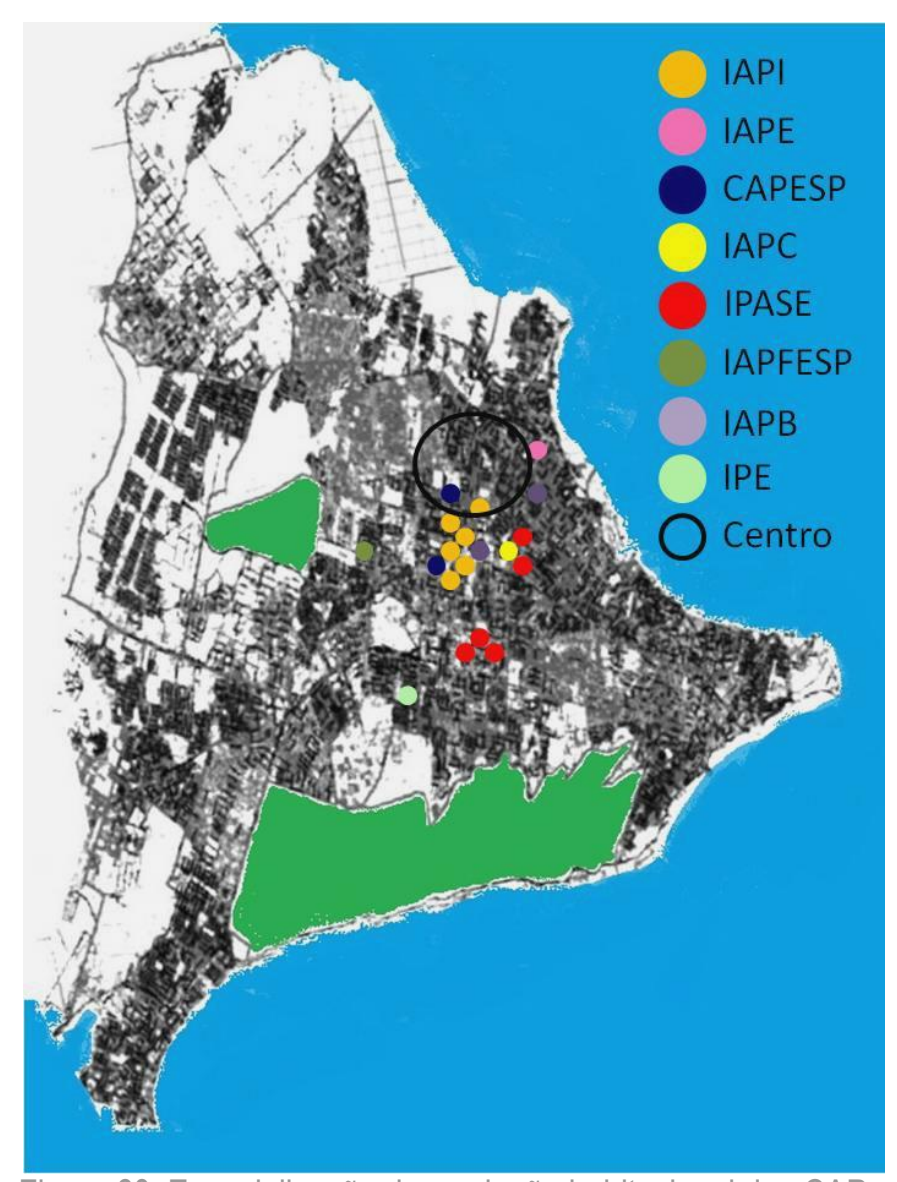

Figura 60: Espacialização da produção habitacional das CAPs e dos IAPs em Natal.

Fonte: Elaboração própria, com base cartográfica da Prefeitura e dados coletados no INSS-RN. contudo, que essas ações indiretas diziam respeito especialmente às unidades mais simples, com menor área construída e rebuscamento arquitetônico. Quadro parecido foi observado em Cidade Alta, um dos primeiros bairros natalenses. Mais precisamente, observou-se que os pleitos concedidos aos trabalhadores cujos rendimentos mensais eram pequenos e às ações imobiliárias que se caracterizavam como sociais correspondiam, em sua grande maioria, aos imóveis situados nos bairros mais carentes, centrais, de natureza urbana e mista, principalmente comercial e residencial, como nos supracitados bairros do Alecrim e da Cidade Alta, que juntos abrigam $50,53 \%$ do volume total de financiamentos liberados pelos IAPs e pelas CAPs em Natal. 0 contrário foi percebido em Petrópolis e Tirol, onde foram locadas as residências de maior

\footnotetext{
${ }^{381}$ A sua função predominantemente comercial é observado desde o seu surgimento, acompanhando as vias de escoamento de produtos para o interior do estado (rodovias) e para os estados vizinhos, principalmente Pernambuco (BEZERRA, 2005), sendo marcado inicialmente como a área de hotéis e restaurantes. Aos poucos, as fábricas foram se instalando na região, a exemplo da Fábrica de Sabão Moura e Borges e Cia., em 1890. Associado a esse aspecto, o bairro do Alecrim recebeu, desde meados do século XIX, os elementos tidos como indesejáveis na época, como o Hospital dos Alienados, o Leprosário de Assis, o Hospital da Misericórdia e o Cemitério da cidade, provavelmente por sua situação mais limítrofe ao centro e por ser isolado do restante da cidade (Cidade Alta e Ribeira, principalmente) pelo chamado Riacho do Baldo (CASCUDO, 1999; EDUARDO, 2004). Mas, a ocupação definitiva do bairro se deu após a abertura e prolongamento da linha de bonde, que ligava o Alecrim à Cidade Alta e à Ribeira, em 1912. A partir de então, as principais vilas operárias foram ali instaladas.
} 
padrão construtivo, bem como a maioria dos pleitos atuariais na cidade, geralmente dotadas de boa infraestrutura (equipamentos e serviços), modernas, de natureza essencialmente residencial e bem arborizadas, como se verá a seguir. Os imóveis financiados e nesses bairros localizados somam $35,89 \%$ do total concedido na capital norte-riograndense ${ }^{382}$.

Em se tratando excepcionalmente dos conjuntos residenciais edificados diretamente pelos órgãos em Natal, pode-se dizer que os bairros mais contemplados foram Tirol, a partir de meados da década de 1950 e na primeira metade da década de 1960, e Lagoa Nova, principalmente a partir dos anos de 1960, pelo IAPC e IPASE essencialmente (Figura 60). Os Institutos que financiaram imóveis no maior número de bairros da cidade foram o IAPI e o IPASE, que atuaram em praticamente todos os bairros da zona leste, oeste e sul de Natal, enquanto os demais concentraram a sua produção em bairros específicos e considerados "mais adequados" à sua clientela, como foi o caso do IAPC e do IAPB, cujas produções se resumem às unidades habitacionais e terrenos situados nos bairros de Cidade Alta, Petrópolis e Tirol. Outro órgão que apresentou uma ação espacialmente concentrada foi a Caixa de Aposentadorias e Pensões dos Serviços Públicos (CAPESP-RN), no âmbito do qual, $89,47 \%$ da produção foi situada no bairro do Alecrim. O IAP dos Estivadores (IAPE) em conjunto com o IAP dos Transportes e Cargas (IAPTEC), concentraram seus pleitos nos bairro de Petrópolis, que somados correspondem a $56 \%$ do total de processos liberados na cidade.

Apesar de não ter sido considerada na contagem das unidades habitacionais nesta tese, pode-se elencar algumas considerações no que condiz à atuação da Caixa para o Pessoal da Guerra em Natal. Uma delas diz respeito à localização dessas unidades, essencialmente no Alecrim, e a colaboração, junto às ações das CAPs e dos IAPs, para o significativo o crescimento desse bairro a partir da década de 1940 e nas décadas sequentes. No ano de 1950, por exemplo, o Alecrim já comportava mais da metade da população da capital norte-riograndense, correspondendo ao percentual de 50,60\% (103.215 moradores) de seus habitantes, de acordo com os dados do IBGE.

\section{Fortaleza-CE:}

Os pleitos identificados na pesquisa documental em Fortaleza estão distribuídos por diversas cidades do estado cearense, principalmente Fortaleza, Sobral, Crato, Barbalha, Caucaia e Maranguape. Os 16 grupos habitacionais edificados no estado e identificados nos levantamentos, apena dois deles não estão situados em Fortaleza ${ }^{383}$. Os Institutos que mais edificaram conjuntos de moradias foram o IAPI (quatro grupos) e 0 IAPB (três grupos), essencialmente no bairro Aldeota ${ }^{384}$.

Os empreendimentos locados na capital cearense estão distribuídos por sete bairros da cidade: Aldeota, Varjota, Mondubim, Otávio Bonfim, Barra do Ceará, Parangaba e Benfica (Figura 61). Se

\footnotetext{
${ }^{382}$ Cabe ressaltar, no entanto, que algumas das moradias consideradas como sociais foram edificadas em bairros como Tirol, da mesma forma, que grandes moradias foram construídas também no Alecrim.

383 Locados nos municípios de Barreiras e Caucáia. Em três dos conjuntos residenciais não foi possível precisar o bairro.

${ }^{384}$ Mais precisamente, o IAPC, o IAPETC, a CAP da Viação Férrea Cearense e a CAP dos Serviços Públicos do CE construíram ou adquiriram dois grupos habitacionais, cada um.
} 
analisarmos a distribuição dessas realizações na planta atual, tem-se uma atuação centralizada em termos espaciais, com alguns grupos residenciais locados em bairro contíguos ao centro, especialmente representados por Aldeota, Benfica e Otávio Bonfim. No entanto, no momento da implantação daqueles conjuntos, principalmente em fins da década de 1930 e ao longo da década de 1940, essas áreas eram tidas como regiões suburbanas, da mesma forma que os bairros Barra do Ceará e Parangaba. A atuação dos institutos de previdência em Fortaleza chegou a localidades ainda mais distantes, atingindo áreas como 0 bairro do Mondubim, que nos anos de 1940 era tido como zona rural.

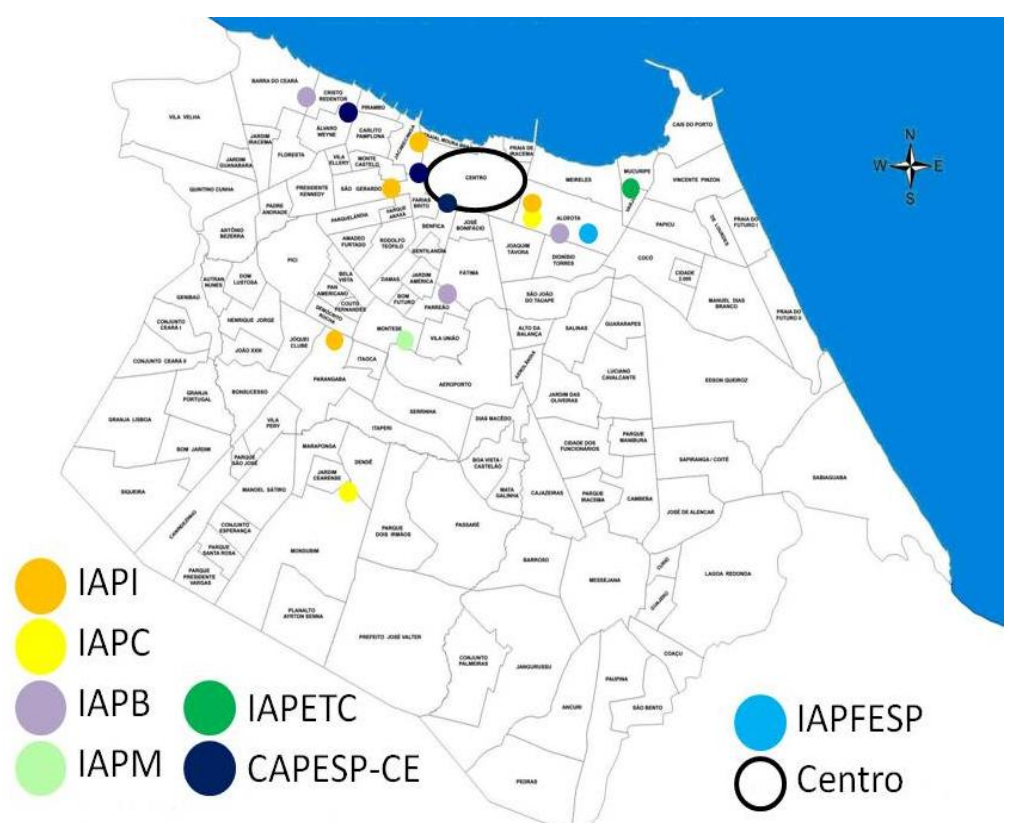

Figura 61: Espacialização da produção habitacional das CAPs e dos IAPs em Fortaleza.

Fonte: Elaboração própria, com base cartográfica da Secretaria de Planejamento e Gestão do Estado do CE, e dados coletados no INSS-CE.
Mais detalhadamente, os grupos residenciais locados no bairro Aldeota foram edificados a partir dos últimos anos da década de 1930, quando ainda era considerada uma área muito distante do centro da cidade, uma área de expansão. $\mathrm{Na}$ década de 1950, o mesmo já era considerado o bairro residencial mais cobiçado de Fortaleza, largamente conhecido como 0 "bairro aristocrático" da cidade, de acordo com os laudos de avaliação dos imóveis na época. Da mesma forma, o bairro de Varjota era tido como área suburbana de Fortaleza até fins da década de 1940. Nesse bairro foi edificada a Vila Antônio Ferreira Filho (IAPECT-1940), que segundo os laudos de avaliações dos imóveis, bem como alguns documentos da época, distava 6 km da cidade, sendo locada "fora dela". Situação semelhante à da Vila Valdemar Falcão (CAPSPCE, 1942), implantada no chamado bairro Floresta, área tida como rural no início da década de 1940.

Posteriormente, os Conjuntos Coqueirinho (IAPI) e Parque Ibiapava (IAPB), construídos na primeira metade na década de 1950, nos bairros de Parquelândia e Barra do Ceará respectivamente, também materializaram a atuação limítrofe dos IAPs e das CAPs em Fortaleza. Naquele período, os citados bairros eram da mesma forma considerados como distantes do centro da cidade e como áreas de expansão da capital cearense. 


\section{Teresina-PI:}

As realizações diretas dos institutos de previdência em Teresina foram mais extremas, por assim dizer, que as observadas nas demais capitais nordestinas aqui estudadas. Quando não situadas no atual centro histórico, os empreendimentos imobiliários foram locados em áreas suburbanas, ao longo das décadas de 1950 e 1960 principalmente (Figura 62). No centro, estão distribuídos, sobretudo, nos bairros Central e, nas áreas distantes, principalmente no bairro dos Comerciários, onde está locado o Conjunto Residencial edificado pelo IAPC, de mesmo nome, que deu origem e intensificou a ocupação da localidade. Caso semelhante ocorreu com os Conjuntos Aeroporto ${ }^{385}$ e Monte Castelo ${ }^{386}$, ambos de propriedade do IPASE, a partir da segunda metade da década de 1960. Essas realizações empreendidas pelos IAPs na capital piauiense resultaram, e contribuíram significantemente, de modo muito mais claro que em outras capitais da região, para a periferização da capital piauiense. Os conjuntos situados no interior do estado, principalmente o Conjunto Nossa Senhora as Lourdes (IPASE-déc.1960)387 em Campo Maior e o Conjunto Boa Esperança (IPASE-1958)388 no município de Parnaíba, também foram edificados em áreas especificadas no laudos como suburbanas.

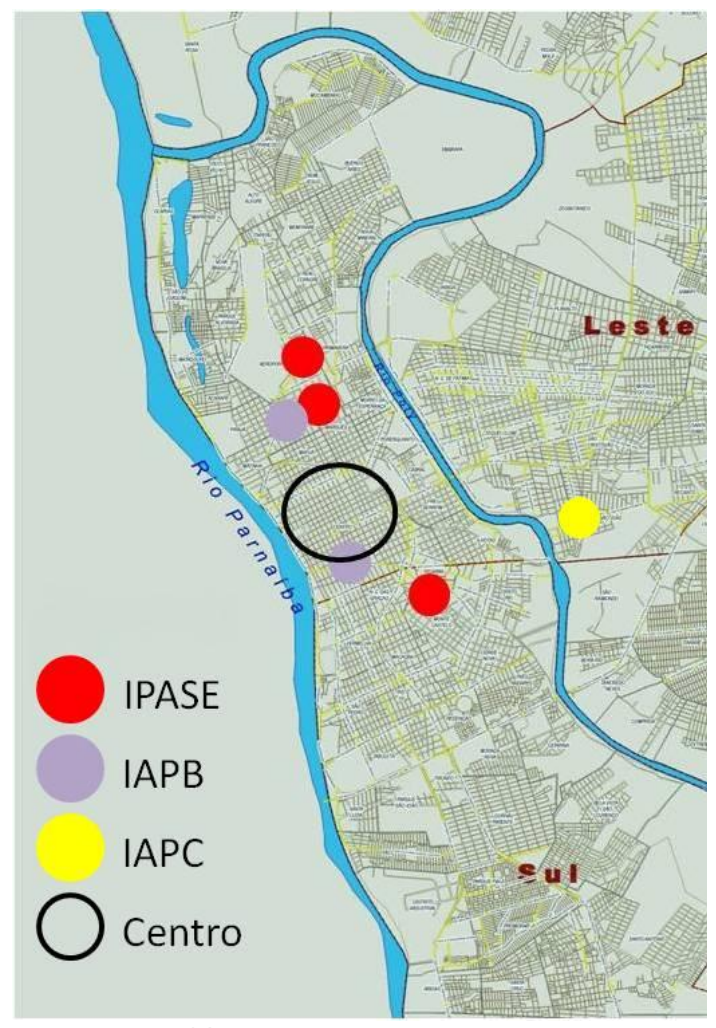

Figura 62: Espacialização da produção habitacional dos institutos de previdência em Teresina.

Fonte: Elaboração própria, com base cartográfica da Prefeitura e dados coletados no INSS-PI.

Uma das justificativas para a atuação mais central389 dos órgãos em Teresina refere-se, essencialmente, ao fato que até os primeiros anos da década de 1950, as atividades comerciais, as repartições públicas e as atividades relacionadas ao lazer, se desenvolviam naquela área, mais precisamente, nas proximidades da Praça Rio Branco e da Praça Pedro II. Essa área também se conformava como a mais densamente ocupada, representando a principal área povoada da cidade, enquanto em outras capitais nordestinas o adensamento e a expansão urbana já se mostrava bem mais acelerada nesse período ${ }^{390}$. 0 preço acessível de terrenos naquela área e a doação de muitas glebas pelo poder público aos

\footnotetext{
385 Composto por mais de 200 unidades habitacionais e outros equipamentos, locados em $25.000,00 \mathrm{~m}^{2}$. A segunda etapa está locada em terreno adquirido por compra feita a terceiros pelo IPASE, em 04 de novembro de 1968.

386 Projeto de autoria do arquiteto Ubirajara Galvão, de 1966, é conformado por 150 casas isoladas.

387 Grupo residencial composto por 198 moradias.

388 Construído em terreno doado pela Prefeitura de Parnaíba e construção mandada fazer por empreitada, no ano de 1957 . Foram edificadas 56 residências.

389 Inclusive em bairro de mesma denominação.

390 Em Natal, por exemplo, na década de 1950, a cidade já contava com aproximadamente dez bairros urbanos, contíguos ao centro da cidade, além de outras ocupações próximas à Praia de Ponta Negra, na zona sul.
} 
institutos de previdência também colaboraram para essa atuação na área central por parte dos órgãos em Teresina. Associado aos supracitados aspectos estava a praticamente ausência de transporte público na capital no período, como destacado em diversos laudos de avaliação de imóveis identificados na pesquisa. Esse fato comprometia consideravelmente a ocupação de áreas mais distantes do centro da cidade.

\section{São Luís-MA:}

Em São Luís, distinguindo do que foi observado nas demais capitais nordestinas, os poucos conjuntos dos IAPs, bem como o conjunto conhecido como Popurlazinha da FCP, foram instalados ao longo do chamado Cominho Grande 391 , que passou a ser estruturado na década de 1930 e, desde então, se conformou como um dos principais vetores de crescimento da cidade, abrangendo a Rua Grande, a Avenida Getúlio Vargas e a Avenida João Pessoa (VASCONCELOS, 2007).

Também se diferenciando do observado em outras localidades como no Recife e em Natal, em São Luís os conjuntos residenciais edificados pelos IAPs estavam encravados em áreas dotadas de infraestrutura básica, servidos de transporte coletivo por bonde e ônibus. Como em João Pessoa, eles foram edificados à margem e/ou próximo do principal eixo de expansão em direção ao mar nesse caso, e ao rio naquele, onde estavam locadas as residências de veraneio. Eixos representados, respectivamente, pela Avenida Epitácio Pessoa e pelo, já citado, Caminho Grande.

Nesse contexto, os conjuntos de menor porte, como o Conjunto Nossa Senhora das Graças e o grupo de moradias do IPASE, que possuíam em média 40 unidades, foram implantados nos bairros mais centrais de João Paulo e Monte Castelo, que conformam uma importante área comercial da cidade (Figura 63). E os grandes conjuntos, com mais de 200 unidades habitacionais, foram situados em áreas mais

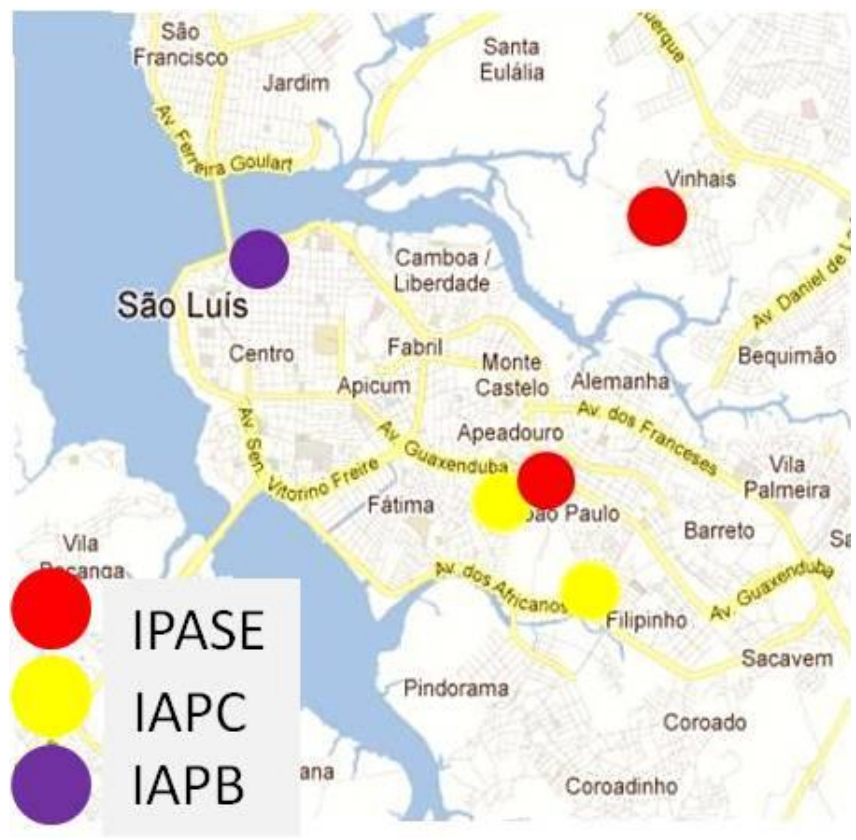

Figura 63: Espacialização da produção habitacional dos órgãos em São Luís.

Fonte: Elaboração própria, com base cartográfica do Google Maps e dados coletados no INSS-MA. distantes. Seguindo a mesma lógica, o conjunto dos Bancários e sua tipologia inovadora para época, também foi locado em área mais distante do centro de São Luís, provavelmente por se destinarem a uma camada populacional mais abastada, para o qual, o transporte coletivo não era um fator preponderante na decisão de compra ou aluguel de uma unidade. Apesar desse aspecto, os edifícios dos bancários, como ficaram

\footnotetext{
391 Estrada aberta com a função inicial de ligar o centro urbano de São Luís até a nascente do Rio Anil, área conhecida como Vila do Anil devido à instalação da fábrica Rio Anil e sua vila operária, região de veraneio da população maranhense até pelo menos a década de 1950.
} 
conhecidos, não eram dotados de espaços e equipamentos públicos ou até mesmo estacionamento, mesmo tendo sido projetado em fins da década de 1950 para as classes mais altas.

Sendo assim, a espacialização da atuação dos poucos escritórios estaduais dos IAPs em São Luís, não abrangeu os limites possíveis da cidade, se concentrando em poucos bairros, principalmente os centrais, e em áreas que se pretendia adensar, essencialmente aquela ao longo do Caminho Grande.

Da mesma forma que não há uma atuação homogênea dos institutos de previdência nordestinos no campo habitacional, entre as décadas de 1930 e 1960, a espacialização de suas ações também não foi. Entendidos e analisados esses diferentes processos e perfis das CAPs e dos IAPs nas sete capitais em questão, especialmente quanto à produção e à concessão de unidades habitacionais, mostra-se importante analisá-los do ponto de vista dos financiamentos, a fim de identificar o caráter de suas políticas habitacionais, bem como a população trabalhadora urbana realmente atendida pelos órgãos. Cabe lembrar, que a questão da apropriação das verbas arrecadas dos trabalhadores e acumuladas nos fundos previdenciários dos supracitados órgãos, para a edificação inclusive de apartamentos de luxo, como assinalado em algumas publicações do gênero, foi largamente colocada em revistas especializadas e publicações das décadas de 1940 a 1960. Esses episódios eram geralmente expostos em formato de crítica e/ou denúncia nos periódicos da época. Mas, essa prática teve suas origens, ao que tudo indica, na própria legislação de criação, estruturação e reforma das primeiras Caixas do ainda Ministério da Agricultura. Esses aspectos serão apresentados a seguir.

\subsection{Os Financiamentos Concedidos: Caracterização e Análises do Perfil Social dos Órgãos}

Desde a década de 1930, os Institutos e Caixas de Aposentadoria e Pensões se propuseram, no campo da moradia, a financiar e/ou edificar unidades habitacionais essencialmente aos trabalhadores mais carentes do país, numa tentativa de instituir uma política pública habitacional brasileira. No entanto, ao se analisar a atuação desses órgãos ao longo dos anos, percebeu-se uma dualidade em suas ações, tendo no plano do discurso e das propostas, um caráter eminentemente social, mas a prática foi marcada por uma atuação significantemente atuarial. Essa dualidade foi por diversas vezes percebida e criticada por setores da opinião pública. Criticas essas, formuladas inclusive no âmbito de suas próprias Carteiras Prediais, como se exemplificou nos capítulos anteriores desta tese.

A vertente atuarial foi amplamente justificada por parte do corpo técnico, pela crise econômica pela qual vinham passando os órgãos ao longo das décadas de 1930 a 1950, como uma alternativa para a não descapitalização da previdência estatal no país. Nesse contexto, os programas sociais, caracterizados pela concepção e/ou financiamento de moradias em larga escala, a juros baixos e amortização de dívida em longo 
prazo, eram vistos como constantes ameaças aos recursos previdenciários ${ }^{392}$. Sendo assim, a própria conjuntura econômica brasileira, já na década de 1940, favoreceu o aumento das ações atuariais dos institutos de previdência. Mais detalhadamente, o crescente desemprego aliado ao aumento da inflação e, consequentemente, ao aumento dos preços dos gêneros, sobretudo, de primeira necessidade, acabaram por resultar cada vez mais na perda do poder aquisitivo das classes assalariadas, ao mesmo tempo em que favoreceram as classes mais abastadas e também o Estado.

Para se ter uma noção mais precisa do quadro inflacionário brasileiro ao longo das décadas de 1940 e 1950, pode-se especificar que a inflação em 1946 no país girava em torno de $22,6 \%$, decaindo para 12,2\% em 1949, mantendo-se entre os percentuais de 11,9 e 12,9\% até 1952, a partir de quando foi novamente elevada para 20,8\%, no ano de 1953 (WANDERLEY, 1990). Outros aspectos que colaboraram ainda mais com essa consideração foram: o não cumprimento do papel que cabia ao Estado e aos empregadores na estrutura tripartite de contribuição; a baixa rentabilidade dos investimentos, sobretudo, habitacionais; e os desvios cada vez mais recorrentes de vultosas quantias acumuladas para a implementação do projeto desenvolvimentista e obras relacionadas a ele.

É importante mais uma vez frisar que não foi somente o poder público ${ }^{393}$ que deixou de honrar com 0 pagamento das contribuições para com a previdência do país e, consequentemente, para com as CAPs e os IAPs, mas também os próprios empregadores o fizeram. Somente no ano de 1956, de acordo com Oliveira et all (1999), as contribuições não recolhidas pelos IAPs, especificamente, foram de aproximadamente Cr $\$ 10.000 .000 .000,00$ de cruzeiros. Operando em déficit orçamentário, como averiguado, os encargos não somente desprendidos para o financiamento e/ou construção de unidades habitacionais, mas também no que concerne a outros serviços, incluindo aposentadoria, serviços médicos, auxílios alimentação, dentre outros, ficaram a cargo dos próprios trabalhadores no Brasil, especialmente os de renda mais baixa - uma vez que eram obrigados aos descontos da previdência, ao passo que os empregadores, deixavam de contribuir. Oliveira et all (1999) atentou ainda para o fato que o não cumprimento das cotas da União e dos empregadores acarretou ainda o aumento dos encargos trabalhistas, essencialmente por meio da elevação das contribuições a serem feitas por aquela parcela populacional394.

O "sobrelucro" do sistema de capitalização resultante do processo de acúmulo dos primeiros anos de atuação dos Institutos e Caixas no país, essencialmente até 1945, foi investido em setores estratégicos da

\footnotetext{
392 Vale lembrar que os Institutos, assim como as CAPs, eram regidos pelo sistema de capitalização, que consistia na arrecadação inicial de recursos (Estado, empregadores e empregados) em um volume maior que o exigido pelas despesas previstas em curto prazo, e que deveriam ser investidos de modo a driblar o desgaste inflacionário. Nesse sistema, os juros cobrados anualmente juntamente com as parcelas de pagamento da dívida ou parte delas, eram acumulados e utilizados como fontes de investimentos ou novamente emprestados na forma de financiamentos. Sendo assim, as reservas acumuladas poderiam garantir o pagamento dos benefícios futuros aos seus associados. Essa especificidade também foi utilizada, por diversas vezes, como justificativa para a realização de um volume consideravelmente maior de ações imobiliárias atuariais ao longo dos anos.

393 A contribuição do Estado para com a previdência era resultante, vale lembrar, de um conjunto de impostos e taxas sobre consumo, bens e serviços que recaia, de qualquer maneira, por sobre os trabalhadores do país.

394 Até 0 ano de 1944 a taxa de desconto mensal obrigatória a ser realizada pelos empregadores nos salários dos seus trabalhadores era de 3\%, sendo elevada para 5\% em 1945 e para $8 \%$ em fins da década de 1950 .
} 
economia, como a Carteira Agrícola do Banco do Brasil, a primeira indústria de celulose e papel do país (Klabin, no Paraná395), a Companhia Nacional de Álcalis, a Companhia Vale do Rio Doce, a Companhia Instituto de Resseguros Brasileira, a Companhia Hidroelétrica de São Francisco, a Fábrica Nacional de Motores e, principalmente, a Companhia Siderúrgica Nacional; as chamadas empresas de economia mista ${ }^{396 .}$ Para se ter uma ideia maior da importância dos institutos de previdência para a instauração da indústria de base no país, basta citar a contribuição do IAPI para a CSN, que só no ano de 1948, chegou a equivaler a Cr\$160.000.000,00 (REVISTA..., 1948); valor nuca reavido pela instituição.

Uma das justificativas para a apropriação das reservas orçamentárias dos institutos de previdência, intensificada, como mostram os balanços econômicos dos órgãos, a partir de meados da década de 1940, pode estar associada à própria conjuntura econômica do país ao longo dessa década. Apesar da situação financeira favorável do Brasil no pós-Segunda Guerra, decorrente principalmente dos acúmulos das exportações nos anos da Guerra, a onda de importação sequente que acompanhou a valorização da moeda brasileira, levou "(...) praticamente ao esgotamento das divisas sem trazer consequências positivas (...)" (FAUSTO, 2007, p.403). Esse quadro induziu o poder público a fazer uso dos valores existentes no cofre da previdência para a concretização de diversos dos seus intentos, inclusive para a edificação de prédios ícones da arquitetura moderna brasileira, como os prédios do Ministério da Educação e Saúde ${ }^{397}$ e do Ministério da Previdência (antigo Ministério do Trabalho, Indústria e Comércio)398. A referida conjuntura econômica brasileira foi perpetuada até a instauração da nova política econômica pelo presidente Dutra, marcada pelo controle das importações de bens de consumo e por estímulos à produção para o mercado interno, que acabou por colaborar ainda mais com o processo de industrialização do país. Apesar dessa significativa alteração da conduta pública no plano da economia, a prática de apropriação das verbas destinadas à previdência e à edificação e/ou ao financiamento de moradias para os trabalhadores urbanos segurados do país, continuou a ser operada.

Ao se proceder a acumulação do capital na comercialização das unidades habitacionais, especialmente, ou seja, ao visar o lucro, os IAPs e as CAPs passaram com os anos a associar a produção de unidades habitacionais à recuperação e à ampliação do capital investido. Atuando dessa forma, deixaram de se conformar como agentes públicos, visando aspectos sociais, para se configurarem como agentes

\footnotetext{
${ }^{395}$ A implantação da Fábrica de Papel e Celulose Klabin se deu ainda na década de 1930, no Paraná. Era tida naquele momento como a maior fábrica de papel da América Latina e conformava-se, além da fábrica, por um setor florestal para a retirada da madeira e reflorestamento, uma estação de tratamento de água, oficinas mecânicas e elétricas, fábrica de cloro e soda cáustica, usina hidrelétrica e termoelétrica, setor de mineração de carvão, represas, serrarias, olarias, estradas e diversos núcleos residenciais, compostos por residências e equipamentos coletivos, dotados de toda a infraestrutura necessária. Suas proporções eram tão significativas que justificou a construção de um ramal da Rede Viação Paraná-Santa Catarina, até suas instalações, em Monte Alegre (CORREIA, 2003).

396 Dentre as obras já citadas no primeiro capítulo desta tese.

397 Cujo projeto foi concebido por equipe conformada por Lúcio Costa, Oscar Niemeyer, Reidy, dentre outros.

398 Projetado pelo arquiteto Mário Santos Maia do Conselho Nacional do Trabalho, entre os anos de 1936 e 1938.
} 
incorporadores capitalistas ${ }^{399}$, se distanciando dos seus objetivos primordiais. Esse foi um dos motivos pelos quais algumas CAPs e IAPs acabaram por atingir, de acordo com as denominações empreendidas por Ribeiro (1997), os submercados normal e monopolista e, consequentemente, públicos-alvo distintos do pretendido por sua política inicialmente social, representados pelas classes de renda média e renda média alta, respectivamente.

A realização de ações atuariais, por vezes, foi colocada como inevitável. Alguns dos presidentes de Institutos afirmavam que ou se abdicava das ações imobiliárias de caráter realmente social (já considerando a existência de "ações sociais de fachada") ou as mesmas eram mantidas, mediante a compensação em outros setores de inversão mais rentáveis:

(...) Assim, só havia duas soluções: desistir desses planos de caráter nitidamente social, ou mantê-los, apesar de deficitários (...). A segunda hipótese foi a adotada. Assim, o Instituto, para pode manter os planos de caráter social, teria de destinar uma parte de suas disponibilidades a inversão de alta renda. Dentro dessa orientação positiva, iniciou o IAPI as suas atividades nesse setor (MADEIRA, abr/1948, s/p).

A intenção de obtenção dos maiores rendimentos possíveis, exposta no Decreto-Lei n.22.872, de 29 de junho de 1933, que criou o IAPM e possibilitou a construção de moradias aos seus associados, dentre outras determinações, pode ter contribuído desde a gênese dos Institutos para uma atuação muito mais atuarial no campo habitacional do que aquela pretendida pelos seus idealizadores, dentre eles o presidente Getúlio Vargas e, consequentemente, a um volume consideravelmente maior de financiamentos para aquisição e construção de moradias para os trabalhadores mais abastados e até para terceiros. Outro aspecto recai sobre a própria estrutura de acumulação dos recursos. Além da obrigatoriedade de depósito dos fundos acumulados no Banco do Brasil, esses direcionamentos mensais vinham acompanhados de uma taxa de juros de $2 \%$, que contribuiu ainda mais para a descapitalização.

Ainda em se tratando da legislação relacionada às CAPs e aos IAPs, outra brecha para a ação atuarial por parte desses órgãos foi percebida em 1937, no Decreto de criação de suas Carteiras Prediais. Nessa legislação, os órgãos ficaram autorizados a utilizar até a metade de suas reservas no campo habitacional, o que vale ressaltar, em muito contribuiu para a ampliação das ações no setor. No entanto, essa elevação da produção, após analisada, não foi necessariamente enquadrada na política social pretendida, e muitos dos empreendimentos foram direcionados aos mais abastados. Isso ocorreu devido a não especificação ou limitação da utilização da verba para determinados setores sociais, nem tampouco

\footnotetext{
399 O incorporador, ou promotor imobiliário como também é conhecido, é o responsável por dirigir o processo de produção. Sua ação pode ser voltada para a apropriação do lucro e do sobrelucro de comercialização e o sobrelucro da localização. Dentre as atividades atribuídas a esse agente, pode-se citar a concepção e estruturação do empreendimento, seus aspectos técnicos, legais, físicos, econômicos, financeiros, operacionais, dentre outros; a mobilização do capital necessário à operação, como a obtenção do financiamento para construção; a contratação de projetos de arquitetura e de engenharia e suas respectivas aprovações; promoção e venda das unidades habitacionais; fiscalização da execução dos serviços; entrega das unidades; efetivação do financiamento ao adquirente por meio de hipoteca, caução de contratos de venda e quitações de crédito; provimento da administração jurídica dos contratos garantidores dos empréstimos até a sua liquidação, etc. (RIBEIRO, 1997). Grande parte dessas funções foram realizadas pelos IAPs e CAPs desde a década de 1930.
} 
condicionou essas ações à aprovação prévia ao Conselho Nacional do Trabalho, como vinha sendo praticado até então; uma forma de coibir certas ações atuariais. Sendo assim, a liberdade de utilização, a elevação do montante a ser empregado nas ações imobiliárias e a redução da burocracia para a concretização das obras e financiamentos, que poderia em muito ter contribuído para a redução do déficit habitacional no país, bem como para a melhora das condições de habitabilidade de muitos trabalhadores brasileiros, foi utilizada em prol essencialmente da capitalização daquelas instituições.

Por meio daquele Decreto passou a ser permitido ainda, que o associado que já possuísse residência pleiteasse outra, o que era até então estritamente proibido, dando margem para que muitos trabalhadores abastados adquirissem mais de um imóvel. Não há uma justificativa sequer para a aprovação dessa determinação no âmbito da política habitacional social dos IAPs e das CAPs, uma vez que o seu objetivo principal era conceder casa aos trabalhadores contribuintes que não tinham condições de angariá-la sem ajuda do Estado. A elevação do limite máximo do financiamento de 30:000\$000 (trinta conto de réis) para 80:000\$000 (oitenta contos de réis) permitida por esse mesmo diploma legal também colaborou para tanto, chamando a atenção dos associados com maior poder aquisitivo para a realização de elevados empréstimos à juros baixos e longo prazo para quitação.

Até para os próprios membros do corpo técnico do Ministério do Trabalho, Indústria e Comércio (MTIC), a ação atuarial das CAPs e dos IAPs no campo habitacional precisava ser contida. De acordo com o engenheiro-arquiteto Rubens Porto, a limitação dos vencimentos salariais dos associados a serem atendidos pelas Carteiras Prediais, bem como a fixação dos valores máximos a serem liberados para empréstimos e financiamentos pelas agências, eram necessidades urgentes:

Quem (...) percorrer as colunas dos vencimentos mensais dos beneficiados, constará que, com raríssimas exceções, os mesmos foram iguais a $500 \$ 000$ (quinhentos mil réis), sendo para mais de $90 \%$ superior a esta importância e nunca a ela inferior.

Ora se, como sabemos, o salário do nosso trabalhador, mesmo o ferroviário, é em imensa maioria, inferior à referida importância evidente será a conclusão que nos impõem os fatos de mudarmos de política no tocante ao palpitante assunto.

Em resumo do que vamos transcrever, com dados exatos, concluímos que, para 110 construção realizadas, foram beneficiados, respectivamente, 12 associados cujos vencimentos são iguais a $500 \$ 000,23$ superiores a $500 \$ 000$ e inferiores a $700 \$ 000,29$, cujos vencimentos eram iguais ou superiores a $700 \$ 000$ e inferiores a 1:000\$000 e finalmente 36 , cujos vencimentos eram iguais ou superiores a esta importância, ou sejam 11, 21, 35 e 33\% (PORTO, 1938, p.149/150).

Foi diante desse quadro, que as ações "não sociais" no campo habitacional foram ganhando cada vez mais espaço, pois eram consideravelmente mais rentáveis. Concomitantemente, os grupos de residências construídos ou adquiridos, tanto os de caráter social, quanto aqueles destinados às camadas mais abastadas da sociedade, não somente aos trabalhadores, iam perdendo qualidade construtiva e projetual ${ }^{400}$. Sendo assim, a possibilidade de aquisição de uma moradia operária de boa qualidade construtiva e a preço

$400 \mathrm{O}$ que veio a se concretizar na atuação do Banco Nacional de Habitação (BNH). 
justificável no país, cada vez mais com o passar dos anos, ficou a cargo dos financiamentos concedidos pelos Institutos para a compra e edificação de moradias por iniciativa dos próprios associados.

De qualquer forma, procedendo à realização de empréstimos a qualquer pessoa física, bem como às inversões em imóveis para a renda das Caixas e Institutos, "tendo em vista manter a estabilidade de seu patrimônio", pode-se equiparar as ações desses órgãos à de qualquer investidor, que busca a melhor forma de aplicação das reservas acumuladas de modo a garantir o maior retorno financeiro. Essas ações contribuíram significantemente para que em conjunto, os IAPs e as CAPs, se tornassem um dos maiores detentores de terras do país. Cabe destacar que parte considerável desse patrimônio acima descrito foi vendida e/ou incorporada ao Banco Nacional de Habitação $(B N H)$, para a construção de seus conjuntos habitacionais, e por órgãos posteriores. De acordo com uma matéria publicada no Jornal O Estado de São Paulo, em 1982, o IAPAS ${ }^{401}$ possuía naquele ano, cerca de 5.700 (cinco mil e setecentos) imóveis distribuídos pelo país, dos quais, 787 (setecentos e oitenta e sete) eram terrenos, muitos deles situados em áreas bastante valorizadas. Apenas no estado de São Paulo, o IAPAS possuía 3,8 bilhões de metros quadrados em terrenos (VENDEM-SE..., 01/1982, p.24).

Diversas críticas foram lançadas ao sistema de apropriação de recursos sociais das CAPs e dos IAPs para a edificação de moradias. Cabe ressaltar, que essa oposição não era contra a intervenção do Estado na provisão de moradias, mas sim, à gestão dos recursos da previdência e às políticas instituídas por esses órgãos, essencialmente por financiar moradias para os contribuintes de classe média e alta, bem como pela apropriação do Estado dos recursos acumulados e o seu emprego em empresas de economia mista e projetos desenvolvimentistas tidos como "caprichosos", como a construção de Brasília:

(...) já tivemos oportunidade de analisar o problema da inversão, em particular quanto ao IAPI, salientado várias causas responsáveis pelo baixo rendimento obtido sobre 0 ativo total. De um modo geral, além de outras causas, o emprego de grandes capitais dos Institutos em empresas controladas pelo Estado tem contribuído para isso. Até o presente momento o IAPI não recebeu um único real de juros dos $\operatorname{Cr} \$ 160.000 .000,00$ que inverteu na Cia. Siderúrgica Nacional. Não estamos negando a grande utilidade desse empreendimento, mas tão somente lembrando uma das fontes de aplicação que por enquanto não têm produzido qualquer rendimento (...). (MADEIRA, 1951, s/p).

O enfoque inicial dado pelos IAPs e CAPs à aposentadoria e às pensões foi, ao longo das décadas, mudando para a moradia e, posteriormente, para a prestação de serviços, sobretudo médicos. A crise financeira do sistema previdenciário do país, iniciada ainda em fins da década de 1930 e perdurada nos anos quarenta, ganhou ainda mais vulto na década de 1950. Tendo crescentes gastos com assistência e serviços médicos, além de prazos para a conclusão dos grupos habitacionais iniciados e para atender às reivindicações operárias nesse sentido, os Institutos e Caixas de Aposentadoria e Pensões se aproximaram do regime de repartição simples. Nesse, a arrecadação anual passou a ser integralmente destinada à

401 O IAPAS foi criado em 1977, por meio da Lei n 6.439, que também instituiu o SINPAS, e juntamente com INAMPS recebeu 0 patrimonial de bens (imóveis) do INPS, FUNRURAL, IPASE e LBA. 
prestação de serviços e à concessão de benefícios, não havendo, ao contrário do que propõe o regime de capitalização, acúmulos financeiros. De acordo com os Relatórios de Exercícios expedidos a partir de meados da referida década, no ano de 1956, as despesas dos IAPs equivaleram a $90 \%$ dos valores arrecadados e, em 1961, um ano após a reforma da Previdência promovida pela LOPS, esses gastos ultrapassaram 100\% do angariado.

A intensificação da problemática habitacional urbana no país, a partir de 1940, e a redução das construções de unidades residenciais para as classes mais carentes, sobretudo a partir de 1950, mormente sob a forma de aluguel, foram contrariadas pelo aumento considerável do volume de construções e financiamentos de moradias e apartamentos destinados às classes média alta e alta, tidos muitas vezes como de luxos, e para o financiamento de obras governamentais, como se pode perceber no trecho de um artigo da época:

(...) 0 dinheiro dos contribuintes foi aplicado em negociatas e obras suntuárias, verdadeiro roubo ao trabalhador já suficientemente sugado pelos patrões... E fora os palácios e arranha-céus onde 0 operário não pode morar, onde o produto do seu suor foi aplicado através do dinheiro que foi obrigado a dar aos Institutos (...) (A "GAIOLA DOURADA"..., 26/05/1947, s/p).

(...) Não se trata de construir edifícios com apartamentos que ninguém pode locar nem comprar - isto não é Previdência Social, mas sim realizações de obras cuja única utilidade é a de figurar nos noticiários em legendas pomposas (BANCÁRIOS, v.26, n.08 e 09, ago/set de 1959).

Nesse sentido, entre os anos de 1945 e 1950, foram financiadas no país 4.942 (quatro mil, novecentos e quarenta e dois) unidades habitacionais para não associados, somente no âmbito do Instituto de Aposentadoria e Pensões dos Industriários (FARAH, 1983). Esse número corresponde a 38.22\% dos financiamentos realizados pelo Instituto no período402.

Em contrapartida, diversos artigos foram publicados em jornais e revistas por parte dos Institutos, ressaltando que o provimento de moradias aos seus associados não era a prioridade da Previdência Social, e que para cumprir com seus deveres principais, usavam da construção, financiamento e venda de unidades mais luxuosas, para equilibrar os cofres das Instituições:

(...) Devemos prestar à Previdência o máximo possível de colaboração no sentido da conveniente divulgação dos seus aspectos essenciais (...). Os Institutos vêm sendo alvo de cerrada crítica. Mas, isso ocorre mais pela incompreensão existente em torno de seus verdadeiros fins que pela existência de falhas insanáveis ou extremamente graves (...) (IAPI, 04/1948).

Ao longo da década de 1950, os gastos do poder público para efetivar a instauração das indústrias, bem como colocar em prática outros dos seus projetos nacional-desenvolvimetistas, vinculados às decrescentes exportações, acarretaram em progressivos déficits orçamentários. Em fins da década, a inflação

402 Volume de produção apresentado por Farah (1983). Vale ressaltar ainda, que não estão sendo consideradas as unidades edificadas e repassadas aos mais abastados, nem os empréstimos para outros fins. 
atingiu o mais alto nível até então, beirando os 40\%. De acordo com Fausto (2007), essa conjuntura foi acarretada principalmente pela construção da nova capital federativa do país. Além disso, destaca o autor, as dívidas ainda não estavam sujeitas às correções monetárias, o que tornava os empréstimos muito atraentes, especialmente aqueles contraídos com condições facilitadas, como vinha operando o poder público e os órgãos de financiamento do Estado, como os institutos de previdência; contribuindo ainda mais para a defasagem dos seus cofres.

Em 1953, por meio do Decreto $n^{0} 33.427$, de 30 de Julho de 1953, os IAPs, a FCP e a Caixa Econômica ficaram autorizados a conceder financiamento a órgãos estaduais e municipais, quando solicitado, devido à intensificação da crise habitacional do país e à incapacidade dessas autarquias em solucionar 0 problema. Essa prática, que já vinha sendo realizada há anos, acabou por se intensificar, contribuindo ainda mais para a descapitalização dos cofres dos institutos de previdência. A questão da apropriação das verbas das CAPs e dos IAPs para realização e obras e projetos estatais, mormente, vinculados às questões urbanas, já era criticada desde a década de 1930 e foi incorporada inclusive na pauta da Jornada de Habitação Econômica, promovida pelo IDORT, em 1941. O engenheiro-arquiteto Rubens Porto também chamou a atenção muitas vezes do poder público para a descapitalização dos cofres previdenciários ocasionada, dentre outros fatores, pelo desvio de verbas públicas sociais para obras urbanas e relacionadas ao impulso econômico que se pretendia dar à indústria de base brasileira.

Diante do supracitado contexto de crise, inadimplência e ações que cada vez visavam os lucros em detrimento a proposta inicial social no campo da moradia, foram propostas diversas reformas legislativas. Nesse sentido, no ano de 1954, foi baixada a Lei n.2.250, que determinou o pagamento dos juros do débito da União para com a previdência. No entanto, o quadro de déficit orçamentário continuou a crescer. Em 1957, o Conselho Nacional de Economia (CNE), propôs uma reforma na estrutura de capitalização dos órgãos e outras funções. As principais proposições defendiam o fim da contribuição tripartite ou pelo menos a redução da contribuição do Estado, que se mostrava fixa e em maior percentagem que as demais. Essa reforma, contudo, só veio a se concretizar em 1961, com a Lei Orgânica da Previdência Social403. Mais precisamente, a LOPS alterou a forma de contribuição tripartite até então vigente, em que o Estado, os empregadores e os empregados participavam na Previdência. A partir de 1961, ao poder público passou a ser atribuída somente às despesas para com a administração dos órgãos, reduzindo consideravelmente os valores arrecadados pelas CAPs e IAPs, contribuindo ainda mais para o processo de descapitalização dos órgãos.

Com o passar dos anos, o "sobrelucro" vislumbrado nos anos iniciais de atuação dos Institutos e Caixas foram se esvaindo devido às sucessivas crises econômicas por que passou o país e o consequente aumento inflacionário. A redução dos lucros também advinha das transações imobiliárias de compra e/ou edificação de moradias e de financiamento de residências para os associados mais carentes, que eram

${ }_{403}$ Pela Lei n.3.807, aprovada em 26 de agosto de 1960, mais precisamente nos Art. 10 e 22ㅇ. 
acompanhados por baixos juros e por longos períodos para amortização da dívida, entre 10 e 25 anos. As reviravoltas econômicas fizeram com que os valores inicialmente desprendidos nos financiamentos se tornassem relativamente baixos ou se depreciassem com o tempo.

O débito da União para com a Previdência Social no Brasil não chegou a ser apresentado até fins da década de 1940, quando o Presidente Dutra esclareceu a questão e destacou a necessidade do pagamento da dívida da União para com a Previdência, para que fosse possível dar prosseguimento a essa política habitacional no país:

(...) os encargos da União por largo tempo foram negligenciados, de forma que sofre com isso o plano de previdência das instituições incumbidas de administrá-lo. Não é possível, destarte, que às suas obrigações antigas se acrescentem outras, se não lhes for assegurada a utilização de todas as reservas previstas. Cumpre examinar, por si mesmo, a questão do débito da União para com os Institutos de previdência e assistência sociais, que constitui, sem dúvida alguma, um dos assuntos mais delicados com que se têm de defrontar os responsáveis pelo destino do país, assim no presente como no futuro (...). A dívida da União ascendida, em 31 de dezembro de 1946, ao montante de Cr\$ 261.465.060,060 (...). No correr de 1947 e em 1948, o débito da União continuou e continuará a avolumar-se (...) (A PREVIDÊNCIA..., 02/04/1948).

Apesar das investidas e dos intentos (no plano do discurso) da administração pública, no início da década de 1960, o débito da União para com os cofres previdenciários elevou-se para a ordem de Cr $\$ 195.000 .000 .000,00$ (cruzeiros novos) e dos empregadores chegou a Cr $\$ 53.000 .000 .000,00$ (cruzeiros novos).

\section{Os financiamentos no Nordeste:}

Antes de explanarmos acerca das características das ações imobiliárias empreendidas pelos órgãos por meio do financiamento no Nordeste, cabe apontar o motivo pelo qual ele foi adotado na política habitacional empreendida pelas CAPs e IAPs a partir da década de 1930. O principal deles refere-se ao elevado valor agregado à mercadoria habitação, o que impossibilita, até os dias de hoje, que a maior parte dos trabalhadores assalariados das faixas de renda mais baixa efetive a sua compra. 0 papel do poder público desde aquele momento foi o de tornar possível esse acesso por meio do crédito imobiliário disponibilizado, sobretudo, pelas Caixas e Institutos de Aposentadoria e Pensões ${ }^{404}$. Nesse contexto, como já foi mencionado, os financiamentos empreendidos por esses órgãos resultaram em lucros graças à amortização do capital inicialmente empregado agregada à taxa de juros, embutida nas parcelas mensais de pagamento e cobradas ao longo do período do financiamento que, por sua vez, foram referidas (no plano no discurso) em outras ações sociais no campo habitacional.

Os critérios e as exigências gerais para que um trabalhador solicitasse um financiamento imobiliário por meio das CAPs e IAPs, desde a década de 1930, eram determinados pelos seus corpos técnicos e pelo

404 Apesar de não terem sido os primeiros órgãos a efetivar financiamentos imobiliários do país, como apontado nos primeiros capítulos desta tese, as CAPs e os IAPs do MTIC representaram o alargamento dessa ação, bem como, sua centralização em órgãos específicos. 
Conselho Nacional do Trabalho e foram apresentados no capítulo 1 desta tese. Foram poucas as variações percebidas quanto a essas especificações nos levantamentos realizados no Nordeste do país, geralmente relacionadas à pontuação concedida para cada categoria de análise (número de filhos, tempo de trabalho, situação da moradia atual, tempo de contribuição, etc.), quando consideradas, ou ainda, ao caráter do empreendimento (construção por iniciativa do instituto de previdência ou do segurado, financiamento para construção, reforma ou empréstimo hipotecário, principalmente).

Nesse sentido, em alguns conjuntos ou grupos de moradias, os Institutos ou Caixas determinavam um perfil de trabalhador a se atendido, como por exemplo, os trabalhadores sindicalizados em determinada organização, como se percebeu no âmbito do IAPB-PB, no episódio de edificação do Conjunto Tambauzinho, em fins da década de 1950, destinado exclusivamente a uma determinada categoria de segurados vinculados ao Sindicato dos Bancários. Outros exemplos foram os diversos conjuntos construídos pelo IPASE em todo 0 Nordeste, destinados somente para os funcionários de uma determinada prefeitura ou funcionários estaduais.

De modo geral, ao ser contemplado por um financiamento para compra ou aluguel de unidade habitacional edificada ou adquirida por aqueles órgãos, o trabalhador após se enquadrar em uma das modalidades de concessão permitidas, mormente a promessa de compra e venda ou o pacto adjeto de hipoteca ${ }^{405}$, deveria pagar, além das taxas mensais para a amortização da dívida, calculada com base no valor do financiamento concedido, no prazo determinado para o pagamento e na taxa de juros aplicada, 0 seguro de garantia ${ }^{406}$, também chamado de "seguro de suplemento de garantia", de valor equivalente a $10 \%$ do valor solicitado 407 .

0 assegurado teria ainda que pagar uma taxa de seguro contra incêndio408 e durante o prazo do contrato, também corriam por conta do outorgado os impostos, taxas e foros, que incidiam ou viessem a incidir sobre a moradia, incluindo a quota de administração ou serviço cobrada pelas CAPs e IAPs que equivaliam a $3 \%$ ou $5 \%$ sobre o valor das despesas ou dos imóveis ${ }^{409}$. Essas taxas e cotas somadas conformavam a prestação mensal a ser paga pelo outorgante comprador ou inquilino por intermédio do

\footnotetext{
${ }^{405} \mathrm{Em}$ ambos os casos, o promitente comprador só seria efetivado como proprietário do imóvel quando estivesse concluída toda a transação, isto é, após o pagamento de todas as quantias devidas ao Instituto ou Caixa com o qual foi firmado contrato. Quando vendidas, os associados pagavam mensalmente as parcelas para amortização da dívida ao Instituto e arcavam com as demais despesas e taxas referentes ao terreno e à residência. Quando hipotecadas, os trabalhadores pagavam juntamente com as prestações mensais referentes ao pleito concedido, as taxas de uso do imóvel que eram descontadas do valor total concedido, e ao sanarem a dívida para com o Instituto o imóvel era transferido legalmente para o associado. Em algumas capitais, como no Recife e em Salvador, havia ainda a possibilidade de aquisição do imóvel após um período de residência nele por meio do pagamento de aluguel. Essa modalidade, como destacado anteriormente, em muito se aproxima da desempenhada no Programa de Arrendamento Residencial (PAR), criado em 1999.

${ }^{406}$ Esse seguro passou a ser exigido nos processos de financiamentos que correspondessem a mais de 70\% do valor do imóvel, de acordo com o Art.1, da Lei o. 2.068, de 09 de novembro de 1953, que alterou o Decreto-Lei o..7.264, de 22 de janeiro de 1945.

407 Poder-se-ia ainda optar pelo pagamento deste seguro com carência ou sem carência. Na modalidade "sem carência", o pleiteante desembolsaria uma quantia inicial, entrada ou sinal, geralmente de $10 \%$ do valor total do financiamento. Na opção "com carência", essa percentagem era incorporada às parcelas mensais de amortização de dívida.

${ }^{408}$ Correspondente a $3 \%$ do valor do financiamento liberado.

409 As despesas de contrato estabelecidas entre as partes interessadas, bem como referentes aos contratos de compra e venda do imóvel, registros, transferências, laudêmio, etc., ficavam a cargo do associado até, pelo menos, a década de 1940.
} 
Instituto ou Caixa, e poderiam ser pagas diretamente no balcão do escritório estadual do órgão ou debitadas na folha de pagamento 410 .

No caso de atraso do pagamento das parcelas mensais ou qualquer outra quantia devida ao Instituto ou Caixa, o contrato poderia ser reincidido caso o órgão decidisse ou seriam pagos juros de até 3\% ao mês. Em caso de incêndio parcial ou total, as obras de reconstrução ou reformas ficariam sob a responsabilidade do Instituto e seriam equivalentes, restritamente, ao valor da indenização ${ }^{411}$. 0 contrato também poderia ser reincidido quando, no caso de incêndio, fosse constatada culpa do associado ou que este, por qualquer motivo se recusasse a cobrir a diferença verificada para a execução das obras de restauração do imóvel. Caso houvesse a quebra do contrato, o associado deveria entregar o imóvel em perfeito estado de conservação e habitabilidade 412 ao IAP ou CAP que, por sua vez, abriria nova concorrência ou protocolo interno para reocupá-lo.

A sublocação só seria permitida caso o associado solicitasse essa ação formalmente por meio de carta redigida e assinada por ele, endereçada à administração do conjunto e/ou do órgão proprietário do imóvel, condicionada à autorização por escrito do Instituto. O segurado deveria ainda apresentar e detalhar naquele documento um motivo justo, que o impedisse de continuar a residir no imóvel pleiteado, sublocandoo sob a sua responsabilidade. De qualquer forma, a coabitação de mais de uma família era estritamente proibida nas unidades de propriedade dos Institutos ou Caixas, durante todo o período de atuação dos órgãos no país.

Quanto ao uso e à conservação do imóvel, o Instituto obrigava o pleiteante a manter, obrigatoriamente, a residência em permanente estado de asseio e de conservação da estrutura, devendo para tanto, serem realizadas as suas custas, quaisquer obras de reparos necessárias ou exigidas pelas autoridades competentes. Nesse sentido, a Caixa ou Instituto de Aposentadoria e Pensões poderia vistoriar 0 seu imóvel sempre que julgasse conveniente verificar o cumprimento das obrigações acima elencadas ${ }^{413}$. Quanto à realização de reformas, essas não seriam permitidas sem o aviso prévio ao Instituto, além do seu

410 Por exemplo, em um financiamento para compra de moradia de propriedade do Instituto no ano de 1957, no valor de Cr $\$ 74.500,00$ (setenta e quatro mil e quinhentos cruzeiros) a serem pagos no prazo de vinte anos, com juros de $6 \%$ ao ano, 0 solicitante pagaria uma entrada correspondente a $10 \%$ do valor solicitado, o que equivalia à $\operatorname{Cr} \$ 7.450,00$ (sete mil quatrocentos e cinquenta cruzeiros). As demais taxas eram calculadas com base no valor restante de $\operatorname{Cr} \$ 67.050,00$ (sessenta e sete mil e cinquenta cruzeiros). 0 cálculo da prestação era realizado da seguinte maneira: amortização e juros sobre o valor concedido de Cr $\$ 67.050,00$, que resultaria em duzentas e quarenta prestações mensais de Cr\$614,62 (seiscentos e quatorze cruzeiros e sessenta e dois centes); somados ao seguro complementar de $10 \%$ do valor restante que seria de $\operatorname{Cr} \$ 27,93$ (vinte e sete cruzeiros e noventa e três centes); acrescidos às despesas do seguro contra fogo sobre o valor restante, equivalente à Cr $\$ 8,83$ (oito cruzeiros e oitenta e três centes), que poderia ser pago anualmente em vinte parcelas de $\operatorname{Cr} \$ 100,56$ (cem cruzeiros e cinquenta e seis centes); mais a taxa de água do Conjunto ou Vila de Cr $\$ 24,40$ (vinte e quatro cruzeiros e quarenta centes), os impostos territorial, predial, etc., correspondentes à Cr $\$ 165,60$ (cento e sessenta e cinco cruzeiros e sessenta centes) e mais a taxa de administração equivalente à $\mathrm{Cr} \$ 55,90$ (cinquenta e cinco cruzeiros e noventa centes). A prestação mensal do associado para a solicitação dessa moradia era, portanto, de $\mathrm{Cr} \$ 897,28$ (oitocentos e noventa e sete cruzeiros e vinte e oito centes).

411 Correspondente ao valor pago pelo seguro contra incêndio.

412 Nesses casos, o trabalhador deveria realizar por conta própria as obras de reforma estrutural, se necessárias, ou de retoques, como a pintura das paredes, reposição de telhas, substituição de sifões, dentre outros elementos.

${ }_{413}$ Cabe lembrar que a unidade habitacional continuava sendo propriedade da Caixa ou Instituto até a liquidação da dívida, qualquer que fosse a modalidade de ação, por parte do segurado. 
expresso consentimento. Os acréscimos não seriam cobertos pelos seguros anteriormente citados. No caso de financiamento concedido para reforma e/ou ampliação de imóveis, era disponibilizado ao associado um prazo de até 180 dias para a conclusão da obra.

Se as reformas fossem em unidades edificadas por construtores ou empresas construtoras, esses deveriam se responsabilizar por elas, devendo o segurado entrar em contato diretamente com as mesmas para a realização das obras. De acordo com as normas gerais, o construtor era obrigado a refazer e/ou reparar todo o trabalho considerado como mal feito e a reparar as falhas que tenham sido evidenciadas pelo uso, até os sessenta dias que cabiam ao segurado a reclamação.

Para alguns dos conjuntos, vilas ou imóveis isolados de propriedade dos Institutos, enquanto não fossem realizadas as instalações de água e esgotos pelo Estado, bem como as regularizações da energia elétrica pela Companhia de Energia atuante na localidade, como previsto em lei desde a década de 1920, 0 associado teria a sua disposição, um depósito de água destinado ao abastecimento comum (caixa d'água suspensa ou até mesmo chafariz) e seria responsável por todas as despesas relativas a ele, inclusive de empregados para o acionamento e conservação das bombas, como também no que diz respeito à energia da unidade habitacional e à iluminação do logradouro. Cabe já assinalar que em grande parte desses empreendimentos, a dotação de serviços e infraestrutura ficou a cargo do próprio solicitante, como se verá mais detalhadamente adiante.

Para os financiamentos solicitados para a construção de moradias por iniciativa do segurado, caso 0 órgão, mais precisamente o seu escritório estadual, não possuísse um setor ou departamento específico de engenharia, responsável pela elaboração de projetos e pela execução das obras, o IAP ou a CAP indicava profissionais para o cumprimento dessa tarefa. Em alguns processos dos órgãos no Nordeste foi percebia a disponibilização de engenheiro ou arquiteto pela própria prefeitura, como na capital norte-riograndense. Mais precisamente, em Natal, a massiva maioria dos laudos de avaliações dos imóveis financiados pelos referidos órgãos na cidade e trabalhados nesta tese, foram assinados por um engenheiro da prefeitura municipal, Wilson Oliveira Miranda, que também se responsabilizou pelos projetos e a execução de diversas unidades habitacionais na referida cidade. Em outros casos, esses profissionais foram alocados dos escritórios centrais, no Rio de Janeiro, para a execução de projetos e/ou obras dos órgãos nordestinos, como percebido no âmbito do IAPB-PB, que solicitou os serviços do arquiteto carioca Ulysses Bularmaqui, para a elaboração do projeto do Edifício Presidente João Pessoa, em 1957.

Percebeu-se ainda, que alguns dos escritórios estaduais mais capacitados tecnicamente, como 0 escritório estadual do IAPC-PE elaborou diversos projetos, essencialmente verticais, e se responsabilizou pela execução das obras de conjuntos residenciais em São Luís, João Pessoa e Salvador, como será mais detalhadamente exemplificado no capítulo seguinte. Cabe lembrar que o engenheiro ou 0 arquiteto que compunha o corpo técnico de um escritório central ou estadual de um Instituto ou Caixa, quando conformado como um profissional contratado pelo órgão, poderia exercer suas atividades projetuais, de acompanhamento 
de obras, dentre outras, nas mais diversas localidades de atuação, quando fosse necessário ou a convite do órgão em qualquer uma de suas instâncias.

Nos casos em que um construtor era contratado para a edificação das moradias, o pagamento deste equivalia em média a 5\% do valor avaliado para a edificação da unidade, e era realizado em parcelas de acordo com o número de etapas de execução da obra, que comumente eram cinco: 1) fundação, 2) reboco, 3) colocação de piso e cobertura, 4) esquadrias e pintura e 5) saneamento; sendo a última parcela paga após a entrega da obra ${ }^{414}$. Esse contrato era estabelecido entre três possibilidades: a primeira, entre o profissional e o Instituto ou Caixa, caso se tratasse da construção de grupos de moradias ou conjuntos habitacionais, a segunda entre o construtor e o segurado, para a edificação de unidades isoladas, e havia episódios ainda em que o contrato era assinado entre o construtor ou empresa construtora e o segurado, com interveniência do Instituto, como percebido em alguns grupos de habitações edificados pelo IPASE e pelo IAPC, em João Pessoa.

Nessas ocorrências, geralmente, o terreno era de propriedade do órgão, que já contava com os projetos arquitetônicos das unidades e os disponibilizava em concorrência aos construtores interessados. 0 financiamento também era concedido pelo Instituto ou Caixa, mas a construção do prédio, essencialmente sua vistoria e acompanhamento, ficavam sob a cargo do segurado "(...) não cabendo ao INSTITUTO responsabilidade de qualquer natureza (...)" (LAUDO..., 17/10/1952, p.3). Em qualquer um dos casos, 0 contrato entre o promitente construtor e 0 interessado era lavrado em cartório. A escolha do construtor poderia se dar por meio de indicação do órgão, concorrência aberta (entre pessoas físicas ou empresas atuantes na cidade ou na região, principalmente) ou concorrência interna, ou administrativa como já foi especificado, na qual, somente os profissionais licenciados nos Institutos ou Caixas poderiam competir415.

Ao contrato era anexado um memorial construtivo ou, como era comumente chamado na época, de acordo com o caderno de encargos, plantas e especificações aprovado pela Divisão de Engenharia do Instituto, onde eram especificadas desde o preparo do terreno, cavas, fundações e a estrutura (paredes, vigas e vergas), passando pelos detalhamentos das esquadrias, suas dimensões, materiais e marcas, até as especificações dos revestimentos de piso e parede em cada um dos cômodos, como cores, texturas,

\footnotetext{
${ }^{414}$ No caso específico do IAPI, esse parcelamento se dava de acordo com a Resolução de Serviço n.351, de 26 de julho de 1949, e que continuou como referência até, pelo menos, fins de 1952 (LAUDO..., 17/10/1952). No IPASE, mais especificadamente, os parcelamento se dava após: 1) concluída a laje de impermeabilização e demarcadas as paredes externas e internas da edificação; 2) concluído o levantamento de todas as paredes até a altura para receber o madeiramento do forro e iniciado o telhado; 3) quando emboçadas e rebocada as paredes internas e externas, com todos os marcos e aduelas colocados, e iniciadas as instalações de água e luz; 4) concluídos os revestimentos das fachadas, com peitoris e soleiras colocados, bem como 0 assoalho, com as tubulações de água concluídas, faltando apenas a colocação das torneiras e aparelhos, com o serviço de energia elétrica finalizado, faltando apenas a fiação e 0 arremate, além do sistema de esgoto em vias de conclusão; 5) quando concluída a colocação das esquadrias internas e externas, assim como toda a fiação elétrica e a colocação dos ladrilhos, faltando apenas a colocação dos aparelhos de banheiro e equipamentos de cozinha (o que indicava que eram geralmente previstos em projeto), que já deveriam estar depositados na obra; 6 ) depois de concluídas todas as obras contratadas, lavados todos os revestimentos, com 0 assoalho raspado, afagado, calafetado e encerado, com todos os aparelhos e equipamentos em perfeito estado de funcionamento, com 0 terreno limpo e pronto para ser habitado. Com todos os tramites legais concluídos e as chaves entregues ao Instituto.

$415 \mathrm{Em}$ todas as obras financiadas pelos IAPs e CAPs eram fixadas placas identificando esse aspecto; 0 que veio a se confirmar com regra nas construções civis atualmente.
} 
metragens, marcas, técnica para colocação, etc. Em alguns casos eram descritos, inclusive, o formato, os parafusos, buchas e brocas que seriam utilizadas para a fixação de luminárias, lustres e/ou arandelas. 0 construtor era ainda o responsável por solicitar as exclusões das taxas e laudêmios que viessem a incidir sobre o(s) imóvel(is), nas repartições competentes, cabendo a ele, inclusive, providenciar as exigências construtivas porventura feitas. Era ainda o construtor que se responsabilizava pela colocação dos funcionários e da obra em seguro e ainda pela elaboração de todos os cálculos estruturais e de instalações de água, luz e esgotamento sanitário, sendo disponibilizado pelo Instituto ou Caixa apenas os projetos arquitetônicos. A demolição e outros encargos que fossem existentes no terreno antes de iniciadas as obras de edificação também ficavam a cargo daquele profissional, inclusive qualquer dano que viesse a ocorrer nas obras vizinhas, a terceiros e às vias públicas. Nos casos de obras contratadas por empreitada, a ligação das unidades às redes de serviço era, da mesma forma, da alçada do construtor, junto às repartições e companhias concessionárias da época. Nos casos da contratação se dar entre o profissional ou empresa e um IAP ou CAP diretamente, o órgão designava um engenheiro para a realização da fiscalização das obras, devendo ser atendida pelo construtor, quaisquer solicitações feitas por esse profissional quanto à edificação e à legalização dos serviços ${ }^{416}$.

No que se refere à edificação de unidades por parte dos Institutos e das Caixas, essencialmente às locadas em grupos e conjuntos habitacionais, as reclamações só poderiam ser feitas em relação aos defeitos construtivos, principalmente os indispensáveis de correção para a habitabilidade do associado e sua família, evidenciados após a entrega do prédio. Essas manifestações deveriam, necessariamente, serem realizadas por escrito em, no máximo, sessenta dias após a data de entrega do imóvel417. Passado esse prazo, 0 Instituto só se responsabilizaria pela solução e/ou reparo de defeito construtivo que poderia pôr em risco a estabilidade e a segurança do imóvel e de seus moradores, de acordo com o Art.125 do Código Civil Brasileiro 418 .

Sem sombra de dúvidas, o processo mais burocrático evidenciado ao longo da pesquisa dizia respeito às solicitações para a aquisição de um imóvel já edificado por terceiros. Nesses casos, além de todos os critérios, exigências e responsabilidades elencadas acima, o segurado ainda deveria apresentar uma diversidade de documentos e atestados, que em muito contribuíram para a morosidade de algumas

\footnotetext{
416 Nenhuma modificação nas plantas poderia ser empreendida sem a ordem expressa do fiscal, devidamente ratificada pela Divisão de Engenharia do órgão em questão.

417 Mesmo prazo concedido aos construtores.

418 Esse especificava que o construtor seria responsável pelos reparos construtivos até o prazo de cinco anos decorridos da data do Habite-se concedido pelo poder público
} 
transações ${ }^{419}$. O grande volume de certidões de comprovação e/ou negativas, bem como suas consequências a médio e longo prazo no tocante à atuação dos IAPs e das CAPs no campo habitacional, não só no Nordeste, mas também no restante do país, foram apontados por Rubens Porto, como já colocado no capítulo 2, como um dos grandes empecilhos à efetivação de uma política pública habitacional eficiente no Brasil. Essas observações são colocadas por outros profissionais desde os primeiros anos da década de 1930, mas diante do averiguado em campo, a exigência de uma gama de comprovações continuou a ser praticada, pelo menos no tocante às ações de compra de imóveis de terceiros diretamente pelos segurados por meio de financiamento concedido pelos supracitados órgãos.

Em se tratando dos valores possíveis de financiamentos imobiliários, de maneira geral, as portarias e regulamentos publicados no período de estruturação e reforma das CAPs do MTIC, até meados da década de 1930, como colocado no primeiro capítulo desta tese, especificaram que os valores concedidos por aqueles órgãos, não poderiam comprometer mais de 30\% do salário do associado. Em 1934, as CAPs e os recémcriados IAPs do MTIC, passaram a operar empréstimos financiados de modo que até $40 \%$ do salário do trabalhador pudesse ser comprometido, num teto de 30:000\$000 (contos de réis). A partir de 1937, com a criação das Carteiras Prediais daqueles Institutos, a margem dos financiamentos foi elevada para 80:000\$000 (oitenta contos de réis) ${ }^{420}$.

$\mathrm{Na}$ década de 1940, outra Portaria Federal relativa à concessão de pleitos especificou que as solicitações deveriam estar abaixo de $\operatorname{Cr} \$ 75.000,00$ (setenta e cinco mil cruzeiros) até meados da década e inferiores à $\mathrm{Cr} \$ 200.000,00$ (duzentos mil cruzeiros) a partir de então. De acordo com as referidas Portarias, os IAPs e as CAPs não poderiam conceder financiamentos cujas parcelas ultrapassassem $70 \%$ do valor do salário do requisitante, podendo o valor máximo concedido variar de quatro a duzentos e cinquenta vezes 0 salário do associado, em algumas instituições. No entanto, em alguns Institutos, como no IAPTEC-RN, mesmo após o aumento das reservas destinadas à construção e à aquisição de moradias concedido por meio de lei em 1944 e, consequentemente, do aumento do teto dos financiamentos, o referido Instituto só realizava empréstimos imobiliários de, no máximo, Cr $\$ 150.000,00$ (cento e cinquenta mil cruzeiros), para aquisição de terrenos ou imóveis, bem como para a construção em terrenos ou obras de reparos em imóveis de propriedade do associado.

Cabe lembrar que da mesma forma que a estruturação das ações imobiliárias e a escolha do partido arquitetônico e urbanísticos das unidades habitacionais edificadas pelas Caixas e Institutos eram facultadas, muitas vezes, ao seu corpo técnico e variavam de escritório para escritório estadual, os limites e outras

\footnotetext{
${ }^{419}$ Exigia-se: provas de identificação e estado civil registradas em cartório; certidões negativas de ação ou execução entre as partes e os cônjuges nos últimos dez anos; certidão negativa de protesto de qualquer título ou documento em nome das partes interessadas, cônjuges e proprietários anteriores nos últimos cinco anos; comprovar a plena capacidade da vida civil, incluindo certidões do empregador; recibos de pagamento dos impostos e taxas que recaiam sobre o imóvel no último exercício em cobrança; comprovante de regularidade de domínio do imóvel pretendido, bem como dos proprietários anteriores, nos últimos vinte anos, incluindo as escrituras de compra e venda, troca, doação, cartas de arrendamento e adjudição, etc., devidamente transcritas no Registro de Imóveis; e documento mencionando ainda as características construtivas e de localização do imóvel.

420 Foram diversas e variadas as determinações outorgadas nesse sentido ao longo dos anos subsequentes.
} 
especificações quanto aos financiamentos praticados também o eram. Essa gama de determinações e 0 grande número de legislação resultante em muito dificultaram as análises dos dados quanto ao caráter social daqueles órgãos no Nordeste do país. Vale ressaltar ainda, que os salários mínimos no país sofreram diversos reajustes e adaptações devido às trocas de moedas e à inflação, sobremaneira. Associado a isso estava o fato que os valores dos vencimentos mensais no Brasil foram determinados, por muitos anos, de acordo com as categorias trabalhistas (bancários, comerciários, ferroviários, etc.) e, dentre elas, por cargo ocupado, variando ainda de região para região.

Diante do exposto, para a classificação do caráter da atuação das Caixas e Institutos de Aposentadoria e Pensões no Nordeste, tomou-se como base o salário mínimo praticado durante os anos de 1943 a 1951, que, de acordo com os dados do IBGE, se mostrou estável, variando de capital para capital no Nordeste de $\operatorname{Cr} \$ 200,00$ a $\mathrm{Cr} \$ 240,00$ (cruzeiros) ${ }^{421}$. Vale ressaltar que devido às diversas variações acima elencadas, esse foi também o período tomado como recorte temporário para as análises dos financiamentos empreendidos nas sete capitais nordestinas nesta tese estudadas. Esses anos abarcam o período de maior volume de ações realizadas pelas CAPs e pelos IAPs no campo habitacional no país, como já largamente apontado pela historiografia especializada.

Para a supracitada análise, considerou-se também a classificação socioeconômica praticada pela Fundação João Pinheiro, que define quatro faixas de renda: a primeira faixa, até três salários mínimos; a segunda faixa vai de três a cinco salários mínimos; a terceira faixa de renda corresponde aos trabalhadores que recebiam entre cinco e dez salários mínimos; e a quarta e última faixa de renda abrange os trabalhadores que recebiam mensalmente mais de dez salários mínimos naquela época. Sendo assim, foram considerados como pertencentes à classe alta os associados que se enquadravam na quarta faixa de renda, como classe média os contribuintes cujos salários correspondiam aos valores especificados na terceira faixa, e classe média baixa e de renda baixa, os trabalhadores cujos salários não ultrapassavam $\mathrm{Cr} \$ 1.075,00$ (mil e setenta e cinco cruzeiros), no caso de Natal e João Pessoa, por exemplo.

Adotou-se ainda como critério de análise, o teto do financiamento estipulado pela legislação outorgada em meados da década de 1940, que determinou que as fianças imobiliárias não poderiam ultrapassar o limite de duzentas e cinquenta vezes o salário do requerente. Isso corresponde, considerando 0 valor do salário mínimo empreendido em Natal e João Pessoa, que era de Cr\$215,00 (duzentos e quinze cruzeiros) ${ }^{422}$, ao valor de $\mathrm{Cr} \$ 53.750,00$ (cinquenta e três mil, setecentos e cinquenta cruzeiros) adotado, nesta tese, como o valor máximo dos financiamentos com caráter social. Mais precisamente, classificou-se como: financiamento social, aquele que apresentava valor de até $\operatorname{Cr} \$ 53.750,00$ (cinquenta e três mil, setecentos e cinquenta cruzeiros); financiamento intermediário, aquele equivalente à até duas vezes o valor

${ }^{421}$ Mais precisamente, os valores dos vencimentos mensais dos trabalhadores em cada uma das capitais nordestinas eram: Cr $\$ 200,00$ (cruzeiros) em São Luís e Teresina, Cr $\$ 210,00$ no Recife, Maceió e Aracajú; Cr $\$ 215,00$ em Natal e João Pessoa e Cr\$240,00 em Fortaleza e Salvador (IBGE, 2006); sendo esses os valores considerados para as análises do caráter da atuação das CAPs e dos IAPs no Nordeste do país.

422 Para exemplificação das categorias de análise. 
do financiamento social, isto é, à Cr\$107.500,00 (cento e sete mil e quinhentos cruzeiros); e financiamento atuarial, aquele cujo valor ultrapassasse os $\operatorname{Cr} \$ 107.500,00$ (cento e sete mil e quinhentos cruzeiros), para aquelas cidades.

Dessa forma, no tocante aos valores dos financiamentos concedidos pelos referidos órgãos, levou-se em consideração quatro critérios de análises: a classificação socioeconômica da Fundação João Pinheiro delimitada com base no salário apresentado pelo IBGE; os salários efetivamente recebidos pelos trabalhadores associados às Carteiras Prediais dos supracitados órgãos; os valores dos financiamentos concedidos àqueles trabalhadores; e o valor máximo de financiamento determinado pela legislação federal no período de 1945 a 1950.

Para a organização e para exposição desses dados, não se tomou como baliza o modelo de planos e classes imobiliárias praticado pelos IAPs e pelas CAPs em suas mais variadas apresentações (variando de órgão para órgão e de estado para estado), muito menos o modelo organizacional imutável conformado pelos Planos A, B e C, adotado por alguns autores e fadado ao erro, como colocado nos capítulos anteriores. Elencou-se as descrições daquelas ações como a forma mais adequada para se proceder a divisão dos financiamentos. Dessa maneira, os dados levantados nas pesquisas in loco serão apresentados em sete categorias: 1) compra ou aluguel de unidades habitacionais edificadas pelas CAPs e IAPs; 2) compra ou aluguel de unidades adquiridas de terceiros; 3) compra de terreno e construção de casa por iniciativa dos associados; 4) edificação de residência em terreno de propriedade do segurado; 5) reformas ou ampliação de moradias; 6) encampação de dívida hipotecária ou ampliação do financiamento; 7) outros empréstimos imobiliários, não necessariamente vinculados à moradia, cujas variações serão apresentadas ao longo do texto.

\section{Salvador-BA:}

Vale destacar inicialmente, que em Salvador, parte das análises relacionadas ao caráter da atuação das CAPs e dos IAPs foi comprometida pelo fato que a maior parte dos processos levantados nos arquivos da agência do INSS-BA somente especificava o valor cobrado pelo aluguel, uma vez que o repasse daquelas moradias aos segurados por venda só se deu em meados para fins da década de 1960. Esse período foi marcado pela variação do custo do salário e também transcende o recorte temporal definido para as supracitadas análises, que inicia no ano de 1943 e finda em 1951.

Nesse sentido, observou-se que nas poucas unidades financiadas no período, procedeu-se essencialmente pleitos diretos, de modo equilibrado pelo IAPETC $(31,03 \%)$, IAPI $(29,31 \%)$, IAPFESP $(25,86 \%)$ e IAPC $(24,13 \%)^{423}$. Se levarmos em consideração que a CAP dos Serviços Urbanos do Estado da Bahia e Sergipe foi incorporada à CAPFESP e, posteriormente, ao IAPFESP, tem-se a maior participação no

\footnotetext{
423 Um aspecto curioso identificado nesse período em Salvador, é que a CAP dos Portuários da Bahia, órgão responsável pelo primeiro empreendimento habitacional identificado em Salvador, já havia sido incorporado pelo IAPM, mas não foram identificadas no levantamento, ações imobiliárias desse Instituto na cidade, ao longo das décadas de 1940 a 1960.
} 
que concerne ao financiamento de moradias por parte dos órgãos, que passa a corresponder a 37,93\% dos pleitos concedidos entre 1941 e 1953, em Salvador.

Em se tratando exclusivamente dos financiamentos, percebeu-se que a maior parte se referia a pleitos de até $\operatorname{Cr} \$ 60.000,00$ (cruzeiros) ${ }^{424}$, correspondendo a 44 processos de financiamento $(51,78 \%)$, decrescendo em número à medida que esse valor ia aumentando (Figura 64). Porém, a percentagem de trabalhadores atendidos, tidos como de classe alta, foi significantemente maior que a social $(29,41 \%$ contra 20,00\%). De acordo com os dados apresentados, percebe-se que os segurados de classe média e alta foram os mais contemplados com financiamentos em Salvador, totalizando $50,58 \%$ do realizado pelas CAPs e pelos IAPs nessa localidade (Figura 65) 425 .

\begin{tabular}{|c|c|c|c|c|c|c|c|c|c|}
\hline \multicolumn{10}{|c|}{ FINANCIAMENTOS CONCEDIDOS EM SALVADOR (1943-1951) } \\
\hline \multirow[t]{2}{*}{ Institutos } & \multicolumn{2}{|c|}{ Até Cr $\$ 60.000,00$} & \multicolumn{2}{|c|}{$\begin{array}{l}\mathrm{De} C \mathrm{Cr} \$ 60.000,00 \\
\text { até Cr\$ } 1020.00,00\end{array}$} & \multicolumn{2}{|c|}{ Acima } & \multicolumn{2}{|c|}{ N.E. } & \multirow[t]{2}{*}{ Total } \\
\hline & No. & $\%$ & No. & $\%$ & No. & $\%$ & No. & $\%$ & \\
\hline IPASE & 04 & 80 & 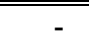 & - & 01 & 20 & (- & - & 05 \\
\hline IAPI & 09 & 52,95 & 01 & 5,88 & 03 & 17,64 & 04 & 23,53 & 17 \\
\hline IAPC & 05 & 35,71 & 03 & 21,43 & 04 & 28,58 & 02 & 14,28 & 14 \\
\hline IAPB & $-\overline{-}$ & $-\overline{-}$ & 03 & 37,5 & 04 & 50 & 01 & 12,5 & 08 \\
\hline CAP/IAPFESP & 12 & 80,81 & 02 & 13,33 & 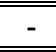 & - & 01 & 6,66 & 15 \\
\hline $\begin{array}{c}\text { CAPESP- } \\
\text { BA/SE } \\
\end{array}$ & 06 & 85,72 & - & - & 01 & 14,28 & - & - & 07 \\
\hline IAPETC & 07 & 38,88 & 09 & 50 & - & - & 02 & 11,12 & 18 \\
\hline $\begin{array}{c}\text { N.E. } \\
\end{array}$ & 01 & 100 & - & - & - & - & - & - & 01 \\
\hline Total Absoluto & \multicolumn{2}{|c|}{44} & \multicolumn{2}{|c|}{18} & \multicolumn{2}{|c|}{13} & \multicolumn{2}{|c|}{10} & 85 \\
\hline Atuação & \multicolumn{2}{|c|}{$51,76 \%$} & \multicolumn{2}{|c|}{$21,17 \%$} & \multicolumn{2}{|c|}{$15,3 \%$} & \multicolumn{2}{|c|}{$11,76 \%$} & $100 \%$ \\
\hline
\end{tabular}

Figura 64: Quadro de classificação dos valores dos pleitos concedidos aos associados pelas CAPs e IAPs em Salvador.

Fonte: Elaboracão próbria com base nos dados coletados no INSS-BA.

\begin{tabular}{|c|c|c|c|c|c|c|c|c|c|c|c|}
\hline \multicolumn{12}{|c|}{ SALÁRIOS DOS TRABALHADORES SALVADOR (1943-1951) } \\
\hline \multirow[t]{2}{*}{ Institutos } & \multicolumn{2}{|c|}{$\begin{array}{l}\text { Até Cr\$ } \\
720,00\end{array}$} & \multicolumn{2}{|c|}{$\begin{array}{c}\text { De Cr\$ } 720,00 \\
\text { até Cr\$ } \\
1.200,00\end{array}$} & \multicolumn{2}{|c|}{$\begin{array}{l}\text { De } \operatorname{Cr} \$ 1.200,00 \\
\text { até } \operatorname{Cr} \$ 2.400,00\end{array}$} & \multicolumn{2}{|c|}{ Acima } & \multicolumn{2}{|c|}{ N.E. } & \multirow[t]{2}{*}{ Total } \\
\hline & №. & $\%$ & №. & $\%$ & №. & $\%$ & No. & $\%$ & No. & $\%$ & \\
\hline IPASE & 04 & 80 & 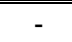 & 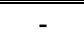 & 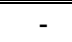 & 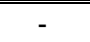 & 01 & 20 & 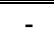 & 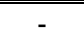 & 05 \\
\hline IAPI & 02 & 11,76 & 03 & 17,65 & 02 & 11,76 & 05 & 29,42 & 05 & 29,42 & 17 \\
\hline IAPC & - & - & 02 & 14,28 & 05 & 35,72 & 05 & 35,72 & 02 & 14,28 & 14 \\
\hline IAPB & 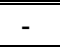 & 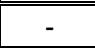 & - & - & 02 & 25 & 05 & 62,5 & 01 & 12,5 & 08 \\
\hline CAP/IAPFESP & 07 & 46,66 & 01 & 6,66 & 06 & 40,02 & 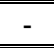 & - & 01 & 6,66 & 15 \\
\hline $\begin{array}{c}\text { CAPESP- } \\
\text { BA/SE } \\
\end{array}$ & 03 & 42,80 & 02 & 28,57 & 02 & 28,57 & - & - & - & - & 07 \\
\hline IAPETC & - & - & - & - & 01 & 5,56 & 09 & 50 & 08 & 44,44 & 18 \\
\hline N.E. & 01 & 100 & - & - & - & - & - & 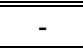 & - & - & 01 \\
\hline Total Absoluto & \multicolumn{2}{|c|}{17} & \multicolumn{2}{|c|}{08} & \multicolumn{2}{|c|}{18} & \multicolumn{2}{|c|}{25} & \multicolumn{2}{|c|}{17} & 85 \\
\hline Atuação & \multicolumn{2}{|c|}{$20 \%$} & \multicolumn{2}{|c|}{$9.41 \%$} & \multicolumn{2}{|c|}{$21.17 \%$} & \multicolumn{2}{|c|}{$29,41 \%$} & \multicolumn{2}{|c|}{$20 \%$} & $100 \%$ \\
\hline
\end{tabular}

Figura 65: Quadro de classificação dos salários dos associados dos órgãos em Salvador.

Fonte: Elaboração própria com base nos dados coletados no INSS-BA.

424 O valor do salário mínimo na época em Salvador era, de acordo com o IBGE, de Cr\$210,00 (cruzeiros).

425 Ao longo do texto, como já deve ter sido percebido, foram apresentados os montantes não especificados nos processos imobiliários concedidos (instituto de previdência, valores de salários, financiamento, etc.), uma vez que se optou por detalhar nesta tese, os números relativos e os percentuais absolutos da produção dos órgãos nas capitais nordestinas estudadas, mesmo que esses valores não exerçam impacto significativo na análise da política pública habitacional empreendida pelas CAPs e IAPs na região. 
Os Institutos que mais atenderam essas parcelas populacionais foram o IAPB $(87,50 \%)$ e o IAPC (71,44\%). O IAPETC apesar de concentrar seus feitos, sobretudo, no campo social, concedendo $88,88 \%$ de financiamentos sociais e intermediários na cidade, não disponibilizando um pleito sequer atuarial entre $1943 \mathrm{e}$ 1951, de acordo com os dados levantados, concentrou a sua política habitacional para atender aos segurados essencialmente de classe alta $(50 \%)$. Isto é, os valores dos financiamentos se enquadravam no "campo social", mas a população atendida era de renda alta.

Em contrapartida, e contrariando uma tendência que viria a se repetir na maioria das capitais nordestinas, como se verá adiante, o IPASE foi o órgão que mais atendeu aos trabalhadores inseridos na classe de renda baixa em Salvador ( $80 \%$ de suas realizações no período), por meio de pequenos financiamentos. Uma das possíveis justificativas recai no fato que muitos dos terrenos nos quais o Instituto edificou seus grupos de moradias foram doados pelo governo do estado da Bahia, sendo reduzido consideravelmente o valor dos financiamentos por esse aspecto.

\section{Recife- PE:}

De acordo com os relatórios de produção de moradias, os escritórios estaduais das CAPs e dos IAPs no Recife edificaram entre os anos de 1943 e 1951, 2.922 unidades habitacionais, distribuídas em 13 conjuntos residenciais. Desse volume, $8,83 \%$ foi levantado na pesquisa documental, o equivalente a 258 processos imobiliários. Sendo esse o montante analisado para a determinação do caráter da atuação dos referidos órgãos na cidade. Também se considerou o valor do salário mínimo praticado na capital, no referido período, que de acordo com as publicações censitárias do IBGE da década de 1940, permaneceu fixo em Cr\$ 210,00 (cruzeiros).

No Recife, deparou-se com uma atuação, por parte dos supracitados órgãos, mais próxima da social que a evidenciada em Salvador. Em conjunto, a classe de renda baixa e média baixa, representam $31 \%$ dos pleitos concedidos. Mais especificadamente, os trabalhadores cujos vencimentos mensais não ultrapassam três salários mínimos correspondem à camada social mais contemplada com financiamentos na cidade $(16,66 \%)$. Apesar de apresentar uma percentagem muito próxima à da classe alta $(13,17 \%)$, ainda se configura como um diferencial na região Nordeste do país, como será colocado ao longo deste capítulo (Figura 66).

Os financiamentos também seguem a linha social observada em relação aos vencimentos salariais dos trabalhadores recifenses atendidos pelas CAPs e pelos IAPs entre 1943 e 1951. Em 44,96\% dos pleitos liberados na cidade os valores são menores que $\mathrm{Cr} \$ 52.500,00$ (cruzeiros). As ações sociais, por sua vez, foram empreendidas principalmente pelo IAPFESP (82,75\%) e pelo IAPC (50\%). Já o IPASE e o IAPI, empregaram $52,39 \%$ e $38,39 \%$ de suas reservas, no período em questão, em ações imobiliárias para os segurados que recebiam mais de dez salários mínimos na época (Figura 67). 


\begin{tabular}{|c|c|c|c|c|c|c|c|c|c|c|c|}
\hline \multicolumn{12}{|c|}{ SALÁRIOS DOS TRABALHADORES DO RECIFE (1943-1951) } \\
\hline \multirow[t]{2}{*}{ Institutos } & \multicolumn{2}{|c|}{$\begin{array}{l}\text { Até Crs } \\
630,00\end{array}$} & \multicolumn{2}{|c|}{$\begin{array}{c}\mathrm{De} \operatorname{Cr} \$ 630,00 \\
\text { até } \mathrm{Cr} \$ \\
1.050,00\end{array}$} & \multicolumn{2}{|c|}{$\begin{array}{c}\text { De Cr\$ } \\
1.050,00 \text { até } \\
\text { Cr } \$ 2.100,00\end{array}$} & \multicolumn{2}{|c|}{ Acima } & \multicolumn{2}{|c|}{ N.E. } & \multirow[t]{2}{*}{ Total } \\
\hline & NN. & $\%$ & №. & $\%$ & No. & $\%$ & No. & $\%$ & №. & $\%$ & \\
\hline IPASE & - & - & - & - & - & - & 11 & 52,39 & 10 & 47,61 & 21 \\
\hline IAPC & 09 & 9,78 & 28 & $\overline{30,43}$ & 19 & 20,66 & 08 & 8,7 & 28 & $\overline{30,43}$ & 92 \\
\hline IAPI & 04 & 22,23 & 06 & 33,33 & 02 & 11,11 & 01 & 5,5 & 05 & 27,77 & 18 \\
\hline IAPB & - & - & - & - & - & - & 12 & 50 & 12 & 50 & 24 \\
\hline IAPETC & - & - & - & - & - & - & - & - & 30 & 100 & 30 \\
\hline IAPFESP & 20 & 34,48 & - & - & - & - & - & - & 38 & 65,52 & 58 \\
\hline N.E. & 10 & 666,66 & 03 & 20 & - & - & 02 & 13,34 & - & 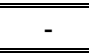 & 15 \\
\hline Total Abs. & \multicolumn{2}{|c|}{43} & \multicolumn{2}{|c|}{37} & \multicolumn{2}{|c|}{21} & \multicolumn{2}{|c|}{34} & \multicolumn{2}{|c|}{123} & 258 \\
\hline Atuação & \multicolumn{2}{|c|}{$16,66 \%$} & \multicolumn{2}{|c|}{$14,34 \%$} & \multicolumn{2}{|c|}{$8,14 \%$} & \multicolumn{2}{|c|}{$13,17 \%$} & \multicolumn{2}{|c|}{$47,67 \%$} & $100 \%$ \\
\hline
\end{tabular}

Figura 66: Quadro de classificação dos salários dos associados dos órgãos no Recife.

Fonte: Elaboração própria com base nos dados coletados no INSS-PE.

\begin{tabular}{|c|c|c|c|c|c|c|c|c|c|}
\hline \multicolumn{10}{|c|}{ FINANCIAMENTOS CONCEDIDOS NO RECIFE (1943-1951) } \\
\hline \multirow{2}{*}{ Institutos } & \multicolumn{2}{|c|}{ Até Cr\$52.500,00 } & \multicolumn{2}{|c|}{$\begin{array}{l}\mathrm{De} \operatorname{Cr} \$ 52.500,00 \\
\text { até Cr\$ } 105.000,00\end{array}$} & \multicolumn{2}{|c|}{ Acima } & \multicolumn{2}{|c|}{ N.E. } & \multirow{2}{*}{ Total } \\
\hline & No. & $\%$ & №. & $\%$ & №. & $\%$ & №. & $\%$ & \\
\hline IPASE & - & - & 07 & 33,33 & 11 & 52,39 & 03 & 14,28 & 21 \\
\hline IAPC & 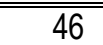 & $\overline{50}$ & 09 & 9,78 & $\overline{18}$ & $\overline{19,56}$ & 19 & $\overline{20,66}$ & 92 \\
\hline IAPI & 08 & 44,44 & 02 & 11,11 & 07 & $\overline{38,39}$ & 01 & 5,56 & 18 \\
\hline IAPB & 04 & 16,67 & 08 & 33,33 & 04 & 16,67 & 08 & 33,33 & 24 \\
\hline IAPETC & - & - & 15 & 50 & 15 & 50 & - & 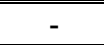 & 30 \\
\hline IAPFESP & 48 & 82,75 & - & $\overline{-1}$ & $\overline{-1}$ & $\overline{-1}$ & $\overline{10}$ & $\overline{17,35}$ & 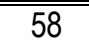 \\
\hline N.E. & $\overline{10}$ & 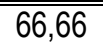 & 05 & $\overline{33,34}$ & 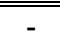 & 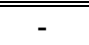 & 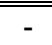 & 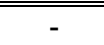 & 15 \\
\hline Total Abs. & \multicolumn{2}{|c|}{116} & \multicolumn{2}{|c|}{46} & \multicolumn{2}{|c|}{55} & \multicolumn{2}{|c|}{41} & 258 \\
\hline Atuação & \multicolumn{2}{|c|}{$44,96 \%$} & \multicolumn{2}{|c|}{$\overline{17,83 \%}$} & \multicolumn{2}{|c|}{$21,31 \%$} & \multicolumn{2}{|c|}{$15,9 \%$} & $\overline{1100 \%}$ \\
\hline
\end{tabular}

Figura 67: Quadro de classificação dos valores dos pleitos concedidos aos associados pelos órgãos no Recife.

Fonte: Elaboração própria com base nos dados coletados no INSS-PE.

Diversos exemplos de ações atuariais empreendidas por esses órgãos podem ser citados. Dentre eles, um dos pleitos solicitados por um segurado do IAPB, morador do Conjunto dos Bancários (1957), em Olinda. Inicialmente foi pleiteada, pelo associado, a aquisição de um dos imóveis do referido Conjunto e, em menos de um ano, foi solicitada a majoração do financiamento em mais $\operatorname{Cr} \$ 89.875,00$ (cruzeiros), alegando 0 reajustamento do imposto pelo construtor e 0 aumento do custo dos materiais de construção 426 . Esse aumento foi pleiteado diretamente à Divisão de Engenharia do IAPB, mas não foi aprovada. Em carta encaminhada pelo segurado ao IAPB, mediante a não autorização da elevação do financiamento, foi especificado que "(...) todos os funcionários do Banco do Brasil, que solicitaram empréstimos na mesma época do meu, obtiveram, através da Caixa do próprio Banco, a suplementação desejada (...)" (SOLICITAÇÃO..., 16/09/1958, p.01). Essa citação indica que, naquela época, muitos foram as elevações de pleitos realizadas pelos segurados ao IAPB e/ou casos de favorecimento. Cabe lembrar que, a maioria dos

${ }^{426}$ Nesse Conjunto, em específico, o contrato de construção foi assinado diretamente entre os segurados e o construtor. 
financiamentos concedidos por esse Instituto já se enquadravam na categoria atuarial da política dos IAPs, sendo ainda mais reforçada por ações dessa estirpe.

A partir das análises, observou-se que as ações empreendidas pelos referidos órgãos no Recife se aproximam mais de uma política habitacional social, que as atuações dos demais escritórios estaduais dos Institutos e Caixas de Aposentadoria e Pensões no Nordeste. Uma provável justificativa para tanto, recai por sobre a representatividade e o volume de ações realizadas pelos órgãos nessa capital nordestina, que podem ter acarretado uma maior fiscalização.

\section{João Pessoa-PB:}

O número de financiamentos concedidos entre os anos de 1943 e 1951 em João Pessoa é significantemente mais baixo que aqueles identificados na maior parte das cidades nordestinas abordadas nesta tese. Dos 1.798 processos de financiamento para compra ou edificação de residência, autorizados pelos Institutos e Caixas atuantes naquela localidade, apenas 4,40\% foram liberados nesse período e levantados nesta pesquisa ${ }^{427}$. Dos 79 processos imobiliários trabalhados para a análise do caráter da atuação habitacional dos órgãos na capital paraibana, 47 estavam locados em conjuntos ou grupos habitacionais de propriedade dos IAPs e da CAPFESP (59,50\%) e 32 diziam respeito às operações indiretas (40,50\%).

Analisando-se somente os valores liberados para as ações imobiliárias, verificou-se uma sobressaliência dos financiamentos de caráter médio, que representam quase a metade dos pleitos levantados (46,05\%). Enquanto os financiamentos efetivamente sociais correspondem apenas a $22,78 \%$ do identificado. Somadas as solicitações médias e atuariais, tem-se um total de $74,68 \%$ dos financiamentos praticados naquele período em João Pessoa (Figura 68). Ao se averiguar os valores das liberações

\begin{tabular}{|c|c|c|c|c|c|c|c|c|c|}
\hline \multicolumn{10}{|c|}{ FINANCIAMENTOS CONCEDIDOS EM JoÃo PESSOA (1943-1951) } \\
\hline \multirow[t]{2}{*}{ Institutos } & \multicolumn{2}{|c|}{$\begin{array}{c}\text { Até Cr\$ } \\
53.750,00\end{array}$} & \multicolumn{2}{|c|}{$\begin{array}{c}\text { De Cr\$ } \\
53.750,00 \\
\text { até Cr\$ } \\
107.500,00\end{array}$} & \multicolumn{2}{|c|}{ Acima } & \multicolumn{2}{|c|}{ N.E. } & \multirow[t]{2}{*}{ Total } \\
\hline & No. & \%\% & No. & $\%$ & №. & $\%$ & No. & 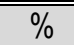 & \\
\hline IPASE & 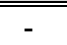 & ב- & $\overline{113}$ & $\overline{441,93}$ & 17 & 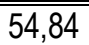 & 01 & $\overline{3,23}$ & 31 \\
\hline IAPC & - & - & 03 & 42,85 & 04 & 57,15 & - & - - & 07 \\
\hline IAPI & 11 & 40,74 & 16 & 59,26 & - & - & - & - & 27 \\
\hline IAPB & - & $-\overline{-}$ & - & - & 03 & 100 & - & - & 03 \\
\hline IAPFESP & 07 & 87,5 & $\overline{-1}$ & $\overline{-1}$ & $\overline{-1}$ & 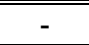 & 01 & 12,5 & 08 \\
\hline $\begin{array}{l}\text { IAPETC } \\
\end{array}$ & - & - & 03 & 100 & - & - & 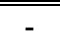 & $2-$ & 03 \\
\hline $\begin{array}{l}\text { N.E. } \\
\text { N. }\end{array}$ & - & - & $\bar{~}$ & 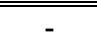 & - & ב- & - & ב- & $\overline{-1}$ \\
\hline Total Absoluto & \multicolumn{2}{|c|}{18} & \multicolumn{2}{|c|}{35} & \multicolumn{2}{|c|}{24} & \multicolumn{2}{|c|}{02} & 79 \\
\hline Atuação & \multicolumn{2}{|c|}{$22,78 \%$} & \multicolumn{2}{|c|}{$44,3 \%$} & \multicolumn{2}{|c|}{$30,38 \%$} & \multicolumn{2}{|c|}{$2,53 \%$} & $100 \%$ \\
\hline
\end{tabular}

${ }^{427}$ Vale destacar que nesse recorte temporal não foram identificados processos concedidos pelo IAPM, assim como observado no Recife. 
imobiliárias em relação aos vencimentos mensais dos segurados ${ }^{428}$, percebeu-se que $86,07 \%$ dos trabalhadores contemplados recebiam acima de cinco salários mínimos na época, chegando em muitos casos, a ultrapassar os dez salários (34,17\%). Somente $5,06 \%$ do total de associados possuía salário de até Cr\$ 645,00 (cruzeiros) e 1,26\% recebiam entre três e cinco salários mínimos. Mais uma vez, observa-se um atendimento privilegiando as classes médias e altas da sociedade (Figura 69).

\begin{tabular}{|c|c|c|c|c|c|c|c|c|c|c|c|}
\hline \multicolumn{12}{|c|}{ 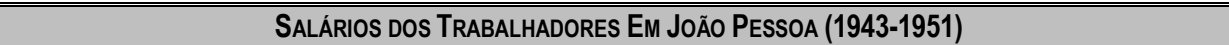 } \\
\hline \multirow[t]{2}{*}{ Institutos } & \multicolumn{2}{|c|}{$\begin{array}{l}\text { Até } \mathrm{Cr} \$ \\
645,00\end{array}$} & \multicolumn{2}{|c|}{$\begin{array}{c}\text { De Cr\$ } \\
645,00 \text { até } \\
\text { Cr\$ } 1.075,00\end{array}$} & \multicolumn{2}{|c|}{\begin{tabular}{|c|} 
De Cr $\$ 1.075,00$ \\
até Cr $\$$ \\
$2.150,00$ \\
\end{tabular}} & \multicolumn{2}{|c|}{ Acima } & \multicolumn{2}{|c|}{ N.E. } & \multirow[t]{2}{*}{ Total } \\
\hline & No. & $\%$ & №. & $\%$ & №. & $\%$ & №. & $\%$ & №. & $\%$ & \\
\hline IPASE & - & - & - & - & 14 & $45,16 \%$ & 14 & 45,16 & 03 & 9,68 & 31 \\
\hline IAPC & - & - & - & - & 02 & 28,57 & 04 & 257,14 & 01 & 14,29 & 07 \\
\hline IAPI & 01 & 3,73 & 01 & 3,73 & 25 & 92,59 & - & - & - & - & 27 \\
\hline IAPB & $\overline{-1}$ & $\overline{-1}$ & - & $\overline{-1}$ & $\overline{-1}$ & $\overline{-1}$ & 03 & 100 & $\overline{-1}$ & - & 03 \\
\hline IAPFESP & 03 & 37,50 & - & - & - & - & 03 & 37,50 & 02 & 25 & 08 \\
\hline IAPETC & 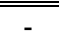 & - & - & - & 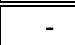 & - & $\bar{~} 03$ & $\overline{c 100}$ & - & - & 03 \\
\hline N.E. & - & - & - & - & - & - & - & - & - & - & - \\
\hline Total Abs. & & 04 & & & & 41 & & & & D6 & 79 \\
\hline Atuação & & $06 \%$ & & & & $1,9 \%$ & & & & $6 \%$ & $100 \%$ \\
\hline
\end{tabular}

Ao se cruzar os valores dos financiamentos praticados com as categorias de ações imobiliárias identificadas nessa capital, foi verificado que a maior parte dos pleitos equivale à compra de unidades de propriedade dos próprios Institutos ou Caixas $(83,30 \%)^{429}$ e, dessa percentagem, 55,55\% era de financiamentos intermediários e $33,33 \%$ de financiamentos sociais, sendo essa categoria imobiliária a mais próxima de uma ação social praticada pelos órgãos em João Pessoa. Quando cruzados os dados dos salários com os dos empréstimos concedidos, verificou-se que $63,82 \%$ do total concedido foi de financiamentos médios e atuariais liberados, exclusivamente, para os trabalhadores que recebiam acima de cinco salários mínimos na época. Desses, 30,00\% eram de financiamentos atuariais (acima de $\operatorname{Cr} \$$ $107.500,00$ cruzeiros) concedidos a segurados da classe alta $(88,88 \%)$.

Nesse contexto, os órgãos que mais praticaram ações sociais em relação aos pleitos totais do período foram o IAPI (13,92\%) e a CAPFESP/IAPFESP (8,86\%), cujos valores liberados não ultrapassavam Cr $\$ 53.750,00$ (cruzeiros). Em contrapartida, a população atendida que se enquadrava nas classes menos abastadas (classe de renda baixa e média baixa) só correspondeu a 6,33\% dos trabalhadores contemplados. O Instituto que mais se conformou como atuarial, por outro lado, foi o IPASE, com 39,24\% dos processos identificados no período, dos quais, $45,16 \%$ foram concedidos a segurados recebedores de mais de dez salários mínimos e 54,84\% eram de financiamentos com valores acima de $\operatorname{Cr} \$ 107.500,00$ (cruzeiros).

428 O salário base praticado em João Pessoa entre os anos de 1943 e 1951, segundo o IBGE, era de Cr\$215,00 (cruzeiros).

429 Lembrar que em alguns grupos de moradias situados nos bairros de Torre e Expedicionários, como no Conjunto Santa Júlia (IAPC) por exemplo, os terrenos eram de propriedade dos Institutos e as edificações foram financiadas por eles, mas a construção das unidades propriamente dita ficou a cargo dos segurados, de acordo com as premissas construtivas estipuladas pelos órgãos para aquelas localidades. 
No caso específico das ações indiretas, diversos foram os casos de financiamentos que ultrapassavam Cr $\$ 500.000,00$ (cruzeiros) 430 e que correspondiam a terrenos com mais de $1.500 \mathrm{~m}^{2}$ e áreas construídas superiores a $200 \mathrm{~m}^{2}$. Quanto aos rendimentos mensais desses segurados, diversos chegavam a Cr\$13.000,00 cruzeiros no ano de 1955. Essas unidades estavam comumente locadas em áreas centrais valorizadas, modernas e de classe média alta e alta, como na Av. Epitácio Pessoa, a principal avenida da cidade de João Pessoa ${ }^{431}$, e nos bairros próximos à beira-mar como Tambiá e Tambaú, como especifica claramente um dos laudos de avaliação:

(...) o p.p. é bastante confortável e está situado em um bairro novo, saudável, em (...) logradouro dos melhores da cidade, quanto à sua situação a meia distância do centro e da praia de Tambaú, que é o melhor balneário da capital (...) (Laudo de avaliação, 14/09/1945. p.05).

Ainda em se tratando das unidades isoladas, um dado curioso que merece ser destacado é que na capital paraibana foram identificados processos de refinanciamento de imóvel para aproveitamento da verba angariada para outro fim, o que se convenciona chamar de hipotecar a residência. Essa ação foi realizada no âmbito do IPASE, já no ano de 1946 (especificando-se o Plano C, nesse escritório estadual), atendendo a um segurado tido como de classe alta ${ }^{432}$ por meio de um financiamento atuarial de $\operatorname{Cr} \$ 240.000,00$ (duzentos e quarenta mil cruzeiros), muito acima do praticado naquela época para as demais categorias imobiliárias em João Pessoa. Mais detalhadamente, a hipoteca referia-se a uma residência edificada em área bastante valorizada da cidade, o Parque Solón de Lucena ou Lagoa, como atualmente essa área é conhecida:

(...) trata-se de uma casa de acabamento luxuoso, situada no Parque Solón de Lucena, o melhor logradouro da cidade, próximo ao centro, e onde se encontram situados as mais luxuosas residências da capital (...) (LAUDO DE AVALIAÇÃO-IPASE, 06/01/1946).

Outro dado interessante é que todas as reformas e/ou ampliações de moradias identificadas na pesquisa em João Pessoa correspondem a financiamentos com valores acima de Cr $\$ 107.500,00$ (cruzeiros), tidos como atuariais. Em alguns casos, os valores solicitados pelo segurado do Instituto chegavam a meio milhão de cruzeiros, em meados da década de 1950. Esse foi o caso do processo autorizado pelo IPASE, para um juiz do trabalho (presidente da Junta de Conciliação e Julgamento), no ano de 1955, para ampliação de sua moradia, de acordo com o Plano $\mathrm{C}$ daquele escritório estadual, localizada na Avenida Epitácio Pessoa, no bairro Tambauzinho. A moradia já possuía antes do pleito uma área construída de $400,00 \mathrm{~m}^{2} \mathrm{e}$ foi solicitado mais $\mathrm{Cr} \$ 500.000,00$ (cruzeiros) para a sua ampliação (construção de outro pavimento). Trata-se de valor bastante alto até para os padrões atuariais praticados não somente na localidade em questão, mas também para toda a região Nordeste. Vale salientar ainda, que essa quantia foi liberada para um membro de

${ }^{430}$ Como o valor do financiamento concedido pelo IPASE a Agenor Barbosa de Lucena, coletor federal do estado da Paraíba, no ano de 1956.

431 Importante vetor de crescimento da cidade a partir, sobretudo, de 1950, em direção à praia de Tambaú e uma via de acesso nova e área bastante valorizada na época.

${ }_{432}$ Recebedor de uma quantia mensal acima de 10 salários mínimos, mais precisamente, $\operatorname{Cr} \$ 3.800,00$ (cruzeiros), naquele ano. 
órgão subordinado ao CNT e, consequentemente, ao MTIC, diretamente relacionado aos institutos de previdência, um provável indício de favorecimento.

Mais um caso que permeia por essa linha, diz respeito à concessão de financiamento para 0 proprietário da firma A. F. do Amaral e Filhos, em 1952. Mais precisamente, esse trabalhador solicitou ao IAPC um financiamento de Cr\$290.000,00 (cruzeiros), para a construção de residência em terreno de sua propriedade (Plano B-II daquele escritório estadual), localizado no bairro Jaguaribe, sendo recebedor de um salário de $\mathrm{Cr} \$ 8.000,00$ (cruzeiros), na época. A partir desse caso, percebeu-se que apesar de se propor a edificar ou financiar unidades habitacionais aos segurados mais carentes do Instituto ou Caixa, alguns órgãos atenderam, muitas vezes, aos empregadores.

Sendo assim, pode-se constatar que mesmo praticando financiamentos intermediários, que por sua essência já não são completamente sociais, entre os anos de 1941 e 1953 em João Pessoa, as CAPs e os IAPs atuantes atenderam essencialmente a uma parcela da população que se enquadrava nas classes média alta e alta principalmente $(86,07 \%)$. Isto ocorreu mesmo nos casos de compra de unidades de propriedade dos órgãos, que a historiografia existente sobre a temática afirma ser uma ação de caráter social. Ousa-se considerar a atuação dos órgãos na referida capital como sendo a que mais se distancia da política habitacional social pretendida e empreendida pelas CAPs e IAPs no Nordeste do país.

\section{Natal-RN:}

Em Natal, dos 560 processos imobiliários levantados na pesquisa documental, 231 foram autorizados entre os anos de 1943 e 1951433, o que corresponde a 41,25\% do total levantado. Mais detalhadamente, a CAPESP foi a única Caixa que realizou pleitos no período em concomitância aos IAPs. Vale ainda ressaltar, que a referida CAP só concedeu financiamentos nesse período na cidade, o equivalente a 21,64\% do concedido por todos os órgãos na capital norte-riograndense, não atuando no cenário da habitação posteriormente. Enfocou suas ações, mormente, na venda de unidades habitacionais de sua propriedade, locadas em grupos residenciais $(46,94 \%)$ e empreendeu uma modalidade imobiliária específica, 0 financiamento para a construção de moradias em terrenos doados ao funcionalismo público pelo Estado $(34,70 \%)$, por meio, quase que exclusivamente, de financiamentos sociais $(71,43 \%)$ - que acompanham a lógica da doação do lote a ser edificado. Apesar de conceder quase a totalidade de financiamentos sociais, a CAPESP atendeu, sobretudo, aos trabalhadores inclusos na classe média, que abarcaram $87,76 \%$ dos pleitos concedidos pelo órgão no período.

\footnotetext{
433 Não foram considerados para a análise do caráter da atuação dos IAPs e das CAPs em Natal, os processos imobiliários cujo ano não foi especificado, que corresponde a 30,53\% (171 processos) do montante levantado no INSS-RN. Os três processos onde não foi possível precisar o instituto responsável, coincidentemente, referem-se à aquisição de terreno e edificação de residência por parte dos segurados de classe média alta, contemplados com financiamentos médios. No caso específico de Natal, optou-se pro agrupar os pleitos diretos e indiretos numa mesma análise, devido ao significativo volume dessas ações se comparada às demais capitais nordestinas.
} 
O IPASE, que incorporou a CAPESP-RN posteriormente, atendeu essencialmente aos trabalhadores das camadas de classe média alta e alta, que somadas chegam a representar $72,71 \%$ dos associados atendidos pela sua política habitacional no período em questão. Os financiamentos mais realizados pelo órgão foram os de caráter médio (63,63\%), tanto no que diz respeito às unidades concedidas de modo direto quanto àquelas realizadas por iniciativa dos segurados. Sua atuação no período, dessa forma, se caracteriza como intermediária alta, e representa $18,19 \%$ do empreendido pelo Instituto na cidade e $3,92 \%$ do montante de financiamentos concedidos em Natal.

O IAPB realizou no período, principalmente, a concessão de financiamentos para a aquisição de imóveis já construídos de propriedade de terceiros (45,84\%). Sua atuação no recorte temporal supracitado equivale a $36,36 \%$ do realizado pelo Instituto na cidade e 4,28\% do empreendido por todos os órgãos entre as décadas de 1940 e 1960, em Natal. Privilegiou os financiamentos atuariais (33,33\%), acima de Cr\$107.500,00 (cruzeiros), bem como os trabalhadores recebedores de mais de dez salários mínimos na época $(66,67 \%)$, se configurando como uma atuação essencialmente atuarial.

O IAP dos Comerciários, por sua vez, foi o responsável por 11,68\% das realizações dos Institutos e Caixas no período que compreende os anos de 1943 a 1951, e por 31,03\% do realizado pelo órgão na cidade, em todo o recorte temporal adotado nesta tese. Em se tratando das características dos pleitos, esse órgão concentrou suas ações essencialmente no financiamento de residências a serem construídas no terreno do segurado $(55,57 \%)$. Em termos do caráter de sua atuação, pode-se dizer que ele em muito se aproxima do IAPB na cidade, disponibilizando verba, sobretudo, para os financiamentos atuariais e para os segurados, considerados aqui, como pertencentes à classe alta de Natal $(55,57 \%)$.

O IAPE e o IAPETC, em conjunto, foram responsáveis pela liberação de $22,80 \%$ dos pleitos dos órgãos na cidade e por $5,62 \%$, se considerado o montante levantado no referido período. Suas atuações se concentraram, mormente, no financiamento para a venda ou aluguel de imóveis de sua propriedade (84,62\%), atendendo as classes média baixa e média alta $(46,15 \%)$, por meio de financiamentos sociais $(46,15 \%)$.

Já o IAPI, foi responsável pela liberação de 93 pleitos no período, que corresponde a $55,35 \%$ do realizado aos industriários em Natal e a 40,26\% do empreendido pelos órgãos em conjunto, ao longo dos nove anos em questão (1943 a 1951). Nesse período, o IAPI concedeu quase que exclusivamente financiamentos sociais $(89,25 \%)$, que atenderam essencialmente aos trabalhadores de renda baixa $(45,16 \%)$ e média baixa (33,33\%), se conformando como o órgão que concretizou mais ações próximas a uma política habitacional social em Natal ${ }^{434}$, assim como vislumbrado no Recife. Essas ações foram materializadas na venda de unidades de propriedade do Instituto e em financiamentos para a compra de casas de terceiros pelos seus segurados, principalmente, que representam respectivamente $49,47 \%$ e $34,41 \%$ dos pleitos realizados pelo IAPI no período de 1943 a 1951.

434 Apesar de também ter atendido às classes média alta e alta $(21,54 \%)$. 
Observou-se que, apesar de terem aprovado e liberado um número significativo de financiamentos sociais, os IAPs principalmente, atenderam aos trabalhadores que recebiam mais de sete salários mínimos na época (Figura 70). Sendo assim, foram atendidos tanto os associados de menor poder aquisitivo quanto aqueles que recebiam maiores quantias mensais de seus empregadores, o que correspondeu à perda do caráter social das ações dos IAPs na cidade, previstas por lei no momento da criação das Carteiras Prediais. Mais especificadamente, dos sete Institutos de Aposentadorias e Pensões mais atuantes em Natal, apenas um, o IAPI, apresentou caráter essencialmente social, enquanto os demais Institutos se dedicaram a atender os associados cujos rendimentos mensais os classificavam como classe média alta e classe alta 435 . Da percentagem total de trabalhadores inclusos na classe baixa, $91,30 \%$ foi contemplada pelo IAPI. Quadro semelhante foi percebido em se tratando dos financiamentos sociais, dos quais, $59,71 \%$ foram liberados aos industriários natelenses (Figura 71).

\begin{tabular}{|c|c|c|c|c|c|c|c|c|c|c|c|}
\hline \multicolumn{12}{|c|}{ SALÁRIOS dOS TRABALHADORES EM NATAL (1943-1951) } \\
\hline \multirow[t]{2}{*}{ Institutos } & \multicolumn{2}{|c|}{$\begin{array}{l}\text { Até Cr\$ } \\
645,00\end{array}$} & \multicolumn{2}{|c|}{$\begin{array}{c}\text { De Cr\$ } \\
645,00 \text { até } \\
\text { Cr\$1.075,00 }\end{array}$} & \multicolumn{2}{|c|}{$\begin{array}{c}\text { De } \mathrm{Cr} \$ \\
1.075,00 \text { até } \\
\mathrm{Cr} \$ 2.150,00\end{array}$} & \multicolumn{2}{|c|}{ Acima } & \multicolumn{2}{|c|}{ N.E. } & \multirow[t]{2}{*}{ Total } \\
\hline & №. & $\%$ & №. & $\%$ & NN. & $\%$ & No. & $\%$ & №. & $\%$ & \\
\hline IPASE & 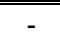 & 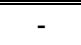 & 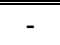 & 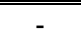 & 09 & 40,90 & 07 & 31,81 & 06 & 27,27 & 22 \\
\hline IAPB & - & - & - & - & 08 & 33,33 & 16 & 66,67 & 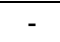 & 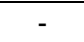 & 24 \\
\hline IAPC & - & - & - & - & 08 & 29,62 & 15 & 255,57 & 04 & 14,81 & 27 \\
\hline IAPE/IAPETC & - & - & 02 & 15,38 & 04 & 30,77 & - & - & 07 & 53,85 & 13 \\
\hline IAPI & 42 & 45,16 & 31 & 33,33 & 16 & 17,21 & 04 & 4,30 & - & - & 93 \\
\hline CAPESP & 04 & 8,16 & 26 & 53,06 & 17 & 34,70 & 02 & 4,08 & 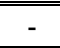 & - & 49 \\
\hline N.E. & - & - & - & - & 03 & 100 & - & - & - & - & 03 \\
\hline $\begin{array}{c}\text { Total } \\
\text { Absoluto }\end{array}$ & \multicolumn{2}{|c|}{46} & \multicolumn{2}{|c|}{59} & \multicolumn{2}{|c|}{65} & \multicolumn{2}{|c|}{44} & \multicolumn{2}{|c|}{17} & 231 \\
\hline Atuação & \multicolumn{2}{|c|}{$19,91 \%$} & \multicolumn{2}{|c|}{$25,54 \%$} & \multicolumn{2}{|c|}{$28,14 \%$} & \multicolumn{2}{|c|}{$19,04 \%$} & \multicolumn{2}{|c|}{$7,36 \%$} & $100 \%$ \\
\hline
\end{tabular}

Figura 70: Quadro de especificação dos valores salariais recebidos pelos trabalhadores contemplados com financiamentos imobiliários concedidos pelas CAPs e IAPs em Natal.

Fonte: Elaboração própria com base nos dados do INSS-RN.

\begin{tabular}{|c|c|c|c|c|c|c|c|c|c|}
\hline \multicolumn{10}{|c|}{ FINANCIAMENTOS CONCEDIDOS EM NATAL (1943-1951) } \\
\hline \multirow[t]{2}{*}{ Institutos } & \multicolumn{2}{|c|}{ Até Cr\$53.750,00 } & \multicolumn{2}{|c|}{$\begin{array}{l}\text { De Cr\$ } \$ 3.750,00 \\
\text { até Cr\$ } 107.500,00\end{array}$} & \multicolumn{2}{|c|}{ Acima } & \multicolumn{2}{|c|}{ N.E. } & \multirow[t]{2}{*}{ Total } \\
\hline & No. & $\%$ & No. & $\%$ & No. & $\%$ & No. & $\%$ & \\
\hline IPASE & 02 & 9,09 & 14 & 63,63 & 04 & 18,19 & 02 & 9,09 & 22 \\
\hline IAPB & 05 & 20,83 & 06 & 25 & 08 & 33,33 & 05 & 20,83 & 24 \\
\hline IAPC & 08 & 29,62 & 04 & 14,81 & 15 & 55,57 & - & - & 27 \\
\hline IAPE/IAPETC & 06 & 46,15 & - & - & - & - & 07 & 53,85 & 13 \\
\hline IAPI & 83 & 89,25 & 04 & 4,30 & 04 & 4,30 & 02 & 2,15 & 93 \\
\hline CAPESP & 35 & 71,43 & - & - & 02 & 4,08 & 12 & 24,49 & 49 \\
\hline N.E. & - & - & 03 & 100 & - & - & - & - & 03 \\
\hline Total Absoluto & \multicolumn{2}{|c|}{139} & \multicolumn{2}{|c|}{31} & \multicolumn{2}{|c|}{33} & \multicolumn{2}{|c|}{28} & 231 \\
\hline Atuação & \multicolumn{2}{|c|}{$60,17 \%$} & \multicolumn{2}{|c|}{$13,42 \%$} & \multicolumn{2}{|c|}{$14,29 \%$} & \multicolumn{2}{|c|}{$12,12 \%$} & $100 \%$ \\
\hline
\end{tabular}

Figura 71: Quadro de classificação dos valores dos pleitos concedidos aos associados pelos órgãos em Natal.

Fonte: Elaboração própria com base nos dados coletados no INSS-RN.

435 O IAPB e o IAPC, principalmente, atenderam os trabalhadores destas classes de renda. 
Traçando-se um quadro geral da atuação das CAPs e dos IAPs em Natal, entre os anos de 1943 e 1951, em escala crescente, observou-se que dos 231 associados atendidos, apenas 19,91\% eram pertencentes à classe menos favorecida, $25,54 \%$ à classe média baixa, 28,18\% à classe média alta e praticamente o mesmo percentual de trabalhadores assistidos faziam parte da faixa de renda alta $(19,05 \%)$. No tocante às características dos financiamentos, $60,17 \%$ equivaliam aos pleitos sociais, $13,42 \%$ aos financiamentos considerados como intermediários e 14,28\% aos financiamentos tidos como atuariais 436 .

Isso nos leva a crer que, conscientemente ou não, o corpo técnico responsável pela avaliação, análise e liberação dos processos imobiliários dos Institutos e Caixas em Natal, quando autorizava a realização de uma ação imobiliária para um associado de classe média alta e alta, empreendia financiamentos sociais ou médios. Outra observação que merece ser aqui apontada, diz respeito ao fato que nos diversos casos em que o pleito concedido excedia o teto estabelecido pelo governo federal, não era especificada a sua caracterização, plano, classe ou descrição da solicitação, como ocorreu principalmente no âmbito do IAPE/IAPTEC, em Natal. Outro aspecto interessante acerca da atuação dos institutos de previdência na cidade corresponde ao fato de não terem sido evidenciados financiamentos para a realização de obras de infraestrutura ou de serviços em parcerias entre os IAPs e as administrações locais, como verificado em diversas localidades do país, inclusive para a construção de Brasília.

\section{Fortaleza-CE:}

O mesmo quadro atuarial identificado nas capitais nordestinas estudadas até o momento pode ser percebido em Fortaleza. Apesar da maior parte dos financiamentos na cidade terem sido sociais, com valores inferiores a $\mathrm{Cr} \$ 60.000,00$, num total de $55,93 \%$ dos pleitos liberados (Figura 72), os salários dos

\begin{tabular}{|c|c|c|c|c|c|c|c|c|c|}
\hline \multicolumn{10}{|c|}{ FINANCIAMENTOS CONCEDIDOS EM FORTALEZA (1943-1951) } \\
\hline \multirow[t]{2}{*}{ Institutos } & \multicolumn{2}{|c|}{ Até Cr $\$ 60.000,00$} & \multicolumn{2}{|c|}{$\begin{array}{l}\mathrm{De} C \mathrm{Cr} \$ 60.000,00 \\
\text { até Cr\$ } 120.000,00\end{array}$} & \multicolumn{2}{|c|}{ Acima } & \multicolumn{2}{|c|}{ N.E. } & \multirow[t]{2}{*}{ Total } \\
\hline & No. & $\%$ & No. & $\%$ & No. & $\%$ & No. & $\%$ & \\
\hline IPASE & 01 & $\overline{100}$ & $\overline{-1}$ & - & $2-$ & 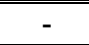 & $2-$ & - & 01 \\
\hline IAPI & 30 & 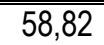 & 12 & 23,53 & 09 & 82,33 & - & - & 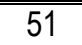 \\
\hline IAPC & 11 & 47,82 & 11 & 47,82 & 01 & 4,36 & - & - & 23 \\
\hline IAPB & 03 & 30 & 05 & 50 & - & - & 02 & 20 & 10 \\
\hline IAPFESP & $-\overline{-}$ & 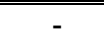 & 01 & 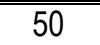 & 01 & $\overline{50}$ & $\overline{-1}$ & 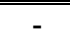 & 202 \\
\hline IAPE & 01 & 100 & - & - & 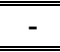 & - & $\overline{-1}$ & $\overline{-1}$ & $\overline{01}$ \\
\hline IAPTEC & 10 & 55,55 & 02 & 11,11 & 05 & 27,77 & 01 & 5,57 & 18 \\
\hline CAPESP-CE & 10 & 83,33 & 02 & 16,67 & - & - & - & - & 12 \\
\hline N.E. & - & - & - & - & - & - & - & - & - \\
\hline Total Absoluto & \multicolumn{2}{|c|}{66} & \multicolumn{2}{|c|}{33} & \multicolumn{2}{|c|}{16} & \multicolumn{2}{|c|}{03} & 118 \\
\hline Atuação & \multicolumn{2}{|c|}{$55,93 \%$} & \multicolumn{2}{|c|}{$27,96 \%$} & \multicolumn{2}{|c|}{$13,56 \%$} & \multicolumn{2}{|c|}{$2,55 \%$} & $100 \%$ \\
\hline
\end{tabular}

Figura 72: Quadro de classificação dos valores dos pleitos concedidos aos associados pelos órgãos em Fortaleza. Fonte: Elaboração própria com base nos dados coletados no INSS-CE.

${ }^{436}$ Esse quadro se configura dessa maneira devido ao grande número de financiamentos sociais concedido pelo IAPI na cidade, equivalendo a 80 processos. 
trabalhadores atendidos se enquadravam essencialmente nas faixas de renda média alta $(29,66 \%)$ e alta $(23,72 \%)$ (Figura 73 ). Analisando-se as atuações individualmente, 0 instituto de previdência que mais procedeu a uma política social437 foi a CAP dos Serviços Públicos do Ceará atendendo, sobretudo, os trabalhadores das classes de renda baixa e média baixa $(58,33 \%)^{438}$. Em contraposição às ações do IAPC e do IAPI que se concentraram na liberação de pleitos imobiliários para os trabalhadores mais abastados. Cabe lembrar que o aspecto preponderante para a identificação do viés de atuação dos órgãos é o salário recebido pelos trabalhadores contemplados, já que por diversas vezes, foram concedidos financiamentos considerados sociais para segurados com boas condições financeiras.

\begin{tabular}{|c|c|c|c|c|c|c|c|c|c|c|c|}
\hline \multicolumn{12}{|c|}{ SALÁRIOS DOS TRABALHADORES DE FORTALEZA (1943-1951) } \\
\hline \multirow[t]{2}{*}{ Institutos } & \multicolumn{2}{|c|}{ Até $\mathrm{Cr} \$ 720,00$} & \multicolumn{2}{|c|}{$\begin{array}{c}\text { De Cr\$ } 720,00 \\
\text { até } \\
\text { Cr\$1.200,00 }\end{array}$} & \multicolumn{2}{|c|}{$\begin{array}{l}\text { De } \operatorname{Cr} \$ 1.200,00 \\
\text { até } \operatorname{Cr} \$ 2.400,00\end{array}$} & \multicolumn{2}{|c|}{ Acima } & \multicolumn{2}{|c|}{ N.E. } & \multirow[t]{2}{*}{ Total } \\
\hline & №. & $\%$ & No. & $\%$ & №. & $\%$ & No. & $\%$ & №. & $\%$ & \\
\hline IPASE & 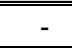 & 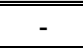 & 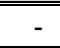 & - & 01 & 100 & 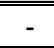 & - & 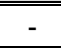 & 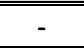 & 01 \\
\hline IAPI & 07 & 13,72 & 10 & 19,6 & 11 & 21,56 & 18 & 35,3 & 05 & 9,82 & 51 \\
\hline IAPC & 02 & $7,7,52$ & 07 & 30,43 & 08 & 34,78 & 06 & 27,27 & - & - & 23 \\
\hline IAPB & - & - & 01 & 10 & 09 & 990 & - & - & 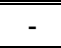 & 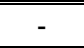 & 10 \\
\hline IAPFESP & 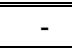 & 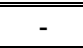 & - & - & - & - & 02 & 100 & 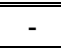 & - & 02 \\
\hline IAPE & 01 & 100 & - & - & - & - & - & - & - & - & 01 \\
\hline IAPETC & 02 & 111,11 & 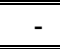 & 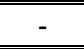 & 02 & 111,11 & 02 & 111,11 & 12 & 666,67 & 18 \\
\hline CAPESP-CE & 01 & 8,33 & 06 & 50 & 04 & 33,33 & - & 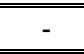 & 01 & 8,33 & 12 \\
\hline N.E. & - & - & - & - & - & - & - & 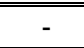 & - & - & - \\
\hline Total Abs. & \multicolumn{2}{|c|}{13} & \multicolumn{2}{|c|}{24} & \multicolumn{2}{|c|}{35} & \multicolumn{2}{|c|}{28} & \multicolumn{2}{|c|}{18} & 118 \\
\hline Atuação & \multicolumn{2}{|c|}{$11,01 \%$} & \multicolumn{2}{|c|}{$20,33 \%$} & \multicolumn{2}{|c|}{$29,66 \%$} & \multicolumn{2}{|c|}{$23,72 \%$} & \multicolumn{2}{|c|}{$15,28 \%$} & $100 \%$ \\
\hline
\end{tabular}

Figura 73: Quadro de classificação dos valores dos salários recebidos pelos trabalhadores em Fortaleza. Fonte: Elaboração própria com base nos dados coletados no INSS-CE.

Um exemplo comum de pleito atuarial enquadrado na categoria social concedido, bem como de favorecimento, foi observado no âmbito do IAPB, em 1956. O próprio delegado do IAPB em Fortaleza solicitou alto financiamento no valor de meio milhão de cruzeiros, na época, para a compra de terreno e edificação de moradia. Após aprovado pelo órgão, alterou a natureza do empréstimo, desistindo da compra do lote e passando a operar a edificação de residência em terreno de sua propriedade. Porém, 0 alto valor do pleito $(\mathrm{Cr} \$ 500.000,00)$ foi mantido. Posteriormente, alegando alta nos preços dos materiais de construção, 0 delegado do IAPB solicitou a elevação do financiamento em mais $\operatorname{Cr} \$ 300.000,00$, totalizando $\operatorname{Cr} \$ 800.000,00$ (cruzeiros), ainda em 1956. Mesmo com todas as modificações e equivalendo a uma quantia considerável na época, o processo foi enquadrado no Plano B da delegacia regional do Instituto dos Bancários, na classe social.

\footnotetext{
437 Foram desconsideradas as atuações do IPASE, do IAPM e do IAPE cujos processos identificados não foram suficientes para amparar as análises para suas atuações. No âmbito do IAPETC, a avaliação também foi consideravelmente comprometida, pelo fato de não ser especificado, na maioria dos processos imobiliários, os valores dos vencimentos mensais dos trabalhadores atendidos na cidade. Esse quadro se mostra semelhante a outros no Nordeste, como já visto anteriormente.

438 Essa Caixa, especificamente, contava com a verba de Cr\$996.816,30 (cruzeiros), em 12 de setembro de 1947, de acordo com documentos da época, para a edificação de moradias em Fortaleza. Em 14 de novembro de 1949, esse montante foi elevado para Cr\$6.997.837,70 (cruzeiros), refletido no aumento de sua atuação no campo habitacional no período.
} 
Vale ressaltar que a liberação de um empréstimo por parte dos Institutos e Caixas passava por três etapas de avaliações, por assim dizer: a realizada do ponto de vista técnico (especificações, orçamentos e avaliações dos imóveis), jurídico (certidões negativas e outras exigências legais) e em se tratando das questões financeiras (salários, contribuições, valor do financiamento, etc.) e, mesmo assim, aquele exemplo teve um prosseguimento normal. Sem contar que, para a liberação de pleitos dessa envergadura, segundo 0 Decreto n.15.175-A, aprovado em 03 de julho de 1948, só seria possível após aprovação do MTIC, o que não ocorreu.

\section{Teresina-PI:}

Em Teresina, da mesma forma que em João Pessoa, deparou-se com uma atuação bastante atuarial. Política essa seguida inclusive por Institutos que comumente apresentavam um caráter mais social, como foi 0 caso do IAPI. O escritório estadual desse órgão na cidade atendeu à população, bem como concedeu financiamentos, que classificam suas ações como atuariais. Mais precisamente, $50 \%$ dos pleitos liberados e $100 \%$ dos segurados contemplados ocupam a categoria atuarial e a faixa de renda alta, respectivamente. Nesse Instituto, em especial, foram atendidos engenheiros, diretores de empresas e propagandistas viajantes cujos vencimentos mensais chegavam a Cr $\$ 8.000,00$ (cruzeiros), no ano de 1949. O IPASE seguiu essa mesma tendência atuarial, assim como na maioria dos estados do Nordeste do país, como percebido ao longo deste capítulo. Nele, $87,5 \%$ dos financiamentos liberados se enquadravam como médios e atuariais, e $75 \%$ dos segurados de sua Carteira Imobiliária eram da classe alta, recebendo mais de dez salários mínimos praticados na época (Figuras 74 e 75).

\begin{tabular}{|c|c|c|c|c|c|c|c|c|c|}
\hline \multicolumn{10}{|c|}{ FINANCIAMENTOS CONCEDIDOS EM TERESINA (1943-1951) } \\
\hline \multirow{2}{*}{ Institutos } & \multicolumn{2}{|c|}{ Até Cr\$50.000,00 } & \multicolumn{2}{|c|}{$\begin{array}{l}\text { De Cr\$ } \$ 5.000,00 \\
\text { até Cr\$ } 100.000,00\end{array}$} & \multicolumn{2}{|c|}{ Acima } & \multicolumn{2}{|c|}{ N.E. } & \multirow{2}{*}{ Total } \\
\hline & No. & $\%$ & №. & $\%$ & No. & $\%$ & №. & $\%$ & \\
\hline IPASE & 01 & 12,5 & 02 & 25 & 05 & 62,5 & - & 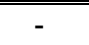 & 08 \\
\hline IAPI & 02 & 33,33 & - & - & 03 & 50 & 01 & 16,67 & 06 \\
\hline IAPC & 15 & 31,25 & 23 & 47,91 & 10 & 20,84 & - & - & 48 \\
\hline N.E. & - & $2-$ & 02 & 100 & - & 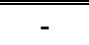 & - & - & 02 \\
\hline Total Absoluto & \multicolumn{2}{|c|}{18} & \multicolumn{2}{|c|}{27} & \multicolumn{2}{|c|}{18} & \multicolumn{2}{|c|}{01} & 64 \\
\hline Atuação & \multicolumn{2}{|c|}{$28,12 \%$} & \multicolumn{2}{|c|}{$42,18 \%$} & \multicolumn{2}{|c|}{$28,12 \%$} & \multicolumn{2}{|c|}{$1,58 \%$} & $100 \%$ \\
\hline
\end{tabular}

\begin{tabular}{|c|c|c|c|c|c|c|c|c|c|c|c|}
\hline \multicolumn{12}{|c|}{ SALÁRIOS DOS TRABALHADORES EM TERESINA (1943-1951) } \\
\hline \multirow[t]{2}{*}{ Institutos } & \multicolumn{2}{|c|}{ Até $\mathrm{Cr} \$ 600,00$} & \multicolumn{2}{|c|}{$\begin{array}{c}\text { De } \operatorname{Cr} \$ 600,00 \text { até } \\
\operatorname{Cr} \$ 1.000,00\end{array}$} & \multicolumn{2}{|c|}{$\begin{array}{l}\text { De } \operatorname{Cr} \$ 1.000,00 \\
\text { até } \operatorname{Cr} \$ 2.000,00\end{array}$} & \multicolumn{2}{|c|}{ Acima } & \multicolumn{2}{|c|}{ N.E. } & \multirow[t]{2}{*}{ Total } \\
\hline & №. & $\%$ & $\mathrm{~N}^{\circ}$. & $\%$ & $\mathrm{~N}^{0}$. & $\%$ & №. & $\%$ & №. & $\%$ & \\
\hline IPASE & 02 & 25 & - & 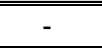 & 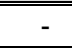 & - & 06 & 75 & 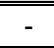 & 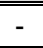 & 08 \\
\hline IAPI & - & - & 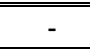 & - & - & 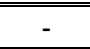 & 06 & 100 & 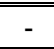 & - & 06 \\
\hline IAPC & 06 & 12,5 & 10 & 20,83 & 17 & 35,41 & 15 & 31,22 & - & - & 48 \\
\hline N.E. & - & - & 02 & 100 & - & - & - & - & - & - & 02 \\
\hline Total & \multicolumn{2}{|c|}{08} & \multicolumn{2}{|c|}{12} & \multicolumn{2}{|c|}{17} & \multicolumn{2}{|c|}{27} & \multicolumn{2}{|c|}{ - } & 64 \\
\hline Atuação & \multicolumn{2}{|c|}{$12,51 \%$} & \multicolumn{2}{|c|}{$18,75 \%$} & \multicolumn{2}{|c|}{$26,56 \%$} & \multicolumn{2}{|c|}{$42,18 \%$} & \multicolumn{2}{|c|}{ - } & $100 \%$ \\
\hline
\end{tabular}

Figuras 74 e 75: Quadros de classificação dos valores dos salários recebidos pelos trabalhadores e dos pleitos concedidos aos associados pelos órgãos em Teresina.

Fonte: Elaboração própria com base nos dados coletados no INSS-PI. 
Foi no âmbito do IAPC que foram verificados, além do maior número de pleitos aprovados entre os anos de 1943 e 1951 (75\%), uma política habitacional mais próxima da social no cenário teresinense, no que se refere aos pleitos. Os financiamentos que se enquadravam nessa faixa $(83,33 \%$ do volume total liberado nessa categoria), diziam respeito, sobretudo, à compra de imóveis de terceiros e à reforma de residências empreendidas por seus associados, muitos dos quais, não ultrapassaram Cr\$30.000,00 (cruzeiros), em 1945. Contudo, em relação aos salários dos trabalhadores atendidos, o IAPC seguiu a mesma linha de atuação do IAPI e do IPASE em Teresina. A quase totalidade dos pleiteantes atendidos pela sua política habitacional era conformada por empregadores e não por empregados, como se costuma evidenciar. Esses segurados eram especialmente de classe alta (31,22\% dos atendidos pelo órgão) e alguns chegavam a receber $\mathrm{Cr} \$ 9.000,00$ de vencimento, em 1950.

De modo geral, em Teresina, a mesma percentagem de financiamentos atuariais identificada foi vislumbrada no campo social $(28,12 \%)$, se sobressaindo os financiamentos médios $(42,18 \%)$. Todavia, a parcela populacional mais atendida pela política habitacional empreendida na cidade pelos Institutos de Aposentadoria e Pensões foi de faixa de renda alta $(42,18 \%)$.

\section{São Luís-MA:}

Como as solicitações de financiamentos de moradias concedidas em São Luís são de período posterior ao considerado para análise do caráter social ou não da atuação das CAPs e dos IAPs nesta pesquisa, como destacado no primeiro tópico deste capítulo, optou-se por não incluir os dados levantados na localidade nas considerações finais sobre 0 assunto ${ }^{439}$. No entanto, algumas observações podem ser apontadas aqui. Dentre elas, percebeu-se que apesar dos financiamentos serem muito próximos em termos de valores, os salários dos segurados contemplados, assim como nas demais cidades nordestinas aqui estudadas, variavam bastante. Da mesma forma que ocorreu na maior parte das capitais, em São Luís, também foram observados casos atuariais inseridos em ações imobiliárias tidas como sociais.

Como percebido, as políticas habitacionais empreendidas pelos institutos de previdência no Nordeste variavam em se tratando de diversos aspectos, ocorrendo tanto no âmbito dos diferentes órgãos atuantes numa mesma capital, quanto no que concerne às distintas delegacias estaduais de um mesmo Instituto ou Caixa de Aposentadoria e Pensões. Dentre as variantes evidenciadas, podem ser apontadas: a abrangência das ações de um determinado órgão a nível municipal ou estadual; a significância de sua produção no que tange ao atendimento da população trabalhadora e ao déficit de moradia em determinada localidade; 0 período de suas ações; o perfil do trabalhador atendido, como também do pleito concedido; e a espacialização da atuação e sua representatividade na ocupação e/ou para o adensamento de um bairro ou, até mesmo, para a conformação de um vetor de crescimento e/ou orientação de expansão de uma cidade.

\footnotetext{
439 Somente o conjunto Filipinho do IAPC se encaixa nos critérios da pesquisa, mas o número ínfimo de fichas levantadas sobre ele não podem respaldar toda a atuação do órgão na cidade de São Luís.
} 
Entendidos os aspectos que compunham a política habitacional das Caixas e Institutos de Aposentadoria e Pensões nas capitais nordestinas em questão, bem como as características, particularidades e/ou especificidades inerentes a cada uma delas, resta-nos analisar as concretizações dos órgãos no campo da moradia, essencialmente, os aspectos arquitetônicos e urbanísticos, além de identificar os profissionais, engenheiros e arquitetos, envolvidos nessas ações. 


\section{O • • CAPítulo 4}

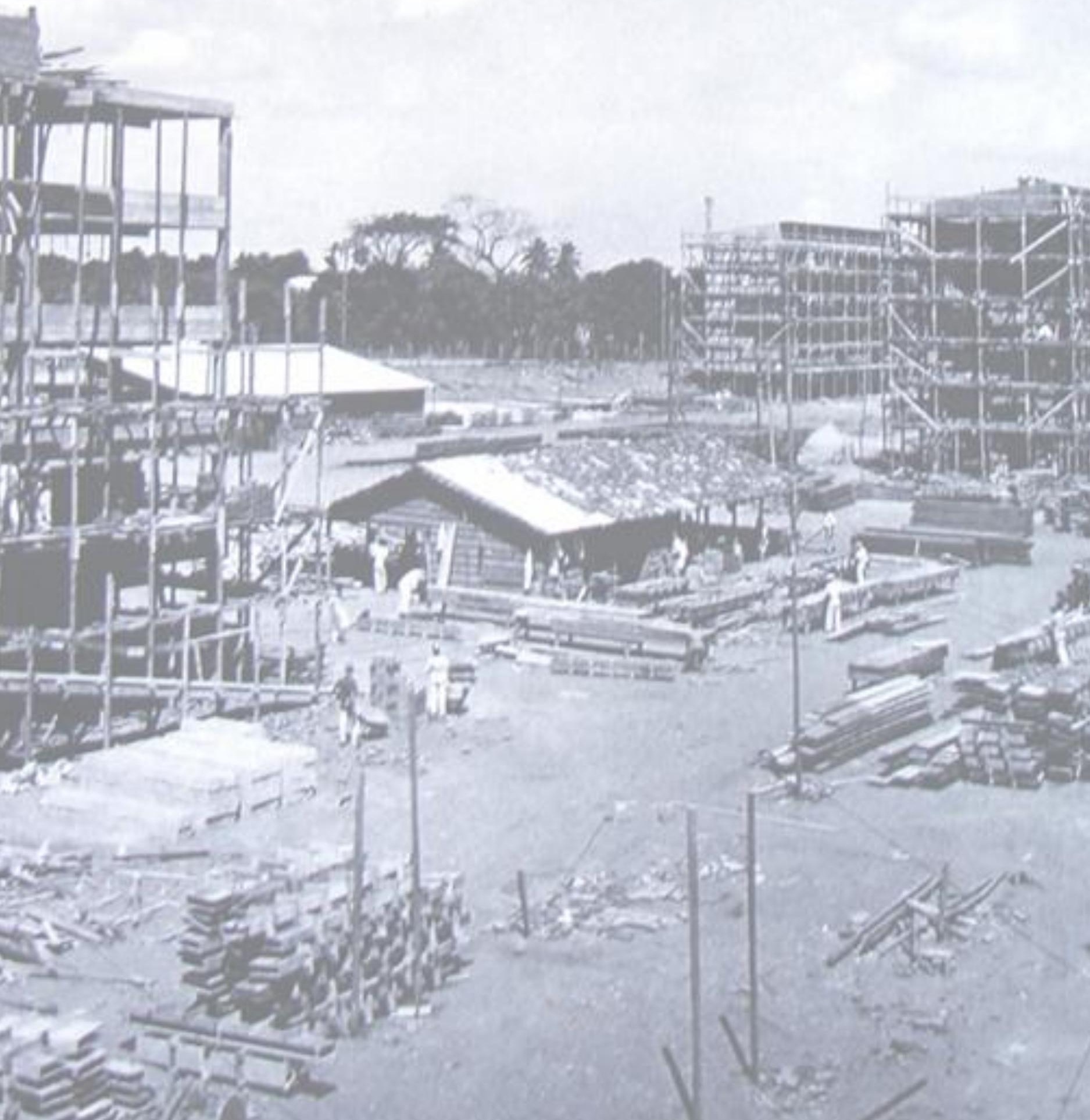




\section{Capítulo 4: A Arquitetura e o Urbanismo}

O enfoque principal do presente capítulo é apontar e analisar as características arquitetônicas e urbanísticas das ações imobiliárias empreendidas pelas Caixas e Institutos de Aposentadoria e Pensões nas sete capitais nordestinas por esta tese enfocadas. Mais precisamente, o objetivo concentra-se, sobretudo, em apresentar os variados exemplos e modelos incorporados e/ou adotados pelos órgãos e seus corpos técnicos, a fim de identificar e analisar as especificidades e particularidades dessa produção habitacional nas sete capitais nordestinas abordadas nesta tese. Num plano secundário, pretendeu-se identificar e, quando possível, discorrer acerca do extenso quadro de profissionais, engenheiros e arquitetos principalmente, envolvidos em todo esse processo, essencialmente, nas concepções projetuais dessas realizações.

Sendo assim, as informações e dados coletados sobre o assunto, assim como, as apreciações e conclusões formuladas nesse contexto, serão apresentadas de acordo com as tipologias e ações imobiliárias identificadas ao longo da pesquisa, especialmente agrupadas em três grandes blocos de análises. São eles: os grupos residenciais unifamiliares, coletivos e mistos. No âmbito dessas considerações serão analisadas separadamente; as ações empreendidas diretamente pelas CAPs e IAPs e seus profissionais associados e/ou licenciados, no sentido da edificação desses exemplares; e aquelas realizações apenas financiadas pelos órgãos, o que se convencionou chamar de ações indiretas. Também se atentou para a diferenciação entre as ações diretas e as aquisições de grupos já edificados, num período anterior ao recorte temporal, como foram alguns casos identificados em Natal e Fortaleza, por exemplo440.

Por vezes, procederam-se algumas subdivisões, a citar, grupos de casas unifamiliares isoladas, geminadas ou em fila, ou mistos (quanto à tipologia unifamiliar). Quanto aos empreendimentos verticais, consideraram-se os edifícios isolados e os grupos de blocos, sendo eles ou não mistos em se tratando da função desempenhada. Por meio desta classificação foi possível distinguir a produção direta e indireta daquela apenas financiada pelos supracitados órgãos e edificada a cargo dos próprios associados às suas Carteiras Prediais, chamada aqui de unidades isoladas 441.

\subsection{Grupos Habitacionais Edificados pelas CAPs e IAPs}

Acredita-se que a adoção e a defesa da tipologia unifamiliar como principal modelo para a concepção de moradias às famílias brasileiras ao longo do século $X X$, como é de comum consenso, advém desde o período do Brasil Império, ganhando força a partir da Proclamação da República, no contexto de crescimento e reformas urbanas executadas nas principais cidades do país. Essa ação afinou-se às demandas sociais colocadas pela Igreja Católica.

${ }^{440} \mathrm{~A}$ aquisição de vilas e conjuntos já edificados por meio das CAPs e dos IAPs, vale salientar, não traduzem ou representam o perfil dos órgãos quanto à arquitetura e ao urbanismo pretendido ou empreendido ao longo das décadas de 1930 a 1960.

441 A concepção projetual e a edificação dessas unidades contavam com a colaboração de outros profissionais para além dos funcionários técnicos e/ou licenciados das CAPs e dos IAPs. 
Mais precisamente, para alguns teólogos da Igreja Católica, desde o século XIX, os males do mundo contemporâneo ocidental, especialmente a secularização e descristianização, eram oriundos das cidades. Foi a partir de então, que a doutrina social cristã foi tomando cada vez mais os problemas relacionados ao urbano como de sua alçada. No Brasil, esses problemas eram encarados pela doutrina católica como ameaçadores de sua instituição religiosa, uma vez que a população progressivamente urbana se contagiava por outras correntes de pensamento que não o cristão442 (SANTIAGO, 1999). Após a Revolução de 1930, a Igreja Católica se vinculou com mais intimidade ao Estado para a solução dos problemas sociais do país ${ }^{443}$. A partir de meados dessa década essa associação passou a ocorrer por meio essencialmente da Ação Católica, com a instalação no Brasil de um movimento já em curso na Europa - 0, já mencionado, Grupo de Ação Social. 0 seu objetivo era o de divulgar a doutrina social católica, avaliar as condições de vida e de trabalho das camadas populares a fim de proporcionar soluções aos problemas evidenciados, bem como colaborar com 0 Estado na vigilância das leis trabalhistas, das condições de vida e da garantia de moradia aos trabalhadores brasileiros (GOMINHO, 2007); representando, sobretudo, pela defesa da moradia própria ${ }^{444}$. Vale destacar que diversos dos profissionais envolvidos na estruturação e nas reformas das Caixas e Institutos no campo habitacional, bem como alguns engenheiros e arquitetos dedicados à reforma da moradia urbana no país, estavam associados a essas ideias, participando inclusive ativamente do Grupo de Ação Social e dos eventos e realizações decorrentes, como foi o caso de Rubens Porto (Chefe da Seção de Engenharia do CNT), Waldemar Falcão (Ministro do MTIC) e, até mesmo, declaradamente, o presidente Getúlio Vargas.

Inserida no contexto de reforma social e do homem que pretendia ser instituída pelo catolicismo, a família era tida como núcleo principal da sociedade, a primeira e mais importante célula social, na qual os valores morais deveriam ser aprendidos e difundidos entre seus membros e entre outros núcleos familiares, consolidando assim as bases da estrutura social ideal445. Uma das principais maneiras para se efetivar esse

\footnotetext{
442 Para Reis (1998), esse quadro foi resultante da carência social verificada no país nas primeiras décadas do século XX e teve como um forte aliado às formas cristãs de atuação que possuíam um caráter bastante intervencionista. Em sua concepção, essas ações empreendidas pela Igreja Católica estavam bastante vinculadas às questões políticas.

${ }_{443}$ Esse caminho já vinha sendo trilhado desde a década anterior, com a criação da Associação das Senhoras Brasileiras e da Liga das Senhoras Católicas, nos anos 1920, principalmente. Nesse momento, segundo Reis (1998), a Igreja passou a atuar para além da caridade e da política, exigindo por parte do poder público e da própria população ações preventivas, principalmente em se tratando dos problemas das classes operárias. Segundo lamamoto (1982), essa forma de atuação marcou a profissionalização da assistência social e o modo como se deu o envolvimento dos organismos da Igreja na questão social brasileira, a partir da década de 1930.

444 Solicitações como a instauração do ensino religioso nas escolas do país, a defesa da indissolubilidade do matrimônio e a validade do casamento religioso para fins civis foram recorrentemente divulgadas pela Igreja naquela ocasião. Requeria-se, mais precisamente, a formação de educadores sociais e familiares, a valorização dos atributos femininos numa casa e numa família, a formação e a consolidação moral da população brasileira em prol da família, a legitimação do assistencialismo no país e 0 reconhecimento dele por parte do poder público; a valorização do trabalho e do trabalhador; e a defesa da propriedade (IAMAMOTO, 1982; REIS, 1998).

445 Os avanços técnicos e científicos evidenciados na sociedade naquele momento, assim como as novas relações trabalhistas que vinham ganhando espaço, sendo marcadas dentre outras pela independência cada vez maior da mulher, e até mesmo as novas relações interpessoais, além dos crescentes casos de divórcios, estavam comprometendo a estrutura social e deveriam ser readequados, na concepção católica. Acreditava-se que o meio influenciava diretamente o comportamento dos homens e que era por meio reforma de seus lares, sua estrutura e sua organização, seria possível alcançar os objetivos catolicistas (GOMINHO, 2007).
} 
intento era por meio da educação do trabalhador, da regulamentação das relações entre patrões e empregados e da promoção de uma residência adequada (salubre, higiênica e regrada). O lar aos moldes burguês passou então a ser tido como ideal para acomodar o modelo familiar adequado.

A Igreja Católica representou um importante formador de opinião, nesse sentido. Para ela, a casa era um importante instrumento para o fortalecimento dos laços familiares. Um espaço aconchegante e confortável era tido como base essencial para agregar os moradores e consolidar uma vida doméstica regrada. A lgreja acreditava que essa relação saudável só seria possível em uma moradia unifamiliar, mostrando-se contra a habitação coletiva e suas derivações, onde não eram mantidos, de acordo com suas convicções, os bons comportamentos e a moral cristã. De modo geral, a moradia preconizada deveria apresentar a quantidade de cômodos suficiente para o desenvolvimento adequado das atividades de um lar, boa qualidade, segurança física e moral, água e instalações sanitárias, boa localização, além de espaço para horta e jardim, de modo que cada membro exercesse devidamente suas missões morais como, esposa, esposo, mãe, pai e filhos, e missões materiais de dona de casa e chefe de família, além de profissional (CUNHA, 1948; NASCIMENTO, 2006). A separação entre moradores de diferentes idades e sexo em quartos distintos, a diferenciação entre as áreas destinadas aos moradores daquelas dos visitantes e empregados, a especialização de espaços, assim como, o distanciamento da moradia das edificações próximas e da rua, também foram colocadas pela Igreja como essenciais à privacidade da família brasileira.

A propriedade foi então adotada como parte fundamental do processo de reforma social católica, uma vez que ao adquirir uma residência própria, o trabalhador cuidaria melhor dela e se integraria de forma mais completa à sociedade, alcançando-se assim maior estabilidade social (MELLO, 1990; NASCIMENTO, 2006). Foi inserida nesse contexto que as vilas e núcleos operários das primeiras décadas do século XX foram incentivados pela Igreja e largamente defendidos em suas formulações ${ }^{446}$. Em contrapartida, o modo de viver das camadas mais carentes da população, sobremaneira, as favelas e os cortiços, foram recriminados e desencorajados. Diversos estudos investigativos acerca do modo de vida daquela parcela populacional foram realizados pela Igreja no país e uma série de proposições foi divulgada para a solução dos "problemas" evidenciados nessas comunidades. $O$ desmonte e/ou a reforma das favelas, ou ainda a realocação de seus moradores, para que os habitantes fossem reeducados e reajustados socialmente, se conformaram como as principais alternativas. Isso se deve ao fato que, a semelhança do pensamento higiênista e sanitarista de fins do século XIX e início do século XX, a lgreja Católica considerava as tipologias habitacionais das camadas populares e mais carentes de nossa sociedade como focos de "pragas sociais", tais como a disseminação de

\footnotetext{
446 As moradias higiênicas que compunham esses grupos habitacionais também eram consideradas como instrumentos de normalização e de controle social por parte dos católicos e a religião foi utilizada, muitas vezes, para o controle e reformulação do perfil dos trabalhadores brasileiros (CORREIA, 2003).
} 
doenças, elevação dos índices de marginalidade e desemprego, assim como de promiscuidade resultante, essencialmente, da superlotação verificada nas supracitadas tipologias ${ }^{447}$.

Essas premissas foram rebatidas e incorporadas, mormente, nas realizações habitacionais dos empregadores, proprietários de fábricas especialmente, em suas vilas e núcleos fabris. Esses agrupamentos habitacionais, suas tipologias residenciais, seus programas e conjuntos se conformaram como modelos para a atuação estatal no campo da moradia social posteriormente e, dessa forma, para a edificação de unidades destinadas aos trabalhadores por meio das CAPs e dos IAPs ${ }^{448}$. No Brasil, o modelo preconizado de moradia operária aproximava-se, de modo geral, das diretrizes construtivas observadas, sobretudo na Europa, preconizando-se a construção de casas salubres, cômodas, sólidas e econômicas. Essas especificações foram apresentadas e defendidas em diversos eventos em todo o mundo ${ }^{449}$. Uma mesma vila poderia se conformar por distintas tipologias habitacionais, distribuídas de acordo com o cargo ocupado pelo trabalhador/operário na empresa. De acordo com Correia (2004), usualmente esses empreendimentos seguiam critérios como a padronização em série e a proposição de um programa que ao mesmo tempo propiciasse um mínimo conforto aos seus habitantes e uma máxima economia na construção. Associado a isso ainda estavam, por vezes, a rigidez de plantas arquitetônicas e a uniformização das fachadas, aspectos também observados no âmbito das realizações imobiliárias dos institutos de previdência no Nordeste do país.

Para além desses atores sociais, diversos médicos, engenheiros e arquitetos, principalmente, defendiam a tipologia unifamiliar como a mais adequada à realidade econômica e social das famílias dos trabalhadores urbanos brasileiros ${ }^{450}$. Essas figuras participaram do debate e da reformulação do modelo e

447 A forma de enfrentar o problema das favelas nas cidades criou uma tradição, comandada pela assistência social da Igreja Católica e baseada na construção e melhoria de residências, representando uma etapa do processo de desfavelização, defendido pela elite política. Jornais de publicação própria, revistas financiadas e elaboradas por órgãos específicos, folhetos, panfletos distribuídos à população em geral e até mesmo o discurso dos padres e/ou educadores nas escolas e igrejas verbalizavam esses anseios. Merece também destaque nessa função, a realização das Semanas de Ação Social e dos Congressos Brasileiros de Serviço Social. A partir da década de 40 foram criadas diversas instituições de assistência ao trabalhador associadas à doutrina católica como a LBA - Legião Brasileira de Assistência (1942) e a Fundação Leão XIII (1946), no Rio de Janeiro, além de diversas escolas e frentes de trabalhos que passaram a surgir a partir de então. Importantes elementos de divulgação dos ideais de vida e de homem preconizados e galgados pela Igreja Católica em nosso país foram os assistentes e, posteriormente, os agentes sociais. A figura do agente social nasceu no contexto de criação do Serviço Social no país, no ano de 1938, uma instituição federal, vinculada ao recém-criado Conselho Nacional da Saúde e subordinada ao Ministério da Educação e Saúde. O Serviço Social no Brasil teve sua origem no amplo movimento social que a Igreja Católica desenvolveu com o objetivo de "recristianizar" a sociedade, no crescimento da industrialização, das populações e das áreas urbanas e da necessidade de controlar a massa operária. Paralelamente, se vislumbrou a ação conjunta do poder público com a Igreja Católica em todo o território nacional.

448 A produção de moradias pelos patrões para os seus empregados tem suas raízes fincadas na estrutura social brasileira do período colonial, mais especificadamente na senzala dos escravos. Mas foi, sobretudo, a partir das duas últimas décadas do século XIX, que a construção de vilas operárias nas cidades por empresas ganhou vulto no país (CORREIA, 1998).

449 Em Paris, por exemplo, foram realizadas exposições organizadas pelo Grupo de Economia Social, instituído a partir de 1867, que apresentavam à população diversas soluções, inclusive modelos e projetos de casas operárias, móveis e até utensílios, oferecendo prêmios em dinheiro aos industriais responsáveis por grupos edificados que promovessem a harmonia social e o bemestar de seus operários. Em segundo plano, o intuito da realização dessas exposições era o de conscientizar os trabalhadores do valor da habitação proposta. No território brasileiro, as reuniões que defendiam esse modelo de moradia eram de caráter essencialmente médico inicialmente e ocorreram, principalmente, a partir dos primeiros anos do século XX (CORREIA, 2004).

450 Por volta de fins do século XIX vislumbrou-se no Brasil a possibilidade de "transformar a casa num espaço modelar, base da edificação de um novo trabalhador" (CORREIA, 2004, p.23). 0 interesse das elites brasileiras pela saúde e bem estar da população proletária se deu quando essa parcela populacional passou a ter consciência de que as epidemias, originadas nos aglomerados urbanos pobres, se alastravam por toda a cidade. Foi a partir desse momento, que teve início uma grande campanha de Continua na página seguinte. 
das propostas de moradia econômica, popular e/ou social brasileira, bem como, contribuíram para a uma intervenção mais sistemática e eficiente do poder público, nesse sentido, ao longo das décadas de 1920 e 1930, essencialmente. Em âmbito nacional, merecem destaque três eventos, em especial: o IV Congresso Ibero-Americano de Arquitetos (1930)451, o I Congresso de Habitação (1931)452 e a Jornada de Habitação Econômica (1942) ${ }^{453}$.

higienização e moralização das classes pobres, essencialmente pelos letrados da época. Lemos (1976, p.153) coloca que também corroborou para tanto, a consolidação do "critério burguês de bem morar" entre a população mais abastada nos primeiros anos do século XX. As intervenções de cunho higienista na casa pobre urbana, propostas e defendidas por médicos e engenheiros sobremaneira, eram representadas principalmente por alterações na planta, pela introdução de novos materiais na construção, pelo melhoramento no acabamento da edificação - geralmente relacionado à impermeabilização dos espaços - e pela ligação das residências às novas redes de água e esgotos. Mais especificadamente, os almejos de engenheiros e médicos naquele momento eram materializados na criação de espaços, como a área de serviço, jardins e recuos laterais, que permitiam a abertura de janelas nos cômodos, satisfazendo as necessidades de melhoria da salubridade, os níveis adequados de iluminação e ventilação naturais, além do distanciamento da casa para com as vizinhas e com a rua; o que garantia maior privacidade às famílias. A criação de vãos intermediários entre o solo e o primeiro piso das residências (porões) elevando-a, a drenagem e a impermeabilização do solo, 0 aumento do número de cômodos das moradias também foram vislumbradas como alternativas para se contrapor à promiscuidade $\mathrm{e}$ adequar as habitações às novas noções de conforto colocadas pelas elites da época. Essas foram as temáticas mais recorrentes observadas em eventos médicos, de higiene e de saneamento, que ocorreram no país, sobremaneira, a partir de fins do século XIX e nas primeiras décadas do século seguinte (CHALHOUB, 1996; CORREIA, 2004).

451 O evento ocorreu no Brasil e contou com a participação de aproximadamente setenta representantes do exterior convidados, entre engenheiros e arquitetos, de países como Argentina, Uruguai, Chile, Estados Unidos, Canadá, Espanha, Portugal, Áustria, Polônia, Inglaterra, França, Cuba, Panamá, Venezuela e Peru, além de diversos participantes brasileiros. Dentre os delegados dos estados do nosso país estão figuras de renome como José Mariano Filho, como um dos representantes de Pernambuco, Affonso Eduardo Reidy, do Rio de Janeiro, Francisco Prestes Maia, Flávio de Carvalho e Arthur Saboya, de São Paulo e Carmem Portilho do Rio Grande do Norte (ABREU, 1930). De modo geral, as quatro primeiras edições do Congresso Pan-Americano de Arquitetura, realizados nos anos de 1920, 1923, 1927 e 1930, se empenharam em discutir e propor soluções aos problemas de moradia das classes menos abastadas (GAP, 1985).

452 Promovido pelo Instituto de Engenharia de São Paulo e patrocinado pela Secretaria da Viação e Obras Públicas e pela Prefeitura Municipal do estado, o evento contou com a participação de ilustres profissionais no campo da engenharia e da arquitetura, além de diversas importantes organizações e escritórios. Pode-se citar, nesse sentido: a Associação Paulista de Medicina, o Clube de Engenheiros de Pernambuco, o Escritório Técnico de Ramos de Azevedo, o arquiteto Gregório Warchavchik, o Instituto Paulista de Arquitetos, representantes da prefeitura municipal do Recife, a Sociedade Construtora Brasileira Lida e a Sociedade Comercial e Industrial Suíça. Foram num total de 227 participantes inscritos no evento. Conformou-se pela realização de palestras, visitas guiadas, apresentação de trabalhos acerca de temáticas específicas, além de exposição de novos materiais de construção. As obras visitadas no evento foram àquelas empreendidas pela Companhia City no Pacaembu, de Gregori Warchavchik, da Light and Power, na Serra do Cubatão, à Fábrica Nacional de Cimento, ao Parque da Cantareira e Horto Botânico. A exposição, por sua vez, foi organizada pelos engenheiros Carlos A. Gomes Cardim Filho e Álvaro da Costa Vidigal. O total de visitantes durante os vinte e cinco dias de sua realização foi de 41.000 pessoas, revelando o seu sucesso e alcance ao público em geral. Os trabalhos apresentados foram agrupados em seis temáticas: I - habitação econômica (programas, loteamentos do terreno e distritos); II habitações coletivas (casas de apartamentos, inquilinos e proprietários); III - racionalização dos materiais de construção (processos de construção, padronização e condições de conforto); IV - codificação (códigos estaduais e municipais, exames de residência e recepção de materiais); V - financiamento das construções (problemas de capital nas construções); e VI - livre (assuntos não contemplados nas temáticas anteriores) (ANAIS..., 1931). Utilizando-se as palavras do engenheiro Henrique Dória, um dos idealizadores do evento, a organização de um congresso acerca da moradia se mostrava oportuna naquele momento de reconstrução social e econômica do país (iniciado após a Revolução de 1930), prestando serviço tanto à população, quanto às administrações públicas, à classe de arquitetos e engenheiros, aos construtores, além das indústrias de construção civil. De acordo com o supracitado engenheiro, era preponderante se criar no Brasil a preocupação americana da "Social Engeering", deixando de lado as questões puramente estéticas no tocante à edificação de moradias sociais, bem como "criar" um espírito de associação no país. Citou como exemplos, nesse sentido, a organização de eventos semelhantes pela prefeitura de Lion, na França, e a atuação de organizações associativas norte-americanas como a National Housing Association e a The National Civic Federation (ANAIS..., 1931).

${ }_{453}$ Esse evento foi promovido pelo Instituto de Organização Racional do Trabalho (IDORT) e possuía como objetivo principal reavaliar os métodos e explanar acerca das experiências relativas à habitação econômica no país. Contou com a participação de diversos profissionais de diferentes áreas e se conformou por conferências e exposições de ideias e projetos, intitulado "Casa Popular", ocorrendo simultaneamente em São Paulo e no Rio de Janeiro. Nela, a residência foi enfocada sob a ótica social, financeira, técnica e urbanística. Dentre os temas apontados como merecedores de análises e estudos mais aprofundados por parte do poder público e os distintos profissionais vinculados à temática estava a questão das consequências que a atividade Continua na página seguinte. 
Também influenciados pelo debate internacional acerca da moradia, especialmente em se tratando de algumas teorias urbanas dos séculos XIX e XX, como o ideal de Cidade-Jardim de Howard, de algumas das formulações dos primeiros CIAMs e decorrentes deles, como a unidade de vizinhança, alguns dos profissionais engenheiros e arquitetos participantes desses eventos, associavam o modelo da moradia unifamiliar ao modelo mínimo de habitação, alcançado por meio da economia de espaços, decorrentes de estudos ergométricos e da subtração das circulações, além do uso de novos materiais e técnicas construtivas para a redução do tempo da construção e o custo para tal.

Os aspectos conclusivos acerca desses assuntos, dentre outros, eram redigidos em forma de projetos de leis ou documentos monográficos e encaminhados às autoridades, com 0 intento de se proceder a reformas legislativas e/ou chamar a atenção do poder público para determinados assuntos elencados como de significativa importância para aqueles profissionais, como o fez o próprio Rubens Porto, dentre tantos outros profissionais. Essa prática colaborou, indubitavelmente, para o alargamento da atuação direta das CAPs e, mais tarde, dos IAPs no campo habitacional e destacou a importância da reforma da célula habitacional social em nosso país, a citar o apelo para criação de uma Caixa de Crédito Hipotecário agregada ao seguro de vida e de propriedade, que foi acatada pelo poder público ainda em 1930, com a generalização das Carteiras Prediais e o alargamento da política de financiamento e empréstimos habitacionais, preterida para além de Porto, pelo engenheiro Roberto Simonsen desde a década de 1920454.

Em se tratando especificamente do Congresso Pan-Americano de $1930^{455}$, defendia-se para os assentamentos locados em áreas suburbanas, o modelo de moradia unifamiliar isolada no lote e que fosse “(..) dadas (...) as dimensões necessarias para que os edificios fiquem afastados dos alinhamentos e sufficientemente separados dos predios vizinhos (...)" (ABREU, 1930, p.23). Proposta semelhante foi observada no cerne I Congresso de Habitação de 1931, sendo formulada especialmente pelo sócio fundador e titular do

industrial acarretou aos centros urbanos brasileiros, essencialmente as concentrações operárias mal alojadas que originam e agravam a crise de moradias populares no país e a difusão dos cortiços (CORREIA, 2004): justificativa para se considerar só os três eventos citados. Devido à abrangência dos acontecimentos e diversidade dos meios de divulgação de propostas e soluções no campo da moradia social ao longo de todo o século XX no Brasil, nos detemos ao aprofundamento desses três primeiros grandes eventos que abordaram a temática. Cabe ainda frisar, que se deu especial atenção às realizações e, consequentemente, às discussões e debates em torno da habitação no país, colocadas e/ou instigadas por profissionais brasileiros ou estrangeiros que atuaram no cenário brasileiro, entre os anos, sobretudo, de 1920 e 1940; período de criação, estruturação e reforma das CAPs e IAPs no campo da moradia social. O objetivo principal disto foi identificar possíveis influências e/ou contribuições na atuação daqueles órgãos. É necessário destacar ainda, que o debate em torno da moradia e o modo de morar, não somente no Brasil, mas também em todo o mundo, não se restringiu ao período acima especificado, perdurando até os dias atuais. E, mesmo no recorte temporal desta tese, foram diversos os momentos de importantes discussões, como os observados nas décadas de 1950 e 1970 , mas que transbordam o objetivo supracitado e não cabem ser aqui analisados.

454 Foi o fundador da Companhia Santista de Habitações Econômicas, em 1912, sendo considerado um dos pioneiros na construção de moradias operárias no país. Em seu discurso era recorrente os apelos para uma intervenção mais contundente do poder público nesse campo (O PROBLEMA..., 1916). Também participou da Jornada de Habitação Econômica empreendida pelo IDORT, em 1942. Nesse evento foi o responsável pela palestra inaugural, na qual, destacou a importância do estabelecimento de uma estratégia governamental para o equacionamento do problema habitacional do país (FARAH, 1983).

455 Não se pode deixar de apontar essas realizações e as referências que se conformaram para as ações empreendidas em nosso país. A realização de um Congresso Pan-Americano daquela envergadura no Brasil, exatamente no período de reformulações públicas, econômicas e sociais, em 1930, foi indubitavelmente uma importante porta de entrada e de difusão daqueles modelos habitacionais e proposições nesse sentido no país. 
Instituto Central dos Arquitetos do Rio de Janeiro, o engenheiro Marcello Taylor Carneiro de Mendonça ${ }^{456 .}$ Por meio dele foi defendida a concepção de Cidades-Jardins como solução ideal para o problema de moradia das classes operárias no Brasil ${ }^{457}$. Condenava, nesse sentido, os modelos de habitações coletivas, as quais, somente deveriam ser aceitas em países onde 0 analfabetismo fosse praticamente nulo e para os empregados "(...) de certa categoria e nunca para o operário" (MENDONÇA, 1931, p.143). Essa citação também atesta que alguns dos estigmas relacionados à moradia do pobre no país, típicos das décadas anteriores, ainda estavam arraigados nos discursos e nas práticas de profissionais ao longo dos anos de 1930. Apesar de anterior ao alargamento da produção direta e do financiamento de habitações, empreendidos principalmente pelos IAPs do MTIC, Marcello Taylor antecipou o que viria a ocorrer no âmbito desses órgãos, sobretudo, no Nordeste. Nessa região geográfica do país, os Institutos centralizaram e enfocaram a produção de exemplares de moradia coletiva vertical nas categorias mais abastadas das carteiras profissionais atendidas, como se verá mais detalhadamente a seguir.

Outra importante contribuição teórica acerca da moradia no I Congresso de Habitação foi dada por Bruno Simões Magro458. Esse engenheiro-arquiteto reconheceu que a habitação econômica deveria, como qualquer outra, ser salubre, sólida, confortável e edificada de modo a conservar a saúde psíquica e mental de seus moradores, mas, além disso, essa moradia deveria ser situada em locais de fácil acesso, a uma pequena distância do centro da cidade. Defendia, nesse sentido, veementemente a casa isolada, mas afirmava que algumas questões de ordem econômica exigiam o agrupamento das moradias em linha ou geminadas em blocos ${ }^{459}$, mas se mostrava contra a concepção da torre de apartamentos, que deveria ser evitada por questões de ordem moral, higiênica e social. Coincidentemente foram aquelas as tipologias mais empreendidas pelas CAPs e IAPs no Nordeste do país, como se verá adiante.

\footnotetext{
${ }^{456}$ Apresentou no evento o trabalho intitulado "Casas populares - Cidades-Jardins".

${ }^{457} \mathrm{Foi}$, nesse sentido, formulada a principal conclusão do evento acerca das moradias unifamiliares, tida como a principal solução "(...) da magma questão da habitação operaria, uma das melhores que se podem apresentar, é a construcção de bairros-jardins, ou mesmo, em casos particulares, de cidades-jardins. É a solução perfeita sob o ponto de vista hygienico e social e que o I Congresso de Habitação apoia (...) (ANAIS..., 1931, p.37-41). Para tanto era mister que o Estado e a iniciativa privada procedessem 0 barateamento dos custos com transporte, tanto no que concerne ao transporte público, por um meio de locomoção rápida, como no que tange à aquisição de um automóvel. Somente assim, a população menos abastada poderia se instalar na periferia, como defendido por estudiosos e profissionais na França, Inglaterra e EUA, onde havia grande oferta de terrenos a um custo reduzido, em casas isoladas e, dessa maneira, reduzir o número de favelas e "cabeças de porco" que continuavam a crescer em número e tamanho nas cidades em todo o país. Sua proposta de moradia operária ideal foi balizada nas diversas experiências de CidadesJardins em países como a Inglaterra (Sunlight, Bournville, Letchworth, etc.), França (Plessis Robinson, Dugny, Stains, Suresnes, Cachant, Drancy, Nanterre, Cretoile, etc.), Alemanha, Estados Unidos, Bélgica, Áustria, Hungria, Dinamarca, etc. Cita como referência direta a Tergnier, a maior Cidade-Jardim da França concebida pela Cia de Estrada de Ferro do Norte, de acordo com 0 projeto do engenheiro M. Dautry (MENDONÇA, 1931).

458 Em sua tese "Habitações econômicas".

459 Aceitava o agrupamento de quatro a seis casas térreas ou de dois pavimentos, desde que possuíssem terreno para o cultivo de plantas e animais, de acordo com os hábitos do nosso povo (MAGRO, 1931).
} 


\section{- Moradias Unifamiliares Isoladas:}

Apesar de se proporem a conceder moradias mais condizentes com a nova realidade dos trabalhadores urbanos e das cidades do país, como colocado no primeiro capítulo desta tese, os institutos de previdência atuantes no cenário habitacional nordestino desde, sobretudo, a década de 1930, conceberam moradias consoantes ao modelo difundido no início do século XX, representadas principalmente por unidades habitacionais isoladas, geminadas duas a duas ou em fila, dispostas ao longo de uma ou mais vias ou em torno de um pátio.

Casos semelhantes a certas realizações da CAP da Light no Rio de Janeiro, como já colocado, também foram observadas em algumas das capitais nordestinas aqui trabalhadas. São exemplos, as residências da Vila Aldeota do IAPI (1948)460 (Figura 77) e da Vila da CAPFESP (1938) (Figura 78), em Fortaleza.

Algumas inovações são percebidas e podem ser associadas à demanda higienista, representadas pela ligação das residências às redes de serviços disponíveis nas cidades naquele momento, essencialmente a distribuição de água encanada e a coleta de esgotos por meio do sistema de fossas sépticas e/ou canais. Outras só foram possíveis decorrentes dela, como a integração da cozinha e do banheiro ao corpo da casa, também associada ao uso do sifão. A disposição do banheiro social, como passou a ser comumente chamado, entre a sala e a cozinha começou a se configurar comum no país, a partir da década de 1930, ganhando força nos anos seguintes. Novos materiais e elementos também foram utilizados e/ou incorporados nessas moradias ainda filiadas à arquitetura tradicional, especialmente o ladrilho hidráulico e a lavanderia em cimento armado no recuo lateral da residência. Esse aspecto, em especial, se tornou recorrente nas unidades habitacionais edificadas pelas CAPs, IAPs e pela FCP, nesse período em todo o país e, posteriormente, pelo BNH e suas $\mathrm{COHABs.} \mathrm{Vale} \mathrm{salientar,} \mathrm{contudo,} \mathrm{que} \mathrm{ainda} \mathrm{nos} \mathrm{primeiros} \mathrm{anos}$ da década de 1960 foram encontrados exemplares edificados por Institutos, nos quais, o banheiro social estava disposto no fundo do lote, integrado ao corpo da casa, mas o acesso se dava pela cozinha, como na

460 Projeto de Antônio Rufino da Silva, localizado no bairro de Aldeota.

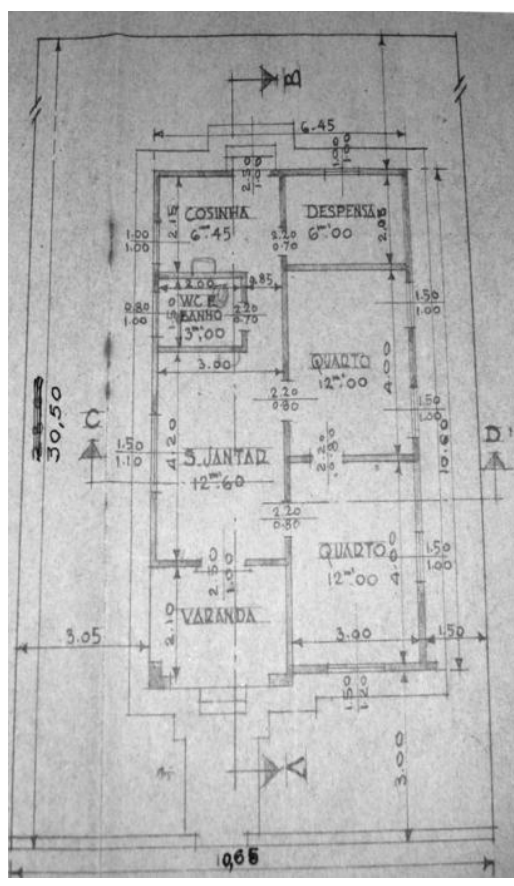

Figura 77: Planta baixa de moradia da Vila Aldeota do IAPI-CE, com cômodos interligados. Fonte: INSS-CE.

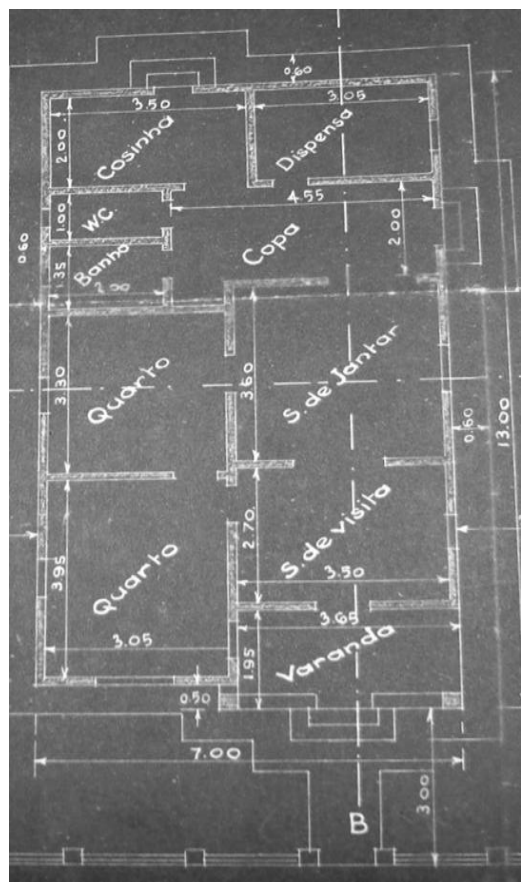

Figura 78: Planta baixa de unidade da Vila da CAPESP-CE. Fonte: INSS-CE. 
Vila Operária do IAPB (1963), projetada pelo engenheiro José Alves de Dantas, em Teresina ${ }^{461}$ (ver imagens 79 e 80).

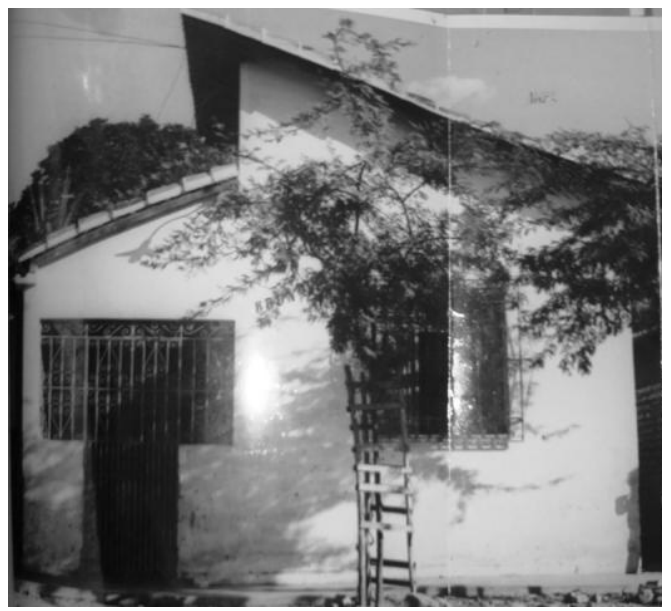

Esses grupos de moradias variavam, mormente, entre pequeno e médio porte sem contarem com equipamentos coletivos - apesar de algumas vezes serem previstos em projeto - situados em variadas localizações nas cidades ${ }^{462}$. Assim o foi ao longo das décadas de 1930 a 1960, em praticamente todas as localidades estudadas, com exceção de Salvador, onde se destacou a produção vertical, como será colocado adiante. Em se tratando dos aspectos formais, essas casas mantiveram, na maior parte das vezes, a disposição dos

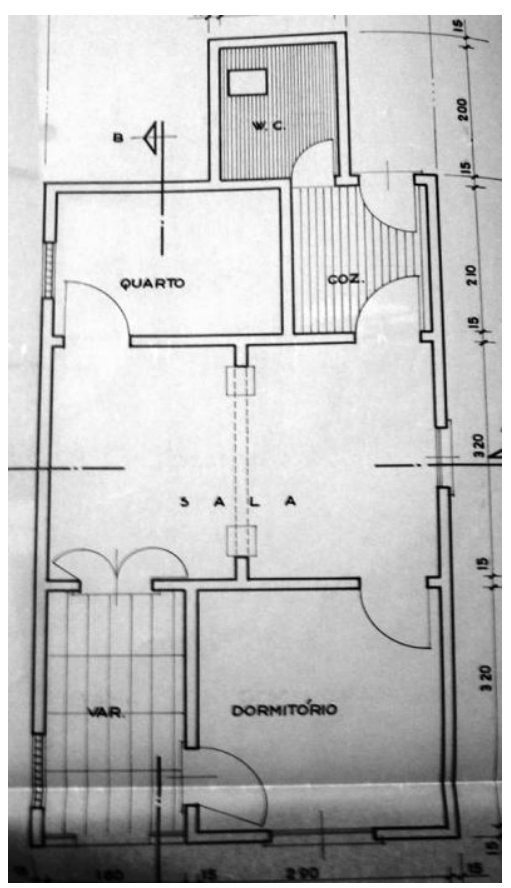

Figuras 79 e 80: Fachada e planta baixa de residência da Vila dos Bancários em Teresina. Fonte: INSS-PI. ambientes em planta ao longo de um corredor, a utilização de materiais de revestimento baratos, como a madeira e o cimento, e no tocante as fachadas se aproximavam da simplicidade e volumetria das tipologias conhecidas como chalezinhos ou bangalôs, como na Vila Ipiranga (IAPI1938), em Fortaleza (Figuras 81 e 82, pág.258), e na primeira etapa do Conjunto Henrique de La Roque (IAPC-1954)463, em João Pessoa (Figura 83, pág.258).

Essa singeleza empreendida em diversas realizações das CAPs e dos IAPs no Nordeste, especialmente em se tratando dos materiais utilizados, não somente nos exemplares com referências higienistas e à arquitetura do período colonial, se aproxima do preconizado pelo engenheiro-arquiteto Amador Cintra do Prado464. Esse profissional defendia o modelo da casa de colono, feita de meio tijolo e assentada em barro, com piso atijolado, pé-direito reduzido e telha vã era o tipo satisfatório de moradia para os mais carentes no país 465 . 0 forro, por sua vez, deveria ser abandonado para que houvesse uma maior

\footnotetext{
${ }^{461}$ As águas desencontradas da cumeeira da residência, em diferentes alturas, também concediam a essas moradias um ar mais inovador quanto à volumetria, apesar da fachada ser mantido o esquema porta e janela.

462 Próximo ao centro ou nos bairros conseguintes a ele, e em áreas limítrofes da cidade, algumas tidas como suburbanas e outras até rurais, como já apontado no capítulo anterior.

463 Esse empreendimento foi realizado em duas etapas e consta de 168 unidades habitacionais, que estão localizadas nas Ruas Escada José Vieira, Esperidião Rosa, Nabuco de Assis, Av. Expedicionários e outras, do bairro Expedicionários. A segunda etapa foi edificada em 1959.

464 Especialmente em seu artigo "Casas rurais adaptadas a casas operárias", apresentado no I Congresso de Habitação, em 1931. 465 Em sua opinião, o piso de tijolo, ao contrário do assoalho comum, secava rapidamente quando lavado e evitava 0 comprometimento do material pela umidade, como ocorria com a madeira.
} 
circulação do $\operatorname{ar}^{466}$ (ANAIS..., 1931). Essas sugestões de revestimento de piso, assim como 0 de cimento queimado, e o abandono dos forros, em muito foram empregados nas unidades habitacionais edificadas diretamente pelas Caixas e Institutos de Aposentadoria e Pensões, especialmente no Nordeste do país.

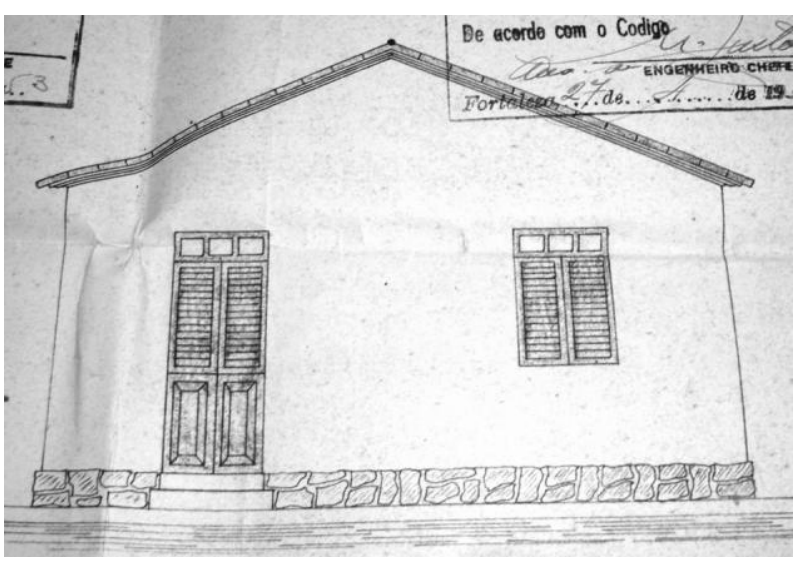

Figura 81: Fachada de uma das tipologias habitacionais da Vila Ipiranga (IAPI-1938), na capital cearense. Fonte: INSS-CE.

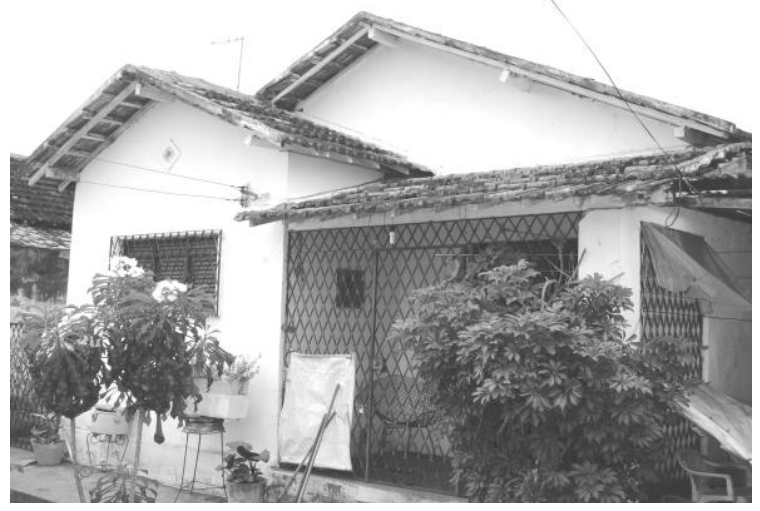

Figura 83: Residência da Vila Henrique de La Roque (IAPC1954), em João Pessoa.

Fonte: Arquivo Pessoal.

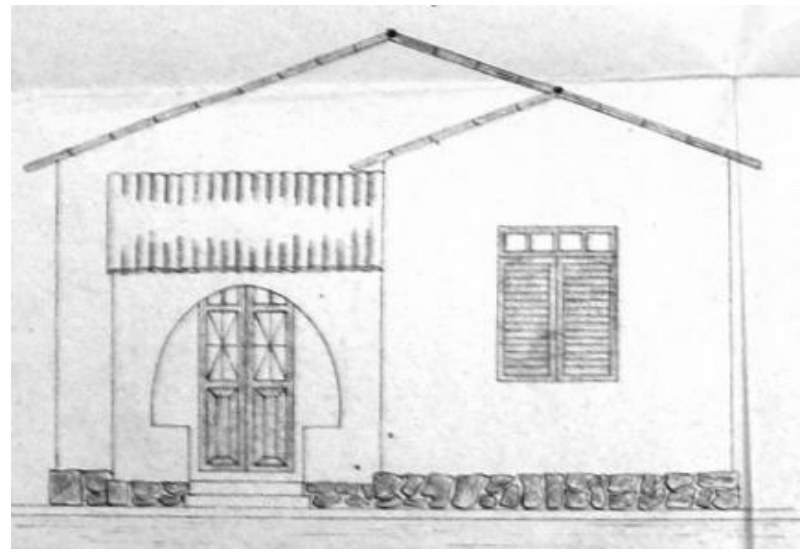

Figura 82: Outra tipologia de moradia da Vila Ipiranga em Fortaleza.

Fonte: INSS-CE.

Em contrapartida, a utilização de materiais típicos da região, como a taipa, a madeira e/ou o sapê dentre tantos outros, não foi largamente incorporada nessa produção, como preconizado por Rubens Porto. Esse aspecto foi veementemente defendido por esse engenheiro-arquiteto em seu manual para edificação de conjuntos residenciais, como já colocado, bem como por outros profissionais participantes de eventos que abordaram a temática da moradia urbana no país ${ }^{467}$, a citar o engenheiro Constantinowsky ${ }^{468}$ - que também atentou para a importância da realização dos estudos para o desenvolvimento de materiais mais resistentes, duráveis e baratos ${ }^{469}$. Os poucos exemplos encontrados nesta pesquisa referem-se, sobremaneira, a moradias resultantes de ações imobiliárias indiretas (iniciativa dos associados), e estão locadas, sobretudo, na cidade de Natal. Os casos mais recorrentes nessa

\footnotetext{
466 Defendia ainda, o revestimento com argamassa comum por questão de economia, a utilização de folhas de janelas cegas ao invés de venezianas que eram mais caras, além da redução do pé-direito, bem como da espessura das paredes, o que resultaria numa redução de até $20 \%$ dos custos para a construção da unidade habitacional (ANAIS..., 1931).

${ }^{467}$ Por exemplo, no ceio do IV Congresso Pan-Americano de Arquitetos foi considerada a necessidade de regulamentações de construção para 0 estudo de soluções mínimas de moradia, tomando por base os materiais de construção próprios dos locais. 0 principal precursor dessas colocações foi o arquiteto Fernando Capurro, que apresentou trabalho intitulado "Vivenda mínima" no evento, o qual sugere a utilização de materiais baratos e disponíveis na região, como o barro armado, o sapê, as folhas de coniferas, dentre outros, para a redução dos custos de construção e, consequentemente, de repasse das moradias (ABREU, 1930). 468 Também participante do IV Congresso Pan-Americano de Arquitetos.

$469 \mathrm{O}$ arquiteto cita, nesse contexto, diversos novos materiais que estavam sendo testados e ou empregados em diversas partes do mundo como o "duraluminium", a "nirosta", as novas composições de amianto, a "ebonita", materiais leves como o vidro, além dos novos materiais isolantes de calor e/ou de som (ABREU, 1930, p.42).
} 
capital remetem a residências cuja estrutura externa é em alvenaria de tijolo e as paredes internas em taipa. Essas unidades estão situadas, essencialmente, nos bairros mais centrais da cidade, como o Alecrim, e foram concebidas principalmente pelo IAPI470.

Em alguns casos, aquele modelo tradicional foi rearranjado, recebendo também elementos de composição de viés modernista, como observado no Conjunto J.K (IPASE-1960), em João Pessoa471 (Figura 84). Nesse grupo de moradias, além da suavização das empenas da coberta e do destaque dado para 0 terraço de entrada com dupla função, acesso e garagem, percebeu-se uma modificação em se tratando do fechamento do lote. Na maior parte das vezes, essa separação do espaço público do privado se dava por meio de baixos muros em alvenaria de tijolo, com motivos em massa e/ou detalhamentos em cornijas, recebendo ainda elementos vazados, mas que nesse Conjunto, cederam espaço para a sobriedade da linha reta e dos gradis em ferro. Em outros, essa adaptação veio acompanhada pelo uso de distintas formas e materiais de revestimentos, como no Conjunto Jacinto Medeiros (IPASE-1964), projetado pelo engenheiro Antônio Carlos Martins Ribeiro, também locado na capital paraibana (Figura 85).

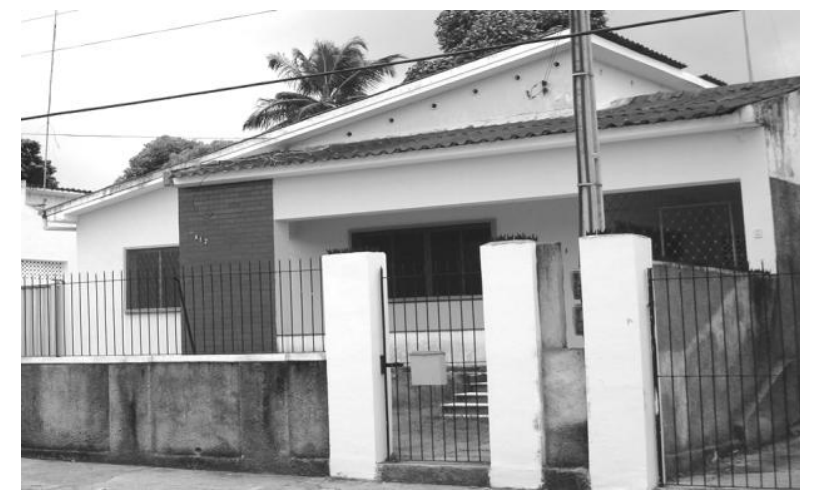

Figura 84: Residência do Conjunto JK (IPASE-1960), em João Pessoa.

Fonte: Arquivo pessoal.

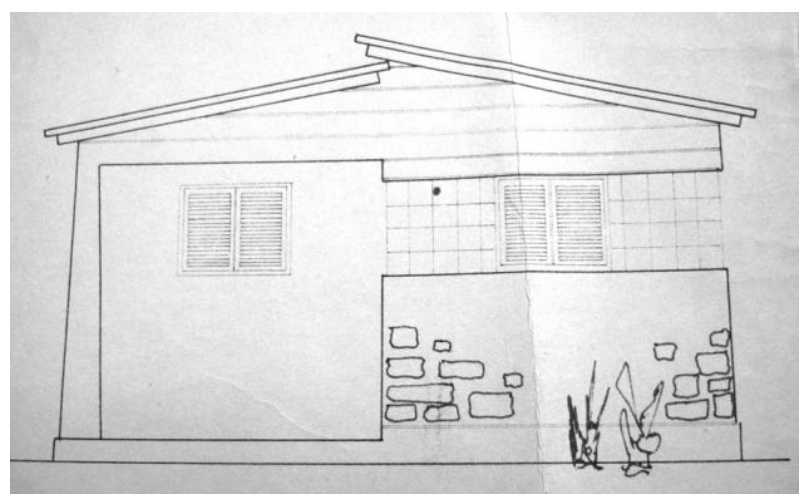

Figura 85: Fachada de unidade habitacional do Conjunto Jacinto Medeiros, em João Pessoa. Fonte: INSS-CE.

Por vezes, esses grupos se configuraram como de médio à grande porte, como foi o caso do Conjunto Filipinho (IAPC-1950), localizado no bairro de mesmo nome, em São Luís. Conformado por 320 unidades habitacionais, esse conjunto faz referências diretas aos bangalôs largamente edificados na cidade nos primeiros anos do século XX, incrementados com alguns elementos do vocabulário moderno, especialmente a parede de combogó na lateral do terraço de entrada, destituída de sua função, se portando como elemento anteparo visual, e atendendo aos preceitos higienistas, especialmente em se tratando dos recuos laterais e grandes aberturas para o exterior. A planta segue o modelo quadrangular regular típica da atuação das CAPs e dos IAPs, com cômodos com áreas mínimas, ausência de grandes circulações e área de serviço com lavanderia em cimento armado prevista em projeto (Figuras 86 e 87, pág.260). Vale ressaltar que o emprego de combogós como barreira visual, em paredes de terraço de entrada e/ou nos baixos muros

\footnotetext{
470 Para o aprofundamento desta questão consultar Almeida (2007).

471 Composto por 50 residências que foram concluídas em 1960.
} 
frontais das edificações, foi comumente encontrado nas cidades nordestinas pesquisadas, a citar as residências da segunda etapa do Conjunto Henrique de La Roque (IAPC-1959), em João Pessoa (Figura 88).

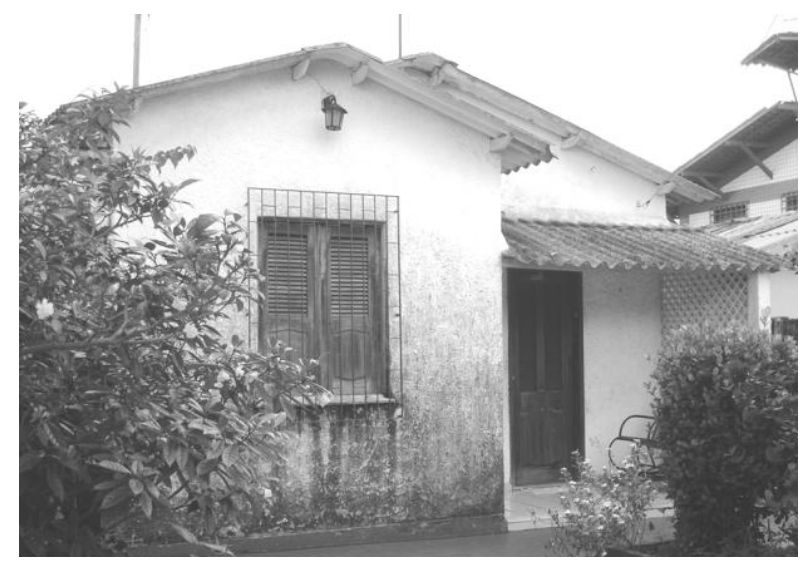

Figura 86: Residência do Conjunto Filipinho (IAPC-1950), em São Luís. Fonte: Arquivo pessoal

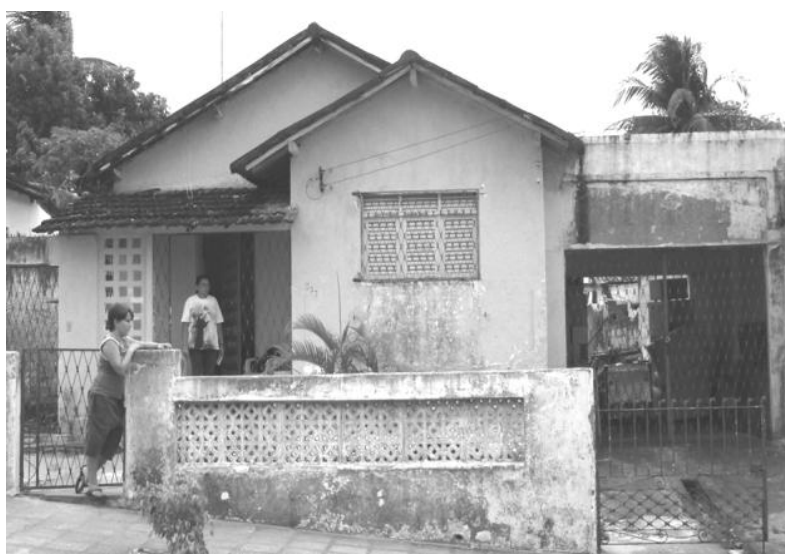

Figura 88: Unidade habitacional da segunda etapa do Conjunto Residencial Henrique de La Roque, em João Pessoa. Fonte: Arquivo pessoal

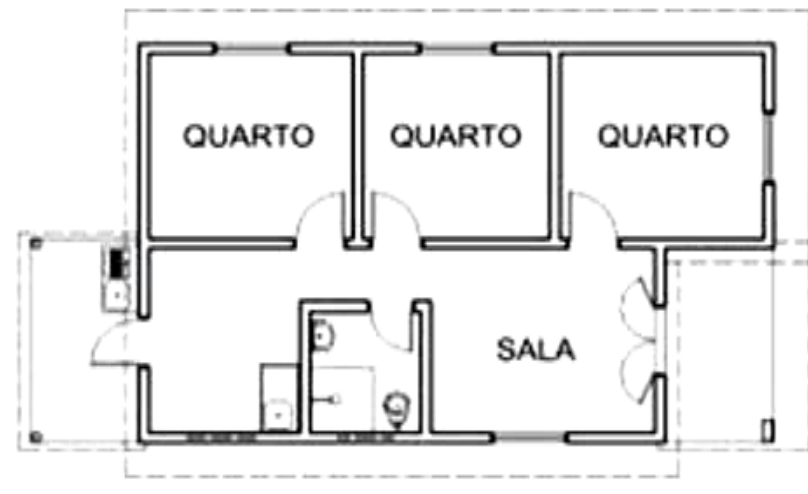

Figura 87: Planta baixa de unidade do Conjunto Residencial Filipinho (IAPC-1950).

Fonte: VASCONCELOS, 2007.

Em planta, também é facilmente percebido um número reduzido de ambientes, quase sempre representados por uma sala, cozinha, banheiro, área de serviço e um ou dois quartos. Essa simplificação do programa da moradia se mostra condizente com o defendido nas discussões em torno da moradia econômica em eventos nacionais e internacionais. No Brasil, era preterida pelos profissionais associados à lógica higienista e sanitarista, entre médicos e engenheiro, empreendida pelos proprietários de vilas e núcleos fabris e, no âmbito

da atuação das CAPs e IAPs, foi consolidada. Ao longo dos anos, essa simplificação chegou a conformar um padrão, uma espécie de protótipo aplicado a qualquer ambiente ou terreno, independente das especificidades locais relacionadas ao clima, ao terreno e, até mesmo ao costume da população, especialmente percebidas quando se analisa as pranchas dos conjuntos de moradias edificados e/ou financiados pelo BNH e suas COHABs.

Mais detalhadamente, esse aplanamento da área construída das moradias bem como do programa da habitação social urbana brasileira, ia ao encontro das proposições de profissionais como Rubens Porto e, para além do ceio habitacional/previdenciário vinculado ao Estado, de figuras como do médico Nelson Mendes Caldeira, presidente o IDORT, do engenheiro Henrique Léfevre, do Instituto de Engenharia, e do engenheiro Léo Ribeiro de Morais, do Instituto de Arquitetos, dentre outros participantes da Jornada de 
Habitação Econômica, promovida pelo Instituto de Organização Racional do Trabalho (IDORT) ${ }^{472}$, em 1941 (REVISTA..., 1945). Para a maior parte dos profissionais participantes do evento, a moradia deveria ser compacta e eficiente, com planta simples composta de sala única, corredores mínimos, quartos pequenos para exercerem as simples funções de dormir e vestir, geralmente em número de três, de modo a separar pais, filhas e filhos e, em algumas vezes, quintal espaçoso, que ocupava segundo alguns profissionais, importante função no processo de criação e educação das crianças. Os cômodos deveriam ser agrupados de acordo com a função, suficientes para abrigar de modo higiênico, privativo e confortável as famílias brasileiras (REVISTA..., 1942). Percebe-se, nesse sentido, uma mescla de filiações de proposições, além das já citadas colocações de demanda higienista, essas sugestões, por assim dizer, se mostram consoantes às proposições vinculadas à Igreja Católica, bem como ao preconizado em diversas reuniões científicas e de arquitetura de nível internacional, como nos amplamente discutidos Congressos Internacionais de Arquitetura Moderna (CIAMs), principalmente em suas três primeiras edições.

Outros profissionais engajados na reforma da habitação destinada aos trabalhadores do país seguiram essa linha de pensamento, como foi o caso de Antônio Janunzzi473 e do já mencionado engenheiroarquiteto Bruno Simões Magro474. Mais detalhadamente, esse profissional defendia a redução dos espaços da casa urbana destinada aos trabalhadores, de modo a evitar a "intromissão" de pensionistas no seio das famílias, tido como um elemento bastante prejudicial. Para tanto, era preciso dar às famílias carentes moradias com o número suficiente de cômodos e áreas adequadas para o desenvolvimento de suas atividades. Seguindo essa vertente de pensamento, Bruno Simões Magro, criticou a redução do número e a fusão de ambientes numa residência, como proposto por alguns profissionais europeus, à semelhança das kleinest-haus, dos alemães, cuja peça principal era a 'salle commune' dos franceses - cozinha, sala de

472 Órgão que se destacou no contexto de reforma da moradia no Brasil, contribuindo para que os ditames da arquitetura moderna fossem incorporados em parte das realizações estatais a partir, sobretudo, da década de 1930. O IDORT foi criado em 1924, sob a denominação de Instituto Paulista de Eficiência, pela Associação Comercial de São Paulo, uma sociedade civil sem fins lucrativos, que passou a receber o título de Instituto em 1931. Desde a sua criação, o IDORT se incubia de estimular a adoção de métodos científicos nos diferentes ramos de atividade. As suas formulações foram amplamente divulgadas entre as décadas de 1930 e 1950 por meio da Revista de Organização Científica, das proposições das Jornadas pelo órgão patrocinadas, além de folhetos, conferências, programas de rádio e por meio de uma biblioteca especializada por ele constituída. As Jornadas organizadas pelo referido órgão passaram a acontecer anualmente a partir de 1930. Dentre elas pode-se citar a Jornada de Organização Científica na Administração Municipal, a Jornada da Alimentação, a Jornada contra o Desperdício nos Transportes e a de Habitação. Na década de 1940, os quase mil sócios associados ao órgão e o corpo técnico que o compunha eram vinculados à imagem de "pioneiros do movimento de racionalização no país" (CORREIA, 2004, p.81). O IDORT assumiu então o papel de centro intelectual do industrialismo brasileiro no que se concerne ao tema da racionalização, promovendo as ideias de taylonização no país. Esse método foi implantado no Brasil, sobretudo, a partir da década de 1930 e foi vinculado às justificativas técnicas e científicas para a efetivação dos programas sociais no país, aplicados tanto nos diversos setores da produção, como nas moradias - racionalização dos espaços da casa e das tarefas domésticas - e nas cidades - racionalização dos serviços públicos, do sistema de circulação, dentre outros (CORREIA, 2004). As conclusões do evento estavam concentradas na substituição de residências precárias por unidades edificadas a baixo custo (planejamento em série, taylonização do canteiro de obra, padronização dos elementos construtivos por outros pré-fabricados, treinamento dos trabalhadores, etc.), na simplificação do programa da moradia com novas disposições e dimensões de cômodos, na redução dos ornamentos e nas rotinas de trabalho doméstico e educação do morador, além da adequação da casa e dos valores dos aluguéis aos salários dos trabalhadores. Apontava-se também para a importância da intervenção estatal por meio da reformulação dos códigos de obras (REVISTA..., 1942).

473 Também participante do IV Congresso Pan-Americano de Arquitetos (1930), defendendo a tese intitulada "Casas baratas", na qual foram apresentadas soluções de planta para o aproveitamento máximo do espaço da habitação.

474 No contexto do I Congresso de Habitação, de 1931. 
trabalho e de refeição ao mesmo tempo e, muitas vezes, também dormitório. Para o profissional, nesse modelo não se verifica o isolamento adequado dos quartos desejado pelas famílias em nosso país. Vale lembrar que o modelo da moradia muitas vezes empreendido pelas CAPs e pelos IAPs no Nordeste, pelo menos, seguia a tendência de separar pais e filhos no ambiente de dormir propondo, mormente, plantas compostas por dois ou três quartos, como foi mais comumente encontrado nos levantamentos realizados. Num segundo plano, cabe frisar que a proibição da sublocação - criticada por Simões Magro e não aconselhada por Rubens Porto - foi incorporada aos regulamentos relacionados às moradias edificadas e/ou financiadas pelos institutos de previdência atuantes naquela região geográfica do país.

Esses profissionais apontavam a economia de espaço e de materiais como os primeiros passos para a concepção de moradias baratas. Era dessa economia que resultaria o aumento do número de unidades habitacionais a serem edificadas pelo Estado, principalmente. A construção em série tornaria possível a padronização dos elementos construtivos e contribuiria para a redução dos custos na construção. Era importante também que os profissionais brasileiros adquirissem a consciência que as soluções tidas como boas em outros países, não necessariamente eram adequadas ao nosso ambiente, principalmente ao nosso clima e recursos naturais, especialmente em se tratando da adequação das casas baratas às especificidades geográficas e sociais de cada região brasileira. Essas proposições anteciparam algumas discussões acerca do regionalismo na arquitetura, que permeou muitas das críticas formuladas em torno da arquitetura e do urbanismo modernos, num momento seguinte 475 .

Para a concepção dessas novas plantas também eram preponderantes os estudos das novidades técnicas da construção moderna, das novas teorias sobre ventilação, novos materiais ${ }^{476}$, estudos práticos e teóricos sobre a insolação e refrigeração, a fim de aumentar o conforto da moradia e reduzir os custos, pois, a maior dificuldade no projeto/edificação de unidades econômicas era conciliar os baixos custos à boa qualidade, como alegado por Rubens Porto (1938). Assim era preciso que profissionais exigissem propriedade de material e o racional emprego da mão de obra. Como já apontado no segundo capítulo, Rubens Porto, bem como outros engenheiros e arquitetos, como Simões Magro, fez referências diretas às realizações e publicações Ernest May, especialmente ao seu artigo acerca da casa para o mínimo de existência, apresentada no II CIAM, que ocorreu em Frankfurt, na Alemanha477; que crer-se configurar como uma das principais balizas para a construção de moradias por parte das Caixas e Institutos.

Seguindo uma tendência mais atuarial, grupos residenciais construídos por certas delegacias estaduais dos Institutos, especialmente do IPASE e do IAPB, eram previstos para as camadas médias da

\footnotetext{
475 Vale lembrar que já no Manifesto de 1925, Gropius colocou que a arquitetura e suas construções deveriam ser adaptadas à região a ser atendida (WARCHAVCHIK, 1958).

476 Para Magro (1931), poderia se obter maiores economias na construção de moradias com a utilização de novos materiais de construção em uso em outros países, mas não permitidos nos regulamentos sanitários no Brasil.

477 De acordo com Magro (1931, p.64), os princípios construtivos preconizados por May para Frankfurt em muito se aproximam das soluções empreendidas para o problema habitacional pelos profissionais brasileiros, principalmente em se tratando do "standard mínimo de vida".
} 
sociedade, cujas unidades apresentavam uma arquitetura mais elaborada, plantas mais complexas e uma qualidade construtiva superior a muitos empreendimentos contemporâneos. Essa linha de atuação foi aos poucos focando os trabalhadores mais abastados, ganhando força a partir da década de 1950 e se firmando no cenário habitacional do país com o BNH e o próprio IPASE, que continuou a operar nesse sentido.

Exemplos dessa vertente de atuação, no que concerne aos conjuntos e vilas residenciais com casas isoladas unifamiliares, podem ser citados. Um deles, diz respeito ao Conjunto Paulo Gentile ou Conjunto Tirol, como era popularmente conhecido em Natal, em meados da década de 1940. Esse Conjunto foi edificado pelo IPASE ${ }^{478}$ e consta de trinta moradias com área construída de $100 \mathrm{~m}^{2}$, que foram repassadas por meio de venda financiada, tida como média ${ }^{479}$, em 1946. Nessas unidades, os materiais comumente encontrados, especialmente aqueles de revestimentos, como o piso de cimento queimado ou em mosaico de alvenaria ou até mesmo as folhas de portas e janelas em madeira lisa, deram lugar ao ladrilho hidráulico de boa qualidade nas áreas frias das residências, bem como ao piso em taco e forro em madeira de primeira, e revestimentos de parede com cores diferenciadas. Já são percebidas garagens cobertas em laje de concreto para automóveis, aspecto que não se mostrava muito recorrente nas realizações habitacionais dos Institutos e Caixas no país naquela época, apesar da coberta ainda remeter à arquitetura tradicional (Figura 89). Caso semelhante foi vislumbrado na Vila Joaquim Nabuco (IAPETC-1942), no Recife (Figura 90).

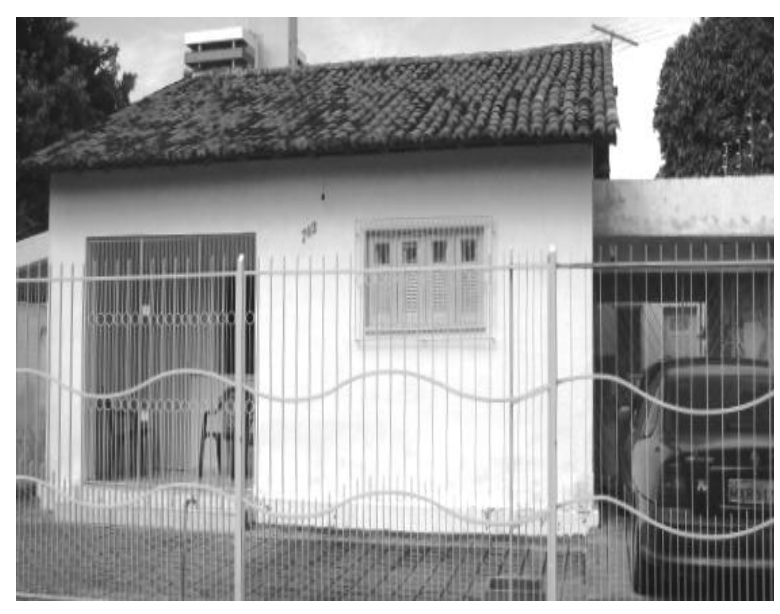

Figura 89: Residência do Conjunto Paulo Gentile (IPASE1945), em Natal.

Fonte: Arquivo pessoal.

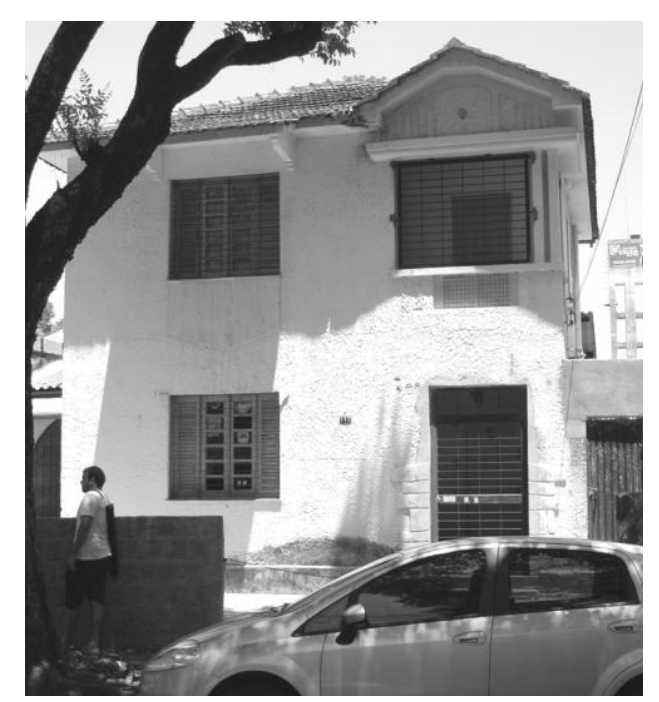

Figura 90: Moradia da Vila Joaquim Nabuco (IAPETC-1942), no Recife.

Fonte: Arquivo Pessoal.

Diversos empreendimentos contaram com a doação da área a ser edificada por parte do poder público, como foi identificado no âmbito de órgãos como a CAPESP/IAPFESP, as CAP de Serviços Urbanos e o IPASE, sobremaneira. Em Natal, a Vila 19 de Abril (IAPC-1948), se mostra um exemplo. O terreno para a sua edificação foi doado pelo Governo do Estado no mesmo ano de sua construção, por meio do Decreto n.476. Apesar de estar situada em uma área privilegiada da cidade, no abastado bairro de Petrópolis, o valor de localização não foi agregado às moradias de $40 \mathrm{~m}^{2}$, e o financiamento permaneceu

\footnotetext{
${ }^{478} \mathrm{Em}$ terreno adquirido por compra à Sociedade de Construções Gerais Lida.

479 Em torno de $\mathrm{Cr} \$ 75.000,00$ (cruzeiros).
} 
de caráter social480. A simplificação da planta segue a lógica mínima, assim como suas fachadas que receberam somente caiação simples.

Grupos de residências também foram concebidos em parcerias entre institutos de previdência diferentes, entre uma delegacia específica e um órgão privado, ou ainda entre um IAP ou CAP e outro órgão estatal, como a Fundação da Casa Popular (FCP), como vislumbrado no Conjunto Cel. Vitorino Corrêa, projetado do engenheiro João Batista Gabriel (IPASE/FCP-1953), em Teresina481. Houve casos ainda em que a conformação dos conjuntos não ocorreu como o habitual. São exemplos, os Conjuntos Henrique de La Roche (IAPC-1950) e Presidente João Goulard (IPASE-1958), ambos locados no bairro Expedicionários, em João Pessoa. Nos casos usuais, um Instituto adquiria o terreno onde ia ser implantado o conjunto residencial por meio de compra a terceiros, o que incluía empresas e sociedades proprietárias de terras, ou por doação realizada pelo Estado (âmbito municipal ou, como era mais comum, pelo governo do estado) e em seguida procedia à edificação das unidades habitacionais e ao posterior repasse ou comercialização aos associados. Nos casos acima elencados, os grupos residenciais foram se conformando ao longo dos anos. O IAPC-PB e o IPASE-PB abriam concorrência para a concessão das unidades de moradia e à medida que os contratos eram fechados iniciava-se a construção, quase sempre em blocos de cinco ou dez residências. Devido a essa peculiaridade foi encontrada uma diversidade de datas de início do financiamento de um mesmo conjunto nessa cidade. Alguns chegavam a perdurar por mais de uma década.

Acerca da incorporação dos ditames modernos da arquitetura e do urbanismo nas realizações dos referidos órgãos nas sete capitais do nordeste do país estudadas, pode-se aventar que aspectos locais e relativos ao volume dessas ações interferiram no repertório resultante. Em Natal, por exemplo, os jornais em circulação na década de 1940 colocavam que havia por parte dos profissionais vinculados aos IAPs e às CAPs, assim como por setores das elites, o estigma de que a arquitetura moderna era deveras cara para atender às necessidades das camadas carentes, além de requerer mão de obra especializada, o que em muito encarecia a obra. Por esse motivo, provavelmente, grande parte das residências tidas como modernas encontradas na cidade foi financiada e não edificada pelos institutos de previdência. De fato, os elevados custos para aquisição de materiais como o cimento e a falta de outros materiais e elementos adequados para a concepção de edificações em arquitetura moderna no país até a década de 1930 e, em particular, durante a II Guerra Mundial, foi uma realidade brasileira ${ }^{482}$. Warchavchik (1928, p.85) sintetizou bem esse quadro:

(...) Em São Paulo, dada a carestia de cimento e a falta de (...) materiais adequados à construção moderna, ainda não é possível fazer 0 que já se fez em outras partes do

\footnotetext{
480 Variando entre $\operatorname{Cr} \$ 9.000,00$ e $\operatorname{Cr} \$ 11.000,00$ (cruzeiros), em 1946.

481 Conformado por 28 residências construídas em alvenaria de tijolo e cobertas de telhas, com três arcos de frente, edificadas em terreno doado pelo governo de estado ao IPASE, em 08 de novembro de 1948. Infelizmente as imagens referentes a esse grupo residencial não puderam ser angariadas por falta de dados referentes à localização do empreendimento, sobremaneira.

482 Para se ter noção dos elevados custos para a aquisição de materiais de construção, nesse período, basta apontar o preço cobrado por um milheiro de tijolos, que custava antes da Guerra $\operatorname{Cr} \$ 60,00$ (sessenta cruzeiros), passou a ser de aproximadamente Cr\$130,00 (cento e trinta cruzeiros) nos primeiros anos da década de 1940.
} 
mundo. A indústria local, se bem que em estado de incessante progresso, ainda não fabrica [também] as peças necessárias, (...), de bom gosto e de boa qualidade (...). Estamos sempre peados pela obrigação de empregar material importado, 0 que vem a encarecer muito as construções (...) (WARCHAVCHIK, 1928, p.85).

Dessa forma, a construção empregando concreto, adequada às diretrizes econômicas e estéticas de profissionais como Le Corbusier e Gropius, na Alemanha, França e nos EUA, no Brasil era deveras cara e, "a economia torna-se uma fraude perfeitamente caracterizada" (WARCHAVCHIK, 1928, p.85). Nesse sentido, não se pode deixar de citar também a ausência de padronização técnica e dimensional de elementos, inclusive o tijolo, e ferragens no Brasil até meados da década de 1930. No I Congresso de Habitação de 1931, mais precisamente, essa foi uma das principais temáticas debatidas, no ceio da qual foi concluído que:

(...) o Instituto de Engenharia, em collaboração com outras associações technicas, entidades industriais e commerciais e repartições technicas do Governo, - inicie um movimento tendente a reduzir ao menor numero possivel as multiplas variedades, ora existentes, de cada um dos elementos de fabricação nacional utilizados em uma construcção. Afim de dar inicio immediato á 'Pratica Simplificada' dos materiaes de construcção, iniciando-a com um elemento simples como o tijolo (...). (...) É oportuna a fixação de dimensões certas e definidas para os nossos tijolos communs - reduzindo a grande variedade de typos existentes. Esta simplificação deverá ser baseada na mais ampla collaboração de todos os interessados e elaborada por uma Commissão (...) 0 PRIMEIRO CONGRESSO DE HABITAÇÃO julga necessário que as Repartições Technicas Municipaes e do Estado congreguem seus esforços em torno do Laboratório de Ensaio de Materiaes da Escola Polytechnica de S.Paulo para que, sob o patrocínio do Instituto de Engenharia, e com a collaboração das Associações Technicas, dos fabricantes e dos consumidores - sejam estudadas as especificações dos nossos materiaes de construcção (ANAIS..., 1931, p.37-41).

No Nordeste, um exemplo interessante de apropriação parcial das premissas modernas em fachada, bastante encontrado nas sete cidades aqui estudadas, pode ser materializado pelas casas que compõem a Vila dos Bancários (IAPB-1939), na capital baiana. Esse grupo de 18 unidades habitacionais edificado pelo Instituto, no bairro de Brotas, apresenta elementos como o plano de fachada simples, sem ornamentos ou detalhes em alto ou baixo relevo, que acompanha o volume único e cúbico da moradia, além de um terraço de entrada em formato irregular que quebra a regularidade do corpo da edificação, dando maior movimento à sua fachada principal. A cobertura desse ambiente em fina camada de concreto sustentada por esguios pilares se contrapõem ao telhado em quatro águas. Esse passadismo, como colocado em alguns laudos de avaliação dos imóveis, foi de certa forma rebatido em planta - estruturada ao longo de um extenso corredor de mais de 3m de comprimento (Figuras 91 a 93, na página seguinte). Esse é um exemplo de "formalismo de fachada", parafraseando Warchavchik (1958, p.176), no qual, a forma plástica subverte ao construtivo, que caracterizou o "pseudo-moderno" ou ainda o "os efeitos visuais do academismo modernizado", segundo aquele autor. 

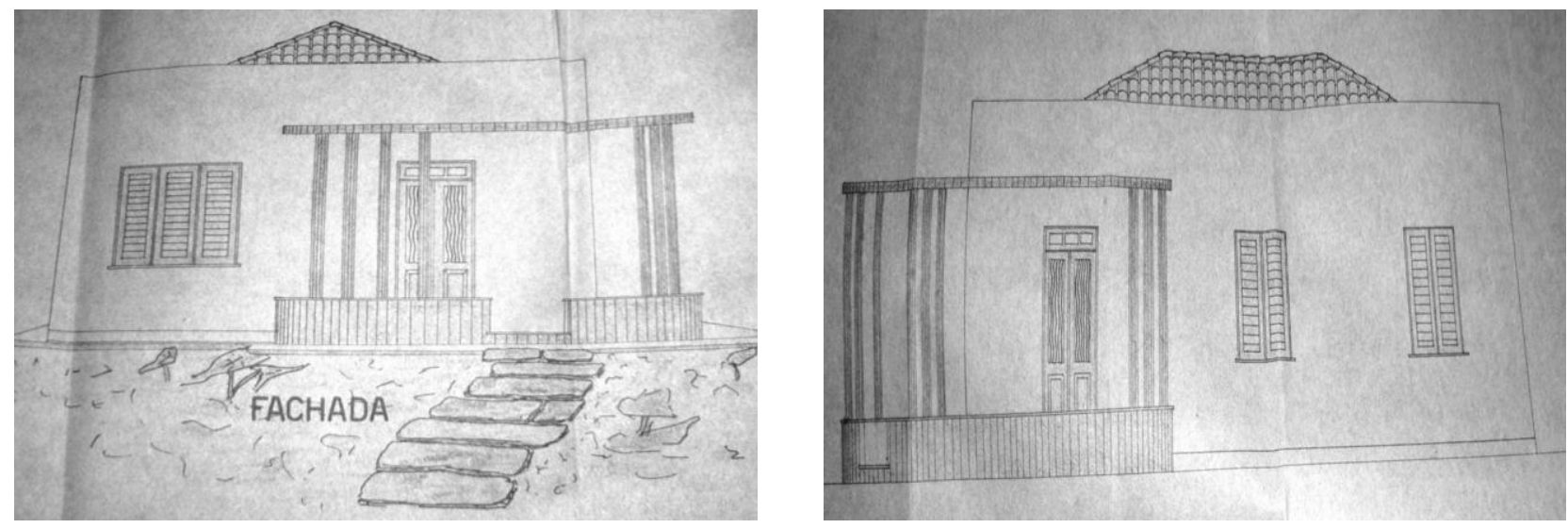

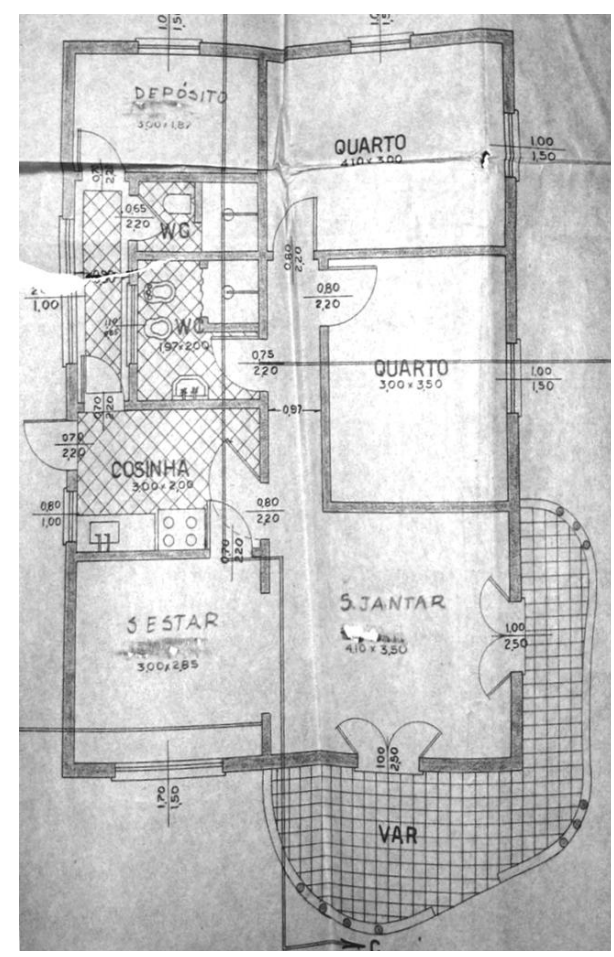

Figuras 91 a 93: Fachada frontal, lateral e planta baixa de unidade habitacional da Vila dos Bancários, no bairro de Brotas em Salvador. Fonte: INSS-BA.

Em se tratando do mobiliário, poucos foram os casos em que ele foi previsto em conjunto com a unidade habitacional no Nordeste. Um desses exemplos espaçados foi a Vila Aldeota (1938), edificada pela CAP dos Ferroviários da Rede de Viação Cearense, no bairro de mesmo nome, em Fortaleza ${ }^{483}$. Nela foram previstas uma sala de jantar, com mesa elástica, seis cadeiras e uma cristaleira, e quarto com cama de casal, guarda roupa e duas cabeceiras. Vale lembrar que Rubens Porto era a favor de se pensar o mobiliário juntamente com as unidades econômicas, essencialmente os armários embutidos para aproveitamento dos desvãos do telhado e espaços sob as escadas, com dimensões e funções mais adequadas às "novas" moradias dos trabalhadores do país. Da mesma forma foi colocado pelo engenheiro Simões Magro, provavelmente outra referência à experiência de May, em Frankfurt. Contudo, apesar de se filiarem a alguns pressupostos da arquitetura moderna, essas moradias eram bangalôs com telhados complexos em seis águas, além do terraço de entrada, e alguns ornamentos nas fachadas principais, essencialmente em se tratando da "tipologia 6", representados por apliques em massa, em formatos geométricos (Figuras 94 a 96). Essa profusão de ornamentos era condenada pelo idealizador e formulador das premissas de construção de unidades habitacionais e de conjuntos residenciais pelas CAPs e IAPs no país. Também era descartada e criticada por muitos dos engenheiros e arquitetos associados à nova arquitetura que se pretendia instituir no país.

483 Grande Vila edificada em etapas. Possui oito tipologias de planta e fachada. 

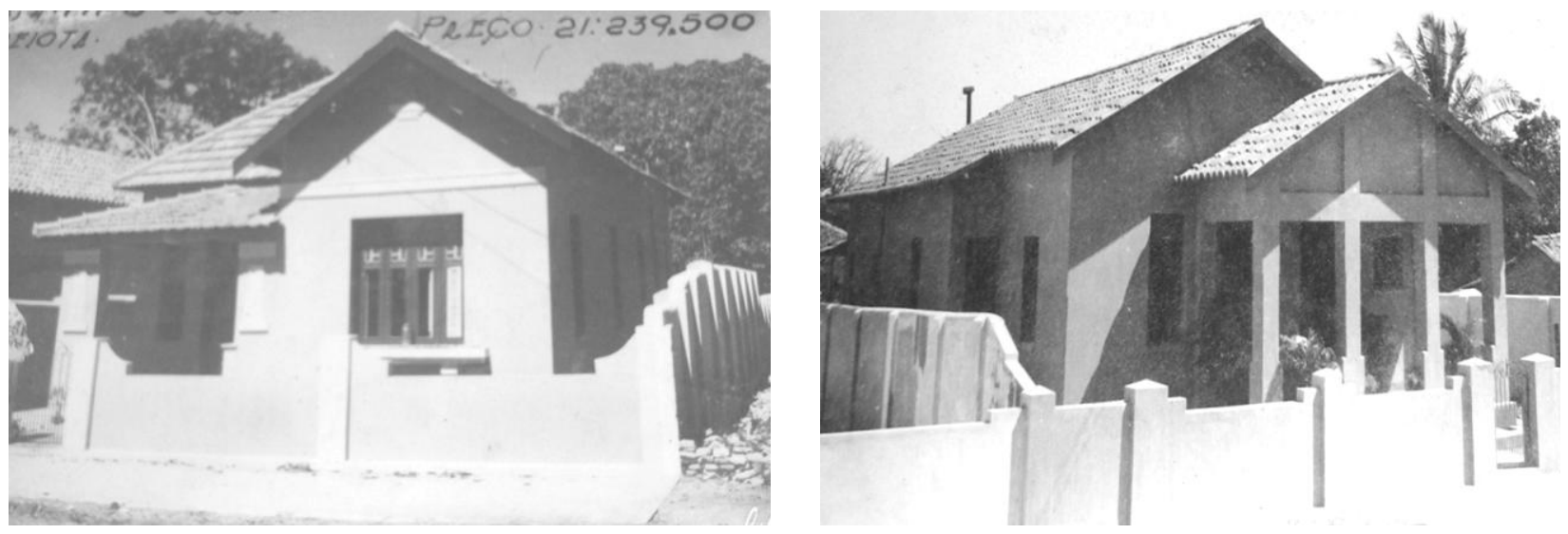

Da mesma forma que a previsão de mobiliário em conjunto com as unidades habitacionais, poucos foram os grupos de moradias que apresentaram em projeto equipamentos coletivos e de lazer, como foi o caso do Conjunto Monte Castelo (IPASE-1964), em Teresina. O projeto do arquiteto Ubirajara Galvão é conformado por 160 unidades habitacionais, além de igreja, praças, associação de moradores, casa para idosos, quadras de esportes e campo de futebol. As

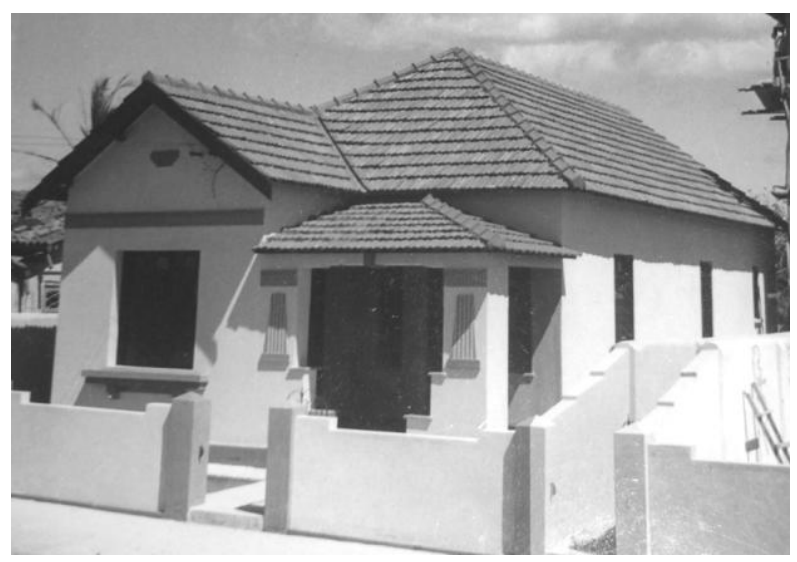

Figuras 94 a 96: Diferentes tipologias habitacionais da Vila dos ferroviários da Rede Cearense, no bairro de Aldeota. Fonte: INSS-CE. moradias em planta e em fachada podem ser traduzidas por simplicidade, conformando-se de sala, dois ou três quartos, banheiro, cozinha, com ou sem área de serviço484. Na fachada principal só são percebidas duas grandes janelas com veneziana de madeira e a cobertura em duas águas perpendiculares às vias (Figura 97, na página seguinte). Os lotes e as principais aberturas das edificações foram direcionadas aos ventos dominantes, em variados ângulos, aproveitando-se também as curvas de nível do terreno, evitando grandes movimentos de terra e reduzindo o custo para a concepção do Conjunto, como preconizado por Rubens Porto e, consequentemente, estando em sintonia com algumas proposições dos chamados urbanistas utópicos de fins do século XIX e início do século XX, em especial ao modelo de Cidade-Jardim e suas variações (Figuras 98 e 99, na página seguinte). Esse modelo de implantação também foi muito esporádico no que concerne à construção de grupos de moradias unifamiliares isoladas no lote, diretamente pelos Institutos e Caixas de Aposentadoria e Pensões no Nordeste.

${ }^{484}$ Casas cobertas com telhas do tipo popular, como especificado nos laudos de avaliação dos imóveis. O Conjunto é conformado por dez quadras, divididas em 160 lotes residenciais, dos quais, 20 eram do tipo A (terraço social, duas salas, três quartos, banheiro, cozinha, terraço de serviço e lavanderia), 15 do tipo $B$ (terraço social, sala, três quartos, banheiro, cozinha e lavanderia) e 125 do tipo C (terraço social, sala, dois quartos, banheiro, cozinha e lavanderia). 


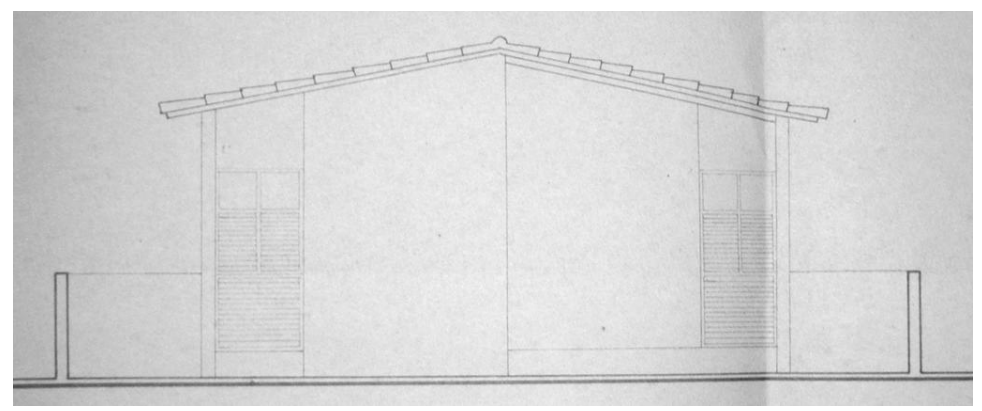

Figura 97: Fachada das residências do Conjunto Monte Castelo (IPASE1964), em Teresina.

Fonte: INSS-PI
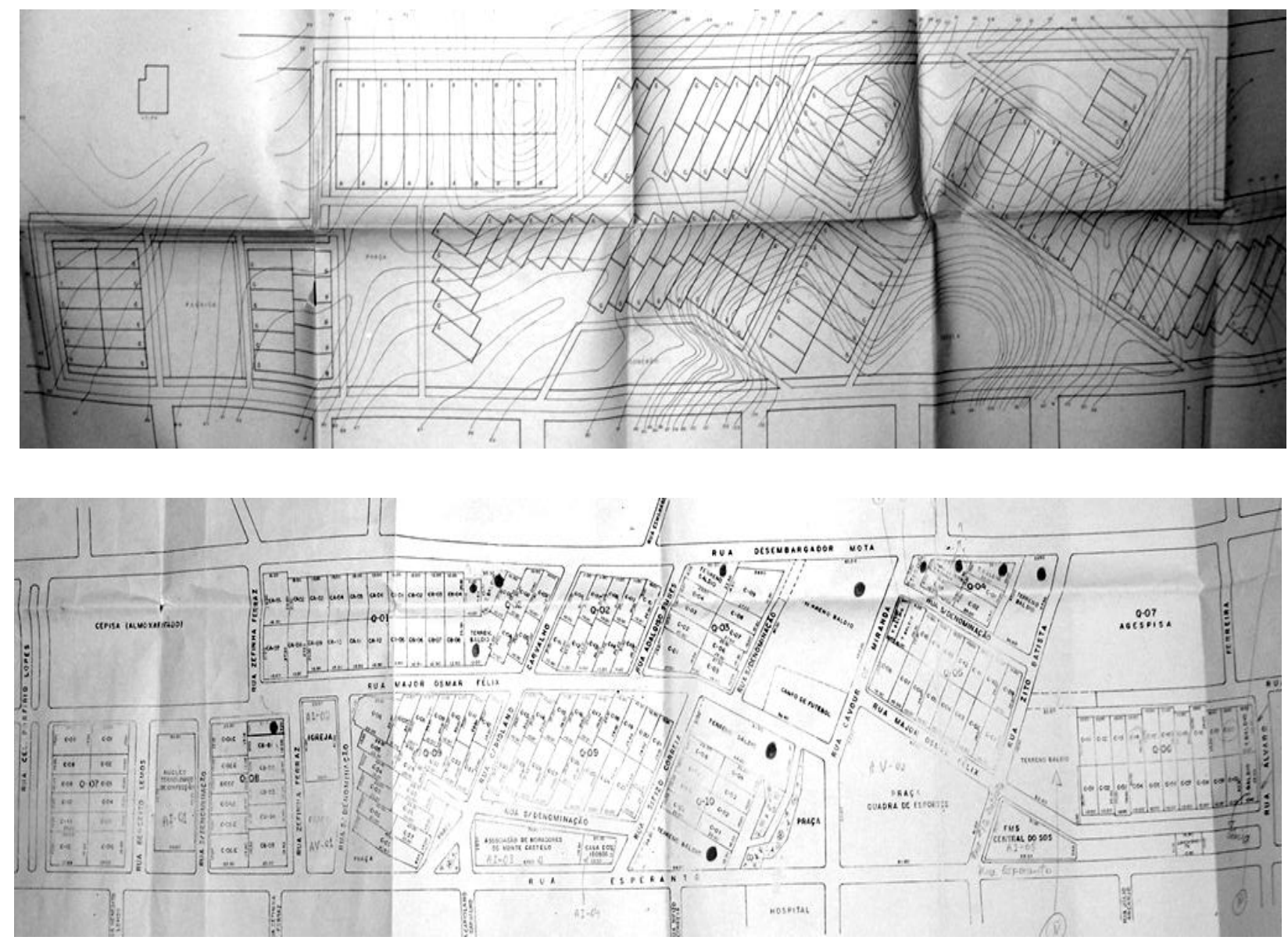

Figuras 98 e 99: Implantação do Conjunto Monte Castelo.

Fonte: INSS-PI.

Outra implantação diferenciada evidenciada nos levantamentos realizados nessa Região foi a do I Conjunto Aeroporto (IPASE-1964), situado no bairro de mesmo nome, também em Teresina ${ }^{485}$. Nela, segundo o engenheiro Raimundo Fortes de Cerqueira, as moradias foram intercaladas nos lotes de acordo com diferentes dimensões de recuos frontais, de modo que o vento circulasse sinuosamente, evitando-se os chamados corredores, que acabavam por não atender a todas as unidades de modo satisfatório, além de

485 Vale salientar que todos os grupos de moradias edificados pelos IAPs em Teresina, no recorte temporal estudado, refere-se a conjuntos residenciais unifamiliares. 
garantir certo ritmo ao grupo de moradias, evitando-se "a monotonia e a repetição das fachadas", criticada por alguns profissionais e que veio a se tornar comum, anos depois (Figura 100). Próximo a esse modelo de implantação pode-se citar ainda a primeira etapa do Conjunto do IPASE ${ }^{486}$, em Parnaíba, município do Piauí, projetada pelo já citado arquiteto Ubirajara Galvão, em 1964 (Figura 101).

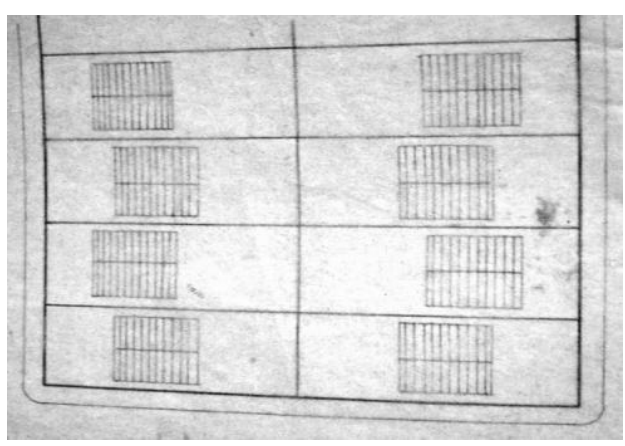

Figuras 100 e 101: Implantação dos Conjuntos Aeroporto I, em Teresina, e Parnaíba, no município de mesmo nome, edificados pelo IPASE na década de 1960.

Fonte: INSS-PI.

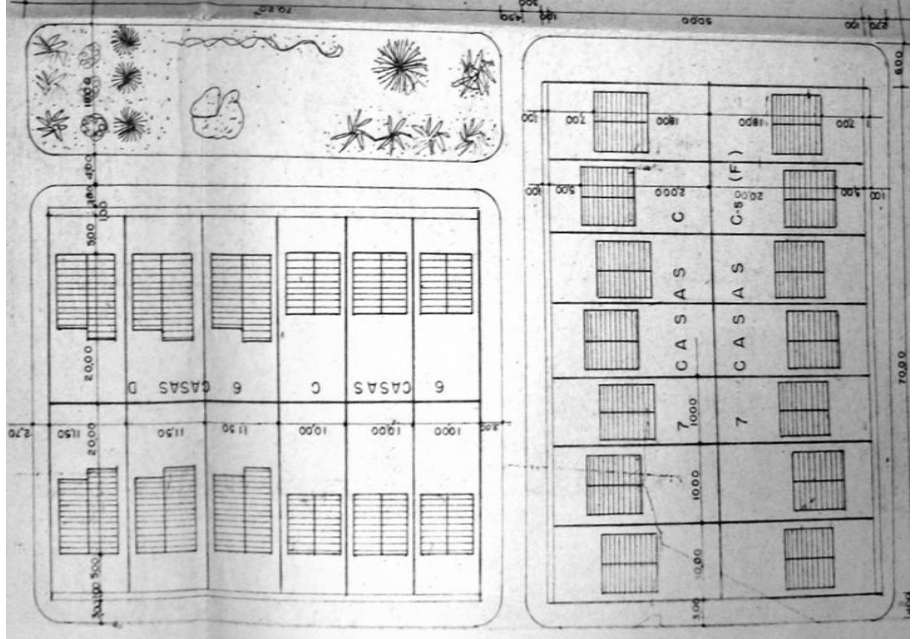

\section{- Moradias Geminadas Duas a Duas:}

De modo geral, os grupos de moradias geminadas duas a duas, em fila ou linha, como especificado em diversos laudos de avaliação de imóveis trabalhados nesta tese, eram recorrentes nas realizações efetivadas pelos empregadores, donos de fábricas principalmente, para a moradia dos operários brasileiros desde fins do século XIX. Essa tipologia, mais precisamente, continuou a ser empreendida no âmbito das Caixas e Institutos de Aposentadoria e Pensões ao longo das décadas de 1930 a 1960, sobretudo, no Nordeste do país.

Da mesma forma que evidenciado nos grupos de moradias unifamiliares isoladas no lote, muitos dos exemplares geminados seguiam a linha dos bangalôs, com telhados em variadas águas, agregado ou não ao pequeno terraço de entrada, ou a do chalezinho e terraço de entrada, como pode ser percebido na Vila Operária dos Ferroviários (IAPFESP-1951)487, situada no subúrbio de Paripe, em Salvador, edificada pelo engenheiro A. Paulo da Matta (Figura 102) e no primeiro grupo de moradias

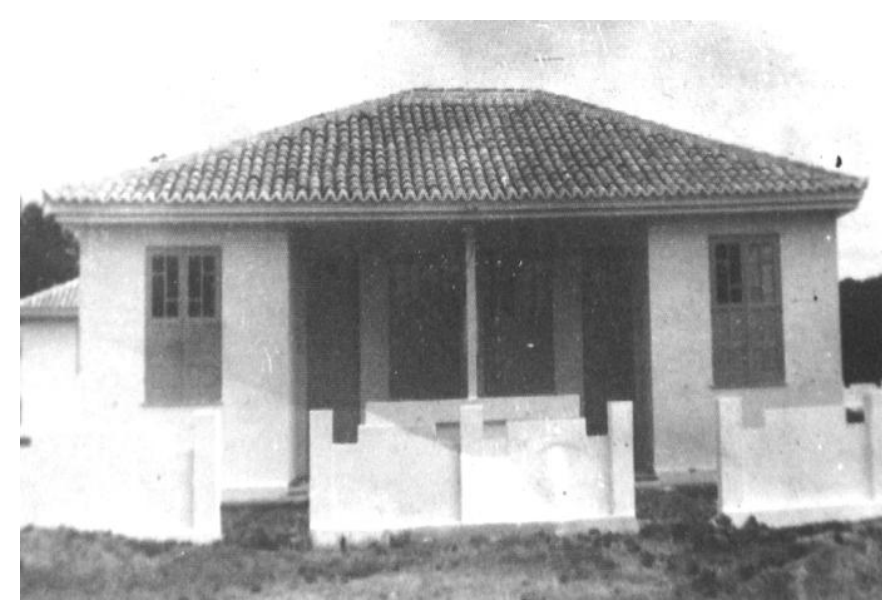

Figura 102: Residências geminadas duas a duas da Vila dos Ferroviários, localizada no bairro Paripe em Salvador. Fonte: INSS-BA.

486 Composta por trinta residências.

487 Vila edificada pela Sociedade Construtora Residencial Lida, sendo servida e água e luz, e repassadas aos funcionários da Via Férrea Federal Luso Brasileira, em 12 de maio de 1951, por meio de venda financiada em Cr\$65.000,00 (financiamento médio). 
Santa Júlia (IPASE-1954), em João Pessoa (Figura 103). Outros exemplos que seguiram essa vertente foram encontrados no Recife, como nas Vilas Getúlio Vargas (IAPETC-1943) (Figura 104) e São Miguel (IAPB1940), com seus beiras típicos do período colonial e telhados voltados para as vias (Figura 105).

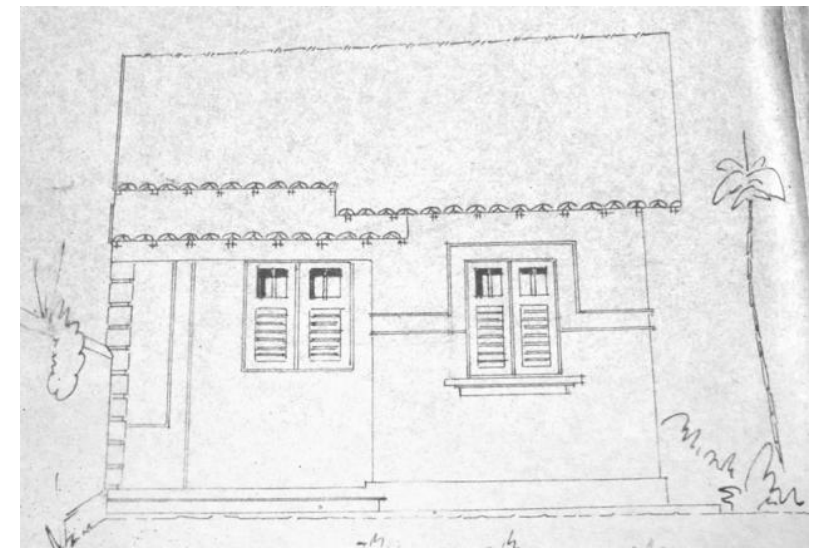

Figura 103: Fachada das moradias do I Conj. Santa Júlia, em João Pessoa.

Fonte: INSS-PB

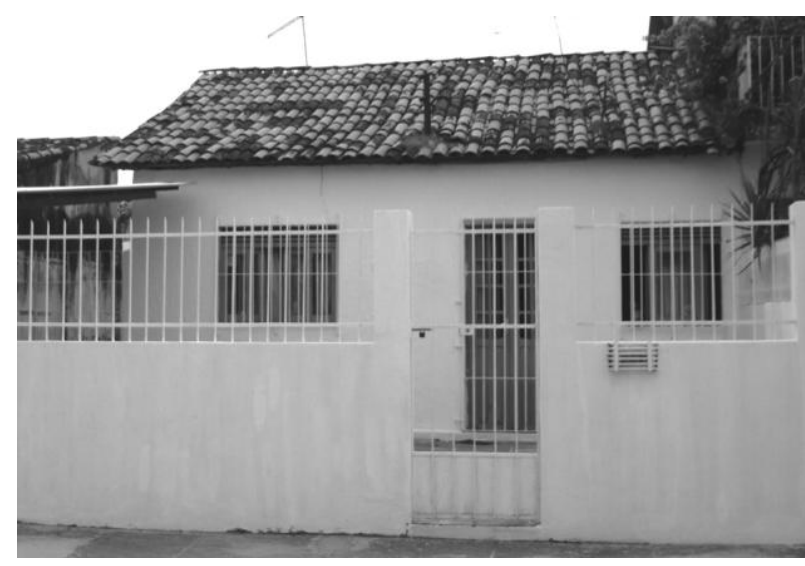

Figura 105: Residência da Vila São Miguel (IAPB-1940), no Recife.

Fonte: Arquivo pessoal.

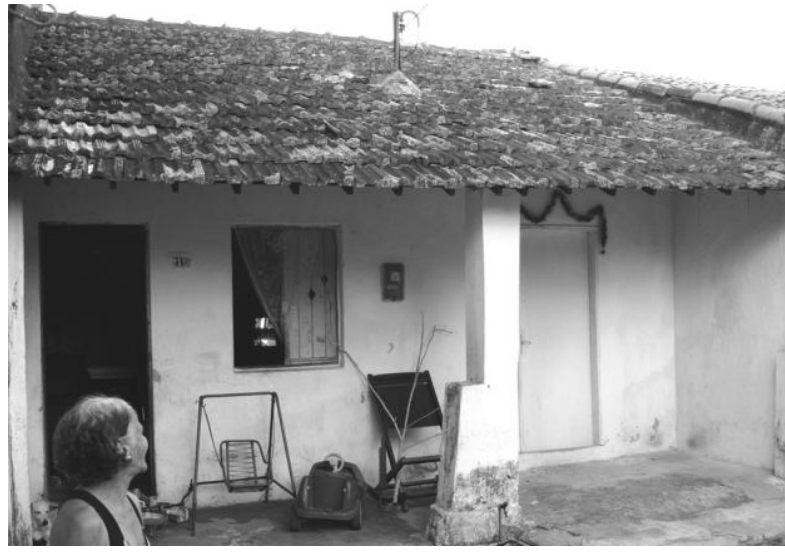

Figura 104: Residência da Vila Getúlio Vargas (IAPETC1943), no Recife.

Fonte: Arquivo pessoal.

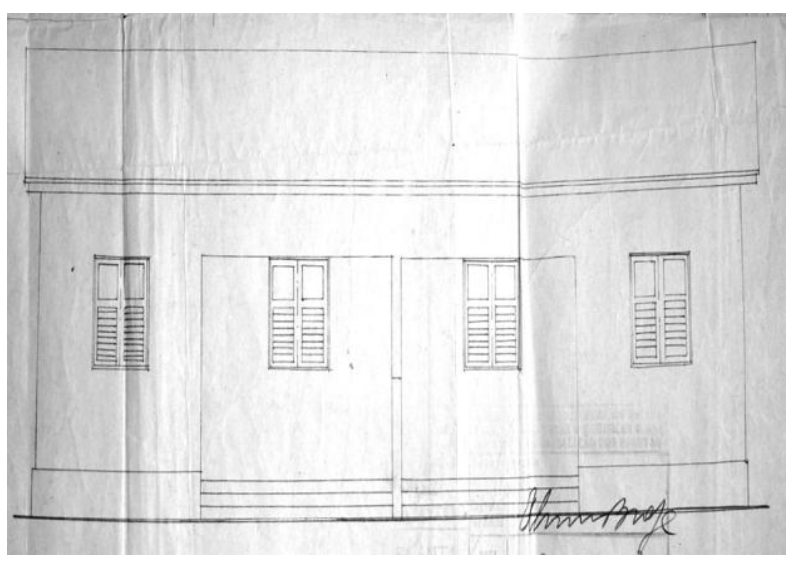

Figura 106: Fachada principal dos blocos geminados da Vila Presidente Dutra, da década de 1940, no Recife. Fonte: INSS-PE.

Como percebido, a grande maioria das moradias era do tipo porta e janelas com telhado com caimento para a via. Outros exemplos nesse sentido foram o Conjunto Coqueirinho (IAPI-1952) ${ }^{488}$, em Fortaleza, e na Vila Presidente Dutra (IAPFESP-1947), no Recife ${ }^{489}$ (Figura 106), que em muito se aproxima da solução formal empreendida pelo engenheiro-arquiteto Bruno Simões Magro, na tipologia 3 das residências da Vila Operária da Estrada de Ferro Sorocabana (1928-1930), apresentada no I Congresso de

488 Composto por 150 unidades habitacionais e vias projetadas, numa área de $50.000 \mathrm{~m}^{2}$, doada pela prefeitura de Fortaleza em 10 de setembro de 1940. As unidades contavam com pequena área coberta na entrada, sala, quarto, banheiro, cozinha e área de serviço $\left(38 \mathrm{~m}^{2}\right)$, destinadas aos trabalhadores mais carentes da carteira trabalhista.

489 Vila edificada em duas etapas. Na primeira etapa, as unidades foram edificadas ainda pela Caixa dos Ferroviários da Great Western, à custa de sua fazenda, conforme escritura lavrada em 08 de setembro de 1948, no 5o Ofício de Notas. A entrega das chaves das residências ocorreu em 01 de junho de 1948, na presença do Presidente da CAP (Romeu Pais Barreto) e do engenheiro da Carteira Imobiliária. 
Habitação. Por vezes, os grupos de moradias geminadas duas a duas receberam elementos do repertório da arquitetura moderna, como pilares em formatos diferenciados e blocos em alvenaria vazados, como no Loteamento San Martim (IAPC-1958), também localizado na capital pernambucana (Figura 107).

Em outros exemplos, a fachada associada à arquitetura moderna fora concebida por meio do uso de platibandas para encobrir as águas do telhado em telhas canais principalmente, ou invertendo o sentido da empena para o fundo do lote, como nas 32 residências edificadas pelo IAPB (1958), no bairro de Tambaú, em João Pessoa490. Em algumas dessas unidades habitacionais, além da cobertura invertida, por assim dizer, as esquadrias das portas e janelas, bem como 0 terraço, receberam um destaque por meio da diferença de planos, e também são percebidos os combogós, esses com aspecto semelhante aos das venezianas (Figura 108). Nesse grupo de moradias, a disposição dos ambientes em planta se difere do comumente encontrado. Nela, o esquema regular em um único bloco retangular ou quadrado deu lugar a um aglutinado de blocos quadrangulares, composto por sala, três quartos, banheiro, cozinha e, para além delas, um terraço posterior por meio do qual se tinha acesso à lavanderia em cimento, ao banheiro de serviço e ao quintal da residência (Figura 109). Em outras residências desse grupo observou-se que o padrão de duas águas paralelas

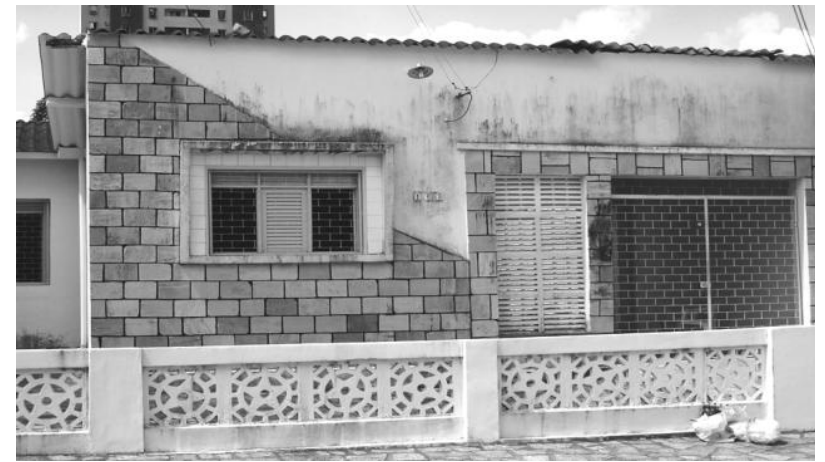

Figura 108: Residência do Conjunto Tambauzinho (IAPB1958), em João Pessoa. Fonte: Arquivo pessoal.

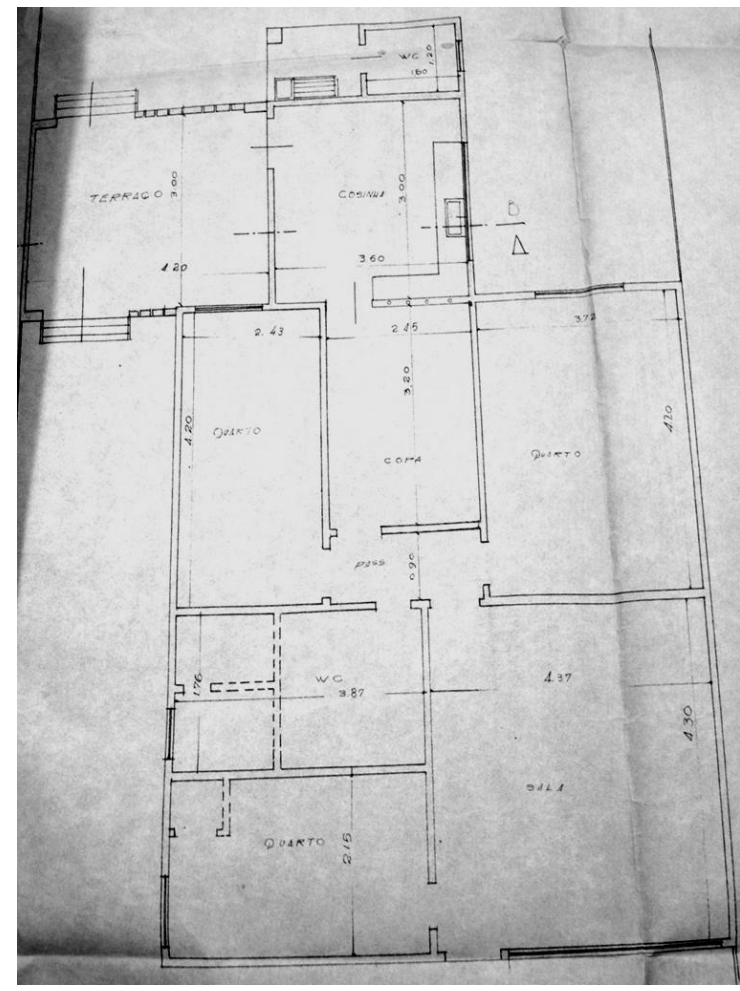

Figura 109: Planta baixa de unidade do Conjunto Tambauzinho (IAPB-1958), em João Pessoa. Fonte: INSS-PB.

490 Refere-se ao Conjunto Presidente João Pessoa ou, como ficou conhecido, Conjunto Tambauzinho. 
à via foi rearranjado, um desdobramento do modelo tradicional (Figura 110).

Em planta, referências ao elenco moderno foram percebidas nas moradias que conformam os grupos de casas Santa Júlia (IPASE-1954/1955)491, apesar da fachada remeter aos bangalôs, como colocado anteriormente. No arranjo dos cômodos, percebeu-se além da ausência de corredores e da compactação do programa, com integração da copa e da cozinha, a chamada cozinha americana ${ }^{492}$, como em poucas residências edificadas diretamente pelas CAPs e IAPs no

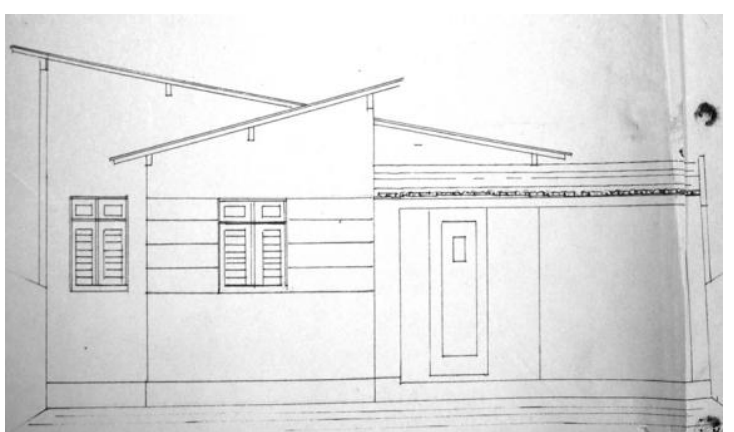

Figura 110: Fachada de unidade do Conjunto Tambauzinho (IAPB-1958), em João Pessoa Fonte: INSS-PB. Nordeste (Figura 111). A proposta de integração da sala, com copa e a cozinha, era uma solução amplamente difundida na Alemanha e na França, sobremaneira. $\mathrm{O}$ estudo detalhado dos espaços, do mobiliário e da sinomorfia da cozinha, por sua vez, foi decorrente principalmente dos trabalhos de economia doméstica norte-americana, com destaque para 0 livro publicado em 1915, por Christine Frederick e Mary Pattison ${ }^{493}$. Também foi empreendida largamente por Ernest May em suas realizações habitacionais em Frankfurt, bem como permeou diversos dos seus escritos, como no trabalho "Die Wohnung fur das Existenzminimum" (a habitação para o mínimo nível de vida), apresentado no II CIAM, sendo incorporada ao repertório moderno brasileiro.

Nesse sentido, não se é mais percebida a existência e aglutinação de ambientes denominados de sala de recepção, visita, estar e jantar. Nas moradias vinculadas à arquitetura moderna, essa

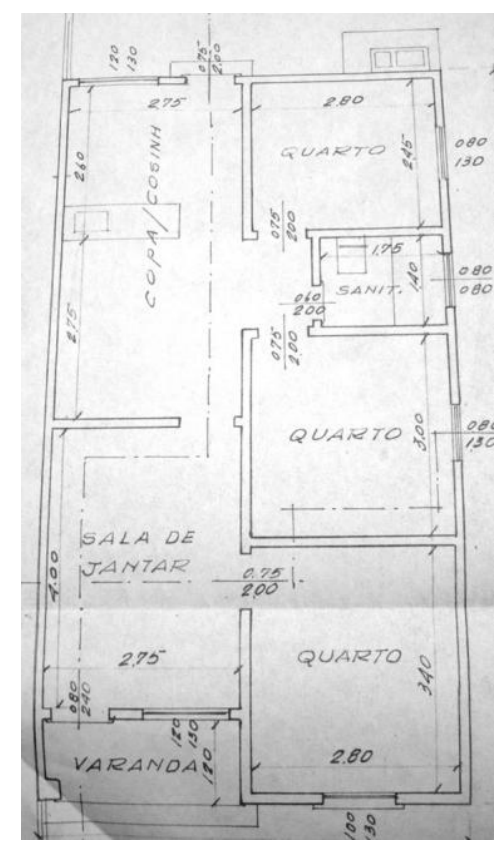

Figura 111: Planta baixa de unidade habitacional do Grupo Santa Júlia (IPASE-1955), em João Pessoa. Fonte: INSS-PB. diversidade de usos foi substituída por uma sala com grandes dimensões, quase sempre dividida em compartimento de estar e de refeição, que se convencionou chamar de sala única ou sala com dois ambientes, interligada por meio de pequena passagem ou porta corrediça, quase sempre, à cozinha. Diversas moradias seguindo essa configuração em planta foram concebidas por renomados arquitetos modernos no bairro de Weissenhof, decorrente da exposição de Stuttgart, em 1928. Como colocou Warchavchik (1928-b),

491 Terreno adquirido pelo IPASE por compra a terceiros em 04 de outubro de 1950.

492 Denominação especificada em diversos documentos que conformam os processos imobiliários, especialmente nos laudos de avaliação.

493 Uma das primeiras cozinhas a serem produzidas em série seguindo esses princípios foi concebida pela Bauhaus de Weimar, em 1923 (BRUNA, 2010). 
as divisões dos compartimentos internos não obedeciam mais os antigos padrões, o sistema de determinar para cada cômodo de uma residência uma função da vida já não era mais aceito.

Por vezes foi encontrado nos grupos de moradias de diferentes Institutos numa determinada cidade, uma aproximação e até mesmo semelhança em se tratando do partido arquitetônico (fachadas e plantas) e urbanístico dos empreendimentos. Isso ocorreu, sobretudo, na cidade do Recife, onde os conjuntos edificados pelo IPSEP e IPASE, se parecem bastante. Outros exemplos dizem respeito às Vilas Assis Ribeiro (IAPFESP-1943) (Figura 112) e J. Leonel Residente Alvin (IAPFESP-1940) (Figura 113), localizadas nos bairros de Afogados e Ibura do Norte, respectivamente.

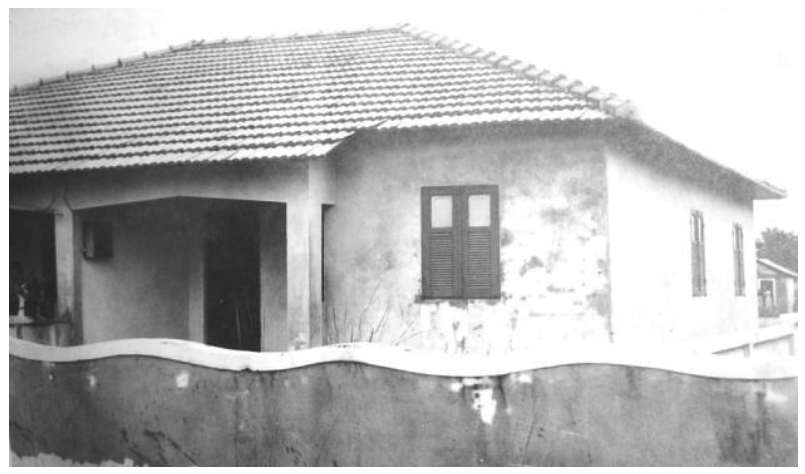

Figura 112: Residência da Vila Assis Ribeiro (IAPFESP-1943), no Recife.

Fonte: Arquivo pessoal.

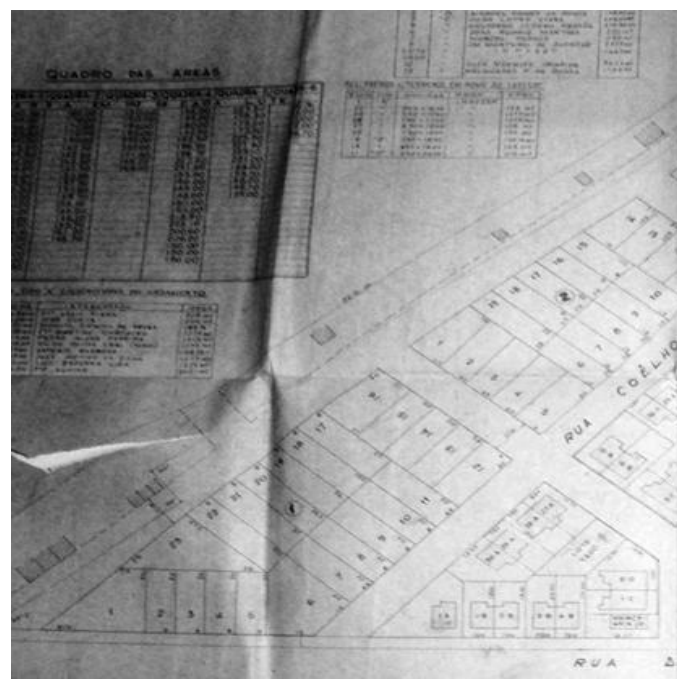

Figura 114: Planta do Conjunto Waldemar Falcão (CAPESP-1943), em Fortaleza.

Fonte: INSS-CE.

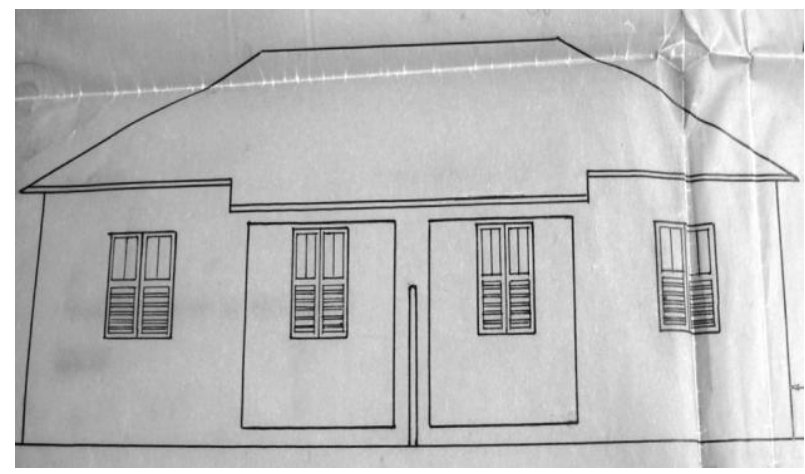

Figura 113: Fachada de moradia da Vila Residente Alvin (IAPFESP-1940), no Recife. Fonte: INSS-PE

IAP DOS FERROVIÁRIOS E EMPREGADOS EM SERVICCOS PÜBL DELEGACIA REGIONAL DO CEARÁ SETOR IMOBILIÁRIO

LEVANTAMENTO DA VILA VALDEMAR FALCÃo

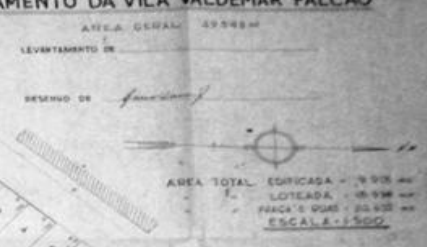

Quanto à disposição desses conjuntos no terreno, foram percebidas implantações que se davam em torno de um equipamento coletivo ou público, como uma escola, a exemplo do Conjunto Waldemar Falcão (CAP dos Serviços Públicos do CE-1943), também em Fortaleza494 (Figura 114). As 61 moradias edificadas nesse Conjunto são geminadas duas a duas e, em planta, se apresentam em três tipologias - A (30

494 O terreno de $50.000 \mathrm{~m}^{2}$ foi doado à CAP pela Rede de Viação Cearense (União), para a edificação de moradias aos ferroviários de Fortaleza, em 02 de agosto de 1938. Estava situado próximo à via férrea no sentido Barra do Ceará, no bairro do Urubu, naquela época. $O$ Conjunto ocupou apenas $30.000 \mathrm{~m}^{2}$ do terreno doado. $O$ restante foi dividido em cinco quadras loteadas nas décadas de 1940 a 1950. 
moradias), B (17 unidades) e C (14 residências) -, que variavam de acordo com o número de quartos. Além das unidades foi previsto escola, açougue/mercearia e farmácia, locados em grupo no centro do Conjunto, como defendido pelo engenheiro-arquiteto Rubens Porto em seus escritos.

Implantações que seguiam a topografia da área onde foram assentadas as edificações também foram encontradas, como no Conjunto da Mangueira (IAPB-1961), localizado no bairro de mesmo nome, no Recife. Suas cinquenta moradias geminadas duas a duas e uma escola primária foram dispostas em lotes que levavam esse aspecto em consideração, bem como a direção dos ventos dominantes e a incidência solar nas fachadas das moradias (Figura 115). Aquelas unidades habitacionais que estavam voltadas para oeste, receberam terraço em toda extensão frontal da edificação.

\section{- Moradias Geminadas em Linha:}

Como nas categorias anteriores, foram identificados diversos grupos de moradias geminadas em linha, edificados pelas Caixas e Institutos de Aposentadoria e Pensões no Nordeste, consoantes ao modelo de moradia difundido nas primeiras décadas do século $X X$. Em Natal, por exemplo, o primeiro grupo de moradias edificado por um Instituto que se tem notícias na cidade, a Vila São Pedro (IAPI-

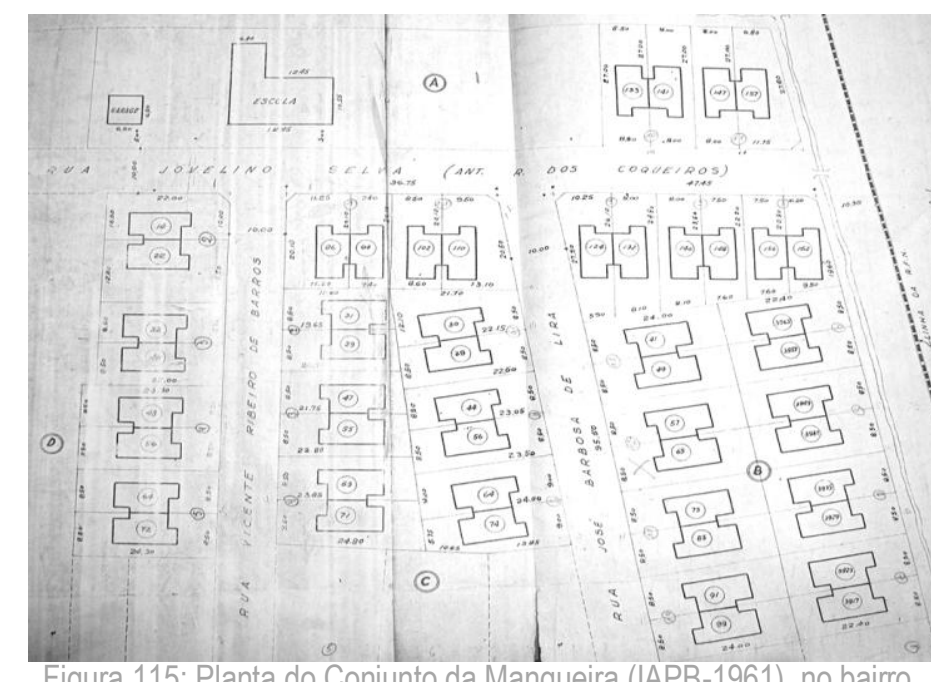

Figura 115: Planta do Conjunto da Mangueira (IAPB-1961), no bairro de mesmo nome, no Recife. Fonte: INSS-PE.

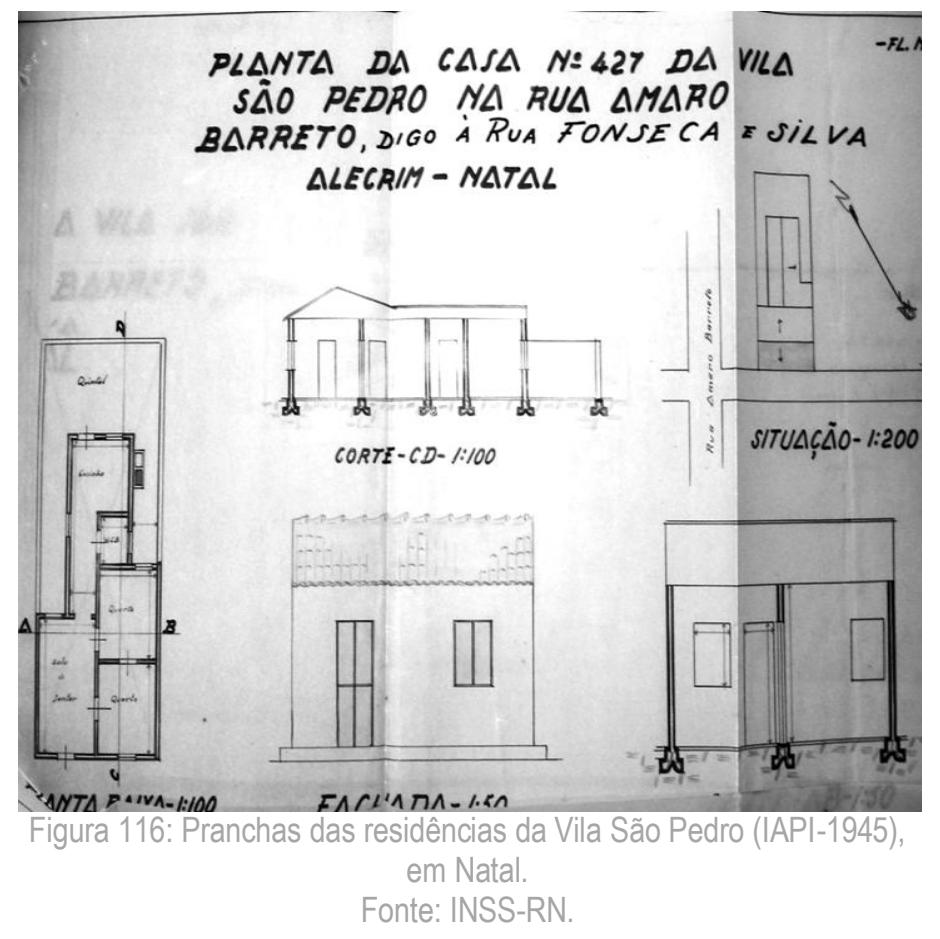
$\mathrm{RN} / 1946)^{495}$, mostra-se fiel àquela lógica do início do século XX. As nove moradias estão dispostas a frente de um pátio e são geminadas em fila com recuos laterais na parte posterior da planta, para onde se abrem as janelas de um dos dois quartos que a compõe e da sala com dois ambientes. Sobressai-se a filiação arquitetônica em planta e fachada à arquitetura brasileira do período colonial, com cômodos interligados entre

495 Vila situada no bairro de natureza comercial e residencial popular, o Alecrim. Foi edificada pelo Instituto em área adquirida por compra em 1946. Os lotes possuíam $79 \mathrm{~m}^{2}$ e as residências que a compunha apresentavam $45 \mathrm{~m}^{2}$ de área construída, sendo repassadas para os associados por meio de financiamentos sociais que variavam entre $\operatorname{Cr} \$ 26.000,00$ e $\operatorname{Cr} \$ 29.000,00$ (cruzeiros), um pouco acima da média praticada na cidade, provavelmente devido à infraestrutura e serviços que acompanhavam essa realização na cidade, bem como à sua adequação às exigências higiênicas em voga em Natal, naquela época. 
si, como pode ser percebido em se tratando dos dormitórios, com fachada tradicional do tipo porta e janela e acabamento em caiação simples (Figura 116).

Outras referências arquitetônicas também foram observadas no âmbito dos grupos das CAPs/IAPs, sobretudo, em Natal e em Salvador. Na Vila Platinick (IAPB-1947) ${ }^{496}$, as fachadas das residências fazem menções à arquitetura Decó, apresentando diversos elementos em relevo, como linhas no plano principal e no peitoril das janelas, além de platibanda escalonada adornada com falsos entalhamentos em massa (Figura 117). Apesar de se conformar como um exemplar geminado - com o banheiro locado na parte posterior do corpo da casa com acesso pela área de serviço e cômodos interligados -, em planta são percebidas inovações quando à ventilação e à iluminação graças aos recuos laterais na parte posterior da unidade (para os quais são abertas as portas e janelas dos cômodos frontais: duas salas e dois quartos), além da copacozinha, do suprimento do corredor e da existência de área de serviço coberta. Esse cômodo, em especial, não apresenta mais semelhança ao alpendre da "casa colonial", sendo dotado de lavanderia em cimento armado e área revestida com ladrilho hidráulico (Figura 118).

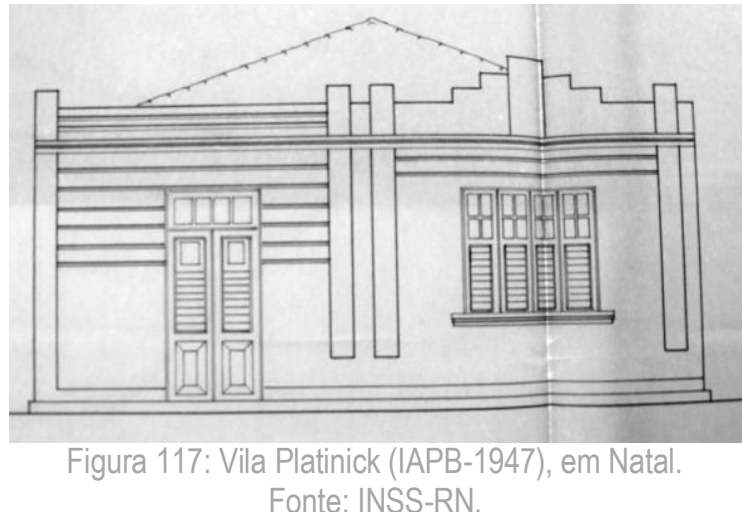

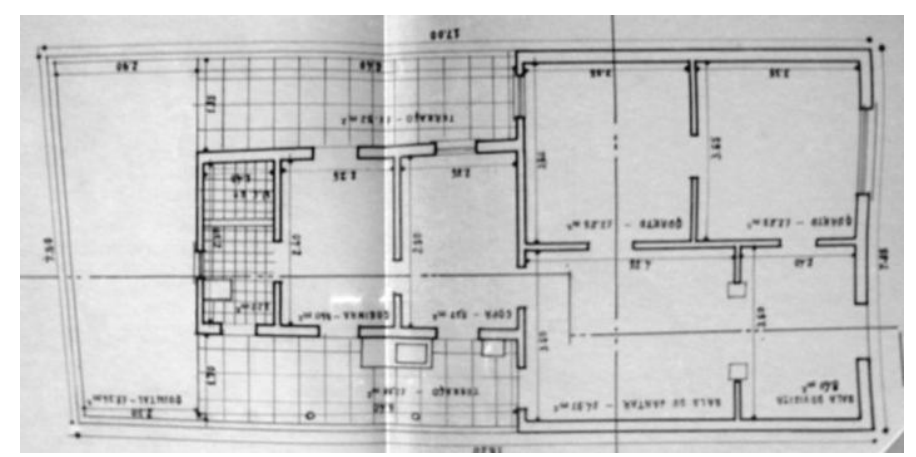

Figura 118: Planta baixa padrão da Vila Platinick, com destaque para os recuos laterais. Fonte: INSS-RN

A mesma tendência foi observada na Vila Gaspar (1940), da CAP dos Serviços Públicos dos Estados da BA e SE, locada no bairro Quintas, em Salvador ${ }^{497}$. Nela, as fachadas das residências, especialmente a platibanda escalonada e os peitoris das janelas trabalhados em gesso, remetem ao Decó. As plantas, em contrapartida, remetem ao padrão difundido no período colonial, com cômodos interligados por portas e margeando um comprido corredor. Apesar da cozinha estar incorporada ao corpo da casa, o acesso ao

\footnotetext{
496 Vila locada no bairro de Cidade Alta, tido como área valorizada na época de sua construção. Equivale também a um dos poucos exemplares que apresentaram alguma infraestrutura adequada, sendo servido de água encanada e luz, mas a canalização do esgoto despejava os detritos diretamente na via pública, ainda em fins da década de 1940. O número exato de unidades habitacionais que a compunha não pode ser precisado devido à falta de dados encontrados na pesquisa, bem como à descaracterização atual da vila. As moradias foram repassadas aos bancários abastados natalenses por meio de promessa de venda, graças a financiamentos atuariais, em média de $\operatorname{Cr} \$ 250.000,00$ (cruzeiros). Tal quantia estava bem acima daquelas apuradas nos demais financiamentos concedidos para aquisição de moradias operárias localizadas em vilas de propriedade das Carteiras Prediais, pelos Institutos e Caixas de Aposentadorias e Pensões na capital norte-riograndense. As unidades apresentavam área construída de aproximadamente $90 \mathrm{~m}^{2}$. O responsável pela sua concepção projetual também não pode ser apontado por falta de dados.

497 Vila destinada aos funcionários da Cia Energia Elétrica da Bahia. Suas unidades foram vendidas aos segurados por meio de financiamento social e destinada aos trabalhadores mais carentes. Sua estrutura era em alvenaria de tijolo simples, com uma área construída de apenas $37,42 \mathrm{~m}^{2}$.
} 
banheiro nessas moradias ainda ocorre pelo exterior, através da saída de serviço, ou porta da cozinha, como já foi colocado (Figuras 119 e 120).

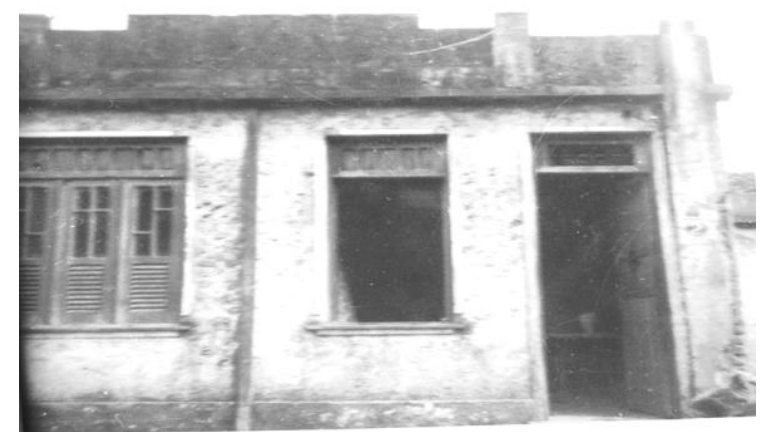

Figura 119: Residência da Vila Gaspar (CAPESP-BA). Fonte: INSS-BA.

Poucas são as variações quanto à configuração da planta ou até mesmo em se tratando do seu formato, encontradas nos levantamentos documentais realizados. Uma delas foi identificada no grupo de residências, atualmente chamado de Conjunto Nossa Senhora das Graças (IAPC-1953), situado no bairro de João Paulo, no centro da cidade de

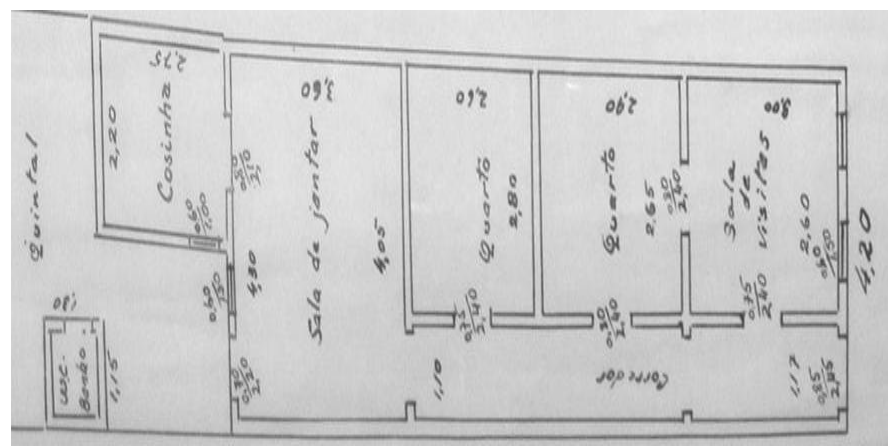

Figura 120: Planta baixa das residências da Vila Gaspar em Salvador. Fonte: INSS-BA.

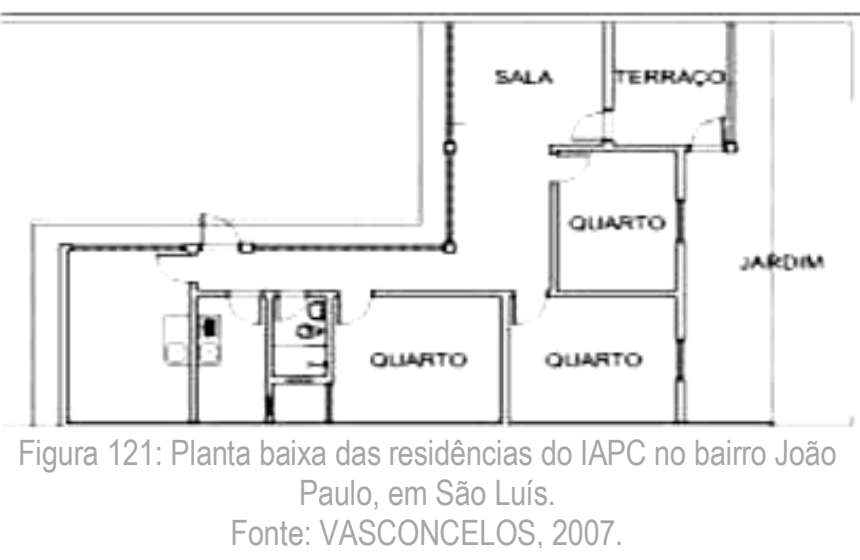

São Luís. Dentre as quarenta moradias que compõem esse conjunto há um grupo de dez residências que apresentam tanto em termos arquitetônicos quanto em planta, diferencial em relação às demais moradias edificadas pelos órgãos no Nordeste. A planta em formato de $L$ é ladeada por jardins, numa proposta de interação do espaço interno com o externo, por meio de grandes janelas e panos de vidros que margeiam a parte posterior da planta. O recuo que compõem o jardim de contemplação, situado logo após a garagem/terraço de entrada da residência, garante a ventilação e a iluminação natural de seus cômodos ${ }^{498}$ (Figura 121).

Apesar do programa dessas residências não fugir do padrão edificado nos demais grupos de moradias, a configuração da planta se aproxima das proposições e concepções associadas à ideia de organicismo e suas variações, e se distancia das plantas regulares, geralmente quadrangulares, dos institutos de previdência. Em se tratando da fachada, essas moradias se destacam do entorno e dos demais grupos que compõem o "conjunto" por diversos aspectos. O primeiro deles refere-se ao pé-direito duplo incomum na cidade, além dos grandes rasgos das janelas de vidro e madeira e suas bandeiras em brise-soleil de alvenaria que chegam até a cobertura, sustentada por mãos-francesas em madeira de lei, do abundante uso do revestimento em pedra e de treliças também em madeira que impedem a visibilidade do terraço de entrada

\footnotetext{
498 De acordo com o projeto original deste grupo de residências, em específico, dispor as plantas das dez unidades encaixadas umas as outras, numa espécie de jogo de montagem.
} 
em algumas casas e de panos de combogós, em outras. Esse artifício para o revestimento de parte da fachada principal de uma moradia foi bastante empreendido por Vilanovas Artigas em suas residências de fins da década de 1940 e dos primeiros anos de 1950, como na Casa Trostli (São Paulo-1948) e na Casa D’Estefani (São Paulo-1950). Voltando à São Luís, são ainda percebidos blocos pré-fabricados de combogós, destituídos de sua função, nos muros frontais originais daquelas residências (Figuras 122 e 123).
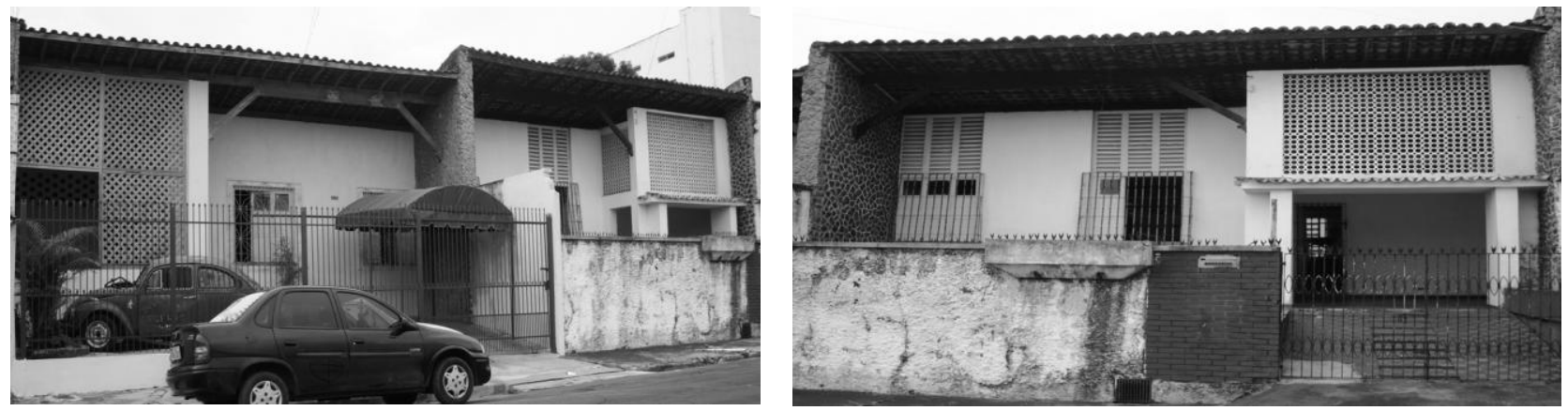

Figuras 122 e 123: Moradias em linha do Conjunto maranhense Nossa Senhora das Graças (IAPC-1953). Fonte: Arquivo pessoal.

Quanto à implantação, a maior parte dessas realizações seguia o esquema das vilas operárias do início do século, sendo dispostas geminadas ao longo de uma ou mais vias de

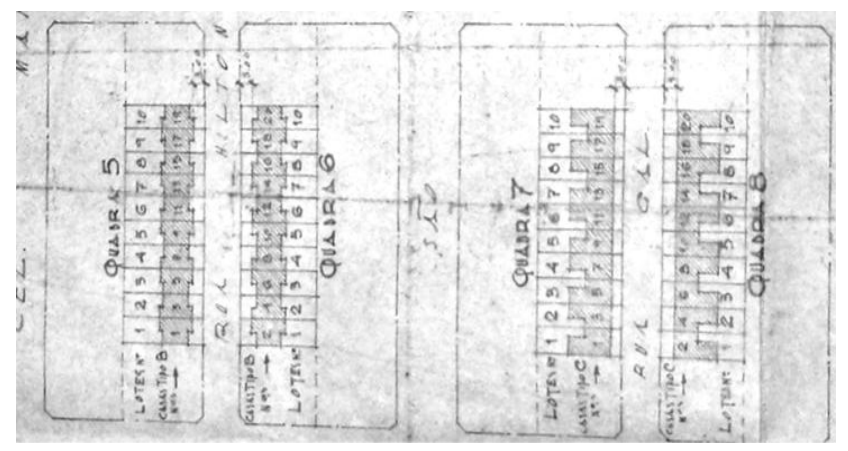
acesso, como na Vila Antônio Ferreira Filho (IAPE-1940), em Fortaleza, edificada pelo engenheiro Paulo Moreira Filho 499 (Figura 124). Outros exemplos permeiam pela configuração regular de lotes, quadras e arruamentos, como na Vila dos Estivadores, situada no bairro recifense de Santo Amaro (Figura 125), composta por seis quadras retangulares, numa das quais a implantação dos lotes residenciais

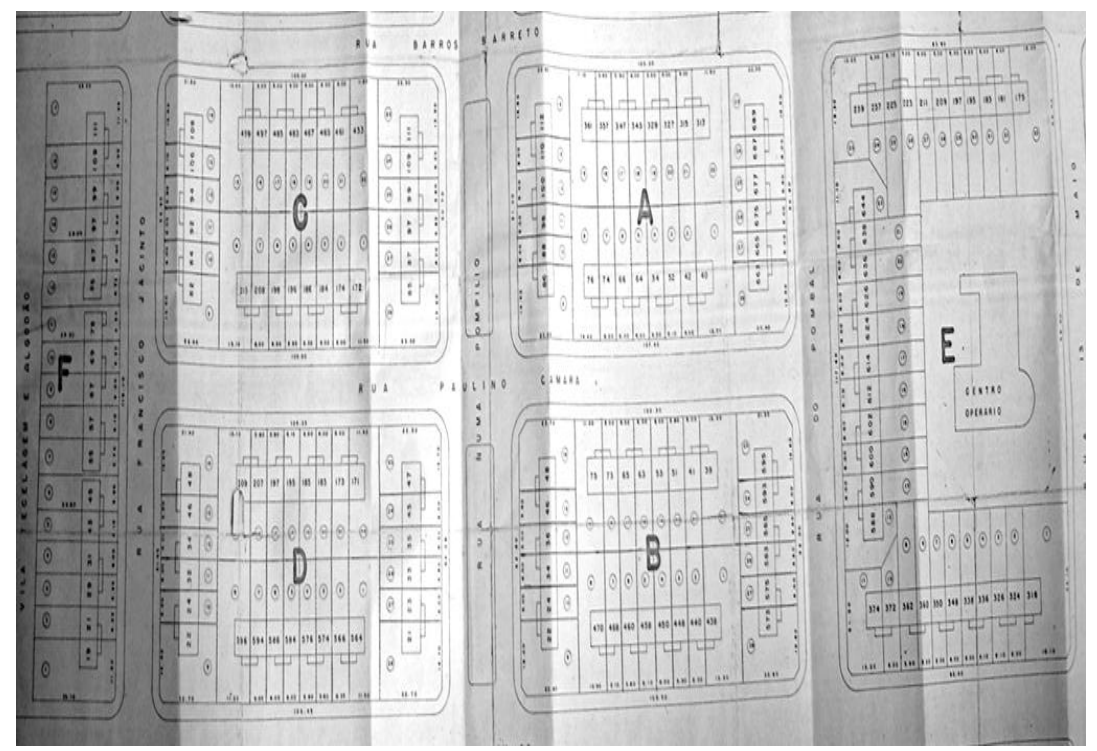

Figuras 124 e 125: Plantas das Vilas do IAPE, em Fortaleza, e dos Estivadores (IAPETC-1941), no Recife, respectivamente. Fonte: INSS-CE e PE.

499 Engenheiro encarregado da construção das unidades habitacionais do referido grupo de moradias. 0 profissional encarregado pelo projeto desse Conjunto não foi identificado por falta de dados. 0 terreno para a edificação das 56 moradias foi adquirido por compra a terceiros em novembro de 1940. As residências são compostas por varanda, sala, quarto, banheiro, cozinha e área de serviço, num total de $42 \mathrm{~m}^{2}$. 
se deu em torno do único equipamento previsto, um centro operário500. Mais precisamente, esse grupo de moradias é conformado por seis quadras especificadas de "A" a "F", projetados de acordo com a estadual Lei n.7.427 de 1961, que determinava a dimensão e disposição de lotes e glebas naquela área da cidade. Os lotes variam em tamanho de testada (de $6,00 \mathrm{~m}$ a $14,40 \mathrm{~m})$, em extensão $(20,40 \mathrm{~m}$ a $23,00 \mathrm{~m}$ ) e configuração (retangular, trapezoidal, em $L$, etc.). Sendo as quadras A, B, C e D compostas por 28 lotes, cada uma, a quadra $\mathrm{E}$ por 33 lotes em formato de "L" e um centro operário e a quadra F por 17 lotes. Eram no total 162 unidades habitacionais geminadas em blocos de 6, 8 e 11 moradias (casas com tipo de acabamento modesto e conjugada em ambos os oitões) ${ }^{501}$. No entorno da Vila, na época de sua edificação, estavam locadas a Vila Getúlio Vargas, também do IAPETC, a Vila de Tecelagem de Seda e Algodão da década de 1920/30, a Sementeira da Prefeitura e o prédio do Serviço Social Contra o Mocambo (década de 1940).

Um exemplo de conjunto de moradias unifamiliares geminadas em linha que apresentou um número considerável de equipamentos e serviços foi o Conjunto João XXIII (IAPB-1949), também no Recife, projetado e executado pelos engenheiros Caetano Francisco Durões Neto (edificações) e Clovis Eugênio de Melo (plantas de loteamento, arruamento e locações) ${ }^{502}$. Esse Conjunto ocupava uma área de $152.715 \mathrm{~m}^{2}$, dos quais, $35.219,37 \mathrm{~m}^{2}$ foram destinados às 119 unidades habitacionais ${ }^{503}$, distribuídas em oito quadras residenciais, além de uma quadra de esportes, uma praça e um parque que, por vezes, era chamado de horto504. Observando a implantação, os lotes foram dispostos de modo a acompanhar 0 arruamento préexistente, assim como, se adequar à topografia de parte do terreno (Figura 126).

\footnotetext{
500 Foi edificada pelo próprio IAPETC e o terreno foi havido por doação do Estado de Pernambuco, em junho de 1943, de acordo com a escritura. 0 projeto foi do arquiteto Fernando de Barros Borba e o desenho da planta encontrada no arquivo, de Walter Lopes. Abrange as Ruas Marques do Pombal, Barros Barreto, Pedro Afonso, 13 de Maio, Numa Pompilho, Francisco Jacinto e Paulino Câmara, no bairro da Boa Vista, na freguesia de Santo Amaro. Sendo servida de água, luz e esgoto desde edificada, além de logradouro calçado, com iluminação pública, meio-fio e arborização, em "(...) zona densamente povoada, cuja proximidade ao centro urbano justifica uma valorização progressiva (...)" (LAUDO..., 07/10/1946).

501 As moradias dessa vila seguiam o padrão tradicional do tipo porta e janela, com planta simples composta por sala, copa, cozinha, dois dormitórios, banheiro e cozinha $\left(42 \mathrm{~m}^{2}\right)$. 0 aluguel das unidades ocorreu no ano de 1941 , indicando que as unidades foram concluídas nesse ano ou pouco antes. $\mathrm{O}$ aluguel, ao contrário do percebido na maior parte dos conjuntos aqui estudados, foi realizado por tempo indeterminado, como assinalado no próprio contrato de aluguel, de 02 de setembro de 1941. 0 valor na época era de $55 \$ 800$ (contos de réis), de acordo com a Portaria SCM-334, de 24 de julho de 1940. Até o ano de 1948, ainda eram percebidas solicitações para alugar os imóveis por parte dos trabalhadores segurados. A venda das unidades para os associados que residiam nas moradias por meio do pagamento de aluguel, inserido no projeto de alienação dos imóveis dos institutos de previdência, começou a ocorrer no ano de 1966 e perdurou até 1969.

502 Abrange as Ruas Itamonte, Andirá, Urupés, Itaúna, Itamonte, Maranguape, Ipitanga, Itapetininga e Estrada do Curado, no bairro do Curado, na freguesia do Tejipó. Próximo ao Primeiro Conjunto Areias do IAPI e do IAPC. Esses empreendimentos contribuíram significativamente para a ocupação da área e para a povoação do bairro que hoje é chamado de Jardim São Paulo.

${ }^{503}$ Compostas por dois ou três quartos, varanda, sala, cozinha, banheiro, área e dependência de serviço completa, variando em quatro tipologias que se diferenciavam quanto ao tamanho do lote, à área construída, ao volume da construção e ao partido arquitetônico adotado. Sendo divididas da seguinte forma: TIPO I - 05 unidades com área de 74,20m²; TIPO II - 44 unidades com área de $96 \mathrm{~m}^{2} ;$ TIPO III - 42 unidades com 70,45m²; e TIPO IV - 28 unidades com 94,60m². Mais precisamente, eram 47 unidades com dois quartos e 72 com três dormitórios. Pelas áreas edificadas, dá para se perceber que não se tratam de residências mínimas e/ou destinadas à população de baixa renda, aspecto comprovado pelos valores atuariais praticados nos financiamentos, bem como pelos salários dos trabalhadores atendidos. Essas unidades habitacionais foram repassadas aos associados por meio de contratos de compra e venda assinados no ano de 1968, indicando que entre 1949 e 1968, os imóveis permaneceram alugados aos segurados.

504 Mais detalhadamente, o terreno era dividido em: quadra A (4 lotes $\left./ 1.100,00 \mathrm{~m}^{2}\right)$, quadra B (15 lotes $\left./ 4.050,00 \mathrm{~m}^{2}\right)$, quadra C (31 lotes e quadra de esportes $\left./ 12.4700,00 \mathrm{~m}^{2}\right)$, quadra $D\left(22\right.$ lotes $\left./ 6.851,00 \mathrm{~m}^{2}\right)$, quadra $E\left(20\right.$ lotes $\left./ 5.195,00 \mathrm{~m}^{2}\right)$, quadra $F$ (5 lotes e Continua na página seguinte.
} 
Muitos desses modelos de grupos residenciais unifamiliares foram perpetuados na década de $1960 \mathrm{e}$ nos anos posteriores, nos quais, o IPASE, como já se sabe, continuou operando no campo habitacional por meio da edificação de médios e grandes conjuntos habitacionais, compostos principalmente por unidades geminadas duas a duas, que se tornou o arquétipo para a edificação desses exemplares, no Nordeste do país. Em Natal, os três conjuntos edificados pelo IPASE na segunda metade da década de 1960, que conformam o atual Conjunto Potilândia, é um exemplo505. As mais de quinhentas residências construídas pelo órgão, no bairro de Nova Descoberta, foram concebidas em blocos duplos geminados, com varanda e janelas de frente, e empena da cobertura em telha francesa paralela às vias que compõem o Conjunto. Percebe-se que essa tipologia é um desdobramento da porta e janela ou porta e janelas, associada à cobertura com caimento para a rua, acrescentando-se a área de entrada coberta, típica das realizações das CAPs e dos IAPs no país, que acabaram por otimizar a iluminação natural e a ventilação dos cômodos iniciais do corpo da casa (Figura 127).
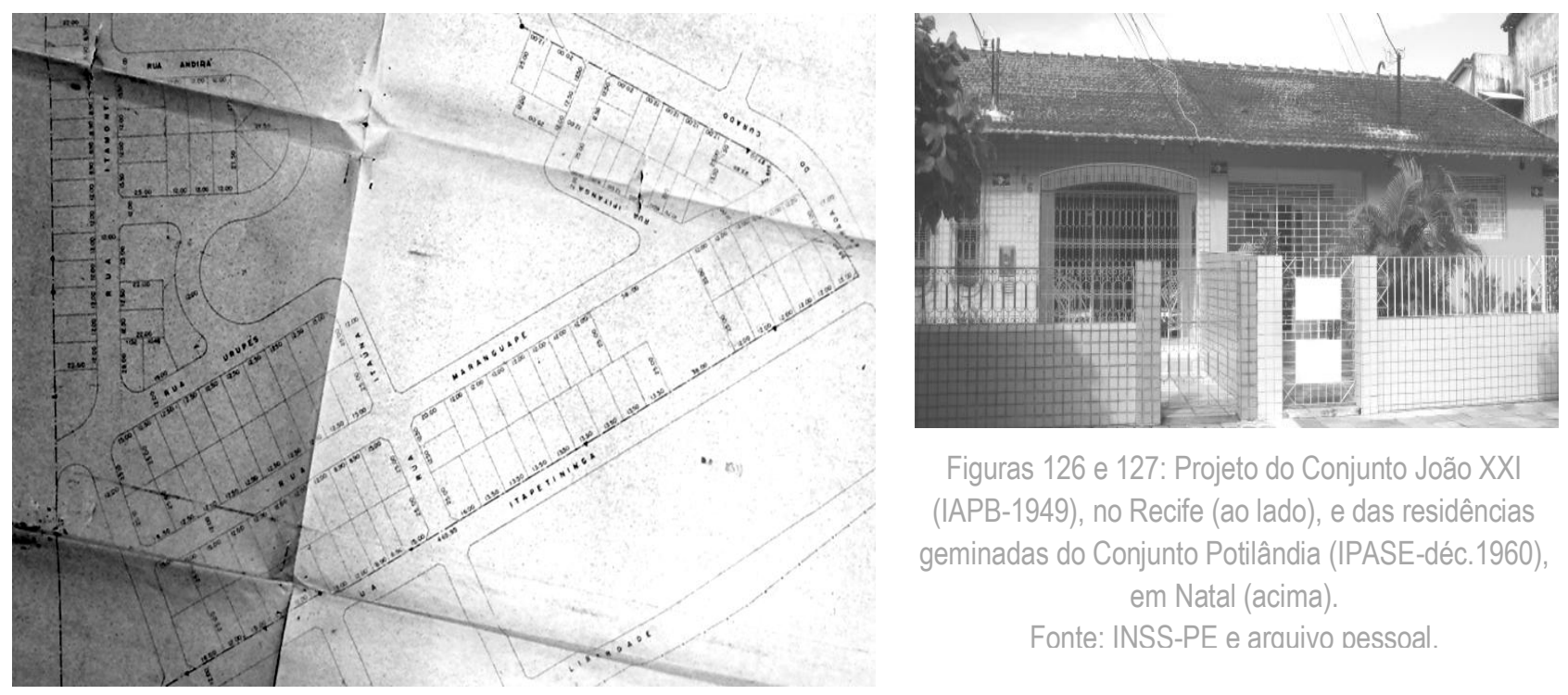

O mesmo pode-se aventar acerca da planta dessas residências, que foram frequentes a partir de meados dos anos 1960 em todo o país. Constavam, mormente, do já citado e típico terraço de entrada, sala com um ou dois ambientes, dois ou três quartos, cozinha e banheiro, geralmente totalizando 50 a $70 \mathrm{~m}^{2}$. As poucas variações diziam respeito à existência de uma segunda sala e da área de serviço, quase sempre restrita ao tanque de lavar roupas em cimento armado, locado sob o beiral da fachada lateral ou posterior, para onde se abria a porta de serviço, a chamada porta da cozinha. Por vezes, o terraço de entrada apresentava dupla função, de abrigo das intempéries e garagem para automóvel, aumentando em área quando ocorria. $\mathrm{O}$ piso em taco de madeira, a telha cerâmica, os ladrilhos hidráulicos em cores marcantes e 0

praça/2.601,00m²), G (17 lotes $\left./ 4.031,00 \mathrm{~m}^{2}\right), \mathrm{H}\left(14\right.$ lotes $\left./ 4.420,00 \mathrm{~m}^{2}\right)$ e horto $\left(3.047 \mathrm{~m}^{2}\right)$. Os lotes possuíam diferentes configurações e dimensões.

505 Moradias com área construída em torno de $50 \mathrm{~m}^{2}$, compostas por terraço de entrada, sala, dois quartos, cozinha e banheiro. 
forro em concreto também se tornaram recorrentes a partir de meados da década de 1960, no Nordeste do país.

\section{- Tipologias Mistas Unifamiliares:}

De acordo com as formulações do engenheiro-arquiteto Rubens Porto, a combinação de diferentes tipologias habitacionais unifamiliares num grande conjunto residencial era adequada por atender de modo homogêneo às necessidades de diferentes famílias de trabalhadores, especialmente em se tratando do número de filhos e da renda. Esse modelo de conjunto também foi defendido por diversos outros profissionais no país, merecendo destaque as proposições do já citado engenheiro Marcello Taylor Carneiro de Mendonça, defensor da empregabilidade do conceito howardiano de Cidade-Jardim. Em sua concepção, nos agrupamentos habitacionais dever-se-ia evitar a uniformidade, que equivalia a um grave erro nas concepções desse tipo, uma vez que tornava o ambiente "(...) banal e monótono", não incitando o trabalhador a adquirir 0 imóvel (MENDONÇA, 1931, p.144). Os profissionais deveriam, nesse sentido, trabalhar com agrupamentos distintos e originais, como casas isoladas e agrupadas, no número máximo de oito.

Como evidenciado nas demais categorias de análises de grupos unifamiliares construídos pelos Institutos e Caixas, algumas realizações em muito se assemelhavam às vilas operárias do início do século, recebendo inclusive essa denominação, como foi o caso das Vilas Operárias dos Marítimos (IAMP-1963)506 e dos Ferroviários (CAPESP/IAPFESP-1955) em Cabedelo-PB, mesmo tendo sido edificadas ao longo das décadas de 1950 e 1960. No que tange especificadamente à Vila Ferroviária, é interessante observar que em planta diversas diretrizes da arquitetura moderna foram incorporadas, como a integração do banheiro e da cozinha ao corpo da casa, a ausência de circulações na forma de corredor, a singularidade do programa e das dimensões da residência $\left(47,55 \mathrm{~m}^{2}\right)$ e a área de serviço dotada com lavanderia em cimento armado. No entanto, o acesso ao banheiro social ainda se dava pela área de serviço, no exterior da residência (Figuras 128 e 129).

Referências mais sóbrias foram evidenciadas em São

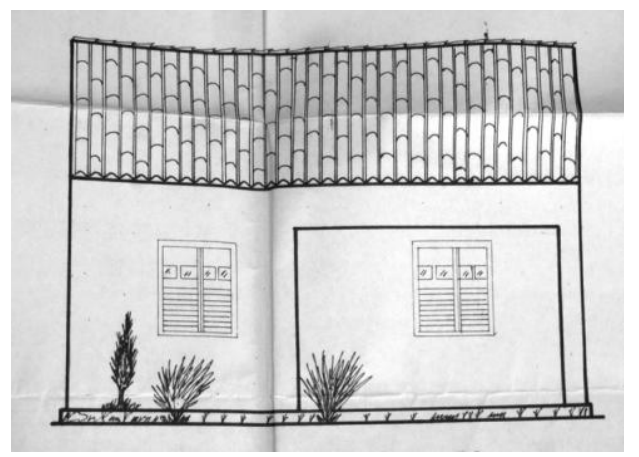

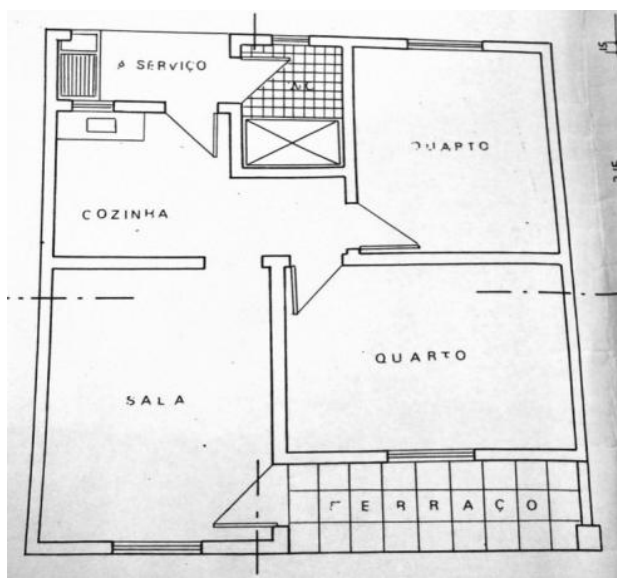

Figuras 128 e 129: Fachada e planta baixa das moradias da Vila Ferroviária em Cabedelo-PB. Fonte: INSS-PB.

506 Vila conformada por 81 residências dispostas em uma área de $14.755,90 \mathrm{~m}^{2}$ de propriedade da União (terreno da Marinha). 
Luís, principalmente em se tratando das fachadas das residências que compõem o Conjunto José Bonifácio (IPASE- 1953) ${ }^{507}$, no bairro de Vinhais, projetado pelo arquiteto recifense Beraldo Dário Borges. Se distanciando das realizações mais comumente encontradas nesta pesquisa, as unidades habitacionais do tipo B e C apresentam fachadas conformadas basicamente por linhas retas, num plano de parede limpo e a cobertura em laje plana de concreto armado508 (Figuras 130 e 131). As unidades assobradadas também apresentam referências à arquitetura moderna, de linhas e ângulos retos, na qual, os pilares e as aberturas dos terraços de entrada e da varanda frontal dão movimento à fachada principal da edificação por meio do jogo de cheio e vazios. Percebe-se ainda a utilização do concreto armado nas lajes de piso (Figura 132). Essas unidades atenderam, como especificado nos processos levantados e documentos sobre 0 empreendimento, desde os segurados mais abastados - que passaram a residir nas casas do tipo $A$, com dois pavimentos - até aos trabalhadores mais carentes.
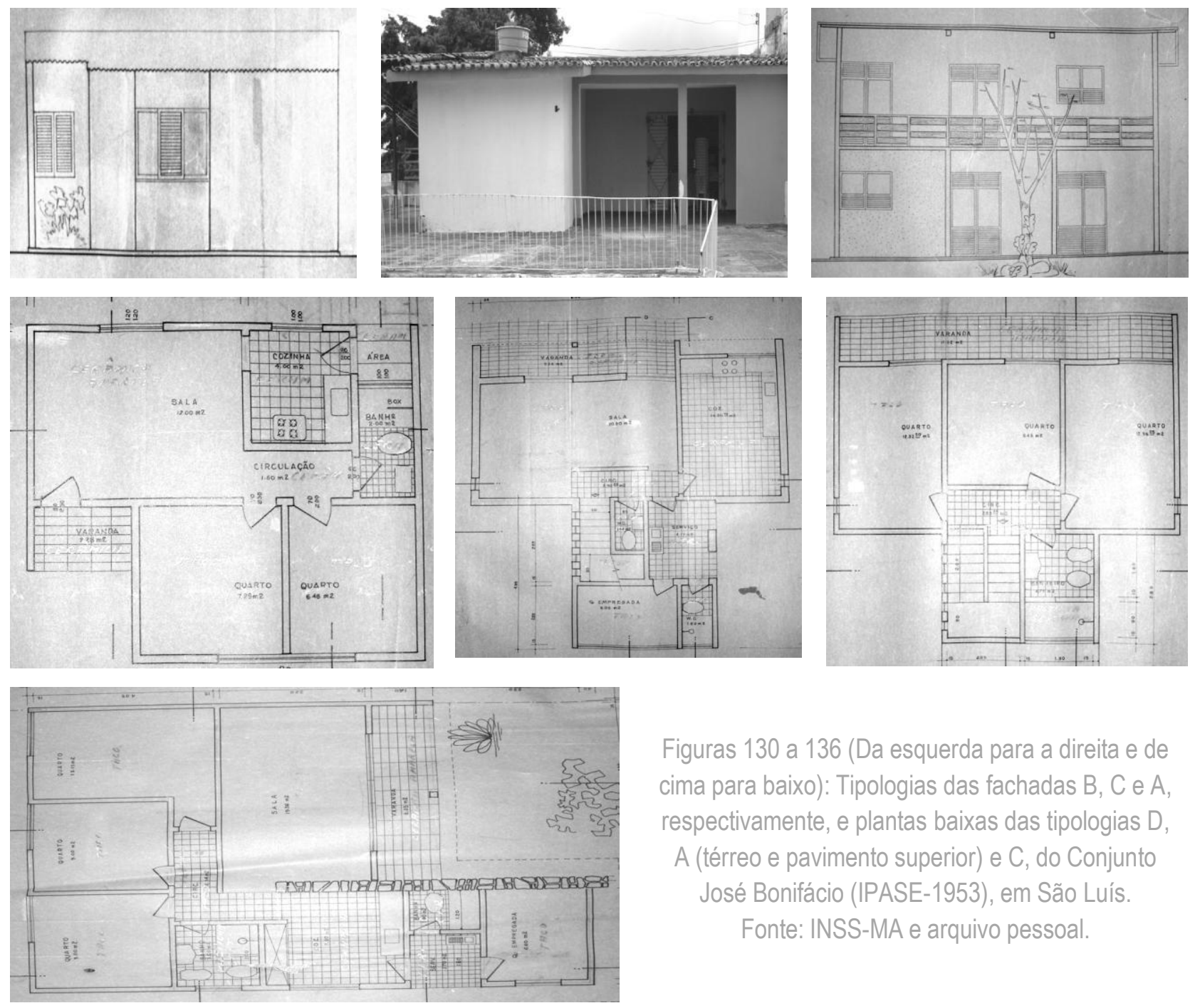

Figuras 130 a 136 (Da esquerda para a direita e de cima para baixo): Tipologias das fachadas B, C e A, respectivamente, e plantas baixas das tipologias $D$,

A (térreo e pavimento superior) e C, do Conjunto José Bonifácio (IPASE-1953), em São Luís.

Fonte: INSS-MA e arquivo pessoal.

507 Conjunto edificado para os funcionários públicos estaduais do Maranhão ao longo das décadas de 1950 e 1960. Composto por um total de 536 unidades habitacionais, que variavam em quatro tipologias, dentre isoladas, geminadas duas a duas, com dois pavimentos, e outras variações quanto à planta, em relação ao número de dormitórios (um a quatro quartos), com ou sem área e dependências de serviços.

508 Alterações posteriores realizadas nas casas do conjunto acrescentaram coberturas em telha canal ou de fibrocimento às lajes modernas. 
Observa-se, dessa maneira, uma hierarquização da ocupação habitacional nesse conjunto, típica das vilas operárias, nas quais, os tipos de moradias existentes eram distribuídos aos operários de acordo com 0 cargo ocupante na fábrica. Acredita-se que o fato desses grupos residenciais terem sido tão comuns na cidade até a década de 1950, esse aspecto tenha sido incorporado nas realizações dos IAPs em São Luís, especialmente em se tratando das fileiras das casas geminadas, muito próximas ao observado na Vila Passos, no Retorno da Fabril e na Vila Gracinha, no bairro Madre de Deus, como colocado por Vasconcelos (2007). As configurações das plantas que compõem esse Conjunto também se distanciam um pouco do que era comumente encontrado nas realizações dos institutos de previdência atuantes no Nordeste do país. Apresentavam disposições de ambientes que conformavam plantas com formatos em L ou T (Figuras 133 a 136, página anterior). Em se tratando da implantação desse conjunto, podem ser feitas aproximações à concepção de bairros-jardins e à unidade de vizinhança, com vias de maior fluxo estruturadoras do conjunto margeando-0, adaptação das construções e vias às curvas de nível do terreno ${ }^{509}$, existência de boulevard central com canteiros bem arborizados, além de muitas praças e áreas verdes e algumas ruas cul-de-sac (Figura 137).
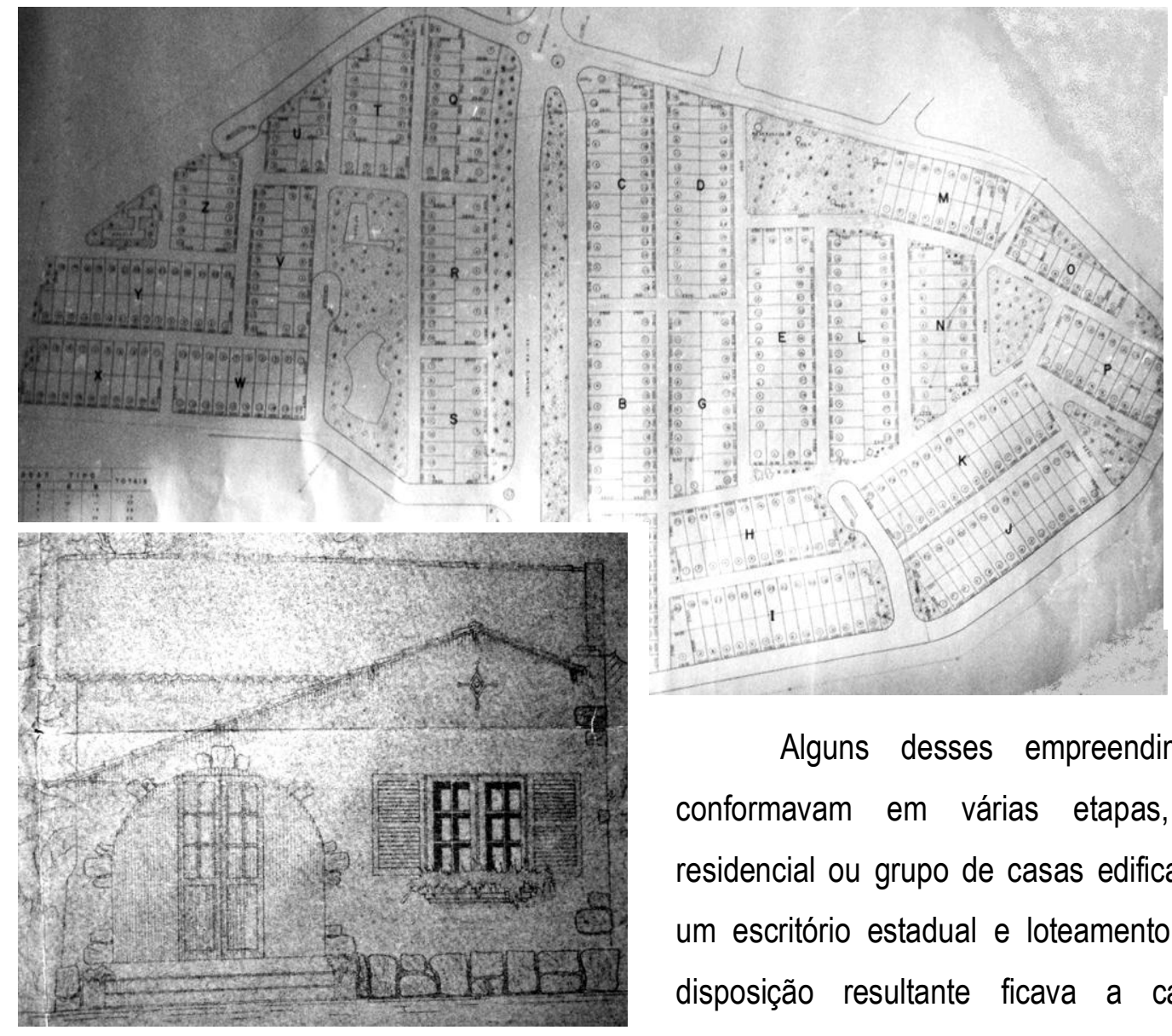

Figura 137 (ao lado): Implantação do Conjunto José Bonifácio (IPASE1953), em São Luís. Fonte: INSS-MA.

Figura 138 (ao lado e abaixo): Fachada das residências da primeira etapa do Conjunto Henrique Eboli (CAPESP), em Natal. Fonte: INSS-RN

Alguns desses empreendimentos mistos se conformavam em várias etapas, abrangendo vila residencial ou grupo de casas edificado diretamente por um escritório estadual e loteamento, cuja arquitetura e disposição resultante ficava a cargo dos próprios segurados. Esse foi o caso do Conjunto Henrique Eboli (CAPESP-RN/1945), no bairro natalense do Alecrim, composto por uma vila de dez casas, um conjunto

509 Como operado por Carlos Frederico Ferreira no Conjunto Jardim Piratininga (IAPI-1946), em Osasco-SP. 
residencial edificado pelo órgão com trinta unidades habitacionais e um loteamento composto por mais trinta lotes. A Vila inicial apresenta referências em planta à arquitetura tradicional, com cômodos interligados e fachadas com paredes duplas, e em fachada ao Missões, devido ao terraço com arcadas e apliques em pedra na fachada principal, beirais e jardineiras (Figura 138). Em 1948 foram concluídas outras trinta residências, geminadas duas a duas ${ }^{510}$. Essas possuíam planta mais íntima à arquitetura moderna, não apresentando corredores especialmente, mas a fachada continuou a se filiar à tradicional porta e janela, com variação apenas nas águas da cobertura $^{511}$ (Figura 139).

Alguns desses conjuntos apresentavam uma grande diversidade de tipologias de planta e fachada, como foi o caso do Conjunto Sítio da Roseira (IPASE-1948), situado no bairro de Rosarinho, no Recife. Grupo composto por 96 moradias isoladas e geminadas duas a duas, divididas entre popular isolada e geminada (média e boa) ${ }^{512}$, atendendo a diferentes faixas de renda dos servidores do estado de Pernambuco,

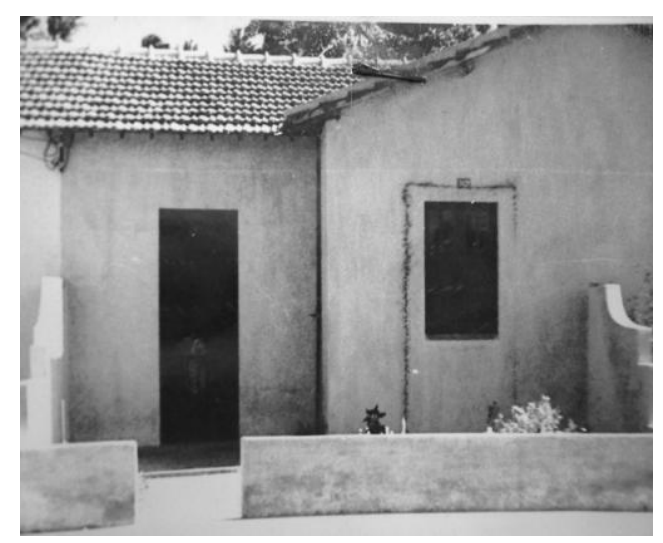

Figura 139: Residências da segunda etapa do Conjunto Henrique Eboli, em Natal. Fonte: INSS-RN. como preconizado por Rubens Porto em seu manual de edificação de conjuntos habitacionais (Figuras 140 a 142). Seguindo as sugestões e balizas elaboradas por esse engenheiro-arquiteto, o Conjunto conhecido ainda como Roseira, também foi locado em área afastada da cidade, onde os valores dos terrenos eram mais acessíveis; o que possibilitou a aquisição de uma grande gleba para a sua concepção.
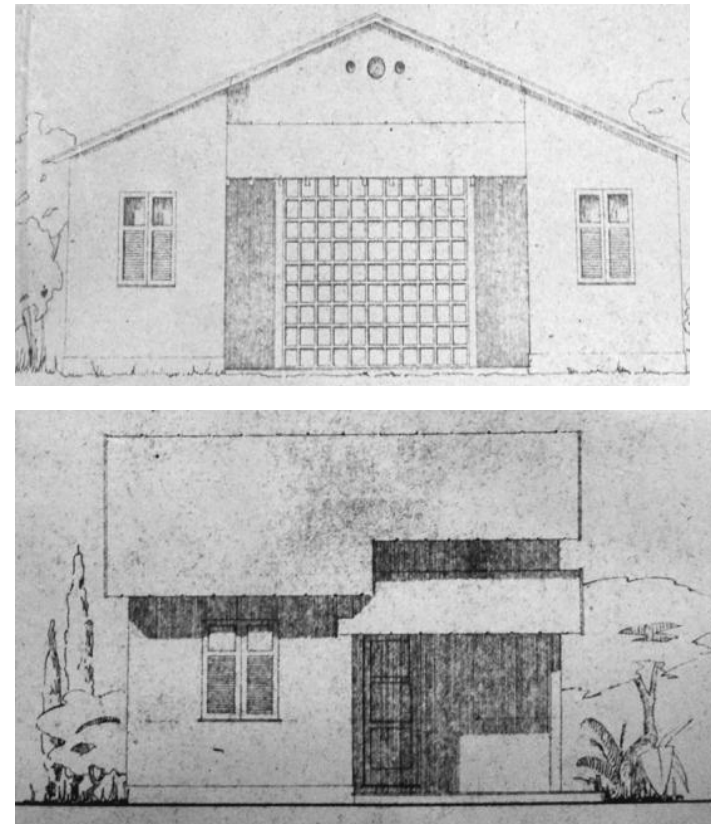

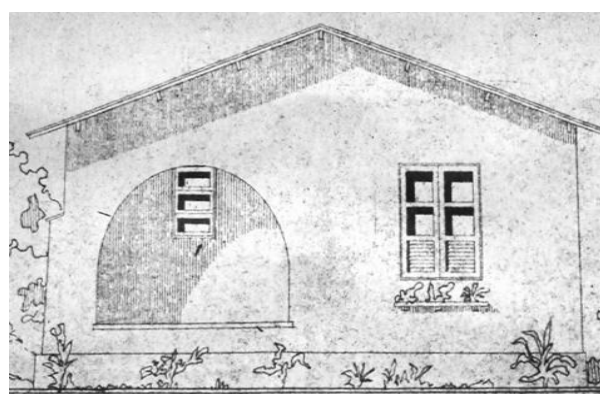

$$
\begin{gathered}
\text { Figuras } 140 \text { a 142: } \\
\text { Tipologias } \\
\text { habitacionais } \\
\text { verificadas no } \\
\text { Conjunto Sítio do } \\
\text { Rosário (IPASE- } \\
\text { 1948), no Recife. } \\
\text { Fonte: INSS-PE. }
\end{gathered}
$$

Nesta categoria de análise também foram percebidas parcerias entre os IAPs e CAPs e outros órgãos, como aquela entre o IPE (Instituto de Previdência dos Servidores do Estado do Rio Grande do Norte), a FCP,

5100 terreno onde foram edificadas as 30 residências da segunda etapa do conjunto, bem como o loteamento posterior, foi doado pelo Interventor Federal do Rio Grande do Norte, em 1946, de acordo com o Decreto-Lei n.655, de 13 de dezembro daquele ano. Essas moradias foram disponibilizadas, sobretudo, aos funcionários da Repartição de Saneamento de Natal, por meio de venda financiada com valores entre Cr $\$ 24.000,00$ e $\mathrm{Cr} \$ 50.000,00$ (cruzeiros).

511 As moradias resultantes do financiamento para edificação por iniciativa dos trabalhadores (loteamento) apresentaram variações tanto em planta e implantação, quanto em fachada.

512 Como especificado nos laudos de avaliação das unidades, bem como nos documentos relacionados ao supracitado Conjunto. 
a FUNDAHP (Fundação de Habitação Popular do RN) ${ }^{513}$ e outros agentes financiadores nacionais e internacionais, como a Caixa Econômica Federal, a SUDENE (Superintendência de Desenvolvimento do Nordeste) $)^{514}$ e a USAID (Aliança para o Progresso) ${ }^{515}$, nos primeiros anos da década de 1960, para a edificação do primeiro grande conjunto residencial da cidade, a Cidade da Esperança ${ }^{516}$. Na primeira etapa do conjunto, edificada em terreno doado pelo Governo do Estado e projetada pelo arquiteto Ubirajara Galvão517, constavam noventa unidades reservadas aos segurados do IPEP518. Essa etapa, o referido arquiteto seguiu 0 padrão urbanístico de zoneamento de funções, de acordo com as premissas em voga na década de 1960519 . Observa-se a valorização dos passeios (com grandes dimensões) e das esquinas, que receberam tratamento especial e foram utilizadas como jardins bem arborizados e espaços para convívio social, não sendo ocupadas com lotes residenciais. Para além das quadras regulares residenciais, havia ainda duas superquadras destinadas a abrigar os equipamentos coletivos, com $278 \mathrm{~m}$ e $316 \mathrm{~m}$ de largura e comprimento

\footnotetext{
513 No Rio Grande do Norte, assim como em diversas localidades do país, a administração estadual se mostrou contra a política da FCP e de cobrança de taxas sobre a venda e transmissão de bens que seriam arrecadados pelo Estado, decretada na segunda metade da década de 1940, em decorrência da criação do órgão. Como forma de coibição foi criada a Fundação da Habitação Popular do Rio Grande do Norte (FUNDHAP). Esse órgão permaneceu inoperante até 1963, quando passou a atuar no campo habitacional norte-riograndense, graças à outorga do Decreto Estadual n.1.102, de 12 de agosto de 1963. A FUNDHAP passou então a buscar objetivos no estado, que em muito se assemelhavam aos da Fundação da Casa Popular (ALMEIDA, 2007).

514 Criada diante da perpetuação da precariedade econômica e social em que se encontrava a maior parte das cidades do Nordeste, em 1959. O propósito principal desse órgão era o de substituir a política assistencialista, até então desenvolvida, por medidas mais sociais a fim de modificar a região, com a implantação de obras de infraestrutura, desenvolvimento industrial e reestruturação agrária. Foi a partir, principalmente da sua criação, que a industrialização começou efetivamente a ser implementada nessa região do país.

515 A USAID surgiu em fins da década de 1950 durante uma reunião dos países americanos em Punta Del Este e equivalia à aliança entre esses países e o governo norte-americano para a execução de projetos assistencialistas e julgados urgentes. No Brasil, os projetos eram repassados pelos governos estaduais à SUDENE e por ela, entregues à Comissão nos EUA. A Aliança brasileira passou quase um ano inativa após a assinatura do convênio. Teve início propriamente no Nordeste, mais especificadamente pelo estado do Rio Grande do Norte, para o qual foi destinado inicialmente vinte e cinco milhões de dólares para a execução dos planos de educação e moradia previstos pelo prefeito Djalma Maranhão e os governadores Dinarte Mariz e Aluízio Alves (ALMEIDA, 2007). A solução dos problemas vinculados à moradia e à habitação naquele estado foi considerada pelo Ministro Tancredo Neves como uma solução pioneira e muito útil como experiência para os convênios dos demais estados brasileiros (ALVES, 2001). Foi formulado nesse sentido o Plano de Habitação Popular do Rio Grande do Norte, que previa a edificação de 3.000 moradias populares na capital, nos primeiros anos da década de 1960 (ALMEIDA, 2007). De acordo com a GAP (1985), a Aliança para o Progresso começou a destinar recursos para o campo habitacional aos demais estados do Brasil, a partir do ano de 1961. 0 assassinato do presidente Kennedy em 22 de novembro de 1963 deu início à desmobilização da USAID.

516 Construído de acordo com as especificações do Plano de Habitação Popular do CED, que previa a construção de mais de 300.000 moradias populares no estado, além de melhoramentos na infraestrutura e serviços para atender essas unidades. Foi projetado em duas etapas executadas entre os anos de 1963 e 1974.

517 Conformada por quinhentas moradias, espaços verdes para uso comum, equipamentos comunitários e uma Igreja.

518 Órgão criado em 1961, no âmbito do I Plano de Previdência dos Servidores, que compunha o I Plano de Desenvolvimento Econômico e Social do Rio Grande do Norte, elaborado pela Comissão Estadual de Desenvolvimento (CED), instituída pelo governador Aluísio Alves (o principal relator da LOPS também na década de 1960), naquele ano. Os objetivos desses órgãos e Planos estavam relacionados à superação da "estagnação" econômica a qual o estado se encontrava em virtude essencialmente da precariedade da infraestrutura existente, da escassez de recursos e do baixo nível de renda da população. Para a sua implementação, o governo criou o Fundo de Desenvolvimento Econômico e Social (FDES), por meio da Lei n.2.795 de 1962, conformado essencialmente pelos recursos advindos do Imposto Sobre Vendas e Consignações (ALMEIDA, 2007). Vale ressaltar, que até a instituição deste órgão, só havia na capital norte-riograndense pequenos grupos residenciais de até 100 unidades habitacionais, construídos ou adquiridos pelas CAPs e pelos IAPs ou vilas militares edificadas na cidade a partir da II Guerra Mundial.

$519 \mathrm{~A}$ área possuía aproximadamente $120.000 \mathrm{ha}$. Para os lotes foi reservada uma parcela equivalente a $47,11 \%$ do terreno, isto é, 43,81 ha. As vias de circulação tanto de pedestres quanto de automóveis correspondiam a uma área de 18,08ha (19,44\%), enquanto aos equipamentos comerciais e comunitários foram reservadas parcelas de 0,87ha $(0,94 \%)$ e 12,69ha (13.65\%), respectivamente. Havia ainda 7,65 ha $(8,13 \%)$ destinados às áreas verdes e 9,98ha (10,75\%) às áreas livres.
} 
de 44m. Em planta e nas publicações do memorial do projeto, encontradas nos periódicos locais, percebe-se nessa primeira etapa uma aproximação urbanística desse empreendimento à unidade de vizinhança de Clarence Perry ${ }^{520}$. Em se tratando das unidades, elas apareceram em tipologias isoladas e geminadas duas a duas, em três modelos distintos: o chamado "embrião", com apenas um dormitório; e casas com dois ou três quartos, a serem aplicadas quaisquer que fosse a orientação do lote. Essas primeiras moradias do tipo porta e janelas foram construídas com material doado por empresários, pela população em geral e financiados pelas parcerias, e foram erguidas sob a forma de mutirão, composto pelos moradores a serem beneficiados $^{521}$, que se conformou uma prática construtiva posteriormente (Figura 143).

\section{- Moradias Coletivas:}

Tipologia habitacional evidenciada desde fins do século XIX, no âmbito de teorias, propostas e modelos urbanísticos filiados, mormente, à noção de cidade ideal. Essas formulações elaboradas com o intuito de solucionar o problema da moradia

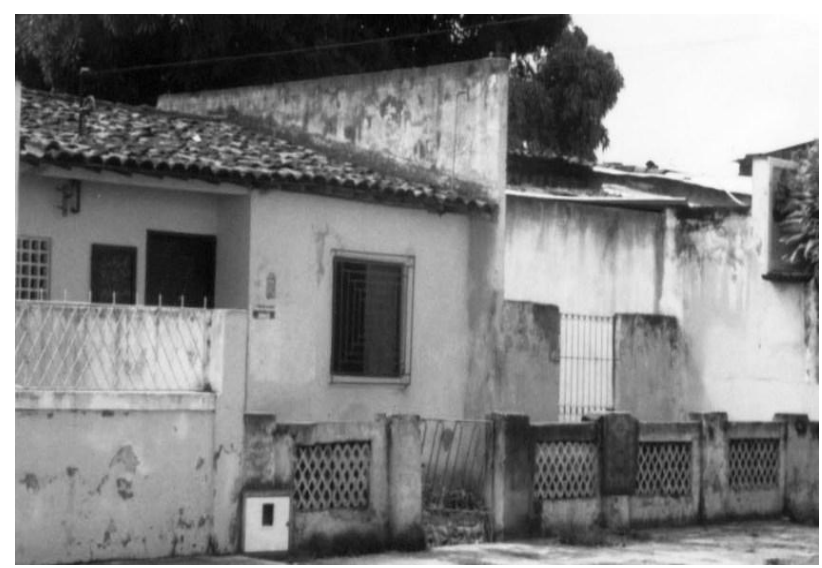

Figura 143: Residência do IPE (1964), no Conjunto Cidade da Esperança em Natal.

Fonte: Arquivo pessoal.

e da cidade, diante do rápido crescimento e péssimas condições de salubridade e habitabilidade evidenciadas, foram retomadas e analisadas nas primeiras décadas do século seguinte, especialmente nos anos de 1920, no contexto de reconstrução da Europa no Pós-Primeira Guerra e da ascensão das sociaisdemocracias. Debates acerca do papel e da responsabilidade social do Estado para com os problemas urbanos e dos profissionais engenheiros e arquitetos para com a moradia, também se tornaram recorrentes a partir de então. Essas temáticas ganharam representatividade, sobretudo, nos Congressos Internacionais de Arquitetura Moderna (CIAMs) ${ }^{522}$, nos anos seguintes. Modelos habitacionais verticais como os preconizados por Charles Fourrier no Falanstério e Tony Garnier em sua Cidade Industrial, além dos exemplares das

\footnotetext{
${ }^{520}$ Apenas na primeira etapa do projeto, que consta de amplas áreas de lazer, verdes e de uso comum, a influência do urbanismo moderno se mostra mais clara.

${ }^{521}$ Essa foi uma das exigências da USAID para a concessão do financiamento para a construção da primeira etapa do Conjunto. Nesse contexto, os moradores não desprenderiam recursos para a aquisição de residências e, em troca, ofereceriam a mão de obra.

522 Esses eventos propunham, mais precisamente, a transformação da estrutura social e econômica partindo da célula da habitação que deveria ser condizente com o "período maquinista", pelo qual, os centros urbanos europeus vinham passando. Questões como, renda mínima, valor de aluguel, custo da construção, padrões de conforto, redução de circulação interna, agrupamento e dinamização de atividades numa residência, sobretudo a feminina, assim como, normas construtivas e relacionadas à urbanização, foram quesitos amplamente discutidos nesses Congressos. Novos modelos de moradias e de conjuntos residenciais foram propostos. Diversos deles enfatizaram a organização do bloco, as vias de acesso e circulação de pedestres e automóveis, a área ocupada pela edificação, o volume resultante da construção, a abertura de janelas e o número de camas. Foi difundida a concepção de edifício coletivo com grandes alturas e serviços centralizados, atendendo ao problema de grande adensamento das cidades. Essas edificações deveriam apresentar, no geral, estruturas independentes dando liberdade para concepção de plantas e fachadas. No âmbito urbano, desde a Declaração de La Sarraz, que marcou o início das atividades dos CIAMs, tratou-se da necessidade de substituição da ocupação e divisão caótica da terra e da especulação imobiliária por uma política de terra coletiva (AYMONINO, 1973; FRAMPTON, 1997).
} 
comunas soviéticas, höfes e siedlungens europeias, formulações e ações como as empreendidas por Ernest May, Gropius e Le Corbusier, entre outros profissionais, tiveram impacto e refletiram na atuação de profissionais e no debate acerca da moradia coletiva vertical no Brasil, e foram reportadas para novos modelos habitacionais de conjuntos residenciais, de bairros e até mesmo de cidades ${ }^{523}$.

Outra importante fonte de contribuição para a concepção de conjuntos de moradias coletivas verticais, nesse contexto, foram os Neues Bauen, que desenvolveram pesquisas com ênfase na identificação/desenvolvimento de inovações projetuais voltadas para a produção de unidade mínima, de unidades padrão e o agrupamento delas, como também para o funcionalismo e propostas de equipamentos complementares à moradia. Para Bruna (2010), esses arquitetos adotaram a habitação operária coletiva como a temática central de atuação. Propunham que os profissionais arquitetos abandonassem as posturas subjetivas oriundas, em sua concepção, das preocupações exclusivamente estéticas, e se dedicassem às formas científicas para a solução do problema da habitação. Nesse sentido, a moradia deveria ser edificada por meio de técnicas e concepções formais muito diversificadas, de traços comuns, que compunham uma nova tipologia arquitetônica, materializada na Alemanha, essencialmente, pelo siedlungen. Merece destaque, nesse quadro, a atuação do já citado arquiteto Ernest May524 na Alemanha, que se configura como importante referência para diversos profissionais no âmbito das CAPs e dos IAPs.

De modo geral, no Brasil, desde as últimas décadas do século XIX até por volta da década de 1940, vislumbrou-se certa resistência à produção de habitações coletivas devido à imagem negativa que era associada a essa tipologia habitacional, principalmente, relacionada a questões de ordem moral e de privacidade (CORREIA, 2004). Profissionais, como o engenheiro Bruno Simões Magro, compartilhavam dessa ideia, e acrescentavam que a concepção da torre de apartamentos também deveria ser evitada por questões de ordem higiênica (MAGRO, 1931). Se por um lado, as habitações coletivas eram largamente criticadas pela proximidade entre vizinhos, por outro, eram defendidas pelos termos de redução de custo no processo construtivo e com transporte, por solucionar o problema da alta densidade dos bairros e das cidades, e por favorecer as relações em comunidade, baseadas em grande parte, nas experiências das sociais-democracias e provenientes dos primeiros CIAMs. No âmbito mais específico das CAPs e dos IAPs, essa tipologia era aconselhada quando o terreno fosse escasso e quando se visasse obter, além do bem

\footnotetext{
523 Outras formulações que contribuíram para a reforma da moradia no Brasil foram dadas pelos estudos e publicações da Bauhaus. Criada por Walter Gropius permaneceu na cidade de Welman até 1926, quando foi transferida para Dessau, concomitantemente ao início do projeto de recuperação econômica do país. A produção era voltada para a concepção de protótipos industriais aplicados na arquitetura, além de móveis e outros objetos. A partir da década de 1930, a administração da Escola foi assumida por Mies van der Rohe, que direcionou a Bauhaus para um viés mais técnico e formal no setor construtivo (KOPP, 1990). Na ideologia dessa escola alemã no campo arquitetônico, os binômios forma-função e economia-eficiência estavam comumente presentes, nos quais, a habitação mínima era tida como instrumento para se alcançar um novo modo de vida e um novo comportamento social.

$524 \mathrm{O}$ referido arquiteto foi responsável pelo programa habitacional de Frankfurt, junto ao poder público, a partir de fins da década de 1910. Projetou diversos conjuntos como o Praunheim, o Römerstadt e o Westhausen, que totalizam aproximadamente 4.000 unidades habitacionais. Diversas inovações plásticas e construtivas foram observadas nesses exemplos de moradia social coletiva, merecendo destaque o mobiliário projetado e a cozinha de Frankfurt (BRUNA, 2010).
} 
estar das camadas mais carentes, uma boa renda para o capital empregado (MENDONÇA, 1931), como se verá mais detalhadamente a diante.

As primeiras inclinações projetuais no campo da moradia social no país foram para a tipologia habitacional da moradia unifamiliar isolada no terreno, com grande quintal, como colocado no primeiro tópico deste capítulo. Foi após 1930, sobretudo, que os conjuntos coletivos ganharam campo de produção no país. Essa mudança se deu, para além das formulações decorrentes dos debates internacionais, devido à atuação e produção de alguns arquitetos e engenheiros brasileiros. Para Attílio Correia Lima, uma das importantes figuras nesse sentido, as casas isoladas com seus espaços livres e jardins representavam depósitos de velharias e remetiam aos tempos e costumes arcaicos, enquanto os conjuntos coletivos produzidos em série, densos, possibilitavam às vantagens da produção industrial em massa, baixando 0 custo da construção e elevando o padrão da unidade de habitação, assim como, possibilitando a edificação de grandes equipamentos de uso coletivo e de lazer em concordância com os novos parâmetros da vida moderna (LIMA, 1963).

Alguns eventos realizados no Brasil tomaram a moradia coletiva como escopo importante, é também contribuíram para a intensificação da edificação de blocos de apartamentos. Dentre eles pode-se apontar o já citado IV Congresso Pan-Americano de Arquitetos, de 1930. O Congresso foi organizado em oito temáticas ${ }^{525}$, pelas quais os aspectos relacionados a essa tipologia de moradia foram abordados e importantes conclusões foram formuladas nesse sentido, especialmente na temática III: "o arranha-céu e a sua conveniência sob vários aspectos: higiênico, econômico, social e estético". Na qual, recomendou-se a realização de estudos e a "(...) edificação cooperativa, ou seja, a divisão das casas por andares e departamentos, por venda fraccionada, como uma das formas para resolver o problema residencial urbano para operarios e empregados (...)" (ABREU, 1930, p.55-56) $)^{526}$.

Mais detalhadamente, a primeira sessão do evento cujo título traduzia um tema bastante controverso na época, "Regionalismo e internacionalismo na arquitetura contemporânea - a orientação espiritual da arquitetura na América", contou com a participação de alguns profissionais brasileiros, dentre eles 0 engenheiro Flávio de Carvalho527, que apresentou seu ideal de cidade, no trabalho "A cidade do homem nu", por meio do qual, criticou não somente a cidade e as edificações que estavam sendo concebidas até aquele momento, como também todo o estilo de vida da população, reprimida e arraigada de preconceitos advindos

\footnotetext{
525 Eram elas: regionalismo e internacionalismo na arquitetura contemporânea - a orientação espiritual da arquitetura na América (tema I), o ensino da arquitetura (tema II), o arranha-céu e a sua conveniência sob vários aspectos: higiênico, econômico, social e estético (tema III), a solução econômica do problema residencial (tema IV), urbanismo e arquitetura paisagística (tema V), a regulamentação da profissão de arquiteto - um arquiteto para época presente (tema VI), defesa do patrimônio artístico, principalmente arquitetônico, das nações americanas (tema VII), organização dos concursos nacionais e internacionais de arquitetura (tema VIII), como julgar a tendência da moderna arquitetura - decadência ou ressurgimento? (tema IX) e parques escolares, universitários, hospitalares, esportivos e de diversos (tema X) (ABREU, 1930).

526 Já vale ser frisado que, a partir da década de 1950 principalmente, a venda fracionada de unidades habitacionais dos conjuntos coletivos verticais, sobremaneira, foi incorporada nas ações imobiliárias empreendidas pelas Caixas e Institutos de Aposentadoria e Pensões no país.

${ }^{527}$ Estudou engenharia e pintura na Inglaterra, retornando ao Brasil em 1923 (GUERRERO, 2010).
} 
principalmente da Igreja Católica e do pensamento burguês, que impediam o progresso (CARVALHO, 1932). O engenheiro propunha, nesse contexto, uma transformação total do homem e de sua moradia ${ }^{528}$, que deveria ser racional e pensada em conjunto com aos avanços da ciência como as comunas soviéticas, abdicando-se do modelo unifamiliar529 (CARVALHO, 1931).

Naquele momento, professores, pensadores e autônomos envolvidos com a construção civil do Brasil e de outros países participantes do evento já atentavam para a necessidade das municipalidades regulamentarem a edificação e a localização dos arranha-céus, considerando-os sob os pontos de vista da insolação, da circulação, da estética 530 e da perspectiva urbanas, sendo aconselhável submeter os projetos a uma comissão oficial531 (ABREU, 1930). Essa proposta em muito se assemelha aos objetivos base do CNT, no âmbito das CAPs, desde os primeiros anos da década de 1920 e, posteriormente, dos IAPs do MTIC. Esse assunto também mereceu especial atenção no I Congresso de Habitação (1931) e permeou por todas as discussões e formulações do Congresso, especialmente em se tratando da sessão intitulada "habitações coletivas (casas de apartamentos, inquilinos e proprietários)". Nela, concluiu-se que os modelos habitacionais coletivos deveriam ser empreendidos de modo semelhante àqueles edificados na Alemanha. Novamente foram vislumbradas referências diretas às realizações de Ernest May e aos siedlungens.

Diversos outros profissionais se empenharam em pensar e propor novas soluções para a moradia urbana brasileira, especialmente coletiva532. Na década de 1940, o já citado arquiteto Attílio Corrêa Lima fortemente influenciado pelos postulados modernos, adotou a tipologia de moradia coletiva para os operários, como o modelo condizente com o desenvolvimento industrial e com o progresso científico daquele tempo. A residência unifamiliar, segundo o arquiteto, só deveria ser adotada quando a questão econômica não correspondesse a um fator preponderante no projeto. No parecer inicial do arquiteto para a Cidade Operária da Fábrica Nacional de Motores, elaborado no ano de 1941, percebe-se com mais afinco suas diretrizes construtivas. Nesse sentido, Attílio defendia a produção em série de blocos residenciais com quatro pavimentos, distanciados uns dos outros por parques cuja dimensão correspondia a duas vezes à altura do edifício, dotados de lavanderias e cozinhas coletivas centralizadas. As unidades habitacionais deveriam variar entre 35 e $70 \mathrm{~m}^{2}$ (considerada área ideal para uma família com cinco membros), com sala, cozinha e quartos

\footnotetext{
528 Chamada pelo arquiteto de habitação para o homem antropofágico (ANAIS..., 1930).

529 Sua cidade era uma espécie de constelação de laboratórios e centros distribuídos em círculos concêntricos (GUERRERO, 2010). Na cidade do homem nu não existiriam os conceitos de propriedade. No primeiro anel estaria o centro de pesquisas (composto pelo centro de gestação e o centro hospitalar), anexo a ele estaria o centro de ensino e orientação do novo homem e 0 centro erótico, onde estariam dispostos os centros de alimentação e religião, de acordo com o mecanismo freudiano. A locomoção seria toda subterrânea e a administração centralizada. As residências seriam organizadas pelas necessidades do novo homem e situadas em locais apropriados. Fora da "grande máquina" estariam as indústrias e os campos de produção (CARVALHO, 1931). As moradias deveriam ser concebidas de acordo com a nova arquitetura, sem referências ao passado e sem adornos.

530 Em particular deveria ser exigido o tratamento arquitetônico de todas as fachadas visíveis da edificação vertical (ABREU, 1930).

531 Essa comissão seria dotada de poder de libertação e veto de construção (ABREU, 1930).

532 Em contrapartida ao ceticismo de profissionais como Oscar Niemeyer, para o qual a habitação barata não se mostrava um atrativo e/ou desafio projetual, e Vilanova Artigas, que encarava a questão como artifício da burguesia para sua sobrevivência (CAVALCANTI, 1986).
} 
(CORREIA, 1999). Percebe-se também em suas diretrizes uma aproximação com as formulações de Gropius no segundo e terceiro CIAM em relação à moradia coletiva, e da cidade-jardim vertical de Le Corbusier.

Vale aqui lembrar, que o engenheiro-arquiteto Rubens Porto não se mostrava a favor das tipologias coletivas verticais para as famílias numerosas dos trabalhadores. Em sua concepção, como já colocado no segundo capítulo desta tese, o mais adequado para esses casos era a edificação de núcleos de moradias unifamiliares em áreas distantes do centro urbano, dotadas de serviços e equipamentos públicos de modo a torná-los autossuficientes ${ }^{533}$.

Uma resistência ainda maior a essa tipologia foi percebida no Nordeste, inclusive no âmbito dos próprios Institutos e Caixas atuantes na Região, como pode ser averiguado em carta enviada ao Presidente do IAPC, no Rio de Janeiro, pelo delegado do escritório estadual do Instituto no Recife, em 1949, em se tratando do primeiro projeto apresentado para a construção do Edifício Capibaribe na cidade:

(...) As plantas (...) do Edifício Capibaribe não satisfazem ao meu ver as condições requeridas para a habitação no Nordeste. 0 agrupamento de muitos apartamentos por andar, o que se verifica no projeto, não é bem recebido em nosso meio. 0 nordestino ainda habituado à vida em casa individual, não aceita a moradia coletiva, principalmente quando o número de vizinhos é numeroso. A diversidade de tipo de apartamento também verificada no projeto, é fator outro que afastará candidatos, visto que os pequenos apartamentos são preferidos sempre por pêssoas solteiras, e de vida, às vezes, irregular. Questão predominante nas habitações do Nordeste é a ventilação. 0 projeto aprovado se ressente dessa particularidade. A situação de apartamentos que não tenham a visão para a rua principal dá ao nordestino a impressão de constrangimento e de reclusão. (...). Consta o projeto aprovado de uma enorme área de corredores, servidos por três elevadores comuns ao serviço e ao transito de moradores. Esta disposição é sempre condenável e motivo para desvalorização do edifício (CARTA..., 04/07/1949, p.01).

Analisando-se essa citação, diversos aspectos que se colocavam contra a concepção habitacional coletiva vertical são percebidos. A primeira observação a se fazer é que o projeto acima descrito ia ao encontro das diretrizes construtivas e arquitetônicas formuladas por Rubens Porto para empreendimentos dessa envergadura e tipologia habitacional. $O$ projeto do Edifício Capibaribe se mostrava adequado àquelas especificações projetuais e foi submetido à aprovação do delegado e do presidente do IAPC, em fins da década de 1940, recebendo parecer desfavorável. Mais precisamente, o bloco seria destinado aos solteiros segurados do IAPC na capital pernambucana, com um número considerável de pavimentos, de apartamentos e diferentes configurações de planta, além de localizado em área central da cidade, mas, mesmo assim, não agradou ao corpo técnico daquele Instituto. Esse aspecto revela que não era unânime a concordância desse modelo habitacional, proposto pelo referido engenheiro-arquiteto do CNT, por alguns profissionais com poder de decisão alocados em certas instituições previdenciárias no país, como no caso acima citado do IAPC-PE. Outro aspecto aponta que o parecer, favorável ou não, para a edificação de unidades verticais de moradias coletivas dependia também da região geográfica do país na qual o empreendimento seria locado. Percebe-se

533 Rubens Porto preconizava a moradia coletiva vertical, especialmente locada no centro, para os segurados solteiros e/ou para casais sem filhos, como já colocado no segundo capítulo desta tese. 
também, a perpetuação de um discurso arraigado de estigmas, como a associação do "ser solteiro" às atividades de natureza duvidável. Dessa forma, aventa-se que a questão cultural pertinente à sociedade nordestina e os estigmas associados a ela, especialmente presentes no imaginário de algumas figuras com força de deliberação no âmbito dos órgãos, como o presidente ou o delegado de um determinado escritório estadual, contribuíram significantemente para a adoção preterível de unidades unifamiliares nas capitais aqui estudadas.

Antes de discorremos acerca dos empreendimentos habitacionais verticais edificados pelas delegacias regionais dos institutos de previdência no Nordeste é importante destacar que, ao contrário do que foi vislumbrado no centro-sul do país, essa produção não se concentrou na construção da supracitada tipologia de moradia. Esses empreendimentos nas capitais do Rio de Janeiro e em São Paulo, sobretudo, já estavam inseridos no contexto de verticalização daquelas cidades, enquanto no Nordeste, essas realizações foram pontuais e contribuíram para o início desse processo e/ou o intensificaram. Na maior parte das cidades estudadas, os conjuntos ou edifícios coletivos verticais identificados foram a exceção da atuação das CAPs e dos IAPs no campo habitacional. Em cidades como Natal, João Pessoa e São Luís, foi construído apenas um conjunto ou prédio residencial, em outras, como em Teresina, não foi encontrado nenhum exemplar concebido até meados da década de 1960. Naquelas cidades, dividiam o cenário vertical essencialmente os edifícios sedes das delegacias regionais dos Institutos e Caixas. Em Natal, o edifício do IPASE se enquadra nesse contexto, como se verá adiante.

\section{- Edifícios isolados:}

Apesar de terem construído diversos exemplares de moradia coletiva vertical no Nordeste do país, foram poucos os que se referiam a prédios isolados e, mais reduzido ainda, o número de edifícios que apresentavam altos gabaritos, locados especialmente nas cidades de João Pessoa e do Recife. De modo geral, esses exemplares foram edificados, sobretudo, pelo IAPC e pelo IAPB, mas ao contrário do que alguns autores colocam, como Bonduki

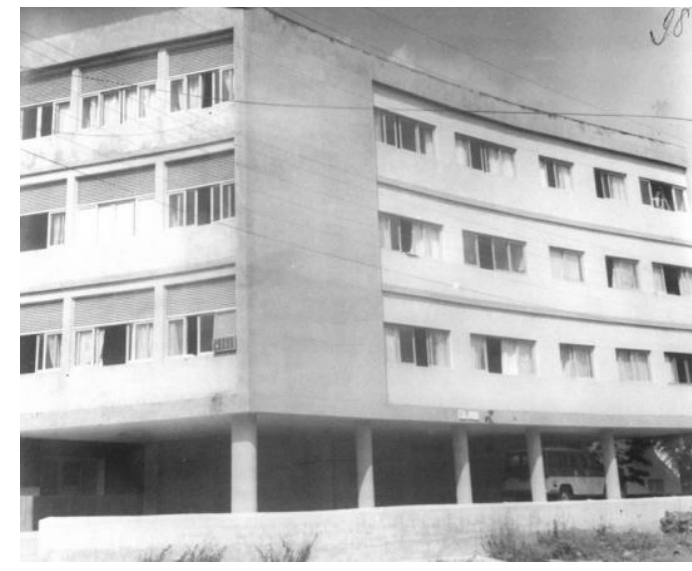

Figura 144: Edifício Joia (IAPB-1950), em Boa Viagem, no Recife. Fonte: INSS-PE. (2002) e Bruna (2010), no Nordeste, essas tipologias não foram projetadas para os trabalhadores urbanos solteiros e/ou de classe baixa. Diziam respeito, sobretudo, a grandes apartamentos com três quartos e áreas construídas que se aproximavam dos $100 \mathrm{~m}^{2}$, vendidos por meio de empréstimos atuariais, quase sempre, e destinados às famílias abastadas. Esses empreendimentos foram situados, essencialmente, em áreas centrais ou em bairros residenciais destinados às camadas populares de maior renda, alguns mais afastados, como foi o caso de prédios encontrados em Boa Viagem, no Recife. Um exemplo, nesse sentido, foi o Edifício Joia (IAPB-1950), composto por dez unidades habitacionais, com $80 \mathrm{~m}^{2}$ de área construída, tidas como de 
luxo, distribuídas em três pavimentos encimados de pilotis de seção circular, com dupla função de garagem e espaço para convívio (Figura 144).

A maior parte dos edifícios verticais identificados nos levantamentos realizados é representada por edifícios onde são desenvolvidas mais de uma atividade. O Edifício Presidente João Pessoa (IAPB-1957), localizado na capital de mesmo nome, é um dos mais interessantes exemplos nesse sentido534. Conformavase como o único exemplar do gênero na cidade, comportando em uma mesma estrutura as funções de morar, comercial e institucional, nos dezoito andares mais elevados da época ${ }^{535}$. 0 prédio, cujo projeto foi de autoria do arquiteto carioca Ulysses Petrônio Burlamaqui, foi construído inicialmente para abrigar a delegacia do IAPB na cidade de João Pessoa, segundo com acordo firmado com 0 governo do estado, em meados da década de 1950536. O referido Edifício foi situado na área mais valorizada da cidade, naquele momento, próximo às repartições públicas, centro bancário e comercial, colégios, cinema, pronto socorro, etc. Locado em um terreno de $1.037,10 \mathrm{~m}^{2}$, apresenta uma área construída de aproximadamente $10.000 \mathrm{~m}^{2}$ (Figura 145). Era originalmente conformado por jardim frontal, playground, 49 apartamentos ${ }^{537}$ servidos por duas torres com dois elevadores cada uma, espaço para a delegacia do Instituto, para uma escola de música, um ambulatório para atender aos bancários segurados do IAPB, além de pontos comerciais. Um dado interessante acerca dessa construção refere-se ao temor da população pessoense em ocupar as suas unidades, especialmente devido ao alto gabarito do prédio, não percebido até então na cidade, bem como à topografia do terreno no qual foi implantado, com considerável inclinação, como especificado em alguns laudos de avaliação dos apartamentos ${ }^{538}$.

Em se tratando do volume da edificação, são observados dois grandes blocos quadrangulares regulares, em forma de paralelepípedo, edificados em sentidos opostos, 0 primeiro horizontalmente e 0 segundo vertical (Figura 146). Percebe-se, assim, o claro emprego do binômio forma-função corbusiano, no qual, a mudança de uso é
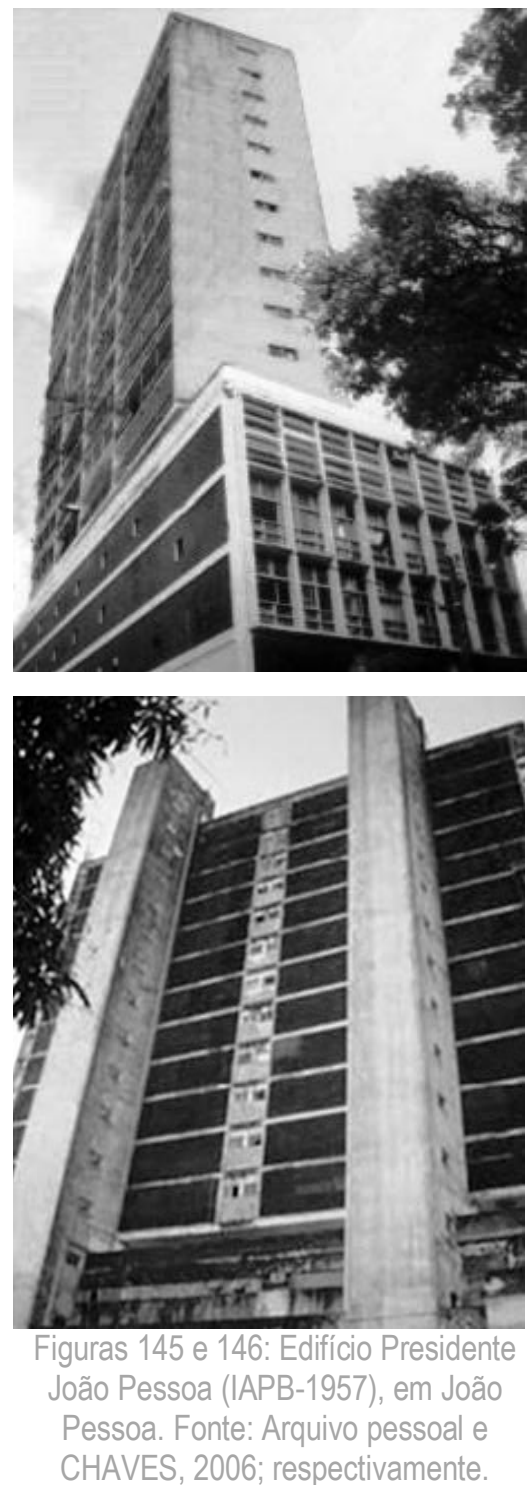

534 Localizado na Av. General Osório, no bairro Varadouro (centro), em área tombada como patrimônio histórico de João Pessoa. Vale ressaltar que não foi encontrado nenhum outro conjunto residencial coletivo na capital paraibana.

535 Há menções de bloco com doze pavimentos e dezesseis pavimentos nos laudos de avaliação dos imóveis. No entanto, não se sabe se essa imprecisão de dados refere-se a mudanças no projeto, a diferentes projetos concorrentes ou a um simples erro no registro da informação.

${ }^{536}$ Terreno doado pelo Governo do Estado da Paraíba, de acordo com escritura lavrada em cartório, em 18 de fevereiro de 1957.

537 Dispostos em número de quarto apartamentos por andar, nos doze pavimentos destinados à moradia.

538 Segundo Chaves (2006), essas habitações permaneceram praticamente inabitadas até 0 ano de 1962. 
acompanhada por distinções no volume da edificação e/ou por seu tratamento formal, por meio da utilização de diferentes materiais construtivos e/ou de revestimento. Mais detalhadamente, o primeiro volume horizontal incorpora as funções comercial e institucional, enquanto o bloco vertical comporta as unidades habitacionais ${ }^{539}$. As fachadas desse volume também seguem àquele binômio. Aquela para os quais estão voltados os espaços frios e comuns do prédio - cozinha, área e dependência de serviços e circulação horizontal dos pavimentos - recebeu um extenso plano de combogós interrompido apenas pelas caixas das escadas e dos elevadores em concreto (Ver figura 146). Em contrapartida, a fachada principal, para a qual, se abrem as janelas dos ambientes sociais e íntimos (salas e quartos) dos apartamentos recebeu gradis nas varandas $^{540}$, sacadas do corpo principal do edifício, conformando uma espécie de caixa saltada, e planos de vidros nas janelas, num segundo plano. São ainda percebidos finos pilares cilíndricos que aparentam sustentar as coberturas das sacadas, semelhante à Casa Benedito Levi (São Paulo-1944), de Vilanova Artigas, além de um jogo secundário de pilares de seção circular e pilastras retangulares intercalados nessa face do edifício (Figura 147). Essa face da edificação se contrapõe a do volume inferior, que a semelhança da fachada posterior recebeu tratamento com combogós. São também evidenciados brise-soleil no volume térreo, na fachada de acesso à edificação (ver figura 145).
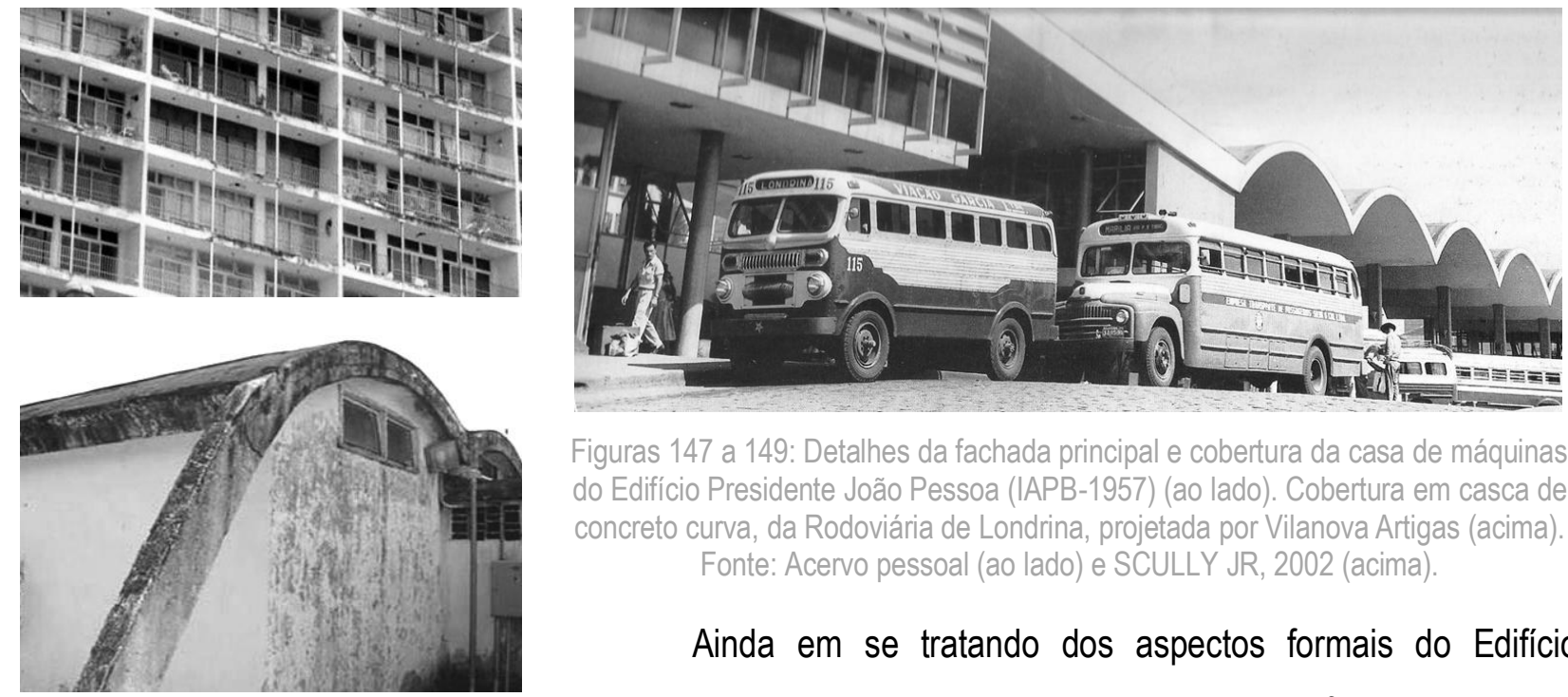

Figuras 147 a 149: Detalhes da fachada principal e cobertura da casa de máquinas do Edifício Presidente João Pessoa (IAPB-1957) (ao lado). Cobertura em casca de concreto curva, da Rodoviária de Londrina, projetada por Vilanova Artigas (acima). Fonte: Acervo pessoal (ao lado) e SCULLY JR, 2002 (acima).

Ainda em se tratando dos aspectos formais do Edifício

Presidente João Pessoa percebe-se, em uma das fachadas laterais, o uso de pilotis de grandes seções circulares na base da edificação, responsáveis pelo nivelamento do prédio com o terreno, que evitaram o custoso movimento de terra. Evidencia-se ainda um plano de grandes pilares com perfil retangular, que realizam a transição entre os volumes horizontal e vertical, também percebido no Pedregulho projetado por Affonso Eduardo Reidy (1946), e comporta a área de lazer da edificação e 0 playground. Da mesma forma que vislumbrado no Conjunto Pedregulho também, mais precisamente no ginásio de esportes, e como especificado no memorial de construção, a cobertura da casa de máquinas do 
referido Edifício é em casca curva de concreto (Figura 148). Uma solução próxima ainda da empreendida por Vilanova Artigas na Rodoviária de Londrina (Figura 149). O teto-jardim corbusiano está igualmente presente na aludida construção, recebendo adição de um pequeno apartamento para solteiro com um quarto, além da já mencionada casa de máquinas.

Em planta, percebe-se a existência de um longo corredor, que cruza toda a edificação (da fachada leste a oeste), para o qual estão voltados todos os acessos sociais e de serviços dos quatro apartamentos que compõe o pavimento (Figura 150). Esse corredor foi em parte incorporado às unidades habitacionais e possibilitou a conformação das áreas de serviço, com lavanderia. São evidenciadas duas tipologias de planta por andar, com dois ou três quartos, além de três ou quatro varandas, sala com dois ambientes, circulação, banheiro, cozinha, área e dependência de serviço completa. Um diferencial dessa concepção refere-se ao avarandamento de todos os ambientes íntimos e sociais, que compõem a fachada principal do prédio, voltada para a Rua Peregrino de Carvalho. A questão da ventilação natural foi enfatizada pelo arquiteto nesse projeto por meio da indução de canais de vento ou ventilação cruzada como é conhecida, ocasionada por meio da diferença da pressão interna dos apartamentos com a do exterior, provocada pelo posicionamento e dimensões das aberturas ${ }^{541}$. Era previsto ainda uma banheira com água aquecida a gás em cada uma das unidades. Aspecto que, vale salientar, encareceu em muito o custo desprendido para a construção, que foi refletido, por sua vez, no preço de repasse dessas habitações para os associados, angariadas por financiamentos atuariais.

Outro exemplo de prédio misto é o Edifício Inconfidência (IAPI-1945), no Recife (Figuras 151 e 152). Foi projetado pelos arquitetos Carlos Frederico Ferreira e Hélio Duarte, de acordo com a concorrência aberta para a sua edificação no início da década de

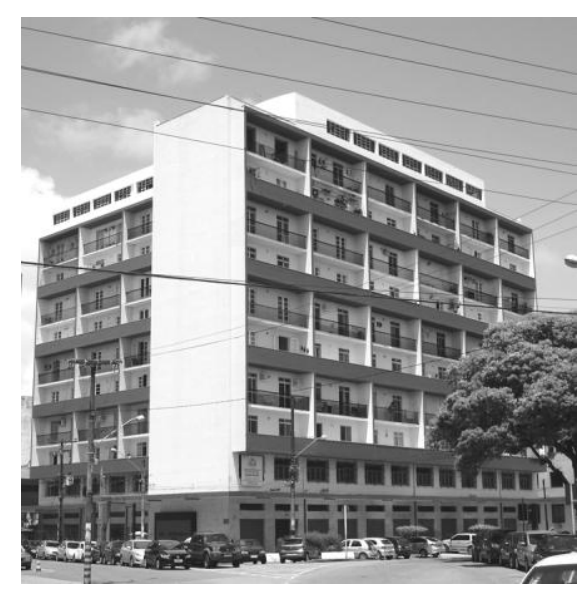

Figura 151: Edifício Inconfidência (IAPI1945), no Recife.

Fonte: Arquivo pessoal.

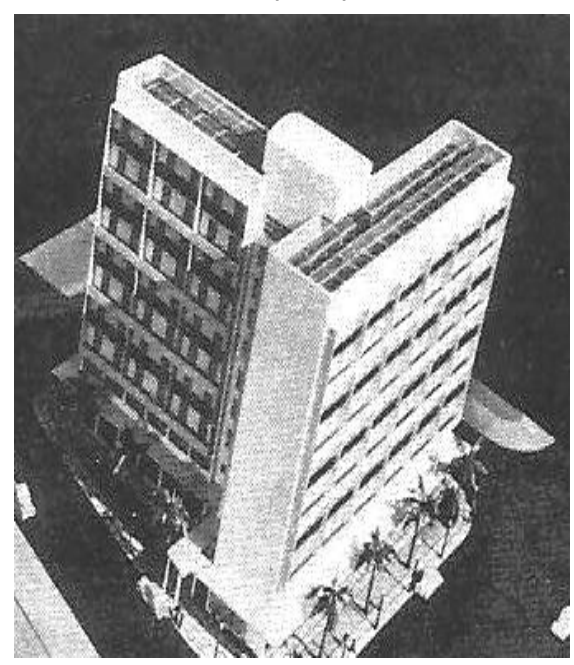

Figura 152: Maquete do Ed. Inconfidência de Carlos Frederico Ferreira e Hélio Duarte, da década de 1940.

Fonte: BRUNA, 2010.

541 Uma parede inclinada em 450 foi concebida para contribuir para essas trocas, segundo o memorial do projeto. 
1950. Combinações de plantas duplex nos oito pavimentos habitacionais, com área destinada às atividades relacionadas à administração do IAPI no Recife, no décimo pavimento, associada a pontos comerciais com sobrelojas que ocupam a base do prédio, garantiam certa autossuficiência à edificação que se aproxima do modelo de unidade de habitação corbusiano. Esse Edifício agrega em planta e no tratamento formal, diversos outros preceitos da arquitetura moderna, como a sobriedade das fachadas, panos de vidro, jogo de volumes, passarela coberta em concreto armado sustentada por esguios pilotis, redução de espaços internos, dentre outros (Figura 153). Se diferencia dos demais exemplares da categoria pela composição acima elencada, bem como pelo volume em $L$ e pelo jogo de cheios e vazios, alcançado pelo arquiteto por meio do tratamento das varandas do apartamento. Algumas acompanham a solução continuada com peitoris em metal, empreendida também por Ulysses Petrônio no Edifício Presidente João Pessoa, em outras o peitoril mostrase fechado em alvenaria, conformando balcões (Figura 154). Essa alternância se mostra semelhante ao executado pelos irmãos M.M.M. Roberto, no Edifício Anchieta (IAPC-1943), em São Paulo.
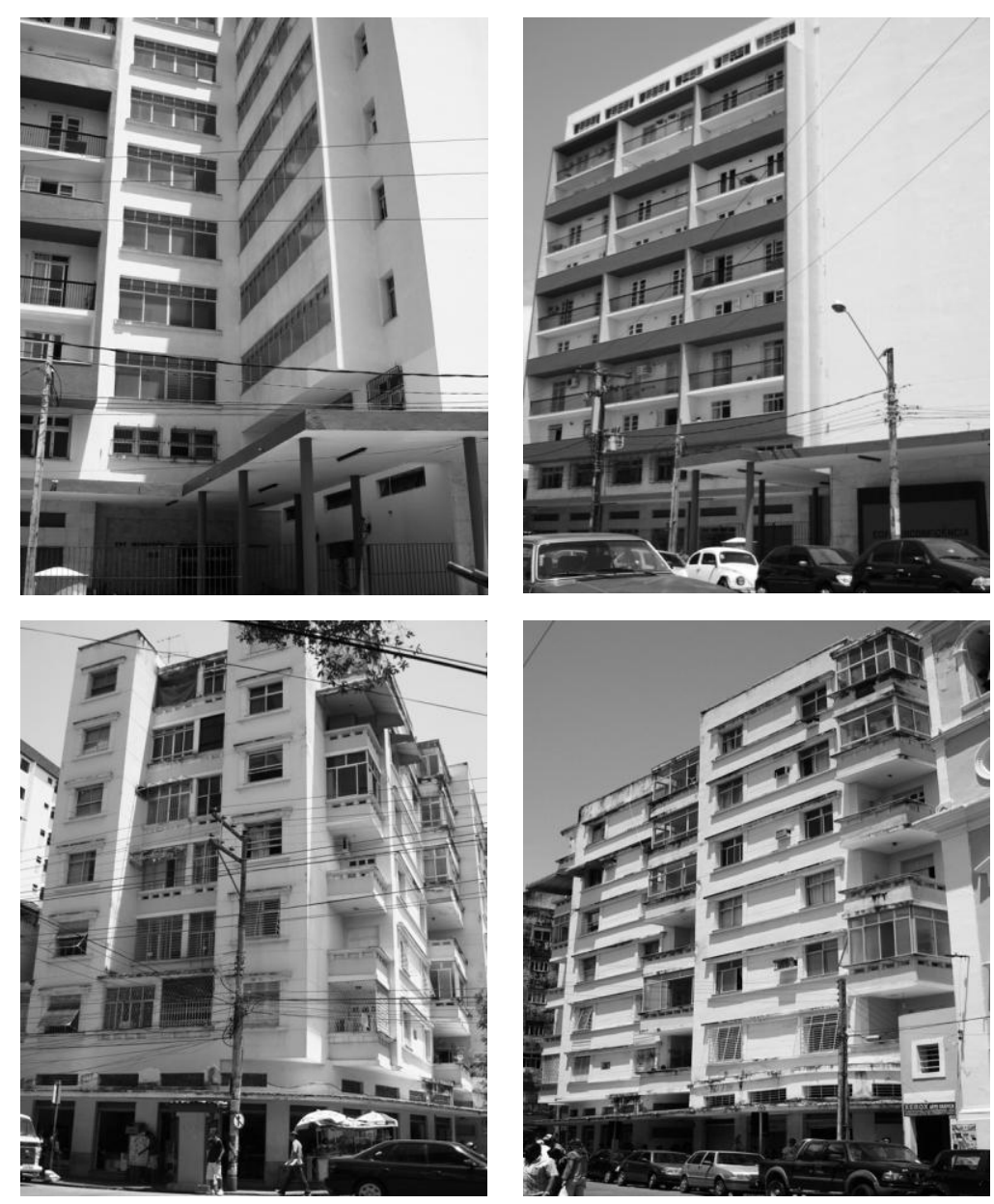

Figuras 153 a 156: Detalhes das fachadas dos Edifícios Inconfidência (IAPI1945) e Gervásio Pires (IAPC-1940), no Recife.

Fonte: Arquivo pessoal.

Outro exemplar de uso desta tipologia é o Edifício Gervásio Pires (IAPC-1941), edificado no bairro de Boa Vista, também no Recife, composto por sete pavimentos habitacionais encimados em um bloco de lojas. Em se tratando da arquitetura, esse exemplar se aproxima de algumas proposições do Art Decó, com linhas marcadas nos molduramentos das janelas e nas varandas sacadas do corpo do edifício escalonado, além da fina laje abaloada que contorna a edificação (Figuras 155 e 156).

De modo geral, no tocante às plantas, observou-se que ambientes como a copa, a cozinha, o banheiro e as dependências de serviços, as chamadas áreas frias, ganharam especial atenção nas unidades

habitacionais locadas em edifícios coletivos, em especial. Isso ocorreu consoante à tendência iniciada ainda na década de 1920 em âmbito internacional, de otimização de determinados espaços, sobretudo, da cozinha das edificações. $O$ enfoque a esse ambiente se deu no contexto de emancipação da figura feminina, que 
passou a ocupar um importante papel na concepção das moradias. Diante da crescente representatividade no mercado de trabalho por parte da mulher, as atividades domésticas deveriam ser minimizadas.

\section{- Conjuntos de blocos:}

Defendidos por figuras de renome internacional como Gropius e Le Corbusier, esse modelo de conjunto residencial encontrou resistência para ser implantado em boa parte do país, como colocado anteriormente. No âmbito dos Institutos e Caixas de Aposentadoria e Pensões, a escolha por essa tipologia habitacional levava em consideração, primeiramente, as verbas disponíveis em caixa e a questão do custo de aquisição do terreno, em segundo plano, considerava-se o número de segurados numa determinada cidade, o salário médio recebido por esses associados, assim como os hábitos domésticos e sociais das diferentes populações atendidas. Esse, possivelmente, foi um dos fatores preponderantes para a adesão ou não a prédios de moradias coletivas com altos gabaritos. A questão da padronização, por sua vez, foi bastante colocada e apontada como aspecto positivo dessas realizações no campo habitacional, percebidas principalmente no âmbito do IAPB em todo o Nordeste. A decisão pela edificação de conjuntos de edifícios verticais vinha, quase sempre, acompanhada por estudos preliminares ou mesmo de pesquisas de opinião realizadas entre os trabalhadores segurados pelas Carteiras Prediais dos Institutos e Caixas, promovidos na maior parte das vezes, por seções ou órgãos especializados, como foi vislumbrado em carta elaborada pelo Departamento de Inversões do IAPB ao delegado em Fortaleza:

(...) No caso particular de Fortaleza, foram promovidos estudos preliminares pelo Serviço Social, no sentido de orientar a aquisição do terreno. Esses estudos resultaram na definição da classe bancária, por terreno próximo à praia. Efetuada a colheita de propostas ficou patenteado, pelas características dos terrenos em vista - não somente quanto às areas como aos seus valôres - que não seria econômico o planejamento de lotes residências para a construção de casas isoladas, porquanto o maior dos terrenos - que tem $12.100 \mathrm{~m}^{2}$ de área -, permitiria a construção apenas de 44 residências, (...) Adicionando a esse valôr o preço da construção, nunca inferior a Cr $\$ 250.000,00$, seria anti-econômico planeja-las, se atentarmos para o fato de aumentar o seu custo, das cotas correspondentes a abertura de ruas, juros de inversões e etc. (...) vem procurando o Instituto não somente solucionar o problema de moradia dos seus associados em Fortaleza, (...), como também enquadrar essa solução dentro de um plano socialmente racional, no que tange à aplicação equilibrada dentro de suas possibilidades, atendendo o máximo de associados, dentro de suas reais possibilidades econômicas e financeiras. Concluindo as apreciações que nos cumpria tecer sobre 0 assunto, sugerimos a adoção de medidas no sentido de orientar a construção (...) para uma solução de edifícios de apartamentos (...) (CARTA..., 30/04/1954, p.01).

Os conjuntos residenciais conformados por prédios de moradias, exclusivamente, foram encontrados em Salvador, Recife, Fortaleza e São Luís. Em planta, esses conjuntos verticais apresentaram o mesmo padrão, que acompanhou as realizações do gênero coletivo em praticamente todas as cidades nordestinas pesquisadas. Os apartamentos que compunham esses edifícios apresentavam, mormente, sala com um ou dois ambientes, dois ou três quartos, banheiro social, cozinha e área de serviço. Vale ressaltar, que a dependência de serviço, composta por quarto e banheiro, pouco apareceu nos exemplares unifamiliares 
edificados pelas CAPs e IAPs no Nordeste. Da mesma forma, o depósito ou despensa, que recorrentemente apareceu nas realizações dos IAPs em São Paulo, mais precisamente, como observado no Conjunto Santo Antônio (IAPB-1951) de autoria do arquiteto Nicolau Barbieri e no Conjunto Nove de Julho (IAPB-1956) de Plínio Arruda Botelho, apresentados por Bruna (2010), não foram encontrados nos prédios edificados pelos órgãos nas sete capitais nordestinas pesquisadas. É vislumbrado ainda em concordância com as realizações isoladas, o agrupamento de cômodos tidos como frios em setores específicos da planta, por vezes com acesso independente do social, mas ainda não eram percebidas paredes hidráulicas.

Em se tratando das áreas internas de uso coletivo nos blocos, o hall social atendia geralmente dois ou quatro apartamentos. A circulação vertical, especialmente traduzida pelas caixas de escadas, estava situada em volumes que saltam do corpo principal do edifício ou, como era mais comum, integrado a ele, sendo apenas distinguida a mudança de uso por meio de panos de combogós ou treliças em madeira. 0 corredor se conformava como elemento estruturador tanto da planta-tipo dos pavimentos, quanto das unidades habitacionais. Era ao longo dele que, mormente, estavam dispostos os cômodos e os próprios apartamentos. A sua redução, defendida por diversos profissionais envolvidos no debate em torno da moradia econômica e suas variações no país e em outras partes do mundo, como já colocado nesta tese, praticamente não foi percebida nos exemplares dos conjuntos de moradia coletiva vertical no Nordeste. $\mathrm{Na}$ maior parte das vezes, também, a planta desses empreendimentos era espelhada, em torno do eixo central conformado pelo elevador e/ou pela escada.

Diferente do observado no âmbito dos edifícios verticais isolados, a maior parte das realizações dessa natureza identificada no Nordeste é conformada por volumes prismáticos simples, com quatro pavimentos assentados diretamente ao chão ou sobre pilotis $^{542}$, que traduziam uma simplicidade arquitetônica nas fachadas e em planta. Da mesma forma, na maior parte desses exemplares, os elevadores foram suprimidos, como preconizado por Rubens Porto, e o

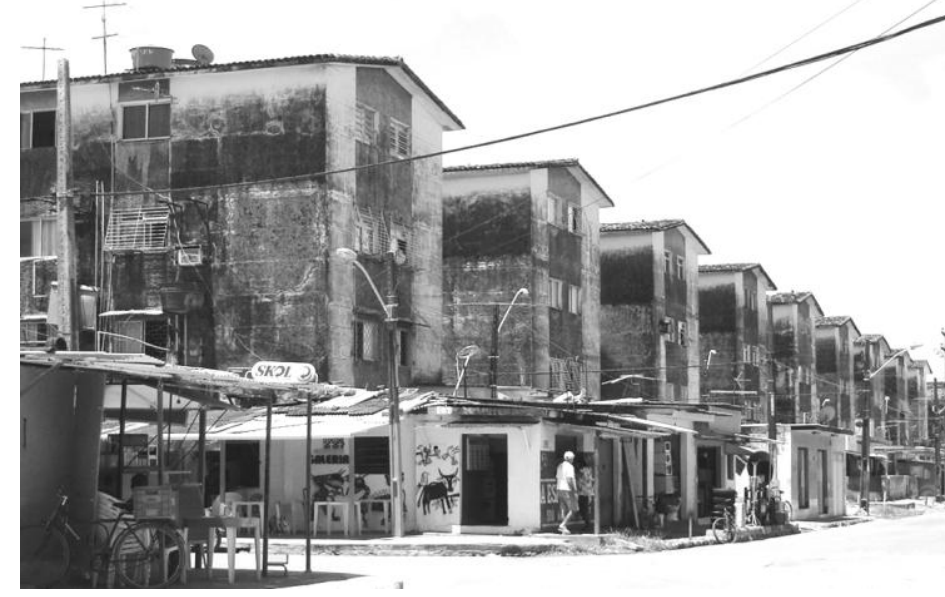

Figura 157: Conjunto Brigadeiro Francisco Bentes Monteiro (IPASE/SUDENE-1964).

Fonte: Arquivo pessoal. teto-jardim foi substituído por coberturas em telha canal ou cerâmica, por questões de economia de projeto ou relacionadas à capacitação da mão de obra e/ou à escassez de materiais, como no Conjunto Brigadeiro Francisco Bentes Monteiro, o Chico City (IPASE/SUDENE-1964), no Recife (Figura 157).

542 Quando apresentavam pilotis, os blocos geralmente possuíam três pavimentos de apartamentos. 
Poucos foram os casos que fugiam a essa regra, encontrados, sobretudo, na capital pernambucana, como no Conjunto Lafaiete Coutinho ou Casa Amarela (IAPC-1945), como ficou conhecido543. Nele, as 486 unidades habitacionais, de $43,57 \mathrm{~m}^{2}$, estão dispostas em blocos de dois pavimentos (térreo e primeiro andar), com um a oito
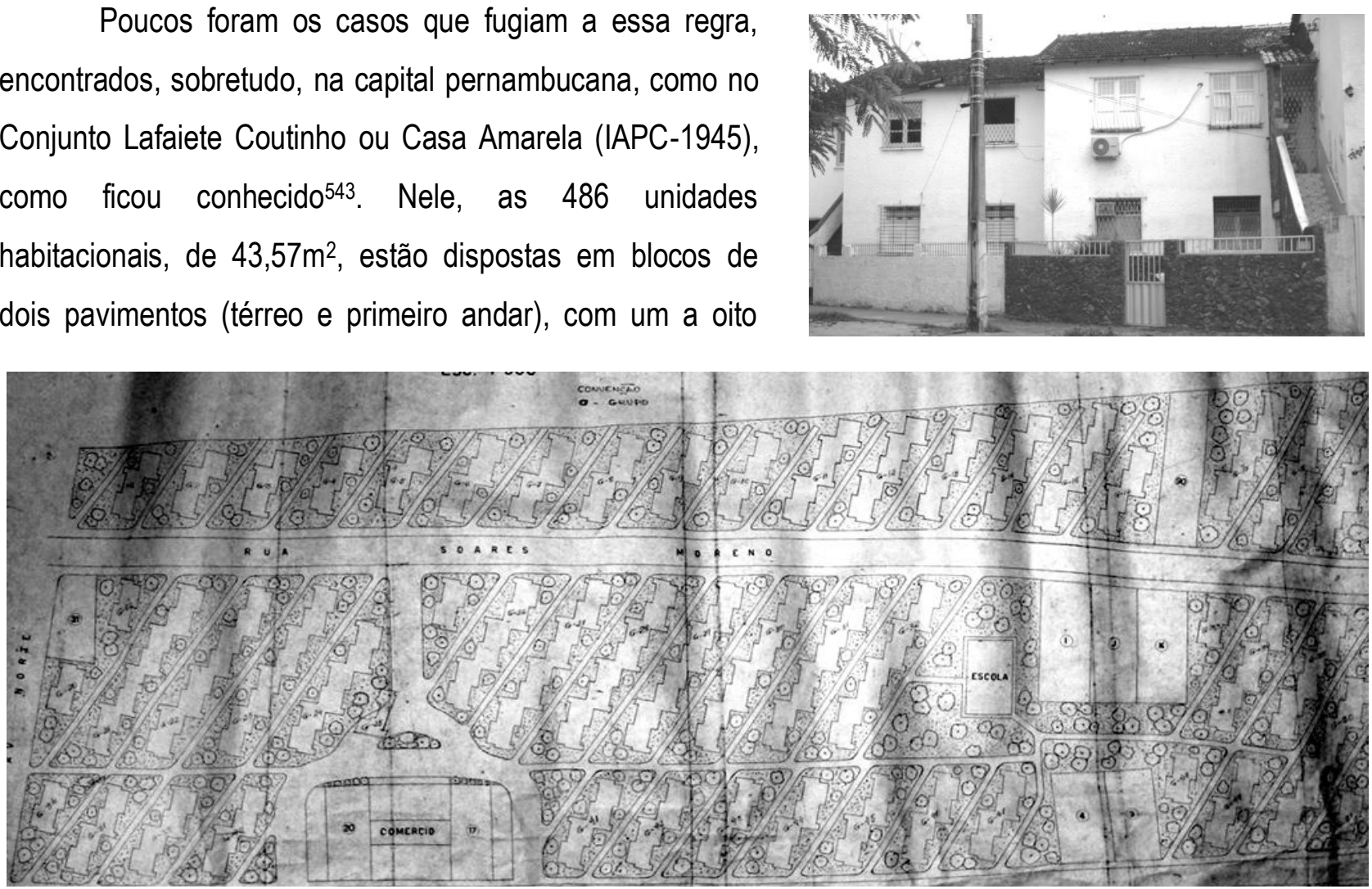

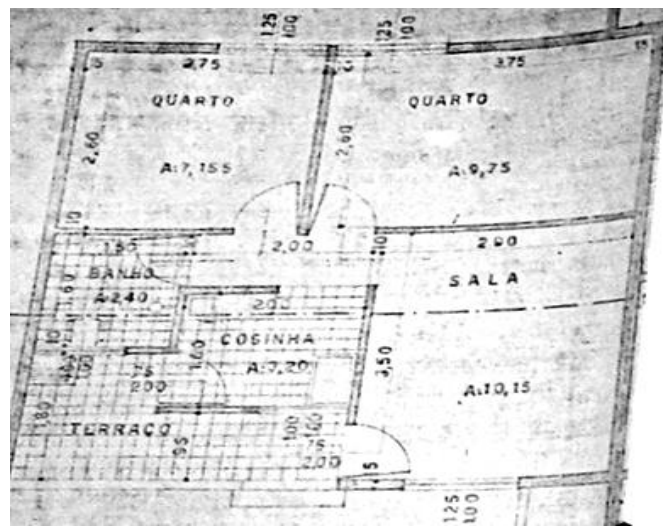

Figuras 158 a 160: Residência, planta-tipo e implantação do Conjunto Casa Amarela (IAPC1945), no Recife. Fonte: Arq. pessoal e INSS-PE.

unidades por andar, em estrutura em alvenaria e concreto, e cobertura em telhas ${ }^{544}$ (Figura 158). Todas as edificações e quadras estão voltadas para o sudeste (disposição inclinada no sentido do vento predominante), há uma abundância de áreas verdes e não são percebidas delimitações dos espaços públicos e privados, por meio de muros (Figura 159). Em planta, se percebe a simplicidade de programa defendida pelo corpo técnico do CNT para as realizações no campo habitacional das CAPs e dos IAPs no país, sendo conformadas apenas por terraço de entrada, sala, dois quartos, cozinha e banheiro. Um aspecto interessante da disposição dos cômodos das unidades deste Conjunto é que o terraço de entrada possibilita o acesso tanto para a área social como de serviço, pela cozinha (Figura 160). Vale frisar, que esse Conjunto se conforma como o mais próximo em termos de

543 O imóvel foi construído pelo IAPC, em terreno adquirido de terceiros (Raul Cesário de Melo, sua esposa Maria Augusta Cesário de Melo e de Henrique Barros Cavalcanti e sua mulher Alzira Guimarães Cavalcanti), conforme escritura de compra lavrada em cartório, à margem do qual foi feita a avaliação da construção em 28 de maio de 1953 (ano de conclusão). O Conjunto abrange uma área de $46.625 \mathrm{~m}^{2}$ e está situado no bairro de Casa Amarela.

544 Inicialmente previa-se a construção de tetos-jardins, mas, por questões relacionadas à economia de projeto e ao clima local, optou-se pela sua substituição por telhas cerâmicas. Mais precisamente, o Conjunto possui um prédio da administração $\left(218,20 \mathrm{~m}^{2}\right)$, um grupo escolar $\left(631,57 \mathrm{~m}^{2}\right)$, um prédio da assistência social $\left(303,65 \mathrm{~m}^{2}\right)$ e 52 grupos (todos blocos com 2 pavimentos) com 486 unidades habitacionais $\left(21.175,02 \mathrm{~m}^{2}\right)$, sendo 243 térreas e $243 \mathrm{em}$ pavimento superior. Atualmente, o espaço onde deveria funcionar a sede administrativa é ocupado por um posto médico. A escola estadual (Professor Mota e Albuquerque) foi edificada em troca da doação da área para a construção do Conjunto. 
implantação, do partido das edificações (com dois pavimentos encimadas por uma grande laje plana inicialmente pensada) e de planta das unidades, ao modelo ideal apontado por Rubens Porto e analisado minuciosamente no segundo capítulo desta tese.

Outro exemplo de conjunto de blocos de apartamentos com dois pavimentos é o Conjunto Imperatriz (CAP dos Serviços Públicos do Estado da BA e SE, 1951), em Salvador. Locado no bairro de Itapagipe, era conformado por pequenos blocos com dois pavimentos e um apartamento por andar. Tanto em fachada quanto em planta, esses exemplares se aproximam do repertório arquitetônico moderno, apresentando volume prismático regular simples, diferenciação da fachada quando ao uso em planta, por meio do emprego de elementos, representados nesse caso pela pastilha cerâmica e combogós circulares, principalmente, além do teto-jardim, associado a um programa simplificado, com espaços reduzidos, não existindo circulações em formato de corredor (Figuras 161 a 163). Esse projeto recebeu um parecer "louvável" da Seção de Engenharia do CNT, no Rio de Janeiro, sendo considerado moderno e arrojado.
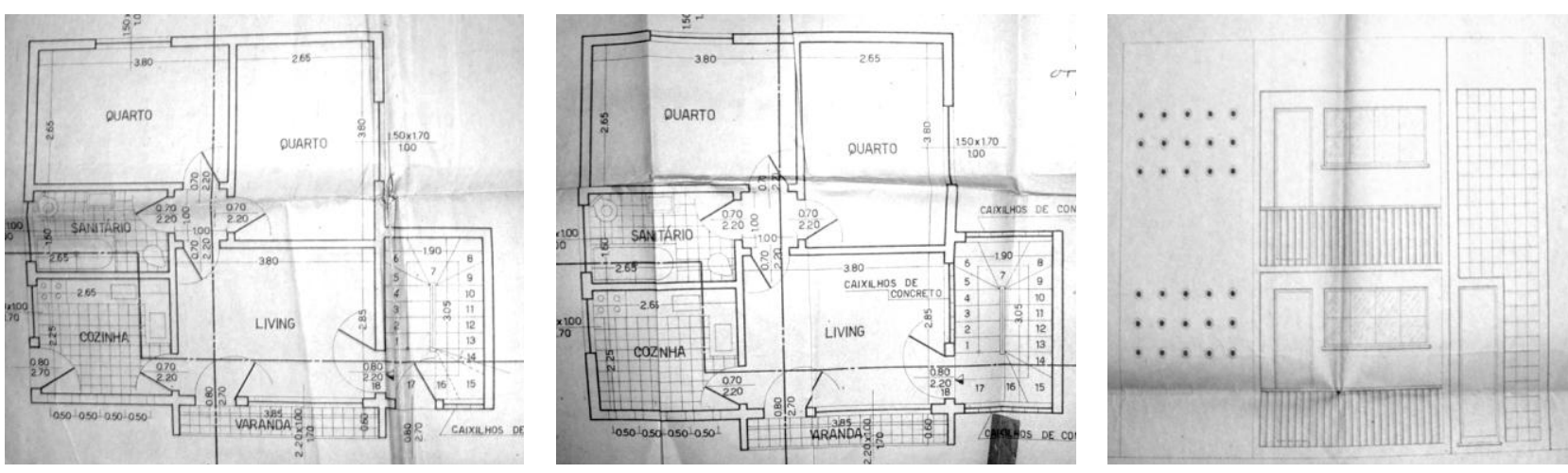

Figuras 161 a 163: Plantas do pavimento térreo e superior e fachada das residências do Conjunto Imperatriz (CAPESP-BA/SE), em Salvador, edificado na década de 1950. Fonte: INSS-BA.

Um grupo vertical que apresentou diferentes volumetrias de blocos foi o Conjunto Juscelino Kubitschek (IAPB-1949), em Salvador, o qual possuía tanto edifícios com quatro pavimentos assentados diretamente no chão, quanto bloco sobre pilotis com três pavimentos de apartamentos $^{545}$. Pode-se apontar ainda o uso de diferentes materiais e cores nas fachadas desse empreendimento; uma prática muito comum na época (Figura 164).

Observa-se, dessa forma, que quanto à volumetria, a maior parte dos exemplares em muito se aproximava das siedlungens, sendo conformadas por blocos regulares, mormente, com três ou quatro

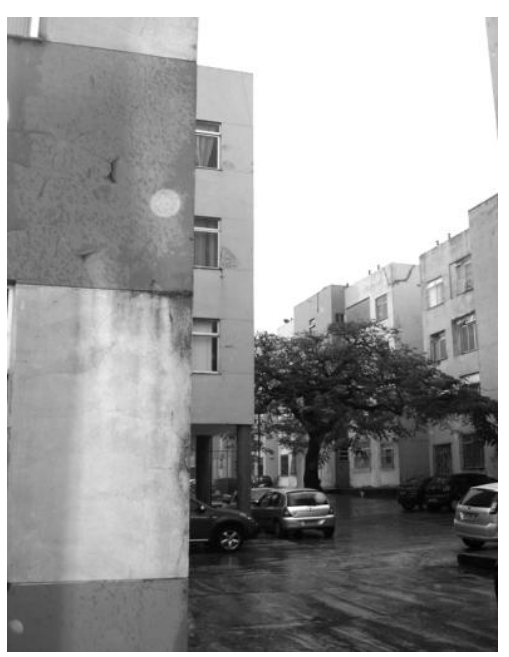

Figura 164: Conj. JK (IAPB-1949), no Recife.

Fonte: Arquivo pessoal.

545 Conjunto edificado pelo IAPC, em terreno adquirido em abril de 1949 de Adelgicio Olindo de Mello S. Silva e Humberto Pacheco de Miranda. Os blocos 1 a 5 são compostos por quatro pavimentos, cada um com dois apartamentos, e o bloco 6 é conformado por três pavimentos sobre pilotis. As 46 unidades apresentam a mesma planta, conformada por sala, três quartos, banheiro, cozinha e dependência de empregada completa, totalizando $84 \mathrm{~m}^{2}$. 
pavimentos, nos quais, os planos cheios das fachadas só eram interrompidos por meio das esquadrias em vidro, como observado nos exemplos acima elencados e na fachada principal dos quatro blocos de quatro pavimentos que compõem o II Conjunto Areias (IAPI-1960), no Recife546 (Figura 165). Contudo, ao contrário daqueles exemplares europeus, poucos foram os conjuntos que apresentaram aberturas em pano de vidro protegidas com peitoris ou sacadas com barras em ferro. Suas fachadas eram limpas, sem detalhes aplicados com o intuito de destacar a horizontalidade ou demarcar a verticalidade da construção, como percebido na maior parte das realizações verticais isoladas.

Mais precisamente, no caso do Nordeste, os panos de vidro foram muitas vezes substituídos por janelas de correr com venezianas em madeira e vidro, provavelmente por questões de economia de projeto e associadas ao clima da região, marcado por altas temperaturas, e pela intensa e constante incidência de raios solares nas fachadas das edificações, devido à proximidade de muitas das cidades à Linha do Equador. Da mesma forma,

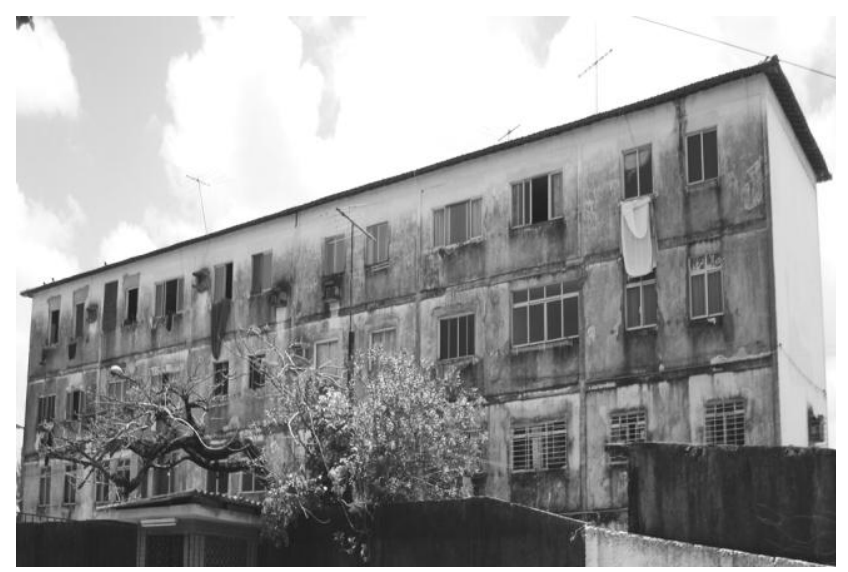
Figura 165: Vista de um dos blocos do II Conjunto Areias do IAPI (1960), no Recife. Fonte: Arquivo pessoal. foram comumente encontrados nessa região, edifícios que recebem tratamento com panos de treliças em madeira, combogós ou brise, em cerâmica ou alvenaria, nas fachadas. Vale salientar, que esse volume prismático regular e a configuração quase modelar da planta-tipo que traduziram a maior parte das realizações das Caixas e Institutos de Aposentadoria e Pensões no Nordeste do país, antecipam em mais de dez anos a rigidez arquitetônica de fachada e de disposição dos cômodos nos apartamentos, a qual, a historiografia especializada imputa como posterior, datando da atuação do BNH no campo habitacional, a partir de meados da década de 1960, como pode ser percebido nas diversas etapas do Conjunto dos Comerciários de Salvador (1966) e no Conjunto Costa e Silva (IPSEP/SUDENE-1966), no Recife.

No tocante às faces dos edifícios, foram percebidos ainda elementos reentrantes que dão destaque às janelas das fachadas principais, assim como grandes planos salientes que as emolduram, como percebido no Conjunto dos Bancários em São Luís ${ }^{547}$ (Figura 166). Essa solução também foi bastante utilizada por Attílio Corrêa Lima, em suas realizações habitacionais coletivas, como no Conjunto Várzea do Carmo, em

$546 \mathrm{O}$ terreno de $8.776,00 \mathrm{~m}^{2}$ foi desmembrado de uma quadra em forma trapezoidal regular e havido pelo IAPI por compra à Sociedade de Terrenos do Ibura Lida (SOTIL), conforme escritura lavrada em 07 de agosto de 1951. A construção foi realizada pelo próprio IAPI, em 1960. O conjunto fica a margem da Av. Recife (terreno de esquina), ou quarta perimetral como era chamada na época. É importante ressaltar que aquela Sociedade vendeu outros terrenos onde foram construídos conjuntos por Caixas e Institutos na cidade do Recife, como o Conjunto IPSEP no atual bairro do Ibura.

547 Conjunto composto por oito blocos de apartamentos, com quatro pavimentos sem pilotis, totalizando 48 unidades habitacionais, localizado atualmente no bairro Centro, da capital maranhense. Esse conjunto se conformou como o único exemplar vertical edificado por um escritório estadual de IAP em São Luís, bem como o único modelo de edificação dessa tipologia em toda a cidade, na época. A capital maranhense não contava nem com prédios em pavimentos que abrigavam as sedes de delegacias regionais naquele modelo. 
São Paulo (IAPI-1942). A disposição dessas aberturas, deslocada ora para a esquerda ora para a direita, confere um ritmo a esses planos do conjunto maranhense (Figura 167). São ainda percebidos brises ao nível do patamar intermediário das escadas que auxiliam especialmente na iluminação (Figura 168). Os combogós foram empregados como elementos de vedação das áreas de serviços dos apartamentos; artifício pouco encontrado no Nordeste nesse momento. Seguindo à tradição local, percebe-se o emprego de cerâmicas emoldurando as caixas das entradas principais dos oito blocos de apartamentos que constituem o supracitado Conjunto (Figura 169). O programa dos apartamentos é o mesmo do padrão exposto acima, mas a disposição dos cômodos em planta, bem como as fachadas dos edifícios não o seguem a risca. 0 eixo estruturador dos ambientes continua a ser o corredor, com um pouco mais de $3 \mathrm{~m}$, e também se percebe o setor de serviço em planta. No entanto, o eixo do edifício não está centralizado, devido ao fato do pavimento-tipo ser conformado por um apartamento com três quartos e outro com dois (Figura 170).
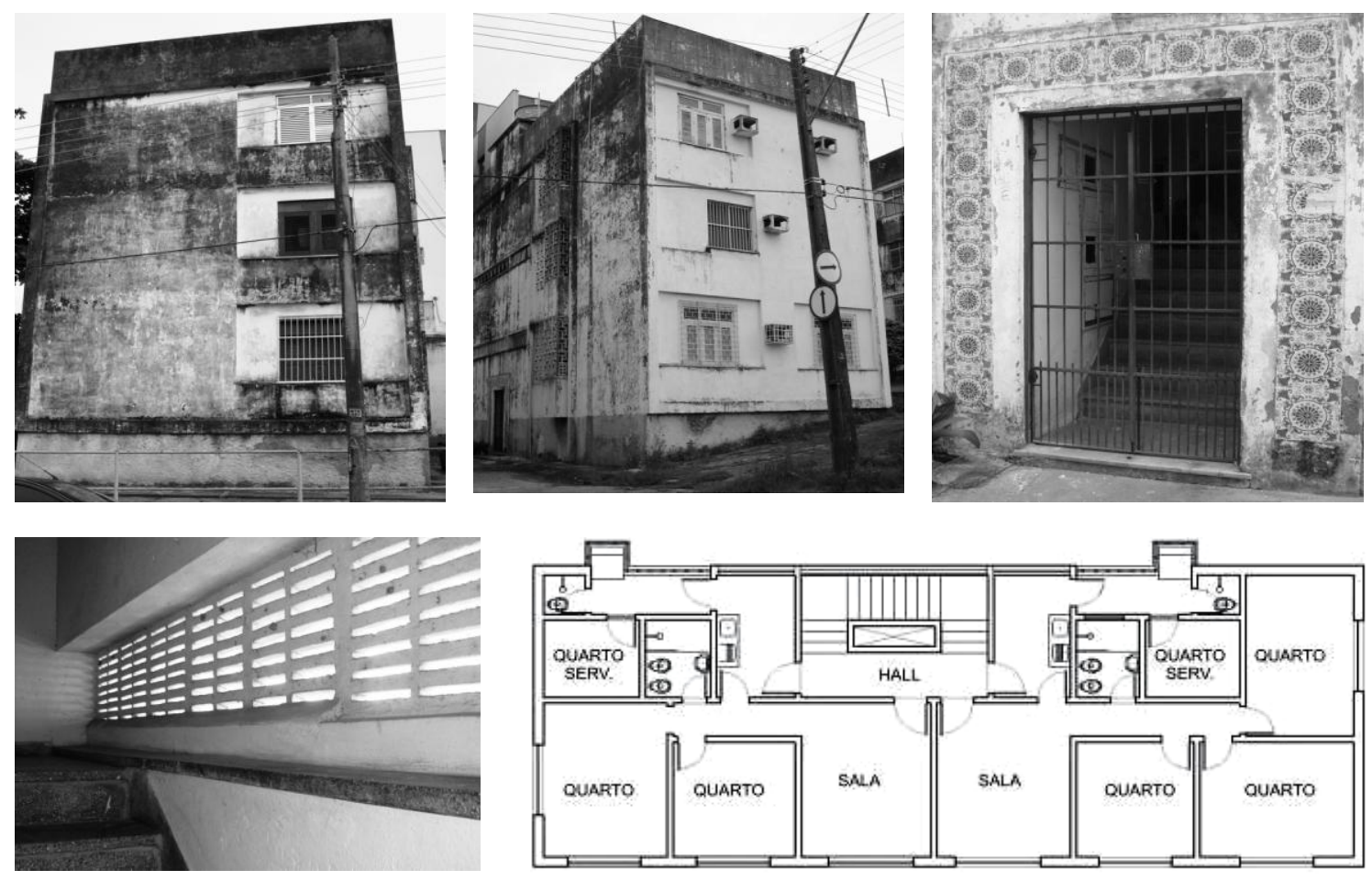

Figuras 166 a 170: Fachadas dos blocos, planta-tipo, detalhes da porta de entrada e das escadas dos edifícios do Conjunto dos Bancários, em São Luís.

Fonte: Arquivo pessoal.

Quanto à implantação dos blocos dos conjuntos coletivos verticais nordestinos, foram observadas cinco diferentes formas. A primeira e a mais comum é a disposição paralela dos blocos no terreno margeando uma via, como foi o caso do Conjunto dos Bancários (IAPB-1957) ${ }^{548}$, em São Luís (Figura 171), ou disposto

548 A implantação dos blocos que compõem esse conjunto não seguiu as premissas de implantação ou distanciamento preconizadas na arquitetura e no urbanismo modernos, especialmente em se tratando das formulações de Gropius nos CIAMs. Mais precisamente, os prédios foram edificados paralelamente e a proximidade entre eles compromete 0 atendimento de todas as unidades de modo homogêneo no que tange à iluminação e à ventilação natural. 
na profundidade do lote, como no Conjunto Mutti Carvalho (IAPB-1958) ${ }^{549}$, em Salvador (Figura 172). A segunda é o arranjo laminar ou de blocos geminados, evidenciando a horizontalidade desses empreendimentos, como foi percebido no Conjunto Governador Antônio Balbino (IAPC-1954)550, também localizado na capital baiana (Figura 173). Uma variação da implantação em linha foi encontrada nos Conjuntos soteropolitanos Monte Serrat (IAPC-1957)551 e J.K (IAPC-1949), na qual, os blocos que os compõem conformam um L, acompanhando a via perpendicular ao conjunto (Figuras 174 e 175). A terceira disposição vislumbrada é, na verdade, uma mescla das duas primeiras, de modo que são percebidos blocos sequenciados e paralelos. Há ainda a implantação do tipo intercalado ou pirâmide, como percebido no Conjunto dos Industriários (IAPI-1952), também em Salvador (Figura 176), e em grelha, como no já citado Conjunto Chico City (IPASE-1964), no Recife (Figura 177, na página seguinte).
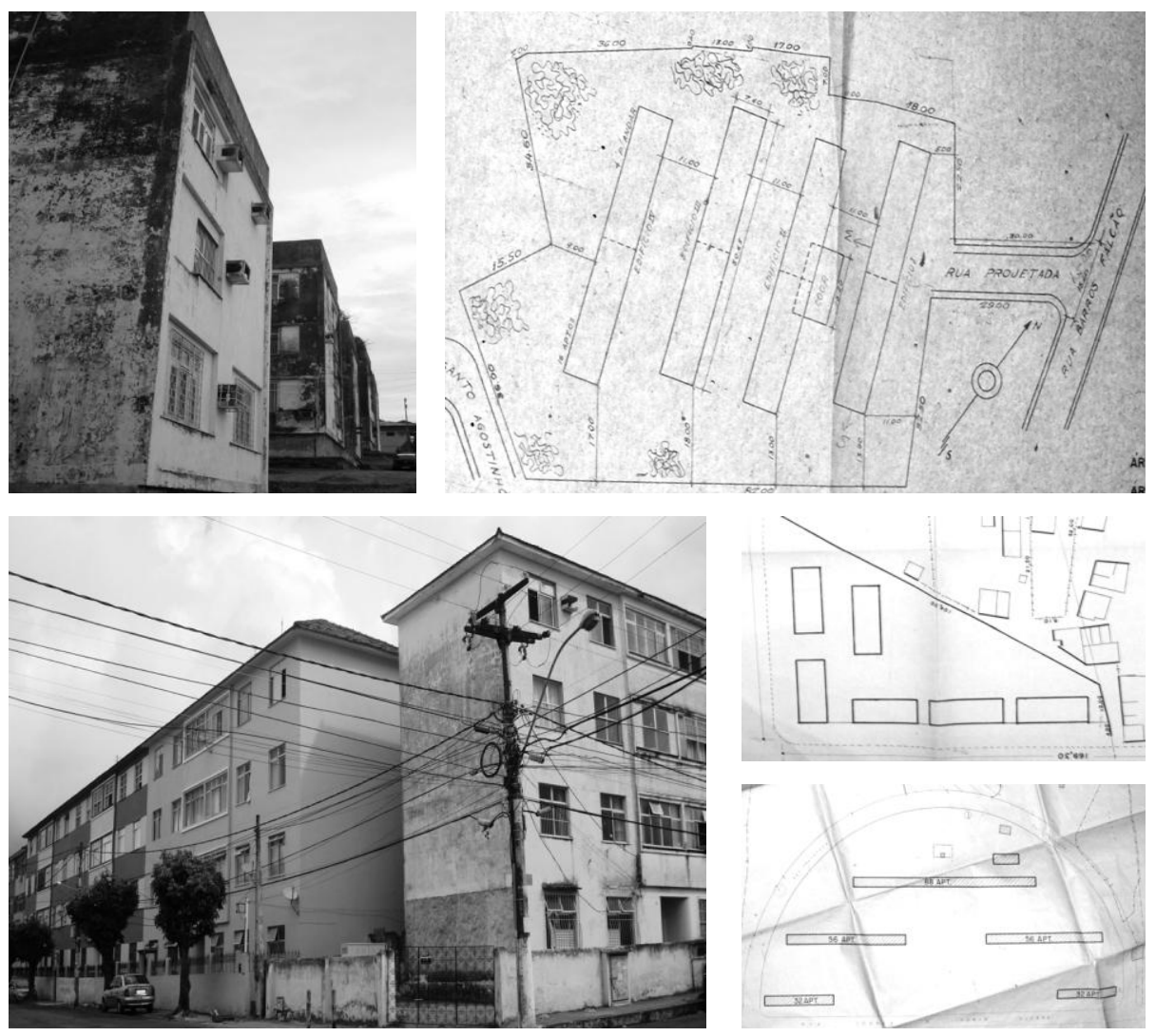

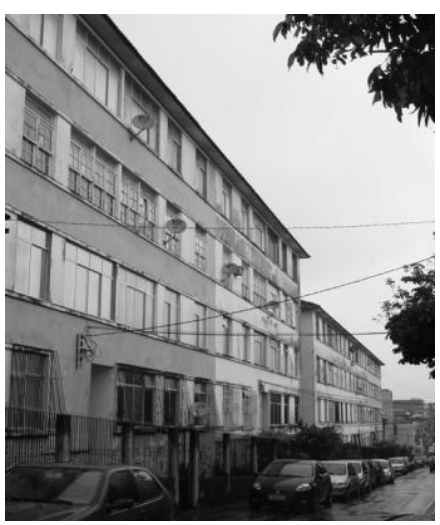

Figuras 171 a 176 (da esquerda para a direita e de cima para baixo): Vista do Conjunto do IAPB-MA; implantação do Conjunto Mutti Carvalho (IAPB-BA); Vista do Conjunto Antônio Balbino (IAPC-BA); Vista do Conjunto Monte Serrat e implantação do JK, ambos IAPC-BA, além da implantação do Conjunto do IAPI-BA. Fonte: Arquivo nessoal e INSS.

549 Composto por quatro blocos com quatro pavimentos sobre pilotis com quatro apartamentos por andar. A área do conjunto é de $7.230 \mathrm{~m}^{2}$, adquirido por compra feita a terceiro pelo Instituto, em 19 de agosto de 1940. A área construída que compreende os quatro blocos equivale a $1.540,25 \mathrm{~m}^{2}$. Em planta seguiam a distribuição padrão de sala, três quartos, banheiro, cozinha, área e dependência de serviço completa (banheiro e quarto), com $90 \mathrm{~m}^{2}$ cada um. 0 térreo em pilotis apresenta apenas duas caixas de escada e depósito em cada um dos blocos.

550 Construção iniciada em 1954 e concluída em 1963. Constava inicialmente de dois blocos laminares de apartamentos com quatro pavimentos e 10 unidades por andar, além de dois pontos comerciais, que apesar de previstos em projeto, não foram executados, sendo transformados em unidades para aluguel. Terreno de $2.300 \mathrm{~m}^{2}$ de área foi adquirido do governo da Bahia em 19 de abril de 1941. As unidades são compostas por sala, três quartos, banheiro, cozinha, área e dependência de serviço completa $\left(75 \mathrm{~m}^{2}\right)$, e foram inicialmente alugadas aos segurados do IAPC.

551 Situado próximo ao Conjunto Antônio Balbino e ao loteamento de mesmo nome, também de propriedade do IAPC, no bairro Itapagipe. Conforma uma área de aproximadamente $700.000 \mathrm{~m}^{2}$. O referido Conjunto é composto por cinco blocos, três interligados entre si e os outros dois conjugados, de quatro pavimentos, com dois apartamentos por andar. A distribuição dos ambientes em planta na maior parte do Conjunto (35 unidades) segue o esquema das unidades do Conjunto Antônio Balbino, com área construída de $78 \mathrm{~m}^{2}$, e as outras cinco unidades, locadas no térreo, possuem apenas dois quartos e um total de $70 \mathrm{~m}^{2}$. Assim como naquele, os apartamentos foram inicialmente alugados aos comerciários associados à Carteira Predial do IAPC. 


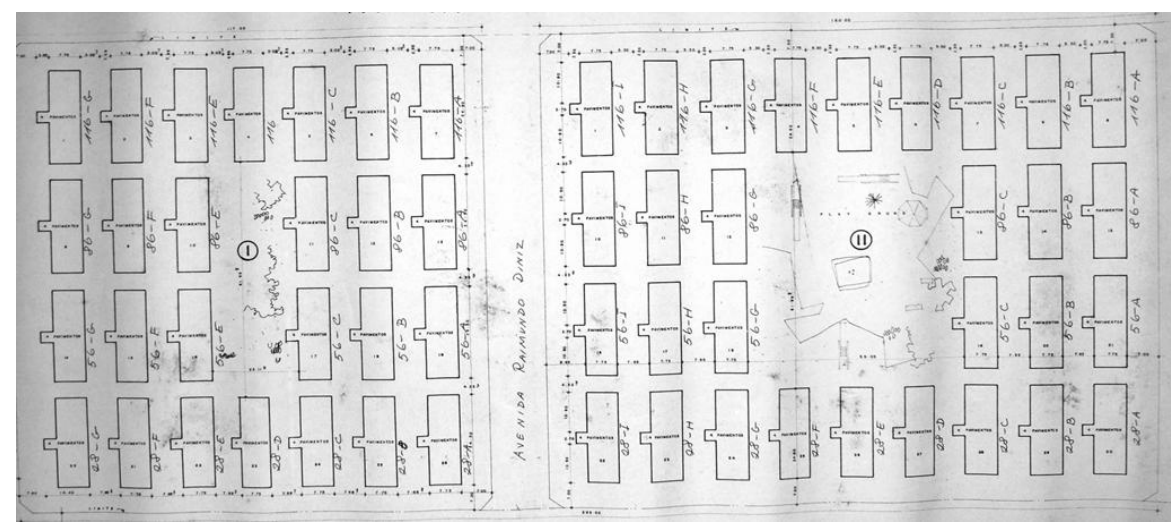

Figura 177: Implantação do Conjunto Chico City (IPASE/SUDENE-1964), no Recife.

Fonte: INSS-PE

Como nas demais categorias de análises dos grupos habitacionais, eram comuns conjuntos coletivos verticais destituídos de equipamentos coletivos e/ou de lazer, como foi o caso do Conjunto dos Bancários (IAPB-1954), em São Luís. Os únicos conjuntos de edifícios verticais encontrados ao longo da pesquisa, nos quais foram efetivamente implantados os equipamentos coletivos, de serviço e lou lazer previstos em projeto, dizem respeito aos Conjuntos J.K (IAPC-1949) e dos Industriários (IAPI-1952), ambos localizados em Salvador, e o Conjunto Chico City, no Recife, que eram dotados de quadras de esportes, além de jardins e playgrounds. A maior parte desses espaços encontra-se atualmente abandonada por falta de uso e/ou manutenção.

O Conjunto do Salvador (IAPI-1952) ou Conjunto dos Industriários como é conhecido, acima mencionado, também se conforma como um dos maiores conjuntos edificados nessa categoria no Nordeste e o maior da capital baiana. Composto por cinco grandes blocos laminares com quatro pavimentos sobre pilotis, sem elevador, esse Conjunto atende a 264 famílias ${ }^{552}$. A dimensão e a extensão dos blocos projetados pelo engenheiro civil Almir Ferreira Santos chamam a atenção do transeunte e se destacam no entorno (Figura 178). Refere-se a um dos poucos conjuntos cujas obras de construção se enquadraram nas propostas do Taylorismo para os canteiros de obras, defendido pelo IDORT principalmente, bem como representa um dos poucos episódios onde foi montada uma pequena fábrica de pré-moldados, à semelhança do Conjunto Realengo no Rio de Janeiro (Figura 179). Apresenta ainda elementos do repertório moderno, como os já citados pilotis, a simplicidade das fachadas e em planta, sendo percebidos ainda, elementos circulares cuja função era auxiliar à ventilação e à iluminação natural das caixas de escada de acesso aos apartamentos. $A$ cobertura não segue a linha do teto-jardim, sendo visível a uma pequena inclinação e a utilização de telhas de amianto, prevista desde o projeto. No entanto, vale salientar que são percebidos alguns problemas

\footnotetext{
552 De acordo com os documentos históricos e os laudos de avaliações encontrados sobre esse empreendimento, o Conjunto era servido de água, luz, esgoto e telefone desde a sua construção, efetivada numa área de $32.732 \mathrm{~m}^{2}$. 0 terreno foi adquirido pelo Instituto por compra feita a Juvenal de Lacerda Gordilho, em 05 de maio de 1948. São vislumbrados cinco blocos com quatro pavimentos e 14 unidades habitacionais por andar $\left(55,13 \mathrm{~m}^{2}\right.$ cada uma), que ocupam $14.588 \mathrm{~m}^{2}$ da área total. Sua construção perdurou por mais de uma década, sendo iniciada em 1952 e concluída em 1964.
} 
relacionados à ventilação e à iluminação do banheiro social de algumas unidades, cuja janela abre para a cozinha do apartamento.
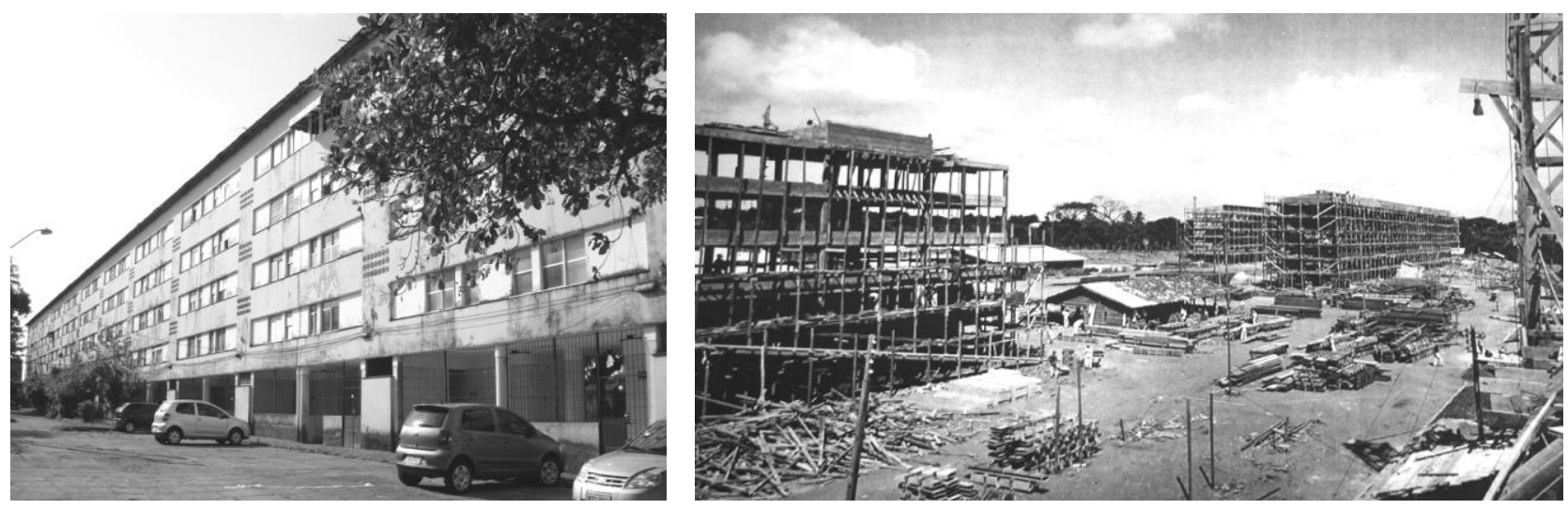

Figuras 178 e 179: Blocos laminares e construção do Conjunto dos Industriários (IAPI-1952), no atual bairro do IAPI em Salvador. Fonte: Arquivo pessoal.

\section{- Conjuntos Mistos e Outros Exemplares:}

De modo geral, os conjuntos mistos de casas unifamiliares e edifícios coletivos verticais, apresentam uma maior aproximação das diretrizes da arquitetura e do urbanismo modernos no cerne dos institutos de previdência no Nordeste. Em Natal, por exemplo, os quatro únicos exemplares de moradia coletiva identificados na cidade faziam parte do Conjunto Residencial Nova Tiro (IAPC-1957), 0 atual Condomínio São Sebastião, cujo projeto foi de autoria do arquiteto Moacyr Maia553. A sua implantação segue a noção da unidade de vizinhança, adaptada à escada de conjunto. Os blocos de apartamentos e os equipamentos previstos estão dispostos margeando o Conjunto, enquanto as residências e os

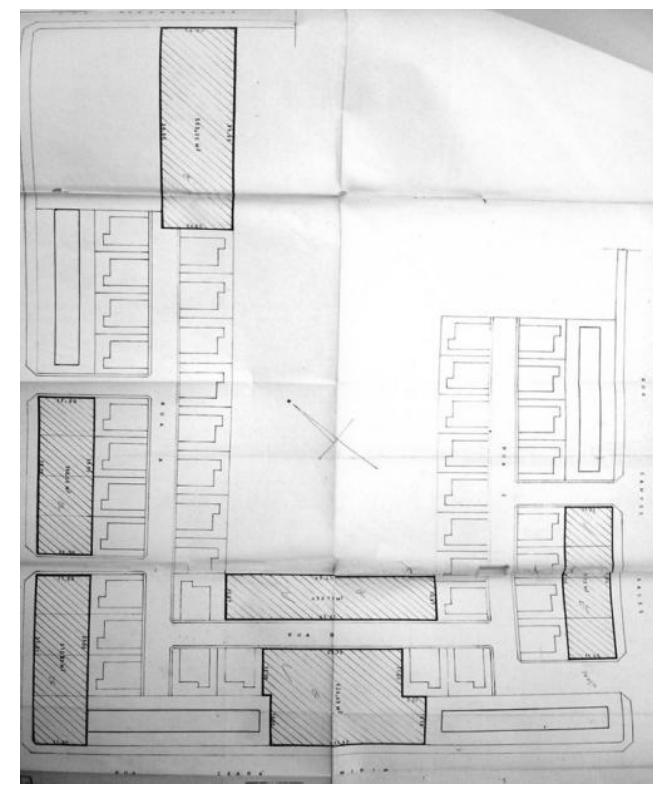

Figura 180: Implantação do Conj. Nova Tirol (IAPC-1957), em Natal. Fonte: IN.S.S-RN espaços coletivos foram locados no interior da quadra, protegidos dos fluxos constantes de veículos das avenidas circundantes. Essas edificações são interligadas por meio de ruas cul-de-sac ${ }^{554}$ (Figura 180). Da mesma forma que a maior parte dos conjuntos de edifícios verticais, os blocos de apartamentos do Conjunto

553 Esse conjunto é conformado por quarenta unidades isoladas e geminadas duas a duas, além de quatro blocos de apartamentos, distribuídos numa área de $10.440,00 \mathrm{~m}^{2}$. Está localizado, ao contrário do que a historiografia especifica para o centro-sul do país, em um bairro residencial novo na época de sua construção, o Tirol, destinado à população de média e alta renda. Refere-se também a um dos poucos exemplares dotados por boas instalações elétricas, servido de água encanada e ligado ao sistema de esgotamento sanitário da cidade de Natal. O terreno foi adquirido pelo IAPC por compra feita ao desembargador Rômulo da Fonseca Tinoco, pela quantia de $\operatorname{Cr} \$ 36.543,00$ (cruzeiros), em fevereiro de 1942. O projeto original previa a construção de quarenta unidades habitacionais isoladas e oito blocos de apartamentos com quatro pavimentos e dois apartamentos por andar, além de escola e centro social, de acordo com a noção de unidade de vizinhança. Mas, somente as quarenta casas e quatro blocos foram edificados.

554 Mais precisamente, a área destinada aos blocos correspondia a $2.000 \mathrm{~m}^{2}$, a área destinada às moradias era de $4.000 \mathrm{~m}^{2}$, enquanto o espaço reservado para a construção dos equipamentos de uso comum era de $1.500 \mathrm{~m}^{2}$. A área restante seria reservada às vias de acesso e circulação e aos grandes espaços arborizados. 
Nova Tirol se conformavam por volumes prismáticos simples com quatro pavimentos não dotados de elevador. Os pilotis e o teto-jardim foram suprimidos e substituídos por apartamentos térreos (em dois blocos), por pontos comerciais (nos demais) e por cobertura em telha francesa, "mais adequada ao clima local", ocultadas por platibandas. Também seguindo aquele padrão, percebe-se 0 emprego de outros elementos da linguagem moderna como o plano vazado de combogós, utilizado pelo arquiteto para destacar a caixa de escada e dar ênfase à mudança de função na fachada, além de volumes salientes nas sacadas, que dão certo movimento àquele plano. Em contrapartida, aliados aos elementos modernos ainda podem ser identificados alguns ornamentos, representados especialmente pelo frontão sobre a platibanda no bloco IV (Figura 181).
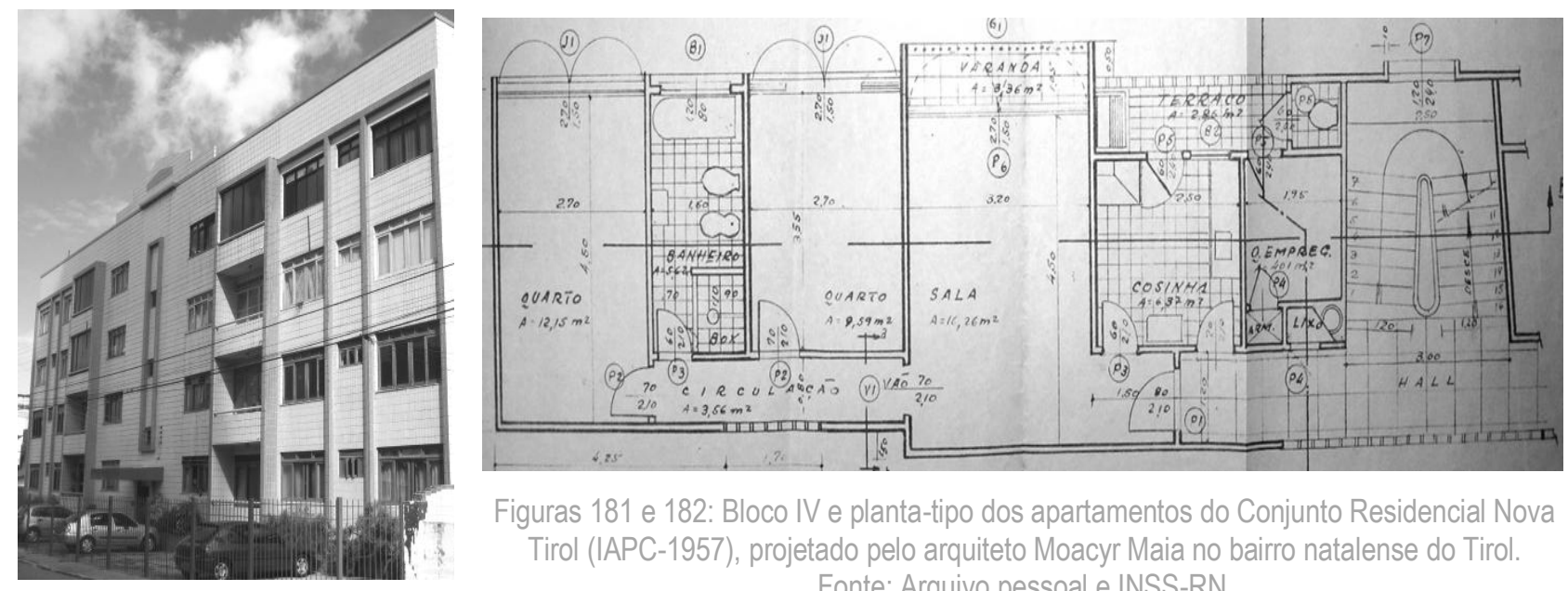

Figuras 181 e 182: Bloco IV e planta-tipo dos apartamentos do Conjunto Residencial Nova Tirol (IAPC-1957), projetado pelo arquiteto Moacyr Maia no bairro natalense do Tirol. Fonte: Arquivo pessoal e INSS-RN.

Em se tratando da disposição dos ambientes em planta, percebe-se uma preocupação quanto à dimensão dos cômodos, que podem ser imputados como mínimos. A utilização de um modelo padrão, uma planta-tipo, em todo o conjunto também pode ser verificada ${ }^{555}$. Observando a dimensão e a distribuição dos cômodos na planta-tipo dos apartamentos do Conjunto Residencial Nova Tirol, percebe-se que apesar dos espaços se organizarem ao longo de um corredor com quase $5 \mathrm{~m}$ de extensão, os ambientes se apresentam dispostos de modo não tradicional, com concentração dos espaços frios (cozinha, área de serviço e banheiro de empregada) e separação física e visual das áreas íntimas, daquelas comuns e de serviço (Figura 182).

A análise das plantas das quarenta moradias que compõem o Conjunto Nova Tirol em Natal também revela a sintonia do projeto com os preceitos da arquitetura moderna. Da mesma forma que as unidades coletivas, o programa da casa é simplificado, e as dimensões dos cômodos mínimas. A circulação na forma de corredor, comum nas moradias do período, praticamente inexiste. A disposição dos ambientes se dá de acordo com a insolação local, com os espaços frios situados na parte oeste da planta e os quartos no sentido oposto, sendo privilegiados pela insolação diurna. Nas fachadas observa-se também a utilização de

555 A planta-tipo das unidades dos blocos possuía: sala $\left(16,25 \mathrm{~m}^{2}\right)$, varanda $\left(3,36 \mathrm{~m}^{2}\right)$, dois quartos $\left(9,59 \mathrm{~m}^{2}\right.$ e $\left.12,15 \mathrm{~m}^{2}\right)$, banheiro $\left(5,62 \mathrm{~m}^{2}\right)$, circulação $\left(3,56 \mathrm{~m}^{2}\right)$, cozinha $\left(6,37 \mathrm{~m}^{2}\right)$, área de serviço $\left(2,86 \mathrm{~m}^{2}\right)$ e quarto de empregada $\left(4,01 \mathrm{~m}^{2}\right)$, totalizando $64 \mathrm{~m}^{2}$ de área útil. 
elementos como a laje plana que protege o terraço frontal e a parede de combogós, em conjunto com elementos tradicionais, como a cobertura em duas águas em telha colonial (Figuras 183 e 184).
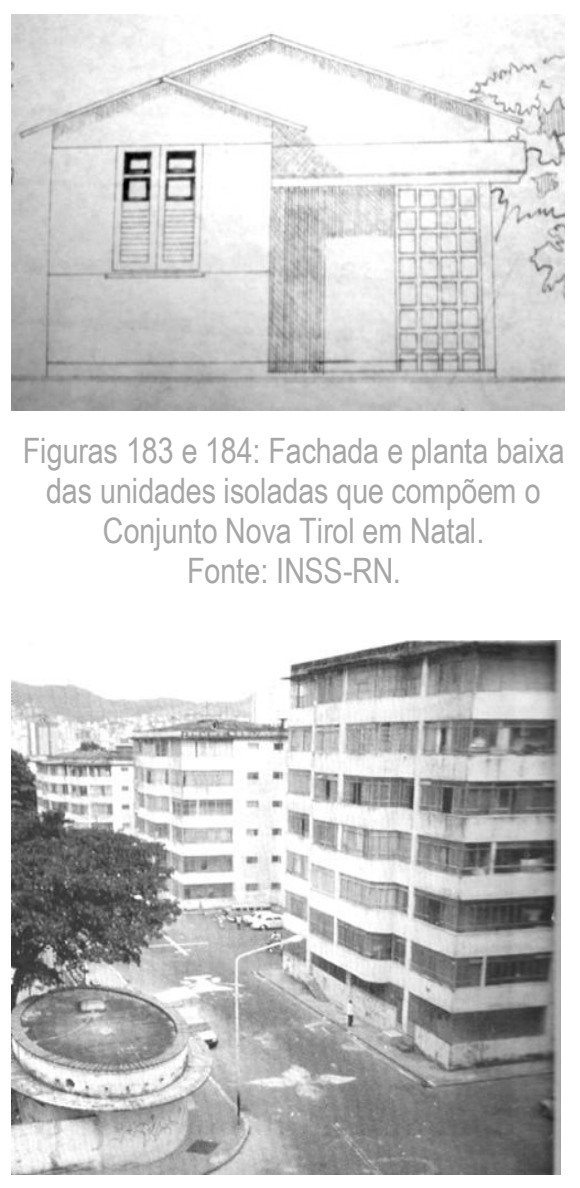

Figura 186: Conjunto São Cristovão, em Belo Horizonte (IAPI-1948).

Fonte: BONDUKI, 2002.
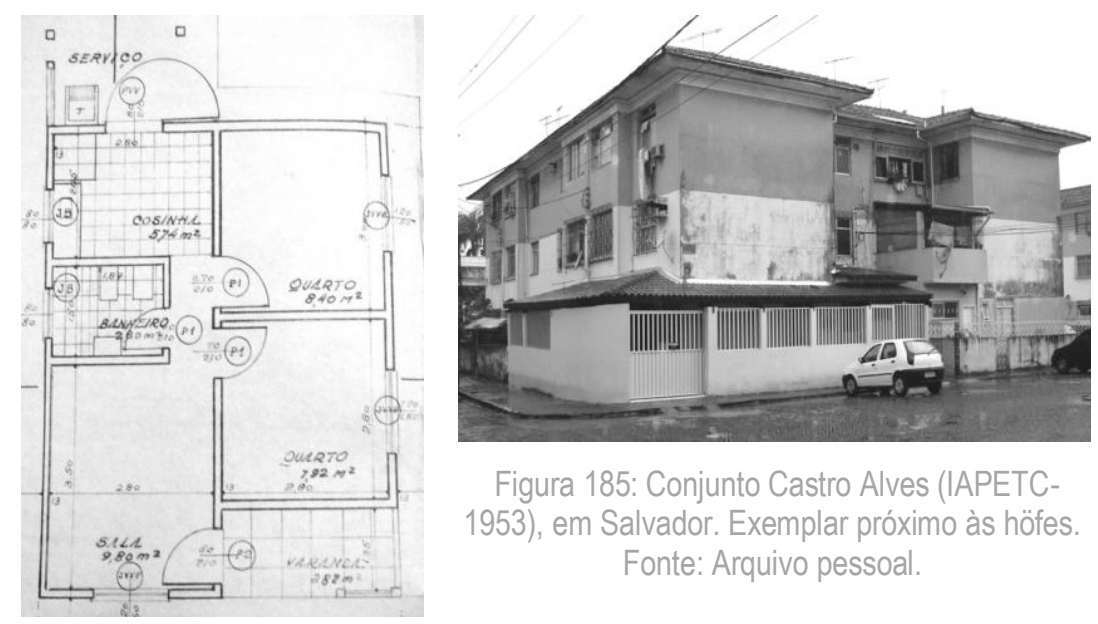

Figura 185: Conjunto Castro Alves (IAPETC1953), em Salvador. Exemplar próximo às höfes. Fonte: Arquivo pessoal.

Outro exemplar de implantação urbana diferenciada e próxima a um modelo tido como moderno refere-se ao Conjunto Castro Alves (IAPETC-1953), em Salvador. Nele, os sete blocos que o compõem apresentam estrutura muito próxima às höfes vienenses típicas da década de 1920, apresentando uma área interna aberta, destinada ao lazer e/ou contemplação556 (Figura 185). Essa tipologia mostra-se semelhante à empreendida no Conjunto Residencial São Cristovão (IAPI-1948) pelos engenheiros White L. da Silva, José Barreto de Andrade e Antônio Neves, em Belo Horizonte 557 (Figura 186) (ARAÚJO, 2009; CASTRIETA, 2009), o qual, Bonduki (2002) afirma equivocadamente ser o único exemplar do gênero no país. A distinção de ambos se dá em relação à implantação e, principalmente, à dimensão. Enquanto o Conjunto mineiro é composto por nove grandes blocos de apartamentos, dispostos de modo semicircular, num total de 928 unidades habitacionais ${ }^{558}, 0$ Conjunto baiano é conformado por sete blocos que abrigam aproximadamente 200 famílias $^{559}$. A implantação do Conjunto Castro Alves, por sua vez, se dá em linha, próxima ao observado, salvo a densidade da

\footnotetext{
556 Terreno doado pelo Governo do Estado da Bahia no início da década de 1950. A construção do Conjunto foi iniciada em 1953 e concluída três anos depois, sendo servido de água, luz, esgoto e telefone. No seu parecer foi indicada a intenção em aproximar a construção a uma Höfe.

${ }^{557} \mathrm{O}$ terreno para a edificação desse conjunto foi doado pela prefeitura de Belo Horizonte, totalizando $7.000 \mathrm{~m}^{2}$. Foi edificado para abrigar 3.000 trabalhadores de baixa renda, no centro da cidade. A gestão e a administração do conjunto ficaram a cargo da CASA (Companhia Auxiliar de Serviços de Administração), do Rio de Janeiro, de acordo com contrato firmado em 29 de novembro de 1940. Ao contrário de muitas das realizações estatais no campo da moradia no país, a população já residente no terreno antes da edificação do Conjunto foi contemplada no projeto, por meio da doação de unidades residenciais (ARAÚJO, 2009; CASTRIETA, 2009).

${ }^{558}$ Além de área de lazer, escola, igreja, associação de moradores e área verde circundante. Na área interna do conjunto estão dispostas praças, quadras de esporte, jardins e playgrounds. Alguns blocos são interligados por passarelas (ARAÚJO, 2009; CASTRIETA, 2009). Atualmente o conjunto é tombado como patrimônio nacional, processo que deveria abarcar muitas outras realizações dos institutos de previdência no país.

559 Conta ainda com uma associação de trabalhadores, quadras de esporte, playgrounds e diversas áreas verdes.
} 
edificação, da Höfe Kall Marx, da década de 1920, em Viena. A planta-tipo dos apartamentos com programa (sala, dois quartos, BWC e cozinha) e dimensões mínimas $\left(70 \mathrm{~m}^{2}\right)$, sem corredores, também se aproximam do repertório moderno (Figura 187).
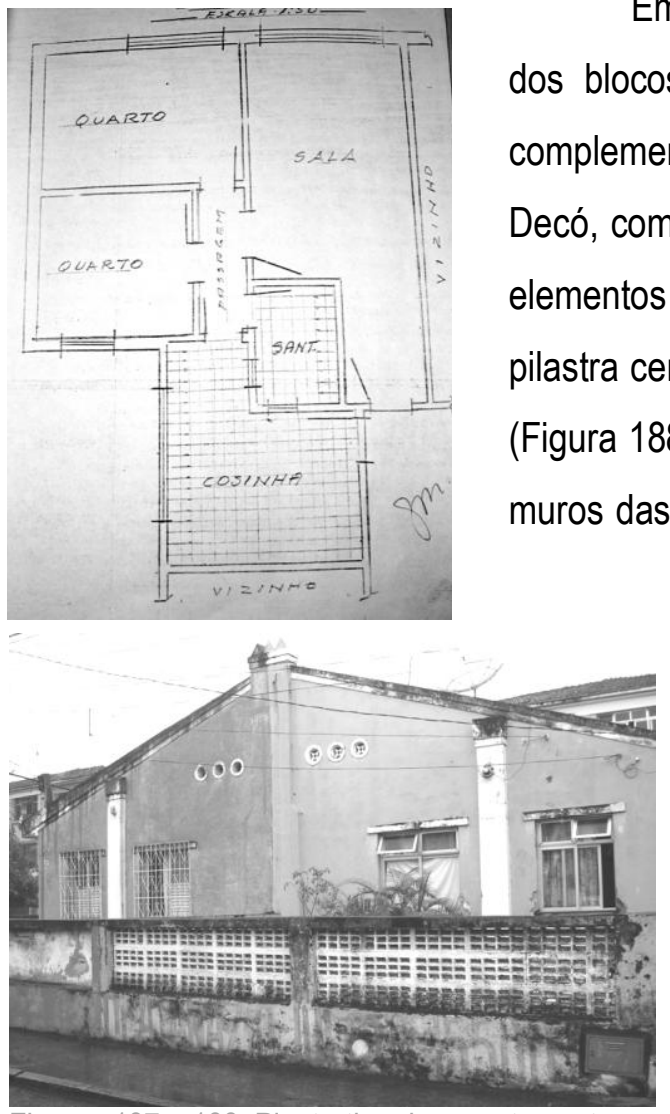

Figuras 187 e 188: Planta-tipo dos apartamentos e moradias geminadas duas a duas do Conjunto Castro Alves (IAPETC-1953), em Salvador. Fonte: INSS-BA e arquivo pessoal; respectivamente.

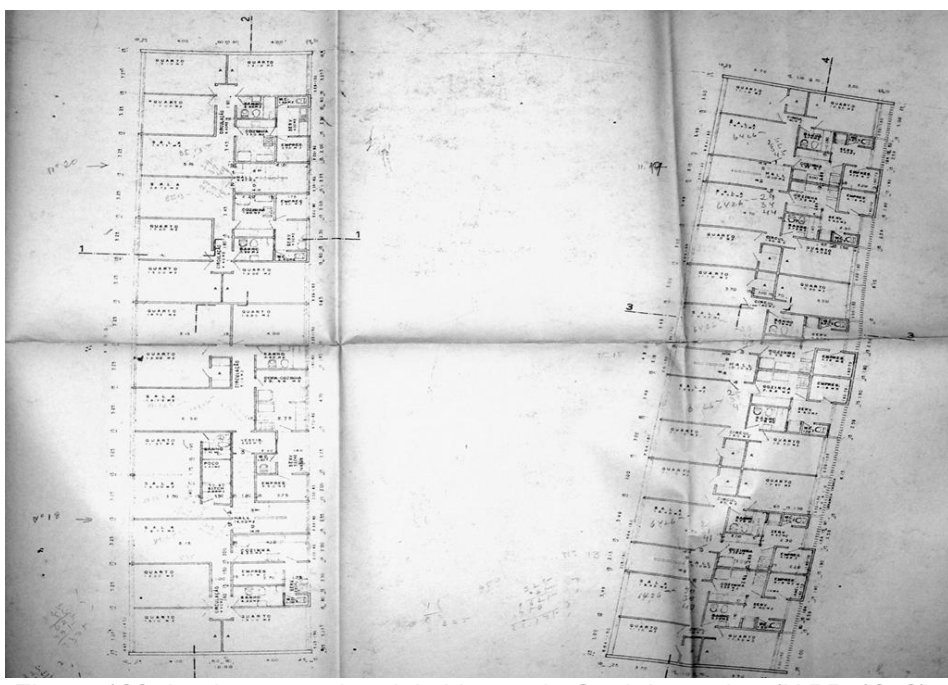

Figura 189: Implantação dos dois blocos do Conj. Itapagipe (IAPB-1953), em Salvador. Fonte: INSS-BA.

Em contrapartida à arquitetura e ao urbanismo de viés modernos dos blocos de apartamentos, as unidades unifamiliares geminadas que complementam o conjunto apresentam elementos que remetem ao Art Decó, como as aberturas circulares em fachada, além de falsas pilastras e elementos decorativos como as três pequenas pirâmides encimadas da pilastra central, que sugerem uma chaminé do vocabulário da estética fabril (Figura 188). Referências à arquitetura modernas são percebidas ainda nos muros das moradias geminadas duas a duas, especialmente pelo emprego de linhas retas e blocos pré-fabricados de combogós.

O Conjunto Almirante Valdermar Mota ou Conjunto Itapagipe (IAPB-1953)560, também em Salvador, é outro exemplar de conjunto misto identificado na pesquisa documental. Percebe-se uma pequena inclinação na implantação dos dois blocos de apartamentos existentes, separados por uma área comum ajardinada, por questões relacionadas ao aproveitamento da ventilação dominante (orientação nordeste), segundo os arquitetos Diógenes Rebouças e José Bina Fonyat561 (Figura 189). Mostra-se também um caso atípico de tratamento diferenciado das fachadas principais. 0 primeiro bloco, cuja fachada principal remete aos ambientes de uso social, recebeu grandes panos de vidro de modo que os vazios se sobressaem, em concordância com as premissas corbusianas (Figura 190). O segundo bloco, cujas aberturas dos espaços de serviços abrem para a fachada principal,

560 Terreno adquirido por compra feita à Companhia Carris da Bahia, em 30 de dezembro de 1944 e a terceiros em 25 de novembro de 1953, além de faixas de terras doadas pela prefeitura de Salvador. O conjunto é composto por dois blocos de quatro pavimentos (44 unidades) sem elevador, que somam uma área de $4.012,80 \mathrm{~m}^{2}$, além de 22 residências assobradadas.

561 Ambos eram professores do curso de arquitetura, da Escola de Belas Artes de Salvador, na época. 
recebeu um grande pano de combogós e faixas vazadas em toda a sua extensão, associada a placas e linhas em concreto com diferentes cores, com embasamento em pedra (Figura 191). 0 uso do concreto nessa edificação é enfatizado e a diferenciação de cores em ambos os blocos dão a impressão de se tratar de dois edifícios independentes e não integrantes de um mesmo conjunto. No que concerne à planta, evidencia-se uma variedade de quatro tipologias ${ }^{562}$, atendidas por uma torre de escada a cada dois ou três apartamentos, sendo três torres por bloco. As moradias unifamiliares, por sua vez, se aproximam em muito do modelo empreendido pelo arquiteto Moacyr Maia, em residências nos bairros de Tirol e Petrópolis (IAPC-1957), em Natal, sendo representadas, sucintamente, por moradias com um pavimento superior e cobertura em quatro águas (Figura 192).
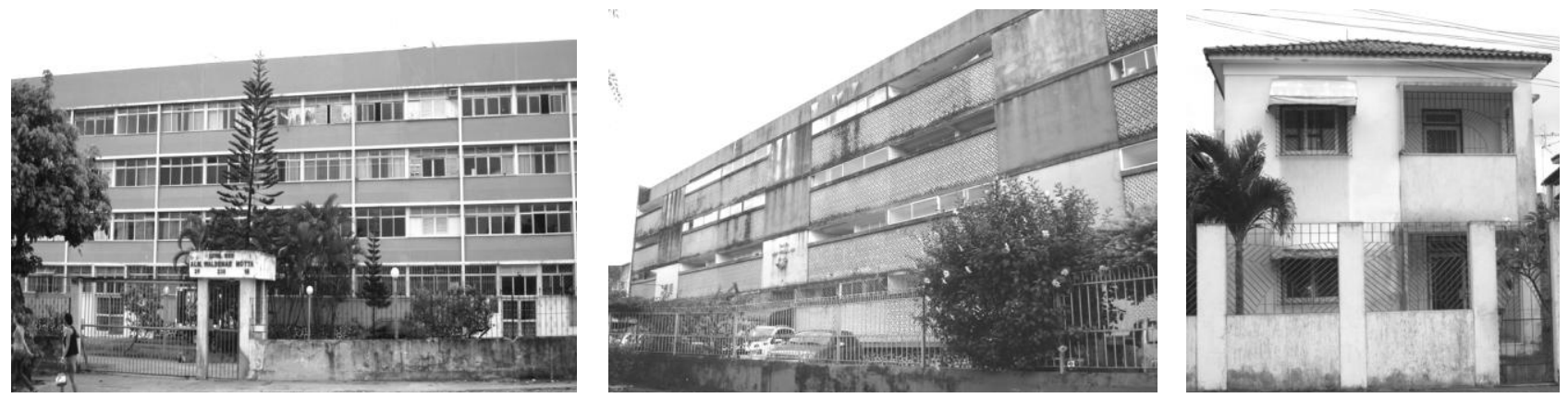

Figuras 190 a 192: Blocos de apartamentos e moradias isoladas que compõem o Conjunto Almirante Valdemar Mota ou Itapagipe (IAPB-1953), em Salvador. Fonte: Acervo pessoal.

Outra vertente de implantação foi aquela, na qual, as edificações unifamiliares e/ou coletivas foram assentadas em quadras quadrangulares regulares distribuídas ortogonalmente no terreno. Mormente, essas moradias, blocos e edifícios de apoio, quando existiam, estavam dispostos paralelamente entre si, com a concentração de equipamentos e serviços no centro do empreendimento, onde são percebidas aproximações às propostas de zoneamentos elaboradas nos primeiros CIAMs. O Conjunto General Euler Bentes Monteiro (IPASE-1964), edificado no bairro de lbura do Norte no Recife, se configura como um exemplo nesse sentido. Esse grupo de moradias, composto por 816 apartamentos e 184 casas, apresenta grandes quadras destinadas exclusivamente às moradias unifamiliares, aos blocos de apartamentos, ao lazer e aos serviços. $\mathrm{A}$ dimensão e a proporção das áreas ocupadas também seguiam às proposições do engenheiro-arquiteto Rubens Porto para os grandes conjuntos residenciais ${ }^{563}$. Mais precisamente são 16 quadras contendo blocos de apartamentos e outras 8 quadras com casas geminadas duas a duas, além de duas quadras centrais. A primeira contém uma edificação que abriga o serviço médico e a administração do conjunto, além de uma

\footnotetext{
562 Tipo 1 (4 unidades): sala, quarto, banheiro e cozinha, só aparecem no bloco B; tipo 2 (6 unidades): sala, dois quartos, banheiro, cozinha e área de serviço; tipo 3 (21 unidades): igual ao tipo anterior, acrescido de quarto de serviço; e tipo 4 (13 unidades): igual ao tipo 3 acrescido de um quarto.

563 Mais detalhadamente, as dimensões eram: quadra A $\left(7.488,00 \mathrm{~m}^{2}\right)$, B $\left(9.600,00 \mathrm{~m}^{2}\right), C\left(7.254,00 \mathrm{~m}^{2}\right), \mathrm{D}\left(9.300,00 \mathrm{~m}^{2}\right), \mathrm{E}$ $\left(7.020,00 \mathrm{~m}^{2}\right), \mathrm{F}\left(9.000,00 \mathrm{~m}^{2}\right), \mathrm{G}\left(7.020,00 \mathrm{~m}^{2}\right)$ e H $\left(9.000,00 \mathrm{~m}^{2}\right)$, num total de $65.682,00 \mathrm{~m}^{2}$ destinados à construção de edifícios coletivos. As quadras I a P, destinada à construção de moradias, geminadas duas a duas, os chamados lotes populares possuíam: I $\left(4.680,00 \mathrm{~m}^{2}\right), \mathrm{J}\left(6.000,00 \mathrm{~m}^{2}\right), \mathrm{K}\left(4.680,00 \mathrm{~m}^{2}\right), \mathrm{L}\left(6.000,00 \mathrm{~m}^{2}\right), \mathrm{M}\left(4.680,00 \mathrm{~m}^{2}\right), \mathrm{N}\left(6.000,00 \mathrm{~m}^{2}\right), 0\left(4.680,00 \mathrm{~m}^{2}\right)$ e P $(6.000,00$ $\mathrm{m}^{2}$ ), totalizando uma área de $42.720,00 \mathrm{~m}^{2}$. A área destinada às ruas foi de $44.938,00 \mathrm{~m}^{2}$ e para as praças foram reservados $10.680,00 \mathrm{~m}^{2}$. A área total do conjunto é de 164.020,00 $\mathrm{m}^{2}$.
} 
praça (Praça Marechal Soares Dendréa), espaço conhecido atualmente, como Praça da SUDENE. Na segunda quadra central, são encontradas uma sala comunitária, uma escola (Lauro Diniz), um ginásio (Delmiro Gouveia) e uma área arborizada. As quadras onde estão locados os blocos de apartamentos são enumeradas de "A" a "H".

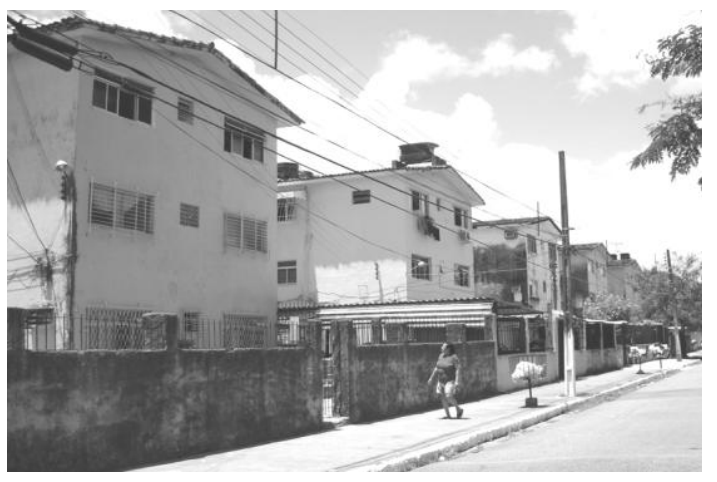

As unidades habitacionais do referido Conjunto foram destinadas aos trabalhadores segurados do IPASE, especialmente aos funcionários da SUDENE, no Recife ${ }^{564}$. São, no total, 136 blocos de apartamentos com três pavimentos e dois apartamentos por andar, edificados em alvenaria de tijolo de seis furos, revestido de massa única interna e externamente, e coberto em telha colonial

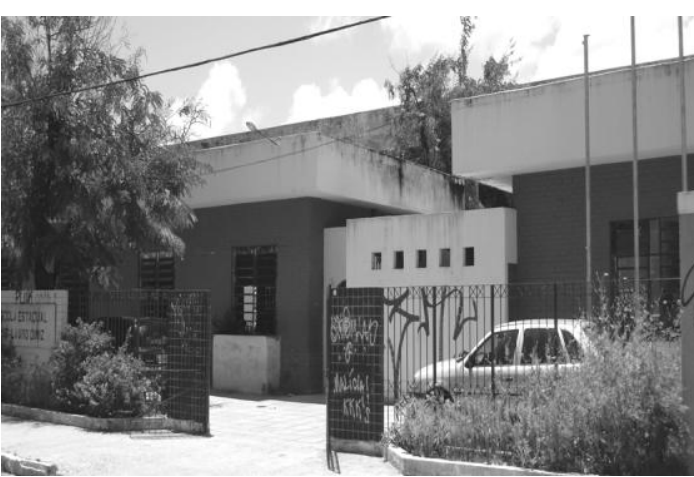

Figuras 193 e 194: Blocos de apartamentos e escola primária do Conjunto General Euler Bentes Monteiro (IPASE-1964), no Recife.

Fonte: Arquivo pessoal. assentada sobre laje de forro pré-moldadas, com piso de taco e mosaico565 (Figura 193). 0 volume segue o padrão prismático quadrangular construído diretamente sobre 0 terreno, com fachadas sem detalhes ou ornamentos. Somente podem ser apontados panos e blocos de combogós em alvenaria responsáveis pela iluminação e ventilação da escadaria e área de serviço, respectivamente. Em contrapartida, as moradias unifamiliares geminadas duas a duas, seguiam o modelo de moradias porta e janelas, com cobertura em telha com caimento para a via566. Arquitetonicamente, a edificação que mais se destaca nesse empreendimento é, sem sombra de dúvidas, a escola, que se aproxima da concepção neoplástica, na qual, os volumes se assemelham a caixas que se conectam formando um todo coeso; como verificado na residência Schröder, em Utrecht (1924), de Gerrit Rietveid, e em diversos outros exemplos filiados ao chamado Estilo Internacional, das décadas de 1920 e 1930 (Figura 194). Em todas as unidades habitacionais desse conjunto foram previstos, pelo menos em um dos quartos, armários embutidos, como também defendido por Rubens Porto.

Em se tratando do uso diferenciado de materiais no tratamento das fachadas e edificação dos conjuntos, merece ser citado o I Conjunto Areias (IAPI-1943), também no Recife. Esse empreendimento é conformado por 368 unidades habitacionais, entre moradias unifamiliares geminadas duas a duas e dois

564 O estabelecimento da parceria entre o IPASE e a SUDENE, nessa cidade, começou a ser discutida ainda nos primeiros anos da década de 1960, mas somente em 1964 ele foi firmado. A comercialização das unidades só começou a ser realizada em 1968; 0 provável ano de conclusão do Conjunto. A alienação desses imóveis perdurou até 1972.

565 Todos os blocos foram construídos com frente para o nascente.

566 Em planta foram percebidas três tipologias: A, para as residências unifamiliares, com $69,58 \mathrm{~m}^{2}$, conformada por sala com um ambiente, dois quartos, banheiro, cozinha e área de serviço com lavanderia; $B\left(79,82 \mathrm{~m}^{2}\right)$ e $C\left(86,32 \mathrm{~m}^{2}\right)$, para os apartamentos, com dois ou três quartos, respectivamente, além de sala com dois ambientes, banheiro, cozinha, área e dependência de serviço completa. 
blocos de apartamentos, além de dez pontos comerciais isolados, dois edifícios comerciais e uma escola (Figura 195). Destaca-se, nesse sentido, a utilização de pedra para o revestimento das caixas de escada e 0 emprego de blocos de combogós em alvenaria nas fachadas principais dos blocos residenciais, mais precisamente associados às esquadrias das salas dos apartamentos (Figuras 196 e 197). Vale ressaltar que esse artifício era geralmente empregado nas fachadas secundárias e/ou posteriores das edificações concebidas pelos IAPs e pelas CAPs no país, mas a sua utilização como elemento em destaque na composição formal da edificação foi bastante rara. As unidades geminadas, por sua vez, apesar de seguirem a tendência porta e janelas com pequena varanda de entrada, apresentavam elementos pouco habituais para essas moradias, como as janelas em vidro e metal (basculantes) e pilares em formato de "V" em metal (Figura 198).
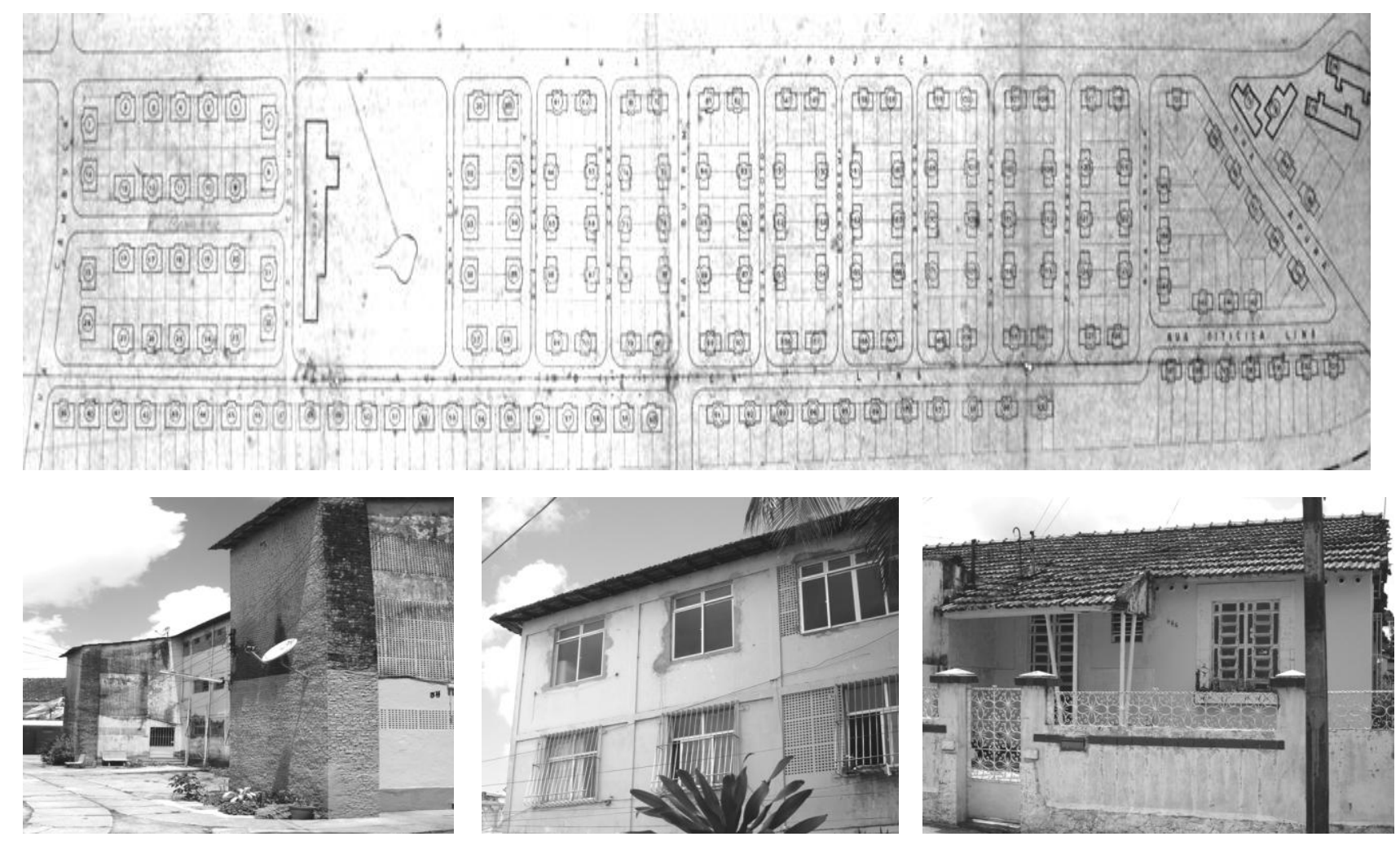

Figuras 195 a 198: Implantação, blocos de apartamentos, detalhes combogós e unidades geminadas duas a duas do I Coniunto Areias (IAPI-1943). no Recife. Fonte: INSS-PE e arauivo nessoal.

\subsection{Unidades Habitacionais Financiadas pelos Órgãos}

\section{- Grupos de Moradias:}

Como dito anteriormente, a prática da concessão de financiamento para a construção de grupos habitacionais por parte das Caixas e Institutos de Aposentadoria e Pensões no Nordeste foi recorrente. Em quase todas as capitais estudadas, com exceção de Teresina, foram identificados exemplares que se encaixam nessa categoria. Em Salvador, por exemplo, foram encontrados três empreendimentos financiados pelos órgãos, e dizem respeito a edifícios verticais de moradia coletiva. São exemplos, os Edifícios Helena 
(1955) e Morais (1957), localizados no bairro de Brotas ${ }^{567}$, ambos financiados pelo IAPC (Figura 199). Destacam-se tanto pela volumetria em formato de $L$, quanto por apresentar elementos pouco comuns na época, como as áreas de garagem previstas em conjunto com o bloco de apartamentos, além de área destinada a festas; um espaço aberto conformado pelos pilotis. As caixas d'água dos prédios também chamam atenção devido à sua forma, semelhante a uma gota, interligada às caixas de escada e de elevador dos prédios. Apesar de não apresentar teto-jardim, a cobertura é em fibrocimento com empena invertida para o centro do edifício, sendo ocultada por platibandas. Há ainda, o Edifício Nosso Senhor do Bonfim (IAPC-

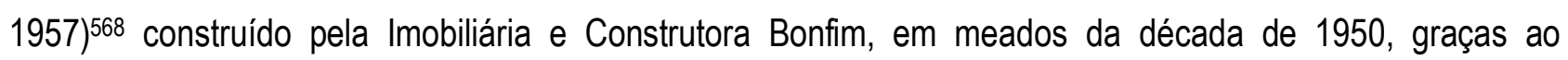
financiamento concedido pelo IAP dos Comerciários. Os elementos empregados e a planta da construção seguem o padrão mínimo especificado na maior parte dos conjuntos verticais, com volumetria simples, fachada laminar e panos de combogós destacando a mudança de uso nas fachadas, além de pilotis e de tetojardim (Figura 200). Nesse edifício, em especial, o corredor é o elemento estruturador e de destaque na planta-tipo. É por meio dele, que se tem acesso a todos os apartamentos do pavimento.

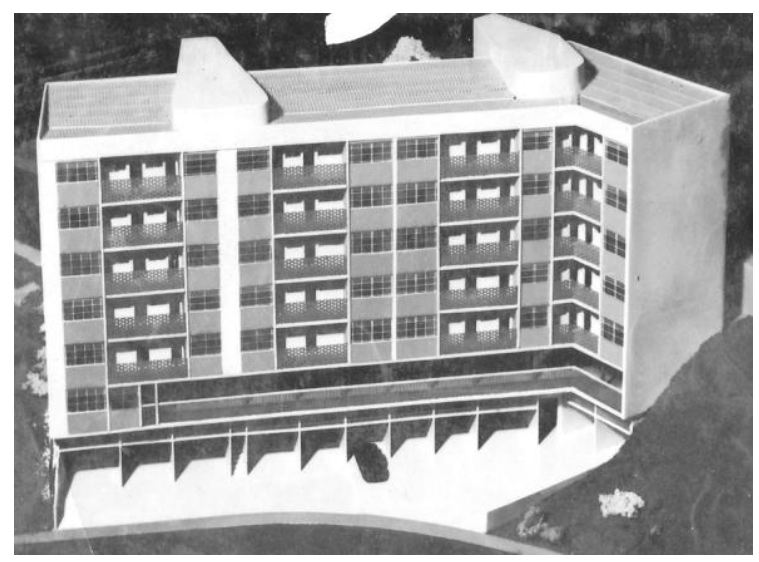

Figura 199: Maquete do Edifício Morais, em Salvador, financiado pelo IAPC em meados da década de 1950. Fonte: INSS-BA.

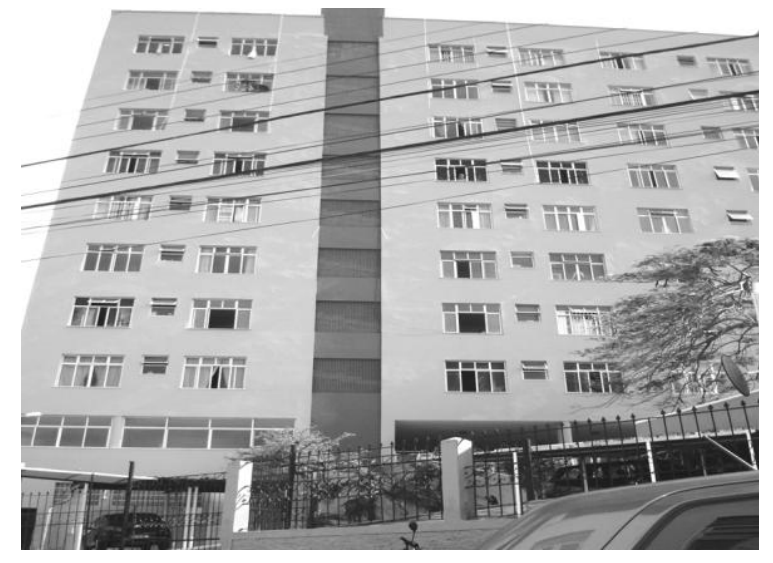

Figura 200: Edifício Nosso Senhor do Bonfim (IAPC1957), em Salvador.

Fonte: Arquivo pessoal.

Assim como em Salvador, no Recife, as edificações financiadas pelas Carteiras Prediais dos institutos de previdência atuantes na cidade, correspondem essencialmente a edifícios de apartamentos, como 0

567 Os dois são edifícios com seis pavimentos (quatro acima do nível da rua e dois abaixo dela) com duas unidades andar, edificados em alvenaria de tijolos e concreto armado, com cobertura em fibrocimento e materiais de primeira qualidade (são especificados, inclusive, azulejos KLABIN e esquadrias em ipê). Os apartamentos contavam ainda com aquecedor elétrico e armários embutidos em dois quartos, destinados à classe média alta, conformados por varanda, sala, três quartos, cozinha, banheiro, área de serviço e dependência de empregada completa, num total de $80 \mathrm{~m}^{2}$.

568 Edifício de nove pavimentos servido por duas torres de elevadores, atendendo a quatro apartamentos por andar, num total de 36 unidades habitacionais. Está situado no bairro de Santo Antônio e composto por apartamentos-tipo de $82,50 \mathrm{~m}^{2}$, com hall de entrada, living, três quartos, sendo dois com armários embutidos, banheiro, cozinha, depósito, área e dependência de serviço completa. O terreno onde se encontra encravado é irregular e mede $1.636,50 \mathrm{~m}^{2}$ e foi adquirido por compra a Carlos Guedes Gagliano, em outubro de 1956. A construção da obra foi financiada pelo IAPC à Construtora Bonfim pela quantia de Cr\$15.510.000,00 (cruzeiros) 
intitulado Ed. Gilka (IAPC-1953) e o Igarassu (IPASE-1957)569 (Figura 201), edificados no bairro de Boa Viagem, e o Edifício Capibaribe (IAPC-1945), no bairro de Boa Vista.

Antes de qualquer coisa, vale frisar que a historiografia local, focada em descrever e estudar 0 processo de verticalização no Recife, como Loureiro \& Monteiro (1998), Naslavky, (1998 e 2004) e Amorim (2003), não especificaram, muito provavelmente por falta de dados, que esses empreendimentos foram financiados pelos Institutos de Aposentadoria e Pensões na cidade, especialmente em se tratando do Edifício Capibaribe, que representa um importante exemplar, nesse sentido, já tendo sido a edificação mais alta de

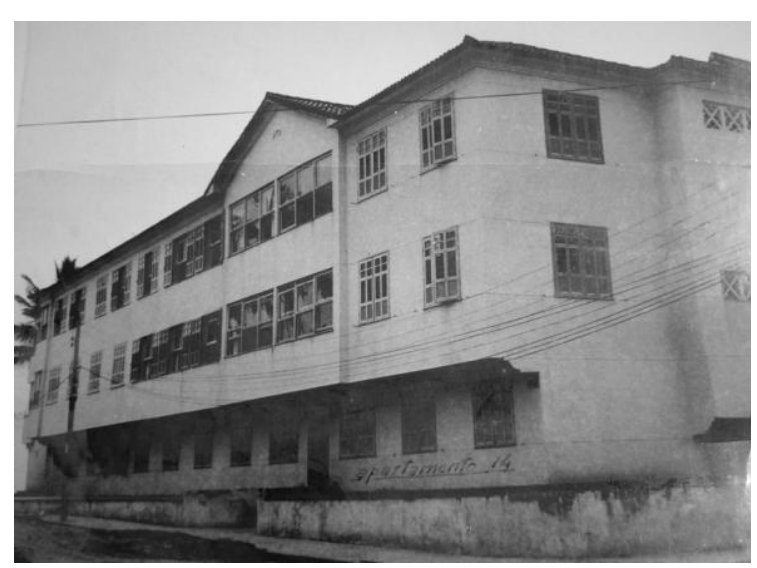
Figura 201: Edifício Igarassu (IPASE-1957), no Recife. Fonte: INSS-PE.

todo o Norte e Nordeste do país. A solicitação do pleito para a construção desse Edifício no Recife foi inicialmente solicitada pela Sociedade Construtora e Comercial Jogentil Lida, uma empresa com sede em Fortaleza, com assinatura do engenheiro Adolfo Campelo Gentil570, em 11 de julho de 1945. 0 terreno onde foi construído o Capibaribe foi adquirido pela Sociedade, por compra feita a terceiros, em 13 de junho de 1945571. O prazo estimado para a construção do prédio foi de dois anos, a contar da data de assinatura do contrato, em 1945. No entanto, devido a problemas projetuais e relacionados à aprovação das plantas, 0 processo ainda estava em trâmite em 1947. No ano seguinte, diante da não aprovação da planta arquitetônica, além de complicações financeiras, o empreendimento foi adquirido por compra pela firma construtora Figueira \& Jucá, que elaborou outro projeto para a edificação ${ }^{572}$. Esse, de autoria do arquiteto Hugo de Azevêdo Marques, constava de dois edifícios, um exclusivamente residencial e um misto com dois

${ }^{569} \mathrm{O}$ terreno foi comprado de Sergio Loreto Filho e Leopoldina de Albuquerque Melo Loreto, em maio de 1953. 0 edifício foi construído pela Sociedade Imobiliária Terrenos e Incorporação Limitada (SITI), por seu engenheiro representante Manoel Santos da Figueira, com financiamento do IPASE. A Sociedade se responsabilizou pela compra do terreno, a construção e as vendas das unidades, lavradas no Cartório de Notas do Rio de Janeiro, e o IPASE se configurou como credor.

570 Essa empresa atuou no Rio de Janeiro, Salvador, Recife, Natal, Fortaleza e Belém do Pará, de acordo com o timbre dos documentos da década de 1940 .

571 Mais detalhadamente, o terreno era de propriedade de Eduardo Alberto Simões e sua mulher Guilhermina Rosa de Pinho Simões e foi disponibilizado pela Marinha, de acordo com a Certidão do Domínio da União, por meio do pagamento de foro anual. 0 valor orçado pelo construtor (a Sociedade) para a edificação do imóvel em 11 de julho de 1945 foi de $\mathrm{Cr} \$ 16.000 .000,00$ (cruzeiros) e sua solicitação feita ao IAPC em maio de 1945. Em 18 de setembro do mesmo ano, foram aprovadas pelo presidente do IAPC, as bases preliminares da operação, conforme Resolução n.128.245, de 22 de setembro de 1946. Por despacho em 27 de dezembro de 1945 do presidente, foi autorizado o financiamento de Cr $\$ 9.400 .000,00$ (cruzeiros), correspondentes a cerca de $60 \%$ do quantum da avaliação.

5720 primeiro projeto referia-se a construção de edifício com 16 pavimentos e seis apartamentos por pavimento, num total de 96 unidades habitacionais, com diversos tipos de plantas. 0 bloco possuiria uma área construída de $10.177,80 \mathrm{~m}^{2}$, projetado pelo arquiteto Georges Munier. Os cálculos estruturais para a execução do primeiro projeto foram elaborados pela Seção Técnica da Filial da Sociedade no Recife (concreto armado). O projeto estava de acordo com o Regulamento de Construções da Prefeitura Municipal do Recife, de 1936, e à NB-1, assim como estava em concordância com as proposições de Rubens Porto para esses empreendimentos, mas não foi considerado adequado pelo corpo técnico do IAPC, no Recife. 
pontos comerciais no andar térreo, num total de 80 apartamentos distribuídos em 21 pavimentos (cada bloco) e área total de $12.118,80 \mathrm{~m}^{2}$ (Figura 202).

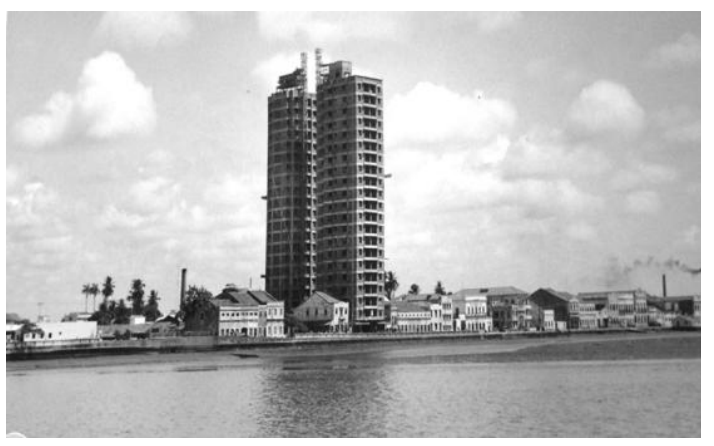

Os dois primeiros pavimentos da edificação foram destinados às lojas e garagens, no total de cinquenta vagas cobertas, aspecto incomum nas realizações dos IAPs e das CAPs não somente no Nordeste, mas também em todo 0 país, especialmente pelo grande número de vagas previstas ${ }^{573}$. A partir do segundo pavimento estavam dispostas as unidades habitacionais, duas por andar 574 , tido

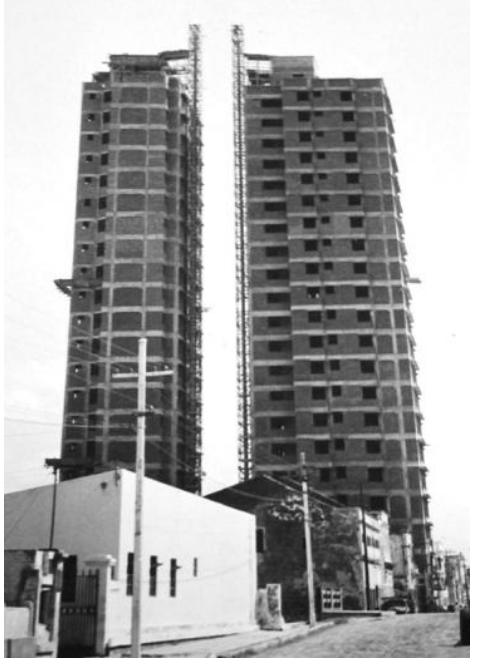

Figura 202 e 203: Edifício Capibaribe (IAPC-1945) na época da construção.

Fonte: INSS-PE. pelo arquiteto como o limite para que fosse mantido o mínimo de privacidade entre as famílias, dando impressão de habitarem uma residência unifamiliar isolada no lote. De acordo com o parecer do projeto dado pelo engenheiro Carlos Gastão Tassano, da Divisão de Engenharia do IAPC, no Rio de Janeiro, "(...) trata-se de construção usual na capital federal para obras do gênero (...)" (PARECER..., 29/08/1949, p.02). Os apartamentos apresentavam dimensões “(...) próprias para famílias mais numerosas, como é comum em nosso meio (...)" (CARTA..., 04/07/1949), em detrimento às unidades para solteiros, anteriormente previstas. Observa-se a preocupação de orientação das aberturas para o exterior no sentido predominante do vendo, tirando-se também partido do cenário natural do entorno conformado principalmente pelo Rio Capibaribe. Colaborando para a ventilação uniforme em ambos os blocos, não havia aberturas na fachada posterior do primeiro prédio, disposto perpendicularmente em relação ao segundo (Figura 203).

Em se tratando do tratamento formal o próprio arquiteto o descreveu como “(...) estilisado na moderna arquitetura funcional, (...) estabelece em suas linhas um conjunto agradável e imponente, desfrutando a paisagem local (...)" (CARTA..., 04/07/1949). Mais precisamente o volume prismático regular quadrangular da edificação é destacado por duas janelas de canto em vidro, ainda tímidas em dimensão, localizadas nas saliências de cada lateral dos volumes, responsáveis pela iluminação e ventilação de dois dos três quartos das unidades. Todas as aberturas receberam ainda uma espécie de beiral em cimento armado. A planta, de grandes dimensões, revela a destinação do empreendimento aos trabalhadores mais abastados que, em

573 De acordo com as descrições, a distribuição dos espaços no bloco A se dava da seguinte forma: pavimento térreo (lojas), primeiro (sobrelojas e rampas de acesso para a garagem, no subterrâneo), segundo (2 apartamentos), terceiro ao vigésimo primeiro (2 apartamentos por andar), vigésimo segundo (casa de máquina) e vigésimo terceiro (caixa d'água).

574 Cada uma das torres era servida de elevador social e de serviço. De acordo com o arquiteto, essa solução tornava independente cada grupo de apartamentos, melhorava sobremodo o transporte vertical e estabelecia uma completa separação da parte de serviço da social. 
conjunto às grandes circulações, a afasta das proposições típicas da arquitetura moderna, assim como, da política habitacional social que se pretendia instituir.

O Edifício Gilka (1953), também de autoria do arquiteto Hugo de Azevêdo Marques e de natureza mista, foi empreendido por um grupo de segurados e, da mesma forma que 0 Capibaribe, financiado pelo IAPC. Em termos arquitetônicos, se difere quanto ao volume, tratamento formal e também no tocante à disposição e às dimensões dos cômodos em plantas (Figura 204). Edificado poucos anos depois daquele, o Edifício Gilka apresenta mais vinculação ao vocabulário moderno, no qual, diversos elementos foram incorporados, para além dos combogós e do teto-jardim, como grandes janelas de canto, empreendidas largamente por Frank L. Wright, desde o início do século XX, como na residência Ward Willitts (1900-1902), em Illions-EUA. Esse elemento foi, posteriormente, defendido e utilizado por Le Corbusier no contexto da planta e fachada livres.

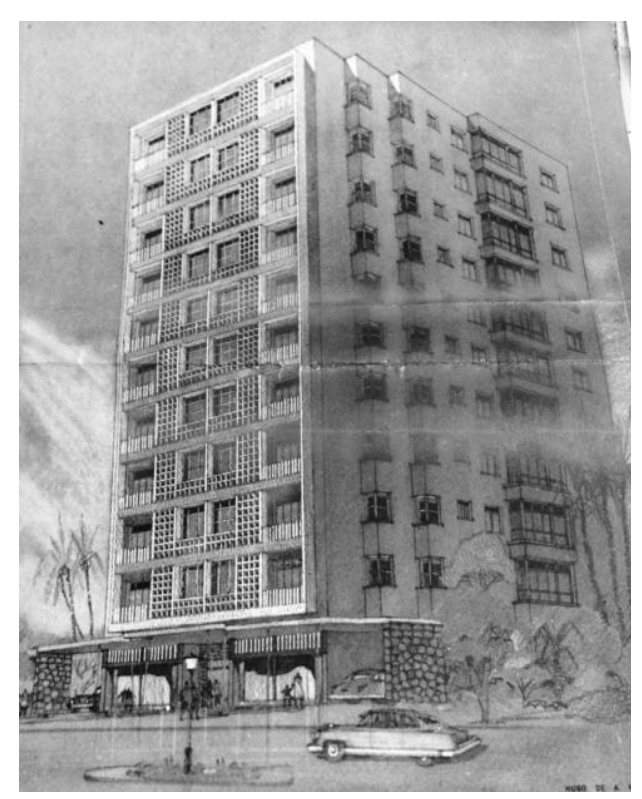

Figura 204: Perspectiva artística do Edifício Gilka (IAPC-1953), em Boa Viagem, no Recife. Fonte: INSS-PE. A configuração da planta se assemelha a um "V", recebendo quatro apartamentos por andar (em três tipologias distintas), onde são vislumbrados grandes fossos cuja função principal era otimizar a ventilação dos cômodos de serviço; solução pouco comum na época. Ainda em planta, observa-se a separação definitiva das áreas de convívio social daqueles espaços íntimos, por meio de uma porta corrediça em madeira, configurando uma setorização do apartamento que passou a ser recorrente no país posteriormente. Um diferencial diz respeito à tentativa de trazer para o interior de um apartamento, o terraço associado à sala de estar comum nas moradias unifamiliares, recebendo inclusive essa denominação por parte do arquiteto. Esse cômodo apresentava grandes dimensões $\left(12 \mathrm{~m}^{2}\right)$ comparando-se às varandas geralmente evidenciadas em blocos coletivos e estava locado especialmente nos apartamentos voltados para a via principal. Esse "terraço" não se configurava como um ambiente totalmente aberto ou exposto visualmente aos transeuntes, recebendo um pano de combogós em alvenaria, bem como uma grande janela em vidro, nesse sentido. A solução de vedação de áreas sociais por meio desse elemento moderno, também foi percebida ainda timidamente no Conjunto Areias (IAPI-1943), como colocado anteriormente.

Em João Pessoa, o I e II Conjunto do IPASE (1963/1966) e o Conjunto Presidente João Goulart (1963) foram edificados por meio de financiamentos pelo IPASE, em parcerias com $01^{\circ}$ Grupamento de Engenharia do Exército e com a empresa construtora Carmelo Ruffo, dentre outras. Nos Conjuntos do bairro 
dos Estados ${ }^{575}$, os volumes de algumas das moradias são um rearranjo do tipo chalezinho, conformando dois blocos volumétricos, recebendo garagem, elementos como pilares de seções circulares mínimos e elementos vazados na composição das fachadas (Figura 205). Em outras, o padrão tradicional com telhado em duas águas foi mantido, diferenciando daquele pelo acréscimo de terraço frontal com parede de combogós lateral e cobertura em fina laje plana, como empreendia Mies van der Rohe ${ }^{576}$ e Frank Lloyd Wright, em seus projetos residenciais datados da década de 1930577 . Havia ainda, variações de composição, nas quais, as moradias receberam cobertura em telha canal em apenas uma água e, como consequência, apresentavam um pé direito bastante elevado, findando num terraço coberto na lateral do lote (Figura 206). Nas moradias do Conjunto João Goulart, por sua vez, o padrão próximo ao bangalô, recebeu elementos do repertório da arquitetura moderna, como esquadrias basculantes em ferro e vidro, pilares de sustentação do terraço frontal e da garagem em formato diferenciado, além de cerâmicas com motivos geométricos e cores primárias fortes (Figura 207).
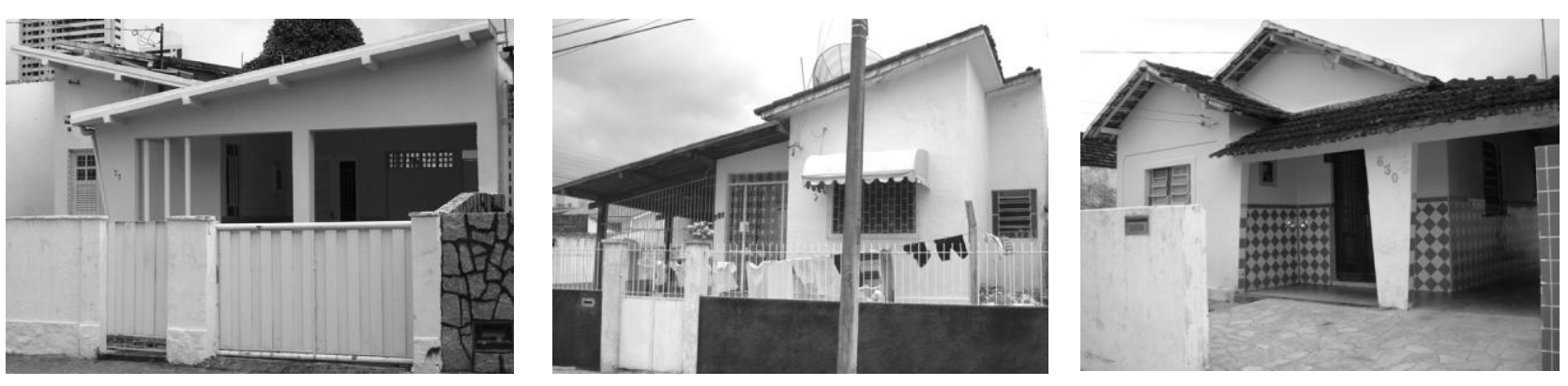

Figuras 205 a 207: Tipologias habitacionais do I e II Conjunto do IPASE (1963/1966) e no Conjunto Presidente João Goulart (IPASE-1963).

Fonte: Arquivo pessoal.

Um aspecto interessante associado a essa vertente de atuação dos institutos de previdência em João Pessoa, refere-se à burocracia enfrentada pelos segurados para se conseguir uma residência, que também estava diretamente relacionada à morosidade para a assinatura de um contrato de financiamento. 0 pleiteante, depois de se submeter a uma concorrência interna, ou administrativa como por vezes era chamada, e ser considerado qualificado com apto à operação, teria geralmente que esperar a conclusão de outra concorrência interna, agora entre empresas construtoras, para que a obra fosse iniciada. Em alguns casos, esse processo percorria mais de dois anos. Esse foi um dos principais motivos pelos quais evidenciouse a atuação de mais de uma construtora, ou empreiteiro privado, na edificação de um mesmo conjunto de residências em João Pessoa. Isso ocorria pelo fato que alguns dos escritórios estaduais das CAPs e IAPs, locados na cidade, não estavam dotados, ainda na década de 1950, de uma seção de engenharia ou até mesmo de um corpo técnico fixo, conformado por meio de profissionais, engenheiros e arquitetos

575 Os terrenos para a edificação das unidades do Conjunto foram doados pelo Governo do Estado, em 1963. Mas, as unidades só foram concluídas e comercializadas na segunda metade da década. Na primeira etapa foram concebidas 70 unidades habitacionais, locadas na Av. Sergipe e Rua General José Bentes Monteiro.

576 Como pode ser observado no pavilhão da Alemanha na Exposição de 1929, em Barcelona.

577 Inclusive na Casa da Cascata, além de diversos profissionais brasileiros que incorporaram esse elemento em suas realizações. 
principalmente, contratados diretamente pelo órgão, como percebido na maioria das capitais nordestinas. Outros, mesmo quando dotados de uma equipe, esta não estava apta, capacitada tecnicamente e/ou não era suficientemente para o projeto, execução e/ou fiscalização de obras de grande porte, ou que requeresse novas técnicas de construção, como foi o caso do Edifício Presidente João Pessoa (IAPB-1958), citado nos tópicos anteriores. Nesses casos, especialmente na capital paraibana, as CAPs e os IAPs recorreram algumas vezes a empresas privadas que atuavam na cidade ou construtoras locadas em cidades próximas. Observou-se ainda a recorrência a outro escritório estadual na região e seu corpo técnico, essencialmente no Recife, ou ao escritório central do órgão, no Rio de Janeiro.

Em Natal, foram seis grupos de residências adquiridos e apenas um financiado pelos órgãos na cidade ${ }^{578}$. Apesar daqueles não representarem o enfoque desta seção da tese, vale ressaltar que esse elevado número de vilas adquiridas na cidade ocorreu, sobretudo, a partir da segunda metade da década de 1940, no contexto de pós-II Guerra e de agravamento da crise habitacional na cidade. Esses exemplares seguiam a lógica da implantação das vilas operárias largamente empreendidas por proprietários de fábricas em todo o país, no início do século XX, principalmente. Conformavam-se, mormente, por unidades geminadas em fila, margeando uma pequena via particular de acesso - muitas das quais estreitas para a passagem de automóvel. Mais precisamente, em planta seguiam o modelo largamente utilizado nas construções do período colonial, com cômodos dispostos em fila (consecutivos margeando um comprido corredor ou interligados entre si), acompanhando a configuração dos estreitos e compridos lotes, nos quais foram implantados ${ }^{579}$. Na maior parte das vezes, sem iluminação e/ou ventilação adequadas devido à ausência ou à pequena dimensão das aberturas para o exterior, apresentando ainda problemas quanto à salubridade do ambiente, por não possuir ligações adequadas às redes de infraestrutura existentes na cidade, especialmente de água e esgotos, mesmo em meados da década de 1940, quando foram adquiridas por compra pelos Institutos em Natal. Alguns desses exemplares não apresentavam ainda gabinetes sanitários incorporados ao corpo da casa, estando locados, quando existiam, anexo a ele, com o acesso pela cozinha ou área de serviço ou separado nos demais cômodos, mormente, no quintal ou no final do lote.

Devido à ausência de ligações à rede de distribuição de água e/ou coleta de esgoto sanitário dos imóveis que compunham essas pequenas vilas, o que contrariava as determinações de higiene estipuladas pelos escritórios centrais, eram comumente encontrados chafarizes ou reservatórios coletivos para armazenagem de água, os chamados cacimbões, cuja manutenção e limpeza eram de responsabilidade dos próprios moradores, o que contrariava o idealizado por alguns dos profissionais envolvidos com a causa, como Rubens Porto. Em se tratando do esgotamento, biqueiras e canos aparentes eram percebidos, bem como relatados de constantemente casos de alagamento ou de acúmulo de dejetos e/ou detritos nas áreas

\footnotetext{
578 Foram eles: Vila Régis (IAPI-1947), Vila Gomes (IAPI-1947), Vila São João (IAPI-1948), Vila Seabra (1949), Vila Lustosa (IPASE-1950) e as casas da Rua Manoel Miranda (IPASE, 1953).

579 Foram encontrados casos, inclusive, de fogões de alvenaria na cozinha, como na Vila Gomes (IAPI-RN/1947).
} 
comuns ou vias desses grupos de moradias ${ }^{580}$, como observado no âmbito da Vila Gomes do IAPI (1947) ${ }^{581}$. É importante atentar para esse detalhe. Mesmo se mostrando inadequadas para a moradia, como colocado por publicações diversas dos órgãos de regimento como o CNT ou mesmo pelas próprias delegacias regionais, as CAPs e os IAPs adquiriram esses exemplares para se conformarem como moradia de muitos dos trabalhadores urbanos carentes, vinculadas às suas Carteiras Prediais.

Em se tratando do único exemplar cuja construção foi financiada em Natal, a Vila Janete (IAPI-1947) ${ }^{582}$, pode-se dizer que ela se destaca pelo tratamento formal e pelo revestimento dado às fachadas das suas unidades, vinculados à arquitetura moderna. Suas residências se sobressaem no entorno por apresentarem fachadas conformadas por linhas retas, destituídas de ornamentos, e platibandas escondendo as empenas das cobertas. O leve escalonamento em algumas residências e as molduras nas platibandas retas, por meio de linhas ou gigante como eram comumente chamadas, em outras, podem se conformar ainda como uma aproximação ao Art Decó. Observa-se ainda que no embasamento a

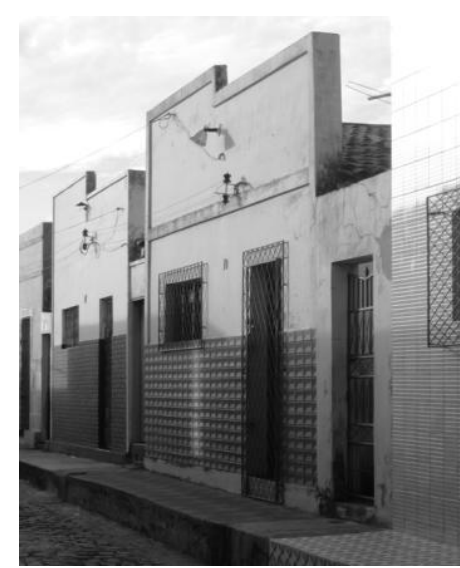

Figura 208: Moradias unifamiliares em linha da Vila Janete (IAPI1947), em Natal. Fonte: ALMEIDA, 2007. utilização de diversos materiais, especialmente cerâmica e pedra, que chegavam até o nível dos peitoris das janelas (Figura 208).

Em Fortaleza, foi o Conjunto Mondubin (1955) o financiado pelo IAPC na cidade. Esse grupo de cinco edifícios coletivos com três pavimentos e oito pontos comerciais ${ }^{583}$ encontra-se situado no bairro de mesmo nome e foi edificado pela Construtora Alfa Lida e seu engenheiro José Oswaldo Pontes, que também corresponde ao contratante do projeto, de acordo com o contrato firmando em 28 de novembro daquele ano e informações da concorrência pública realizada em 16 de novembro de 1955584. Esse Conjunto possui uma volumetria distinta dos demais conjuntos coletivos edificados ou financiados pelos órgãos no Nordeste, em formato "H" (Figura 209). Apresenta ainda elementos diferenciados nas faces dos edifícios, como faixas de

\footnotetext{
580 A maior parte dos relatos encontrados nos laudos de avaliação desses imóveis em Natal, diz respeito à canalização de esgoto aparente e o despejo de detritos diretamente na rua, que resultavam em constantes odores nesses grupos de moradias.

581 Também situada no Alecrim. As dezessete casas dessa Vila foram edificadas por Pedro Gomes, no ano de 1942, e adquiridas pelo IAPI em 1947, já sob propriedade de Manoel Gadelha de Freitas. Essa aquisição pode ter ocorrido por etapas, uma vez que nos laudos e processos imobiliários são percebidas diferentes datas de aquisição, ao longo dos anos de 1947 e 1948. Eram residências do tipo popular ou operário, como verificado nos laudos, com áreas construídas em torno de $40 \mathrm{~m}^{2} \mathrm{a} 62 \mathrm{~m}^{2}$, concedidas por meio de financiamento social, de Cr\$17.000,00 cruzeiros, em média.

582 Essa vila encontra-se localizada no bairro Alecrim e foi construída em 1947 por Eliseu Marques Carneiro devido ao financiamento concedido em 11 de novembro de 1947, pelo o IAP dos Industriários. É composta por dezoito unidades de alvenaria de tijolo, bem como um tanque d'água com torneira responsável, na época, pelo abastecimento de água aos seus moradores. As moradias, cuja área variava de $42 \mathrm{~m}^{2}$ a $57 \mathrm{~m}^{2}$, estão dispostas ao longo de uma estreita via central, em dois blocos com nove moradias em cada lado, alinhadas na testada do lote. Foram repassadas aos seus associados por meio de venda e concessão de financiamentos sociais, que permeavam entre $\operatorname{Cr} \$ 12.000,00$ e $\operatorname{Cr} \$ 16.000,00$ (cruzeiros).

583 Localizados no andar térreo de dois blocos (quatro pontos comerciais em cada).

584 De acordo com edital publicado no Diário Oficial do estado do Ceará, em outubro de 1955. As obras foram fiscalizadas pelo engenheiro Frederico Maia do IAPC. Tanto as unidades habitacionais quanto os pontos comerciais foram alugados aos segurados. Problemas relacionados à ocupação das unidades foram evidenciados devido à distância da construção em relação ao centro da cidade de Fortaleza.
} 
cores que marcam a horizontalidade das edificações, embasamento escalonado em cimento e esquadrias em formato de "T", nas quais, as folhas principais são em madeira e as bandeiras, mais compridas que as janelas, em vidro585 (Figura 210). Um aspecto curioso acompanha a edificação desse Conjunto. Desde os estudos preliminares empreendidos pelo corpo técnico do Instituto e das especificações do edital para a concorrência de construção, os comerciários de Fortaleza, especialmente aqueles associados aos sindicatos de trabalhadores vinculados ao IAPC, se mostraram contra a localização do Conjunto em área tão distante do centro comercial, tida em meados da década de 1950, como zona rural. Mas, mesmo assim, os trâmites burocráticos e projetuais foram prosseguidos. Vale salientar, como destacado pela imprensa da época, que 0 referido Instituto possuía grandes glebas de terreno no bairro de Aldeota, mais próximo do centro e bem valorizado na cidade. Os blocos foram concluídos em 1957 e até 1959 não haviam sido completamente ocupados. Como resultado, uma proposta inicialmente social acabou por se destinar aos trabalhadores mais abastados da categoria profissional. Esse episódio foi considerado pelos segurados dos órgãos em Fortaleza, como uma "desastrosa aplicação dos capitais do IAPC".
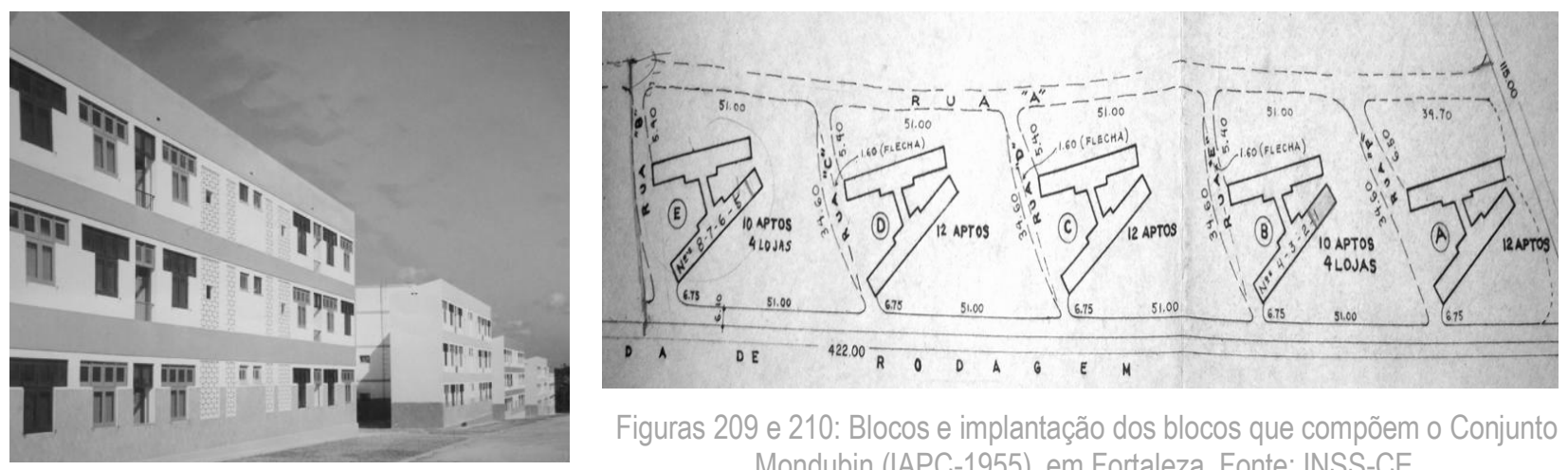

Figuras 209 e 210: Blocos e implantação dos blocos que compõem o Conjunto Mondubin (IAPC-1955), em Fortaleza. Fonte: INSS-CE.

\section{- Moradias Isoladas (iniciativa dos segurados):}

De modo geral, as unidades edificadas isoladamente por iniciativa dos trabalhadores urbanos segurados das Carteiras Imobiliárias dos institutos de previdência no Nordeste, estavam muito mais filiadas à arquitetura e ao urbanismo modernos, apresentando soluções volumétricas, de implantação, de fachada e de planta mais inovadoras que as moradias resultantes dos empreendimentos diretos realizados pelos órgãos e acima elencados. De qualquer modo, em ambos os casos, essas inovações estavam muito mais presentes nas fachadas que nas plantas das edificações.

Vale salientar, que o inverso também ocorreu, de modo que foi observada uma filiação mais próxima à arquitetura moderna em planta que na fachada da construção, como foi o caso da moradia 30 , no bairro soteropolitano de Rio Vermelho, cuja construção foi realizada pela Empresa Construtora e Imobiliária Lida e financiada pelo IAPI, na década de 1950. Nela, as fachadas apresentam diversos apliques em pedra, remetendo inclusive a uma chaminé, além de jardineira trabalhada em pedra, massa e gradis e cobertura em duas águas, com empenas perpendiculares à via, enquanto a planta se apresentava simplificada em se

${ }^{585}$ Modelo próximo ao utilizado em diversas edificações de Le Corbusier, como na Residência Jaoul (1952), em Neuilly. 
tratando do programa e das dimensões (Figuras 211 e 212). Houve casos ainda, em que elementos modernos foram incorporados em fachadas de tendências Missões, como em algumas moradias financiadas pelo IAPC em Natal, na década de 1940 (Figuras 213 e 214). Outras referências arquitetônicas foram encontradas nas fachadas das unidades financiadas pelos órgãos no Nordeste, como se verá mais detalhadamente a seguir (Figura 215).
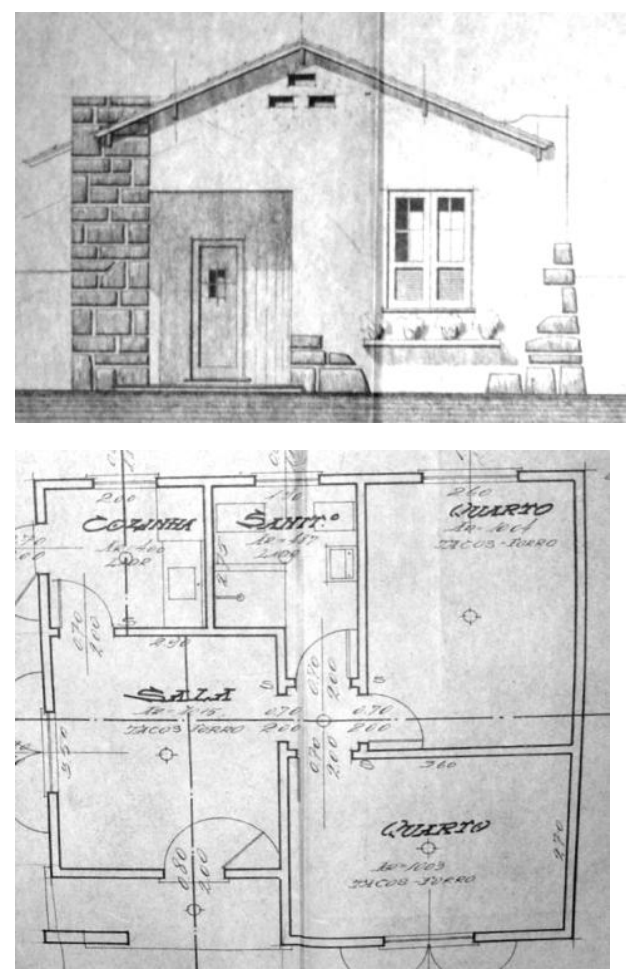

Figuras 211 e 212: Moradia financiada pelo IAPI (1950), em Salvador Fonte: INSS-BA.
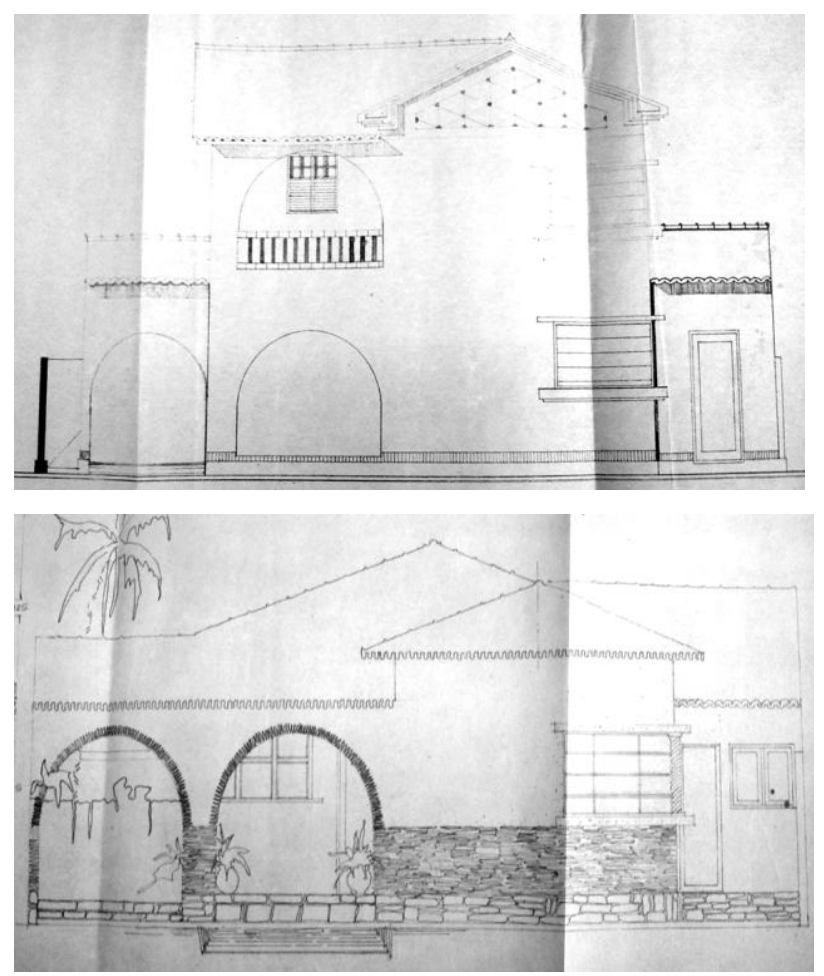

Figuras 213 e 214: Moradias financiadas pelo escritório do IAPC em Natal, na década de 1940, localizadas no bairro de Petrópolis e Cidade Alta.Fonte: INSS-RN.

Variadas são as justificativas para tanto. Uma delas remete à própria essência dessa ação imobiliária praticada pelas CAPs e IAPs, que tendia muito mais ao atuarial que as demais, sendo caracterizada por pleitos liberados com valores elevados e juros altos. Essas ações garantiam, ao mesmo tempo, um maior

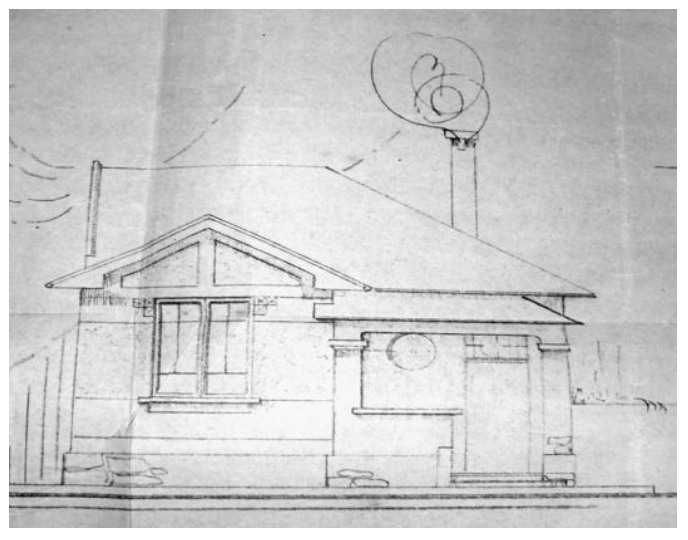

Figura 215: Moradia financiada pelo IAPC em Salvador, no ano de 1947. Fonte: INSS-BA. retorno financeiro aos órgãos e uma maior liberdade e possibilidade de realizações aos trabalhadores. Esse aspecto também foi refletido, logicamente, na qualidade e diversidade de materiais empregados nessas construções, especialmente em se tratando do uso do vidro e do concreto armado. Sendo assim, era muito mais comum encontrar exemplares com mais de um pavimento, panos de vidro, lajes e coberturas em concreto - 0 teto-jardim -, rampas, grandes escadas curvas, dentre outros, nessas moradias, que naquelas edificadas diretamente pelos órgãos no Nordeste. 
Indubitavelmente, as principais referências dizem respeito à arquitetura dita moderna, como observado nas residências locadas no loteamento Alameda Bons Ares, no bairro de Brotas, em Salvador, muitas das quais foram financiadas pelo IPASE ao longo da década de 1960 e edificadas principalmente pelo engenheiro Carlos Pires de Almeida, a exemplo da residência n.302 (Figuras 216 e 217), dentre muitas outras nessa cidade. Aproximações à arquitetura organicista também foram encontradas na capital baiana, como foi o caso de diversas casas financiadas pelo IAPC, na Vila Rio Branco, também no bairro de Brotas, em meados da década de 1950. Nelas, as plantas seguiam a configuração em U, cujos ambientes estavam todos voltados aos jardins, havendo integração entre os espaços internos e externos da moradia por meio dos grandes panos de vidro e terraços que circundavam toda a residência (Figura 218). Em fachada, essas moradias também apresentavam referências modernas.
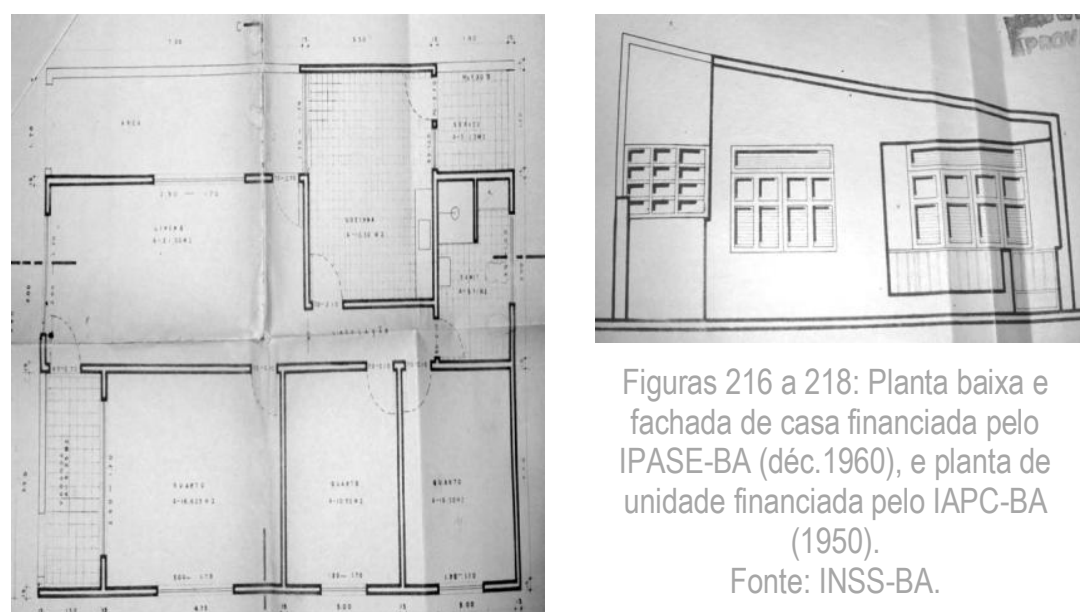

Figuras 216 a 218: Planta baixa e fachada de casa financiada pelo IPASE-BA (déc.1960), e planta de unidade financiada pelo IAPC-BA (1950).

Fonte: INSS-BA.

Mais precisamente, seguindo o repertório moderno, foram encontradas moradias com venezianas do tipo basculante, pivotante e guilhotina em madeira e vidro, principalmente; panos de vidros nas fachadas principais (Figura 219); elementos de ventilação como brisesoleil e combogós, empregados em ambientes mesmo abertos, como varandas, terraços e/ou áreas de acesso principal à residência, mais como barreiras visuais para garantir uma maior privacidade ao terraço frontal de moradias (Figura 220). Ainda no tocante aos aspectos formais, foi recorrente a aparição de pequenas varandas ou terraços de entrada, cuja cobertura em concreto armado era sustentada por esguios pilotis (Figura 221, na página seguinte), pilares com perfis e seções retangulares, cilíndricos ou em formato de "V" ou "Y", aos moldes de Niemeyer (Figura 222, na página seguinte). Alguns desses
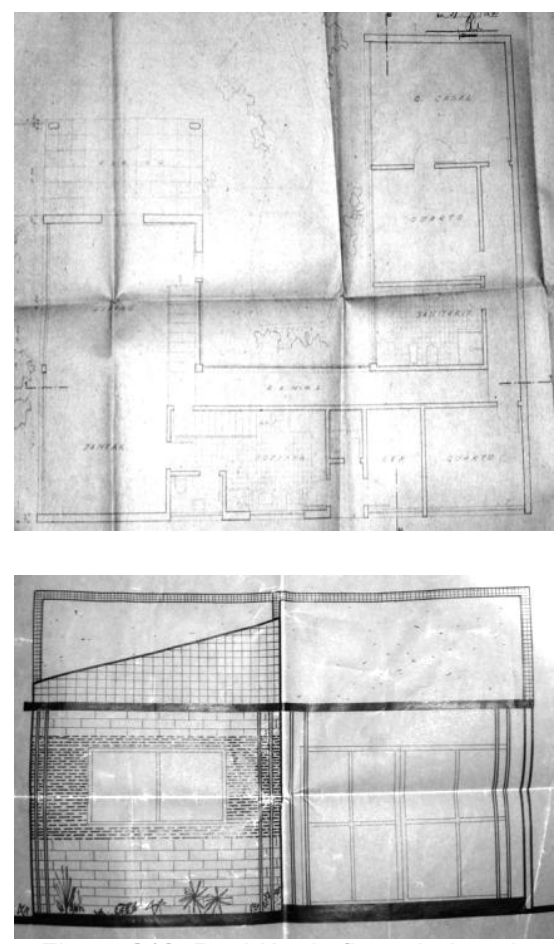

Figura 219: Residência financiada pelo IPASE (1960), em Teresina. Fonte: INSS-PI

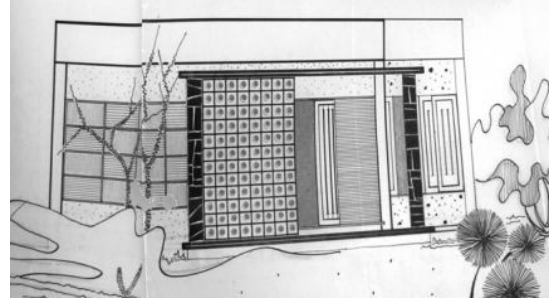

Figura 220: Moradia financiada pelo IPASE (1964), em Teresina. Fonte: INSS-PI. 
pilares se estendiam pela estrutura da edificação, como o fez Vilanova Artigas no Ginásio de Itanhaem-SP (1959) ${ }^{586}$ e no Ginásio de Guarulhos-SP (1960) (Figura 223). Percebeu-se ainda, a integração de painéis de pintura e mosaicos às edificações (Figura 224).
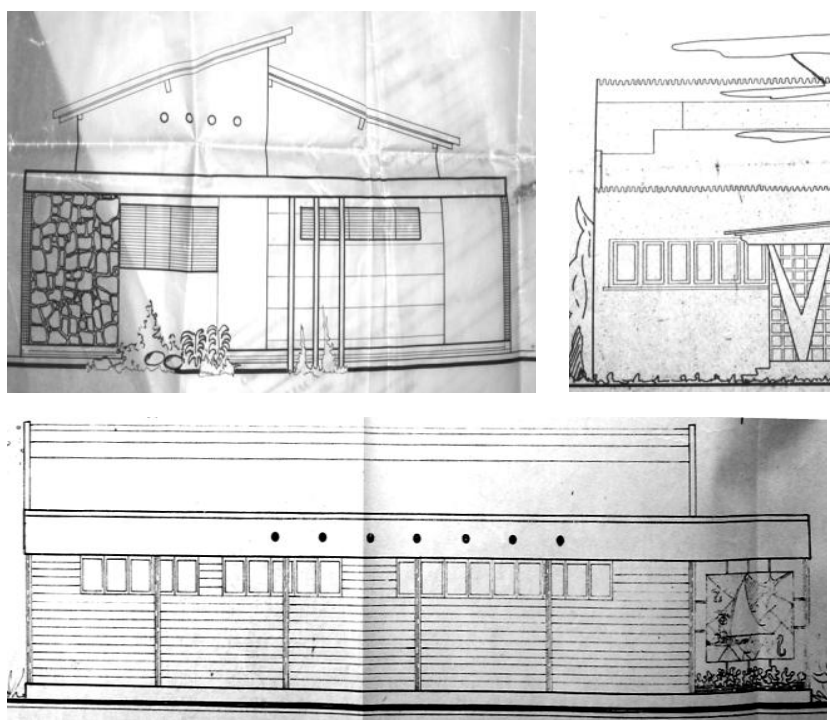

Figuras 221 a 227 (Da esq. para dir. e de cima para baixo): Residências financiadas pelo IPASE-PI (60), IAPB-RN (50), IPASE-PB (59), IPASE-RN (50), IAPI-PB (49), IAPB-RN (50) e IPASE-PI (44). Fonte: INSS-PI, RN e PB.
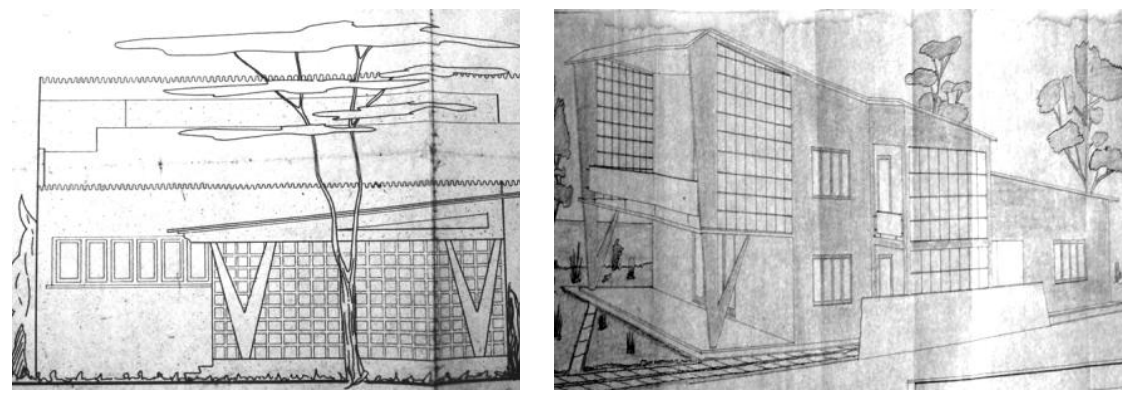

Somente em João Pessoa, essa tendência não pode ser verificada. Nessa cidade, em específico, foram poucos os exemplares encontrados na pesquisa em campo que se vinculavam à "nova arquitetura". Um desses projetos foi o da residência edificada pela Empresa Construtora Carmelo Ruffo Lida, por meio do financiamento concedido pelo IAPI a um linotipista do jornal $A$ Imprensa, no ano de 1949. Nela, é facilmente percebida a simplicidade e a sobriedade da fachada principal, alcançada por meio do uso de linhas e ângulos retos e do teto plano (Figura 225). Cabe ressaltar, que a referida Empresa teve muita importância no cenário da construção civil e arquitetura filiada às diretrizes modernas na capital paraibana, entre os anos de 1940 e 1950, principalmente.

As fachadas das edificações isoladas financiadas no Nordeste se mostravam bem diferenciadas quanto ao embasamento, ao corpo e à platibanda ou à cobertura. 0 embasamento era comumente resguardado de materiais que são associados à ideia de resistência como a pedra, principalmente em tons de rosa e cinza, o ladrilho hidráulico e o marmorite, remetendo à sua função primeira de sustentação da edificação (Figura 226). Em alguns casos, 0 embasamento chegava até a altura dos peitoris das janelas (Figura 227) ou até a linha da platibanda. Esse artifício foi bastante utilizado nas moradias edificadas na década de 1950, especialmente em Natal.

586 Em colaboração com o arquiteto Carlos Cascaldi. 
O corpo da casa, onde se encontram as aberturas das portas e janelas em madeira ou ferro, muitas vezes, não recebia tratamento qualquer e estava livre de ornamentos. Quando aparentavam, tratava-se de molduramentos em gesso ou recebiam destaque devido a reentrâncias ou projeções de determinadas áreas das fachadas (distinção de planos), chegando a tomar toda a fachada principal, em alguns casos, pelo uso de revestimentos $^{587}$ (Figura 228). As platibandas, por sua vez, não recebiam tratamento algum, ou eram destacadas por linhas, azulejos, altos-relevos e/ou pintadas com cores marcantes (Figura 229), que também serviam como uma espécie de moldura, essencialmente, para a distinção dos limites das casas quando geminadas. Poucos foram os casos de moradias em que a platibanda recebia o revestimento com outro tipo de material, como o tijolo aparente (Figura 230).

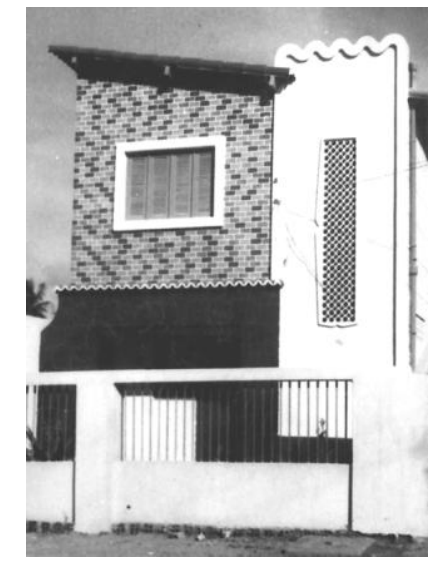

Relacionado aos volumes das moradias, houve uma larga utilização da configuração trapezoidal, bem como a combinação de vários volumes (Figuras 231 e 232). Há variação de formas prismáticas retangulares ou cúbicas, com as trapezoidais (Figura 233), volumes diferenciados, conformados essencialmente pelas empenas das coberturas, algumas geminadas conformando as chamadas "asas de borboleta" (Figura 234, na página seguinte), além dos volumes cúbicos simples ou o jogo deles (Figura 235, na página seguinte). Em se tratando dos telhados, encontrou-se comumente, o jogo de diferentes direções e formatos das águas das coberturas que, vale frisar, quase nunca eram planas. Em outras edificações se utilizava platibanda para ocultar as águas do telhado em telha de amianto ou em telha canal.

$587 \mathrm{O}$ uso de azulejos no tratamento das fachadas, vale ressaltar, st modernas nas cidades pesquisadas.
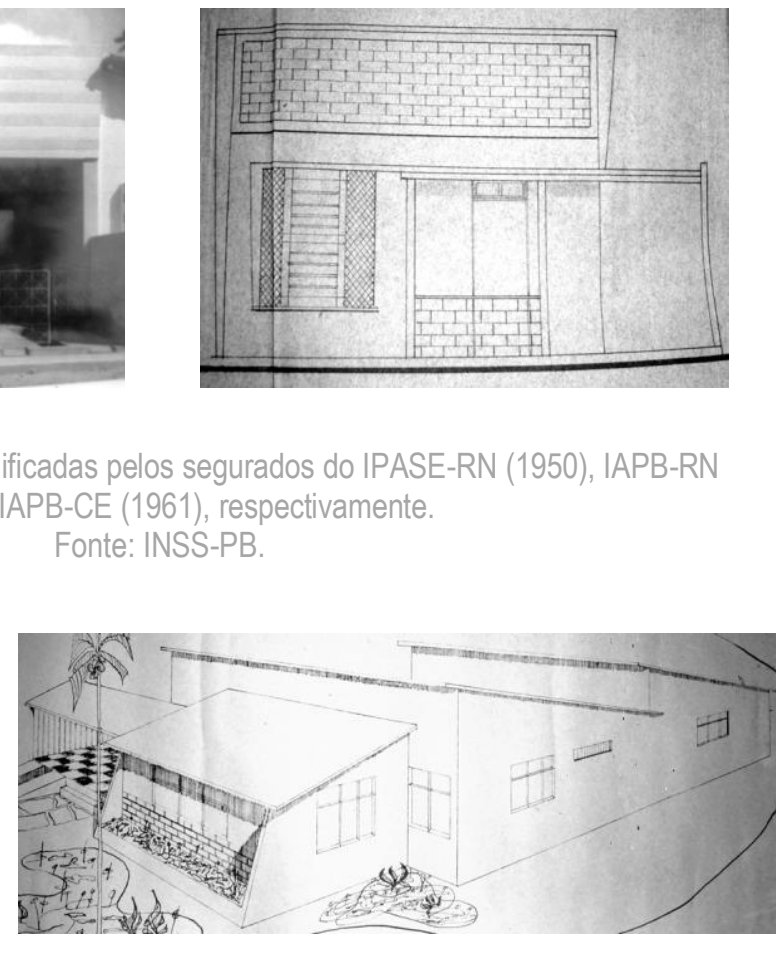

radias edificadas pelos segurados do IPASE-RN (1950), IAPB-RN Fonte: INSS-PB.
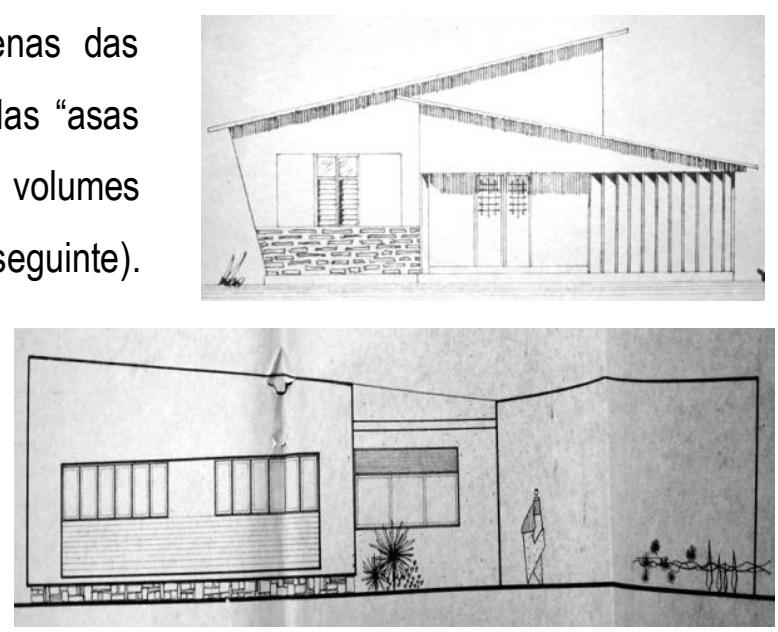

Figuras 231 a 233: Moradias financiadas pelo IAPB, na década de 1950, no Recife (2) e em Natal (1). Fonte: INSS-PE e RN. 


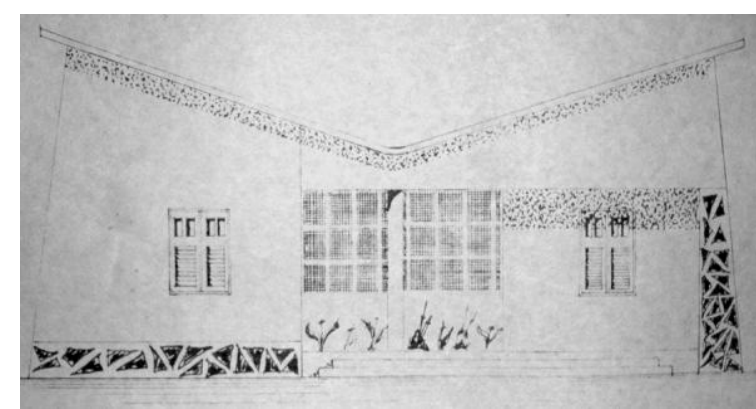

Figura 234: Habitação geminada com cobertura asa de borboleta (IAPB-PE). Fonte: INSS-PE.

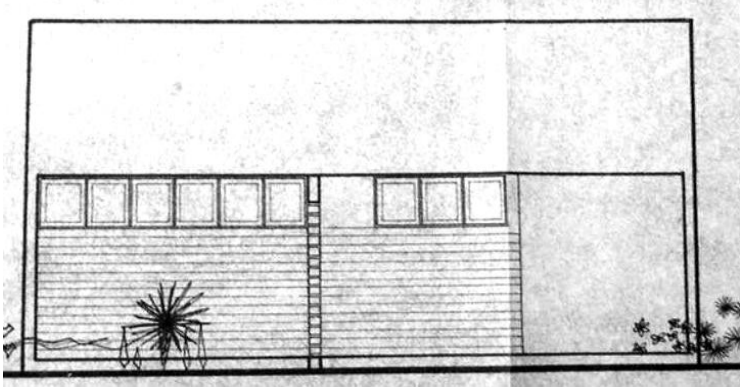

Figura 235: Volumetria simples de moradia financiada pelo IAPC em Natal. Fonte: INSS-RN.

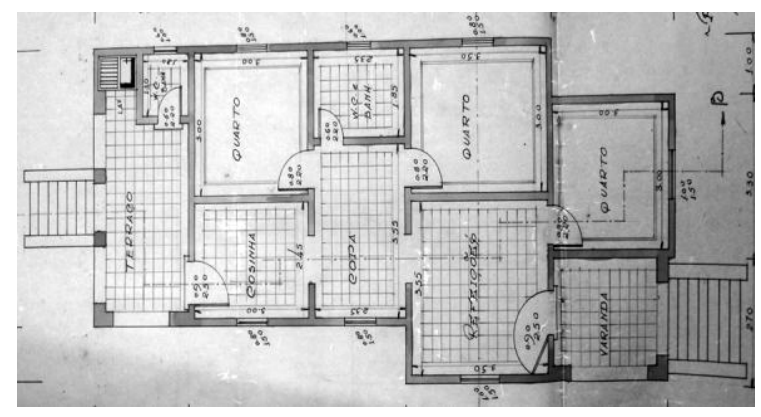

Figura 236: Planta baixa de habitação edificada por segurado do IPASE em João Pessoa.

Fonte: INSS-PB.

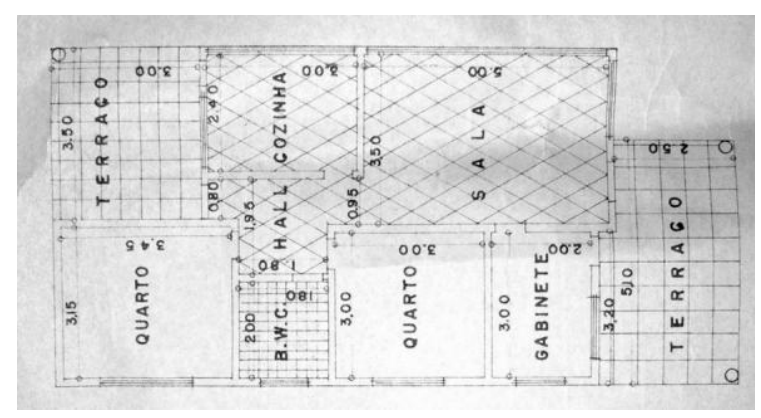

Figura 237: Planta de residência financiada no Recife. Fonte: INSS-PE.
No tocante às plantas, foram largamente encontrados exemplares residenciais com cômodos conformados com pequenas dimensões, disposições de ambientes e das aberturas para o exterior levando-se em consideração a orientação solar e a direção dos ventos predominantes, aspecto muito importante para as habitações locadas na região Nordeste, além da setorização das plantas em espaços sociais e de serviço e a supressão das grandes circulações, na forma de corredores, sendo esses substituídos por pequenos halls, por saletas privadas e/ou de televisão, como foram chamadas, ou pela copa, como observado na planta da moradia edificada com o financiamento concedido pelo IPASE, em 1950, em João Pessoa (Figura 236).

Observou-se em diversos projetos no Recife, a existência de cômodos especializados, principalmente os chamados gabinetes, o que conhecemos hoje como escritório, dispostos quase que exclusivamente na parte frontal da planta, próximo à entrada da moradia ou com acesso independente ao corpo da casa. A área de serviço e suas variações de denominação, como terraço de serviço ou ainda espaço para empregados, como em alguns momentos foi denominada, nessa capital nordestina apresentou uma dimensão maior que nas demais cidades pesquisadas, sendo integrada definitivamente ao corpo da casa (Figura 237). Em alguns exemplares, esse cômodo estava integrado à copa que, por vezes, se converteu em terraço de refeições, um ambiente aberto vinculado à cozinha, dando para a parte posterior da residência (Figura 238). Em outros casos, os setores de serviço foram implantados no fundo do lote, separados do corpo da 
casa (Figura 239). Essa prática se tornou recorrente anos mais tarde, na maioria das cidades nordestinas, especialmente nas casas locadas nos grandes conjuntos habitacionais edificados a partir, sobretudo, da década de 1970, naquela região.

Foram também encontrados entre as moradias edificadas pelos associados e financiadas pelos institutos de previdência, os chamados jardins de inverno, pérgulas ou pergolados, elementos que favorecem as trocas térmicas nos ambientes da residência, além de otimizar a iluminação natural nos cômodos onde estão locados (Figura 240 e 241).

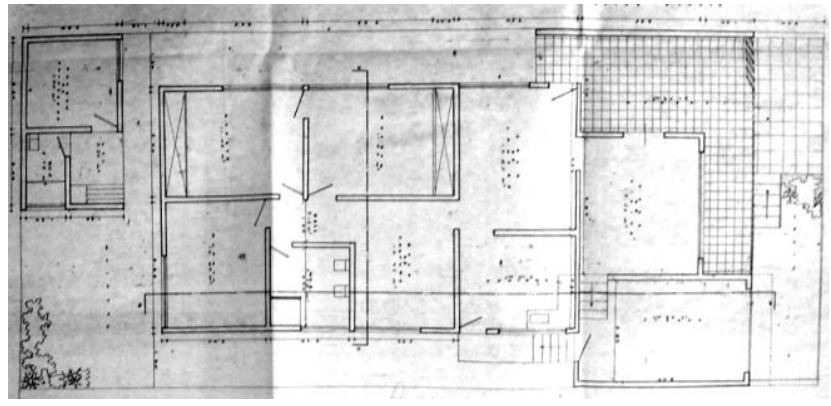

Figura 239: Planta baixa de habitação financiada pelo IAPB em Natal, na déc.1950. Destaque para a área de serviço separada do corpo da casa. Fonte: INSS-RN.

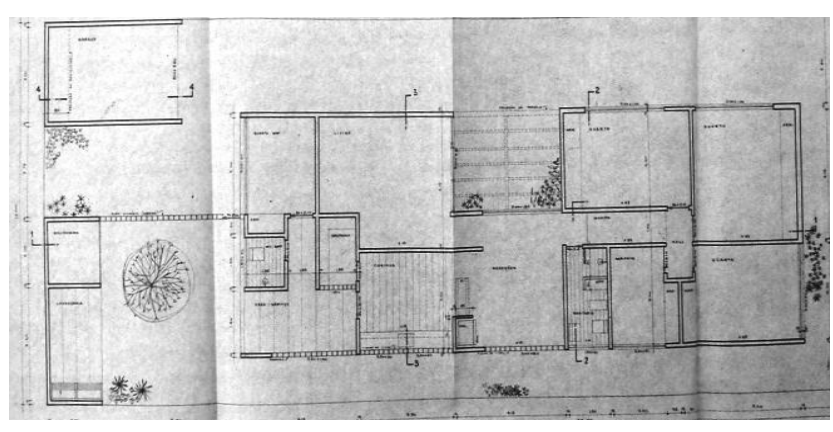

Figura 241: Planta de casa financiada pelo IAPB em Natal. Atentar para a grande pérgula prevista.

Fonte: INSS-RN.

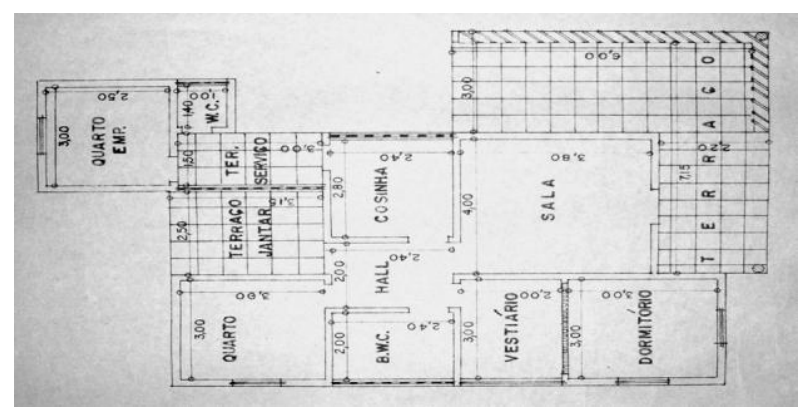

Figura 238: Planta de moradia no Recife. Destaque para o terraço de refeições.

Fonte: INSS-PE.

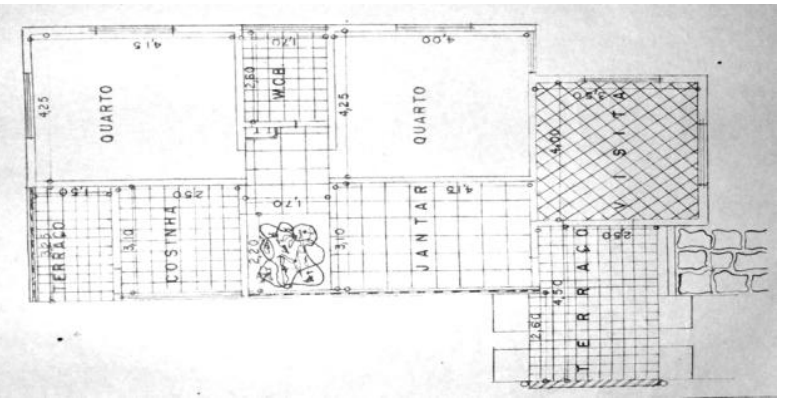

Figura 240: Planta de moradia edificada no Recife. Detalhe para o jardim de inverno previsto. No laudo de avaliação o projeto foi denominado muito satisfatório. Fonte: INSS-PE

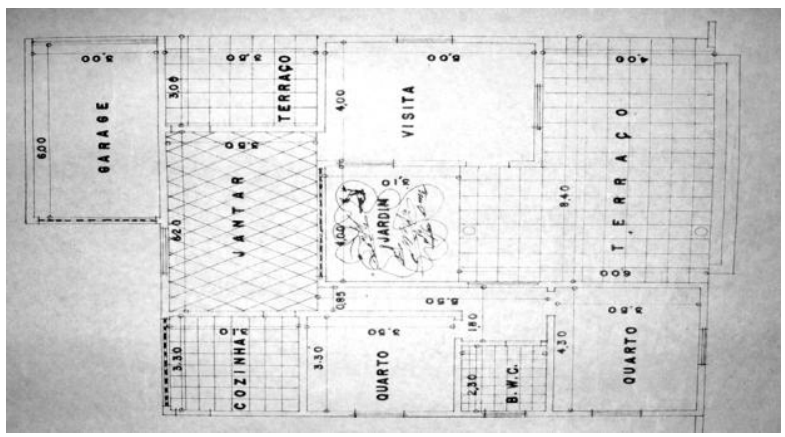

Figura 242: Planta de casa no Recife. Atentar para o jardim de inverso no centro da residência. Fonte: INSS-PE.

Algumas vezes, esses elementos se configuravam como o centro da casa, em torno do qual eram dispostos todos os outros ambientes (Figura 242), seguindo a tendência mais organicista, também se aproximando da adaptação da construção às especificidades locais, pretendida por diversos profissionais vinculados ao debate em torno da moradia e, inclusive, relacionados diretamente nos institutos de previdência, como foi o caso de Rubens Porto. Cabe aqui ressaltar que, apesar da importância desses elementos e da sintonia ao clima local, quente e por vezes seco, eles foram pouco utilizados nas construções associadas às CAPs e IAPs no Nordeste, com a exceção do Recife, sendo mais vislumbrado nas cidades e 
projetos locados no centro-sul do país, como diversos dos projetos empreendidos por Vilanova Artigas em São Paulo e Carlos Gastão, no interior do estado.

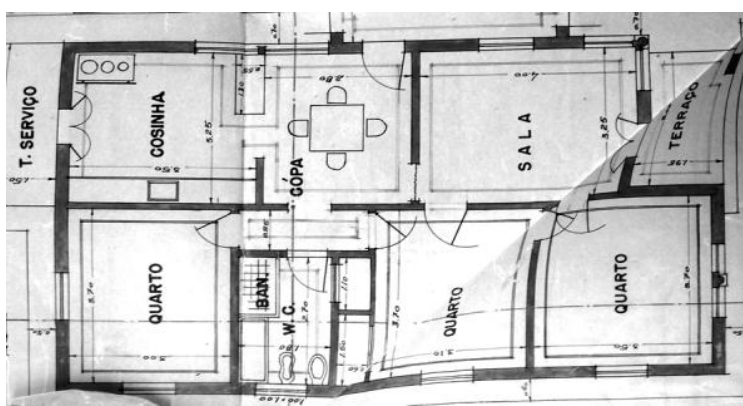

Figura 243: Planta de residência financiada pelo IAPB em Natal, na década de 1950. Fonte: INSS-RN.

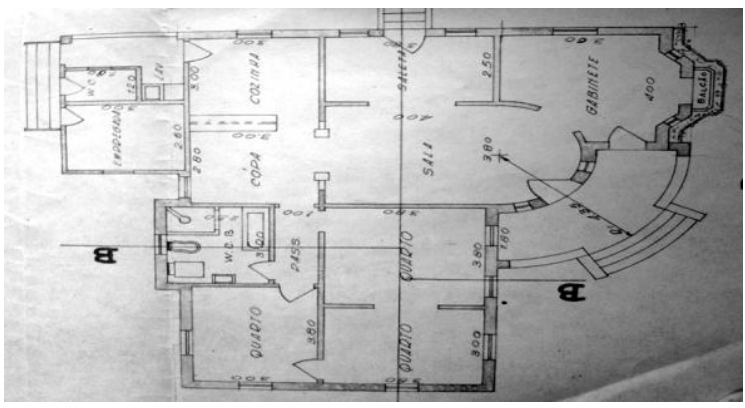

Figura 244: Planta baixa de residência construída com financiamento concedido pelo IAPB em João Pessoa, em 1949.

Fonte: INSS-PB.

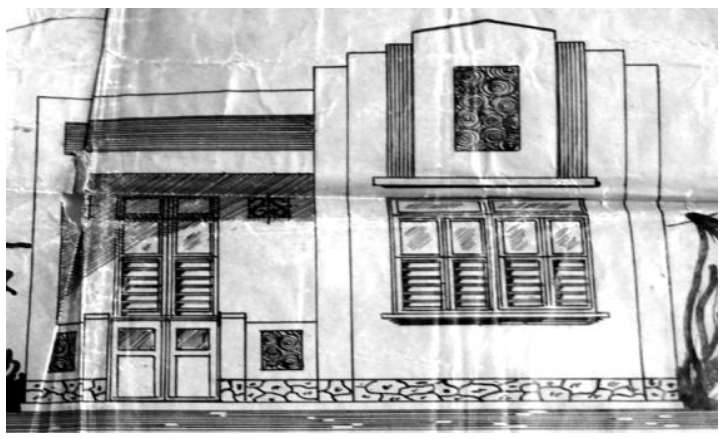

Figura 245: Fachada de moradia, com traços Decó, financiada pela CAP do Nordeste Brasileiro, no Recife. Fonte: INSS-PE.
Os elementos mais recorrentes nas plantas das moradias financiadas pelos segurados foram, sem sombra de dúvidas, a copa-cozinha e a chamada cozinha americana ${ }^{588}$ (Figura 243). Percebe-se que as realizações de Ernest May, em Frankfurt, e os estudos empreendidos nesse sentido, foram incorporados por profissionais brasileiros. No âmbito dos institutos de previdência aqui estudados, esse ambiente foi defendido por Rubens Porto, como apontado no segundo capítulo desta tese.

Em relação à configuração da planta, a maioria se enquadrava no modelo quadrangular regular, principalmente retangular, da disposição dos ambientes domésticos. As variações encontradas referem-se à sobreposição de volumes quadrangulares ou associação de blocos deles. Poucos foram os casos que "fugiram" dessa regra. Isso foi percebido mesmo quando se tinha uma maior liberdade de criação por parte dos engenheiros e arquitetos, e maiores verbas disponibilizadas para a concepção projetual e a construção das unidades, nos processos que se enquadravam na categoria atuarial. Em alguns poucos exemplares foram evidenciadas paredes curvas (Figura 244).

Apesar de escritos relacionados à arquitetura moderna no país afirmarem que a nova forma de projetar e de construir com linhas bem definidas e planos limpos era "compreensível" para uma elite "espiritualizada e culta" (MARTINS, 2006, p.57), diversos dos exemplares edificados no Nordeste, graças aos financiamentos concedidos pelos institutos de previdência, nos quais, o gosto do cliente operava, não seguiam essa tendência em fachada. Os exemplares identificados nos levantamentos documentais e in loco apresentaram ainda outras referências arquitetônicas. Em Jaboatão dos Guararapes, região metropolitana do Recife, a residência edificada em terreno do segurado da CAP do

588 Definida nos laudos de avaliação dos imóveis (financiados e a serem edificados) como sendo resultante da integração da copa com a cozinha, por meio de balcão ou meia parede, muitas vezes associado ao uso abundante de armários. 
Nordeste Brasileiro, em 1946, em Tejipió, possui aproximações ao Art Decó, com linhas e elementos decorativos no plano de fachada e platibandas escalonadas (Figuras 245). Outras referências ao Decó e ao

Missões foram encontradas em João Pessoa, nas quais, percebeu-se a utilização de elementos escalonados, principalmente nas platibandas, elementos vazados destituídos de sua função se conformando apenas como ornatos, largo emprego de pedras nos muros e fachadas e parapeitos em gradis trabalhados, elementos em estuque nos quadros de portas e janelas, utilização de arcos para trabalhar a abertura dos terraços, além de peitoris trabalhados em gesso, jardineiras e namoradeiras (Figuras 246 e 247).

Mesclas de referências da arquitetura típica do período colonial com elementos do Decó também foram percebidas (Figura 248). Diversas residências ecléticas podem ainda serem exemplificadas (Figuras 249 e 250), algumas com shingle styler589 (aplicações de ripas nas faces da moradia), além da previsão de maciças chaminés revestidas em pedra ou tijolo aparente (Figura 251). Ainda em se tratando das fachadas, há moradias que apresentam ornados em estuque ou argamassa de gesso, próximo às cártulas ${ }^{590}$, com molduras em volutas, portas e janelas com arquitraves trabalhadas ou lisas e paredes e pilares com frisos, que remetem à arquitetura neoclássica e alguns elementos do

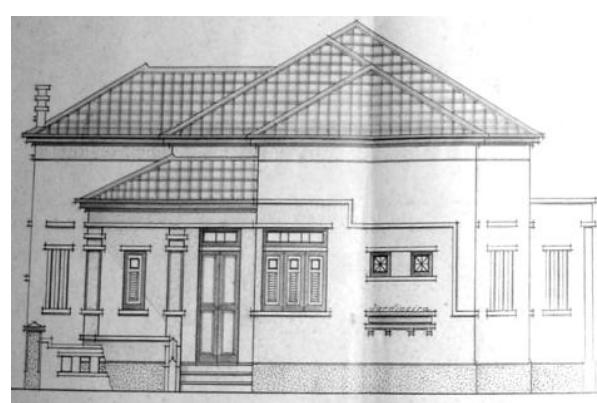

Figura 248: Fachada de residência em Fortaleza (IAPC-1947). Fonte: INSS-CE.

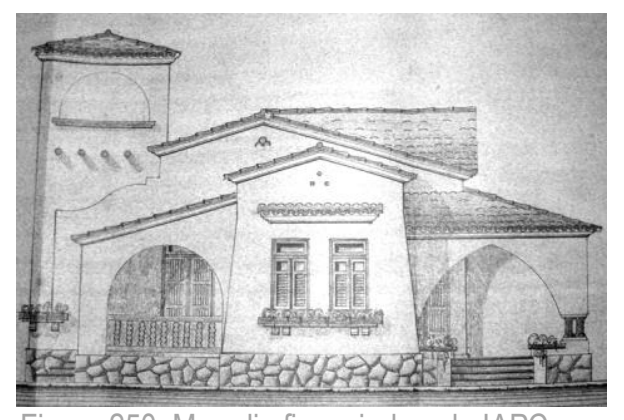

Figura 250: Moradia financiada pelo IAPC em Fortaleza.

Fonte: INSS-CE.

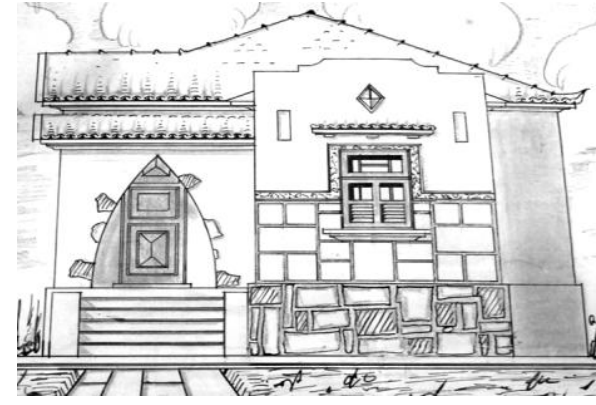

Figura 246: Fachada principal de moradia financiada pelo IPASE em João Pessoa. Fonte: INSS-PB.

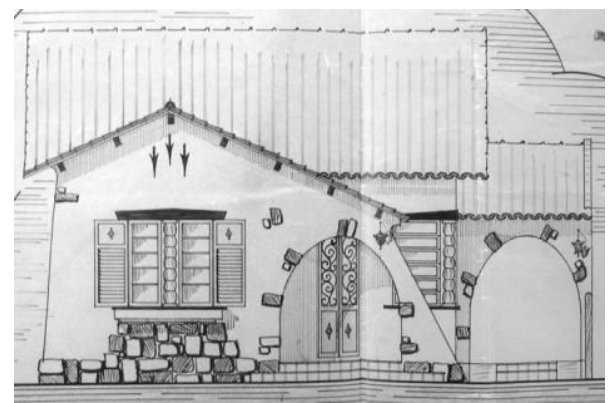

Figura 247: Residência edificada por segurado do IAPB em Natal, na década de 1950. Fonte: INSS-RN.

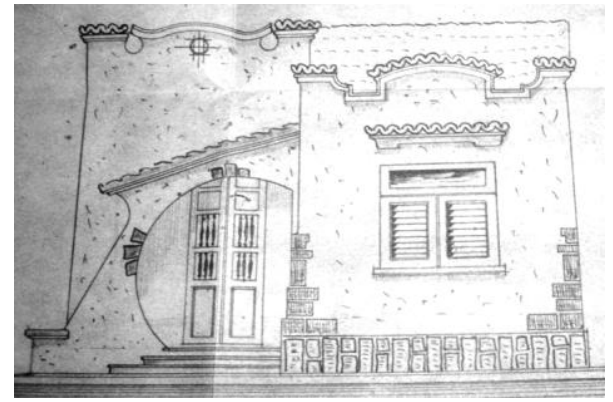

Figura 249: Residência financiada pelo IAPI em Fortaleza. Fonte: INSS-CE.

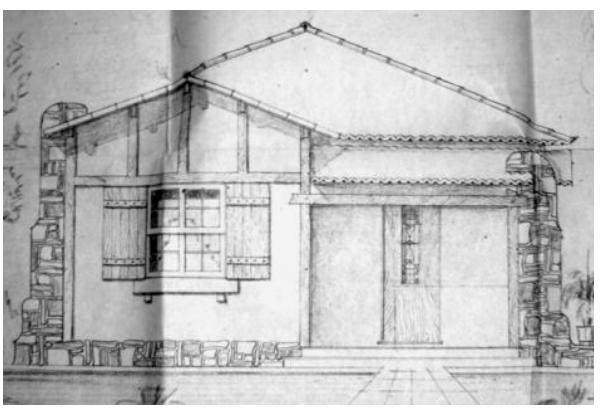

Figura 251: Habitação edificada em Fortaleza (IAPI-CE)

Fonte: INSS-RN.

589 Tradução literal: estilo de ripas (JR. SCULLY, 2002).

590 De acordo com Francis D. K. Ching (1999, p.209), cártula refere-se a uma superfície oval, oblonga, ligeiramente convexa e circundada por ornatos em volutas, para abrigar um motivo decorativo pintado ou em baixo relevo. 
barroco luso-brasileiro ${ }^{591}$, como o tratamento do coroamento da moradia e suas platibandas com curvas e/ou contracurvas (Figuras 252 e 253). $O$ uso de cores vibrantes e diferenciadas nessas nas moradias financiadas pelos institutos de previdência no Nordeste também pode ser apontado.

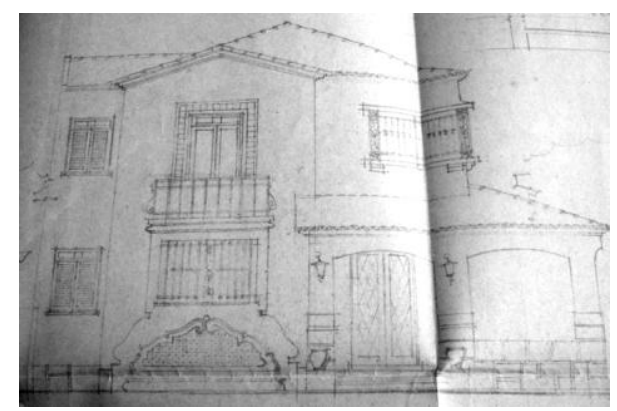

Figuras 252 e 253: Moradias edificadas com financiamentos concedidos pelo IAPC em Recife e em Natal, respectivamente. Fonte: INSS-PE e RN.

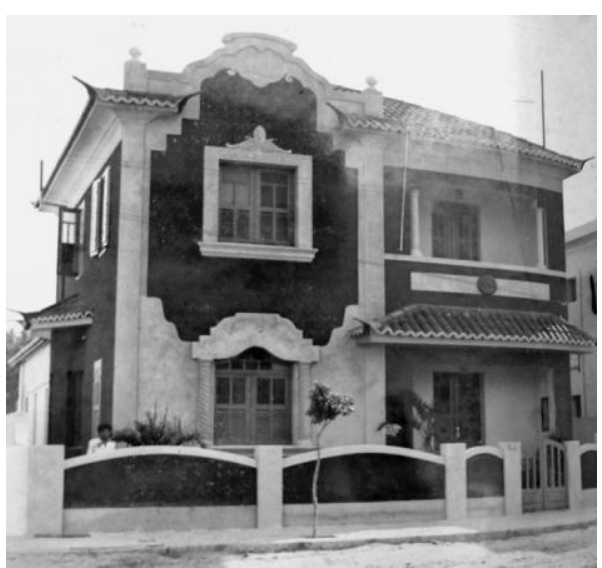

Apesar dos maiores investimentos desprendidos para essas construções, ainda foram poucos os exemplares assobradados e com mais de um pavimento identificados. Quando percebidos, referiam-se às unidades edificadas a partir de fins da década de 1950 e ao longo da primeira metade da década de 1960, sobretudo, por meio do IAPB e do IPASE, e estavam localizadas nas áreas nobres das cidades pesquisadas, como já colocado no capítulo anterior. Essas construções estavam quase sempre associadas ao uso de elementos modernos e de materiais construtivos mais caros como o vidro, o ferro e, principalmente, 0 concreto armado, empregado essencialmente em lajes de piso e cobertura, paredes portantes ou estruturais, ou ainda em elementos pontuais, como em alguns pilares, em marquises, escadas, rampas ou em coberturas de terraços, varandas e garagens. Pouco percebidas foram as varandas e elementos em balanço.

\subsection{Os Profissionais Envolvidos Nos processos de avaliação, projeto, construção e fiscalização habitacional}

Como brevemente aludido no primeiro capítulo desta tese, a estrutura organizacional das CAPs e dos IAPs do MTIC em muito se assemelhavam ${ }^{592}$. De abrangência federal, a partir da década de 1930, sobremaneira, eram organizados e balizados a esse nível, por regimentos e órgãos federais, como o MTIC e no âmbito mais especifico, pelo CNT e seu corpo técnico ${ }^{593}$. De modo geral, a organização de um instituto de

\footnotetext{
${ }^{591}$ No qual o ornamento ganha autonomia sobre a forma e a função da edificação, adquirindo ares cenográficos.

${ }^{592}$ Cabe lembrar que antes da criação dos IAPs do MTIC, as CAPs, com exceção do funcionalismo público, se conformavam como instituições de âmbito específico, mormente, uma empresa, o que acarretava em distintas organizações. Poucas foram as Caixas que fugiam a esse quadro. Algumas possuíam universo de atuação municipal, estadual ou regional, mesmo depois da reforma de 1931, como foi o caso da CAP do Nordeste Brasileiro.

593 As ações dos Institutos e Caixas no campo habitacional eram fiscalizadas pelos fiscais designados pelo CNT, desde 1926, graças ao Decreto $n^{0} 5.109$, de 20 de dezembro, que também instituiu as CAPs para as empresas marítimas e fluviais do país. Também era da competência do CNT, a partir de 1930, impor multas, caçar mandatos dos membros do Conselho Administrativo das CAPs, inclusive do presidente e promover pelos meios legais as suas decisões. As formas de repreensão eram notificação, convocação, processo judicial e, em última instância e dependendo da ação, processo criminal. Todas as decisões e resoluções eram publicadas no Diário Oficial (DECRETO N.20.465, 01/10/1930).
} 
previdência no campo da moradia era representada em seu mais alto nível, pelo presidente do Instituto ou Caixa, locado no escritório central, no Rio de Janeiro. A esse se juntavam outros profissionais que compunham o seu Conselho Administrativo ou Comissão Deliberativa, constituída por membros que já exerciam funções públicas, escolhidos pelo Presidente da República ${ }^{594}$. Ao presidente do Instituto ou Caixa cabia superintender todos os negócios e operações do órgão, presidir as reuniões da Comissão Deliberativa, prestar contas da administração, dentre outras funções ${ }^{595}$. À Comissão Deliberativa ficou a responsabilidade de resolver assuntos que the forem submetidos pelo presidente do órgão, além de votar os orçamentos, aprovar os balanços anuais, organizar o quadro do pessoal, fixando-lhe as remunerações, autorizar 0 presidente a fazer operações de crédito e a adquirir e alienar bens, autorizar novas operações de seguro, mediante proposta do departamento ou seção atuarial, julgar recursos e interpostos de atos do presidente 596 .

Os Institutos e Caixas de Aposentadoria e Pensões eram representados na maior parte dos estados da federação por uma delegacia regional ou, como era especificado por vezes, um escritório estadual, regido pelo delegado regional. Os delegados eram determinados pelo presidente da CAP/IAP e a eles cabiam todos os poderes necessários, inclusive o de assinar documentos, para a completa execução das ações dos Institutos em cada um dos estados em que atuavam. Havia ainda procuradores, nomeados pelo delegado estadual, responsáveis pela validação dos registros dos processos e escrituras nos cartórios das cidades. Subordinado ao delegado estava ainda o Departamento ou Serviço de Engenharia, o qual era composto, por sua vez, por uma seção de projeto e execução e outra financeira, conformado por engenheiros fiscais e projetistas, bem como arquitetos; a chamada Carteira Predial.

Esses profissionais compunham o corpo técnico dos referidos órgãos ou estavam associados a eles por meio de contrato ou de licença. Nesses casos, os seus serviços quando solicitados, poderiam ocorrer por indicação, geralmente do Departamento, quando existia, ou diretamente pelo delegado de um escritório. Nesse sentido, foram observados diversos casos de indicações ou convite de profissionais por parte de órgãos públicos e até mesmo diretamente por governadores e prefeitos, como foi o episódio da Construção do Realengo, de Carlos Frederico Ferreira. Mas, cabe ressaltar, que essa modalidade fora percebida, mormente, na escolha de engenheiros avaliadores, responsáveis por dar o parecer deliberativo ou proibitivo para a execução de uma construção, reforma e/ou concessão de financiamento.

Outra possibilidade de escolha de profissional vislumbrada era a concorrência, que poderia ser determinada de cinco maneiras: diretamente pelo presidente da República; pelo Ministro do Trabalho Indústria e Comércio, através do Conselho Nacional do Trabalho; pelo presidente de um Instituto ou Caixa; pelo delegado de um escritório estadual; ou por decisão do seu corpo técnico (seção ou departamento de

\footnotetext{
594 Incluído um delegado do Conselho Federal do Serviço Público Civil.

595 Como admitir e dispensar os empregados do instituto de previdência e impor-lhes penalidades, além de representar o Instituto em suas relações com terceiros ou em juízo, podendo constituir mandatários.

596 Além de reunir-se quatro vezes por mês e sempre que for convocado pelo presidente e resolver os casos omissos nos regulamentos.
} 
engenharia e/ou projeto). A concorrência também poderia ocorrer de quatro formas. Internamente, no âmbito de uma delegacia estadual, na qual, somente os profissionais contratados ou licenciados poderiam participar. Internamente, no cerne de um determinado Instituto ou Caixa, quando qualquer profissional associado ao órgão, na rede de delegacias que o compunha, poderia se submeter. Poderia ser aberta, porém, restrita aos profissionais das CAPs e dos IAPs em escala nacional, ou aberta para todos os profissionais liberais e escritórios do ramo. Geralmente, nesses casos, a concorrência era determinada pelo presidente da República ou pelo chefe da seção de engenharia do CNT, como o foi o engenheiro-arquiteto Rubens Porto.

A mesma diversidade acima elencada foi vislumbrada no âmbito da produção direta, mais precisamente, das obras de edificação de grupos habitacionais. Por vezes, o projeto era de responsabilidade de engenheiro ou arquiteto do órgão, e a edificação das unidades era realizada por contrato de empreitada, firmado com alguma empresa da região ${ }^{597}$. Houve casos, contudo, que inclusive os cálculos estruturais foram desenvolvidos por empresas ou estabelecimentos terceirizados, como as muitas parcerias estabelecidas entre o IPASE, sobretudo, e os Grupamentos de Engenharia do Exército Brasileiro. Em outros, ocorreu parcerias entre delegacias estaduais de um mesmo órgão, como já citado entre escritórios locados no Recife, João Pessoa e São Luís.

Essas distintas possibilidades de atuação e as diferentes formas de vinculação de engenheiros e arquitetos, principalmente, associados à escassez de dados acerca dos processos projetuais e de construção dos grupos de moradias edificados e financiados pelas CAPs e IAPs no Nordeste, em muito dificultaram a identificação e o caráter da atuação do corpo técnico dessas instituições, na pesquisa ora apresentada. Alguns equívocos quanto a essa questão também foram encontrados na historiografia especializada, como 0 já citado caso do arquiteto Carlos Frederico Ferreira. Levando-se em consideração esses distintos aspectos, serão na sequência apresentados uma gama de profissionais envolvidos direta ou indiretamente nas ações habitacionais empreendidas pelas Caixas e Institutos de Aposentadoria e Pensões no Nordeste do país. É importante destacar que a filiação direta, neste tópico considerada, se dava por meio do projeto, edificação e fiscalização de obras de construção de conjuntos de moradias e pelas avaliações de imóveis, que se pretendia financiar, ou ainda, ações de empréstimo que se pretendia autorizar. As operações indiretas, por sua vez, referiam-se essencialmente aos construtores ou às empresas de construção civil, autorizados pelos órgãos a edificar unidades isoladas em terrenos adquiridos ou de propriedade dos segurados de suas Carteiras Prediais 598.

Vale ressaltar também, que muitos foram os profissionais que transitaram por todas essas modalidades imobiliárias disponibilizadas pelos institutos de previdência. Também é válido destacar, que esse

\footnotetext{
597 Que se tornou comum especialmente no tocante à atuação do $\mathrm{BNH}$, posteriormente.

598 Cabe lembrar, que essa classificação mostra-se distinta daquela empreendida no âmbito das ações imobiliárias das CAPs e dos IAPs, na qual, ações indiretas eram aquelas realizadas por iniciativa dos segurados, quer fossem construção ou financiamento, e ações diretas, aquelas realizadas pelos institutos de previdência no sentido da edificação de unidades habitacionais, geralmente locadas em conjuntos residenciais.
} 
tópico da tese não se propõe a esgotar as possibilidades de identificação e análise da atuação dos engenheiros e arquitetos associados aos referidos órgãos, muito menos, o de apontar toda a produção profissional dessas figuras, ou aspectos relacionados às formações e às influências incorporadas ${ }^{599}$. Esses, só foram apontados quando julgado necessário ou configurado possível. De qualquer modo, estudos mais aprofundados sobre a questão ainda precisam ser desenvolvidos, para que seja possível entender efetivamente a produção arquitetônica e urbanística do Nordeste, rompendo as barreiras da suposta Escola do Recife e para além das atuações de profissionais largamente estudados pela historiografia, que em análises equivocadas, traduzem o repertório construído em toda a Região.

É claro que alguns dos profissionais atuantes no ceio das CAPs e IAPs no Nordeste correspondem a figuras ilustres do meio arquitetônico e urbanístico do país, como os arquitetos Diógenes Rebouças e José Bina Fonyat, que projetaram o Conjunto Waldemar Mota ou Conjunto Itapagipe (IAPB-1953), em Salvador, ou mesmo os arquitetos Carlos Frederico Ferreira e Hélio Duarte, responsáveis pelo projeto do Ed. Inconfidência (IAPI-1942), no Recife. Mas outra gama de profissionais, inclusive projetistas e construtores sem formação acadêmica, incumbidos da concepção e edificação de uma diversidade de moradias ou grupo delas nas capitais nordestinas, ainda permanece desconhecida. É com o intento de corrigir um pouco desse lapso historiográfico acerca dos corpos técnicos das CAPs e dos IAPs no Nordeste, que esse tópico da tese foi desenvolvido.

Em se tratando do supracitado Conjunto Itapagipe (IAPB1953), na capital baiana, é importante frisar que esse exemplar corresponde a um dos principais ícones da arquitetura moderna no âmbito dos institutos de previdência baianos. Nele são empreendidos desde as premissas urbanas, passando pela implantação dos edifícios e das moradias, até os aspectos construtivos relacionados à técnica e ao material empregado. Concreto armado, panos de vidro, de combogós e aço podem ser percebidos nos dois edifícios coletivos que fazem parte do conjunto. Diógenes Rebouças (1914-1994), um dos seus idealizadores, graduou-se primeiramente em agronomia (1933)600 e em artes plásticas (1937)601, para só então enveredar para a arquitetura, conseguindo o título em 1952, na Escola de Belas Artes da Bahia.

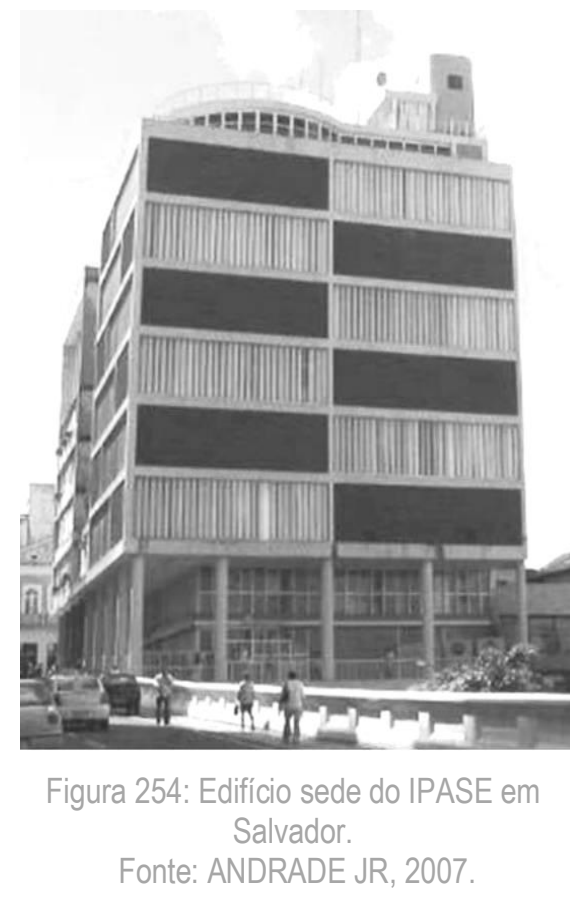
Para outro Instituto, o IPASE, projetou ainda o prédio da sede administrativa, em 1952, que apresenta os

599 Vale ressaltar as dificuldades de acesso e o escasso tempo para levantamento desses dados em arquivos das cidades, para além das agências do INSS, do arquivo público dos estados, dos Institutos Históricos e Geográficos e diversas bibliotecas, nesse sentido.

$600 \mathrm{Na}$ Escola Agrícola da Bahia.

$601 \mathrm{Na}$ Escola de Belas Artes da Bahia. 
conhecidos cinco elementos corbusianos (Figura 254). Fora do cerne das CAPs e dos IAPs, projetou junto a Paulo Antunes Ribeiro, o Hotel da Bahia (1947), atualmente tombado pelo Instituto do Patrimônio Artístico e Cultural da Bahia, o Estádio Octávio Mangabeira (1942)602, os prédios da Escola Politécnica da Bahia e da Faculdade de Farmácia e de Arquitetura da UFBA, as Avenidas do Contorno e Centenário, dentre muitas outras obras. Foi inclusive o primeiro presidente do Instituto dos Arquitetos no estado (IAB-BA) (ANDRADE JÚNIOR e LEAL, 2007). Além disso, desenvolveu trabalhos de pintura e foi docente do curso de Arquitetura da Universidade Federal da Bahia.

O arquiteto José Bina Fonyat (1918-1977), por sua vez, graduou-se em arquitetura no início da década de 1950, na Faculdade de Arquitetura da Universidade do Brasil, no Rio de Janeiro, e a convite da Escola de Belas Artes da Universidade da Bahia, retornou à Salvador para lecionar na instituição. Nas cadeiras de "composição da arquitetura" e "teoria e filosofia da arquitetura", ministradas por ele, evidenciou-se a importância da plástica associada à função na concepção da obra arquitetônica603 (FONYAT FILHO, 1959). Sua obra mais importante para além das realizadas no

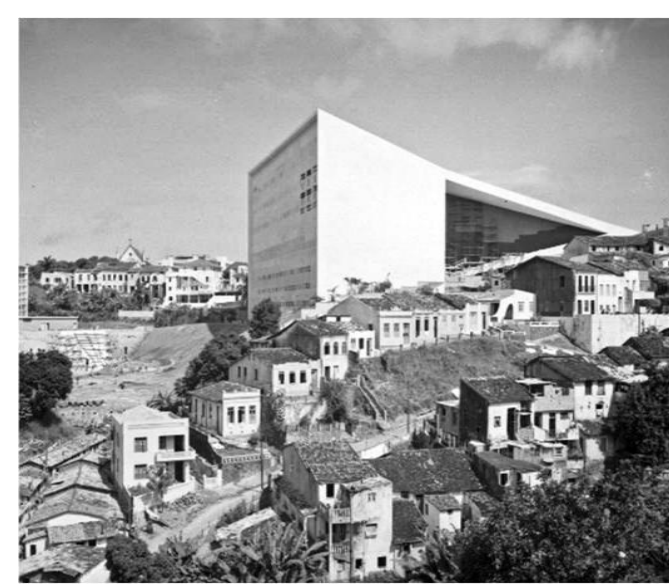

Figura 255: Teatro Castro Alves em Salvador. Fonte: www.tca.ba.gov.br. âmbito do IAPB foi, indubitavelmente, o Teatro Castro Alves $(1957)^{604}$, no qual, destaca-se a ampla rampa de acesso e a volumetria prismática triangular (Figura 255). Muitos outros foram os engenheiros e arquitetos que projetaram, edificaram, vistoriaram ou avaliaram unidades habitacionais na capital soteropolitana. Mais especificamente foram identificados quinze profissionais e empresas envolvidos em ações imobiliárias relacionadas à edificação de moradias, fossem elas locadas em conjuntos ou isoladas, além de quatorze engenheiros relacionados às avaliações de imóveis na cidade soteropolitana.

No Recife, os profissionais atuantes na cidade e vinculados às ações diretas e indiretas dos IAPs e das CAPs, somam um total de trinta e seis ${ }^{605}$. Vale ressaltar, que a maior parte deles era formada em engenharia ou arquitetura pela Escola de Belas Artes Pernambucana ou pela Escola Politécnica do Recife, sendo poucas as figuras que fugiam a essa regra, como foi o caso dos já mencionados arquitetos Carlos Frederico Ferreira e Hélio Duarte, vencedores do concurso interno aberto pela delegacia do IAPI no Recife, para a edificação do Edifício Inconfidência, de natureza mista, que abrigou a sede administrativa do Instituto,

\footnotetext{
602 Implodido em 2010 para dar lugar ao novo estádio, que está em fase de construção, para os jogos da FIFA 2014.

603 Com influências declaradas pelo próprio arquiteto das premissas imputadas e defendidas por Lúcio Costa e Niemeyer nesse sentido (FONYAT FILHO, 1959).

604 Projetado em parceria com o engenheiro Humberto Lemos Lopes e os arquitetos Ubirajara Motta Lima Ribeiro e João Carlos Bross.

605 Mais detalhadamente, foram encontrados oito engenheiros responsáveis por avaliações de imóveis e vinte e oito engajados com projetos e edificações.
} 
bem como pontos comerciais e unidades habitacionais para os seus segurados. Acredita-se que esse quadro se conformou dessa maneira, por dois principais motivos: a existência de instituições de formação capacitadas na capital, como as acima elencadas, e graças à realização de diversas viagens empreendidas por órgãos de classe, como foi o caso do Sindicato dos Engenheiros de Pernambuco, que ao longo da década de 1940, principalmente, promoveu junto aos seus associados, diversas excursões pelo Brasil para 0 conhecimento e visita a edificações inovadoras e modernas da época. Muitas dessas viagens foram realizadas para o Rio Grande do Sul, aspecto não apontado, geralmente, pela historiografia especializada, que concentra seus focos de análises no eixo Rio de Janeiro-Belo Horizonte-São Paulo:

Através de uma iniciativa do Sindicato dos Engenheiros e com o apoio do então prefeito de Porto Alegre, Dr. Loureiro da Silva, os engenheiros do Recife realizaram em janeiro do ano de 1942, uma viagem de observação e estudos ao Rio Grande do Sul. A comitiva contava com os seguintes membros: Horácio Campello de Souza, Luiz Freire, Napoleão de Albuquerque, Tolentino de Carvalho, Umberto Gondim, Antônio Bezerra Baltar, Pelópidas da Silveira e José Césio Regueira Costa, todos sob direção do engenheiro Sizenando Carneiro Leão. Os engenheiros visitaram, além das obras de urbanização da capital, o interior do Estado. Dentre as obras municipais visitadas, receberam maior atenção os serviços de água e esgoto, a abertura da Av. Borges de Medeiros e seus arranha-céus, a Avenida Farrapos e o novo mercado. (...). Outra oportunidade de reflexão do ponto de vista da aproximação entre as duas cidades, foram as conferências realizadas na Sociedade de Engenharia de Porto Alegre, a cargo de alguns membros da comitiva. $O$ engenheiro Antônio Baltar, ministrou uma exposição acerca dos Aspectos Sociais e Econômicos do Governo de Pernambuco, fazendo uma importante alusão de como vêm sendo encarados os problemas no Estado, enfatizando a ação da Cruzada Social Contra o Mocambo e os resultados alcançados. Como figuras de principal interesse aos olhares dos urbanistas gaúchos estavam as vilas populares, o plano de financiamento das residências, o sistema de indenizações, as vultosas obras de saneamento ligadas à campanha, além de outras realizações como a Caixa de Crédito Imobiliário e o Instituto de Previdência do Estado. À época da visita, ambas as cidades estavam passando por um imenso trabalho de remodelação urbana e, desta forma, fazia-se importante o intercâmbio de informações. Recife e Porto Alegre, apesar de compartilhar de técnicos de grande valor, viviam em realidades financeiras diferentes; a primeira, vivendo uma época de declínio econômico, enquanto que a segunda via-se, em franco crescimento. O domínio técnico, reconhecido nacionalmente aos profissionais pernambucanos, muito teve a acrescentar à emergente leva de técnicos gaúchos, e estes, por sua vez, chamaram a atenção de nossos técnicos para novas soluções criativas e inovadoras (...). (UMA VISITA..., 1942, p.05).

Quando não eram pernambucanos, os profissionais atuantes ali se estabeleceram, como foi o caso do arquiteto Francês radicado no Recife, Georges Henry Munier, responsável pelo primeiro projeto arquitetônico do Edifício Capibaribe, também em Santo Amaro, no ano de 1949. Esse projeto, apesar de não ter sido aprovado pelo presidente do IAPC e edificado, sintetiza muitos dos preceitos estipulados por Rubens Porto para os investimentos habitacionais em edifícios verticais, como brevemente colocado no início do capítulo. Nesse projeto são percebidos além de um alto gabarito (16 pavimentos), uma variedade de tipologias de plantas, destinadas essencialmente à moradia dos segurados solteiros, que passariam a habitar em unidades próximas ao centro comercial da cidade e, consequentemente, do seu trabalho, como também defendido por Porto. Assim como esse engenheiro-arquiteto não estabeleceu diretrizes construtivas ou 
especificou sobre garagens e/ou abrigos de automóveis em seu manual, o arquiteto francês não o fez para a primeira versão do Edifício Capibaribe.

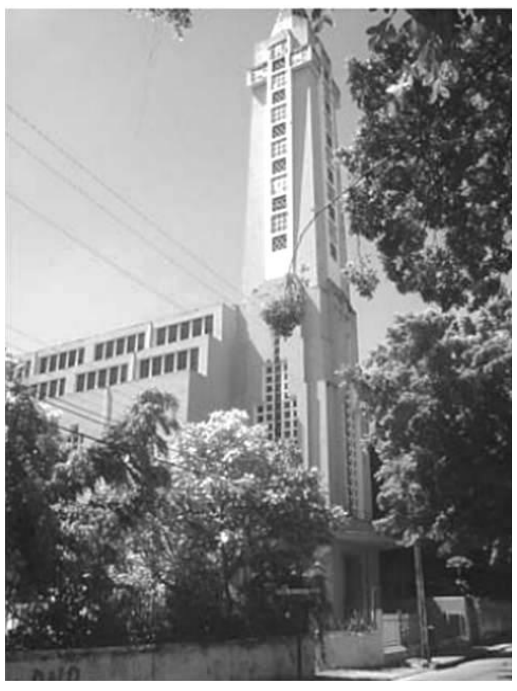

Figura 256: Igreja Nossa Senhora da Fátima, no Recife. Fonte: SMITH, 2008.

Munier foi também 0 arquiteto responsável pelo projeto da Igreja de Nossa Senhora de Fátima, de 1934, localizada junto ao Palácio da Soledade ${ }^{606}$, além de diversas casas de arquitetura tida purista com traços Decó, contemporâneas às empreendidas por Warchavchik (datadas do ano de 1931), localizadas no bairro de Boa Vista e Santo Amaro, mais precisamente na Avenida Visconde de Suassuna e na Rua Bispo Cardozo Aires (SMITH e FREITAS, 2008) (Figuras 256 e 257). Participou ainda do movimento de criação da Escola de Belas Artes no Recife, em 1931. Anterior a sua "fase moderna" associada à vertente purista, Munier projetou na década de 1920, o Edifício Arnaldo Dubeux, o antigo prédio da Bolsa de Valores do Recife e da Paraíba, localizado no Marco Zero, onde atualmente

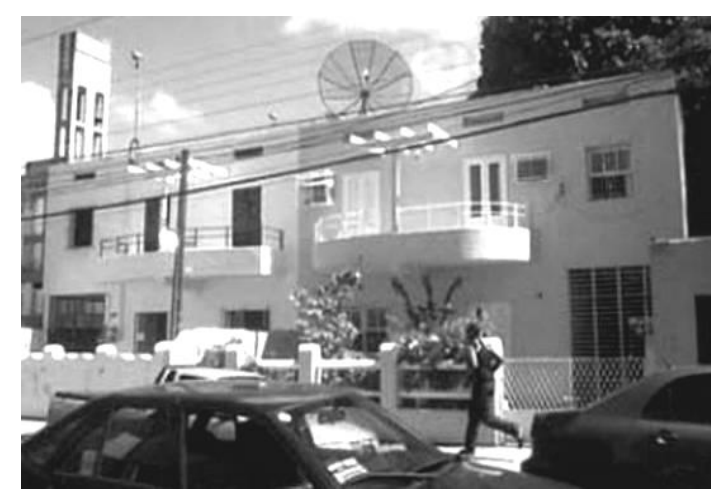

Figura 257: Residências de Munier no Recife. Fonte: SMITH, 2008. funciona a Caixa Cultural Recife. Essa edificação apresenta filiação à arquitetura eclética e foi tombada em 1998 como patrimônio nacional607.

Ao primeiro projeto do Edifício Capibaribe, não edificado, foi seguido o elaborado pelo arquiteto Hugo de Azevêdo Marques, sendo efetivamente concebido. Esse arquiteto, carioca radicado no Recife, era tido pelas publicações da época como um "(...) profissional de comprovada capacidade, radicado em nosso meio e

conhecedor das particularidades locais (...)" (CARTA..., 04/07/1949, p.01), que agregou os ditames modernos às especificidades recifenses, especialmente em se tratado do clima e do solo. Também foi 0 arquiteto responsável pelo projeto do Edifício Gilka (IAPC-1953), onde essa sintonia também se mostrou evidente, como colocado nos tópicos anteriores. Concebeu outros projetos na cidade como o Estádio da llha do Retiro (Sport Clube Recife), em parceria ao arquiteto italiano radicado em Natal Giácomo Palumbo. Obra inaugurada em 1937 e que segue as linhas modernas. Porém, outras referências arquitetônicas foram associadas à sua produção, como os conhecidos Edifícios Almare e Almare Anexo (1942 e 1943) (NASLAVSKY, 1998), e a

${ }^{606}$ Ambos tombados pelo IPHAN.

607 Munier atuou ainda em outras cidades como Fortaleza, João Pessoa, Campina Grande e Natal. Nessa, projetou o Grande Hotel da cidade, inaugurado em 1944. Em Fortaleza, foi o responsável pelo Palácio do Comércio, em linhas Decó. Ainda em Fortaleza, projetou a Catedral Metropolitana, a Igreja da Sé. A construção da catedral de Fortaleza iniciou-se em 1939, e levou quase 40 anos para ser concluída (a inauguração oficial foi em 22 de dezembro em 1978). A igreja construída em estilo gótico romano abriga 5.000 pessoas e é a terceira maior do Brasil atualmente. Em João Pessoa foi o responsável pela execução do Plano de Remodelação e Extensão da Cidade de João Pessoa, mais precisamente na área do Parque Solón. De acordo com Fúlvio Teixeira (2008), 0 arquiteto permaneceu na cidade até o ano de 1945. 
famosa "casa navio" (década de 1940) em Boa Viagem, demolida na década de 1980, com fortes referências ao Decó. Entre os anos de 1950 e 1960, Hugo Marques edificou ainda uma variedade de residências, principalmente, em Campina Grande, como destacado por Freire (2010)608.

Além dos profissionais acima elencados atuantes no Recife, podem ainda ser citados vários nomes. Um deles é Gerson Carneiro Leão, engenheiro responsável pelo projeto e pela edificação de diversas residências isoladas financiadas pelo IPASE, principalmente, para seus segurados. Referiam-se essencialmente a moradias modernas tanto em planta quanto em fachada. Foi também, um dos engenheiros responsáveis pela construção da ESAP (Escola Superior de Agricultura de Pernambuco), na década de 1950. Mais precisamente, projetou o pavilhão central com formato de leque com referências à arquitetura moderna. Outro nome é Olímpio Jader de Magalhães Melo, engenheiro civil pernambucano e graduado no Recife. Atuou junto ao IAPC nas cidades de Recife e Maceió de 1945 a 1965, por meio essencialmente da avaliação de imóveis dos seus conjuntos, como no Conjunto Lafaiete Coutinho, no bairro recifense de Casa Amarela, na década de 1940, e Presidente João Goulart, em Olinda, na década de 1960. Também participou do processo de alienação de imóveis realizado em 1962 pelo Instituto, no Conjunto Residencial do Prado, em Maceió. Foi ainda professor da Escola Técnica do Recife, membro da Divisão de Ensino Industrial do Departamento Nacional de Educação, do Quadro Permanente do Ministério da Educação e Saúde ${ }^{609}$, e diretor do SENAI Departamento Regional de Pernambuco, no exercício de 1970. Outra figura relevante foi Sizenando Carneiro Leão, engenheiro civil formado no Recife. Atuou junto ao IAPC, na década de 1950. Fazia parte da comissão do Instituto para a fiscalização das obras do Edifício Capibaribe. Foi também professor de engenharia da Escola Politécnica do Recife e presidente do Sindicato dos Engenheiros de Pernambuco, entre os anos de 1930 e 1944, pelo menos. Juntamente a outros profissionais do estado, realizou diversas viagens pelo país, a exemplo da supracitada ida à Porto Alegre em 1942, para conhecer importantes obras que estavam sendo realizadas nessa cidade, como destacado pelo engenheiro pernambucano Pelópidas da Silveira:

(...) No final da década de 30, o Sindicato dos Engenheiros de Pernambuco, presidido pelo saudoso colega Sizenando Carneiro Leão, promovia viagens, em grupo, de seus associados, às regiões mais desenvolvidas do país, com resultados altamente proveitosos para o Nordeste. Em 1938, participei a uma viagem a São Paulo, onde visitamos importantes obras e tivemos a oportunidade de conhecer, em pormenores, o notável Instituto de Pesquisas Tecnológicas, o IPT, à época anexo à Escola Politécnica (...). Essa visita foi, sem dúvida, o ponto de partida, para o Sindicato encetar uma corajosa luta, com o objetivo de ser criado, em Pernambuco, um instituto tecnológico aos moldes do de São Paulo. Nosso presidente, Sizenando Carneiro Leão, (...), assumiu o comando desse ambicioso projeto. Ao lado dele, ficamos engajados Murilo Domingues Coutinho, Antônio Bezerra Baltar e eu. Levamos o assunto ao engenheiro Gercino de Pontes, à época Secretário de Viação e Obras Públicas, encontrando, nesse colega, um apoio inestimável (...) (GUSMÃO FILHO, 2005, p.50).

608 Dentre eles: o Edifício do SESI (1954), da Associação Comercial (1954), do Banco Industrial de Campina Grande (1957), o primeiro grande edifício da cidade, Paraná (1962), o Hotel Ouro Preto (1961), o Edifício Palomo (1962), Lucas (1963) e a Clínica Santa Clara (1968) (FREIRE, 2010).

609 Criado pelo Decreto-lei n.7.190, de 22 de dezembro de 1944. 
Observa-se, dessa forma, que o engenheiro Sizenando Carneiro Leão foi um dos principais idealizadores e responsáveis pela criação do ITEP (Instituto de Tecnologia do Estado de Pernambuco), em 1942, graças à outorga de decreto-lei pelo interventor federal de Pernambuco Agamenon Magalhães, outrora Ministro do Trabalho, Indústria e Comércio (MTIC), em 13 de outubro daquele ano. 0 referido engenheiro participou ainda do Centenário dos Engenheiros Civis que ocorreu em Chicago, no ano de 1952 (DOU, 1952, pag.06) e ganhou nome de ruas e travessas no Recife, posteriormente.

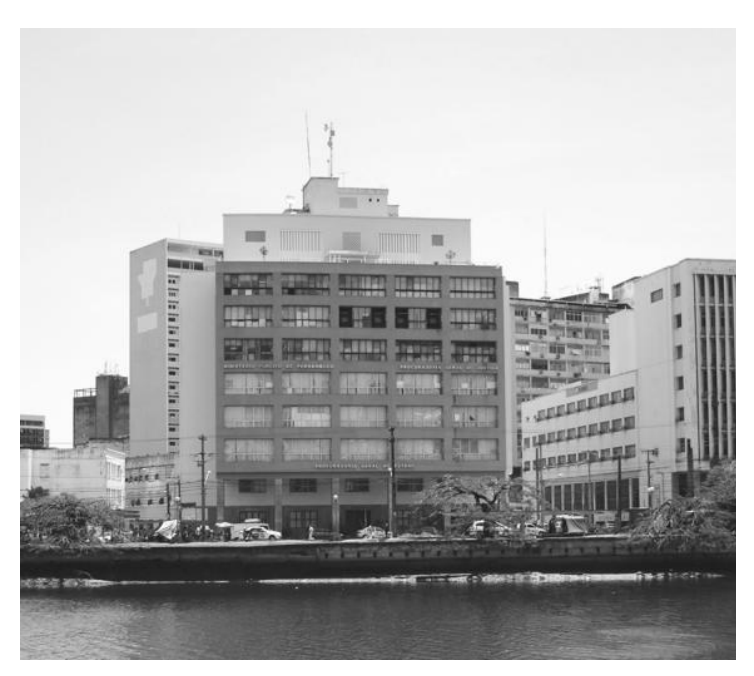

Figura 258: Sede do IPSEP no Recife. Fonte: Arquivo pessoal.

Para além dos projetos habitacionais empreendidos pelas CAPs e IAPs no Recife, ainda se destaca no cenário local o Edifício Independência, edificado em 1936 para abrigar a sede administrativa do IPSEP (Figura 258). O projeto foi do arquiteto Roberto Campello610 e apresentava consonância às "vanguardas expressionistas alemães" difundidas pelas revistas internacionais (MARQUES e NASLAVSKY, 2004, p. 105). Algumas empresas também se destacaram no cenário da construção civil recifense, como a Sociedade Construtora e Comercial Jorgentil, que solicitou junto ao IAPC, em 1945, a edificação do Edifício Capibaribe. Essa empresa foi a responsável pela construção de diversos edifícios e obras de distintas naturezas em todo o país. Em 1946, por exemplo, venceu a concorrência pública realizada pelo Governo Municipal de Fortaleza, para a edificação dos abrigos de ônibus da cidade (A JORGENTIL..., 12/01/1946, p.06). Não se pode deixar de mencionar ainda, a Comissão de Melhoramentos Municipais do Recife, criada pelo Decreto estadual n.379, em 20 de março de 1931. Essa Comissão foi responsável pela distribuição gratuita de plantas de moradias econômicas, bem como de diversos projetos de vilas/grupos de moradias operárias, que foram instaladas na capital pernambucana. Muitas delas foram financiadas pelas Caixas e Institutos de Aposentadoria e Pensões. Essa ação foi aclamada e incorporada por outras municipalidades, como em Natal, cujas elites locais pretendiam estabelecer reformas para tornar a cidade "alinhada, assobradada e uniforme", o que seria alcançado por meio da proibição de certas construções, garantida por um serviço de fiscalização organizado, cujo modelo era o Recife (CENSURA ESTÉTICA..., 12/01/1932). No âmbito das ações indiretas, vale ainda ressaltar que os escritórios estaduais locados no Recife abrigaram o maior número de engenheiros e arquitetos, licenciados, contratados ou indicados no Nordeste.

610 Não foram encontradas maiores informações acerca desse profissional. 
Em João Pessoa, profissionais atuantes na cidade ao longo das décadas de 1930 a 1950, especialmente no campo da construção particular, como os paraibanos Carlos Alberto Carneiro da Cunha611, Roberval Guimarães, Leonardo Stuckert Fialho612 e Mário Glauco di Láscio613, além de alguns arquitetos atuantes no Recife ou lá radicados, como o arquiteto carioca Acácio Gil Borsoi e o português Delfim Amorim (ROCHA, 1987; TINEM, 2005; etc.), amplamente estudados pela historiografia local especialmente, não podem ser associados às ações das CAPs e dos IAPs no campo habitacional na capital paraibana614. Diferente do observado na maior parte das capitais nordestinas trabalhadas, os engenheiros e arquitetos atuantes em João Pessoa não eram da cidade. Dentre eles, se destaca a produção do arquiteto carioca Ulysses Petrônio Burlamaqui, que chegou a ser comparado aos arquitetos de maior renome no país pelos periódicos da cidade, na segunda metade da década de 1950:

(...) o Prof. Ulysses Burlamaqui é um dos mais destacados arquitetos brasileiros, figurando, sem favor nenhum, entre Oscar Niemeyer, Mindlin, Irmãos Roberto e outros, responsáveis pelo progresso da arquitetura brasileira, considerada, hoje, como uma das mais evoluídas do mundo (...) (O IAPB..., 1957, p.01).

Ulysses graduou-se em arquitetura pela Universidade do Brasil, em 1950, e foi contemporâneo dos arquitetos Flávio Marinho Rego, que trabalhou com Niemeyer, e Marco Konder ${ }^{615}$. Em entrevista concedida por esse arquiteto, publicada no Vitruvius, a linha de produção arquitetônica de Ulysses Burlamaqui era muito próxima a de Niemeyer:

(...) era uma figura muito engraçada porque era todo 'certinho', todo almofadinha, e era ótimo em apresentações de projetos (...) conhecido tanto porque caprichava muito nas suas apresentações da faculdade com maquetes muito bem feitas e também pelo fato de copiar nitidamente as idéias de Oscar Niemeyer (...). Por ocasião de uma exposição organizada pelo NEDAB (Núcleo de Estudos e Divulgações da Arquitetura Brasileira) (...) e que foi realizada no Ministério. Lá havia projetos de alunos inclusive Ulysses. Aí contaram que o Oscar esteve na exposição e, ao se deparar, com o projeto de Ulysses, exclamou que não havia mandado nenhum projeto para lá. (...). Cabe dizer que ele tinha muito bom gosto, se vestia muito bem e ficou logo rico com a arquitetura (...) (BARBOSA e MATTOS, 2007, s/p).

Foi realizando obras como o Ed. Presidente João Pessoa (1957), para 0 IAPB em João Pessoa, e o Ed. Riosul (1975) no Rio de Janeiro, que Ulysses se destacou no cenário arquitetônico nacional (Figura 259). Seu projeto carioca, angariado por meio de concurso privado realizado em meados da década de 1970, corresponde ao primeiro Shopping Center da cidade e se configura como o mais alto edifício do Rio de Janeiro. O edifício se destaca no entorno pelo seu

\footnotetext{
611 Paraibano formado na Escola de Belas Artes do Recife (ROCHA, 1987).

612 Paraibanos formados pela Escola Nacional de Belas Artes (ROCHA, 1987).

613 Também formado na Escola de Belas Artes do Recife (ROCHA, 1987).

614 Desde quando se tornou capitania, a Paraíba, principalmente as cidades de João Pessoa e Ca estreito com o vizinho Pernambuco.

615 Ingressaram na instituição no ano de sua criação.
}

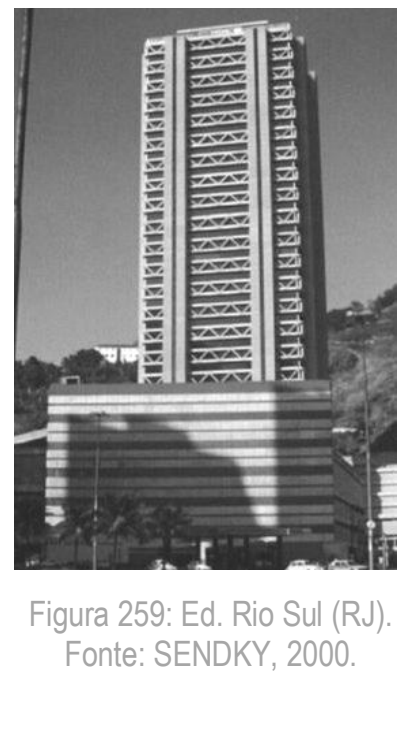


alto gabarito e pelas gigantescas treliças em concreto protendido moldadas in loco. Para Czajikowski (2000, p.18), esse projeto representou um exemplo do "inútil brutalismo estrutural" e de "complexas circulações variadas" responsáveis pelo longo período de crise na produção carioca. Ulysses foi ainda, professor do Centro de Letras e Artes da UFRJ, nos anos oitenta.

Outro profissional identificado no cenário pessoense, vinculado às CAPs e aos IAPs, sobre o qual se encontrou informações, foi o engenheiro baiano radicado na cidade, Serafin Rodriguez Martinez. Serafim edificou diversas residências isoladas em João Pessoa e foi o fundador e o primeiro diretor geral do DER da Paraíba, em 1946, em decorrência do qual, foi elaborado o Primeiro Plano Rodoviário Estadual do estado. Também foi um dos responsáveis pela criação da Escola de Engenharia da Paraíba e chegou a ser reitor da UFPB, na década de $1980^{616}$.

Ainda em se tratando das unidades isoladas, a maior parte foi edificada por profissionais licenciados pelos órgãos na cidade de João Pessoa, essencialmente por construtores sem formação superior, como Joaquim Pereira do Nascimento, Humberto Ruffo, João Cavalcanti de Menezes e Antônio Gama. Dentre os engenheiros civis identificados podem ser citados: Vicente Xavier de Oliveira, Benigno Walter Barcigo, Tarcigo Pereira da Costa (vinculado à construtora Severino João da Silva), José Pedro e Fagundes, João Batista e Oswaldo Nobre Fontes. Entre os arquitetos foram apontados projetos de autoria de Antônio de Oliveira e Clodoaldo Jamelo. Todos esses profissionais atuaram no âmbito do IPASE, IAPI, IAPC e IAPB617.

As viagens empreendidas para intercâmbio profissional que ocorreram entre profissionais do RecifeSão Paulo e Recife-Rio Grande do Sul, supramencionadas, também ocorreram no âmbito da formação acadêmica, especialmente de engenheiros entre outros estados, a exemplo da viagem realizada pelos alunos da Escola Politécnica da Paraíba para Natal, como aludido no periódico local da década de 1960, encabeçada pelo engenheiro Vinícius Londres da Nóbrega, que também participou da construção do Conjunto do IAPI em João Pessoa, e edificou diversas residências para os segurados do Instituto:

Uma embaixada de universitários do $3^{\circ}$ ano de engenharia civil da Escola Politécnica desta cidade seguirá hoje com destino a Natal, no Rio Grande do Norte, presidida pelo professor Vinícius Londres da Nóbrega, catedrático de Hidráulica Teórica e Aplicada. (...) A finalidade da excursão é dar prosseguimento as aulas práticas adotadas recentemente pela diretoria da Escola Politécnica visando a mais complexa formação profissional dos futuros engenheiros diplomados em Campina Grande (...) Os universitários campinenses viajarão às 13 horas de hoje, devendo receber aulas (...) diretamente nas obras do porto de Natal, de acordo com o "slogan" já em vigor entre os professores da Escola Politécnica da "aula certa no lugar exato" (SEGUEM..., 02/06/1960, p.01).

Semelhante ao vislumbrado em João Pessoa, em Natal, figuras conhecidas por suas propostas e projetos de arquitetura inovadora, não projetaram ou estavam envolvidos em outras ações imobiliárias

\footnotetext{
616 Faleceu em 1999.

617 No levantamento documental não foram encontrados processos realizados pelos demais órgãos na cidade que apontaram os profissionais envolvidos.
} 
empreendidas pelos órgãos na cidade, de acordo com os dados levantados ${ }^{618}$. Esse foi o caso do engenheiro Antônio Tejo e do arquiteto Arialdo Pinho619, convidados pelo governo municipal da cidade para a elaboração do Código de Obras de Natal, em 1956 (ALMEIDA, 2007), além dos arquitetos natelenses Raphael Galvão Júnior ${ }^{620}$ e Agnaldo Muniz ${ }^{621}$ e dos engenheiros Munir Aby Faraj e Ary Guerra da Cunha Lima, bem como arquitetos locais com formações no Recife, como José Maria dos Santos Fonseca, Manoel Coelho, Raymundo Costa Gomes ${ }^{622}$, João Maurício de Miranda e Daniel Hollanda.

É importante observar que esse quadro de profissionais diferenciados dos que habitualmente edificavam na cidade foi instituído apesar das investidas públicas locais para a adequação das novas construções, inclusive as realizadas por órgãos públicos como as CAPs e os IAPs, à arquitetura empreendida por alguns daqueles engenheiros e arquitetos, tida como "(...) modelos airosos e estheticos dos centros urbanos de bom gosto como Recife (...)" (A NATAL..., 30/10/1928, p.07), um "(...) estilo novo de ângulos, de arestas e de planos (...)", caracterizado pela conformação de "(...) fachadas simples, de paralelas distanciadas e de traços francos (...)", peculiares à arquitetura "prática e moderna" (VIDA..., 31/08/1932, p.04). Mais precisamente, a Intendência Municipal de Natal organizou em 17 de março de 1928, uma exposição com os projetos do engenheiro Clodoaldo Dantas, engenheiro construtor do Recife, para incentivar edificações condizentes com as linhas modernas, que em muito contribuiriam para o projeto proposto pela elite administrativa para Natal (EXPOSIÇÃO..., 17/03/1928, p.02)623. Mas, poucos foram os profissionais recifenses atuantes no âmbito das Caixas e Institutos de Aposentadoria e Pensões em Natal.

Em contrapartida, diversos foram os profissionais locais com formação no Rio de Janeiro que projetaram conjuntos residenciais, a exemplo dos arquitetos Ubirajara Pereira Galvão e Moacyr Maia e o engenheiro Kleber de Carvalho Bezerra624. Esse engenheiro foi importante figura natalense no processo de criação da Escola de Engenharia da UFRN (1959), sendo um dos seus fundadores. Kleber de Carvalho Bezerra foi ainda, diretor do Departamento de Viação e Obras Públicas durante o governo de Aluízio Alves, nos primeiros anos da década de 1960 e Secretário de Transportes e Obras Públicas no governo de José Agripino Maia, já na década de 1980. Foi um dos inovadores na construção de concreto armado na cidade, segundo documentos da época, inclusive no âmbito dos IAPs e CAPs atuantes em Natal. Fora contratado por diversos dos seus associados abastados para a edificação de grandes moradias.

\footnotetext{
${ }^{618}$ Assim como em João Pessoa, o arquiteto português Delfim Amorim projetou importantes edificações em Natal, como edifício Sede e clube de lazer do América Futebol Clube, em 1959.

${ }^{619}$ Arialdo foi considerado pelos periódicos locais como o "(...) arquiteto que revolucionou e modernizou a cidade de Natal (...)" (A REPÚBLICA, 1959, p.07).

620 Responsável pelo projeto do Edifício do IPASE (1957), na cidade.

${ }^{621}$ Autor dos projetos do Cine Nordeste (1958) e da sede do América Futebol Clube (1959).

622 Projetou o antigo Terminal Rodoviário da Ribeira (1956) e a Associação dos Subtenentes e Sargentos do Exército de Natal ASSEN (1963).

${ }^{623} \mathrm{Na}$ mesma linha, em 1929, foi organizado o concurso anual dos três melhores projetistas e dos proprietários dos mais bonitos e modernos prédios da cidade, cuja premiação era a restituição total do valor da construção elou metade dele (O'GRADY, 1929). 624.
} 
O arquiteto natalense Moacyr Maia, por sua vez, atuou em Natal junto ao IPASE e ao IAPC, na década de 1950, e ao IPE já na década de 1960. Foi o responsável pelo projeto do Conjunto Nova Tirol (IAPC-1957) e da segunda etapa do Conjunto Cidade da Esperança (IPE-1964), e o edifício sede do IPE (1962) ${ }^{625}$, além de diversas edificações isoladas contratadas pelos associados ou a ele indicadas pelos Institutos acima elencados. Exerceu ainda funções junto à Carteira Predial do IPASE no tocante à fiscalização de obras e avaliações de imóveis que eram objeto de promessa de compra e/ou venda ou adjetos de hipoteca, na década de 1950. Moacyr graduou-se em arquitetura pela Escola Nacional de Belas Artes do Rio de Janeiro, em abril de 1954, quando retornou à Natal, de certa forma desiludido com o que estava sendo operado na capital federativa em termos arquitetônicos, como destacou Trigueiro (2010). Essa situação foi bem retratada pelo próprio arquiteto em palestra comemorativa aos quarenta anos do CREA-RN:

(...) uma enorme especulação imobiliária e a exigência cada vez maior de aproveitamento de áreas, que nesse caso, se traduzia em apartamentos minúsculos que tinham por objetivo a obtenção de lucros e pouco interessava a qualidade de vida daqueles que ali estivessem interessados a morar (...) (PALESTRA..., 2009).

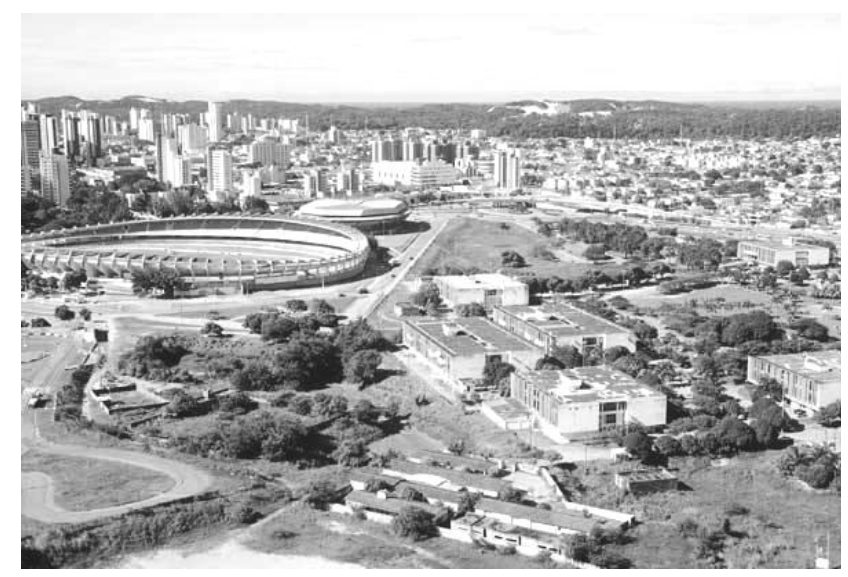

Figura 260: Vista aérea do já demolido Estádio João Machado e do Ginásio Humberto Nesi, à direita o Centro Administrativo, em Natal. Fonte: Tribuna do Norte, 2010.

Regressando à Natal, logo se associou aos arquitetos de maior renome na cidade na época, Ubirajara Galvão e João Maurício. Na capital, o seu principal feito foi o Estádio João Machado, conhecido popularmente como Machadão626, em 1967, cuja inspiração adveio declaradamente do também arquiteto Milton Roberto, especialmente do Maracanã, no Rio de Janeiro (TRIGUEIRO, 2010) (Figura 260). No estado do Rio Grande do Norte projetou ainda diversos edifícios como o Instituto de Educação das cidades de Mossoró (1957) e de Caicó (1957), a sede do DER-RN (1962), o prédio da

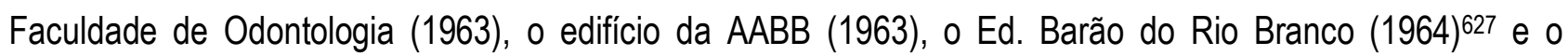
Ginásio de Esportes Humberto Nesi, o Machadinho (1992), em Natal, e foi professor da disciplina Arquitetura e Construção Civil na UFRN, em 1967, além de ocupar cargos relacionados ao planejamento na prefeitura de Natal, na década seguinte.

O arquiteto natelense Ubirajara Galvão também se formou pela Escola de Belas Artes do Rio de Janeiro, e foi o responsável pelo projeto da primeira etapa do Conjunto Cidade da Esperança (1964), junto ao IPE, em Natal. Para além dos conjuntos dos institutos de previdência projetados pelo arquiteto outros os seguiram, inclusive junto ao BNH. Outras realizações de vulto e importância para a cidade foram projetadas

\footnotetext{
625 Em parceria com os arquitetos Daniel Geraldo Gomes de Hollanda e João Maurício Fernandes de Miranda.

626 Esse ícone da arquitetura natelense foi demolido devido às reformas exigidas à cidade para sediar a Copa da FIFA de 2014.

627 O mais importante centro comercial da época.
} 
por ele, como o Centro Administrativo da Cidade e a Escola de Música da UFRN, seguindo os traços modernos, como volumetria simples e grandes rampas de acesso. No Centro Administrativo, em especial, foram empregados os princípios de Cidade-Jardim (ver figura 260). A sua ação foi recorrente em outras localidades nordestinas, principalmente no estado do Piauí, mais especificadamente nas cidades de Teresina e Parnaíba, onde projetou diversos conjuntos de moradias edificados pelo IPASE, a exemplo dos Conjuntos Monte Castelo, na capital, e Esperança, no interior. Essas realizações foram consagradas essencialmente na década de 1960, e continuaram a serem empreendidas por aquele Instituto nos anos seguintes, já sob a subordinação ao novo Plano de Habitação.

De modo geral, em Teresina, os profissionais que empreenderam as avaliações dos imóveis a serem edificados ou financiados pelos institutos de previdência, também construíram diversas moradias, como foram os casos dos engenheiros civis Eloi do Egito Coelho e João Gabriel Batista, no âmbito do IPASE, e do engenheiro José Carlos Pires de C. F. Castelo Branco, junto ao IPASE e ao IAPC, dentre outros.

O engenheiro civil formado pela Escola Politécnica da Bahia (1946) e geógrafo João Gabriel Batista (1920-2010) se destacou nesse cenário. Responsável por grande parte das avaliações dos imóveis a serem financiados (para aquisição ou construção), bem como dos laudos para a edificação de grupos habitacionais, especialmente executados pelo IPASE, também foi o responsável pelo projeto e pela execução do Conjunto José Vitorino Corrêa (1953), localizado no bairro de Nossa Senhora das Dores da capital piauiense. Esse Conjunto era composto por vinte e oito unidades isoladas no lote e construídas de acordo com os princípios arquitetônicos considerados modernos na época, principalmente em se tratando das plantas das edificações. Além de atuar junto ao IPASE, na cidade, foi engenheiro fiscal de obras empreendidas pelo Serviço Nacional da Malária no Nordeste, da Estrada de Ferro Central do Piauí e do Departamento de Estradas e Rodagens do estado. Foi ainda professor da Faculdade Católica de Filosofia e da Universidade Federal do Piauí, artista plástico, Secretário de Viação e Obras Públicas e de Agricultura, Indústria e Comércio do Piauí628, membro da Academia Piauiense de Letras, além de escritor, tendo redigido importantes publicações acerca da geografia e da história do estado629.

Em Fortaleza ${ }^{630}$, também foi vislumbrada a atuação de outros personagens para além do cenário cearense, como foi o caso do engenheiro norte-riograndense Omar O'Grady, que foi prefeito de Natal (19241929)631. O'Grady atuou junto ao IAPC e ao IAPB na cidade, projetando o I Conjunto Vila Aldeota (1947),

628 Durante o mandato do prefeito Gayoso e Almendra, na segunda metade da década de 1950.

629 O referido engenheiro faleceu aos 89 anos, em março de 2010, em Teresina.

${ }^{630} \mathrm{Em}$ Fortaleza, a pesquisa deparou-se com variadas dificuldades para a identificação dos profissionais que estavam envolvidos com as ações imobiliárias das CAPs e dos IAPs na capital. A primeira delas refere-se ao fato de que, em praticamente todos os processos de ações diretas, não havia a especificação dos profissionais, especialmente os engenheiros avaliadores. Outro aspecto comprometedor está associado ao registro dessas informações. Na maior parte dos documentos encontrados na cidade, os registros e assinaturas foram feitos somente à mão, sem a utilização de carimbo ou especificação à máquina datilográfica, como se procedia naquela época; o que em muito dificultou a interpretação. De qualquer modo, assim como nos supracitados casos, a gama de engenheiros e arquitetos atuantes em Fortaleza corresponde a um montante considerável, totalizando quarenta profissionais.

631 Outro engenheiro envolvido com a política, que também desenvolveu projetos no âmbito dos IAPs foi o engenheiro Gentil Ferreira (falar o que ele foi e a formação). Proprietário de uma empresa de construção de renome em Natal, Gentil Ferreira foi 0 Continua na página seguinte. 
além de moradias isoladas para os segurados daquele Instituto. A primeira vila dos bancários na cidade era conformada por quatorze residências isoladas no lote com traços simples típicos da arquitetura moderna. 0 mesmo procedia em se tratando do dimensionamento e disposição dos ambientes em planta, segundo os laudos de avaliação do Conjunto. O referido engenheiro graduado nos Estados Unidos, no Illinois Institute of Technology, em 1917, trabalhou por dois anos naquele país. Seguiu a linha inovadora e modernizadora desde seu egresso à Natal enquanto recém-formado, quando passou a atuar junto à Inspetoria Federal de Obras Contra as Secas e, em 1924, à prefeitura da cidade, como Intendente Municipal. Mais precisamente, Omar O'Grady foi um dos principais responsáveis pela incorporação de ditames modernos na cidade na primeira metade da década de 1920 e, posteriormente, junto ao corpo técnico do IAPC em Natal e Fortaleza. Na capital do Rio Grande do Norte, uma das suas principais iniciativas foi "(...) pôr Natal em sintonia com 0 mundo, a partir de sua importante ligação com o centro aeroviário internacional"632 (DANTAS, 1998, p.95) e a consequente elaboração do Plano de Sistematização, em 1929633, que traduz seu ideário de cidade, bem como a sua filiação arquitetônica, também percebida nas construções em Fortaleza.

No interior do estado do Ceará, mais precisamente na cidade do Crato e, posteriormente em sua capital, se sobressaiu a figura do construtor Tiburcio Rodrigues de Melo. Segundo relatos encontrados nos documentos históricos levantados e em alguns periódicos da época, Tiburcio foi o responsável pela edificação da grande maioria dos empreendimentos financiados pelas CAPs e IAPs naquela cidade. Para além deles, edificou o Grande Hotel do Crato, o Colégio Diocesano e a Rodoviária Wilson Roriz, além do Edifício São Francisco, o maior da região, entre as décadas de 1940 a 1960. Foi inclusive convidado a participar da construção de Brasília, como construtor licenciado.

Em São Luís, especialmente, como já colocado no capítulo anterior, a maior parte das realizações diretas foi executada pelo IPASE em parceria com $5^{\circ}$ Grupamento de Engenharia, não sendo apontados nos processos imobiliários, os profissionais responsáveis pelas avaliações, projeto, execução e fiscalização das obras dos conjuntos residenciais. Mesmo nos processos imobiliários relacionados às ações indiretas, aos financiamentos, quase a totalidade deles não especificou os engenheiros e/ou arquitetos envolvidos. Em apenas um dos documentos, apareceu a figura do engenheiro civil Almir Aguiar Guedes, como responsável pela avaliação para a compra de moradias já edificadas por parte dos segurados do IPASE, bem como a

responsável pela edificação de diversas residências modernas na cidade, a maior parte das quais, faz uso do concreto armado e do vidro, seguindo as premissas corbusianas. Assim como Omar O'Grady, Gentil Ferreira foi prefeito de Natal (1931-1932 e 19361940). Foi o principal responsável pela fundação do Clube de Engenharia na cidade, em 1936, e da construção do Mercado Municipal da cidade, também na década de 1930.

632 Foi nesse contexto edificado o Aero Clube do Rio Grande do Norte no ano de 1929. Vale ressaltar que Natal se configurava como uma parada obrigatória de aviões e hidroaviões de diversas partes do mundo, devido ao seu posicionamento geográfico estratégico, se conformando cada vez mais como um importante entreposto no cenário da aviação mundial, consolidado anos depois com a ocorrência da II Guerra Mundial.

633 Plano de autoria de Giacomo Palumbo, com sua colaboração, bem como da engenheira Carmen Portinho. Esse Plano, dentre outras ações, previa o zoneamento da cidade em "(...) quarteirões administrativo, commercial, industrial, a cidade recreio [bairrojardim] e os bairros residencial e operario (...)" (PREFEITURA..., 1981a), a exemplo das proposições corbusianas formuladas no IV CIAM. 
Construtora Cleon Furtado, a qual competia a construção de algumas unidades habitacionais isoladas, mas nenhuma informação adicional foi encontrada sobre eles.

Observou-se, assim, que o quadro heterogênio observado quanto à política empreendida pelos órgãos nas sete capitais nordestinas abordadas nesta tese também foi vislumbrado em relação à qualificação das realizações no campo da moradia empreendidas ou financiadas pelos institutos de previdência aqui estudados. Em algumas cidades, como colocado no capítulo anterior, os Institutos e Caixas adquiriram moradias mais que edificaram, em outras, as ações focaram, sobremaneira, a construção de pequenos grupos residenciais horizontais. Muitos outros exemplos e referências podem ainda ser apontados, essencialmente, em se tratando das características arquitetônicas e urbanísticas dessas realizações.

Por outro viés, a ausência e/ou a superficialidade de informações disponíveis acerca dos profissionais no cerne das Caixas e Institutos de Aposentadoria e Pensões no Nordeste, revela a necessidade do aprofundamento e, até mesmo, de realização de novas pesquisas para além das figuras já identificadas e estudadas pela historiografia. Sendo essa, uma importante vertente para o conhecimento não só das produções e realizações no campo da construção civil por parte desses personagens e seus significados no âmbito dos órgãos em questão, mas também para um maior conhecimento da própria arquitetura brasileira, compreendida num período de difusão de novos princípios arquitetônicos e urbanísticos (Ver Anexo G). 


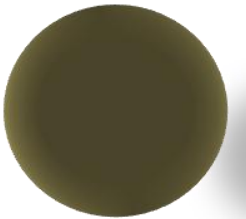
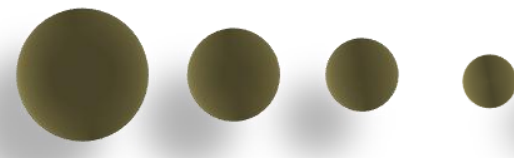 \\ FINAIS}

-

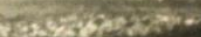

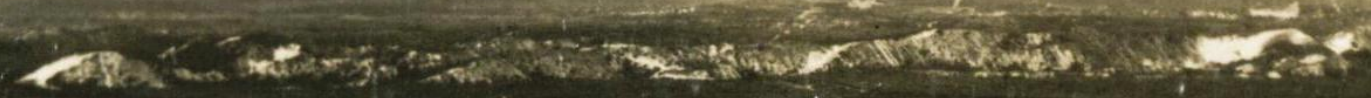

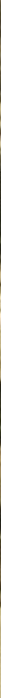




\section{CONSIDERAÇõES FINAIS}

Antes de apresentar as questões conclusivas acerca, principalmente, da política pública habitacional e da produção de moradias pelas CAPs e IAPs do MTIC nas sete capitais nordestinas abordadas nesta tese, vale ressaltar com mais afinco algumas observações inesperadas e, até mesmo, surpreendentes acerca da atuação desses institutos de previdência, de modo mais abrangente, no território nacional.

A primeira delas diz respeito ao fato que as Caixas e os Institutos de Aposentadoria e Pensões não somente organizaram o sistema previdenciário e trabalhista no país e procederam ao alargamento das ações diretas do poder público no campo habitacional, mas também financiaram a execução de inúmeras obras urbanas, desde abertura de vias e rodovias, construção e/ou ampliação de estradas de ferro, redes de abastecimento d'água, redes elétricas, telefônicas, sistemas de coleta de esgotos, obras de saneamento, como construção de canais e até obras de hidrelétricas, dentre outras, que foram realizadas pelo Estado em todo o Brasil, contribuindo significantemente para o processo de urbanização de muitas cidades brasileiras. Mostraram-se ainda, importantes impulsionadores da industrialização em nosso país ao financiarem a implantação, edificação e/ou ampliação de diversas indústrias de base, as chamadas empresas de economia mista, como a Companhia Vale do Rio Doce, a Companhia Siderúrgica Nacional, a Companhia Hidrelétrica Vale do Rio Doce, dentre muitas outras. Tal ação significou uma captação de poupança forçada para a realização de investimentos em setores tidos como estratégicos da economia do país por parte do Estado.

As CAPs e os IAPs, principalmente, não somente abrigaram os profissionais, engenheiros e arquitetos, pioneiros da arquitetura e do urbanismo modernos, como destacou Bruna (2010), e impulsionaram a edificação dos primeiros modernos conjuntos residenciais do país, como também financiaram as principais realizações nesse sentido, para além do campo da moradia. Muitos hospitais, ambulatórios, bancos, hotéis e sedes institucionais, inclusive os edifícios do Ministério da Educação e Saúde e do Ministério do Trabalho, além da já citada construção de Brasília, ícones da nova arquitetura que estava sendo instituída, foram construídos com aquelas verbas previdenciárias, angariadas, sobretudo, por meio das contribuições mensais dos trabalhadores urbanos brasileiros ao longo das décadas de 1940 e 1950.

Dessa forma, destaca-se com mais afinco, que foram os próprios trabalhadores urbanos brasileiros, especialmente àqueles recebedores dos menores salários ${ }^{634}$, os verdadeiros financiadores de diversos processos vinculados ao crescimento e/ou à modernização das cidades brasileiras ao longo das décadas de 1940 e 1950, sobremaneira. O Estado, na realidade, se configurou muito mais como idealizador e estruturador dessas ações, empreendendo as reformas legislativas e institucionais pertinentes, além de desempenhar importante contribuição no âmbito da fiscalização, que realizador propriamente dito, principalmente em se tratando das questões habitacionais em nosso país.

\footnotetext{
634 Uma vez que muitos dos empregadores - a semelhança do Estado -, não honraram com o pagamento das cotas previdenciárias, previstas em lei, e representada pela contribuição tripartite.
} 
A partir do estudo e análise das resoluções nacionais, projetos de lei, leis, decretos, mensagens de Governo, cartas, pareceres técnicos, processos imobiliários e teses formuladas acerca da atuação das Caixas e dos Institutos de Aposentadorias e Pensões no campo da moradia social foi possível a identificação de uma série de referências e modelos adotados para a estruturação desses órgãos ao longo da primeira metade do século XX. Acredita-se que houve influência das entidades e organizações sociais e de classe precedentes, para a instauração da própria previdência estatal em nosso país. Essas organizações se tornaram a referência direta para o modelo estatal. As semelhanças podem ser enumeradas facilmente, passando pelos benefícios oferecidos, pela forma de arrecadação, organização interna e de associação. Dessa forma, diferentes partidos, sindicatos oficiais, montepios, caixas e sociedades de socorros mútuos, dentre outras entidades e associações, tiveram papéis importantes na estruturação do movimento operário no país, que culminaram na elaboração das leis trabalhistas e no alargamento da intervenção direta do poder público no campo da previdência social e da habitação.

Paralelamente às investidas dos trabalhadores e suas ações reivindicatórias, a conjuntura propiciada pelas mudanças do papel estatal para com as questões sociais - essencialmente a previdência, o trabalho e a moradia -, vislumbradas na América do Norte e na Europa se mostraram fundamentais para a decisão de intensificação da intervenção direta do poder público brasileiro nesses campos. Esse redirecionamento da postura estatal se materializou inicialmente pela modificação de todo o aparato estatal no campo da seguridade social, especificadamente, que culminou também na criação do Conselho Nacional do Trabalho (CNT) e das Caixas de Aposentadoria e Pensões (CAPs) subordinadas ao Ministério da Agricultura, a partir de 1923.

$\mathrm{Na}$ década de 1930, intensificou-se entre as administrações públicas e as elites intelectuais e econômicas do país um intento comum; o de modernizar as cidades brasileiras, sua infraestrutura e serviços, bem como embelezá-las, em oposição à superada configuração das cidades e edificações da época do Brasil colônia. Esses anseios progressistas e modernizadores do governo em diferentes instâncias são vislumbrados desde o início do período republicano, sendo marcados por uma política de investimentos preferenciais nas capitais, que ganharam vulto no decorrer dos anos de 1930, com o projeto de consolidação da identidade nacional. Concomitantemente, nessa época, o poder público passou efetivamente a considerar que o problema de escassez e das condições das moradias das camadas mais carentes da população, e em um segundo momento da classe média, era de sua competência; concretizando a tendência iniciada na década anterior.

Personagens políticos, como os primeiros ministros do Trabalho, Indústria e Comércio, além de profissionais engenheiros e/ou arquitetos que participaram do debate e da reforma em torno daqueles campos, bem como da estruturação das repartições criadas e/ou ampliadas nesse sentido foram, indubitavelmente, indispensáveis para a mudança vislumbrada essencialmente no que concerne à habitação urbana no Brasil. Esse foi o caso do engenheiro-arquiteto Rubens Porto, cujo prestígio profissional, revelado 
pelos cargos de importância ocupados ao longo de sua carreira, como também pela diversificada bagagem intelectual observada em suas formulações e pelas referências em seus escritos, proporcionou não somente que suas propostas fossem consideradas e acatadas por diversas autoridades, essencialmente pelos Ministros do Trabalho Agamemnom Magalhães e Waldemar Falcão e, inclusive, pelo Presidente Getúlio Vargas, para os quais Porto também foi assessor técnico. Esses aspectos possibilitaram ainda o contato do profissional com uma gama de dados e informações que balizaram suas proposições no campo habitacional, tendo destaque os dados coletados nos sete anos de levantamentos e estudos realizados no âmbito do CNT, e visitas a diversas realizações europeias no campo da moradia e as soluções empreendidas por distintas instituições financeiras e de previdência do mundo.

Suas proposições culminaram, essencialmente, na criação dos Institutos de Aposentadorias e Pensões (IAPs) do MTIC, em 1933, e no alargamento da atuação desses órgãos no campo habitacional, com a liberação de até metade de suas reservas para a aquisição, construção e/ou financiamento de moradias aos trabalhadores brasileiros. Dentre os Institutos e Caixas que mais seguiram o proposto por Porto, destacam-se o IAP dos Marítimos (IAPM) e o IAP dos Industriários (IAPI), tanto no que se refere às ações imobiliárias quanto às diretrizes construtivas indicadas pelo referido engenheiro-arquiteto. Por outro lado, com base nas diversas referências citadas por Rubens Porto em seus artigos, legislação e livro, bem como percebidas a partir de análises de suas colocações, constatou-se que suas proposições para a construção habitacional não se vinculam apenas aos princípios corbusianos, mas também a proposições de pensadores católicos dos séculos XIX e XX, às propostas e realizações empreendidas pelos chamados urbanistas utópicos e, principalmente, às ações efetivadas no campo da moradia pelas sociais-democracias europeias da década de 1920, sobretudo, àquelas idealizadas e executadas por Ernest May, em Frankfurt.

De modo geral, a atuação dos institutos de previdência em questão se caracterizou por uma política social excludente. Apesar da proposta social inicial e de estarem inclusos no contexto previdenciário do país, cuja essência era a de conceder auxílios à população carente e/ou necessitada, as CAPs e os IAPs não abarcaram essa parcela populacional no que diz respeito à disponibilização e ao repasse de unidades habitacionais, atendendo somente os trabalhadores urbanos, sobremaneira, com carteira assinada e contribuintes a mais de cinco anos para com a previdência. Esse quadro excluía do processo as camadas mais carentes, os trabalhadores rurais, autônomos e os informais urbanos, além dos desempregados.

No Nordeste, observou-se que mesmo no âmbito dos próprios órgãos ocorreram casos de privilégios no atendimento das solicitações imobiliárias. Mais detalhadamente, esse aspecto foi percebido em duas principais ocasiões. A primeira delas pode ser observada no âmbito das Carteiras Prediais dos referidos órgãos, nas quais, os segurados com maiores salários, tidos como médios e altos, e aqueles ocupantes dos melhores cargos foram beneficiados em detrimento aos associados mais carentes. Os institutos de previdência atenderam, nesse sentido, muitos que já possuíam moradia, alguns dos quais, eram inclusive empregadores. A segunda forma refere-se às categorias trabalhistas. Na qual, os funcionários públicos, 
fossem eles federais, estaduais ou municipais, foram mais contemplados. Trabalhadores esses que recebem, via de regra, bons vencimentos salariais e são assistidos por outros benefícios gratuitos inerentes à profissão - como isenção do pagamento de transportes urbanos, verificada desde, pelo menos, as primeiras décadas do século XX -, não se configurando como uma camada social carente de políticas públicas.

Observou-se, nesse contexto, que desde 1927, o Instituto de Previdência dos Funcionários Públicos da União, que também se configurou como modelo para a estruturação dos IAPs do MTIC posteriores, eram autorizados a investir até $80 \%$ de suas reservas no plano da habitação635. Parcela essa que sequer se aproxima do máximo permitido pelo poder público para investimentos no setor imobiliário por parte dos demais institutos de previdência. Vale salientar ainda que, naquele momento, as realizações habitacionais empreendidas pelo Instituto dos Funcionários Públicos, muitas vezes, se dava sem custo algum para os trabalhadores, uma vez que eles não realizavam contribuições mensais junto a esse órgão, ficando a cargo somente do poder público o seu custeio. Esse foi o caso das unidades habitacionais edificadas em Brasília com a verba previdenciária.

Acerca desse episódio constatou-se que mesmo se destinando aos funcionários públicos federais, sobremaneira, as moradias edificadas na nova capital federativa não foram financiadas pelo Instituto dos Funcionários Públicos da União, já absorvido pelo IPASE naquela ocasião, mas sim e principalmente, pelo Instituto de Aposentadoria e Pensões dos Industriários. Essas residências, locadas em edifícios coletivos ou isoladamente, foram repassadas aos trabalhadores sem custo algum para eles, sendo totalmente custeadas pelo Estado que, vale salientar, nunca pagou os empréstimos realizados junto à Carteira Predial do IAPI. É importante lembrar que havia inicialmente certa resistência à ocupação da nova capital por parte dos funcionários públicos e a "doação" de unidades foi a forma encontrada pela administração pública para induzir a ocupação e o adensamento de Brasília naquela ocasião. Dessa maneira, além de possibilitar a edificação da nova capital, os Institutos e Caixas das demais categorias trabalhistas, especialmente dos industriários, foram os principais propulsores da própria ocupação das primeiras unidades residenciais ali edificadas, vale frisar, graças às contribuições dos trabalhadores do país.

Embora mais maduras, as ações estatais no campo da moradia social, vislumbradas a partir de meados da década de 1930 até a década de 1960 no Nordeste, foram acompanhadas pela limitação dos instrumentos públicos de fiscalização e controle da ocupação e uso do solo da cidade, essencialmente voltados às moradias. Esse fator, dentre outros, leva-nos a concluir que a produção do solo, ainda naquele momento, ficou a cargo, como no início do século, sobretudo, dos interesses privados. Verificou-se também, que a ação estatal no campo da moradia social nas sete capitais estudadas foi acompanhada, em diversos momentos, por indícios de segregação espacial e social. De modo geral, a segregação garantiu às classes mais abastadas, mesmo no âmbito das Carteiras Trabalhistas, áreas de uso exclusivo, livres de deterioração,

$635 \mathrm{Em} 1933$, esse percentual foi elevado para 90\%. 
capacitadas de toda infraestrutura e equipamentos necessários. As camadas mais carentes, por sua vez, muitas vezes foram resguardadas em áreas específicas, mormente, mais distantes do centro das cidades ou em bairros reservados para elas; contribuindo para o crescimento das periferias nessa região do país.

Esse quadro também foi representado pelo crescimento e diversificação das favelas já existentes em diversas das capitais da região, pela proliferação de ocupações de terrenos vazios, inclusive remanescentes dos conjuntos residenciais construídos e/ou financiados pelos órgãos, bem como pela intensificação do mercado informal de terras, marcada principalmente pela proliferação dos loteamentos clandestinos, como foram observados principalmente nas cidades de Salvador e do Recife. Sendo assim, a atuação governamental no campo da moradia no Brasil vem há anos contribuindo para tanto, principalmente por deixar de lado de seus projetos e programas habitacionais a população mais necessitada, sem rendimento fixo e aquela recebedora de até três salários mínimos. Colaboraram também nesse processo de favelização das cidades nordestinas as ações especulativas tanto no mercado de terras como no imobiliário; a elevação dos custos de mão de obra e técnicos, além do próprio material de construção; a redução do poder aquisitivo dos brasileiros, dentre outros.

Outro aspecto inesperado identificado com a realização da presente pesquisa, diz respeito ao volume da produção habitacional empreendidas pelas CAPs e pelos IAPs no Nordeste do país, que se mostrou significantemente maior que aquele especificado nas publicações do gênero, se aproximando do montante imputado por Farah (1983) às Regiões Norte, Nordeste e Sul em conjunto. Mais precisamente, foram identificados 21.995 (vinte e um mil novecentos e noventa e cinco) financiamentos concedidos aos trabalhadores nordestinos ${ }^{636}$. A produção dos institutos de previdência no Nordeste corresponde a 17,73\% do total nacional, representado por 123.995 moradias $^{637}$. Os órgãos mais atuantes nesse sentido foram o IPASE, o IAPC e o IAPI, nessa ordem 638 .

Por outro lado, mostra-se importante lembrar que a concessão de financiamentos para a compra ou edificação de residência ou terreno atendia não somente ao associado beneficiado, mas também toda a sua família. Para se ter a noção real da atuação dos referidos órgãos no campo habitacional brasileiro seria necessário a realização de um levantamento minucioso dos dados de produção total, incluindo os financiamentos e outras ações imobiliárias atuariais; o que se mostra quase impossível de proceder devido à falta de dados e registros oficiais acerca dessa produção no país. No entanto, pode-se vislumbrar uma estimativa mais aproximada da população realmente atendida no Nordeste utilizando-se as informações angariadas nas pesquisas em campo, confrontando-as aos dados censitários do tamanho médio da família

\footnotetext{
636 Dos quais, 2.545 (dois mil quinhentos e quarenta e cinco) processos imobiliários foram efetivamente levantados. Cabe lembrar ainda que nesse volume de unidades habitacionais identificado não foram contabilizadas a produções dos referidos órgãos em Maceió e Aracajú; não abordadas nesta tese.

${ }^{637}$ E a $62,46 \%$ do total atribuído por Farah (1983) para os órgãos nas regiões Norte, Nordeste e Sul do país.

638 Responsáveis, respectivamente, por $22,48 \%, 21 \%$ e $20,18 \%$ do total de processos levantados nas sete capitais nordestinas em questão.
} 
brasileira para cada uma das capitais estudadas ${ }^{639}$. Dessa forma, cruzando-se o total de pleitos identificados na região com as taxas acima mencionadas tem-se um montante de 106.483 (cento e seis mil quatrocentos e oitenta e três) pessoas atendidas pela política das CAPs e IAPs no Nordeste do país, entre as décadas de 1930 e 1960. Esse valor corresponde a $9,05 \%$ do número de prédios residenciais urbanos nordestinos, incluindo os das capitais Maceió e Aracajú, em 1940, e equivale a 9,55\% da população residente nos centros urbanos do nordeste, no mesmo período.

Essa afirmativa contraria a tese que a produção de moradias pelos IAPs e pelas CAPs foi ínfima comparando-as ao BNH, a partir de 1964, comumente encontrada na historiografia. Ambas as atuações chegaram a atender, cada um em seu período, a aproximadamente $10 \%$ da população residente nas principais cidades do Nordeste. Por outro lado, é importante ressaltar que não se pode estabelecer uma análise comparativa numérica entre os órgãos, exatamente porque as atuações se deram em períodos distintos, cujos fatores de influência e/ou interferência (conjuntura política, econômica e social) eram bastante diferentes. Apenas pode se proceder a uma análise qualitativa entre as supracitadas produções, que também se aproximam, cabe frisar. Uma análise quantitativa só seria cabível entre órgãos atuantes no mesmo espaço de tempo, como foi o caso dos IAPs/CAPs e da Fundação da Casa Popular (FCP), entre os anos de 1946 e 1964. No período compreendido entre os referidos anos, a FCP edificou um total de 18.132 unidades habitacionais, em todo o país, de acordo com os dados apresentados pela historiografia, que corresponde a um décimo das moradias providas pelas Carteiras Prediais das Caixas e dos Institutos, que totalizaram 123.995 moradias.

No tocante ao período de atuação dos órgãos nas sete capitais aqui estudadas, observou-se que a ação das Caixas e Institutos de Aposentadoria e Pensões subordinadas ao MTIC no campo da moradia social teve início, efetivamente, a partir de 1944, extrapolando o ano de 1964 até, pelo menos, o final da década de 1960. A concessão de financiamentos e a edificação de unidades habitacionais empreendidas por aqueles órgãos de previdência estatal se deu de modo crescente até o ano de 1950 nas referidas localidades, a partir de quando, passou a ocorrer de forma bastante variável, com picos nos anos de 1952 (quando ocorreu um breve recesso da aplicação das Leis do Inquilinato e, consequentemente, o congelamento dos aluguéis), 1957 e 1958 (períodos de agravamento da crise habitacional na maior parte das cidades estudadas). Outro pico de atuação evidenciado se deu em 1964, sendo marcado essencialmente pela atuação do IPASE e de outras instituições previdenciárias oficiais de instância estadual e municipal, como o IPSEP, o IPE, dentre outras (Figura 262).

Em se tratando das hipóteses iniciais desta tese, como conjecturado inicialmente, apesar da maior parte das ações das CAPs e dos IAPs no campo habitacional no Nordeste se referir a financiamentos sociais 
e, por vezes, intermediários, os trabalhadores mais contemplados por concessões de financiamentos foram aqueles ocupantes de cargos mais altos, recebedores de maiores salários. Nesse sentido, de acordo com as análises do caráter das ações imobiliárias empreendidas no terceiro capítulo, atestou-se que as críticas e denúncias divulgadas essencialmente nos periódicos das décadas de 1930 a 1960, quanto à apropriação das verbas arrecadadas dos trabalhadores segurados do país e acumuladas nos fundos previdenciários das CAPs e dos IAPs para o atendimento de uma parcela populacional não carente de políticas públicas habitacionais e, inclusive, para a edificação de unidades habitacionais de luxo, tinham fundamento.

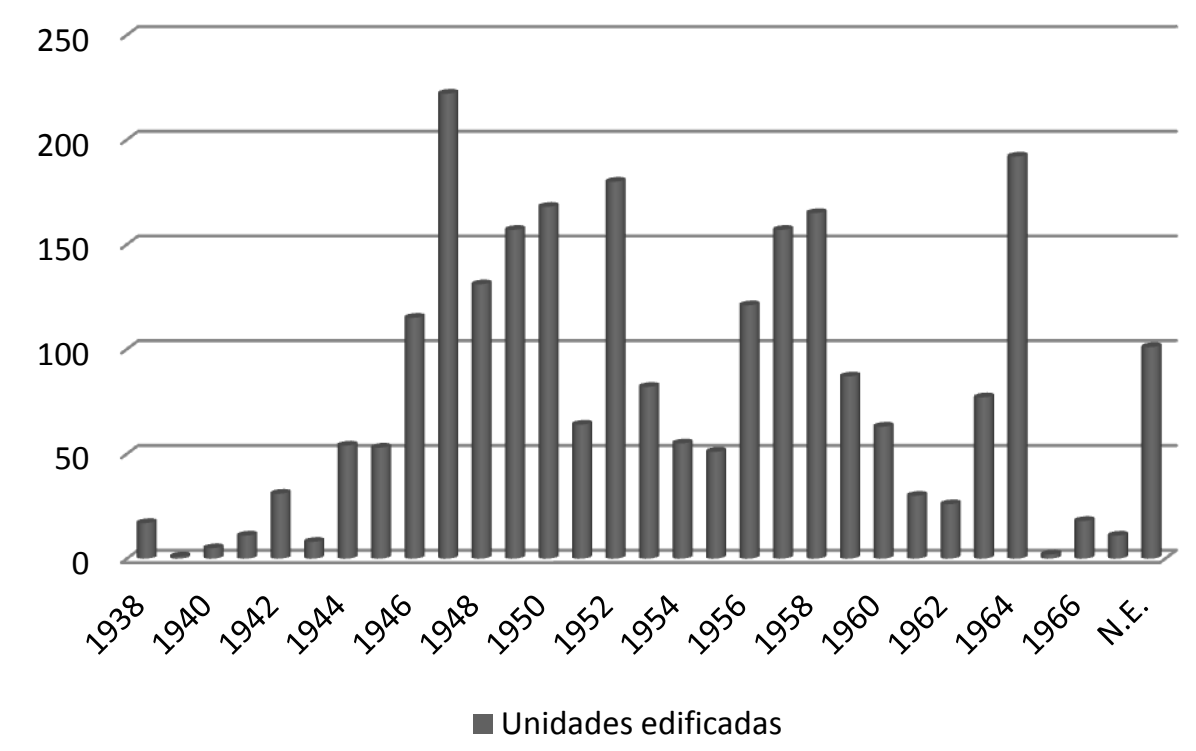

Figura 262: Gráfico Geral do Período de Atuação das CAPs e dos IAPs no campo da moradia, nas sete capitais nordestinas estudadas. Fonte: Elaboração própria com base nos dados levantados nas Agências do INSS na BA, PE, PB, RN, CE, PI e MA.

Mais precisamente, constatou-se que no plano da alocução, praticava-se a política de inversão para a constituição de um patrimônio de bens reais para os institutos de previdência e de condicionamento dos programas habitacionais sociais a ações atuariais, para não gerar a descapitalização dos órgãos. Só que na prática, essa subordinação deu lugar a um desprezo das ações sociais no campo habitacional no Nordeste, já a partir de fins da década de 1940. Chegou-se, em alguns casos, a considerar esse tipo de atuação, que visava o sobrelucro devido às altas taxas de juros praticadas sem controle estatal, como sendo uma inversão de caráter nitidamente social. Nela, os lucros seriam empregados na concepção de moradias baratas para os operários; o que não procedeu. Ao visarem o lucro em suas atividades imobiliárias, as Caixas e os Institutos deixaram, muitas vezes, de se conformarem como agentes públicos para se aproximarem dos agentes incorporadores capitalistas.

Os principais aspectos que colaboraram para a descapitalização dos referidos órgãos e, consequentemente, para uma atuação mais capitalista foram: o não cumprimento do papel que cabia ao Estado e aos empregadores na estrutura tripartite de contribuição; a baixa rentabilidade dos investimentos, sobretudo, habitacionais (taxas de juros fixas e amplo prazo para a amortização da dívida); os desvios cada 
vez mais recorrentes de vultosas quantias acumuladas para a implementação do projeto desenvolvimentista e obras relacionadas a ele; além dos momentos de crise econômica pelos quais o país passou ao longo das décadas de 1930 a 1950.

No Nordeste, mais detalhadamente, entre os anos de 1943 e 1951, período de congelamento do salário mínimo dos trabalhadores do país e de análise do perfil da atuação dos órgãos nas sete capitais nesta tese estudadas, foram identificados 835 (oitocentos e trinta e cinco) pleitos de financiamentos, dos quais, 654 (seiscentos e cinquenta e quatro) especificavam os valores dos salários recebidos pelos segurados contemplados $^{640}$. Destes, $58,5 \%$ foram recebidos por trabalhadores tidos como de classe média alta e alta. É curioso atestar isso apesar do número de financiamentos atuariais ter sido consideravelmente menor que os financiamentos sociais e médios, não chegando a representar 20\% dos processos aprovados ${ }^{641}$ (Figuras 263 e 264). Esse aspecto nos leva a crer que muitos dos segurados abastados, em conivência com os conselhos administrativos dos escritórios estaduais dos institutos de previdência e dos órgãos responsáveis pela fiscalização de suas ações, solicitaram financiamentos baixos para driblar o sistema.

\begin{tabular}{|c|c|c||c||c|c|}
\hline CAPITAIS & ATÉ 3 SALÁRIOS & $\begin{array}{c}\text { DE 3 A 5 } \\
\text { SALÁRIOS }\end{array}$ & $\begin{array}{c}\text { DE 5 A 10 } \\
\text { SALÁRIOS }\end{array}$ & $\begin{array}{c}\text { ACIMA DE 10 } \\
\text { SALÁRIOS }\end{array}$ & TOTAL \\
\hline \hline Salvador & 17 & 08 & 18 & 25 & 68 \\
\hline \hline Recife & 43 & 37 & 21 & 34 & 135 \\
\hline \hline João Pessoa & 04 & 01 & 41 & 27 & 73 \\
\hline Natal & 46 & 59 & 65 & 44 & 214 \\
\hline \hline Fortaleza & 13 & 24 & 35 & 28 & 100 \\
\hline \hline Teresina & 08 & 12 & 17 & 27 & 64 \\
\hline \hline TotaL & $\mathbf{1 3 1 ( 2 0 \% )}$ & $\mathbf{1 4 1 ( 2 1 , 5 \% )}$ & $\mathbf{1 9 7 ( 3 0 , 2 \% )}$ & $\mathbf{1 8 5 ( 2 8 , 3 \% )}$ & $\mathbf{6 5 4 ( \mathbf { 1 0 0 \% } )}$ \\
\hline
\end{tabular}

Figura 263: Tabela Geral dos Salários Recebidos pelos Segurados das CAPs e IAPs no Nordeste (1943-1951). Foi apresentado somente o número de processos que especificaram os salários dos segurados.

Fonte: Elaboração própria com base nos dados levantados nas Agências do INSS na BA, PE, PB, RN, CE, PI e MA.

\begin{tabular}{|c||c||c||c||c|}
\hline \hline CAPITAIS & SOCIAIS & INTERMEDIÁRIOS & ATUARIAIS & TOTAL \\
\hline \hline Salvador & 44 & 18 & 13 & 75 \\
\hline Recife & 116 & 46 & 55 & 217 \\
\hline \hline João Pessoa & 18 & 35 & 24 & 77 \\
\hline \hline Natal & 139 & 31 & 33 & 203 \\
\hline \hline Fortaleza & 66 & 33 & 16 & 115 \\
\hline \hline Teresina & 18 & 27 & 18 & 63 \\
\hline \hline TotAL & $\mathbf{4 0 1 ( 5 3 , 5 \% )}$ & $\mathbf{1 9 0 ( 2 5 , 3 \% )}$ & $\mathbf{1 5 9 ( 2 1 , 2 \% )}$ & $\mathbf{7 5 0 ( 1 0 0 \% )}$ \\
\hline
\end{tabular}

Figura 264: Tabela Geral dos Financiamentos Concedidos aos Segurados das CAPs e IAPs no Nordeste (1943-1951). Foi apresentado somente o número de processos em que o valor do financiamento foi especificado.

Fonte: Elaboracão própria com base nos dados levantados nas Aqências do INSS na BA. PE. PB. RN. CE. PI e MA.

Dessa forma, observou-se que as CAPs e os IAPs atuantes na maior parte das capitais nordestinas, não empreenderam uma política genuinamente social, contemplando os trabalhadores que recebiam até

640 Valor total especificado na figura 263.

641 É importante destacar que dos 850 processos imobiliários levantados entre os anos de 1941 e 1953 nas capitais nordestinas em questão, em 750 (setecentos e cinquenta) especificou-se o valor dos financiamentos praticados $(88,24 \%)$. 
cinco salários mínimos, como pretendido pelo poder público, no contexto de alargamento das ações habitacionais dos órgãos na década de 1930. Intento também colocado por outros atores sociais, principalmente engenheiros e arquitetos engajados na solução dos problemas habitacionais do país naquele momento. Mais detalhadamente, afirma-se que os referidos institutos de previdência empreenderam uma política habitacional voltada, sobretudo, à faixa populacional trabalhadora regular, recebedora de sete a mais de dez salários mínimos no Nordeste.

Também em concordância com as pressuposições iniciais, foram os modelos unifamiliares, isolados ou geminados, os mais recorrentes nas sete capitais nordestinas estudadas (Figura 265). Destoando um pouco do que cogitava anteriormente, não foram os grupos residenciais adquiridos pelos institutos de previdência já edificados os preteridos pelos órgãos para a moradia dos trabalhadores mais carentes no Nordeste. Diversos foram as vilas e os conjuntos residenciais unifamiliares, essencialmente, edificados com esse propósito nas sete cidades estudadas, mormente, compostos por poucas unidades habitacionais, não dotados de espaços e/ou equipamentos coletivos. Somente em Natal, a aquisição de moradias e grupos residenciais já construídos por parte dos órgãos ocupou papel de destaque.

\begin{tabular}{|c|c|c|c|c|c|c|c|c|}
\hline TIPOLOGIAS & BA & PE & PB & RN & CE & PI & MA & TOTAL \\
\hline Unifamiliares Isoladas & 03 & 14 & 06 & 06 & 07 & 07 & 08 & 51 \\
\hline $\begin{array}{c}\text { Unifamiliares Geminadas } \\
\text { (duas a duas) }\end{array}$ & 03 & 13 & 03 & 03 & 04 & - & - & 26 \\
\hline $\begin{array}{c}\text { Unifamiliares Geminadas } \\
\text { (em linha) }\end{array}$ & 01 & 01 & 01 & 03 & 03 & - & 01 & 10 \\
\hline $\begin{array}{c}\text { Tipologias Unifamiliares } \\
\text { Variadas }\end{array}$ & - & 03 & 03 & 02 & - & - & 01 & 09 \\
\hline $\begin{array}{l}\text { Edifícios Coletivos } \\
\text { Isolados }\end{array}$ & - & 06 & 01 & - & - & - & - & 07 \\
\hline Conj. Coletivos Verticais & 09 & 04 & - & - & 01 & - & 01 & 15 \\
\hline Conj. Tipologia Mista & 02 & 03 & - & 01 & - & - & - & 06 \\
\hline Const. Financiadas & 06 & 05 & 03 & 01 & 01 & - & - & 16 \\
\hline Grupos Adquiridos & $\begin{array}{l}- \\
\end{array}$ & $\begin{array}{l} \\
\end{array}$ & $\begin{array}{l}- \\
\end{array}$ & 06 & 01 & - & - & 07 \\
\hline TOTAL & 24 & 49 & 17 & 22 & 17 & 07 & 11 & 147 \\
\hline
\end{tabular}

Figura 265: Grupos de Moradias Edificados e/ou Financiados pelas CAPs e IAPs no Nordeste (1930-1964).

Fonte: Elaboração própria com base nos dados levantados nas Agências do INSS na BA, PE, PB, RN, CE, PI e MA.

Ainda em relação às hipóteses inicialmente formuladas, os edifícios coletivos verticais ou grupos deles, como se conjecturava, foram destinados principalmente aos associados mais abastados, especialmente os edifícios isolados com altos gabaritos. Os casos pontuais de grupos de moradias coletivas destinadas e efetivamente financiadas aos trabalhadores recebedores de baixos salários, identificados nas pesquisas em campo, eram representados por blocos de três ou quatro pavimentos assentados diretamente sobre o solo, muitas vezes, não dotados de equipamentos de uso coletivos e/ou de lazer.

A questão da espacialização das ações das Caixas e Institutos de Aposentadoria e Pensões no Nordeste, por sua vez, variou bastante de órgão para órgão, e de capital para capital nordestina, não sendo adequado se referir a uma atuação em áreas centrais de órgãos com reservas mais vultosas e uma atuação 
mais periférica daqueles escritórios que atendiam às categorias trabalhistas menos privilegiadas em termos financeiros, como se pensava inicialmente. Como verificado, alguns dos empreendimentos destinados aos mais carentes, fossem eles coletivos ou unifamiliares, foram alocados em áreas centrais. Aspectos relacionados ao retardamento dos processos especulativos imobiliários, bem como à prática da doação de terras das mais variadas dimensões por parte de diferentes agentes, incluindo o poder público em suas instâncias estadual e municipal, contribuíram consideravelmente para esse quadro heterogêneo.

Levando-se em conta os dados apresentados ao longo da tese, observou-se que em Natal, por exemplo, a produção das CAPs e dos IAPs se concentrou na aquisição e na edificação de pequenos grupos de moradias unifamiliares para trabalhadores, em todo o recorte temporal estudado. Foram pontuais e esporádicos os exemplares que fugiam a essa regra. Apenas um conjunto se conformou como de médio porte e outro de tipologia mista, vertical coletiva e unifamiliar. As verbas disponíveis para as ações imobiliárias indiretas das delegacias regionais atuantes na cidade foram destinadas, sobretudo, ao financiamento de unidades isoladas edificadas por profissionais (nem sempre vinculados aos órgãos), sendo a maior parte deles terceirizados pelos contemplados com empréstimos imobiliários. Em outras capitais, em contrapartida, procedeu-se quase que exclusivamente à construção direta, como em São Luís e Teresina, sendo pontuais os financiamentos indiretos para a construção e/ou aquisição de unidades habitacionais por iniciativa dos segurados. Em termos tipológicos, apenas um exemplar coletivo vertical foi identificado nas duas supracitadas capitais nordestinas.

Em João Pessoa, assim como na capital piauiense, a maior parte das ações diretas das CAPs e dos IAPs (por iniciativa própria) no campo habitacional é representada por conjuntos habitacionais de casas unifamiliares, essencialmente térreas, isoladas no lote, com jardim frontal e quintal, seguidas das unidades geminadas duas a duas. Essas moradias seguiam o esquema geral em planta de sala única, cozinha, passagem e variando de dois a três quartos, com dependência de empregada e/ou lavanderia. Esses projetos, não apresentavam equipamentos coletivos, como quadras de esporte, centros sociais, escolas, etc. e geralmente não eram previstos estacionamentos. Situação semelhante foi vislumbrada em Fortaleza, cujo diferencial principal se refere à espacialização da produção pelos órgãos, que se deu mais distante do centro, na atual área metropolitana.

No Recife e em Salvador, em especial, deparou-se com atuações mais impactantes em número de unidades edificadas e/ou financiadas, qualidade construtiva e em se tratando das tipologias habitacionais, a maior parte das vezes coletiva e vertical, com referências à linguagem moderna, se aproximando dos casos percebidos no centro-sul do país. Vale ressaltar que além de comportar o maior número de conjuntos efetivos (dotados de equipamentos), foi também na capital baiana que foram encontrados o maior número de conjuntos de edifícios verticais na pesquisa. Essa produção concentrada também aproxima a atuação das CAPs e dos IAPs, naquela cidade, às realizações evidenciadas e destacadas por publicações do gênero no 
centro-sul do país. Dos 24 empreendimentos identificados nos levantamentos documentais e históricos lá empreendidos, 17 se referiam a exemplares coletivos verticais e apenas 07 a conjuntos unifamiliares.

Outra consequência inesperada da atuação dos referidos institutos de previdência nas sete cidades nordestinas estudadas está relacionada exatamente à verticalização. Descobriu-se que os órgãos previdenciários em questão iniciaram e/ou impulsionaram a verticalização em grande parte das cidades nordestinas. Apesar de não se conformarem a maior parte das realizações no campo habitacional empreendidas pelas CAPs e pelos IAPs ( $23,33 \%$ da produção total), os edifícios e conjuntos coletivos verticais construídos e/ou financiados por aqueles institutos de previdência, além das próprias sedes institucionais dos órgãos, se configuraram como o primeiro ou um dos primeiros prédios altos na maioria das capitais, a citar Salvador, Recife, João Pessoa, Natal, Teresina e São Luís; contribuindo, indubitavelmente, para a intensificação dessa prática na região. Essa tipologia habitacional foi empreendida, sobretudo, por dois Institutos, o IAPB e o IAPC. De modo geral, a atuação do IAPB por meio da edificação de exemplares verticais nas cidades do Nordeste, como observado em São Luís, João Pessoa e Salvador, ocorreu em fins da década de 1950, mais precisamente entre os anos de 1956 e 1958, nos casos observados. A atuação do IAPC, por sua vez, ainda em se tratando de exemplares de moradia coletiva vertical, no Recife e em Natal, se deu anteriormente, a partir de meados da década de 1940, antes que a do IAPB e do IAPI, cujos edifícios de moradia verticais só passaram a serem recorrentes a partir da década de 1960, nas cidades nordestinas estudadas. Ao IPASE foi atribuída a maior parte das sedes administrativas dos escritórios estaduais, como foi o caso de suas sedes em Natal e Teresina, que se configuraram como os primeiros edifícios verticais dessas cidades.

Provavelmente, o pequeno número de edifícios coletivos verticais encontrados nas cidades nordestinas trabalhadas, excetuando Salvador, como já colocado, deveu-se ainda aos estigmas relacionados a essa tipologia habitacional, especialmente em se tratando das noções de moral, higiene e privacidade. Percebe-se que para além dos ditames modernos da construção preconizadas principalmente por Rubens Porto, e mais fortes que eles, estavam as convicções e doutrinamentos cristãos, arraigados à cultura brasileira naquele momento, que acabaram por se tornarem uma das justificativas para a sobressaliência da produção de unidades unifamiliares nessa região do país. Muito do retardamento da construção de edifícios de apartamentos no Nordeste estava também associada à ideia de aglomeração popular promovida nas tipologias habitacionais das classes de renda baixa. Foram ainda encontrados relatos da associação dos blocos de apartamentos aos chamados pardieiros e aos grandes cortiços e mocambos das primeiras décadas do século XX. No geral, era a classe média que rejeitava inicialmente esse "modelo" de moradia.

Outros agravantes foram percebidos, como o medo de tragédias - desmoronamentos e quedas - e vinculados ao próprio porte da edificação, algumas vezes encimados em pilotis, os quais a população acreditava não serem suficientes para comportar o peso da construção. Alguns empreendimentos estavam locados em terrenos íngremes, o que contribuiu ainda mais para aquele temor. Havia ainda ressalvas 
relacionadas à falta de privacidade, à higiene e à limpeza das unidades. $\mathrm{O}$ declarado desaconselho dessa tipologia habitacional para abrigar as famílias numerosas dos trabalhadores no Nordeste, formuladas no âmbito do próprio CNT após a saída de Rubens Porto (na década de 1940, principalmente), também contribuiu para tanto.

Esses aspectos, associados aos elevados custos cobrados tanto para o aluguel quanto para a aquisição dessas unidades habitacionais, também representavam uma forma de "exclusão" das classes menos favorecidas, sendo mais acessível à população mais abastada. Questões relacionadas ao distanciamento de alguns dos conjuntos residenciais coletivos do centro das cidades, como o Conjunto Mondubim de Fortaleza, também auxiliaram para o baixo interesse em empreendimentos dessa envergadura, com muitos gabaritos, no Nordeste. Algumas dessas realizações passaram consideráveis espaços de tempo desocupadas, como foram encontrados casos em Salvador, no Recife e em Fortaleza.

Quando concebidos, foram percebidos blocos com poucas unidades habitacionais por pavimento, mormente, em número de dois. Nos casos em que a quantidade de apartamentos por andar era maior, geralmente 0 acesso às unidades se dava em blocos de circulação vertical independentes (caixas de escada e elevadores), de modo que atendessem ao número de dois apartamentos. Uma das explicações nesse sentido foi exposta pelo delegado do IAPC no Recife, na década de 1940, e referia-se à associação dessas tipologias àquelas largamente empreendidas pelos rentistas no início do século $X X$, nas quais, um significativo número de pessoas era alojado ao longo de extensos corredores, principalmente; configuração repudiada pela classe média nordestina em geral.

No tocante à qualidade dos conjuntos edificados e/ou financiados pelos órgãos em questão, percebeu-se que ao passo que ocorreu a aceleração da construção e da concessão de financiamentos de moradias no país, tanto por parte dos IAPs/CAPs quanto da Fundação da Casa Popular, a partir de meados da década de 1940, houve também uma perda da qualidade projetual e construtiva das unidades e dos próprios conjuntos, bem como uma redução do número dos equipamentos no Nordeste, ao contrário do destacado por Farah (1983) acerca da produção a nível nacional. Observou-se também, uma retomada de modelos e referências habitacionais anteriores ao início da atuação desses órgãos associadas, sobretudo, às vilas operárias e higiênicas do início do século XX. Os projetos mais inovadores tanto de moradias coletivas quanto de unidades unifamiliares ou conjuntos mistos, que marcaram a atuação dos Institutos e Caixas nos primeiros anos, especialmente no centro-sul do país na década de 1940, foram cedendo lugar à padronização e a solidificação de modelos pré-concebidos, independente das condições climáticas locais, do terreno e dos aspectos culturais da região. Essa tendência continuou sendo propagada por órgãos instituídos posteriormente, como o Banco Nacional de Habitações (BNH).

Nesse contexto, a afirmativa que os projetos arquitetônicos e urbanísticos dos conjuntos habitacionais do BNH, com suas COHAB's, CDHU's, dentre outros, foi perdendo qualidade projetual e, como colocado por Bruna (2010, p.246), “(...) perdendo inventividade e acabaram fossilizando-se em algumas fórmulas 
repetitivas e altamente empobrecedoras da cidade (...)" é correta, e se aplica também à produção anterior. A análise e a identificação da produção habitacional das CAPs e dos IAPs no Nordeste do país revelaram que essa fossificação ou estagnação e retrocesso, como se preferir, a que se refere o autor, teve início no âmbito dos próprios Institutos e Caixas de Aposentadoria e Pensões.

O conjunto residencial baiano, Almirante Waldemar Motta (IAPB-1957), se configura como um dos exemplos da precária qualidade projetual e construtiva de alguns dos grupos de residências edificados ou cuja construção foi contratada pelos Institutos e Caixas para a moradia de seus segurados. Parte desse conjunto passou quase um ano desocupada após serem entregues as chaves dos apartamentos, devido aos inúmeros problemas construtivos e de acabamento evidenciados por seus moradores. Esses defeitos referiam-se essencialmente aos serviços de esgotos, de abastecimento d'água e instalações elétricas (caixas d'água com vazamentos, curtos elétricos, problemas na ligação dos fogões ao gás, dentre outros). Também foram encontrados exemplos de solicitações para correção da instalação das esquadrias, portas e janelas, do piso, a instalação de hidrantes para a limpeza das escadas, no caso de edifício de apartamento, e de vazamentos d'água, que comprometiam a pintura e os demais acabamentos das unidades. A repetição de modelos de fachada e planta também foi encontrada nas cidades do Recife, João Pessoa e São Luís.

Muitas vezes, os conjuntos adquiridos e até mesmo aqueles edificados pelas Caixas e Institutos de Aposentadoria e Pensões estudados nesta tese foram implantados em áreas sem infraestrutura de transportes e serviços básicos. A ausência de um controle eficaz para a implantação efetiva de serviços, comércio e lazer quando previstos nos projetos por parte dos corpos técnicos e juntas administrativas desses órgãos e, num segundo plano, pelo próprio poder público em suas instâncias estadual e municipal, colaboraram para tanto. A falta de infraestrutura e serviços observada em grande parte dos conjuntos erigidos pelos referidos institutos de previdência no Nordeste, deram por vezes um aspecto insalubre a diversos daqueles empreendimentos. Esse foi o caso de alguns conjunto edificados pelos órgãos no Recife, a citar o Conjunto Chico City. Dessa forma, apesar de se proporem a edificar unidades habitacionais higiênicas aos trabalhadores urbanos do país, sobremaneira, aqueles órgãos continuaram, em vários casos, a operar como os rentistas proprietários de cortiços, cabeças de porco e mocambos, seguindo sua lógica de mercado e colaborando para o agravamento dos problemas nas cidades, em especial do Nordeste do país.

Outro problema facilmente encontrado nos grupos residenciais edificados na região Nordeste diz respeito a não adaptação dos conjuntos ao automóvel, que também ocorreu no centro-sul do país como assinalado por Bruna (2010). Esse aspecto se mostrou recorrente mesmo depois das décadas de 1950 e de 1960, quando a indústria automobilística no país já estava consolidada. Uma das justificativas encontrada inclusive nos pareceres dos projetos dos conjuntos residenciais, especialmente nos coletivos, recaia sobre 0 fato da população carente, para a qual se destinavam a maior parte das realizações das CAPs e dos IAPs no plano do discurso, não possuir condições de angariar um veículo. A consequência direta dessa adaptação foi atestada no posterior aproveitamento e/ou apropriação dos espaços abertos dos conjuntos, fossem eles 
coletivos, semipúblicos ou até mesmo públicos, para estacionamentos, com 0 intuito de sanar essa deficiência.

Dos 147 (cento e quarenta e sete) grupos residenciais fruto de ações diretas e indiretas por parte dos órgãos em questão, identificados e/ou analisados nesta tese, apenas 52 (cinquenta e dois) previam em projeto esses espaços. Vale salientar, que apesar do número considerável de realizações que apresentavam abrigos para automóveis, a maior parte deles correspondia a vilas ou conjuntos unifamiliares edificados a partir da segunda metade da década de 1950. Dentre os grupos coletivos verticais, os que mais sofriam com esse problema, apenas 10 (dez) dos 28 (vinte e oito) empreendimentos edificados diretamente pelos órgãos previam estacionamento em projeto e foram efetivamente executados. Diante dessa conjuntura, os moradores e, por vezes, a própria administração do conjunto se encarregou de reformar e/ou adaptar os espaços livres para estacionamento. Atualmente, em praticamente todos os grupos onde não foram pensados ou concretizados vagas para veículos (aproximadamente $64 \%$ do total de conjuntos ou edifícios coletivos verticais identificados) houve a apropriação de jardins, praças, passeios de pedestres, pilotis, e vias internas e de acesso para esse fim. Essas adaptações em muito colaboraram para a descaracterização desses conjuntos.

A apropriação de espaços livres nos conjuntos edificados ou financiados pelas CAPs e IAPs no Nordeste não está associada somente a não previsão ou execução de estacionamentos, mas também de outros equipamentos coletivos, como quadras de esportes, praças, parques, refeitórios, lavanderias, ou ainda o não cumprimento das etapas de construção das unidades habitacionais previstas em projeto, dentre outros diversos exemplos, que colaboraram para a apropriação desses espaços para o uso privado. Em se tratando especificadamente dos equipamentos coletivos e de lazer, foram evidenciados apenas 14 (quatorze) grupos de moradias $(9,33 \%$ do total identificado), fossem elas coletivas ou unifamiliares, que apresentavam esses elementos. Esses aspectos também foram os principais responsáveis pela intensificação das ocupações irregulares e invasões das áreas livres e/ou remanescentes desses empreendimentos, como verificado no Recife e Salvador, principalmente.

Vale lembrar que em alguns conjuntos edificados pelos IAPs e CAPs, a dotação de serviços e infraestrutura ficou a cargo do próprio órgão que, por vezes, reservava parcelas do terreno adquirido por compra ou doação, para a abertura de ruas, como foi o caso do Conjunto JK (IAPC-1949), em Salvador. Nele, dos $32.265,91 \mathrm{~m}^{2}$ adquiridos pelo Instituto na Rua Tiradentes (bairro Pilar), 6.732,50 $\mathrm{m}^{2}$ foram reservados para a implantação do conjunto: $3.732,50 \mathrm{~m}^{2}$ para a edificação dos seis blocos que o compunham e os restantes $3.000,00 \mathrm{~m}^{2}$ para o alargamento das vias de acesso ao empreendimento. O restante do terreno de $20.535,41 \mathrm{~m}^{2}$ ficou obsoleto e acabou por se tornar alvo de invasões ${ }^{642}$ - mesmo após a incorporação dessas

642 Essa área adjacente ao Conjunto e às Ruas Eráclito F. de Carvalho, Duarte da Costa e Carneiro da Rocha, foi pouco a pouco sendo indevidamente ocupada por barracos e outras tipologias habitacionais precárias, que culminaram no processo de reintegração de posse, solicitado pelo INPS, na década de 1970, contra aproximadamente 60 ocupantes irregulares. Em meados da Continua na página seguinte. 
áreas ao patrimônio do BNH, em fins da década de 1960. Algumas dessas ocupações começaram a ocorrer já na década de 1950. Outro exemplo de invasão de área remanescente que pode ser citado é o Conjunto Castro Alves (IAPETC-1939), também localizado em Salvador.

A inexistência de instrumentos urbanísticos reguladores adequados à realidade das transformações dos grupos de moradias adquiridos ou edificados pelos IAPs e pelas CAPs também se conformou como um fator que contribuiu, indubitavelmente, para a descaracterização das construções não só no Nordeste, mas também em todo o país. $O$ resultado dessa política foi a construção de conjuntos e grupos residenciais sem arborização, com moradias que não ofereciam, por vezes, um adequado padrão de conforto à população.

A descaracterização observada nos grupos residenciais e, na maioria das vezes, intensificada ao longo dos anos, possuiu outras justificativas. Além da questão da segurança pública, que generalizou o uso de gradis, grades, cercas, muros e outros elementos para a proteção dos condôminos dos conjuntos, alterando as fachadas das edificações, pode-se citar a falta de consciência coletiva dos próprios moradores. 0 posicionamento individualista de alguns dos trabalhadores contemplados com uma unidade habitacional pelo programa habitacional das CAPs e dos IAPs colaborou, sem sombra de dúvidas, para a execução de muitas obras, como: a construção de marquises; coberturas para áreas de serviço ou ampliação da cozinha, se apropriando dos espaços térreos comuns, no caso de edifícios de apartamentos; o fechamento com alvenaria de tijolo de vãos, pilotis, coberturas e até varandas e terraços para se proceder a sublocação desses espaços, ou a sua utilização para outras atividades além de moradia, como comércio, ou simplesmente para ampliar a área construída do imóvel. Esses aspectos são mais facilmente percebidos nos conjuntos verticais e mistos estudados. Dos 35 (trinta e cinco) conjuntos verticais encontrados, edificados direta ou indiretamente, apenas 15 (quinze) não foram alterados por meio de ampliação ou construções posteriores.

É claro que isso também ocorreu após a constatação de problemas estruturais e/ou de natureza emergencial, como foi o caso do Conjunto Brigadeiro Francisco Correia de Melo, o Chico City (IPASE-1964), no Recife. Nesse grupo residencial, desde a ocupação das unidades habitacionais por parte dos segurados contemplados, em fins da década de 1960, foram evidenciados problemas relacionados à distribuição de água nos apartamentos, devido à falta de força e à pequena dimensão dos canos d'água projetados para 0 Conjunto, bem como relacionadas ao saneamento da área, que em épocas de chuvas resultava quase sempre em alagamentos. Diante desse quadro e da ausência de ação no sentido de solucionar o problema por parte do IPASE, os moradores do referido Conjunto se uniram em condomínio e instalaram, por iniciativa própria, uma pequena caixa d'água de fibrocimento acima das janelas das áreas de serviço ou da cozinha dos apartamentos ${ }^{643}$. Esses problemas projetuais também indicam o descaso para com a execução dos

década de 1970 , as ocupações regulares do terreno já tomavam $11.155,00 \mathrm{~m}^{2}$ do terreno, mas ainda havia uma faixa de $9.378,41 \mathrm{~m}^{2}$ que estavam sob a posse de ocupantes irregulares e $8.000,00 \mathrm{~m}^{2}$ do terreno ainda estava livre.

${ }_{643}$ Estrutura montada em madeira e formada por prancha e mãos francesas. Em se tratando das obras de saneamento da área, até Continua na página seguinte. 
projetos dos conjuntos, assim como a perda de qualidade construtiva e arquitetônica desses empreendimentos.

Por vezes, as alterações arquitetônicas procedidas nas fachadas das edificações foram incentivadas e, até mesmo, executadas pela própria administração do conjunto ou síndico de determinado bloco. Nesse sentido, foram observadas obras independentes em um determinado edifício de apartamento ou em parte deles num conjunto. Essas obras podem ser representadas por uma simples pintura, passando pela abertura de janelas, construção de beirais nos edifícios, nas portas de acesso ao bloco ou nas janelas dos apartamentos de alguns pavimentos, como vislumbrado no Conjunto dos Bancários em São Luís, chegando inclusive à apropriação dos tetos-jardins ou telhados, por meio da construção de coberturas, espaços de lazer ou de festas, até a edificação de uma nova unidade habitacional, como no Edifício 18 Andares em João Pessoa.

A própria conversão de espaços comuns em espaços privados, nos conjuntos verticais e mistos principalmente, pelo uso de cercas, grades e até mesmo de alvenaria para a instituição de condomínios independentes também colaboraram para a descaracterização daquelas unidades. Muitas vezes, essas ações resultaram numa diversidade/variações de partidos arquitetônicos de fachadas num mesmo conjunto, que dificultaram inclusive a sua identificação, como foi o caso do Conjunto dos Comerciários, localizado no bairro de Brotas, em Salvador. No qual, há edifícios murados com portões e cercas elétricas e outros sem nenhuma demarcação. Há ainda, prédios onde não se percebe mais a cobertura original e, em outros, 0 número e a disposição das aberturas das janelas foi completamente alterada, mostrando-se difícil distinguir visualmente as etapas de sua construção644.

Outra importante consequência da atuação das CAPs e dos IAPs no Nordeste do país foi o fato que alguns dos seus empreendimentos, especialmente os grandes conjuntos residenciais, induziram e/ou possibilitaram, geralmente por meio de obras de infraestrutura e serviços, 0 adensamento de determinadas áreas nas cidades. Por exemplo, após a implantação do Conjunto do Salvador ou do IAPI (IAPI-1952), como é popularmente conhecido, o bairro soteropolitano de Santo Antônio cresceu consideravelmente e a região onde se encontra o referido empreendimento conforma atualmente um grande bairro da cidade de Salvador, 0 bairro IAPI645.

Em se tratando das questões relacionadas à arquitetura dos grupos residenciais, especificamente, muito se fala na contemporaneidade e na inovação das edificações concebidas pelas Caixas e Institutos de Aposentadoria e Pensões no centro-sul do país, inseridas no contexto de reforma da moradia urbana no país

\footnotetext{
0 ano de 2011 o referido empreendimento sofria com alagamentos nos períodos chuvosos.

644 Aquelas que foram projetadas e executadas pelo IAPC e as subsequentes, edificadas pelo BNH, na década de 1970.

6450 Conjunto do IAPI também se configura como um dos principais exemplos baianos de apropriação irregular das suas áreas remanescentes, que permaneceu ocupada por posseiros até meados da década de 1980. Outro episódio de ocupação dos terrenos dos Institutos conhecido pela população baiana, refere-se ao terreno de $274.212,75 \mathrm{~m}^{2}$ originalmente de propriedade do IPASE, na Avenida Paralela, próximo ao Jockey Clube da Bahia, que foi ocupado por mais de mil posseiros e acabou por resultar numa cena de violência na cidade.
} 
pretendida por diversos setores das elites e, em parte, pelo próprio pode público e pelos órgãos a ele subordinados. Mais detalhadamente, essa tendência é observada na historiografia brasileira que se deteve a estudar a atuação das administrações públicas no campo da moradia social e recai no equívoco de retratar a produção, essencialmente, dos Institutos de Aposentadoria e Pensões como definidora de marco histórico no sentido da instauração ou emprego da arquitetura e urbanismo moderno, como se sua atuação só fosse vinculada a essa vertente arquitetônica e ao seu repertório compositivo/construtivo. A quase totalidade dos exemplos citados nas principais publicações do gênero é retratada daquela forma, dando a impressão ao leigo, de se configurar como uma produção arquitetônica e urbanística homogênea.

Contudo, apesar das investidas oficiais, do corpo técnico do Conselho Nacional do Trabalho e das publicações acima mencionadas, cabe destacar que alguns órgãos, como a CAP da Central do Brasil e da Light, no Rio de Janeiro, e diversos escritórios estaduais dos órgãos distribuídos pela região nordeste do país, continuaram a produzir moradias de viés eclético, bem como retomaram interesses e motivos de arquiteturas anteriores. São observadas, nesse contexto, edificações que remetiam em implantação, em planta e fachada à arquitetura urbana do período colonial, caracterizada por extensas circulações, com solução de cômodos alinhados ao longo de um corredor, adaptando-se ao lote, especialmente quartos interligados situados na região frontal da residência, acrescida de cozinha e sanitário incorporados ao corpo da moradia, nos fundos da casa - graças às inovações como a água encanada, esgotos e sifões -, anexas ao seu corpo principal ou na parte posterior do lote. Além da adaptação às demandas higienistas, com a criação dos recuos laterais que permitem a ventilação e a iluminação natural em todos os cômodos. As fachadas que seguem essa linha projetual são geralmente caracterizadas por porta e janela ou porta e janelas, com acabamento em caiação simples. As construções são cobertas, sobremaneira, com telha colonial.

Outras fazem referência às edificações século XIX, fazendo emprego de frontões triangulares, estuques e referências ao vocabulário clássico, em especial nos coroamentos das construções e em pilares e pilastras. Alguns grupos de moradias financiados e/ou edificados pelo corpo técnico das sessões de engenharia das Carteiras Prediais das CAPs e IAPs no Nordeste tomavam partido da utilização de materiais como o ferro e o vidro, das linhas sinuosas e das formas orgânicas, principalmente nos terraços de entrada e nas fachadas principais de algumas residências, sobretudo, naquelas resultantes de ações indiretas. Referências ao Art Dèco são percebidas por meio do emprego das linhas retas, volumes simples ou pela utilização de peitoris em metal e esquadrias circulares, principalmente. São referências ainda as platibandas escalonadas e caixas de portas e janelas com alguns molduramentos. Foram identificados também casos em que engenheiros e/ou arquitetos conceberam moradias próximas ao Missões, inspirado na arquitetura colonial hispânico-americana difundida pelo cinema hollywoodiano a partir da década de 1930 no Brasil. Essa vertente arquitetônica se caracteriza pela utilização de uma diversidade de materiais, principalmente a pedra - em muros e fachadas - e o ferro - em esquadrias e gradis -, bem como pela utilização do gesso pintado para dar textura às paredes. Essas aproximações são percebidas especialmente no embasamento das moradias, que 
iam, mormente, até o peitoril da janela, nas platibandas que recebiam molduras retas por meio de linhas ou gigantes como eram comumente chamadas e, principalmente, nos terraços em arco pleno com apliques em pedra na fachada, beirais e jardineiras. Essas características são percebidas, sobretudo, nos conjuntos horizontais de moradias unifamiliares tão comuns no Nordeste do país.

A diversidade de referências passa ainda pelo Neocolonial, fazendo inclusive menções aos bangalôs, populares na América do Norte e caracterizados por edificações térreas, com varandas na entrada principal; chegando à já citada sobriedade moderna das linhas retas e volumes simples. Remetendo à linguagem moderna, observaram-se menções principalmente ao teto-jardim. Algumas vezes esse elemento era apenas sugerido por meio da utilização de platibandas obstruindo a visão das empenas das cobertas ou até mesmo pelo emprego de telha canal, reduzindo-se a inclinação do telhado, como percebido em diversas unidades de conjuntos residenciais locados em João Pessoa. Outros elementos foram mesclados em planta e fachada à arquitetura tradicional, como pilares em formatos diferenciados e/ou pilotis e os panos de vidros, associados à sobriedade das fachadas e dos volumes.

Foram nas residências destinadas às camadas mais abastadas e nos prédios de apartamentos que a maior parte desse repertório da arquitetura moderna foi identificada, seguindo a linha de produção da iniciativa privada já observada no centro-sul do país. A propagação dessa arquitetura, por assim dizer, pode ter sido influenciada dentre outros meios de difusão, pelos profissionais envolvidos no processo projetual e construtivo das CAPs e dos IAPs no Nordeste, bem como pela simples imitação ou mimese das residências dos mais abastados que estavam sendo edificadas com financiamentos concedidos ou não por aqueles órgãos.

A tendência da incorporação de elementos modernos em fachada, observada nas realizações indiretas, também foi rebatida nos edifícios e grupos coletivos verticais, construídos e principalmente financiados pelas CAPs e IAPs no Nordeste, sendo nessa categoria encontrados os principais exemplos nesse sentido. Mais precisamente, observou-se que os prédios isolados, estavam mais arraigados aos princípios da arquitetura moderna, sendo assentados sobre pilotis, apresentando teto-jardim, além de outros aspectos e elementos daquele repertório, como a independência da fachada em relação à planta, as varandas e balcões sacados do corpo do edifício, os panos de vidro e/ou de combogós, brises e janelas de canto. Os grupos de edifícios, de modo geral, seguiam o mesmo padrão construtivo, implantados diretamente no chão, mesclando elementos de diversas referências e apresentando baixo gabarito, numa aproximação às proposições de Rubens Porto, apresentadas em seu manual. Porém, em planta, na maior parte das vezes, as realizações coletivas continuaram a operar a sua estruturação por meio de um extenso corredor.

Vale frisar, que não se encara essa incorporação parcial ou pontual como uma simplificação ou uma banalização dos elementos ou da própria arquitetura moderna, como o fazem alguns autores. Acredita-se ser importante encarar essa prática tão comum no Nordeste, como uma adaptação do repertório daquela 
referência, de modo que ela se moldasse ao estilo de vida e aos aspectos físico-climáticos locais, fundindo-se as formas antigas às novas técnicas e elementos modernos.

Em se tratando dos aspectos urbanos, as referências que se mostraram mais recorrentes, estavam associadas, sobremaneira, à "tradição Garden City". Os conjuntos residenciais concebidos sobre essa lógica consistiam em um arranjo diferenciado de organização territorial, especialmente, que implicava em um novo ambiente urbano, com baixa densidade e dotado de grandes espaços verdes, na maior parte das vezes, mesclado aos princípios higienistas e sanitaristas. O Conjunto Lafayete Coutinho, no Recife, e o Conjunto Cidade Nova, em Natal, são alguns exemplos filiados àquele modelo urbano.

A questão da utilização de materiais próprios da região na construção de habitações empreendidas pelas CAPs e pelos IAPs foi colocada e defendida por vários profissionais, com destaque para o engenheiroarquiteto Rubens Porto, no âmbito do CNT ao longo da década de 1930, para o arquiteto Fernando Capurro, participante do IV Congresso Pan-Americano de Arquitetos, em 1930, e para os arquitetos Bruno Simões Magro e José Mariano Filho, no contexto do I Congresso de Habitação, de 1931. No entanto, apenas na cidade de Natal foi identificado um exemplar edificado diretamente pelos supracitados institutos de previdência fazendo uso da taipa: a Vila São Pedro (IAPI-1946). Essa técnica foi especialmente observada nos processos imobiliários indiretos, por iniciativa dos associados, principalmente no que condiz aos empréstimos para reforma de residência.

Sendo assim, a presente tese trouxe a tona um conhecimento mais extensivo da produção arquitetônica e urbanística de órgãos federais fora do eixo Rio de Janeiro e São Paulo, recuperando distintas contribuições profissionais e, consequentemente, recuperando a produção de um número significativo de arquitetos para além dos protagonistas da história atual. Uma produção com valor histórico (produção habitacional nordestina dos anos de 1940), documental (registro da forma de atuação do Estado e dos profissionais subordinados a eles no campo da moradia social), arquitetônico e urbanístico (diferentes filiações e referências construtivas), paisagístico (de destaque na paisagem urbana) e, inclusive, referencial (apregoado à imagem mental da população, se configurando por vezes como marcos estabelecidos), que merecia ser registrado.

Em se tratando da importância posterior das CAPs e dos IAPs não somente no Nordeste, mas também no restante do país, vislumbrou-se que muitas das características e especificidade das suas atuações, principalmente no campo da moradia, foram perpetuadas por diversos outros órgãos federais subsequentes e podem ser facilmente identificadas em programas e ações no campo da moradia social mais recentes. Mais especificadamente, da mesma forma que os referidos órgãos, o Banco Nacional de Habitação (BNH), que entre os anos de 1964 e 1986 financiou cerca de quatro milhões e meio de moradias no país, alocou apenas uma parcela ínfima de seus recursos (13\%) para a promoção de habitações sociais para 
famílias com renda mensal de até cinco salários mínimos ${ }^{646}$. Outros exemplos remetem aos objetivos e à estruturação da Fundação da Casa Popular - FCP - (1946), à falta de qualidade projetual identificada no âmbito das Cohab's (1964), aos modelos de financiamentos promovidos pela Caixa Econômica Federal CEF - (1986), e até mesmo à base do Programa de Arrendamento Residencial - PAR - (1999); aspectos que merecem ser estudados mais profundamente.

Em se tratando da abrangência das ações do Banco Nacional de Habitação, vale ressaltar que um dos aspectos que contribuiu consideravelmente para a extensão e alcance da atuação do BNH no país foi a incorporação dos terrenos de propriedade da União (incluindo parte daqueles de propriedade das CAPs, dos IAPs e de outros órgãos concomitantes, como a FCP) para compor o seu patrimônio, o qual foi utilizado para a edificação dos seus conjuntos habitacionais, sem custo algum para o referido Banco. Esse aspecto também colaborou para que os empreendimentos do BNH apresentassem uma grande quantidade de unidades e extensão. $O$ referido Banco também recebeu investimentos e verbas provenientes de acordos internacionais, contribuindo também para uma maior expressividade de sua atuação no campo habitacional no Brasil.

Também merece ser destacado aqui que o BNH desfrutou de todo o aparato físico (edificações, conjuntos iniciados, dentre outros) e profissional (empregados remanescentes) herdados de algumas das CAPs e dos IAPs, além de seu legado em se tratando de estruturação e das ações imobiliárias (todo 0 caminho foi traçado pelas CAPs, IAPs e pela FCP nesse sentido), restando ao BNH essencialmente adequar esses aspectos aos seus objetivos. Esses se configuram como outros motivos que reforçam a ideia de não ser justa ou coerente à comparação da produção dos IAPs, em conjunto com as CAPs e a FCP, àquela identificada e já largamente estudada pela historiografia imputada ao Banco Nacional de Habitação.

De modo geral, semelhante à atuação dos institutos de previdência no Nordeste de fins da década de 1950, as ações do BNH no campo habitacional brasileiro é caracterizada pela disseminação do modelo de casa própria, situada em grandes conjuntos habitacionais sem infraestrutura e/ou equipamentos coletivos, localizados, na maior parte das vezes, nas periferias das cidades do país. Da mesma forma que os órgãos que o precederam focaram suas ações no campo habitacional, a produção e, consequentemente, a atuação do referido Banco foi sendo comprometida ao longo dos anos, especialmente pelas repetidas crises financeiras que assolaram o país até a década de 1980.

No quadro formulado pela historiografia especializada e por reflexões sobre o assunto, pode-se traçar um panorama da atuação do poder público no campo habitacional do país, mais precisamente, em se tratando da formulação de uma política pública habitacional brasileira. Observou-se que o processo iniciado

646 Apesar do BNH representar o maior alargamento da atuação estatal no que condiz à produção direta de unidades habitacionais pelo poder público no país desde 1930, não chegou a definir uma política habitacional voltada para a população verdadeiramente necessitada, aquela com renda abaixo dos cinco salários mínimos e, principalmente, aquela parcela populacional à margem do mercado formal de trabalho. Outras semelhanças permeiam por entre as solicitações de financiamento e/ou aquisição de moradias via $\mathrm{BNH}$ que se mostraram muito próximas às especificadas nos regulamentos, sobremaneira, dos IAPs do MTIC, bem como por todo o processo de análise e liberação de pleitos imobiliários no ceio daquele Banco. Os cálculos das prestações de amortização de dívida mensais, a serem pagas pelos trabalhadores do país, tanto no âmbito dos institutos de previdência pré-BNH, como no que concerne àquele Banco, baseavam-se nas diretrizes da Tabela Prince. 
na década de 1930 com os Institutos de Aposentadoria e Pensões subordinados ao Ministério do Trabalho, Indústria e Comércio, como imputa as publicações sobre o tema, tido como o embrião da política pública habitacional instituída com a criação do BNH, na verdade, foi iniciada muitos anos antes. As ações do poder público, nesse sentido, efetivadas diretamente ou pelos diversos órgãos de higiene e fundados com 0 propósito de financiar e/ou edificar moradias desde fins do século XIX, atestam essa afirmativa. Iniciando sua intervenção ainda insipiente e timidamente pela outorga de legislação restritiva e/ou punitiva ou mesmo de incentivos fiscais o poder público começou a traçar esse caminho e culminou, na diversificação dos IAPs do MTIC para todas as carteiras trabalhistas do país.

Mais precisamente, o caminho iniciado com a legislação perpassou pela concretização de diversas parcerias público/privadas e, num segundo momento, entre suas distintas instâncias e outros atores sociais, como a Igreja Católica, bancos e agências de fomentos, inclusive internacionais, até culminarem no alargamento da ação estatal no setor habitacional do país, por meio da construção e financiamento de unidades habitacionais destinadas aos trabalhadores com carteira assinada (CAPs/IAPs) e sua ampliação para outros setores sociais, a partir de 1946 com a criação da Fundação da Casa Popular (FCP) e, de forma muito mais incisiva, pelo BNH, em 1964. Órgãos como as mútuas, os montepios, as caixas beneficentes, algumas caixas de socorros privadas, principalmente as de empresas, a Caixa de Pensões da Imprensa Nacional (CAPIN) e o Instituto de Previdência dos Servidores da União foram referências diretas à instituição daqueles órgãos a partir das décadas de 1920 e 1930, como já colocado, e se configuraram como elementos importantes e indispensáveis para a abertura e continuidade desse caminho, paulatino e progressivo, para a instauração da política pública habitacional no país, em meados da década de 1960.

Dessa maneira, acredita-se que tenha havido diversos momentos-chave no que tange a instauração de uma política pública habitacional coesa em nosso país, ao longo de fins do século XIX e no século seguinte. O primeiro deles pode ser obervado ainda na década de 1910, quando o poder público passou a edificar diretamente moradias no Brasil, inclusive por meio da CPIN. O segundo na década de 1920 representado pela consideração do problema habitacional como um problema da alçada estatal, pela intensificação de ações em parcerias público-privadas. Na década de 1930 foram três os momentos, o início da atuação das Caixas de Aposentadoria e Pensões do MTIC no campo habitacional; a instauração e a diversificação dos IAPs do MTIC; e a criação de suas Carteiras Prediais, em 1937. Na década seguinte, a criação da FCP representa o principal momento, compiladas e/ou fundidas no novo plano habitacional da década de 1960.

Sendo assim, o que se procedeu foi uma continuidade das atuações dos órgãos, políticas e programas habitacionais. Vale destacar que isso não se refere à continuidade da existência das instituições e propostas, mas sim, à absorção e à repetição de diversos aspectos, positivos ou não, evidenciados desde as CAPs e os IAPs. Muitos desses aspectos, cabe salientar, comuns àqueles órgãos desde a década de 1930, são percebidos inclusive quanto ao acesso à moradia e às características tipológicas, construtivas e de 
implantação. A questão da inadimplência também se configura como um problema recorrente desde os primeiros anos de 1930, em nosso país.

Assim como as Caixas e Institutos de Aposentadoria e Pensões, a FCP e o BNH em menor escala, também procederam à política mista de aluguel e de aquisição. Sabe-se que no âmbito das Caixas e Institutos do MTIC praticou-se tanto a política de aluguel quanto a política da casa própria. Mais precisamente, procedeu-se o financiamento para a aquisição ou edificação de uma moradia pelos órgãos e 0 aluguel de unidades habitacionais de sua propriedade aos segurados. 0 que não se tinha conhecimento é que essas políticas não foram sequenciadas no período de existência dos órgãos, como colocado por Farah (1983) e Bonduki (2002), nem periodizada como comumente colocado pela historiografia647. Elas ocorreram concomitantemente e sua adoção variou entre as categorias dos Institutos e Caixas e, mais precisamente, de escritório estadual para escritório estadual de cada um dos órgãos no Nordeste. Em João Pessoa, Natal e Fortaleza, por exemplo, evidenciou-se uma sobrepujança da venda de imóveis tanto em se tratando das unidades isoladas, quanto daquelas locadas em grupos de moradias. Em Salvador, Teresina e São Luís, em contrapartida, percebeu-se uma superioridade das ações de aluguel. Por vezes, percebeu-se a coexistência da política de venda no âmbito das unidades isoladas e da política de aluguel para os conjuntos de moradias, como foi constatado no Recife.

Mesmo após a instituição de uma nova política de habitação, representada pelo Plano Nacional de Habitação, no Governo de Fernando Henrique Cardoso (1995-2002), e a criação, dentre outros programas, do PAR (Programa de Arrendamento Residencial), cuja principal característica foi o arrendamento residencial de unidades habitacionais com a opção de compra no final do prazo contratado de 15 anos, com atuação principalmente nas capitais, semelhanças com as CAPs e os IAPs podem ser apontadas. Nesse sentido, diversas publicações que abordam as questões habitacionais pós-BNH, especialmente àquelas que se detém ao estudo do PAR, o consideram como conformador de uma nova política pública habitacional, por mesclar aspectos da política de aluguel e de imóveis, procedendo ao arrendamento das unidades produzidas. No entanto, vale frisar com bastante afinco, que isso já era executado por diversos Institutos de Aposentadoria e Pensões, de modo que os imóveis por eles financiados permaneciam de sua propriedade até o pagamento completo do financiamento pelo segurado. Enquanto pagavam as taxas mensais de amortização da dívida, os pleiteantes também procediam com o pagamento de uma taxa administrativa semelhante à taxa de arrendamento mensal praticada no PAR. A possibilidade de contratação de uma empresa privada para gerir os contratos de arrendamento, assim como, as taxas dos condomínios, também já poderiam ser vislumbradas no âmbito das Caixas e dos Institutos, ou poderiam ser realizados pelos próprios órgãos. Ambos também previam e realizaram políticas baseadas na modernização da legislação que incidia sobre o campo da moradia no país, em se tratando de incentivos fiscais, exigências para se conceber financiamentos, dentre

647 Mormente, coloca-se uma produção concentrada na concepção da casa própria até o ano de 1945, e entre 1945 e 1955 voltada para aluguel e, a partir de então, novamente focada na casa própria. 
outros $^{648}$. Esses aspectos também inclinam para a necessidade de estudos mais aprofundados sobre 0 assunto.

Sendo assim, o que se observou no Brasil foi uma relativa continuidade da política de financiamentos a juros baixos para a habitação social, no plano do discurso, e, na prática, a concessão desses empréstimos essencialmente aos que comprovassem capacidade de pagamento, como também, a continuidade da exclusão de uma grande parcela da população sem condições efetivas de angariar uma moradia no país. Atuando dessa maneira, a administração pública se configurou como uma das mais significativas responsáveis pelo agravamento e acúmulos dos problemas relacionados à moradia da população de baixa renda, com o passar do tempo em nosso país.

Em se tratando dos aspectos tipológicos, observou-se que as unidades seguiram a tendência iniciada pelas CAPs e pelos IAPs, via de regra, na década de 1950, quanto ao baixo padrão arquitetônico e construtivo. Mais precisamente, percebeu-se ao longo desses anos ${ }^{649}$, uma produção habitacional com características de certa forma homogêneas, apesar do incentivo à diversidade tipológica, com predominância dos blocos com quatro pavimentos sem elevadores, nos casos de unidades coletivas, e unidades isoladas, com simplicidade de fachada e cobertura em duas águas, tipo chalezinho650, locadas em conjuntos residenciais de pequeno e médio porte 651 dotados de alguns equipamentos - 0 que não se tornou regra - e implantados de modo fragmentado no espaço urbano. É claro que os programas e políticas instituídas posteriormente às CAPs e aos IAPs inovaram em distintos aspectos, mas, em linhas gerais, a essência da política habitacional daqueles órgãos e sua produção resultante em muito foi mantida652.

Por outro viés, sabe-se que desde as ações estatais das sociais-democracias europeias da década de 1920, a política de aluguel mostra-se uma alternativa viável para minimizar os problemas habitacionais. No Brasil, embora o aluguel tenha feito parte das políticas de habitação no século XX - CAPs, IAPs, FCP, BNH, etc. -, o Estado não promoveu uma política de aluguel consistente, sendo mais voltada para a difusão da propriedade privada. Uma das justificativas para a maior prioridade dada à venda de moradias em detrimento ao mercado de aluguel no Nordeste do país, possivelmente está associada ao fato da mercadoria habitação representar uma forma de investimento rentável, de valorização crescente, via de regra, e também seguro, diante das crises financeiras, essencialmente inflacionárias, tão comuns em nosso país ao longo das décadas de 1930 a 1960, ao ver das entidades e administradores públicos da época; um importante meio de

\footnotetext{
${ }^{648}$ Apesar do PAR inovar no sentido de leis regulamentares quanto ao uso do solo e às questões ambientais, não observadas no âmbito daqueles órgãos, algumas das quais não foram efetivamente consolidadas.

649 Salvo alguns poucos exemplares produzidos pelas CAPs e IAPs concluídos naquela década, que são louvados pela historiografia.

${ }^{650}$ Aspectos percebidos essencialmente na região Nordeste do país.

651 Salvo alguns exemplos concebidos pelo BNH nos anos de sua atuação.

652 Uma das inovações que merecem ser citadas, nesse sentido, diz respeito à diversidade de frentes de atuação do PAR, por exemplo, que previa no plano do discurso além da edificação de moradias, a reforma e a revitalização de edificações localizadas nos centros das cidades, bem como a sua adaptação para uso residencial. Outra distinção refere-se aos fundos para 0 financiamento dessa nova política que foram bem mais diversificadas que os dos IAPs e órgãos seguintes, representada pelo Orçamento Geral da União (OGU), recursos do BID, Fundo de Arrendamento Residencial, além do FGTS (AZEVEDO, 2000).
} 
capitalização da população urbana daquela região do país, no sentido de inseri-la no cenário econômico brasileiro de modo mais ativo. Mais precisamente, naquele momento acreditava-se, de acordo com os documentos oficiais e históricos, que a indústria da construção civil era uma importante acionadora das demais indústrias do país. Talvez por isso, as questões que permearam a construção civil, especialmente relacionada à moradia, tenham recebido tamanha atenção do poder público naquela ocasião. Suprindo, ou melhor, se propondo a atenuar o déficit de moradias urbanas, evidenciado ao longo daqueles anos - crise que vale salientar atingiu inclusive a classe média na década de 1940 -, o Estado atendeu a outros reclames e reivindicações, tanto populares como de setores letrados.

É importante assinalar ainda, que o crédito habitacional no país, por sua vez, também intensificado com as Caixas e Institutos, mostra-se uma estratégia política que já apresentou indícios suficientes de não ser a mais adequada para a situação brasileira, uma vez que a massiva parcela populacional do país, aquela que ganha entre zero a três salários mínimos, não é assistida. Por uma perspectiva diferente, pode-se evidenciar uma contradição no que se trata da intervenção estatal no campo habitacional. Por meio da construção de moradias propriamente dita, conformou-se um setor público de construção de habitações, e se posicionando dessa forma, o poder público criou as condições necessárias para a produção de unidades habitacionais em massa. No entanto, ao fornecer crédito para construção, o Estado ampliou a demanda por moradia para outras camadas mais abastadas que, de certa forma, funcionou como um entrave à expansão das suas atividades sociais. Ampliando a possibilidade de aquisição da mercadoria casa, por meio de crédito, aumentou-se a necessidade de moradias por outros setores da população, ou simplesmente a intenção em adquirir um ou mais de um imóvel. Sendo assim, a partir de 1930, a administração pública passou a combate o déficit habitacional por um lado, aumentando ao mesmo tempo, a demanda por moradia; comprometendo assim, a solução do problema habitacional no país.

Essa seria uma das muitas justificativas para o êxito limitado dos programas e políticas públicas habitacionais do Brasil, pensadas e pretendidas, que em diversos momentos históricos foram adaptadas e/ou modificadas para o atendimento dos anseios das classes média alta e alta, como foi observado no âmbito das Carteiras Prediais dos Institutos e Caixas de Aposentadoria e Pensões. Nelas, os associados ocupantes dos cargos mais altos e aqueles que recebiam os maiores salários foram os que mais solicitaram e receberam concessões e financiamentos para a construção e/ou compra de residência; o que muito provavelmente ocorreu no âmbito de outros programas e órgãos que atuaram no campo da moradia no país. A presente tese também expôs como uma política habitacional caracterizada, sobretudo, por seu caráter social, a partir de pequenas adaptações, pode privilegiar segmentos abastados da sociedade.

Essa certa continuidade de ações e, consequentemente, a perpetuação de erros implantados desde a década de 1930 no campo da habitação social brasileira, tanto no que diz respeito às ações imobiliárias quanto às tipologias adotadas, são aspectos que merecem uma melhor atenção da historiografia especializada, se conformando também como uma possível vertente de análise a ser seguida pela autora. 
Por outro lado, revela-se a necessidade de reavaliar a história da arquitetura moderna brasileira e de sua habitação no período pré-BNH, fundamentando essa revisão em estudos essencialmente baseados em dados primários. 



\section{REFERÊNCIAS}

ABREU, Jayme Cunha da Gama e. Relatório dos sucessos mais importantes verificados no IV Congresso PanAmericano de Arquitetos apresentado ao Exmo. Sr. Dr. governador do estado da Bahia. Bahia: Imprensa Oficial do Estado, 1930.

A CASA = Revista de arquitetura e urbanismo. Rio de Janeiro: década de 1940. Publicação mensal.

ACRÓPOLE = Revista de arquitetura e urbanismo. São Paulo: 1938-1970. Publicação mensal.

A GAIOLA dourada dos Institutos. Orientação Socialista, Rio de Janeiro, n.198, mai. de 1947.

AGUIAR, Jorfeli Vieira. Alienação de imóveis residenciais e não residenciais. Rio de Janeiro: INPS - Instituto Nacional de Previdência Social, 1971.

A JORGENTIL venceu concorrência para a construção dos abrigos públicos. Correio do Ceará, Fortaleza, p.06, 12 de jan. de 1946.

ALBUQUERQUE, Alexandre. Palestra inaugural do I Congresso de Habitação. In: Anais do Primeiro Congresso de Habitação. São Paulo: Instituto de Engenharia, 1931. 1931. p.301-310.

Códigos Municipais. In: Anais do Primeiro Congresso de Habitação. São Paulo: Instituto de Engenharia,

ALMEIDA, Caliane C. Oliveira de. Habitação Social: origens e produção (Natal, 1889-1964). 2007. Dissertação (Mestrado em Arquitetura e Urbanismo) - Escola de Engenharia de São Carlos (EESC), Universidade de São Paulo (USP), São Carlos, 2007.

ALVES, Aluízio. 0 que eu não esqueci: reminiscências políticas (1933-2001). Rio de Janeiro: Leo Cristiano Editorial, 2001.

ALVIM, Ruy Carlos Machado. Uma história crítica da legislação previdenciária Brasileira. Rio de Janeiro: Ministério da Previdência Social, s/d. Relatório Técnico, RDT 18/12.

A NAÇÃO. Rio de Janeiro, s/n, p.01, 11 de abril, 1937.

ANAIS do I Congresso de Habitação. São Paulo: Instituto de Engenharia, 1931.

ANDRADE, Carlos R. M. de. Barry Parker: um arquiteto inglês na cidade de São Paulo. 1998. Tese (Doutorado em Arquitetura e Urbanismo) - Faculdade de Arquitetura e Urbanismo, Universidade de São Paulo, São Paulo, 1998.

. Ressonâncias do tipo cidade-jardim no urbanismo de cidades novas no Brasil. In: Seminário de História da

Cidade e do Urbanismo, 6, 2000, Natal. Anais... Natal: PPGAU, 2000. 1CD.

ANDRADE JÚNIOR, Nivaldo Vieira de; LEAL, João Legal. Arquitetura moderna e reciclagem do patrimônio edificado: a contribuição baiana de Diógenes Rebouças. In: Docomomo Brasil, 7, 2007, Porto Alegre. Anais... Porto Alegre: UFRS, 22 a 24 de out. de 2007.

ANDRADE, Luis Aureliano Gama de; AZEVEDO, Sérgio de. Habitação e poder: da Fundação da Casa Popular ao Banco Nacional da Habitação. Rio de Janeiro: Zahar Editores, 1982. 135p.

ANTONUCCI, Denise; ACKEL, Luiz Gonzaga Montans; SILVA, Taisa Nogueira; SCHWEIGERT, Roberto. Verticalização, habitação social e multifuncionalidade: edifícios dos IAPs em São Paulo. In: Fórum de Pesquisa da FauMackenzie, 3, 2007, São Paulo. Anais... São Paulo: FAU/Mackenzie, 2007. 15p.

A PREVIDÊNCIA social na mensagem do chefe do governo. Revista dos Industriários, Rio de Janeiro, n.02, 12 abri. de 1948.

ARANTES, Otilia F. Do universalismo moderno ao regionalismo pós-crítico - Conferência pronunciada no 10 Congresso Docomomo Brasil. Salvador: junho de 1995. s/p.

ARAÚJO, Rosa Maria Barbosa de. A política social de Vargas e o Ministério de Lindolfo Collor: uma experiência reformista. Rio de Janeiro: Fundação Getúlio Vargas/Centro de Pesquisa e Documentação da História Contemporânea do Brasil, 1979.

A REPÚBLICA, Natal, n.608, p.01, 03 dez. de 1932.

A REPÚBLICA = jornal oficial. Natal: Imprensa estadual, 1890-1964. Publicação diária.

AS CAIXAS e as casas. O Trabalho, Porto Alegre, s/n, p.02, 16 de junho de 1937.

AUGSBURG: da riqueza medieval à prosperidade de hoje. Coleção Cidades e Roteiros, 2004. Disponível em: http://www.dw-world.de/dw/article/0,2144,1239075,00.html. Acesso em: abr/mai.. de 2008.

AYMONINO, C. Origenes y desarrollo de la ciudad moderna. Barcelona: Gustavo Gili, 1973. 232p.

. La vivienda racional. Ponencias de los congressos CIAM 1929-1930. Barcelona: Gustavo Gili, 1973. 
AZEVEDO, Raquel de. A resistência anarquista: uma questão de identidade (1927-1937). São Paulo: Arquivo do Estado/Imprensa Oficial, 2002.

AZEVEDO, Sérgio de. Política de habitação popular e desenvolvimento: dilemas, desafios e perspectivas. In: DINIZ, Eli (org.). Políticas públicas para áreas urbanas: dilemas e alternativas. Rio de Janeiro: ZAHAR, 1982.

BALERA, Wagner. A Seguridade Social na Constituição de 1988. São Paulo: Revista dos Tribunais, 1989.

BANCÁRIO. Boletim do IAPB, Rio de Janeiro, v.6, n.8-9, ago./set. de 1959.

BARBOSA, Antônio Agenor de Melo; MATTOS, Juliana. Entrevista de Marcos Konder. Vitrúvius, n.029.02, 08 de jan. de 2007. Disponível em: http//www.vitruvius.com.br/revistas/read/entrevista/08.029/3297? page=3. Acessado em: jan./fev. de 2012.

BENEVOLLO, Leonardo. Historia de la architectura moderna. Barcelona: Gili, 1974.

As origens da urbanística moderna. 2ed. (Tradução: Conceição Jardim e Eduardo L. de Nogueira). Lisboa: Perspectiva, 1987.

BERMAN, Marshall. Tudo que é sólido se desmancha no ar: a aventura da modernidade. São Paulo: Companhia das Letras, 1987.

BEZERRA, Josué Alencar. A reafirmação de um bairro: um estudo geo-histórico do bairro do Alecrim na cidade de Natal-RN. 2005. Dissertação (Mestrado em Geografia) - Departamento de Geografia, Universidade Federal do Rio Grande do Norte, Natal, 2005.

BLAY, Eva Alterman (org.). A luta pelo espaço: textos de sociologia urbana. Rio de Janeiro: Vozes, 1978, 179p.

BLAY, Eva Alterman. Eu não tenho onde morar: vilas operárias na cidade de São Paulo. São Paulo: Nobel, 1985.

BOLETIM do Ministério do Trabalho, Indústria e Comércio (Rio de Janeiro). O problema da habitação operária, n.35, julho de 1937.

BOLETIM do Ministério do Trabalho, Indústria e Comércio (Rio de Janeiro). 0 problema da habitação operária, n.36, agosto de 1937.

BOLETIM do Ministério do Trabalho, Indústria e Comércio (Rio de Janeiro). O problema da habitação operária, n.44, abril de 1938.

BOLETIM do Ministério do Trabalho, Indústria e Comércio (Rio de Janeiro). O problema da habitação operária, n.45, maio de 1938.

BOLETIM do Ministério do Trabalho, Indústria e Comércio (Rio de Janeiro). O problema da habitação operária, n.30, fevereiro de 1937.

BONATES, Mariana Fialho. Ideologia da casa própria... sem casa própria. O Programa de Arrendamento Residencial na cidade de João Pessoa-PB. 2007. Dissertação (Mestrado em Arquitetura e Urbanismo) - Departamento de Arquitetura e Urbanismo, Universidade Federal do Rio Grande do Norte, Natal, 2007.

BONDUKI, Nabil (org.). Habitat: as práticas bem sucedidas em habitação, no meio ambiente e gestão urbana nas cidades brasileiras. São Paulo: Studio Nobel, 1996.

BONDUKI, Nabil. Vargas, arquitetura moderna e a origem da habitação social no Brasil. In: Seminário de História da Cidade e do Urbanismo (SHCUR), 4, 1996, Rio de Janeiro. Anais... Rio de Janeiro: FAU/UFRJ, 1996. p.980-992.

Origens da habitação social no Brasil: arquitetura, Lei do Inquilinato e difusão da casa própria. São

Paulo: Estação Liberdade: FAPESP, 2002.

BORALHO, José. Como se (re)conhece São Luís? Os vários nomes da cidade e suas representações. Revista Ótima, ano II, n.12, s/p, ago./set. de 2009.

BRASIL. Leis e Decretos federais. Conjunto legislativo sobre habitação publicado no país entre os anos de 1889 e 1969. Levantamento realizado nos anos de 2008 e 2012 em arquivos jurídicos físicos do país.

BRUAND, Yves. Arquitetura Contemporânea no Brasil. São Paulo: Perspectiva, 1981. 400p

BRUNA, Paulo. Os primeiros arquitetos modernos. Habitação Social no Brasil, 1930-1950. 1998. Tese (Livre docência em Arquitetura e Urbanismo) - Faculdade de Arquitetura e Urbanismo, Universidade de São Paulo, São Paulo, 1998.

Os primeiros arquitetos modernos. Habitação Social no Brasil, 1930-1950. São Paulo: EDUSP, 2010.

BUCKINGHAM, James S. National Evils and Practical Remedies. Londres: Peter Jackson \& Co, 1849.

CAMISASSA, Maria Marta dos Santos; et al. Uma análise do impacto da Bauhaus nos projetos residenciais modernos brasileiros. In: Seminário Docomomo Brasil, 8, 2009, Rio de Janeiro. Anais... Rio de Janeiro: UFRJ, set/2009. 
CAMPINHO, Fábio. Sindicalismo de Estado: controle e repressão na Era Vargas (1930-1935). Revista Eletrônica do CEJUR, Paraná, v.1, n.1, ago/dez de 2006. 22p.

CANEDO, Letícia Bicalho. 0 Sindicalismo bancário em São Paulo. São Paulo: Símbolo, 1978.

CANELLAS, Alfredo. Constituição interpretada pelo STF, Tribunais Superiores e textos legais. São Paulo: Freitas Barros, 2005. 1400pg.

CARPINTÉRO, Marisa Varanda Teixeira. A construção de um sonho: "habitação econômica", projetos e discussões (São Paulo, 1917-40). 1990. Dissertação (Mestrado em Arquitetura e Urbanismo) - Departamento de Arquitetura e Urbanismo, Universidade de Campinas, Campinas, 1990.

Imagens do conforto: a casa operária nas primeiras décadas do século XX em São Paulo. In: BRESCIANI, Stella (org.). Imagens da cidade - séculos XIX e XX. São Paulo: Marco Zero/FAPESP, 1993.

CARTA elaborada pelo arquiteto Hugo de Azevêdo Marques, endereçada ao presidente do IAPC, no Rio de Janeiro. Instituto de Aposentadoria dos Comerciários, Recife, 04 de jul. de 1949. 4p.

CARTA elaborada pelo Departamento de Inversões do IAPB, no Rio de Janeiro, endereçada ao delegado do órgão, em Fortaleza. Instituto de Aposentadoria dos Bancários, Fortaleza, 30 de abr. de 1954. 2p.

CARTA elaborada pelos ocupantes do Conjunto Almirante Waldemar Motta, enviada ao presidente do IAPB, no Rio de Janeiro. Instituto de Aposentadoria dos Bancários, Salvador, 22 de abr. de 1959, p.01 e 02.

CARTA elaborada pelo segurado Waltercio Gonçalves da Silva, morador do Conjunto Almirante Waldemar Motta, enviada ao presidente do IAPB, no Rio de Janeiro. Instituto de Aposentadoria dos Bancários, Salvador, 05 de set. de 1963, p.01 e 02.

CARTA endereçada ao Ministro do Trabalho, Indústria e Comércio, Hugo de Araújo Farias, pela comissão de 65 segurados do IAPC-BA para a edificação de moradias. Instituto de Aposentadoria dos Comerciários, Salvador, 07 de abr. de 1954, p.01.

CARTA endereçada ao Ministro do Trabalho, Indústria e Comércio pelo delegado do IAPC-BA. Instituto de Aposentadoria dos Comerciários, Salvador, 28 de mai. de 1955, p.01.

CARVALHO, Flávio de. Uma tese curiosa: a cidade do homem nu. Diário da Noite, Rio de Janeiro, s/p, 01 de julho de 1931.

. Uma concepção da cidade de amanhã. Diário da Noite, Rio de Janeiro, s/p, 17 de março de 1932.

CARVALHO, J. M. de. A formação das almas: o imaginário da república no Brasil. São Paulo: Cia das Letras, 1990.

CASADEI, Salete; GÓIS, Cláudia C. Políticas sociais comparadas (1). Revista Espaço Acadêmico, Maringá-PR, ano VI, n.70, s/p, mar. de 2007. ISSN: 1519-6186

CASAS para o operário. Correio da Manhã, Rio de Janeiro, s/n, p.03, 07 de agosto, 1937.

CASCUDO, Luís da Câmara. História da cidade de Natal. 2 ed. Natal: UFRN, 1980.

. O novo plano da cidade II, a Ribeira no "Master Plan". A República, Natal, n. 252, p. 01, 3 nov. 1929.

. História da Cidade do Natal. Natal: IGH/RN, 1999.

CAVALCANTI, Lauro. Casas para o povo. Rio de Janeiro: Museu Nacional, 1986.

CENSURA estética. A República, Natal, n.358, p.01, 12 jan.1932.

CHALHOUB, Sidney. Cidade febril: cortiços e epidemias na Corte Imperial. São Paulo: Cia das Letras, 1996.

CHAVES, Carolina Marques Chaves. 0 Edifício 18 andares em João Pessoa. João Pessoa: UFPB, 2006. Relatório de Pesquisa.

João Pessoa: verticalização, progresso e modernidade, 1958-1975. 2008. Monografia (Graduação em

Arquitetura e Urbanismo) - Departamento de Arquitetura e Urbanismo, Universidade Federal da Paraíba, João Pessoa, 2008.

CHING, Francis D. K. Dicionário visual da arquitetura. São Paulo: Martins Fontes, 1999.

CHOAY, Françoise. A regra e o modelo. Sobre a teoria da arquitetura e do urbanismo. (Tradução Geraldo Gerson de Souza). São Paulo: Perspectiva, 1985.

. Urbanismo: utopias e realidades. Uma antologia. 3 ed. São Paulo: Perspectiva, 1992.

CLEMENTINO, Maria do Livramento. Economia e urbanização: o Rio Grande do Norte nos anos 70. Natal: EDURN, 1995.

CONGRESSO Internacional de Mutualidade e Previdência Social, 1923. In: Biblioteca Nacional, Código II $231,5,19$, n.3. 
CONSTRUÇÕES clandestinas. Conjuntura Econômica, Rio de Janeiro, s/a, s/n, 04 de dez. de 1950.

CONTRATO de locação de imóvel pertencente ao Conjunto Coqueirinho. Instituto de Aposentadoria e Pensões dos Industriários, Fortaleza, 28 de ago. de 1953.

CORREIA, Telma de Barros. Pedra: plano e cotidiano operário no Sertão. Campinas: Papirus, 1998.

O modernismo e o núcleo febril: o Plano da Cidade Operária da FNM de Attilio Correia Lima. In: Docomomo Brasil, 3, 1999, São Paulo. Anais... São Paulo: USP, dez. de 1999.

O modernismo e o núcleo fabril: o Plano de Attilio Correia Lima para Volta Redonda. Anais do IX Encontro Nacional da ANPUR. Rio de Janeiro, janeiro de 2001.

Estado e empresas na criação e gestão de vilas operárias e núcleos fabris: parcerias, cooperações e conflitos. In: Encontro Nacional da ANPUR, 10, 2003, Belo Horizonte. Anais... Belo Horizonte: UFMG, mai. de 2003. CD-ROM.

A construção do habitat moderno no Brasil - 1870-1950. São Carlos: Rima, 2004.

CRISTIANISMO social. O Diário, Belo Horizonte, s/n, p.04, 01 de ago. de 1937.

CUNHA, Maria Célia G. da. Repercussão do problema da habitação proletária na estabilidade familiar. 1984. Trabalho de Conclusão de Curso (Graduação em Ciências Sociais) - Instituto Social do Rio de Janeiro, Universidade Federal do Rio de Janeiro, Rio de Janeiro, 1948.

CZAJKOWSKI, Jorge (org.). Guia da arquitetura moderna no Rio de Janeiro: arquitetura, engenharia, urbanismo, paisagismo e mobiliário urbano. Rio de Janeiro: Casa da Palavras/Prefeitura do Rio de Janeiro, 2000, 210p.

DANTAS, Garibaldi. O Urbanismo. A República, Natal, n.211, p.01, 17 set. 1929.

DANTAS, George Alexandre Ferreira. Natal "Caes da Europa": o Plano de Sistematização no contexto da modernização da cidade (1920-1930). 1998. Trabalho de Conclusão de Curso (Graduação em Arquitetura e Urbanismo) - Departamento de Arquitetura e Urbanismo, Universidade Federal do Rio Grande do Norte, Natal,1998.

DA SILVA, Américo Pereira. Typo racional de habitação. In: Congresso de Habitação, 1, 1931, São Paulo. Anais... São Paulo: Instituto de Engenharia, 1931. p.149-164.

DEL ROIO, Marcos José. $1^{\circ}$ de Maio - Cem anos de Luta. São Paulo: Global/Oboré, 1986.

A gênese do Partido Comunista (1919-29). p.223-248. In: FERREIRA, Jorge; REIS, Daniel Aarão (orgs.). A formação das tradições, 1889-1945. Coleção As Esquerdas do Brasil. vol.1. Rio de Janeiro: Civilização Brasileira, 2007. 586p.

DOU = Diário Oficial da União. Rio de Janeiro: Imprensa Nacional, 1930-1969. Publicação diária.

DOU - Diário Oficial da União. Seção 01, p.06, 29 de ago. de 1952.

DORIA, Henrique. Sugestões para a solução do problema das casas operárias. In: Congresso de Habitação, 1, 1931,

São Paulo. Anais... São Paulo: Instituto de Engenharia, 1931. p.51-54.

EDIÇÃO comemorativa do $1^{\circ}$ Congresso Pan-Americano de Arquitetos. Acrópole, São Paulo, ano VII, n.81 e 82 , jan/fev de 1945.

EDUARDO, Ítalo. Direito Previdenciário - custeio: teorias e jurisprudência. 2ed. Rio de Janeiro: Editora Ímpetos, 2002.

ENGELS, Friedrich. A situação dos trabalhadores na Inglaterra. Rio de Janeiro: Editorial Presença, 1975.

ENTREVISTA de Almino Monteiro Alvares Affonso, Ministro do Trabalho em 1964. In: GOMES, Angela de Castro (coord.). Ministério do Trabalho: uma história vivida e contada. Rio de Janeiro: CPDOC, 2007.

ESTUDO, planejamento e construção do conjunto residencial da Penha. Revista dos Industriários, Rio de Janeiro, n.18, p.5, jan. de 1951.

EXPOSIÇÃO de plantas para construcções na prefeitura desta capital, hoje às 13 horas. A República, Natal, n.60, p.02, 17 mar.1928.

FALLON, Valère. Princípios da economia social. Rio de Janeiro, 1924.

FARAH, Marta Ferreira. Estado e habitação no Brasil: o caso do Instituto da Previdência. In: Espaço e Debates, n.16, ano V, p.73-82.

Estado, previdência social e habitação. 1983. Dissertação (Mestrado em Ciências Humanas) Faculdade de Filosofia, Letras e Ciências Humanas, Universidade de São Paulo, São Paulo, 1983.

FARIA, Anacleto de $O$. As alterações do contrato de locação de imóveis residenciais urbanos no Direito brasileiro. São Paulo: FEA-USP, 1981.

FAUSTO, Boris. História do Brasil. 12 ed. São Paulo: Edusp, 2007. 
FAVORÁVEL ao sistema atual dos financiamentos imobiliários do IPASE. O Estado de São Paulo, São Paulo, s/n, p.05, 04 de jul. de 1962.

FERNANDES, Rubem César. Privado, porém público: o terceiro setor na América Latina. Rio de Janeiro: Relume Dumará, 1994.

FERREIRA, Angela Lúcia de Araújo. De la producción del espacio urbano a la creación de territorios en la ciudad: un estudio sobre la constituición de lo urbano en Natal, Brasil. 1996. Tese (Doutorado em Geografia) - Universidade de Barcelona, Barcelona, 1996.

FERREIRA, Jorge; REIS, Daniel Aarão (orgs.). A formação das tradições, 1889-1945. Coleção As Esquerdas do Brasil. vol.1. Rio de Janeiro: Civilização Brasileira, 2007. 586p.

FICHER, Sylvia. Arquitetura Moderna Brasileira. São Paulo: Projeto, 1981.

Os arquitetos da Poli: ensino e profissão em São Paulo. São Paulo: Edusp, 2005.

FINANCIAMENTO para construção. O Trabalho, Porto Alegre, s/n, p.02, 29 de maio, 1937.

FONYAT FILHO, José Bina. Veneziana e vidro - a ocorrência. Acrópole, São Paulo, n.251, p.384 e 385, set. de 1959.

FORTY, Adrian; ANDREOLI, Alizabetta. Arquitetura Moderna Brasileira. Nova York: Phaindon Press L., 2004. 239p. FRAMPTON, Kenneth. História Crítica da Arquitetura Moderna. São Paulo: Martins Fontes, 1997.

FREIRE, Adriana Leal de Almeida. Modernização e modernidade: uma leitura sobre a arquitetura moderna de Campina Grande (1940-1970). 2010. Dissertação (Mestrado em Arquitetura e Urbanismo) - Escola de Engenharia de São Carlos, Universidade de São Paulo, São Carlos, 2010.

FREITAS, Maria Luiza. "O lar conveniente": os Engenheiros e Arquitetos e as Inovações Espaciais e Tecnológicas nas Habitações Populares de São Paulo (1916-1931). 2005. Dissertação (Mestrado em Arquitetura e Urbanismo) Escola de Engenharia de São Carlos, Universidade de São Paulo, São Carlos, 2005.

FREYRE, Gilberto. Sobrados e mocambos. São Paulo: Cia Ed. Nacional, 1936.

GAP, Grupo de Arquitetura e Planejamento. Habitação Popular: inventário da ação governamental. São Paulo: Finep/Projeto Editores Associados, 1985.

GOMES, Angela de Castro (coord.). Ministério do Trabalho: uma história vivida e contada. Rio de Janeiro: CPDOC, 2007.

GOMES, Fábio Guedes. Conflito social e Welfare State: Estado e desenvolvimento social no Brasil. Revista de Administração Pública, Rio de Janeiro, v.04, n.02, março/abril, 2006.

GOMES, Gustavo Maia. Velhas secas em novos sertões: continuidade e mudanças na economia do semiárido e dos serrados nordestinos. Brasília: Instituto de Pesquisa Econômica Aplicada (IPEA), 2001. 294p.

GOMES, Paulo César. O espaço na modernidade. São Paulo: AGB/Marco Zero, 1988.

GOMINHO, Zélia de Oliveira. Venezuela Americana x Mucambópoles. 0 Estado Novo na cidade do Recife nas décadas de 30 e 40. Recife: Livro Rápido, 2007.

GOODWIN, Philip L. Brazil Builds: Architecture New and Old (1652-1942). New York: The Museum of Modern Art, 1943.

GORELIK, Adrián. Lo Moderno en Debate: Ciudad, Modernidad, Modernización". Universitas Humanista, Bogotá, n. 56, p. 10-27, 2003.

Das vanguardas a Brasília: cultura urbana e arquitetura na América Latina. Belo Horizonte: UFMG, 2005.

GUERRERO, Inti. A cidade do homem nu: de um "plano diretor antropofágico" a uma exposição: catálogo. São Paulo, 2010, s/p. Catálogo da exposição promovida pelo Museu de Arte Moderna de São Paulo, 15 de abril a 13 de junho de 2010.

GUSMÃO FILHO, Jaime de A. Pelópidas: O Homem E a Obra. Recife: UFPE, 2005.

HABITAÇÃO POPULAR: inventário da ação governamental. Rio de Janeiro: FINEP/GAP, 1985.

HALL, Peter. Cidades do amanhã. (Tradução: Pérola de Carvalho). São Paulo: Companhia das Letras, 1998.

HCURB - Grupo de Pesquisa História da Cidade e Urbanismo. Banco de Imagens (1886-1970). Natal: UFRN, 2008.

HISTÓRIA do Departamento de Estradas e Rodagens. Disponivel em http://www.der.pb.gov.br/index.php?option

=com_content\&view=article\&id=301\&lemid=103. Acessado em: 18 de mar. de 2012.

HISTÓRIA do sindicato dos bancários. Disponível em http://www.spbancarios.com.br/história.asp. Acessado em 26/08/2010. 
HOWARD, E. Cidades-Jardins de amanhã. (Tradução Marco Aurélio Lagonego, Introdução: Dácio A. B. Otoni). São Paulo: Estudos Urbanos, Série Arte e Vida Urbana, Hucitec, 1996.

IAMAMOTO, Marilda. Relações sociais e serviço social no Brasil: esboço de uma interpretação históricometodológica. São Paulo: Cortez / CELATS, 1982.

IAPI. 0 seguro social. A indústria brasileira. 0 Instituto do Industriário. Rio de Janeiro: IAPI, 1950.

INSS-NE. Processos de concessão de financiamentos (1938-1964). Levantamento realizado nos anos de 2008 a 2011. Nordeste: 2008/2011.

INSS-NE. Processos de concessão de financiamentos (1938-1964). Imagens. Levantamento realizado pela autora nos anos de 2008 a 2012. Nordeste: 2008 a 2012.

INSTITUTO BRASILEIRO DE ESTATÍSTICA. Anuário estatístico do Brasil, Ano II, 1936. Rio de Janeiro: Tipografia do Departamento de Estatística e Publicidade, 1936. p.307.

INSTITUTO BRASILEIRO DE GEOGRAFIA E ESTATÍSTICA. Anuário Estatístico do Brasil (1941). Rio de Janeiro, 1941.

de Janeiro, 1990.

Estatísticas históricas do Brasil: séries econômicas demográficas e sociais de 1550 a 1988. 2. Ed. Rio

Estatísticas do Século XX. Rio de Janeiro: Centro de Documentação e Disseminação de Informações, 2006.

INSTITUTO de Aposentadoria e Pensões dos Bancários. C.I.R. 19/64 - Recursos Imobiliários. Fortaleza: IAPB, 1964, p.01.

JR. SCULLY, Vincent. Arquitetura moderna: a arquitetura da democracia. (Tradução: Ana Luiza Dantas Borges). São Paulo: Cosac \& Naify, 2002.

KOPP, Anatole. Quando o moderno não era um estilo e sim uma causa. São Paulo: Nobel, 1991.

KOSTOF, Spiro. A History of Architecture: settings and rituals. New York: Oxford University Press, 1985.

KOURY, Ana Paula; BONDUKI, Nabil; MANOEL, Sálua Kairuz. Análise tipológica da habitação econômica no Brasil (1930-1964). In: Docomomo Brasil, 5, 2005. Anais... CD ROM.

LAMAS, J. M. R. G.. Morfologia urbana e desenho da cidade. Lisboa: Fundação Calouste Gulbenkian, 1992.

LAPOLLI, André. Um resgate da Vila do IAPI: Cidade-Jardim, urbanismo naturalista ou arquitetura ambiente. In: Encontro Nacional da Associação Nacional de Pós-Graduação e Pesquisa em Planejamento Urbano e Regional ANPUR, 11, 2005, Salvador. Anais... Salvador: UFBA, 25 a 27 de mai de 2005. p.01-28.

LAUDOS de avaliação de imóveis. Arquivos dos setores de patrimônio elou engenharia das agências do INSS no NE. INSS: 1930-1969.

LAVRIERI, Maria Beatriz Ferreira; LAVIERI, João Roberto; RABAY, Glória (org.). A questão urbana na Paraíba. João Pessoa: Editora Universitária, 1999.

LE CORBUSIER. A Carta de Atenas. São Paulo: EDUSP, 1942.

Por uma arquitetura. São Paulo: Perspectiva, 1973.

. Urbanismo. São Paulo; Martins Fontes, 1992.

Precisões sobre um estado presente da arquitetura e do urbanismo. Carlos Eugênio Marcondes de Moura (Tradução). São Paulo: Cosac \& Naif, 2004.

LEMOS, Carlos A. C. Cozinhas, etc. São Paulo: Perspectiva, 1978.

Alvenaria burguesa: breve histórico da arquitetura residencial de tijolos em São Paulo a partir do ciclo econômico liderado pelo café. 2 ed. São Paulo: Nobel, 1985.

Casas Proletárias em São Paulo. São Paulo: FAU-USP, 1993.

$264 p$.

Casa Paulista: história das moradias anteriores ao ecletismo trazido pelo café. São Paulo: EDUSP, 1999.

LEPETIT, Bernard. Por uma nova história urbana. São Paulo: EDUSP, 2001.

LIMA, Luiza Maria Medeiros. Modernismo à prestação: traços e linhas da arquitetura nas moradias financiadas pelos IAP's (Natal, décadas de 1940-1960). 2011. Trabalho de Conclusão de Curso (Graduação em Arquitetura e Urbanismo) Departamento de Arquitetura e Urbanismo, Universidade Federal do Rio Grande do Norte, Natal, 2011.

LINDEN, Marcel van der (ed.). Social security mutualism. The comparative history of Mutual Benefit Societies. Bern: Lang, 1996, p. 13-14. 
LIRA, José Tavares Correia de. Mocambo e cidade: habitação popular, urbanismo moderno e utopia vernácula regionalista. Tese de Doutorado em Arquitetura e Urbanismo. São Paulo: FAU-USP, 1996.

Modernidade e economia de morar no Recife (1930-1964). In: SAMPAIO, Ruth Amaral de. A promoção privada de habitação econômica e a Arquitetura Moderna. São Paulo: Rima, 2002.

LOSEKANN, Silvana. 0 casarão da antiga Bolsa de Valores abrigará Caixa Cultural Recife. DEFENDER (Defesa Civil do Patrimônio Histórico) - Organização da sociedade civil para o interesse público. Notícias Nacionais de 21 de nov. de 2009. Disponível em: http://www.defender.org.br/casarao-da-antiga-bolsa-de-valores-abrigara-caixa-culturalrecifel. Acessado em novembro de 2012.

LUCA, Tânia Regina de. 0 sonho do futuro assegurado. O mutualismo em São Paulo. São Paulo: Contexto, 1990.

MACHADO, Roberto. Da (n)ação da norma. Rio de Janeiro: Graal, 1978.

MADEIRA, João Lyra. A aplicação dos fundos nos Institutos e Caixas. Revista dos Industriários, Rio de Janeiro, n.2, abr. de 1948.

de 1951.

Aspectos financeiros do Instituto dos Industriários. Revista dos Industriários, Rio de Janeiro, n.23, out.

MAGRO, Bruno Simões. Habitações econômicas. In: Congresso de Habitação, 1, 1931, São Paulo. Anais... São Paulo: Instituto de Engenharia, 1931, p.55-80.

MALLOY, J. Política de bem-estar social no Brasil: histórico, conceitos, problemas. Revista de Administração Pública, Rio de Janeiro, abr. 1976.

MARICATO, Ermínia. A produção capitalista da casa (e da cidade) no Brasil industrial. São Paulo: Editora Alfa Omega, 1979.

Habitação e cidade. São Paulo: Atual, 1997.

MARQUES, Sonia; NASLAVSKY, Guilah. Estilo ou causa? Como, quando e onde? Os conceitos e limites da historiografia nacional sobre o Movimento Moderno. In: Seminário Docomomo Brasil, 3, 1999, São Paulo. Anais... São Paulo: 1999.

MARTINEZ, Wladimir Novaes. Novas contribuições na seguridade social: entidades de fins filantrópicos. São Paulo: Companhia das Letras, 1997.

MARTINS, Ana Carolina Amaral; SILVA, Helga Santos da; ARAÚJO, Ludmila; SANTOS, Mauro César de Oliveira. As representações sociais das moradias dos IAPI's. In: Congresso Brasileiro e I Ibero-americano de Habitação Social, 2, 2006, Florianópolis. Anais... Florianópolis: UFSC, 14 a 17 de nov. de 2006.

MARTINS, Carlos A. Ferreira (org.). Arquitetura do século XX e outros escritos: Gregori Warchavchik. São Paulo: Cosac Naify, 2006. 200p.

0 fixo e o fluxo: arquitetura na fronteira entre o construído e o sócio-cultural. In: FELDMAN, Sarah; FERNANDES, Ana (orgs.). O urbano e o regional no Brasil contemporâneo. Salvador: EDUFBA/FEUNESP/ANPUR, 2007. p.191-204.

MELLO, Eduardo Kneese de. Centro de debates culturais (exposição). Ribeirão Preto: IAB, 13 nov. 1950.

Memorial descritivo do Edifício da Rua Japurá. São Paulo: FAU-USP, 1990.

MELO, Alexandra Consulin Seabra de. Yes, nós temos arquitetura moderna! Reconstituição e análise da arquitetura residencial moderna em Natal nas décadas de 1950 e 1960, 2004. Dissertação (Mestrado em Arquitetura e Urbanismo) - Departamento de Arquitetura e Urbanismo, Universidade Federal do Rio Grande do Norte, Natal, 2004.

MELO, Marcus André. A cidade dos mocambos: Estado, habitação e lutas sociais no Recife (1920/1960). Espaço e Debates - Revista de estudos regionais e urbanos, São Paulo, ano V, n.14, 1985.

Interesses, atores e ação estratégica na formação de políticas sociais: a não-política da casa popular (1946/1947), Revista de Ciências Sociais, ano 06, n.15. Disponível em http://www.anpocs.org.br/portal/publicacoes/. Acessando em 26 de abril de 2008. Publicação de setembro de 1990.

O Estado, o boom do século e a crise da habitação: Rio de Janeiro e Recife (1937-1946). In: FERNANDES, Ana; GOMES, Marco Aurélio (orgs). Cidade e História. Salvador: Universidade da Bahia, 1992.

MENDONÇA, José Maria Nunes. Evaristo de Morais - militância e política na história da vida, p.199-222. In: FERREIRA, Jorge; REIS, Daniel Aarão (orgs.). A formação das tradições, 1889-1945. Coleção As Esquerdas do Brasil. vol.1. Rio de Janeiro: Civilização Brasileira, 2007. 586p.

MENDONÇA, Marcello Taylor Carneiro de. Casas populares - Cidades Jardins. In: Congresso de Habitação, 1, 1931, São Paulo. Anais... São Paulo: Instituto de Engenharia, 1931. p.139-147. 
MINDLIN, Henrique E. Arquitetura Moderna no Brasil. (Tradução de Paulo Pedreira). Rio de Janeiro: Aeroplano Editora/IPHAN, 2000.

MOOG, Clodomiro Vianna. Lindolfo Collor e a questão social no Brasil, p.19-45. In: ELMANO, Cardim (org.). Posse de Vianna Moog no Instituto Histórico e Geográfico Brasileiro - Discursos. Rio de Janeiro: Gráfica Olímpia Editora, 1978.

n.08, jul. de 1944

Retrato de Lindolfo Collor. Lanterna Verde - Boletim da Sociedade Felipe de Oliveira, Rio de Janeiro, MORAIS, Evaristo de. . O Estado de São Paulo, São Paulo, s/a, n.10, s/p, 10 de nov. de 1990.

MOREIRA, Fernando Diniz (org.). Arquitetura moderna no Norte e Nordeste do Brasil: universalidade e diversidade. Recife: FASA/Docomomo-PE, 2007.

NASCIMENTO, Flávia Brito do. Lar e Família: o discurso assistencialista sobre habitação popular nos anos 40 e 50.

RISCO - Revista de Pesquisa em Arquitetura e Urbanismo do Programa de Pós-Graduação da EESC-USP, São Carlos, ano II, n.03, p.45-59, fevereiro de 2006.

Conjuntos residenciais modernos: valor e preservação. In: Docomomo Brasil, 7, 2007, Porto Alegre. Anais... Porto Alegre: UFRS, 22 a 24 de out. de 2007. 13p.

NASLAVSKY, Guilah. Modernidade arquitetônica no Recife: arte, técnica e arquitetura de 1920 a 1950. 1998. Dissertação (Mestrado em Arquitetura e Urbanismo) - Faculdade de Arquitetura e Urbanismo, Universidade de São Paulo, São Paulo, 1998.

Arquitetura moderna em Pernambuco, 1951-72: as contribuições de Acácio Gil Borsoi e Delfim Fernandes Amorim. 2004. Tese (Doutorado em Arquitetura e Urbanismo) - Faculdade de Arquitetura e Urbanismo, Universidade de São Paulo, São Paulo, 2004.

OBRAS da City. Construcções de architecto Gregori Warchavchik. 0 Estado de São Paulo, São Paulo, 28 de maio de 1931.

O'GRADY, Omar. Os problemas da cidade. A República, Natal, n. 121, p. 01, 01 jul. 1929. Suplemento especial.

O IAPB inicia construção (10 andares) do seu edifício sede. A União, João Pessoa, p.01, 25 de out. de 1957.

OLIVEIRA, Francisco de. Crítica à razão dualista. São Paulo: CEBRAP Brasiliense, 1971.

OLIVEIRA, Francisco Eduardo B. de; BELTRÃO, Kaizô; DAVID, Antônio Carlos de Albuquerque. A dívida da União com a Previdência Social: uma perspectiva histórica. Texto n.638. Rio de Janeiro: IPEA (Instituto de Pesquisa Econômica Aplicada), 1999.

O PAíz, Rio de Janeiro, n.16.681-2, p.04 e 05, 23 e 24 de jun. de 1923.

O PROBLEMA da Habitação Operária. Boletim do Ministério do Trabalho, Indústria e Comércio (Rio de Janeiro). 1937.

O PROBLEMA das casas para operários. Boletim do Departamento Estadual do Trabalho. São Paulo: 1916.

OS CONJUNTOS residenciais de Santo André e Osasco. Acrópole, São Paulo, n.53, set. 1942.

O SEMINÁRIO de habitação e Reforma Urbana (SHRU). Arquitetura - Revista do Instituto de Arquitetura do Brasil, Rio de Janeiro, n.15, setembro de 1963.

OS TRABALHADORES paulistas reagem. O Estado de São Paulo, São Paulo, s/n, 17 de dez. de 1958.

PAIVA, Marlúcia. Igreja e política no RN. Natal: Sebo Vermelho, 2000. 203p.

PALESTRA do arquiteto na ocasião do 40 do CREA-RN. Natal: CREA, 28 de abr. de 2009.

PANSARDI, Marcos Vinícius. Republicanos e operários: os primeiros anos do movimento socialista no Brasil (18891903). 1993. Dissertação (Mestrado em Ciências Políticas) - Universidade de Campinas, Campinas, 1993.

PARA A CONSTRUÇÃO de residências destinadas aos operários. A República, Natal, n.3458, p.01, 25 de jul. de 1942.

PARA que o operário tenha casa própria. A Nação, Rio de Janeiro, s/n, p.01-02, 17 de dezembro de 1938.

PARECER dado pelo engenheiro Carlos Gastão Tassano, da Divisão de Engenharia do IAPC, no Rio de Janeiro, para a edificação do Edifício Capibaribe, no Recife. Instituto de Aposentadoria e Pensões dos Comerciários, Rio de Janeiro, 29 de ago. de 1949. 5p.

PECHMAN, Robert Moses (org.). Olhares sobre a cidade. Rio de Janeiro: Ed. UFRJ, 1994.

PEREIRA, Fúlvio Teixeira de Barros. Difusão da arquitetura moderna na cidade de João Pessoa (1956-1974). 2008. Dissertação (Mestrado em Arquitetura e Urbanismo) - Escola de Engenharia de São Carlos, Universidade de São Paulo, São Carlos, 2008. 
PEREIRA JÚNIOR, Aécio. Evolução histórica da previdência social e os direitos fundamentais. 2007. Dissertação (Mestrado em Direito) - Faculdade de Direito, Universidade de Campinas, Campinas, 2007.

PEREIRA, Marizo Vitor; NOBRE, Paulo José Lisboa; FURUKAVA, Camila; OLIVEIRA, Aquiles Alberto Ramos de Pina. Edifício do IPASE, em Natal/RN: o "mais moderno da cidade", em 1955. In: Seminário Docomomo Brasil, 8, 2009, Rio de Janeiro. Anais... Rio de Janeiro: UFRJ, set de 2009.

PERUZZO, Dilvo. Habitação: controle e espoliação. São Paulo: Cortez Editora, 1984. 133p.

PICCINI, Andrea. Cortiços na cidade: conceito e preconceito na reestruturação do centro urbano de São Paulo. 2ed. São Paulo: Annablume, 2004.

PISTORI, Gerson Lacerda. Direito de greve: origens históricas e sua repercussão no Brasil. Caderno de Doutrina e Jurisprudência da Ematra XV, Campinhas, v.1, n.2, mar./abr. de 2005.

PORTARIA que autorizou o aluguel das unidades do Conjunto Residencial General Euler Bentes Monteiro pelo IPAS. IPASE, Recife, n.100, de out. de 1966.

PORTARIA SCM-192. Especifica as determinações das ações do IAPI. INSS, Natal, 28/11/1939. Processo 879B, p.5. PORTINHO, Carmem Velazcos. Os progressos constantes da aviação. A República, Natal, n. 85, p. 01, 16 abr. 1929.

A participação do RN no $4^{\circ}$ Congresso Pan-Americano de Architectura (em entrevista ao Jornal do Brasil,

RJ). A República, Natal, n.150, p.01, 02 jul. de 1930.

PORTO, Rubens. 0 problema das casas operárias e os Institutos e Caixas de Pensões. In: Semana da Ação Social, 2, 1938, Rio de Janeiro. Rio de Janeiro: Ministério do Trabalho, Indústria e Comércio, 1938.

. O problema da vivenda popular. Arquitetura e Urbanismo, São Paulo, Nov/dez de 1939.

PROBLEMA habitacional e inversões privadas. Conjuntura Econômica, Rio de Janeiro, 18 de mar. de 1964.

RAGO, Margareth. Do cabaré ao lar: a utopia da cidade disciplinar. Brasil 1890-1930. 2ed. Rio de Janeiro: Paz e Terra, 1987.

RESOLUÇÃO do INPS. Instituto Nacional de Previdência Social. n.101-2, de 30 de nov. de 1967.

RESOLUÇÃO do INPS. Instituto Nacional de Previdência Social. n.101-4, de 11 de jan. de 1968.

RESULTADOS de uma administração eficiente. Jornal do Comércio, Rio de Janeiro, s/n, 04 de fev. de 1956.

REVISTA do IDORT = Revista de organização científica. São Paulo: Instituto de Organização Científica do Trabalho, 1937-1945. Publicação mensal.

REVISTA do IAPI = Revista dos Industriários. Rio de Janeiro: IAPI, 1940-1960. Publicação semestral.

RIBEIRO, Luiz César de Queiroz. Dos cortiços aos condomínios fechados: as formas de produção da moradia na cidade do Rio de Janeiro. Rio de Janeiro: Civilização Brasileira, 1997. 358p.

RIBEIRO, Luiz César de Queiroz; AZEVEDO, Sérgio de. A crise da moradia nas grandes cidades: da questão da habitação à reforma urbana. Rio de Janeiro: EDUFRJ, 1997. 283p. p.13-32.

RIBEIRO, Luiz César de Queiroz; PECHAMAN, Robert M.. 0 que é questão da moradia? São Paulo: Brasiliense, 1992.

ROCHA, Mércia Parente. Manifestação da Arquitetura Moderna em João Pessoa. João Pessoa: UFPB, 1987.

RODRIGUES, Leônidas Martins. Conflito industrial e sindical no Brasil. São Paulo: Difusão Européia do Livro, 1966.

ROLNIK, Raquel. História Urbana: História na cidade?. In: FERNANDES, Ana, GOMES, Marco A. de A. F. (orgs). CIDADE \& HISTÓRIA: Modernização das cidades brasileiras nos séculos XIX e XX. Salvador: UFBA, ANPUR, 1992. p. $27-29$.

A cidade e a lei. São Paulo: Nobel, 1997.

RUSSOMANO, Mozart Victor. Curso de Previdência Social. Rio de Janeiro: Forense, 1978.

SÁ, Marcos Moraes. Ornamento e modernismo: a construção de imagens na arquitetura. Rio de Janeiro: Rocco, 2005.

SACHS, Celine. São Paulo: políticas públicas e habitação popular. São Paulo: EDUSP, 1999.

SAMIS, Alexandre. Presenças indômitas: José Oiticica e Domingos Passos. p.89-111. In: FERREIRA, Jorge; REIS, Daniel Aarão (orgs.). A formação das tradições, 1889-1945. Coleção As Esquerdas do Brasil. vol.1. Rio de Janeiro: Civilização Brasileira, 2007. 586p.

SAMPAIO, Maria R. A; LEMOS, Carlos A. C. Casas Proletárias em São Paulo. São Paulo: FAUUSP, 1993. 169p. 
SAMPAIO, Maria Ruth Amaral. A influência da arquitetura moderna em alguns conjuntos habitacionais construídos pelos IAPS em São Paulo. In: Seminário de História da Cidade e do Urbanismo (SHCUR), 4, 1996, Rio de Janeiro. Anais... Rio de Janeiro: FAU/UFRJ, 1996. p.1142-1151.

SAMPAIO, Maria Ruth Amaral (org.). A promoção privada de habitação econômica e a arquitetura moderna. São Paulo: Rima/FAPESP, 2002.

SANTIAGO, Carla Ferretti. O lugar de morar: Estado, Igreja e moradores na produção de habitação popular em Belo Horizonte. 1999. Dissertação (Mestrado em Filosofia) - Faculdade de Filosofia e Ciências Humanas, Universidade Federal de Minas Gerais, Belo Horizonte, 1999.

SANTOS, Mauro; DUARTE, Gabriel; CASTELLOTTI, Flavio. Intervenções habitacionais de grande escala dos Institutos de Aposentadoria e Pensão (IAP's) - uma avaliação pós-ocupação da evolução arquitetônica e urbana dos Conjuntos Habitacionais da Penha e Realengo, Rio de Janeiro. In: Anais do NUTAU, 2002. p.331-340. CD ROM.

SANTOS, Mauro César de Oliveira; BURSZTYN, Ivana; TURA, Luís Fernando; SILVA, Helga Santos da; MARTINS, Ana Carolina Amaral; CORREIA, Ludmila. As representações sociais das moradias dos IAPI's. In: Seminário MatoGrossense de Habitação de Interesse Social, 1, 2005, Cuiabá. Anais... Cuiabá: UFMT, 25 de nov. de 2005. p.59-65.

SCHMIDT, Benedito Bisso. Os partidos socialistas na nascente República. p.131-183. In: FERREIRA, Jorge; REIS, Daniel Aarão. A formação das tradições: 1889-1945. Coleção As Esquerdas do Brasil, n.1. Rio de Janeiro: Civilização Brasileira/CNPq, 2007.

SEGAWA, Hugo. Arquitetura no Brasil: 1900-1990. São Paulo: EDUSP, 2002.

Modernidade pragmática: uma arquitetura dos anos 1920/40 fora dos manuais. Revista Projeto, São Paulo, n.191, p.73-85, 1995.

SEGUEM hoje sobre a presidência do professor Vinicius Londres da Nóbrega. Diário da Borborema. Campina Grande, 02 de jun. de 1960.

SERÁ uma realidade, breve, a casa própria do trabalhador nacional. Diário da Noite, Rio de Janeiro s/n, p.04, 24 de dezembro, 1937.

SILVA JR., Adhemar Lourenço da. As sociedades de socorros mútuos: estratégias privadas e públicas (estudo centrado no Rio Grande do Sul-Brasil, 1854-1949). 2004. Tese (Doutoramento em História) - Faculdade de Filosofia e Ciências Humanas, Universidade Pontifícia Católica, Porto Alegre, 2004.

SMITH, Roberta Lílian Bezerra; FREITAS, Marcelo de Brito Albuquerque Pontes. Estudo para a preservação da arquitetura moderna na cidade do Recife (1930 a 1960). In: Docomomo Norte e Nordeste, 2, 2008, Salvador. Anais... Salvador: Faculdade de Arquitetura da UFBA, 04 a 07 de junho de 2008.

SOLICITAÇÃO de alargamento de financiamento para edificação de moradia no Recife. IAPB, Recife, 16 de set. de 1958.

SOMEKH, Nadia. A cidade vertical e o urbanismo modernizador. São Paulo: EDUSP; Estúdio Nobel; FAPESP, 1997.

SOUZA, Ângela Godilho. Limites do Habitat: segregação e exclusão na configuração urbana contemporânea de Salvador e perspectivas no final do século XX. Salvador: EDUFA, 2000.

SOUZA, Itamar de. As moradias em Natal. Tribuna do Norte, Natal, n.765, p.06, 29/07/1943.

SZÜCS, Carolina Palermo, et al. Vila operária: eficiência de uma tipologia. In: I Congresso de Habitação Social Ciência e Tecnologia, 1, 2003, Florianópolis. Anais... Florianópolis: UFSC, 27 a 29 de ago de 2003.

TEIXEIRA, Fúlvio. Difusão da arquitetura moderna em João Pessoa (1956-1974). 2006. Dissertação (Mestrado em Arquitetura e Urbanismo) - Escola de Engenharia de São Carlos, Universidade de São Paulo, São Carlos, 2006.

TINEM, Nelci. $\mathbf{O}$ alvo do olhar estrangeiro. Brasil na historiografia da arquitetura moderna. João Pessoa: Editora Universitária, 2006.

TINEM, Nelci; TAVARES, Lia; TAVARES, Marieta. Arquitetura moderna em João Pessoa - a memória moderna e local de um movimento internacional. In: Docomomo Brasil, 4, 2005, Rio de Janeiro. Anais... Rio de Janeiro: UFRJ, 2005.

TOLEDO, Edilene. A trajetória anarquista no Brasil na Primeira República. p.55-87. In: FERREIRA, Jorge; REIS, Daniel Aarão (orgs.). A formação das tradições, 1889-1945. Coleção As Esquerdas do Brasil. vol.1. Rio de Janeiro: Civilização Brasileira, 2007. 586p.

TOTTI FILHO, Paschoal. Caixa de Recursos para Inquilinos. In: Congresso de Habitação, 1, 1931, São Paulo. Anais... São Paulo: Instituto de Engenharia, 1931. 
TRAJANO FILHO, Francisco Sales. D.V.O.P.: arquitetura moderna, Estado e modernização (Paraíba, década de 1930), 2003. Dissertação (Mestrado em Arquitetura e Urbanismo) - Escola de Engenharia de São Carlos, Universidade de São Paulo, São Carlos, 2003.

Do rio ao mar: uma leitura da cidade de João Pessoa entre duas margens. In: TINEM, Nelci (org.). Fronteiras, marcos e sinais: leituras das ruas de João Pessoa. João Pessoa: Editora Universitária/Prefeitura Municipal de João Pessoa, 2006.

TRIGUEIRO, Edja; CAPPI, Fernanda; NASCIMENTO, Maísa. Modernismo potiguar: vida, reprodução e quase morte. In: Docomomo Norte-Nordeste, 3, 2010, João Pessoa. Anais... João Pessoa: UFPB, 2010.

UMA VISITA de engenheiros pernambucanos ao Rio Grande do Sul. Recife: Biblioteca Pública Estadual Presidente Castelo Branco, nov. de 1942. 268p.

VALADARES, Licia do Prado. Habitação em questão. Rio de Janeiro: Zahar, 1981.

VARGAS, Getúlio. A nova política do Brasil. Vol. 10. Rio de Janeiro: José Olímpio Editora, 1945.

VARON, Conceição. E a história se repete... as vilas operárias e os conjuntos residenciais dos IAPs no Rio de Janeiro. 1988. Dissertação (Mestrado em Arquitetura e Urbanismo) - Faculdade de Arquitetura e Urbanismo, Universidade de São Paulo, São Paulo, 1988.

VASCONCELOS, Paulo Eduardo Silva de. Habitação social em São Luís do Maranhão: um estudo sobre a produção de habitação dos Institutos de Previdência e do Banco Nacional da Habitação, 2007. Monografia (Graduação em Arquitetura e Urbanismo). São Luís: UEMA, 2007.

Os Institutos de Aposentadorias e Pensões e o Sistema Financeiro de Habitação do Governo Autoritário Peças Chaves da História Social em São Luís. In: Seminário Docomomo Brasil, 8, 2009, Rio de Janeiro. Anais... Rio de Janeiro: UFRJ, set/2009

VAZ, Lílian Fessler. Modernidade e moradia: habitação coletiva no Rio de Janeiro, séculos XIX e XX. Rio de Janeiro: 7Letras, 2002. 180p. p.145 - 172.

VEIGA, A. L. et al. Conjunto IAPI: resgate de imagem e qualidade de vida. In: Anais do ANTAC, SOBRAC, ABREGO, 2004. p.331-339. CD ROM.

VÉLEZ, Ricardo Rodríguez. Lindolfo Collor e a plataforma modernizadora da Aliança Liberal, p.27-47. In: Anais da Semana de Lindolfo Collor, 1, 1988, Belém. Anais... Belém: Tribunal Regional do Trabalho da Oitava Região, 1988.

VENDEM-SE imóveis residenciais. Tratar com a Previdência. 0 Estado de São Paulo, São Paulo, s/n, p.24, 17 de jan. de 1982.

VIANNA, Mônica Peixoto. Núcleos residenciais da CESP: o processo de desmonte. 2006. Dissertação ( Mestrado em Arquitetura e Urbanismo) - Escola de Engenharia de São Carlos, Universidade de São Paulo, São Carlos, 2006.

VIDA social de arquitetura. A República, Natal, n.534, p.04, 31/08/1932.

VISCARDI, Cláudia Maria Ribeiro; JESUS, Ronaldo Pereira. A experiência mutualista e a formação da classe trabalhadora no Brasil. p.21-52. In: FERREIRA, Jorge; REIS, Daniel Aarão. A formação das tradições: 1889-1945. Coleção As Esquerdas do Brasil, n.1. Rio de Janeiro: Civilização Brasileira/CNPq, 2007.

WANDERLEY, Guilherme dos Santos. Que Brasil é este? Manual de indicadores políticos e sociais. Rio de Janeiro: Editora Vértice/UFERJ, 1990.

WARCHAVCHIK, Gregori. Ainda as teorias de Le Corbusier. Correio Paulistano, São Paulo, 14 de set. de 1928. p.79-87. In: MARTINS, Carlos A. Ferreira (org.). Arquitetura do século XX e outros escritos: Gregori Warchavchik. São Paulo: Cosac Naify, 2006. 200p.

Características da construção moderna. Correio Paulistano, São Paulo, 21 de nov. de 1928-b. p.125-132. In: MARTINS, Carlos A. Ferreira (org.). Arquitetura do século XX e outros escritos: Gregori Warchavchik. São Paulo: Cosac Naify, 2006. 200p.

WARCHAVCHIK, Gregori. Importância e diretivas da arquitetura brasileira. Acrópole, São Paulo, fev. de 1958. p.175181 In: MARTINS, Carlos A. Ferreira (org.). Arquitetura do século XX e outros escritos: Gregori Warchavchik. São Paulo: Cosac Naify, 2006. 200p.

WEFFORT, Francisco. Estados e massas no Brasil. Revista Civilização Brasileira, Ano I, n.07, p.135-159, mai. de 1966.

XAVIER, Roberta Costa. Residências na orla marítima de João Pessoa: um patrimônio moderno. In: Seminário Docomomo Brasil, 8, 2009, Rio de Janeiro. Anais... Rio de Janeiro: UFRJ, set/2009.

ZEVI, Bruno. Storia dell'Architectura Moderna. Torino: G. Einaudi, 1955. 
ANEXO A - Processos Imobiliários Levantados no Nordeste (INSS)

\begin{tabular}{c|c|c} 
CAPITAL NoRdestinA & $\begin{array}{c}\text { No DE PROCESSOS } \\
\text { LEVANTADOS }\end{array}$ & $\begin{array}{c}\text { No DE IMAGENS CAPTADAS } \\
\text { (ARQUIVOS E IN LOCO) }\end{array}$ \\
\hline Salvador (BA) & 300 & 1.003 \\
\hline Recife (PE) & 625 & 2.515 \\
\hline João Pessoa (PB) & 304 & 506 \\
\hline Natal (RN) & 560 & 840 \\
\hline Fortaleza (CE) & 350 & 971 \\
\hline Teresina (PI) & 260 & 532 \\
\hline São Luís (MA) & 196 & 392 \\
\hline Total LeVANTADo & 2.595 & 6.759
\end{tabular}




\section{ANEXO B - Instituições visitadas e documentos levantados (no país).}

\begin{tabular}{|c|c|c|}
\hline Instituições & Cidade & Material Pesquisado \\
\hline Biblioteca Nacional & $\begin{array}{l}\text { Rio de } \\
\text { Janeiro/RJ }\end{array}$ & $\begin{array}{c}\text { Bibliografia da pesquisa. } \\
\text { Periódicos locais raros (O Operário). } \\
\text { Resoluções Nacionais. } \\
\text { Revistas (O Observador Econômico). }\end{array}$ \\
\hline $\begin{array}{c}\text { Biblioteca da Escola de } \\
\text { Engenharia de São Carlos- } \\
\text { USP }\end{array}$ & São Carlos/SP & $\begin{array}{c}\text { Bibliografia da pesquisa. } \\
\text { Bibliografia específica das disciplinas. } \\
\text { Dissertações e Teses sobre habitação. }\end{array}$ \\
\hline $\begin{array}{l}\text { Biblioteca da Escola } \\
\text { Politécnica da USP }\end{array}$ & São Paulo/SP & $\begin{array}{l}\text { Bibliografia da pesquisa. } \\
\text { Bibliografia específica das disciplinas. } \\
\text { Dissertações e Teses sobre habitação. }\end{array}$ \\
\hline $\begin{array}{c}\text { Biblioteca da Faculdade de } \\
\text { Arquitetura de São Paulo } \\
\text { (FAU-USP) } \\
\end{array}$ & São Paulo/SP & $\begin{array}{c}\text { Bibliografia da pesquisa. } \\
\text { Bibliografia específica das disciplinas. } \\
\text { Dissertações e Teses sobre habitação. }\end{array}$ \\
\hline $\begin{array}{c}\text { Biblioteca Central da } \\
\text { Universidade Federal de } \\
\text { Brasília } \\
\end{array}$ & Brasília/DF & $\begin{array}{l}\text { Bibliografia da pesquisa. } \\
\text { Dissertações e Teses sobre habitação. }\end{array}$ \\
\hline $\begin{array}{c}\text { Biblioteca Central da } \\
\text { Universidade Federal do Rio } \\
\text { de Janeiro (UFRJ) } \\
\end{array}$ & $\begin{array}{l}\text { Rio de } \\
\text { Janeiro/RJ }\end{array}$ & $\begin{array}{c}\text { Bibliografia da pesquisa. } \\
\text { Bibliografia específica das disciplinas. } \\
\text { Dissertações e Teses sobre habitação. }\end{array}$ \\
\hline $\begin{array}{l}\text { Bibliotecas das } \\
\text { Universidades Federais das } \\
\text { Capitais Nordestinas }\end{array}$ & $\begin{array}{l}\text { UFMA, UFPI, } \\
\text { UFCE, UFRN, } \\
\text { UFPB, UFPE } \\
\text { e UFBA } \\
\end{array}$ & $\begin{array}{l}\text { Bibliografia da pesquisa. } \\
\text { Dissertações e Teses sobre habitação. }\end{array}$ \\
\hline $\begin{array}{l}\text { Biblioteca do Ministério da } \\
\text { Previdência }\end{array}$ & Brasília/DF & $\begin{array}{l}\text { Resoluções Nacionais acerca das ações das } \\
\text { CAPs, dos IAPs e do Conselho e } \\
\text { Departamento Nacional do Trabalho, além de } \\
\text { legislação e documentos relacionados a esses } \\
\text { órgãos. }\end{array}$ \\
\hline $\begin{array}{l}\text { Biblioteca do Ministério do } \\
\text { Trabalho }\end{array}$ & $\begin{array}{l}\text { Brasilia/DF e } \\
\text { Rio de } \\
\text { Janeiro/RJ }\end{array}$ & $\begin{array}{c}\text { Resoluções Nacionais acerca da } \\
\text { construça/financiamento de moradias. } \\
\text { Relatórios de Ações. } \\
\text { Boletins do MTIC. } \\
\text { Legislação. } \\
\end{array}$ \\
\hline $\begin{array}{l}\text { Instituto Nacional de } \\
\text { Seguridade Social }\end{array}$ & $\begin{array}{l}\text { Rio de } \\
\text { Janeiro/RJ }\end{array}$ & $\begin{array}{c}\text { Processos realizados pelos IAPs. } \\
\text { Legislação. } \\
\text { Relatórios de Ações. }\end{array}$ \\
\hline $\begin{array}{l}\text { Biblioteca da Caixa } \\
\text { Econômica Federal }\end{array}$ & $\begin{array}{l}\text { Brasília/DF e } \\
\text { Rio de } \\
\text { Janeiro/RJ }\end{array}$ & Relatórios de Ações dos IAPs. \\
\hline $\begin{array}{l}\text { Arquivo Municipal do Rio de } \\
\text { Janeiro }\end{array}$ & $\begin{array}{c}\text { Rio de } \\
\text { Janeiro/RJ }\end{array}$ & $\begin{array}{l}\text { Periódicos Raros } \\
\text { Legislação. }\end{array}$ \\
\hline Arquivo do Senado Nacional & Brasília/DF & $\begin{array}{c}\text { Legislação } \\
\text { Relatórios de Governo }\end{array}$ \\
\hline $\begin{array}{c}\text { Biblioteca do Palácio da } \\
\text { Justiça e da Câmara dos } \\
\text { Deputados }\end{array}$ & Brasília/DF & $\begin{array}{l}\text { Legislação } \\
\text { Relatórios de Governo }\end{array}$ \\
\hline $\begin{array}{c}\text { Arquivos Imobiliários dos } \\
\text { Escritórios Estaduais do } \\
\text { INSS }\end{array}$ & $\begin{array}{l}\text { MA, PI, CE, } \\
\text { RN, PB, PE e } \\
\text { BA }\end{array}$ & $\begin{array}{c}\text { Processos realizados pelos IAPs. } \\
\text { Legislação. } \\
\text { Relatórios de Ações. } \\
\text { Levantamento Iconográfico }\end{array}$ \\
\hline
\end{tabular}




\section{ANEXO C - Instituições visitadas e documentos levantados (nas capitais).}

\begin{tabular}{|c|c|}
\hline Arquivos Locais & Material Pesquisado \\
\hline $\begin{array}{l}\text { Biblioteca Central Zila Mamede } \\
\text { (Natal-RN) }\end{array}$ & $\begin{array}{c}\text { Bibliografia rara acerca de Natal. } \\
\text { Periódicos Criptografados. } \\
\text { Dissertações e Teses sobre habitação na cidade. }\end{array}$ \\
\hline $\begin{array}{l}\text { Memorial Câmara Cascudo } \\
\text { (Natal-RN) }\end{array}$ & $\begin{array}{l}\text { Publicações do Historiados sobre Natal } \\
\text { (Poesias, resenhas, artigos e livros). } \\
\text { Iconografia sobre o crescimento da cidade. }\end{array}$ \\
\hline $\begin{array}{l}\text { Arquivo Público do Estado do } \\
\text { Rio Grande do Norte }\end{array}$ & $\begin{array}{c}\text { Documentos Oficiais } \\
\text { (Leis, Decretos, Mensagens de Governo, Relatórios } \\
\text { Técnicos e Regulamentos de Higiene). } \\
\text { Periódico A República. }\end{array}$ \\
\hline $\begin{array}{l}\text { Instituto Histórico e Geográfico } \\
\text { do Rio Grande do Norte }\end{array}$ & $\begin{array}{c}\text { Periódicos Locais } \\
\text { (A República, Jornal de Natal, Jornal do Natal, Tribuna } \\
\text { do Norte, O Nortista, O Comerciário, etc.) } \\
\text { Cartas da Intendência Municipal. }\end{array}$ \\
\hline Fundação José Augusto & Iconografia acerca de Natal. \\
\hline Cúria da Catedral & $\begin{array}{l}\text { Jornal A Ordem. } \\
\text { Publicações relacionadas à atuação social da Igreja em } \\
\text { Natal. }\end{array}$ \\
\hline Arquivo da Câmara Municipal & Relatórios, Atas e Cartas da Intendência Municipal. \\
\hline $\begin{array}{l}\text { Arquivo do Setor de Patrimônio } \\
\text { Imobiliário do INSS-RN }\end{array}$ & $\begin{array}{c}\text { Processos de financiamento realizados pelos IAPs nas } \\
\text { décadas de } 1930 \text { a } 1960 \text {, em Natal. } \\
\text { Iconografia sobre a produção das CAPs e dos IAPs. } \\
\text { Mapas e Plantas relacionadas. }\end{array}$ \\
\hline Núcleo Temático da Seca & $\begin{array}{c}\text { Dados estatísticos e históricos sobre as secas } \\
\text { ocorridas no estado do RN. }\end{array}$ \\
\hline $\begin{array}{l}\text { Secretaria do Meio Ambiente e } \\
\text { Urbanismo - SEMURB }\end{array}$ & Mapas e imagens cartográficas de Natal. \\
\hline $\begin{array}{c}\text { Instituto Histórico e Geográfico } \\
\text { da Paraíba } \\
\end{array}$ & $\begin{array}{l}\text { Periódicos Locais } \\
\text { Cartas da Intendência Municipal. }\end{array}$ \\
\hline $\begin{array}{l}\text { Arquivo Público do Estado da } \\
\text { Paraíba }\end{array}$ & $\begin{array}{c}\text { Documentos Oficiais } \\
\text { (Leis, Decretos, Mensagens de Governo, Relatórios } \\
\text { Técnicos e Regulamentos de Higiene). } \\
\text { Periódicos Locais }\end{array}$ \\
\hline $\begin{array}{l}\text { Arquivo do Setor de Patrimônio } \\
\text { Imobiliário do INSS-PB }\end{array}$ & $\begin{array}{l}\text { Processos de financiamento realizados pelos institutos } \\
\text { de previdência nas décadas de } 1930 \text { a 1960, em João } \\
\text { Pessoa. } \\
\text { Iconografia sobre a produção habitacional, mapas e } \\
\text { plantas relacionadas. }\end{array}$ \\
\hline $\begin{array}{l}\text { Secretaria do Meio Ambiente e } \\
\text { Urbanismo - SEMAR-PI }\end{array}$ & Mapas e imagens cartográficas de Teresina. \\
\hline $\begin{array}{l}\text { Instituto Histórico e Geográfico } \\
\text { do Piauí }\end{array}$ & $\begin{array}{c}\text { Periódicos Locais } \\
\text { Cartas da Intendência Municipal. } \\
\end{array}$ \\
\hline $\begin{array}{l}\text { Arquivo do Setor de Patrimônio } \\
\text { Imobiliário do INSS-PI }\end{array}$ & $\begin{array}{c}\text { Processos de financiamento realizados pelos Institutos } \\
\text { e Caixas em Teresina. } \\
\text { Iconografia sobre a produção habitacional, mapas e } \\
\text { plantas relacionadas. }\end{array}$ \\
\hline $\begin{array}{c}\text { Biblioteca Central da } \\
\text { Universidade Federal do Piauí } \\
\text { (UFPI) } \\
\end{array}$ & $\begin{array}{l}\text { Trabalhos e livros acerca do crescimento urbano e da } \\
\text { história de Teresina. }\end{array}$ \\
\hline $\begin{array}{c}\text { Biblioteca Comunitária } \\
\text { Jornalista Carlos Castello } \\
\text { Branco (BCCB) }\end{array}$ & $\begin{array}{l}\text { Trabalhos e livros acerca do crescimento urbano e da } \\
\text { história de Teresina. }\end{array}$ \\
\hline
\end{tabular}




\begin{tabular}{|c|c|}
\hline $\begin{array}{c}\text { Acervo do Grupo de Pesquisa } \\
\text { HABarq (UFPI) }\end{array}$ & Material relacionado à produção arquitetônica do Piauí \\
\hline $\begin{array}{l}\text { Arquivo do Setor de Patrimônio } \\
\text { Imobiliário do INSS-MA }\end{array}$ & $\begin{array}{c}\text { Processos de financiamento realizados pelos IAPs e } \\
\text { CAPs em São Luís e outros municípios do estado. } \\
\text { Iconografia sobre a produção de moradias, mapas e } \\
\text { plantas relacionadas. }\end{array}$ \\
\hline Arquivo Central do INSS-MA & $\begin{array}{l}\text { Processos de financiamento realizados pelos Institutos } \\
\text { e Caixas em São Luís e outros municípios do estado. } \\
\text { Iconografia sobre a produção arquitetônica e } \\
\text { urbanística, bem como mapas e plantas relacionadas. }\end{array}$ \\
\hline $\begin{array}{l}\text { Biblioteca Central da } \\
\text { Universidade Estadual do } \\
\text { Maranhão (UEMA) }\end{array}$ & $\begin{array}{l}\text { Trabalhos e livros acerca do crescimento urbano e da } \\
\text { história da capital maranhense e material relacionado à } \\
\text { produção arquitetônica do estado. }\end{array}$ \\
\hline CDOC do INSS-CE & $\begin{array}{l}\text { Processos de financiamento realizados pelos IAPs e } \\
\text { CAPs em Fortaleza e outros municípios do estado. } \\
\text { Iconografia sobre a produção de unidades } \\
\text { habitacionais, mapas e plantas relacionadas. }\end{array}$ \\
\hline $\begin{array}{c}\text { Biblioteca Central da } \\
\text { Universidade Federal do Ceará } \\
\text { (UFC) }\end{array}$ & $\begin{array}{l}\text { Trabalhos e livros acerca do crescimento urbano e da } \\
\text { história da capital cearense e material relacionado à } \\
\text { produção arquitetônica do estado. }\end{array}$ \\
\hline $\begin{array}{l}\text { Arquivo do Setor de Patrimônio } \\
\text { Imobiliário do INSS-PE }\end{array}$ & $\begin{array}{l}\text { Processos de financiamento realizados pelas CAPs e } \\
\text { IAPs no Recife e outros municípios do estado de } \\
\text { Pernambuco. } \\
\text { Iconografia sobre a produção dos órgãos. } \\
\text { Mapas e Plantas relacionadas. }\end{array}$ \\
\hline $\begin{array}{l}\text { Arquivo Central do INSS-PE } \\
\text { (Bonfim) }\end{array}$ & $\begin{array}{c}\text { Processos de financiamento realizados pelas CAPs e } \\
\text { IAPs e outros municípios do estado de Pernambuco. } \\
\text { Iconografia sobre a produção, mapas e plantas } \\
\text { relacionadas. }\end{array}$ \\
\hline $\begin{array}{l}\text { Biblioteca da Universidade } \\
\text { Federal de Pernambuco (UFPE) }\end{array}$ & $\begin{array}{l}\text { Trabalhos e livros acerca do crescimento urbano e da } \\
\text { história da capital pernambucana e material } \\
\text { relacionado à produção arquitetônica do estado. }\end{array}$ \\
\hline $\begin{array}{l}\text { Arquivo do Setor de Patrimônio } \\
\text { Imobiliário do INSS-BA }\end{array}$ & $\begin{array}{l}\text { Processos de financiamento realizados pelos IAPs e } \\
\text { pelas CAPs em Salvador e outros municípios do estado } \\
\text { da Bahia. } \\
\text { Iconografia sobre a produção dos órgãos. } \\
\text { Mapas e Plantas relacionadas. }\end{array}$ \\
\hline CREA-BA & $\begin{array}{l}\text { Informações sobre a formação e a produção de } \\
\text { engenheiros e arquitetos atuantes entre as décadas de } \\
1930 \text { a } 1960 \text { na cidade de Salvador, principalmente. }\end{array}$ \\
\hline $\begin{array}{c}\text { Biblioteca Central da } \\
\text { Universidade Federal da Bahia } \\
\text { (UFBA) }\end{array}$ & $\begin{array}{l}\text { Trabalhos e livros acerca do crescimento urbano e da } \\
\text { história da capital baiana e material relacionado à } \\
\text { produção arquitetônica do estado. }\end{array}$ \\
\hline
\end{tabular}


ANEXO D - Modelos de fichas para levantamento de documentos oficiais e periódicos.

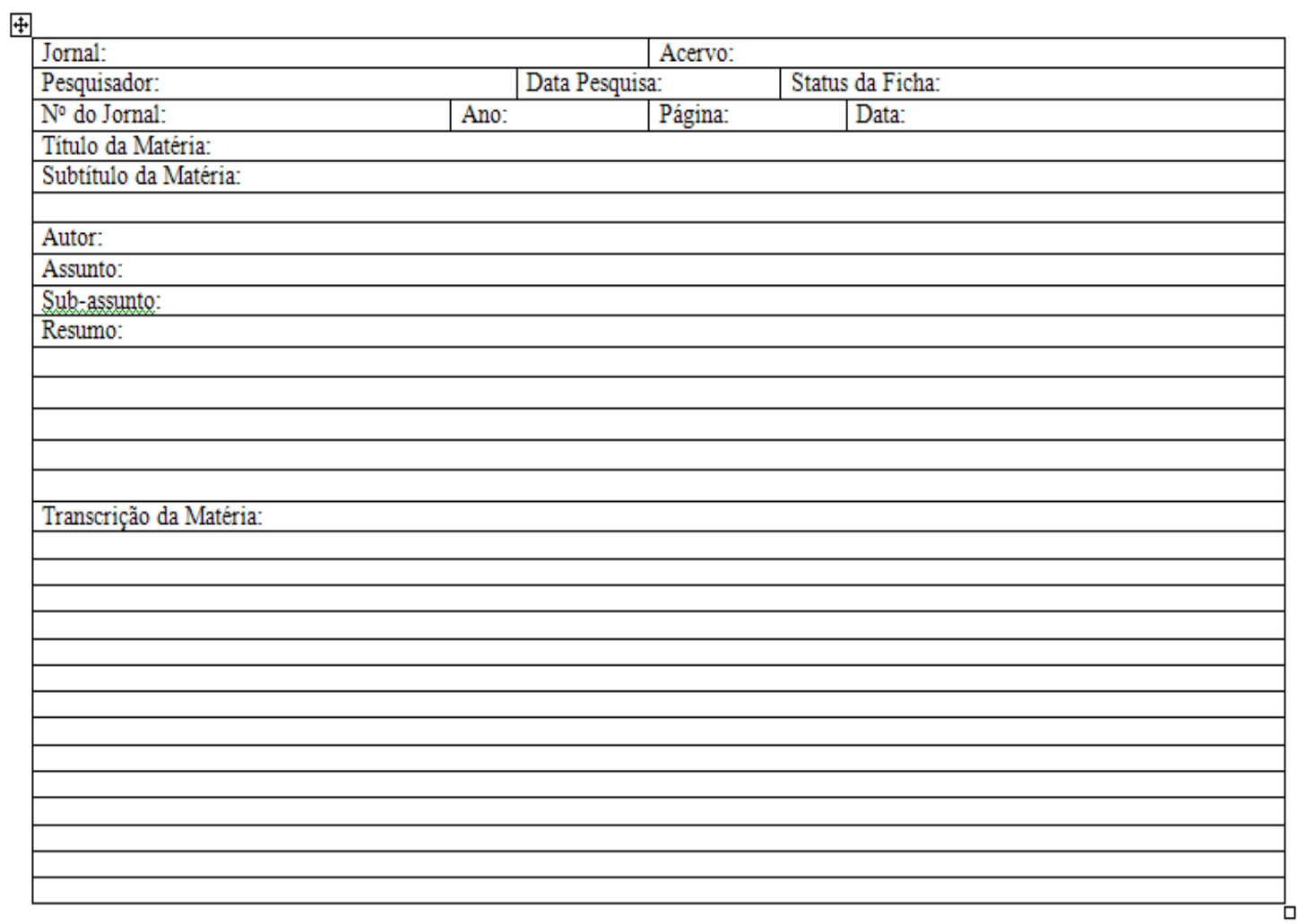

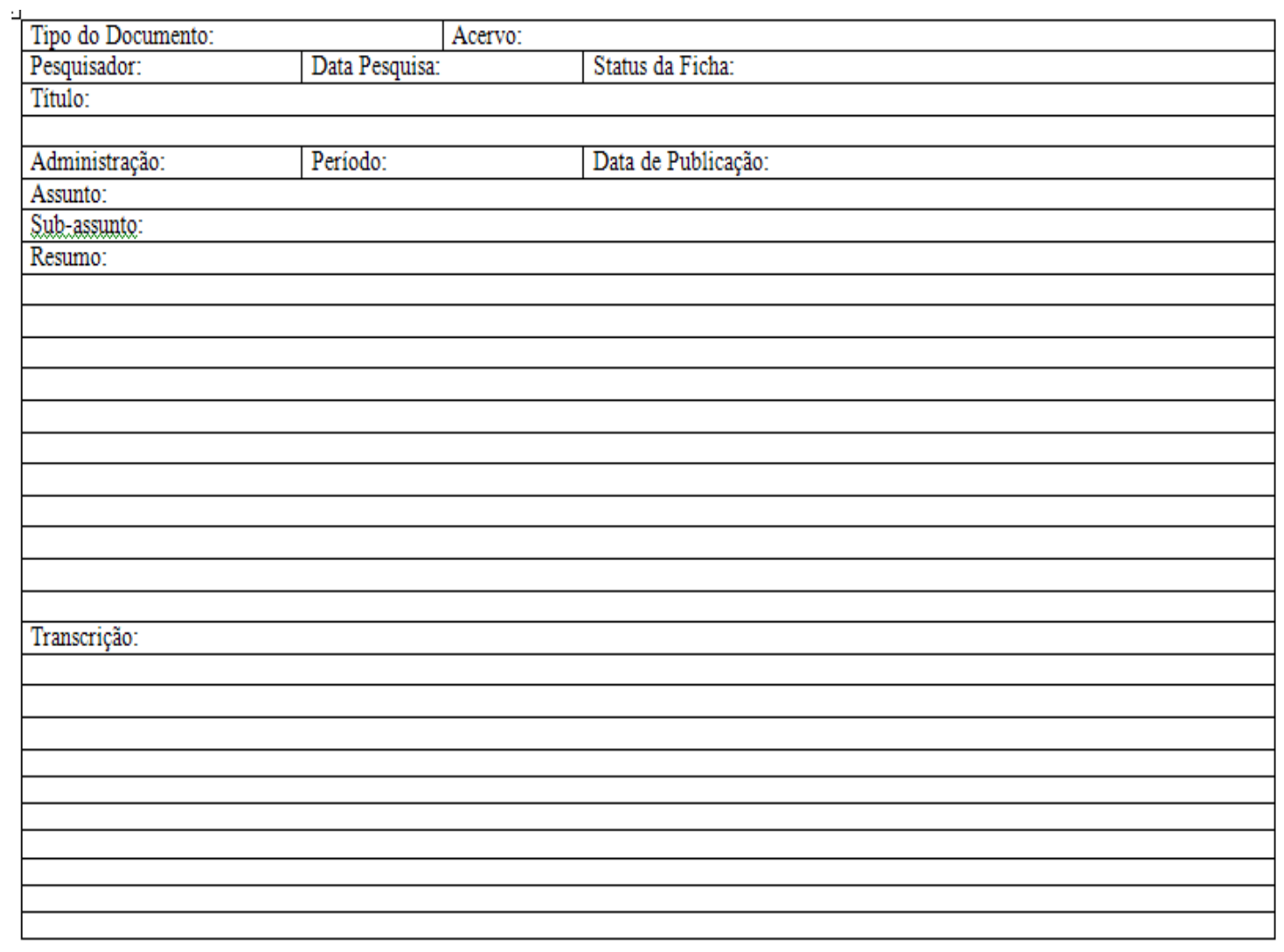


ANEXO E - Modelo de ficha para levantamento dos processos imobiliários nas agências do INSS no Nordeste

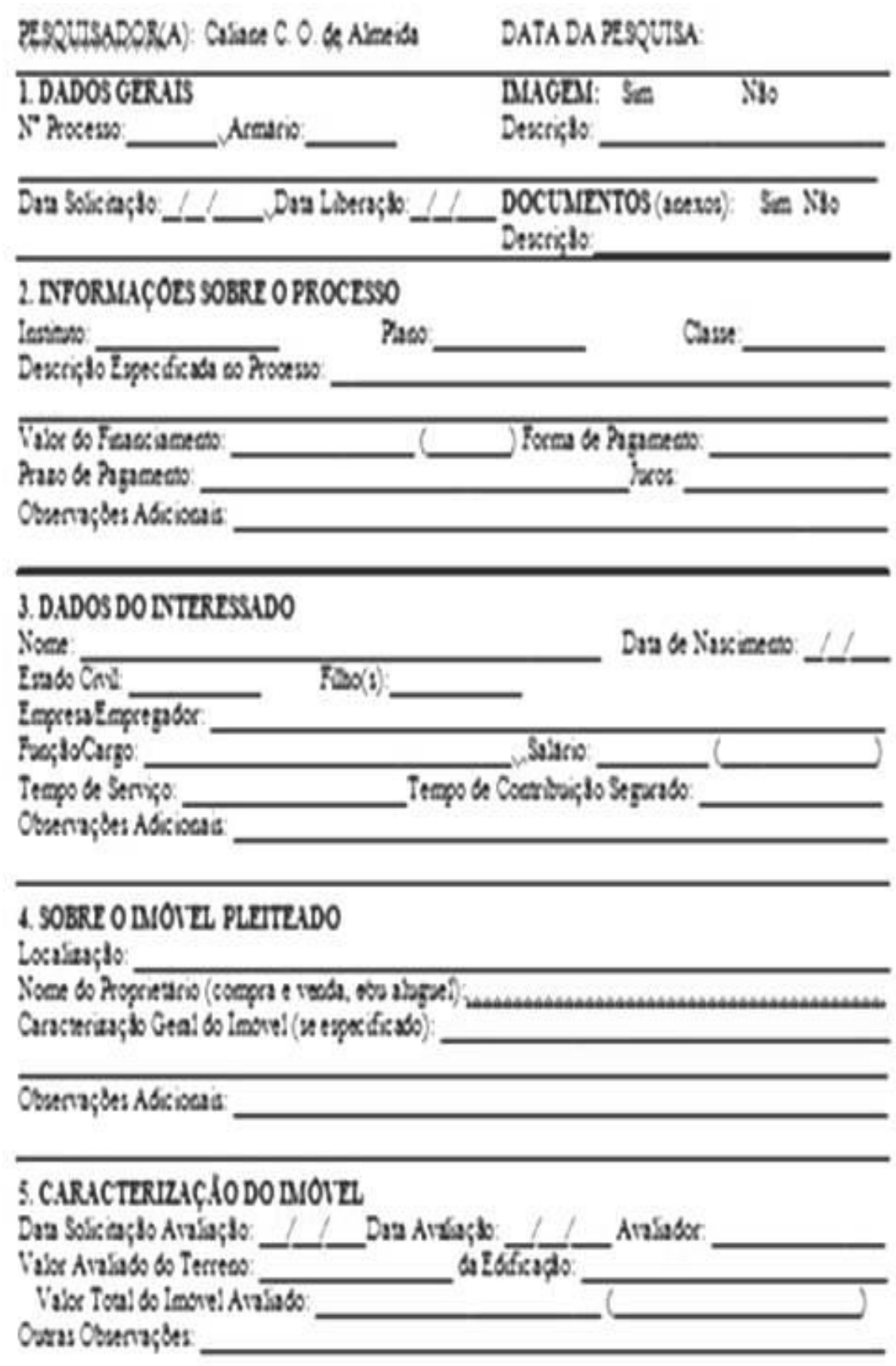


ANEXO F: Print Screen do banco de dados elaborado para o armazenamento dos dados levantados nas agências do INSS no Nordeste.

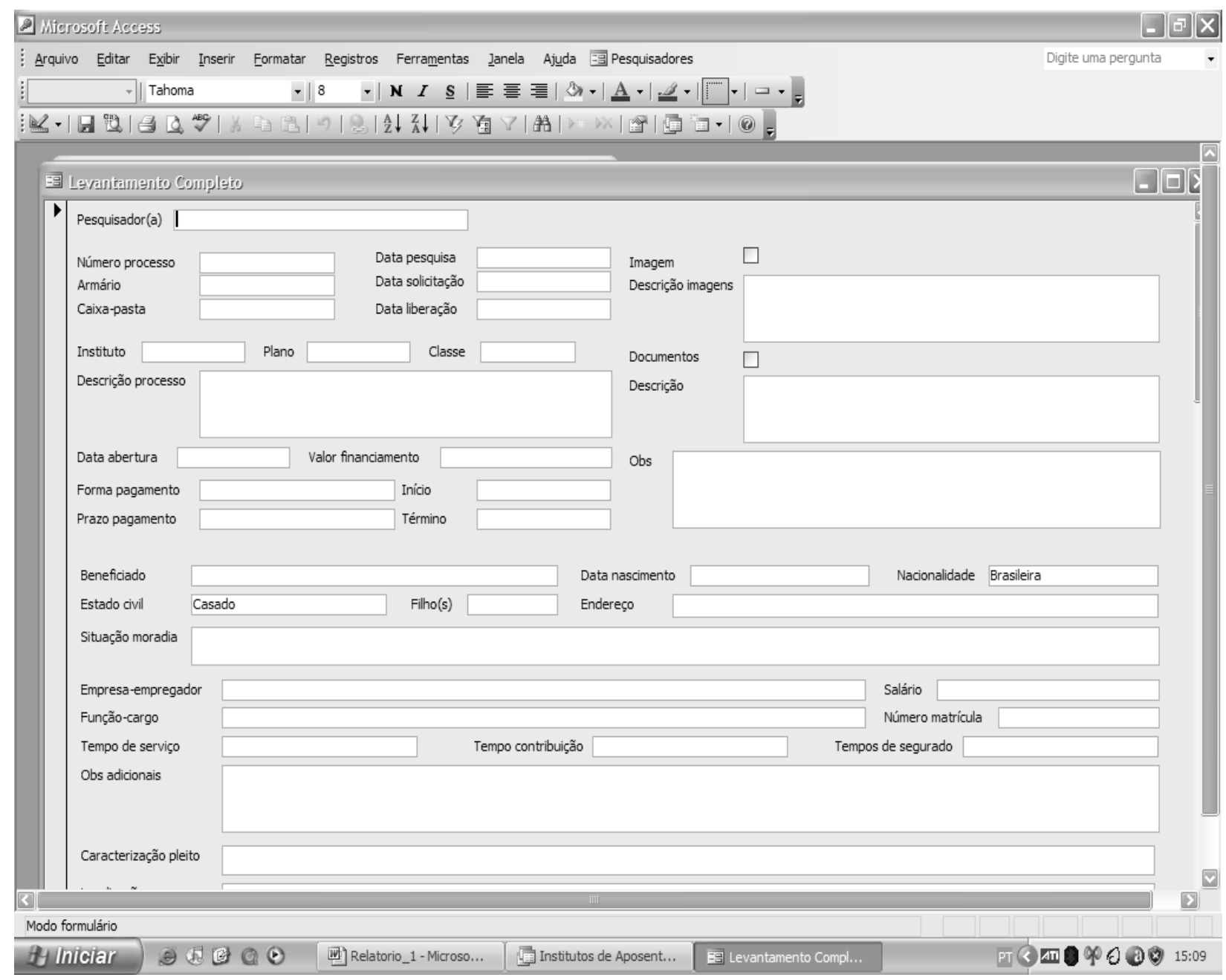




\section{ANEXO G: LISTAGEM COMPLETA DOS PROFISSIONAIS VINCULADOS DIRETA E INDIRETAMENTE COM AS CAPS E OS IAPS NO NORDESTE.}

\begin{tabular}{|c|c|c|c|c|}
\hline \multicolumn{5}{|c|}{ Profissionais vinculados à atuação das CAPs e IAPs no campo habitacional no Nordeste } \\
\hline Ano & Profissional & Cidade & Órgão & Observações \\
\hline $\begin{array}{l}1946 / \\
1951\end{array}$ & $\begin{array}{l}\text { Eng. Aristides Barreto } \\
\text { Neto }\end{array}$ & Fortaleza-CE & $\begin{array}{l}\text { IAPC/CAP } \\
\text { Serv. Púb. CE }\end{array}$ & Avaliação de imóveis isolados \\
\hline $\begin{array}{l}1960 \\
\text { (déc.) }\end{array}$ & Kleber Bezerra & Teresina-PI & IPASE & Avaliação de imóveis isolados \\
\hline $\begin{array}{l}1948 / \\
1953\end{array}$ & $\begin{array}{l}\text { Arq. Hugo de Azevêdo } \\
\text { Marques }\end{array}$ & Recife-PE & IAPC & $\begin{array}{l}\text { Projeto do Edifício Capibaribe (Santo Amaro-1949) e do } \\
\text { Edifício Gilka (Boa Viagem-1953) }\end{array}$ \\
\hline $1949-$ & $\begin{array}{l}\text { Eng. Clovis Eugênio de } \\
\text { Melo }\end{array}$ & Recife-PE & IAPB & $\begin{array}{c}\text { Serviços de levantamento planimétrico e altimétrico do Conj. } \\
\text { João XXII (Jardim São Paulo) }\end{array}$ \\
\hline $\begin{array}{l}1940 / \\
1947\end{array}$ & Eng. Omar O'Grady & Fortaleza-CE & $\begin{array}{l}\text { IAPC/ } \\
\text { IAPB }\end{array}$ & $\begin{array}{c}\text { Projetou residências isoladas para o IAPC e o I Conj. Vila } \\
\text { Aldeota para o IAPB }\end{array}$ \\
\hline $\begin{array}{r}1960 \\
\text { (déc.) }\end{array}$ & Eng. Eduardo Almeida & Teresina-PI & IPASE & Edificou moradias isoladas \\
\hline $\begin{array}{c}1950 \text { e } \\
1960 \\
\text { (déc.) }\end{array}$ & Arq. Ubirajara Galvão & Natal-RN & IPE & Projetou a primeira etapa do Conj. Cidade da Esperança \\
\hline $\begin{array}{l}1952 / \\
1964\end{array}$ & Eng. Moacyr Maia & Natal-RN & $\begin{array}{l}\text { IPASE/IPE/IA } \\
\text { PC }\end{array}$ & $\begin{array}{c}\text { Responsável pelos projetos da segunda etapa do Conj. } \\
\text { Cidade da Esperança (IPE/SUDENE) e do Conjunto Conj. } \\
\text { Nova Tirol (IAPC) }\end{array}$ \\
\hline $\begin{array}{l}1946 / \\
1952\end{array}$ & Eng. Carmelo Ruffo & João Pessoa-PB & IAPI/IAPC & $\begin{array}{c}\text { Construtor civil licenciado. Em } 1946 \text { aparece como } \\
\text { engenheiro contratado do IAPI. Na década seguinte, edificou } \\
\text { unidades habitacionais isoladas por meio do IAPC }\end{array}$ \\
\hline $\begin{array}{l}1953 / \\
1958 \\
\end{array}$ & $\begin{array}{l}\text { Const. Joaquim Pereira } \\
\text { do Nascimento }\end{array}$ & João Pessoa-PB & IPASE/IAPB & Construtor civil licenciado. Edificou moradias isoladas \\
\hline $\begin{array}{l}1945- \\
1965\end{array}$ & $\begin{array}{l}\text { Eng. Olímpio Jader de } \\
\text { Magalhães Melo }\end{array}$ & Recife-PE & IAPC & $\begin{array}{l}\text { Assinou laudos de avaliação dos imóveis do Conj. Lafaiete } \\
\text { Coutinho, em Casa Amarela, e Presidente João Goulart, em } \\
\text { Olinda }\end{array}$ \\
\hline $\begin{array}{l}1948- \\
1963\end{array}$ & $\begin{array}{l}\text { Eng. Wilson de Oliveira } \\
\text { Miranda }\end{array}$ & Natal-RN & $\begin{array}{l}\text { IAPI//APB/ } \\
\text { IPASE }\end{array}$ & $\begin{array}{c}\text { Avaliou a maior parte das unidades a serem edificadas e } \\
\text { financiadas na cidade por distintos órgãos. Era engenheiro } \\
\text { da prefeitura. }\end{array}$ \\
\hline $\begin{array}{l}1948- \\
1963 \\
\end{array}$ & Efrem Lima Filho & Natal-RN & IPASE & Delegado do Instituto \\
\hline $\begin{array}{l}1949- \\
1962\end{array}$ & $\begin{array}{l}\text { Eng. Caetano Francisco } \\
\text { Durões Neto }\end{array}$ & Recife-PE & IAPB & $\begin{array}{l}\text { Engenheiro concursado do Ministério da Aeronáutica, em } \\
\text { 1948. Projetou e construção do Conj. João XXII (Jardim São } \\
\text { Paulo) }\end{array}$ \\
\hline $\begin{array}{l}1949- \\
1959\end{array}$ & $\begin{array}{l}\text { Firma Comterra de } \\
\text { Pernambuco Lida }\end{array}$ & Recife-PE & IAPB & $\begin{array}{l}\text { Responsável pelos serviços de terraplanagem do Conj. João } \\
\text { XXII (Jardim São Paulo) }\end{array}$ \\
\hline $\begin{array}{l}1953- \\
1958\end{array}$ & Eng. Mario de S. Aguiar & Recife-PE & IAPC & $\begin{array}{l}\text { Avaliador das propostas de financiamento/venda de imóveis } \\
\text { do Ed. Capibaribe }\end{array}$ \\
\hline $\begin{array}{l}1949- \\
1951\end{array}$ & $\begin{array}{c}\text { Eng. Sizenando } \\
\text { Carneiro Leão }\end{array}$ & Recife-PE & IAPC & $\begin{array}{l}\text { Execução e fiscalização das obras do Ed. Capibaribe (Santo } \\
\text { Amaro) }\end{array}$ \\
\hline $\begin{array}{l}1947- \\
1949\end{array}$ & $\begin{array}{l}\text { Alvaro Paulo Krucio } \\
\text { Dias }\end{array}$ & Fortaleza-CE & IAPC & Delegado do Instituto \\
\hline $\begin{array}{l}1947- \\
1948\end{array}$ & $\begin{array}{l}\text { Const. Manoel Ribeiro } \\
\text { de Abreu }\end{array}$ & Fortaleza-CE & IAPI & Edificou moradias isoladas \\
\hline $\begin{array}{l}1941- \\
1942\end{array}$ & $\begin{array}{l}\text { Francisco Carlos } \\
\text { Oliveira }\end{array}$ & Fortaleza-CE & $\begin{array}{l}\text { CAP Ser. Púb. } \\
\text { CE }\end{array}$ & - \\
\hline $\begin{array}{l}1940 \\
\text { (déc.) }\end{array}$ & $\begin{array}{l}\text { Raimundo Pereira } \\
\text { Nóbrega }\end{array}$ & Recife-PE & $\mathrm{n} / \mathrm{e}$ & $\begin{array}{l}\text { Desenvolveu projetos isolados para os segurados dos } \\
\text { Institutos no Recife. Grande parte de seus projetos } \\
\text { residenciais possuiam jardins internos em planta }\end{array}$ \\
\hline $\begin{aligned} 1950 \\
\text { (déc.) }\end{aligned}$ & $\begin{array}{l}\text { Antônio Maria de } \\
\text { Figueiredo }\end{array}$ & Recife-PE & $\mathrm{n} / \mathrm{e}$ & $\begin{array}{l}\text { Projetou e construiu casas para associados, na Estrada dos } \\
\text { Remédios, em Afogados. }\end{array}$ \\
\hline $\begin{array}{l}1950 \\
\text { (déc) }\end{array}$ & $\begin{array}{l}\text { Empresa Construtora } \\
\text { Imobiliária Lida }\end{array}$ & Salvador-BA & IAPI e IAPC & Edificou moradias isoladas \\
\hline $\begin{array}{l}1950 \\
\text { (déc.) }\end{array}$ & $\begin{array}{c}\text { Construtora Luiz } \\
\text { Pereira de Araújo Lida }\end{array}$ & Salvador-BA & Variados & Edificou diversas residências isoladas na cidade \\
\hline $\begin{array}{r}1950 \\
\text { (déc.) }\end{array}$ & $\begin{array}{l}\text { Construtora Severino } \\
\text { João da Silva }\end{array}$ & João Pessoa-PB & IAPI & $\begin{array}{c}\text { Contratada pelo IAPI (exclusividade). Responsável pela } \\
\text { execução das obras do Conj. do IAPI na cidade, onde } \\
\text { também edificou unidades isoladas }\end{array}$ \\
\hline $\begin{array}{r}1950 \\
\text { (déc.) }\end{array}$ & $\begin{array}{l}\text { Eng. José Robalinho de } \\
\text { Barros }\end{array}$ & Cabedelo-PB & IAPM & Participou do trâmite da vila dos portuários \\
\hline 1960 & Eng. José Rolderick & João Pessoa-PB & IAPB & Engenheiro da Construtora Carmelo Ruffo (1925-2002). \\
\hline
\end{tabular}




\begin{tabular}{|c|c|c|c|c|}
\hline (déc.) & Leão & & & $\begin{array}{c}\text { Ficou responsável pela execução das obras do Conj. JK e } \\
\text { docente da Escola de Engenharia da Paraíba, quando de } \\
\text { sua criação em } 1956\end{array}$ \\
\hline $\begin{array}{c}1950 \text { e } \\
1960 \\
\text { (déc.) }\end{array}$ & $\begin{array}{l}\text { Construtora Carmelo } \\
\text { Ruffo Lida }\end{array}$ & João Pessoa-PB & IPASE & $\begin{array}{l}\text { Responsáveis pelas obras (por empreitada) de edificação } \\
\text { dos Conjuntos JK e João Goulart, bem como do } 2^{\circ} \text { Bloco de } \\
\text { residências Santa Júlia }\end{array}$ \\
\hline 1938 & $\begin{array}{l}\text { Joaquim Guedes } \\
\text { Martins }\end{array}$ & Rio de Janeiro & $\begin{array}{l}\text { CAP Viação } \\
\text { Férrea } \\
\text { Cearense } \\
\end{array}$ & Presidente da Caixa \\
\hline 1940 & Aristóteles Ferreira & Salvador-BA & IAPB & Avaliação de imóveis isolados \\
\hline 1940 & $\begin{array}{l}\text { Arq. Manoel Junqueira } \\
\text { Bandeira }\end{array}$ & Alagoinha-BA & $\begin{array}{l}\text { CAP Serv. } \\
\text { Públicos da } \\
\text { BA/SE }\end{array}$ & Projetou o Conjunto Graças \\
\hline 1941 & $\begin{array}{l}\text { Arq. Fernando de } \\
\text { Barros Borba }\end{array}$ & Recife-PE & IAPE/IAPETC & $\begin{array}{c}\text { Projeto, construção e posterior levantamento da Vila dos } \\
\text { Estivadores (Santo Amaro) }\end{array}$ \\
\hline 1942 & $\begin{array}{l}\text { Arq. Carlos Frederico } \\
\text { Ferreira }\end{array}$ & Recife-PE & $\mid \mathrm{API}$ & $\begin{array}{c}\text { Carioca. Projetou em parceria com o arq. Hélio Duarte, o } \\
\text { Edifício Inconfidência }\end{array}$ \\
\hline 1942 & Arq. Hélio Duarte & Recife-PE & IAPI & $\begin{array}{c}\text { Carioca. Projetou em parceria com o arq. Carlos Frederico } \\
\text { Ferreira, o Edifício Inconfidência }\end{array}$ \\
\hline 1943 & Joel de Oliveira & Fortaleza-CE & $\begin{array}{l}\text { CAP Serv. } \\
\text { Púb. CE }\end{array}$ & Avaliação de imóveis isolados \\
\hline 1943 & $\begin{array}{l}\text { Augusto Alves dos } \\
\text { Santos }\end{array}$ & Salvador-BA & IAPETC & Avaliação de imóveis isolados \\
\hline 1943 & Eng. Carlos Maciel & Recife-PE & IAPI & Responsável pelo projeto do Conj. Areias (Areias) \\
\hline 1943 & José Abreu Paleta & Rio de Janeiro & IAPFESP & Presidente do Instituto \\
\hline 1944 & Eng. Otávio Tavares & Natal-RN & IPASE & Avaliação de imóveis isolados \\
\hline 1944 & $\begin{array}{l}\text { Eng. João Capristano } \\
\text { da Silva Pontes }\end{array}$ & Recife-PE & IAPC & $\begin{array}{l}\text { Responsável pelo loteamento e pelo projeto, } \\
\text { respectivamente, da Vila Cordeiro ou San Martim }\end{array}$ \\
\hline 1944 & Jarbas Peixoto & Rio de Janeiro & IAPC & Presidente do Instituto \\
\hline 1945 & $\begin{array}{c}\text { Eng. Engenheiro } \\
\text { Vicente Xavier de } \\
\text { Oliveira } \\
\end{array}$ & João Pessoa-PB & IPASE & Avaliação de imóveis isolados \\
\hline 1945 & Arq. Georges Munier & Recife-PE & IAPC & Elaborou o primeiro projeto do Ed. Capibaribe \\
\hline 1945 & $\begin{array}{l}\text { Eng. Gerson Carneiro } \\
\text { Leão }\end{array}$ & Recife-PE & IPASE & $\begin{array}{l}\text { Responsável por projetos e execução de obras residenciais } \\
\text { isoladas }\end{array}$ \\
\hline 1945 & $\begin{array}{l}\text { Eng. Adolfo Campelo } \\
\text { Gentil }\end{array}$ & Recife-PE & IAPC & $\begin{array}{c}\text { Engenheiro chefe da Sociedade Construtora e Comercial } \\
\text { Jogentil Lida, atuou com construção em diversos estados do } \\
\text { país, como no Rio de Janeiro, Salvador, Recife, Natal, } \\
\text { Fortaleza e Belém }\end{array}$ \\
\hline 1945 & $\begin{array}{l}\text { Sociedade Construtora } \\
\text { e Comercial Jogentil } \\
\text { Lida }\end{array}$ & Recife-PE & IAPC & $\begin{array}{l}\text { Responsável pela solicitação de construção do Edifício } \\
\text { Capibaribe. }\end{array}$ \\
\hline 1945 & $\begin{array}{l}\text { Eng. Serafin Rodriguez } \\
\text { Martinez }\end{array}$ & João Pessoa-PB & IPASE & Edificação de unidades isoladas \\
\hline 1946 & $\begin{array}{l}\text { Eng. Geldson da Silva } \\
\text { Pinto }\end{array}$ & Recife-PE & IAPB & $\begin{array}{l}\text { Assinou laudos de avaliação de imóveis do conjunto do IAPB } \\
\text { e em projetos de residências a serem construídas pelos } \\
\text { associados com financiamento do instituto. }\end{array}$ \\
\hline 1946 & $\begin{array}{l}\text { Eng. Francisco Porfício } \\
\text { Sampaio }\end{array}$ & Fortaleza-CE & $\begin{array}{l}\text { CAP Ser. Púb. } \\
\text { CE }\end{array}$ & Engenheiro da Rede de Viação Cearense \\
\hline 1946 & $\begin{array}{l}\text { Eng. Luiz Sabóia de } \\
\text { Albuquerque }\end{array}$ & Fortaleza-CE & IAPC & Avaliação de imóveis isolados \\
\hline 1946 & $\begin{array}{l}\text { Eng. Luiz Marinho de } \\
\text { Andrade }\end{array}$ & Fortaleza-CE & IAPC & Avaliação de imóveis isolados \\
\hline 1946 & $\begin{array}{l}\text { Eng. José Ribeiro da } \\
\text { Silva }\end{array}$ & Natal-RN & IAPI & Avaliação de imóveis isolados \\
\hline 1946 & $\begin{array}{l}\text { Eng. Mario Raposo } \\
\text { Bandeira }\end{array}$ & Natal-RN & IAPI & Avaliação de imóveis isolados \\
\hline 1946 & $\begin{array}{l}\text { Eng. Francisco Porficio } \\
\text { Sampaio }\end{array}$ & Fortaleza-CE & IAPFESP & Eng. da Rede de Viação Cearense \\
\hline 1946 & Virgílio Buffocie & Salvador-BA & $\begin{array}{l}\text { CAP Ser. Pub. } \\
\text { BA e SE }\end{array}$ & Edificou moradias isoladas \\
\hline 1946 & $\begin{array}{l}\text { Eng. Domingos Pereira } \\
\text { do Nascimento }\end{array}$ & Teresina-PI & IPASE & Edificou moradias isoladas \\
\hline 1946 & $\begin{array}{l}\text { Eng. Egeu Mário de } \\
\text { Almeida Gomes }\end{array}$ & Teresina-PI & IAPC & Edificou moradias isoladas \\
\hline 1946 & $\begin{array}{l}\text { Eng. Samoel Antônio } \\
\text { dos Santos }\end{array}$ & Teresina-PI & IAPC & Edificou moradias isoladas \\
\hline 1946 & $\begin{array}{l}\text { Marcio de Almeida } \\
\text { Gomes }\end{array}$ & Teresina-PI & IAPC & Edificou moradias isoladas \\
\hline 1946 & Eng. Luiz Noya Volfson & Natal-RN & IAPB & Edificou moradias isoladas \\
\hline
\end{tabular}




\begin{tabular}{|c|c|c|c|c|}
\hline 1946 & $\begin{array}{l}\text { Const. Antônio Teófilo } \\
\text { Cavalcanti }\end{array}$ & Natal-RN & IAPB & Edificou moradias isoladas \\
\hline 1946 & $\begin{array}{l}\text { Ezequiel Miranda de } \\
\text { Oliveira }\end{array}$ & Rio de Janeiro & IAPC & Presidente do Instituto \\
\hline 1947 & Eng. Arlindo Alves Pinto & Fortaleza-CE & IAPC & Avaliação de imóveis isolados \\
\hline 1947 & $\begin{array}{l}\text { Eng. Antônio Cláudio } \\
\text { Araújo }\end{array}$ & Fortaleza-CE & IAPC & Avaliação de imóveis isolados \\
\hline 1947 & $\begin{array}{l}\text { Eng. Antônio Rodrigues } \\
\text { e Silva } \\
\end{array}$ & Fortaleza e Sobral-CE & IAPC & Avaliação de imóveis isolados \\
\hline 1947 & Eng. Ulysses Almeida & Fortaleza-CE & IAPI & Também projetou e edificou moradias isoladas na cidade \\
\hline 1947 & $\begin{array}{l}\text { Eng. Antônio Ferreira } \\
\text { Antero }\end{array}$ & Fortaleza-CE & IAPC & Avaliação de imóveis isolados \\
\hline 1947 & $\begin{array}{l}\text { Fernando de Almeida } \\
\text { Baggi }\end{array}$ & Salvador-BA & IAPI & Avaliação de imóveis isolados \\
\hline 1947 & $\begin{array}{l}\text { Eng. Almir Aguiar } \\
\text { Guedes }\end{array}$ & São Luís-MA & IPASE & Avaliação de imóveis isolados \\
\hline 1947 & Eng. Rodrigo Lopes & Natal-RN & IAPI & Avaliação de imóveis isolados \\
\hline 1947 & $\begin{array}{l}\text { Eng. L. R Holanda } \\
\text { Cavalcanti }\end{array}$ & Recife-PE & $\begin{array}{l}\text { CAPFESP-PE } \\
\text { e AL }\end{array}$ & $\begin{array}{c}\text { Projetou diversas unidades isoladas para os segurados no } \\
\text { bairro de Tejipó }\end{array}$ \\
\hline 1947 & $\begin{array}{l}\text { Eng. Osvaldo José do } \\
\text { Nascimento Magalhães }\end{array}$ & Recife-PE & IAPFESP & $\begin{array}{l}\text { Responsável pela construção da Vila Presidente Dutra } \\
\text { (Afogados) }\end{array}$ \\
\hline 1947 & $\begin{array}{l}\text { Eng. Oscar Ramos de } \\
\text { Albuquerque }\end{array}$ & Recife-PE & $\begin{array}{l}\text { CAPFESP-PE } \\
\text { e AL }\end{array}$ & $\begin{array}{l}\text { Engenheiro civil graduado pela Escola Politécnica de } \\
\text { Pernambuco, em 1921. Projetou diversas unidades isoladas } \\
\text { para os segurados no bairro de Tejipó }\end{array}$ \\
\hline 1947 & $\begin{array}{l}\text { Eng. Antônio Rodrigues } \\
\text { da Silva }\end{array}$ & Sobral-CE & IAPC & Edificou moradias isoladas \\
\hline 1947 & $\begin{array}{l}\text { Eng. Plínio Hermes } \\
\text { Monteiro }\end{array}$ & Fortaleza-CE & $\begin{array}{l}\text { CAP Ser. Púb. } \\
\text { CE }\end{array}$ & $\begin{array}{l}\text { Edificou três residências na Rua Padre Cícero, bairro } \\
\text { Benfica }\end{array}$ \\
\hline 1947 & $\begin{array}{l}\text { Construtora e Eng. } \\
\text { Antônio Rufino da Silva }\end{array}$ & Fortaleza-CE & |API & Responsável pela edificação da Vila Aldeota. \\
\hline 1947 & $\begin{array}{l}\text { Const. José Falb } \\
\text { Rangel }\end{array}$ & Fortaleza-CE & IAPC & Edificou moradias isoladas \\
\hline 1947 & Eng. Alberto Sá & Fortaleza-CE & IAPC & Edificou moradias isoladas \\
\hline 1947 & $\begin{array}{c}\text { Tiburcio Rodrigues de } \\
\text { Melo }\end{array}$ & Crato-CE & IAPC & $\begin{array}{l}\text { Construtor licenciado. Edificou moradias isoladas. Recebeu } \\
\text { nome de Rua em Fortaleza }\end{array}$ \\
\hline 1947 & $\begin{array}{l}\text { Raimundo Nonato } \\
\text { Portela de Melo }\end{array}$ & Teresina-PI & IAPC & Edificou moradias isoladas \\
\hline 1947 & Wilson de Pádua Paula & Teresina-PI & IAPC & Edificou moradias isoladas \\
\hline 1947 & $\begin{array}{l}\text { Elizeu Marques } \\
\text { Carneiro }\end{array}$ & Natal-RN & IAPI & Edificou a Vila Janete \\
\hline 1947 & $\begin{array}{l}\text { Eng. Arq. Clodoaldo } \\
\text { Jamelo }\end{array}$ & João Pessoa-PB & IAPC & Edificou moradias isoladas \\
\hline 1947 & J. Perales Aires & Fortaleza-CE & $\begin{array}{l}\text { CAP Ser. Púb. } \\
\text { CE }\end{array}$ & Eng. encarregado pela Comissão de Engenharia da CAP \\
\hline 1948 & Romulo Souto Proença & Caucáia-CE & IAPETC & Avaliação de imóveis isolados \\
\hline 1948 & Alberto Sá & Fortaleza-CE & IAPB & Avaliação de imóveis isolados \\
\hline 1948 & Eng. Luiz Pires Chaves & Teresina-PI & $\mathrm{n} / \mathrm{e}$ & Avaliação de imóveis isolados \\
\hline 1948 & $\begin{array}{l}\text { Firma Construtora } \\
\text { Figueira \& Jucá }\end{array}$ & Recife-PE & IAPC & Responsável pela execução do Ed. Capibaribe \\
\hline 1948 & Construtora Pinto & Fortaleza-CE & $\begin{array}{l}\text { CAP Ser. Púb. } \\
\text { CE }\end{array}$ & Edificou moradias isoladas \\
\hline 1948 & $\begin{array}{l}\text { Eng. Calos Valério } \\
\text { Costa }\end{array}$ & Tersina_PI & $\mathrm{n} / \mathrm{e}$ & Edificou moradias isoladas \\
\hline 1948 & Eng. Rodrigo Lopes & Natal-RN & CAPESP & Edificou moradias isoladas \\
\hline 1948 & $\begin{array}{l}\text { Antônio de Oliveira } \\
\text { Silva }\end{array}$ & João Pessoa-PB & IAPI & Projetista. Edificou moradias isoladas \\
\hline 1948 & $\begin{array}{l}\text { Eng. Afonso Souza } \\
\text { Pitangueira }\end{array}$ & Salvador-BA & CAPFESP & Diretor da Carteira Predial da Caixa \\
\hline 1949 & Eng. Romeu Figueiredo & Recife-PE & IAPC & $\begin{array}{l}\text { Elaborou parecer e contribuiu para a aprovação para a } \\
\text { construção do Edifício Capibaribe }\end{array}$ \\
\hline 1949 & $\begin{array}{l}\text { Eng. José Euclides } \\
\text { Caracas }\end{array}$ & Fortaleza-CE & IAPC & Fazia parte do corpo técnico do órgão central \\
\hline 1949 & $\begin{array}{l}\text { Eng. Antônio Santana } \\
\text { Júnior }\end{array}$ & Fortaleza-CE & $\begin{array}{l}\text { CAP Ser. Púb. } \\
\text { CE }\end{array}$ & Avaliação de imóveis isolados \\
\hline 1949 & $\begin{array}{l}\text { Eng. Heitor de Oliveira } \\
\text { Albuquerque }\end{array}$ & Fortaleza-CE & $|A P|$ & Avaliação de imóveis isolados \\
\hline 1949 & $\begin{array}{l}\text { Rivaldo Radier de } \\
\text { Aquino }\end{array}$ & Fortaleza-CE & $\begin{array}{l}\text { CAP Ser. Aér. } \\
\text { e Telecomun. }\end{array}$ & Avaliação de imóveis isolados \\
\hline 1949 & Frederico Ernesto & Fortaleza-CE & CAP Serv. & Avaliação de imóveis isolados \\
\hline
\end{tabular}




\begin{tabular}{|c|c|c|c|c|}
\hline & Draenert & & $\begin{array}{c}\text { Aéreo e } \\
\text { Telecomun./IA } \\
\text { PI }\end{array}$ & \\
\hline 1949 & $\begin{array}{l}\text { Sérgio Pereira de } \\
\text { Cerqueira }\end{array}$ & Salvador-BA & IAPI & Avaliação de imóveis isolados \\
\hline 1949 & Cícero Ferraz de Souza & Teresina-PI & IPASE & Avaliação de imóveis isolados \\
\hline 1949 & $\begin{array}{c}\text { Eng. José João Neves } \\
\text { Rodrigues } \\
\end{array}$ & Teresina-PI & IAPI & Avaliação de imóveis isolados \\
\hline 1949 & $\begin{array}{l}\text { Eng. Osvaldo C. } \\
\text { Cavalcanti }\end{array}$ & Recife-PE & $\begin{array}{l}\text { CAP dos Serv. } \\
\text { Aéreos }\end{array}$ & Execução das obras da Vila Jardim São Paulo (Torre) \\
\hline 1949 & $\begin{array}{l}\text { Eng. Otaviano de } \\
\text { Oliveira }\end{array}$ & Recife-PE & $\begin{array}{l}\text { CAP dos Serv. } \\
\text { Aéreos }\end{array}$ & $\begin{array}{c}\text { Presidente do CREA-PE em } 1957 \text { e entre 1960-63. Projetou } \\
\text { a Vila Jardim São Paulo (Torre) }\end{array}$ \\
\hline 1949 & $\begin{array}{l}\text { Eng. Civil e Militar José } \\
\text { Antônio de Santana } \\
\text { Medeiros }\end{array}$ & Fortaleza-CE & IAPC & Edificou moradias isoladas \\
\hline 1949 & Marcelo Barros & Fortaleza-CE & IPASE & Edificou moradias isoladas \\
\hline 1949 & $\begin{array}{l}\text { Construtora } \\
\text { Organização Comercial } \\
\text { Lida } \\
\end{array}$ & Fortaleza-CE & IAPI & Edificou moradias isoladas \\
\hline 1949 & $\begin{array}{l}\text { Eng. Luciano Ribeiro } \\
\text { Pampiona }\end{array}$ & Fortaleza-CE & IAPC & Edificou moradias isoladas \\
\hline 1949 & $\begin{array}{l}\text { Eng. Paulo Moreira } \\
\text { Filho } \\
\end{array}$ & Fortaleza-CE & IAPETC & $\begin{array}{c}\text { Responsável pelo projeto e execução da Vila Antônio } \\
\text { Ferreira Filho }\end{array}$ \\
\hline 1949 & Eng. Gontran Coelho & Fortaleza-CE & IAPC & Edificou moradias isoladas \\
\hline 1949 & $\begin{array}{l}\text { Eng. Amilcar de Morais } \\
\text { Fernandes Távora }\end{array}$ & Fortaleza-CE & IAPI & Edificou moradias isoladas \\
\hline 1949 & $\begin{array}{c}\text { Construtora Cearense } \\
\text { Lida }\end{array}$ & Fortaleza-CE & IAPETC & Edificou moradias isoladas \\
\hline 1949 & $\begin{array}{l}\text { Eng. Carlos Galvão } \\
\text { Castro }\end{array}$ & Teresina-PI & IAPI & Edificou moradias isoladas \\
\hline 1949 & $\begin{array}{l}\text { Eng. Pedro Lucas } \\
\text { Cunha }\end{array}$ & Natal-RN & IAPB & Engenheiro construtor do IAPB (corpo técnico principal) \\
\hline 1949 & $\begin{array}{l}\text { Eng. Joaquim Pereira } \\
\text { Dantas }\end{array}$ & Natal-RN & $\begin{array}{l}\text { CAP Sev. } \\
\text { Púb. RN }\end{array}$ & $\begin{array}{l}\text { Engenheiro responsável pelas construções empreendidas } \\
\text { pela CAP na cidade }\end{array}$ \\
\hline 1949 & $\begin{array}{l}\text { Eng. Manoel Henrique } \\
\text { de Trigueiro }\end{array}$ & Natal-RN & CAPESP & Edificou moradias isoladas \\
\hline 1949 & José Fernandes Vieira & Natal-RN & $\begin{array}{l}\text { CAP Ser. Púb. } \\
\text { RN }\end{array}$ & Edificou moradias isoladas \\
\hline 1949 & Humberto Ruffo & João Pessoa-PB & IAPB & Edificou moradias isoladas \\
\hline 1949 & Antônio Gama & João Pessoa-PB & IAPI & Construtor. Edificou moradias isoladas \\
\hline 1949 & José Pedro e Fagundes & João Pessoa-PB & IAPI & Construtor (aparece como empregado do IAPI) \\
\hline 1949 & $\begin{array}{l}\text { Eng. Carlos Gastão } \\
\text { Tassano }\end{array}$ & Rio de Janeiro & IAPC & $\begin{array}{c}\text { Engenheiro oficial da seção de engenharia do IAPC, no Rio } \\
\text { de Janeiro, até o ano de 1964, quando solicitou } \\
\text { aposentadoria. }\end{array}$ \\
\hline 1949 & Luiz Soares Bezerra & Fortaleza-CE & IAPETC & Delegado do Instituto \\
\hline 1949 & Milton Santos & Fortaleza-CE & IAPETC & Delegado do Instituto \\
\hline 1949 & Maurício Gentil & Fortaleza-CE & IAPB & Delegado do Instituto \\
\hline 1950 & Eng. Alberto Sá & Fortaleza-CE & $\begin{array}{l}\text { IAPB e CAP } \\
\text { Ser. Aér. e } \\
\text { Tel. } \\
\end{array}$ & Avaliação de imóveis isolados \\
\hline 1950 & $\begin{array}{l}\text { Eng. Fernando } \\
\text { Cysneiros }\end{array}$ & Fortaleza-CE & IAPC & Avaliação de imóveis isolados \\
\hline 1950 & $\begin{array}{c}\text { Fernando Brandão } \\
\text { Corrêa }\end{array}$ & Salvador-BA & IAPC & Avaliação de imóveis isolados \\
\hline 1950 & Eng. Luiz Noya Volfsos & Natal-RN & IAPI/CAPESP & Assinou laudos de avaliação da Vila Gomes, no Alecrim \\
\hline 1950 & $\begin{array}{l}\text { Eng. Sebastião } \\
\text { Menezes }\end{array}$ & Natal-RN & IAPC & Avaliação de imóveis isolados \\
\hline 1950 & $\begin{array}{l}\text { Eng. José Gonçalves } \\
\text { de Carvalho Melo }\end{array}$ & João Pessoa-PB & IPASE & Avaliação de imóveis isolados \\
\hline 1950 & Const. Joaquim Guedes & Fortaleza-CE & IAPC & Edificou moradias isoladas \\
\hline 1950 & Const. Luiz Nogueira & Fortaleza-CE & IAPC & Edificou moradias isoladas \\
\hline 1950 & Higino Correia & Salvador-BA & IAPFESP & Edificou moradias isoladas \\
\hline 1950 & Orlando Camardelli & Salvador-BA & IAPFESP & Edificou moradias isoladas \\
\hline 1950 & $\begin{array}{l}\text { Eng. Gentil Ferreira } \\
\text { Souza }\end{array}$ & Natal-RN & IAPB & Edificou moradias isoladas \\
\hline 1950 & Damião Frota Sales & Fortaleza-CE & IAIP & Chefe do Serviço Imobiliário \\
\hline 1951 & Eng. Joan Gonçalves & Natal-RN & CAPESP & Assinou laudos de avaliação da Vila Henrique Eboli, \\
\hline 1951 & $\begin{array}{l}\text { Construtora Sociedade } \\
\text { Técnica de }\end{array}$ & Fortaleza-CE & IAPI & Edificou moradias isoladas \\
\hline
\end{tabular}




\begin{tabular}{|c|c|c|c|c|}
\hline & Construções & & & \\
\hline 1951 & $\begin{array}{l}\text { Const. Aloy Correa } \\
\text { Leitão }\end{array}$ & Fortaleza-CE & IAPI & $\begin{array}{l}\text { Edificou moradias isoladas. Foi aluno do Colégio Militar do } \\
\text { Ceará até } 1927\end{array}$ \\
\hline 1951 & $\begin{array}{l}\text { Eng. Abelardo Paulo da } \\
\text { Matta }\end{array}$ & Salvador-BA & IAPFESP & $\begin{array}{c}\text { Projetou e executou as obras da Vila Operária dos } \\
\text { Ferroviários (Paripe) }\end{array}$ \\
\hline 1951 & Const. Pedro Ciarlin & Natal-RN & $\mathrm{n} / \mathrm{e}$ & Edificou moradias isoladas \\
\hline 1952 & Valdo Noronha & Teresina-PI & IPASE & Avaliação de imóveis isolados \\
\hline 1952 & $\begin{array}{l}\text { Eng. Nilson Rocha de } \\
\text { Oliveira }\end{array}$ & Natal-RN & IAPI & Avaliação de imóveis isolados \\
\hline 1952 & Eng. Luiz Carrilho Filho & João Pessoa-PB & IPASE & Avaliação de imóveis isolados \\
\hline 1952 & $\begin{array}{l}\text { Eng. Almir Ferreira } \\
\text { Santos }\end{array}$ & Salvador-BA & IAPI & $\begin{array}{l}\text { Projetou e executou o Conj. do Salvador ou Conj. dos } \\
\text { Industriários }\end{array}$ \\
\hline 1952 & Antônio Alves Neto & Teresina-PI & IAPC & Edificou moradias isoladas \\
\hline 1952 & $\begin{array}{l}\text { Eng. Dielson Alves de } \\
\text { Carvalho }\end{array}$ & Teresina-PI & IPASE/IAPC & Edificou moradias isoladas \\
\hline 1952 & $\begin{array}{l}\text { Eng. Eloi do Egito } \\
\text { Coelho }\end{array}$ & Teresina-PI & IPASE & $\begin{array}{c}\text { Formado em engenharia em 1923, em Minas Gerais. } \\
\text { Edificou moradias isoladas }\end{array}$ \\
\hline 1952 & Eng. Otávio Tavares & Natal-RN & IPASE & Edificou moradias isoladas \\
\hline 1952 & $\begin{array}{l}\text { Eng. Manoel Elpídio da } \\
\text { Silva }\end{array}$ & Natal-RN & IPASE & Diversas construções isoladas financiadas pelo Instituto \\
\hline 1952 & $\begin{array}{l}\text { Eng. Antônio Carvalho } \\
\text { de Almeida }\end{array}$ & Natal-RN & IAPI & Edificou moradias isoladas \\
\hline 1952 & $\begin{array}{l}\text { João Cavalcanti de } \\
\text { Menezes }\end{array}$ & João Pessoa-PB & IAPI & Construtor de unidades isoladas \\
\hline 1952 & $\begin{array}{l}\text { Eng. Targino Pereira da } \\
\text { Costa }\end{array}$ & João Pessoa-PB & IAPI & $\begin{array}{c}\text { Engenheiro da Construtora Severino João da Silva, vistoriou } \\
\text { obras do Conj. do IAPI. Edificou o primeiro Mercado de } \\
\text { Araruna-PB, em } 1934 \text {. }\end{array}$ \\
\hline 1952 & $\begin{array}{l}\text { Eng. Vinicius Londres } \\
\text { da Nóbrega }\end{array}$ & João Pessoa-PB & IAPI & $\begin{array}{c}\text { Engenheiro da Construtora Severino João da Silva. } \\
\text { Participou da construção das residências do Conj. do IAPI. } \\
\text { Professor da Escola Politécnica da Paraíba. }\end{array}$ \\
\hline 1952 & José Dias Fernandes & Campina Grande-PB & IAPI & $\begin{array}{c}\text { Construtor empregado do IAPI. Edificou moradias no } \\
\text { município }\end{array}$ \\
\hline 1952 & $\begin{array}{c}\text { Antônio Pereira da } \\
\text { Costa }\end{array}$ & Santa Rita-PB & IAPI & $\begin{array}{c}\text { Construtor empregado do IAPI. Edificou moradias no } \\
\text { município }\end{array}$ \\
\hline 1953 & Nogueira Passos & Salvador-BA & IAPB & $\begin{array}{c}\text { Possuía contrato aberto com a Instituição, podendo atuar em } \\
\text { todo o território nacional em qualquer IAP ou CAP }\end{array}$ \\
\hline 1953 & Manoel Augusto Leone & Salvador-BA & IAPB & Avaliação de imóveis isolados \\
\hline 1953 & $\begin{array}{l}\text { Epaminondas } \\
\text { Rodrigues }\end{array}$ & Salvador-BA & IAPB & Avaliação de imóveis isolados \\
\hline 1953 & $\begin{array}{l}\text { Construtora A. Brito } \\
\text { Cavalcanti }\end{array}$ & Recife-PE & CAP NE BR & $\begin{array}{l}\text { Firma contratada por empreitada para a edificação da Vila } \\
\text { Presidente Dutra, em Areias. }\end{array}$ \\
\hline 1953 & $\begin{array}{l}\text { Arq. Diógenes } \\
\text { Rebouças }\end{array}$ & Salvador-BA & IAPB & $\begin{array}{l}\text { Projetou, junto ao arq. José Bina Fonyat, o Conjunto } \\
\text { Almirante Valdermar Mota ou Conjunto Itapagipe }\end{array}$ \\
\hline 1953 & Arq. José Bina Fonyat & Salvador-BA & IAPB & $\begin{array}{l}\text { Projetou, junto ao arq. Diógenes Rebouças, o Conjunto } \\
\text { Almirante Valdermar Mota ou Conjunto Itapagipe }\end{array}$ \\
\hline 1953 & Manoel Martins Viana & Teresina-PI & IPASE & Edificou moradias isoladas \\
\hline 1953 & $\begin{array}{l}\text { Eng. João Gabriel } \\
\text { Batista }\end{array}$ & Teresina-PI & IPASE & $\begin{array}{c}\text { Projetou e fiscalizou as obras do Conj. Cel. Vitorino Corrêa, } \\
\text { além de diversas unidades isoladas na cidade }\end{array}$ \\
\hline 1953 & $\begin{array}{l}\text { Arq. Beraldo Dário } \\
\text { Borges }\end{array}$ & São Luís-MA & IPASE & Projetou o Conjunto José Bonifácio \\
\hline 1953 & $\begin{array}{l}\text { Tancredo Halley de } \\
\text { Alcantara }\end{array}$ & Fortaleza-CE & IAPM & Delegado do Instituto \\
\hline 1954 & $\begin{array}{l}\text { Eng. Serafin Rodriguez } \\
\text { Martinez }\end{array}$ & João Pessoa-PB & IAPI & Avaliação de imóveis isolados \\
\hline 1955 & $\begin{array}{l}\text { Arq. Maria de Lourdes } \\
\text { Beniez }\end{array}$ & Recife-PE & IAPC & $\begin{array}{c}\text { Assinou laudos de avaliação dos imóveis do Conj. Lafaiete } \\
\text { Coutinho, em Casa Amarela }\end{array}$ \\
\hline 1955 & $\begin{array}{c}\text { Eng. Edmilson } \\
\text { Medeiros da Fonseca }\end{array}$ & Natal-RN & IPASE & Avaliação de imóveis isolados \\
\hline 1955 & Construtora Alfa Lida & Fortaleza-CE & IAPC & Empresa responsável pela construção do Conj. Mondubin \\
\hline 1955 & $\begin{array}{l}\text { Eng. José Oswaldo } \\
\text { Pontes }\end{array}$ & Fortaleza-CE & IAPC & $\begin{array}{c}\text { Engenheiro da Construtora Alfa Lida responsável pela } \\
\text { construção do Conj. Mondubin. Posteriormente foi diretor } \\
\text { geral do Departamento Nacional de Obras Contra as Secas } \\
\text { (DNOCS-1979). }\end{array}$ \\
\hline 1955 & $\begin{array}{l}\text { Eng. Ary Carvalho } \\
\text { Ornellas }\end{array}$ & Salvador-BA & IAPC & Edificou moradias isoladas \\
\hline 1955 & $\begin{array}{l}\text { Luíz Edmundo } \\
\text { Kruschewsky }\end{array}$ & Salvador-BA & IAPC & Edificou moradias isoladas \\
\hline 1955 & Gilson Silva Pinto & Salvador-BA & IAPC & Edificou moradias isoladas \\
\hline 1955 & $\begin{array}{l}\text { Eng. José Correia } \\
\text { Costa }\end{array}$ & Natal-RN & IPASE & Responsável pelo projeto do Conj. Paulo Gentile \\
\hline
\end{tabular}




\begin{tabular}{|c|c|c|c|c|}
\hline 1955 & Olavo Oliveira & Rio de Janeiro & IAPC & Presidente do Instituto (advogado, professor e político) \\
\hline $\begin{array}{c}1957- \\
1964 / 195 \\
2\end{array}$ & $\begin{array}{l}\text { Eng. João Gabriel } \\
\text { Batista }\end{array}$ & Teresina-PI & IPASE/IAPI & $\begin{array}{l}\text { A maior parte das avaliações dos imóveis financiados pelo } \\
\text { Instituto no período }\end{array}$ \\
\hline 1956 & Eng. Romulo de Santos & Fortaleza-CE & IAPETC & Avaliação de imóveis isolados \\
\hline 1956 & $\begin{array}{l}\text { Arq. José Liberal de } \\
\text { Castro }\end{array}$ & Fortaleza-CE & IAPB & $\begin{array}{l}\text { Avaliação de imóveis isolados. Arquiteto cearense formado } \\
\text { na Faculdade de Arquitetura da Universidade do Brasil, no } \\
\text { Rio de Janeiro. Retornou à Fortaleza nos anos de 1950, e } \\
\text { participou da instauração da Faculdade de Arquitetura da } \\
\text { UFCE, em } 1965 .\end{array}$ \\
\hline 1956 & José Amaury Araújo & Fortaleza-CE & IAPB & Avaliação de imóveis isolados \\
\hline 1956 & $\begin{array}{l}\text { Eng. Eloi do Egito } \\
\text { Coelho }\end{array}$ & Teresina-PI & IPASE & Avaliação de imóveis isolados \\
\hline 1956 & Eng. Milson Dantas & Natal-RN & IPASE & Avaliação de imóveis isolados \\
\hline 1956 & $\begin{array}{l}\text { Eng. Antônio Ramo } \\
\text { Tejo }\end{array}$ & Natal-RN & IPASE & Avaliação de imóveis isolados \\
\hline 1957 & Eng. Luiz Bento & Recife-PE & IPASE & $\begin{array}{l}\text { Assinou laudos de avaliação dos imóveis do Ed. Igarassu, } \\
\text { em Boa Viagem }\end{array}$ \\
\hline 1957 & $\begin{array}{l}\text { Mauro Fernandes de } \\
\text { Lacerda Passos }\end{array}$ & Salvador-BA & IAPB & Avaliação de imóveis isolados \\
\hline 1957 & $\begin{array}{l}\text { Carlos Alberto de } \\
\text { Araújo Costa }\end{array}$ & Teresina-PI & IPASE & Avaliação de imóveis isolados \\
\hline 1957 & $\begin{array}{c}\text { Eng. José Carlos Pires } \\
\text { de Carvalho Fortes } \\
\text { Castelo Branco }\end{array}$ & Teresina-PI & IPASE & Avaliação de imóveis isolados \\
\hline 1957 & Eng. Marcelo Cabral & Natal-RN & IAPC & Avaliação de imóveis isolados \\
\hline 1957 & $\begin{array}{l}\text { Sociedade Imobiliária } \\
\text { Terrenos e } \\
\text { Incorporação Limitada } \\
\text { (SITI } \\
\end{array}$ & Recife-PE & IPASE & Construção e incorporação do Ed. Igarassu \\
\hline 1957 & $\begin{array}{l}\text { Eng. Manoel Santos da } \\
\text { Figueira }\end{array}$ & Receife-PE & IPASE & $\begin{array}{c}\text { Projeto e construção do Ed. Igarassu. Também participou do } \\
\text { projeto e das obras da Barragem Mãe D’Água-BA }\end{array}$ \\
\hline 1957 & $\begin{array}{c}\text { Imobiliária e } \\
\text { Construtora Bonfim } \\
\end{array}$ & Salvador-BA & IAPC & Edifício Nosso Senhor do Bonfim \\
\hline 1957 & $\begin{array}{l}\text { Eng. Ricardo Alves de } \\
\text { Assunção Maia }\end{array}$ & Teresina-PI & IPASE & Edificou moradias isoladas \\
\hline 1957 & $\begin{array}{l}\text { Arq. Ulysses Petrônio } \\
\text { Bularmaqui }\end{array}$ & João Pessoa-PB & IAPB & $\begin{array}{l}\text { Projetou o Edifício Presidente João Pessoa, conhecido como } \\
\qquad 18 \text { andares }\end{array}$ \\
\hline 1957 & Eng. João Batista & João Pessoa-PB & IPASE & Edificou moradias isoladas \\
\hline 1957 & $\begin{array}{l}\text { Eng. Messias Tavares } \\
\text { da Cruz }\end{array}$ & Salvador-BA & IAPC & Chefe de Aplicações Financeiras do Instituto \\
\hline 1957 & $\begin{array}{l}\text { Eng. Afonso Souza } \\
\text { Pitangueira }\end{array}$ & Salvador-BA & IAPC & Delegado do Instituto \\
\hline 1958 & Solano de Morais & Salvador-BA & IAPB & Avaliação de imóveis isolados \\
\hline 1958 & $\begin{array}{c}\text { Benedito Toledo } \\
\text { Patrício } \\
\end{array}$ & Salvador-BA & IAPB & Avaliação de imóveis isolados \\
\hline 1958 & $\begin{array}{c}\text { Eng. Francisco } \\
\text { Rodrigues Sobrinho }\end{array}$ & Teresina-PI & IAPC & Avaliação de imóveis isolados \\
\hline 1958 & Eng. Carlos Almeida & Teresina-PI & IPASE & Edificou moradias isoladas \\
\hline 1958 & $\begin{array}{l}\text { Eng. José Cunha de } \\
\text { Carvalho }\end{array}$ & Teresina-PI & IPASE & Edificou moradias isoladas \\
\hline 1958 & $\begin{array}{l}\text { Construtora Carmelo } \\
\text { Ruffo Lida }\end{array}$ & João Pessoa-PB & IPASE & $\begin{array}{c}\text { Responsável pela edificação do Conj. Presidente João } \\
\text { Goulart }\end{array}$ \\
\hline 1958 & $\begin{array}{l}\text { Sinfronio Cesar } \\
\text { Coutinho }\end{array}$ & Rio de Janeiro & IAPETC & $\begin{array}{l}\text { Chefe da Divisão de Aplicação de Reservas do Instituto. } \\
\text { Participou do trâmite burocrático da Vila Presidente Arlindo } \\
\text { Maciel }\end{array}$ \\
\hline 1959 & Mário B. Pinto & Salvador-BA & IPASE & Avaliação de imóveis isolados \\
\hline 1959 & Frederico Maia & Salvador-BA & IAPC & Avaliação de imóveis isolados \\
\hline 1959 & $\begin{array}{l}\text { Eng. Oswaldo Nobre } \\
\text { Fontes }\end{array}$ & João Pessoa-PB & IPASE & $\begin{array}{c}\text { Engenheiro civil responsável pelo projeto e cálculos das } \\
\text { residências em Santa Júlia. Primeiro corpo docente da } \\
\text { Escola de Engenharia (1956) e projetou diversas residências } \\
\text { na Av. Cabo Branco }\end{array}$ \\
\hline 1959 & $\begin{array}{l}\text { Eng. Benigno Walter } \\
\text { Bargigo }\end{array}$ & João Pessoa-PB & IPASE & Edificou moradias isoladas \\
\hline 1959 & $\begin{array}{l}\text { Eng. Eraldo Machado } \\
\text { Lemos }\end{array}$ & Rio de Janeiro & IAPC & Presidente do Instituto \\
\hline 1960 & $\begin{array}{l}\text { Arq. Adauto S. S. } \\
\text { Pereira }\end{array}$ & Recife-PE & IAPI & $\begin{array}{l}\text { Assinou laudos de avaliação dos imóveis do Conj. de Areias } \\
\text { (IAPI-1960) }\end{array}$ \\
\hline 1960 & Eng. Paulo A. F. Castro & Recife-PE & IAPI & $\begin{array}{l}\text { Assinou laudos de avaliação dos imóveis do Conj. de Areias } \\
\text { (IAPI-1960) }\end{array}$ \\
\hline
\end{tabular}




\begin{tabular}{|c|c|c|c|c|}
\hline 1960 & $\begin{array}{l}\text { Eng. Kleber de } \\
\text { Carvalho Bezerra }\end{array}$ & Natal-RN & IPASE & Avaliação de imóveis isolados \\
\hline 1960 & $\begin{array}{l}\text { Eng. Paulo Gonçalves } \\
\text { dos Santos }\end{array}$ & Recife-PE & IAPC & $\begin{array}{l}\text { Assinou laudos de vistorias das obras e imóveis do Conjunto } \\
\text { Casa Amarela. }\end{array}$ \\
\hline 1960 & $\begin{array}{l}\text { Const. José Pascoal } \\
\text { Duarte }\end{array}$ & Teresina-PI & IPASE & Edificou moradias isoladas \\
\hline 1960 & Eng. Antônio Barbosa & Teresina-PI & IPASE & $\begin{array}{c}\text { Edificou moradias isoladas } \\
\end{array}$ \\
\hline 1960 & $\begin{array}{l}\text { Eng. Cícero Ferraz de } \\
\text { Souza Martins }\end{array}$ & Teresina-PI & $\mathrm{n} / \mathrm{e}$ & $\begin{array}{c}\text { Edificou moradias isoladas. Edificou também o Hospital } \\
\text { Getúlio Vargas em Teresina }\end{array}$ \\
\hline 1960 & $\begin{array}{l}\text { Eng. Kleber de } \\
\text { Carvalho Bezerra }\end{array}$ & Natal-RN & IPASE & $\begin{array}{c}\text { Pernambucano erradicado em Natal. Edificou diversas } \\
\text { moradias nos bairro de Tirol e Petrópolis, utilizando concreto } \\
\text { armado }\end{array}$ \\
\hline 1960 & $\begin{array}{l}\text { Construtora Alpiniano } \\
\text { Viegas Lida }\end{array}$ & João Pessoa-PB & IPASE & $\begin{array}{l}\text { Participou junto à Construtora Carmelo Ruffo da empreitada } \\
\text { para a edificação do Conjunto JK }\end{array}$ \\
\hline 1960 & $\begin{array}{l}\text { Anildo Antônio de } \\
\text { Barros }\end{array}$ & Recife-PE & IAPI & Chefe da Seção de Administração do IAPI-PE \\
\hline 1960 & Marcelo Cordeiro & Recife-PE & IAPI & Chefe do Serviço Imobiliário do IAPI-PE \\
\hline 1960 & $\begin{array}{l}\text { Agamenon Cornélio da } \\
\text { Silva } \\
\end{array}$ & Recife-PE & IAPI & Delegado do IAPI-PE \\
\hline 1960 & $\begin{array}{c}\text { Ricardo Marinho da } \\
\text { Costa }\end{array}$ & Recife-PE & IAPI & Chefe da Seção do Conj. Residencial Areias \\
\hline 1961 & $\begin{array}{l}\text { Eng. José Alves de } \\
\text { Lobão Veras }\end{array}$ & Teresina-PI & IAPB & Avaliação dos imóveis da Vila dos Bancários na cidade \\
\hline 1961 & $\begin{array}{l}\text { Eng. José Alves de } \\
\text { Dantas }\end{array}$ & Teresina-PI & IAPB & Avaliação dos imóveis da Vila dos Bancários na cidade \\
\hline 1963 & $\begin{array}{c}\text { Empresa de } \\
\text { Construções e Projetos } \\
\text { Lida } \\
\end{array}$ & Recife-PE & IPASE & $\begin{array}{l}\text { Projeto e construção de moradias em terrenos adquiridos e } \\
\text { dos segurados }\end{array}$ \\
\hline 1963 & $\begin{array}{l}\text { Eng. Mário Aquias de } \\
\text { Souza }\end{array}$ & Recife-PE & IPASE & $\begin{array}{c}\text { Engenheiro da Empresa de Construções e Projetos Lida e } \\
\text { foi o responsável por construções e projetos de residências } \\
\text { contratadas diretamente pelos associados e financiadas } \\
\text { pelos Institutos e Caixas na cidade. }\end{array}$ \\
\hline 1963 & $\begin{array}{l}\text { Eng. José Alves de } \\
\text { Dantas }\end{array}$ & Teresina-PI & IAPB & $\begin{array}{l}\text { Responsável pelo projeto e edificação da vila dos bancários } \\
\text { na cidade. }\end{array}$ \\
\hline 1963 & $\begin{array}{l}\text { Construtora Cleon } \\
\text { Furtado }\end{array}$ & São Luís-MA & IAPB & $\begin{array}{c}\text { Responsável pela edificação de diversas residências no } \\
\text { loteamento APICUM }\end{array}$ \\
\hline 1963 & Eng. Romulo Campelo & Salvador-BA & IAPB & Delegado do Instituto \\
\hline 1963 & $\begin{array}{l}\text { Eng. Carlos Nielsen } \\
\text { Koeptcke }\end{array}$ & Salvador-BA & IAPB & Eng. do corpo técnico do Instituto \\
\hline 1964 & Sebastião Wilde Jap & Salvador-BA & IPASE & Avaliação de imóveis isolados \\
\hline 1964 & E. A. Alencar & Teresina-PI & IPASE & $\begin{array}{l}\text { Realizou todas as avaliações para a venda dos imóveis do } \\
\text { Conj. Aeroporto }\end{array}$ \\
\hline 1964 & Carlos Pires de Almeida & Salvador-BA & IPASE & Edificou moradias isoladas \\
\hline 1964 & Arq. Ubirajara Galvão & Teresina-PI & IPASE & $\begin{array}{c}\text { Responsável pelos projetos do Conj. Monte Castelo, em } \\
\text { Teresina e da primeira etapa do Boa Esperança, na cidade } \\
\text { de Parnaíba-PI. }\end{array}$ \\
\hline 1964 & $\begin{array}{l}\text { Const. Décio dos } \\
\text { Santos }\end{array}$ & Teresina-PI & IPASE & Edificou moradias isoladas \\
\hline 1964 & $\begin{array}{l}\text { Eng. Ain de Oliveira } \\
\text { Furtado }\end{array}$ & Teresina-PI & IPASE & Edificou moradias isoladas \\
\hline 1964 & $\begin{array}{l}\text { Eng. Edwa L. C. } \\
\text { Almeida }\end{array}$ & Teresina-PI & IPASE & Edificou moradias isoladas \\
\hline 1964 & $\begin{array}{l}\text { Eng. Luiz Francisco } \\
\text { Rêgo }\end{array}$ & Teresina-PI & IPASE & Engenheiro do DNOCS. Edificou moradias isoladas \\
\hline 1964 & $\begin{array}{l}\text { Eng. Raimundo Fortes } \\
\text { de Cerqueira }\end{array}$ & Teresina-PI & IPASE & $\begin{array}{c}\text { Responsável pelo projeto e execução da segunda etapa do } \\
\text { Conj. Boa Esperança, em Parnaiba e do I Conj. Aeroporto, } \\
\text { em Teresina. Formado em engenharia militar e de } \\
\text { construção pelo IME, em } 1964\end{array}$ \\
\hline 1964 & $\begin{array}{l}\text { Eng. Antônio Carlos } \\
\text { Martins Ribeiro }\end{array}$ & João Pessoa-PB & IPASE & Projetou o Conj. Jacinto Medeiros \\
\hline 1965 & Eng. Clesiandes Melo & Recife-PE & IAPC & $\begin{array}{l}\text { Avaliações dos imóveis do Conjunto Presidente João } \\
\text { Goulart, em Peixinhos-Olinda }\end{array}$ \\
\hline 1966 & Edmar de Queiroz & Fortaleza-CE & IAPI & Delegado do Instituto \\
\hline 1966 & $\begin{array}{l}\text { Eduardo Mauro } \\
\text { Fernandes Bastos }\end{array}$ & Rio de Janeiro & IAPI & Presidente do Instituto \\
\hline 1974 & Eng. Kleber Moreira & Teresina-PI & IPASE & Avaliação de imóveis isolados \\
\hline
\end{tabular}


HABITAÇÃo SOCIAL NO NORDESTE:

A ATUAÇÃo dAS CAPS E dOS IAPs (1930-1964) 